
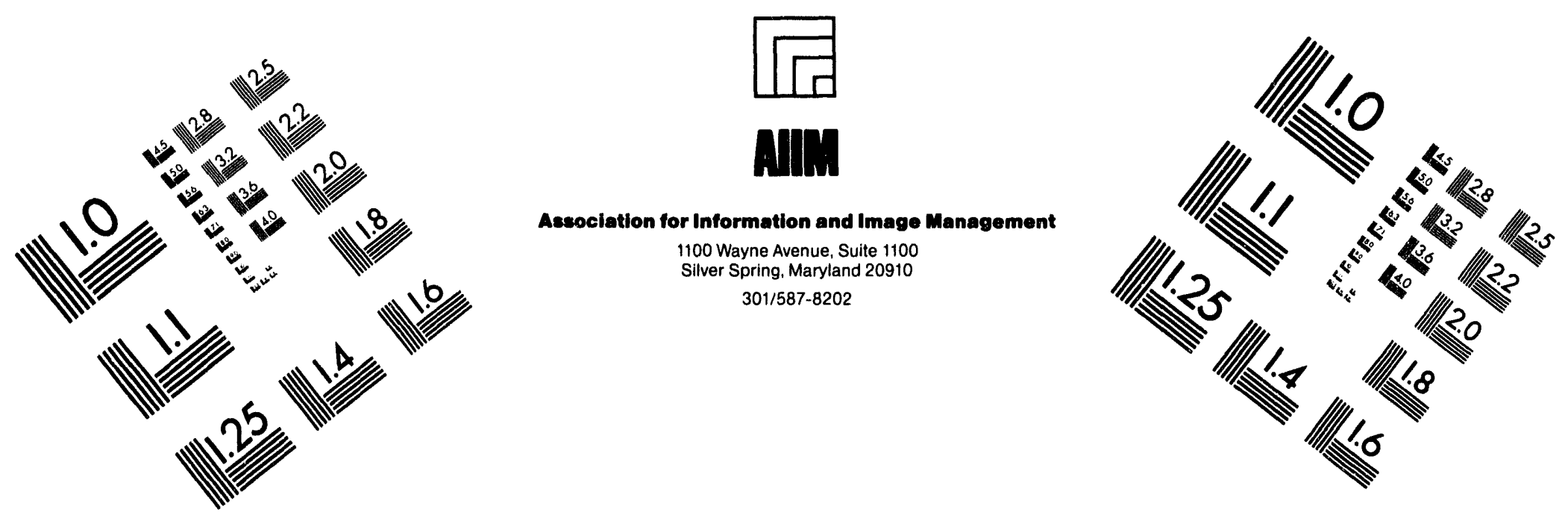

\title{
Centimeter
}

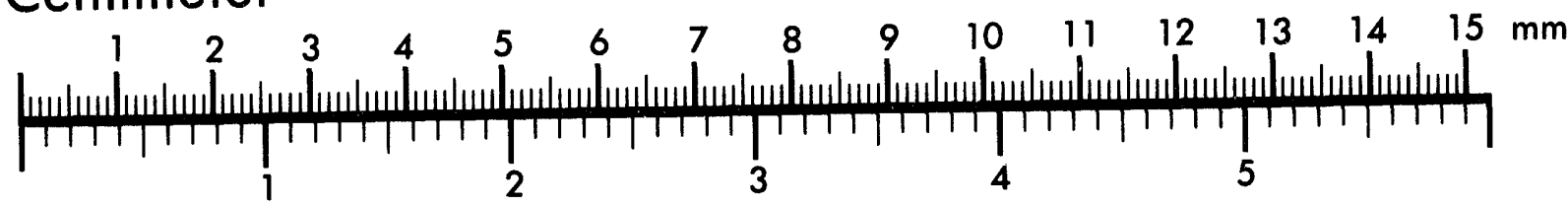
Inches
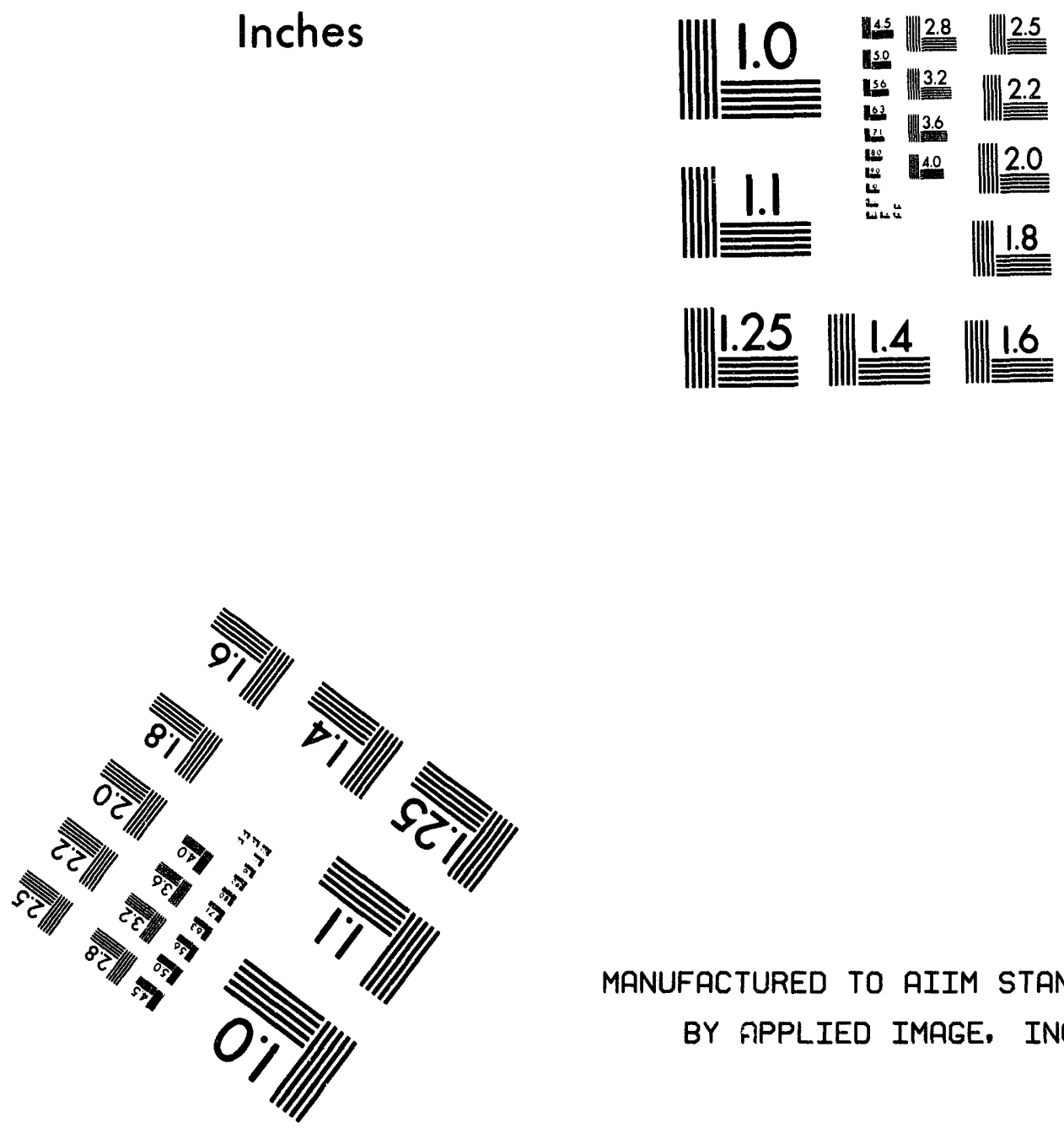

MANUFACTURED TO AIIM STANDARDS BY APPLIED IMAGE, INC.

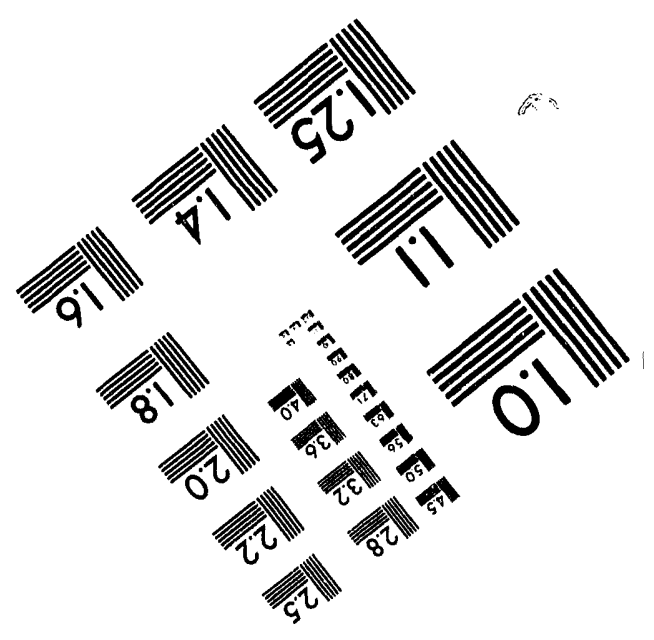



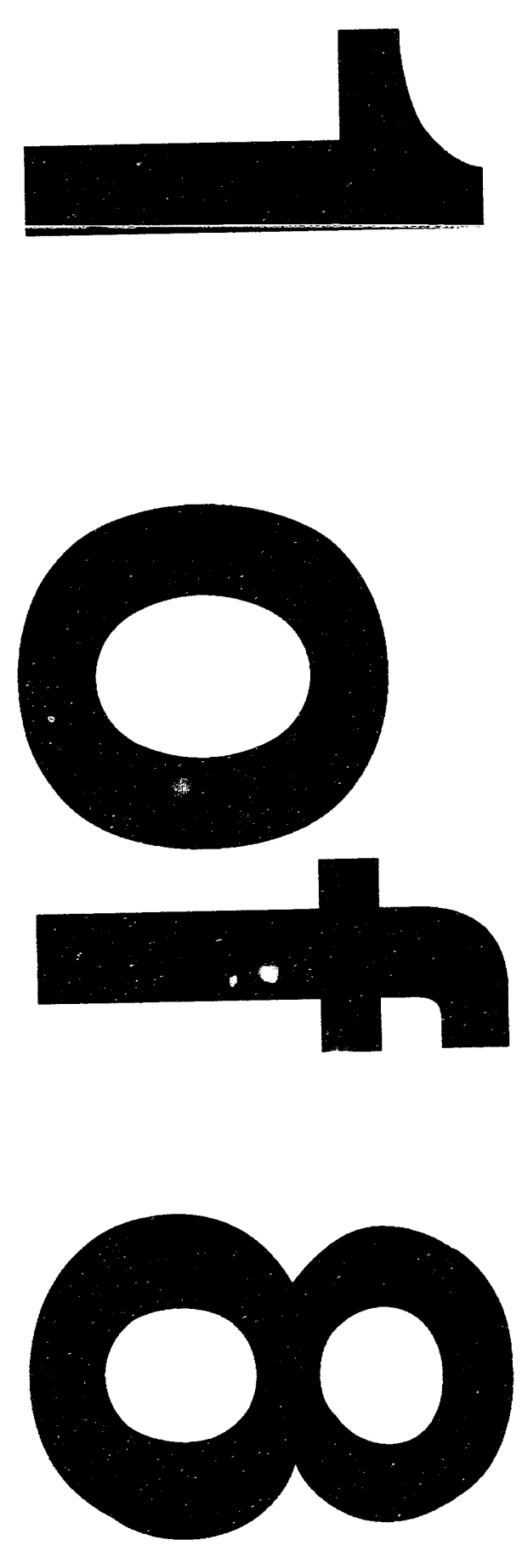


\section{Department of Energy Programmatic Spent Nuclear Fuel Management and \\ Idaho National Engineering Laboratory Environmental Restoration and Waste Management Programs Draft Environmental Impact Statement}

\section{Volume 2 \\ Part A}

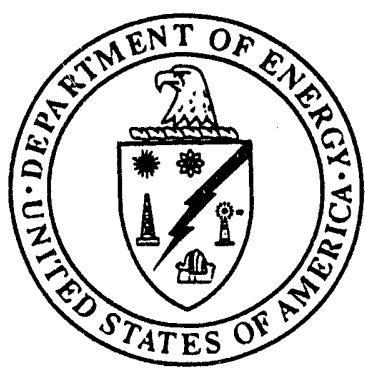

June 1994 


\section{COVER SHEET}

RESPONSIBLE AGENCIES: Lead Federal Agency: U.S. Department of Energy Cooperating Federal Agency: U.S. Department of the Navy

TITL: Department of Energy Programmatic Spent Nuclear Fuel Management and Idaho National Engineering Laboratory Environmental Restoration and Waste Management Programs Draft Environmental Impact Statement.

CONTACT: For further information on this Environmental Impact Statement call or contact:

Public Comments on the SNF and INEL EIS

Attention: Tom Wichmann

DOE Idaho Operations Office

P.O. Box 3189

Idaho Falls, ID 83403-3189

$1-800-682-5583$

For general information on the U.S. Department of Energy NEPA process call 1-800-472-2756 to leave a message or contact:

Carol Borgstrom, Director

Office of NEPA Oversight (EH-25)

U.S. Department of Energy

1000 Independence Avenue, SW

Washington, D.C. 20585

202-586-4600

ABSTRACT: This document analyzes at a programmatic level the potential environmental consequences over the next $\mathbf{4 0}$ years of alternatives related to the transportation, receipt, processing, and storage of spent nuclear fuel under the responsibility of the U.S. Department of Energy. It also analyzes the site-specific consequences of the Idaho National Engineering Laboratory sitewide actions anticipated over the next 10 years for waste and spent nuclear fuel management and environmental restoration. For programmatic spent nuclear fuel management, this document analyzes alternatives of no action, decentralization, regionalization, centralization and the use of the plans that existed in 1992/1993 for the management of these materials. For the Idaho National Engineering Laboratory, this document analyzes alternatives of no action, ten-year plan, minimum and maximum treatment, storage, and disposal of U.S. Department of Energy wastes.

PUBLIC COMMENTS: Public meetings on the Draft Environmental Impact Statement will be announced in June 1994. Written and oral comments on the Draft Environmental Impact Statement will be accepted until September 30,1994, at the Idaho address and telephone number provided above. The U.S. Department of Energy will consider these public comments in preparing the Final Environmental Impact Statement. 
he U.S. Department of Energy's

(DOE's) Environmental Impact

Statement (EIS) for Programmatic Spent

Nuclear Fuel Management and Idaho

National Engineering Laboratory

Environmental Restoration and Waste

Management Programs [DOE/EIS-

0203-D] is divided into two volumes:

- Volume 1, DOE Programmatic Spent Nuclear Fuel

Management

- Volume 2, Idaho National Engineering Laboratory Environmental Restoration and Waste Management Programs (including site-specific spent nuclear fuel management).

Volume 1 comprises five primary sections and nine key appendices. The five primary sections provide (a) an introduction and overview to DOE's spent nuclear fuel management program throughout the nation, (b) the purpose and need for action to manage spent nuclear fuel, (c) management alternatives that are under consideration, (d) the affected environment, and (e) potential environmental consequences caused by the implementation of each alternative. The information contained in these sections relies, in part, upon more detailed information and analyses in the nine key appendices. These appendices describe and assess the site-specific spent nuclear fuel manageı „ent programs at three primary DOE facilities and several alternative sites, the naval reactors spent nuclear fuel management program, offsite transportation of spent nuclear fuel, and environmental consequences data. Two additional appendices include a glossary and a list of acronyms and abbreviations.

Volume 2 is similarly constructed. Five primary sections are presented that provide (a) the purpose and need for an integrated 10-year er vironmental restoration, waste management, and spent nuclear fuel management program at the Idaho National Engineering Laboratory,

(b) background, (c) management alternatives under consideration, (d) the affected environment, and (e) potential environmental consequences associated with the implementation of each alternative. The information presented in these sections relies, in part, upon four key appendices, which include a basic description of radioactivity and toxicology (chemical effects), agency consultation letters, detailed project summaries, and technical methodologies and key data. Two additional appendices include $a$ glossary and a list of acronyms and abbreviations.

Each volume provides an index and a glossary, as well as a list of references to enable the reader to further review and research selected topics. DOE has established reading rooms and information locations across the United States where these references may either be reviewed or obtained for review through interlibrary loan. The addresses, phone numbers, and hours of operation for these reading rooms and information locations are provided at the end of this EIS Summary.

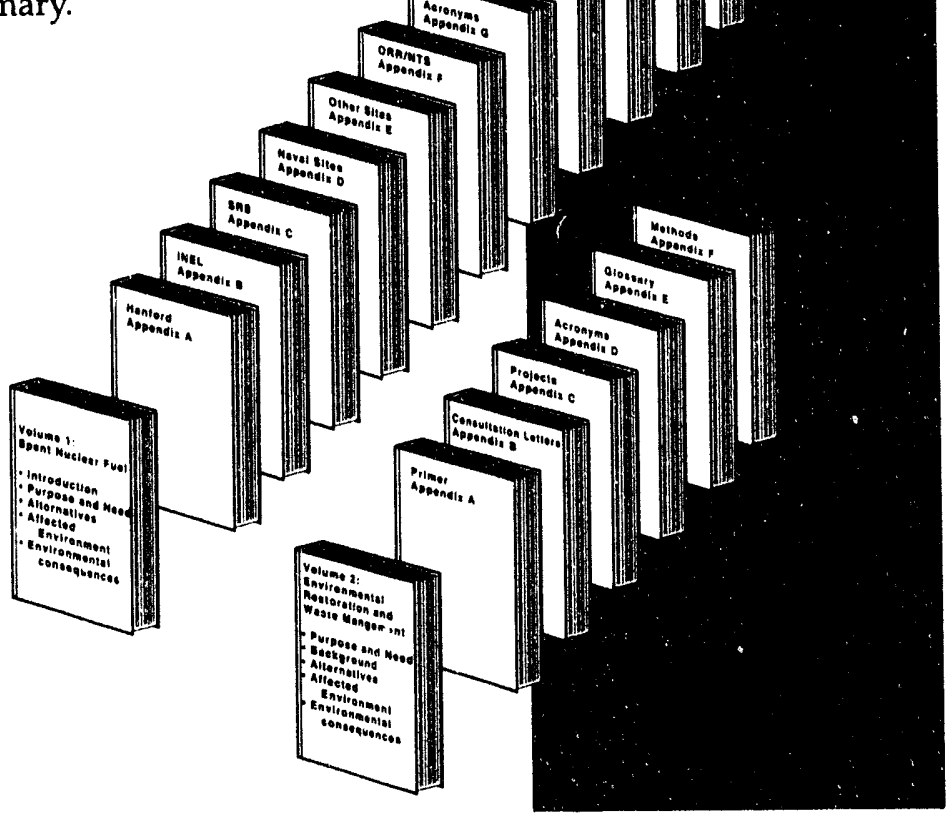


Reader's Guide .

Volume 2-INEL Environmental Restoration and Waste Management .......... 1

Overview ..................................................................................................... 1

Waste Management, Environmental Restoration, Spent Nuclear Fuel, and Technology Development at the INEL ........................................................... 3

Waste Management ................................................................................. 3

Environmental Restoration ........................................................................... 3

Spent Nuclear Fuel .............................................................................................. 4

Technology Development ........................................................................... 6

Purpose and Need for Future Environmental Restoration and Waste

Management .............................................................................................. 7

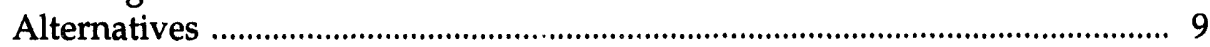

Alternative A (No Action) .................................................................... 10

Alternative B (Ten-Year Plan) ................................................................. 10

Alternative C (Minimum Treatment, Storage, and Disposal) .................. 11

Alternative D (Maximum Treatment, Storage, and Disposal) .................. 13

Affected Environment at the INEL .................................................................. 15

Environmental Consequences ......................................................................... 17

Air Quality ................................................................................................. 17

Cultural Resources ….......................................................................... 18

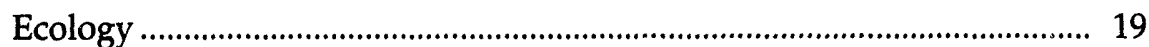

Groundwater Quality .......................................................................... 19

Normal Operations Impacts ............................................................................... 20

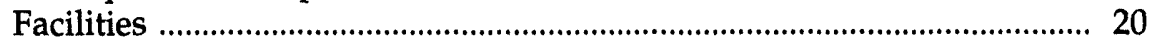

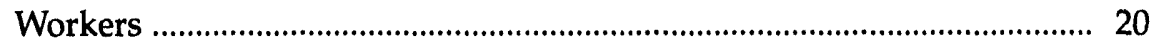

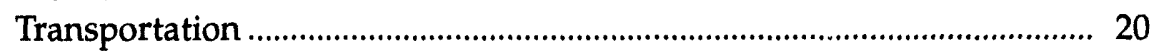

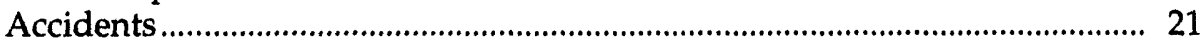

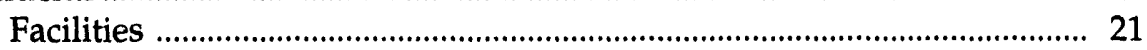

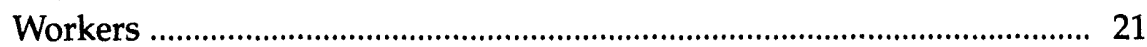

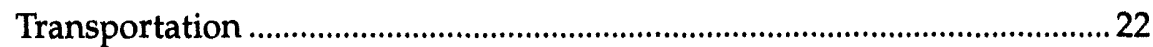

Consultations and Environmental Requirements .......................................... 23

Attachment-Reading Rooms and Information Locations ............................ 25

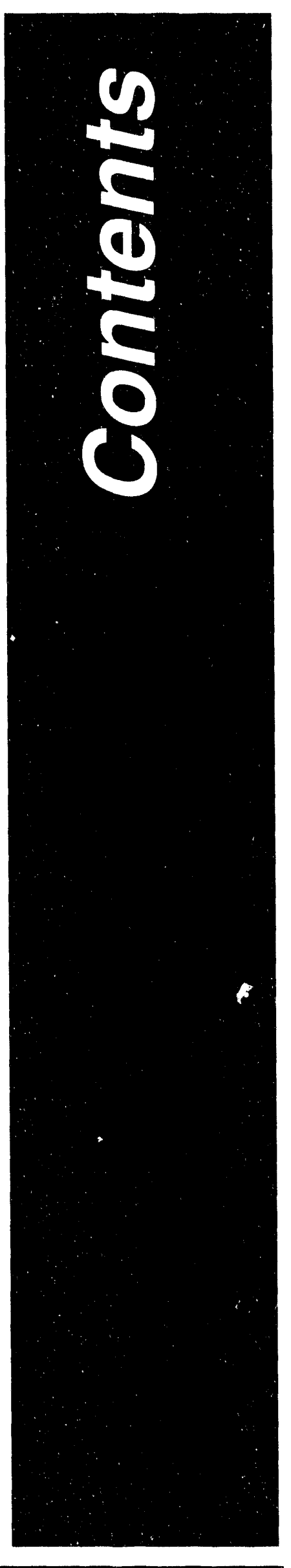


verview

The Idaho National Engineering Laboratory's mission is to develop, demonstrate, and deploy advanced engineering technology and systems to improve national competitiveness and security, to make the production and use of energy more efficient, and to improve the quality of life and the environment. The environmental restoration program includes activities to assess and clean up inactive Idaho National Engineering Laboratory operations, including waste sites where there are known or suspected releases of harmful substances into the environment, and to safely manage contaminated surplus nucle : facilities. Waste management program activities are designed to protect Idaho National Engineering Laboratory employees, the public, and the environment in the design, construction, maintenance, and operation of treatment,

The Idaho National Engineering Laboratory is located in southeastern Idaho. storage, and disposal facilities in a cost-

effective, environmentally sound, regulatory compliant, and publicly acceptable manner.

\section{What Are Environmental Restoration and Waste Management?}

Environmental Restoration: The cleanup and restoration of sites and

decontamination and decommissioning of facilities contaminated with radioactivu and/ or hazardous substances during past operaticns.

Waste Management: The planning, coordination, and direction of those functions related to generation, minimization, handling, treatment, st Jrage, transportation, and disposal of waste, as well as associated surveillance and maintenance activities.

Spent nuclear fuel management at the Idaho National Engineering Laboratory includes (a) accepting and examining shipments from generators or from other storage sites, (b) setting standards and approving methods for storing spent nuclear fuel and preparing (stabilizing) it for such storage, (c) constructing and operating facilities for stabilization, plus interim storage, (d) consolidating storage and retiring outdated storage facillties, and (e) developing criteria and technologies for ultimate disposition of spent nuclear fuel (or its components). DOE is developing spent nuclear fuel management plans for a 40-year timeframe that are anticipated to be sufficlent to cover the period during which ultimate disposition will be established and implemented for DOE's spent nuclear fuel. 


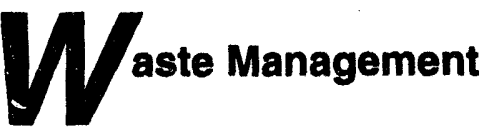

Waste management includes minimization, characterization, treatment, storage, and disposal of waste generated from ongoing Idaho National Engineering Laboratory activities and from the Environmental Restoration Program. The Waste Management Program ensures that current and future waste management practices minimize any additional adverse environmental impacts. This is accomplished through such practices as waste reduction and recycling, and treatment technologies such as volume reduction and waste separation techniques. Every operating facility within the nine major facility areas at the Idaho National Engineering Laboratory produces waste that must be managed. Table 1 summarizes the primary functions of each facility area.

\section{Environmental Restoration}

The Idaho National Engineering Laboratory Environmental Restoration Program addresses contamination resulting from the past 50 years of operations. The goals of the

Environmental Restoration Program are to clean up past environmental contamination and to decontaminate and decommission facilities that are no longer needed (surplus). The cleanup program is conducted under a Federal Facility Agreement and Consent Order, entered into by the DOE, the U.S.

Environmental Protection Agency, and the State of Idaho, in accordance with the Comprehensive Environmental Response, Compensation, and Liability Act of 1980, as amended.

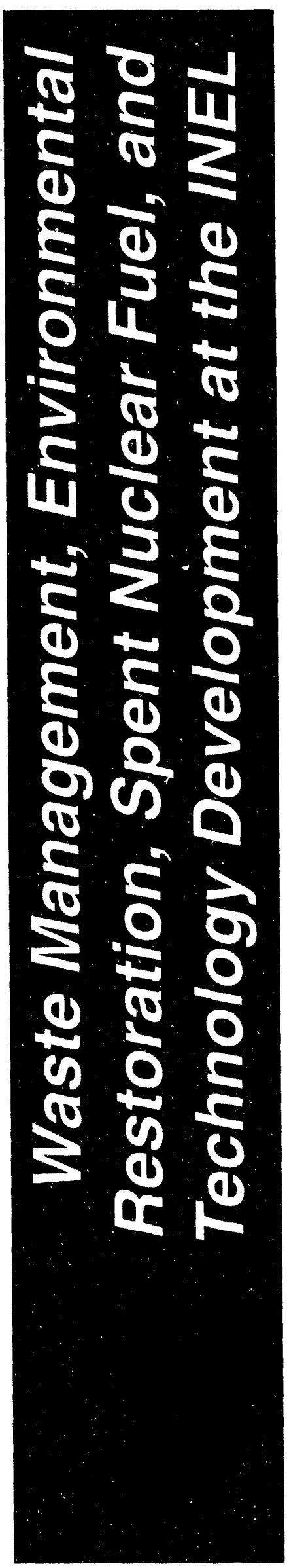

Since 1986, over 400 suspected release sites have been identified for investigation. Potential release sites were grouped together for efficiency into 10 areas called Waste Area Groups. Nine of the groups are roughly equivalent to the major facility areas at the Idaho National Engineering Laboratory.

Waste Area Group 10 includes a sitewide area associated with the Snake River Plain Aquifer and surface and subsurface areas that are not addressed by the other nine Waste Area Groups. Of the more than 400 sites, over 100 have been proposed or designated as requiring no further action.

Sources of contamination include spills, abandoned tanks, septic and injection wells. Contaminated sites range in size from large facilities such as the pits and trenches at the Radioactive Waste Management Complex to small areas where minor spills have occurred.

Environmental restoration also involves safely managing contaminated surplus nuclear facilities until they are decontaminated for reuse or are decommissioned. systems, percolation ponds, landfills, 


\section{Spent Nuclear Fuel}

Since the 1950s, spent nuclear fuel removed from nuclear-powered naval vessels and naval reactor prototypes has been shipped to the Naval
Reactors Facility located at the Idaho National Engineering Laboratory. Spent nuclear fuel has also been received from university, commercial, industrial, DOE, and other U.S. Government and foreign reactors.

Table 1. Functions of major facillty areas at the Idaho National Engineering Laboratory.

\begin{tabular}{ll}
\hline Major facility area & \multicolumn{1}{c}{ Function performed } \\
\hline Test Area North & Handle and evaluate irradiated materials; support \\
& $\begin{array}{l}\text { energy and defense programs; support testing of } \\
\text { casks for interim storage of spent nuclear fuel; study } \\
\text { spent nuclear fuel transportation; store spent nuclear } \\
\text { fuel. }\end{array}$
\end{tabular}

Test Reactor Area Study effects of radiation on materials, fuels, and equipment; manage seven reactors (two operating, two in standby, three disactivated); perform chemistry and physics experiments.

Idaho Chemical Processing Plant

Receive and store spent nuclear fuel; prepare high-level liquid and solid waste for disposal; develop and apply technologies for eventual disposal of spent nuclear fuel, disposal of sodiumbearing and high-level waste, minimization of waste generation, and management of radioactive and hazardous wastes.

Central Facilities Area

Provide technical and support services for the Idaho National Engineering Laboratory, including environmental monitoring and calibration laboratories, communication systems, security, fire protection, medical services, warehouse, cafeteria, vehicle and equipment pools, and bus operations; operate Hazardous Waste Storage Facility and Idaho National Engineering Laboratory Landfill Complex.

Power Burst Facility/ Support waste management-related research Auxiliary Reactor Area (volume reduction and waste immobilization); develop decontamination, waste storage and treatment technologies.

\section{Experimental \\ Breeder Reactor-1/ \\ Boiling Water \\ Reactor Experiment} National Historic Landmark

Radioactive Waste Management Complex

Naval Reactors Facility (Expended Core Facility)

Argonne National Laboratory-West
Store and dispose of wastes; support research and development for interim storage of transuranic waste, low-level waste disposal, buried waste remediation technologies, and environmental cleanup technologies.

Receive and conduct examination of spent nuclear fuel to support fuel development and performance analyses.

Develop and test breeder reactor technology; store transuranic waste; support research and develupment of spent nuclear fuel treatment technologies. 
Spent nuclear fuel continues to be generated at the Idaho National Engineering Laboratory by reactor operations. Naval reactor fuel, currently examined at the Naval Reactors Facility, is transferred to the
Idaho Chemical Processing Plant for storage at a rate of about 1 metric ton per year. Spent nuclear fuel is stored at a number of site areas in various dry and wet storage facilities awaiting ultimate disposition.
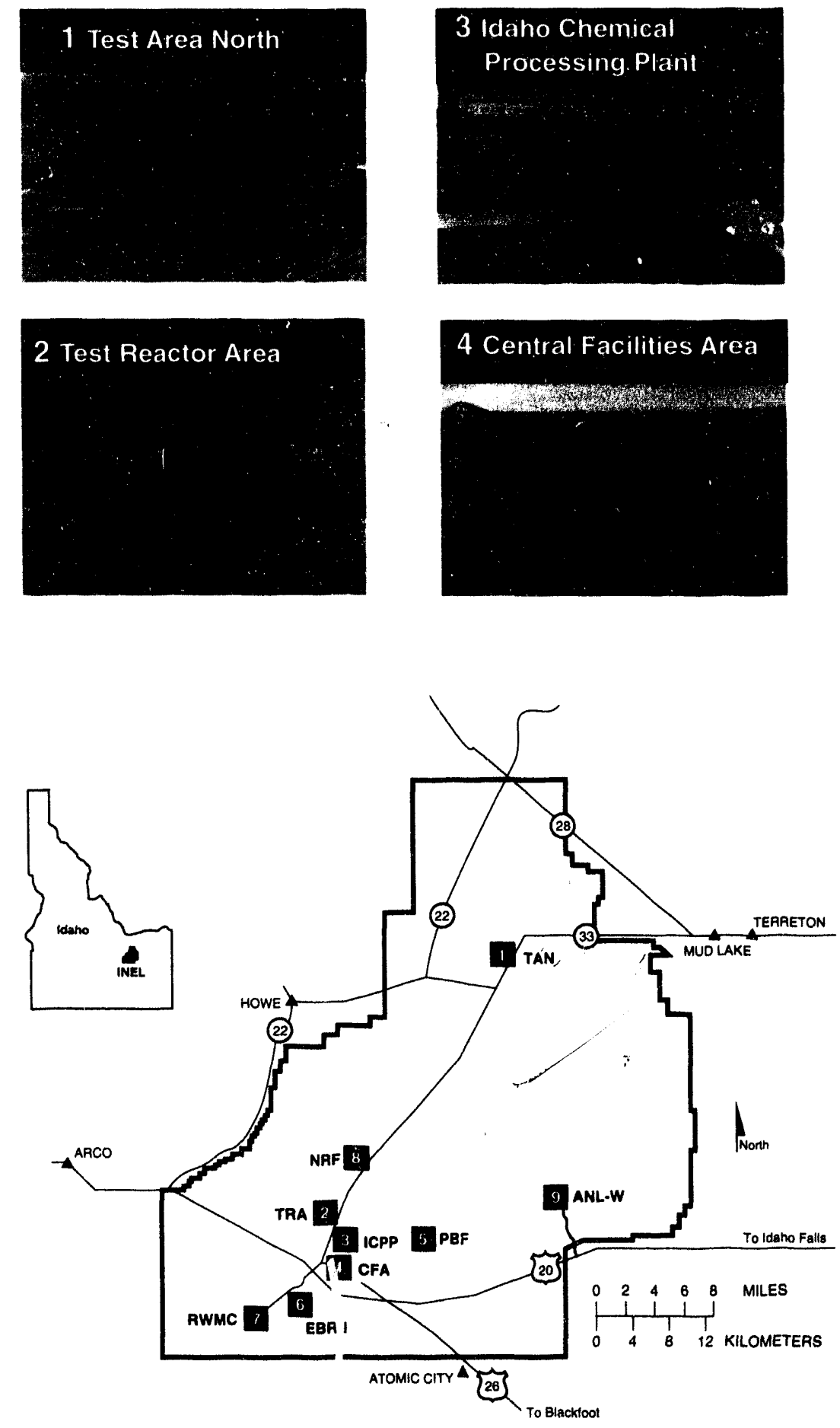

Major facility areas located at the Idaho National Engineering Laboratory site.
4 Central Facilities Area
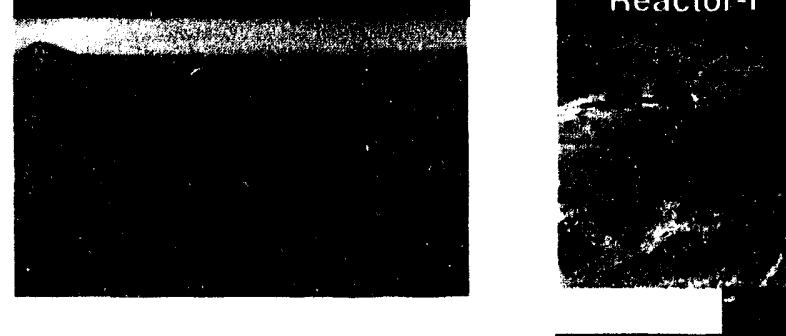

7 Radioactive Waste: Management Compls

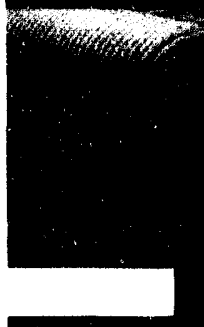

8 Naval Reactor:
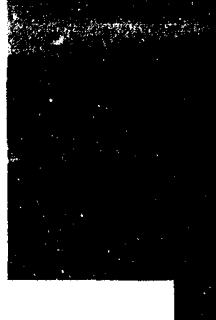

\section{Argonne Nation Laboratory-Wo:}




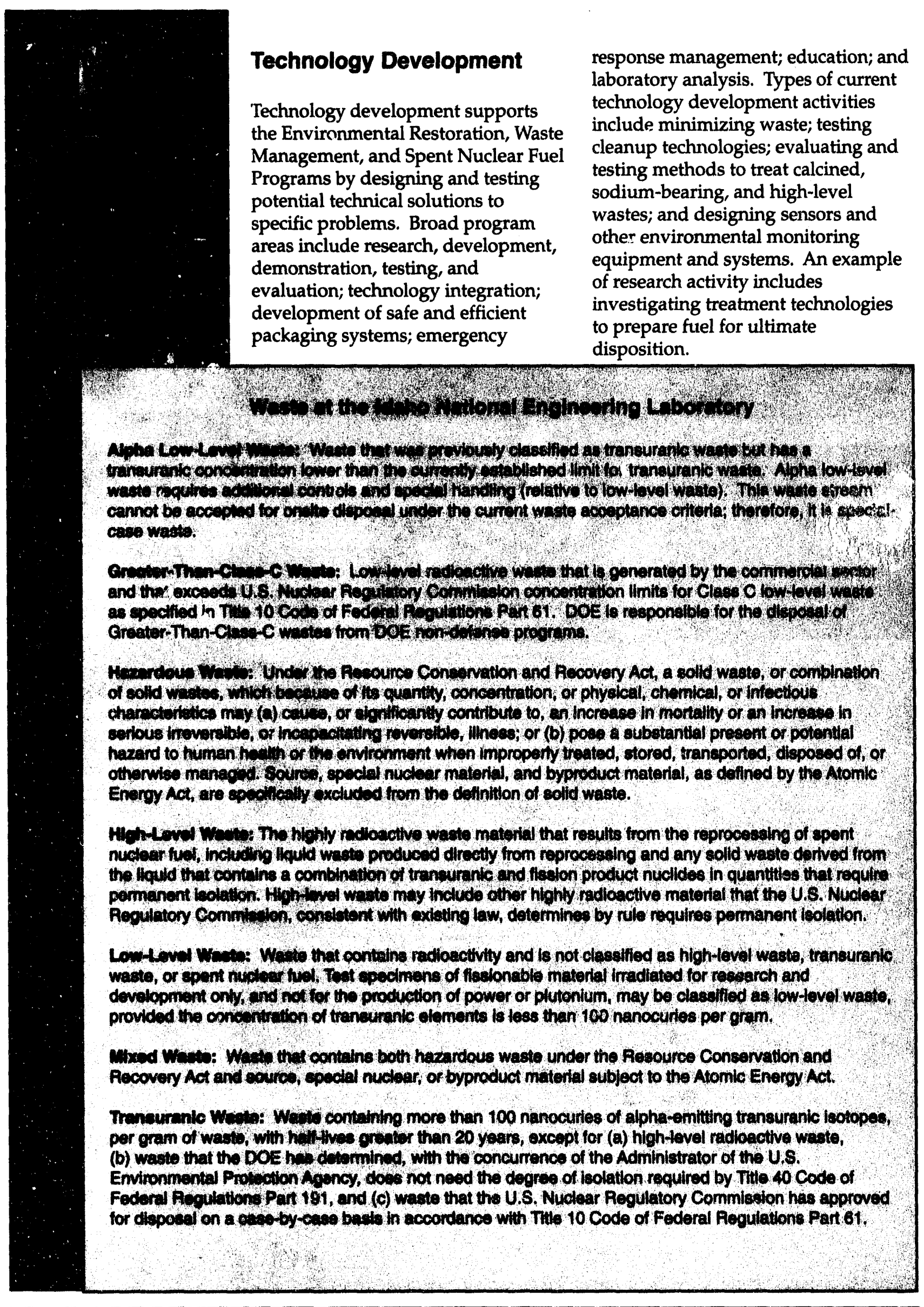


$\mathrm{OE}$ is responsible by law for spent nuclear fuel management, waste management, and environmental restoration at the Idaho National Engineering Laboratory in southeastern Idaho. Under the Atomic Energy Act of 1954, DOE is also responsible for managing certain spent nuclear fuels. DOE also is responsible for managing wastes and controlling hazardous substances in a manner that protects human health and the environment under the Comprehensive

Environmental Response, Compensation, and Liability Act of 1980 , as amended; the Resource Conservation and Recovery Act of 1976; the Federal Facility Compliance Act of 1992; and other laws. DOE is committed to comply with these and all other applicable Federal and State laws and regulations, DOE orders, and interagency agreements governing spent nuclear fuel, environmental restoration, and waste management.

Over the past 50 years, DOE activities have resulted in the accumulation of spent nuclear fuel; waste requiring treatment, storage, and disposal; and sites requiring cleanup. To better fulfill its responsibilities, DOE needs to develop and implement a program for spent nuclear fuel management, environmental restoration, and waste management at the Idaho National Engineering Laboratory. To establish an effective program for the foreseeable future (focused on the next 10 years), DOE needs to make site-specific decisions that would accomplish three major goals: (a) support research and development missions at the Idaho National Engineering Laboratory; (b) comply with legal requirements governing spent nuclear fuel management, environmental restoration, and waste management, and (c) manage spent nuclear fuel, treat, store, and dispose oi waste, and conduct environmental restoration activities at the Idaho National Engineering Laboratory in an environmentally sound mannar.

To achieve these goals, DOE needs to develop appropriate facilities and technologies to manage waste and spent nuclear fuel expected during the next 10 years; to more fully integrate all environmental restoration and waste management activities at the Idaho National Engineering Laboratory to achieve cost and operational efficiencies; and to minimize environmental impacts from environmental restoration and waste management activities.

\section{What Are the Decielons to Bo Wado Besed on Thls ElS?}

Gost Nuclear Fuel: What to the appropriate atrategy of the Idaho National Englneering Liboratory to implement DOE's national spent nuclear fuel decisions regarding treneportation, receipt, proceasing, and storage of epent nuclear fuel? What is the approprlate storage capactly for spent nuclear tuel?

Environmental fectoration end Wapto Menegement: What is the appropriate strategy of the Idaho National Engineering Laboratory to Implement DOE's national environmental restoration and waste management declsions?

What is the appropriate cleanup strategy under the Comprehensive Environmental Response, Compensation, and Llability Act of 1980, as amended, and the Federal Facility Agreement and Consent Order of 1991 ?

What are the necessary cepeblilties, faciltiles, reesarch and development, and technologies for treating, storing, and disposing of each waste type?

What treatment technologles should be used for sodium-bearing and high-level wastes and cthor radiogetivo and mixed wasto? 
OE has chosen four alternatives that represent a range of possible actions. Each alternative includes components for cleanup, decontamination and decommissioning, waste management, and spent nuclear fuel management. Infrastructure, technology development, and transportation were also considered. The alternatives, which reflect the public scoping process, take the following factors into account:

- The sources of waste and spent nuclear fuel that (a) exist at the Idaho National Engineering Laboratory by June 1995 , (b) would be generated between 1995 and 2005, and (c) might be transported to the Idaho National Engineering Laboratory from other sites.

- The practical waste and spent nuclear fuel management options, including characterization, storage, and disposal, or stabilization (spent nuclear fuel) and treatment (waste).

- The locations at which the waste and spent nuclear fuel management could reasonably be undertaken, either on or off the Idaho National Engineering Laboratory site.

Given this, DOE determined the projects and actions needed to manage the waste and spent nuclear fuel associated with each alternative. This EIS provides the analysis required under the National Environmental Policy Act for certain projects that DOE proposes as part of the spent nuclear fuel, environmental restoration, and waste management program at the Idaho National Engineering Laboratory.

The Idaho National Engineering Laboratory-specific management actions that DOE selects are likely to be a combination of specific elements from within the several alternatives analyzed. As yet, DOE has not identified a preferred alternative. A preferred alternative will be identified in the final EIS, following receipt and consideration of public comments on the draft EIS.

However, the Navy, as a cooperating agency, has stated a preferred alternative to continue refueling and

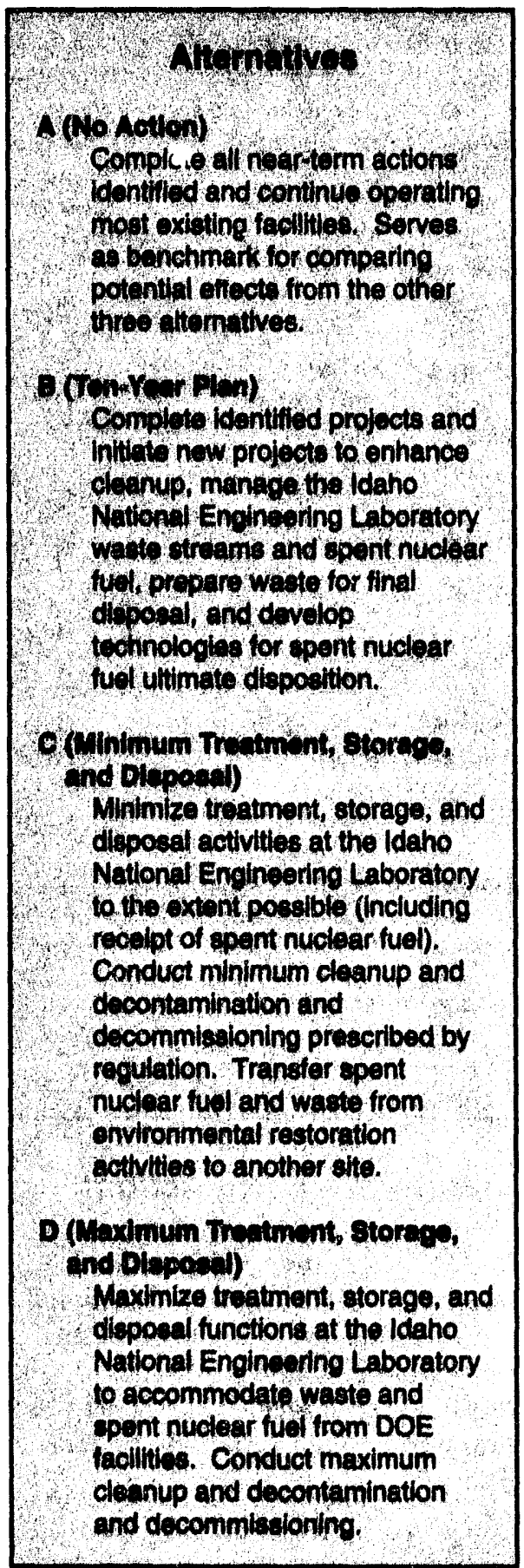

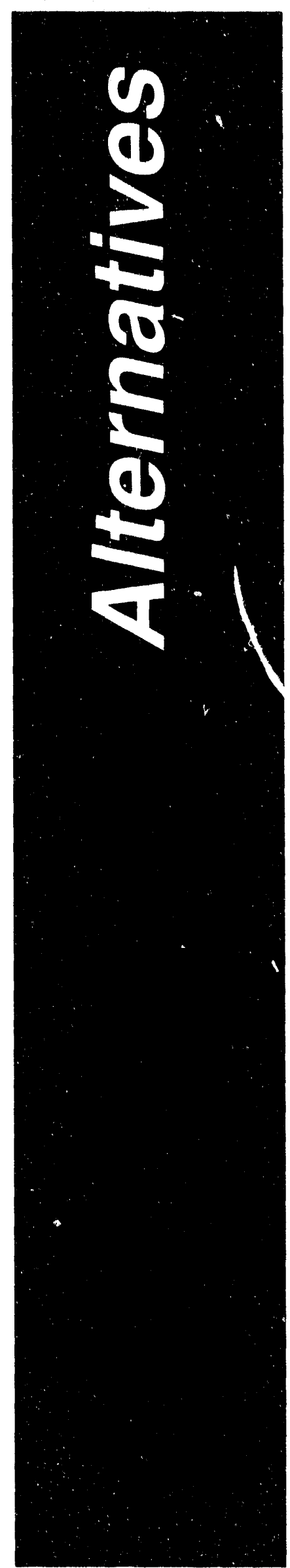


defueling nuclear-powered vessels and prototypes, and to transport spent fuel to the Idaho National Engineering Laboratory for full examination and interim storage, using the same practices as in the past. restoration and waste management program at the Idaho National Engineering Laboratory would also continue. There would be no shipments of spent nuclear fuel to the Idaho National Engineering Laboratory, with the exception of shipments of naval fuel during an

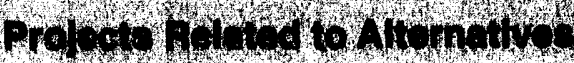

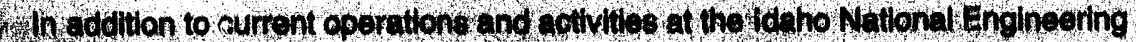

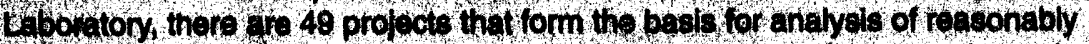

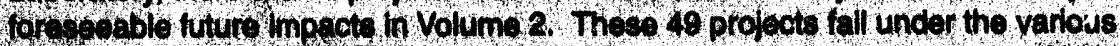
Aithatives A, B, C, and D. The 49 projects include twotve projocts whose Nitional Emiremmental Polloy fet cooumonthten is already completod or ts expected to bo conploted bolere the Reoord of Dectelon. An oblective of Volume 2 and its appendloes 18 to provide sufficient enelysis for another twelvo projects (listod below) to allow timely doployment if necded tor the project. DOE would ovaluate the romaining 25 projects on a creo-by-case basis to determine if any adoflional NEPA or further ovaluation is needed b tore implementing the projed

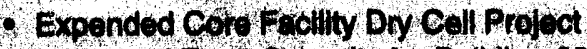

- Incressed Prak Capecity tor Bullang 696 at the ld ho chomiel Proossing of

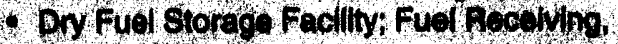
Canning/Cheracterizalon, and shipping

- Fort st, Vrah opont Nucles Fyel Shipmon end Stotore

- Tank Fain Mosl Removal Frojed

- Wasto Immoblikation Faollty

- High L ovel Tank Fam Now Tanks

- Enppingltander station

- Waste Exporimental Roducilon Faclity Inoingration

- Norinolnerable Mored Waste Treatment

- Industriv Commercial Landitl Expansion

- Crivipit Expanslons

Alemetye
B, D
B, D
B, C, D
B, D
$B, C, D$
$B, C, D^{\circ}$
$C, D$
$C$
$B, D$
$B, D^{\circ}$
$B, C, D$
$B, D^{\circ}$

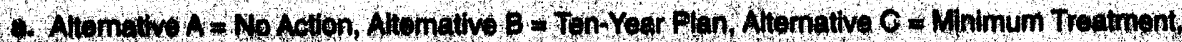

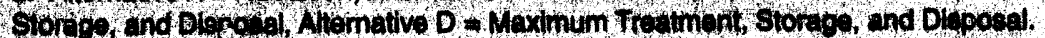

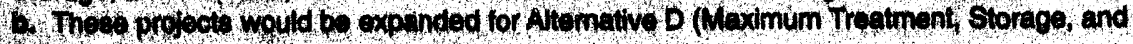
Q10.01)

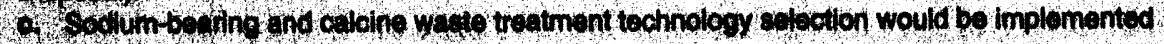
Wount the faclity.

approximately threeyear transition period. Existing inventories of spent nuclear fuel would remain in storage onsite. Activities and projects would include those that may be initiated after June 1995 but that have been evaluated under the National Environmental Policy Act by that date.

New activities would be limited to those required to maintain safe operation. Implementation of Alternative A (No Action) would not fully meet all negotiated agreements and commitments under the Federal Facility Agreement and Consent Order and obligations to receive spent nuclear fuel from universities and Fort St. Vrain.

Alternative A (No

Alternative A (No Action)

Under Alternative A (No Action), existing environmental restoration and waste management operations and projects would continue. Research and development and infrastructure facilities and projects that support the environmental
Action) represents a baseline against which the potential environmental impacts of the other alternatives are compared.

\section{Alternative B (Ten-Year Plan)}

Under Alternative B (Ten-Year Plan), existing environmental restoration and waste management facilities and 
projects would continue to be managed. In addition to current facilities and projects, those proposed for 1995 through 2005 would be implemented to meet the current Idaho National Engineering Laboratory mission and to comply with negotiated agreements and commitments.

Under this alternative, spent nuclear fuel, environmental restoration, and waste management activities would be continue $d$ and enhanced to meet expanded spent riaclear fuel and waste handling needs. These enhanced activities would be needed to comply with regulations and agreements and would result from acceptance of additional offsite materials and waste. Waste generation from onsite sources would increase because of increased decontamination and decommissioning and environmental restoration activities. Spent nuclear fuel and selected waste would be received from other DOE sites. Onsite management would emphasize greater treatment and disposal capabilities, compared to Alternative A (No Action). Additional cleanup and decommissioning and decontamination projects would be conducted under this alternative.

\section{Alternative $\mathbf{C}$ (Minimum Treatment, Storage, and Disposal)}

\section{Under Alternative $\mathrm{C}$ (Minimum} Treatment, Storage, and Disposal), ongoing Idaho National Engineering Laboratory spent nuclear fuel and waste management activities, along

\section{Atternativo A (No Aotion)}

Spent Wuelear Fuel: Phase out examination of naval spent nuclear fuel after an epproximate three-year transition perlod; no other fuels would be recelved; phase out storage poels at Bullding 603 of the Idaho Chemical Processing Plant.

Environmental Rectoration: Conduct no activities other than already approved projects; decontaminate and decommission Auxiliary Reactor Area (ARA) $1 /$ and Bolling Water Reactor Experiment (BORAX)-V; clean up groundwater af, d vadose zone contamination; retrieve and treat Pit $\theta$ waste.

Milohelovel Wets: Convert liquid to solld calcine.

Trmouranio Wuoto: Retrieve/move transuranic and alpha low-level waste to new compliant storaga; ship transuranic waste offsite for disposal; accept offitte waste for storage on case-by-case basis.

Low-Leval Whate: Treat onsite and offisite; dispose of onsite in existing facility.

Mixed Low Level Waato: Treat onsite (nonincineration).

Crementhen-eleas-c Waste: Continue management programs.

Herirdove Wobte: Ship offsite for treatment, storage, and disposal. with materials and waste, would be transferred to other locations to the extent possible. Possible locations include DOE facilities, other Government sites, or private sector locations to the extent possible. Minimal treatment, storage, and disposal activities would be located at the Idaho National Engineering Laboratory.

Waste and spent nuclear fuel would not be received from offsite sources for management by the Idaho National Engineering Laboratory. Whenever feasible, wastes generated from onsite environmental restoration activities would be minimized by emphasizing institutional controls over treatment options. Only current cleanup and decommissioning and decontamination projects would be conducted under this alternative. Existing onsite spent nuclear fuel and waste management capability

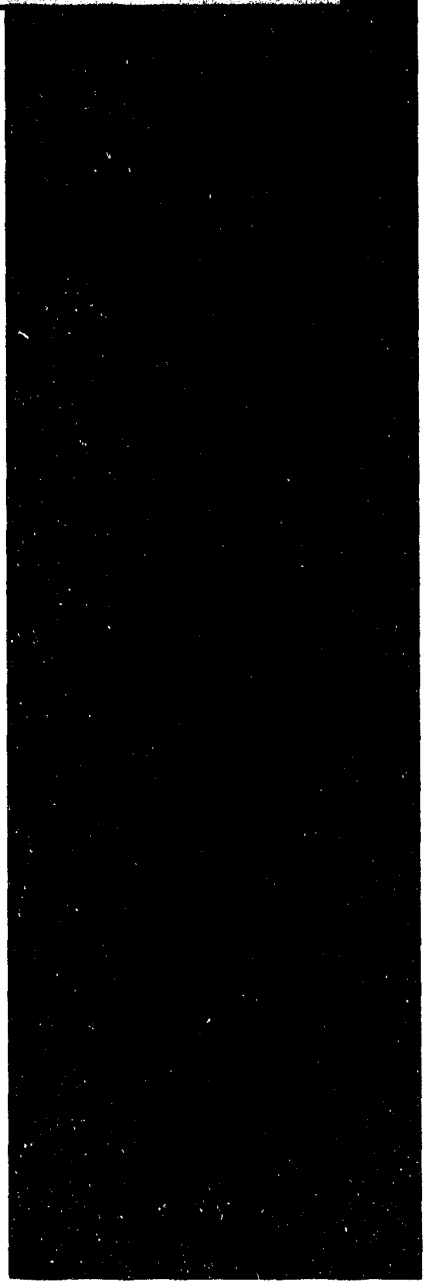




\section{Alternative B (Ten-Year Plan)}

Spent Nuolear Fuels Receive additional offsite spent nuclear fuel; examine and store naval spent nuclear fuel; complete Expended Core Faeilty Dry Cell Project and expand storage capacity in pools at Building 666 of the Chemical Processing Plant: phase out pools at Building 603 of the ldaho Chemical Processing Plant; phase in new dry storage; Jemonstrate actinide recycle at Argonne National Laboratory-West.

Environmental Rostoration: Conduct all planned projects in all Waste Area Groups; decontaminate and decommlssion Auxillary Reactor Area (ARA)-H, Boiling Water Reactor Experiment (BORAX)-V, Engineering Test Reactor, Materlals Test Reactor, Fuel Processing Complex, Fuel Receipt/Storage Facility, Headend Processing Plant, Wasto Calcine Facility, and Central Liquid Waste Processing Faclity; clean up groundwater contamination and vadose zone; clean up buried wastes and Idaho Chemical Processing Plant; retrieve and treat Pit 9 wastes.

High-Level Waste: Select the technology to convert liquid to calcine; construct a facility to immobillze both llquid and solid calcins for operation in 2008.

Traneuranlo Waste: Retrieve/move transuranic and alpha low-level waste to new compllant storage; treat offsite and onsite transuranic and alpha low-level waste; ship transuranic waste offsite for disposal; accept transuranic waste from offsite for treatment.

Low-Level Waate: Treat onsite and offsite; construct and operate additional treatment and disposal facilities onsite.

Mixed Low-Levol Waste: Treat onsite by incineration and nonincineration; construct and operate facilities to treat waste by incineration and nonincineration; construct and operate disposal facility; ship waste oftsite for treatment and disposal.

Creater-than-Clase-C Waste: Recelve sealed sources for recycle or storage; construct dedicated storage facility.

Hazardous Waate: Ship offsite for treatrnent, storage, and disposal.

\section{Alternative C (Minimum Treatment, Storage, and Disposal)}

Spent Nuclear Fuel: Ship Idaho National Engincering Laboratory spent nuclear fuel Inventory to DOE Centrallzation site; continue to examine and store naval spent nuclear fuel during approximate three-year transition period; phase out spent nuclear fuel handiling tacilities; demonstrate actinide recycle at Argonne National Laboratory-West.

Environmental Reatoration: Conduct all planned projects for all Waste Area Groups; decontaminate and decommission Auxiliary Reactor Area (ARA)-II, and Boiling Water Reactor Experiment (BORAX)-V; focus on institutional controls to the extent possible for cleanup projects; clean up groundwater and vadose zone; clean up buried waste and Idaho Chemical Processing Plant; retrieve and treat Pit 9 wastes.

High-Level Waste: Select technology and construct immobilization faclity to start operation in 2015; select technology and develop treatment to minimize volume of high-activity waste; construct replacement liquid storage tanks.

Transuranic Waste: Retrieve/move transuranic and alpha low-level waste to new compliant storage; ship transuranic waste offsite for disposal; ship waste to offsite DOE facility for storage.

Low-Level Waste: Ship to other DOE faclities for treatment, storage, and disposal.

Mixed Low-Level Waste: Ship offsite for treatment, storage, and disposal.

Greater-than-Class-c Waste: Discontinue management programs.

Hezzardous Waste: Ship offsite for treatment, storage, and disposal. 


\section{Alternative D (Maximum Treatment, Storage, and Disposal)}

Spent Nuclear Fuel: Examine and store naval spent nuclear fuel; receive DOE spent nuelear fuel; expand storage capacity in pools at Building 666 of the ldaho Chemical Plant; phase in expanded dry storage; phase out storage pools; at Bullding 603 of the Idaho Chemical Processing Plant; phase in spent nuclear fuel stabilization; demonstrate actinide recycle.

Environmental Restoration: Conduct planned projects for all waste area groups; decontaminate and decommission Auxillary Reactor Area (ARA)-II, Bolling Water Reactor Experiment (BORAX)-V, Engineering Test Reactor, Materlals Test Reactor, Fuel Proceesing Complex, Fuel Recelpt/Storage Facility, Headend Processing Plant, Waste Calcine Facility, and Central Liquid Waste Processing Facility; focus on residential future land use to the extent possible for cleanup projects; clean up groundwater and vadose zone; clean up burled wastes and the Idaho Chemical Processing Plant; retrieve and treat Plt 9 wastes.

High-Lovel Waste: Convert liquid to calcine; select terhnology and construct immobilization tacility to start operation in 2015; select technology and develop treatment to minimize high-activity waste; construct replacement liquid storage tanks.

Transuranic Waste: Retrieve/move transuranic and alpha low-level waste to new compliant storage; ship transuranic waste offsite for disposel; accept offsite transuranic waste; treat offsite and onsite transuranic waste and alpha low-level waste; dispose of alpha low-level waste at new onsite facility.

Low-Level Waste: Receive offsite waste; treat waste onsite; construct and operate additional treaiment and disposal facilities onsite.

Mixed Low-Level Waste: Receive offsite waste; treat waste onsite by incineration and nonincineration: construct facilities for onsite incineration and nonincineration treatment; construct and operate new disposal faclity; ship waste offsite for treatment and disposal.

Creater-than-Clase-C Wate: Receive sealed sources for recycle or storage; construct dedicated storage facility.

Hezardous Waete: Ship waste offsite for treatment, storage, and disposal; possibly construct onsite treatment, storage, and disposal facility.

would be expanded to the extent needed to comply with regulations and agreements.

\section{Alternative D (Maximum Treatment, Storage, and Disposal)}

\section{Under Alternative D (Maximum}

Treatment, Storage, and Disposal), spent nuclear fuel and waste would be transferred from other DOE facilities to the Idaho National Engineering Laboratory for management to the extent possible. Environmental restoration activities would emphasize residential use as the preferred end land use, which potentially would result in maximum waste generation.
Implementation of this alternative would require additional projects not yet defined or the expansion of identified projects [compared to Alternative B (Ten-Year Plan)].

Acceptance of waste and spent nuclear fuel from other sites would be maximized. Wastes generated from environmental restoration and waste management activities onsite would be increased over that of the other alternatives. Spent nuclear fuel and environmental restoration and waste management activities at the Idaho National Engineering Laboratory would be continued and enhanced to meet current and expanded spent nuclear fuel and waste handling needs. These

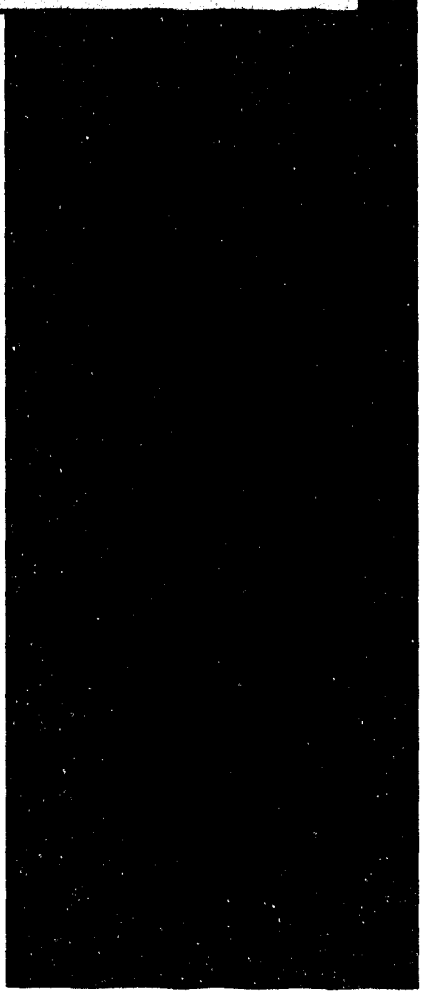




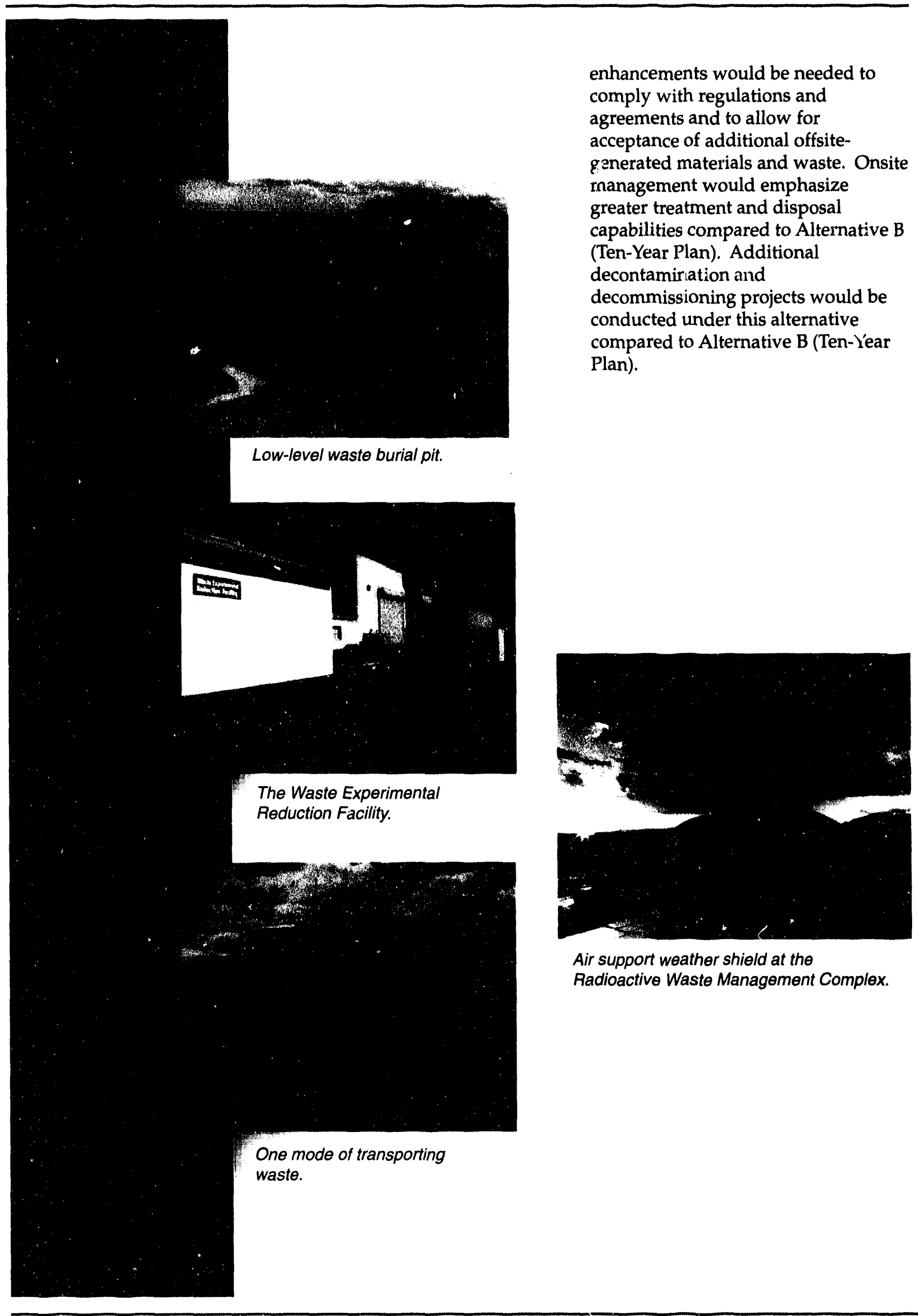


he Idaho National Engineering

Laboratory is located on

2,304 square kilometers (890 square miles) west of the City of Idaho Falls in southeast Idaho. The site sits on the Eastern Snake River Plain and is bordered by the Bitterroot, Lemhi, and Lost River mountain ranges. Local rivers and streams drain the mountain $v^{*}$ - tersheds, but most surface water is diverted for irrigation before it reaches the site boundaries. Site activities do not directly affect surface water quality outside the site because current discharges from facilities go to seepage and evaporation basins or storm water injection wells.

The Idaho National Engineering Laboratory overlies the Snake River Plain Aquifer, the largest aquifer in Idaho. Subsurface water quality near the site is affected by natural water chemistry and contaminants originating at the site. Previous waste discharges to unlined ponds and deep wells have introduced radionuclides, nonradioactive metals, inorganic salts, and organic compounds into the subsurface. Because of improved waste management practices, these discharges no longer occur and groundwater quality continues to improve. Only extremely low concentrations of radioactive iodine (iodine-129) and tritium have ever migrated beyond the site boundary; tritium no longer migrates offsite and iodine-129 concentrations are well below maximum contaminant levels (upper allowable limit in drinking water) established by the U.S. Environmental Protection Agency.

Idaho National Engineering Laboratory activities result in radiological air emissions; however, these are very low (less than background radiation) and well within standards. Nonetheless, Idaho National Engineering Laboratory workers may be exposed to radiation through their work. Those who may receive more than 0.1 rem per year (DOE's administrative limit is $2.0 \mathrm{rem}$ ) are monitored. About 32 percent of workers monitored between 1987 and 1991 received measurable radiation doses.

The Idaho National Engineering Laboratory primarily consists of open, undeveloped land covered predominantly by sagebrush and grasslands with animal communities typical of these vegetation types. Two Federal endangered and six candidate animal species have the potential for occurring, and seven animal species of special concern (State listing) occur at the Idaho National Engineering Laboratory. Ten plant species identified as sensitive, rare, or unique by other Federal agencies and the Idaho Native Plant Society also occur at the Idaho National Engineering Laboratory. Radionuclides have been found above background levels in individual plants and animals adjacent to facilities, but not at the population, community, or ecosystem levels.

The Idaho National Engineering Laboratory site has a varied inventory of cultural resources. These include fossil localities, prehistoric archaeological sites, historic sites, areas important to Native American people for religious and traditional reasons,

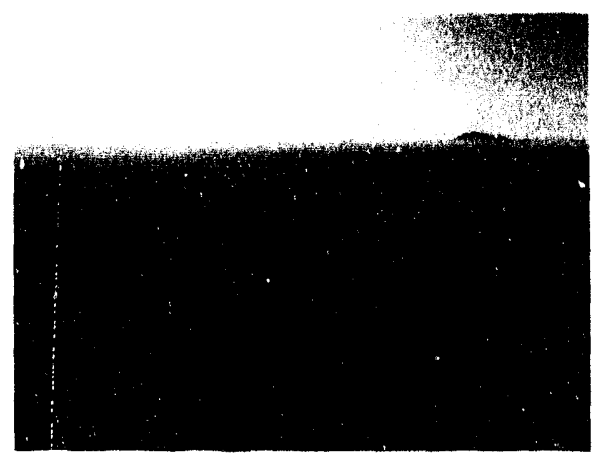

View of the Snake River Plain.

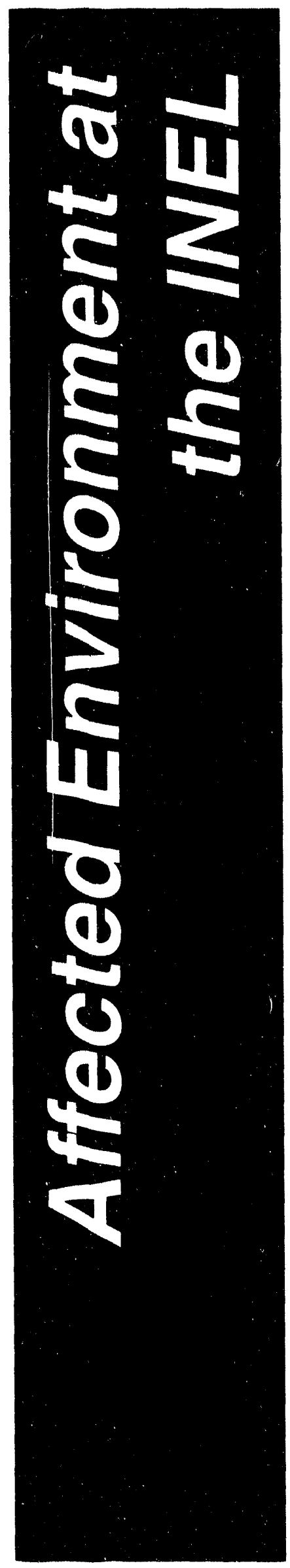




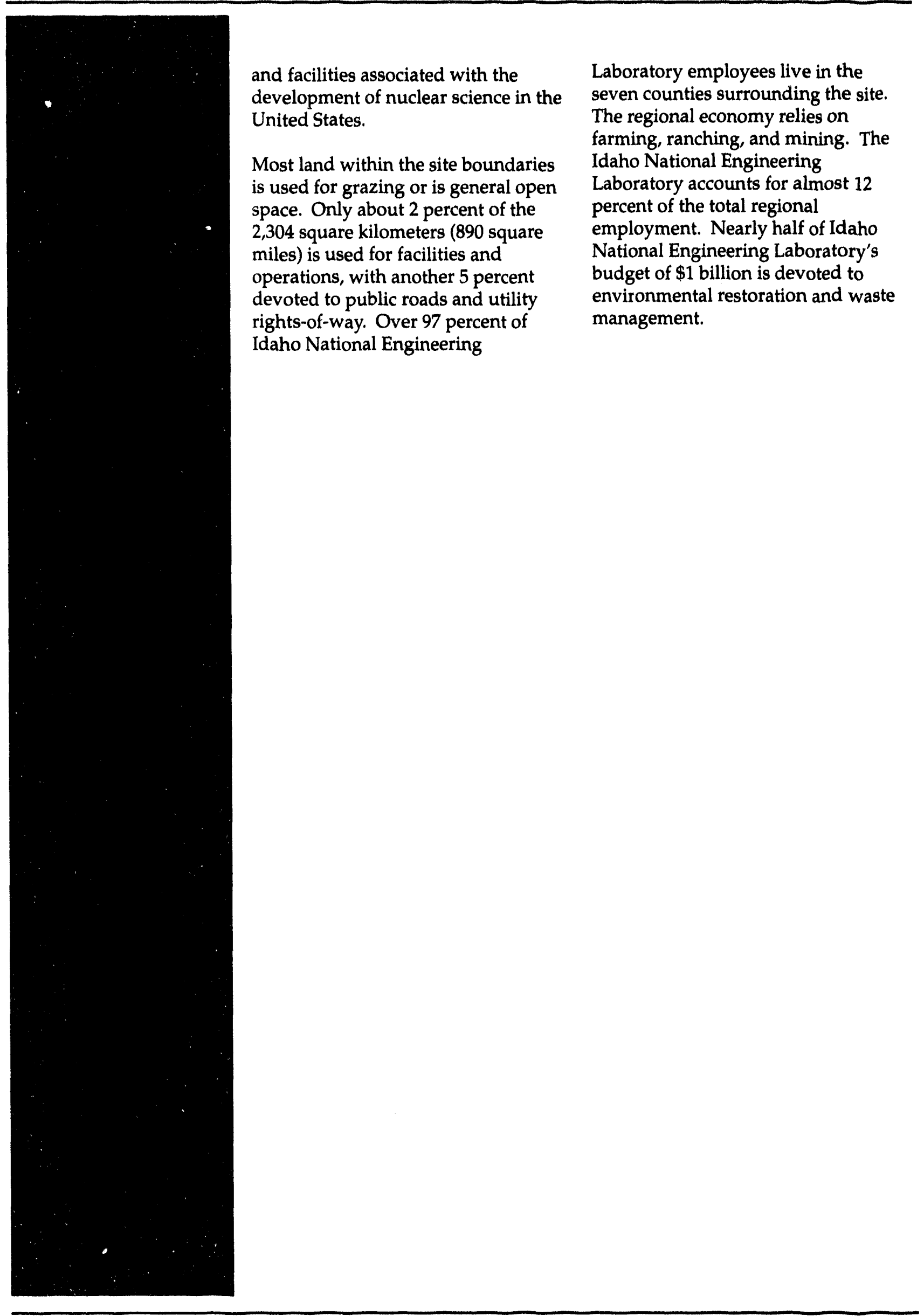


he environmental consequences of

the site-specific alternatives have

been assessed for the Idaho National

Engineering Laboratory and the surrounding region. The environmental impact analyses are based on conservative assumptions (that is, impacts are usually overestimated). Analytical approaches are designed to be a reasonable projection of the maximum reasonably foreseeable consequences. The potential effects of each alternative were estimated by evaluating each individual project proposed for the alternative, summing the projects' collective effects under each alternative, and including interactions among the individual projects that compose each alternative. Cumulative impacts were determined by evaluating past, present, and reasonably foreseeable future actions of DOE and non-DOE projects or activities, in combination with the alternatives.

Although the impact to each environmental discipline (for example, land use or employment) is assessed in greater detail in Volume 2, this Summary focuses on potential adverse impacts that DOE has found to be of greater interest to the public, as demonstrated through the scoping process and other public involvement programs at the Idaho National Engineering Laboratory.

\section{Air Quality}

Atmospheric visibility has been specifically designated as an air-qualityrelated value under the 1977 Prevention of Significant Deterioration

Amendments to the Clean Air Act. A U.S. Environmental Protection Agency developed computer code was used to conservatively estimate potential visibility impacts at the nearby Craters of the Moon Wilderness Area

[20 kilometers (12 miles) southwest of the Idaho National Engineering Laboratoryl. The code calculates contrast and color shift for two assumed plume-viewing backgrounds-the horizon sky and a dark terrain object.

The results indicate that for all alternatives, the potential for visual impacts at Craters of the Moon Wilderness Area without the use of mitigation measures cannot be ruled out. Use of more refined visibility models could yield more favorable results, although it is likely that additional facility controls would still be required. DOE would mitigate the potential effects and ensure that visibility is not impaired by using combustion control equipment and other best available control technologies as required.

Conservative modeling analyses were also performed to assess the potential impacts from radionuclides, toxic pollutants (for example, me cury) and criteria pollutants (for example, particulates). The results indicate, under Alternatives B (Ten-Year Plan) and D (Maximum Treatment, Storage, and Disposal), that projected concentrations of mercury levels at the site boundary would be equal to (Alternative B) or about 10 percent higher (Alternative $D$ ) than the recently promulgated State of Idaho standard of 1 microgram per cubic meter. Hydrochloric acid levels at the maximum site boundary and public road locations would be about two-thirds of the applicable standard of 7.5 micrograms per cubic meter for both Alternatives $B$ and $D$. The cumulative effects of baseline conditions and impacts of Alternatives $B$ and $D$ result in levels of hydrochloric acid at the maximum public road location that would be about one-third higher than the standard. These cumulative effects are reported for information purposes only, since the standard only applies to emissions from new (and not existing) facilities.

Projected levels of toxic air pollutants at onsite locations would

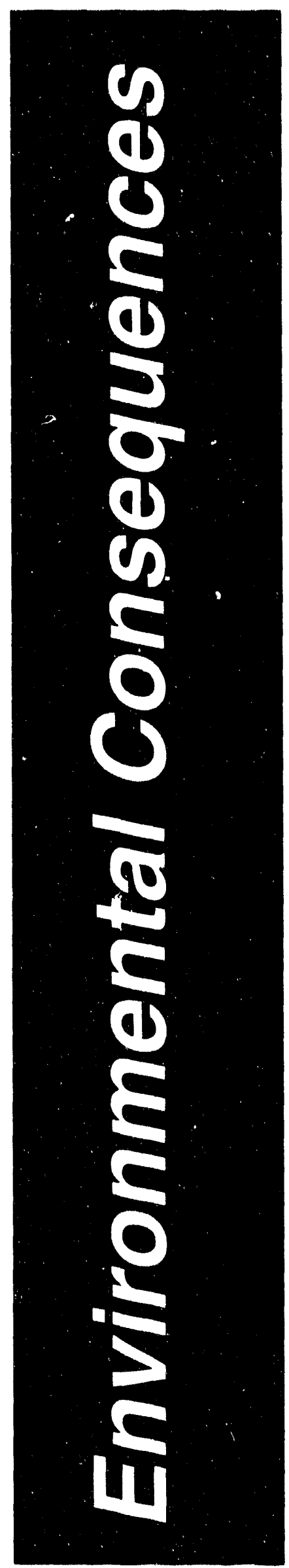




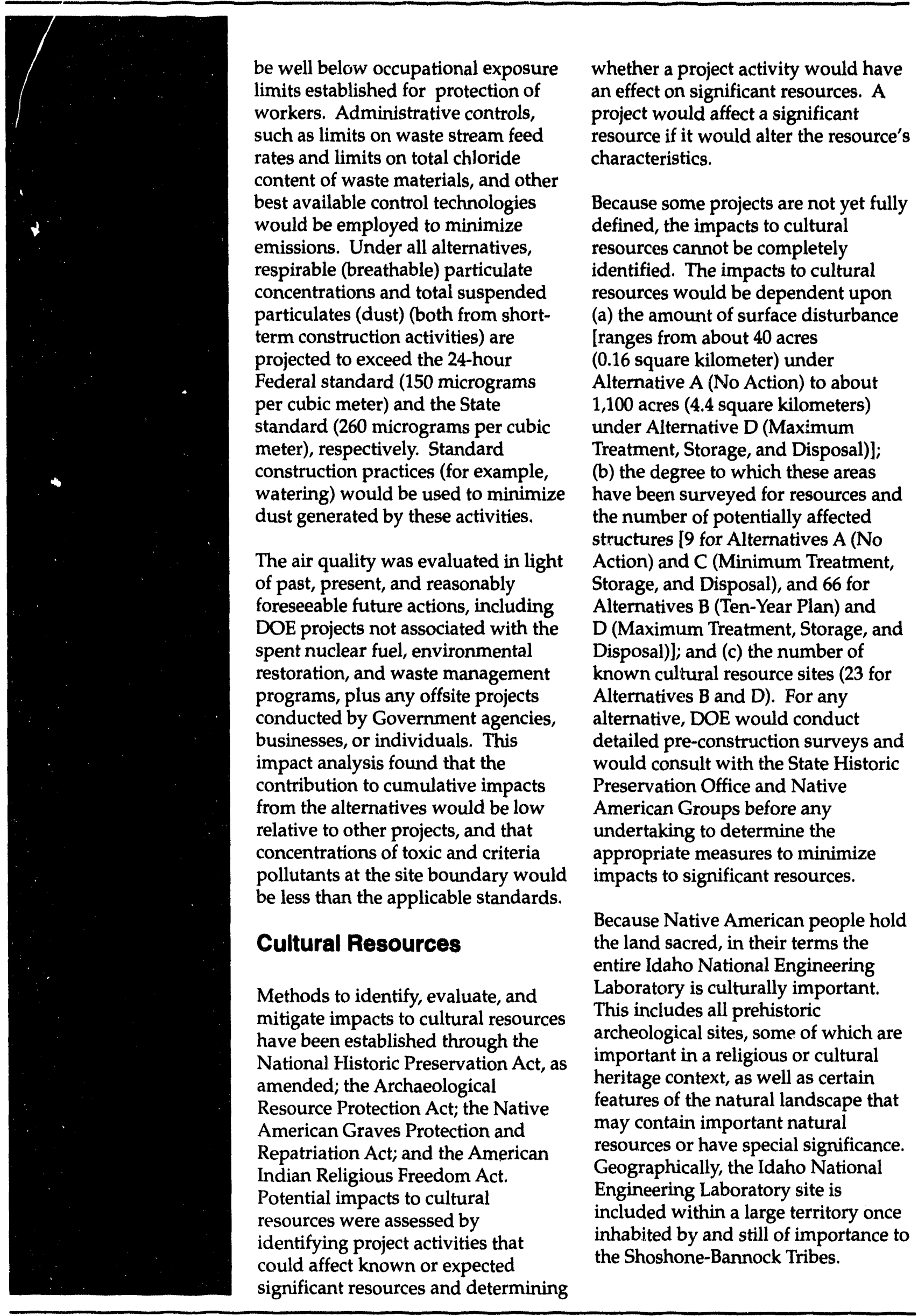




\section{Ecology}

The Idaho National Engineering

Laboratory primarily consists of open, undeveloped land covered

predominantly by sagebrush and grasslands with animal communities typical of these vegetation types.

Radionuclides have been found above background levels in individual plants and animals adjacent to facilities, but not at the population, community, or ecosystem levels.

Under Alternatives A (No Action) and $C$ (Minimum Treatment, Storage, and Disposal), limited environmental restoration activities would be undertaken, resulting in the long-term presence of radioactive and hazardous wastes in the environment. Plants and animals would continue to be exposed to these wastes. Alternatives B (TenYear Plan) and D (Maximum Treatment, Storage, and Disposal) would result in a decrease in radioactive uptake over the long-term as environmental restoration activities proceed.

Implementation of any alternative would result in the loss of habitat from facility modification and construction. Alternative D (Maximum Treatment, Storage, and Disposal) would have the greatest estimated consequence, claiming about 1,100 acres (4.4 square kilometers) of additional habitat, of which 840 acres ( 3.4 square kilometers) would be newly disturbed, and 230 acres ( 0.93 square kilometer) would be revegetated, resulting in a net loss of about 890 acres ( 3.6 square kilometers). Alternative A (No Action) would have the least relative impact, disturbing only about 40 acres ( 0.16 square kilometer) of habitat, 5 acres ( 0.02 square kilometer) of which would be newly disturbed.

Estimated habitat loss from each alternative was assessed in light of other DOE and non-DOE projects. When these projects were considered together, it was estimated that Alternative A (No
Action) would disturb 310 acres (1.23 square kilometers), followed by Alternatives $C$ (Minimum Treatment, Storage, and Disposal) [550 acres (2.2 square kilometers)], B (Ten-Year Plan) $[2,200$ acres (8.9 square kilometers)], and D (Maximum Treatment, Storage, and Disposal) $[3,000$ acres (12 square kilometers)]. To minimize habitat loss, DOE would conduct surveys and consult with appropriate Federal and State agencies before facility construction or modification. If necessary, current project planning would be modified to minimize surface disturbances.

\section{Groundwater Quality}

Previous operations have introduced radionuclides, nonradioactive metals, inorganic salts, and organic compounds into the subsurface.

Radionuclide concentrations in the Snake River Plain Aquifer beneath the site have generally decreased since the mid 1980s because of changes in disposal practices, radioactive decay, adsorption of radionuclides to rocks and minerals, and dilution by natural surface water and groundwater entering the aquifer. Extremely low

concentrations of iodine-129 and tritium have migrated outside of site boundaries. Although nonradioactive metals, inorganic salts, and organic compounds have been detected in the aquifer, none

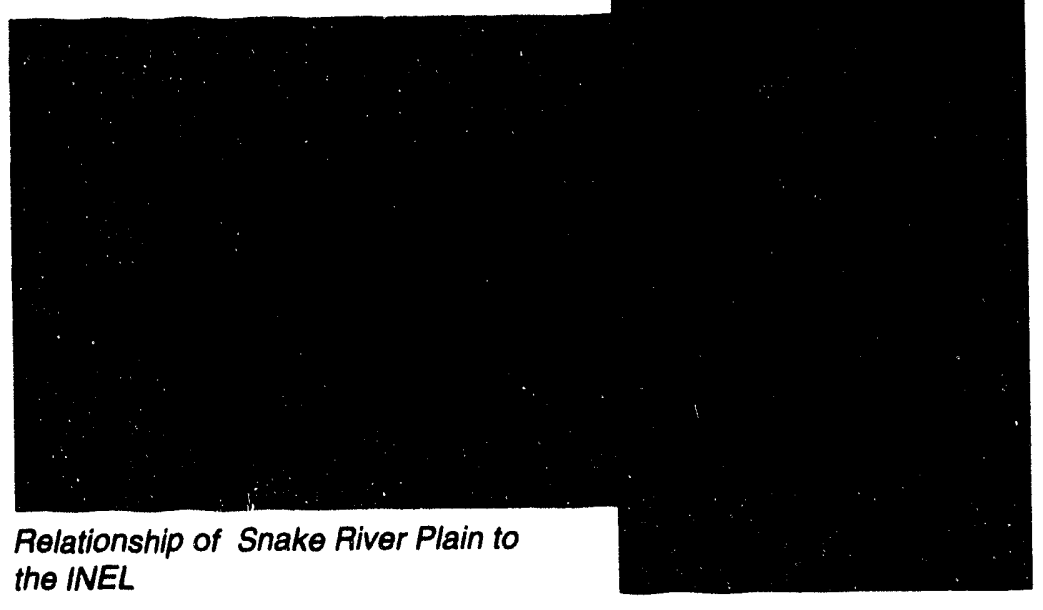


have migrated beyond site boundaries. Modeling to estimate radionuclide (and other constituent) migration was performed. Tritium, iodine-129, and strontium-90 are discussed because they appear to have had the most impact on groundwater quality.

Drinking water at the Idaho National Engineering Laboratory site may contain small concentrations of tritium, strontium-90, and iodine-129. Over a 50-year working period, this radioactivity could result in about a 20-millirem dose to an individual worker. This radiation dose is well within regulatory limits and is very small compared to other sources of occunational radiation exposure.

\section{Normal Operations Impacts}

Potential impacts from any alternative would occur to workers and the public from exposures to radiation during routine operations of facilities and during routine transportation of spent nuclear fuel and radioactive waste. Additional radiation impacts could also occur as the result of accidents at facilities or during transportation.

\section{Facilities}

Idaho National Engineering Laboratory facilities release small amounts of radionuclides to the air in levels that are within regulatory standards. Estimates of latent cancer fatalities are based on exposures to 10 years of Idaho National Engineering Laboratory operations under each alternative. The likelihood of the maximally exposed worker contracting a fatal cancer ranges from about 1 chance in 40,000 [Alternetive D (Maximum Treatment, Storage, and Disposali] to about 1 chance in 1,000,000 [Alternative $A$ (No Action)]. For the maximally exposed member of the public living offsite, the likelihood ranges from 1 chance in 200,000 [Alternative D
(Maximum Treatment, Storage, and Disposal)] to about 1 chance in $1,000,000$ [Alternatives $A$ and $C$ (Minimum Treatment, Storage, and Disposal)]. In the nearby population of about 132,000 , it is estimated that less than one latent cancer fatality would occur in the 10-year period for all alternatives.

\section{Workers}

Impacts to workers at the Idaho National Engineering Laboratory from routine occupational hazards were also assessed. It is estimated that routine exposure to radiation would result in an estimated 1.0 latent cancer fatality [Alternative A (No Action)] to 1.1 [Alternatives B (Ten-Year Plan) and $D$ (Maximum Treatment, Storage, and Disposal)] additional latent cancer fatalities over 10 years of Idaho National Engineering Laboratory operations in a worker population of 9,255 to 10,288 .

These same populations of workers would also report between 3,100 and 3,600 occupationally-related injuries and illnesses over 10 years of Idaho National Engineering Laboratory operations. Work place hazards would be reduced by the worker and radiological-safety programs and regulatory standards currently in place.

\section{Transportation}

During the incident-free transportation of waste and spent nuclear fuel, the general population living and traveling along the transport route would be exposed to radiation from the passing shipments. Transportation workers would also be exposed. The total number of fatalities for the shipments would be the sum of the estimated number of radiationrelated latent cancer fatalities for transportation workers and the general population and the estimated number of nonradiological fatalities from vehicular emissions. 
Over the 10-year period 1995 through 2005 , if waste shipments were made by truck, the estimated number of total fatalities would range from 0.10 to 1.4. If waste shipments were made by rail, the estimated number of total fatalities would range from 0.02 to 0.3 .

Over the 40-year period 1995 through 2035, if spent nuclear fuel shipments were made by truck, the estimated number of total fatalities would range from 0.06 to 1.6. If spent nuclear fuel shipments were made by rail, the estimated number of total fatalities would range from 0.06 to 0.2 .

\section{Accidents}

A potential exists for accidents at facilities associated with the treatment, storage, and disposal of radioactive and hazardous materials. Accidents can be categorized into events that are abnormal (for example, minor spills), events that a facility was designed to withstand, and events that a facility was not designed to withstand (but whose impacts may be offset or mitigated). A range of accidents was considered and consequences were estimated for a member of the public at the nearest site boundary [for the population (about 132,000 ) within 50 miles] and for the workers. In addition, accident analyses were performed for the transport of spent nuclear fuel and radioactive waste.

\section{Facilities}

The maximum reasonably foreseeable accident for facility operations, is the same among the alternatives and involves spent nuclear fuel. A severe earthquake damages a facility and causes spent nuclear fuel to melt, resulting in a radiological release. Although such an event is unlikely ( 1 chance in 100,000 years), the maximally exposed individual at the site boundary would incur an estimated risk of increased latent cancer fatalities of 1 chance in about 40 million. In the surrounding population of 132,000 this postulated accident could result in at most seven additional latent cancer fatalities.

\section{Workers}

The maximum reasonably foreseeable radiological accident for workers results from an earthquake causing a facility collapse. This event has a likelihood of about one chance in 3,300 years. As many as 50 workers could be subjected to potentially fatal prompt exposures. Workers that survive the initial event could see increased risk of developing a latent fatal cancer to one chance in 90 . The maximum reasonably foreseeable hazardous material accident results from an accidental release of the entire

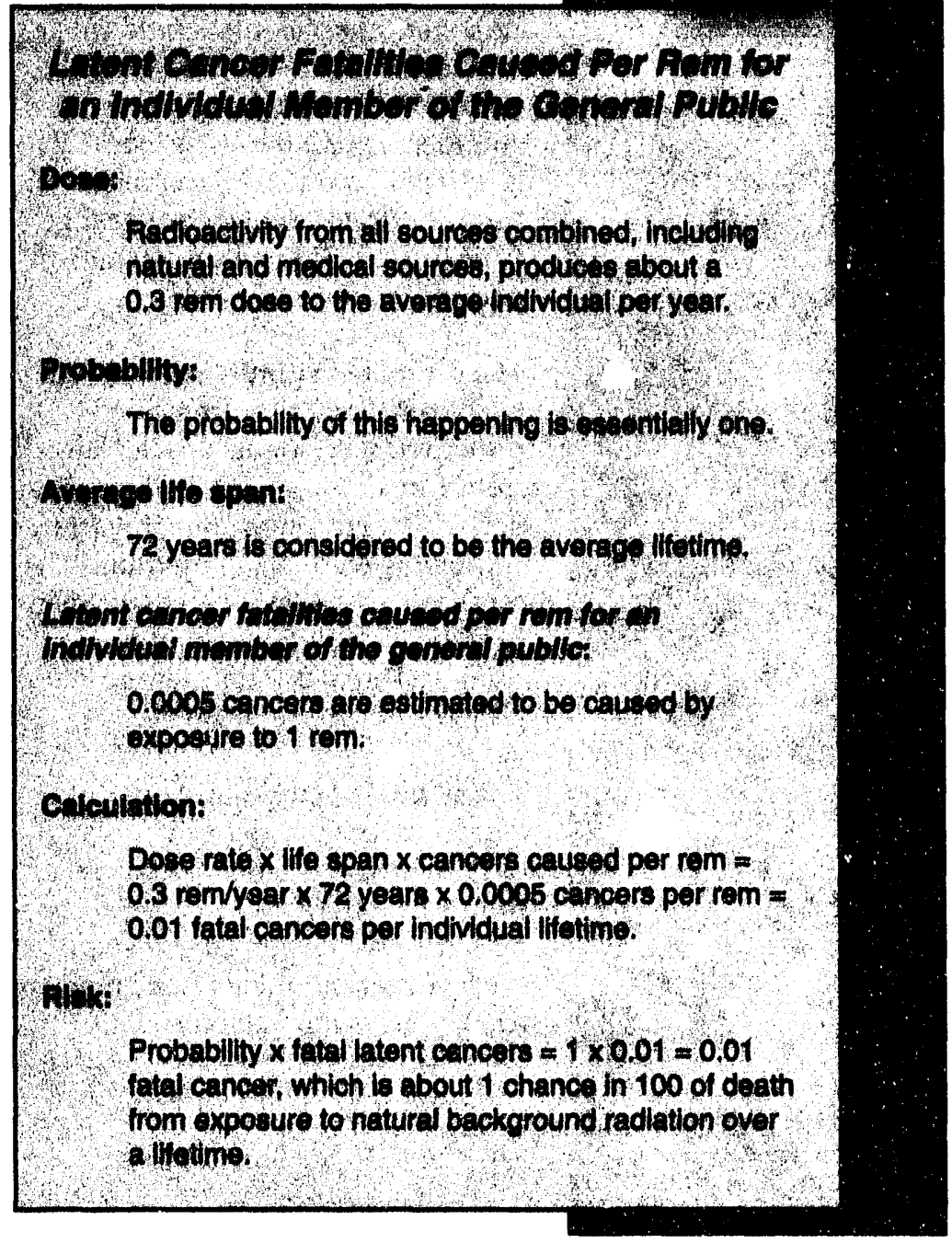


inventory of chlorine gas (a hazardous material) from a facility. The event has about one chance per 100,000 years and could cause fatalities to as many as 100 workers. Such a release also would be the maximum reasonably foreseeable hazardous material accident for public consequences, but no fatalities would be expected.

\section{Transportation}

During the shipment of waste and spent nuclear fuel, radiological accidents and traffic accidents could occur. To determine the accident risk from transporting waste and spent nuclear fuel, a complete spectrum of accidents was evaluated.

The estimated cumulative risk of a latent cancer fatality from radiological accidents would range from 1 in 1,300 to 1 in 340 for the period 1995 through 2005 if waste shipments were made by truck. The estimated cumulative accident risk from traffic accidents would range from 0.30 to 3.4 fatalities for the period 1995 through 2005.

The estimated cumulative risk of a latent cancer fatality from radiological accidents would range from 1 in 17,000 to 1 in 2,900 for the period 1995 through 2005 if waste shipments were made by train. The estimated cumulative accident risk from traffic accidents would range from 0.003 to 0.04 fatalities for the period 1995 through 2005.

The estimated cumulative risk of a latent cancer fatality from radiological accidents would range from 1 in 240,000 to 1 in 830 for the period 1995 through 2035 if spent nuclear fuel shipments were made by truck. The estimated cumulative accident risk due to traffic accidents would range from 0.047 to 1.0 fatalities for the period 1995 through 2035.

The estimated cumulative risk of a latent cancer fatality from radiological accidents would range from 1 in 240,000 to 1 in 1,800 for the period 1995 through 2035 if spent nuclear fuel shipments were made by train. The estimated cumulative accident risk from traffic accidents would range from 0.047 to

0.85 fatalities for the period 1995 through 2035.

The consequences for various maximum foreseeable accidents also were evaluated for spent nuclear fuel and waste. The maximum foreseeable accident for spent nuclear fuel or waste shipments was for a rail shipping cask containing special-case commercial spent nuclear fuel. This hypothetical accident, which was estimated to have a probability of about 1 in 10 million, was estimated to result in 55 radiationrelated latent cancer fatalities.

Development of DOE's environmental justice implementation strategy is currently in progress, and appropriate results will be incorporated into the final EIS. Although the analysis in this draft EIS indicates there are no significant impacts from normal operations to any member of the general public, it is uncertain whether any low-income or minority communities may be disproportionately located along the designated transportation corridors. The public comment period will provide an opportunity to obtain additional information in this regard. Further analysis is planned to be included in the EIS, as appropriate and practicable. 
$\mathrm{OE}$ is committed to operating the Idaho National Engineering Laboratory in compliance with all applicable environmental laws, regulations, executive orders, DOE orders, and permits and compliance agreements with regulatory agencies. To ensure compliance with permits and other applicable legal requirements, regulatory agencies conduct inspections at the Idaho National Engineering Laboratory. In addition, DOE has a comprehensive program for conducting internal audits or inspections and selfassessments, incluaing periodic reviews conducted by interdisciplinary teams of experts. DOE has prepared and issued a site-specific environmental compliance planning manual. This manual contains step-by-step methods to maintain compliance with the various requirements of Federal and State agencies that regulate operations at the Idaho National Engineering Laboratory.

The DOE regulations that implement the National Environmental Policy Act require consultation with other agencies, when appropriate, to incorporate any relevant requirements as early as possible in the process. During preparation of the EIS, DOE initiated consultation with Federal and State agencies. The U.S. Fish and Wildlife Service and the State Historic Preservation Office have responded to DOE's request for consultation. The information provided has been considered in the analyses of the EIS.

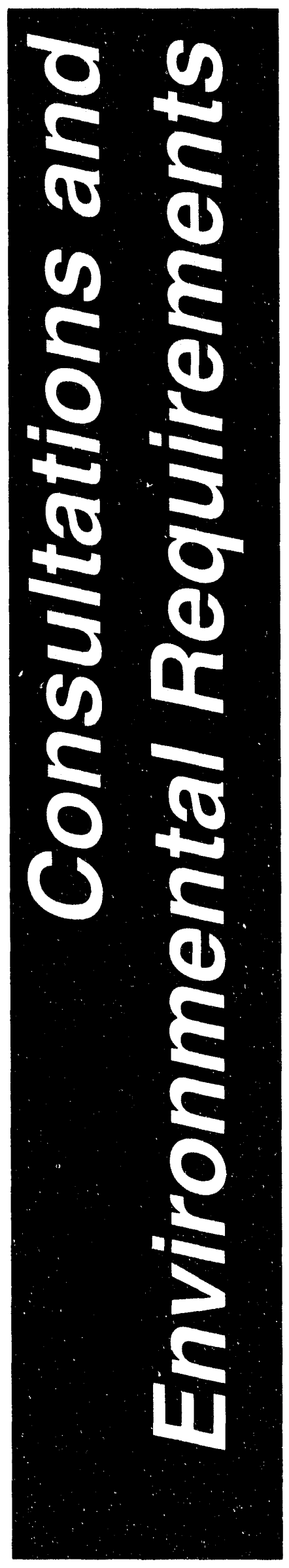




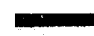




\section{Department of Energy Reading Rooms}

Public Reading Room for U.S. Dopartment of Energy Headquarters

Room 1E-190, Forrestal Building

Freedom of Information Reading Room

1000 Independence Avenue, SW

Washington, DC 10585

(202) 586-6020

Monday-Friday 9:00 a.m. to 4:00 p.m.

Public Reading Room for U.S.

Department of Energy

Oakland Operations Office

Environmental Information Center

1301 Clay Street, Room $700 \mathrm{~N}$

Oakland, CA 94612

(510) 637-1762

Monday-Friday 8:30 a.m. to 5:00 p.m.

Public Reading Room for U.S.

Department of Energy

Rocky Flats Operations Office

Front Range Community College Library

3645 W. 112th Ave.

Level B, Center or the Building

Westminister, CO 80030

(303) 469-4435

Monday and Tuesday 10:30 a.m. to 6:30 p.m., Wednesday 10:00 a.m. to 4:00 p.m., Thursday 8:00 a.m. to 4:00 p.m.

Public Reading Room for U.S.

Department of Energy

Idaho Operations Otfice

Public Reading Room

1776 Science Center Drive

Idaho Falls, ID 83402

(208) 526-9162

Monday-Friday 8:00 a.m. to 5:00 p.m.

Public Reading Room for U.S.

Department of Energy

University of Illinois at Chicago Library

Government Documents Section

801 South Morgan Street

Chicago, IL 60607

(312) 996-2738

Monday-Friday 8:00 a.m. to 10:00 p.m., Saturday 10:00 a.m. to 5:00 p.m.
Publlc Reading Room for U.S.

Department of Energy

National Atomic Museum

20358 Wyoming Boulevard, SE

Albuquerque, NM 87185

(505) 845-4378

Monday-Friday 9:00 a.m. to 5:00 p.m.

Publlc Reading Room for U.S.

Department of Energy

Novada Operations Office

Coordination and Information Center

3084 South Highland Drive

P.O. Box 98521

Las Vegas, NV 89106

(702) 295-0731

Monday-Friday 7:00 a.m. to 4:00 p.m.

Public Information Room for U.S.

Department of Energy

Fernald Operations Office

Public Environmental Center

JANTER Building 10845

Hamilton-Cleves Highway

Harrison, $\mathrm{OH} 445030$

(513) 738-0164

Monday and Thursday 9:00 a.m. to 8:00 p.m., Tuesday, Wednesday, Friday 9:00 a.m. to 4:30 p.m., Saturday 9 a.m. to 1 p.m.

Public Reading Room for U.S.

Department of Energy

Savannah River Operations Otfice

Public Reading Room

Road 1A, Building 703A, D232

Aiken, SC 29802

(803) 725-1408

Monday-Thursday 8:00 a.m. to 11:00 p.m., Friday 8:00 a.m. to 5:00 p.m., Saturday 10:00 a.m. to 5:00 p.m., Sunday 2:00 p.m. to 11:00 p.m.

Public Reading Room for U.S.

Department of Energy

Oak Ridge Operations Offlce

Public Reading Room

55 Jefferson Avenue

Oak Ridge, TN 37831

(615) 576-1216

Monday-Friday 8:00 a.m. to 11:30 a.m. and 12:30 p.m. to 5:00 p.m.

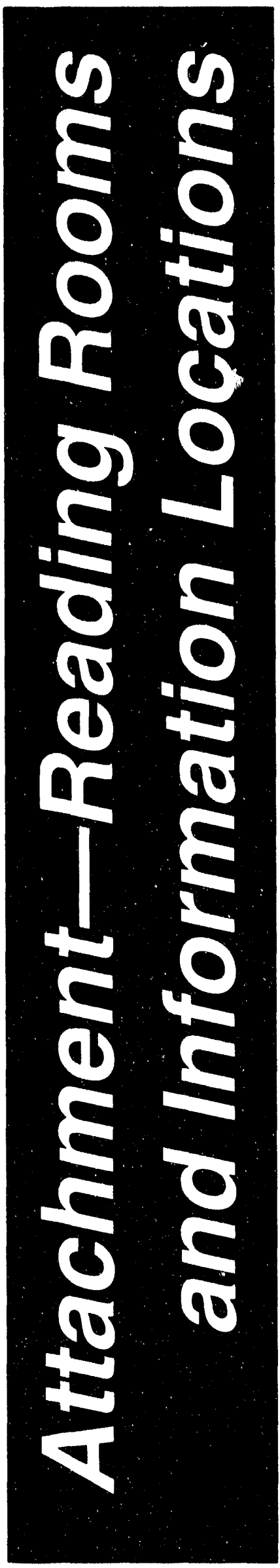


Publlc Reading Room for U.S.

Department of Energy

Richland Operations Office

Washington State University Tri-Cities

100 Sprout Road, Room 130 West

Richland, WA 99352

(509) 376-8583

Monday-Friday 8:00 a.m. to $12: 00 \mathrm{p} . \mathrm{m}$. and

1:00 p.m. to $4: 00$ p.m.

\section{Navy Information Locations}

\section{Norfolk Naval Shipyard}

\section{Chesapeake Central Library}

298 Cedar Rd.

Chesapeake, VA 23320-5512

(804) 436-8300

Monday-Thursday 9:00 a.m to 9:00 p.m., Friday and Saturday 9:00 a.m to 5:00 p.m., Sunday 1:00 p.m to 5:00 p.m.

\section{Newport News Public Library \\ Grissom Branch \\ 366 Deshazor Dr.}

Newport News, VA 23602

(804) 886-7896

Monday-Thursday 9:00 a.m. to 9:00 p.m., Friday and Saturday 9:00 a.m. to 6:00 p.m.

\section{KIIn Library}

301 East City Hall Ave.

Norfolk, VA 23510

(804) $441-2429$

Monday-Thursday 9:00 a.m. to 9:00 p.m., Friday $9: 00$ a.m. to 5:00 p.m., Saturday

9:00 a.m. to 5:00 p.m.

\section{Hampton Public Library \\ 4207 Victoria Boulevard \\ Hampton, VA 23669 \\ (804) 727-1154}

Monday-Thursday 9:00 a.m. to 9:00 p.m., Friday and Saturday 9:00 a.m. to 5:00 p.m.

\section{Portsmouth Public Library}

Main Branch

601 Court St.

Portsmouth, VA 23704

(804) 393-8501

Monday-Thursday 9:00 a.m to 9:00 p.m, Friday and Saturday 9:00 a.m to 5:00 p.m.
Virginia Beach Central Library

4100 Virginia Beach Blvd.

Virginia Beach, VA 23452

(804) 431-3001

Monday-Thursday 10:00 a.m. to 9:00 p.m., Friday and Saturday 10:00 a.m. to 5:00 p.m., Sunday 1:00 p.m. to 5:00 p.m.

\section{Puget Sound Naval Shipyard}

\section{Kitsap Regional Llbrary \\ 1301 Sylvan Way \\ Bremerton, WA 98310}

(206) 377-7601

Monday-Thursday 9:30 a.m. to 9:00 p.m., Friday and Saturday 9:30 a.m. to 5:30 p.m., Sunday 12:30 p.m. to 5:30 p.m.

\section{Kitsap Reglonal Library}

Downtown Branch

612 5th Ave.

Bremerton, WA 98310

(206) 377-3955

Monday-Friday 10:00 a.m. to 6:00 p.m.

\section{Suzallo Library SM25}

University of Washington Libraries

University of Washington

Seattle, WA 98185

(206) 543-9158

Monday-Thursday 7:30 a.m. to 12:00 midnight, Friday 7:30 a.m. to 6:00 p.m., Saturday 9:00 a.m. to 5:00 p.m., Sunday $12: 00$ p.m. to $12: 00$ midnight

\section{Portsmouth Naval Shipyard}

Rice Public Library

8 Wentworth Street

Kittery, ME 03904

(207) 439-1553

Monday-Wednesday, Friday 10:00 a.m. to 5:00 p.m., Thursday 10:00 a.m. to 8:00 p.m., Saturday 10:00 a.m. to 4:00 p.m.

\section{Portsmouth Public Library}

8 Islington Street

Portsmouth, $\mathrm{NH} 03801$

(804) 393-8501

Monday-Thursday 9:00 a.m. to 9:00 p.m., Friday and Saturday 9:00 a.m. to 5:00 p.m.

\section{Pearl Harbor Naval Shlpyard}

Alea Public Llbrary 99-143 Monalua Rd.

Alea, HI 96701

(808) 488-2654

Monday and Thursday 10:00 a.m. to

8:00 p.m., Tuesday, Wednesday, Friday, Saturday 10:00 a.m. to 5:00 p.m.

Hawail State Library 478 South King Street Honolulu, HI 96813 (808) 586-3535

Monday, Wednesday, Friday, Saturday 9:00 a.m. to 5:00 p.m., Tuesday, Thursday 9:00 a.m. to $8: 00$ p.m.

Pearl Clty Public Library 1138 Waimano Home Rd. Pearl City, HI 96782 (808) 455-4134 Monday-Wednesday 10:00 a.m. to 8:00 p.m., Thursday-Saturday 10:00 a.m. to 5:00 p.m., Sunday 1:00 p.m. to 5:00 p.m.

\section{Pearl Harbor Naval Base LIbrary}

Code 90L

1614 Makalapa Dr.

Pearl Harbor, HI 96860-5350

(808) 471-8238

Tuesday-Thursday 10:00 a.m. to 7:00 p.m. Friday and Saturday 9:00 a.m. to 5:00 p.m.

\section{Kesseiring Site}

\section{Albany Public Library}

Reference and Adult Services

161 Washington Ave.

Albany, NY 12210

(518) $449-3380$

Monday-Thursday 9:00 a.m. to 9:00 p.m., Friday 9:00 a.m to 6:00 p.m., Saturday 9:00 a.m. to $5: 00$ p.m.

Saratoga Springs Public Library 320 Broadway

Saratoga Springs, NY 12866

(518) 584-7860

Monday-Thursday 9:00 a.m. to 9:00 p.m., Friday 9:00 a.m. to 6:00 p.m., Saturday 9:00 a.m. to $5: 00$ p.m., Sunday $1: 00$ p.m. to 5:00 p.m. 
Schenectady County Library

99 Clinton Street

Schenectady, NY 12305

(518) 388-4511

Monday-Thursday, 9:00 a.m. to 9:00 p.m., Friday-Saturday, 9:00 a.m. to 5:00 p.m., Sunday 1:00 p.m. to $5: 00$ p.m.

\section{Other Locations}

Main Llbrary
University of Arizona
Tucson, AZ 85721
(602) 621-6433
Sunday-Thursday 8:00 a.m. to 1:00 a.m., Fri-
day-Saturday 9:00 a.m. to 5:00 p.m.

\section{Main Library}

University of California at Irvine

Government Publications Receiving Dock

Irvine, CA 92717

(714) 856-7290

School Hours: Monday-Thursday 8:00 a.m. to 7:00 p.m., Friday 8:00 a.m. to 5:00 p.m., Saturday and Sunday 1:00 p.m. to 11:00 p.m. Summer Hours: Monday-Friday 8:00 a.m. to 5:00 p.m., Saturday and Sunday 1:00 p.m. to $5: 00$ p.m.

\section{Pleasanton Public Library - Reference Desk \\ 400 Old Bernal Avenue \\ Pleasanton, CA 94566 \\ (510) 462-3535 \\ Monday and Tuesday 1:00 p.m. to 8:00 p.m., Wednesday and Thursday 10:00 a.m. to 6:00 p.m., Saturday 2:00 p.m. to 6:00 p.m., Sunday 1:00 p.m. to 5:00 p.m.}

\section{San Dlego Public Library}

820 "E" Street

San Diego, CA 92101

(619) 236-5867

Monday-Thursday 10:00 a.m. to 9:00 p.m., Friday and Saturday 9:30 a.m. to 5:30 p.m., Sunday 1:00 p.m. to 5:00 p.m.

\section{Denver Public Library}

1357 Broadway

Denver, CO 80203

(303) 640-8845

Monday-Wednesday 10:00 a.m. to 9:00 p.m., Thursday-Saturday 10:00 a.m. to 5:30 p.m., Sunday 1:00 p.m. to 5:00 p.m.
George A. Smathers Libraries, Library West

University of Florida Library, Room 241

P.O. Box 117001

Gainesville, FL 32611-7001

(904) $392-0367$

Monday-Thursday 8:00 a.m. to 9:30 p.m.,

Friday 8:00 a.m. to 5:00 p.m., Sunday

2:30 p.m. to $9: 30$ p.m.

\section{Atlanta Public Library \\ 1 Margaret Mitchell Square \\ Atlanta, GA 30303 \\ (404) $730-1700$}

Monday 9:00 a.m. to 6:00 p.m., TuesdayThursday 9:00 a.m. to 8:00 p.m., Friday 9:00 a.m. to 5:00 p.m., Saturday 10:00 a.m. to $5: 00$ p.m.

\section{Reese Library}

Augusta College

2500 Walton Way

Augusta, GA $30904-2200$

(706) $737-1744$

School Hours: Monday-Thursday 7:45 a.m. to $10: 30$ p.m., Friday 7:45 a.m. to 5:00 p.m. Saturday 9:00 a.m. to 5:00 p.m., Sunday 1:30 p.m. to $9: 30$ p.m. Summer Hours: Monday-Friday 8:00 a.m. to 5:00 p.m.

\section{Chatham-Effingham-Liberty \\ Regional Library \\ 2002 Bull Street \\ Savannah, GA 31401 \\ (912) 234-5127}

Monday-Thursday 9:00 a.m. to 9:00 p.m., Friday 9:00 a.m. to 6:00 p.m., Saturday 10:00 a.m. to $6: 00$ p.m.

\section{Parks Library}

lowa State University

Government Publications Department

Ames, IA 50011-2140

(515) 294-3642

School Hours: Monday-Thursday 7:30 a.m. to $12: 00$ midnight, Friday $7: 30$ a.m. to 10:00 p.m., Saturday 10:00 a.m. to 10:00 p.m., Sunday 12:30 p.m. to 12:00 midnight, Summer Hours: MondayThursday 7:30 a.m. to 10:00 p.m., Friday 7:30 a.m. to 5:00 p.m., Saturday 12:30 p.m. to $5: 00$ p.m., Sunday $12: 30$ p.m. to 10:00 p.m.
Bolse Public Llbrary

715 South Capitol Boulevard

Boise, ID 83702

(208) 384-4023

Monday-Friday 10:00 a.m. to 6:00 p.m., Tuesday-Thursday 10:00 a.m. to 9:00 p.m., Saturday 1:00 p.m. to 5:00 p.m.

Idaho Department of Health and Welfare Idaho Natlonal Engineering Laboratory Oversight Program Library

1410 North Hilton

Boise, ID 83706

(208) 334-0498

Monday-Friday 8:00 a.m. to 5:00 p.m.

Idaho State Library

325 West State Street

Boise, ID 83702

(208) 334-2152

Monday-Friday 9:00 a.m. to

5:00 p.m.

\section{Shoshone-Bannock Library}

Bannock and Pima Streets, HRDC Building Fort Hall, ID 83203

(208) 238-3882

Monday-Friday 8:00 a.m. to $4: 30$ p.m.

Idaho Falls Public Library

457 Broadway

Idaho Falls, ID 83402

(208) 529-1462

Monday-Thursday 8:00 a.m. to 7:00 p.m, Friday 8:00 a.m. to 5:00 p.m., Saturday

9:00 a.m. to $1: 00$ p.m.

University of Idaho Library

Rayburn Street

Moscow, ID 83844-2353

(208) 885-6344

Monday-Friday 8:00 a.m. to 12:00 midnight, Saturday 9:00 a.m. to 12:00 midnight, Sunday 10:00 a.m. to 12:00 midnight

\section{Pocatello Public Library}

812 East Clark Street

Pocatello, ID 83201

(208) 232-1263

Monday-Thursday 10:00 a.m. to 9:00 p.m, Friday and Saturday 10:00 a.m. to 6:00 p.m. 
Twin Falls Public Library

434 Second Streot East

Twin Falls, ID 83301

(208) 733-2964

Monday-Thursday 10:00 a.m. to 6:00 p.m,

Friday 10:00 a.m. to 5:00 p.m., Saturday

12:00 p.m.to 5:00 p.m.

Main Library, Third Floor

University of llinois

801 South Morgan, Mail Code 234

Chicago, IL 60607

(312) 413-2594

Monday-Thursday 7:30 a.m. to 10:00 p.m., Friday 7:30 a.m. to 5:00 p.m., Saturday

10:00 a.m. to 5:00 p.m., Sunday 1:00 p.m. to 9:00 p.m.

\section{Documents Library, 200-D}

University of llinois

1408 W. Gregory Drive

Urbana, IL 61801

(217) 244-2060

School Hours: Monday-Thursday 8:00 a.m. to $12: 00$ midnight, Friday 8:00 a.m. to 6:00 p.m., Saturday 9:00 a.m. to 6:00 p.m., Sunday 1:00 p.m. to $12: 00$ midnight, Summer Hours: Monday-Thursday 8:00 a.m. to 9:00 p.m., Friday 8:00 a.m. to 6:00 p.m., Saturday $9: 00$ a.m. to 5:00 p.m., Sunday 1:00 p.m. to $5: 00$ p.m.

\section{Engineering Library}

Purdue University

West Lafayette, IN 47907

(317) 494-2871

School Hours: Monday-Friday 8:00 a.m. to 12:00 midnight, Saturday 9:00 a.m. to 5:00 p.m., Sunday 12:00 p.m. to 12:00 midnight, Summer Hours: Monday-Friday 8:00 a.m. to 8:00 p.m.

\footnotetext{
Manhattan Public Library

Julliette and Poyntz

Manhattan, KS 66502

(913) 776-4741

Monday-Friday 9:00 a.m. to 9:00 p.m., Saturday 9:00 a.m. to 6:00 p.m., Sunday

2:00 p.m. to $6: 00$ p.m.
}

\section{Massachusetts Instlite of Technology Sclence Library 160 Memorial Drive Building 14 Cambridge, MA 02139 \\ (617) 253-5685}

Monday-Thursday 8:00 a.m. to $12: 00$ midnight, Friday and Saturday 8:00 a.m. to 8:00 p.m., Sunday 12:00 p.m. to $12: 00$ midnight

\section{O'Leary Library}

University of Massachusetts

1 University Ave

Lowell, MA 01854

(508) 934-3205

School Hours: Monday-Thursday 7:30 a.m. to $11: 00$ p.m., Friday 7:30 a.m. to 5:00 p.m., Saturday 10:00 a.m. to 6:00 p.m., Summer Hours: Monday-Friday 8:30 a.m. to 9:00 p.m., Sunday 2:00 p.m. to 7:00 p.m.

\section{Worcester Public Library \\ 3 Salem Square \\ Worchester, MA 01608 \\ (508) 799-1655}

Monday and Wednesday 12:00 p.m. to

9:00 p.m., Tuesday 10:00 a.m. to 9:00 p.m., Thursday-Saturday 10:00 a.m. to 5:30 p.m.

\section{Bethesda Public Library}

7400 Arlington Road

Bethesda, MD 20814

(301) 986-4300

Monday-Thursday 10:00 a.m. to 8:30 p.m., Friday 10:00 a.m. to 5:00 p.m., Saturday 9:00 a.m. to 5:00 p.m., Sunday 1:00 p.m. to 5:00 p.m.

\section{Gaithersburg Regional Library}

18330 Montgomery Village Avenue

Gaithersburg, MD 20879

(301) $840-2515$

Monday-Thursday 10:00 a.m. to 8:30 p.m., Friday 10:00 a.m. to 5:00 p.m., Saturday 9:00 a.m. to 5:00 p.m., Sunday 1:00 p.m. to 5:00 p.m.
Hyatteville Public Library

6530 Adelphi Road

Hyattsville, MD 20782

(301) $779-9330$

Monday-Thursday 10:00 a.m. to 9:00 p.m. Friday 10:00 a.m. to $6: 00$ p.m., Saturday 10:00 a.m. to 5:00 p.m., Sunday 1:00 p.m. to 5:00 p.m.

\section{Ann Arbor Public Library}

343 South 5 th Avenue

Ann Arbor, MI 48104

(313) $994-2333$

Monday 10:00 a.m. to 9:00 p.m., TuesdayFriday 9:00 a.m. to 9:00 p.m., Saturday 9:00 a.m. to $6: 00$ p.m., Sunday $1: 00$ p.m. to 5:00 p.m.

\section{Zanhow Library}

Saginaw Valley State University

7400 Bay Road

University Center, MI 48710

(517) $790-4240$

School Hours: Monday-Thursday 8:00 a.m. to $11: 00$ p.m., Friday 8:00 a.m. to 4:30 p.m., Saturday 9:00 a.m. to 5:00 p.m., Sunday 1:00 p.m. to 9:00 p.m. Summer Hours: MondayThursday 8:00 a.m. to $10: 30$ p.m., Friday 8:00 a.m. to 4:30 p.m., Saturday 10:00 a.m. to $2: 00$ p.m., Sunday 1:00 p.m. to 5:00 p.m.

\section{Ellis Library}

University of Missouri

Columbia, MO 65201

(314) 882-0748

School Hours: Monday-Thursday 7:30 a.m. to $12: 00$ midnight, Friday $7: 30$ a.m. to $11: 00$ p.m.,Saturday 9:00 a.m. to 9:00 p.m., Sunday 12:00 p.m. to 1:00 a.m. Summer Hours: Monday and Thursday 8:00 a.m. to 8:00 p.m., Tuesday, Wednesday, and Friday 8:00 a.m. to 5:00 p.m., Saturday 12:00 p.m. to 5:00 p.m.

\section{Curtis Laws Wilson Library \\ University of Missouri Library \\ Folla, MO 65401-0249 \\ (314) 341-4227}

School Hours: Monday-Thurstlay 8:00 a.m. to $12: 00$ midnight, Friday 8:00 a.m. to 10:30 p.m., Saturday 8:00 a.m. to 5:00 p.m., Sunday 2:00 p.m. to $12: 00$ midnight, Summer Hours: Monday-Friday 8:00 a.m. to 10:00 p.m., Saturday 8:00 a.m. to 5:00 p.m., Sunday 2:00 p.m. to $10: 00$ p.m. 


\section{D.H. HIII Llbrary \\ North Carolina State University \\ P.O. Box 7111 \\ Raleigh, NC 27695-7111 \\ (919) 515-3364}

School Hours: Monday-Thursday 7:00 a.m. to 1:00 a.m., Friday 7:00 a.m. to 6:00 p.m., Saturday 9:30 a.m. to 5:30 p.m., Sunday 1:00 p.m. to 1:00 a.m. Summer Hours: Monday-Thursday 7:00 a.m. to 11:00 p.m., Friday 7:00 a.m. to 6:00 p.m., Saturday 9:30 a.m. to 5:30 p.m., Sunday 1:00 p.m. to 11:00 p.m.

\section{Omaha Publlc Library}

215 S. 15th Street

Omaha, NE 68102

(402) 444-4800

Monday-Thursday 9:00 a.m. to 9:00 p.m., Friday and Saturday 9:00 a.m. to 5:30 p.m., Sunday 1:00 p.m. to 5:00 p.m.

\section{General Library}

University of New Mexico

Albuquerque, NM 87131-1466

(505) 277-5441

School Hours: Monday-Thursday 8:00 a.m. to $9: 00$ p.m., Friday 8:00 a.m. to 5:00 p.m., Saturday and Sunday 1:00 p.m. to 5:00 p.m., Sumímer Hours: Monday-Friday 8:00 a.m. to 6:00 p.m., Saturday 10:00 a.m. to 5:00 p.m.

\section{U.S. DOE Community Reading Room}

1450 Central Avenue, Suite 101

MS C314

Los Alamos, NM 87544

(505) 665-2127

Monday-Friday 8:00 a.m. to 5:00 p.m.

\section{Lockwood Library}

State University of New York-Buffalo

Buffalo, NY 14260-2200

(716) 645-2816

School Hours: Monday-Thursday 8:00 a.m. to $10: 45$ p.m., Friday 8:00 a.m. to $9: 00$ p.m., Saturday 9:00 a.m. to 5:00 p.m., Sunday 1:00 p.m. to 10:45 p.m., Summer Hours: Monday, Wednesday, Thursday, and Friday 9:00 a.m. to 6:00 p.m., Tuesday 9:00 a.m. to 10:00 p.m. Sunday 1:00 p.m. to 9:00 p.m.

\section{Englneering Library \\ Cornell University \\ Carpenter Hall, Main Floor \\ Ithaca, NY 14853 \\ (607) 255-5762}

School Hours: Monday-Thursday 8:00 a.m to $11: 00$ p.m., Friday 8:00 a.m. to $6: 00$ p.m. Saturday 10:00 a.m. to 6:00 p.m., Sunday 12:00 p.m. to 11:00 p.m., Summer Hours: Monday-Friday 8:00 a.m. to 6:00 p.m., Saturday $12: 00$ p.m. to $6: 00$ p.m.

\section{Cardinal Hayes Llbrary \\ Manhattan College \\ 4531 Manhattan College Parkway \\ Riverdale, NY 10471 \\ (718) 920-0100}

School Hours: Monday-Thursday 8:00 a.m. to $11: 00$ p.m., Friday 8:00 a.m. to $6: 30$ p.m. Saturday 10:00 a.m. to 5:00 p.m., Sunday 1:00 p.m. to 11:00 p.m., Summer Hours: Monday-Friday 8:30 a.m. to 6:30 p.m.

\section{Brookhaven National Laboratory}

25 Brookhaven Avenue, Bullding 477 A

P.O. Box 5000

Upton, NY 11973-5000

(516) 282-3489

Monday-Friday 8:30 a.m. to 9:00 p.m., Saturday and Sunday 10:00 a.m. to 6:00 p.m.

\section{Columbus Metropolitan Library}

96 South Grant Avenue

Columbus, $\mathrm{OH} 43215$

(614) 645-2710

Monday-Thursday 9:00 a.m. to 9:00 p.m., Friday and Saturday 9:00 a.m. to 6:00 p.m. Sunday 1:00 p.m. to $5: 00$ p.m.

\section{Kerr Library}

Oregon State University

Corvallis, OR $97331-4905$

(503) 737-0123

Monday-Friday 7:45 a.m. to 2:00 a.m., Saturday and Sunday 10:00 a.m. to 2:00 A.m.
Brantford Price Millar Llbrary

Portland State University

934 S.W. Harrison

Portland, OR 97201

(503) $725-4617$

Monday-Friday 8:00 a.m. to 10:00 p.m., Saturday $10: 00$ a.m. to $10: 00$ p.m., Sunday

$11: 00$ a.m. to $10: 00$ p.m.

\section{Patteo Library}

Pennsylvania State University

University Park, PA 16801

(814) 865-2112

School Hours Monday-Thursday 8:00 a.m. to $12: 00$ midnight, Friday $8: 00$ a.m. to 10:00 p.m., Saturday 8:00 a.m. 10 9:00 p.m., Sunday 1:00 p.m. to $12: 00$ midnight, Summer Hours: Monday-Thursday 7:45 a.m. to 10:00 p.m., Friday 7:45 a.m. to 9:00 p.m., Saturday 8:00 a.m. to 9:00 p.m., Sunday 1:00 p.m. to $10: 00$ p.m.

\section{Narragansett Public Llbrary}

35 Kingston Road

Narragansett, RI 02882

(401) 789-9507

Monday 10:00 a.m. to 9:00 p.m., TuesdayFriday 10:00 a.m. to 6:00 p.m., Saturday 10:00 a.m. to 5:00 p.m. (Saturday hours September to May only)

\section{Charleston County Main Library}

404 King Street

Charleston, SC 29403

(803) 723-1645

Monday-Thursday 9:30 a.m. to 9:00 p.m., Friday-Saturday 9:30 a.m. to 6:00 p.m., Sunday $2: 00$ p.m. to $6: 00$ p.m.

\section{South Carollna State Library}

1500 Senate Street

Columbia, SC 29201

(803) 734-8666

Monday-Friday 8:15 a.m. to 5:30 p.m., Saturday $9: 00$ to $1: 00$ p.m.

\section{Clinton Public Library}

118 South Hicks Street

Clinton, TN 37716

(615) 457-0519

Monday and Thursday 10:00 a.m. to 8:00 p.m., Tuesday, Wednesday, Friday, Saturday 10:00 a.m. to 5:00 p.m. 
Harriman Public Llbrary

601 Walden Street

Harriman, TN 37748

(615) 882-3195

Monday-Thursday 9:00 a.m. to 5:00 p.m., Friday-Saturday 9:00 a.m. to 1:00 p.m.

\section{KIngaton Public Library}

1000 Bradiord Way Building \#3

Kingston, TN 37763

(615) 376-9905

Monday and Thursday 10:00 a.m. to

7:30 p.m., Tuesday, Wednesday, Friday

10:00 a.m. to $5: 30$ p.m., Saturday

10:00 a.m. to 2:00 p.m.

\section{Lawson MoGhee Public Library \\ 500 West Church Avenue \\ Knoxville, TN 37902 \\ (615) 544-5750}

Monday-Thursday 9:00 a.m. to 8:30 p.m., Friday 9:00 a.m. to 5:30 p.m., Saturday and Sunday 1:00 p.m. to 5:00 p.m.

\section{Oak Ridge Public Library}

Civic Center

Oak Ridge, TN 37830

(615) 482-8455

Monday-Thursday 10:00 a.m. to 9:00 p.m., Friday 10:00 a.m. to 6:00 p.m., Saturday 9:00 a.m. to $6: 00$ p.m., Sunday 2:00 p.m. to $6: 00$ p.m.

\section{Oliver Springs Public Library \\ 607 Easterbrook Avenue \\ Oliver Springs, TN 37840 \\ (615) 435-2509}

Tuesday-Thursday 2:00 p.m. to 4:00 p.m., Saturday 9:00 a.m. to 12:00 midnight

\section{Rockwood Public Library}

117 North Front Avenue

Rockwood, TN 37854

(615) 354-1281

Monday, Wednesday, Friday and Saturday 10:00 a.m. to 5:00 p.m., Tuesday and Thursday 10:00 a.m. to 8:00 p.m.

\section{General Library \\ University of Texas \\ PCL 2.402X \\ Austin, TX 78713 \\ (512) 495.4262}

School Hours: Monday-Friday 8:00 a.m. to 2:00 a.m., Saturday 9:00 a.m. to 2:00 a.m., Sunday 12:00 p.m. to 2:00 a.m., Summer Hours: Monday-Friday 8:00 a.m. to 10:00 p.m., Saturday 9:00 a.m. to 10:00 p.m., Sunday $12: 00$ p.m. to $10: 00$ p.m.

\section{Evans Llbrary}

Texas A\&M University, MS 5000

College Station, TX 77843-5000

(409) 845-8850

School Hours: Monday-Thursday 7:00 a.m. to $12: 00$ midnight., Friday 7:00 a.m. to 7:00 p.m., Saturday 9:00 a.m. to 5:00 p.m., Sunday 1:00 p.m. to $11: 00$ p.m., Summer Hours: Monday-Thursday 7:00 a.m. to 11:00 p.m., Friday 7:00 a.m. to 7:00 p.m., Saturday 9:00 a.m. to 5:00 p.m., Sunday 1:00 p.m. to $11: 00$ p.m.

\section{Marriott Library \\ University of Utah \\ Salt Lake City, UT 84112 \\ (801) 581-8394}

School Hours: Monday-Thursday 7:00 a.m. to $11: 00$ p.m., Friday 7:00 a.m. to 5:00 p.m., Saturday 9:00 a.m. to 5:00 p.m., Sunday 11:00 a.m. to 9:00 p.m. Summers Hours: Monday-Thursday 7:00 a.m. to 10:00 p.m., Friday 7:00 a.m. to 5:00 p.m., Saturday 9:00 a.m. to 5:00 p.m., Sunday 1:00 p.m. to 5:00 p.m.

\section{Alderman Library}

University of Virginia

Charlottesville, VA 22903-2498

(804) 924-3133

School Hours: Monday-Thursday 8:00 a.m. to $12: 00$ midnight, Friday 8:00 a.m. to $6: 00$ p.m., Saturday 9:00 a.m. to 6:00 p.m., Sunday $12: 00$ p.m. to $12: 00$ midnight, Summer Hours: Monday-Thursday 8:00 a.m. to $10: 00$ p.m., Friday 8:00 a.m. to 6:00 p.m., Saturday 9:00 a.m. to 6:00 p.m., Sunday 2:00 p.m. to $10: 00$ p.m.

\section{Owen 8clence \& Enginearing Llbrary Washington State Univeraity Pullman, WA $99164-3200$}

(509) 335-4181

School Hours: Monday-Thursday 8:00 a.m. to $11: 00$ p.m., Friday 8:00 a.m. to $9: 00$ p.m., Saturday $12: 00$ p.m. to $9: 00$ p.m., Sunday 12:00 p.m. to 11:00 p.m., Summer Hours: Monday and Thursday 7:30 a.m. to 11:00 p.m., Tuesday, Wednesday, and Friday 7:30 a.m. to 6:00 p.m., Saturday and Sunday $12: 00$ p.m. to 6:00 p.m.

\section{Foloy Conter}

Gonzaga University

East 502 Boone Avenue

Spokane, WA 99258

(509) 328-4220, extension 3125

School Hours: Monday-Thursday 8:00 a.m. to $12: 00$ midnight, Friday and Saturday 8:00 a.m. to 9:00 p.m., Sunday 11:00 a.m. to 12:00 midnight, Summer Hours: MondayFriday 8:00 a.m. to 9:00 p.m., Saturday 10:00 a.m. to 6:00 p.m., Sunday 1:00 p.m. to $7: 00$ p.m.

\section{Madison Public Library \\ $201 \mathrm{~W}$. Mifflin Street \\ Madison, WI 53703 \\ (608) 266-6350}

Monday-Wednesday 8:30 a.m. to 9:00 p.m. Thursday and Friday 8:30 a.m. to 5:30 p.m. Saturday 9:00 a.m. to 5:30 p.m.

\section{Teton County Public Library}

320 South King Street

Jackson, WY 83001

(307) $733-2164$

Monday, Wednesday and Friday 10:00 a.m. to 5:30 p.m., Tuesday and Thursday 10:00 a.m. to 9:00 p.m., Saturday 10:00 a.m. to 5:00 p.m., Sunday 1:00 p.m. to 5:00 p.m. 


\section{CONTENTS}

CHAPTER 1: PURPOSE AND NEED FOR AGENCY ACTION $\ldots \ldots \ldots \ldots \ldots \ldots$

CHAPTER 2: BACKGROUND $\ldots \ldots \ldots \ldots \ldots \ldots \ldots \ldots \ldots \ldots \ldots \ldots \ldots \ldots \ldots$

2.1 Environmental Impact Statement Scope and Overview ........... 2.1-1

2.1.1 Environmental Impact Statement Content ... . . . . . . . . . 2.1-2

2.1.2 Environmental Impact Statement Scope .................. 2.1-2

2.1.3 Other Related National Environmental Policy Act Documents . . . . . 2.1-5

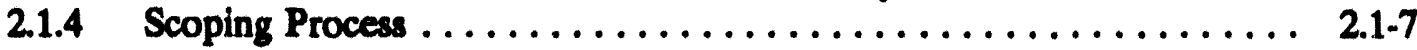

2.2 Idaho National Engineering Laboratory Overview $\ldots \ldots \ldots \ldots \ldots \ldots \ldots$ 2.2-1

2.2.1 General Site Description . . . . . . . . . . . . . .

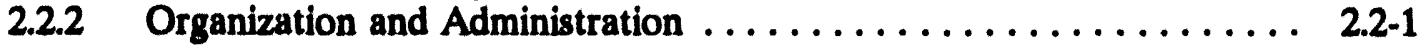

2.2.3 Historic and Current Mission .................... 2.2.3

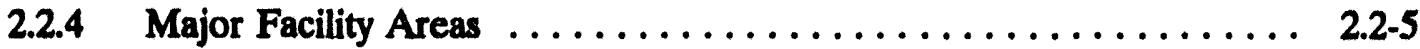

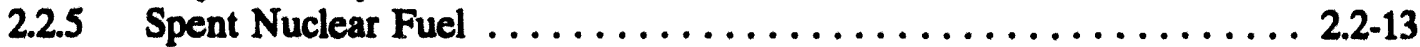

2.2.6 Environmental Restoration ..................... 2.2.24

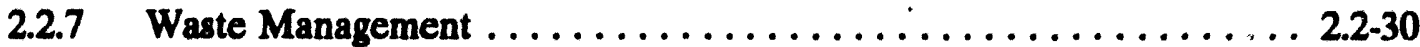

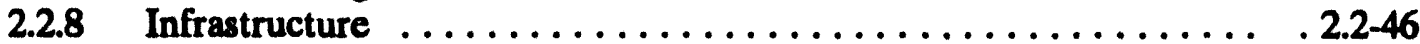

2.2.9 Technology Development ..................... 2.2-47

2.2.10 Activities Not Directly Related to Spent Nuclear Fuel or

Environmental Restoration and Waste Management . . . . . . . . 2.2-48

2.2.11 Regulatory Framework for Environmental Restoration and Waste Management ......................... 2.2-49

CHAPTER 3: ALTERNATTVES $\ldots \ldots \ldots \ldots \ldots \ldots \ldots \ldots \ldots \ldots \ldots \ldots \ldots$

3.1 Description of Alternatives . . . . . . . . . . . . . . . . . . .

3.1.1 Alternatives for Management of Spent Nuclear Fuel . . . . . . . . 3.1-7

3.1.2 Alternatives for Environmental Restoration ............. 3.1-17

3.1.2.1 Remediation ........................ 3.1.17

3.1.2.2 Decontamination and Decommissioning $\ldots \ldots \ldots \ldots . \ldots .20$

3.1.3 Alternatives for Waste Management $\ldots \ldots \ldots \ldots \ldots \ldots \ldots \ldots . \ldots \ldots$

3.1.3.1 High-Level Waste $\ldots \ldots \ldots \ldots \ldots \ldots \ldots \ldots \ldots \ldots \ldots . \ldots \ldots . . \ldots \ldots$

3.1.3.2 Transuranic Waste .................... 3.1-37

3.1.3.3 Low-Level Waste . . . . . . . . . . . . . . . . . . . 3.1-47

3.1.3.4 Mixed Low-Level Waste . . . . . . . . . . . . . . . . . 3.1-55

3.1.3.5 Greater-Than-Class-C Low-Level Waste . . . . . . . . . . . . . 3.1-64

3.1.3.6 Hazardous Waste ...................... 3.1-66

3.1.3.7 Infrastructure . . . . . . . . . . . . . . . . . . 3.1-69 
3.1.4 Technology Development $\ldots \ldots \ldots \ldots \ldots \ldots \ldots \ldots \ldots \ldots \ldots$. 3.1-71

3.2 Alternatives Eliminated from Detailed Analysis $\ldots \ldots \ldots \ldots \ldots \ldots \ldots .2 .1$

3.2.1 Relocate All Idaho National Engineering Laboratory Site

Activities to Another Site $\ldots \ldots \ldots \ldots \ldots \ldots \ldots \ldots \ldots \ldots . . .2 .1$

3.2.2 Restore the Idaho National Engineering Laboratory Site $\ldots \ldots \ldots \ldots$ 3.2-1

3.2.3 No Cleanup or Controls $\ldots \ldots \ldots \ldots \ldots \ldots \ldots \ldots \ldots \ldots \ldots . . .2 .2$

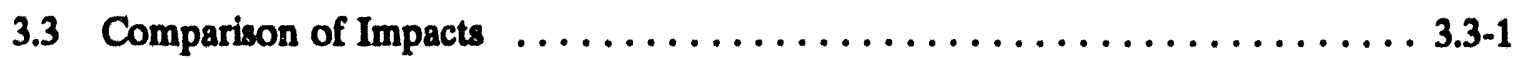

3.3.1 Land Use $\ldots \ldots \ldots \ldots \ldots \ldots \ldots \ldots \ldots \ldots \ldots \ldots \ldots \ldots \ldots, 3.3 .1$

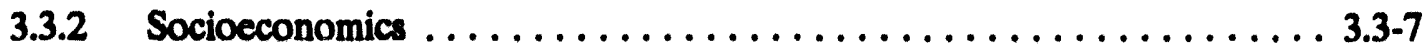

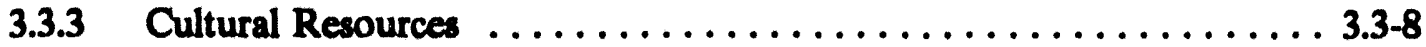

3.3.4 Aesthetic and Scenic Resources ..................... 3.3.9

3.3.5 Geology $\ldots \ldots \ldots \ldots \ldots \ldots \ldots \ldots \ldots \ldots \ldots \ldots \ldots \ldots \ldots \ldots . . .3 .3 .9$

3.3.6 Air Resources ............................... 3.3.10

3.3.7 Water Resources $\ldots \ldots \ldots \ldots \ldots \ldots \ldots \ldots \ldots \ldots \ldots \ldots \ldots, 3.3-12$

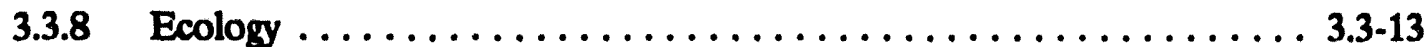

3.3.9 Noise $\ldots \ldots \ldots \ldots \ldots \ldots \ldots \ldots \ldots \ldots \ldots \ldots \ldots \ldots \ldots, 3.3 .14$

3.3.10 Traffic and Transportation $\ldots \ldots \ldots \ldots \ldots \ldots \ldots \ldots \ldots \ldots \ldots, 3.3-14$

3.3.11 Health and Safety $\ldots \ldots \ldots \ldots \ldots \ldots \ldots \ldots \ldots \ldots \ldots \ldots \ldots \ldots \ldots \ldots \ldots \ldots, 3.3 .16$

3.3.12 Idaho National Engineering Laboratory Services $\ldots \ldots \ldots \ldots \ldots \ldots$ 3.3-17

3.3.13 Facility Accidents $\ldots \ldots \ldots \ldots \ldots \ldots \ldots \ldots \ldots \ldots \ldots \ldots \ldots \ldots \ldots, \ldots \ldots .3 .17$

3.3.14 Conclusion $\ldots \ldots \ldots \ldots \ldots \ldots \ldots \ldots \ldots \ldots \ldots \ldots \ldots \ldots \ldots \ldots .3 .3 .19$

CHAPTER 4: AFFECTED ENVIRONMENT $\ldots \ldots \ldots \ldots \ldots \ldots \ldots \ldots \ldots \ldots \ldots .1 .1$

4.1 Introduction $\ldots \ldots \ldots \ldots \ldots \ldots \ldots \ldots \ldots \ldots \ldots \ldots \ldots \ldots \ldots \ldots, 4.1-1$

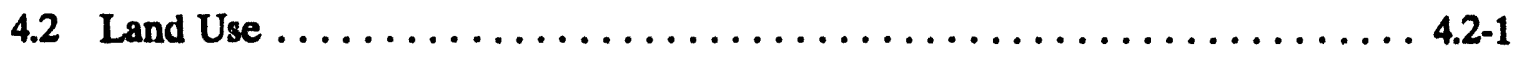

4.2.1 Existing and Planned Land Uses at the Idaho National Engineering Laboratory $\ldots \ldots \ldots \ldots \ldots \ldots \ldots \ldots \ldots \ldots \ldots \ldots . \ldots \ldots .2 .1$

4.2.2 Existing and Planned Land Use in Surrounding Areas $\ldots \ldots \ldots \ldots$ 4.2-4

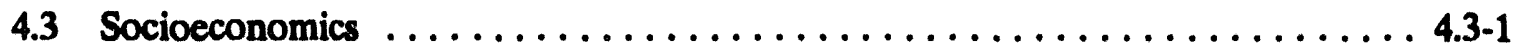

4.3.1 Employment and Income $\ldots \ldots \ldots \ldots \ldots \ldots \ldots \ldots \ldots \ldots, 4.3-1$

4.3.2 Population and Housing $\ldots \ldots \ldots \ldots \ldots \ldots \ldots \ldots \ldots \ldots \ldots \ldots \ldots . . \ldots \ldots .3 .5$

4.3.3 Community Services and Public Finance $\ldots \ldots \ldots \ldots \ldots \ldots \ldots$ 4.3-7

4.4 Cultural Resources $\ldots \ldots \ldots \ldots \ldots \ldots \ldots \ldots \ldots \ldots \ldots \ldots \ldots \ldots, 4.4-1$

4.4.1 Archaeological Sites and Historic Structures $\ldots \ldots \ldots \ldots \ldots \ldots$ 4.4-1

4.4.2 Native American Cultural Resources $\ldots \ldots \ldots \ldots \ldots \ldots \ldots \ldots .4 .4 .3$

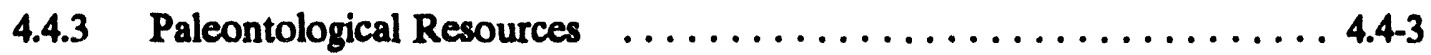

4.5 Aesthetic and Scenic Resources $\ldots \ldots \ldots \ldots \ldots \ldots \ldots \ldots \ldots \ldots \ldots . . \ldots \ldots .1$ 
4.5.1 Visual Character of the Idaho National Engineering Laboratory Site . . 4.5-1

4.5.2 Scenic Areas .............................. 4.5-2

4.6 Geology $\ldots \ldots \ldots \ldots \ldots \ldots \ldots \ldots \ldots \ldots \ldots \ldots \ldots \ldots \ldots \ldots \ldots, 4.6-1$

4.6.1 General Geology .......................... 4.6-1

4.6.2 Natural Resources . . . . . . . . . . . . . . . . . . . . 4.6-4

4.6.3 Seionic Hazards . . . . . . . . . . . . . . . . . . . . . 4.6-4

4.6.4 Volcanic Hazards . . . . . . . . . . . . . . . . . . . . . . . 4.6-9

4.7 Air Resources $\ldots \ldots \ldots \ldots \ldots \ldots \ldots \ldots \ldots \ldots \ldots \ldots \ldots \ldots \ldots . \ldots . . \ldots .1$

4.7.1 Climate and Meteorology $\ldots \ldots \ldots \ldots \ldots \ldots \ldots \ldots \ldots \ldots \ldots . \ldots . \ldots .1$

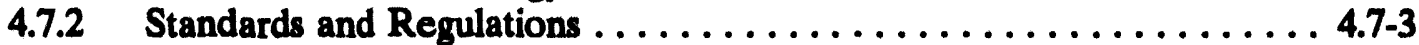

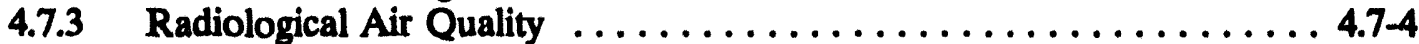

4.7.4 Nonradiological Conditions $\ldots \ldots \ldots \ldots \ldots \ldots \ldots \ldots \ldots \ldots .7 . \ldots \ldots$

4.8 Water Resources $\ldots \ldots \ldots \ldots \ldots \ldots \ldots \ldots \ldots \ldots \ldots \ldots \ldots \ldots . \ldots \ldots$. . . . . . . . . .

4.8.1 Surface Water . . . . . . . . . . . . . . . . . . . . $4.8-1$

4.8.2 Subsurface Water $\ldots \ldots \ldots \ldots \ldots \ldots \ldots \ldots \ldots \ldots \ldots \ldots . \ldots \ldots . . \ldots \ldots$

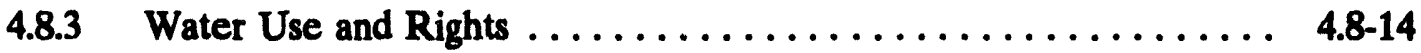

4.9 Ecological Resources $\ldots \ldots \ldots \ldots \ldots \ldots \ldots \ldots \ldots \ldots \ldots \ldots \ldots \ldots . \ldots \ldots$ 4.9.1

4.9.1 Flora $\ldots \ldots \ldots \ldots \ldots \ldots \ldots \ldots \ldots \ldots \ldots \ldots \ldots \ldots \ldots . \ldots \ldots . \ldots \ldots \ldots$

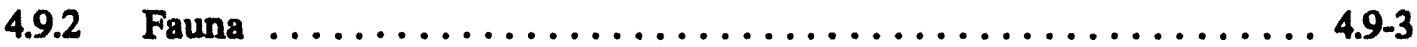

4.9.3 Threatened, Endangered, and Sensitive Species . . . . . . . . . 4.9-3

4.9.4 Wetlands ............................. 4.9.5

4.9.5 Radioecology $\ldots \ldots \ldots \ldots \ldots \ldots \ldots \ldots \ldots \ldots \ldots \ldots \ldots . \ldots \ldots$. $\ldots \ldots .6$

4.10 Noise $\ldots \ldots \ldots \ldots \ldots \ldots \ldots \ldots \ldots \ldots \ldots \ldots \ldots \ldots \ldots \ldots \ldots \ldots \ldots \ldots$

4.11 Traffic and Transportation $\ldots \ldots \ldots \ldots \ldots \ldots \ldots \ldots \ldots \ldots \ldots \ldots \ldots \ldots \ldots \ldots .11-1$

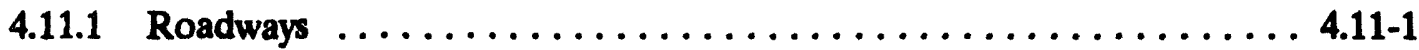

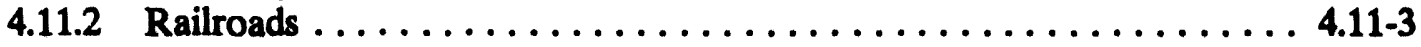

4.11.3 Airports and Air Traffic ...................... 4.11-5

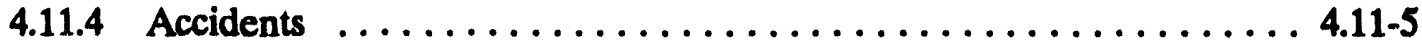

4.11.5 Transportation of Waste and Materials $\ldots \ldots \ldots \ldots \ldots \ldots \ldots . \ldots .11 .5$

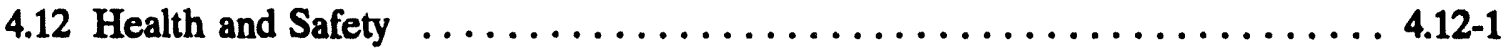

4.12.1 Public Health and Safety . . . . . . . . . . . . . . . . 4.12-1

4.12.2 Occupational Health and Safety . . . . . . . . . . . . . 4.12-11

4.13 Idaho National Engineering Laboratory Services $\ldots \ldots \ldots \ldots \ldots \ldots \ldots$. . . . . . . .

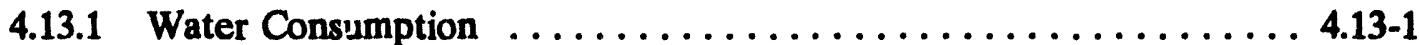

4.13.2 Electricity Consumption $\ldots \ldots \ldots \ldots \ldots \ldots \ldots \ldots \ldots \ldots \ldots \ldots . \ldots \ldots . . \ldots \ldots$ 
4.13.3 Fuel Consumption $\ldots \ldots \ldots \ldots \ldots \ldots \ldots \ldots \ldots \ldots \ldots \ldots, 4.13-2$

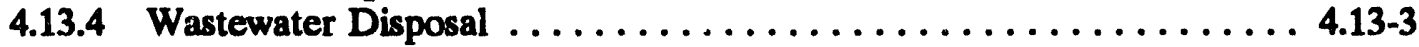

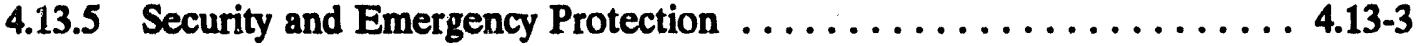

CHAPTER 5: ENVIRONMENTAL CONSEQUENCES $\ldots \ldots \ldots \ldots \ldots \ldots \ldots \ldots . .1 .1$

5.1 Introduction $\ldots \ldots \ldots \ldots \ldots \ldots \ldots \ldots \ldots \ldots \ldots \ldots \ldots \ldots \ldots \ldots \ldots \ldots \ldots \ldots \ldots \ldots, 1-1$

5.2 Land Use $\ldots \ldots \ldots \ldots \ldots \ldots \ldots \ldots \ldots \ldots \ldots \ldots \ldots \ldots \ldots \ldots \ldots \ldots \ldots \ldots, 2-1$

5.2.1 Methodology . . . . . . . .

5.2.2 Land Use Impacts from Alternative $A$ (No Action) .......... 5.2-1

5.2.3 Land Use Impacts from Alternative B (Ten-Year Plan) ......... 5.2-1

5.2.4 Land Use Impacts from Alternative C (Minimum Treatment,

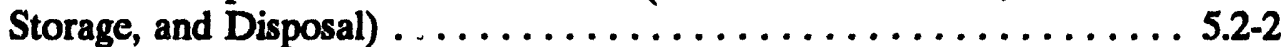

5.2.5 Land Use Impacts from Alternative D (Maximum Treatment,

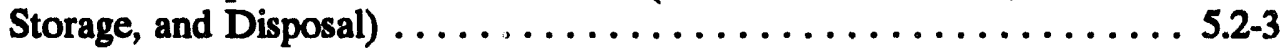

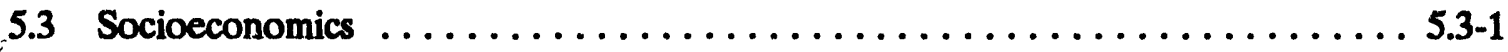

5.3.1 Methodology . . . . . . . . . . . .

5.3.2 Socioeconomic Impacts from Alternative $A$ (No Action) . . . . . . 5.3-2

5.3.3 Socioeconomic Impacts from Alternative B (Ten-Year Plan) ....... 5.3-7

5.3.4 Socioeconomic Impacts from Alternative $\mathrm{C}$ (Minimum Treatment, Storage, and Disposal) $\ldots \ldots \ldots \ldots \ldots \ldots \ldots \ldots \ldots .6 .3 .3-10$

5.3.5 Socioeconomic Impacts from Alternative $D$ (Maximum Treatment, Storage, and Disposal) $\ldots \ldots \ldots \ldots \ldots \ldots \ldots \ldots \ldots . . .3 .3-12$

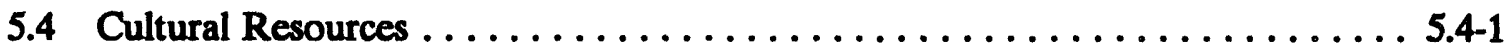

5.4.1 Methodology $\ldots \ldots \ldots \ldots \ldots \ldots \ldots \ldots \ldots \ldots \ldots \ldots \ldots . .6 .4$

5.4.2 Cultural Resource Impacts from Alternative A (No Action) ....... 5.4-2

5.4.3 Cultural Resource Impacts from Alternative B (Ten-Year Plan) .... 5.4-4

5.4.4 Cultural Resource Impacts from Alternative C (Minimum Treatment, Storage, and Disposal) $\ldots \ldots \ldots \ldots \ldots \ldots \ldots$. 5.4-5

5.4.5 Cultural Resource Impacts from Alternative D (Maximum Treatment, Storage, and Disposal) $\ldots \ldots \ldots \ldots \ldots \ldots \ldots \ldots . .6 .46$

5.5 Aesthetic and Scenic Resources .......................... 5.

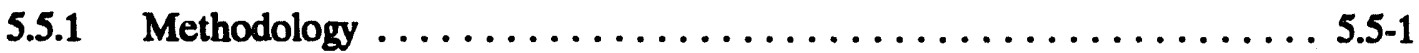

5.5.2 Aesthetic and Scenic Resource Impacts from Alternative A

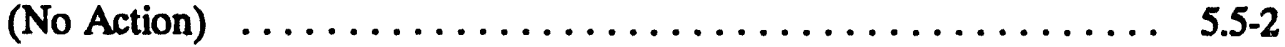

5.5.3 Aesthetic and Scenic Resource Impacts from Alternative B

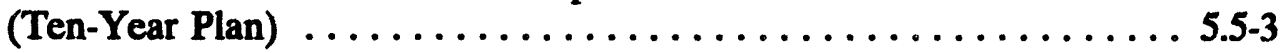

5.5.4 Aesthetic and Scenic Impacts from Alternative C (Minimum Treatment, Storage, and Disposal) . ................ 5.5.5

5.5.5 Aesthetic and Scenic Impacts from Alternative D (Maximum Treatment, Storage, and Disposal) $\ldots \ldots \ldots \ldots \ldots \ldots \ldots \ldots \ldots \ldots \ldots .5 .6$ 
5.6 Geology $\ldots \ldots \ldots \ldots \ldots \ldots \ldots \ldots \ldots \ldots \ldots \ldots \ldots \ldots \ldots \ldots \ldots .6 .6,1$

5.6.1 Methodology .............................. 5.6-1

5.6.2 Geologic Impacts from Alternatives $\ldots \ldots \ldots \ldots \ldots \ldots \ldots \ldots \ldots .6 .6-1$

5.7 Air Resources $\ldots \ldots \ldots \ldots \ldots \ldots \ldots \ldots \ldots \ldots \ldots \ldots \ldots \ldots \ldots \ldots . . \ldots \ldots .7 .1$

5.7.1 Methodology $\ldots \ldots \ldots \ldots \ldots \ldots \ldots \ldots \ldots \ldots \ldots \ldots \ldots \ldots, \ldots .7 .1$

5.7.2 Emission Rates . ............................ 5.7-4

5.7.3 Air Resource Impacts from Alternatives Due to Radiological

Sources ................................... 5.7-9

5.7.4 Air Resource Impacts from Alternatives Due to Nonradiological

Sources ............................... 5.7-16

5.7.5 Air Resource Impacts from Alternatives Due to Mobile Sources ... 5.7-29

5.7.6 Air Resource Impacts from Alternatives Due to Construction ..... 5.7-29

5.7.7 Air Resource Impacts from Alternatives Due to Specific Activities .. 5.7-30

5.8 Water Resources $\ldots \ldots \ldots \ldots \ldots \ldots \ldots \ldots \ldots \ldots \ldots \ldots \ldots \ldots . ., 5.8,1$

$5.8 .1 \quad$ Methodology . . . . . . . . . . . . . . . . . . . . . . 5.8-1

5.8.2 Water Resource Impacts from Alternative A (No Action) ........ 5.8-3

5.8.3 Water Resource Impacts from Alternative B (Ten-Year Plan) ...... 5.8-9

5.8.4 Water Resource Impacts from Alternative C (Minimum

Treatment, Storage and Disposal) $\ldots \ldots \ldots \ldots \ldots \ldots \ldots \ldots \ldots \ldots .6 .8 .11$

5.8.5 Water Resource Impacts from Alternative D (Maximum

Treatment, Storage and Disposal) $\ldots \ldots \ldots \ldots \ldots \ldots \ldots \ldots \ldots . .6 .8 .12$

5.8 .6 Conclusions $\ldots \ldots \ldots \ldots \ldots \ldots \ldots \ldots \ldots \ldots \ldots \ldots \ldots \ldots, 5.8-12$

5.9 Ecology $\ldots \ldots \ldots \ldots \ldots \ldots \ldots \ldots \ldots \ldots \ldots \ldots \ldots \ldots \ldots \ldots \ldots . .6 .9 .1$

5.9.1 Methodology ............................... 5.9.

5.9.2 Ecological Impacts from Alternative $A$ (No Action) ......... 5.9-1

5.9.3 Ecological Impacts from Aiternative B (Ten-Year Plan) $\ldots \ldots \ldots \ldots .9 .9-6$

5.9.4 Ecological Impacts from Alternative C (Minimum Treatment,

Storage, and Disposal) $\ldots \ldots \ldots \ldots \ldots \ldots \ldots \ldots \ldots \ldots \ldots \ldots$. 5.9.9

5.9.5 Ecological Impacts from Alternative D (Maximum Treatment,

Storage, and Disposal) $\ldots \ldots \ldots \ldots \ldots \ldots \ldots \ldots \ldots \ldots \ldots \ldots$. 5.9-9

5.10 Noise $\ldots \ldots \ldots \ldots \ldots \ldots \ldots \ldots \ldots \ldots \ldots \ldots \ldots \ldots \ldots \ldots \ldots . .6 .10 .1$

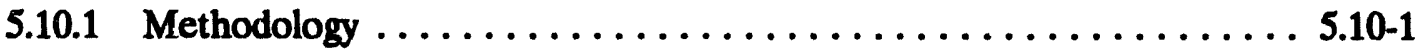

5.10.2 Noise Impacts from Alternatives $\ldots \ldots \ldots \ldots \ldots \ldots \ldots \ldots \ldots .6 \ldots \ldots .10,1$

5.11 Traffic and Transportation $\ldots \ldots \ldots \ldots \ldots \ldots \ldots \ldots \ldots \ldots \ldots \ldots \ldots \ldots \ldots \ldots \ldots, 11-1$

5.11 .1 Methodology $\ldots \ldots \ldots \ldots \ldots \ldots \ldots \ldots \ldots \ldots \ldots \ldots \ldots \ldots . .11-1$

5.11.2 Traffic and Transportation Impacts from Alternatives $\ldots \ldots \ldots \ldots . . \ldots .11-14$

5.12 Health and Safety $\ldots \ldots \ldots \ldots \ldots \ldots \ldots \ldots \ldots \ldots \ldots \ldots \ldots \ldots, \ldots \ldots \ldots, 12-1$ 
5.12.1 Health Effects to the Public and Worker from Releases to the Environment .......................... $5.12-4$

5.12.2 Occupational Health and Safety ................. $5.12-14$

5.13 Idaho National Engineering Laboratory Services $\ldots \ldots \ldots \ldots \ldots \ldots \ldots . . \ldots$. . . . . . .

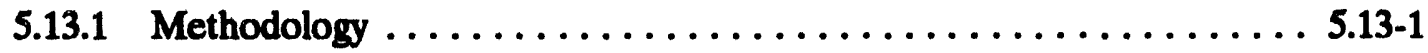

5.13.2 Idaho National Engineering Laboratory Services Impacts from

Alternative A (No Action) . . . . . . . . . . . . . . . 5.13-1

5.13.3 Idaho National Engineering Laboratory Services Impacts from

Alternative B (Ten-Year Plan) . . . . . . . . . . . . . . . .

5.13.4 Idaho National Engineering Laboratory Services Impacts from

Alternative C (Minimum Treatment, Storage, and Disposal) . . . . . 5.13-4

5.13.5 Idaho National Engineering Laboratory Services Impacts from

Alternative D (Maximum Treatment, Storage, and Disposal) ... . . 5.13-5

5.13.6 Summary of Impacts from Alternatives $\ldots \ldots \ldots \ldots \ldots \ldots \ldots . \ldots \ldots$

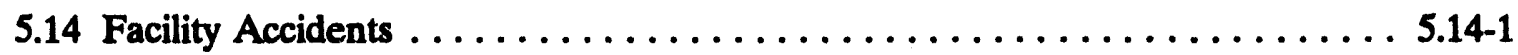

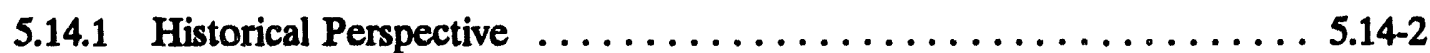

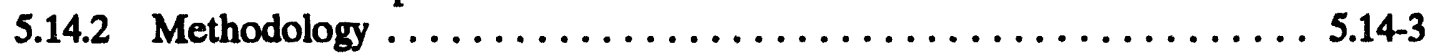

5.14.3 Impacts from Alternative $A$ (No Action) . . . . . . . . . . 5.14-11

5.14.4 Impacts from Alternative B (Ten-Year Plan) . . . . . . . . . 5.14-22

5.14.5 Impacts from Alternative C (Minimum Treatment, Storage, and Disposal $) \ldots \ldots \ldots \ldots \ldots \ldots \ldots \ldots \ldots \ldots \ldots \ldots \ldots \ldots \ldots \ldots \ldots \ldots .14-27$

5.14.6 Impacts from Alternative D (Maximum Treatment, Storage,

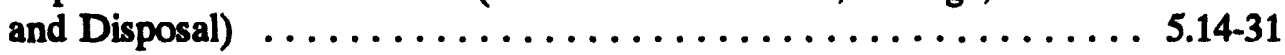

5.15 Cumulative Impacts and Impacts from Connected or Similar Actions . . . . . 5.15-1

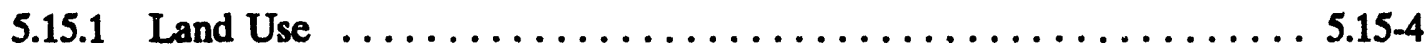

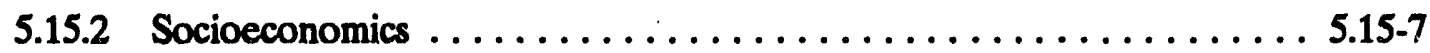

5.15 .3 Cultural Resources $\ldots \ldots \ldots \ldots \ldots \ldots \ldots \ldots \ldots \ldots \ldots \ldots \ldots . \ldots \ldots . \ldots \ldots \ldots$

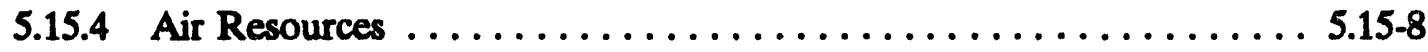

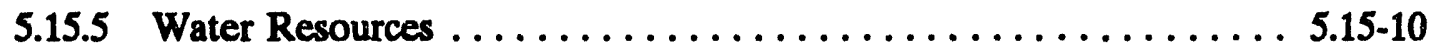

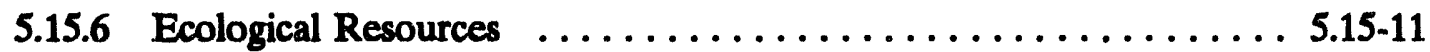

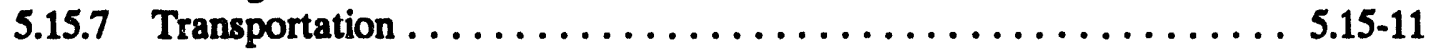

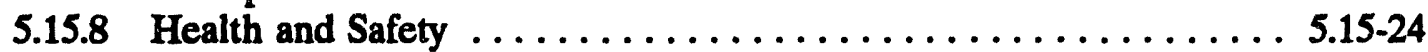

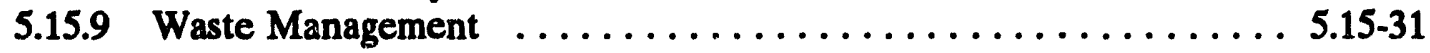

5.16 Adverse Environmental Effects Which Cannot Be Avoided ......... 5.16-1

5.16 .1 Cultural Resources $\ldots \ldots \ldots \ldots \ldots \ldots \ldots \ldots \ldots \ldots \ldots \ldots .16 .1$

5.16 .2 Aesthetic and Scenic Resources ................. 5.16-2

5.16 .3 Air Resources ......................... 5.16-2

5.16 .4 Water Resources ......................... 5.16-2

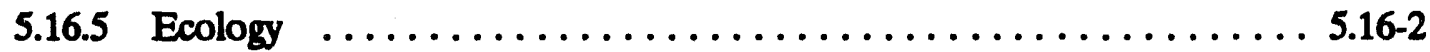

5.17 Relationship Between Short-Term Use of the Environment and the Maintenance and Enhancement of Long-Term Productivity ......... 5.17-1 
5.17 .1 Alternative A (No Action) $\ldots \ldots \ldots \ldots \ldots \ldots \ldots \ldots \ldots . \ldots \ldots . \ldots \ldots$

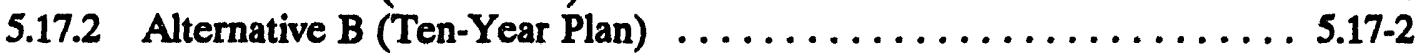

5.17.3 Alternative C (Minimum Treatment, Storage, and Disposal) . . . . . 5.17-3

5.17.4 Alternative D (Maximum Treatment, Storage, and Disposal) . . . . . 5.17-4

5.18 Irreversible and Irretrievable Commitments of Resources $\ldots \ldots \ldots \ldots \ldots . \ldots .18-1$

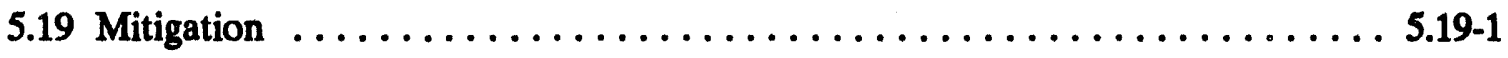

5.19 .1 Cultural Resources $\ldots \ldots \ldots \ldots \ldots \ldots \ldots \ldots \ldots \ldots \ldots \ldots \ldots . \ldots \ldots .19 .1$

5.19.2 Aesthetic and Scenic Resources . . . . . . . . . . . . . 5.19-3

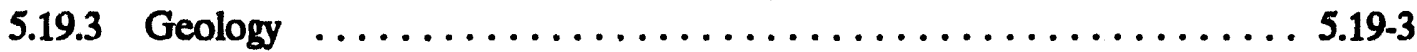

5.19 .4 Air Resources . . . . . . . . . . . . . . . . . . 5.19-4

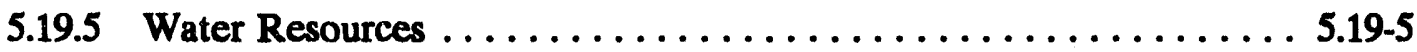

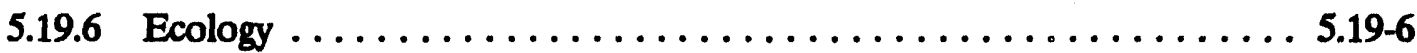

5.19 .7 Transportation $\ldots \ldots \ldots \ldots \ldots \ldots \ldots \ldots \ldots \ldots \ldots \ldots \ldots \ldots . \ldots \ldots . \ldots \ldots$

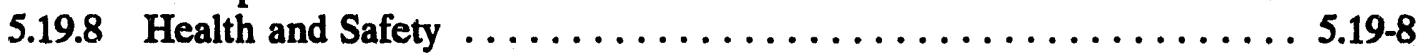

5.19.9 Idaho National Engineering Laboratory Services . . . . . . . . . . 5.19.8

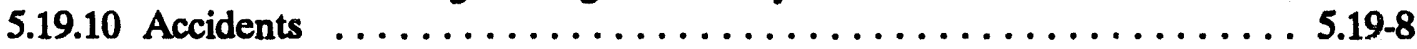

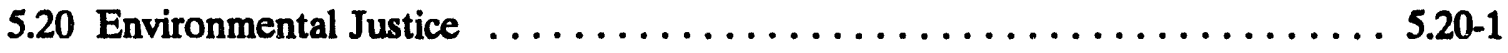

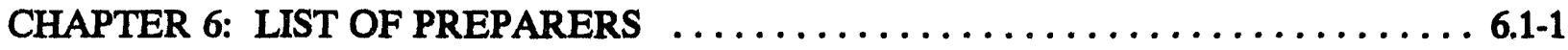

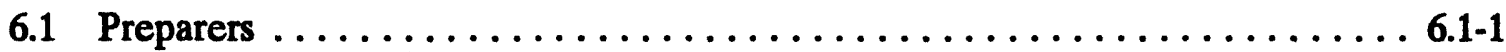

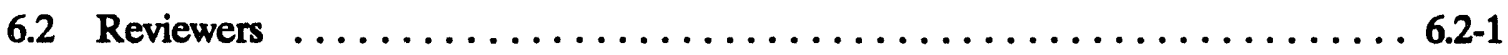

CHAPTER 7: CONSULTATIONS AND ENVIRCNMENTAL REQUIREMENTS $\quad \ldots \quad$ 7.1-1

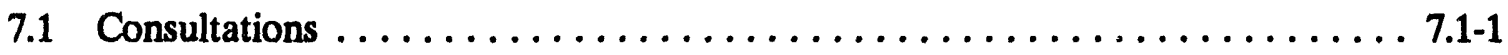

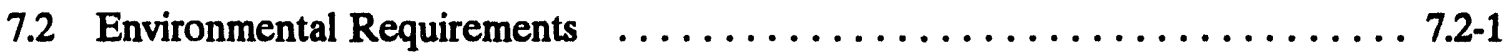

7.2.1 Federal Environmental Statutes and Regulations $\ldots \ldots \ldots \ldots \ldots \ldots$ 7.2-1

7.2.2 Executive Orders ........................ 7.2-12

7.2.3 Department of Energy Regulations and Orders .......... 7.2-14

7.2.4 Idaho Laws and Regulations . . . . . . . . . . . . . . . . .

7.2.5 Compliance Status at Idaho National Engineering Laboratory . . . . . 7.2-21

7.3 Environmental Permits and Licenses $\ldots \ldots \ldots \ldots \ldots \ldots \ldots \ldots \ldots \ldots \ldots \ldots \ldots$

CHAPTER 8: INDEX $\ldots \ldots \ldots \ldots \ldots \ldots \ldots \ldots \ldots \ldots \ldots \ldots \ldots \ldots \ldots$

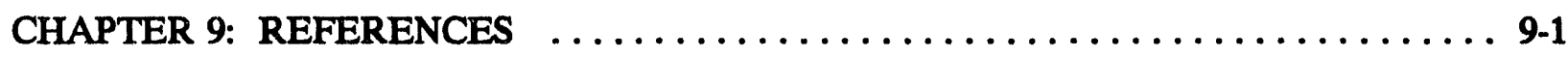




\section{Part B}

APPENDIX A: PRIMER ON RADIOACTIVITY AND TOXICOLOGY $\ldots \ldots \ldots \ldots$ A-1 APPENDIX B: CONSULTATION LETTERS $\ldots \ldots \ldots \ldots \ldots \ldots \ldots \ldots \ldots$ B-1 APPENDIX C: INFORMATION SUPPORTING THE ALTERNATIVES $\ldots \ldots \ldots \ldots$ C-1 APPENDIX D: ACRONYMS AND ABBREVIATIONS $\ldots \ldots \ldots \ldots \ldots \ldots \ldots$ D-1

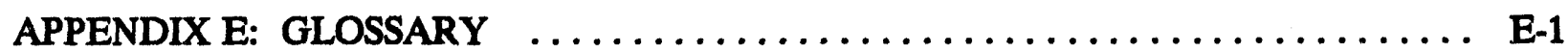
APPENDIX F: TECHNICAL METHODOLOGIES AND KEY DATA $\ldots \ldots \ldots \ldots \ldots$ F-1

F-1 Socioeconomics $\ldots \ldots \ldots \ldots \ldots \ldots \ldots \ldots \ldots \ldots \ldots \ldots \ldots \ldots \ldots, \ldots, 1-1$

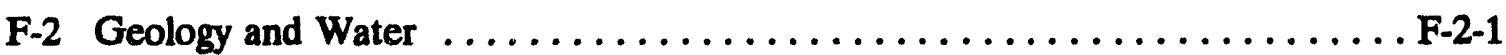

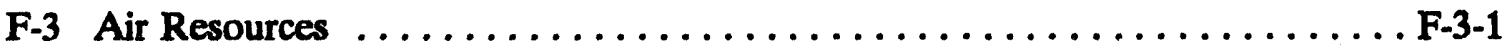

F-4 Health and Safety $\ldots \ldots \ldots \ldots \ldots \ldots \ldots \ldots \ldots \ldots \ldots \ldots \ldots \ldots \ldots \ldots \ldots \ldots,-1$

F-5 Facility Accidents $\ldots \ldots \ldots \ldots \ldots \ldots \ldots \ldots \ldots \ldots \ldots \ldots \ldots \ldots \ldots \ldots \ldots \ldots \ldots \ldots$, F-5-1 


\section{FIGURES}

2.1-1. Comments and issues raised during the comment periods $\ldots \ldots \ldots \ldots \ldots$ 2.1-12

2.2-1. Location of the Idaho National Engineering Laboratory in southeastern

Idaho .................................. $2.2-2$

2.2-2. Major facility areas located at the Idaho National Engineering Laboratory

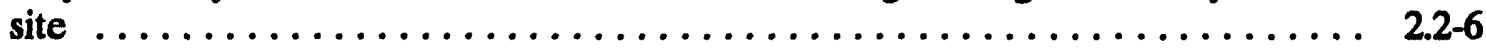

2.2-3. Current spent nuclear fuel management program at the Idaho National

Engineering Laboratory $\ldots \ldots \ldots \ldots \ldots \ldots \ldots \ldots \ldots \ldots \ldots \ldots \ldots \ldots \ldots \ldots . \ldots \ldots$

2.2-4. Flow chart of remedial action process at the Idaho National Engineering

Laboratory ................................ 2.25

2.2-5. Current high-level waste management program at the Idaho National

Engineering Laboratory . . . . . . . . . . . . . . 2.32

2.2-6. Current transuranic waste management program at the Idaho National

Engineering Laboratory . . . . . . . . . . . . . . . . . . . . . . .

2.2-7. Current low-level waste management program at the Idaho National

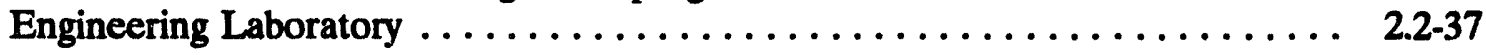

2.2-8. Current mixed low-level waste management program at the Idaho National

Engineering Laboratory . . . . . . . . . . . . . . . . . . . . . 2.39

2.2-9. Current hazardous waste management program at the Idaho National

Engineering Laboratory . . . . . . . . . . . . . . . . . . . . . 2.2-43

2.2-10. Current industrial commercial waste management program at the Idaho

National Engineering Laboratory . . . . . . . . . . . . . 2.45

3.0-1. The basic management decisions for spent nuclear fuel and waste $\ldots \ldots \ldots \ldots$ 3.0-2

3.1-1. The Idaho National Engineering Laboratory location of projects associated with proposed alternatives $\ldots \ldots \ldots \ldots \ldots \ldots \ldots \ldots \ldots \ldots \ldots .1-4$

3.1-2. Spent nuclear fuel: Idaho National Engineering Laboratory locations of projects associated with proposed alternatives $\ldots \ldots \ldots \ldots \ldots \ldots \ldots \ldots$

3.1-3. Management of spent nuclear fuel at the Idaho National Engineering Laboratory under the proposed Alternative A (No Action) . . . . . . . . . 3.1-12

3.1-4. Management of spent nuclear fuel at the Idaho National Engineering Laboratory under the proposed Alternative B (Ten-Year Plan) and Alternative D (Maximum Treatment, Storage, and Disposal) . . . . . . . 3.1-13 
3.1-5. Management of spent nuclear fuel at the Idaho National Engineering Laboratory under the proposed Alternative C (Minimum Treatment,

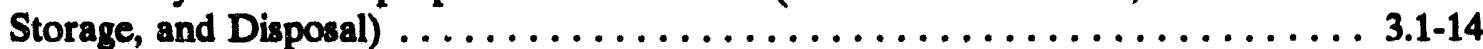

3.1-6. Spent nuclear fuel volumes at the Idaho National Engineering Laboratory for 1995, 2005, and 2035 under the proposed alternatives: Alternative A (No Action), Alternative B (Ten-Year Plan), Alternative C (Minimum Treatment, Storage, and Disposal), and Alternative D (Maximum Treatment,

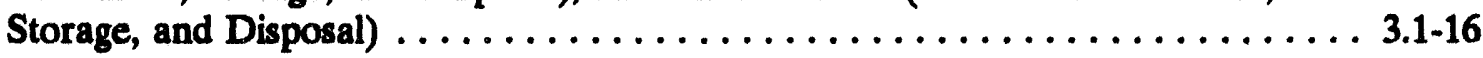

3.1-7. Management of remediation activities at the Idaho National Engineering Laboratory under the proposed alternatives: Alternative A (No Action), Alternative B (Ten-Year Plan), Alternative C (Minimum Treutment, Storage, and Disposal), and Alternative D (Maximum Treatment, Storage, and Disposal)

3.1-8. Environment restoration: Idaho National Engineering Laboratory locations of projects associated with proposed alternatives

3.1-9. Management of decontamination and decommissioning (D\&D) activities at the Idaho National Engineering Laboratory under the proposed alternatives: Alternative A (No Action), Alternative B (Ten-Year Plan), Alternative C (Minimum Treatment, Storage, and Disposal), and Alternative D (Maximum Treatment, Storage, and Disposal) $\ldots \ldots \ldots \ldots \ldots \ldots \ldots \ldots \ldots \ldots \ldots \ldots \ldots \ldots \ldots \ldots \ldots .1-21$

3.1-10. High-level waste: Idaho National Engineering Laboratory locations of projects associated with proposed alternatives

3.1-11. High-level waste volumes at the Idaho National Engineering Laboratory under the proposed alternatives: Alternative A (No Action), Alternative B (Ten-Year Plan), Alternative $C$ (Minimum Treatment, Storage, and Disposal), and Alternative D (Maximum Treatment, Storage, and Disposal) . . . . . . . 3.1-26

3.1-12. Management of high-level waste at the Idaho National Engineering Laboratory under the proposed Alternative A (No Action) . . . . . . . . . . . . . 3.1-29

3.1-13. Management of high-level waste at the Idaho National Engineering Laboratory under the proposed Alternative B (Ten-Year Plan) $\ldots \ldots \ldots \ldots \ldots \ldots \ldots \ldots .1 . \ldots \ldots$

3.1-14. Management of high-level waste at the Idaho National Engineering Laboratory under the proposed Alternative C (Minimum Treatment, Storage, and Disposal)

3.1-15. Management of high-level waste at the Idaho National Engineering Laboratory under the proposed Alternative D (Maximum Treatment, Storage,and Disposal)

3.1-16. Transuranic waste: Idaho National Engineering Laboratory locations of projects associated with proposed alternatives 
3.1-17. Transuranic waste volumes at the Idaho National Engineering Laboratory under the proposed alternatives: Alternative A (No Action), Alternative B (Ten-Year Plan), Alternative C (Minimum Treatment, Storage, and Disposal), and Alternative D (Maximum Treatment, Storage, and Disposal) . . . . . . . . 3.1-41

3.1-18. Management of transuranic waste at the Idaho National Engineering Laboratory under the proposed Alternative A (No Action) $\ldots \ldots \ldots \ldots \ldots \ldots \ldots \ldots \ldots .1 .41$

3.1-19. Management of transuranic waste at the Idaho National Engineering Laboratory under the proposed Alternative B (Ten-Year Plan) . . . . . . . . . . . 3.1-43

3.1-20. Management of transuranic waste at the Idaho National Engineering Laboratory under the proposed Alternative C (Minimum Treatment, Storage, and Disposal) ...................................... 3.1-44

3.1-21. Management of transuranic waste at the Idaho National Engineering Laboratory under Alternative D (Maximum Treatment, Storage, and Disposal) . . . . . . . 3.1-45

3.1-22. Low-level waste: Idaho National Engineering Laboratory locations of projects associated with proposed alternatives $\ldots \ldots \ldots \ldots \ldots \ldots \ldots \ldots \ldots \ldots \ldots \ldots \ldots$

3.1-23. Management of low-level waste at the Idaho National Engineering Laboratory under the proposed Alternative A (No Action) . . . . . . . . . . . . . . .

3.1-24. Management of low-level waste at the Idaho National Engineering Laboratory under the proposed Alternative B (Ten-Year Plan) . . . . . . . . . . . 3.1-51

3.1-25. Management of low-level waste at the Idaho National Engineering Laboratory under the proposed Alternative $\mathrm{C}$ (Minimum Treatment, Storage, and Disposal)

3.1-26. Management of low-level waste at the Idaho National Engineering Laboratory under the proposed Alternative $D \ldots \ldots \ldots \ldots \ldots \ldots \ldots \ldots \ldots \ldots \ldots \ldots \ldots \ldots . \ldots \ldots$

3.1-27. Low-level waste volumes at the Idaho National Engineering Laboratory under the proposed alternatives: Alternative A (No Action), Alternative B (Ten-Year Plan), Alternative C (Minimum Treatment, Storage, and Disposal), and Alternative D (Maximum Treatment, Storage, and Disposal) . . . . . . . . 3.1-54

3.1-28. Mixed low-level waste: Idaho National Engineering Laboratory locations of projects associated with proposed alternatives $\ldots \ldots \ldots \ldots \ldots \ldots \ldots \ldots \ldots .1 .58$

3.1-29. Management of mixed low-level waste at the Idaho National Engineering Laboratory under the proposed Alternative A (No Action) . . . . . . . . . 3.1-59

3.1-30. Management of mixed low-level waste at the Idaho National Engineering Laboratory under the proposed Alternative B (Ten-Year Plan) $\ldots \ldots \ldots \ldots \ldots$ 3-59 
3.1-31. Management of mixed low-level waste at the Idaho National Engineering Laboratory under the proposed Alternative $\mathbf{C}$ (Minimum Treatment, Storage,

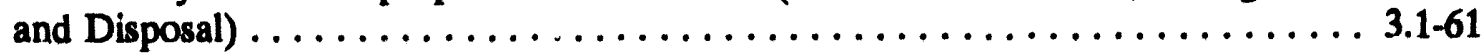

3.1-32. Management of mixed low-level waste at the Idaho National Engineering Laboratory under the proposed Alternative D (Maximum Treatment, Storage, and Disposal) $\ldots \ldots \ldots \ldots \ldots \ldots \ldots \ldots \ldots \ldots \ldots \ldots \ldots \ldots \ldots \ldots \ldots \ldots \ldots \ldots$

3.1-33. Mixed low-level waste volumes at the Idaho National Engineering Laboratory under the proposed alternatives: Alternative A (No Action), Alternative B (Ten-Year Plan), Alternative C (Minimum Treatment, Storage, and Disposal), and Alternative $\mathrm{D}$ (Maximum Treatment, Storage, and Disposal) . . . . . . . 3.1-63

3.1-34. Great-than-Class-C and hazardous waste: Idaho National Engineering Laboratory locations of projects associated with proposed alternatives . . . . . 3.1-65

3.1-35. Management of hazardous waste at the Idaho National Engineering Laboratory under the proposed alternatives: Alternative A (No Action), Alternative B (Ten-Year Plan), Alternative C (Minimum Treatment, Storage, and Disposal), and Alternative D (Maximum Treatment, Storage, and Disposal) . . . . . . 3.1-68

3.1-36. Infrastructure: Idaho National Engineering Laboratory locations of projects associated with proposed alternatives $\ldots \ldots \ldots \ldots \ldots \ldots \ldots \ldots \ldots \ldots \ldots \ldots \ldots \ldots \ldots .1-70$

3.1-37. Technology development: Idaho National Engineering Laboratory locations of projects associated with proposed alternatives $\ldots \ldots \ldots \ldots \ldots \ldots \ldots \ldots \ldots .1 .72$

4.2-1. Idaho National Engineering Laboratory site vicinity map $\ldots \ldots \ldots \ldots \ldots . \ldots .2$

4.2-2. Selected land uses at the Idaho National Engineering Laboratory and in the surrounding region.

4.3-1. Historical and projected employment at the Idaho National Engineering Laboratory . . . . . . . . . . . . . . . . . . . . .

4.3-2. Historical and projected funding at the Idaho National Engineering Laboratory

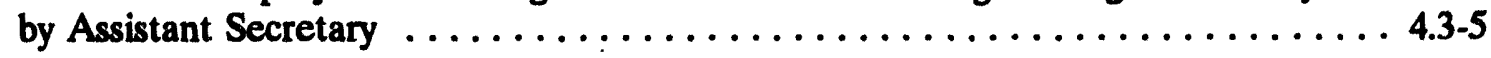

4.3-3. Historical and projected total population for the counties of the region of influence surrounding the Idaho National Engineering Laboratory from 1940

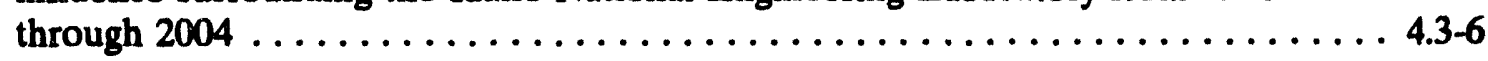

4.6-1. Geologic features in the region of the Idaho National Engineering Laboratory

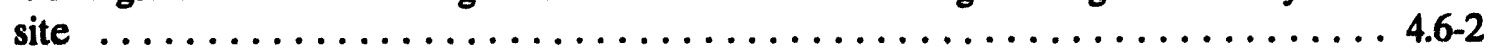

4.6-2. Lithologic logs of deep drill holes on the Idaho National Engineering Laboratory site

4.6-3. Historical earthquakes in the Idaho National Engineering Laboratory region with magnitudes greater than 2.5 (1884 to 1989$) \ldots \ldots \ldots \ldots \ldots \ldots \ldots .6 .6 .5$ 
4.6-4. Contribution of the various seismic sources to the mean peak acceleration at the Idaho Chemical Processing Plant $\ldots \ldots \ldots \ldots \ldots \ldots \ldots \ldots \ldots \ldots . \ldots \ldots$

4.7-1. Annual average wind direction and speed at meteorological monitoring stations on the Idaho National Engineering Laboratory site $\ldots \ldots \ldots \ldots \ldots \ldots \ldots \ldots . . \ldots$ 4.2

4.7-2. Overview of Federal, State and U.S. Department of Energy programs for air quality management $\ldots \ldots \ldots \ldots \ldots \ldots \ldots \ldots \ldots \ldots \ldots \ldots \ldots \ldots . \ldots \ldots$

4.7-3. Comparison of radiation dose to the maximally exposed individual (due to current and foreseeable radiological emissions at the Idaho National Engineering Laboratory site) to the National Emission Standard for Hazardous Air Pollutants dose limit and the dose from background sources .

4.7-4 Comparison of actual hourly emission rates from criteria and toxic air pollutants at the Idaho National Engineering Laboratory site with the annual rates assumed for the maximum emissions scenario

4.8-1. Locations of selected Idaho National Engineering Laboratory site facilities shown with the predicted inundation area for the probable maximum floodinduced overtopping failure of the Mackay Dam

4.8-2. Location of the Idaho National Engineering Laboratory site, Snake River Plain, and generalized groundwater flow direction of the Snake River Plain Aquifer ... 4.8-6

4.9-1. Approximate distribution of vegetation map at the Idaho National Engineering Laboratory site.

4.11-1. Transportation routes in the vicinity of the Idaho National Engineering Laboratory

5.3-1. Total direct and secondary employment by alternatives in region of influence surrounding the Idaho National Engineering Laboratory $\ldots \ldots \ldots \ldots \ldots \ldots . . \ldots$

5.7-1. Comparison of criteria pollutant emission rates at the Idaho National Engineering Laboratory site for alternatives

5.7-2. Cumulative dose for the maximally exposed offsite individual, worker, and total population due to Idaho National Engineering Iaboratory site emissions

5.7-3. Maximum estimated criteria pollutant impacts at the Idaho National Engineering Laboratory site boundary locations by alternative as percentages of the National Ambient Air Quality Standards

5.7-4. Summary of modeling results for visual degradation at the Idaho National Engineering Laboratory site by alternative

5.13-1. Total area of new buildings at the Idaho National Engineering

Laboratory under all the alternatives 
5.13-2. A summary of peak utility usage increases above baseline at the Idaho National Engineering Laboratory for all alternatives

5.14-1. Comparison of fatality rates among workers in various industry groups $\ldots \ldots \ldots .14-3$

5.14-2. Potential radiation exposures from accidents to individual at nearest Idaho National Engineering Laboratory site boundary for Alternative A

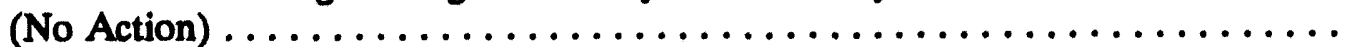

5.14-3. Risk of fatal cancer to individual at nearest Idaho National Engineering Laboratory site boundary from radiation accidents for Alternative A (No Action)

5.14-4. Excess fatal cancers in exposed population from radiation accidents at Idaho National Engineering Laboratory facilities for Alternative $\mathbf{A}$ (No Action)

5.14-5. Potential maximum hazardous chemical concentrations at nearest Idaho National Engineering Laboratory site boundary as a percentage of ERPG3 concentration for Alternative A (No Action)

5.14-6. Potential radiation exposures from accidents to individual at nearest Idaho National Engineering Laboratory site boundary for Alternative B (Ten-Year Plan)

5.14-7. Risk of fatal cancer to individual at nearest Idaho National Engineering Laboratory site boundary from radiation accidents for Alternative B (Ten-Year Plan) . . . . . . . . . . . . . . . . . .

5.14-8. Excess fatal cancers in exposed population from radiation accidents at Idaho National Engineering Laboratory facilities for Alternative B (Ten-Year Plan) $\ldots \ldots \ldots \ldots \ldots \ldots \ldots \ldots \ldots \ldots \ldots \ldots \ldots \ldots \ldots \ldots \ldots \ldots \ldots \ldots$

5.14-9. Potential radiation exposures from accidents to individual at nearest Idaho National Engineering Laboratory site boundary for Alternative C (Minimum Treatment, Storage, and Disposal) $\ldots \ldots \ldots \ldots \ldots \ldots$

5.14-10. Risk of fatal cancer to individual at nearest Idaho National Engineering Laboratory site boundary from radiation accidents for Alternative C (Minimum Treatment, Storage, and Disposal) $\ldots \ldots \ldots \ldots \ldots \ldots$

5.14-11. Excess fatal cancers in exposed population from radiation accidents at Idaho National Engineering Laboratory facilities for Alternative $\mathbf{C}$ (Minimum Treatment, Storage, and Disposal)

5.14-12. Potential radiation exposures from accidents to individual at nearest Idaho National Engineering Laboratory site boundary for Alternative D (Maximum Treatment, Storage, and Disposal) 
5.14-13. Risk of fatal cancer to individual at nearest Idaho National Engineering Laboratory site boundary from radiation accidents for Alternative D (Maximum Treatment, Storage, and Disposal) $\ldots \ldots \ldots \ldots \ldots \ldots \ldots \ldots . \ldots \ldots$ 5.14-34

5.14-14. Excess fatal cancers in exposed population from radiation accidents at Idaho National Engineering Laboratory facilities for Alternative D (Maximum Treatment, Storage, and Disposal)

5.15-1. Annual quantity of radionuclides released at the Idaho National Engineering

Laboratory for operational releases $5.15-28$ 


\section{TABLES}

2.1-1. National Environmental Policy Act reviews related to the site-specific decision, including environmental impact statements and environmental assessments . . . . 2.1-8

2.2-1. Corrective actions addressing spent nuclear fuel storage vulnerabilities at the Idaho National Engineering Laboratory . . . . . . . . . . . . . . . . . 2.2-17

2.2-2. Waste types and contaminants located at Waste Area Groups at the Idaho National Engineering Laboratory . . . . . . . . . . . . . . . . . 2.2-28

3.1-1. Projects at the Idaho National Engineering Laboratory associated with the

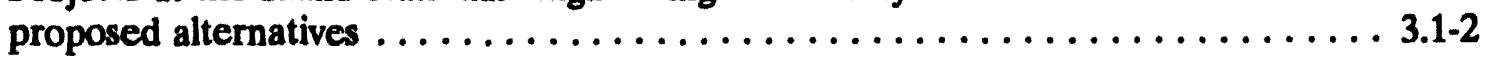

3.1-2. Spent nuclear fuel: Summary of proposed management functions and related projects (denoted by bullets) at the Idaho National Engineering Laboratory

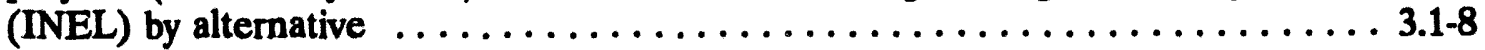

3.1-3. Environmental restoration: Summary of proposed management functions and related projects (denoted by bullets) at the Idaho National Engineering Laboratory (INEL) by alternative $\ldots \ldots \ldots \ldots \ldots \ldots \ldots \ldots \ldots \ldots \ldots \ldots \ldots . \ldots \ldots$

3.1-4. Summary of proposed waste management activities at the Idaho National Engineering Laboratory (INEL) by alternative . . . . . . . . . . . . . . 3.1-24

3.1-5. High-level waste: Summary of proposed management functions and related projects (denoted by bullets) at the Idaho National Engineering Laboratory (INEL) by alternative

3.1-6. Transuranic waste: Summary of proposed management functions and related projects (denoted by bullets) at the Idaho National Engineering Laboratory

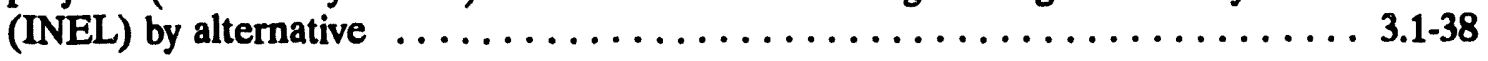

3.1-7. Low-level waste: Summary of proposed management functions and related projects (denoted by bullets) at the Idaho National Engineering Laboratory

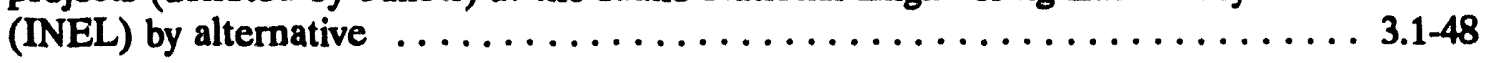

3.1-8. Mixed low-level waste: Summary of proposed management functions and related projects (denoted by bullets) at the Idaho National Engineering Laboratory (INEL) by alternative

3.1-9. Hazardous waste: Summary of proposed management functions and related projects (denoted by bullets) at the Idaho National Engineering Laboratory

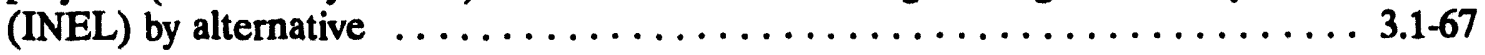

3. -1. Comparison of projected environmental consequences at the Idaho National Engineering Laboratory by alternative $\ldots \ldots \ldots \ldots \ldots \ldots \ldots \ldots \ldots \ldots \ldots \ldots \ldots \ldots .3 .2$ 
4.3-1. Historical labor force and unemployment rates for counties and the region of influence surrounding the Idaho National Engineering Laboratory . . . . . . . . . 4.3-2

4.3-2. Projected labor force, employment, and population in the region of influence surrounding the Idaho National Engineering Laboratory . . . . . . . . . 4.3-2

4.3-3. Number of housing units, vacancy rates, median house value, and median monthly rent by county and the region of influence surrounding the Idaho National Engineering Laboratory $\ldots \ldots \ldots \ldots \ldots \ldots \ldots \ldots \ldots \ldots \ldots \ldots \ldots \ldots$

4.3-4. Summary of public services available in the region of influence surrounding the Idaho National Engineering Laboratory . . . . . . . . . . . . . . . 4.3-9

4.3-5. Total revenues and expenditures by county in the region of influence surrounding the Idaho National Engineering Laboratory for Fiscal Year 1991 . . .

4.7-1. Summary of airborne radionuclide emissions (in curies) from facility areas at the Idaho National Engineering Laboratory site $\ldots \ldots \ldots \ldots \ldots \ldots \ldots$

4.7-2. Annual average and maximum hourly emission rates of nonradiological air pollutants for the actual and maximum baseline cases at the Idaho National

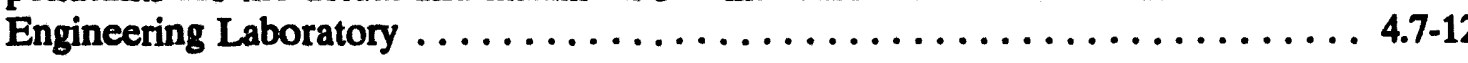

4.7-3. Highest predicted concentrations of toxic air pollutants at onsite locations for the maximum baseline case at the Idaho National Engineering Laboratory site, including foreseeable increases

4.7-4. Ambient air concentrations of criteria pollutants for the maximum baseline scenario at the Idaho National Engineering Laboratory site, including foreseeable increases

4.7-5. Highest predicted concentrations of carcinogenic air pollutants at site boundary locations for the maximum baseline case at the Idaho National Engineering Laboratory site, including foreseeable increases

4.7-6. Highest predicted eight-hour concentration of noncarcinogenic toxic air pollutants at site boundaries and public road locations at the Idaho National Engineering Laboratory site, including foreseeable increases $\ldots \ldots \ldots \ldots \ldots \ldots \ldots$. . . . . . . .

4.8-1. Summary of highest detected contaminant concentrations in groundwater within the Idaho National Engineering Laboratory site (1985 to 1992) . . . . . . . .

4.9-1. Threatened and endangered species, species of special concern, and sensitive species that may be found on the Idaho National Engineering Laboratory site . . . 4.9-4

4.11-1. Baseline traffic for selected highway segments in the vicinity of the Idaho National Engineering Laboratory site .

4.11-2 Baseline annual vehicle miles traveled for traffic related to the Idaho National Engineering Laboratory site 
4.11-3. Loaded rail shipments to and from the Idaho National Engineering Laboratory site $(1988-1992) \ldots \ldots \ldots \ldots \ldots \ldots \ldots \ldots \ldots \ldots \ldots \ldots \ldots \ldots \ldots \ldots . . \ldots \ldots \ldots$

4.11-4. Cumulative doses and fatalities from incident-free onsite shipments at the Idaho National Engineering Laboratory site for 1995 to 2005 . . . . . . . . . . . 4.11-6

4.12-1. Lifetime excess fatal cancer risk due to annual exposure to routine airborne releases at the Idaho National Engineering Laboratory site . . . . . . . . . . 4.12-2

4.12-2. Increased population risk of developing excess fatal cancers due to routine airborne releases at the Idaho National Engineering Laboratory site . . . . . . 4.12-2

4.12-3. Hazard quotients for highest predicted concentrations of noncarcinogenic toxic air pollutants at Idaho National Engineering Laboratory site locations for the maximum baseline case, including foreseeable increases $\ldots \ldots \ldots \ldots \ldots$ 4.12-4

4.12-4. Hazard quotients for highest predicted concentrations of carcinogenic toxic air pollutants at Idaho National Engineering Laboratory site locations for the maximum baseline case, including foreseeable increases $\ldots \ldots \ldots \ldots \ldots .4 .12 .5$

4.12-5. Hazard quotients for highest predicted noncarcinogenic toxic air pollutant concentrations at Idaho National Engineering Laboratory-eight-hour site boundary and public road exposures $\ldots \ldots \ldots \ldots \ldots \ldots \ldots \ldots \ldots \ldots \ldots . \ldots \ldots$

4.12-6. Excess cancer risk based on 70-year exposure to the highest predicted concentrations of carcinogenic air pollutants at Idaho National Engineering Laboratory site boundary locations $\ldots \ldots \ldots \ldots \ldots \ldots \ldots \ldots \ldots \ldots \ldots . \ldots \ldots$

4.12-7. Hazard quotients for ambient air concentrations of criteria pollutants for the maximum baseline scenario at Idaho National Engineering Laboratory site, including foreseeable increases

4.12-8. Exposure-to-dose conversion factors for selected radionuclides . . . . . . . . 4.12-10

5.3-1. Net and cumulative employment and population impacts on the region of influence surrounding the Idaho National Engineering Laboratory by alternative and fiscal year

5.3-2. Impacts on the po National Engineering Laboratory for baseline and alternatives by fiscal year . . . . 5.3-6

5.4-1. Potential impacts to cultural resources at the Idaho National Engineering Laboratory site by project and alternative

5.6-1. Estimated extraction volumes from gravel and borrow pits on the Idaho National Engineering Laboratory site by alternative. . . . . . . . . . . 5.6-2

5.7-1. Summary of radionuclide emissions at the Idaho National Engineering site by alternative and source group $\ldots \ldots \ldots \ldots \ldots \ldots \ldots \ldots \ldots \ldots \ldots \ldots . \ldots \ldots$ 
5.7-2. Summary of criteria pollutant emission rates at the Idaho National

Engineering Laboratory site by alternative and source group $\ldots \ldots \ldots \ldots \ldots \ldots$. $\ldots \ldots$.7

5.7-3. Maximum hourly and annual average emissions of toxic air pollutants at the Idaho National Engineering Laboratory site by alternative . . . . . . . . . 5.7-10

5.7-4. Cumulative dose from airborne emissions at the Idaho National Engineering Laboratory site by alternative and source group $\ldots \ldots \ldots \ldots \ldots \ldots \ldots . \ldots \ldots$. $\ldots \ldots$

5.7-5. Maximum concentrations of criteria pollutants at public access locations at the Idaho National Engineering Laboratory site by alternative . . . . . . . . 5.7-17

5.7-6. Highest predicted concentrations of carcinogenic toxic air pollutants at Idaho National Engineering Laboratory site boundary locations, including cumulative impacts of altenatives and the maximum baseline case $\ldots \ldots \ldots \ldots \ldots \ldots \ldots .7 .20$

5.7-7. Highest predicted eight-hour concentrations of noncarcinogenic toxic air pollutants at the Idaho National Engineering Laboratory site boundary and public roads, including cumulative impacts of alternatives and the maximum

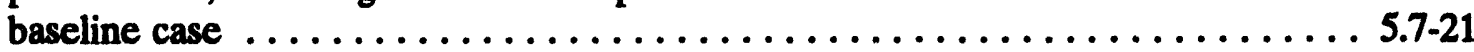

5.7-8. Highest predicted concentrations of toxic air pollutants on the Idaho National Engineering Laboratory site from total emissions by alternative $\ldots \ldots \ldots \ldots \ldots .7-23$

5.9-1. Acres disturbed by alternative from proposed projects to manage or conduct waste stream, spent nuclear fuel, environmental restoration, or infrastructure activities at the Idaho National Engineering Laboratory site . . . . . . . . . 5.9-2

5.11-1. Transportation distances between facilities for waste shipments $\ldots \ldots \ldots \ldots . \ldots 5.11-3$

5.11-2. Incident-free unit risk factors for truck and rail shipments of remote-handled transuranic waste and low-level waste $\ldots \ldots \ldots \ldots \ldots \ldots \ldots \ldots \ldots \ldots . \ldots \ldots$

5.11-3. Incident-free unit risk factors for truck and rail shipments of contact-handled transuranic waste, low-level waste, and mixed low-level waste . . . . . . . . 5.11-5

5.11-4. Shipments of radioactive waste and hazardous materials for Alternatives $A$

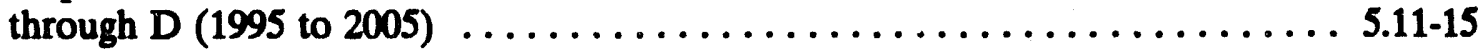

5.11-5. Shipments of spent nuclear fuel for Alternatives $A$ through D (1995 to 2035) . . . . . . . . . . . . . . . . . . . . . . . . .

5.11-6. Cumulative doses and fatalities from incident-free transport of waste for Alternatives A through D (1995 to 2005) . . . . . . . . . . . . . . 5.11-20

5.11-7. Cumulative doses and fatalities from incident-free transport of spent nuclear fuel by truck for Alternatives A through D (1995 to 2035) . . . . 5.11-22

5.11-8. Cumulative doses and fatalities from incident-free transport of spent nuclear fuel by train for Alternatives A through D (1995 to 2035) . . . . 5.11-24 
5.11-9. Maximum reasonably foreseeable accident doses and health effects for onsite transport of spent nuclear fuel for Alternatives A through D (1995 to 2005) . . 5.11-27

5.11-10. Maximum reasonably foreseeable accident doses and health effects for onsite transport of waste for Alternatives A through D (1995 to 2005) . . . . . . . . . 5.11-28

5.11-11. Accident risks for offsite transport of waste for Alternatives A

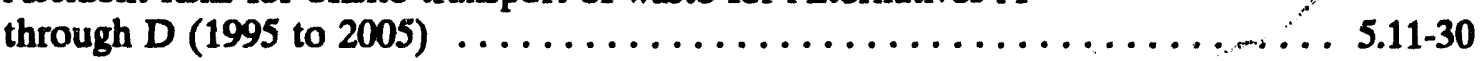

5.11-12. Accident risks for offsite transport of spent nuclear fuel for Alternatives A through D (1995 to 2035) . . . . . . . . . . . . . . 5.11-31

5.11-13. Maximum reasonably foreseeable accident doses and health effects for offsite transport of waste for Alternatives A through D (1995 to 2005) $\ldots \ldots \ldots \ldots$. . . . .

5.11-14. Maximum reasonably foreseeable accident doses and health effects for offsite transport of spent nuclear fuel for Alternatives A through D (1995 to 2035) . . 5.11-33

5.11-15. Summary of releasing accident probability and consequences for nitric acid . . . 5.11-34

5.12-1. Ten-year dose and resulting lifetime fatal cancer risk for maximally exposed individuals by Idaho National Engineering Laboratory alternative . . . . 5.12-3

5.12-2. Ten-year population dose and estimated resulting fatal cancers by Idaho National Engineering Laboratory alternative ................. 5.12-4

5.12-3. Hazard quotients from noncarcinogenic toxic air pollutants at the site boundary and public roads on the Idaho National Engineering Laboratory site by

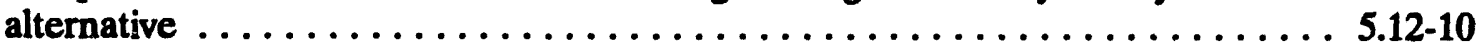

5.12-4. Estimated lifetime cancer risk for offsite individuals from carcinogenic air pollutants by Idaho National Engineering Laboratory alternative . . . . . . . . 5.12-12

5.12-5. Estimated radiological impacts to workers at the Idaho National Engineering

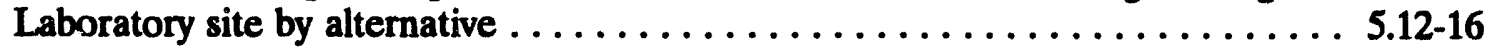

5.12-6. Estimated nonradiological impacts to workers at the Idaho National Engineering Laboratory site by alternative

5.14-1. Idaho National Engineering Laboratory locations with sufficient quantities of radioactive or hazardous material to cause consequences to a member of the public under accident conditions $\ldots \ldots \ldots \ldots \ldots \ldots \ldots \ldots \ldots \ldots \ldots \ldots .14-6$

5.14-2. Potential initiating events for accidents at the Idaho National Engineering Laboratory by estimated frequency range and material type .......... 5.14-9

5.14-3. Impacts from selected maximum reasonably foreseeable radiological accidents at the Idaho National Engineering Laboratory site - Alternative A

- (No Action) 
5.14-4. Assessment of potential secondary impacts of accidents at the Idaho

National Engineering Laboratory site (applicable to all alternatives) $\ldots \ldots \ldots$ 5.14-17

5.14-5. Impacts from selected maximum reasonably foreseeable accidents involving hazardous materials at the Jaho National Engineering Laboratory for

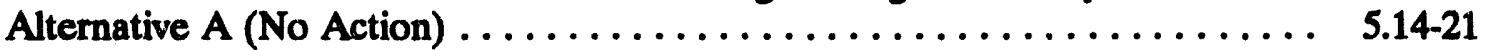

5.14-6. Characteristics of radiological accidents at the Idaho National Engineering Laboratory site under Alternative B (Ten-Year Plan) that differ from those

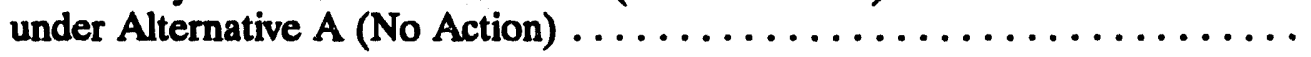

5.14-7. Characteristics of radiological accidents at the Idaho National Engineering Laboratory site under Alternative C (Minimum Treatment, Storage, and Disposal) that differ from those under Alternative A (No Action) .........

5.14-8. Characteristics of radiological accidents at the Idaho National Engineering Laboratory site under Alternative D (Maximum Treatment, Storage, and Disposal) that differ from those under Alternative A (No Action) .........

5.14-9. Characteristics of hazardous material accidents at the Idaho National Engineering Laboratory under Alternative D (Maximum Treatment, Storage, and Disposal) that differ from those under Alternative A (No Action) .......

5.15-1. Other projects to be included for assessment of cumulative impacts $\ldots \ldots \ldots \ldots$

5.15-2. Nonhealth-related cumulative impacts by resource area and alternative

5.15-3. Cumulative transportation-related radiological collective doses and cancer fatalities

5.15-4. Health-related cumulative impacts by alternative

6.1-1. Contributors to the Environmental Impact Statement $\ldots \ldots \ldots \ldots \ldots \ldots$

7.2-1. Federal Facility Agreement/Consent Order status $\ldots \ldots \ldots \ldots \ldots \ldots . \ldots . \ldots 7 . \ldots$

7.2-2. National Environmental Policy Act documents $\ldots \ldots \ldots \ldots \ldots \ldots . \ldots \ldots$

7.2-3. Permits held or applied for by Idaho National Engineering Laboratory $\ldots . . .7 .2-27$

7.2-4. Resource Conservation and Recovery Act permitting status table $\ldots \ldots \ldots$ 7.2-32

7.2-5. Wastewater Land Application Permit status $\ldots \ldots \ldots \ldots \ldots \ldots \ldots . . \ldots \ldots$

7.3-1. Project-specific list of permits, licenses, and so forth, that may be required . . . . 7.3-2 


\section{PURPOSE AND NEED FOR AGENCY ACTION}

The U.S. Department of Energy (DOE) is responsible by law for spent nuclear fuel management, waste management, and environmental restoration at the Idaho National Engineering Laboratory (INEL) in southeastern Idaho. Under the Atomic Energy Act of 1954, as amended, DOE is responsible for managing certain spent nuclear fuels. Under the Comprehensive Environmental Response, Compensation, and Liability Act of 1980, as amended; the Resource Conservation and Recovery Act of 1976; the Federal Facility Compliance Act of 1992; and other laws, DOE is responsible for managing wastes and controlling hazardous substances in a manner that protects human health and the environment. DOE is committed to comply with these and all other applicable Federal and State laws and regulations, DOE orders, and interagency agreements governing spent nuclear fuel and environmental restoration and waste management.

Over the past 50 years, DOE activities have resulted in the accumulation of spent nuclear fuel; waste requiring treatment, storage, and disposal; and sites requiring remediation. To better fulfill its responsibilities, DOE needs to develop and implement a program for spent nuclear fuel management and environmental restoration and waste management activities at the INEL. To establish an effective INEL program [for the foreseeable future, focused on the near term (the next ten years)], DOE needs to make site-specific decisions that would accomplish three major goals: (a) support research and development missions at the INEL; (b) comply with legal requirements governing spent nuclear fuel, environmental restoration, and waste management; and (c) treat, store, and dispose of waste, manage spent nuclear fuel, and conduct environmental restoration activities at the INEL in an environmentally sound manner.

To achieve the goals, DOE needs to develop appropriate facilities and technologies to manage waste and spent nuclear fuels expected during the next ten years; to more fully integrate all environmental restoration and waste management activities at the INEL to achieve cost and operational efficiencies; and to minimize environmental impacts from environmental restoration and waste management activities. More specifically, DOE needs to decide upon the appropriate 
- Strategy for implementing at the INEL, DOE's national spent nuclear fuel decisions regarding transportation, receipt, processing, and storage of spent nuclear fuel.

- Strategy for implementing at the INEL, DOE's environmental restoration and waste management decisions.

- Cleanup strategy for actions required by the Comprehensive Environmental Response, Compensation, and Liability Act of 1980, as amended, and the Federal Facility Agreement and Consent Order of 1991.

- Capabilities, facilities, research and development, and technologies for treating, storing, and disposing of each waste type at the INEL.

- Actions regarding certain projects at the INEL, such as treatment technologies for sodium-bearing and high-level wastes, storage capacity for spent nuclear fuels, and treatment technologies for other radioactive and mixed wastes. 


\section{BACKGROUND}

\subsection{Environmental Impact Statement Scope and Overvlew}

DOE is currently in the process of making major decisions regarding its future activities, both at the national level and specifically at the INEL. Volume 2 of this Environmental Impact Statement (EIS) has been prepared to evaluate environmental impacts resulting from implementing DOE's national decisions at the INEL. This is done by evaluating the programs as a whole, the components of the programs (for example, waste stream management, remediation, decontamination and decommissioning; see Appendix E, Glossary, for a definition of these terms), and various specific projects. DOE intends to decide whether or not to proceed with proposed site-specific projects that would implement the alternatives for management of waste streams and spent nuclear fuel. The proposed projects are discussed in Chapter 3, Alternatives, and Appendix C, Information Supporting the Alternatives, and results of analyses are in Chapter 5, Environmental Consequences.

At the national level, two Programmatic EISs are being prepared to address decisions regarding the overall direction of DOE's Spent Nuclear Fuel (SNF) and Environmental Restoration and Waste Management (ER\&WM) Programs. "Programmatic EIS" is a term for an EIS that covers matters of broad scope, such as agency policy or an agency program that includes a variety of interrelated activities. A Programmatic EIS may be the basis for subsequent analyses of narrower scope that incorporate by reference the general discussions contained in the Programmatic EIS. Volume 1 of this EIS discusses the environmental consequences of DOE's national spent nuclear fuel decisions; the Environmental Restoration and Waste Management Programmatic EIS, scheduled for completion in late 1994, will address the environmental consequences of DOE's national ER\&WM decisions. These national decisions will have potential environmental consequences at the INEL because they will require developing a site-specific strategy to implement the national decisions.

The foreseeable strategy for ER\&WM at the INEL will increasingly emphasize waste avoidance and minimization. Environmental restoration at the INEL will continue into the future, but expected future land use will influence methods of remediation and the amount of 
waste generated. Also, administering spent nuclear fuel and ER\&WM activities at the INEL over the next ten years is expected to require new storage, characterization, retrieval, treatment, and disposal facilities and new waste minimization and avoidance projects. Technology development to support these projects, infrastructure improvements, and a continuing active environmental monitoring program will also be needed.

\subsubsection{Environmental Impact Statement Content}

The SNF and INEL ER\&WM EIS has been prepared in accordance with the National Environmental Policy Act of 1969. The content of this document follows recommendations for the content of EISs made by the Council on Environmental Quality and DOE regulations implementing the National Environmental Policy Act. (Chapter 7, Consultations and Environmental Requirements, gives more details on related environmental statutes and regulations.)

This volume examines potential environmental impacts associated with four alternatives for managing waste, spent nuclear fuel, and related materials at the INEL (see Chapter 3, Alternatives). Alternative A (No Action) entails continued operation and maintenance of current facilities and programs, with only minor changes to some facilities. Alternative B (Ten-Year Plan) entails implementation at the INEL of the existing ten-year plan to comply with regulatory requirements, protect the environment, and support the INEL mission. Alternative $\mathrm{C}$ (Minimum Treatment, Storage, and Disposal) would minimize activities by transporting spent nuclear fuel and wastes to other sites for treatment, processing, characterization, storage, or disposal (or disposition). Alternative D (Maximum Treatment, Storage, and Disposal) would involve receiving and managing the maximum potential amount of spent nuclear fuel and waste at the INEL from other sites.

\subsubsection{Environmental Impact Statement Scope}

This section discusses the scope of the EIS as it relates to INEL's ER\&WM and spent nuclear fuel activities and the timeframe for decisions supported by this EIS. Activities addressed in the EIS primarily include those that have produced and continue to produce radioactive 


\section{DEFINITIONS}

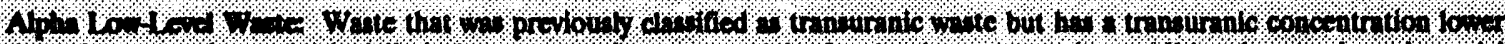

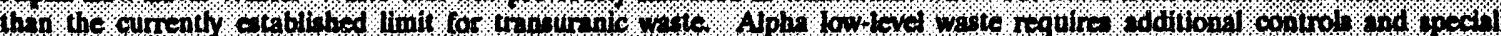

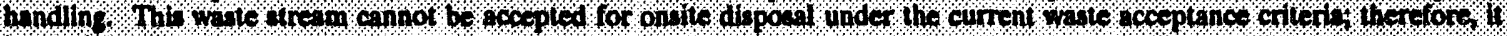

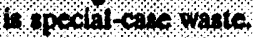

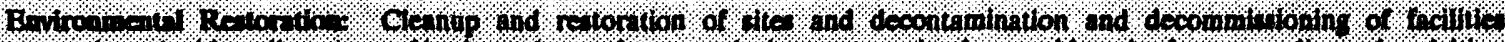

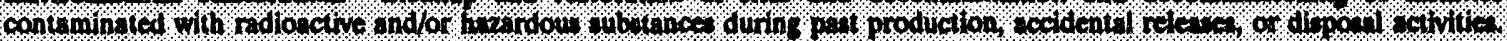

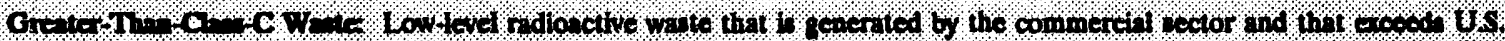

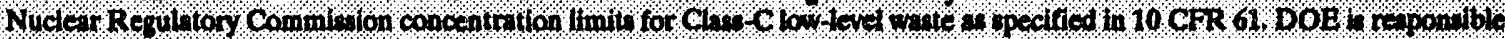

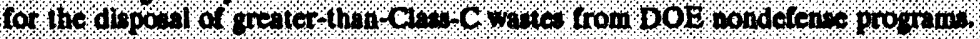

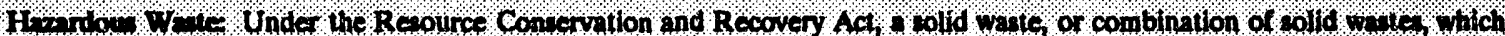

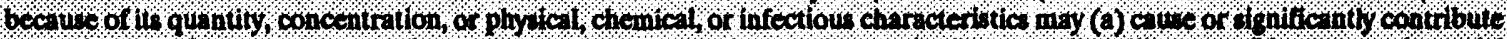

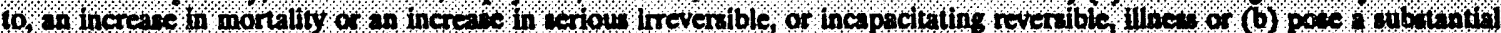

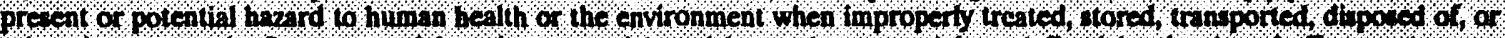

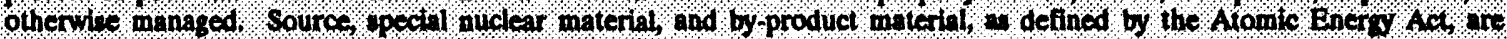
specifically acluded from the definilion of solid waste.

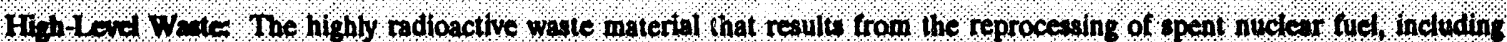

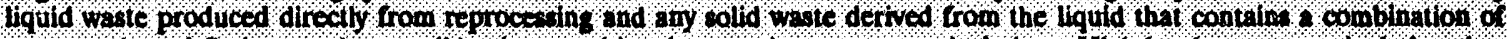
fransuranic und fision product auclides in quantitie that require permanent folation High-level waste pay include otler highty radioactive material that the U.S. Nuclear Regulatory Commision, conststent with eristing law, determines by rule require permanent loolation.

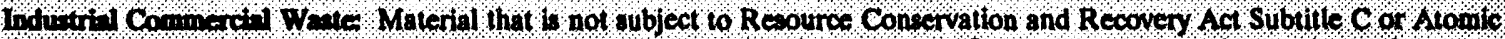

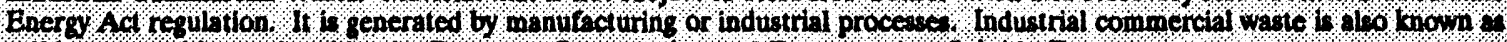
olid waste ind is regulated by the Reeource Coneervation and Recovery Act, subtille D.

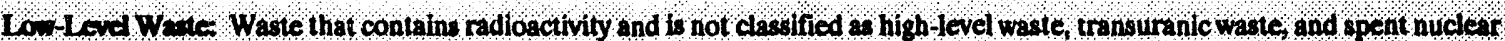
fuel. Teat epecimens of fisionable material irradiated for research and development only, and not for the production of power or plutonlum, nay be clicified as low-level wale, provided the concentration of transuranics is less than 100 nanocunes per ram.

Mired Wetc Wente that contains both hazardous waste under the Recource Conservation and Recovery Act ond ource, ppecial nuclear, or by-product material eubject to the Alomic Energy Act of 1954 (42 USC 2011, at seq).

Rodo-ctive Wotc. Waste that is manged for its radiosctive content.

Spent Nodear Fudi. Fuel that has been withdrawn trom a nuclear reactor following irradiation, the constituent clements of Which have ool been separated. For the purposet of this EIS, spent nuclear fuel also includet uraniumfueptunium target materiaks blanket subassemblies, piece of fuel, and debris.

Trangurnic Wate Waste containing more than 100 nanocuries of alpha-emitting transuranic isotopes, with half-live greater than 20 year, per gram of waste, except for (a) high-level nedioactive wante, (b) waste that DOE has determined, with the concurrence of the Adminiatrator of the U.S. Environmental Protection Agency, does not need the degree of bolation required by 40 CFR 191, or (c) waste that the U.S. Nuclear Regulatory Commission has approved for dispasal on a case-by-case basis in accordance with 10 CFR 61 .

Wele Mana erment The planning, coordination, and direction of those functions related to generation, handling, treatment. storage, transportation, and disposal of waste, as well as aceciated surveillance and maintenance activities.

(high-level, transuranic, low-level, and mixed) wastes, hazardous waste, and industrial commercial waste. Activities that fall outside the scope of the EIS are also identified. This EIS will provide the analysis required under the National Environmental Policy Act for certain projects required to implement the Spent Nuclear Fuel and ER\&WM Programs at the INEL. 


\subsubsection{Environmental Restoration and Waste Management Actlvitles. Waste}

management activities discussed in this EIS are evaluated at both the sitewide (by waste stream management) and project-specific levels. For example, the evaluation of the INEL's waste management program addresses sitewide impacts associated with the treatment, storage, and disposal of waste generated by ongoing remediation, nuclear energy, energy research, and defense programs. Examples of project-specific evaluation related to waste management activities at the INEL include evaluating the need to construct replacement capacity for high-level waste tanks and evaluating the potential environmental consequences of incineration (for example, the Waste Experimental Reduction Facility).

For environmental restoration, potential impacts at the INEL are addressed only at the sitewide level. For example, the EIS evaluates the potential sitewide impacts associated with the INEL program for decommissioning and decontamination or dismantling of facilities scheduled for closure or reuse. Project-specific impacts of activities cannot be specifically quantified at this time, so they are only generally evaluated in this EIS. Project-specific impacts of these activities at the INEL will be quantified and evaluated in the future, as appropriate, as part of Comprehensive Environmental Response, Compensation, and Liability Act actions.

\subsubsection{Spent Nuclear Fuel Activities. This EIS also addresses all INEL activities} related to spent nuclear fuel, except for reactor operations. Specific activities covered by the EIS include fuel receipt, transportation, processing, characterization, storage, and technology for ultimate disposition. Volume 1 of this EIS addresses spent nuclear fuel decisions for the entire DOE-wide system, while Volume 2 addresses spent nuclear fuel activities at the INEL.

\subsubsection{Timeframe. The Record of Decision supported by Volume 2 of this EIS will} determine how DOE manages its ER\&WM and spent nuclear fuel activities at the INEL for the ten-year period from 1995 to 2005 . Volume 1 of this EIS uses a 40-year (1995-2035) timeframe for evaluating potential impacts associated with DOE's programmatic spent nuclear fuel decision. The ten-year timeframe is used in Volume 2 for the evaluation of impacts because too much uncertainty exists to estimate potential project-specific impacts at the INEL beyond the year 2005 . However, some projects to be implemented beyond the ten-year timeframe are evaluated in this EIS (for example, the Waste Immobilization Facility). This is because actions taken in the tenyear timeframe may determine whether these other projects would be needed. In addition, it is 
assumed that any facility constructed or used during the ten-year timeframe may require decontamination and decommissioning in the future (but outside the ten-year timeframe).

\subsubsection{Activitles Outside the Environmental Impact Statement Scope. Various} activities at the INEL fall outside the scope of the EIS and are not addressed in this document. In general, Volume 2 does not evaluate impacts of operations not associated with the ER\&WM and Spent Nuclear Fuel Programs at the INEL. However, some non-ER\&WM and nonspentnuclear-fuel activities are mentioned in appropriate sections when they are relevant to understanding either the affected environment or activities that are expected to occur at the INEL during the next ten years. Such activities include, for example, the generation of waste to be handled by the ER\&WM Program and those related to road maintenance, utilities, fire protection, emergency preparedness, and security. Potential effects of particular non-ER\&WM and nonspent-nuclear-fuel activities are included, when appropriate, in the analysis of cumulative impacts (see Section 5.15, Cumulative Impacts and Impacts from Connected or Similar Actions).

\subsubsection{Other Related National Environmental Pollcy Act Documente}

Five major DOE environmental impact statements are closely related to the SNF and INEL ER\&WM EIS.

\subsubsection{Waste Management Operations Environmental Impact Statement. In 1977,} DOE prepared a Final Environmental Impact Statement (DOE 1977) that evaluated ongoing activities and operations at INEL waste management facilities. The SNF and INEL ER\&WM EIS supersedes this previous document by providing an updated baseline of operations and associated environmental impacts for INEL activities since 1977.

\subsubsection{Environmental Restoration and Waste Management Programmatic}

Environmental Impact Statement. Currently in preparation, the Programmatic ER\&WM EIS is analyzing alternative strategies and policies to maximize efficiency for DOE's national ER\&WM Programs. The SNF and INEL ER\&WM EIS (Volume 2) is being coordinated with the Programmatic EIS. The Draft Programmatic EIS is scheduled to be available for public and agency review by the fall of 1994. The analysis in the Programmatic EIS will support DOE complex-wide decisions on 
- How to cost-effectively manage treatment, storage, and disposal of radioactive, hazardous, and mixed wastes

- Whether to use new or existing technologies to remediate contaminated sites

- How much treatment and what kinds of treatment technologies are needed

- What kind of treatment technology development is needed

- How to set priorities among waste management, environmental restoration, and technology development goals

- How to decontaminate and decommission contaminated surplus facilities.

\subsubsection{Nuclear Weapons Complex Reconfiguration Programmatic Environmental} Impact Statement. DOE is proposing to reconfigure the nation's nuclear weapons network to be smaller, less diverse, and less expensive to operate. The nuclear weapons network includes activities at several locations across the country; and reconfiguration may lead to deactivation, decontamination, and decommissioning of some currently active sites. The environmental impacts associated with reconfiguration are being assessed in this EIS. Although recent international events have led to a reexamination of the scope of this document, the Draft Reconfiguration Programmatic EIS is scheduled to be available in 1994.

\subsubsection{Waste Isolation Pllot Plant Environmental Impact Statement. The Final} Supplemental EIS for the Waste Isolation Pilot Plant, the proposed Federal repository for defense-related transuranic waste located in Carlsbad, New Mexico, was issued in 1990 to support a decision to proceed with a test phase. During the test phase, a limited quantity of waste would have been placed underground at the Waste Isolation Pilot Plant. However, following enactment of the WIPP Land Withdrawal Act in late 1992, DOE decided in 1993 not to proceed with the underground test phase but to perform laboratory tests with waste, along with numerous other in situ and offsite studies, to demonstrate compliance with U. S. Environmental Protection Agency disposal standards (40 CFR 191 Subparts B and C) and the Solid Waste Disposal Act. DOE will 
prepare and issue an additional supplemental EIS at the end of the test program to support a decision on whether or not to proceed with the disposal phase.

\subsubsection{Forelgn Research Reactors Environmental Impact Statement. DOE} proposes to adopt and implement a policy to accept spent nuclear fuel containing enriched uranium that originated in the U.S. but that would come from foreign research reactors. The implementation of this policy would result in foreign research reactor spent nuclear fuel being received at U.S. marine ports of entry and overland transport to DOE sites for storage pending ultimate disposition. The Foreign Research Reactors Draft EIS will be issued in late 1994. Alternatives to be addressed in this EIS include nonrenewal of the policy; storage sites (Hanford Site, INEL, Savannah River Site, Oak Ridge Reservation, and Nevada Test Site); transportation from various ports of entry; and storage technologies.

\subsubsection{Other National Environmental Pollcy Act Documentation. The National} Environmental Policy Act reviews related to the site-specific decision on ER\&WM Programs (including spent nuclear fuel) are listed in Table 2.1-1. The National Environmental Policy Act documents specifically related to the management of spent nuclear fuel are listed in Section 1.3, Scope, of Volume 1 of the EIS.

\subsubsection{Scoping Process}

According to the National Environmental Policy Act, the purpose of the scoping process is to determine, in general, the issues to be addressed in an EIS and to identify those significant issues requiring in-depth analysis.

For the SNF and INEL ER\&WM EIS, the scoping process began on October 22, 1990, when DOE published in the Federal Register its Notice of Intent to prepare a Programmatic EIS that would address ER\&WM activities (including spent nuclear fuel) at all DOE facilities (FR 1990). Public comments were solicited, and DOE released a Draft Implementation Plan to develop the EIS. Following the release of the Draft Plan, a second comment period was conducted via six regional workshops. In these workshops, the public was invited to express opinions and ask questions about the Plan. 
Table 21-1. National Environmental Policy Act reviews related to the site-specific decision, including environmental impact statements and environmental assessments.

\begin{tabular}{|c|c|c|c|}
\hline Description of Action & Status $^{\mathbf{a}}$ & EIS $^{\mathbf{a}}$ & $\mathbf{E A}^{\mathbf{a}}$ \\
\hline Waste management operations at the Idaho National Engineering Laboratory (INEL) & ROD issued 1977 & $\mathbf{x}$ & \\
\hline Special Isotope Separation Project & ROD issued January 1989 & $\mathbf{X}$ & \\
\hline Siting, construction, and operation of New Production Reactor capacity & $\begin{array}{l}\text { Draft EIS issued April } \\
1991\end{array}$ & $\mathbf{x}$ & \\
\hline $\begin{array}{l}\text { Transportation, receipt, and storage of spent nuclear fuel from the Fort St. Vrain } \\
\text { Reactor to the INEL }\end{array}$ & $\begin{array}{l}\text { FONSI issued February } \\
1991^{b}\end{array}$ & & $\mathbf{x}$ \\
\hline $\begin{array}{l}\text { INEL Federal Aviation Administration Explosive Detection System Independent } \\
\text { Validation and Verification Program }\end{array}$ & FONSI issued May 1991 & & $\mathbf{X}$ \\
\hline Test Reactor Area evaporation pond & $\begin{array}{l}\text { FONSI issued December } \\
1991\end{array}$ & & $\mathbf{X}$ \\
\hline Expansion of the INEL Research Center & FONSl issued March 1994 & & $\mathbf{X}$ \\
\hline High-Level Waste Tank Farm Replacement Project & FONSI issued June $1993^{c}$ & & $\mathbf{x}$ \\
\hline Decontamination and selective demolition of Auxiliary Reactor Areas II and III & $\begin{array}{l}\text { FONSI issued September } \\
1993\end{array}$ & & $\mathbf{x}$ \\
\hline Low-level and mixed waste processing at the Waste Experimental Reduction Facility & FONSI issued June 1994 & & $\mathbf{X}$ \\
\hline Retrieval and re-storage of Transuranic Storage Area waste at the INEL & FONSI issued May 1992 & & $\mathbf{X}$ \\
\hline INEL Sewer System Upgrade Project & FONSI issued April 1994 & & $\mathbf{X}$ \\
\hline INEL Consolidated Transportation Facility & FONSI issued April 1993 & & $\mathbf{X}$ \\
\hline Waste Characterization Facility & In preparation & & $\mathbf{X}$ \\
\hline Test Area North Pool Stabilization Project & In preparation & & $\mathbf{X}$ \\
\hline Replacement of the Radiological and Environmental Sciences Laboratory & In preparation & & $\mathbf{x}$ \\
\hline
\end{tabular}


Table 21-1. (continued).

\begin{tabular}{|c|c|c|c|}
\hline Description of Action & Status & EIS $^{\mathbf{a}}$ & $\mathbf{E A}^{\mathbf{a}}$ \\
\hline $\begin{array}{l}\text { Interim action for the cleanup of Pit } 9 \text { at the Radioactive Waste Management } \\
\text { Complex }\end{array}$ & FONSI issued July 1993 & & $\mathbf{X}$ \\
\hline $\begin{array}{l}\text { Interim action to reduce contamination near the injection well and in the surrounding } \\
\text { groundwater at Test Area North at the INEL }\end{array}$ & $\begin{array}{l}\text { FONSI issued October } \\
1992\end{array}$ & & $\mathbf{X}$ \\
\hline Organic contamination in the vadose zone & In preparation & & $\mathbf{X}$ \\
\hline Replacement of the Health Physics Instrumentation Laboratory & In preparation & & $\mathbf{X}$ \\
\hline Continuing operation of the Specific Manufacturing Capability & FONSI issued August 1991 & & $\mathbf{X}$ \\
\hline $\begin{array}{l}\text { Process Equipment Waste and Process Waste Liquid Collection Systems at the Idaho } \\
\text { Chemical Processing Plant }\end{array}$ & FONSI issued June 1990 & & $\mathbf{X}$ \\
\hline Argonne National Laboratory-West Waste Handling Facility & In preparation & & $\mathbf{X}$ \\
\hline Argonne National Laboratory-West Fuel Cycle Facility & FONSI issued May 1990 & & $\mathbf{X}$ \\
\hline
\end{tabular}

a. EIS = environmental impact statement.

$\mathrm{EA}=$ environmental assessment.

ROD = record of decision.

FONSI = finding of no significant impact.

b. The Environmental Assessment was ruled inadequate by the United States District Court for the District of Idaho in June 1993 [Public Service Company of Colorado v. Andrus, 825 F. Supp. 1483 (D. Idaho 1993)].

c. FONSI issued for line upgrades, but not tank replacement. 
On October 5, 1992, DOE published a Notice of Intent to prepare a site-specific EIS on its ER\&WM Programs (including spent nuclear fuel) at the INEL (FR 1992). Scoping meetings were conducted in five different locations in the State of Idaho. DOE made numerous announcements in local newspapers and other media to alert the public about these meetings. The meetings provided both formal and informal ways for the public to express their views and obtain information about the intended scope of analysis. DOE also conducted numerous information briefings with representatives of State and local governments, elected officials, and the Shoshone-Bannock Indian Tribes. This was an effort to provide early notice and information about the document. During these briefings, participants provided input on their concerns and issues.

After public comments were taken and a plan was developed for preparing the EIS, a court order was issued that expanded the scope of the EIS. On June 28, 1993, as an outgrowth of civil lawsuits involving DOE, the State of Idaho, and other parties, the U.S District Court for the District of Idaho ordered DOE to prepare a comprehensive EIS for spent nuclear fuel management. This court order addressed the need to prepare an EIS for the INEL that examines alternatives to the transport, receipt, processing, and storage of spent nuclear fuel at the INEL site. Because of the quantities and types of fuel currently located at the INEL, a fair evaluation of these activities required assessing similar activities throughout the DOE complex. Thus, DOE decided to expand its site-specific EIS for the INEL to incorporate the programmatic decision regarding the management of spent nuclear fuel within the DOE complex, previously part of DOE's ER\&WM Programmatic EIS. This expanded document is the SNF and INEL ER\&WM EIS.

To allow the public an opportunity to comment on the scope of the SNF and INEL ER\&WM EIS, DOE published a Notice of Opportunity on September 3, 1993. DOE used the public and agency comments received during the comment period to identify major issues and to define the alternatives that are evaluated in Volume 2. DOE's responses to comments and issues raised during the comment period are given in the Implementation Plan and its amendments for this EIS (DOE 1993a).

During all four comment periods, DOE received a total of 970 comments addressing 4,321 issues. The issues can be grouped into three types: technical issues, programmatic spent nuclear 
fuel issues, and other issues. Figure 2.1-1 summarizes the 3,128 issues applying to the site-specific decision evaluated in this volume.

The greatest number of issues raised during scoping were statements in opposition to spent nuclear fuel and waste being managed in Idaho. Commenters were concerned about several aspects of spent nuclear fuel and about DOE siting criteria. The most frequently raised technical issue for the INEL was related to materials and waste management. Other frequent comments focused on the National Environmental Policy Act process, DOE credibility, the range of alternatives, water quality, and the expansion of the scope of the EIS. In response to these comments, DOE decided to expand the number of alternatives evaluated in Volume 2 from two to four (see Chapter 3 ).

Reflecting continuing DOE and public concern, the EIS process emphasized data gathering and analyses of potential impacts to water use and water quality. Other areas emphasized include present and future waste streams, hazardous material inventories, impacts to air quality, accident analyses, and transportation analyses. 

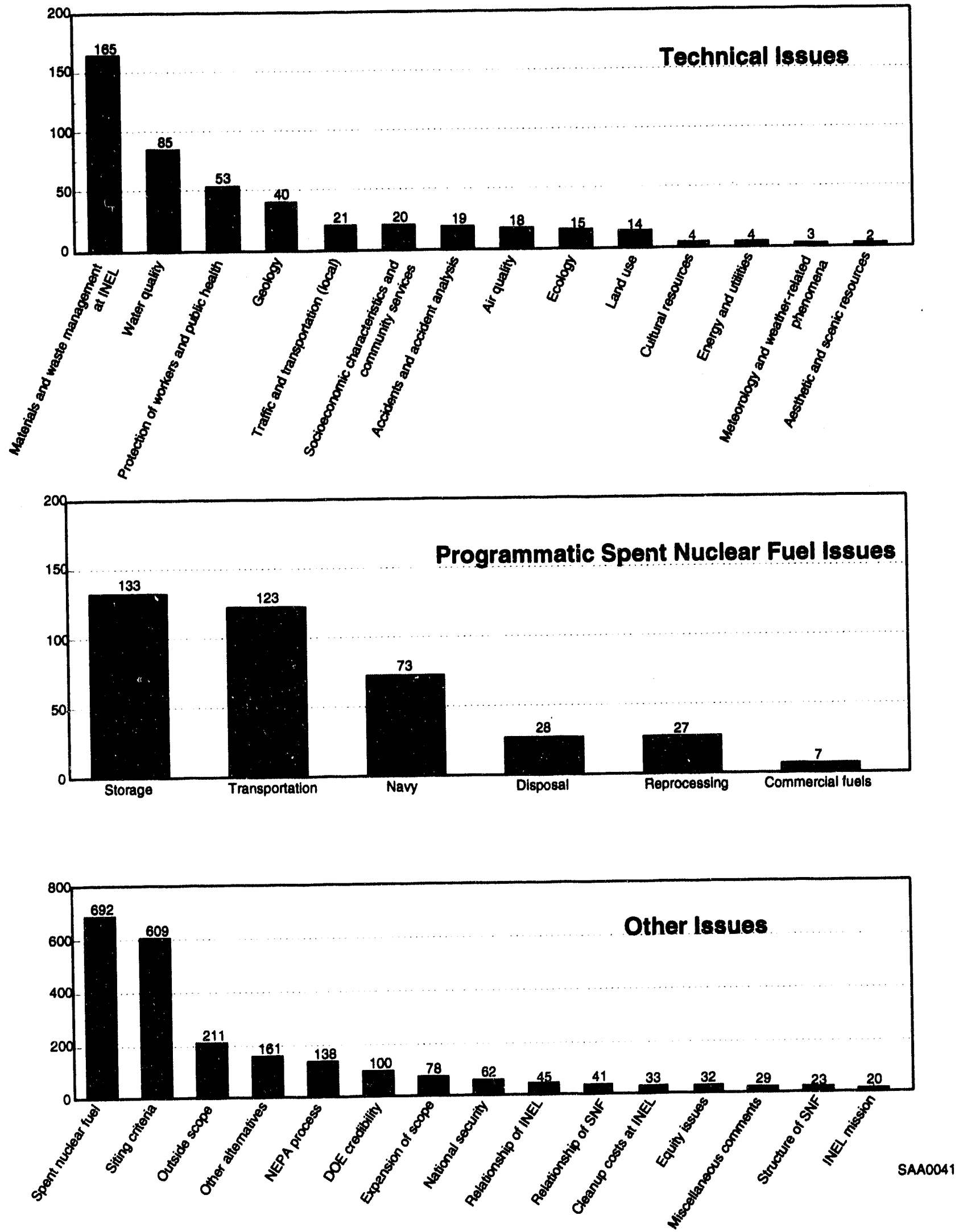

Figure 21-1. Comments and issues raised during the comment periods. 


\subsection{Idaho National EngIneering Laboratory Overvlew}

\subsubsection{Ceneral Stte Description}

The INEL site occupies about 2,300 square kilometers (890 square miles) of dry, cool desert in southeastern Idaho. It is located in the Eastern Snake River Plain (Figure 2.2-1), southwest of Yellowstone National Park (211 kilometers, 132 miles); north of Salt Lake City, Utah (374 kilometers, 234 miles); and east of Boise, Idaho (317 kilometers, 198 miles). The INEL site lies west of the Snake River and near numerous national forests and recreational areas. Population centers near the site are Idaho Falls to the east, Blackfoot to the southeast, Pocatello to the south-southeast, and Arco to the west.

\subsubsection{Organization and Administration}

The INEL is a government-owned site managed by DOE and administered by three DOE operations offices: (a) the Idaho Operations Office (DOE-ID); (b) the Idaho Branch Office of Pittsburgh Naval Reactors (IBO); and (c) the Chicago Operations Office (DOE-CH). Five management and operating contractors support DOE-ID's activities at INEL: EG\&G Idaho, Inc. (EG\&G Idaho); Westinghouse Idaho Nuclear Company (WINCO); Babcock and Wilcox, Idaho, Inc. (B\&W); MK-Ferguson; and Protection Technology Idaho (PTI). DOE-ID currently plans to consolidate its five management and operating contracts into a single contract. Contractor selection is planned for June 1994. Westinghouse Electric Corporation (WEC) supports the Idaho Branch Office of the Pittsburgh Naval Reactors, and Argonne National Laboratory (ANL) supports DOE-CH at the INEL.

As INEL Site Manager, DOE-ID is responsible for site services, environmental control and management, and overall safety and emergency planning functions. Thus, DOE-ID is responsible for ER\&WM activities. The INEL ER\&WM Program is under the DOE Headquarters Office of Environmental Management (EM) established in November 1989. These ER\&WM activities are defined and carried out within the regulatory environment described in Section 2.2.11, Regulatory Framework for Environmental Restoration and Waste Management, and Chapter 7, Consultations and Environmental Requirements. 


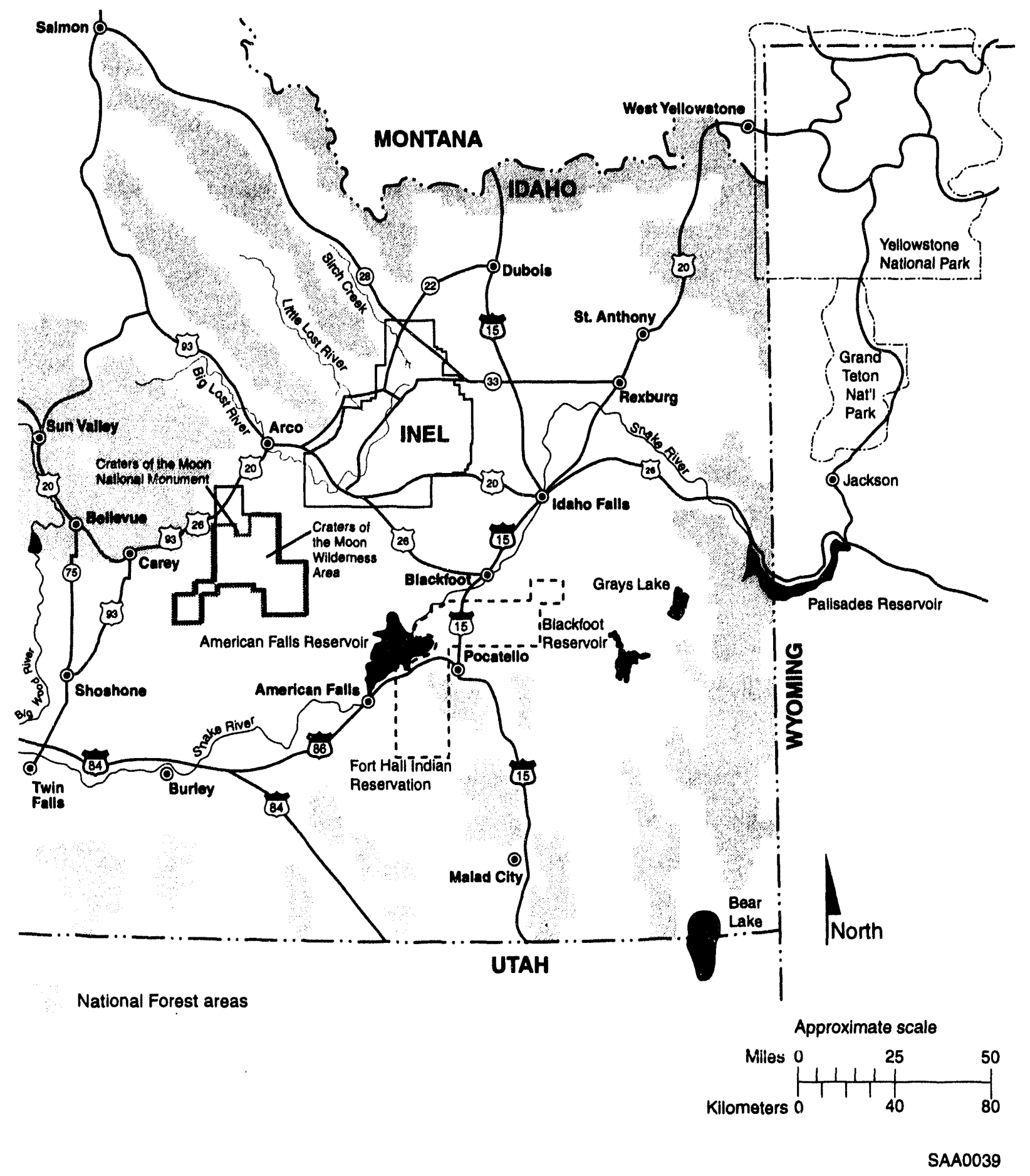

Figure 22-1 Location of the Idaho National Engineering Laboratory in southeastern Idaho. 


\subsubsection{Historic and Current Misolon}

The INEL has long provided research and engineering support to the military, commercial, and government segments of the U.S. economy. Specific activities on the INEL have shifted over time to meet changing national needs. These shifts included changing from the application of nuclear power for commercial and naval uses, to spent nuclear fuel reprocessing and waste storage, to the current emphases on science and technology related to advancing and improving remediation and waste management at the INEL and applying the knowledge gained from the INEL experience to other national needs.

Despite the long history and different operations carried out at the INEL, most of the site has not been directly affected by DOE or other activities. One result of the activities conducted to meet the historic missions of the INEL is the creation of nine major facility areas. These areas and their transportation corridors encompass the majority of industrial development, disturbances, and contamination (with the exception of groundwater) on the INEL site, but comprise only two percent of the total land area of the site.

\subsubsection{History of the Implementation of the INEL MIssion. During World War II,} the U.S. Navy and the U.S. Army Air Corps used a portion of the present site as a gunnery range. In 1949, the site was formally established as the National Reactor Testing Station. Over time, 52 different reactors, most of them first-of-a-kind facilities, were built here. Most of these reactors were phased out or dismantled after their research missions were completed, but several are currently operating or operable (see Section 2.2.4, Major Facility Areas). Highlights of this program include the Experimental Breeder Reactor-I, now a National Historic Landmark, which produced the first usable electrical power from nuclear energy in 1951; and the Boiling Water Reactor Experiment-III, which, in 1955, was the first reactor to light an American town (Arco, Idaho).

Beginning in the 1950s, the Naval Reactors Facility tested and operated prototypes of nuclear reactors for submarines and surface ships. In addition, this facility was a training station for crews on these ships. The Navy discontinued training on the Large Ship Reactor (A1W) facility at the Naval Reactors Facility in 1994 and has announced the 1995 closure of the Submarine Reactor (S5G) prototype. 
Another effort supporting U.S. nuclear programs was reprocessing spent nuclear fuel to recover uranium at the Idaho Chemical Processing Plant. Reprocessing was begun in 1953 and phased out by DOE in April 1992.

Between 1954 and 1989, defenserelated nuclear waste was shipped to the INEL site, primarily from the Rocky Flats Plant in Colorado. Until 1970, this mostly transuranic waste was buried in shallow pits and trenches at the Radioactive Waste Management Complex. After 1970, transuranic waste was stored above ground in specially designed interim storage facilities.

\section{SITE HISTORY}

1949 Formally 4 196ilihed

1950. Ter of tint nuclear wbinurine reactor

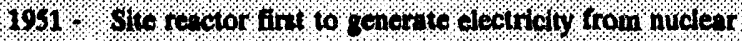
fo, 100

1957. Ridlor atie Wante Mang gement Complar opend

1053 to bo Chemical Procking plont be pan opertion

1955 site re ctor poinerd City of Aro

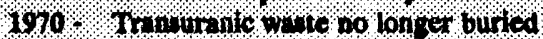

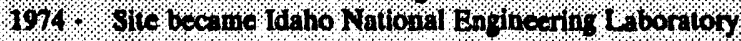
(1)1)

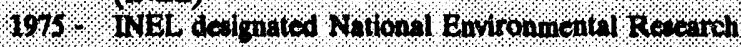
Pork

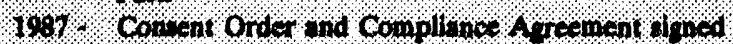

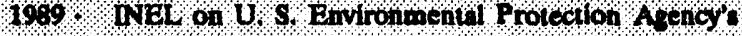

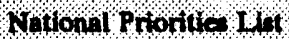

1991 fodent Faclity A reanent and Conent Order Honod

1992 Dection 10 phine out reprocering at the If ho Chemical Proctesing Plant

Since the mid-1970s, one of the specific purposes of the INEL has been to advance science and technology related to environmental characterization and restoration of sites contaminated by earlier operations. In 1974, the National Reactor Testing Station was renamed the Idaho National Engineering Laboratory to reflect its broader mission, which now includes research and engineering for nonnuclear, as well as nuclear, energy programs. One year later, the INEL was designated as a National Environmental Research Park, one of seven in the nation.

These parks were established by DOE to provide protected land areas for research and education in the environmental sciences and to demonstrate the compatibility of energy technology development and use with environmental quality. The INEL site provides an outdoor laboratory where scientists can study changes in the natural environment caused by human activities. DOE has continued to further emphasize the mission of developing restoration and waste management technologies and to implement the requirements from the signing of the Consent Order and Compliance Agreement in 1987 and, since the listing of the INEL on the National Priorities List, the Federal Facility Agreement and Consent Order in 1991, which superseded the Consent Order and Compliance Agreement. 
2.2.3.2 Current Mission. The current INEL mission is to develop, demonstrate, and deploy advanced engineering technology and systems to improve national competitiveness and security, to make the production and use of energy more efficient, and to improve the quality of life and the environment. Areas of primary emphasis at the INEL include waste management and minimization, environmental engineering and restoration, energy efficiency, renewable energy, national security and defense, nuclear technologies, and advanced technology and methods. The ER\&WM Program has DOE's top priority at the INEL.

Specific aspects of the Environmental Restoration Program mission are (a) assess and clean up sites where there are known or suspected releases of harmful substances into the environment and (b) safely manage contaminated surplus nuclear facilities as they are decommissioned. Aspects of the Waste Management Program mission are (a) protect the safety of INEL employees, the public, and the environment in the design, construction, maintenance, and operation of INEL treatment, storage, and disposal facilities; and (b) operate these facilities in a manner that is cost-effective, is environmentally sound, complies with regulations, and is publicly acceptable. While fulfilling these missions, DOE is committed to bringing all INEL facilities into compliance with local, State, and Federal regulations.

\subsubsection{Major Facility Areas}

Mission activities including those associated with ER\&WM occur primarily in nine major facility areas that were developed since the INEL site was established. This section describes the nine areas that exist at the INEL site (see Figure 2.2-2) and the Idaho Falls operations facilities. As the figure shows, most of the facility areas are located in the southwestern portion of the site. These facilities are the result of implementing both historic and current missions.

The specific facilities described in this section include both those where spent nuclear fuel and ER\&WM activities occur (proposed actions evaluated in this EIS) and where nonspent-nuclear-fuel/ER\&WM activities occur (actions generally not evaluated in this EIS with the exception of the wastes they would generate). Information on Spent Nuclear Fuel and ER\&WM Program activities is presented in Sections 2.2.5 (Spent Nuclear Fuel), 2.2.6 (Environmental Restoration), 2.2.7 (Waste Management), and 2.2.10 (Activities Not Directly Related to Spent Nuclear Fuel or Environmental Restoration and Waste Management). 


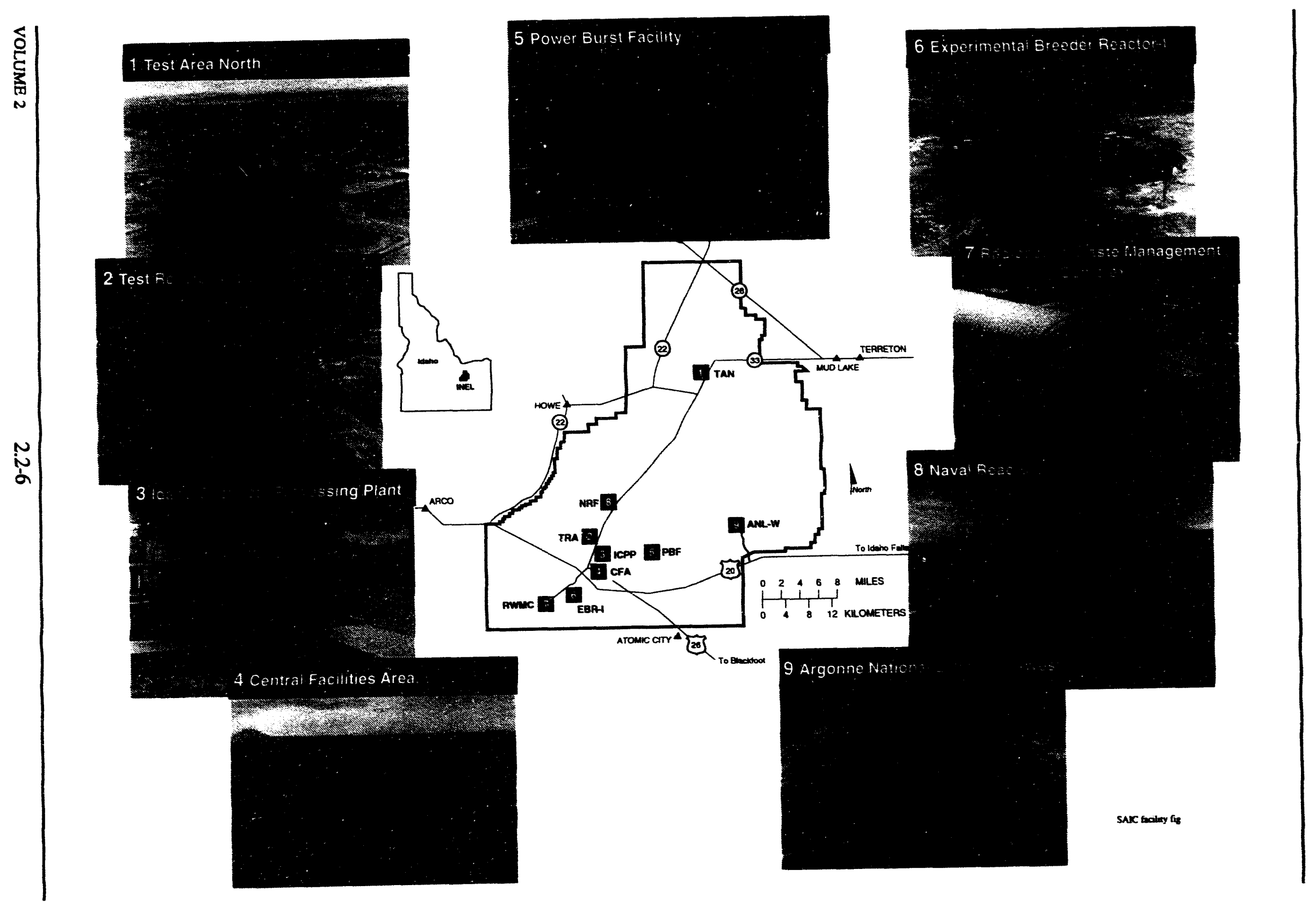

Figure 22-2 Major facility areas located at the Idaho National Engineering Laboratory site. 
The nine major facility areas at the INEL site are Test Area North, Test Reactor Area, Idaho Chemical Processing Plant, Central Facilities Area, Power Burst Facility, Experimental Breeder Reactor-I/Boiling Water Reactor Experiment, Radioactive Waste Management Complex, Naval Reactors Facility, and Argonne National Laboratory-West. In addition to the major facility areas located at the site, numerous support facilities are located in the City of Idaho Falls. The facilities at the site plus all supporting DOE facilities in Idaho Falls make up the INEL.

2.2.4.1 Test Area North. The Test Area North is located in the northern portion of the INEL site on State Highway 33 about 15 miles east of the town of Howe and 12 miles west of the town of Mud Lake. This facility area covers a total area of about 0.8 square kilometers (200 acres).

Test Area North's original purpose was to house the Aircraft Nuclear Propulsion Project, a now-discontinued project to develop nuclear-powered aircraft. Later, this facility area included the Loss-of-Fluid Test Facility, which was used in light-water-reactor accident testing. Structures associated with these earlier operations still exist at Test Area North. Test Area North's current purpose includes handling and evaluating irradiated material, supporting energy research and defense programs (including production of tank armor), and performing flow tests to support reactor safety studies. The facilities also support the testing of casks used for the interim storage of spent nuclear fuel and the study of spent nuclear fuel transportation. In addition, spent nuclear fuel is also stored at Test Area North.

Test Area North's four key facilities related to spent nuclear fuel and ER\&WM are the Initial Engine Test Facility, which was used for the Aircraft Nuclear Propulsion Project, has been inactive since 1978, and consists of seven vacant buildings; the Technical Support Facility, which is used for handling and examining radioactive materials, contains the Process Experimental Pilot Plant, and consists of $\mathbf{4 0}$ structures having administrative, service, and maintenance functions; the Water Reactor Research Test Facility, which is used for reactor flow experiments, includes the Thermal-Hydraulic Experimental Facility Assembly and Test Building, and contains eight structures; and the Containment Test Facility, formerly the Loss-of-Fluid Test Facility, which houses the Specific Manufacturing Capability project that produces tank armor for the U.S. Army and consists of 34 structures. 
2.2.4.2 Tost Roactor Area. The Test Reactor Area covers about 0.4 square kilometers (100 acres) and is located in the southwestern portion of the INEL site. This facility area contains over $\mathbf{7 0}$ buildings, many of which were built as early as 1952. The Test Reactor Area's current purpose is to study the effects of radiation on materials, fuels, and equipment and to perform chemistry and physics experiments. The Test Reactor Area's major facilities include three reactors, four low-power reactors, and a hot cell operation for handling highly radioactive materials. The three reactors are the Materials Test Reactor, the Engineering Test Reactor, and the Advanced Test Reactor. The Materials Test Reactor and Engineering Test Reactor have been deactivated and are planned for decontamination and decommissioning. The Advanced Test Reactor is still operating. It is used for materials testing under reactor conditions and for producing radioisotopes used in medicine, research, and industry.

The four low-power reactors used for criticality measurements are the Engineering Test Reactor Critical Facility (in decommissioning and decontamination), the Advanced Test Reactor Critical Facility (on line), the Advanced Reactivity Measurement Facility (on standby), and the Coupled Fast Reactivity Measurement Facility (on standby).

\subsubsection{Idaho Chemical Processing Plant. The Idaho Chemical Processing Plant} covers approximately 1 square kilometer (250 acres) and contains over 150 buildings. Twenty-one additional buildings are planned for construction. The Idaho Chemical Processing Plant is located near the Test Reactor Area in the southwestern part of the INEL site.

The Idaho Chemical Processing Plant's original purpose was to function as a one-of-a-kind reprocessing facility for government-owned nuclear fuels from research and defense reactors. The plant recovered uranium from spent nuclear fuel so that it could be reused.

The Idaho Chemical Processing Plant's current purpose is to

- $\quad$ Receive and store DOE-assigned nuclear fuels

- Prepare high-level liquid and solid waste for disposition in a permanent repository 
- Develop technologies for the disposition of spent nuclear fuel, sodium-bearing waste, and high-level waste

- Develop and apply technologies to minimize waste generation and manage radioactive and hazardous wastes.

Major operating facilities at the Idaho Chemical Processing Plant include both storage and treatment facilities. Storage facilities provide spent nuclear fuel storage (pools and dry storage), calcine (dry granular waste) storage (in bins), and liquid high-level waste storage (in underground tanks). Treatment facilities include a waste solidification facility for treatment of liquid high-level waste and sodium-bearing waste (New Waste Calcining Facility) and an evaporator used to concentrate low-level waste and mixed low-level waste. Another treatment facility prevents radioactive waste from being discharged to the percolation ponds and recovers nitric acid for reuse. Mixed and low-level waste is handled and stored in the Hazardous and Radioactive Mixed Waste Staging Area and the Hazardous Chemical/Radioactive Waste Facility. Other operating facilities include process development and robotics laboratories.

\subsubsection{Central Facilltios Area. The Central Facilities Area encompasses about 2.2} square kilometers (550 acres) in the southwestern portion of the INEL site and contains over 80 buildings. The Central Facilities Area's purpose is to provide technical and support services for the INEL site. These services include environmental monitoring and calibration laboratories, communication systems, security, fire protection, medical services, warehouses, a cafeteria, vehicle and equipment pools, and bus operations.

Major Central Facilities Area facilities include two waste operations facilities, the Hazardous Waste Storage Facility, and the INEL Landfill Complex. The Hazardous Waste Storage Facility temporarily stores hazardous wastes pending shipment to a commercial, offsite, U. S. Environmental Protection Agency-permitted treatment and disposal site. The Landfill Complex is a facility used to dispose of commercial industrial waste.

2.2.4.5 Power Burat Facillty. The Power Burst Facility is located in a 2.8-squarekilometer (700-acre) area in the southernmost portion of the INEL site off U.S. Highway 20. The original purpose of the Power Burst Facility was for Special Power Excursion Reactor Tests 
(I-IV), which were severe-damage tests of nuclear fuels and materials used in reactors. This facility is currently being considered for a cancer research and treatment program. The reactor support facilities are currently being used for waste management-related research, including the development of radioactive waste volume-reduction techniques and waste immobilization rescarch.

The Power Burst Facility has four major facilities: the Waste Experimental Reduction Facility, which was designed to treat low-level and mixed low-level waste for volume reduction and removal of Resource Conservation and Recovery Act hazardous waste; the Mixed Waste Storage Facility, which provides temporary storage for mixed low-level waste; the Waste Experimental Reduction Facility Waste Storage Building, which stores waste awaiting treatment in the Waste Experimental Reduction Facility and augments the capacity of the Mixed Waste Storage Facility; and the Waste Engineering Development Facility, which is used for treatment, decontamination, and technology development activities.

Near the Power Burst Facility area is the Auxiliary Reactor Area, which currently encompasses 22 buildings.

The Auxiliary Reactor Area's original purpose was to test portable power reactors for the U.S. Army. The program has been phased out, and all reactors have been removed or dismantled. All remaining buildings at the Auxiliary Reactor Area have been identified for decontamination and decommissioning. Currently, all buildings in the area are vacant except for intermittent small-scale testing programs.

\subsubsection{Exporimental Breeder Reactor-J/Bolling Water Reactor Exporiment. This} facility area is located in the southwestern portion of the INEL site and encompasses about 0.04 square kilometers (10 acres). This facility area originally housed the Experimental Breeder Reactor-I, which became the first reactor to generate usable amounts of electricity. Currently, this facility is a National Historic Landmark. Nearby is the Heat Transfer Reactor Experiment Test engine assemblies, which were operated as part of the Aircraft Nuclear Propulsion Program. Also nearby is the Boiling Water Reactor Experiment area. This area originally included five separate experimental reactors, which are not currently being used and are being, or have been, decontaminated and decommissioned. 
2.2.4.7 Radloactive Waste Managoment Complox. This facility area is the most southwestern of all areas at the INEL site. It contains over 35 buildings and covers about 0.58 square kilometers (144 acres).

The original purpose of the Radioactive Waste Management Complex was to dispose of solid radioactive wastes generated at the INEL site and defense wastes (mostly transuranic).

The current purpose of the facility is to provide waste management for interim storage of transuranic waste and disposal of low-level waste. It also supports research and development projects to improve treatment and interim storage of transuranic waste, low-level waste disposal, buried waste remediation technologies, and environmental remediation.

At the Radioactive Waste Management Complex, two main areas, including several major facilities, are currently operating: the Transuranic Storage Area and the Subsurface Disposal Area. The Transuranic Storage Area is dedicated to the management of transuranic waste, including interim storage operations, certification, technology development, and future shipment to the Waste Isolation Pilot Plant. The Stored Waste Examination Pilot Plant, located in the Transuranic Storage Area, is currently on operational standby. The Transuranic Storage Area also includes the following: three asphalt transuranic storage pads, TSA-1, 2, \& 3; an area that stores wastes from buried waste retrieval studies, TSA-R; and an Intermediate Level Transuranic Storage Facility, which handles waste with radiation levels that require remote handling. Four new engineered storage modules meeting Resource Conservation and Recovery Act requirements will be constructed by June 1995 for the waste stored on two of the asphalt pads currently covered by air-support structures.

The Subsurface Disposal Area is dedicated to permanent disposal of low-level waste generated at the INEL site. Related projects support studies of buried waste, remediation technologies, and contaminant migration. The Subsurface Disposal Area includes pits, trenches, and concrete-lined and unlined soil vauits for low-level disposal. One disposal pit (Pit 9) is the subject of a comprehensive demonstration project for buried waste remediation.

2.2.4.8 Naval Reactors Facllty. This facility area, which covers about 0.28 square kilometers (70 acres), is located in the south-central portion of the INEL site. It contains over 70 
buildings. The Naval Reactors Facility is under the jurisdiction of the Naval Nuclear Propulsion Program, a joint DOE-Navy program. Its current purposes are as a research and development facility, for training for nuclear power plant operators, and for inspection of naval spent fuel. However, all reactor operations and training at this facility will cease by May 1995.

The major facility at the Naval Reactors Facility is the Expended Core Facility, where naval fuel and fuel from the facility itself are received and examined to support fuel development and performance analyses. The Expended Core Facility also removes structural material from the fuel assemblies prior to transferring the fuel to the Idaho Chemical Processing Plant for storage.

2.2.4.9 Argonne National Laboratory-Woet. This facility area is the most southeastern facility area on the site and the closest to Idaho Falls [about 43 kilometers (27 miles)]. It houses several major complexes and numerous buildings.

The original purpose of the Argonne National Laboratory-West was as a testing ground for breeder reactor technology. Currently, the Experimental Breeder Reactor-II, the first pooltype liquid metal reactor, still generates electricity for the INEL site. Ongoing research and development of breeder reactor technology and advanced reactor design includes an inherently safe reactor design known as the Integral Fast Reactor that may lead to a future generation of commercial nuclear reactors.

The facility area consists of several major complexes, including the Experimental Breeder Reactor-II, the Transient Reactor Test Facility, the Zero Power Physics Reactor, the Hot Fuel Examination Facility, the Fuel Cycle Facility, and the Fuel Manufacturing Facility. The Experimental Breeder Reactor-II is being used to demonstrate the Integral Fast Reactor concept. The Transient Reactor Test Facility and the Zero Power Physics Reactor are used to conduct reactor analysis and safety experiments. The Hot Fuel Examination Facility provides a large inertatmosphere containment for handling and examining irradiated reactor fuel. The Fuel Cycle Facility has been modified for the Integral Fast Reactor program to demonstrate remote reprocessing and refabrication in the fuel cycle. The Fuel Manufacturing Facility is used to manufacture metallic fuel elements for the fuel cycle. 
Supporting facilities at Argonne National Laboratory-West include the Radioactive Liquid Waste Treatment Facility, the Radioactive Scrap and Waste Facility, the Radioactive Sodium Storage Facility, and the Sodium Process Facility. The Radioactive Liquid Waste Treatment Facility processes low-level (aqueous) liquid waste. Transuranic waste from Argonne National Laboratory-West is stored at the Radioactive Scrap and Waste Facility. Contact-handled mixed waste is stored in the Radioactive Sodium Storage Facility (sodium-contaminated), and remotehandled mixed waste is stored at the Radioactive Scrap and Waste Facility. The Sodium Process Facility was built to process reactor sodium.

2.2.4.10 Idaho Falls Oporations. About 30 percent of the INEL's employees work in Idaho Falls and provide administrative and scientific support and nonnuclear laboratory services. The major facility associated with ER\&WM is the INEL Research Center, which is the location for a wide variety of disciplines and features a prominent plasma research center, biotechnical center, materials research laboratory, and measurement sciences laboratory. Other major facilities include DOE-ID office buildings, the Willow Creek Building, the INEL Supercomputing Center, the Engineering Research Office Building, and many technical support buildings.

\subsubsection{Spent Nuclear Fuel}

Spent nuclear fuel is fuel that has been withdrawn from a nuclear reactor following irradiation, the constituent elements of which have not been separated by reprocessing. Spent nuclear fuel consists of the unused part of the fuel, fission products, transuranics, and the metal cladding or graphite that surrounds the fuel. Spent nuclear fuel still contains material that can potentially be reclaimed and reused.

2.2.5.1 Current Spent Nuclear Fuel Management. Two basic sources of fuel are handled at the INEL: naval vessel and prototype spent nuclear fuel; and university, commercial, U.S. government (including DOE), and foreign reactor spent nuclear fuel. Figure 2.2-3 shows the current spent nuclear fuel activities and their locations at the INEL site.

Spent nuclear fuel removed from nuclear-powered naval vessels and prototypes has been shipped to the Naval Reactors Facility at the INEL site. Shipments have been restricted since 
June 1993 until this SNF and INEL ER\&WM EIS is completed and the Record of Decision has been published.

Spent fuel was unloaded from shipping containers into water pools at the Expended Core Facility for examination. The examined naval spent nuclear fuel was then transferred to the Idaho Chemical Processing Plant at a rate of 1 metric ton per year for storage and reprocessing. In April 1992, DOE decided to phase out reprocessing at the INEL site because the recovered uranium was no longer needed.

Spent nuclear fuel has also been received at the INEL site from university, commercial and industrial, DOE and other U.S. government, and foreign reactors. Some spent nuclear fuel,

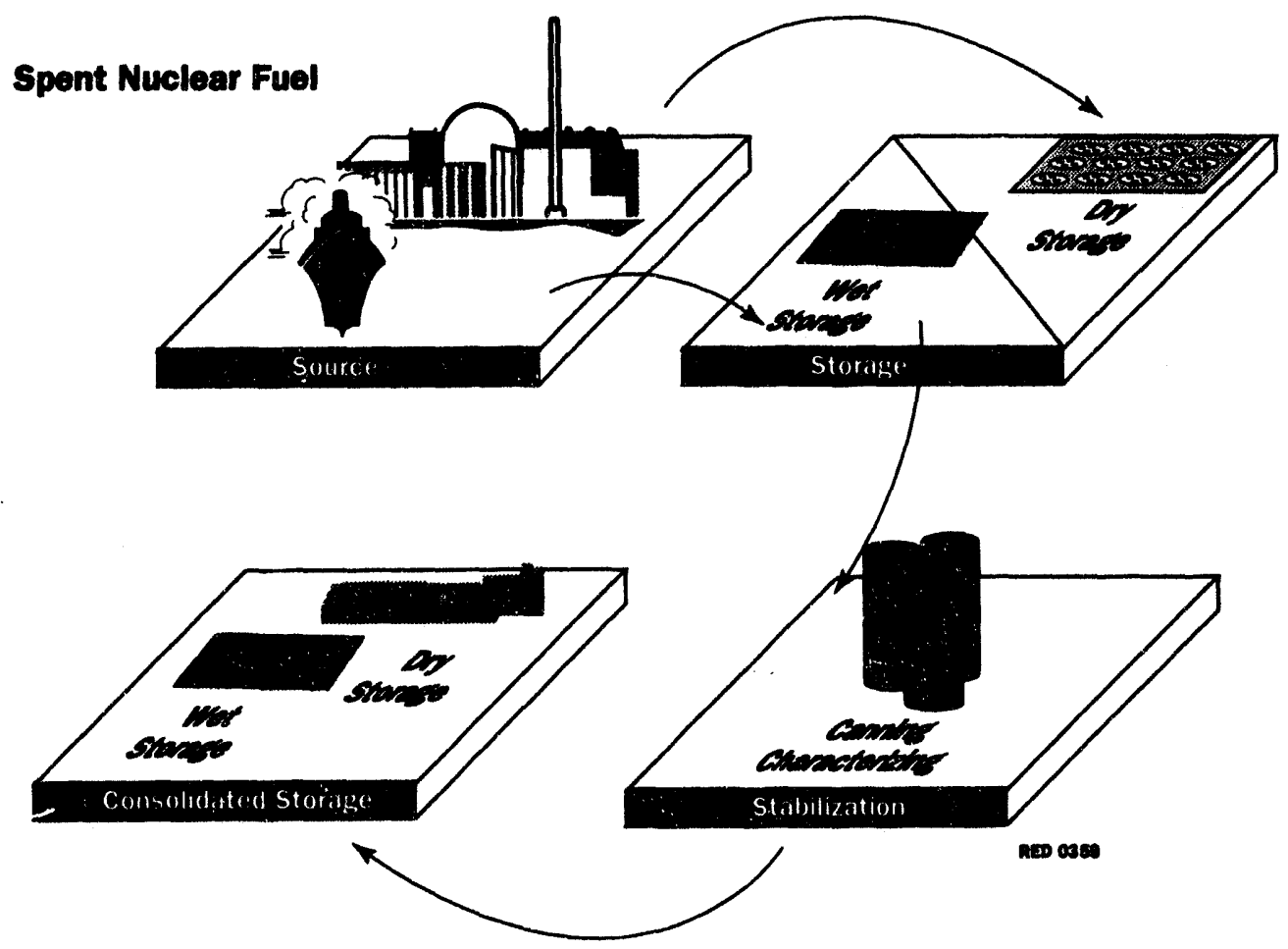

Figure 22-3. Current spent nuclear fuel management program at the Idaho National Engineering Laboratory. 
such as fuel from university reactors and from the Fort St. Vrain reactor in Colorado, was shipped directly to the Idaho Chemical Processing Plant for storage. Damaged Three Mile Island fuel from Pennsylvania was shipped directly to Test Area North for examination and storage.

Spent nuclear fuel continues to be generated and transported on the INEL site. Advanced Test Reactor operations continue to generate about 0.1 metric ton of heavy metal per yea: of spent nuclear fuel that is shipped to the Idaho Chemical Processing Plant for storage. The Experimental Breeder Reactor-II operations at Argonne National Laboratory-West continue to generate about $\mathbf{0 . 3}$ metric ton of heavy metal per year of spent nuclear fuel that is stored at Argonne National Laboratory-West. Naval reactor spent nuclear fuel currently examined at the Naval Reactors Facility is transferred to the Idaho Chemical Processing Plant for storage.

At the INEL site, spent nuclear fuel is stored at five facility areas in various dry and wet storage facilities awaiting final disposition. The areas are Test Area North, Test Reactor Area, Idaho Chemical Processing Plant, Power Burst Facility, and Argonne National Laboratory-West. Because fuel is not being reprocessed and disposition options have not yet been developed for spent nuclear fuel, all onsite spent nuclear fuel generation increases the amount stored at the site.

Several specific spent nuclear fuel management activities are currently occurring at the Idaho Chernical Processing Plant. As described in Chapter 3, Alternatives, spent nuclear fuel stored underwater at the north and middle basins of Building 603 is to be removed by December 31, 1996, and the entire Underwater Fuel Storage Facility at Building 603 is to be emptied by December 31, 2000. Fuel is being transferred to newer storage facilities at the Idaho Chemical Processing Plant. To stabilize the fuel for consolidated storage, equipment would already be installed and operating before the Record of Decision for this SNF and INEL ER\&WM EIS.

DOE is developing spent nuclear fuel management plans for a timeframe (that is, 40 years) that is anticipated to be sufficient to cover the period during which ultimate disposition for the DOE's spent nuclear fuel will be established and implemented.

2.2.5.2 Vulnerability Assessment. In August 1993, the Secretary of Energy commissioned a comprehensive baseline assessment of the environmental, safety, and health 
vulnerabilities associated with the storage of spent nuclear fuel in the DOE complex. $A$ multidiscipline working group comprised of DOE employees and contractors assessed 66 facilities at eight sites to evaluate the inventory and condition of DOE's reactor-irradiated nuclear material, which includes spent nuclear fuel and reactor-irradiated target material. The working group also evaluated the condition of facilities that store spent fuel and identified the vulnerabilities and problems that are currently associated with these facilities. DOE made the working group report to the Secretary (DOE 1993b) available to the public in December 1993. The working group ultimately identified 106 vulnerabilities associated with spent nuclear fuel storage, including 33 at the INEL site. DOE (1993b) identified eight DOE facilities with major vulnerabilities, including one facility at the INEL, the CPP-603 Fuel Storage Facility.

DOE issued a Phase I Plan of Action to address spent fuel storage vulnerabilities in February 1994 (DOE 1994a) and a Phase II Plan of Action in April 1994 (DOE 1994b) and plans to issue a Phase III Plan of Action in September 1994. A summary of specific corrective actions to address the spent fuel storage vulnerabilities identified at the INEL site are listed in Table 2.2-1. This is not a complete list of the corrective actions but does include those with potential adverse environmental consequences. The Phase III Plan of Action, when complete, could add to this list. Many of the corrective actions are currently underway or have been completed. These activities and other planned activities for which the National Environmental Policy Act review is complete before the Record of Decision for this EIS is issued were analyzed under Alternative A (No Action). Activities underway (or to be underway as of June 1995) to address the major vulnerabilities identified at the CPP-603 Fuel Storage Facility would reduce the potential environmental impacts associated with corroded spent fuel, and minimize the release of fissile material to the fuel storage basin; they include the following:

- Replacing the failed System for Nuclear Auxiliary Power fuel containers with stainless steel overpacks

- Removing accessible sludge to help maintain water clarity and reduce release of radionuclides into the storage basin. 
Table 22-1. Corrective actions addressing spent fuel storage vulnerabilities at the Idaho National Engineering Laboratory.

\begin{tabular}{|c|c|c|c|c|}
\hline \multirow[b]{2}{*}{ Facility and concern } & \multirow{2}{*}{$\begin{array}{c}\text { Identification } \\
\text { number }\end{array}$} & \multirow[b]{2}{*}{ Corrective action } & \multirow{2}{*}{$\begin{array}{l}\text { Scheduled } \\
\text { completion date }\end{array}$} & \multirow{2}{*}{$\frac{\text { Alternative }}{\text { A B C D }}$} \\
\hline & & & & \\
\hline \multicolumn{5}{|l|}{$\begin{array}{l}\text { Hot Fuels Bamination Facility at Argonne National } \\
\text { Laboratory-West }\end{array}$} \\
\hline $\begin{array}{l}\text { Lack of an approved safety analysis report for the } \\
\text { facility }\end{array}$ & ID.A.1.1 & $\begin{array}{l}\text { - Safety analysis report will be updated } \\
\text { when mission is defined }\end{array}$ & $\begin{array}{l}\text { To be } \\
\text { determined }\end{array}$ & $\mathbf{X}$ \\
\hline \multicolumn{5}{|l|}{ Radioactive Scrap/Waste Fucility } \\
\hline \multirow[t]{2}{*}{$\begin{array}{l}\text { Corrosion of in-ground carbon steel fuel storage } \\
\text { containers - Argonne National Laboratory-West }\end{array}$} & ID.A.2.1 & $\begin{array}{l}\text { - Complete relocation of } 296 \text { cylinders } \\
\text { into new liners (1994-97) }\end{array}$ & September 1997 & $\mathbf{x}$ \\
\hline & & $\begin{array}{l}\text { - Complete installation of } 608 \text { new liners } \\
(1994-99)\end{array}$ & September 1999 & $\mathbf{X}$ \\
\hline \multicolumn{5}{|l|}{ Zero Power Physias Reactor } \\
\hline \multirow[t]{2}{*}{$\begin{array}{l}\text { Potential localized radioactive releases from cladding } \\
\text { separation from fuels stored in storage vault }\end{array}$} & ID.A.5.1 & $\begin{array}{l}\text { - Reencapsulate fuel in sealed inert } \\
\text { canisters }\end{array}$ & Complete & $\mathbf{X}$ \\
\hline & & $\begin{array}{l}\text { - Periodically inspect a sample of stored } \\
\text { fuel for degradation }\end{array}$ & Ongoing & $\mathbf{x}$ \\
\hline \multicolumn{5}{|l|}{ Test Area North } \\
\hline \multirow[t]{3}{*}{ Inadequate corrosion monitoring at Test Area North } & ID.E.1.1 & $\begin{array}{l}\text { - Remove non-Three Mile Island spent } \\
\text { fuel stored in aluminum coffins }\end{array}$ & March 1995 & $\mathbf{X}$ \\
\hline & & $\begin{array}{l}\text { - Remove non-Three Mile Island spent } \\
\text { fuel stored in stainless steel modules }\end{array}$ & September 1996 & $\mathbf{X}$ \\
\hline & & $\begin{array}{l}\text { - Transfer all spent fuel from Test Area } \\
\text { North Storage Pool }\end{array}$ & September 1998 & $\mathbf{X}$ \\
\hline
\end{tabular}




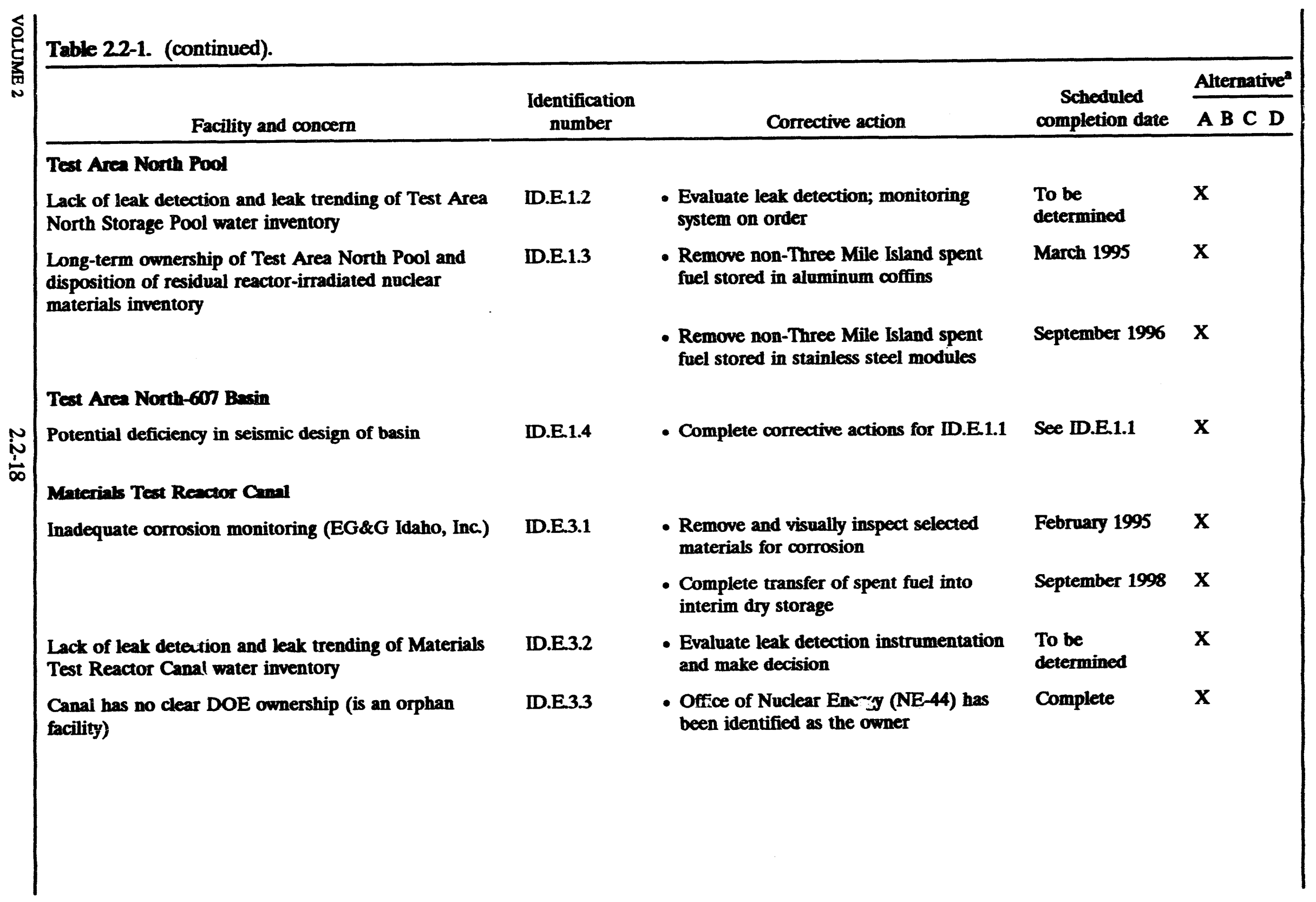


Table 22-1. (continued).

Advanced Reactivity Measurement Facility/Coupled Fast Reactivity Messurement Facility Canal

Has no programmatic ownership (is an orphan facility)

Facility and concern

Identification

number

Scheduled

Alternative

Advanoed Reactivity Measurement Facility

Inadequate corrosion monitoring at Advanced

Reactivity Measurement Facility/Coupled Fast

- Remove and visually inspect selected materials for corrosion

February 1995

A B C D

Rexctivity Measurement Facility Canal (EG\&G Idaho, Inc.)

\section{Power Burst Facility}

Inadequate corrosion monitoring

ID.E.5.1

- Complete transfer of spent fuel into interim dry storage

September 1996

ID.E.4.2
- Office of Nuclear Energy (NE-44) has been identified as the owner

Complete

$\mathbf{X}$

- Remove and visually inspect selected materials for corrosion

- Complete transfer of spent fuel into interim dry storage

\section{CPP-603 Basins}

Corrosion of aluminum associated with fuel and release of fissile material and radionuclides into the basin environment

ID.W.1.01

- Overpack failed System for Nuclear Auxiliary Power fuel containers

July 1994

$\mathbf{X}$

- Complete upgrade of basin radionuclide

December 1996 removal/support systems

- Complete canning and transfer of 423 fuel units

December 2000 
Table 22-1. (continued).

\section{Table 221. (continued).}

Facility and concern

Identification

Scheduled

completion date

Alternative

CPP-603 Bexins (continued)

Uncharacterized water content of fuel now stored or to

ID.W.1.02

be encapsulated in containers

Establish technology for nondestructive examination of canisters and

December 1995

$\mathbf{X}$ measurement of contents

- Complete fuel storage canister water content measurements

Institutional criticality control of stored reactor-

ID.W.1.03

- Complete development of Basis for

September $1997 \quad \mathrm{X}$

irradiated nuclear materials Interim Operation for unresolved safety questions

- Complete procedures and training to implement Basis for Interim Operation

No repacking capability at CPP-603 (required to help minimize the effects of corrosion on the fuel assemblies and ensure safe storage of the fuel)

Excessive corrosion of fuel handling units at CPP-603

ID.W.1.06

- Complete Operational Readiness Review activities for canning

- Complete canning and transfer of 423 fuel units

- Transfer first 189 fuel units from CPP-603 to CPP-666

- Transfer second 189 fuel units from CPP-603 to CPP-666

- Transfer remaining fuel units from CPP-603 to CPP-666

December $1994 \mathrm{X}$

December 1994 X

December 1997 X

December $2000 \quad X$

September $1994 \quad \mathrm{X}$

December $1995 \quad X$

December $1996 \mathrm{X}$ 
Table 22-1. (continued).

Worker exposures and releases to the environment during encapsulation of fuel in CPP-603 basins

\section{CPP-603 Basins (continued)}

Lack of leak detection and leak trending of release of fission products into the environment from the spent fuel storage basins at CPP-603

Basin wall failure and superstructure collapse from a large seismic event and baskets could fail, potentially resulting in a criticality

ID.W.1.07

dentification

number

Corrective action

Scheduled

completion date

Alternative

A B C D

- Complete installation of higher accuracy June 1994

$\mathbf{X}$

level monitoring equipment

- Continue periodic observation of three monitoring wells

ID.W.1.10

- Complete removal of accessible sludge

Continue

$\mathbf{X}$

June 1994

$\mathbf{X}$

- Complete upgrade of basin radionuclide removal/support systems

- Implement operating procedures for fuel recovery/encapsulation

ID.W.1.11

- Complete Basin Water Removal Program Plan

- Complete transfer of fuel to CPP-666 or dry storage

- Complete removal of basin water

ID.W.1.12

- Overpack failed System for Nuclear Auxiliary Power fuel containers

- Complete upgrade of basin radionuclide removal/support systems

- Complete canning and transfer of $\mathbf{4 2 3}$ fuel units
December $1996 \mathrm{X}$

Continue

X

September 1996

$\mathbf{X}$

December $2000 \quad X$

December $2003 \quad X$

July 1994

$\mathbf{X}$

December 1996

$\mathbf{X}$

December $2000 \mathrm{X}$ 
Table 22-1. (continued).

Table 22-1. (continued).

Facility and concern
CPP-666 Baxins
Corrosion of aluminum clad fuel and release of fissile

Identification number environment

Susceptibility to damage and downgrading of engineered safety features at CPP-603 basins

\section{CPP-60B/Irndinted Puel Storage Facility}

Ignition of brittle cardboard fuel containers at the facility

Roof collapse and control room equipment failure

from a large seismic event
ID.W.2.1

- Implement improved monitoring of CPP-666 water

- Design and procure new stainless steel baskets

ID.W.2.2

- Review criticality configuration and document controls

- Evaluate engineered safety features and monitoring/preventive maintenance programs

ID.W.3.2

- Complete electrical upgrade project

- Complete transfer of fuels in cardboard containers to Oak Ridge

ID.W.3.3

- Complete seismic craluation of fuel storage rack inside vault

- Complete seismic evaluation of concrete structure and roof
Scheduled

completion date

Altermative

A B C D

September $1995 \times \mathrm{X}$

September $1998 \quad$ X X X

September $1994 \quad \mathrm{X}$

September $1996 \mathrm{X}$

October $1994 \quad X$

September $1995 X$

September $1994 X$

September $1995 \mathrm{X}$ 
Table 22-1. (continued).

CPP-603 Feel Element Cuming Facility

Possible degraded Peach Bottom fuel

ID.W.4.2

- Inspect containers to determine

condition and support retrieval

March 1995

Alternative

\section{CPP-749 Drymells}

Potentially degrading aluminum fuel cans and baskets

ID.W.5.2 (Westinghouse Idaho Nuclear Company)

- Complete 20 fuel transfers into second generation dryweils

- Complete 25 fuel transfers into second generation drywells

$\mathbf{X}$

a. $\mathbf{A}=$ Alternative $\mathbf{A}$ (No Action).

B = A.lternative B (Ten-Year Plan).

C = Alternative C (Minimum Treatment, Storage, and Disposal).

D = Alternative D (Maximum Treatment, Storage, and Disposal). 
Many of the specific INEL spent nuclear fuel Plan of Action projects could result in emissions, worker exposure, or other potential environmental impacts. The potential environmental impacts that could result from each project or corrective action item were not analyzed individually but were collectively enveloped by the spent nuclear fuel management activities reported and analyzed for each alternative in Volume 2. Successful completion of the corrective actions would reduce the near-term environmental, safety, and health risks associated with spent fuel storage at the INEL site.

The working group report identified a vulnerability associated with a lack of a path for the ultimate disposition of spent nuclear fuel stored at INEL facilities. The Plan of Action identifies the completion of this EIS as a corrective action to address this vulnerability. In fact, this EIS is intended to support decisions needed to safely manage spent nuclear fuel until future decisions regarding its ultimate disposition are made and implemented.

\subsubsection{Environmental Restoration}

Since the 1970s, the INEL Environmental Restoration Program has addressed contamination issues resulting from the past $\mathbf{4 5}$ years of operations at the site. Environmental restoration includes two major program elements: (a) remediation and (b) decontamination and decommissioning.

2.2.6.1 Remediation. Remediation is the process of assessing and cleaning up releases and threatened releases of hazardous substances, including radioactive substances at the INEL. The remediation program at the INEL is conducted under the Federal Facility Agreement and Consent Order, entered into by DOE, the U. S. Environmental Protection Agency, and the State of Idaho pursuant to the Comprehensive Environmental Response, Compensation, and Liability Act (CERCLA).

The INEL follows the remedial action process (Figure 2.2-4) established under CERCLA and its implementing regulation, the National Contingency Plan. Under CERCLA, the INEL entered into the Federal Facility Agreement and Consent Order, which provides site-specific direction for the remedial action process. This process directs both the assessment and cleanup of 

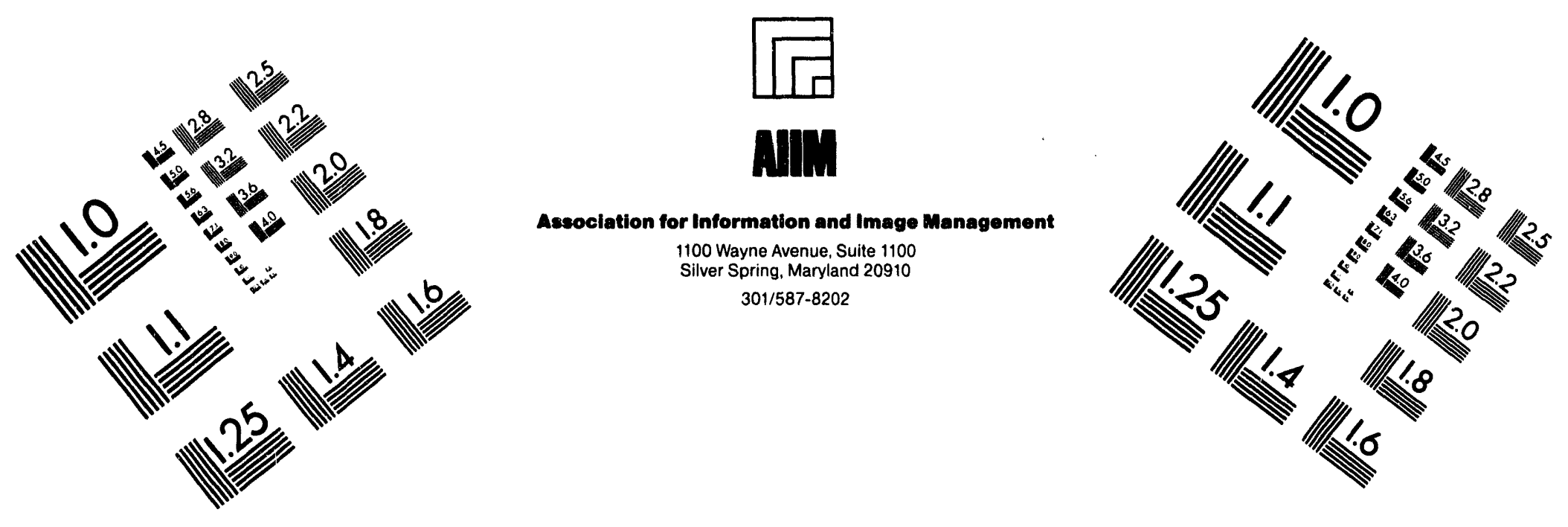

\section{Centimeter}

$\begin{array}{llllllllllllllll}1 & 2 & 3 & 4 & 5 & 6 & 7 & 8 & 9 & 10 & 11 & 12 & 13 & 14 & 15 & \mathrm{~mm}\end{array}$

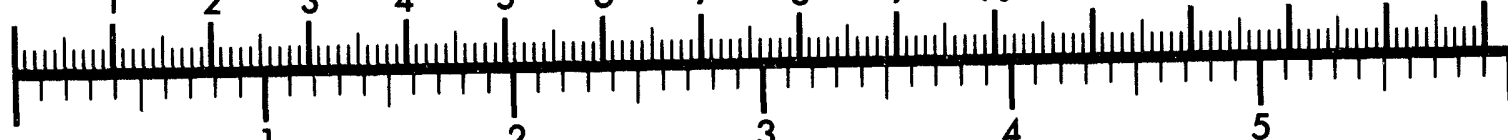
Inches

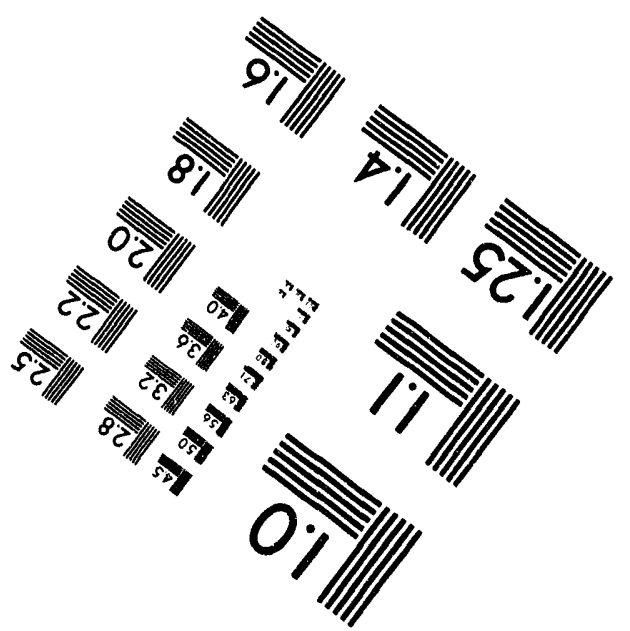

MANUFACTURED TO AIIM STANDARDS

BY APPLIED IMAGE, INC.

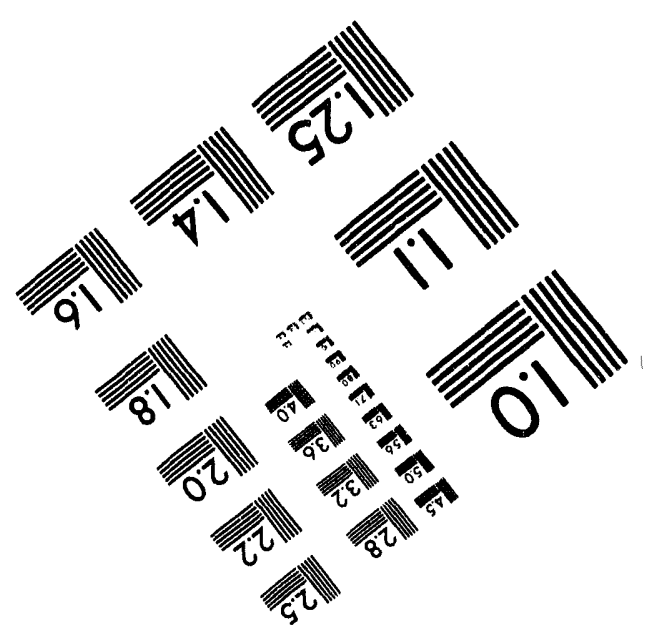



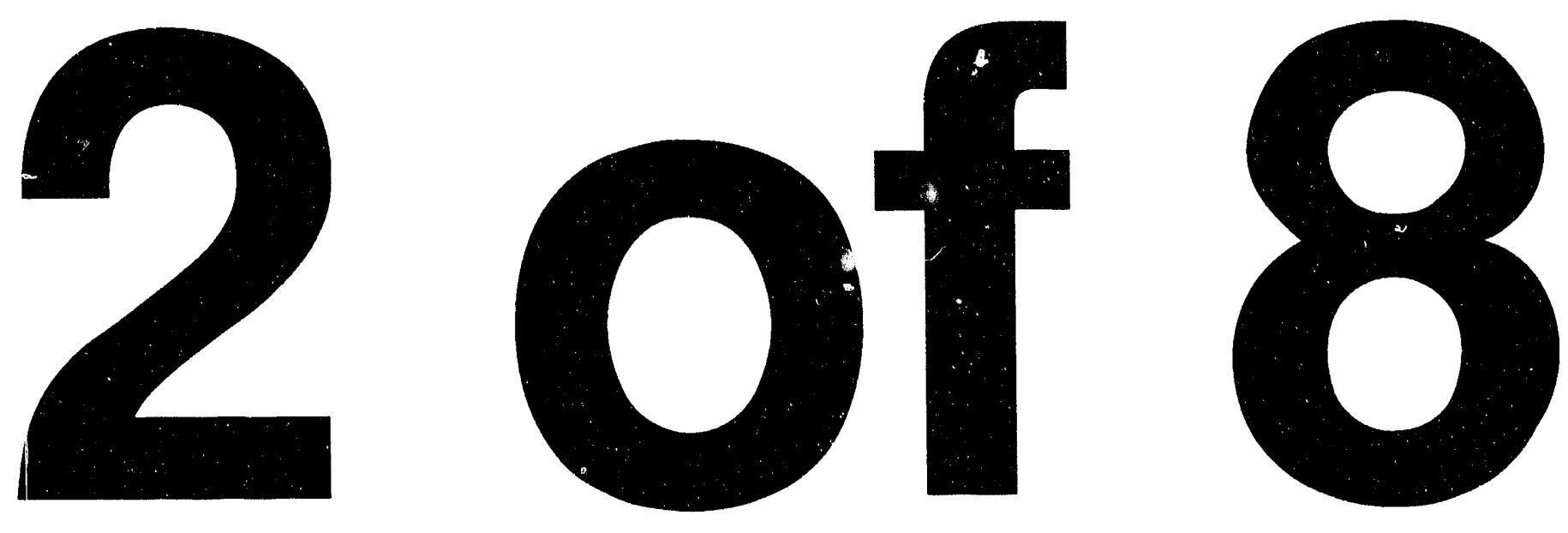


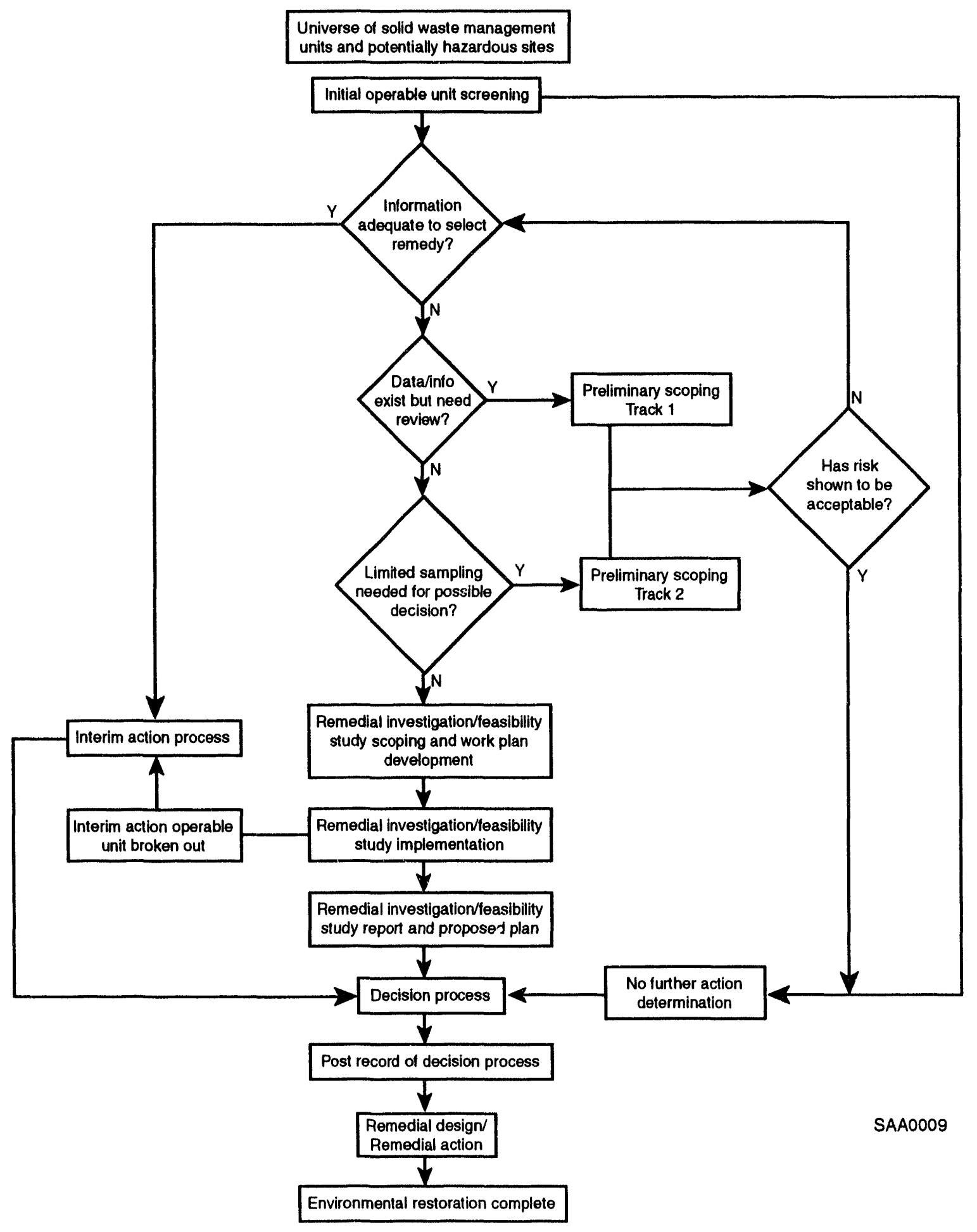

Figure 22-4. Flow chart of remedial action process at the Idaho National Engineering Laboratory. 
release sites and is designed to support an informed risk management decision regarding which remedy is most appropriate for a given site. The process is flexible enough to be tailored to the specific circumstances of individual potential release sites.

Flexibility in the process is allowed by following different assessment tracks. Track 1 studies are for sites that will not likely require any cleanup action and can be assessed with existing available information. Track 2 studies are for sites or operable units that require field data collection to make a determination as to the potential risk. Both Track 1 and 2 studies are considered preliminary scoping studies. A Remedial Investigation/Feasibility Study is a more rigorous study for sites where more extensive characterization of contamination, assessment of risk, and evaluation of cleanup alternatives are required to reach a final cleanup decision.

If at any time it is determined that a threat exists and there is greater urgency to reach the cleanup phase, an interim action may be implemented. Removal actions may also be implemented for small sites with relatively simple cleanups that will achieve progress toward the long-term remedial action.

Once a study is complete and an interim or final action is identified, a proposed plan is issued for public comment. The proposed plan summarizes the investigation and risk assessment and identifies the preferred cleanup alternative. When all comments have been considered, a CERCLA Record of Decision is issued that selects the cleanup alternative. This Record of Decision also establishes the cleanup objectives and criteria that will be met to adequately protect human health and the environment. The Remedial Design/Remedial Action phase occurs after the cleanup is authorized by this Record of Decision. Remedial action is successfully completed when DOE-ID and the regulatory agencies agree that all the requirements established in the Record of Decision have been met.

DOE has identified and currently is implementing the remediation process on areas at the INEL site where hazardous substances have been or are suspected of having been released to the environment. Since 1986, over 400 suspected release sites have been identified at the INEL site for investigation (DOE-ID 1991). Currently, over 100 of the suspected release sites have been proposed or designated as requiring no further action.

VOLUME 2 
Release sites with similar contamination problems are grouped together into operable units to promote management and cleanup efficiency. Operable units are, in turn, grouped into 10 location areas called Waste Area Groups (WAGs), for efficiency in managing the assessment and cleanup process. Nine of these Waste Area Groups are roughly equivalent to the major facility areas identified in Section 2.2.4, Major Facility Areas (see Figure 2.2-2). Waste Area Group 10 includes a site-wide area associated with the Snake River Plain Aquifer and surface and subsurface areas that are not addressed by the other nine Waste Area Groups.

Sources of contamination at the INEL include spills, abandoned tanks, septic systems, percolation ponds, landfills, and injection wells. Contaminated sites range from large facilities, such as the Subsurface Disposal Area (pits and trenches) at the Radioactive Waste Management Complex (WAG 7), to small areas in various locations where minor spills may have occurred. Table 2.2-2 summarizes current information on wastes and contaminants for each Waste Area Group.

Numerous proven technologies are suitable for cleanup of the potential release sites identified at the INEL. These technologies include containment (capping, vertical barriers, and subsurface horizontal barriers), immobilization (solidification and stabilization), physical processes (separation, soil washing, vacuum extraction, air stripping, filtration, ion exchange, and membrane separation), thermal processes (incineration, pyrolysis, wet oxidation, or in situ vitrification), chemical processes (reduction/oxidation, neutralization, precipitation, and dechlorination), and biological processes (aerobic and anaerobic digestion and biodegradation).

\subsubsection{Decontamination and Decommissioning. Decontamination and} decommissioning activities are concerned with safely managing contaminated surplus nuclear facilities until they are decontaminated for reuse or decommissioned. A long-term goal for DOE is to decontaminate and decommission all contaminated surplus facilities as funds become available to ensure that human health and the environment are protected.

After a facility ceases operations, but prior to its being accepted into the Decontamination and Decommissioning Program, it enters the Facility Transition Program. The purpose of this program is to provide a consistent approach to determine whether a facility is available for reuse 
Table 2.2-2. Waste types and contaminants located at Waste Area Groups at the Idaho National Engineering Laboratory.

\begin{tabular}{|c|c|c|c|c|}
\hline $\begin{array}{l}\text { Waste Area } \\
\text { Group } \\
\text { (WAG) }\end{array}$ & Location & Waste site & Main contaminants of concern & Types of waste \\
\hline WAG 1 & Test Area North & $\begin{array}{l}\text { Underground storage tanks, pits, ponds, railroad } \\
\text { turntable }\end{array}$ & $\begin{array}{l}\text { Acids, petroleum products, asbestos, fission products, organic } \\
\text { wastes, heavy metals }\end{array}$ & $\begin{array}{l}\text { Hazardous, mixed, } \\
\text { radioactive }\end{array}$ \\
\hline WAG 2 & Test Reactor Area & $\begin{array}{l}\text { Leaching pond, underground storage tank, } \\
\text { rubble piles, cooling towers, injection well, } \\
\text { french drains, spills }\end{array}$ & $\begin{array}{l}\text { Organic wastes, petroleum products, fission products, heavy } \\
\text { metals }\end{array}$ & $\begin{array}{l}\text { Hazardous, mixed, } \\
\text { radioactive }\end{array}$ \\
\hline WAG 3 & $\begin{array}{l}\text { Idaho Chemical Processing } \\
\text { Plant }\end{array}$ & $\begin{array}{l}\text { Septic tanks, cesspools, seepage pits, spills, fly } \\
\text { ash pit, injection well, sewage treatment plant, } \\
\text { gravel pits, french drains }\end{array}$ & $\begin{array}{l}\text { Organic wastes, petroleum products, fission products, } \\
\text { transuranic radionuclides, asbestos, acid salts, heavy metals }\end{array}$ & $\begin{array}{l}\text { Hazardous, mixed, } \\
\text { radioactive }\end{array}$ \\
\hline WAG 4 & Central Facilities Area & Spills, underground tanks, landfill, leach fields & $\begin{array}{l}\text { Ordnance, salts of acids, petroleum products, heavy metals, } \\
\text { fission products, asbestos, organic wastes }\end{array}$ & $\begin{array}{l}\text { Hazardous, mixed, } \\
\text { radioactive }\end{array}$ \\
\hline WAG 5 & $\begin{array}{l}\text { Power Burst Facility/ } \\
\text { Auxiliary Reactor Area }\end{array}$ & $\begin{array}{l}\text { Evaporation ponds, sanitary sewer, waste sumps, } \\
\text { storage pads }\end{array}$ & $\begin{array}{l}\text { Fission products, petroleum products, heavy metals, organic } \\
\text { wastes }\end{array}$ & $\begin{array}{l}\text { Hazardous, mixed, } \\
\text { radioactive }\end{array}$ \\
\hline WAG 6 & $\begin{array}{l}\text { Experimental Breeder } \\
\text { Reactor-I/ Boiling Water } \\
\text { Reactor Experiment }\end{array}$ & $\begin{array}{l}\text { Reactor burial site, trash dump, fuel oil tanks, } \\
\text { septic tanks, leach pond, spills }\end{array}$ & Heavy metals, organics, fission products, petroleum products & $\begin{array}{l}\text { Hazardous, mixed, } \\
\text { radioactive, solid }\end{array}$ \\
\hline WAG 7 & $\begin{array}{l}\text { Radioactive Waste } \\
\text { Management Complex }\end{array}$ & $\begin{array}{l}\text { Soil vaults, acid pit, waste pits and trenches, } \\
\text { septic tank }\end{array}$ & $\begin{array}{l}\text { Fission products, transuranic radionuclides, organic wastes, } \\
\text { salts of acids, ordnance, heavy metals }\end{array}$ & $\begin{array}{l}\text { Radioactive, } \\
\text { hazardous, mixed }\end{array}$ \\
\hline WAG 8 & Naval Reactors Facility & $\begin{array}{l}\text { Landfills, spill sites, wastewater disposal } \\
\text { systems, storage areas }\end{array}$ & Heavy metals, organics, petroleum products, radionuclides & $\begin{array}{l}\text { Hazardous, } \\
\text { radioactive }\end{array}$ \\
\hline WAG 9 & $\begin{array}{l}\text { Argonne National } \\
\text { Laboratory-West }\end{array}$ & $\begin{array}{l}\text { Tanks, wastewater handling/disposal systems, } \\
\text { pits, ditches, ponds, drains }\end{array}$ & $\begin{array}{l}\text { Heavy metals, fission products, petroleum products, } \\
\text { diaxins/furans }\end{array}$ & $\begin{array}{l}\text { Hazardous, mixed, } \\
\text { radioactive }\end{array}$ \\
\hline WAG 10 & $\begin{array}{l}\text { Miscellaneous (including } \\
\text { Snake River Plain } \\
\text { Aquifer) }\end{array}$ & $\begin{array}{l}\text { Organic Moderated Reactor Experiment, } \\
\text { ordnance areas, liquid corrosive chemical } \\
\text { disposal area, leach pond }\end{array}$ & Salts of acids, fission products, organic wastes, ordnance & $\begin{array}{l}\text { Hazardous, mixed, } \\
\text { radioactive }\end{array}$ \\
\hline
\end{tabular}

a. Source: Fugate et al. (1993). 
or a candidate for decontamination and decommissioning. This phase consists of (a) termination of facility operations; (b) placement of the facility on the Surplus Facilities List, if no other mission is identified; (c) establishment of a surveillance and maintenance program to monitor the remaining known hazards and to maintain the facility in a safe condition; (d) achievement of safe shutdown/deactivation; and (e) transfer of the facility to the DOE Office of Environmental Restoration.

The Surplus Facilities List can be found in the INEL D\&D Long-Range Plan (Buckland et al. 1993). Some of the larger surplus facilities on this list are Auxiliary Reactor Area-II, Boiling Water Reactor Experiment-V, Engineering Test Reactor facilities, Materials Test Reactor facilities, Fuel Processing Complex, Fuel Receipt/Storage Facility, Headend Processing Plant, and the Waste Calcine Facility.

After a facility has been accepted into the Decontamination and Decommissioning Program, a long-term surveillance and maintenance program is established and shutdown and deactivation is advised. Typical activities for safe shutdown include

- Removing special nuclear material, hazardous chemicals, combustible materials, and sources of radioactivity

- $\quad$ Ensuring that the minimum necessary confinement systems (both structures 'nd heating and ventilating) are working

- $\quad$ Controlling access of personnel.

Surveillance and maintenance activities are performed, which include monitoring remaining known hazards and maintaining the facility in a safe condition until it is ready for decontamination and decommissioning.

Next, a project plan is written. The project plan identifies the preferred decontamination and decol.Imissioning options, DOE's proposed strategy for compliance with the National Environmental Policy Act, and the relationship to the Comprehensive Environmental Response, Compensation, and Liability Act. The options that can be considered under the decontamination 
and decommissioning program vary depending on the condition of the facilities, but generally fall under one of four categories: safe storage, in-place stabilization (such as entombment), decontamination for reuse, and dismantlement. Various types of radioactive waste (for example, low-level, mixed low-level, high-level, transuranic) in varied quantities could potentially result from decontamination and decommissioning activities, depending on the previous use of a particular facility.

The next step is to complete an environmental review with the preparation of a safety analysis and risk assessment and then reach a documented decision defining the proposed scope and end condition of the project.

Next, a decommissioning plan is prepared, the surveillance and maintenance program is phased out, a contractor is selected, and the plan is executed. After completion of the decommissioning plan, the closeout documentation is prepared and an independent verification is conducted to ensure the plan has been met.

Postoperations activities, where appropriate, consist of long-term surveillance and maintenance or other controls to carry out the final disposition of the project. These activities would continue to ensure protection of human health and the environment.

\subsubsection{Waste Management}

Waste management activities under the ER\&WM Program include minimization, characterization, treatment, storage, and disposal of wastes generated from ongoing INEL activities and from other major sources, such as environmental restoration and decontamination and decommissioning activities. The Waste Management Program ensures that current and future waste management practices minimize any additional adverse environmental impacts. During the past four decades, hazardous and radioactive waste has been produced, stored, treated, and/or disposed of at the INEL site. In addition, every operating facility produces waste that must be managed. Several general types of wastes are managed at the INEL, as discussed in the following sections. (See Appendix E, Glossary, for definitions of waste types.) Because mixed low-level waste represents the great majority of mixed waste, it is discussed separately in Section 2.2.7.1.4. 
Mixed high-level waste and mixed transuranic waste are discussed under the high-level waste and transuranic waste sections, 2 2.7.1.1 and 2.2 .7 .1 .2 , respectively.

2.2.7.1 Radioactive Waste. Radior tive waste is grouped into several categories, depending on the amount and types of radioactivity it contains (for example, low-level waste) or the source of the waste (for example, high-level waste). The definitions for radioactive waste come from limits established primarily by the Atomic Energy Act and DOE orders. (More information on radioactivity is given in Appendix A, Primer on Radioactivity and Toxicology.) Presently, there are four radioactive waste streams managed at the INEL: high-level, transuranic, low-level, and mixed low-level.

2.2.7.1.1 High-Level Waste-The term high-level radioactive waste means (a) the highly radioactive material resulting from reprocessing of spent nuclear fuel, including liquid waste produced directly in reprocessing and any solid material derived from such liquid waste that contains fission products in sufficient concentrations, and (b) other highly radioactive material that the U. S. Nuclear Regulatory Commission, consistent with existing law, determines by rule requires permanent isolation. Radioactive sodium-bearing liquid (produced by decontamination activities) is also managed as high-level liquid waste (see Appendix E, Glossary, for a definition of sodium-bearing waste). The current INEL high-level waste management program, as depicted in Figure 2.2-5, is conducted at the Idaho Chemical Processing Plant.

From 1953 to 1992, high-level liquid waste at the INEL resulted from reprocessing spent nuclear fuel; however, reprocessing was phased out in 1992. Certain other processes generate waste handled as high-level liquid waste. For example, the process equipment waste evaporator, which concentrates low-level waste, and the Liquid Effluent Treatment and Disposal Facility, which processes evaporator vapors, both generate such waste. Also, the calcined bed from the New Waste Calcining Facility (described below) is periodically dissolved and stored as high-level waste. These sources generated about 560 cubic meters ( 730 cubic yards) of liquid high-level waste in 1993.

Liquid waste is temporarily stored in eleven 1,100-cubic-meter (300,000-gallon) stainless steel tanks contained in concrete vaults at the Idaho Chemical Processing Plant. Only one tank contains high-level waste from previous reprocessing. Most of the remaining liquid waste is 


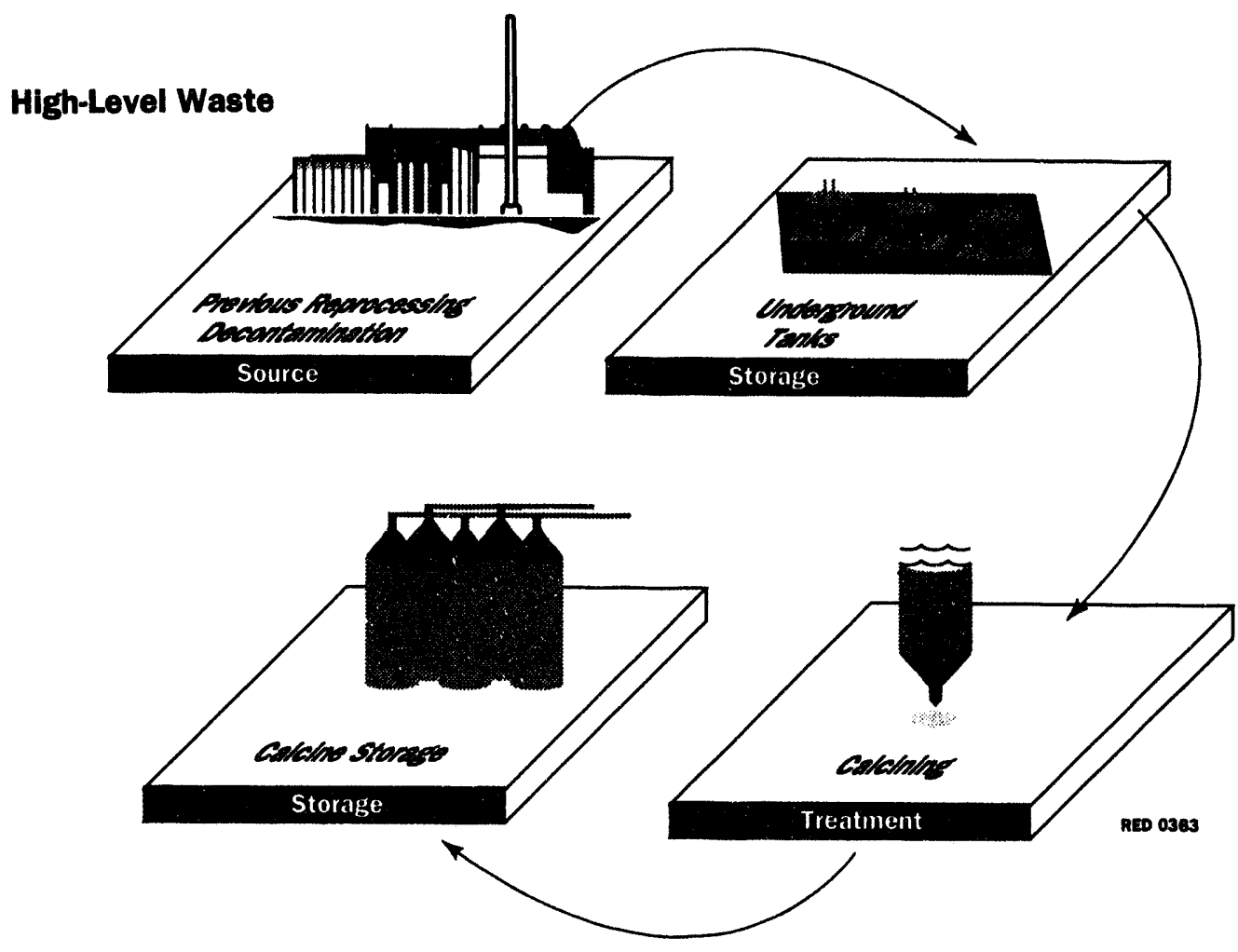

Figure 2.2-5. Current high-level waste management program at the Idaho National Engineering Laboratory.

sodium-bearing, which is stored separately in some of the 11 tanks. A project to upgrade the piping associated with all the tanks is in progress.

These tanks are required to be taken out of service in the next two decades (some in 2009, the rest in 2015). They were built to the standards existing at the time of construction (1950-1965) but do not meet all current standards. A project was in progress to replace these aging tanks; however, once fuel reprocessing was phased out in 1992 at the Idaho Chemical Processing Plant, it was not clear that the new tanks would be required. DOE commissioned a study to evaluate all feasible options for emptying the existing tank farm and to determine the need for replacement tanks (Palmer et al. 1994). Options from that study form the basis for the alternatives described in Chapter 3. 
High-level liquid waste has been blended routinely with sodium-bearing liquid and solidified (calcined) at the New Waste Calcining Facility. Calcining transforms the waste into dry, noncorrosive granules. For calcination, sodium-bearing wastes have also been blended with purchased chemicals (aluminum nitrate) because the sodium-bearing waste cannot be directly calcined. The calcining process is not scheduled to resume until 1996. Equipment to concentrate the sodium-bearing waste by evaporation is being installed during the current shutdown of the New Waste Calcining Facility.

The calcined waste is stored at the Idaho Chemical Processing Plant in stainless steel closed bins inside near-surface concrete vaults. Seven sets of bins have been built: five sets are full; the sixth set is partially full.

Because the calcined waste remains a Resource Conservation and Recovery Act (RCRA) hazardous waste, it is regulated under RCRA and is subject to land disposal restrictions. Ultimately, DOE envisions that the calcined waste would be converted to an immobilized form and disposed of at a geologic repository.

2.2.7.1.2 Transuranic Waste-Transuranic waste is defined as radioactive waste having concentrations greater than 100 nanocuries per gram of transuranic elements (elements which have an atomic number greater than 92) with half-lives greater than 20 years. The radioactive nuclides in transuranic waste emit alpha radiation, which requires minimal shielding when outside the body but can severely damage lung tissue if inhaled. Transuranic wastes require long-term isolation from the environment.

Transuranic waste results primarily from research and development; processing, shaping, and handling plutonium and plutonium-contaminated materials; and decontamination and decommissioning of INEL facilities. Additional waste may be generated by spent nuclear fuel processing. Some transuraniv waste [about 0.15 percent of INEL stored waste (DOE 1992)] contains high levels of radioactivity and may require more than minimal shielding and remote handling. The current INEL transuranic waste management program is depicted in Figure 2.2-6.

In the early 1980 s, the definition of transuranic waste was revised from greater than 10 to greater than 100 nanocuries per gram. As a result, nearly half of the waste now in storage at the 


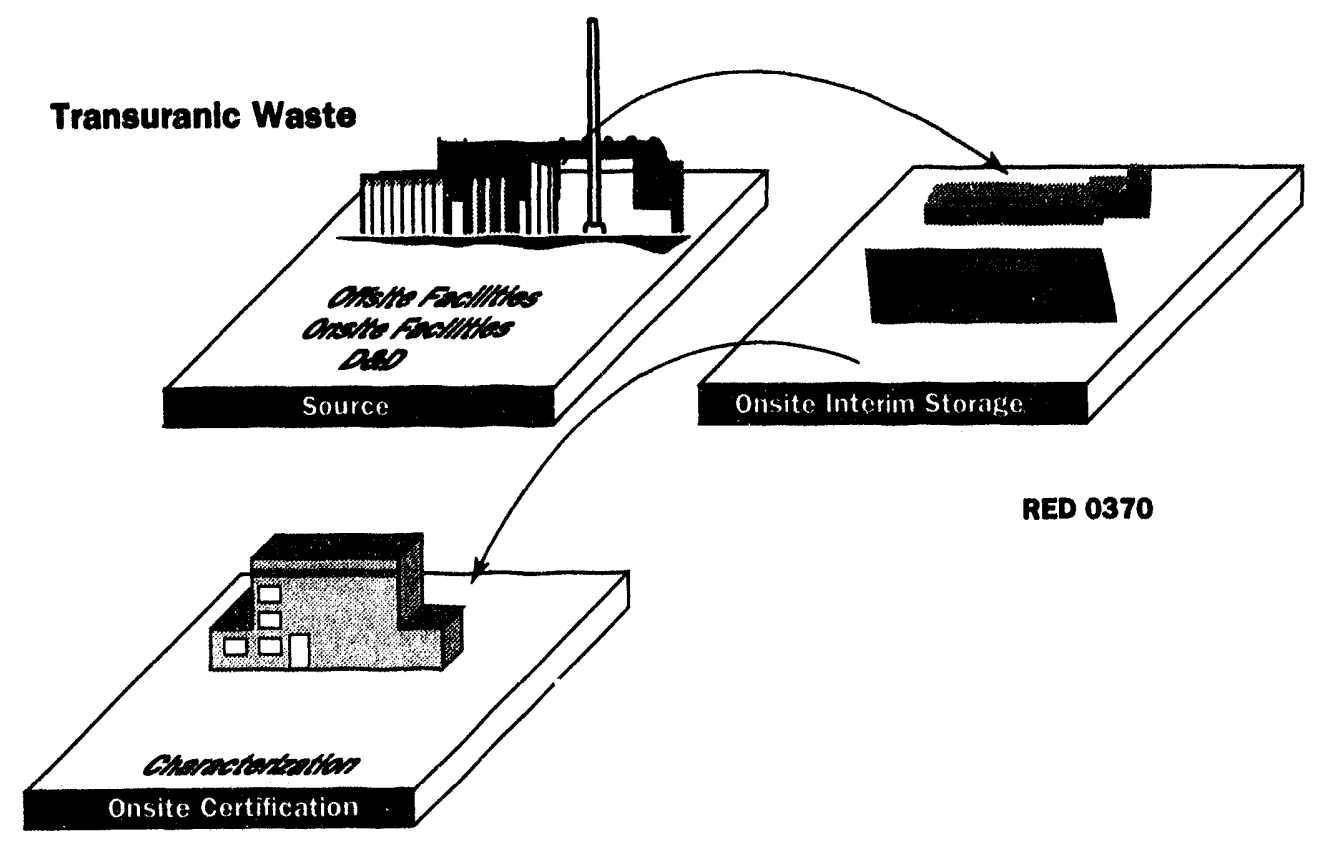

Figure 22-6. Current transuranic waste management program at the Idaho National Engineering Laboratory.

Transuranic Storage Area of the Radioactive Waste Management Complex is expected to fall below the current limit (Pole 1993). The waste falling between the 10-and-100-nanocuries-pergram limit is now called alpha low-level waste. Although this waste is technically considered lowlevel waste rather than transuranic waste, it cannot be disposed of at the INEL because it does not meet all INEL low-level waste acceptance criteria (DOE-ID 1993a). Alpha low-level waste and transuranic waste are often mixed with other hazardous wastes. Alpha low-level wastes and alpha mixed low-level wastes are managed together at the INEL site. Both of these waste types are managed as a part of the transuranic waste stream.

Since 1954, the INEL site has received transuranic waste from both offsite and onsite waste generators for disposal or interim storage. When transuranic waste was first accepted at the Radioactive Waste Management Complex, it was disposed of in pits and trenches. This waste was 
often intermixed with low-level waste. After 1964, transuranic waste was placed into pits and trenches separate from low-level waste. In 1970, national policy mandated that newly generated transuranic waste be placed into retrievable storage pending permanent disposition at some other facility. The Transuranic Storage Area was established at the Radioactive Waste Management Complex to provide this interim storage. The transuranic waste stored at the Radioactive Waste Management Complex represents over half the retrievable transuranic waste in the entire DOE complex.

Although there is still no permanent facility for transuranic waste, it is managed assuming that it will be retrieved from storage, repackaged, certified to meet disposition facility requirements, and shipped to the Waste Isolation Pilot Plant for final disposition. A strategy for disposing of alpha low-level and mixed low-level waste has yet to be established. Challenges to overcome include

- Storage space for transuranic waste at the INEL site is limited.

- Disposal facilities are not currently available at INEL site for alpha low-level waste.

- Certification or licensed transportation systems do not exist for remote-handled transuranic waste.

- Some stored transuranic waste at the INEL site is incompatible with the U. S. Nuclear Regulatory Commission-licensed shipping container (TRUPACT II).

- Waste Isolation Pilot Plant uncertainties: waste acceptance criteria unknown, whether to accept previously buried transuranic waste, and availability.

A small ar tount of transuranic waste is being generated onsite (Pole 1993). Transuranic waste generated at the Test Reactor Area is stored at the Radioactive Waste Management Complex. Throug' 1 an agreement with the State of Idaho, Argonne National Laboratory-East ships to the INEL site a small amount of transuranic waste generated as a result of INEL-related activities. Transuranic waste is also generated from environmental remediation and 
decontamination and decommissioning projects. Shipnents of transuranic waste may also be accepted on a case-by-case basis from the Rocky Flats Plant.

Transuranic and alpha low-level waste are stored on asphalt pads covered with soil and in air support buildings at the Transuranic Storage Area of the Radioactive Waste Management Complex. New storage facilities, which meet State and U. S. Environmental Protection Agency Resource Conservation and Recovery Act requirements for hazardous waste storage, are being constructed to replace these older facilities. Waste is being removed from the older storage facilities and placed into new storage as these structures are completed. Waste received from offsite is placed into storage pending characterization. Small quantities of transuranic waste generated by current operations are also being placed into storage. Some transuranic waste is also stored at the Radioactive Scrap and Waste Facility at Argonne National Laboratory West.

DOE expects that much of the transuranic waste stored at the INEL site will have to be repacked and/or treated to meet the waste acceptance criteria for the Waste Isolation Pilot Plant. Activities are underway at the INEL to prepare to ship stored certified transuranic waste to the Waste Isolation Pilot Plant for disposition. The Stored Waste Examination Pilot Plant, which would support the retrieval and certification of transuranic waste for ultimate shipment to the Waste Isolation Pilot Plant, is on operational standby. A new waste characterization facility is planned to provide required analyses of 10 percent of wastes before shipment.

DOE is investigating the feasibility of constructing a facility (the Idaho Waste Processing Facility) that could be used to treat alpha mixed low-level waste. The facility would first be used for treatment of alpha mixed low-level waste and later to repackage or treat transuranic waste that could be certified to meet both transportation criteria and the Waste Isolation Pilot Plant waste acceptance criteria. DOE is also investigating the possibility of offsite commercial treatment of transuranic and alpha mixed low-level waste.

Approximately 65,000 cubic meters (87,000 cubic yards) of transuranic and alpha low-level waste are currently in storage at the INEL site in facilities that do not meet the requirements of the Resource Conservation and Recovery Act. Another 37,000 cubic meters (50,000 cubic yards) have been disposed of by burial in pits and trenches at the Subsurface Disposal Area of the Radioactive Waste Management Complex. 
2.2.7.1.3 Low-Level Waste-Low-level waste is best defined in terms of what it is not. Low-level waste is radioactive waste that is not high-level, transuranic, or by-product material containing uranium or thorium from processed ore. Most low-level waste contains shortlived radionuclides and generally can be handled without additional shielding or remote handling equipment. The current INEL low-level waste management program is depicted in Figure 2.2-7.

Low-level waste is generated at the Test Reactor Area, Idaho Chemical Processing Plant, Central Facilities Area, Power Burst Facility, Radioactive Waste Management Complex, Naval Reactors Facility, and Argonne National Laboratory-West. About two-thirds of the waste generated is treated to reduce volume and stabilize it before disposal. The waste has been treated through incineration, either onsite at the Waste Experimental Reduction Facility located

Low-Level Waste

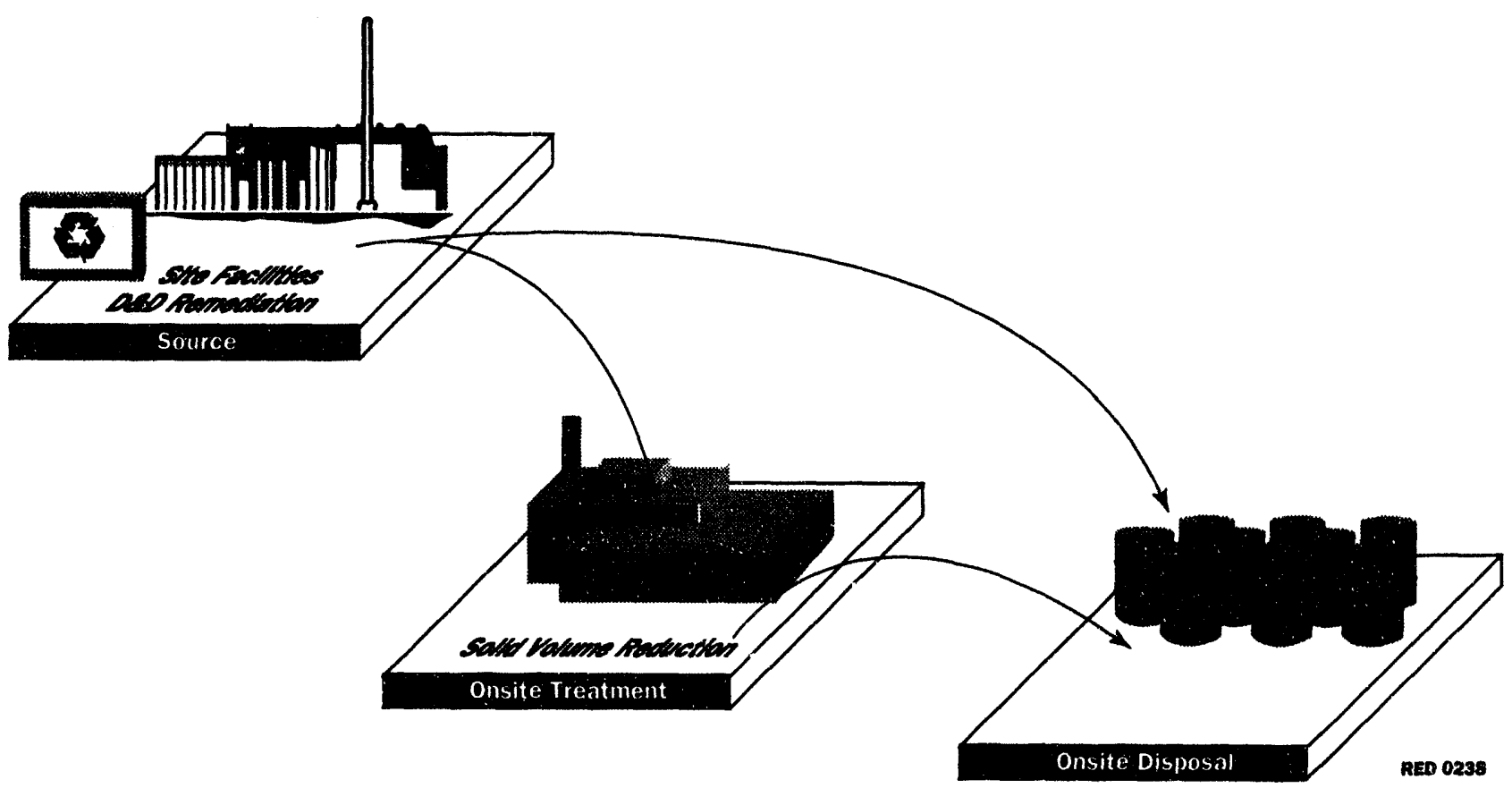

Figure 22-7. Current low-level waste management program at the Idaho National Engineering Laboratory. 
at the Power Burst Facility or at an offsite commercial facility, or is treated through compaction or size reduction at the Waste Experimental Reduction Facility. This facility is currently on operational standby. Operation of the Waste Experimental Reduction Facility was suspended during 1991 through 1993 to upgrade the facility. During the shutdown, an environment assessment (DOE 1993c) was prepared. Based on this environmental assessment and a Finding of No Significant Impact issued in June 1994, DOE is undertaking supplemental volume reduction activities at the Waste Experimental Reduction Facility with offsite incineration at commercial facilities. This offsite incineration includes shipment of the waste from the INEL site and accepting the resulting ash at the INEL site for disposal at the Radicactive Waste Management Complex.

Waste incineration is a process by which combustible waste materials are burned, producing combustion gases, noncombustible residue, and ash. Incineration destroys organic components of waste that cannot be disposed of directly in a landfill. Incineration also reduces the mass and volume of the waste. Reductions in volume of 200 to 1 if ash is not stabilized, or 70 to 1 if ash is stabilized in cement, are typical. Such reduction lessens transportation and disposal requirements. Incineration is the method required by the U. S. Environmental Protection Agency for many hazardous and mixed waste types.

Solid low-level waste is disposed of through shallow land burial at the Radioactive Waste Management Complex in pits and concrete-lined soil vaults in the Subsurface Disposal Area. The Subsurface Disposal Area occupies approximately 0.35 square kilometers (88 acres). As of 1991, the total available capacity for low-level waste disposal in the area was 37,000 cubic meters (48,000 cubic yards). An additional 67,000 cubic meters $(88,000$ cubic yards) of expansion capacity is potentially available. About 38 percent of solid low-level waste generated onsite is sent directly to the Radioactive Waste Management Complex without treatment.

Most liquid low-level waste is concentrated at the Idaho Chemical Processing Plant. The vapor from the Idaho Chemical Processing Plant process equipment waste evaporator is then processed by the Liquid Effluent Treatment and Disposal Facility and the gaseous effluent vented out the high-efficiency particulate air filtered stack. The material remaining after evaporation (which is mixed waste) is then pumped to the Idaho Chemical Processing Plant tank farm. Some small volumes of radioactive liquids are also solidified at the Waste Experimental Reduction 
Facility and disposed of at the Radioactive Waste Management Complex. All of Argonne National Laboratory-West's low-level (aqueous) liquid waste is processed at that facility's Radioactive Liquid Waste Treatment Facility. It is volume-reduced to a sludge and then shipped to the Radioactive Waste Management Complex. Small volumes are discharged to the doublelined pond at the Test Reactor Area. Potential low-level waste from storm runoff at Test Area North is handled through an ion exchange system.

\subsection{Mixed Low-Level Waste-Mixed low-level waste contains Resource} Conservation and Recovery Act (RCRA)-controlled substances and is radioactive. It is managed according to RCRA requirements becausc of its RCRA hazardous waste characteristics and according to the Atomic Energy Act because of its radioactive components. The current INEL mixed low-level waste management program is depicted in Figure 2.2-8.

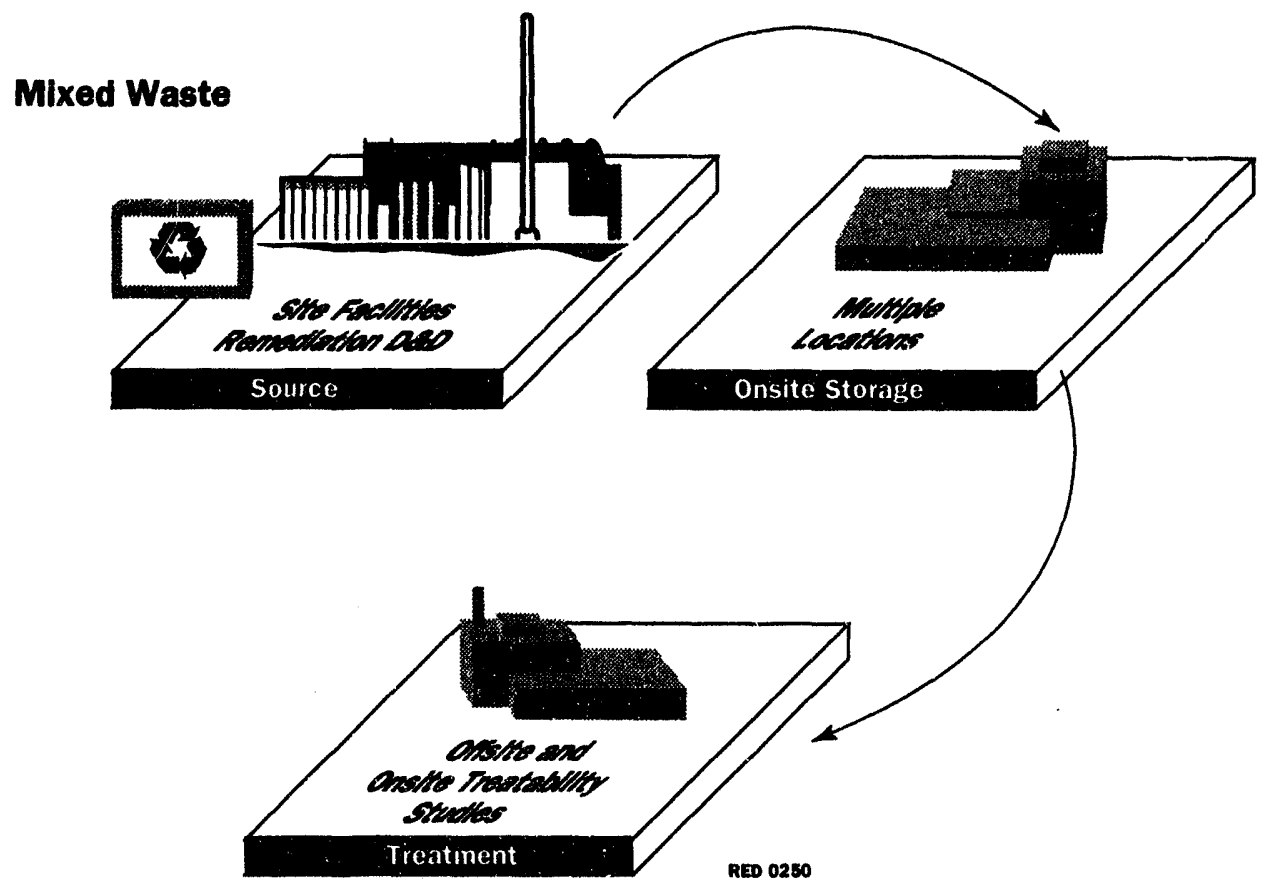

Figure 2.2-8. Current mixed low-level waste management program at the Idaho National Engineering Laboratory. 
Mixed low-level waste is further divided into two categories for management purposes: alpha mixed low-level waste and beta/gamma mixed low-level waste. The difference between the categories is the quantity of transuranic radionuclides in the mixed waste. Most of the alpha mixed low-level waste stored at the INEL site is waste that has been reclassified from mixed transuranic waste. Most of the mixed low-level waste currently stored at the INEL site is alpha mixed low-level waste shipped to the INEL for storage and treatment from offsite generators. This alpha mixed low-level waste is managed as part of the transuranic waste stream and is described more fully in Section 2.2.7.1.2, Transuranic Waste.

Under U. S. Environmental Protection Agency regulations, mixed low-level waste must be treated before land disposal, and disposal facilities must meet RCRA minimum technology requirements. The RCRA hazardous waste portion of mixed low-level waste is subject to the land disposal restrictions of the Act. Land disposal restrictions prohibit the disposal of any RCRAcontrolled waste generated after waste-specific prohibitions are in effect. Storage of restricted wastes is prohibited unless the wastes are being stored for the purpose of accumulating sufficient quantities for treatment. As a general rule, if no treatment technologies are available for such wastes, storage is prohibited. As discussed in Sections 7.2.1.8 and 7.2.5.9, Federal Facility Compliance Act, mixed waste treatment plans are currently under development. The potential activities and methods identified in the plans are reflected in the alternatives described in Chapter 3, Alternatives, and analyzed in Chapter 5, Environmental Consequences.

Mixed low-level waste is generated at Test Area North, Test Reactor Area, Idaho Chemical Processing Plant, Central Facilities Area, Power Burst Facility, Radioactive Waste Management Complex, Naval Reactors Facility, Argonne National Laboratory-West, and the Idaho Falls facilities. Sources include environmental restoration, production operations, laboratory activities, construction, maintenance, and research and development activities.

Waste minimization is also being used at the INEL to eliminate potential sources of mixed low-level waste before generation. These efforts include using improved operating practices, technology changes, raw material changes, product changes, waste avoidance through recycling, and othe- actions. 
Eleven hundred cubic meters (1,400 cubic yards) of mixed low-level waste are currently onsite and stored in permitted (or interim status) storage facilities onsite. Existing permitted storage capacity is 1,800 cubic meters $(2,300$ cubic yards).

Most mixed low-level waste at the INEL is stored at the Mixed Waste Storage Building (or Waste Experimental Reduct on Facility Waste Storage Building) at the Power Burst Facility area. In addition, smaller quantities of mixed low-level waste are stored at the Hazardous Chemical/Radioactive Waste Facility at the Idaho Chemical Processing Plant and at the Radioactive Sodium Storage Facility, Building 703, and the Radioactive Scrap and Waste Facility at Argonne National Laboratory-West. The majority of mixed low-level waste at the INEL is waiting treatment and disposal; a small amount is being treated through ongoing treatability studies broth onsite and offsite.

As part of the site treatment plans required by the Federal Facility Compliance Act, preferred treatment options have been identified to eliminate the hazardous waste component for many types of mixed low-level waste (DOE-ID 1993b). Existing treatment facilities include the Waste Experimental Reduction Facility incinerator and stabilization system and the Waste Engineering Development Facility stabilization system, all of which are currently on operational standby. Additional facilities include a portable water treatment unit, debris treatment at the Idaho Chemical Processing Plant, and the high-efficiency particulate air filter leach system at the Idaho Chemical Processing Plant. Commercial treatment options are being considered for mixed low-level waste.

In addition, some of the mixed low-level waste streams require new forms of treatment. These wastes include contaminated lead, one-of-a-kind wastes, and contaminated polychlorinated biphenyls. (Polychlorinated biphenyls are hazardous substances managed under the Toxic Substances Control Act.) DOE is conducting treatability studies and research onsite and at university and commercial facilities in order to identify new forms of treatment for disposal at onsite and offsite DOE or commercial facilities.

Ultimately, mixed wastes will be treated and disposed of in accordance with applicable regulations. All RCRA-controlled wastes generated at the INEL are evaluated to certify that they are not radioactively contaminated. If this certification cannot be made, then the wastes are 
managed as mixed low-level waste. If analyses verify that treated characteristic mixed low-level waste no longer exhibits the characteristic and therefore is no longer hazardous, ard if the treated waste meets Radioactive Waste Management Complex radioactive waste acceptanie criteria, it is reclassified as low-level waste and sent to the Radioactive Waste Management Complex for disposal. DOE requirements, as outlined in DOE orders, require all DOE-generated radioactive waste to be disposed of on a DOE site. Mixed waste, treated to meet Land Disposal Restrictions, must be disposed of at a DOE facility. Commercial disposal of small quintities of mixed low-level waste are currently exempt from DOE requirements for disposal at a DOE site.

Liquid low-level mixed waste is concentrated at the Idaho Chemical Processing Plant. The condensed vapor (condensate) from the Idaho Chemical Processing Plant process equipment waste evaporator is then processed by the Liquid Effluent Treatment and Disposal Facility and the vapor vented out the high-efficiency particulate air filtered stack. The material remaining after evaporation (which is mixed waste) is then pumped to the Idaho Chemical Processing Plant tank farm.

\subsection{Greater-Than-Class-C Low-Level Waste-Greater-than-Class-C waste}

exceeds U. S. Nuclear Regulatory Commission concentration limits for Class-C low-level waste specified in 10 CFR 61 and thus exceeds limits for shallow land burial. The Low-Level Radioactive Waste Policy Act of 1985 requires DOE to ensure safe disposal of this waste. In May 1989, the U. S. Nuclear Regulatory Commission (NRC) promulgated a rule that requires greater-than-Class-C waste to be disposed of in a deep geologic repository, unless the NRC approves disposal elsewhere.

Under the Low-Level Waste Policy Amendments Act of 1985 (Public Law 99-240), the Federal government is responsible for the disposal of greater-than-Class-C low-level waste generated by licensees of the NRC and Agreement States. DOE was identified as the Federal agency responsible for this effort. In February 1989, a report to Congress from DOE (DOE 1989) stated that it plans to accept and manage limited quantities of greater-than-Class-C lowlevel waste until a disposal facility is developed. DOE has assigned management responsibility for this effort to the INEL. The Radioactive Waste Management Complex currently stores a total of about 25 cubic meters ( 33 cubic yards) of greater-than-Class-C waste. This waste was received in 1987 and 1988 from two offsite commercial generators. 
2.2.7.2 Hazardous Waste. A hazardous waste is any solid waste, not otherwise precluded from regulation under the Resource Conservation and Recovery Act (RCRA), that exhibits the characteristics of ignitability, corrosivity, reactivity, or toxicity, as defined by RCRA, or which has been otherwise determined to pose a hazard and which has been designated hy the RCRA as a listed hazardous waste. Examples of hazardous wastes include paint thinner, lead, and chromium wastes. The U. S. Environmental Protection Agency has also established requirements for management of these materials. The hazardous waste program at the INEL also manages substances regulated by the Toxic Substances Control Act, such as polychlorinated biphenyls. The current INEL hazardous waste management program is depicted in Figure 2.2-9.

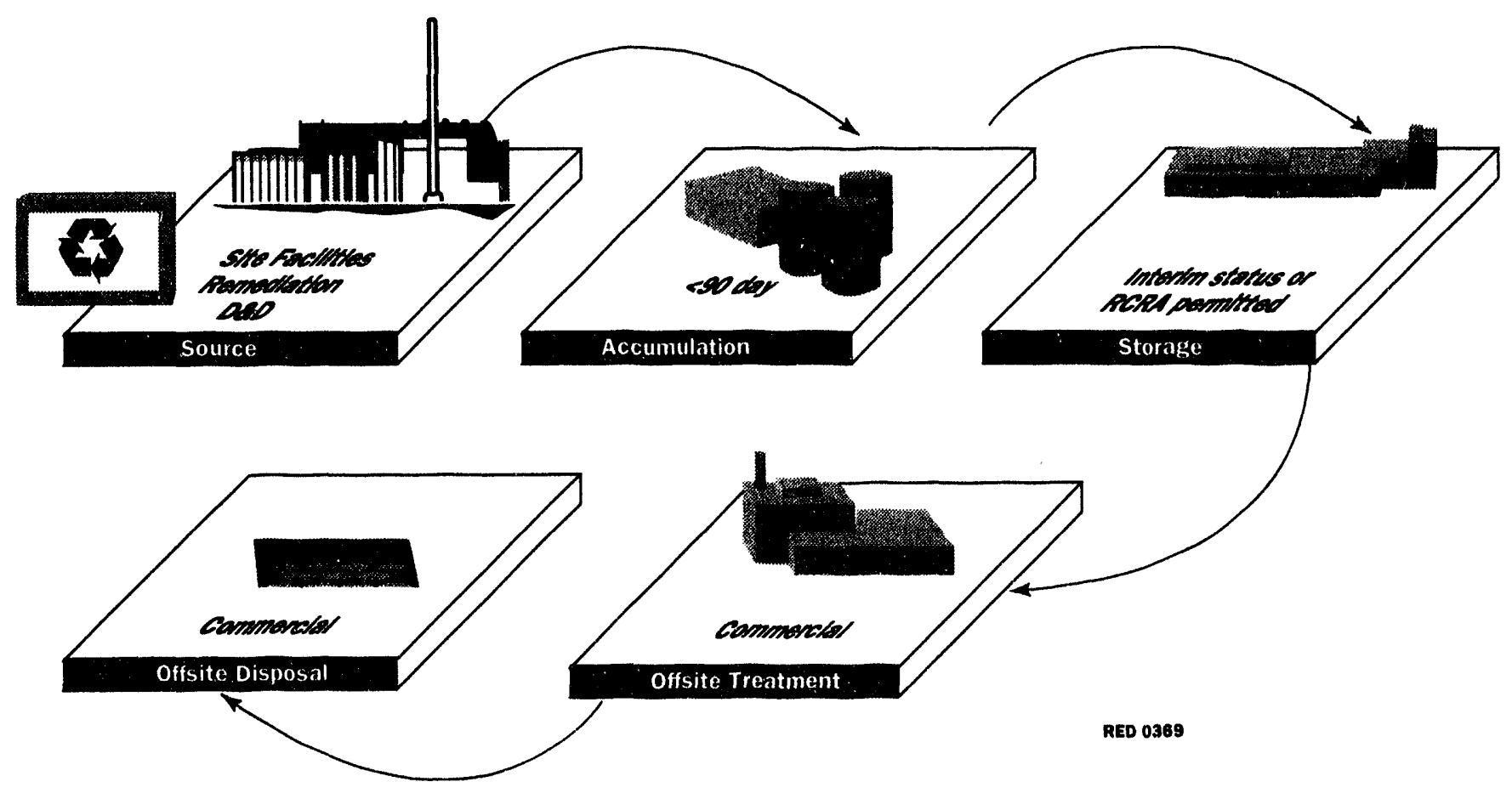

Figure 22-9. Current hazardous waste management program at the Idaho National Engineering Laboratory. 
Hazardous waste at the INEL is currently generated at the Radioactive Waste Management Complex, Central Facilities Area, Power Burst Facility, Naval Reactors Facility, Test Area North, Test Reactor Area, Argonne National Laloratory-West, Idaho Chemical Processing Plant, and Idaho Falls facilities. Decontamination and decommissioning and remediation activities also generate hazardous waste. About 1 percent of the total waste generated at the INEL is hazardous waste.

To reduce the quantity of hazardous waste, waste generated at the INEL is recycled, reused, or reprocessed where possible. Also, some hazardous substances used at the INEL may be replaced by nonhazardous substances. Recyclable hazardous waste at the INEL includes metals (such as bulk lead, mercury, chromium), solvents, fuel, and other waste materials. Recyclable materials are shipped periodically as sufficient quantities are accumulated or as negotiated with recycling shippers and vendors. The total volume of recyclable hazardous waste from the INEL in 1992 was 760 cubic meters (980 cubic yards).

Under RCRA, hazardous waste generated at the INEL may remain for less than 90 days at designated accumulation points. The waste is then transported to a RCRA interim status or permitted status storage facility. The Hazardous Waste Storage Facility at the Central Facilities Area is the major onsite RCRA Part B-permitted storage facility. The facility is designed primarily to prepare the waste for shipment to an offsite RCRA-permitted treatment facility prior to offsite disposal. The majority of the hazardous waste generated annually at the INEL is shipped offsite for treatment and disposal.

Hazardous waste generated in a radioactively controlled area or suspected of being radioactive cannot be shipped offsite until it is surveyed for radioactivity. If the waste is radioactively contaminated, it is classified and managed as mixed waste (see Section 2.2.7.1.4, Mixed Low-Level Waste). Highly reactive or unstable materials, such as waste explosives, are addressed on a case-by-case basis and are either stored, burned, or detonated at the Reactive Storage and Treatment Area near the Auxiliary Reactor Area. (More detailed information on toxic substances is given in Appendix A, Primer on Radioactivity and Toxicology.) 
2.2.7.3 Industrial Commercial Waste. Both industrial and commercial wastes are nonhazardous materials. The current INEL industrial commercial waste management program is depicted in Figure 2.2-10.

Industrial waste is nonhazardous waste generated during manufacturing or industrial processes. At the INEL, sanitary waste is included in this category. (See Appendix E, Glossary, for a definition of sanitary waste.) Over 94 percent of the waste generated at the INEL is classified as industrial commercial (DOE-ID 1993c) and disposed of at the Central Facilities Area Landfill (site) and the Bonneville County Landfill (Idaho Falls facilities).

The portion of the INEL Landfill Complex targeted for landfill use is approximately 90 hectares (220 acres), which is estimated to be adequate capacity for 30 to 50 years. Landfills I and II are closed; Landfill III comprises two separate areas: the industrial commercial waste disposal area (not in use) and the currently used disposal area. The current disposal area is located in a 4.8-hectare (12-acre) gravel pit north of Landfill II. Although nearly filled, part of the industrial commercial area of Landfill III is still used to dispose of waste containing asbestos.

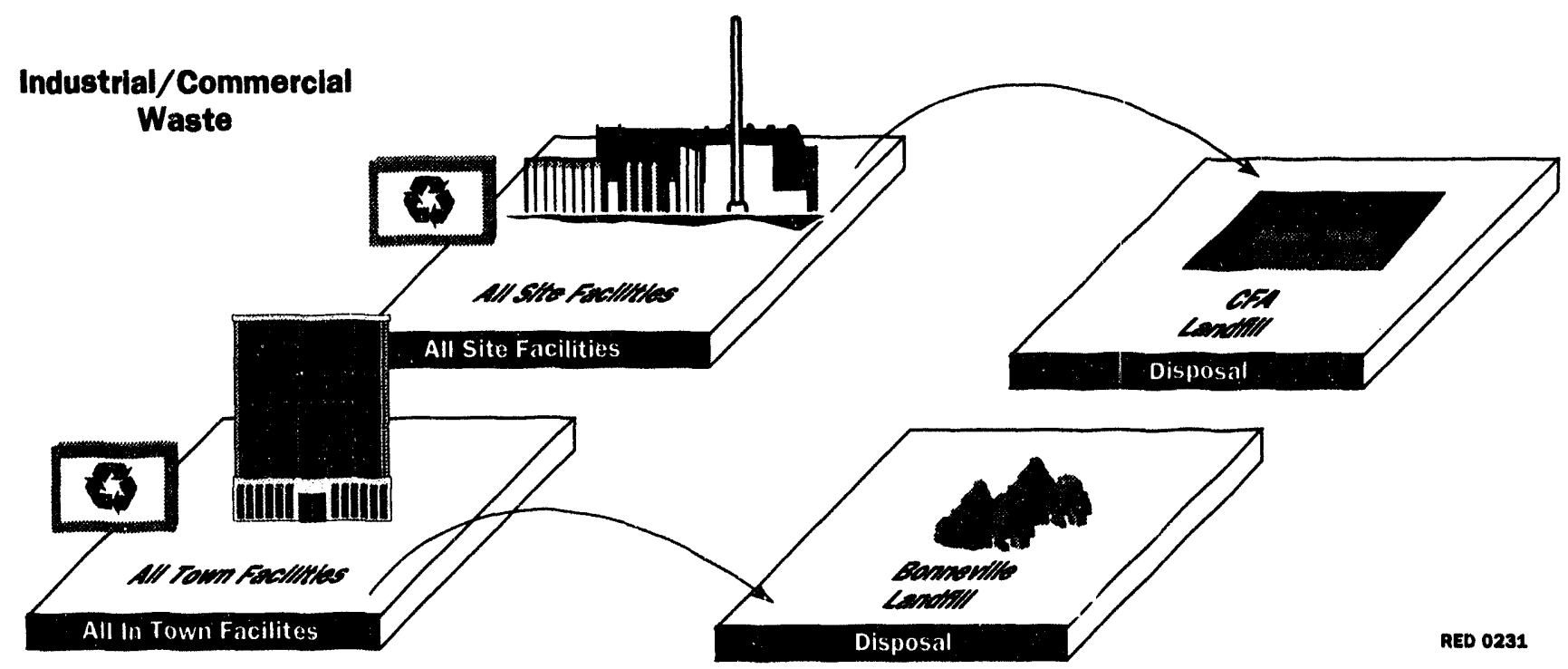

Figure 22-10. Current industrial commercial waste management program at the Idaho National Engineering Laboratory. 
Waste types disposed of at the INEL Landfill Complex include asbestos; asphalt; cafeteria garbage; dirt and gravel; masonry and concrete; scrap metal; trash; sweepings; weeds, grass, and trees; and wood and scrap lumber.

An active recycling program has been started to reduce the amount of industrial commercial waste. This recycling program is coupled with a concerted effort to ensure that waste materials are properly segregated. In addition, a materials exchange program has been initiated; this program arranges for unused materials stored at one INEL facility to be reused at other facilities. Through 1991, 320,000 kilograms (700,000 pounds) of office waste and 3,100 kilograms (6,800 pounds) of scrap metal were recycled at the INEL. Efforts are underway to expand the recycling program to include asphalt and metals and to convert scrap wood into mulch.

DOE's long-term goal is to greatly reduce the amount of industrial commercial waste generated through an intensive program of waste avoidance, recycling, and segregation.

\subsubsection{Infrastructure}

DOE is responsible for ensuring the continued safe operation of INEL facilities. One aspect of this activity is infrastructure support. The current program of infrastructure support at the INEL includes general plant projects to maintain and upgrade the current facilities, buildings, roads, and utilities that support operations. Other aspects of DOE's responsibility involves upgrading facilities, replacing equipment, maintaining facilities and equipment, providing environmental monitoring, and ensuring that quality control and quality assurance programs are in place.

Present infrastructure upgrades include general plant projects for utility and facility upgrades and maintenance, as well as larger line item projects. Ongoing projects include upgrades and additions to the INEL Research Center, sewer and utility upgrades, and a new INEL transportation facility. Near-term projects include the replacement of the Radiological and Environmental Sciences Laboratory and a new Health Physics Instrument Laboratory.

A major support service for the ER\&WM Program is the INEL environmental monitoring program. This monitoring program is designed to determine if waste management practices are 
adversely affecting the environment and, if so, how these practices need to be changed to decrease or eliminate the effects (DOE-ID 1992). The monitoring program includes air, surface water, drinking water, nonradiological discharges, ambient (surrounding) radiation levels, and plants and animals. Various locations within and outside the perimeter of all facilities and the INEL site as a whole are monitored. DOE has also signed an agreement with the State of Idaho to set up an independent State program to monitor INEL operations. The U. S. Environmental Protection Agency and the State of Idaho each have regulatory authority for different aspects of environmental compliance at the site.

The long-term goal is to provide the necessary support required for ER\&WM projects and to continue to ensure that operations are conducted as safely as possible, including minimum radiation exposure and minimum risk to personnel, facilities, the public, and the environment.

\subsubsection{Technology Development}

Technology development supports ER\&WM by designing and testing potential technical sclutions to specific problems related to ER\&WM. Broad program areas under technology development include research, development, demonstration, testing, and evaluation; technology integration; infrastructure support for developing and improving safe and efficient packaging systems; emergency response management; education; and laboratory analysis. Types of current technology development activities at the INEL include developing waste minimization; testing remediation technologies; evaluating and testing methods to treat calcined high-level, sodiumbearing, and other waste types; and designing sensors and other environmental monitoring equipment and systems.

In 1992, DOE had proposed to engage in research and development activities for technology development and demonstration required to assure that spent nuclear fuel could be appropriately prepared for disposition in a geologic repository. Any such repository is not expected to be available until after the year 2010. DOE has therefore changed its focus in this effort to develop the upfront work necessary to better define the spent fuel research and development program. However, DOE is utilizing a system approach to technology development for preparing spent nuclear fuel for safe interim storage and ultimate disposition in a geologic repository. 


\subsubsection{Activities Not Directly Related to Spent Nuclear Fuel or Environmental Restoration and Waste Management}

Many activities at the INEL are identified in Section 2.2.4, Major Facility Areas. Some of these activities, for example, the operation of nuclear reactors, fall outside the scope of this document. This is because Chapter 5, Environmental Consequences, of Volume 2 evaluates impacts only if they are associated with environmental restoration, waste management, and spent nuclear fuel operations at the INEL. Nonetheless, some activities at the INEL not directly related to spent nuclear fuel or ER\&WM are mentioned in appropriate sections of this document when they are relevant to understanding either the management of waste or the restoration of contaminated sites and facilities. Hazardous materials are included in this section due to their potential impact on human health, safety, and the environment.

2.2.10.1 Hazardous Materials. Hazardous materials are broadly defined as hazardous substances, hazardous chemicals, or toxic substances. The Emergency Planning and Community Right-to-Know Act, Section 312, requires an annual inventory of hazardous chemicals at the INEL. Hazardous chemicals are managed at the INEL to prevent harmful impacts to human health and safety and the environment.

The 1992 hazardous chemicals inventory lists 774 hazardous chemicals used at the INEL in quantities of 0.5 kilogram (one pound) or greater. Volumes range from 0.5 kilogram (one pound) of numerous chemicals to a maximum single volume of approximately $1,100,000$ kilograms $(2,400,000$ pounds) of fuel oil (Priestly 1992, Slaughterbeck 1993).

The number of hazardous chemicals and the total weight of any chemicals routinely used at the INEL changes from day to day and from facility to facility. Year-to-year inventories are maintained and accounted for through the annual Emergency Planning and Community Right-toKnow Act reports for INEL facilities. The percentage of hazardous materials used onsite that become hazardous waste or part of a hazardous waste cannot be determined. 
2.2.10.2 Support Services. DOE provides safety services, security and safeguards, utilities and plant services, environmental compliance, and emergency preparedness. A program of emergency preparedness for site areas and facilities has been developed based on prevention, planning, response, and recovery (DOE-ID 1993d).

\subsubsection{Regulatory Framework for Environmental Restoration and Waste Management}

Various laws and regulations govern environmental restoration and waste management at the INEL. These regulations affect choices in treatment, storage, and disposal; drive cleanup schedules; and provide standards against which the impacts of the alternatives are measured. Agreements between DOE-ID, regulatory agencies, and governmental agencies have been signed to provide guidance on the implementation of these laws. In addition, DOE Headquarters and DOE-ID issue orders and supplemental directives that implement laws, regulations, and requirements; give specific responsibilities; and describe implementation processes and procedurcs. Additional information on environmental regulations, compliance, and DOE-ID's compliance status can be found in Chapter 7, Consultations and Environmental Requirements. 


\section{ALTERNATIVES}

For this EIS, the DOE is evaluating four alternatives for the Spent Nuclear Fuel Program and the Environmental Restoration and Waste Management Program that represent a broad range of possible actions at the INEL over the next ten years.

These alternatives were developed during the public scoping process. DOE initially proposed the No Action and TenYear Plan alternatives. These alternatives were modified, and two other alternatives were added in response to comments received

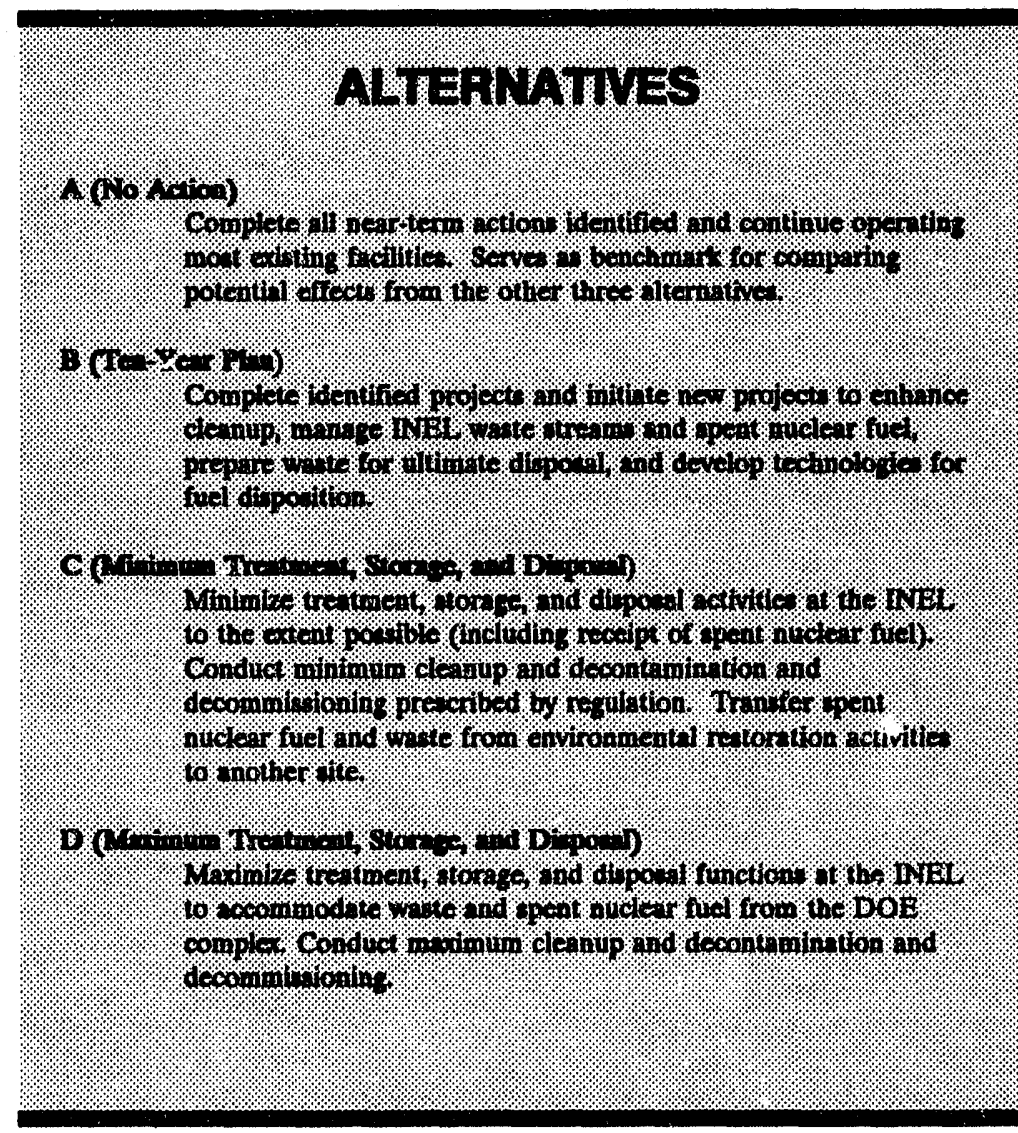
during the scoping process. Each alternative includes cumponents for remediation, decontamination and decommissioning, waste management, and spent nuclear fuel management. Infrastructure, technology development, and transportation requirements were also considered for each alternative.

Alternative A (No Action) must be considered under the National Environmental Policy Act. It serves as a benchmark for comparing potential effects of the other alternatives. In addition, three proposed action alternatives are considered in this EIS: Alternative B (Ten-Year Plan), Alternative C (Minimum Treatment, Storage, and Disposal), and Alternative D (Maximum Treatment, Storage, and Disposal). As illustrated in Figure 3.0-1, the proposed action alternatives for waste and spent nuclear fuel were shaped by management decisions involving sources, disposition options, and location options. 


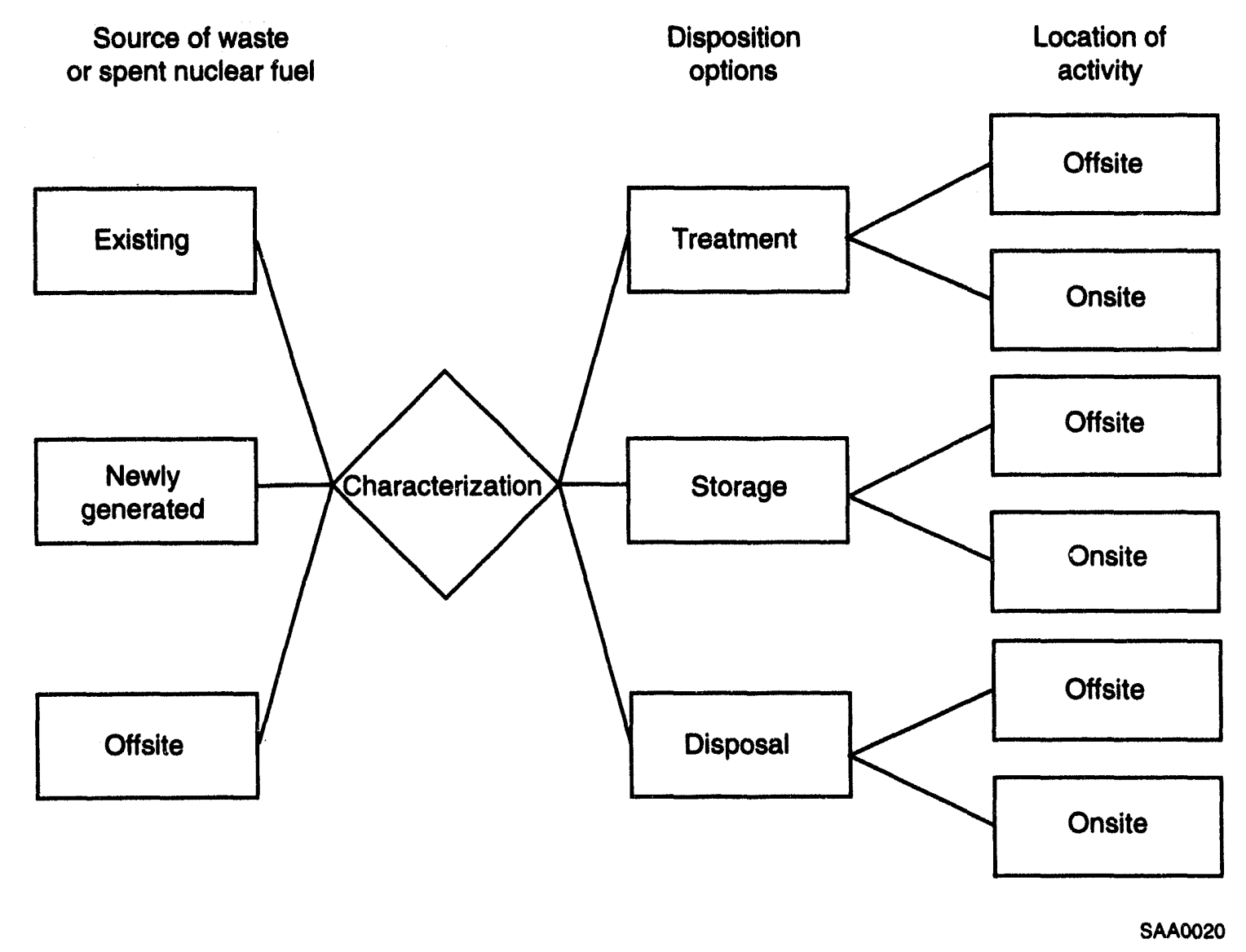

Figure 3.0-1. The basic management decisions for spent nuclear fuel and waste. 
The options for sources of spent nuclear fuel or waste are (a) that existing at the INEL site by June 1, 1995; (b) that generated at the INEL site between 1995 and 2005; and (c) that transported to the INEL site from other sites. The general handling options for spent nuclear fuel or waste would include characterization, treatment (processing for spent nuclear fuel), storage, disposition, or stabilization. Location options for handling activities would be either on the INEL or off the INEL.

Specific components of the alternatives were identified from a list of potential INEL projects and activities for the next ten years (through 2005), as reported by DOE planning documents and program managers. Relevant projects for which documentation under the National Environmental Policy Act is expected to be complete before June 1, 1995, are considered part of Alternative A (No Action). Other potential projects were candidates for inclusion in the various action alternatives, along with reasonable alternative actions. Section 3.1 describes the alternatives, and Appendix C, Information Supporting the Alternatives, gives detailed descriptions of the projects.

The alternatives represent different ways of accomplishing the following at the INEL:

a. Implementing reasonably foreseeable DOE-wide programmatic decisions for spent nuclear fuel, environmental restoration, and waste management.

b. Continuing existing research and development missions.

c. Fulfilling [except for Alternative A (No Action)] DOE and national requirements governing spent nuclear fuel, environmental restoration, and waste management.

DOE has not yet selected a preferred alternative; it will identify one in the Final EIS. The Navy, as a cooperating agency, however, has identified its preferred alternative for naval spent nuclear fuel management-to continue refueling and defueling of nuclear-powered vessels and prototypes, and to transport spent nuclear fuel to the Idaho National Engineering Laboratory for full examination and interim storage, using the same practices as in the past. 


\subsection{Description of Alternatives}

This section summarizes each of the four alternatives first at a general level, emphasizing management decisions. Starting with Section 3.1.1, the description is more specific, comparing and contrasting how spent nuclear fuel, environmental restoration, and each waste stream (such as high-level waste, hazardous waste, or mixed low-level waste) would be managed under the various alternatives. The discussion identifies functions, activities, projects, amounts of waste, and technology development associated with each alternative for each waste stream. The proposed projects associated with all four alternatives are presented in Table 3.1-1, and their locations are shown on Figure 3.1-1.

\section{Alternative A (No Action)}

Under Alternative A (No Action), existing environmental restoration and waste management operations, facilities, and projects would continue to be managed. This includes continuing existing environmental restoration, waste management, decontamination and decommissioning, research and development, and infrastructure facilities and projects that support the Environmental Restoration and Waste Management Program at the INEL. There would be no shipments of spent nuclear fuel to the INEL, with the exception of shipments of naval spent nuclear fuel during an approximately three-year transition period. Existing inventories of spent nuclear fuel stored at the INEL would remain. Activities and projects include those that may be initiated after June 1, 1995, but that have been evaluated under the National Environmental Policy Act regulations by June 1, 1995. New activities would be limited to minor environmental safety and health activities needed to maintain safe operation. No new major upgrades would be undertaken. Implementation of this alternative would not fully meet all negotiated agreements and commitments (that is, the Federal Facility Agreement and other consent orders). This includes contractual obligations to receive university and Fort St. Vrain spent nuclear fuel. 
Table 3.1-1. Projects at the Idaho National Engineering $L_{i}$ joratory associated with the proposed alternatives.

\begin{tabular}{|c|c|}
\hline Project name & Alternative ${ }^{\mathbf{a}}$ \\
\hline Expended Core Facility Dry Cell Project ${ }^{b}$ & $\mathbf{B}, \mathbf{D}$ \\
\hline Increased Rack Capacity for CPP- $666^{b}$ & $\mathbf{B}, \mathbf{D}$ \\
\hline Additional Increased Rack Capacity (CPP-666) & $\mathbf{B}, \mathbf{D}$ \\
\hline $\begin{array}{l}\text { Dry Fuel Storage Facility; Fuel Receiving Canning/Characterization and } \\
\text { Shipping }{ }^{b}\end{array}$ & $\mathrm{~B}, \mathrm{C}, \mathrm{D}^{\mathrm{c}}$ \\
\hline Fort St. Vrain Spent Nuclear Fuel Shipment and Storage ${ }^{b}$ & B, D \\
\hline Spent Fuel Processing & $\mathbf{D}$ \\
\hline Experimental Breeder Reactor-II Blanket Processing & B, D \\
\hline Actinide Recycle Demonstration & B, C, D \\
\hline $\begin{array}{l}\text { Central Liquid Waste Processing Facility Decontamination and } \\
\text { Decommissioning (D\&D) }\end{array}$ & B, D \\
\hline Engineering Test Reactor D\&D & B, D \\
\hline Materials Test Reactor D\&D & B, D \\
\hline Fuel Processing Complex (CPP-601) D\&D & B..D \\
\hline Fuel Receipt and Storage Facility (CPP-603) D\&D & $\mathbf{B}, \mathbf{D}$ \\
\hline Headend Processing Plant (CPP-640) D\&D & B, D \\
\hline Waste Calcine Facility (CPP-633) D\&D & B, D \\
\hline Tank Farm Heel Removal Project ${ }^{b}$ & $\mathrm{~B}, \mathrm{C}, \mathrm{D}$ \\
\hline Waste Immobilization Facility ${ }^{d}$ & B, C, D \\
\hline High-Level Tank Farm New Tanks ${ }^{b}$ & C, D \\
\hline New Calcine Storage & D \\
\hline Radioactive Scrap/Waste Facility & $\mathrm{B}, \mathrm{C}, \mathrm{D}$ \\
\hline Private Sector Alpha-Contaminated Mixed Low-Level Waste Treatment & $\mathbf{B}, \mathbf{D}$ \\
\hline $\begin{array}{l}\text { Radioactive Waste Management Complex Modifications to Support Private } \\
\text { Sector Treatment of Alpha-Contaminated Mixed Low-Level Waste }\end{array}$ & B, D \\
\hline Idaho Waste Processing Facility & $\mathrm{B}, \mathrm{D}^{\mathbf{c}}$ \\
\hline Shipping/Transfer Station ${ }^{b}$ & $\mathrm{C}$ \\
\hline Waste Experimental Reduction Facility Incineration ${ }^{b}$ & B, D \\
\hline Mixed/Low-Level Waste Treatment Facility & B, D \\
\hline Mixed/Low-Level Waste Disposal Facility & $B, D^{c}$ \\
\hline
\end{tabular}


Table 3.1-1. (Continued).

\begin{tabular}{|c|c|}
\hline Project name & Alternative $^{2}$ \\
\hline Nonincinerable Mixed Waste Treatment ${ }^{b}$ & $\mathrm{~B}, \mathrm{D}^{\mathrm{c}}$ \\
\hline Remote Mixed Waste Treatment Facility & B, D \\
\hline Sodium Processing Project & B, D \\
\hline Greater-Than-Class-C Dedicated Storage & B, D \\
\hline Hazardous Waste Treatment, Storage, and Disposal Facilities & D \\
\hline Industrial/Commercial Landfill Expansion ${ }^{b}$ & B, C, D \\
\hline Gravel Pit Expansions ${ }^{b}$ & $\mathrm{~B}, \mathrm{D}^{\mathbf{c}}$ \\
\hline Central Facilities Area Clean Laundry and Respirator Facility & B, D \\
\hline Calcine Transfer Project (Bin Set \#1) & B, D \\
\hline Plasma Hearth Process Project & B, D \\
\hline Test Area North Pool Fuel Transfere & A, B, D \\
\hline Remediation of Groundwater Contamination ${ }^{e}$ & A, B, C, D \\
\hline Pit 9 Retrieval $^{e}$ & A, B, C, D \\
\hline Vadose Zone Remediation ${ }^{e}$ & A, B, C, D \\
\hline Auxiliary Reactor Area (ARA)-II D\&De & A, B, C, D \\
\hline Boiling Water Reactor Experiment (BORAX)-V D\&D & A, B, C, D \\
\hline High-Level Tank Farm Replacement (upgrade phase) ${ }^{e}$ & $A, B, C, D$ \\
\hline Transuranic Storage Area Enclosure and Storage Project ${ }^{e}$ & A, B, C, D \\
\hline Waste Characterization Facility ${ }^{e}$ & A, B, C, D \\
\hline Waste Handling Facilitye & $A, B, C, D$ \\
\hline Health Physics Instrument Lab ${ }^{e}$ & $A, B, C, D$ \\
\hline Radiological and Environmental Sciences Laboratory Replacement ${ }^{e}$ & A, B, C, D \\
\hline \multirow{3}{*}{\multicolumn{2}{|c|}{$\begin{array}{l}\text { a. Alternative A (No Action), Alternative B (Ten-Year Plan), Alternative C (Minimum Treatment, } \\
\text { Storage, and Disposal), Alternative D (Maximum Treatment, Storage, and Disposal). } \\
\text { b. Projects that have received additional evaluation under the National Environmental Policy Act. } \\
\text { c. These projects would be expanded for Alternative D (Maximum Treatment, Storage, and Disposal). }\end{array}$}} \\
\hline & \\
\hline & \\
\hline \multicolumn{2}{|c|}{$\begin{array}{l}\text { d. Sodium-bearing and calcine waste treatment technology selection would be implemented through this } \\
\text { facility. }\end{array}$} \\
\hline $\begin{array}{l}\text { e. These ongoing or planned projects are included in the environmental at } \\
\text { Environmental Impact Statement (EIS). National Environmental Policy } \\
\text { is expected to be completed before the Record of Decision for this EIS. }\end{array}$ & $\begin{array}{l}\text { ed in this } \\
\text { on has been or }\end{array}$ \\
\hline
\end{tabular}




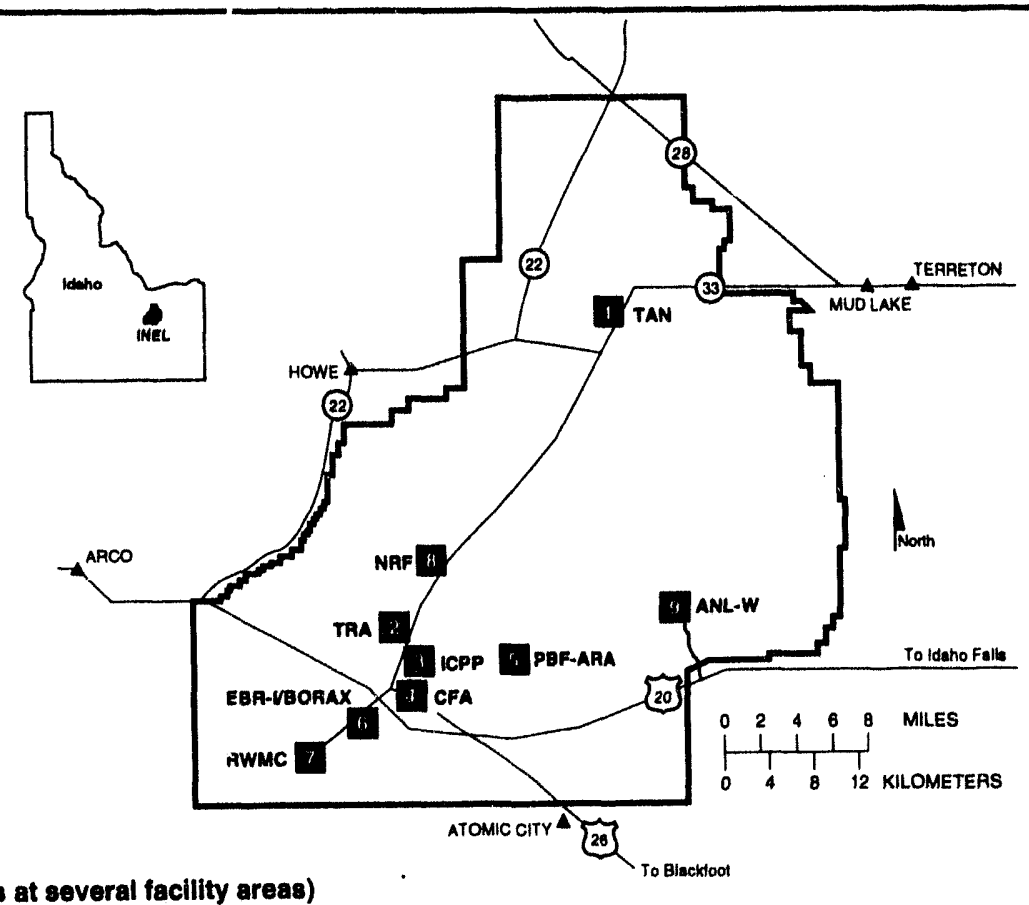

INEL (pits at several facility areas)

- Gravel Pit Expansions

Test Area North (TAN)

- TAN Pool Fuel Transfer

- Remediation of Groundwater

Contamination [Environmental Restoration (ER)]

Test Reactor Area (TRA)

- Engineering Test Reactor

[Decontamination and Decomissioning (D\&D)]

- Materials Test Reactor (D\&D)

Test Area North or Test Reactor Area

- Greater-Than-Class-C Dedicated Storage

Idaho Chemical Processing Plant (ICPP)

- New Calcine Storage

- Tank Farm Heel Removal Project

- High-Level Tank Farm New Tanks

- High Level Tank Farm Replacement (upgrade phase)

- Calcine Transfer Project (Bin Set \#1) [Technology Development (TD)]

- Waste Immobilization Facility

- Additional Increased Rack Capacity (CPP-666)

- Dry Fuel Storage Facility; Fuel Receiving. Canning/Characterization, and Shipping

- Fort St. Vrain Spent Nuclear Fuel Shipment and Storage

- Increased Rack Capacity for CPP.666

- Spent Fuel Processing

- Fuel Processing Complex (CPP-601) D\&D

- Fuel Receipt and Storage Facility (CPP-603) D\&D

- Headend Processing Plant (CPP-640) D\&D

- Waste Calcine Facility (CPP-633) D\&D

Central Facilities Area (CFA)

- Industrial/Commercial Landfill Expansion

- Health Physics Instrument Laboratory

- Radiological Environmental Sciences Laboratory Replacement

- CFA Clean Laundry and Respirator Facility

Power Burst Facility (PBF)/Auxiliary Reactor Area (ARA)

- Nonincinerable Mixed Waste Treatment

- Waste Experimental Reduction Facility Incineration

- ARA-II (D\&D)

Figure 3.1-1. The Idaho National Engineering Laboratory location of projects associated with proposed alternatives.
Experimental Breeder Raactor (EBR)-V Boilling Water Reactor Experiment (BORAX)

- BORAX-V (D\&D)

Radioactive Waste Management Complex (RWMC)

- Shipping/Transfer Station

- RWMC Modifications to Support

Private Sector Treatment of Alpha-Contaminated Mixed

- Waste Characterization Facility

- Transuranic Storage Area Enclosure and Storage Project

- Pit 9 Retrieval (ER)

- Vadose Zone Remediation (ER)

Radioactive Waste Management Complex

(2.5 miles east)

- Idaho Waste Processing Facility

- Private Sector Alpha-Contaminated Mixed Low-Level Waste Treatment

- Hazardous Waste Treatment, Storage and Disposal Facilities

- Mixed/Low-Level Waste Treatment Facility

- Mixed/Low-Level Waste Disposal Facility

8. Naval Reactors Facility (NRF)

- Expended Core Facility Dry Cell Project

Argonne National Laboratory-West (ANL-W)

- Remote Mixed Waste Treatment Facility

- Radioactive Scrap/Waste Facility

- Central Liquid Waste Processing Facility (D\&D)

- EBR-II Blanket Processing

- Plasma Hearth Process Project (TD)

- Actinide Recycle Demonstration

- Sodium Processing Project

- Waste Handling Facility

RED 0244 Low-Level Waste 


\section{Alternative B (Ten-Year Plan)}

Under Alternative B (Ten-Year Plan), existing environmental restoration and waste management facilities and projects would continue to be managed. Besides existing facilities and projects, currently proposed projects for 1995 through 2005 would be implemented. These projects would be implemented to continue to meet INEL's historic role and to assist in ensuring regulatory compliance. Implementation of this alternative would meet negotiated agreements and commitments (that is, the Federal Facility Agreement and other consent orders).

Under Alternative B (Ten-Year-Plan), spent nuclear fuel and environmental restoration and waste management activities would be continued and enhanced to meet current and expanded spent nuclear fuel and waste handling needs. These enhanced activities would be needed to comply with regulations and agreements and would result from acceptance of additional offsitegenerated materials and waste. New waste generation would increase (reflecting regulatory requirements and increased environmental restoration activities). Spent nuclear fuel and selected waste would be received from other sites. Onsite management would emphasize greater treatment and disposal capabilities compared with Alternative A (No Action). Additional remediation and decommissioning and decontamination projects would be conducted under this alternative compared with Alternative A (No Action). Environmental restoration activities would be conducted in accordance with the Federal Facility Agreement and Consent Order and Action Plan. Also, some spent nuclear fuel and more waste management activities would be directed to the INEL from other DOE sites.

\section{Alternative C (Minimum Treatment, Storage, and Disposal)}

To the extent possible, under Alternative C (Minimum Treatment, Storage, and Disposal) ongoing INEL spent nuclear fuel, waste management activities, and materials and waste would be transferred to other locations. Possible locations include DOE facilities, other government sites, or private sector locations. Minimal treatment, storage, and disposal activities would be located at the INEL site under this alternative.

Under Alternative C (Minimum Treatment, Storage, and Disposal), neither waste nor spent nuclear fuel would be received from other sites for management. Whenever feasible, wastes 
generated from environmental restoration activities would be minimized by emphasizing institutional controls over treatment options. Also, many of the spent nuclear fuel and waste management activities currently occurring or proposed under Alternative B (Ten-Year Plan) and Alternative D (Maximum Treatment, Storage, and Disposal) would be transferred to other sites. Existing onsite spent nuclear fuel and waste management capability would be expanded to the extent needed to comply with regulations and agreements.

\section{Alternative D (Maximum Treatment, Storage, and Disposal)}

To the extent possible, under Alternative D (Maximum Treatment, Storage, and Disposal) spent nuclear fuel and waste would be transferred from other DOE facilities to the INEL site for management. Environmental restoration activities would emphasize residential use as the preferred end land use, which potentially would result in maximum waste generation. Implementing this alternative would result in the need for additional projects not yet defined or for the expansion of identified projects compared with those identified in Alternative B (TenYear Plan).

Under Alternative D (Marimum Treatment, Storage, and Disposal), acceptance of waste or spent nuclear fuel from other sites would be maximized. Compared with other alternatives, wastes generated from environmental restoration and waste management activities potentially would be greater. Spent nuclear fuel and environmental restoration and waste management activities at the INEL would be continued and enhanced to meet current and expanded spent nuclear fuel and waste handling needs. These enhancements would be needed to comply with regulations and agreements and to allow for acceptance of additional offsite-generated materials and waste. New waste generation would increase to a maximum possible level (reflecting regulatory requirements and increased environmental restoration activities). Onsite management would emphasize greater treatment and disposal capabilities compared with Alternative $\mathbf{A}$ (No Action). In addition, the capabilities required would be greater compared with Alternative B (Ten-Year Plan) because of the additional waste (a) accepted from other sites or (b) generated because of proposed spent nuclear fuel processing, environmental restoration, and waste management treatment activities. Additional decommissioning and decontamination projects would be conducted under this alternative compared with Alternative A (No Action). 


\subsubsection{Alternatlves for Management of Spent Nuclear Fuel}

\begin{tabular}{|c|c|c|}
\hline & & spont Nublear ruel \\
\hline Ninerintis 4 & & 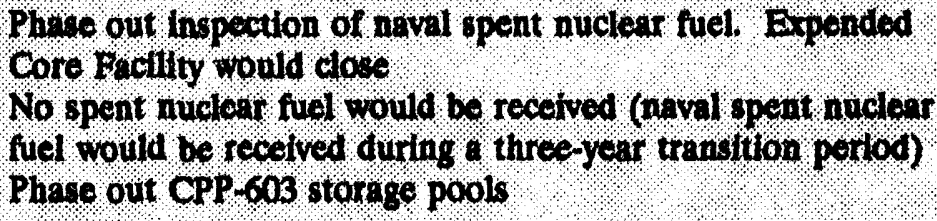 \\
\hline Wrentivo B & 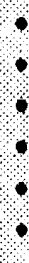 & $\begin{array}{l}\text { Emamine and store naval spent nuclear fuel } \\
\text { Receive additional oftsite spent nuclear fuel } \\
\text { Phese out CPP-603 storage pools } \\
\text { Expand storage capacity in existing CPP- } 666 \text { pools } \\
\text { Phase in dry storage } \\
\text { Demonstrate uctinide recycle }\end{array}$ \\
\hline$N=m+n=0$ & & $\begin{array}{l}\text { Phase out inspection of nayal spent nuclear fuel. Expended } \\
\text { Core Facility would close } \\
\text { Ship all spent nuclear tual to U. S. Department of Bacrgy } \\
\text { (DOE) centralization site } \\
\text { Phase out spent nuclear fuel handling faclities } \\
\text { Demonstrate actinide recyclo }\end{array}$ \\
\hline Altontive D & 6 & $\begin{array}{l}\text { Examine and store naval spent nuclear fuel } \\
\text { Recelve DOE complex wide spent nuclear fuel } \\
\text { Phase out CPP } 603 \text { storage pools } \\
\text { Rxpand storage capacity in existing CPP- } 666 \text { pools } \\
\text { Phase in expanded dry storage } \\
\text { Demonstrate actinide recycle } \\
\text { Phase in spent nuclear fuel processing }\end{array}$ \\
\hline
\end{tabular}

The goal for the alternatives to manage spent nuclear fuel at the INEL is to provide safe and environmentally responsible interim storage until a suitable geologic repository is available. The basic potential and existing activities and facilities to manage spent nuclear fuel are illustrated in figures associated with each alternative description, and details are given by alternative in Table 3.1-2. The locations of the projects associated with spent nuclear fuel alternatives are shown on Figure 3.1-2. The activities and facilities are organized by options available for the management decision on how to handle spent nuclear fuel. 
Table 3.1-2 Spent nuclear fuel: Summary of proposed management functions and related projects (denoted by bullets) at the Idaho National Engineering Laboratory (INEL) by alternative.

\begin{tabular}{|c|c|c|c|c|c|}
\hline Alternative & Transportation & Stabilization & Storage & $\begin{array}{l}\text { Research and } \\
\text { development }\end{array}$ & $\begin{array}{l}\text { Naval fued } \\
\text { comination }\end{array}$ \\
\hline $\begin{array}{c}\text { A } \\
\text { (No Action) }\end{array}$ & $\begin{array}{l}\text { Naval spent nuclear fuel } \\
\text { shipped to INEL site during } \\
\text { 3-year transition period } \\
\text { No other spent nuclear fuel } \\
\text { shipments to INEL site } \\
\text { Onsite spent nuclear fuel } \\
\text { transfer in existing casks for } \\
\text { consolidation }\end{array}$ & $\begin{array}{l}\text { Minimum actions required to safely } \\
\text { store spent nuclear fuel } \\
\text { Continue canning/characterization of } \\
\text { spent nuclear fuel including fuel } \\
\text { removed from CPP-603 }\end{array}$ & $\begin{array}{l}\text { Onsite consolidation at various } \\
\text { eristing Idabo National } \\
\text { Engineering Laboratory } \\
\text { facilities } \\
\text { - Test Area North Pool Fuel } \\
\text { Transfer } \\
\text { Phase out CPP-603 wet storage }\end{array}$ & $\begin{array}{l}\text { Contimue eristing } \\
\text { research and } \\
\text { development } \\
\text { activities }\end{array}$ & $\begin{array}{l}\text { Phase out } \\
\text { examination and } \\
\text { Expended Core } \\
\text { Facility after } 3 \text {-year } \\
\text { transition period }\end{array}$ \\
\hline $\begin{array}{c}\text { B } \\
\text { (Ten-Year } \\
\text { Plan) }\end{array}$ & $\begin{array}{l}\text { Additional receipts of non- } \\
\text { Department of Energy } \\
\text { (DOE) domestic research } \\
\text { spent nuclear fuel, plus spent } \\
\text { nuclear fuel from Fort St. } \\
\text { Vrain, West Valley, and some } \\
\text { foreign research reactors } \\
\text { Naval spent nuclear fuel from } \\
\text { defueling points plus onsite } \\
\text { transfer for interim storage } \\
\text { Casios for offsite receipts } \\
\text { supplied by others } \\
\text { Onsite spent nuclear fuel } \\
\text { transfer in cristing castos for } \\
\text { consolidation }\end{array}$ & $\begin{array}{l}\text { Current INEL spent nuclear fuel } \\
\text { inventury stabilized as ptanned } \\
\text { Offite receipts stabilized as needed } \\
\text { (beyond stabilization provided by } \\
\text { originating site for transportation) } \\
\text { - Dry Fuel Storage Facility, Fuel } \\
\text { Receiving/Canning Characterization }\end{array}$ & $\begin{array}{l}\text { Onsite consolidation plus } \\
\text { upgrading and expansion of } \\
\text { storage to accommodate offite } \\
\text { receipts } \\
\text { - Test Area North Pool Fuel } \\
\text { Transfer } \\
\text { - Increased Ract Capacity for } \\
\text { CPP-666 } \\
\text { - Additional Increased Ract } \\
\text { Capecity (CPP-666) } \\
\text { - Fort St. Vrain Spent Nuclear } \\
\text { Fuel Shipment and Storage } \\
\text { Phase out miscellaneous } \\
\text { storage facilities and CPP-603 } \\
\text { wet storage } \\
\text { Phase in dry storage } \\
\text { - Dry Fuel Storage Facility, } \\
\text { Fuel Receiving. } \\
\text { Canning/Characterization, and } \\
\text { Shipping }\end{array}$ & $\begin{array}{l}\text { Research and } \\
\text { development } \\
\text { activities expanded } \\
\text { as planned } \\
\text { - Buperimental } \\
\text { Breoder Reactor- } \\
\text { II Blanket } \\
\text { Processing } \\
\text { - Actinide } \\
\text { Recycle } \\
\text { Demonstration }\end{array}$ & $\begin{array}{l}\text { Examination at } \\
\text { eristing Expended } \\
\text { Core Facility } \\
\text { - Expended Core } \\
\text { Facility Dry Cell } \\
\text { Project }\end{array}$ \\
\hline
\end{tabular}


Table 3.1-2 (Continued).

\begin{tabular}{|c|c|c|c|c|c|}
\hline Alternative & Transportation & Stabilimation & Storage & $\begin{array}{l}\text { Research and } \\
\text { development }\end{array}$ & $\begin{array}{l}\text { Naval fued } \\
\text { camination }\end{array}$ \\
\hline $\begin{array}{l}\text { C } \\
\text { (Minimum } \\
\text { Treatment, } \\
\text { Storage, and } \\
\text { Disposal) }\end{array}$ & $\begin{array}{l}\text { Current (1995) INEL spent } \\
\text { nuclear fuel imventory shipped } \\
\text { offsite to selected DOE } \\
\text { centralization site } \\
\text { Onsite spent nuclear fuel } \\
\text { transfer for stabilization } \\
\text { before offsite shipment } \\
\text { Naval spent nuclear fuel to } \\
\text { INEL site during 3-year } \\
\text { transition period } \\
\text { Castes for offsite shipments } \\
\text { obtained commercially or } \\
\text { supplied by others }\end{array}$ & $\begin{array}{l}\text { Adequate stabilization for safe offsite } \\
\text { shipment } \\
\text { - Dry Fuel Storage Facility, Fued } \\
\text { Receiving/Canning Characterization } \\
\text { (no storage) }\end{array}$ & $\begin{array}{l}\text { Phase out all spent nuciear fuel } \\
\text { storage facilities at Idaho } \\
\text { Chemical Processing Plant. } \\
\text { Test Area North and } \\
\text { miscellaneous locations, except } \\
\text { Advanced Test Reactor canal }\end{array}$ & $\begin{array}{l}\text { Phase cut of all } \\
\text { spent nuclear fuel } \\
\text { research and } \\
\text { development } \\
\text { activities at INEL } \\
\text { - Actinide } \\
\text { Recycle } \\
\text { Demonstration } \\
\text { Discontinue spent } \\
\text { nuclear fuel } \\
\text { function of } \\
\text { technology } \\
\text { developmeat } \\
\text { activity }\end{array}$ & $\begin{array}{l}\text { Phase out Expended } \\
\text { Core Facility after } 3 \text { - } \\
\text { year transition }\end{array}$ \\
\hline $\begin{array}{c}\text { D } \\
\text { (Maximum } \\
\text { Treatment, } \\
\text { Storage and } \\
\text { Disposal) }\end{array}$ & $\begin{array}{l}\text { Shipment of all spent nuclear } \\
\text { fuel in DOE complex to } \\
\text { INEL site } \\
\text { Naval spent nuclear fuel from } \\
\text { defueling points plus onsite } \\
\text { transfer for interim storage } \\
\text { Casts for offsite receipts } \\
\text { supplied by others } \\
\text { Onsite spent nuclear fuel } \\
\text { transfer in existing castos for } \\
\text { consolidation }\end{array}$ & $\begin{array}{l}\text { Current (1995) INEL spent nuclear } \\
\text { fuel inventory stabilized as planned } \\
\text { Offsite receipts stabilized as needed } \\
\text { - Dry Fuel Storage Facility, Fuel } \\
\text { Receiving/Canning Characterization } \\
\text { Fuel processing as bounding case } \\
\text { - Spent Fuel Processing }\end{array}$ & $\begin{array}{l}\text { Onsite consolidation at various } \\
\text { existing INEL facilities, plus } \\
\text { upgrading and additional } \\
\text { expansion of storage to } \\
\text { accommodate offisite receipts } \\
\text { - Test Area North Pool Fuel } \\
\text { Transfer } \\
\text { - Increased Ract Capacity for } \\
\text { CPP-666 } \\
\text { - Additional Increased Ract } \\
\text { Capacity (CPP-666) } \\
\text { - Fcrt St. Vrain Spent Nuciear } \\
\text { Fuel Shipment and Storage } \\
\text { Phase out miscellaneous } \\
\text { storage facilities and CPP-603 } \\
\text { wet storage }\end{array}$ & $\begin{array}{l}\text { Research and } \\
\text { development } \\
\text { activities expanded } \\
\text { as planned plus } \\
\text { demonstration of } \\
\text { spent nuclear fuel } \\
\text { processing } \\
\text { technologies } \\
\text { - Experimental } \\
\text { Breeder Reactor- } \\
\text { II Bbanket } \\
\text { Processing } \\
\text { - Actinide } \\
\text { Recycie } \\
\text { Demonstration }\end{array}$ & $\begin{array}{l}\text { Examination at } \\
\text { existing Expeaded } \\
\text { Core Facility } \\
\text { - Expended Core } \\
\text { Facility Dry Cell } \\
\text { Project }\end{array}$ \\
\hline & & & $\begin{array}{l}\text { Phace in cepanded dy storage } \\
\text { - Dry Fued Stocage Facility, } \\
\text { Fuel Receiving/Canning }\end{array}$ & & \\
\hline
\end{tabular}




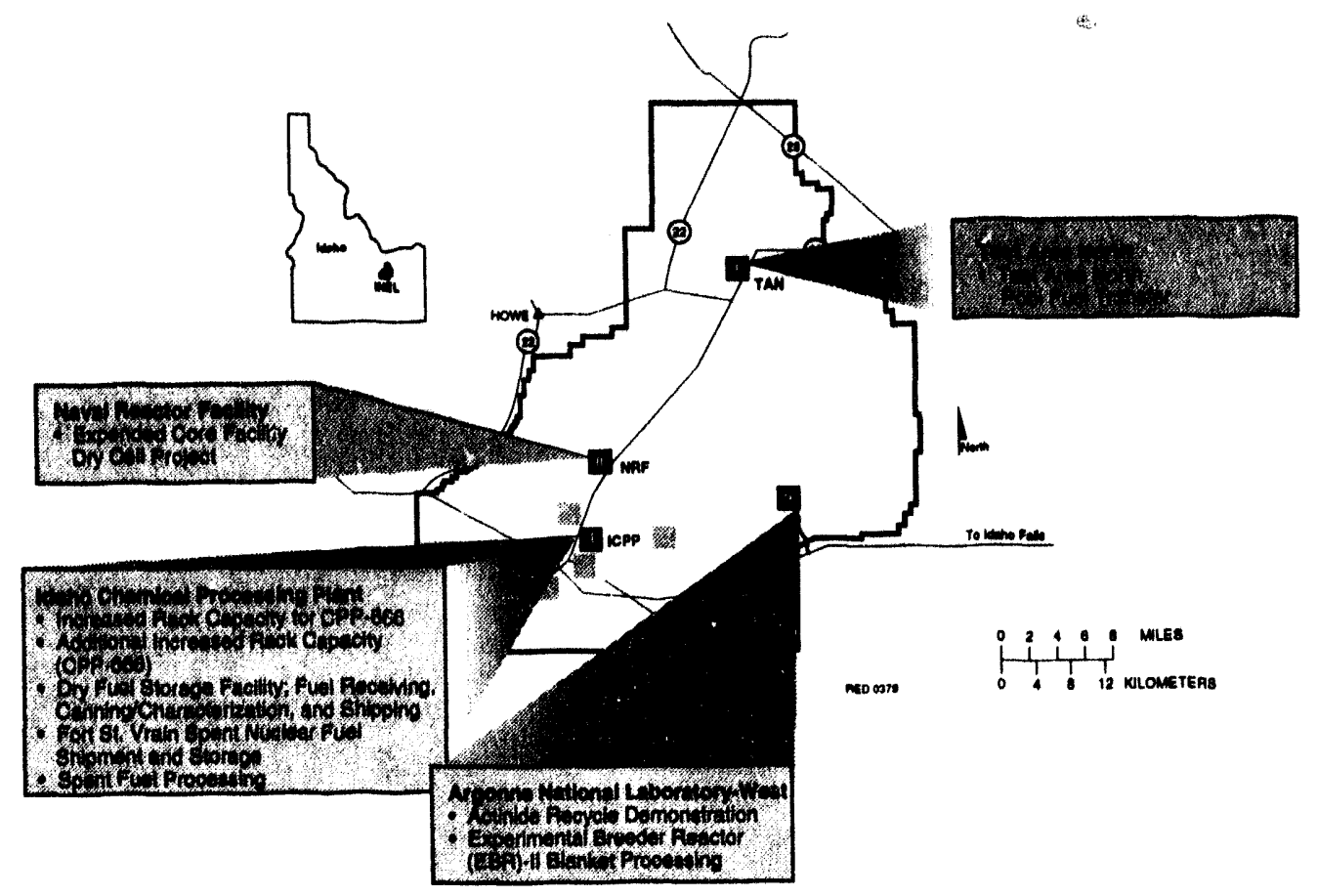

Figure 3.1-2. Spent nuclear fuel: Idaho National Engineering Laboratory locations of projects associated with proposed alternatives.

Each alternative emphasizes various options that implement the three basic management decisions on sources, handling, and locations discussed earlier (Figure 3.0-1). Except for the required NoAction alternative, the combination of technologies, facilities, and projects that implement the options for each alternative were selected to meet the basic goals of the spent nuclear fuel program.

The spent nuclear fuel alternatives in this volume would implement, at the INEL, the alternatives analyzed in Volume 1 of this EIS. Alternative A (No Action) in Volume 2 corresponds to the No-Action alternative (Alternative 1) in Volume 1.

Alternative B (Ten-Year Plan) in Volume 2 encompasses the following Volume 1 alternatives: Decentralization (Alternative 2), 1992/1993 Planning Basis (Alternative 3), and Regionalization by fuel type (Alternative 4a). The Volume 1 Regionalization $4 a$ alternative was used to analyze potential consequences from implementing Alternative B (Ten-Year Plan) of Volume 2. This is because the Regionalization $4 \mathrm{a}$ alternative would handle the largest quantities 
of spent nuclear fuel and have the most activities compared with the other two Volume 1 aiternatives. Therefore, the potential consequences of the Regionalization $4 a$ alternative would bound the potential consequences of Decentralization and the 1992/1993 Planning Basis alternatives, if either were implemented at the INEL.

Alternative C (Minimum Treatment, Storage, and Disposal) of Volume 2 corresponds to the Volume 1 Regionalization $4 \mathrm{~b}$ alternative (regionalization of spent nuclear fuel is not at the INEL) and Centralization alternative 5a (centralization is not at the INEL). This would result in the transport of spent nuclear fuel from the INEL site to the regional or central facility, respectively.

Under Alternative D (Maximum Treatment, Storage, and Disposal) of Volume 2, the INEL site would accept the maximum amount of spent nuclear fuel. This alternative would correspond to the Volume 1 Regionalization $4 \mathrm{~b}$ (1) alternative (INEL is the western regional facility for spent nuclear fuel) and the Centralization $5 \mathrm{~b}$ alternative (INEL is the central facility for spent nuclear fuel). The two Volume 1 alternatives are similar, except that a slightly lower quantity of spent nuclear fuel would be accepted at the INEL under the Regionalization $4 b(1)$ alternative.

Alternative A (No Action) in Volume 2 corresponds to the No-Action alternative in Volume 1 of this EIS. Alternative A (No Action) generally would continue existing operations and handling of spent nuclear fuel (Table 3.1-2, Figure 3.1-3). There would be no shipments of spent nuclear fuel to the INEL site, with the exception of shipments of naval spent nuclear fuel during an approximately three-year transition period. During that transition period, naval spent nuclear fuel would be examined at the Expended Core Facility at the Naval Reactors Facility, and then shipped to the Idaho Chemical Processing Plant for storage. The Expended Core Facility would close after the transition period. Some consolidation of some onsite storage activities would continue. Older storage pools (in Building CPP-603) would be phased out, and the spent nuclear fuel would be canned, as needed, and stored using dry storage methods. 


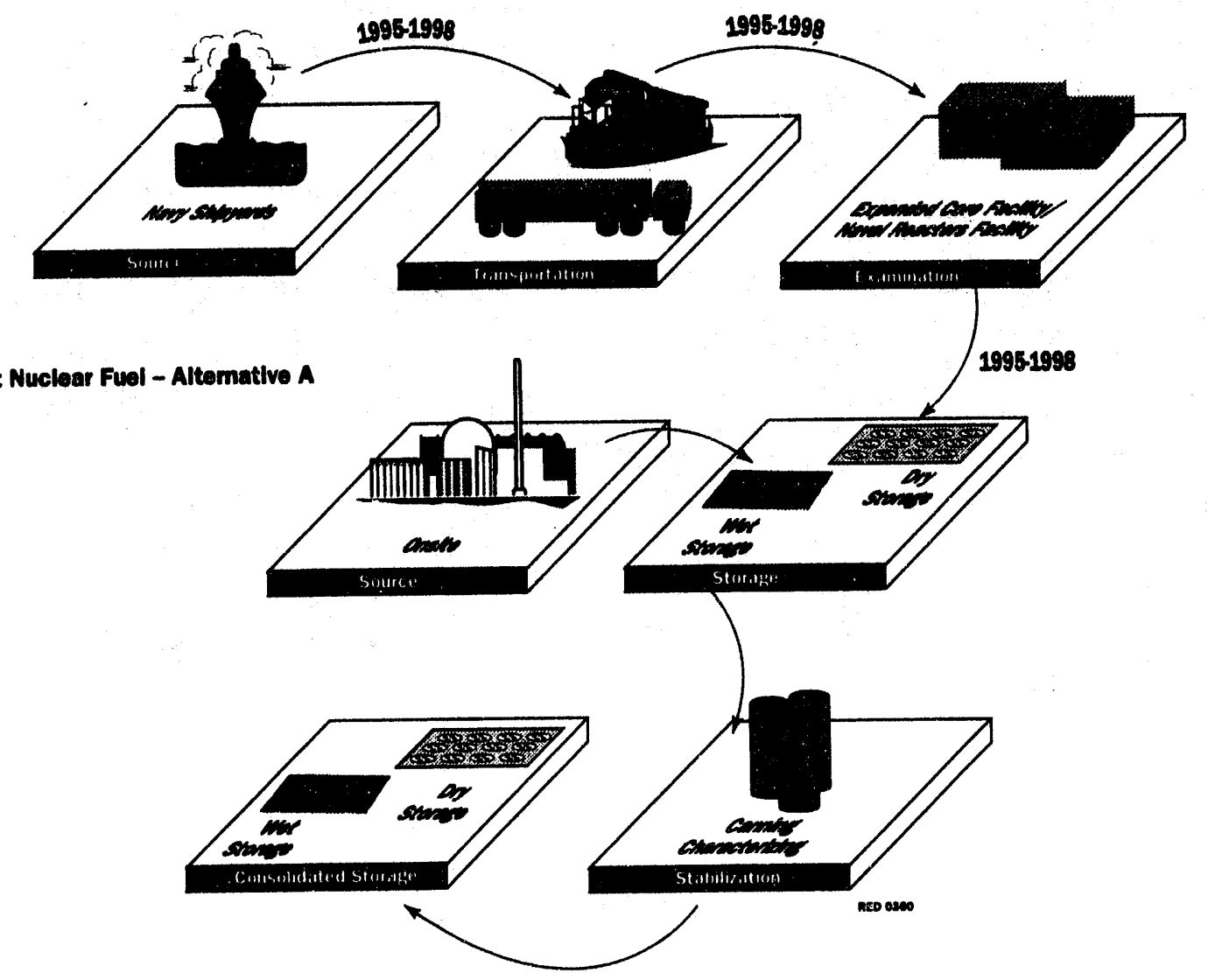

Figure 3.1-3. Management of spent nuclear fuel at the Idaho National Engineering Laboratory under the proposed Alternative A (No Action).

Under Alternative B (Ten-Year Plan), offsite spent nuclear fuel would be received, primarily naval but including Fort St. Vrain, West Valley, and other spent nuclear fuel from some university and foreign research reactors (Figure 3.1-4). Naval spent nuclear fuel would be examined at the Expended Core Facility at the Naval Reactors Facility and then stored at the Idaho Chemical Processing Plant. The Expended Core Facility Dry Cell Project would be executed, as described in Appendix C, Information Supporting the Alternatives. Additional storage would be gained by installing additional racks in the storage pools at the Idaho Chemical 


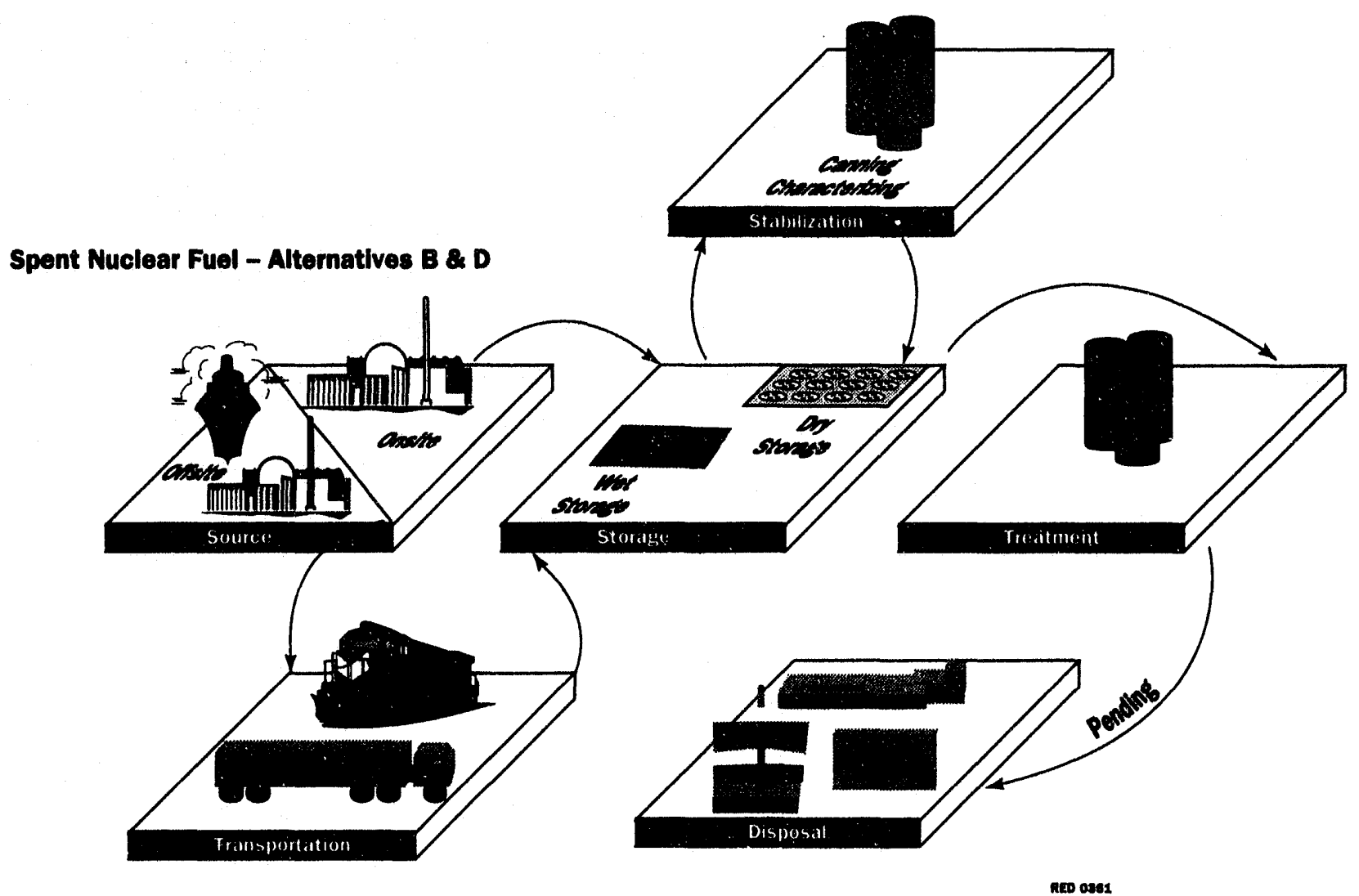

Figure 3.1-4. Management of spent nuclear fuel at the Idaho National Engineering Laboratory under the proposed Alternative B (Ten-Year Plan) and Alternative D (Maximum Treatment, Storage, and Disposal).

Processing Plant (Building CPP-666). Dry storage would be phased in. Consolidation of spent nuclear fuel would occur. This alternative would also allow a demonstration of Experimental Breeder Reactor-II Blanket Processing and the Actinide Recycle Demonstration at Argonne National Laboratory-West.

One important project that would be implemented under both Alternatives B (Ten-Year Plan) and Alternative D (Maximum Treatment, Storage, and Disposal) is the Increased Rack Capacity for the storage pools in Building CPP-666 of the Idaho Chemical Processing Plant. This project would involve replacing and rearranging (commonly called reracking) existing fuel storage racks in three of the six fuel storage area pools located in the Fluorinel Dissolution Process and Fuel Storage (FAST) Facility (Building CPP-666). The fuel storage capacity would be increased by replacing existing racks in three storage pools with new racks. The new racks would be taller and in some instances would have different storage port dimensions and different spacing 
dimensions between ports. The new racks would provide flexibility for storing more fuel of different sizes and shapes in the existing pools without enlarging the pools.

A second potential project (Additional Increased Rack Capacity in CPP-666) would involve reracking existing fuel storage in at least two other pools in CPP-666. This additional capacity project would be implemented only if capacity is needed beyond that supplied by the initial reracking project. This project would be implemented to handle the fuel inventories proposed to be shipped to the INEL site under Alternatives B (Ten-Year Plan) and D (Maximum Treatment, Storage, and Disposal). More complete details on the reracking projects are given in Appendix C, Information Supporting the Alternatives.

Under Alternative C (Minimum Treatment, Storage, and Disposal), the current INEL spent nuclear fuel inventory would be shipped to another DOE site (Figure 3.1-5). Current practices for managing naval spent nuclear fuel at the Idaho Chemical Processing Plant would continue until fuels are removed from the INEL site. Wet storage at Building CPP-603 at the Idaho Chemical Processing Plant would be phased out. The Actinide Recycle Demonstration project at Argonne National Laboratory-West would proceed. Table 3.1-2 provides additional

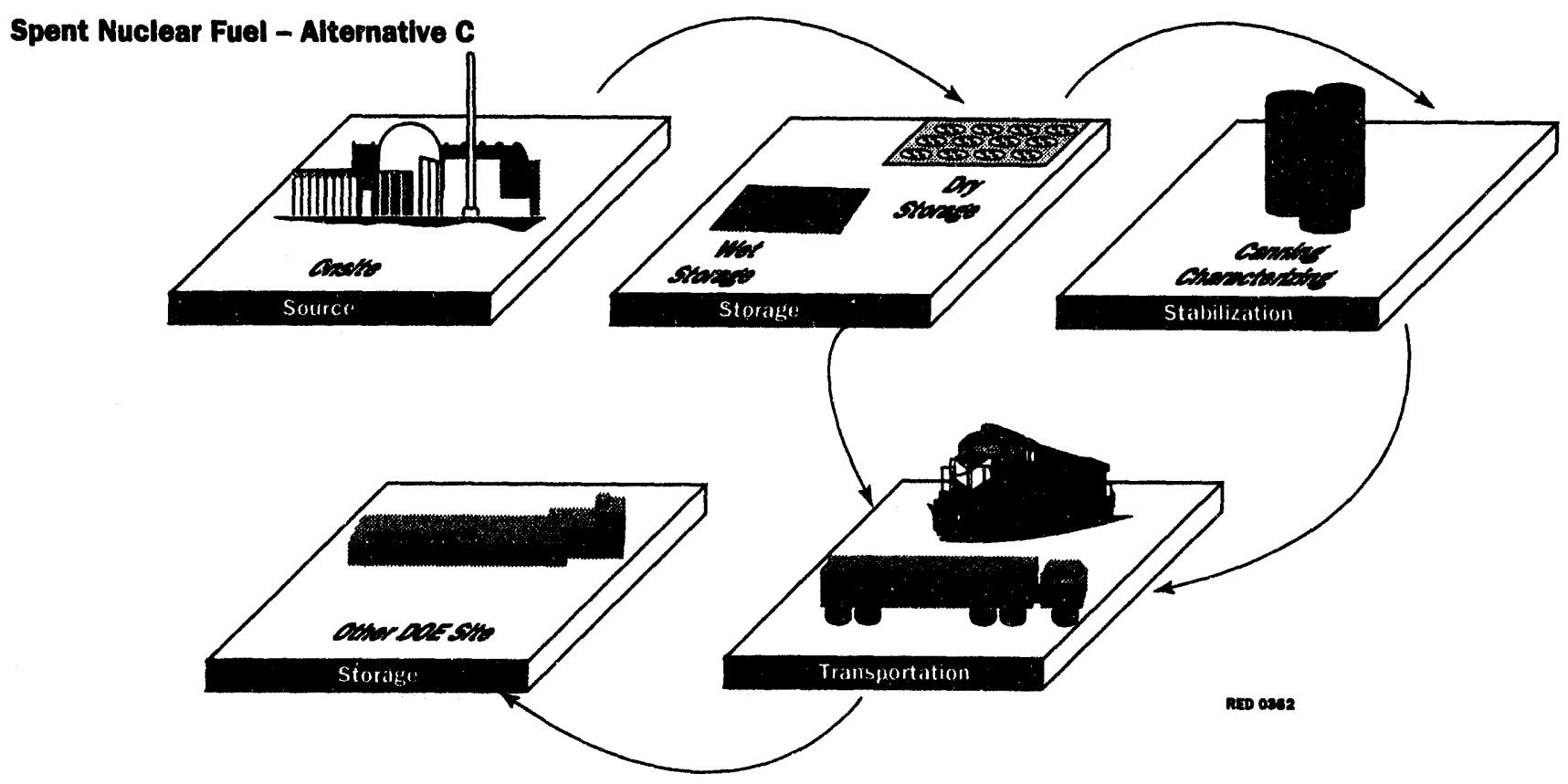

Figure 3.1-5. Management of spent nuclear fuel at the Idaho National Engineering Laboratory under the proposed Alternative C (Minimum Treatment, Storage, and Disposal). 
information on other activities that would be conducted under this alternative. Under Alternative C, less spent nuclear fuel would remain at the INEL site in 2005 , and no fuel would be present by 2035.

Under Alternative D (Maximum Treatment, Storage, and Disposal), the INEL site would receive virtually all spent nuclear fuel for which DOE is responsible. Therefore, the quantity of fuel handled at the INEL site would increase from less than 500 metric tons under the other alternatives to nearly 1,000 metric tons of heavy metal by the year 2005 . Activities required to handle this volume of fuel would include the Expended Core Facility Dry Cell Project, adding additional storage racks to increase spent nuclear fuel storage in pools at the Idaho Chemical Processing Plant (Building CPP-666), and phasing in expanded dry storage (Table 3.1-2). Older storage pools (in Building CPP-603) would be phased out and the spent nuclear fuel canned and stored using dry storage methods. Consolidation of spent nuclear fuel would occur under this alternative. In addition, the demonstration of the Experimental Breeder Reactor-II Blanket Processing and the Actinide Recycle Demonstration project at Argonne National LaboratoryWest would be implemented.

Aqueous processing of spent nuclear fuel to stabilize it for disposition would be considered under Alternative D (Maximum Treatment, Storage, and Disposal). It would be implemented by the Spent Fuel Processing project described in Appendix C, Information Supporting the Alternatives. This project would be initiated at the Idaho Chemical Processing Plant. The existing fluorinel dissolution process, aluminum dissolution, and the solvent extraction system would be upgraded and restarted. In addition, the partially constructed Fuel Process Restoration Facility would be completed.

The quantities of spent nuclear fuel stored at the INEL in 2005 and 2035 (as shown in Figure 3.1-6) reflect the management decisions made for the four alternatives. The year 2035 quantities are consistent with the corresponding Volume 1 alternatives. They result from three sources: (a) 1995 quantities already at the INEL site from sources described in Section 2.2.5, Spent Nuclear Fuel, (b) generation by operating reactors at the INEL site (see also Section 2.2.5), and (c) receipts from offsite. 
The 2005 spent nuclear fuel inventory values reported in Figure 3.1-6 are conservative interpolations between the 1995 basis and the 2035 values. Assumptions that make the 2005 values conservatively high include the following:

- Under Alternative C (Minimum Treatment, Storage, and Disposal), offsite facilities are assumed not to be ready to receive most of the $1995 \mathrm{INEL}$ inventory

- Under Alternative D (Maximum Treatment, Storage, and Disposal), by 2005, the INEL site would accept about one-fourth of the DOE complex-wide spent nuclear fuel by placing the fuel in temporary dry storage.

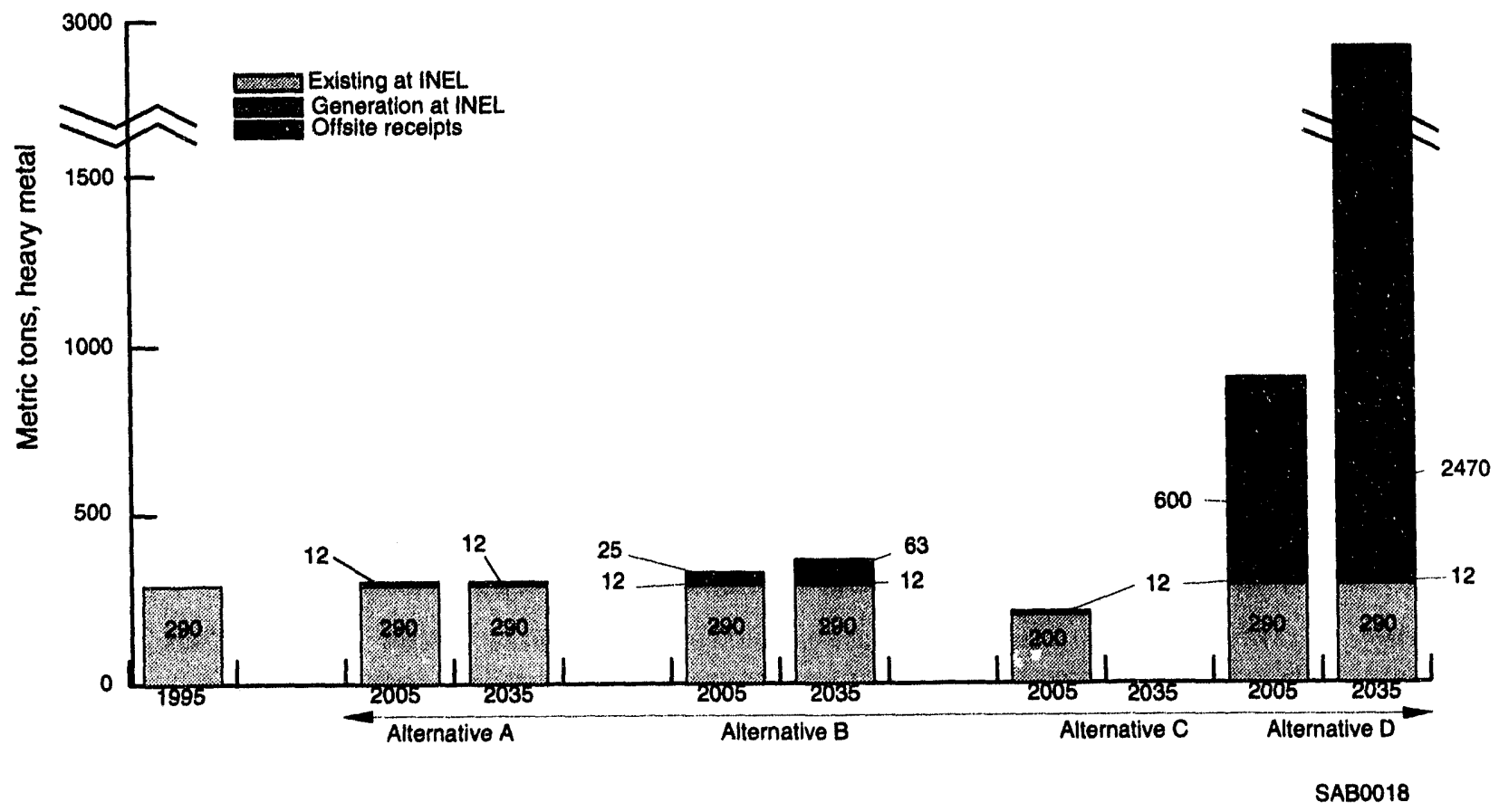

Figure 3.1-6. Spent nuclear fuel volumes at the Idaho National Engineering Laboratory for 1995, 2005, and 2035 under the proposed alternatives: Alternative A (No Action), Alternative B (TenYear Plan), Alternative C (Minimum Treatment, Storage, and Disposal), and Alternative D (Maximum Treatment, Storage, and Disposal). 


\subsubsection{Alternatives for Environmental Restoration}

The environmental restoration alternatives are described separately for remediation and decontamination and decommissioning. The alternatives for these elements of the Environmental Restoration Program follow the basic alternative definitions described in the introduction to Section 3.1. The inclusion (or noninclusion) of proposed projects and the different end land use preferences are the primary attributes that differentiate the alternatives.

3.1.2.1 Remediation. The Federal Facility Agreement and Consent Order Action Plan would be followed under each alternative except Alternative A (No Action). In addition, three projects that would be authorized before June 1, 1995, under the Comprehensive Environmental Response, Compensation, and Liability Act would be completed under all four alternatives (Figure 3.1-7). The projects enumerated below are described in detail in Appendix C, Information Supporting the Alternatives, and their locations are shown in Figure 3.1-8:

- Retrieval and treatment of radioactive and hazardous wastes from Pit 9 at the Radioactive Waste Management Complex

- Remediation of groundwater contamination by removing contaminated groundwater from the aquifer in the vicinity of an injection well at Test Area North

- Remediation of the unsaturated hydrogeologic (vadose) zone by removing volatile organic contamination in the area of the Subsurface Disposal Area at the Radioactive Waste Management Complex.

Under Alternative A (No Action), only existing and ongoing remediation activities would be permitted. These ongoing activities include the three projects described above and initiated remedial investigations and feasibility studies at each waste area group (Table 3.1-3). No additional remedial design and remedial actions would be implemented under this alternative. No end land use would be preferred. 


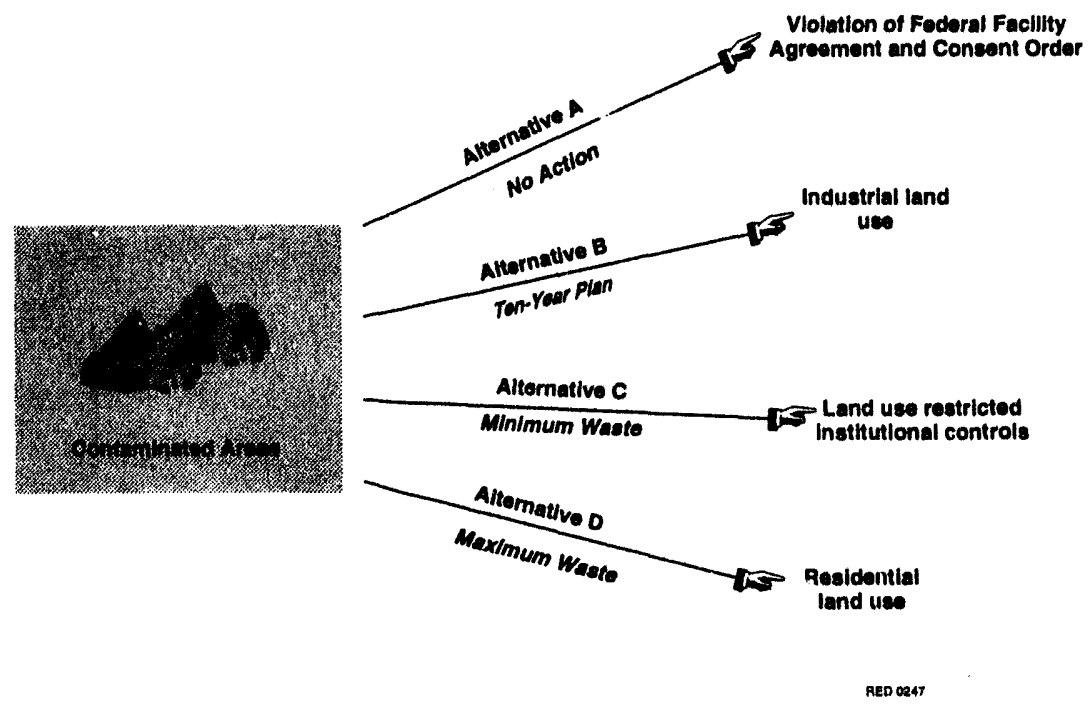

Figure 3.1-7. Management of remediation activities at the Idaho National Engineering Laboratory under the proposed alternatives: Alternative A (No Action), Alternative B (Ten-Year Plan), Alternative C (Minimum Treatment, Storage, and Disposal), and Alternative D (Maximum Treatment, Storage, and Disposal).

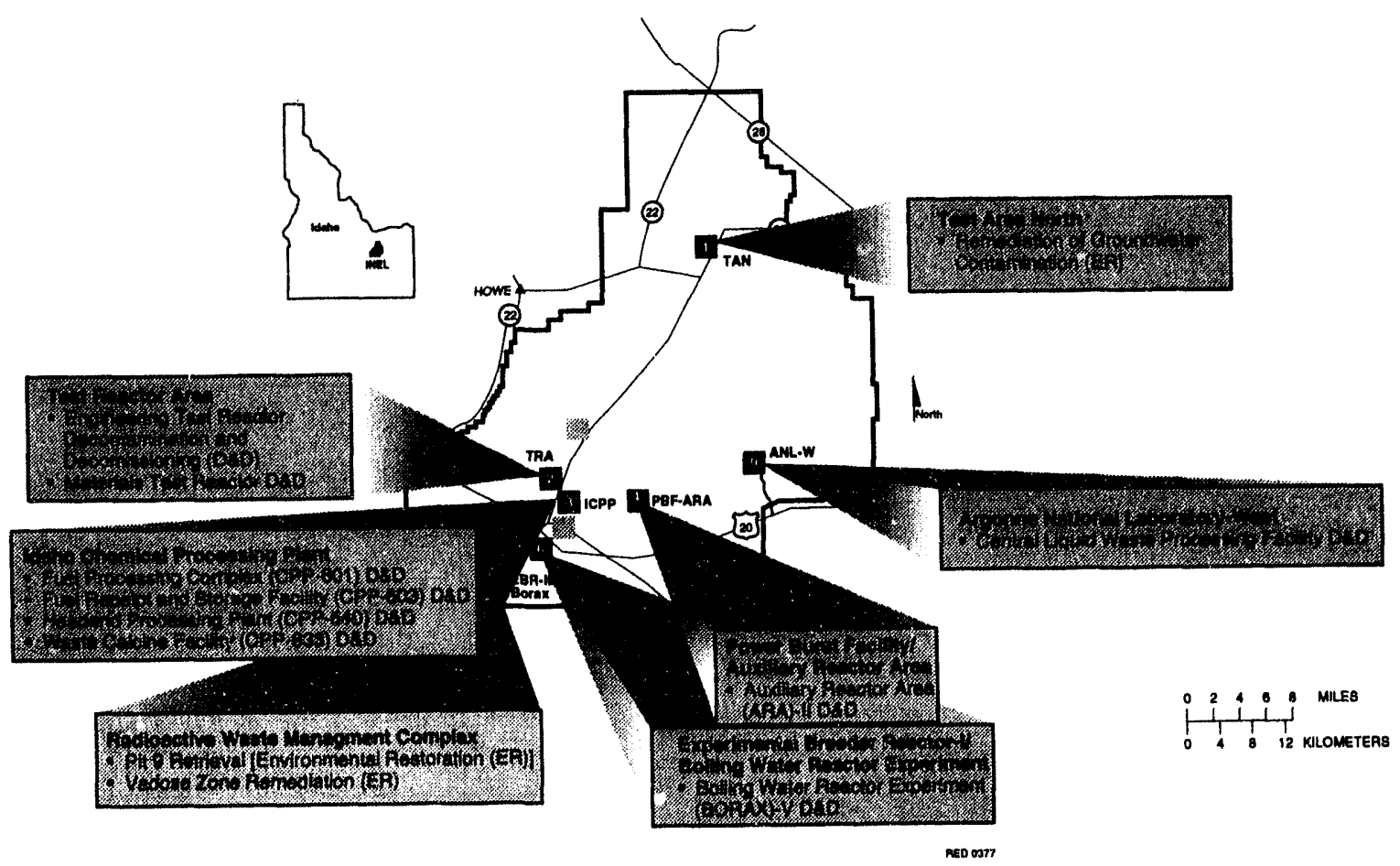

Figure 3.1-8. Environment restoration: Idaho National Engineering Laboratory locations of projects associated with proposed alternatives. 
Table 3.1-3. Environmental restoration: Summary of proposed management functions and related projects (denoted by bullets) at the Idaho National Engineering Laboratory (INEL) by alternative $^{\mathrm{a}}$

\begin{tabular}{|c|c|c|c|}
\hline $\begin{array}{c}\text { A } \\
\text { (No Action) }\end{array}$ & $\frac{\text { B }}{\text { (Ten-Year Plan) }}$ & $\begin{array}{l}\text { C } \\
\text { (Minimum Treatment, } \\
\text { Storage, and Disposal) }\end{array}$ & $\begin{array}{c}\text { D } \\
\text { (Maximum Treatment, } \\
\text { Storage and Disposal) }\end{array}$ \\
\hline $\begin{array}{l}\text { Conduct no activities } \\
\text { other than already } \\
\text { approved projects } \\
\text { under Comprehensive } \\
\text { Environmental } \\
\text { Response, } \\
\text { Compensation, and } \\
\text { Liability Act } \\
\text { (CERCLA) process } \\
\text { FFACO would be } \\
\text { violated } \\
\text { Waste generation } \\
\text { would be minimal } \\
\text { compared to other } \\
\text { alternatives } \\
\text { D\&D Projects } \\
\text { - ARA-II } \\
\text { - BORAX-V } \\
\text { Remediation Projects } \\
\text { - Remediation of } \\
\text { Groundwater } \\
\text { Contamination } \\
\text { - Pit } 9 \text { Retrieval } \\
\text { Remediation } \\
\text { - Ongoing RIFS. }\end{array}$ & $\begin{array}{l}\text { Conduct projects in accordance } \\
\text { with FFA/CO and Action Plan } \\
\text { Waste generation quantity and } \\
\text { increase similar to current } \\
\text { quantities planned } \\
\text { Reuse and partial dismantlement } \\
\text { of D\&D projects } \\
\text { D\&D Projects } \\
\text { - ARA-II } \\
\text { - BORAX-V } \\
\text { - Engineering Test Reactor } \\
\text { - Materials Test Reactor } \\
\text { - Fuel Processing Complex } \\
\text { (CPP-601) } \\
\text { - Fuel Receipt/Storage Facility } \\
\text { (CPP-603) } \\
\text { - Headend Processing Plant } \\
\text { (CPP-640) } \\
\text { - Waste Calcine Facility (CPP- } \\
\text { 633) } \\
\text { - Central Liquid Waste } \\
\text { Processing Facility } \\
\text { Remediation Projects } \\
\text { - Remediation of Groundwater } \\
\text { Contamination } \\
\text { - Pit } 9 \text { Retrieval } \\
\text { - Vadose Zone Remediation } \\
\text { - Complete all RI/FS scheduled } \\
\text { under FFA/CO, including } \\
\text { comprehensive RI/FS for WAGs } \\
1 \text { through } 10 \\
\text { - RIFS-RD/RA for spills, } \\
\text { contaminated soil, tanks, sewage } \\
\text { lagoons, etc. } \\
\text { DE }\end{array}$ & $\begin{array}{l}\text { Conduct projects in } \\
\text { accordance with } \\
\text { FFA/CO and Action } \\
\text { Plan } \\
\text { Seek minimal waste } \\
\text { generation } \\
\text { Surveillance and } \\
\text { maintenance of D\&D } \\
\text { projects } \\
\text { D\&D Projects } \\
\text { - ARA-II } \\
\text { - BORAX-V } \\
\text { Focus on institutional } \\
\text { controls to the extent } \\
\text { possible for } \\
\text { remediation projects } \\
\text { Remediation Projects } \\
\text { - Remediation of } \\
\text { Groundwater } \\
\text { Contamination } \\
\text { - Pit } 9 \text { Retrieval } \\
\text { - Vadose Zone } \\
\text { Remediation } \\
\text { - Complete all RI/FS } \\
\text { scheduled under } \\
\text { FFA/CO, including } \\
\text { comprehensive RI/FS } \\
\text { for WAGs } 1 \text { through } \\
\text { 10 } \\
\text { - RI/FS-RD/RA for } \\
\text { spills, contaminated } \\
\text { soil, tanks, sewage } \\
\text { lagoons, etc. } \\
\text { DE }\end{array}$ & 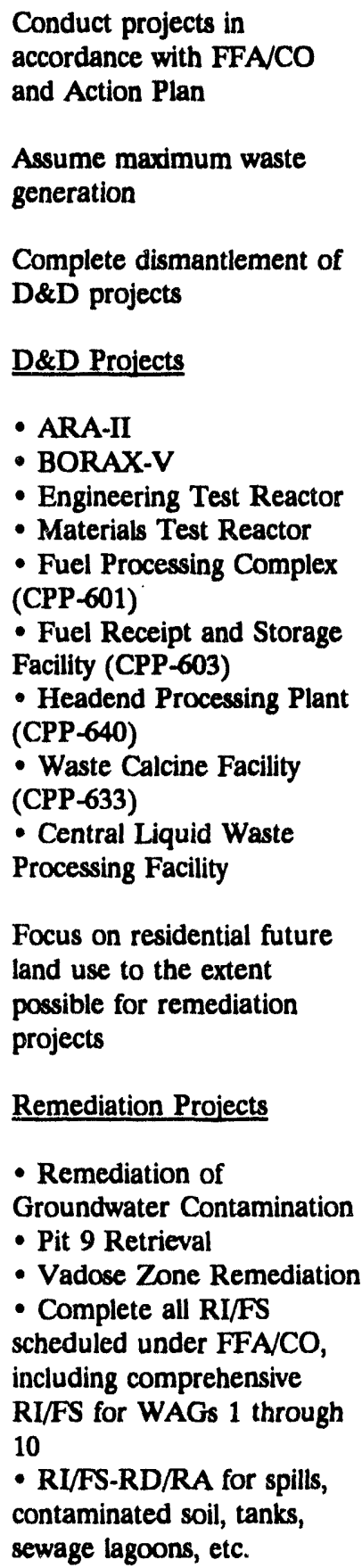 \\
\hline $\begin{array}{l}\text { Ictor -I/Boiling Wate } \\
\text { onne National Labo }\end{array}$ & Snake River Aauifer an & as. & $\begin{array}{l}\text { On and Decommissioning; } \\
\text { RI/FS-remedial investigation/ } \\
\text { Test Reactor Area, 3-Idaho } \\
\text { or Area, 6-Experimental Breeder } \\
\text { ), 8-Naval Reactors Facility, 9- }\end{array}$ \\
\hline
\end{tabular}


Under Alternative B (Ten-Year Plan), all currently planned and new remedial investigations and feasibility studies would be implemented at each waste area group, leading to a comprehensive remedial investigation/feasibility study for all waste area groups. The three ongoing projects would continue. In addition, new remedial design and remedial actions would be implemented under this alternative, as determined by the Record of Decision from the Comprehensive Environmental Response, Compensation, and Liability Act process for each remedial investigation and feasibility study completed.

Under Alternative C (Minimum Treatment, Storage, and Disposal), remediation activities would be the same as identified under Alternative B (Ten-Year Plan). The emphasis of remedial designs and implementation of remedial actions to clean up sites, however, may be less extensive than under Alternative B. This is because the assumed end land use would be to restrict access and use by relying on institutional controls when allowed under the Record of Decision determined under the Comprehensive Environmental Response, Compensation, and Liability Act process. This potentially would result in less waste generated that would be transferred to the Waste Management Program.

Under Alternative D (Maximum Treatment, Storage, and Disposal), remediation activities would be the same as identified under Alternative B (Ten-Year Plan). The emphasis of remedial designs and implementation of remedial actions to clean up sites, however, may be more extensive than under Alternative B. This is because the assumed end land use would be residential when allowed under the Record of Decision determined under the Comprehensive Environmental Response, Compensation, and Liability Act process. This potentially would result in more waste generated that would be transferred to the Waste Management Program.

3.1.2.2 Decontamination and Decommissioning. The decontamination and decommissioning process at the INEL is one of the functions of the Environmental Restoration Program where surplus contaminated facilities are either decontaminated and reused or decommissioned. The details of the process are described in Section 2.2.6.2. The projects under each alternative are listed in Table 3.1-3 and their locations are shown in Figure 3.1-8.

The alternatives and related decontamination and decommissioning actions considered in this EIS are Alternative A (No Action), continuing with ongoing projects and not beginning any 


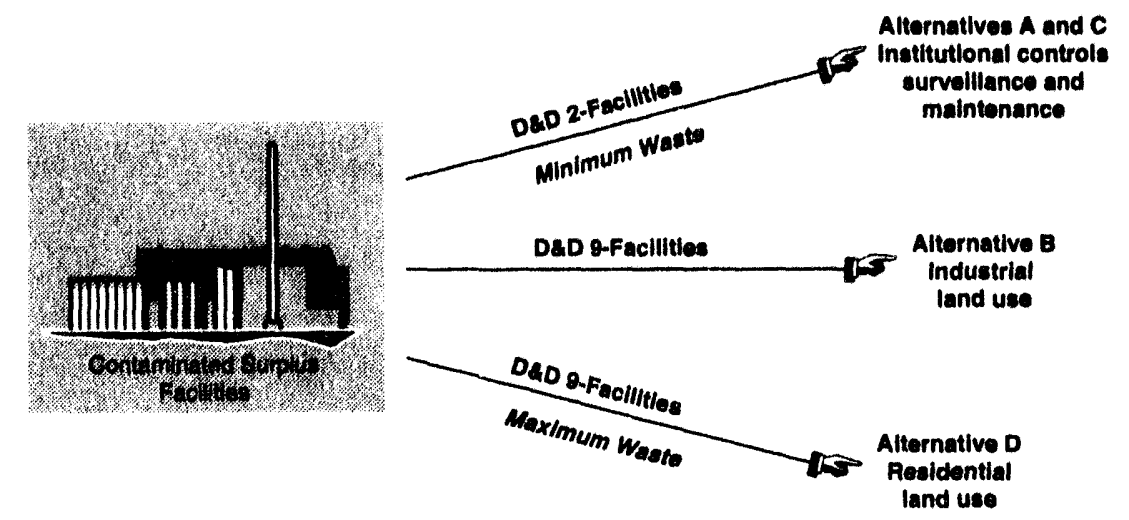

Figure 3.1-9. Management of decontamination and decommissioning (D\&D) activities at the Idaho National Engineering Laboratory under the proposed alternatives: Alternative A (No Action), Alternative B (Ten-Year Plan), Alternative C (Minimum Treatment, Storage, and Disposal), and Alternative D (Maximum Treatment, Storage, and Disposal).

new ones; Alternative B (Ten-Year Plan) continuing with ongoing projects and, in accordance with the established priorities, completing new ones to a level consistent with overall risk reduction and reuse capabilities; Alternative C (Minimum Treatment, Storage, and Disposal) activities would consist primarily of surveillance and maintenance with as little decontamination and dismantlement as possible; and Alternative D (Maximum Treatment, Storage, and Disposal) activities would entail a more complete removal of the facility when it was not going to be reused (Figure 3.1-9).

3.1.2.2.1 Afternative A (No Action)-The two ongoing decontamination and decommissioning projects, Auxiliary Reactor Area-II facilities and the Boiling Water Reactor Experiment (BORAX)-V reactor building, would be completed by 1998 and the wastes (low-level, mixed low-level, hazardous, and industrial commercial) generated would be dispositioned to existing waste handling facilities onsite. For this alternative, the approximate total quantities for all the decontamination and decommissioning projects are estimated to be 1,500 cubic meters (2,000 cubic yards) of low-level waste, 4 cubic meters ( 5 cubic yards) of mixed low-level waste, 5 cubic meters ( 6.5 cubic yards) of hazardous waste, and 350 cubic meters ( 450 cubic yards) of industrial commercial waste. Approximately 3 hectares ( 7 acres) would be restored for reuse. Under Alternative A (No Action), no other facilities would be decontaminated and decommissioned.

3.1.2.2.2 Alternative B (Ten-Year Plan)-All the facilities currently on the Surplus Facilities List scheduled for decontamination and decommissioning at the INEL would be 
decontaminated and decommissioned under this alternative. Besides the two facilities identified under Alternative A (No Action), seven other projects would be initiated, as shown on Table 3.1-3 and Figure 3.1-8. Alternative B (Ten-Year Plan) would emphasize, when possible, reuse or partial dismantlement of the facility.

Current estimates of wastes generated for each project are given in the applicable project summaries in Appendix C, Information Supporting the Alternatives. For this alternative, the approximate total quantities for all the decontamination and decommissioning projects are estimated to be 28,000 cubic meters (37,000 cubic yards) of low-level waste, 10 cubic meters (13 cubic yards) of transuranic wastes, 75 cubic meters (98 cubic yards) of mixed low-levei waste, 6 cubic meters ( 8 cubic yards) of hazardous waste, and 31,000 cubic meters ( 41,000 cubic yards) of industrial commercial waste. Approximately 7 hectares (17 acres) would be restored for reuse.

\subsection{Alternative C (Minimum Treatment, Storage, and}

Disposal)-Decontamination and decommissioning activities under Alternative C (Minimum Treatment, Storage, and Disposal) would be similar to those described under Alternative A (No Action). Under Alternative C (Minimum Treatment, Storage, and Disposal), the use of surveillance and maintenance methods would be preferred over dismantlement if human health and the environment would be adequately protected. The two ongoing projects would continue and the other candidate facilities would be kept in a safe storage status, that is, with a formal surveillance and maintenance program that would keep the facilities in repair and the contents safe and secure. Since this alternative would create several potentially surplus facilities, the surveillance and maintenance program would, if a new mission is not identified for these facilities, be significantly enlarged over the other alternatives.

\subsection{Afternative D (Maximum Treatment, Storage, and Dlsposal)-The} decontamination and decommissioning projects under this alternative would be the same ones as those identified under Alternative B (Ten-Year Plan). Alternative D (Maximum Treatment, Storage, and Disposal) would emphasize, when possible, complete dismantlement and restoration of the site. Under Alternative D (Maximum Treatment, Storage, and Disposal), the volume of wastes generated would be significantly greater than under Alternative B (Ten-Year Plan). Most of these increases would be for low-level waste and industrial commercial waste because the major effect of this activity would be the removal of structures such as wood, metal, and concrete that generally are in these categories. 


\subsubsection{Attornathee for Wasto Managomont}

The following discusses the alternatives for waste management activities under the Environmental Restoration and Waste Management Program. The same three basic management decisions and options discussed earlier are applicable for all waste streams (Figure 3.0-1 and Table 3.1-4). The implementation and emphasis for each management decision option that differentiates each alternative may vary in detail for each waste stream. This is because of the number of waste types that must be managed and several complicating factors:

- Interrelationships among waste types. Distinctions between waste types are not sharp. Treatment may convert one waste type to another. Facilities may be shared among waste types.

- Regulatory limitations. Some waste types cannot be shipped from one location to another. Disposal criteria have not been confirmed and disposal facilities, such as the Waste Isolation Pilot Plant, have not been permitted to accept waste.

- Privatization. Some of the management (treatment, storage, and disposal) activities are already being carried out in private/commercial facilities. DOE should consider expansion of commercial treatment, storage, and disposal.

The alternative descriptions for each waste stream identify the specific facilities and activities that would be required under each alternative to disposition the potential waste quantities. This presentation also allows for a clearer understanding of the differences among alternatives. Six waste streams would be managed. As described and defined in Chapter 2, Background, these waste streams are as follows:

$\begin{array}{ll}\text { - } & \text { High-level waste } \\ \text { - } & \text { Transuranic waste } \\ \text { - } & \text { Low-level waste } \\ \text { Mixed low-level waste }\end{array}$ 
Table 3.1-4. Summary of proposed waste management activities at the Idaho National Engineering Laboratory (INEL) by alternative.

\begin{tabular}{|c|c|c|c|}
\hline $\begin{array}{c}\text { A } \\
\text { (No Action) }\end{array}$ & $\begin{array}{c}\text { B } \\
\text { (Ten-Year Plan) }\end{array}$ & $\begin{array}{c}\text { C } \\
\text { (Minimum Treatment, } \\
\text { Storage, and Disposal) }\end{array}$ & $\begin{array}{c}\text { D } \\
\text { (Maximum Treatment, } \\
\text { Storage, and Disposal) }\end{array}$ \\
\hline $\begin{array}{l}\text { Continue managing } \\
\text { existing operations and } \\
\text { existing waste } \\
\text { management, research } \\
\text { and development, and } \\
\text { infrastructure facilities } \\
\text { and projects } \\
\text { Initiate no new } \\
\text { activities with the } \\
\text { exception of minor } \\
\text { environmental safety } \\
\text { and health activities } \\
\text { that are necessary for } \\
\text { maintaining safe } \\
\text { operation } \\
\text { Start no new major } \\
\text { upgrades or facilities }\end{array}$ & $\begin{array}{l}\text { Continue managing existing } \\
\text { activities } \\
\text { Plan, manage, and implement } \\
\text { currently proposed projects for } \\
1995 \text { through } 2005 \text { to continue } \\
\text { to meet the historic INEL } \\
\text { role; ensure regulatory } \\
\text { compliance; and meet } \\
\text { commitments to the State of } \\
\text { Idaho } \\
\text { May include use of private } \\
\text { sector }\end{array}$ & $\begin{array}{l}\text { Manage waste management } \\
\text { activities by transferring } \\
\text { ongoing activities and waste to } \\
\text { other DOE facilities or other } \\
\text { government or private sector } \\
\text { locations, resulting in minimal } \\
\text { treatment, storage, and } \\
\text { disposal activities on the INEL } \\
\text { site } \\
\text { Receive a minimum amount } \\
\text { of waste from the DOE } \\
\text { complex for purposes of } \\
\text { treatment, storage, or disposal }\end{array}$ & $\begin{array}{l}\text { To the maximum extent } \\
\text { possible, other } \\
\text { Department of Energy } \\
\text { (DOE) facilities would } \\
\text { transfer ongoing } \\
\text { activities and waste to } \\
\text { INEL site, resulting in } \\
\text { maximum treatment, } \\
\text { storage, and disposal } \\
\text { activities on the INEL } \\
\text { site } \\
\text { Besides existing facilities } \\
\text { and projects and } \\
\text { currently planned } \\
\text { projects for } 1995 \\
\text { through } 2005 \text {, manage } \\
\text { additional projects not } \\
\text { defined or defined on a } \\
\text { smaller scale in } \\
\text { Alternative B (Ten- } \\
\text { Year Plan) }\end{array}$ \\
\hline
\end{tabular}

- Greater-than-Class-C waste

- Hazardous waste.

The basic steps in managing these wastes involve determining what wastes would be accepted for management and how and where they would be managed. The sources of wastes would be identified as (a) existing onsite, (b) newly generated onsite on a continuing basis, or (c) shipped in from offsite. Volumes of waste expected to result from these sources would be estimated. Individual batches of waste would be characterized by sampling and analyses to confirm the waste type. Characterization might also be used to determine whether the waste meets, or could potentially meet, the acceptance criteria of existing or proposed facilities for treatment, storage, or disposal. The decision to treat, store pending treatment, and/or dispose would be made, and the location of these waste management steps would be selected. 


\section{High-Level Wasto}

Alternative A • Convert liquid to calcine (solid)

Alternative B $\bullet$ Convert liquid to calcine (solid)

- Construct facility to immobilize both liquid and calcine (for operation in 2008)

Alternative C $: \bullet$ Construct replacement liquid storage tanks

- Develop treatment that minimizes volume of high-activity waste

- Plan operation of new immobilization facility (for 2015)

Alternative D $: \circ$ Construct replacement liquid storage tanks

- Convert liquid to calcine (solid)

- Develop treatment that minimizes volume of high-activity waste

- Plan operation of new immobilization facility (for 2015)

3.1.3.1 High-Lovel Waste. The management of high-level waste under the four alternatives is illustrated in the flow diagrams associated with the descriptions of the four alternatives. The alternatives represent various strategies for completing the process, including various functions and projects, as detailed in Table 3.1-5. Under all four alternatives, storage of liquid in underground tanks and of solid (calcine) in near-surface bins would continue and the upgrade project for storage tank piping (identified in Chapter 2) would be completed. This project and other proposed projects to implement the alternatives would be located at the Idaho Chemical Processing Plant, except for the expansion of high-level waste storage at Argonne National Laboratory-West (see Figure 3.1-10).

As of 1995, the generation and management activities for high-level waste, as described in Chapter 2, Background, would have resulted in both liquid waste and calcine (see Figure 3.1-11). About 15 percent of the liquid waste is high-level resulting from previous reprocessing. This waste is required to be calcined before January 1, 1998. 


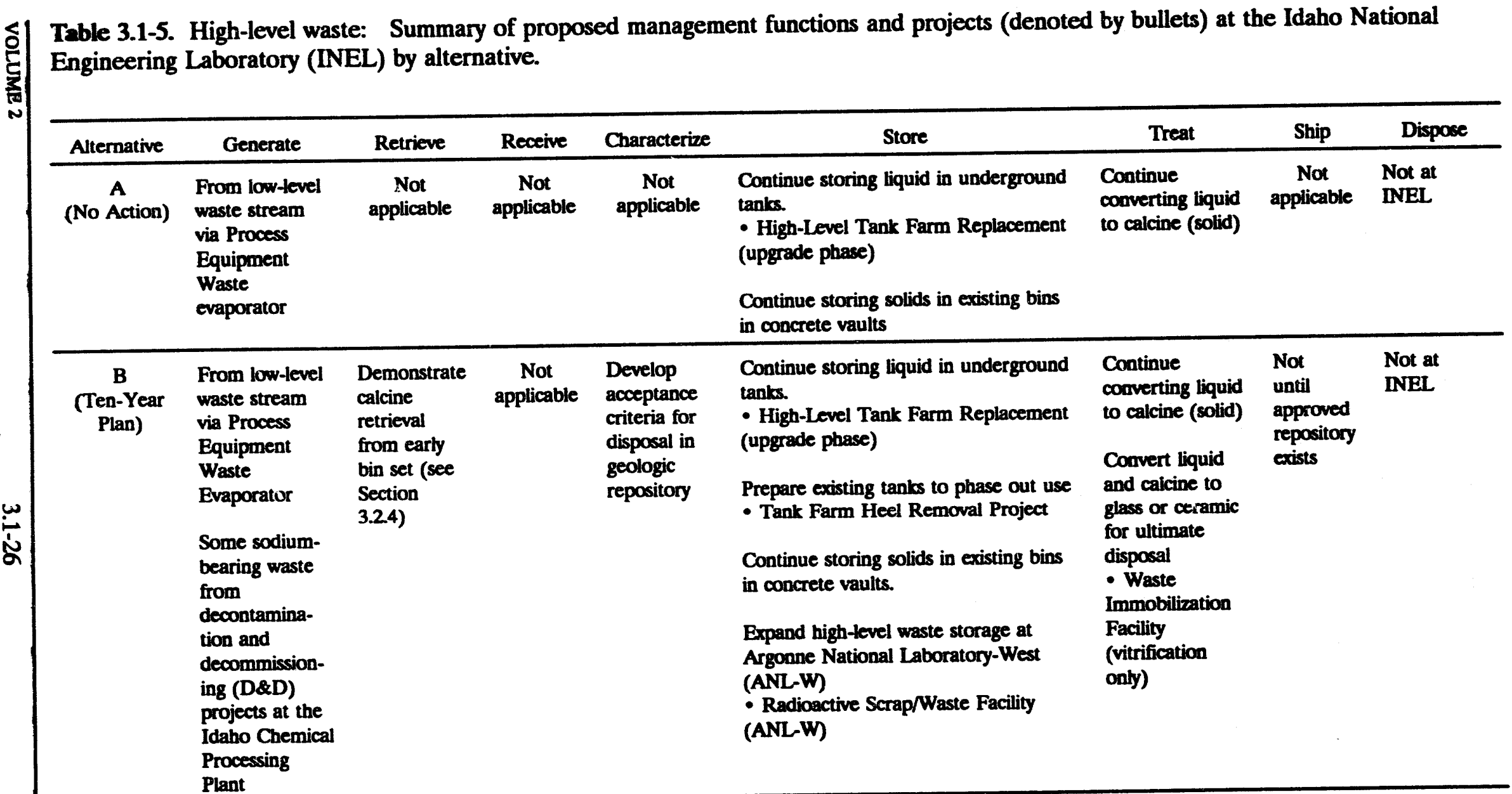




\begin{tabular}{|c|c|c|c|c|c|c|c|c|}
\hline Alternative & Generate & Retrieve & Receive & Characterize & Store & Treat & Ship & Dispose \\
\hline $\begin{array}{c}\text { C } \\
\text { (Minimum } \\
\text { Treatment, } \\
\text { Storage, } \\
\text { and } \\
\text { Disposal) }\end{array}$ & $\begin{array}{l}\text { From low-level } \\
\text { waste stream } \\
\text { via Process } \\
\text { Equipment } \\
\text { Waste } \\
\text { Evaporator }\end{array}$ & $\begin{array}{l}\text { Demonstrate } \\
\text { calcine } \\
\text { retrieval } \\
\text { from early } \\
\text { bin set (see } \\
\text { Section } \\
\text { 3.1.4) }\end{array}$ & $\begin{array}{c}\text { Not } \\
\text { applicable }\end{array}$ & $\begin{array}{l}\text { Develop } \\
\text { acceptance } \\
\text { criteria for } \\
\text { disposal in } \\
\text { geologic } \\
\text { repository }\end{array}$ & $\begin{array}{l}\text { Continue storing liquid in undergrounu } \\
\text { tanks. } \\
\text { - High-Level Tank Farm Replacement } \\
\text { (upgrade phase) } \\
\text { Prepare existing tanks for cease use } \\
\text { - Tank Farm Heel Removal Project } \\
\text { Replace existing liquid storage tanks } \\
\text { - High-Level Tank Farm New Tanks } \\
\text { Continue storing solids in existing bins } \\
\text { in concrete vaults } \\
\text { Expand high-tevel waste storage at } \\
\text { Argonne National Laboratory-West } \\
\text { - Radioactive Scrap/Waste Facility }\end{array}$ & $\begin{array}{l}\text { Convert liquid } \\
\text { and calcine to } \\
\text { glass or ceramic } \\
\text { for ultimate } \\
\text { disposal } \\
\text { - Waste } \\
\text { Immobilization } \\
\text { Facility } \\
\text { (vitrification with } \\
\text { separations) }\end{array}$ & $\begin{array}{l}\text { Not } \\
\text { until } \\
\text { approved } \\
\text { repository } \\
\text { exists }\end{array}$ & $\begin{array}{l}\text { Dispose } \\
\text { low-activity } \\
\text { fraction } \\
\text { from } \\
\text { separations } \\
\text { offsite or at } \\
\text { INEL }\end{array}$ \\
\hline $\begin{array}{c}\text { D } \\
\text { (Maximum } \\
\text { Treatment, } \\
\text { Storage and } \\
\text { Disposal) }\end{array}$ & $\begin{array}{l}\text { From low-level } \\
\text { waste stream } \\
\text { via Process } \\
\text { Equipment } \\
\text { Waste } \\
\text { Evaporator } \\
\text { Sodium-bearing } \\
\text { waste as from } \\
\text { D\&D as in } \\
\text { Alternative B } \\
\text { Also potentially } \\
\text { from processing } \\
\text { spent nuclear } \\
\text { fuel }\end{array}$ & $\begin{array}{l}\text { Demonstrate } \\
\text { calcine } \\
\text { retrieval } \\
\text { from earty } \\
\text { bin set (see } \\
\text { Section } \\
\text { 3.1.4) }\end{array}$ & $\begin{array}{c}\text { Not } \\
\text { applicable }\end{array}$ & $\begin{array}{l}\text { Develop } \\
\text { acceptance } \\
\text { criteria for } \\
\text { disposal in } \\
\text { geclogic } \\
\text { repository }\end{array}$ & $\begin{array}{l}\text { Continue storing liquid in under-ground } \\
\text { tanks. } \\
\text { - High-Level Tank Farm Replacement } \\
\text { (upgrade phase) } \\
\text { Prepare existing tanks for cease use } \\
\text { - Tank Farm Heel Removal Project } \\
\text { Replace existing liquid storage tanks } \\
\text { - High-Level Tank Farm New Tanks } \\
\text { Continue storing solids in existing bins } \\
\text { in concrete vaults and add new bin set } \\
\text { - New Calcine Storage } \\
\text { Expand highttevel waste storage at } \\
\text { Argonne National Laboratory-West } \\
\text { - Radioactive Scrap/Waste Facility }\end{array}$ & $\begin{array}{l}\text { Convert liquid } \\
\text { and calcine to } \\
\text { glass or ceramic } \\
\text { for ultimate } \\
\text { disposal } \\
\text { - Waste } \\
\text { Immobilization } \\
\text { Facility } \\
\text { (vitrification with } \\
\text { separations) }\end{array}$ & $\begin{array}{l}\text { Not } \\
\text { until } \\
\text { approved } \\
\text { repository } \\
\text { exists }\end{array}$ & $\begin{array}{l}\text { Dispose } \\
\text { low-activity } \\
\text { fraction } \\
\text { from } \\
\text { separations } \\
\text { offsite or at } \\
\text { INEL }\end{array}$ \\
\hline
\end{tabular}




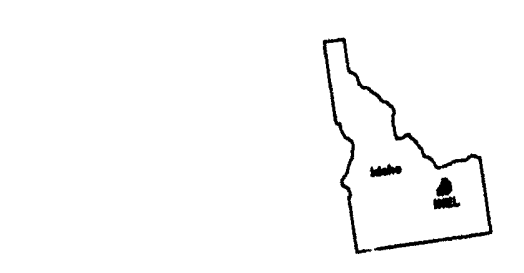

Figure 3.1-10. High-level waste: Idaho National Engineering Laboratory locations of projects associated with proposed alternatives.
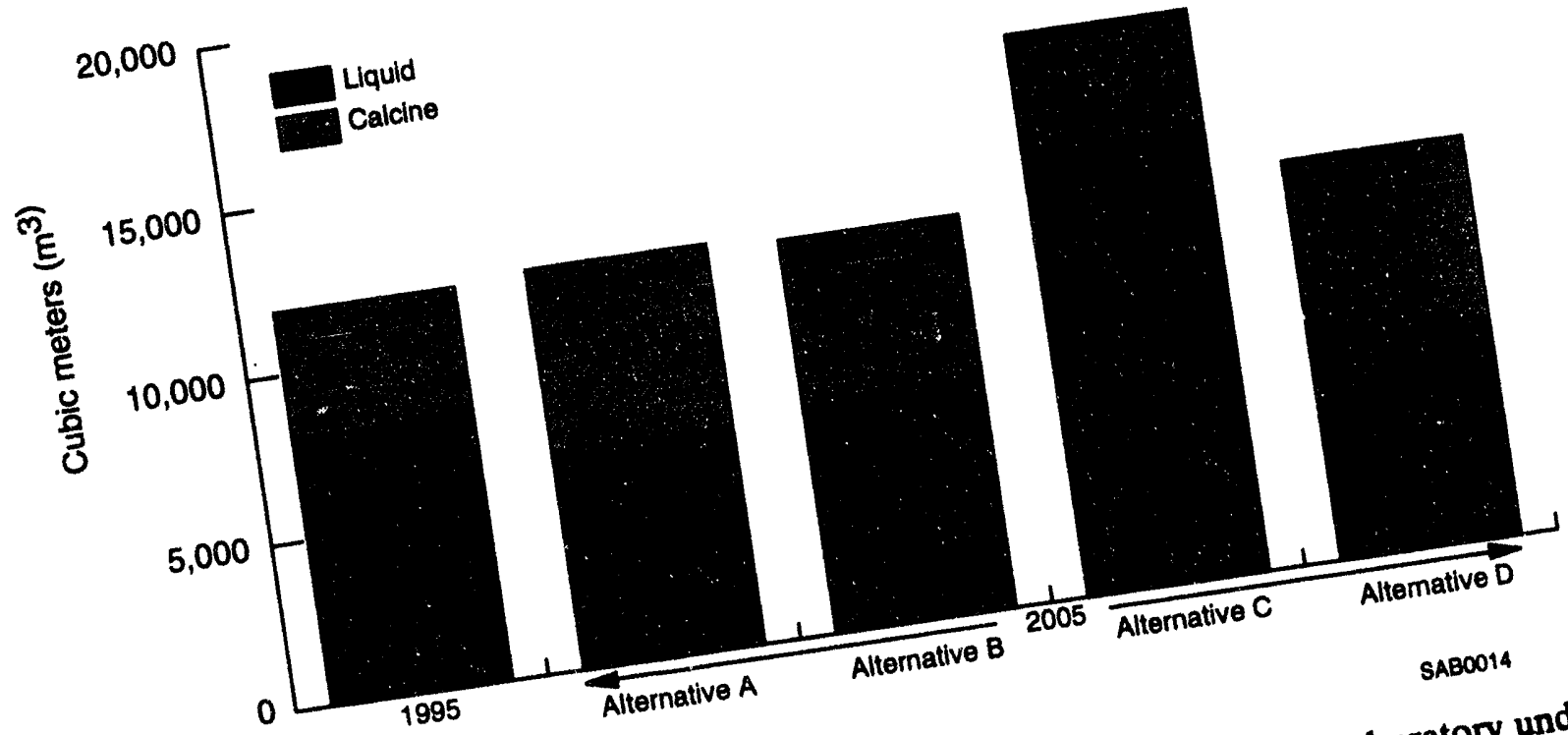

Alternative $\mathrm{A}$

Alternative $\mathrm{C}$

Alterative

SAB O014

Figure 3.1-11. High-level waste volumes at the Idaho National Engineering Laboratory under the proposed alternatives: Alternative A (No Action), Alternative B (Ten-Year Plan), Alternative C (Minimum Treatment, Storage, and Disposal), and Alternative D (Maximum Treatment, Storage and Disposal).

3.1-28

VOLUME 2 


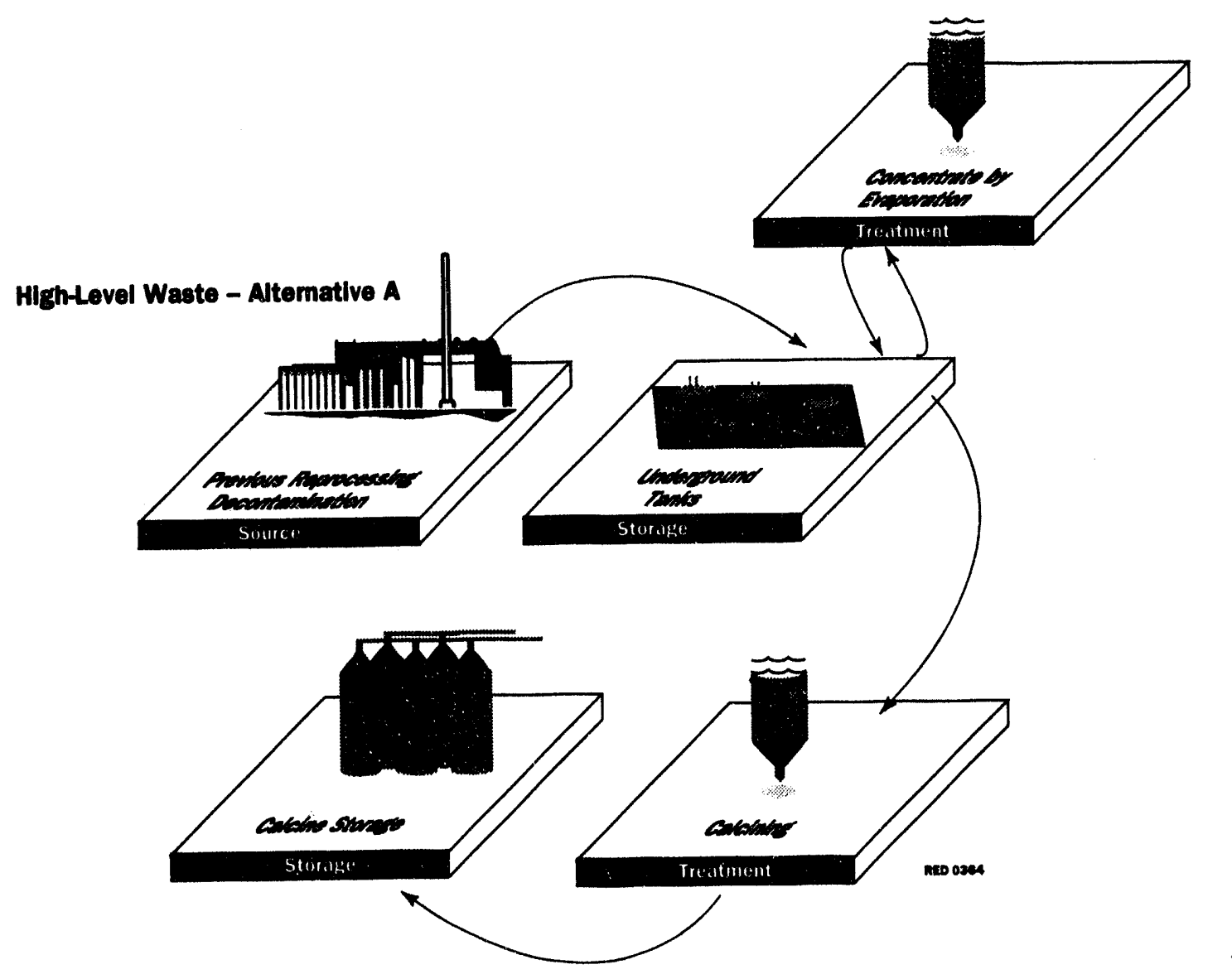

Figure 3.1-12. Management of high-level waste at the Idaho National Engineering Laboratory under the proposed Alternative A (No Action).

3.1.3.1.1 Alternative A (No Action)-Under Alternative A (No Action), liquid waste from other sources and handled as high-level would continue to be generated (Figure 3.1-12). Waste would continue to be stored in existing tanks. Periodic operation to convert liquid waste to calcine in the New Waste Calcining Facility would continue in three 18-month intervals starting in 1996. Since no other projects are authorized under Alternative A (No Actionj, this alternative would not lead toward eliminating storage in the existing liquid storage tanks by 2015 (as required by current agreement). 


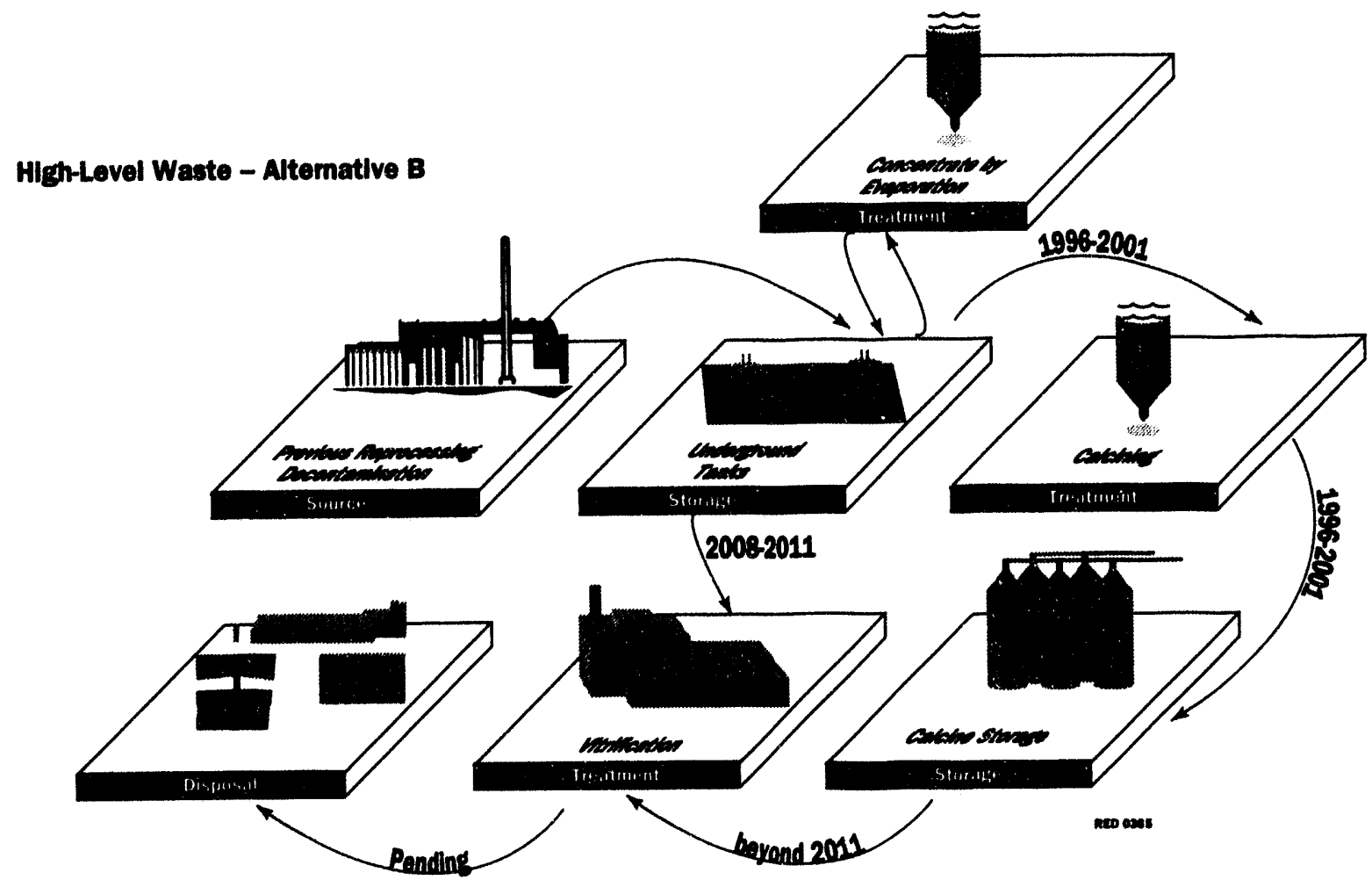

Figure 3.1-13. Management of high-level waste at the Idaho National Engineering Laboratory under the proposed Alternative B (Ten-Year Plan).

3.1.3.1.2 Alternative B (Ten-Year Plan)-Under Alternative B (Ten-Year Plan), the New Waste Calcining Facility would be operated for a total of three years, in two 18-month intervals starting in 1996 (Figure 3.1-13). In the first interval, high-level waste from previous reprocessing would be calcined (as described in Chapter 2, Background) to meet the January 1, 1998, deadline for completing calcining this waste. Then, additional sodium-bearing waste would be calcined, as also described in Chapter 2. The calcine thus generated (see Figure 3.1-11) would fit into existing bin storage. When calcining is not in process, the liquid waste evaporator, currently being installed in the New Waste Calcining Facility, would operate intermittently to concentrate the sodium-bearing liquid waste.

Design and construction would be started on the Waste Immobilization Facility, described further in Appendix C, Information Supporting the Alternatives. This facility, assumed for analysis purposes to be ready to operate in 2008 , would be capable of treating both the liquid waste (including sodium-bearing waste) and the calcine into a form (either glass or glass ceramic) 
that is potentially acceptable for ultimate disposal into a geologic repository. Under Alternative B (Ten-Year Plan), the Waste Immobilization Facility would involve direct vitrification (with only minimum pretreatment) of sodium-bearing liquids and calcined solids.

Without more extensive pretreatment, direct vitrification would produce a comparatively large amount of vitrified, disposable, high-activity solid waste (up to 19,000 cubic meters; 25,000 cubic yards). The Waste Immobilization Facility would potentially include enough storage capacity for the immobilized solid until a repository is available.

Operation of the liquid waste evaporator and the New Waste Calcining Facility, if combined with waste minimization, should allow DOE to meet the Notice of Noncompliance Consent Order requirement to cease use of some Tank Farm tanks by 2009. Operation of the Waste Immobilization Facility (assumed to begin in 2008 with liquid waste as the feed) should allow DOE to meet the Notice of Noncompliance Consent Order requirement to cease use of the remaining Tank Farm tanks by 2015.

The activities necessary to take these storage tanks out of service include the Tank Heel Removal Project (see Appendix $\mathrm{C}$ for details). The remaining few thousand gallons of liquid would be removed from these tanks by new equipment because the "heel" (remaining liquid) is not removable with the existing transfer lines within the tanks.

\subsection{Alternative C (Minimum Treatment, Storage, and Disposal)-Under} Alternative C (Minimum Treatment, Storage, and Disposal) (Figure 3.1-14), newly generated waste is comparable to Alternative A (No Action). Activities consistent with the minimum treatment aspect of the alternative would be implemented. Thus, the projects and activities would include building new tanks for liquid waste storage. New tanks would be needed because the New Waste Calcining Facility would not be used to calcine liquid waste or to concentrate sodiumbearing waste. With neither of these processes operating, more liquid waste would exist under Alternative C (Minimum Treatment, Storage, and Disposal) in 2005 than under any other proposed alternative. (Even under this alternative, calcining would be required to meet the courtmandated deadline of having all high-level waste calcined before January 1, 1998. Calcining was 


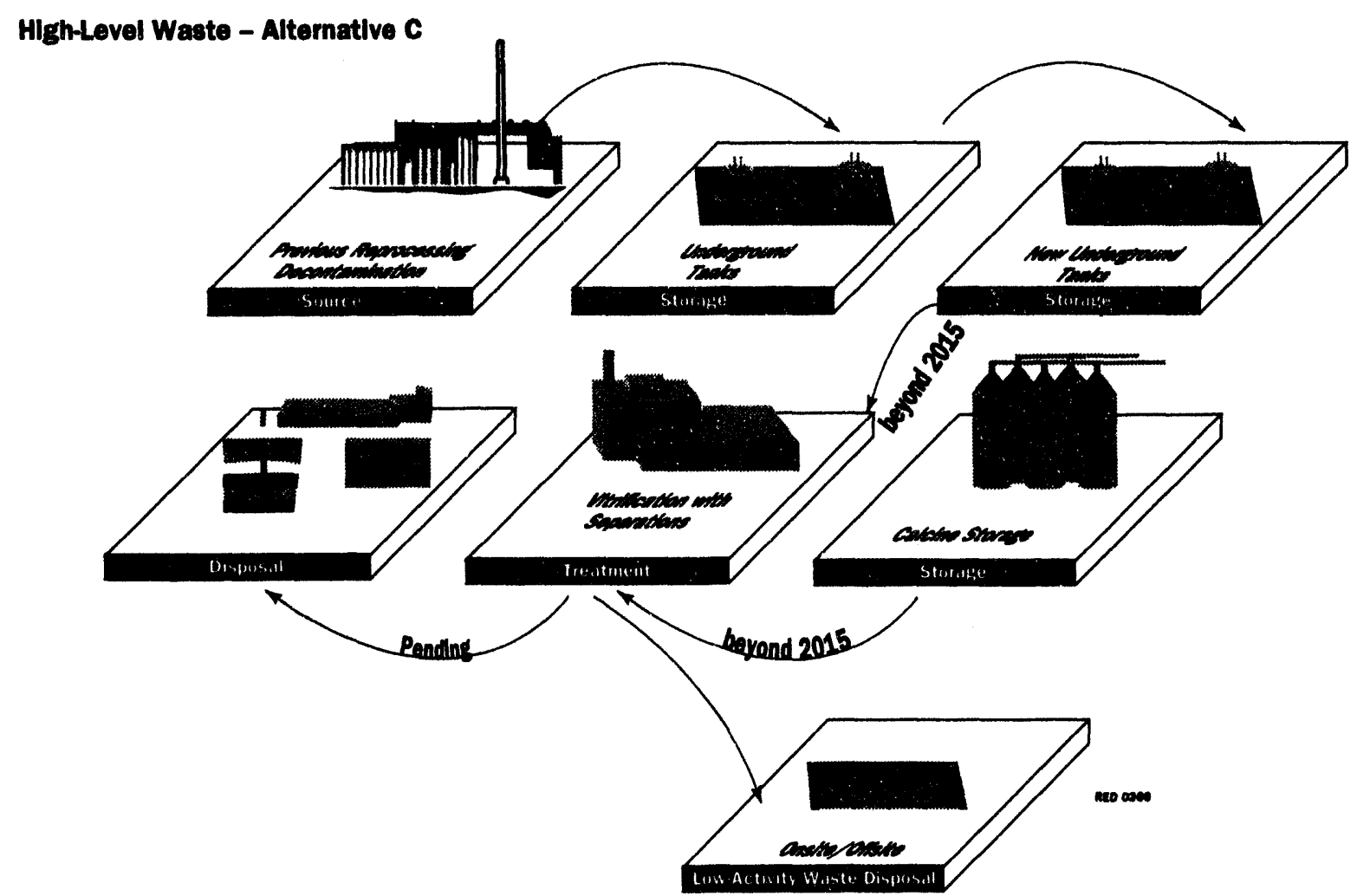

Figure 3.1-14. Management of high-level waste at the Idaho National Engineering Laboratory under the proposed Alternative C (Minimum Treatment, Storage, and Disposal).

not, however, included in the impact analysis for this alternative.) Because the existing liquid waste storage tanks would still be needed to be taken out of service, the Tank Farm Heel Removal Project would proceed under Alternative C (Minimum Treatment, Storage, and Disposal).

Design and construction of the Waste Immobilization Facility would be delayed beyond 2005, and its operation is assumed for analysis purposes to begin in 2015 under this alternative. The Waste Immobilization Facility (described in Appendix C, Information Supporting the Alternatives) would include a separations step for liquid waste before vitrification. Existing calcine would need to be dissolved in an additional pretreatment step before the separation step. The separation options for both sodium-bearing liquid waste and calcine would include precipitation and radionuclide partitioning. Sodium-bearing liquid waste could also be separated by freeze crystallization. 


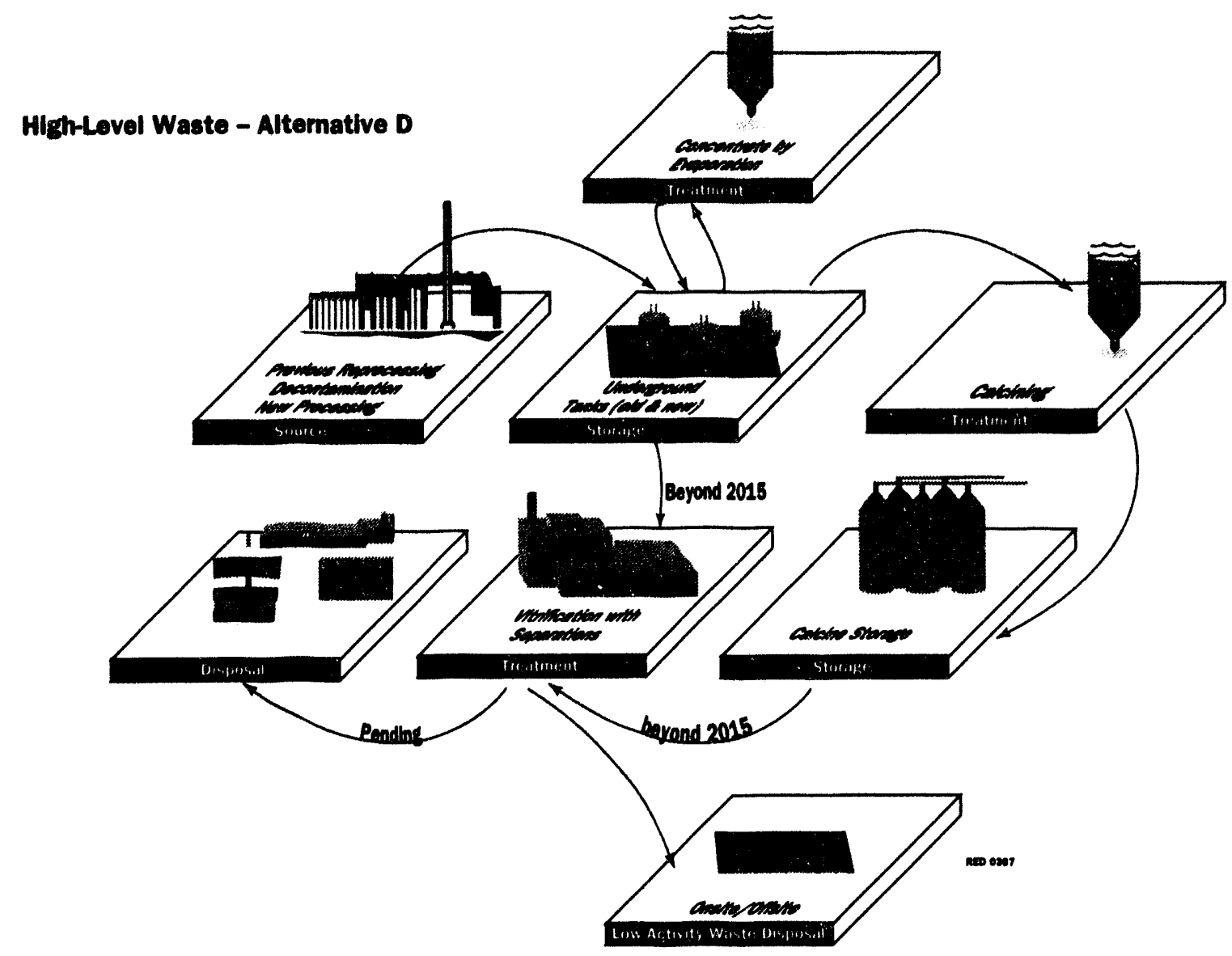

Figure 3.1-15. Management of high-level waste at the Idaho National Engineering Laboratory under the proposed Alternative D (Maximum Treatment, Storage, and Disposal).

Pretreatment would produce a high-activity waste form suitable for placement in a geologic repository and a low-activity waste form that could be delisted or disposed of in a Resource Conservation Recovery Act-approved waste disposal site. The high-activity waste form would be glass or glass ceramic, and low-activity waste form would be grout, glass, or glassceramic. The high-activity waste volume would possibly be only a few percent of that from direct vitrification.

\subsubsection{Alternative D (Maximum Treatment, Storage, and Disposal)-Under}

Alternative D (Maximum Treatment, Storage, and Disposal) (Figure 3.1-15), the newly generated waste would be greater than any other alternative (because of processing of spent nuclear fuel), but no estimate of generation is currently included in this alternative. The maximum number of projects and activities potentially needed to manage high-level waste between 1995 and 2005 are 
included. New projects would be (a) new tanks to store liquid waste, (b) the Tank Farm Heel Removal project, and (c) another bin set to store calcine.

As in Alternative A (No Action), the New Waste Calcining Facility is assumed to operate periodically to the maximum extent permitted between 1995 and 2005 and would produce the same amount of new calcine (see Figure 3.1-11). (Even with the full operation of the New Waste Calcining Facility, new calcine storage is not likely to be needed until well after 2005.) As in Alternative C (Minimum Treatment, Storage, and Disposal), the design and construction of the Waste Immobilization Facility is assumed to begin after 2005; and operation, including separation and vitrification, is assumed for analysis purposes to begin in 2015. The products of the Waste Immobilization Facility, and corresponding disposition options, would be the same as for Alternative C (Minimum Treatment, Storage, and Disposal).

By including both new liquid storage tanks and continued calcining, Alternative D (Maximum Treatment, Storage, and Disposal) would bound the impact on high-level waste management activities of any decision to process spent nuclear fuel under Alternative D. (See Section 3.1.1 and the Spent Nuclear Fuel Processing Project description in Appendix C, Information Supporting the Alternatives.)

3.1.3.1.5 Summary-Major differences and similarities among the four alternatives for high-level waste can be summarized as follows:

- Inventories of liquid waste to be treated are essentially the same for Alternatives A (No Action), B (Ten-Year Plan), and C (Minimum Treatment, Storage, and Disposal). Some small amount of additional sodium-bearing waste would result from decontamination and decommissioning projects at the Idaho Chemical Processing Plant under Alternatives B (Ten-Year Plan) and D (Maximum Treatment, Storage, and Disposal). In addition, more liquid waste would be generated under Alternative D (Maximum Treatment, Storage, and Disposal), if spent nuclear fuel were processed before ultimate disposal.

- All alternatives except Alternative A (No Action) would lead to phase out of existing liquid storage tanks, consistent with previous agreements. New tanks 
would need to be built under Alternatives C (Minimum Treatment, Storage, and Disposal) and D (Maximum Treatment, Storage, and Disposal) to meet this phase out schedule.

- Under all alternatives, liquid would continue to be converted to calcine (an interim solid), but calcining is currently not analyzed under Alternative C (Minimum Treatment, Storage, and Disposal). None of the alternatives, however, would result in the majority of the existing liquid being converted by the year 2005 .

- Existing storage capacity for calcine is sufficient for all alternatives.

- Planning for conversion of both liquid and calcine to a final disposable solid (glass or ceramic) would proceed under all alternatives except Alternative A (No Action). Under Alternatives C (Minimum Treatment, Storage, and Disposal) and D (Maximum Treatment, Storage, and Disposal), the process would be delayed to allow for developing separations methods that reduce the quantity of high-activity waste to be disposed.

- $\quad$ Alternatives B (Ten-Year Plan), D (Maximum Treatment, Storage, and Disposal), and, with calcining, C (Minimum Treatment, Storage, and Disposal) would meet the intent of previous consent orders and of compliance with regulations. Without calcining, Alternative $\mathrm{C}$ (Minimum Treatment, Storage, and Disposal) would fail to meet one mandated date in the modified court order but would result in less highactivity waste having to be disposed in a Federal repository than Alternative B (Ten-Year Plan).

3.1.3.1.6 Technology Selection-DOE has identified reasonable technology alternatives to process sodium-bearing liquid wastes and calcine and is currently evaluating and conducting tests to determine the viability of the competing technologies. In the Record of Decision for this EIS, DOE will select a technology for calcining or processing sodium-bearing liquid waste. In addition, in the Record of Decision for this EIS, DOE will select a technology for converting calcined wastes into an appropriate form for disposal. 
Decisions on these treatment technologies will be made in conjunction with efforts currently being undertaken with the State of Idaho under the Federal Facility Compliance Act. These efforts include identification of potential treatment technologies for mixed wastes and the development of a Site Treatment Plan, which will provide a schedule for the development and implementation of these treatment technologies. A discussion of the evaluation and analyses for these treatment technology alternatives for sodium-bearing wastes and calcine is provided in the Project Summary for the Waste Immobilization Facility given in Appendix C, Information Supporting the Alternatives.

DOE has identified two primary treatment technology alternatives for evaluation: (a) vitrification and (b) separation, followed by vitrification and grouting. Within the separation technology alternative, three options were identified: (a) radionuclide partitioning, (b) precipitation, or (c) freeze crystallization. Either of these two primary technology alternatives could be implemented through the Waste Immobilization Facility. The emissions, effluents, and final waste forms from processes within the Waste Immobilization Facility would depend on the treatment technology alternative selected. This EIS provides a preliminary analysis of the impacts of construction and operation of the Waste Immobilization Facility, including storage of the final waste form, for each of the treatment technology alternatives. The analyses performed for the Waste Immobilization Facility bound the impacts for each of the treatment technology alternatives and also any of the options within the primary treatment technology alternatives identified. Before a decision is made whether to proceed with construction of the Waste Immobilization Facility, further National Environmental Policy Act review will be conducted, as appropriate. 


\section{Transuranic Waste}

Alternative A - Accept offsite transuranic waste for storage on case-by-case basis

- Retrieve/move transuranic and alpha low-level waste to now compliant storage

- Ship transuranic waste offsite for disposal

Alternative B $\bullet$ Accept offsite transuranic waste for treatment

- Retrieve/move transuranic and alpha low-level waste to new compliant storage

- Treat offinite and onsite transuranic and alpha low-level waste

- Ship transuranic watte offsite for disposal

Altemative C $\bullet$ Retrieve/move transuranic and alpha low level waste to new compliant storage

- Ship transuranic waste offsite for disposal

- Ship waste to offsite DOE facility for storage

Altenative D .9. Accept offsite transuranic waste for treatment

- Retrieve/move transuranic and alpha low level waste to new compliant storage

- Treat offsite and onsite transuranic and alpha low-level waste

- Ship transuranic waste offsite for disposal

- Dispose of alpha low-level waste at new onsite facility

3.1.3.2 Transuranic Waste. The management of transuranic waste and alpha low-level waste would involve completing the storage, characterization, treatment, and disposal process illustrated in the flow diagrams associated with the descriptions of the alternatives. The four alternatives, as detailed in Table 3.1-6 and described below, represent various strategies leading to such completion.

Under each of the four alternatives, it is assumed for analysis purposes that the INEL would ship 12,500 cubic meters (16,500 cubic yards) of transuranic waste to the national repository over a period of five years beginning in 2000 . Each of the alternatives also calls for 


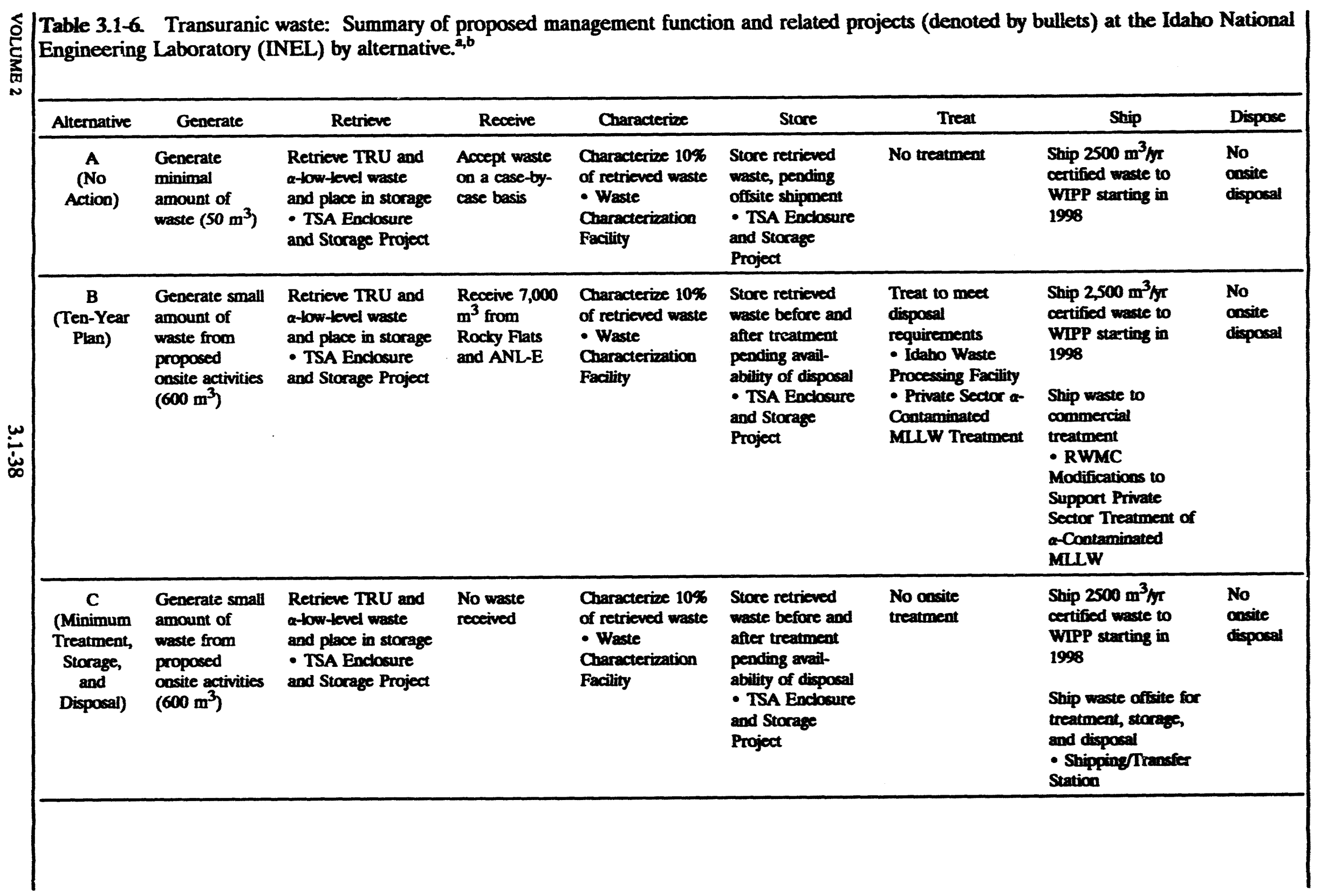




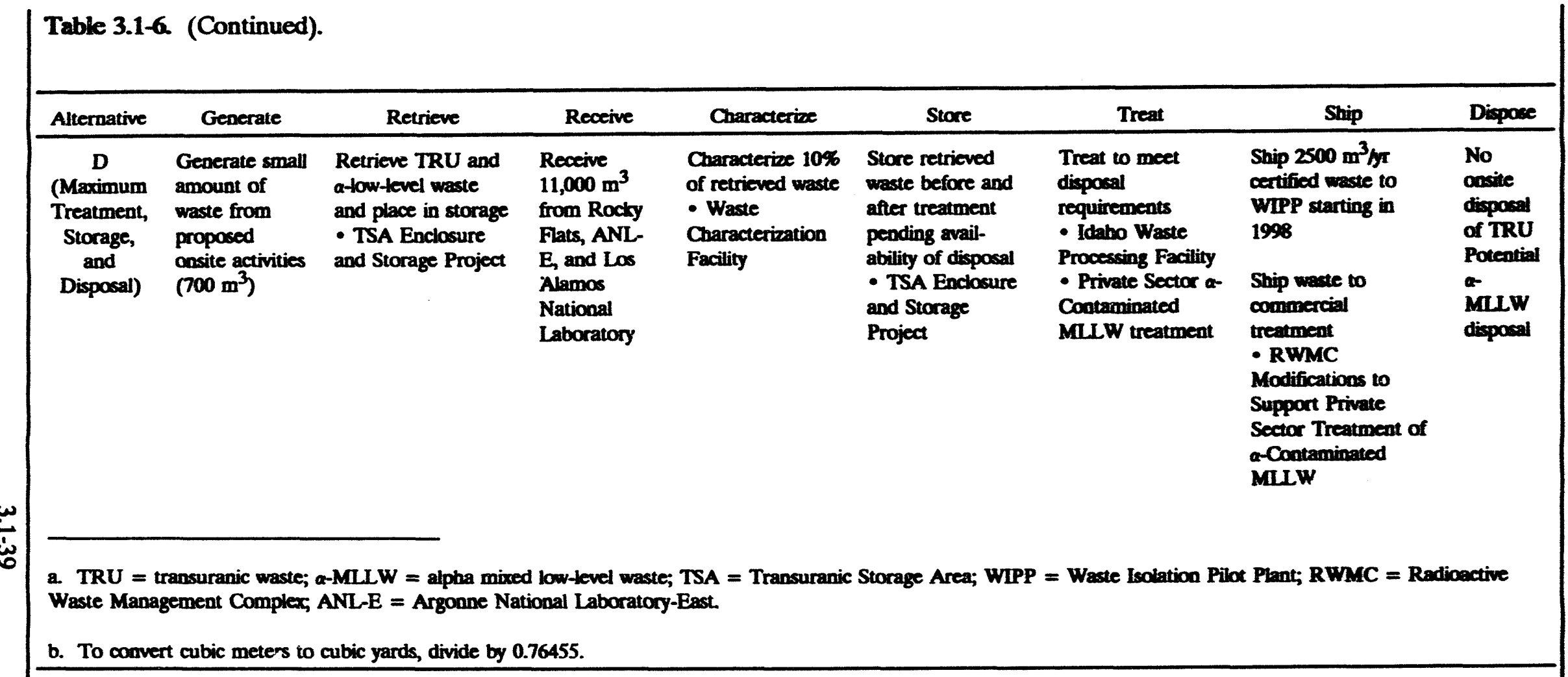


approximately 21,000 cubic meters (27,500 cubic yards) of transuranic and alpha low-level waste to be retrieved from covered storage and placed into new storage modules at the Transuranic Storage Area during the period 1995 through 2005. This retrieval would continue several more years until the entire 52,000 cubic meters $(68,000$ cubic yards) of covered stored transuranic waste is retrieved. Approximately 13,000 cubic meters (17,800 cubic yards) of transuranic and alpha low-level waste in storage in the Air Support Buildings would also be moved into new storage in all alternatives. The locations of this and other projects for transuranic waste associated with all the alternatives are shown in Figure 3.1-16. The inventory of transuranic waste onsite in 2005 for all alternatives is shown in Figure 3.1-17.

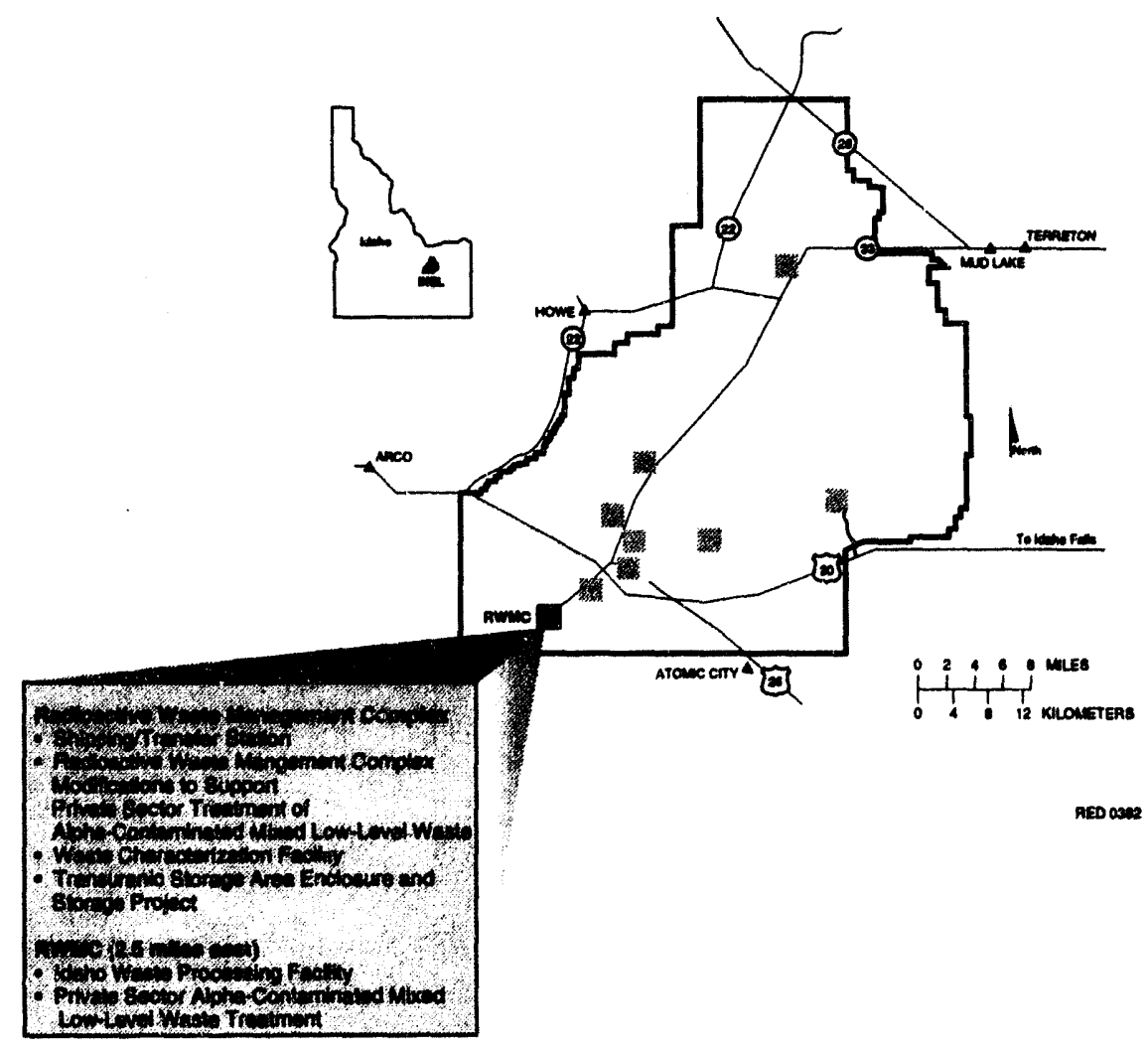

Figure 3.1-16. Transuranic waste: Idaho National Engineering Laboratory locations of projects associated with proposed alternatives. 


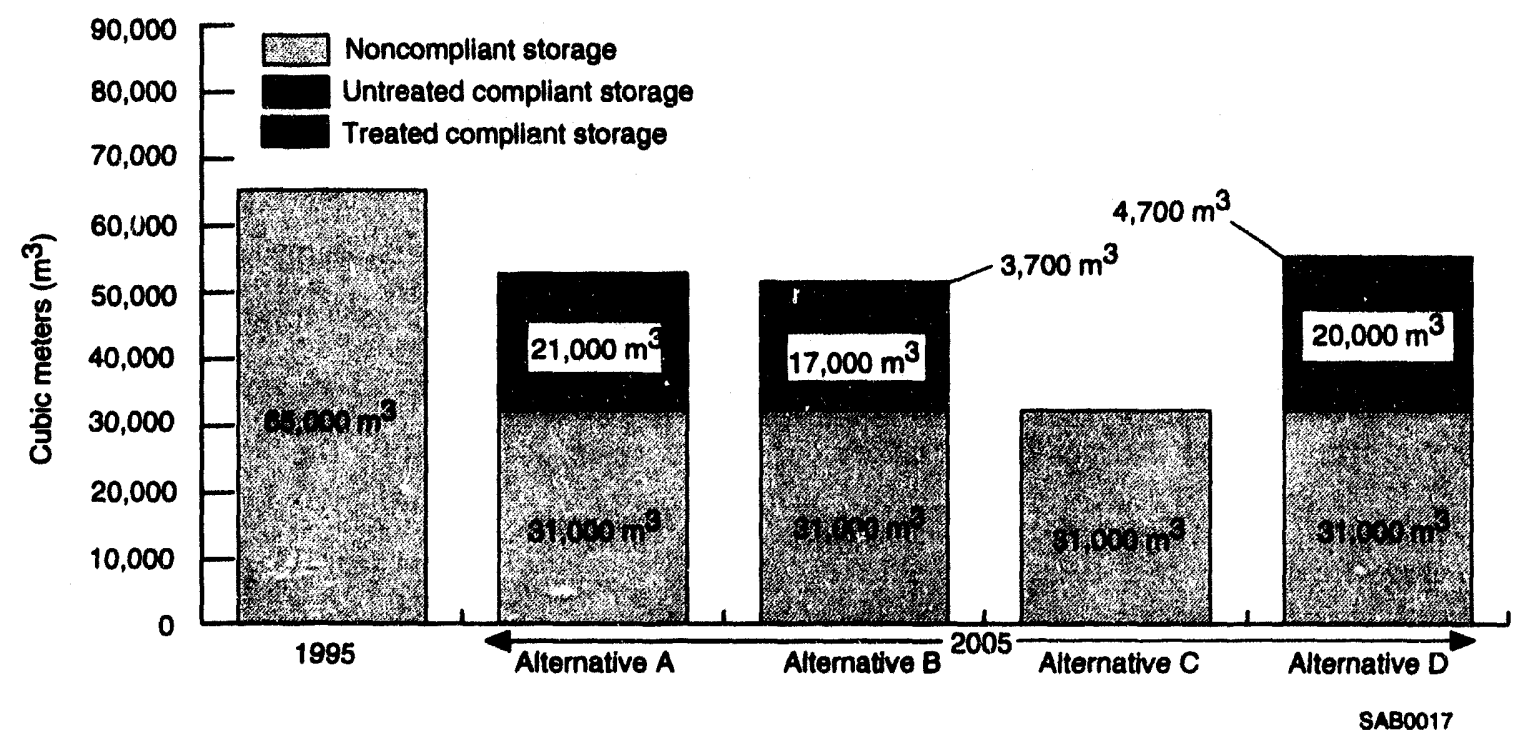

Figure 3.1-17. Transuranic waste volumes at the Idaho National Engineering Laboratory under the proposed alternatives: Alternative A (No Action), Alternative B (Ten-Year Plan), Alternative C (Minimum Treatment, Storage, and Disposal), and Alternative D (Maximum Treatment, Storage, and Disposal).

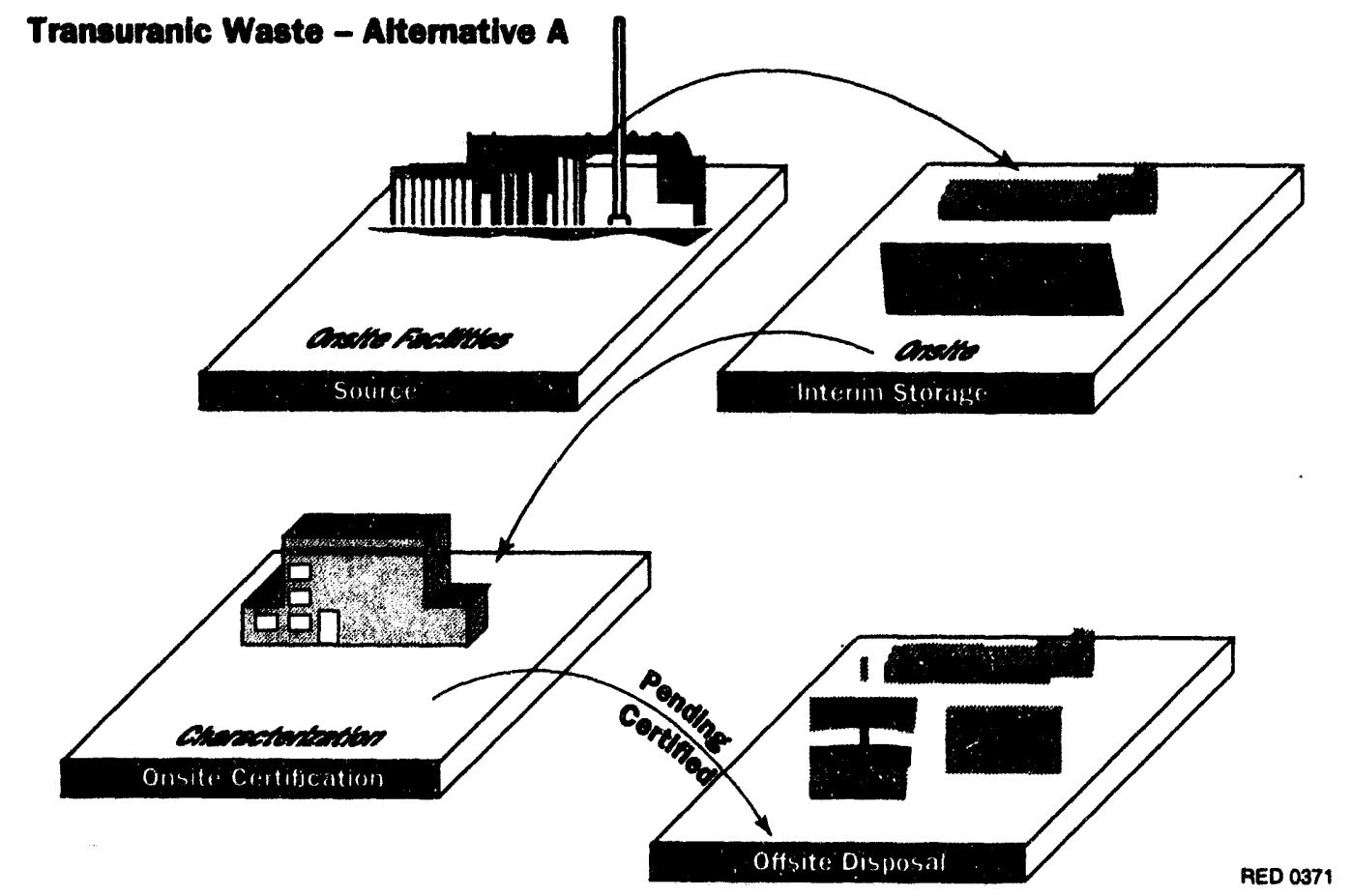

Figure 3.1-18. Management of transuranic waste at the Idaho National Engineering Laboratory under the proposed Alternative A (No Action). 
3.1.3.2.1 Alternative A (No Action)-Alternative A (No Action) would continue the current program of transuranic waste management currently in operation at the INEL (Figure 3.1-18). Small additional quantities of waste would continue to be generated from onsite operations, environmental restoration, and decontamination and decommissioning activities. Nominal additional volumes of waste are received from offsite generators, including Argonne National Laboratory-East and Rocky Flats. New shipments of transuranic waste would continue to be received from offsite sources on a case-by-case basis when approved by the State of Idaho.

Existing transuranic and alpha low-level waste storage facilities on the asphalt pads at the Transuranic Storage Area and in the Air Support Buildings would continue to be used until the waste was retrieved and placed into new storage modules. The current program of examination, certification, and preparation for disposal of transuranic waste in a national repository would also continue. The Stored Waste Examination Pilot Plant for certifying transuranic waste would continue to operate; and retrieved stored waste would be examined, characterized, sorted, reclassified, and repackaged, as necessary at the Stored Waste Examination Pilot Plant and the new Waste Characterization Facility located at the Radioactive Waste Management Complex.

3.1.3.2.2 Alternative B (Ten-Year Plan)-Alternative B (Ten-Year Plan) would supplement the current program of transuranic waste management at the INEL described in Alternative A (No Action) by implementing transuranic and alpha low-level waste treatment projects (Figure 3.1-19). The ultimate aim of these projects would be to prepare transuranic waste for disposal in a national repository. Alpha low-level waste and transuranic waste that could not be certified for disposal would be treated and left in indefinite storage. Waste storage and characterization activities would continue as described in Alternative A (No Action).

Under this alternative, approximately 7,000 cubic meters $(9,000$ cubic yards) of transuranic waste would be received from Rocky Flats and Argonne National Laboratory-East.

Under Alternative B (Ten-Year Plan), DOE would add transuranic and alpha low-level waste treatment capabilities before 2005. Technologies for treating transuranic and alpha lowlevel waste and preferred modes of making the technologies available, whether through the private sector (on or off the site) or through INEL facilities, would be chosen first. Then new 


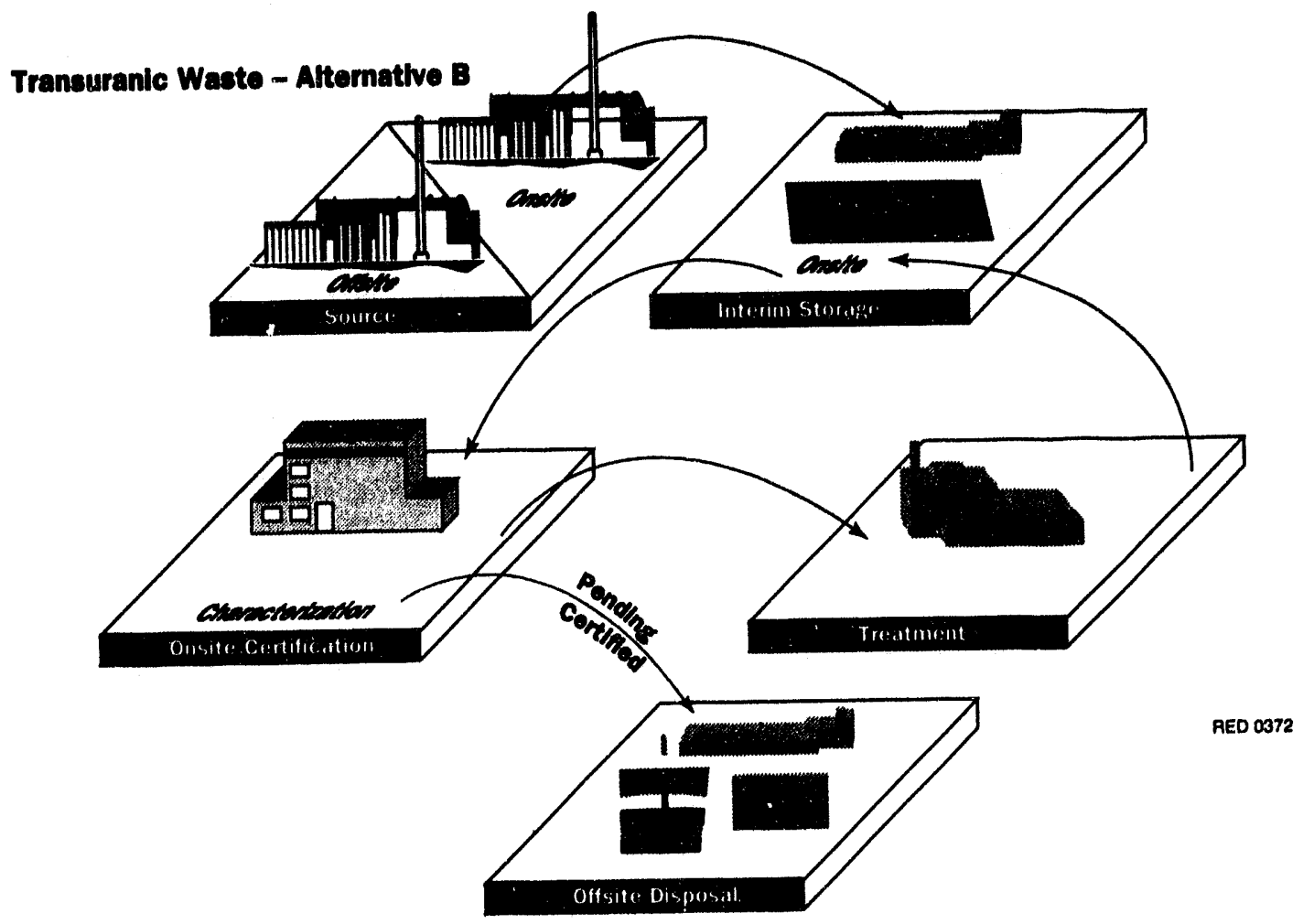

Figure 3.1-19. Management of transuranic waste at the Idaho National Engineering Laboratory under the proposed Alternative B (Ten-Year Plan).

waste treatment facilities would be constructed in two phases-the first to treat alphacontaminated waste and the second to treat transuranic waste.

Approximately 12,200 cubic meters (16,000 cubic yards) of alpha low-level waste would be treated at this facility within the ten-year window of this EIS. Radioactive Waste Management Complex modifications would be performed to support shipment if the facility is off the site. Treatment of transuranic waste would begin immediately after completion of the alpha low-level waste treatment campaign. Additional volumes of transuranic and alpha low-level waste would be treated at this facility sometime after 2005. Alpha low-level waste treatment residuals from the treatment facility would be stored for eventual disposal.

\subsection{Alternative C (Minimum Treatment, Storage, and}

Disposal)-Alternative C (Minimum Treatment, Storage, and Disposal) would shut down, phase 
out, or minimize treatment, storage, and disposal activities at the INEL site (Figure 3.1-20). Therefore, to the maximum extent possible, transuranic and alpha low-level waste would be shipped to another DOE facility for management. Under this alternative, no transuranic waste would be received from offsite generators. Onsite management of wastes would be scaled down to the minimum required by regulations. This alternative would end all technology development and privatization initiatives for transuranic and alpha low-level waste treatment at the INEL site. Selecting this alternative would not, however, end the waste storage and characterization activities, described under Alternative $A$ (No Action), that are required to send waste to a national transuranic waste repository.

Additional storage facilities would also be required to support the retrieval of stored waste and to provide interim storage and staging of waste before shipment.

Shipping all the transuranic and alpha low-level waste stored at the INEL offsite would require expanding transportation and characterization capabilities. The Shipping/Transfer Facility, which is an expansion of the Stored Waste Examination Pilot Plant, would be constructed.

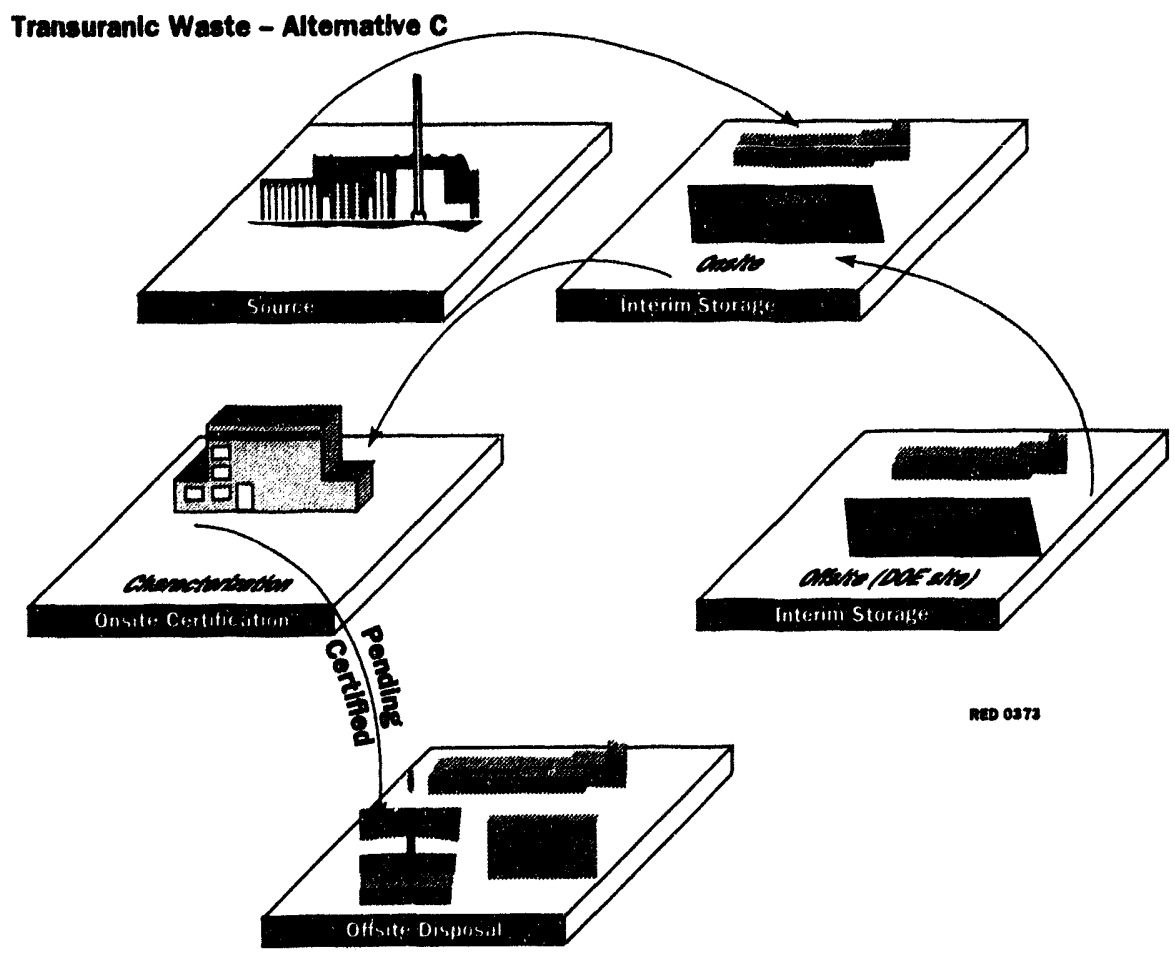

Figure 3.1-20. Management of transuranic waste at the Idaho National Engineering Laboratory under the proposed Alternative C (Minimum Treatment, Storage, and Disposal). 


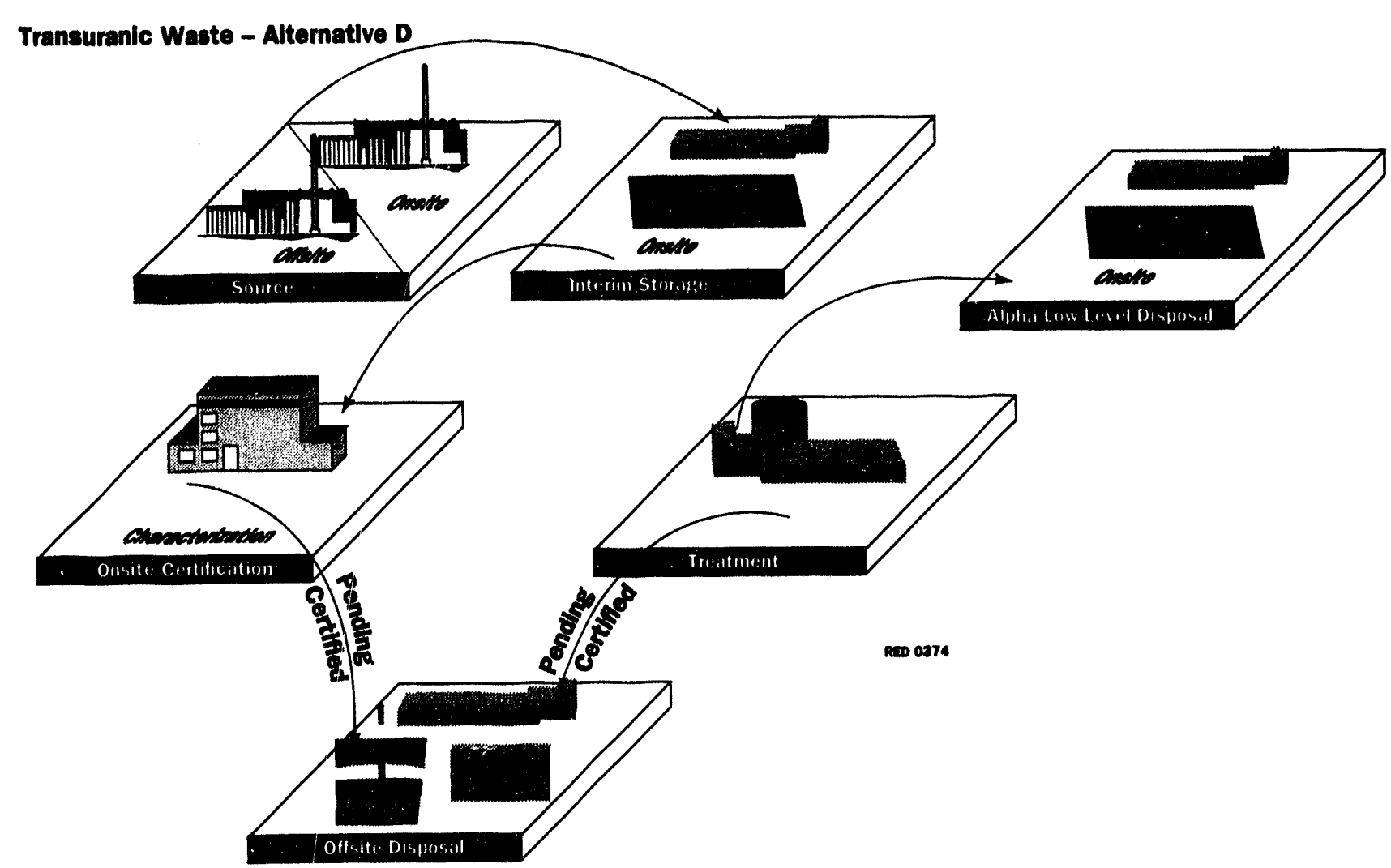

Figure 3.1-21. Management of transuranic waste at the Idaho National Engineering Laboratory under the proposed Alternative D (Maximum Treatment, Storage, and Disposal).

\subsection{Afternative D (Maximum Treatment, Storage, and}

Disposal)-Alternative D (Maximum Treatment, Storage, and Disposal) would increase onsite management of transuranic and alpha low-level waste to accommodate increased waste management support to offsite facilities in the DOE complex (Figure 3.1-21). Under Alternative D (Maximum Treatment, Storage, and Disposal), 11,000 cubic meters (14,400 cubic yards) of transuranic waste would be accepted from offsite generators. A low-level waste disposal facility for alpha low-level waste would also be constructed in the vicinity of the Radioactive Waste Management Complex so that this waste could be finally disposed of.

Implementing this alternative would require accepting additional volumes of waste from offsite facilities for interim storage and building additional new storage. A maximum of approximately 24,000 cubic meters $(31,400$ cubic yards $)$ of transuranic and alpha low-level waste would be in storage in 1999. 
3.1.3.2.5 Summany-The major differences and similarities among the four alternatives for transuranic waste can be summarized as follows:

- Retrieval and transfer of transuranic waste would occur under all alternatives. Transuranic and alpha low-level waste would be retrieved from covered storage and placed into new storage modules. The retrieval would continue until the entire amount of waste in covered storage was retrieved. Waste would also be moved from storage in the Air Support Buildings to new storage.

- Receipt of offsite shipments of transuranic waste would continue under all alternatives except Alternative C (Minimum Treatment, Storage, and Disposal). Under Alternative C (Minimum Treatment, Storage, and Disposal), these shipments would be stopped. Under Alternative A (No Action), these shipments would proceed as approved on a case-by-case basis. Under Alternatives B (TenYear Plan) and D (Maximum Treatment, Storage, and Disposal), volumes of received waste would be increased.

- Under all the alternatives, over a period of five years, 12,500 cubic meters $(16,400$ cubic yards) of transuranic waste would be shipped from INEL to the repository. A facility to provide additional capabilities for waste characterization would be built under each alternative.

- Under Alternatives B (Ten-Year Plan) and D (Maximum Treatment, Storage, and Disposal), waste treatment technologies would be developed and a transuranic waste treatment facility would be constructed to meet current requirements of the U. S. Environmental Protection Agency regulations for land disposal of wastes and reasonably foreseeable waste certification requirements of the Federal repository. Alternative D (Maximum Treatment, Storage, and Disposal) would provide for final disposal of alpha low-level waste. 


\section{Low-Level waste}

Alternative A • Treat onsite and offsite

- Dispose onsite in existing facility

Alternative B • Treat onsite and offsite

- Construct and operate additional treatment and disposal facilities onsite

Alternative C. Ship waste to other Department of Energy facilities for treatment, storage, and disposal

Alternative D $: \bullet$ Receive offsite waste

- Treat onsite

- Construct and operate additional treatment and disposal facilities onsite

3.1.3.3 Low-Level Waste. As explained in Section 2.2.7.1.3, the overall process for lowlevel waste management is minimization before and during generation, storage pending availability of treatment and disposal, treatment as appropriate, and disposal. The four alternatives, as detailed in Table 3.1-7, depicted in figures associated with the descriptions below, represent various strategies for handling newly generated waste. All low-level waste generated before June 1995 would have been treated and disposed. In all the alternatives, a Waste Handling Facility would be constructed at Argonne National Laboratory-West, to help handle and stage its wastes. Figure 3.1-22 depicts the location of this and all new facilities for the handling of low-level waste, and Appendix C, Information Supporting the Alternatives, provides detailed descriptions of the projects.

\subsection{Aftemative A (No Action)-For Alternative A (No Action) (Figure}

3.1-23), the INEL site would handle low-level waste of approximately 47,000 cubic meters $(61,500$ cubic yards) generated onsite from continuing activities over the ten years. Activities would be similar to those described in Chapter 2. In addition to volume reduction by compaction and sizing at the Waste Experimental Reduction Facility and disposal onsite at the Radioactive Waste Management Complex, low-level waste would be incinerated at an existing offsite commercial facility. 


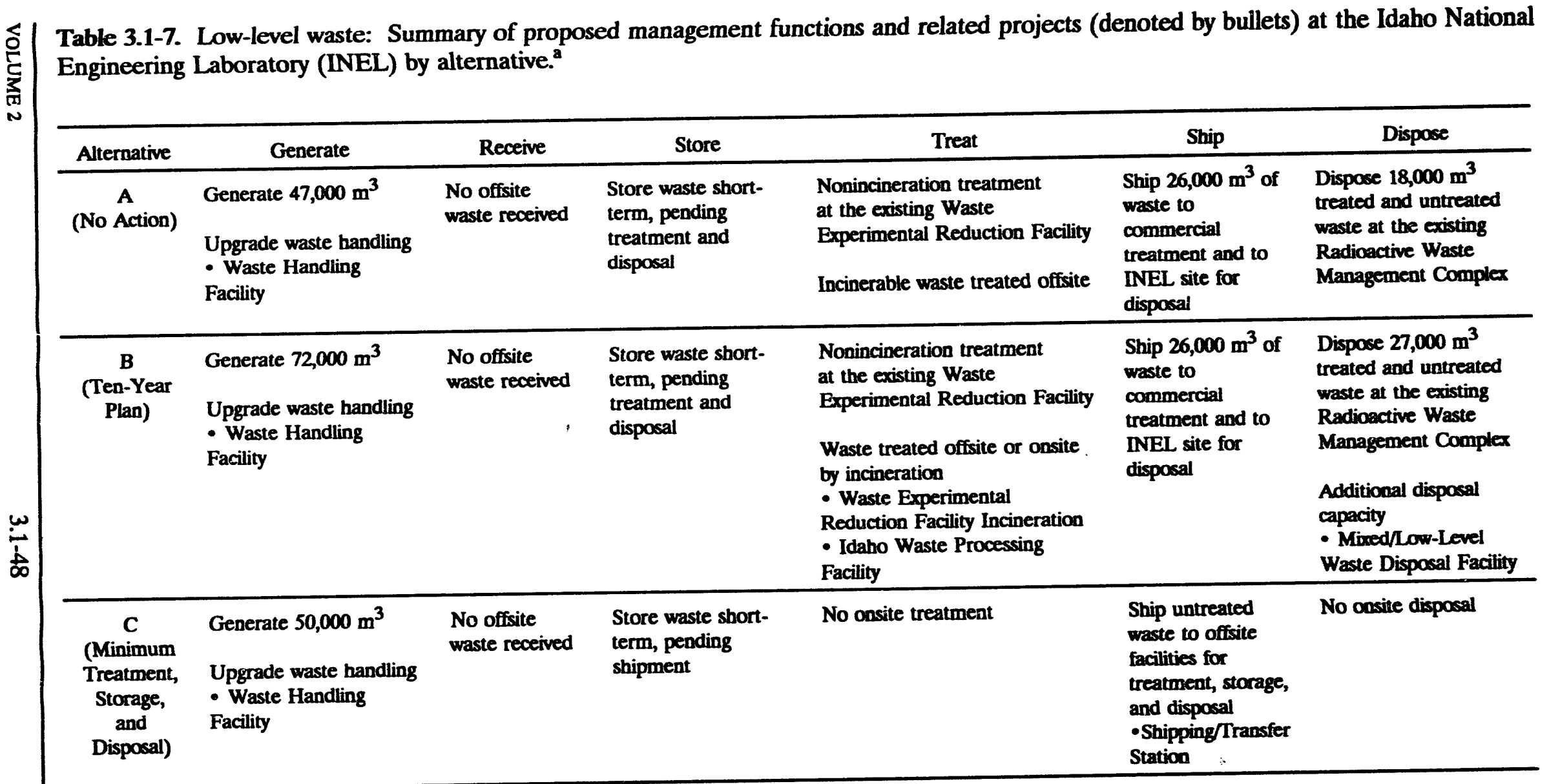




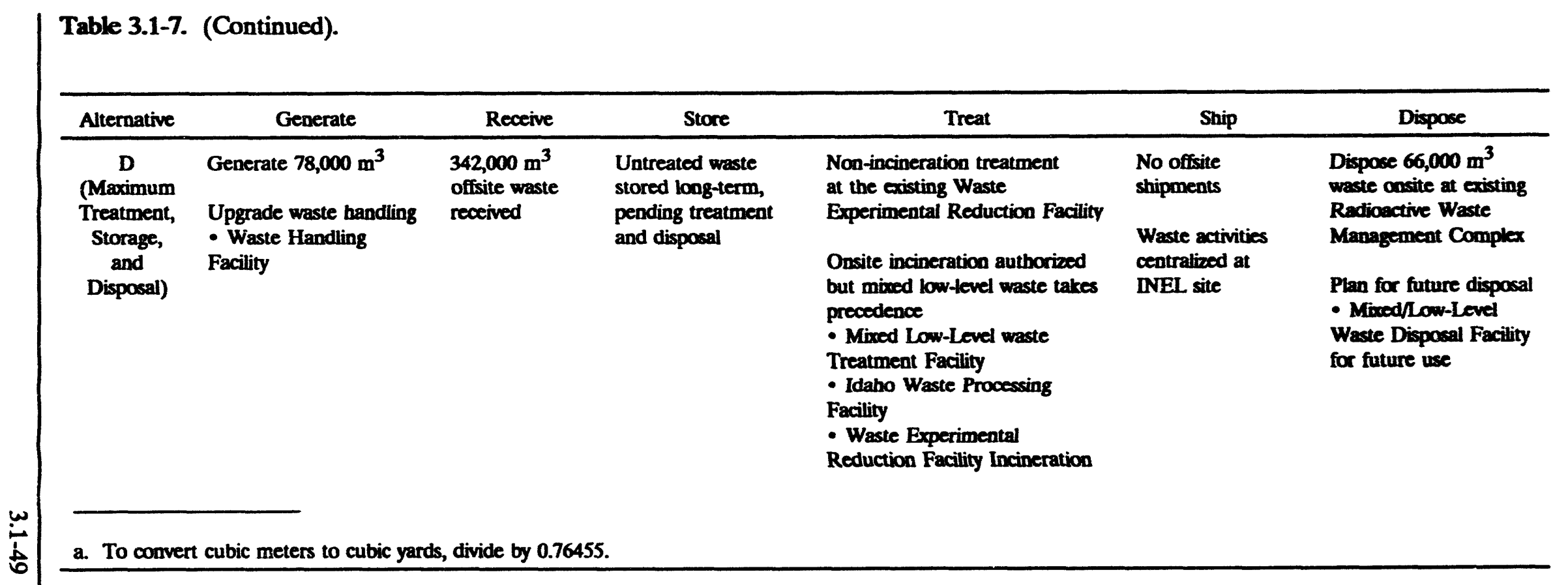




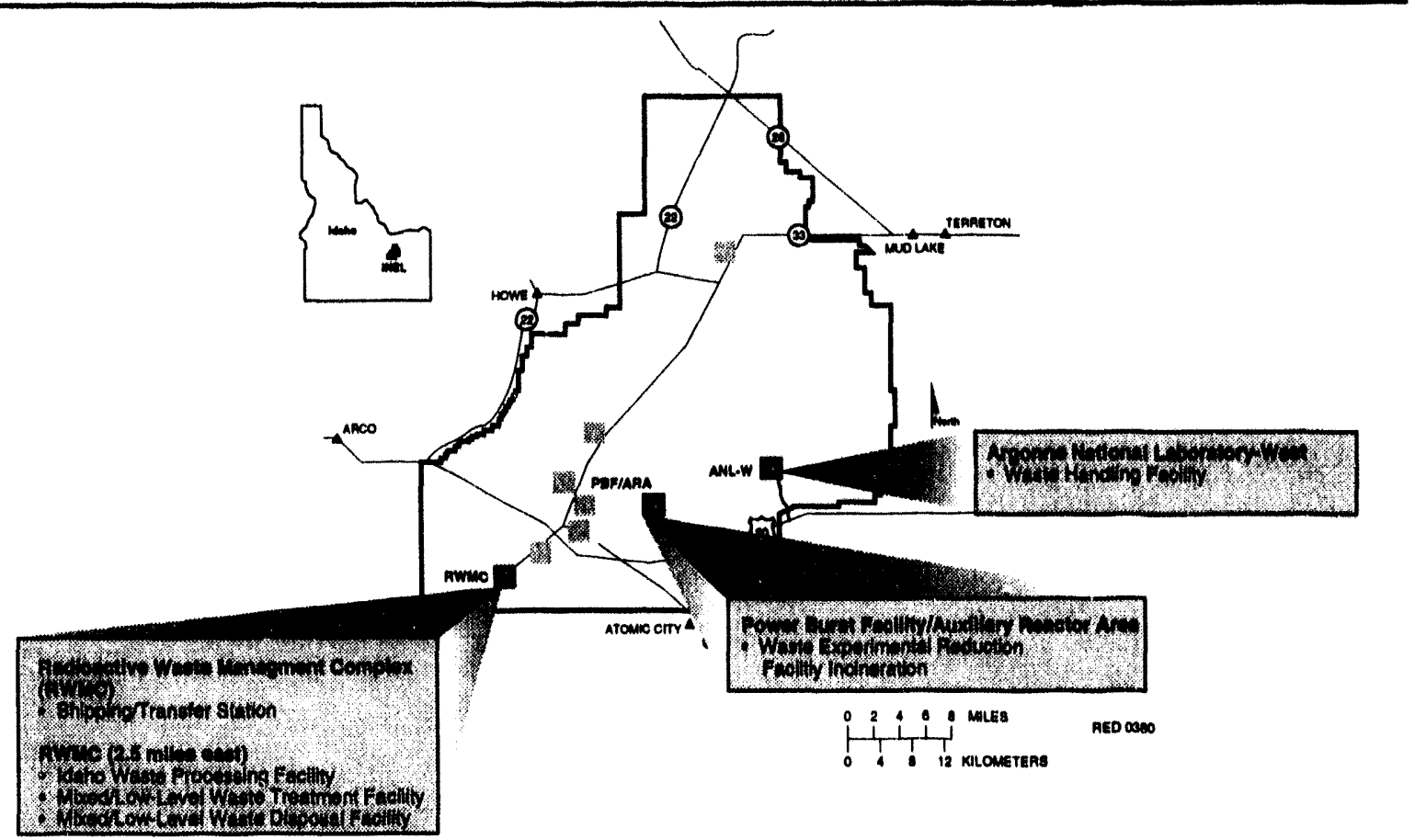

Figure 3.1-22 Low-level waste: Idaho National Engineering Laboratory locations of projects associated with proposed alternatives.

\section{Low Level Waste - Alternative A}

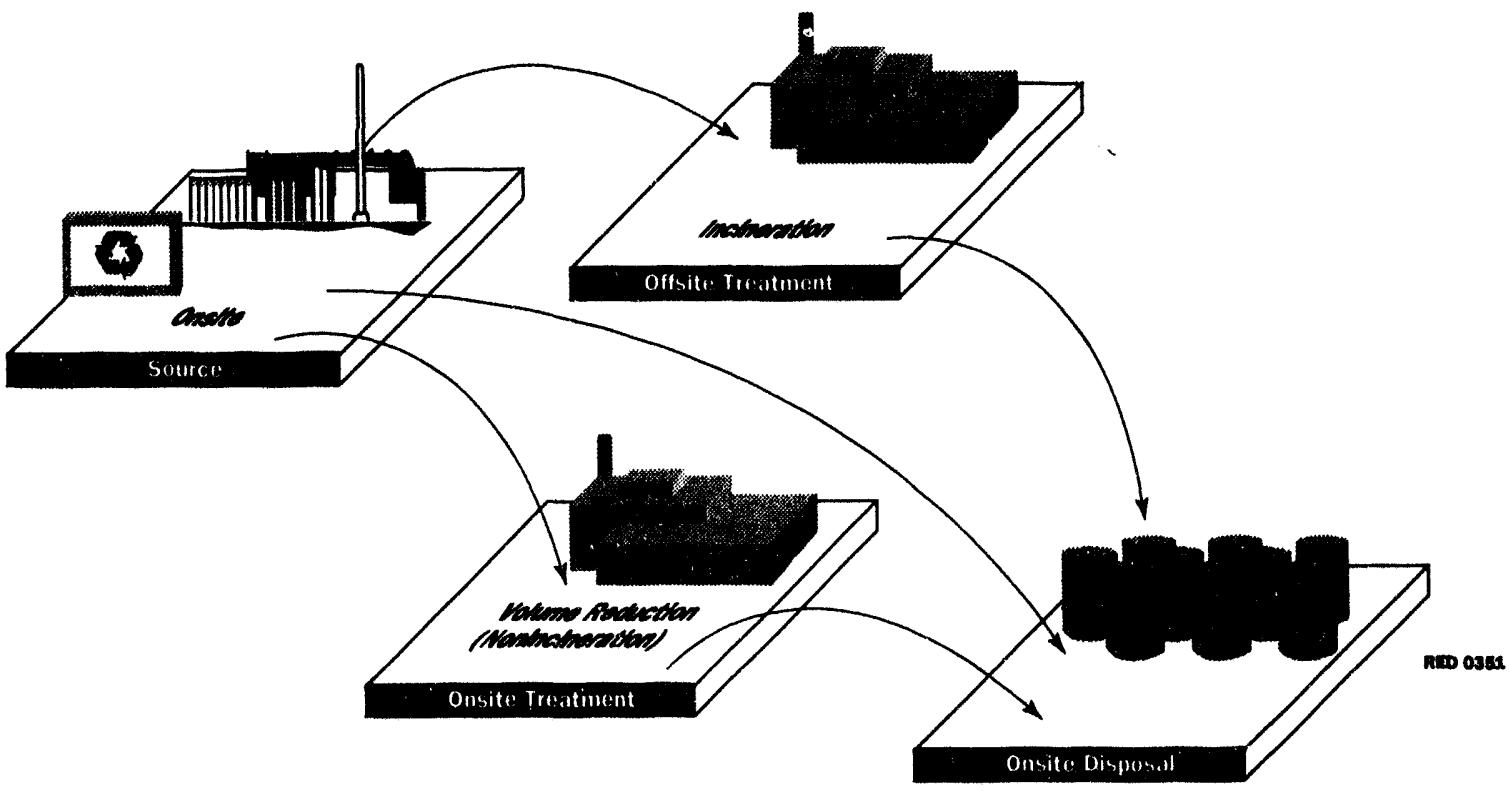

Figure 3.1-23. Management of low-level waste at the Idaho National Engineering Laboratory under the proposed Alternative A (No Action). 


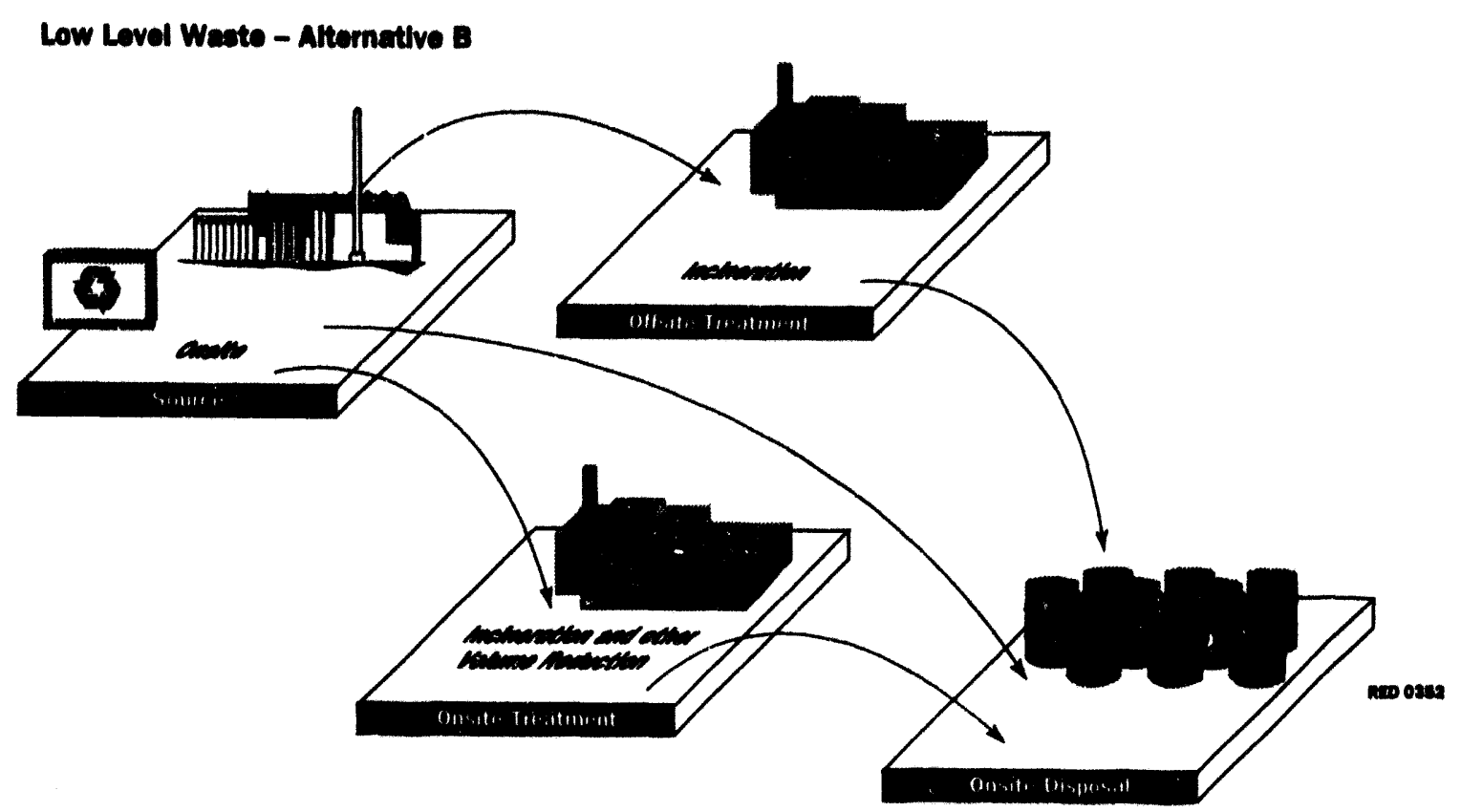

Figure 3.1-24. Management of low-level waste at the Idaho National Engineering Laboratory under the proposed Alternative B (Ten-Year Plan).

3.1.3.3.2 Afternative B (Ten-Year Plan)-Under Alternative B (Ten-Year Plan) (Figure 3.1-24), approximately 72,000 cubic meters (94,000 cubic yards) of low-level waste would be generated during the ten years. This waste would be treated onsite at the Waste Experimental Reduction Facility, using both nonincineration and incineration. Offsite commercial incineration would continue. To treat all waste in a timely manner, most low-level waste would be treated offsite at a commercial facility, and the Waste Experimental Reduction Facility would incinerate primarily mixed low-level waste. The Waste Experimental Reduction Facility is a Resource Conservation and Recovery Act interim status incineration facility located at the INEL site. The facility and the process are described in the Waste Experiment Reduction Facility project summary in Appendix C, Information Supporting the Alternatives. The Idaho Waste Processing Facility, planned as a stand-alone facility near the Radioactive Waste Management Complex, would be constructed for operation after 2005 . 
Waste remaining after onsite and offsite treatment would be disposed at the Radioactive Waste Management Complex. To facilitate future disposal of low-level waste, a Mixed/Low-level Wast - Disposal Facility would be constructed for operation in 2004. This facility would be located 2.5 miles east of the Radioactive Waste Management Facility.

\subsection{Afternative C (Minimum Troatment, Storage, and Disposal)-Under} Alternative C (Minimum Treatment, Storage, and Disposal) (Figure 3.1-25), all low-level waste generated onsite, approximately 50,000 cubic meters (65,400 cubic yards), during the ten years would be shipped to another DOE facility for treatment, storage, and disposal. To support shipping the larger quantities of waste, a Shipping/Transfer Station, which would be located at the Radioactive Waste Management Complex, would be constructed. The INEL would phase out the use of existing onsite treatment and disposal facilities.

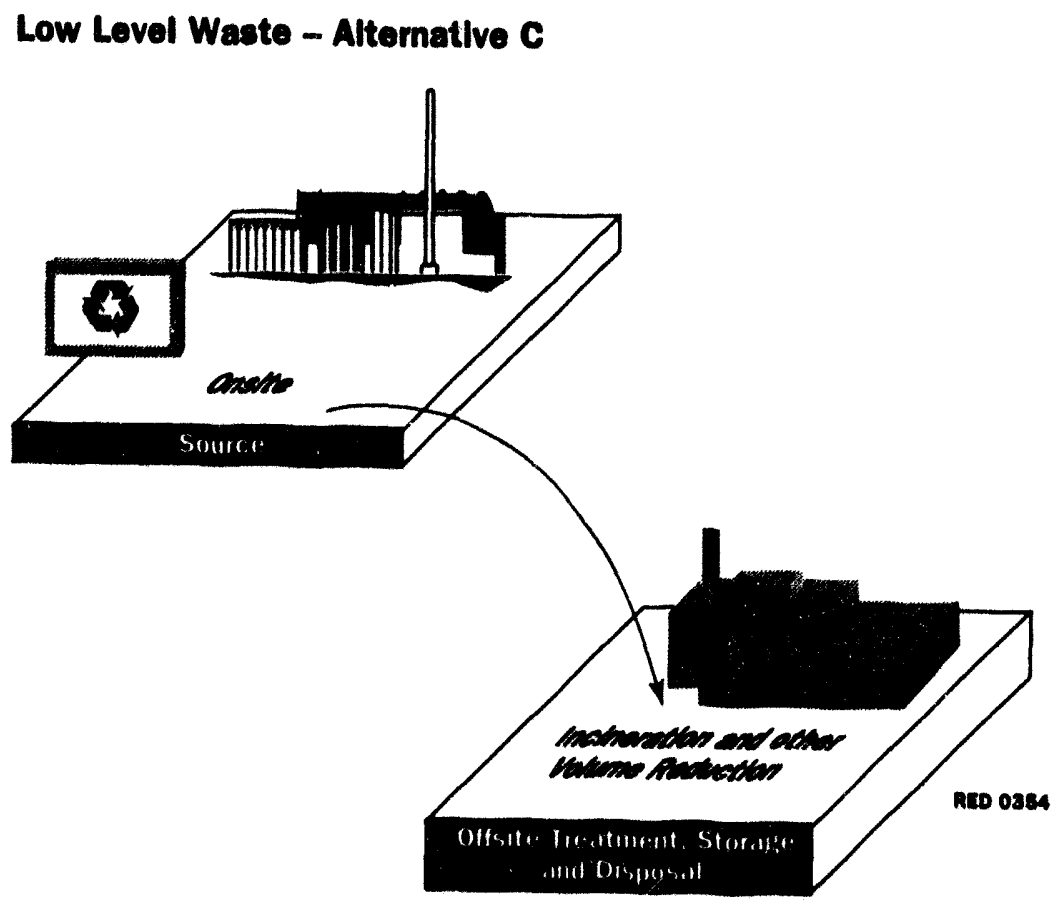

Figure 3.1-25. Management of low-level waste at the Idaho National F igineering Laboratory under the proposed Alternative C (Minimum Treatment, Storage, and Disposal). 


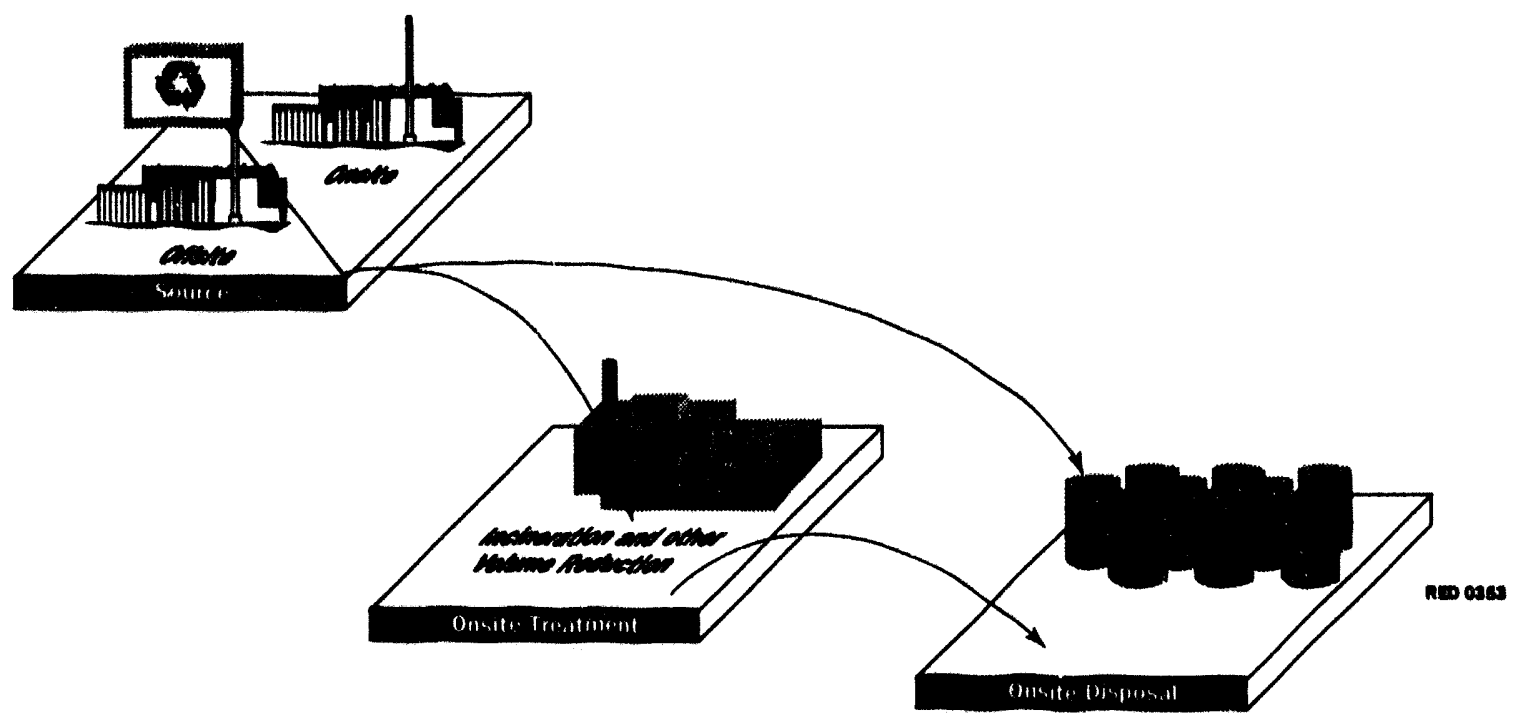

Figure 3.1-26. Management of low-level waste at the Idaho National Engineering Laboratory under the proposed Alternative D (Maximum Treatment, Storage, and Disposal).

\subsection{Aftemative D (Maximum Treatment, Storage, and Disposal)-In}

addition to the onsite treatment and disposal of INEL generated waste described in Alternative B (Ten-Year Plan), 770,000 cubic meters (1,000,000 cubic yards) of offsite waste would be accepted for treatment and disposal at the INEL under Alternative D (Maximum Treatment, Storage, and Disposal) (Figure 3.1-26). Additional waste may be generated from spent nuclear fuel processing activities. All treatment, storage, and disposal would be performed onsite. Although onsite incineration of low-level waste would be within the scope of Alternative $D$, the Waste Experimental Reduction Facility capacity would be used to incinerate mixed low-level waste. The low-level incinerable waste would be stored pending construction and operation of the Idaho Waste Processing Facility. Additional treatment capacity for many of the waste streams eligible for treatment at the Waste Experimental Reduction Facility would be available after 2005 through the operation of the Mixed/Low-Level Waste Treatment Facility. Both facilities would be located 2.5 miles east of the Radioactive Waste Management Complex.

Low-level waste would be disposed in the Radioactive Waste Management Complex until the existing and expanded capacity is filled. All additional waste would be stored pending operation of the Mixed/Low-Level Waste Disposal Facility. This facility would be put into 
operation in 2008 and would be located 2.5 miles east of the Radioactive Waste Management Complex.

3.1.3.3.5 Summary-As shown in Figure 3.1-27, by the year 2005, all low-level waste onsite would have been disposed through the activities in all alternatives except Alternative D (Maximum Treatment, Storage, and Disposal). All alternatives plan to handle waste generated onsite, but Alternative D (Maximum Treatment, Storage, and Disposal) includes plans for handling of waste received from offsite, as well as the onsite waste. In Alternative $D$, significant amounts of waste would remain in storage pending completion of new treatment and disposal facilities onsite. As soon as these planned facilities were operational beyond 2005 , they would allow the waste to be handled appropriately. Alternatives B (Ten-Year Plan) and D (Maximum Treatment, Storage, and Disposal) include facilities to treat, store, and dispose of all waste onsite. Alternative C (Minimum Treatment, Storage, and Disposal) would result in all waste being shipped offsite for treatment, storage, and disposal.

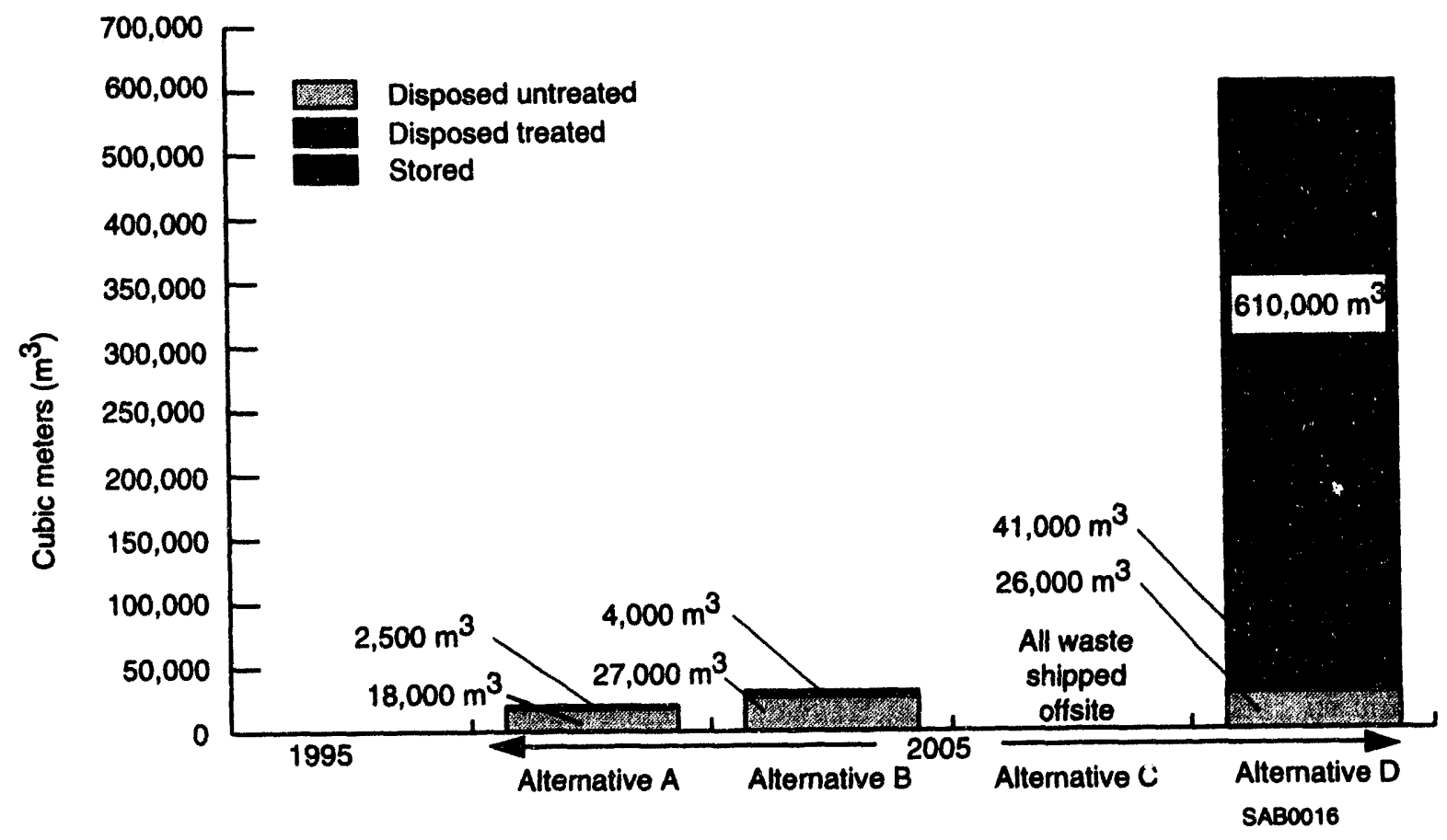

Figure 3.1-27. Low-level waste volumes at the Idaho National Engineering Laboratory under the proposed alternatives: Alternative A (No Action), Alternative B (Ten-Year Plan), Alternative C (Minimum Treatment, Storage, and Disposal), and Alternative D (Maximum Treatment, Storage, and Disposal). 


\section{Miked Low-Level Waste}

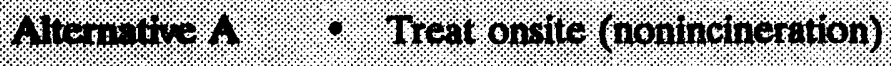

Alternative B .7 .9 Treat Onsite (incineration and nomincineration)

7. Construct and operate new facilities for onsite incineration and nonincineration treatment

- Construct and operate new disposal facility

- Ship warte offite for treatment and disposal

Niternitive C. : : Ship waste offsite for treatment, storage, and disposal

Alernative D .9 Receive offsite waste

- Treat onsite (incineration and nonincineration)

7. Construct and operate new facilities for onsite incineration and nonincineration treatment

- Construct and operate new disposal facility

- Ship waste offisite for treatment and disposal

3.1.3.4 Mred Low-Lovel Wasto. As identified in Section 2.2.7.1.4, the current management of mixed waste is to minimize waste before and during generation, to treat, and to store in permitted facilities onsite pending availability of treatment and disposal. The four alternatives, as detailed in Table 3.1-8 and described below, represent various strategies for implementing this process and dispositioning the waste. The four alternatives focus on different management options (Figure 3.0-1), including receipt of offsite waste, treatment onsite and offsite, and disposal onsite and offsite. In all the alternatives, a Waste Handling Facility would be constructed for Argonne National Laboratory-West waste to provide an accumulation area and storage for less than 90 days. All proposed new mixed low-level waste projects are described in Appendix C, Information Supporting the Alternatives; and Figure 3.1-28 shows their locations. 


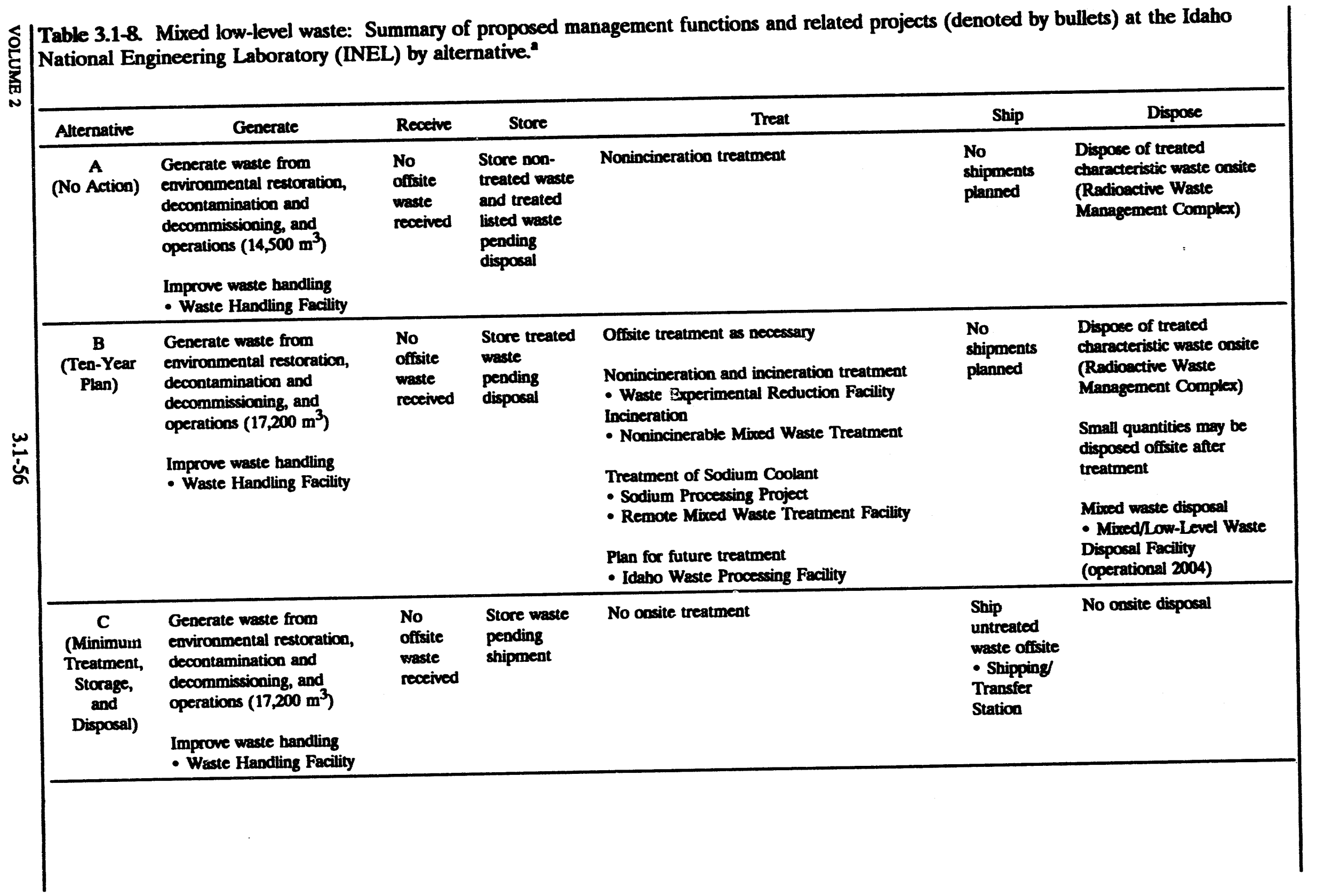




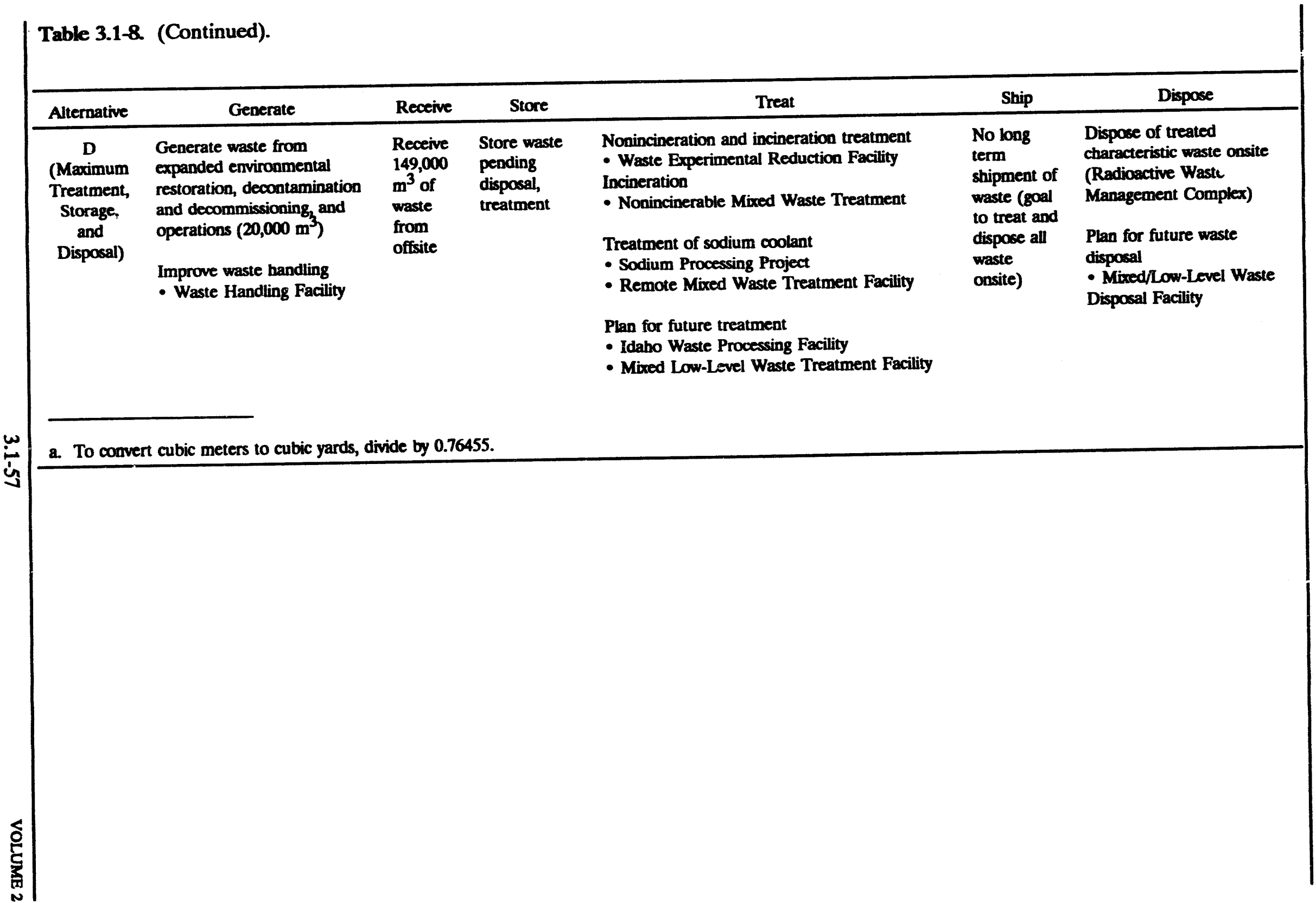




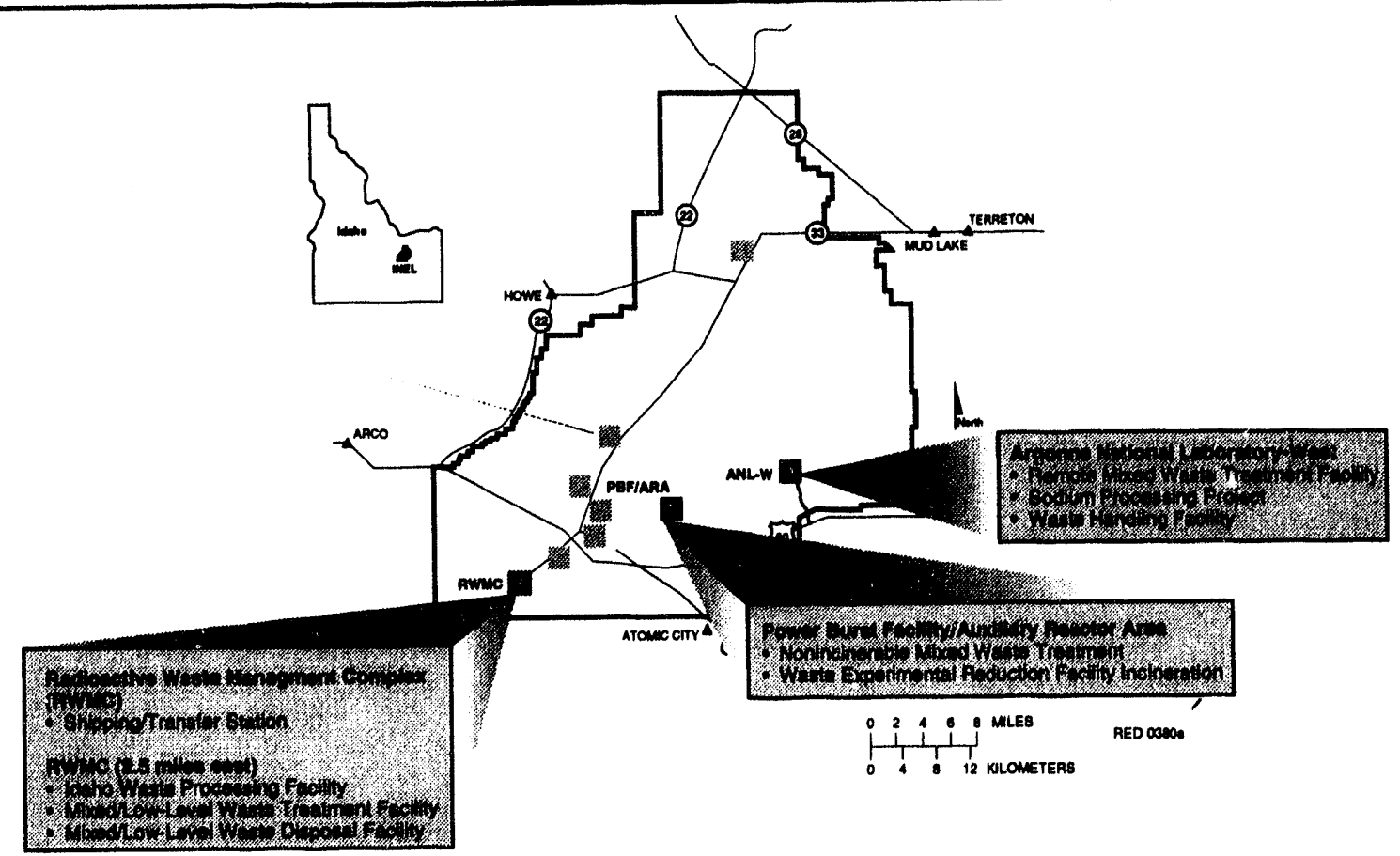

Figure 3.1-28. Mixed low-level waste: Idaho National Engineering Laboratory locations of projects associated with proposed alternatives.

3.1.3.4.1 Alternative A (No Action)-In Alternative A (No Action) (Figure 3.1-29), existing [ 1,100 cubic meters ( 1,440 cubic yards)] and newly generated mixed low-level waste [14,500 cubic meters $(19,000$ cubic yards)] would continue to be stored in existing onsite tacilities. Facilities identified in Chapter 2, Background, including those on operational standby, would operate. Onsite, nonincineration treatment (stabilization) would be performed at the Waste Experimental Reduction Facility, and waste that meets the Waste Acceptance Criteria for the Radioactive Waste Management Complex would be disposed. This alternative would provide for no change in the current handling of mixed waste.

3.1.3.4.2 Afternative B (Ten-Year Plan)_Existing and newly generated waste of approximately 17,000 cubic meters ( 22,000 cubic yards) would be stored in existing facilities, pending onsite incineration and nonincineration treatment and offsite treatment, as needed, under Alternative B (Ten-Year Plan) (Figure 3.1-30). Treated waste meeting the Waste Acceptance Criteria for the Radioactive Waste Management Complex would be disposed onsite. Until disposed, treated and untreated waste would be stored in existing facilities onsite. By 2005, all waste would have been treated and disposed onsite or offsite. 


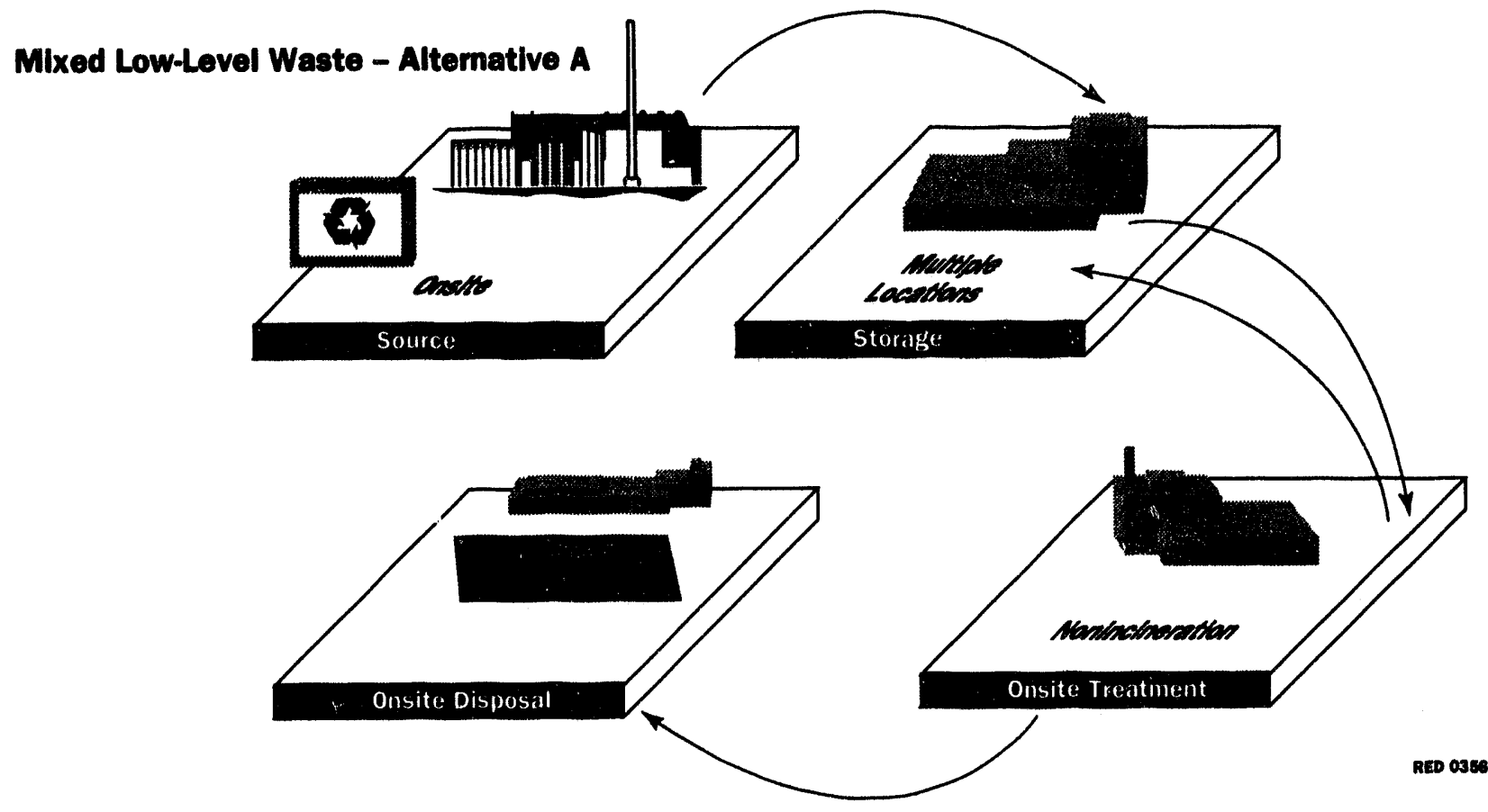

Figure 3.1-29. Management of mixed low-level waste at the Idaho National Engineering Laboratory under the proposed Alternative A (No Action).

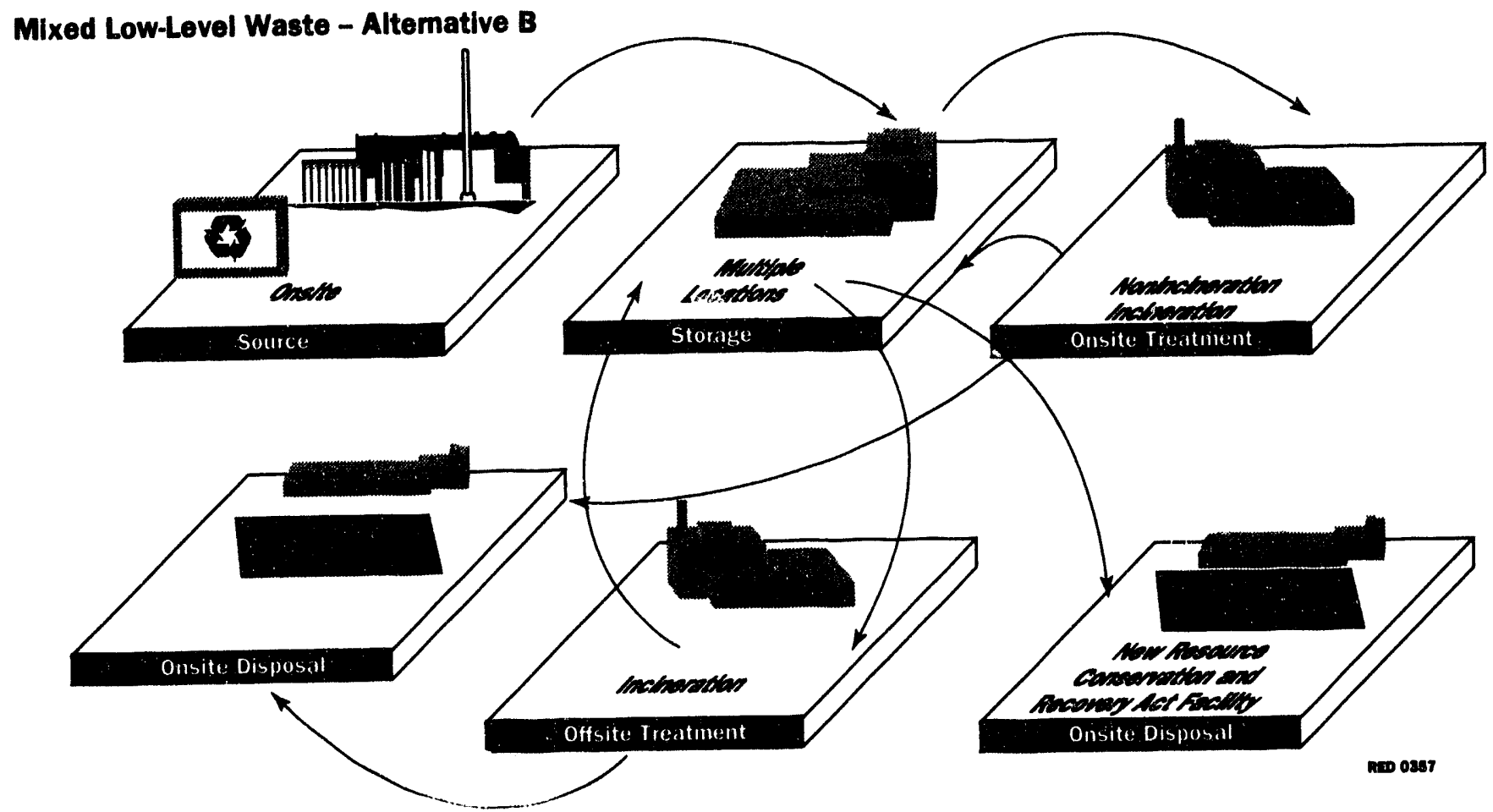

Figure 3.1-30. Management of mixed low-level waste at the Idaho National Engineering Laboratory under the proposed Alternative B (Ten-Year Plan). 
To treat and dispose of most of the mixed waste generated from activities identified as part of Alternative B (Ten-Year Plan), the Waste Experimental Reduction Facility Incineration process would operate. The Nonincinerable Mixed Waste Treatment project, to be located in the Waste Experimental Development Facility, would operate small-scale treatment processes. All mixed waste is assumed to be treated starting in 1996 when the Waste Experimental Reduction Facility and the Waste Experimental Development Facility would be operational. Waste that can be treated and reused (for example, lead) would be returned for commercial or internal laboratory use after treatment. In addition, the Sodium Processing Project and Remote Mixed Waste Treatment Facility, to be located at Argonne National Laboratory-West, would treat coolant waste from metal-cooled breeder reactors.

All waste that cannot be disposed in the Radioactive Waste Management Complex would be disposed in 2004 when the Mixed/Low-Level Waste Disposal Facility would become operational. The planned location for the Mixed/Low-Level Waste Disposal Facility is 2.5 miles east of the existing Radioactive Waste Management Complex.

\subsection{Alternative C (Minimum Treatment, Storage, and}

Disposal)-Existing and newly generated waste of approximately 18,000 cubic meters $(23,500$ cubic yards) would be stored in existing onsite facilities pending shipment to offsite facilities for treatment, storage, and disposal under Alternative $\mathrm{C}$ (Minimum Treatment, Storage, and Disposal) (Figure 3.1-31). All existing treatment and disposal operations would be phased out. To achieve shipment of all waste offsite, a Shipping/Transfer Station would be constructed at the Radioactive Waste Management Complex.

\subsection{Afternative D (Maximum Treatment, Storage, and Disposal)-Under}

Alternative D (Maximum Treatment, Storage, and Disposal) (Figure 3.1-32), approximately 20,000 cubic meters (26,000 cubic yards) of existing waste and newly generated waste and approximately 149,000 cubic meters (195,000 cubic yards) of waste received from offsite would be stored in existing and expanded facilities pending onsite treatment and disposal. Additional waste may be generated from spent nuclear fuel processing activities. All activities identified in Chapter 2 , Background, would continue and would be enhanced during a transition to treating, storing, and disposing all INEL generated mixed low-level waste at the INEL site. 


\section{Mixed Low-Lovel Waste - Altematlve C}

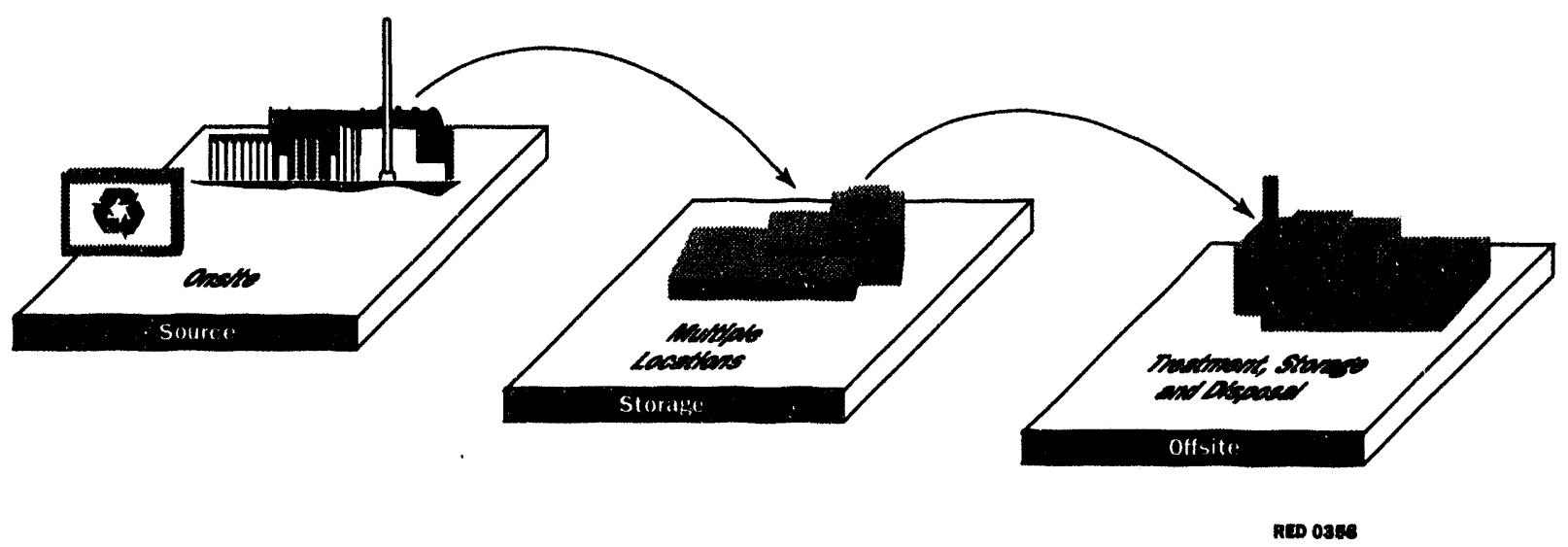

Figure 3.1-31. Management of mixed low-level waste at the Idaho National Engineering Laboratory under the proposed Alternative C (Minimum Treatment, Storage, and Disposal).

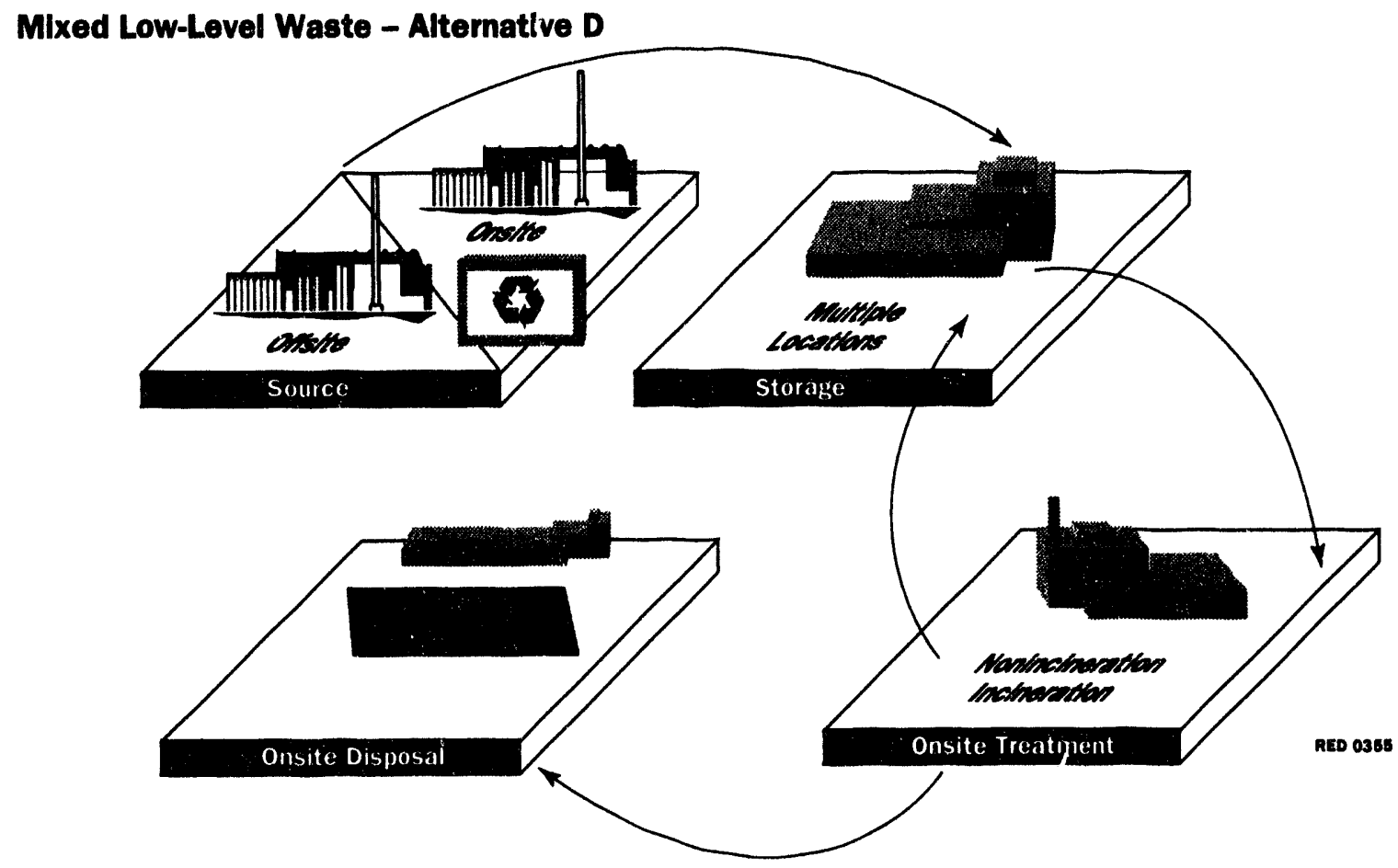

Figure 3.1-32 Management of mixed low-level waste at the Idaho National Engineering Laboratory under the proposed Alternative D (Maximum Treatment, Storage, and Disposal). 
The ten-year focus for this alternative provides a transition to allow time for planning, designing, and constructing facilities. During this transition phase, offsite treatment facilities would be used for offsite-generated incinerable waste. Offsite waste would be characterized by the generator and shipped directly to the commercial incinerator for treatment. Onsite waste would be incinerated in the Waste Experimental Reduction Facility and disposed or stored, as appropriate.

Waste generated both onsite and offsite requiring treatment other than incineration (for example, macroencapsulation or stabilization) would be handled by the nonincinerable mixed waste treatment processes located in the Waste Experimental Development Facility. Sodium coolant waste from sodium-cooled breeder reactors would be treated with the Sodium Processing Project and the Remote Mixed Waste Treatment Facility, to be located at Argonne National Laboratory-West. To minimize the requirement for offsite commercial treatment, onsite treatment facilities would be planned and constructed. The onsite facilities could be commercially or DOE-operated.

After treatment, all waste would be shipped to the Radioactive Waste Management Complex for disposal if appropriate, or storage, pending availability of the Mixed/Low-Level Waste Disposal Facility. Additional storage might be required before availability of appropriate treatment and disposal. Additional transuranic storage modules would be procured and constructed as necessary to store mixed low-level waste in compliance with the Resource Conservation and Recovery Act, pending completion of the new facilities.

3.1.3.4.5 Summary-For mixed low-level waste, Alternatives B (Ten-Year Plan) and D (Maximum Treatment, Storage, and Disposal) would achieve long-term treatment and disposal of INEL waste. Alternative C (Minimum Treatment, Storage, and Disposal) would provide for all INEL waste to be shipped offsite, negating the requirement for INEL treatment and disposal facilities. Without additional storage, mixed waste would be stored in noncompliance with the Resource Conservation and Recovery Act under Alternative A (No Action). The waste inventory onsite in 2005 for all alternatives is shown in Figure 3.1-33. 


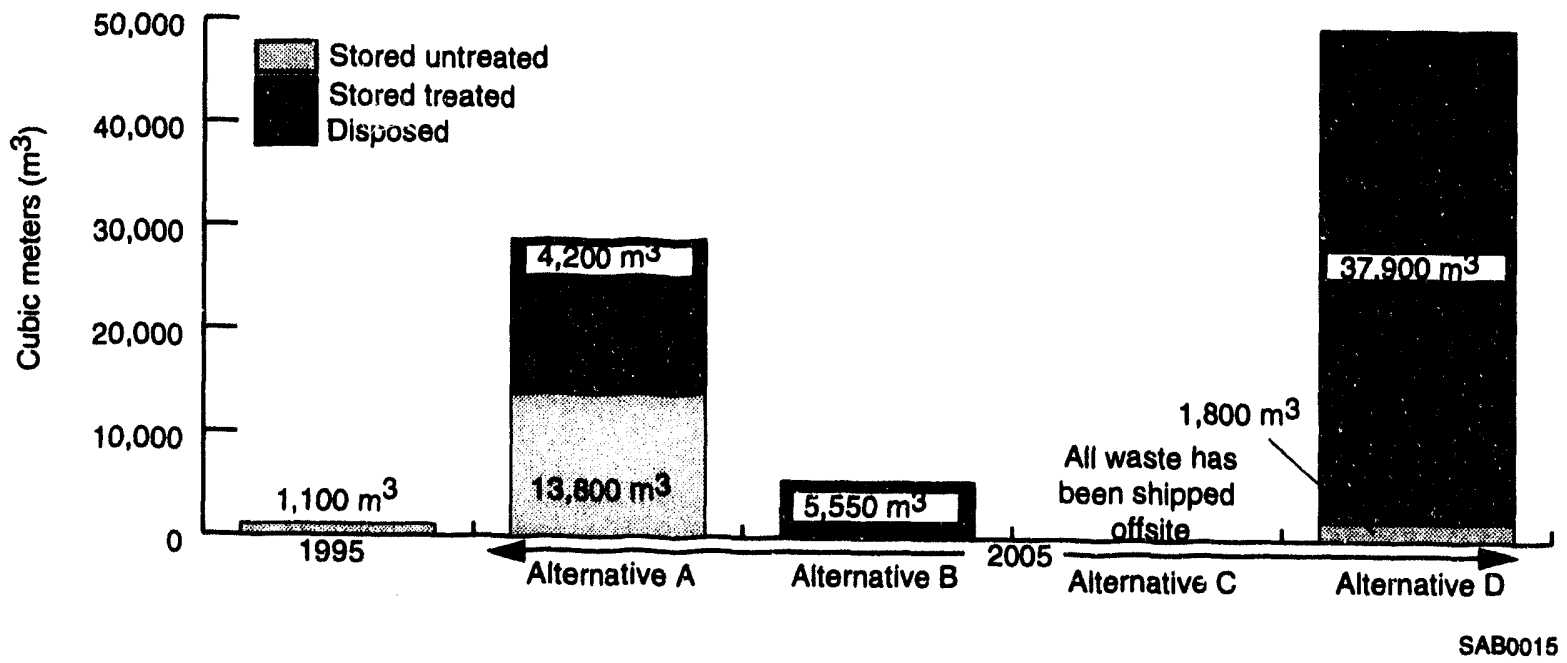

Figure 3.1-33. Mixed low-level waste volumes at the Idaho National Engineering Laboratory under the proposed alternatives: Alternative A (No Action), Alternative B (Ten-Year Plan), Alternative C (Minimum Treatment, Storage, and Disposal), and Alternative D (Maximum Treatment, Storage, and Disposal). 


\section{Greater-Than-Class-C Low-Lovel Waste}

Alternative A 9 Continue greater-than-Clans-C lov-level waste nanigement programs

Altemitive B . 4 ? Receive sealed sources for regycle or storage.

- Construct Greater-Than-Class-C Dedicated Storage Facility

Alternative $\mathrm{C}$ : $\bullet$ Discontinue greater-than-Class $\mathrm{C}$ management programs

Alternative D : 8 , 4 , Recelve sealed sources for recyclefstorage

- . Construct Greater-Than-Class C Dedicated Storage Facility

\subsubsection{Groster-Than-Class-C Low-Lovol Wasto. The INEL has been assigned} responsibility for managing the greater-than-Class-C low-level waste program. Under Alternative A (No Action), this activity would continue. The focus of the program is to determine the disposition of the greater-than-Class-C sources. Projections indicate that approximately 30,000 sealed sources/devices are held by the U. S. Nuclear Regulatory Commission and Agreement State licensees.

Under Alternative B (Ten-Year Plan), the INEL would receive greater-than-Class-C sources to store before determining the final disposition. The U. S. Nuclear Regulatory Commission has estimated that DOE acceptance of up to 2,000 sealed sources over a five-year period could be required to ensure public health and safety. Nearly all these sealed sources would be received and managed as radioactive material suitable for recycle and reuse rather than as greater-than-Class-C low-level waste, because of their continuing functionality and value. While the INEL would attempt to recycle these sources to industry, all these may need storage or disposal over the next 30 years. This would be a baseline rate of 1,000 sources or devices per year. The sources or devices would be unwanted calibration reference sources, instrumentation sources, and radiography sources and devices. These sources or devices would typically be received as leaktight capsules containing strontium- 90 , cesium-137, americium/beryllium, and plutonium/beryllium. Minor amounts of other greater-than-Class-C low-level waste types may be accepted for storage on an as-needed basis. 
Under Alternative C (Minimum Treatment, Storage, and Disposal), all greater-than-ClassC management activities would be transferred to another site. Alternatives B (Ten-Year Plan) and D (Maximum Treatment, Storage, and Disposal) are identical in their receipt and handling of greater-than-Class-C low-level waste. This waste would be stored in monitored, retrievable caslos that are shielded, leaktight, and weather-tight until a disposal facility were developed. The Greater-Than-Class-C Dedicated Low-Level Waste Storage Facility (located at Test Area North, the Test Reactor Area, or a similar INEL location, as indicated on Figure 3.1-34) would provide for consolidated management and storage of the greater-than-Class-C low-level-waste at one centralized location under Alternatives B (Ten-Year Plan) and D (Maximum Treatment, Storage, and Disposal).

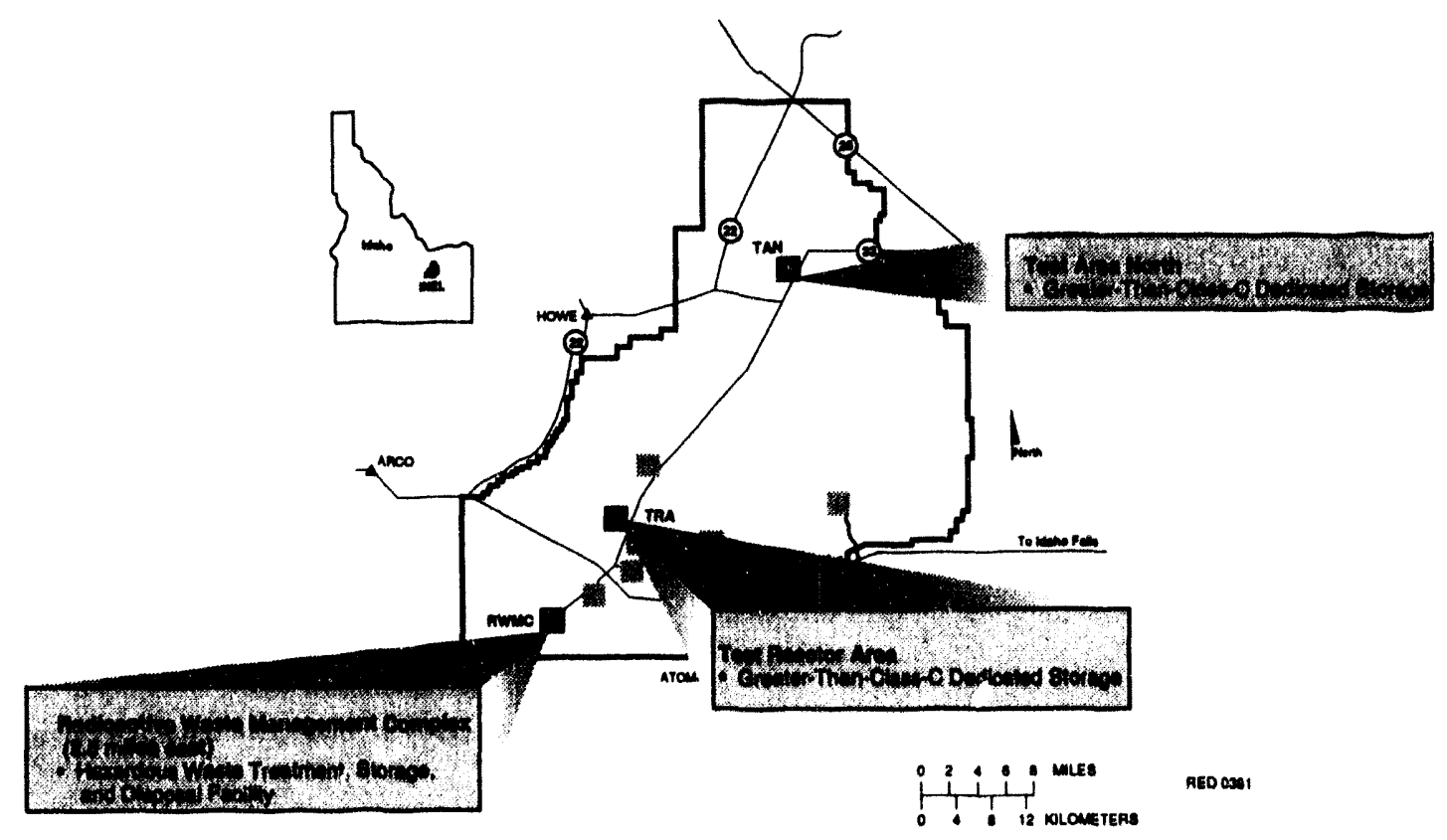

Figure 3.1-34. Greater-than-Class-C and hazardous waste: Idaho National Engineering Laboratory locations of projects associated with proposed alternatives. 


\section{Hazardous Waste}

Altermative A $\bullet$ Ship waste offsite for treatment, storage, disposal

Altemative B $\bullet \quad$ Ship waste offsite for treatment, storage, disposal

Alternative C $\bullet$ Ship yaste offsite for treatment, storage, disposal

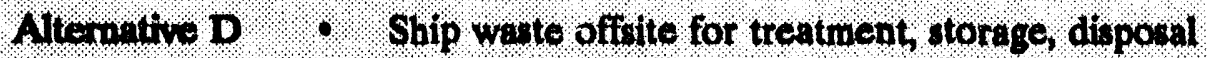

- Potentially desigh and construct Hazardous Waste Treatment. Storage and Disposal Facility

3.1.3.6 Hazardous Wasto. Management practices for hazardous waste at the INEL and throughout the DOE complex rely primarily on the private sector, as shown on Figure 3.1-35. Few changes from these practices are assumed for any alternative, as shown in Table 3.1-9. Alternatives include whether to move toward onsite treatment, storage, and disposal.

Under all alternatives, a new Waste Handling Facility would be placed in service as a central staging area for Argonne National Laboratory-West. This facility and the proposed Hazardous Waste Treatment, Storage, and Disposal Facility are described in Appendix C, Information Supporting the Alternatives. Figure 3.1-34 in Section 3.1.3.5 shows their locations.

All alternatives except Alternative D (Maximum Treatment, Storage, and Disposal) would continue activities identified in Chapter 2 for handling of hazardous waste generated onsite. About 2,700 cubic meters (3,500 cubic yards) would be generated under Alternative A (No Action) and about 12,000 cubic meters (16,000 cubic yards) under Alternatives B (Ten-Year Plan) and C (Minimum Treatment, Storage, and Disposal). Additional waste would be generated from spent nuclear fuel processing and other activities included in Alternative D (Maximum Treatment, Storage, and Disposal). The additional decontamination ard decommissioning activities and environmental restoration activities identified for all alternatives except Alternative $A$ (No Action) would result in additional waste. Onsite activities include treatment of reactives and 
Table 3.1-9. Hazardous waste: Summary of proposed management functions and related projects (denoted by bullets) at the Idaho National Engineering Laboratory (INEL) by alternative.

\begin{tabular}{|c|c|c|c|c|}
\hline Alternative & Store & Treat & Ship & Dispose \\
\hline$\frac{\text { A }}{\text { (No Action) }}$ & $\begin{array}{l}\text { Store short-term pending offsite } \\
\text { shipment } \\
\text { Stage Waste } \\
\text { - Waste Handling Facility }\end{array}$ & Treat reactives onsite & $\begin{array}{l}\text { Ship waste offisite for treatment, } \\
\text { storage, and disposal }\end{array}$ & No consite disposal \\
\hline$\frac{\text { B }}{\text { (Ten-Year Plan) }}$ & $\begin{array}{l}\text { Store short-term pending offisite } \\
\text { shipment } \\
\text { Stage Waste } \\
\text { - Waste Handling Facility }\end{array}$ & Treat reactives onsite & $\begin{array}{l}\text { Ship waste offsite for treatment, } \\
\text { storage, and disposal }\end{array}$ & No onsite disposal \\
\hline $\begin{array}{c}\text { C } \\
\text { (Minimum } \\
\text { Treatment, } \\
\text { Storage, and } \\
\text { Disposal) }\end{array}$ & $\begin{array}{l}\text { Store short-term pending offsite } \\
\text { shipment } \\
\text { Stage Waste } \\
\text { - Waste Handling Facility }\end{array}$ & Treat reactives onsite & $\begin{array}{l}\text { Ship waste offisite for treatment, } \\
\text { storage, and disposal }\end{array}$ & No cosite disposal \\
\hline $\begin{array}{c}\text { D } \\
\text { (Maximum } \\
\text { Treatment, } \\
\text { Storage and } \\
\text { Disposal) }\end{array}$ & $\begin{array}{l}\text { Plan future onsite storage } \\
\text { - Hazardous Waste Treatment, } \\
\text { Storage and Disposal Facility } \\
\text { Stage Waste } \\
\text { - Waste Handling Facility }\end{array}$ & $\begin{array}{l}\text { Treat reactives onsite } \\
\text { Move toward } 80 \% \text { onsite treatment } \\
\text { Plan future onsite treatment } \\
\text { - Hacardous Waste Treatment, Storage, } \\
\text { and Disposal Facility }\end{array}$ & $\begin{array}{l}\text { Continue to ship offsite pending } \\
\text { onsite treatment capabitities }\end{array}$ & $\begin{array}{l}\text { Plan future onsite disposal } \\
\text { - Hacardous Waste Treatment, } \\
\text { Starage, and Disposal Facility }\end{array}$ \\
\hline
\end{tabular}



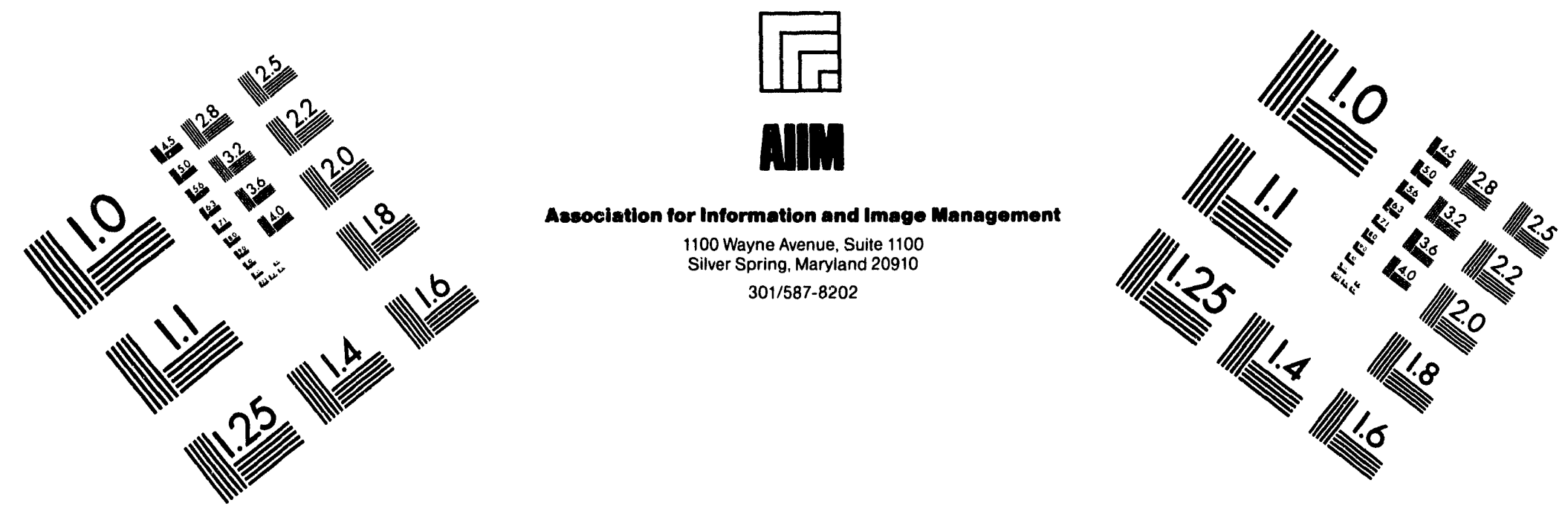

\section{Centimeter}

$\begin{array}{llllllllllllllll}1 & 2 & 3 & 4 & 5 & 6 & 7 & 8 & 9 & 10 & 11 & 12 & 13 & 14 & 15 & \mathrm{~mm}\end{array}$

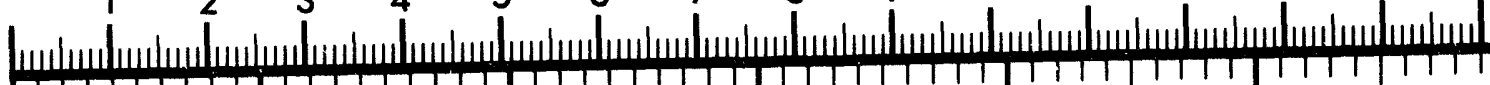

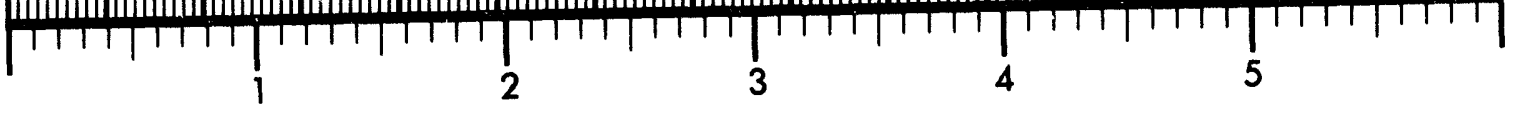

Inches
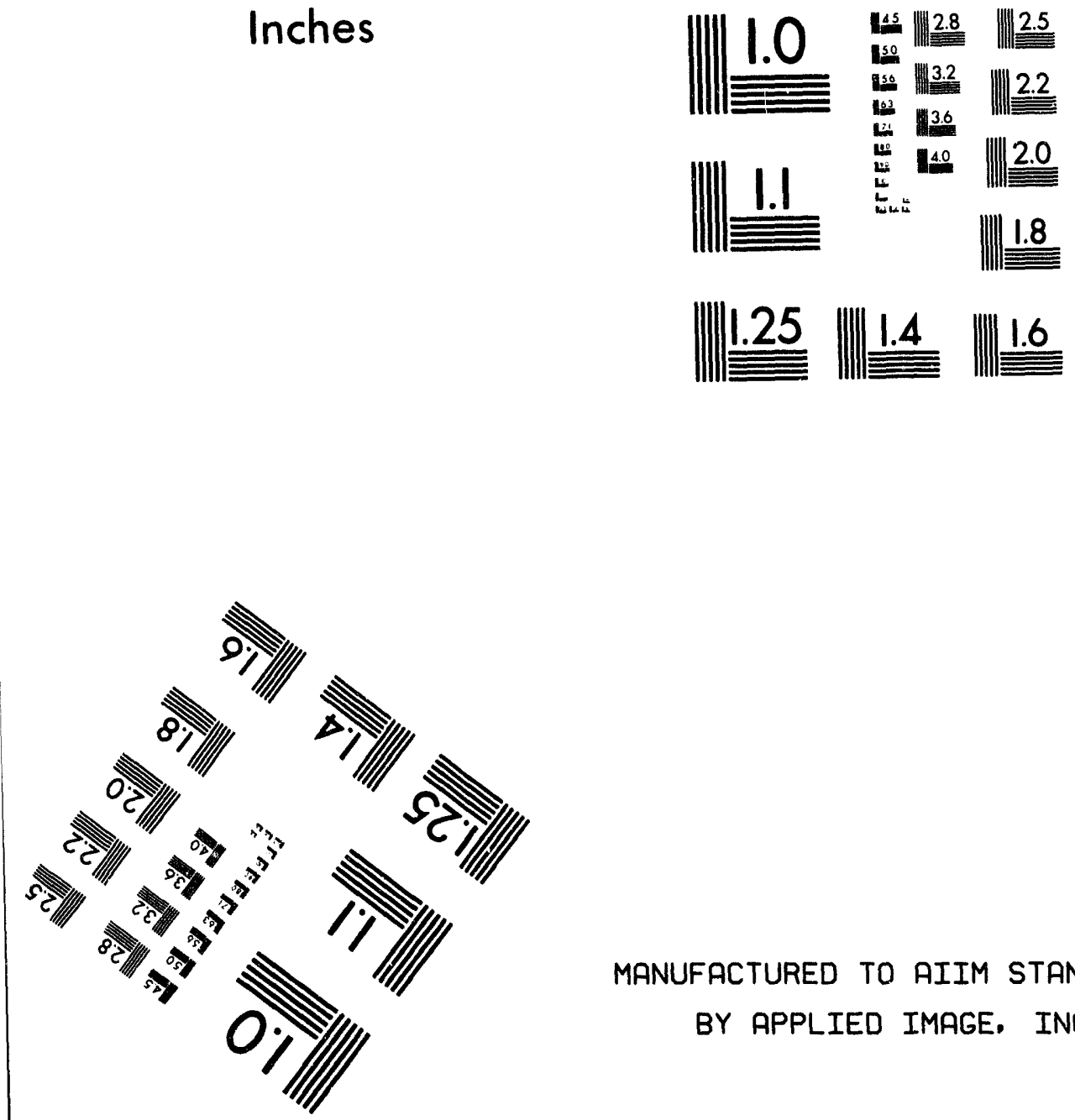

MANUFACTURED TO AIIM STANDARDS

BY APPLIED IMAGE, INC.

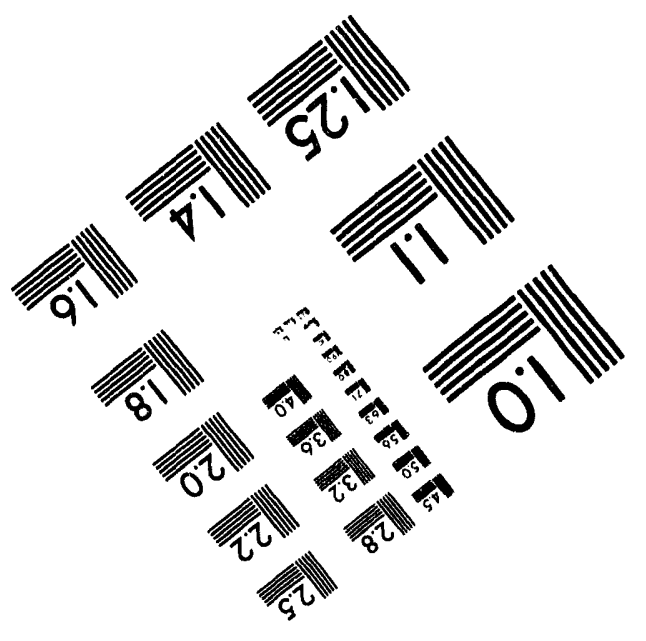



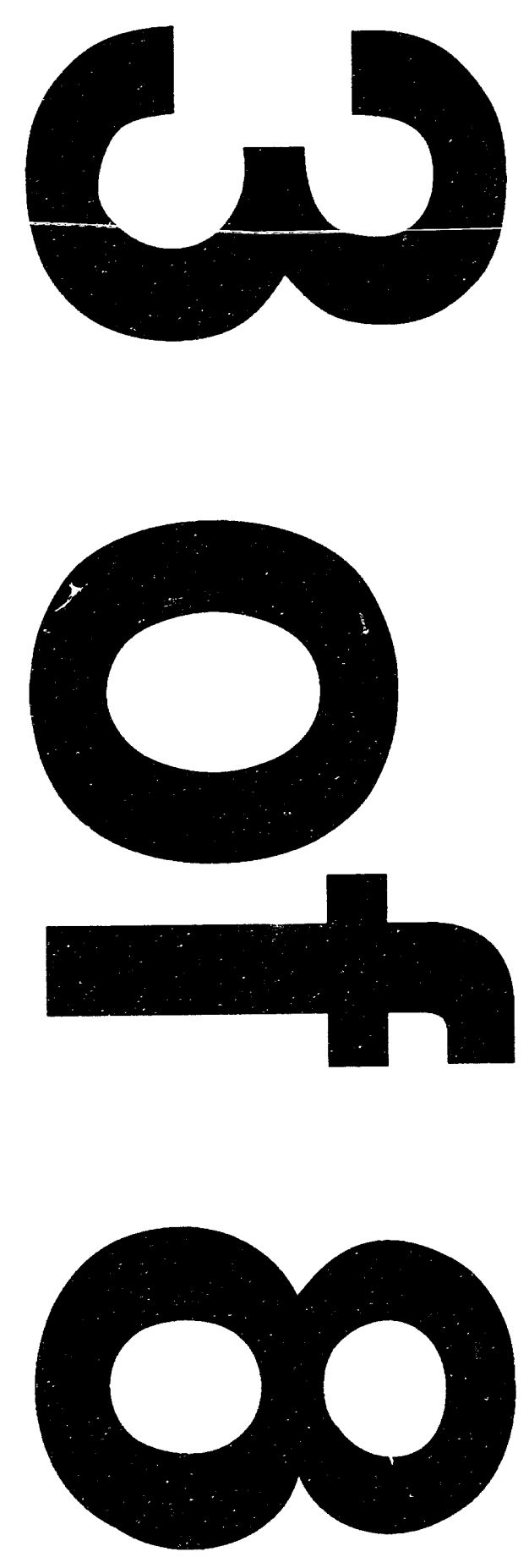


\section{Hazardous - Altematives A, B, C, D}

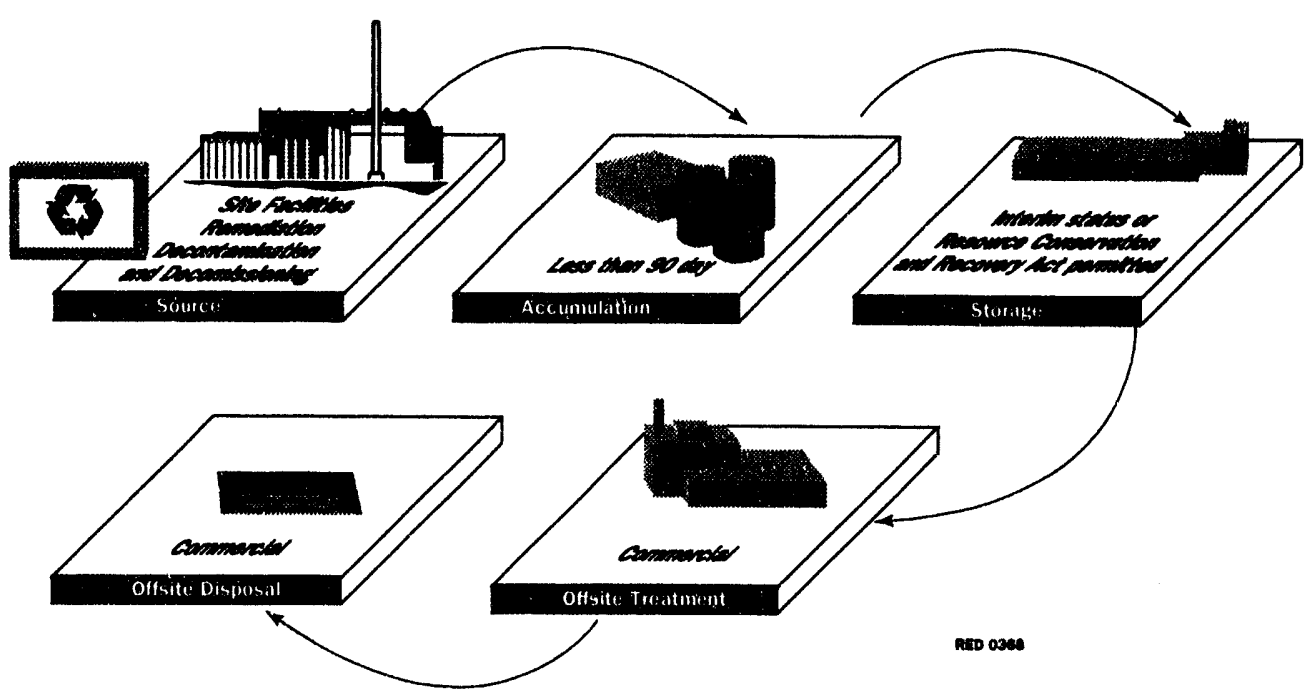

Figure 3.1-35. Management of hazardous waste at the Idaho National Engineering Laboratory under the proposed alternatives: Alternative A (No Action), Alternative B (Ten-Year Plan), Alternative C (Minimum Treatment, Storage, and Disposal), and Alternative D (Maximum Treatment, Storage, and Disposal).

shipment offsite for treatment and disposal of all other hazardous waste for Alternatives A (No Action), B (Ten-Year Plan), and C (Minimum Treatment, Storage, and Disposal). Under Alternative C (Minimum Treatment, Storage, and Disposal), hazardous waste generated at the INEL could be shipped to another DOE site, rather than a commercial facility.

Under Alternative D (Maximum Treatment, Storage, and Disposal), current practices would also continue. DOE has considered consolidating the treatment of all organic hazardous waste at a couple of locations, such as INEL. Organics constitute an estimated 80 percent of all hazardous waste throughout the DOE complex. These plans are not, however, sufficiently firm to be included in Alternative D (Maximum Treatment, Storage, and Disposal). To implement these plans, a new Hazardous Waste Treatment, Storage, and Disposal Facility would be required. This facility, if constructed, would be operational in 2008. Because this operational date is shortly after 2005, hazardous waste could be managed differently (for example, stored) under Alternative D (Maximum Treatment, Storage, and Disposal) than under the other three alternatives.

For all alternatives, all waste would be shipped offsite and no inventory of hazardous waste would remain onsite in 2005. 


\subsubsection{Infrastructure.}

A modern infrastructure exists at the INEL, including a new transportation complex. Also, the site-wide sewer system, new electrical system, and new life safety system have been upgraded. For the different alternatives, however, additional infrastructure projects would be needed. Figure 3.1-36 shows the location of the proposed projects. Under all alternatives, previously approved infrastructure projects would be completed.

Under Alternative A (No Action), those facilities not scheduled for closure would continue to be operated; minor maintenance would be performed to maintain their existing status.

\section{Infrastructure}

Altemative A

- Radiological and Eavironmental Sciences Laboratory Replacement

- Health Physics Instrument

Alternative B $4 \%$ Radiological and Environimental Sciences Laboratory Replacement

- Health Physics Instrument Laboratory.

- Industrial/Commercial Landfill

- Gravel Pit Expansions.

- Central Facilities Area Clean Laundry and Respiralor Facility

Alternative C $:$ : Radiological and Environmental Sciences Laboratory Replacement

- Health Physics Instrument Laboratory

- Industrial/Commercial Landfill

Alternative D 8 • Radiological and Environmental Sciences Laboratory Replacement

- Health Physics Instrument Laboratory

- Expanded Industrial/Commercial Landfill

- Larger Gravel Pit Expansion project

- Central Facilities Atea Clean Laundry and Respirator Facillty

This effort would not correct

outstanding environmental citations that may exist against some aspects of current facility operations.

Under Alternative B (Ten-Year Plan), existing facilities would be upgraded to the extent practicable to comply with the current State and DOE regulations. Industrial commercial landfill facilities would be increased. The gravel pits located at several locations around the INEL site would be expanded. The Clean Laundry and Respirator Facility, located at the Central Facilities Area, would be evaluated for another function. 


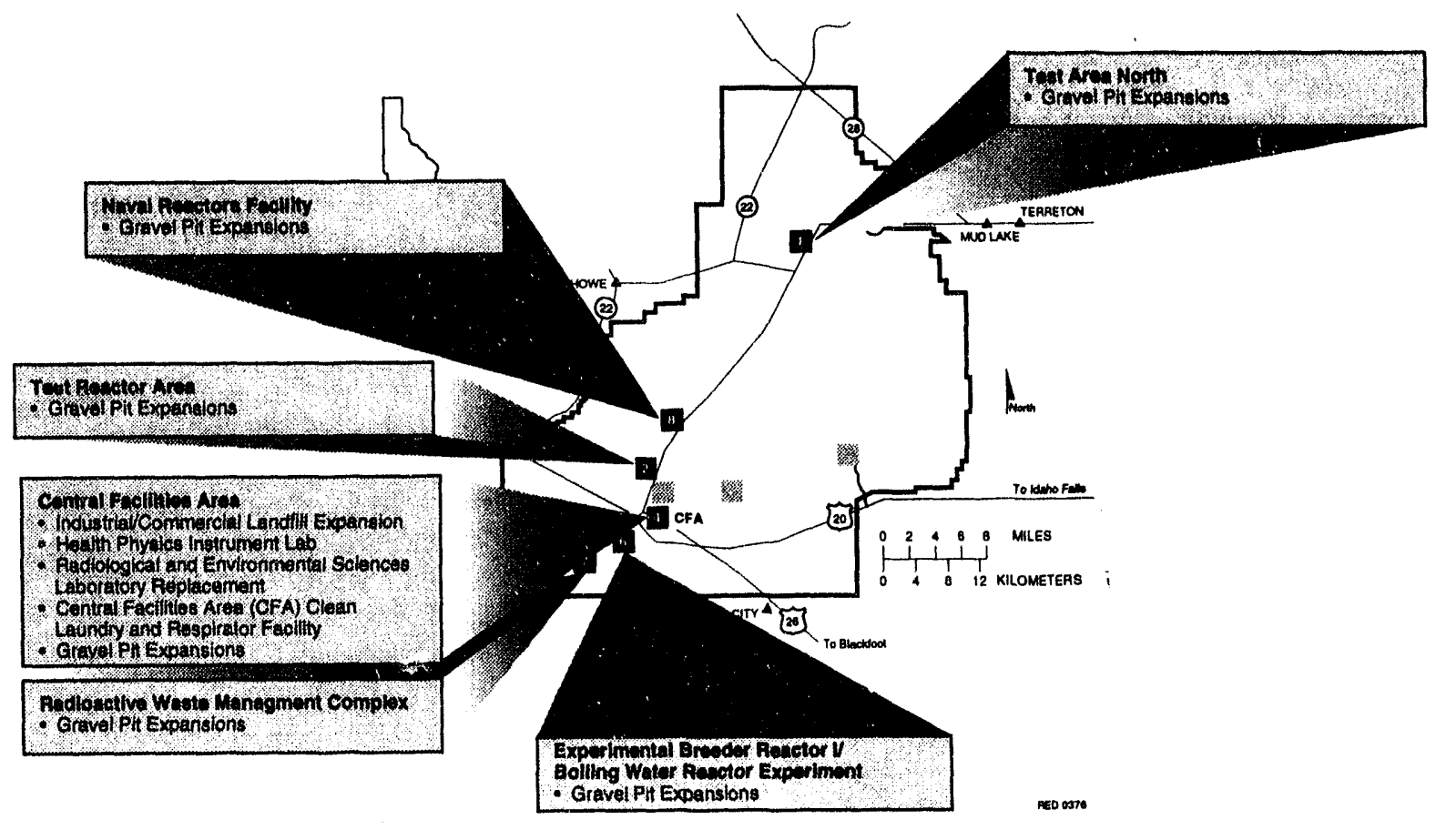

Figure 3.1-36. Infrastructure: Idaho National Engineering Laboratory locations of projects associated with proposed alternatives.

Under Alternative C (Minimum Treatment, Storage, and Disposal), a phaskout plan (excluding those infrastructure activities necessary to support operating reactors, the shipment of spent nuclear fuel and waste offsite, and continuing high-level waste work) would be developed and implemented. The only new project would be a restricted expansion of the industrial commercial landfill to support some continued activities that are necessary under this alternative.

Under Alternative D (Maximum Treatment, Storage, and Disposal), the planned infrastructure projects (landfill and gravel pits) identified for Alternative B (Ten-Year Plan) would be expanded. The reuse of the laundry in the Central Facilities Area would be evaluated. Construction of new (or upgraded) infrastructure support facilities could be necessary, primarily at or near the Radioactive Waste Management Complex. These facilities would consist of new or upgraded offices and the associated support necessary for the additional people who would be working with the increased waste management activities. 


\subsubsection{Technology Development}

Under Alternative A (No Action), only ongoing research, development, demonstration, testing, and evaluation activities would be permitted. Tests on waste treatment technologies and calcined waste and sodium-bearing waste treatment technology studies would continue. Other projects would include radionuclide sensor development, fissile material detection capability, material control and accountability tests, and existing environmental analysis methodology development. Laboratory analyses and existing waste packaging development would also continue. No new technology development initiatives would be begun and existing technology studies would not be expanded.

Under Alternative B (Ten-Year Plan), existing technology development and privatization activities would continue and additional activities would be implemented. Activities discussed under the Alternative A (No Action) would be expanded.

Specific examples of new initiatives include the Calcine Recovery Bin Set (\#1) project and the Plasma Hearth Process project; Figure 3.1-37 shows the location of these projects. The Calcine Recovery Bin Set \#1 project would demonstrate methods to retrieve calcine from bin set \#1 at the Idaho Chemical Processing Plant. The plasma hearth process is a high-temperature thermal treatment process. It uses a plasma arc torch in a refractory lined chamber to destroy organics and stabilize the residuals in a nonleaching, vitrified (glass-type) waste form. Plasma arc technology is used commercially, primarily to produce high purity alloys, and this project would adapt this existing technology.

The key elements of the plasma hearth process technology are (a) extremely high temperature operation that completely destroys organics while stabilizing inorganics; (b) acceptance of a very wide range of waste types without pretreatment; (c) treatment of waste without removing it from the container; (d) generation of separate slag and metallic phases, allowing segregation and possible reuse of the metal; and (e) the preference of many radionuclides (especially the actinides) and toxic heavy metals to migrate to the stable slag phase.

Under Alternative C (Minimum Treatment, Storage, and Disposal), technology development projects for high-level and hazardous waste treatment would continue. Technology 
development and privatization activities for other wastes and spent nuclear fuel, however, would be phased out. Similarly, privatization initiatives for transuranic, low-level, and mixed low-level wastes would be discontinued. New technology development activities would be limited. These limited new initiatives would include activities to minimize waste generation or to improve the treatment of those wastes and materials treated, stored, or disposed at the INEL site.

Technology development activities proposed under Alternative D (Maximum Treatment, Storage, and Disposal) would be similar to those activities in Alternative B (Ten-Year Plan).

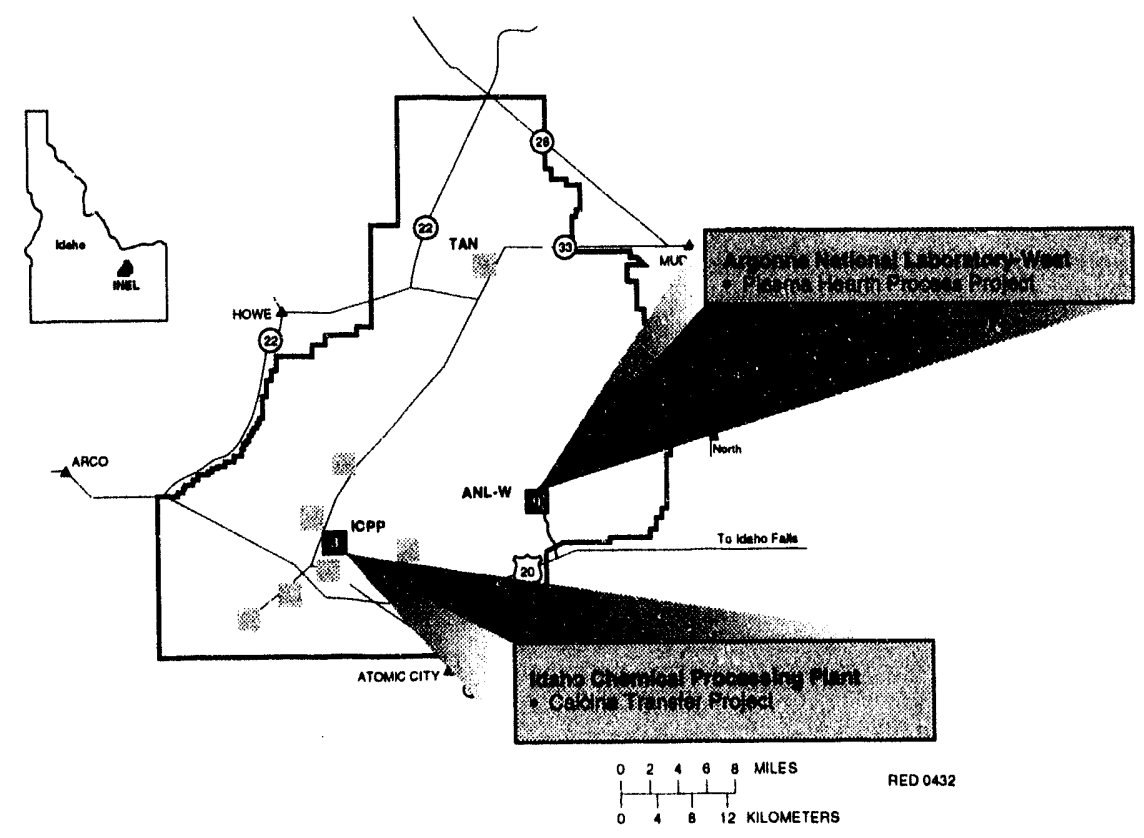

Figure 3.1-37. Technology development: Idaho National Engineering Laboratory locations of projects associated with proposed alternatives. 


\subsection{Alternatives Eliminated from Detailed Analysis}

This section describes alternatives that were considered and subsequently eliminated from further analysis.

\subsubsection{Relocate All Idaho National Engineering Laboratory Site Actlvitles to Another Site}

This alternative was examined to evaluate relocating facilities and activities associated with the specific emphases of the INEL mission.

DOE is considering a reasonable range of alternatives for managing spent nuclear fuel, including alternatives at the INEL site that would involve the transport, receipt, processing, and storage of spent nuclear fuel at sites other than the INEL. The relocation of all spent nuclear fuel activities from the INEL is evaluated in Volume 1 of this Environmental Impact Statement and is also considered under Alternative $\mathrm{C}$ (Minimum Treatment, Storage, and Disposal) of Volume 2. However, total relocation of all spent nuclear fuel activities would not be accomplished completely at the INEL during the ten-year timeframe analyzed in detail in Volume 2. This is because many of the facilities required to handle INEL spent nuclear fuel would not be available until beyond the ten-year period.

Relocating waste management facilities to another site, however, would require shipping of all waste in storage, from ongoing INEL projects (most of which is industrial commercial waste), and from environmental restoration to another site. This alternative is not feasible because neither liquid nor calcined high-level waste can be transported without further treatment and some transuranic waste would require minimal treatment before shipping. Minimal facilities would be required onsite for shipping other wastes offsite as long as other programs continue onsite. Alternative C (Minimum Treatment, Storage, and Disposal) evaluates minimum treatment, storage, and disposal facilities and activities. This alternative has been eliminated from detailed analysis.

\subsubsection{Restore the Idaho National Engineering Laboratory Site}

Restoration of sites may consider special end land uses, such as the following: 
- To provide public access to productive land for agriculture, animal husbandry, recreation, or housing development. Restoring the currently used portions of the INEL site to pristine conditions would not facilitate these uses.

- To extend and preserve a unique or very limited land resource; for example, preagricultural grasslands of the Northern Great Plains. The areas in use on the INEL site do not represent a limited or unique land resource in the area.

- To recreate or preserve an aesthetically pleasing landform or landscape. The disturbed portion of the INEL site is small compared with the entire site area and this area does not include any unusual aesthetic features.

Only about 7 percent of the 2,305-square kilometer (890-square-mile) site is currently used for facilities, including highways. Restoring this area to pristine conditions would be extremely costly without achieving any of the specific objectives identified. In addition, lava beds that have already been disturbed could not be restored to pristine conditions. Eliminating existing public highways is not likely to be acceptable to the public. Thus, this alternative has been eliminated from detailed analysis.

\subsubsection{No Cleanup or Controls}

Leaving the surplused facilities and identified remediation sites with ut cleanup or institutional controls would not only violate the Federal Facility Agreement and Consent Order and Comprehensive Environmental Response, Compensation, and Liability Act and DOE commitments to the public and State of Idaho, but could also pose a threat to the environment and to workers (and possibly the public). Thus, this alternative has been eliminated from detailed analysis. 


\subsection{Comparison of Impacts}

This section compares the potential environmental consequences of implementing each of the four alternatives described in Section 3.1, Description of Alternatives. Each alternative consists of projects and actions that would support a particular direction for environmental restoration, waste management, and spent nuclear fuel programs at the INEL over the next ten years. This brief comparison of impacts is presented to help decisionmakers and the public understard the potential environmental consequences of proceeding with each of the alternatives at the INEL. In its Record of Decision, DOE may also choose to combine projects and activities from more than one alternative.

The following discussion is based on the detailed information presented in Chapter 5 , Environmental Consequences. Also, Table 3.3-1 summarizes the potential impacts of each alternative for the various environmental disciplines and lists proposed mitigation measures that could reduce or eliminate these impacts.

\subsubsection{Land Uee}

In terms of land use (Section 5.2), implementing each of the alternatives would disturb different amounts of acreage-40 acres for Alternative A (No Action), 800 acres for Alternative B (Ten-Year Plan), approximately 350 acres for Alternative C (Minimum Treatment, Storage, and Disposal), and approximately 1,120 acres for Alternative D (Maximum Treatment, Storage, and Disposal). Some of this acreage has been previously disturbed by INEL site activities (87 percent for Alternative A, 30 percent for Alternative B, 64 percent for Alternative $C$, and 25 percent for Alternative D). The remaining acreage is open space. Regardless of the alternative, the total amount of acreage that would be disturbed would represent less than one percent of all land within the INEL site boundary.

Proposed activities at the INEL site would be consistent with existing DOE plans for continued operations, environmental restoration, and waste management and would be similar to uses in existing developed areas on the INEL site (see Section 4.2). None of the alternatives would conflict with existing land use policies for the INEL site, existing uses of lands bordering the INEL site, or local land use plans. 


\begin{tabular}{|c|c|c|c|c|}
\hline Discipline & $\begin{array}{l}\text { Alternative A } \\
\text { (No Action) }\end{array}$ & $\begin{array}{c}\text { Alternative B } \\
\text { (Ten-Year Plan) }\end{array}$ & $\begin{array}{c}\text { Alternative C } \\
\text { (Minimum Treatment, Storage, } \\
\text { and Disposal) }\end{array}$ & $\begin{array}{c}\text { Alternative D } \\
\text { (Maximum Treatment, Storage, and } \\
\text { Disposal) }\end{array}$ \\
\hline Land use ${ }^{a}$ & $\begin{array}{l}\text { About } 40 \text { total acres would be } \\
\text { disturbed; } 5 \text { acres newhy disturbed. } \\
\text { Consistent with existing DOE plans } \\
\text { and policies. No effect on surrounding } \\
\text { land uses or local plans. No adverse } \\
\text { impact expected. } \\
\text { Mitigations: None proposed. }\end{array}$ & $\begin{array}{l}\text { About } 800 \text { total acres would be disturbed; } \\
557 \text { acres newly disturbed. Consistent with } \\
\text { existing DOE plans and policies. No } \\
\text { effect on surrounding land uses or local } \\
\text { plans. No adverse impact expected. } \\
\text { Mitigations: None proposed. }\end{array}$ & $\begin{array}{l}\text { About } 350 \text { total acres would be } \\
\text { disturbed; } 127 \text { acres newty } \\
\text { disturbed. Consistent with } \\
\text { existing DOE plans and policies. } \\
\text { No effect on surrounding land } \\
\text { uses or local plans. No adverse } \\
\text { impact expected. } \\
\text { Mitigations: None proposed. }\end{array}$ & $\begin{array}{l}\text { About } 1,120 \text { total acres would be } \\
\text { disturbed, about } 842 \text { acres newly } \\
\text { disturbed. Consistent with existing DOE } \\
\text { plans and policies. No effect on } \\
\text { surrounding land uses and local plans. } \\
\text { No adverse impact expected. } \\
\text { Mitigations: None proposed. }\end{array}$ \\
\hline $\begin{array}{l}\text { Socio- } \\
\text { economics }\end{array}$ & $\begin{array}{l}\text { Decrease of } 1,280 \text { direct and } \\
\text { secondary jobs by } 2004 \text {. } \\
\text { Corresponding population decrease of } \\
1,700 \text {. No impact on community } \\
\text { services or public frnance. } \\
\text { Mitigations: None proposed. }\end{array}$ & $\begin{array}{l}\text { Increase of } 1,440 \text { direct and secondary } \\
\text { jobs by } 2004 \text {. Corresponding population } \\
\text { increase of } 920 \text {. No impact on community } \\
\text { services or public finance. } \\
\text { Mitigations: None proposed. }\end{array}$ & $\begin{array}{l}\text { Decrease of } 860 \text { direct and } \\
\text { secondary jobs by } 2004 \text {. } \\
\text { Corresponding population } \\
\text { decrease of } 1,500 \text {. No impact } \\
\text { on community services or public } \\
\text { finance. } \\
\text { Mitigations: None proposed. }\end{array}$ & $\begin{array}{l}\text { Increase of } 1,560 \text { direct and secondary } \\
\text { jobs by } 2004 \text {. Corresponding population } \\
\text { increase of } 970 \text {. No impact on } \\
\text { community services or public finance. } \\
\text { Mitigations: None proposed. }\end{array}$ \\
\hline $\begin{array}{l}\text { Cultural } \\
\text { resources }^{\mathrm{a}}\end{array}$ & $\begin{array}{l}\text { About } 40 \text { acres, } 9 \text { structures, no } \\
\text { known sites affected by ground } \\
\text { disturbance, structural modifications, } \\
\text { and so forth. Requires additional } \\
\text { survey for cultural and paleontological } \\
\text { resources. Impacts due to alteration } \\
\text { of setting unlikely. } \\
\text { Mitigations: Specific mitigation } \\
\text { measures (for example, data recovery, } \\
\text { rehabilitation) determined through } \\
\text { consultation with State Historic } \\
\text { Preservation Office and Native } \\
\text { American groups. }\end{array}$ & $\begin{array}{l}\text { Similar to Alternative A, except about } 800 \\
\text { acres, } 66 \text { structures, } 23 \text { known sites } \\
\text { affected. Requires additional survey. } \\
\text { Mitigations: Similar to Alternative A. }\end{array}$ & $\begin{array}{l}\text { Similar to Alternative A, except } \\
\text { about } 350 \text { acres, } 9 \text { structures, } \\
\text { no known sites affected. } \\
\text { Requires additional survey. } \\
\text { Mitigations: Similar to } \\
\text { Alternative A. }\end{array}$ & $\begin{array}{l}\text { About } 1,120 \text { acres, } 66 \text { structures, } 23 \\
\text { known sites affected by ground } \\
\text { disturbance, structural modifications, and } \\
\text { so forth. Requires additional survey. } \\
\text { Potential impacts due to alteration of } \\
\text { setting. } \\
\text { Mitigations: Similar to Alternative A. }\end{array}$ \\
\hline
\end{tabular}


Table 33-1. (continued)

\begin{tabular}{|c|c|c|c|c|}
\hline Discipline & $\begin{array}{l}\text { Alternative A } \\
\text { (No Action) }\end{array}$ & $\begin{array}{l}\text { Alternative B } \\
\text { (Ten-Year Plan) }\end{array}$ & $\begin{array}{c}\text { Alternative } C \\
\text { (Minimum Treatment, Storage, } \\
\text { and Disposal) }\end{array}$ & $\begin{array}{c}\text { Alternative D } \\
\text { (Maximum Treatment, Storage, and } \\
\text { Disposal) }\end{array}$ \\
\hline $\begin{array}{l}\text { Aesthetic and } \\
\text { scenic } \\
\text { resources }\end{array}$ & $\begin{array}{l}\text { No impacts from new construction or } \\
\text { siting. Potential visibility degradation } \\
\text { at Craters of the Moon Class I } \\
\text { Wilderness Area associated with } \\
\text { project emissions. } \\
\text { Mitigations: Combustion control } \\
\text { equipment installed on incinerators to } \\
\text { reduce nitrogen oxide emissions. Use } \\
\text { of standard construction practices to } \\
\text { minimize erosion and dust. }\end{array}$ & $\begin{array}{l}\text { Same as Alternative } A \text { for construction } \\
\text { and siting but greater potential for } \\
\text { visibility degradation. } \\
\text { Mitigations: More stringent combustion } \\
\text { controls to reduce nitrogen coide } \\
\text { emissions. }\end{array}$ & $\begin{array}{l}\text { Same as Alternative B. } \\
\text { Mitigations: Same as } \\
\text { Alternative B. }\end{array}$ & $\begin{array}{l}\text { Same as Alternative B. } \\
\text { Mitigations: Same as Alternative B. }\end{array}$ \\
\hline Geology & $\begin{array}{l}\text { Removal of } 226,000 \text { cubic meters of } \\
\text { aggregate from onsite gravel and } \\
\text { borrow pits. Potentially increased } \\
\text { erosion. Consumption of fossil fuels } \\
\text { and other earth resources. } \\
\text { Mitigations: Possible measures to } \\
\text { control localized erosion. No } \\
\text { mitigation of aggregate necessary. }\end{array}$ & $\begin{array}{l}\text { Similar to Alternative A, except removal } \\
\text { of } 408,000 \text { cubic meters of aggregate. } \\
\text { Mitigations: Same as Alternative A. }\end{array}$ & $\begin{array}{l}\text { Similar to Alternative A, except } \\
\text { removal of } 285,000 \text { cubic meters } \\
\text { of aggregate. } \\
\text { Mitigations: Same as } \\
\text { Alternative A. }\end{array}$ & $\begin{array}{l}\text { Similar to Alternative A, except removal } \\
\text { of about } 1.8 \text { million cubic meters of } \\
\text { aggregate. } \\
\text { Mitigations: Same as Alternative A. }\end{array}$ \\
\hline Air resources & $\begin{array}{l}\text { Radiological emissions similar in type } \\
\text { to those currently experienced, } \\
\text { although rates and doses could vary in } \\
\text { localized areas. Potential impacts on } \\
\text { visibility impairment at Craters of the } \\
\text { Moon Wilderness Area from nitrogen } \\
\text { dioxide emissions would be further } \\
\text { defined and resolved during air } \\
\text { permitting process before projects } \\
\text { could proceed. } \\
\text { Mitigations: Proposed mitigation } \\
\text { includes reducing nitrogen dioxide } \\
\text { emissions as necessary to avoid } \\
\text { visibility impairment and standard } \\
\text { control measures to reduce fugitive } \\
\text { dust generation during construction } \\
\text { activities. }\end{array}$ & $\begin{array}{l}\text { Radiological emissions similar in type to } \\
\text { those currently experienced, although rates } \\
\text { and doses could vary in localized areas. } \\
\text { Unless additionalty controlled, cumulative } \\
\text { impacts of nonradiological emissions could } \\
\text { exceed State of Idaho standards for } \\
\text { mercury and hydrochloric acid. Potential } \\
\text { impacts on visibility impairment at Craters } \\
\text { of the Moon Wilderness Area from } \\
\text { nitrogen dioxide emissions would be } \\
\text { further defined and resolved during air } \\
\text { permitting process before projects could } \\
\text { proceed. } \\
\text { Mitigations: Proposed mitigation includes } \\
\text { reducing nitrogen diocide emissions as } \\
\text { necessary to avoid visibility impairment, } \\
\text { engineering and administrative controls to } \\
\text { reduce mercury and hydrochloric acid } \\
\text { emissions, and standard control measures } \\
\text { to reduce fugitive dust generation during } \\
\text { construction activities. }\end{array}$ & $\begin{array}{l}\text { Radiological emissions similar } \\
\text { in type to those currently } \\
\text { experienced, although rates and } \\
\text { doses could vary in localized } \\
\text { areas. Potential impacts on } \\
\text { visibility impairment at Craters } \\
\text { of the Moon Wilderness Area } \\
\text { from nitrogen dioxide emissions } \\
\text { would be further defined and } \\
\text { resolved during air permitting } \\
\text { process before projects could } \\
\text { proceed. } \\
\text { Mitigations: Proposed } \\
\text { mitigation includes reducing } \\
\text { nitrogen dioxide emissions as } \\
\text { necessary to avoid visibility } \\
\text { impairment and standard } \\
\text { control measures to reduce } \\
\text { fugitive dust generation during } \\
\text { construction activities. }\end{array}$ & $\begin{array}{l}\text { Radiological emissions similar in type to } \\
\text { those currently experienced, although } \\
\text { rates and doses could vary in localized } \\
\text { areas. Unless additionally controlled, } \\
\text { cumulative impacts of nonradiological } \\
\text { emissions could erceed State of Idaho } \\
\text { standards for mercury and hydrochloric } \\
\text { acid. Potential impacts on visibility } \\
\text { impairment at Craters of the Moon } \\
\text { Wilderness Area from nitrogen dioxide } \\
\text { emissions would be further defined and } \\
\text { resolved during air permitting process } \\
\text { tefore projects could procoed. } \\
\text { Mitigations: Proposed mitigation includes } \\
\text { reducing nitrogen dioxide emissions as } \\
\text { necessary to avoid visibility impairment, } \\
\text { enginecring and administrative controls to } \\
\text { noduce mercury and hydrochloric acid } \\
\text { emissions, and standard control measures } \\
\text { to reduce fugitive dust generation during } \\
\text { construction activities. }\end{array}$ \\
\hline
\end{tabular}




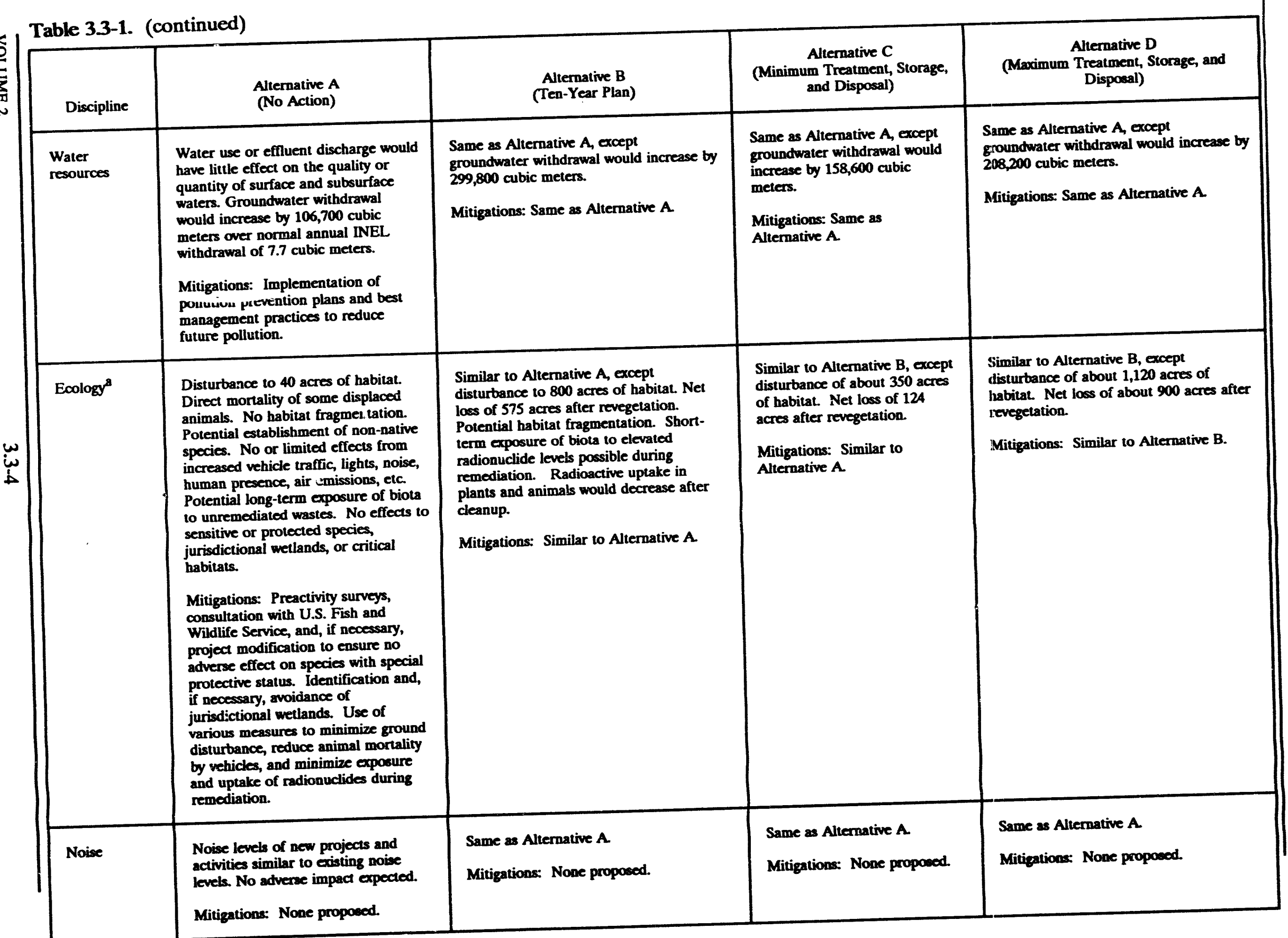


Table 3.3-1. (continued)

\begin{tabular}{|c|c|c|c|c|}
\hline Discipline & $\begin{array}{l}\text { Alternative A } \\
\text { (No Action) }\end{array}$ & $\begin{array}{c}\text { Alternative B } \\
\text { (Ten-Year Plan) }\end{array}$ & $\begin{array}{l}\text { Alternative C } \\
\text { (Minimum Treatment, Storage, } \\
\text { and Disposal) }\end{array}$ & $\begin{array}{c}\text { Alternative D } \\
\text { (Maximum Treatment, Storage, and } \\
\text { Disposal) }\end{array}$ \\
\hline $\begin{array}{l}\text { Traffic and } \\
\text { transportation }\end{array}$ & 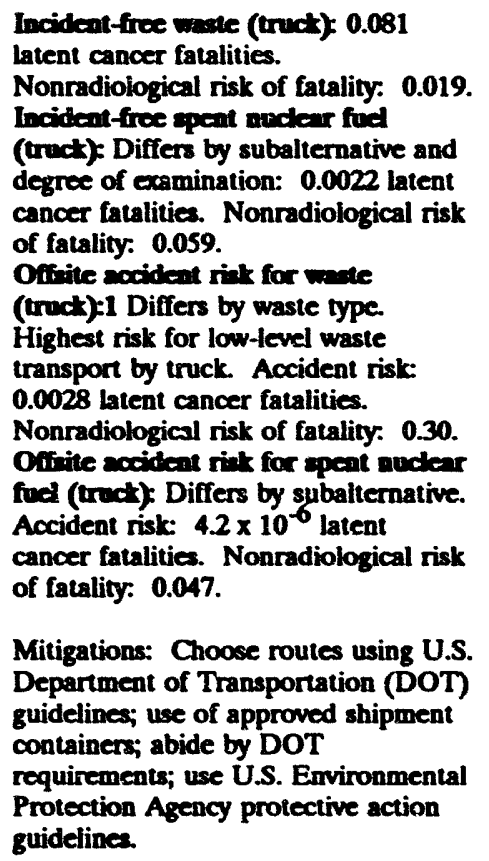 & 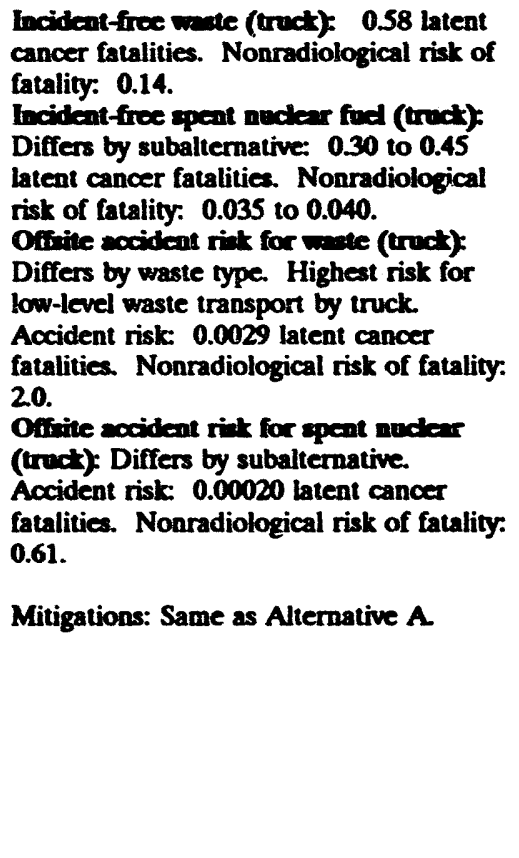 & 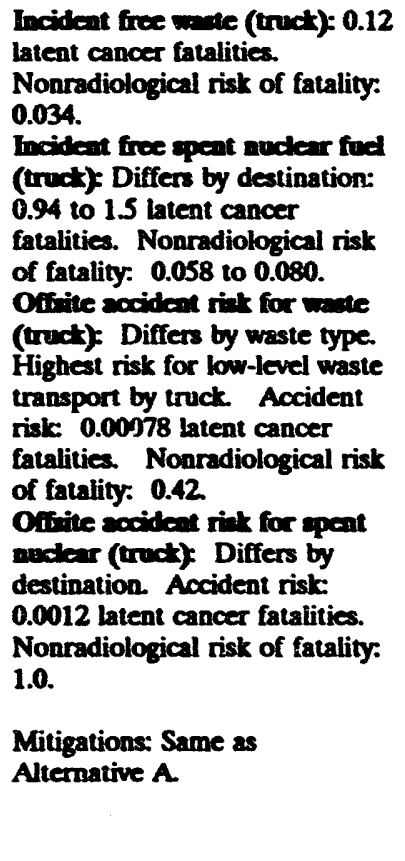 & 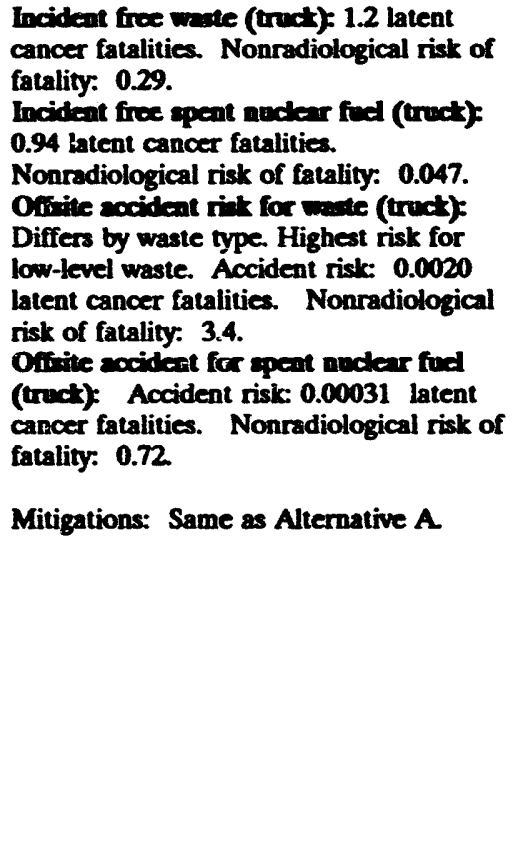 \\
\hline $\begin{array}{l}\text { Health and } \\
\text { safety }\end{array}$ & $\begin{array}{l}\text { Estimated excess cancers and other } \\
\text { health effects, illnesses and injuries } \\
\text { are expected to be less than current } \\
\text { levels each year of site operation. } \\
\text { Mitigations: None proposed. }\end{array}$ & $\begin{array}{l}\text { Same as Alternative A. } \\
\text { Mitigations: None proposed. }\end{array}$ & $\begin{array}{l}\text { Same as Alternative A } \\
\text { Mitigations: None proposed. }\end{array}$ & $\begin{array}{l}\text { Same as Alternative A. } \\
\text { Mitigations: None proposed. }\end{array}$ \\
\hline
\end{tabular}


Table 33-1. (continued)

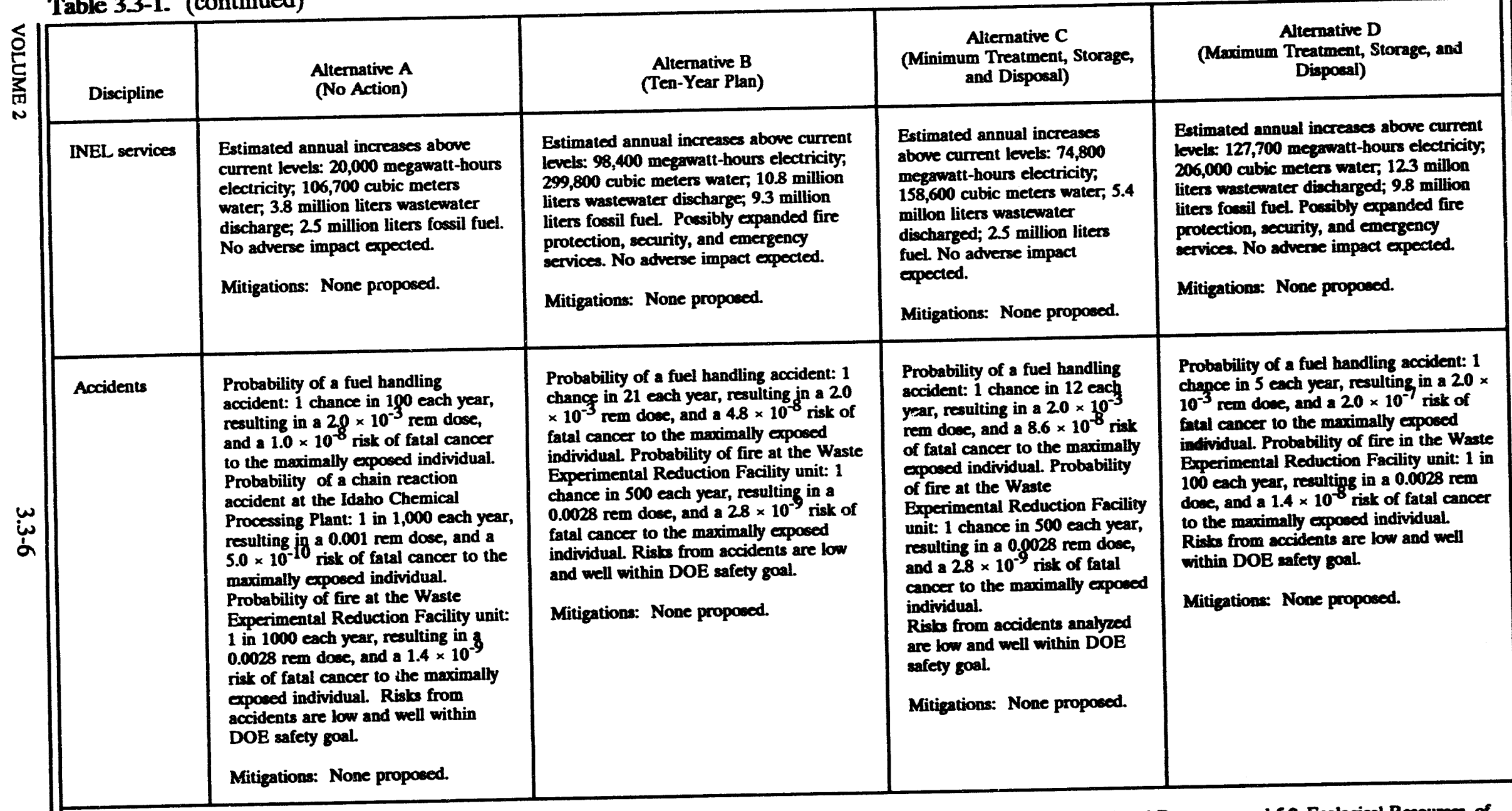

a. Numbers for these sections have been rounded. Exact numbers may be found in Sections 5.2, Land Use, 5.3, Socioeconomics, 5.4, Cultural Resources, and 5.9, Ecological Resources, of Volume 2 of this Environmental Impact Statement. 
No adverse impacts to laind use would be anticipated for any of the alternatives, and no mitigation measures are proposed.

\subsubsection{Socloeconomices}

In evaluating socioeconomic impacts (Section 5.3), each of the four alternatives was analyzed by comparing projected changes in employment, earnings, population, housing, community services, and public finance with 1995 baseline conditions. This analysis was based on the expected changes in employment and population that would occur under each alternative. It is projected that after 1995 , baseline employment at the INEL would decline over the course of the ten-year study period. Therefore, to determine the cumulative changes in employment and population from 1995 to 2005 , changes caused by each alternative were combined with the projected baseline changes.

None of the alternatives would result in greater employment and population in the region of influence by 2005 than in 1995 . However, when compared to projected baseline employment declines, employment increases associated with Alternatives B (Ten-Year Plan) and D (Maximum Treatment, Storage, and Disposal) would partially offset projected baseline employment declines in every year of the study period. Conversely, employment decreases associated with Alternatives A (No Action) and C (Minimum Treatment, Storage, and Disposal) would significantly add to projected baseline employment declines after the year 2000. All four alternatives would generate initial increases in employment, due primarily to construction activities.

Implementation of Alternative A (No Action) would result in an employment decrease of approximately 1,280 jobs by 2005 , with a corresponding population decrease of approximately 1,700 persons. Implementation of Alternative B (Ten-Year Plan) would result in an employment increase of approximately 1,440 jobs by 2005 , with a corresponding population increase of approximately 920 persons. Implementation of Alternative C (Minimum Treatment, Storage, and Disposal) would result in an employment decrease of approximately 860 jobs by 2005 , with a corresponding population decrease of approximately 1,500 persons. Implementation of Alternative D (Maximum Treatment, Storage, and Disposal) would result in an employment increase of approximately 1,560 jobs by 2005 , with a corresponding population increase of approximately 970 persons. 
All four alternatives would, when added to the declining employment baseline, result in cumulative employment and population decreases. Alternative A (No Action) would result in cumulative decreases in employment and population of approximately 3,800 and 5,040, respectively. Alternative B (Ten-Year Plan) would result in cumulative decreases in employment and population of approximately 1,070 and 2,420, respectively. Alternative C (Minimum Treatment, Storage, and Disposal) would result in cumulative decreases in employment and population of approximately 3,370 and 4,840, respectively. Alternative D (Maximum Treatment, Storage, and Disposal) would result in cumulative decreases in employment and population of apprcximately 950 and 2,360, respectively.

Under all alternatives, estimated employment and population changes would not be expected to be sufficient to generate discernible impacts to the economic resources of the region. Therefore, no mitigation measures would be required and no residual impacts would be anticipated.

\subsubsection{Cultural Resources}

As discussed in Section 5.4, potential direct impacts to cultural resources at the INEL site would be caused primarily by ground disturbance from construction activities, vandalism, modifications of historically significant structures, or changes in the environmental setting.

Alternative A (No Action) would disturb 40 acres, at least 9 potentially significant structures, and no known archaeological sites; Alternative B (Ten-Year Plan) would affect 800 acres, 66 structures, and 23 known sites; Alternative C (Minimum Treatment, Storage, and Disposal) would affect approximately 350 acres, 9 structures, and no known archaeological sites; and Alternative D (Maximum Treatment, Storage, and Disposal) would disturb approximately 1,120 acres, 66 structures, and 23 known sites. Only a fraction of the land that would be disturbed under the alternatives has undergone intensive survey for cultural resources (Alternative A, 29 percent; Alternative B, 4 percent; Alternative $C, 13$ percent; Alternative $D, 12$ percent). In the unsurveyed areas, undiscovered archaeological, traditional Native American, and paleontological resources may exist and could potentially be adversely impacted. Therefore, under each of the alternatives, a cultural resource or paleontological survey would be required. 
Except for Alternative D (Maximum Treatment, Storage, and Disposal), none of the alternatives would be likely to adversely affect the environmental setting of potentially significant cultural resources.

Under the regulations of the National Historic Preservation Act, impacts to significant cultural resources that would otherwise be found to be adverse may be reduced by appropriate scientific or historic research or by rehabilitating buildings and structures. The Shoshone-Bannock Tribe would be consulted during planning and while implementing actions potentially affecting traditional cultural properties.

\subsubsection{Aesthetic and Scenic Resources}

No adverse impacts to aesthetic and scenic resources at the INEL would be expected from implementing any of the four alternatives. New facilities would likely be located within or near existing facility areas and at least 0.5 mile ( 0.8 kilometer) from public highways. In all instances, new facilities would resemble existing facilities and would not change the visual character of the INEL site.

Very conservative modeling has indicated that visual impacts at the Craters of the Moon National Monument and its Class I Wilderness Area would be possible. If potential visual impacts at the Craters of the Moon Wilderness Area are confirmed, they would be averted by relocating the projects or by using combustion control equipment to limit nitrogen dioxide emissions in compliance with the Clean Air Act. Standard construction practices would be used to minimize erosion and dust.

\subsubsection{Geology}

Implementing any one of the four alternatives would result in minor, localized impacts on geological resources. The impacts would be caused by excavating and grading at new construction sites and by excavating aggregate material to construct new facilities. Estimates for the required aggregate range from 226,000 cubic meters for Alternative A (No Action) to 1.8 million cubic meters for Alternative D (Maximum Treatment, Storage, and Disposal). A secondary impact to 
geology would be the potential for increased soil erosion. Indirect impacts to geologic resources would include the consumption of fossil fuels, concrete, and other earth resources.

The potential for soil erosion would be mitigated by using construction prantices designed to control storm runoff and slope stability. No other mitigation measures are proposed.

\subsubsection{Air Resources}

Estimates of the type and amount of airborne radionuclide emissions (Section 5.7) likely to result from the various alternatives indicate that in all four cases the types of emissions from proposed activities would be similar to those emitted by current INEL site operations, but that the quantities would vary substantially depending on the waste management option. These releases would occur pitmarily through stacks or vents, although some fugitive emissions could also occur. In all zases, doses would be well below applicable standards and a very small percentage of the natural background dose.

For nonradiological emissions, the predicted maximum concentrations of criteria pollutants in ambient air at INEL site boundary locations, along public roads, and at Craters of the Moon Wilderness Area would be below the primary National Ambient Air Quality Standards for all alternatives. Toxic (hazardous) air pollutants at offsite locations are predicted to be below State of Idaho standards with the exception of mercury and hydrochloric acid under Alternatives B (Ten-Year Plan) and D (Maximum Treatment, Storage, and Disposal). Using conservative assumptions, the State of Idaho standards for mercury (at an INEL site boundary) and hydrochloric acid (at a public road location) would be exceeded at the INEL site boundary and public road locations under Alternatives B (Ten-Year Plan) and D (Maximum Treatment, Storage, and Disposal). These exceedances would be due to projected increases in the baseline level associated with operation of the Idaho Waste Processing Facility or a private sector treatment facility (mercury), and increases associated with incineration at the Waste Experimental Reduction Facility (hydrochloric acid). Administrative and/or engineered controls would be required to reduce emissions to achieve levels that are below the standards. In all instances, predicted onsite concentrations of toxic air pollutants from the alternatives would be well below occupational exposure limits established by the American Conference of Governmental Industrial Hygienists and Occupational Safety and Health Administration. 
The alternatives were evaluated to determine if predicted emissions would exceed established standards for the potential for ozone formation, Prevention of Significant Deterioration increment consumption, degradation of visibility at Craters of the Moon Wilderness Area, stratospheric ozone depletion, acidic deposition, and global warming. The following conclusions were reached:

- For all alternatives, emissions of volatile organic compounds would be expected to have a negligible effect on ozone formation.

- Prevention of Significant Deterioration regulations state that a proposed major project, together with the sum of other major projects in the same impact area, may not contribute to an increase in attainment pollutants above an allowable increment. The maximum onsite increment consumption has been assessed and found not to exceed 41 percent of the allowable increment for 24-hour sulfur dioxide, and lesser amounts for all other averaging times and pollutants. Alternatives B (Ten-Year Plan) and D (Maximum Treatment, Storage, and Disposal) could consume as much as 28 percent of the 24 -hour, and 20 percent of the three-hour, sulfur dioxide increments allowed for Craters of the Moon .Wilderness Area.

- Conservative visibility screen analysis indicated that a potential for visual impacts exists at Craters of the Moon Wilderness Area for all alternatives, due primarily to nitrogen dioxide emissions. Emission controls would be required if more refined modeling still predicts visibility impacts and may, in fact, be required by other regulations, even if visibility degradation criteria are not exceeded.

- While none of the alternatives would involve production or use of ozone-depleting substances, each alternative could potentially release carbon tetrachloride and freon [Alternative D (Maximum Treatment, Storage, and Disposal) only], primarily from incineration projects. These releases would be extremely small compared with global loadings and can be considered to have negligible effects. 
- Emissions of sulfur and nitrogen compounds under Alternative D (Maximum Treatment, Storage, and Disposal) would not be expected to contribute significantly to acidity levels in precipitation cither in the region or over greater distances.

- Emissions of greenhouse gases (carbon dioxide, methane, nitrous oxides, and chlorofluorocarbons) from alternatives would be exceedingly small on a global basis and would not have any detectable effect on global warming.

The alternatives would be expected to provide only a negligible increase in vehicularinduced air quality impacts. Construction of projects associated with each of the proposed alternatives would not be expected to result in exceeding the ambient air quality standards for respirable particulate matter or total suspended particulates at the INEL site boundary, although short-term localized exceedances along onsite public roads could occur.

For Alternatives B (Ten-Year Plan) and D (Maximum Treatment, Storage, and Disposal), air pollutant control equipment, administrative controls, changes in raw material feed, or design changes would likely be required on specific projects to reduce emissions of nitrogen dioxide, sulfur dioxide, hydrochloric acid, and mercury. Control of emissions of nitrogen dioxide would probably be required for Alternative A (No Action) and control of nitrogen dioxide and mercury for Alternative C (Minimum Treatment, Storage, and Disposal).

\subsubsection{Water Resources}

Each alternative was evaluated with respect to its potential impacts on water quality (both surface and subsurface water) and water use (Section 5.8). Computer modeling of contaminant transport in both the unsaturated and saturated zones shows that existing contaminant plumes do not affect regional groundwater quality and that no contaminants are presently migrating offsite in concentrations above U.S. Environmental Protection Agency drinking water standards.

None of the environmental restoration or waste management projects would intentionally discharge radioactive liquid effluents above established standards to subsurface and surface water. Implementation of pollution prevention plans and best management practices would further 
reduce the possibility of future pollution. Therefore, no water quality impacts would be expected for any of the alternatives.

Estimated groundwater withdrawal would increase over the normal annual groundwater withdrawal of 7.7 million cubic meters for all alternatives. The increases would range from 106,700 cubic meters ( 28 million gallons) for Alternative A (No Action) to 299,800 cubic meters (79 million gallons) for Alternative B (Ten-Year Plan). These increases in usage would be within INEL's consumptive use water right of 43 million cubic meters (11.4 billion gallons) per year. No adverse impact on water use would be anticipated.

\subsubsection{Ecology}

Potential ecological effects for all alternatives would vary in scale, depending on the specific locations of proposed activities (Section 5.9). The primary effect would be loss or alternation of habitat. Most would be sagebrush-steppe or previously disturbed habitat. Other potential effects would include direct mortality caused by land clearing, facility removal, or vehicular traffic; displacement of some species; change in habitat use by animals due to human presence nearby; and exposure to radionuclides, hazardous contaminants, and wastes. Habitat fragmentation would be a potential impact in all cases except Alternative A (No Action).

Federal protected and candidate species and State-sensitive species would probably not be affected by implementing any alternative. No critical habitat for protected species has been designated on the INEL site; therefore, no effects would occur. Jurisdictional wetlands and aquatic resources would probably not be affected under any of the alternatives.

Activities under Alternatives A (No Action), B (Ten-Year Plan), C (Minimum Treatment, Storage, and Disposal), and D (Maximum Treatment, Storage, and Disposal) would result in similar types of short-term and long-term ecological impacts, although the size and location of impacted areas would differ. Potential short-term impacts from the alternatives include loss of plant productivity, localized biodiversity loss, and the potential establishment of nonnative plants on the acreage that would be disturbed. The long-term net loss of land productivity would result from constructing and operating new facilities, expanding the landfill, and excavating sand and gravel. For all alternatives except Alternative $\mathrm{A}$, revegetating with native plants and grasses on 
disturbed land would lessen the long-term net loss of potential habitat. Remediation of sites and facilities would lower long-term radionuclide exposure and uptake by plants and animals.

However, in the short-term, remediation may increase exposure and uptake by plants and animals compared with current levels. For Alternatives B, C, and D, potential long-term exposure and uptake would be lower compared with Alternative $A$ as additional sites and facilities would be remediat $x$.

For all alternatives, preactivity surveys for sensitive and protected species and habitats, identification of jurisdictional wetlands, and consultation with appropriate agencies may be required. Needed mitigations would be explicitly identified, based on the results of the surveys and consultations.

\subsubsection{Nolse}

As discussed in Section 5.10, noise impacts at INEL for each alternative would come from noises generated during the transportation of personnel and materials to and from the INEL site and within nearby communities. These noises would largely be a function of the size of the work force and would be related to the use of buses.

Because the overall operations workforce stationed at the INEL site would be expected to decrease during the ten-year study period for all alternatives (see Section 5.3, Socioeconomics), the overall noise level resulting from INEL site bus transportation would be expected to decrease slightly.

No adverse noise impacts would be anticipated, and no mitigation measures would be required.

\subsubsection{Traffic and Tranaportation}

The increased traffic and transportation near the INEL caused by activities associated with all four of the alternatives would be within the capacity of the current road system and would cause minimal impacts (see Section 5.11). 
The risks of health effects from transporting radiological and nonradiological materials were calculated considering both incident-free conditions and accident scenarios. For offsite incident-free transportation of radioactive waste and spent nuclear fuel, about three latent cancer fatalities were estimated to result from all alternatives for both occupational and general population exposures. Less than one nonradiological fatality was estimated for all alternatives for members of the public.

The potential impacts from onsite transportation accidents involving spent nuclear fuel or radioactive waste were evaluated for the alternatives by assessing bounding accident scenarios. The bounding accident scenarios are extremely unlikely events with likelihoods ranging from once in 26,000 years to once in ten million years. For the bounding onsite spent nuclear fuel transportation accident, the fatal cancer risk for the population within 80 kilometers (50 miles) would be on the order of one in a million years for a rural population zone and about one in 29,000 years for a suburban population zone. For the bounding onsite radioactive waste transportation accident, the fatal cancer risk for the population within 80 kilometers (50 miles) would be on the order of two in a million years for a rural population zone and about one in 18,000 years for a suburban population zone.

The potential impacts from offsite transportation accidents involving spent nuclear fuel or radioactive waste were evaluated by calculating the probabilities and consequences from a spectrum of unlikely accidents. The resulting estimates of accident risk were used to compare relative transportation impacts among the alternatives, as shown in Table 3.3-1. For spent nuclear fuel, the radiological risk from transportation accidents would be highest for Alternative $\mathrm{C}$ (Minimum Treatment, Storage, and Disposal) and would be minimized by Alternative A (No Action). For radioactive waste, radiological risk from transportation accidents would be highest for Alternatives A and B (Ten-Year Plan) and the minimum risk would occur under Alternative C.

In addition to radiological risks associated with the accidental release of radioactivity, transportation accidents also pose nonradiological risks, such as risk of fatality from the physical impact sustained during an accident. As shown in Section 5.11, the risk of fatalities from vehicle impacts would be zpproximately 10 to 10,000 times higher than the risk of fatal cancers from accidental release of radioactivity. From this perspective, the nonradiological risk from 
transportation accidents would be highest for Alternative D (Maximum Treatment, Storage, and Disposal) and would be minimized by Alternative A (No Action).

The potential impacts from offsite transportation accidents involving nonradiological hazardous materials and wastes would be bounded by accidents associated with shipments of bulk chemicals. The bounding accident would be a release of nitric acid from a tanker truck and has a likelihood ranging from once in 2,000 years to once in 200,000 years. The accident would be most likely to occur in a rural population zone with neutral weather conditions and one person might be exposed to potentially life-threatening concentrations of nitric acid in the air. The most unlikely accident would occur in an urban population zone under stable weather conditions and could potentially expose over 3,000 persons to life-threatening air concentrations.

The impacts to the regional traffic system around the INEL would be minimal for all alternatives.

Impacts of transportation could be mitigated in a number of ways, including choosing shipment routes using U.S. Department of Transportation routing guidelines and using approved shipment containers.

\subsubsection{Health and Safety}

Under all the alternatives, the activities to be performed by workers and their associated work place hazards would be similar to those for current INEL activities. Conservative estimates of potential impacts to public health and safety were made for all alternatives for both radiological and nonradiological exposures. Implementing any of the alternatives would result in a small potential for additional fatal cancers for the population within 80 kilometers ( 50 miles) of the INEL site due to radiological exposures. The total additional fatal cancers would range from about $\mathbf{0 . 0 0 2}$ for Alternatives A (No Action) and C (Minimum Treatment, Storage, and Disposal) to about 0.05 for Alternative D (Maximum Treatment, Storage, and Disposal). Risk of fatal cancer to the maximally exposed worker would range from one in about 770,000 (Alternatives $\mathrm{A}$ and $C$ ) to one in about 400,000 (Alternative D). The risk of fatal cancer to the maximally exposed offsite individual would range from one in about $1,400,000$ (Alternative $A$ ) to one in about 270,000 (Alternative D). 
Again, using conservative modelling methods and assumptions, exposure to nonradiological substances would not be expected to result in adverse health effects for onsite workers, although benzene contributions in Alternative D (Maximum Treatment, Storage, and Disposal) would represent a very small increase (about 0.1 percent) over the baseline. At the INEL site boundary and public roads, adverse health effects from exposure to mercury and hydrochloric acid cannot be completely ruled out under Alternatives B (Ten-Year Plan) and D. The lifetime cancer risk from offsite concentrations of carcinogenic air pollutants was assessed for offsite individuals at areas predicted to have the highest estimated carcinogen air concentrations. This risk would be approximately one in 500,000 for all alternatives.

Work place hazards would be reduced by the occupational and radiological safety programs and regulatory standards currently in place. Collective radiation doses, resulting health effects, and estimated nonradiological health effects would be expected to be less than current levels for all alternatives because of the expected decline in total employment at the INEL.

\subsubsection{Idaho National Engineering Laboratory Services}

The consumption of electrical energy and fossil-based fuels, the withdrawal of water, and the discharge of wastewater at the INEL site would be greatest under Alternative D (Maximum Treatment, Storage, and Disposal). Under all alternatives, impacts from new facility construction and electrical and utility usage would be expected to be minor. The expected increases in fossil fuel usage would be within the INEL site supply capability. Increases in INEL fire, security, and emergency services might be required for Alternatives B (Ten-Year Plan) and D (Maximum Treatment, Storage, and Disposal).

INEL facilities within the City of Idaho Falls would not be expected to expand under any of the alternatives. Therefore, city services and natural gas supplies would not be impacted by implementation of any of the alternatives.

\subsubsection{Facillty Accidente}

The potential accidents that could occur at INEL facilities during implementation of the alternatives would be expected to be similar to those that have occurred in the past. Additional 
accident scenarios, such as fire, human error, sabotage, and natural phenomena, were identified and analyzed for potential impacts on human health and the environment. The maximum reasonably foreseeable accident scenarios were selected to reflect the waste types, hazardous materials, and decontamination and decommissioning activities applicable to every alternative.

For Alternative A (No Action), limited potential would exist for a fuel handling accident (one chance in 100 of an event each year). Limited potential exists for calcined waste dispersion at the Idaho Chemical Processing Plant (one chance in 100,000 of an event each year). These accidents would produce a one in $\mathbf{1 0 0}$ million risk of fatal cancer per year for a person who receives the maximum possible exposure while standing at the INEL site boundary. Limited potential (one chance in 1,000) would exist for a fire at the Waste Experimental Reduction Facility or the Radioactive Waste Management Complex. Fires at these facilities could release mixed low-level or low-level radioactive waste to the environment; however, the risk of fatal cancer would be less than cited above.

Using the same maximum reasonably foreseeable accident scenarios for Alternative B (Ten-Year Plan), there would be an increased potential (one chance in 21) for a fuel handling accident caused by construction activities and the receipt of additional offsite spent nuclear fuel shipments to the INEL site. Like Alternative A (No Action), the risk of fatal cancer per year for the maximally exposed individual standing at the INEL site boundary would be negligible (one in 21 million). The risk of fire at the Radioactive Waste Management Complex or the Waste Experimental Reduction Facility would increase by a factor of two over Alternative $A$ because of projected waste-handling activities. The risks of fatal cancer per year resulting from these accidents would be one chance in $\mathbf{3 0 0}$ million.

For Alternative C (Minimum Treatment, Storage, and Disposal), there would be limited potential (one chance in 12) for a fuel handling accident due to increased fuel handling activities. The chance of a fire at the Waste Experimental Reduction Facility would be one in 500 because of the increased handling necessary to package and transport mixed low-level and low-level waste from the INEL site. Like Alternatives A (No Action) and B (Ten-Year Plan), the corresponding risk of fatal cancer per year would be negligible for the maximally exposed individual at the site boundary. 
The potential for accidents under Alternative D (Maximum Treatment, Storage, and Disposal) would be greater than under the other alternatives because of the receipt of additional offsite shipments of waste and relatively long-cooled spent nuclear fuel, and spent nuclear fuel processing for ultimate disposal. The additional handling needed to receive and store spent nuclear fuel would be approximately 20 times that of Alternative A (No Action). Although the frequency of potential fuel handling accidents would be greater than under other alternatives, the consequences would not. Likewise, the consequences would be approximately the same for an accidental fire involving mixed low-level and low-level waste. The risk of fire would be expected to be more than ten-fold greater than under Alternative A due to the receipt of DOE complexwide waste for treatment, storage, and disposal.

For all alternatives, the risk of accidents would be low and well within DOE safety goals.

\subsubsection{Conclusion}

The four alternatives present different approaches to organizing environmental restoration, spent nuclear fuel, and waste management activities at the INEL over the next ten years. Each alternative provides some continuity for existing facilities and activities. Implementing each alternative, however, would produce different environmental consequences.

For the various disciplines, these impacts may be major or minor, direct or indirect, adverse or beneficial, long-term or short-term. For example, one difference among the alternatives would be the amount of remediation at the INEL site; and this has implications for environmental consequences. Under all the alternatives except Alternative A (No Action), contaminated areas would be cleaned up in accordance with agreements outlined in the Federal Facility Agreement and Consent Order. The land would then be available for reuse, reducing the potential long-term risks of contamination to human health and the environment. Implementing Alternative A (No Action), however, would continue the current use restrictions for land identified as contaminated, as well as violate DOE commitments and applicable environmental laws.

Among the four alternatives, Alternative C (Minimum Treatment, Storage, and Disposal) would perhaps have the fewest overall environmental consequences for the INEL. Because spent 
nuclear fuel and all waste types, except high-level waste, would be transferred to another site, impacts associated with health and safety, air resources, and water resources would decrease. However, environmental impacts would consequently increase at the receiving DOE site(s). Alternative $\mathrm{C}$ would also offer the least potential for using INEL facilities and developing new technologies to address waste-related issues affecting the total DOE complex.

Alternative D (Maximum Treatment, Storage, and Disposal) would probably have the greatest overall potential for environmental consequences. This alternative would also result in the largest commitment of the INEL resources to sddress waste-related issues throughout the DOE complex.

The alternatives differ in the approximate disturbed acreage within and outside of existing facilities. More land would be disturbed by Alternatives B (Ten-Year Plan) and D (Maximum Treatment, Storage, and Disposal) because of waste management and environmental restoration. Immediate consequences of disturbing land, especially outside current facility areas, would include habitat loss, displacement or mortality of individual plants or animals, and temporary exposure of plants and animals to elevated radionuclide levels.

Different patterns of moving nonradioactive and radioactive materials in each alternative would result in different collective doses to workers and the public during normal (incident-free) transportation. More shipments of waste and spent nuclear fuel are planned for Alternative D (Maximum Treatment, Storage, and Disposal) than for the other alternatives, which would result in correspondingly higher exposures. Alternative A (No Action) would yield the smallest collective dose, while the collective doses for Alternatives B (Ten-Year Plan) and C (Minimum Treatment, Storage, and Disposal) would be approximately equal. 


\section{AFFECTED ENVIRONMENT}

\subsection{Introduction}

Chapter 4 describes the currently existing environment at the Idaho National Engineering Laboratory site, the Idaho Falls facilities, and the surrounding region. Only those areas that might be affected by the proposed environmental restoration and waste management alternatives are included. This chapter provides the environmental conditions against which the potential environmental effects of the various alternatives can be measured. 


\subsection{Land Use}

The INEL site encompasses 570,914 acres (2,310 square kilometers) within Butte, Bingham, Bonneville, Jefferson, and Clark counties (see Figure 4.2-1). This section includes a brief description of existing land uses at the INEL and in the surrounding region, and land use plans and policies applicable to the surrounding area.

\subsubsection{Existing and Planned Land Uses at the Idaho National Engineering Laboratory}

Categories of land use at the INEL site include facility operations, grazing, general open space, and infrastructure such as roads. Facility operations include industrial and support operations associated with energy research and waste management activities (activities also conducted at the Idaho Falls facilities). Land is also used for recreation and environmental research associated with the designation of the INEL as a National Environmental Research Park. Much of the INEL site is open space that has not been designated for specific uses. Some of this space serves as a buffer zone between INEL facilities and other land uses. About 2 percent of the total INEL site area $(11,400$ acres or 46 square kilometers) is used for facilities and operations. Public access to most facility areas is restricted. Approximately 6 percent of the INEL site, or 32,985 acres (134 square kilometers), is devoted to public roads and utility rights-ofway that cross the site. Recreational uses include public tours of general facility areas and the Experimental Breeder Reactor-I (a National Historic Landmark), and controlled hunting, which is generally restricted to half a mile ( 0.8 kilometer) within the INEL boundary. Between 300,000 and 350,000 acres (1,214 and 1,416 square kilometers) are used for cattle and sheep grazing. A 900-acre (4 square kilometers) portion of this land, located at the junction of Idaho State Highways 28 and 33, is used by the U.S. Sheep Experiment Station as a winter feed lot for approximately 6,500 sheep. Grazing is not allowed within 2 miles ( 3 kilometers) of any nuclear facility, and, to avoid the possibility of milk contamination by long-lived radionuclides, dairy cattle are not permitted. Rights-of-way and grazing permits are granted and administered by the U. S. Department of the Interior's Bureau of Land Management. Selected land uses at the INEL and in the surrounding region are presented in Figure 4.2-2.

DOE land use plans and policies applicable to the INEL include the INEL Institutional Plan for FY 1994-1999 (DOE-ID 1993a) and the INEL Technical Site Information Report 


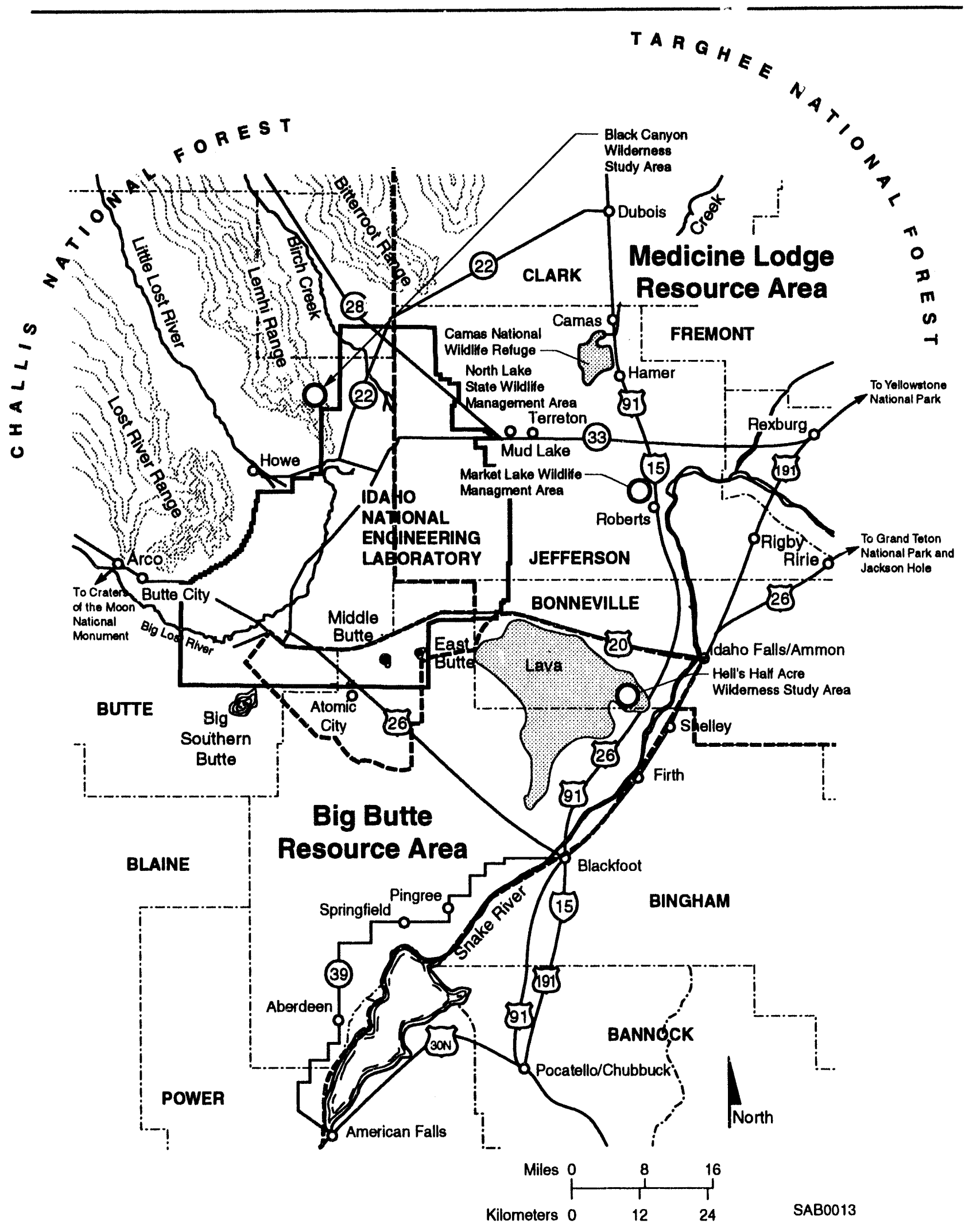

Figure 4.2-1. Idaho National Engineering Laboratory site vicinity map. 


$\begin{array}{ll}\text { ANL-W } & \text { Argonne National Laboratory-West } \\ \text { ARA } & \text { Auxillary Reactor Area } \\ \text { CFA } & \text { Central Facilities Area } \\ \text { EBR-I } & \text { Experimental Breeder Reactor - I } \\ \text { ICPP } & \text { Idaho Chemical Processing Plant } \\ \text { NRF } & \text { Naval Reactors Facility } \\ \text { PBF } & \text { Power Burst Facilly } \\ \text { RWMC } & \text { Radioactive Waste Management Complex } \\ \text { TAN } & \text { Test Area North } \\ \text { TRA } & \text { Test Reactor Area } \\ \text { WERF } & \text { Waste Experimental Reduction Facility }\end{array}$

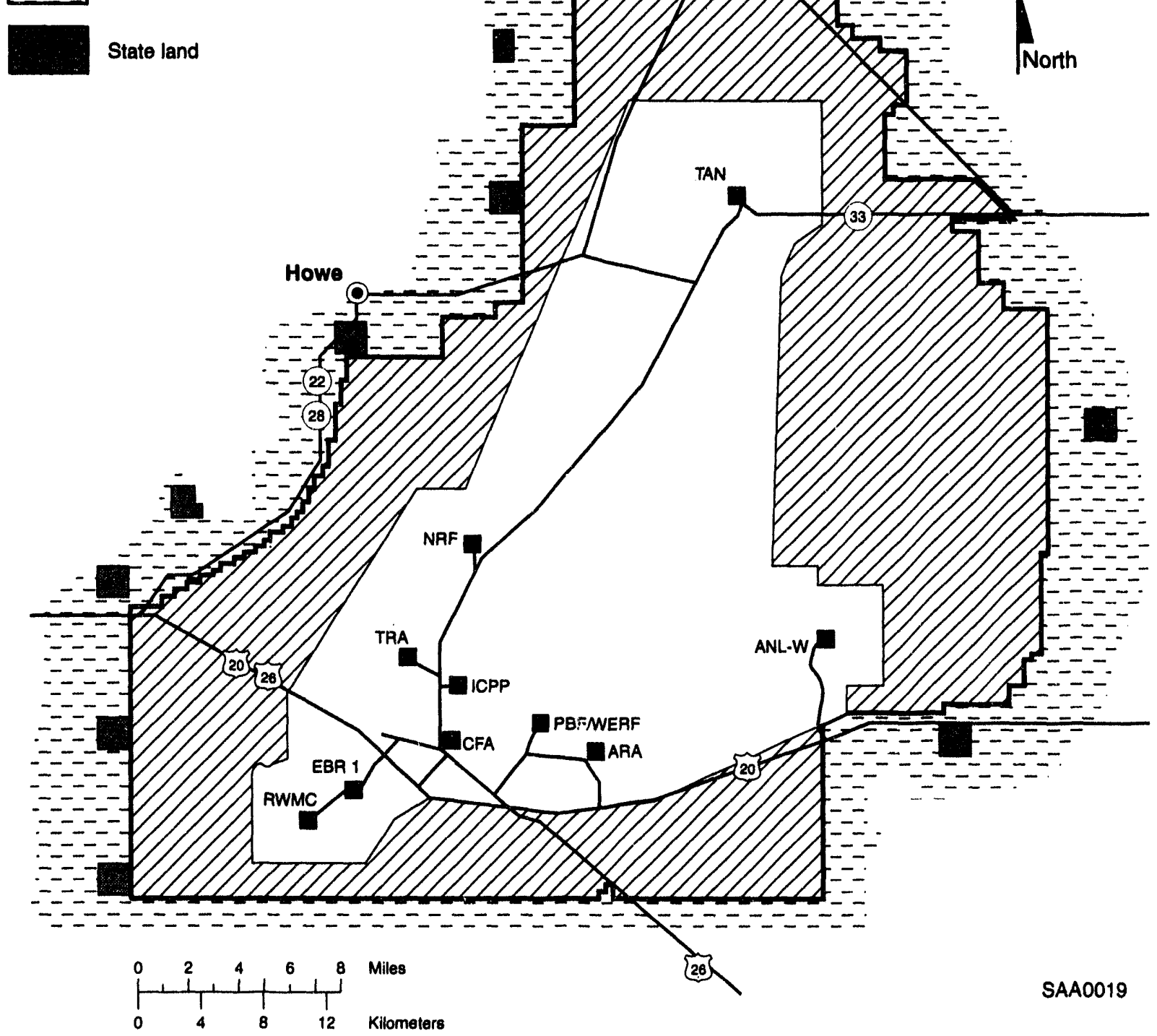

Figure 4.2-2 Selected land uses at the Idaho National Engineering Laboratory site and in the surrounding region. 
(Smith et al, 1993). The Institutional Plan provides a general overview of INEL facilities, outlines strategic program directions and major construction projects, and identifies specific technical programs and capital equipment needs. The Technical Site Information Report presents a 20-year master plan for development activities at the site. In general, it is expected that energy research and waste management activities would continue in existing facility areas and, in some instances, expand into currently undeveloped site areas. These documents also describe environmental restoration, waste management, and spent nuclear fuel activities. Projected future land use scenarios for the next $\mathbf{2 5}$ to $\mathbf{5 0}$ years include outgrowth of current functional areas and possible development of waterfowl production ponds within existing grazing areas.

The INEL site is located within the Medicine Lodge Resource Area (approximately 140,415 acres or 568 square kilometers in the eastern and southern portions of the INEL site) and the Big Butte Resource Area (430,499 acres or 1,742 square kilometers in the central and western portions), both of which are administered by the Bureau of Land Management (see Figure 4.2-1). Under Resource Management Plans, portions of these resource areas are managed for grazing and wildlife habitat. No mineral exploration or development is allowed on INEL land.

No onsite land use restrictions due to Native American treaty rights would exist for any of the alternatives described in this EIS. Potential impacts of the alternatives upon Native American and other cultural resources, and mitigation measures, are discussed in the Chapter 5 Cultural Resources Section 5.4.

\subsubsection{Existing and Planned Land Use in Surrounding Areas}

Lands surrounding the INEL site are owned by the Federal government, the State of Idaho, and private parties. Land uses on federally owned land consist of grazing, wildlife management, range land, mineral and energy production, and recreational uses. State-owned lands are used for grazing, wildlife management, and recreational purposes. Privately owned lands are used primarily for grazing, crop production, and range land.

Small communities and towns located near the INEL boundaries include Mud Lake to the east; Arco, Butte City, and Howe to the west; and Atomic City to the south. The larger communities of Idaho Falls/Ammon, Rexburg, Blackfoot, and Pocatello/Chubbuck are located to the east and southeast of the INEL site. The Fort Hall Indian Reservation is located southeast of 
the INEL site. Recreation and tourist attractions in the region surrounding the INEL site include Craters of the Moon National Monument, Hell's Half Acre Wilderness Study Area, Black Canyon Wilderness Study Area, Camas National Wildlife Refuge, Market Lake State Wildlife Management Area, North Lake State Wildlife Management Area, Yellowstone National Park, Targhee and Challis National Forests, Sawtooth National Recreation Area, Sawtooth Wilderness Area, Sawtooth National Forest, Grand Teton National Park, Jackson Hole recreation complex, and the Snake River (see Figures 4.2-1 and 2-2).

Lands surrounding the INEL site are subject to Federal and State planning laws and regulations. Planning for and use of Federal lands and their resources are governed by Federal rules and regulations that require public involvement in their implementation. Land use planning in the State of Idaho is derived from the Local Planning Act of 1975 (State of Idaho Code 1975). Since the State currently has no land use planning agency, the Idaho legislature requires that each county adopt its own land use planning and zoning guidelines. County plans that are applicable to lands bordering the INEL site include the Clark County Planning and Zoning Ordinance (Clark County 1986), the Clark County Interim Land Use Plan (Clark County 1992), the Bonneville County Comprehensive Plan (Bonneville County 1991), the Bingham County Zoning Ordinance and Planning Handbook (Bingham County 1986), the Jefferson County Comprehensive Plan (Jefferson County 1988), and the Butte County Comprehensive Plan (Butte County 1992). Land use planning for INEL facilities located within the Idaho Falls city limits is subject to Idaho Falls planning and zoning restrictions (City of Idaho Falls 1989, 1992).

All county plans and policies encourage development adjacent to previously developed areas in order to minimize the need to extend infrastructure improvements and to avoid urban sprawl (DOE-ID 1993b). Because the INEL is remotely located from most developed areas, INEL lands and adjacent areas are not likely to experience residential and commercial development, and no new development is planned near the INEL site (DOE-ID 1993b). However, recreational and agricultural uses are expected to increase in the surrounding area in response to greater demand for recreational areas and the conversion of range land to crop land (DOE-ID 1993b). 


\subsection{Socloeconomics}

Socioeconomic resources assessed here are characterized in terms of employment, income, population, housing, community services, and public finance. These resources are often interrelated in their response to a particular action. Changes in employment, for example, may lead to population movements into or out of a region, leading to changes in demand for housing and community services.

The region of influence for the socioeconomic analysis was determined to be a sevencounty area comprised of Bingham, Bonneville, Butte, Clark, Jefferson, Bannock, and Madison counties (see Appendix F, Section F-1, Socioeconomics). Based on a survey of INEL personnel (DOE-ID 1991), over 97 percent of the employees reside in this region of influence. The region of influence also includes the Fort Hall Indian Reservation and Trust Lands (home of the Shoshone-Bannock Tribes), located in Bannock, Bingham, Caribou, and Power counties.

The following sections present a brief overview of existing and projected baseline conditions for each socioeconomic characteristic.

\subsubsection{Employment and Income}

Historically, the regional economy has relied predominantly on natural resource use and extraction; today, farming, ranching, and mining remain important components of the economy. Idaho Falls is the retail and service center for the region of influence, and Pocatello has evolved into an important processing and distribution center and site of higher education institutions. Agriculture and ranching, including buffalo ranching, are important contributors to the economy of the Fort Hall Indian Reservation.

4.3.1.1 Employment. The labor force in the region of influence has increased from 92,159 in 1980 to 104,654 in 1991 (see Table 4.3-1) at an average annual growth rate of approximately 1.2 percent. In 1991, the region of influence accounted for approximately 20 percent of the total State labor force of 504,000 (ISDE 1992). The labor force in the region of influence is expected to increase to 117,128 by 2004 (see Table 4.3-2). 


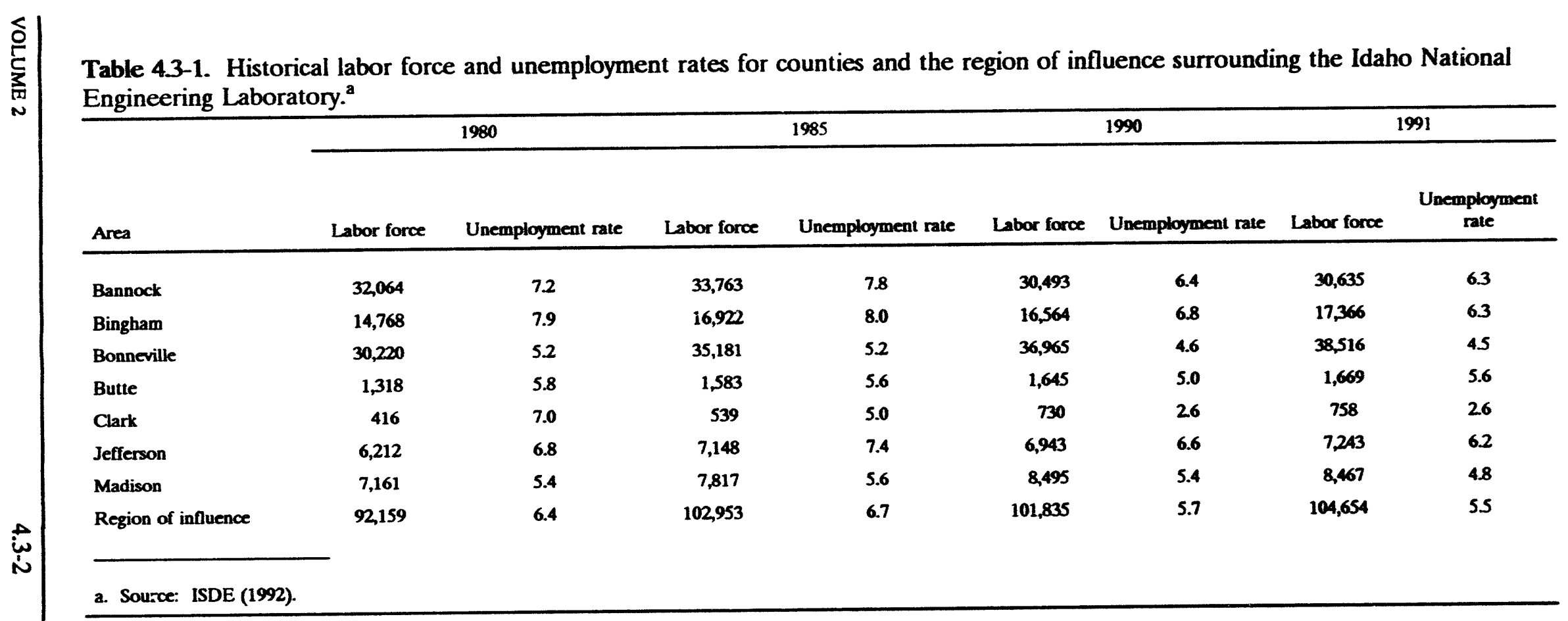

Table 4.3-2 Projected labor force, employment, and population in the region of influence surrounding the Idaho National Engineering Laboratory.

\begin{tabular}{|c|c|c|c|c|c|c|c|c|c|c|}
\hline Category & 1995 & 1996 & 1997 & 1998 & 1999 & 2000 & 2001 & 2002 & 2003 & 2004 \\
\hline Labor force & 108,667 & 109,607 & 110,547 & 111,487 & 112,427 & 113,367 & 114,308 & 115,248 & 116,188 & 117,128 \\
\hline Employment & 101,450 & 102,328 & 103,205 & 104,083 & 104,960 & 105,838 & 106,716 & 107,593 & 108,471 & 109,348 \\
\hline Population & 247,990 & 251,518 & 255,096 & 258,726 & 262,406 & 266,140 & 268,667 & 271,219 & 273,795 & 276,395 \\
\hline
\end{tabular}


Unemployment rates varied considerably among the counties of the region of influence in 1991, ranging from 2.6 percent in Clark County to 6.3 percent in Bannock and Bingham Counties (see Table 4.3-1). Since 1980, the average annual unemployment rate for the region has ranged from 5.3 percent in 1989 to 8.3 percent in 1983. In 1991, the average annual unemployment rate for the region of influence was 5.5 percent compared to the average State-wide rate of 6.2 percent.

Retail trade and educational services are the two largest employment sectors in the region, respectively accounting for 17.6 and 11.4 percent of the 92,875 jobs in 1989 (USBC 1992). In Bonneville County, retail trade accounted for $\mathbf{1 7 . 9}$ percent of the total county employment of 32,016, while professional and related services accounted for 16.8 percent. The largest employment sectors in other counties are manufacturing in Bingham County; retail trade in Bannock and Jefferson Counties; agriculture, forestry, and fishing in Butte and Clark Counties; and educational services in Madison County.

4.3.1.2 Income. Between 1979 and 1989, real median household income increased in Butte, Clark, Jefferson, and Madison counties and decreased in Bannock, Bingham, and Bonneville counties (USBC 1982, 1992). In 1989, median household income ranged from $\$ 23,000$ in Madison County to $\$ 30,462$ in Bonneville County, compared to $\$ 25,257$ for Idaho and $\$ 30,056$ for the nation. Per capita income in 1989 was consistent with median income, with Bonneville County having the highest per capita income $(\$ 12,123)$ and Madison County the lowest $(\$ 7,385)$. However, all counties had per capita income levels below that of the United States of $\$ 14,420$.

4.3.1.3 Idaho National Engineering Laboratory. The INEL plays a substantial role in the regional economy. During Fiscal Year 1990, the INEL directly employed approximately 11,100 personnel, accounting for almost 12 percent of total regional employment. The population directly supported by INEL employment was estimated to be approximately 38,000 persons, or 17 percent of the total regional population. Major employment groups at the INEL are DOE-ID contractors, DOE-ID, Argonne National Laboratory-West, and the Naval Reactors Facility (see Figure 4.3-1). In 1992, total direct INEL employment was approximately 11,600 jobs.

Projections indicate that the total number of jobs at the INEL are expected to be 10,091 in Fiscal Year 1995 and 9,087 in Fiscal Year 2004. Projected decreases in INEL employment are primarily related to expected reduced activities at the Naval Reactors Facility. 


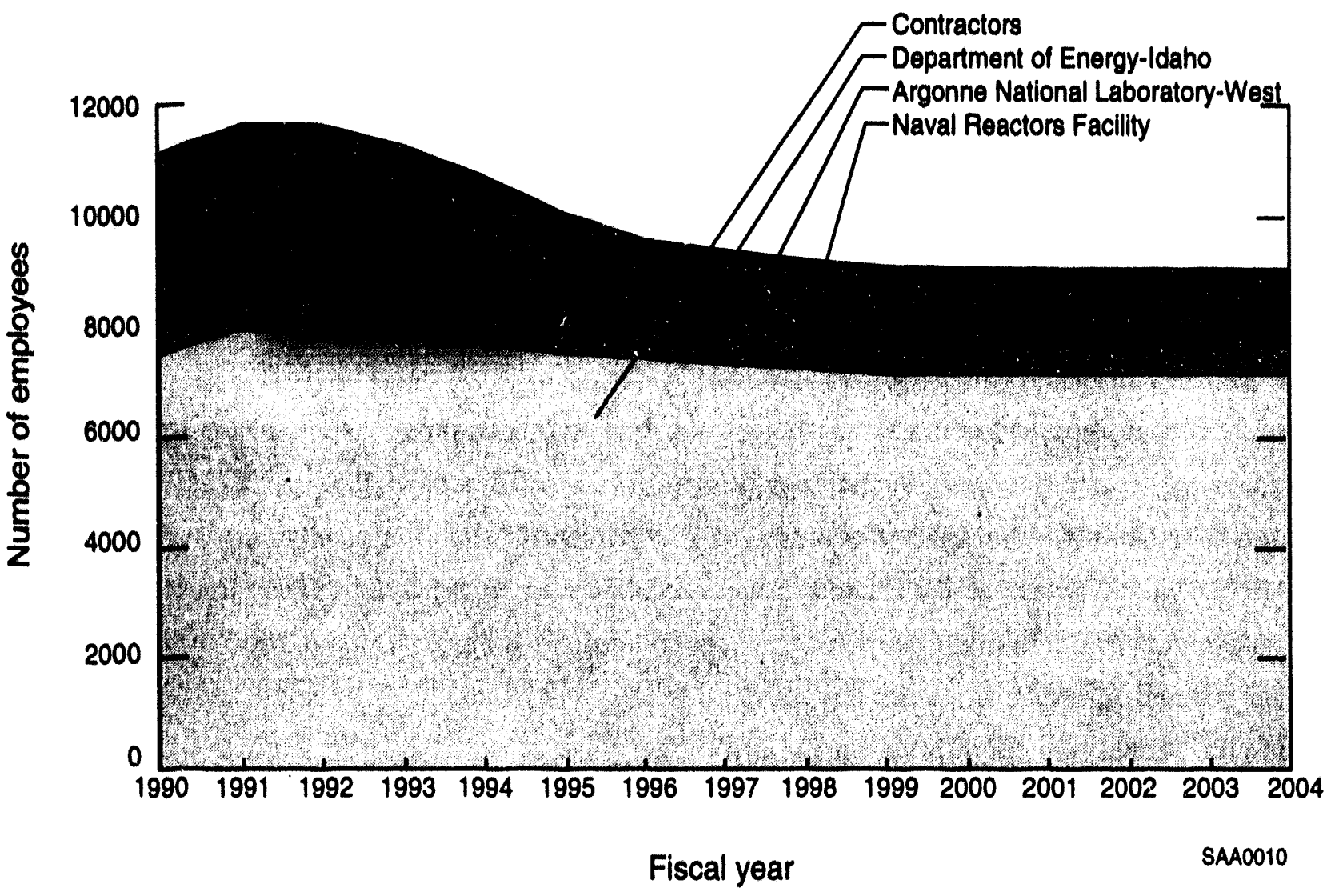

Figure 4.3-1. Historical and projected employment at the Idaho National Engineering Laboratory.

For Fiscal Year 1990, the total budget for the INEL was $\$ 1,100$ million. Financial planning projections for the INEL indicate that funding levels are expected to increase from $\$ 1,005$ million in Fiscal Year 1995 to \$1,025 million in Fiscal Year 2004 (see Figure 4.3-2). These figures do not include funding for projects associated with the alternatives analyzed in Section 5.3, Socioeconomics. The largest program is environmental restoration and waste management, with projected funding of almost \$521 million in Fiscal Year 1995 and \$547 million in Fiscal Year 2004. Funding for environmental restoration and waste management is expected to increase by 5 percent between Fiscal Years 1995 and 2004, while funding for the INEL as a whole is expected to increase by 2 percent. On average, an estimated 46 percent of total INEL expenditures (20 percent of nonpayroll expenditures and 97 percent of payroll expenditures) would be spent within the region of influence.

Wages and salaries paid to INEL employees totaled nearly $\$ 477$ million in Fiscal Year 1992. In addition, $\$ 113.9$ million of direct expenditures were made in the regional economy for 


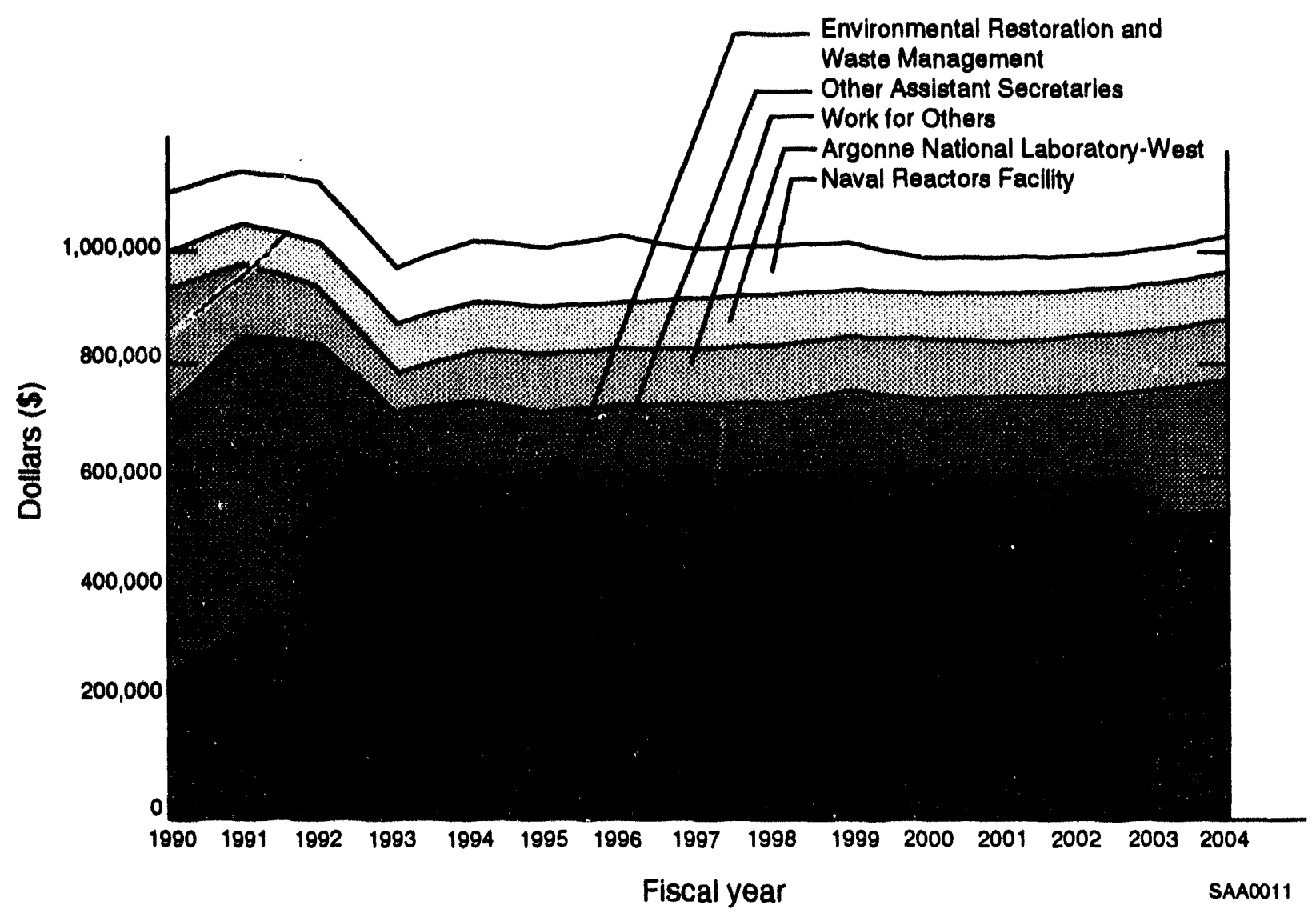

Figure 4.3-2. Historical and projected funding at the Idaho National Engineering Laboratory by Assistant Secretary.

goods and services. Consistent with the projected decrease in employment over the period 1995 to 2005, payroll is also projected to decline. Total INEL payroll is expected to decrease from \$434 million in Fiscal Year 1995 to approximately \$391 million by Fiscal Year 2004 (in 1993 constant year dollars).

\subsubsection{Population and Housing}

Population and housing statistics for the region of influence surrounding the INEL are discussed in the following sections.

4.3.2.1 Population. From 1960 to 1990 , population growth in the region of influence mirrored State-wide growth. During this period, the region's population increased at an average annual rate of approximately 1.3 percent, while the growth rate for the State was 1.4 percent. Between 1980 and 1990, population growth in the region of influence approximately equaled that 
of the State, with an average growth rate of 0.6 percent per year. The region of influence had a 1990 population of 219,713 , which comprised 22 percent of the State's total population of 1,006,749. The most populous counties were Bannock and Bonneville, which together contained over 60 percent of the seven-county total (Figure 4.3-3). Butte and Clark were the least populous of the counties in the region of influence. The largest cities in the region of influence were Pocatello and Idaho Falls, with 1990 populations of approximately 46,000 and 44,000, respectively. In 1990, the Fort Hall Indian Reservation and Trust Lands contained 5,113 residents, with the majority (52 percent) residing in Bingham County.

Population in the region of influence is projected to reach 276,395 persons by 2004 based on population and employment trends (see Table 4.3-2). Over the period 1990 to 2004, the average annual growth rate is projected to be 1.6 percent compared to a projected State-wide annual growth rate of 1.7 percent.

4.3.2.2 Housing. Bonneville and Bannock Counties (which respectively include the cities of Idaho Falls and Pocatello) provided 67 percent of the 73,230 year-round housing units in

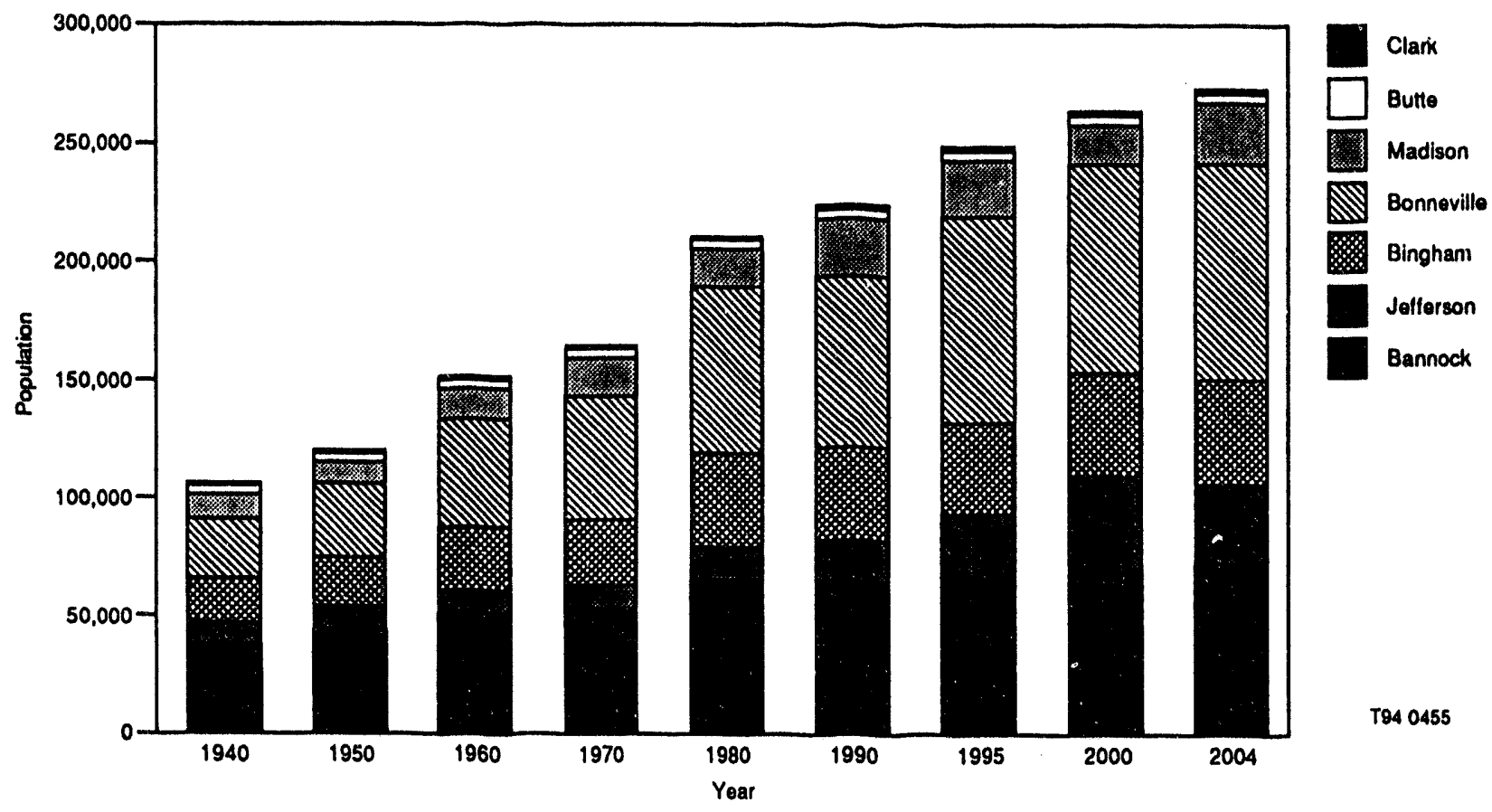

Figure 4.3-3. Historical and projected total population for the counties of the region of influence surrounding the Idaho National Engineering Laboratory from 1940 through 2004. 
the region of influence in 1990 (see Table 4.3-3). Of this number, approximately 70 percent were single-family units, 17 percent were multifamily units, and 13 percent were mobile homes. Most of the multifamily units (75 percent) were located in Bonneville and Bannock Counties. About 29 percent of the occupied housing units in the region were rental units and 71 percent were homeowner units.

The median value of owner-occupied housing units ranged from \$37,300 in Clark County to $\$ 68,700$ in Madison County, and average monthly rents ranged from \$243 in Butte County to \$366 in Bonneville County. In 1990, there were 1,510 occupied housing units on the Fort Hall Indian Reservation and Trust Lands (USBC 1992) and a yacancy rate of 14 percent.

\subsubsection{Community Services and Public Finance}

Selected community services and public finance statistics for the region of influence surrounding the INEL are discussed in the following sections.

Table 4.3-3. Number of housing units, vacancy rates, median house value, and median monthly rent by county and the region of influence surrounding the Idaho National Engineering Laboratory. ${ }^{a}$

\begin{tabular}{|c|c|c|c|c|c|c|}
\hline \multirow[b]{2}{*}{ County/region } & \multicolumn{3}{|c|}{ Homeowner housing units } & \multicolumn{3}{|c|}{ Rental units } \\
\hline & $\begin{array}{l}\text { Number of } \\
\text { units }\end{array}$ & $\begin{array}{l}\text { Vacancy } \\
\text { rates }\end{array}$ & $\begin{array}{l}\text { Median value } \\
\text { (\$) }\end{array}$ & $\begin{array}{l}\text { Number of } \\
\text { units }\end{array}$ & $\begin{array}{l}\text { Vacancy } \\
\text { rates }\end{array}$ & $\begin{array}{c}\text { Median } \\
\text { monthly rent } \\
\text { (\$) }\end{array}$ \\
\hline Bannock & 16,447 & 2.4 & 53,300 & 7,467 & 10.3 & 294 \\
\hline Bingham & 9,010 & 2.0 & 50,700 & 2,955 & 9.2 & 284 \\
\hline Bonneville & 17,707 & 1.9 & 63,700 & 7,375 & 6.2 & 366 \\
\hline Butte & 780 & 4.6 & 41,400 & 302 & 16.2 & 243 \\
\hline Clark & 177 & 1.7 & 37,300 & 114 & 9.6 & 281 \\
\hline Jefferson & 4,000 & 2.0 & 54,300 & 992 & 4.1 & 314 \\
\hline Madison & 3,522 & 1.3 & 68,700 & 2,392 & 2.8 & 299 \\
\hline $\begin{array}{l}\text { Region of } \\
\text { influence }\end{array}$ & 51,674 & 2.1 & (b) & 21,556 & 4.6 & (b) \\
\hline $\begin{array}{l}\text { a. Source: US } \\
\text { b. Not applicat }\end{array}$ & C (1992). & & & & & \\
\hline
\end{tabular}


4.3.3.1 Communtty Services. The following selected community services within the region of influence are considered: public schools, law enforcement, fire protection, and hospital services. Pertinent characteristics of these services for the region of influence are summarized in Table 4.3-4.

Seventeen public school districts and three non-public schools provide educational services for about 57,000 children within the region of influence. Of these students, about 6,500 were dependents of INEL-related employees. During the 1990-1991 academic year, most public school districts spent an average of $\$ 3,000$ to $\$ 4,000$ per student annually. Higher education in the region is provided by the University of Idaho, Idaho State University, Brigham Young University Ricks College, and the Eastern Idaho Technical College.

Law enforcement services in the region are provided by 7 county sheriff's offices, 12 city police departments, and the Idaho State Police. There was a total of 426 sworn officers and 100 other law enforcement personnel in 1991, over 59 percent of which served Bannock and Bonneville counties.

There are 18 fire districts in the region of influence, which operate a total of $\mathbf{3 0}$ fire stations staffed by 179 paid and 313 volunteer firefighters. Bingham, Bonneville, Butte, Clark, and Jefferson counties, which surround the INEL, have developed emergency plans to be implemented in the event of a radiological or hazardous materials emergency. The emergency plans include memoranda of understanding with DOE, procedures for notification and response, listings of emergency equipment and facilities, evacuation routes, and training programs.

Eight hospitals serve the region of influence with a total of over 900 licensed beds and a capacity of nearly 128,000 patient days. Occupancy rates range from 22.0 to 61.7 percent in the region (IDHW 1990). Regional ambulance services are provided by county governments and the Blackfoot, Dubois, Idaho Falls, and Pocatello fire departments. A private ambulance company serves residents in Butte County. The region of influence is also served by four quick response units, two medical helicopters, and two clinics specializing in emergency medical services (Hardinger 1990, U.S. West Directories 1992). 


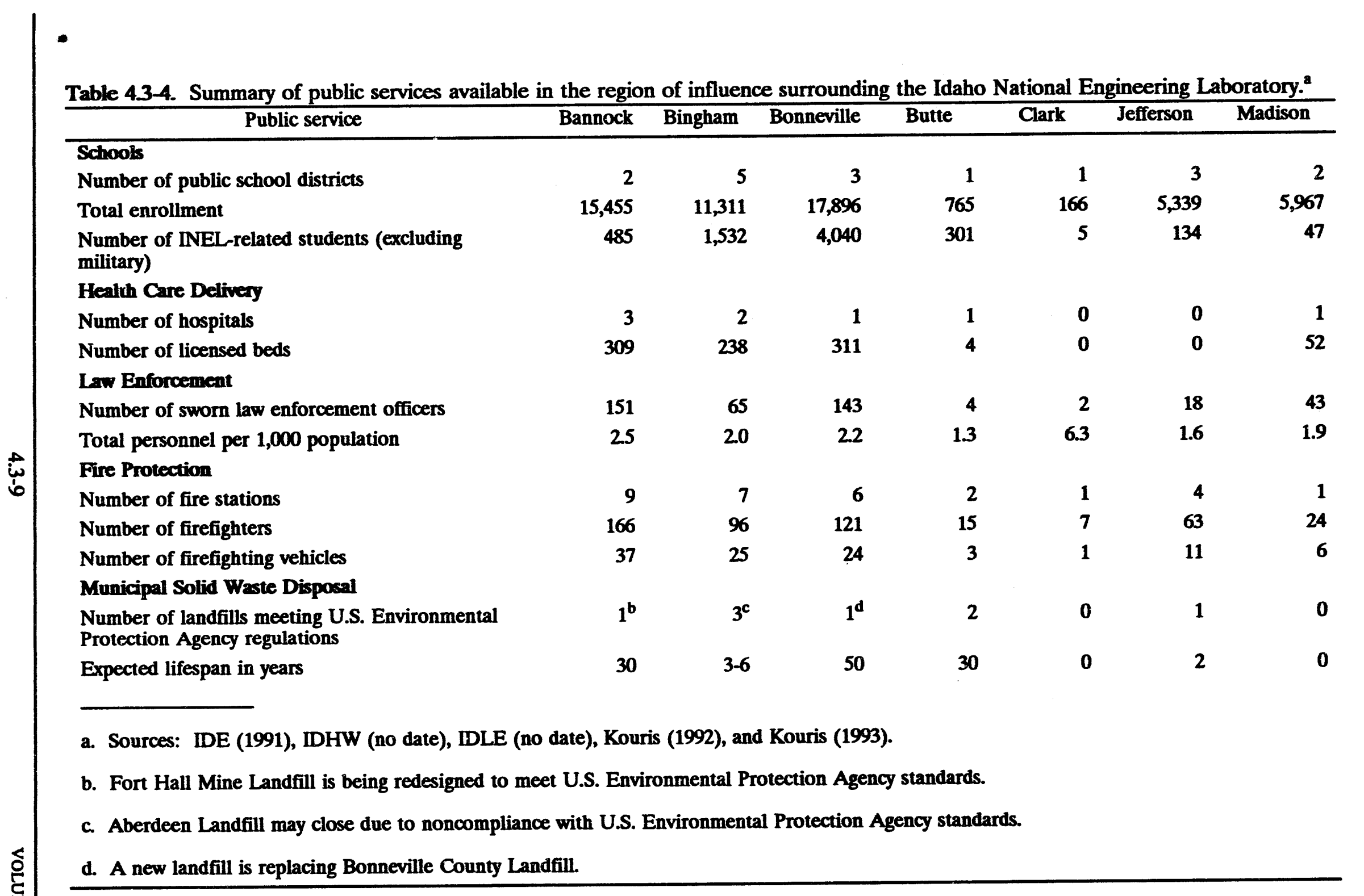


Municipal solid waste generated in the region is transported to county landfills. In 1992 , twelve landfills served the region of influence. Four county landfills (one each in Bannock, Clark, Jefferson, and Madison counties) are being closed before reaching their planned capacity due to noncompliance with new U.S. Environmental Protection Agency standards (CFR 1991). New municipal landfills that meet new U.S. Environmental Protection Agency standards will replace the closed county landfills.

4.3.3.2 Public Finance. In Fiscal Year 1991, total county revenues for the region of influence amounted to approximately $\$ 40$ million (see Table 4.3-5), mostly from taxes and intergovernmental transfers. In 1991, the total assessed value of taxable property in the region of influence was about $\$ 4.47$ billion. In addition to property tax revenues, local governments (cities and counties) also receive revenue from sales tax disbursements and revenue-sharing programs. Approximately 60 to 85 percent of the total revenues received by each county is derived from these two sources.

Although DOE is a Federal agency and exempt from paying State or local taxes, INEL employees and contractors are not. In 1992, INEL employees paid an estimated $\$ 59.6$ million in Federal withholding tax and $\$ 23.5$ million in State withholding tax. Contractors paid approximately \$4 million in sales and use taxes during the same year (DOE-ID 1993).

In 1991, the major categories of county government expenditures were as follows: general government services, 27 percent; road maintenance, 18 percent; public safety, 16 percent; health and welfare programs, 16 percent; sanitation and public works, 9 percent; debt service, 3 percent; trust remittances, 2 percent; and other expenditures, 9 percent. 
Table 4.3-5. Total revenues and expenditures by county in the region of influence surrounding the Idaho National Engineering Laboratory for Fiscal Year 1991.

\begin{tabular}{lcc}
\hline County & $\begin{array}{c}\text { Total revenues } \\
(\$)\end{array}$ & $\begin{array}{c}\text { Total expenditures } \\
(\$)\end{array}$ \\
\hline Bannock & $16,232,274$ & $14,216,708$ \\
Bingham $^{\text {Bonneville }}{ }^{b}$ & $11,434,200$ & $10,708,011$ \\
Butte $_{\text {Clark }}$ & $50,186,650$ & $51,850,100$ \\
Jefferson & $1,417,684$ & $1,397,012$ \\
Madison $_{\text {Seven-county region }}{ }^{c}$ & $1,236,849$ & $1,086,379$ \\
& $4,408,236$ & $4,566,074$ \\
& $5,249,432$ & $5,662,080$ \\
\end{tabular}

a. Sources: Ghan (1992), Bingham County (circa 1992), McFadden (circa 1992), Swager \& Swager (1992a), Swager \& Swager (1992b), Draney, Searle, and Associates (1992), Schwendiman \& Sutton (1992).

b. Bonneville County's financial data are not directly comparable to that of other counties in the region. Bonneville County's financial statements and total revenue data include special accounts for schools, cities, cemeteries, fire districts, ambulance districts, and other special accounts not found in other county budgets. The majority of intergovernmental revenue is funding for these accounts.

c. Bonneville County revenue sources have been excluded from the totals for the seven-county region. 


\subsection{Cultural Resources}

This section discusses all cultural resources at the INEL, including prehistoric and historic archeological sites, historic sites and structures, and traditional resources that are of cultural or religious importance to local Native Amerirans. Paleontological localities on the INEL site are also discussed.

\subsubsection{Archeological Stes and Historic Structures}

As summarized in the INEL Draft Management Plan for Cultural Resources (Miller 1992), the INEL contains a rich and varied inventory of cultural resources. This includes fossil localities that provide an important paleoecological context for the region and the numerous prehistoric archeological sites that are preserved within it. These latter sites, including campsites, lithic workshops, cairns, and hunting blinds, among others, are also an important part of the INEL inventory because they provide information about the activities of aboriginal hunting and gathering groups who inhabited the area for approximately 12,000 years. Archeological sites, pictographs, caves, and many other features of the INEL landscape are also important to contemporary Native American groups for historical, religious, and traditional reasons. Historic sites, including the abandoned town of Powell/Pioneer, a northern spur of the Oregon Trail known as Goodale's Cutoff, many small homesteads, irrigation canals, sheep/cattle camps, and stage/wagon trails, document use of the area during the late 1800 s and 1900 s. Finally, important information on the historical development of nuclear science in America is also preserved in the many scientific and technical facilities constructed within the INEL boundaries.

To date, more than 100 cultural resource surveys have been conducted over approximately 4 percent of the area within the INEL site. During the course of these surveys, most of which have been conducted near major facility areas, 1,506 archeological resources have been identified, including 688 prehistoric sites, 38 historic sites, 753 prehistoric isolates, and 27 historic isolates (Miller 1992, Gilbert and Ringe 1993). Until formal significance evaluations (archeological testing and historic records searches) are completed, all of the cultural sites in this inventory are considered to be potentially eligible for nomination to the National Register of Historic Places. However, all of the isolates have been categorized as unlikely to meet eligibility requirements (Yohe 1993). 
Due to the relatively high density of prehistoric sites on the INEL site and the need to allow for consideration of these resources during Federal undertakings, a preliminary study, which resulted in the development of a predictive model, has been completed to identify areas where densities of sites are apparently highest and the potential impacts to significant archeological resources, as well as the costs of compliance, will likely increase correspondingly (Ringe 1993). This information is intended to provide some guidance for INEL project managers in selecting appropriate areas for new construction. However, it does not take the place of inventories that are required by the National Historic Preservation Act in advance of all ground ästurbing projects (NHPA 1966). The predictive model, which was constructed using a multivariate technique on environmental variables associated with areas containing sites and areas with no sites, shows that prehistoric cultural resources appear to be concentrated in association with certain definable physical features of the land. In this context, very high densities of resources are likely to be found along the Big Lost River and Birch Creek, atop buttes, and within craters and caves. The Lemhi Mountains, the Lake Terreton basin, and a 1.75-mile- (2,800-meter-) wide zone along the edge of local lava fields probably contain a fairly high density of sites. Within the extensive flows of basaltic lava and along the low foothills of the Lemhi Mountains, site density is classified as moderate, and the lowest density of prehistoric resources probably occurs within the floodplain of the Big Lost River and the alluvial fans emerging from the Birch Creek Valley, within the sinks, and within the recent Cerro Grande lava flow. However, a classification of low or medium density does not eliminate the possibility that significant resources exist within those areas. Although this model has not been tested, it is useful as a planning guide for defining those areas most likely to contain archeological resources based on past surveys.

Although no systematic inventory of historically significant facilities associated with the creation and operation of the INEL has been completed, a preliminary study indicated that all INEL facilities will require evaluation (Braun et al. 1993). The Experimental Breeder Reactor-I is a National Historic Landmark listed in the National Register of Historic Places. To date, however, few of the other properties have been formally evaluated for eligibility to the National Register of Historic Places. However, Memoranda of Agreement between DOE, the Idaho State Historic Preservation Office, and the National Advisory Council on Historic Preservation establish that certain structures located at Test Area North (DOE 1993a) and Auxiliary Reactor Area (DOE 1993b) are eligible for nomination, and outline specific techniques for preserving the historic value of the areas in conformance with the requirements of the Historic American 
Building Survey and the Historic American Engineering Record. Other facilities on the INEL site are likely to require similar efforts if scheduled for major modification, demolition, or abandonment.

\subsubsection{Native American Cultural Resources}

Because Native American people hold the land sacred, in their terms the entire INEL reserve is culturally important. This includes all prehistoric archeological sites, some of which are important in a religious or cultural heritage context, as well as certain features of the natural landscape that may contain important natural resources or have special significance.

Geographically, the INEL site is included within a large territory once inhabited by and still of importance to the Shoshone-Bannock Tribes.

Five Federal laws prompt consultation between Federal agencies and Native American Tribes: the National Environmental Policy Act (NEPA 1969), the National Historic Preservation Act, as amended (NHPA 1966), the American Indian Religious Freedom Act (AIRFA 1978), the Archeological Resources Protection Act (ARPA 1979), and the Native American Graves Protection and Repatriation Act (NAGPRA 1990). In accordance with these directives and in consideration of DOE's written Native American Policy (DOE 1990, 1992a), DOE at the INEL has committed to additional interaction and exchange of information with the Shoshone-Bannock Tribes of the nearby Fort Hall Reservation, and is developing procedures for consultation and coordination. This relationship is outlined in a formal Working Agreement between these Tribes and DOE (DOE 1992b).

\subsubsection{P\&leontological Resources}

There are 31 known fossil localities at the INEL site, and available information suggests that the region has relatively abundant and varied paleontological resources. Preliminary analyses suggest that these materials are most likely to be found in association with archeological sites; in areas of basalt flows; in deposits of the Big Lost River, Little Lost River, and Birch Creek; in deposits of Lake Terreton and playas; in some wind and sand deposits; and in sedimentary interbeds or lava tubes within local lava flows (Miller 1992: Table 3-1). 


\subsection{Aesthetic and Scenic Resources}

This section describes the visual character of the INEL site and briefly discusses scenic areas in the vicinity of the INEL. An additional description of visual impacts to offsite areas is contained in Section 4.7, Air Resources.

\subsubsection{Visual Character of the Idaho National Engineering Laboratory Site}

The INEL site is bordered on the north and west by the Bitterroot, Lemhi, and Lost River mountain ranges. Volcanic buttes near the southern boundary of the INEL can be seen from most locations on the site. Most of the INEL site consists of open, undeveloped land, predominantly covered by large sagebrush and grasslands (see Section 4.9, Ecological Resources). Pasture and irrigated farmland border much of the INEL site (see Section 4.2, Land Use).

Nine facility areas are located on the INEL site. Although the INEL has a master plan, no specific visual resource standards have been established. The generally low density INEL facilities look like commercial/industrial complexes, and are dispersed throughout the INEL site. The structures range in height from 10 feet ( 3 meters) to approximately 100 feet (30 meters), with a few stacks and towers that reach up to 250 feet (76 meters). Although many INEL facilities are visible from highways, most facilities are located over half a mile from public roads. The facility closest to a public road ( 0.4 mile or 0.6 kilometer) is the Water Reactor Research Test Facility (about 60 feet or 18 meters in height), located off State Highway 33. This section of Highway 33 is used primarily by the INEL workforce at Test Area North. Chapter 2, Background, contains an aerial view of the INEL facilities that shows the low density of structures compared to the large land area.

About 90 miles of paved public highway run through the INEL site. U.S. Highway 20 runs east and west across the southern portion, and has one rest stop within the INEL boundaries. This is the highway most heavily used by the INEL workforce. It is a direct route from the Idaho Falls area to Boise, Idaho, and recreational areas such as Sun Valley and Craters of the Moon National Monument. The Experimental Breeder Reactor-I, just off Highway 20, is a National Historic Landmark. It had 14,000 visitors in 1992 (Braun 1993), but was closed temporarily for repairs in 1993 . U.S. Highway 26 runs southeast and northwest, intersecting 
Highway 20 near the Central Facilities Area. Idaho State Highways 22, 28, and 33 cross the northeastern part of the INEL site.

\subsubsection{Scenic Areas}

The Craters of the Moon National Monument is located about 15 miles southwest of the INEL site's western boundary. The seasonal visual range from Craters of the Moon is from 81 to 97 miles (Notar 1993). The Monument includes a designated Wilderness Area, for which Class I (very high) air quality standards, or minimal degradation, must be maintained, as defined by the Clean Air Act (CFR 1977, 1990). Under the Clean Air Act, air quality is defined to include visibility and scenic view considerations.

Lands adjacent to the INEL site, under Bureau of Land Management jurisdiction, are designated as Visual Resource Management Class II areas (BLM 1984, 1986). This designation urges preservation and retention of the existing character of the landscape. Lands within INEL site boundaries are designated as Class III and IV, the most lenient classes in terms of modification. The Bureau of Land Management is considering the Black Canyon Wilderness Study Area, located adjacent to the INEL, for Wilderness Area designation (BLM 1986), which, if approved, would result in an upgrade of its Visual Resource Management class from Class II to Class I. 


\subsection{Geology}

This section describes the geological, seismic, and volcanic characteristics of the INEL site and surrounding region.

\subsubsection{Ceneral Ceology}

The INEL site is located on the Eastern Snake River Plain (Figure 4.6-1). The Plain forms a broad northeast-trending crescent-shaped trough with low relief comprised primarily of basaltic lava flows. These flows at the surface range in age from 1.2 million to 2,100 years. The Plain features thin, discontinuous, interbedded deposits of wind-blown loess and sand; water-borne alluvial fan, lacustrine, and flood-plain alluvial sediments; and rhyolitic domes formed 1,200,000 to 300,000 years ago (Kuntz et al. 1990) (Figure 4.6-2). The Plain is bounded on the north and south by the north-to-northwest-trending mountains and valleys of the Basin and Range Province, comprised of folded and faulted rocks that are more than 70 million years old. The Plain is bounded on the northeast by the Yellowstone Plateau. The major episode of Basin and Range faulting began 20 to 30 million years ago and continues today, most recently associated with the October 28, 1983, Borah Peak earthquake [Ms 7.3; 0.022 to 0.078g at the INEL site (Jackson 1985)], which occurred along the Lost River fault, approximately 100 kilometers (62 miles) from INEL site facilities, and the 1959 Hebgen Lake earthquake (Ms 7.5) approximately 150 kilometers (93 miles) from the INEL site (Figure 4.6-1).

The northeast-trending volcanic terrain of the Plain has a markedly different geologic history and tectonic pattern compared to the older folded and faulted terrain of the northwesttrending Basin and Range. The northwest-trending Basin and Range faults have not been observed to extend across the Plain. Three northwest-trending volcanic rift zones are known to lie across the Plain at or near the INEL site; they have been attributed to basaltic eruptions that occurred 4 million to 2,100 years ago (Hackett and Smith 1992, Kuntz et al. 1990).

The seismic characteristics of the Plain and the adjacent Basin and Range Province also are different. Earthquakes and active faulting are associated with Basin and Range tectonic activity. The Plain has historically experienced few and small earthquakes (King et al. 1987, Pelton et al. 1990, WCC 1992, Jackson et al. 1993). 


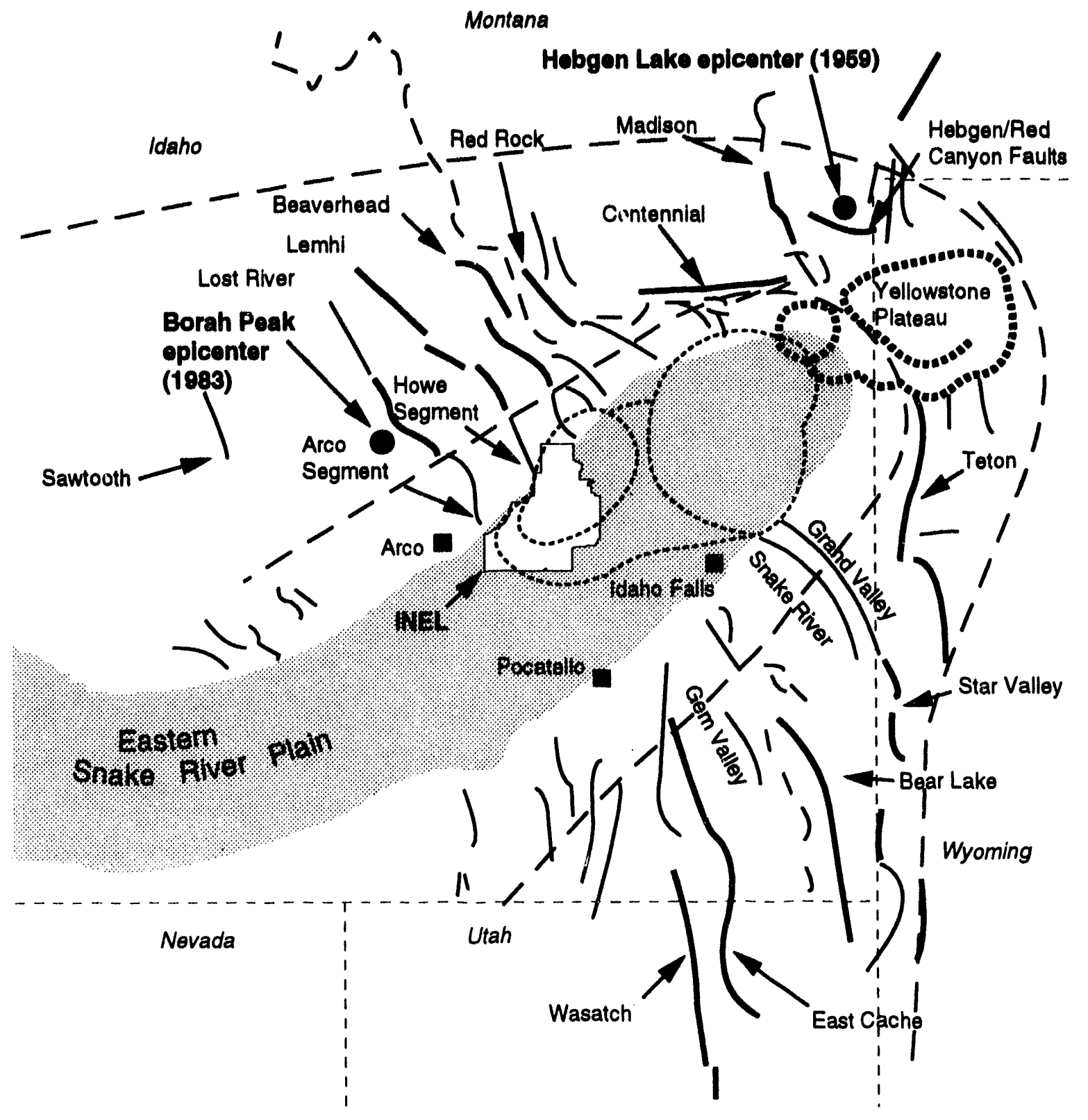

(Map modifled trom Anders et al. 1989 and Hackett and Morgan 1988)
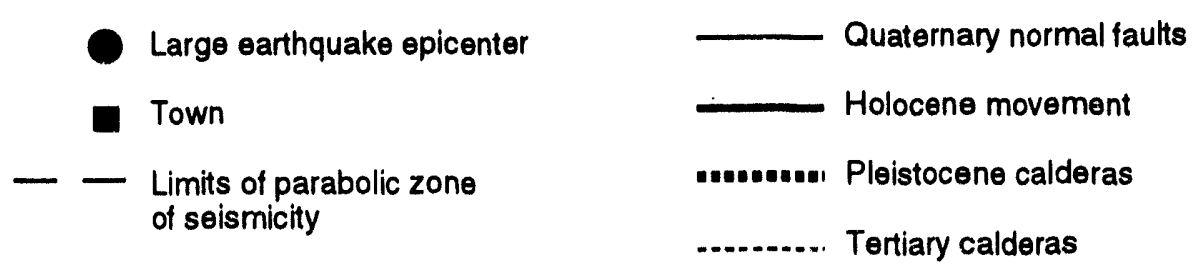

SAA0028

Figure 4.6-1. Geologic features in the region of the Idaho National Engineering Laboratory site. 


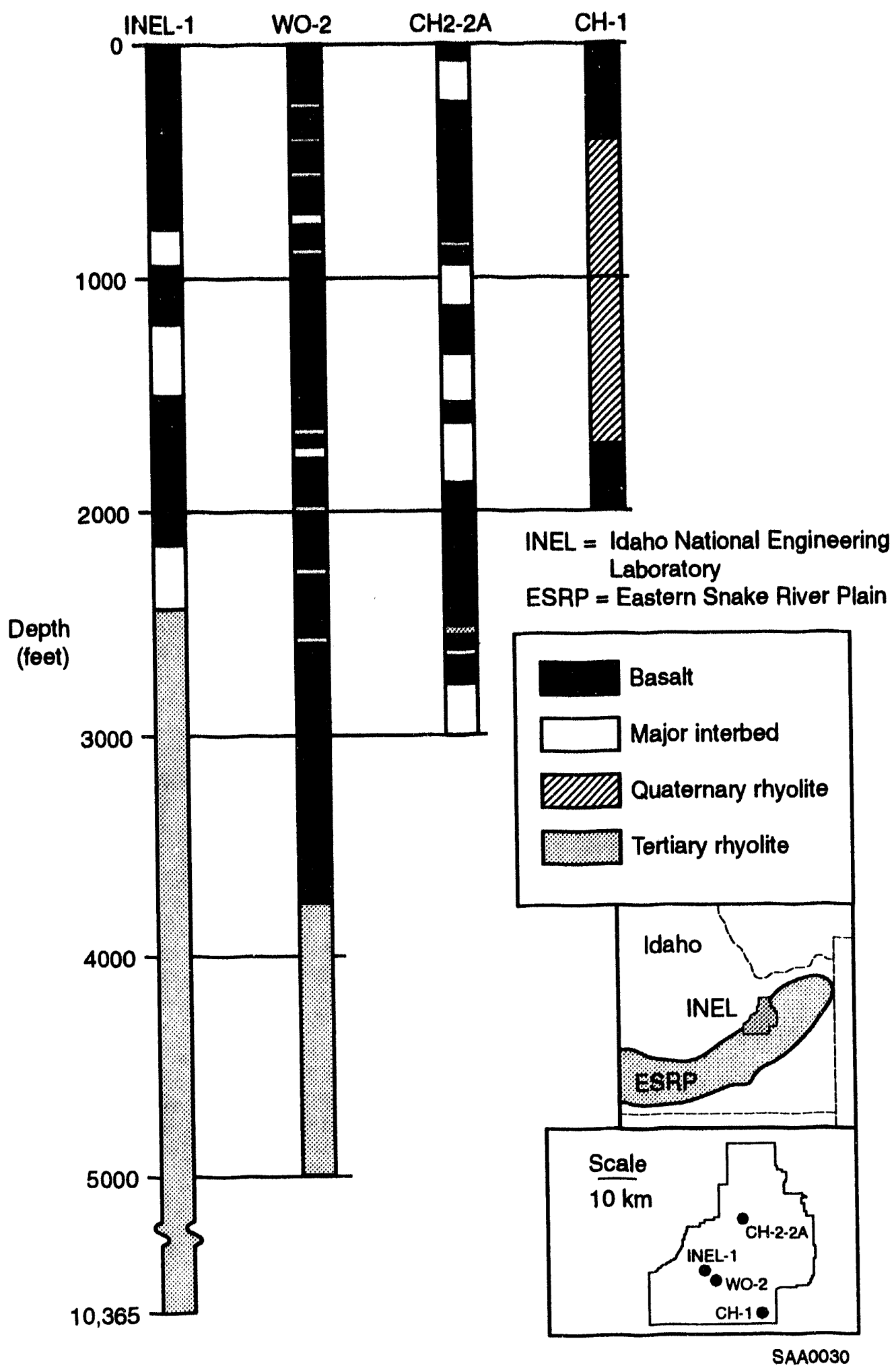

Figure 4.6-2 Lithologic logs of deep drill holes on the Idaho National Engineering Laboratory site (Doherty 1979a,b; Doherty et al. 1979, Hackett and Smith 1992). (To convert from feet to meters, multiply by 0.3048 .) 
A typical soil association occurring on a lava flow on the INEL site consists of three to four soil series differentiated from one another largely on the basis of soil depth. The INEL site landscapes are covered with a thin to thick blanket of eolian sediments, which are deposited in episodes associated with climatic cycles. The thickness of eolian sediments on the INEL site is generally less than 2.1 meters ( 7 feet) and commonly between 0.3 to 0.9 meters ( 1 to 3 feet). Most soils formed in eolian deposits containing a layer of secondary carbonates, which ranges from powdery to cemented.

\subsubsection{Natural Resources}

A geothermal exploration well was drilled at the INEL site to a depth of 3,147 meters $(10,360 \mathrm{feet})$ in 1979 . A temperature of $142^{\circ} \mathrm{C}\left(288^{\circ} \mathrm{F}\right)$ was measured, but no commercial quantities of geothermal fluids were identified (Mitchell et al. 1981). Mineral resources include several quarries or pits within the INEL site boundary to supply sand, gravel, pumice, silt, clay, and aggregate for road construction and maintenance, new facility construction and maintenance, waste burial activities, and ornamental landscaping cinders. During the course of excavation, the gravel pits may be studied to characterize the local surficial geology of the INEL site. Outside the INEL site boundary, mineral resources include sand, gravel, pumice, phosphate, and base and precious metals (Strowd et al. 1981, Mitchell et al. 1981). The geologic history of the Plain makes the potential for petroleum production at the INEL site very low.

\subsubsection{Selsmic Hazards}

The distribution of earthquakes at and near the INEL site from 1884 to 1989 clearly shows that the Plain has a remarkably low rate of seismicity, whereas the surrounding Brisin and Range has a fairly high rate of seismicity (Figure 4.6-3, WCC 1992). The mechanism for faulting and generation of earthquakes in the Basin and Range is attributed to northeast-southwest directed crustal extension.

Several investigators have suggested hypotheses for the low rate of seismic activity within the Plain compared to the Centennial Tectonic Belt (Stickney and Bartholomew 1987) and Intermountain seismic belt (Smith and Arabasz 1991): 


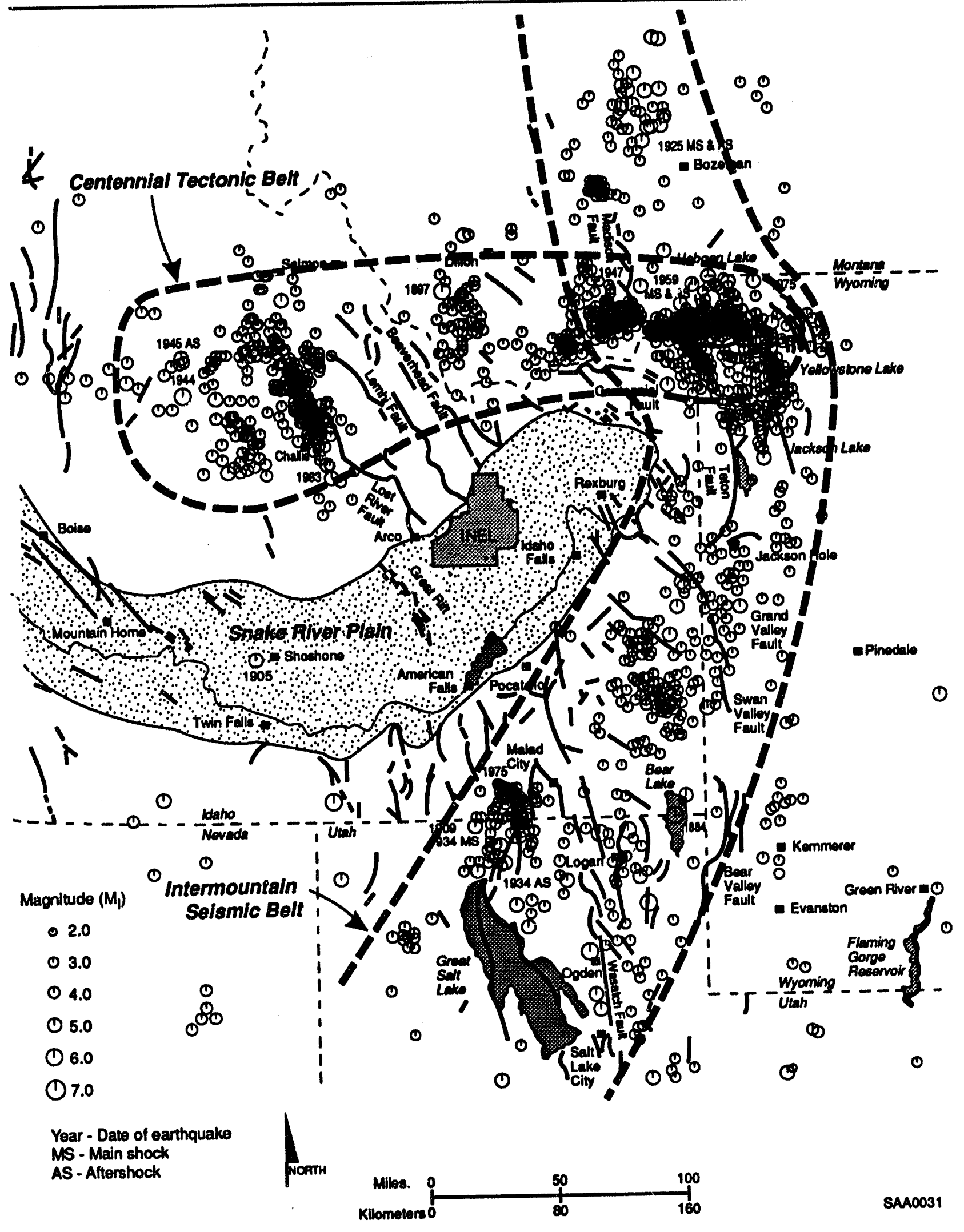

Figure 4.6-3. Historical earthquakes in the Idaho National Engineering Laboratory region with magnitudes greater than 2.5 (1884 to 1989) (WCC 1992). 
- Smith and Sbar (1974) and Brott et al. (1981) suggested that high crustal temperatures beneath the Plain and adjacent region inside the seismic parabola (Figure 4.6-1) resulted in ductile deformation (aseismic creep), in contrast to the brittle deformation (rock fracture) that occurs in the Basin and Range.

- Anders et al. (1989) suggested that the Plain and the adjacent region inside the seismic parabola (Figure 4.6-1) have increased integrated lithospheric strength. They proposed that the presence of mid-crustal mafic intrusive rock strengthens the crust so that it is too strong to fracture (see also Smith and Arabasz 1991).

- Parsons and Thompson (1991) proposed that magmatic dike injection suppresses normal faulting and associated seismicity by altering the local tectonic stress field. As dikes are injected in volcanic rift zones, they push apart the surrounding rocks and decrease differential stress, thereby preventing earthquakes from occurring.

- Recently, Anders and Sleep (1992) proposed that introduction of mantle-derived magma into the midcrust beneath the Plain has decreased faulting and earthquakes by lowering the rate of deformation.

The markedly different late-Tertiary and Quaternary tectonic and seismic histories of the Plain and Basin and Range Province reflect the dissimilar deformational processes acting in each region. Both regions are being subjected to the same extensional stress field (Weaver et al. 1979, Zoback and Zoback 1989, Pierce and Morgan 1992, Jackson et al. 1993); however, crustal deformation within the Plain occurs through dike injection and, in the Basin and Range, through large-scale normal faulting (Rodgers et al. 1990, Parsons and Thompson 1991, Hackett and Smith 1992).

Major seismic hazards include the effects from ground shaking and surface deformation (surface faulting, tilting). Other potential seismic hazards (for example, avalanches, landslides, mudslides, soil settlement, and soil liquefaction) are not likely to occur at the INEL site because the local geologic conditions are not conducive to them. Based on the seismic history and the geologic conditions, earthquakes greater than magnitude 5.5 (and associated strong ground shaking and surface fault rupture) are not likely to be generated within the Plain. However, 
moderate to strong ground shaking can affect the INEL site from earthquakes in the Basin and Range. Patterns of seismicity and locations of mapped faults are used to assess potential sources of future earthquakes and to estimate levels of ground motion at the INEL site. The sources and maximum magnitudes of earthquakes that could produce the maximum levels of ground motions at all INEL site facilities include (WCC 1990, 1992):

- A moment magnitude 7.0 earthquake at the southern end of the Lemhi fault along the Howe and Fallert Springs segments

- A moment magnitude 7.0 earthquake at the southern end of the Lost River fault along the Arco segment

- A moment magnitude 5.5 earthquake associated with dike injection in either the Arco or Lava Ridge-Hell's Half Acre Volcanic Rift Zones and the Axial Volcanic Zone

- A "random" moment magnitude 5.5 earthquake occurring within the Eastern Snake River Plain.

An example of the relationship of the peak ground acceleration on the INEL site to the annual frequency of occurrence of seismic events for various seismic hazards in the region, including the above four events, is illustrated in Figure 4.6-4 (Wong et al. 1993). The curves were developed specifically for the site of the Idaho Chemical Processing Plant in the south-central INEL site and do not directly apply to other INEL site areas. Ground motion contributions from seismic sources not shown on Figure 4.6-4 (that is, Intermountain seismic belt, Idaho Batholith, and Yellowstone Region) are significantly smaller because of their distant locations or lower maximum magnitudes. The INEL Site-Specific Seismic Hazard Study (Wong et al. 1993) will provide curves similar to Figure 4.6-4 for other INEL site areas. INEL site seismic design basis events are determined by the INEL Natural Phenomena Committee and incorporated into the INEL Architectural and Engineering Standards based on studies (WCC 1990). Section 5.14, Facility Accidents, presents the potential impacts of postulated seismic events. 


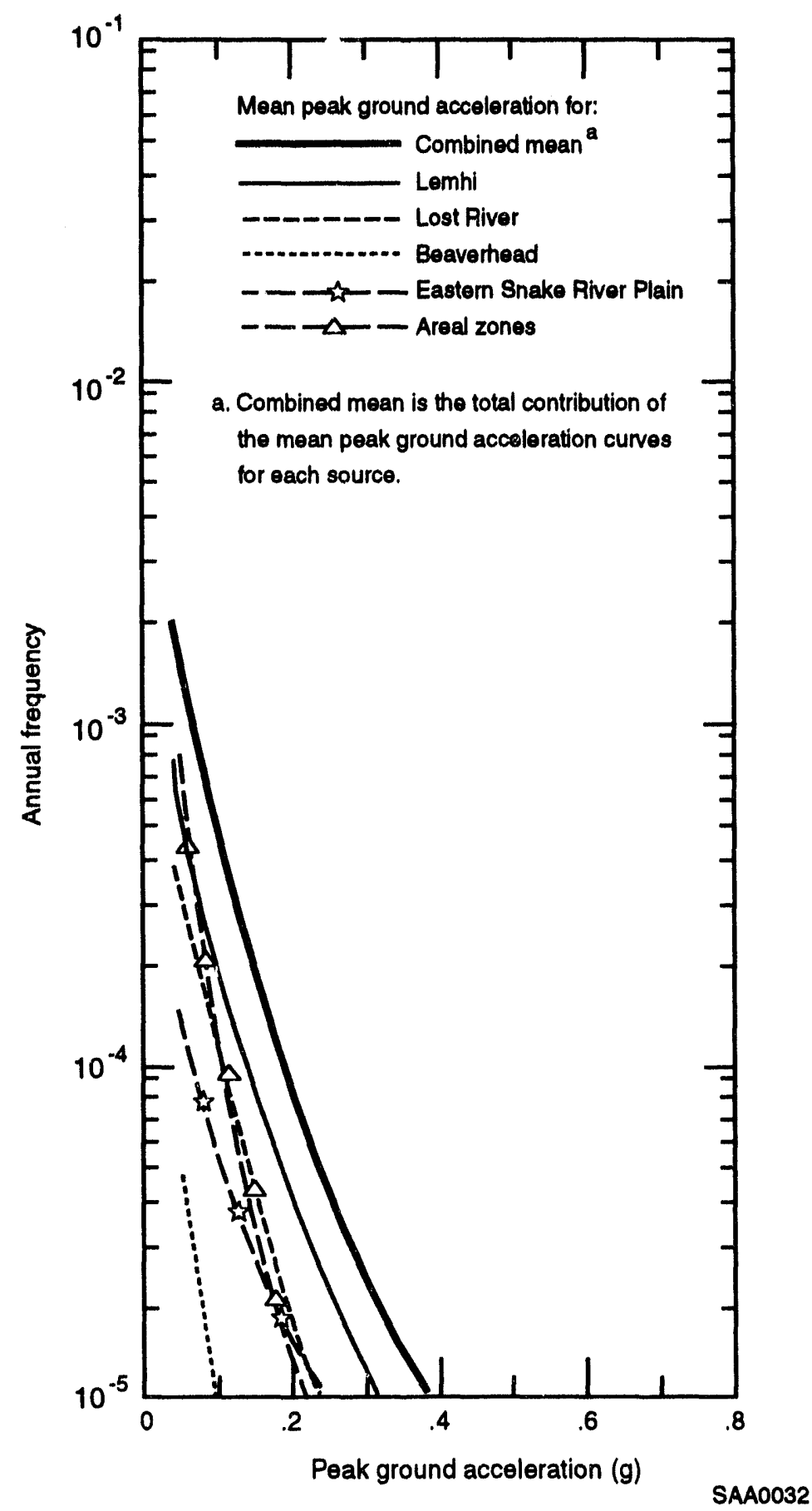

Figure 4.6-4. Contribution of the various seismic sources to the mean peak acceleration at the Idaho Chemical Processing Plant (Wong et al. 1993). 


\subsubsection{Volcanic Hazards}

Volcanic hazards at the INEL site can come from sources inside or outside the Plain's boundaries. Volcanic hazards include the effects of lava flows, ground deformation (fissures, uplift, subsidence), volcanic earthquakes (associated with magmatic processes as distinct from earthquakes associated with tectonics), and ash flows or airborne ash deposits. Most of the basalt volcanic activity occurred from 4 million to 2,100 years ago in the INEL site area. The most recent and closest volcanic eruption occurred 2,100 years ago at the Craters of the Moon National Monument 25 kilometers (15 miles) southwest of the INEL site (Kuntz et al. 1992). The rhyolite domes along the Axial Volcanic Zone formed between 1.2 and 0.3 million years ago and have a recurrence interval of about 200,000 years. Therefore, the probability of future dome formation affecting INEL site facilities is very low.

Catastrophic Yellowstone eruptions have occurred three times in the past 2 million years, but the INEL site lies more than 160 kilometers ( 70 miles) from the Yellowstone Caldera rim, and high-altitude winds would not disperse Yellowstone ash in the direction of the INEL site. For these reasons of infrequency, great distance, and unfavorable dispersal, pyroclastic flows or ash fallout from future Yellowstone eruptions are not expected to impact the INEL site.

Basaltic lava flows and eruptions from fissures or vents may occur. Based on a probability analysis of the volcanic history in and near the southcentral INEL site area, the Volcanism Working Group (1990) estimated that the conditional probability that basaltic volcanism would affect a south-central INEL site location is less than $2.5 \times 10^{-5}$ per year (once per 40,000 years or longer), where the hazard associated with Axial Volcanic Zone volcanism is greatest. The probability of volcanic impact on INEL site facilities farther north, where both silicic and basaltic volcanism have been older and less frequent, is estimated to be less than $10^{-6}$ per year (once every million years or longer). Section 5.14, Facility Accidents, presents the effects of a hypothetical lava flow that covers the INEL Radioactive Waste Management Complex (RWMC). 


\subsection{Air Resources}

This section describes the air resources of the INEL site and the surrounding area. The discussion includes the climatology and meteorology of the region, a summary of applicable regulations, descriptions of radiological and nonradiological air contaminant emissions from existing facilities and facilities expected to become operational before June 1, 1995, and a characterization of existing levels of air pollutants. Additional detail and background information on the material presented in this section is presented in Appendix F, Section F-3, Air Resources.

\subsubsection{Climate and Meteorology}

The Eastern Snake River Plain climate exhibits low relative humidity, wide daily temperature swings, and large variations in annual precipitation. Average seasonal temperatures measured onsite range from $-7.3^{\circ} \mathrm{C}$ (Centigrade) $\left[\left(18.8^{\circ} \mathrm{F}\right.\right.$ (Fahrenheit)] in winter to $18.2^{\circ} \mathrm{C}$ $\left(64.8^{\circ} \mathrm{F}\right)$ in summer, wih an annual average temperature of about $5.6^{\circ} \mathrm{C}\left(42^{\circ} \mathrm{F}\right)$. Temperature extremes range from a summertime maximum of $39.4^{\circ} \mathrm{C}\left(103^{\circ} \mathrm{F}\right)$ to a wintertime minimum of $-45^{\circ} \mathrm{C}\left(-49^{\circ} \mathrm{F}\right)$. Large year-to-year variations in average monthly and seasonal temperatures are common, as are large variations in temperature in different locations. Annual precipitation is light, averaging 22.1 centimeters (8.71 inches), with monthly extremes of zero to 12.8 centimeters (5 inches). The maximum 24-hour precipitation rate is 4.6 centimeters (1.8 inches). The greatest short-term precipitation rates are primarily attributable to thunderstorms, which occur approximately two or three days per month during the summer. The average annual snowfall is 70.1 centimeters (27.6 inches), with extremes of 151.6 centimeters (59.7 inches) and 17.3 centimeters ( 6.8 inches). Relative humidity ranges from an average minimum of 27 percent to a maximum of 79 percent on an annual basis.

The INEL site is in the belt of prevailing westerlies; however, these winds are normally channeled by the mountain ranges bordering the Eastern Snake River Plain into a southwest wind. Most offsite locations experience the predominant southwest/northeast wind flow of the Eastern Snake River Plain, although subtle terrain features near some locations cause considerable variations from this flow regime. An illustration of annual wind flow is provided by the wind roses in Figure 4.7-1. These wind roses show the frequency of wind direction (in other words, the direction from which the wind blows) and speed at three meteorological monitoring 


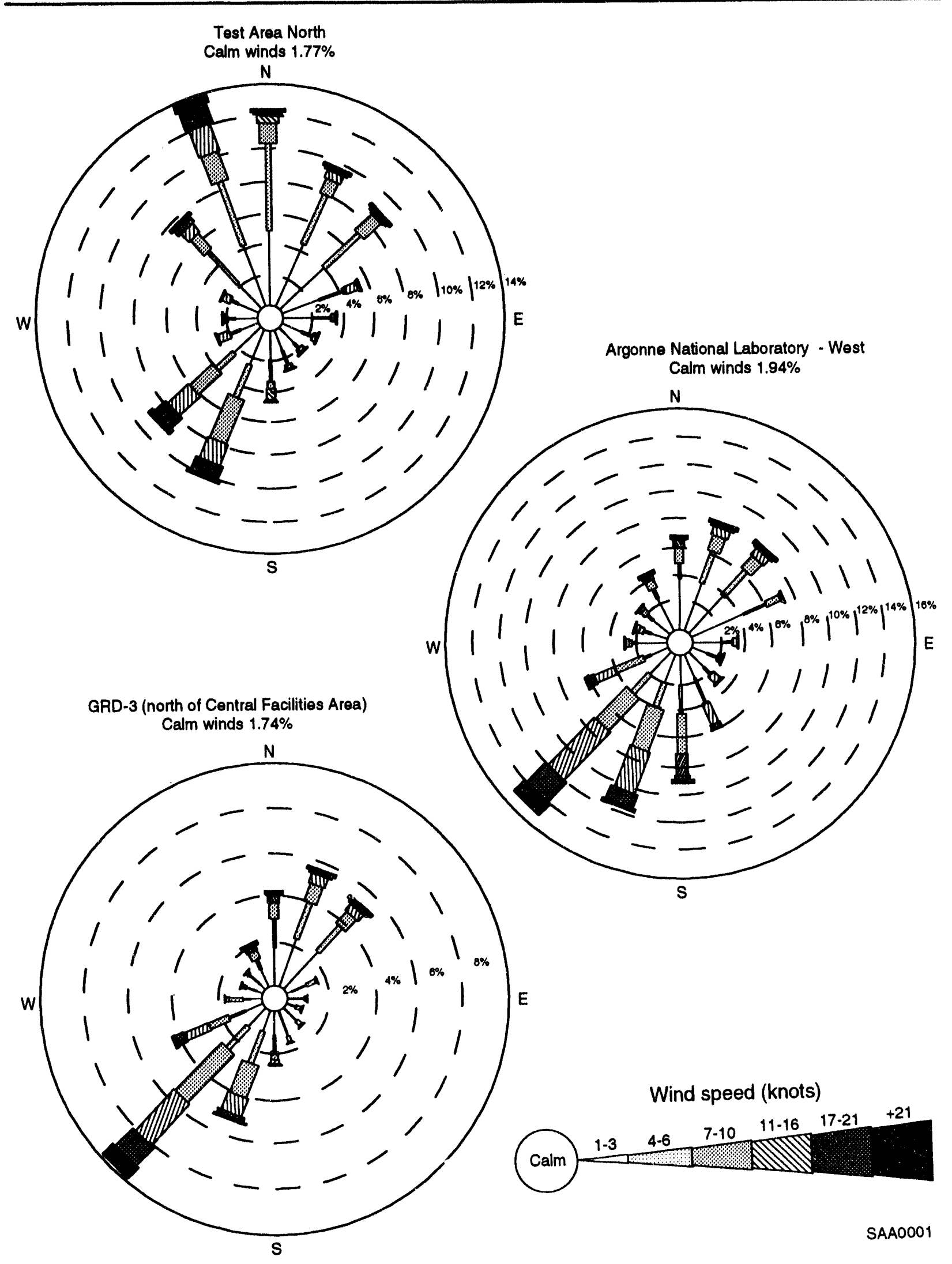

Figure 4.7-1. Annual average wind direction and speed at meteorological monitoring stations on the Idaho National Engineering Laboratory site. 
sites on the INEL site for the period 1988-1992. The highest hourly average near-ground wind speed measured onsite is 22.8 meters per second ( 51 miles per hour) from the west-southwest, with a maximum instantaneous gust of 34.9 meters per second (78 miles per hour) (Clawson et al. 1989). Other than thunderstorms, severe weather is uncommon. Five funnel clouds (tornadoes not touching the ground) and no tornadoes have been reported onsite between 1950 to 1988 . Visibility in the region is good because of the low moisture content of the air and minimal sources of visibility-reducing pollutants. At Craters of the Moon Wilderness Area [approximately 20 kilometers (12.4 miles) southwest of the INEL site], the seasonal visual range is from 130 to 158 kilometers (88 to 97 miles) (Notar 1993).

Air pollutant dispersion is a result of the processes of transport and diffusion of airborne contaminants in the atmosphere. Transport is the movement of a pollutant in the wind field, while diffusion refers to the process whereby a pollutant plume is diluted by turbulent eddies. Vertical diffusion of pollutants may be restricted or enhanced by the temperature gradient of the atmosphere (that is, the change in temperature with altitude). Lapse conditions, which tend to enhance vertical diffusion, occur slightly less than 50 percent of the time. Conversely, thermal stratification or inversion conditions, which inhibit vertical diffusion, occur slightly more than 50 percent of the time. The height to which the pollutants can freely diffuse is known as the mixing depth, while the layer of air from the ground up to the mixing depth is known as the mixed layer. Estimates of the monthly average depth of the mixed layer range from 120 meters ( $400 \mathrm{feet}$ ) in December to 900 meters (3,000 feet) in July. Nocturnal (nighttime) inversions form at approximately sunset and dissipate about 1 to 2 hours after sunrise. These inversions are often ground-based, meaning that the temperature increases with height from the ground (Clawson et al. 1989).

\subsubsection{Standards and Regulations}

Air quality regulations have been established to protect the public from potential harmful effects of air pollution. These regulations (a) designate acceptable levels of pollution in ambient air, (b) establish limits on radiation doses to members of the public, (c) establish limits on air pollutant emissions and resulting deterioration of air quality due to vehicular and other anthropogenic sources, (d) require air permits to regulate (control) emissions from stationary (nonvehicular) sources of air pollution, and (e) designate prohibitory rules, such as rules that 
prohibit open burning. The Federal Clean Air Act (and amendments) provides the framework to protect the nation's air resources and public health and welfare. In Idaho, the U.S.

Environmental Protection Agency and the State of Idaho Department of Health and Welfare, Division of Environmental Quality, are jointly responsible for establishing and implementing programs that meet the requirements of the Federal Clean Air Act. INEL site activities are subject to air quality regulations and standards established under the Clean Air Act and by the State of Idaho (IDHW 1994) and to internal policies and requirements of DOE. Air quality standards and programs applicable to INEL site operations are summarized in Figure 4.7-2 and described in further detail in Appendix F, Section F-3, Air Resources.

\subsubsection{Radiological Air Quality}

The population of the Eastern Snake River Plain is exposed to environmental radiation from both natural and manmade sources. This section summarizes the sources and levels of radiation exposure in this geographical region, including sources of airborne radionuclide emissions from the INEL site. Estimates of radioactivity levels and radiological doses from current INEL site operations, including foreseeable increases (increases from facilities expected to become operational by June 1,1995$)$, are provided and discussed.

\subsubsection{Sources of Radioactivity. The major source of radiation exposure in the} Eastern Snake River Plain is natural background radiation. Sources of radioactivity related to INEL site operations contribute a small amount of additional exposure.

Background radiation includes sources such as cosmic rays; radioactivity naturally present in soil, rocks, and the human body; and airborne radionuclides of natural origin (such as radon). Radioactivity still remaining in the environment as a result of atmospheric testing of nuclear weapons also contributes to the background radiation level, although in very small amounts. The natural background dose for residents of the Eastern Snake River Plain is estimated at 351 millirem per year, with more than half (about 200 millirem per year) caused by the inhalation of radioactive particles formed by the decay of radon (DOE 1992, NCRP 1987).

INEL site operations can result in releasing radioactivity to air either directly (such as through stacks or vents) or indirectly (such as by resuspension of radioactivity on contaminated 


\begin{tabular}{|c|}
\hline Federal Program \\
\hline 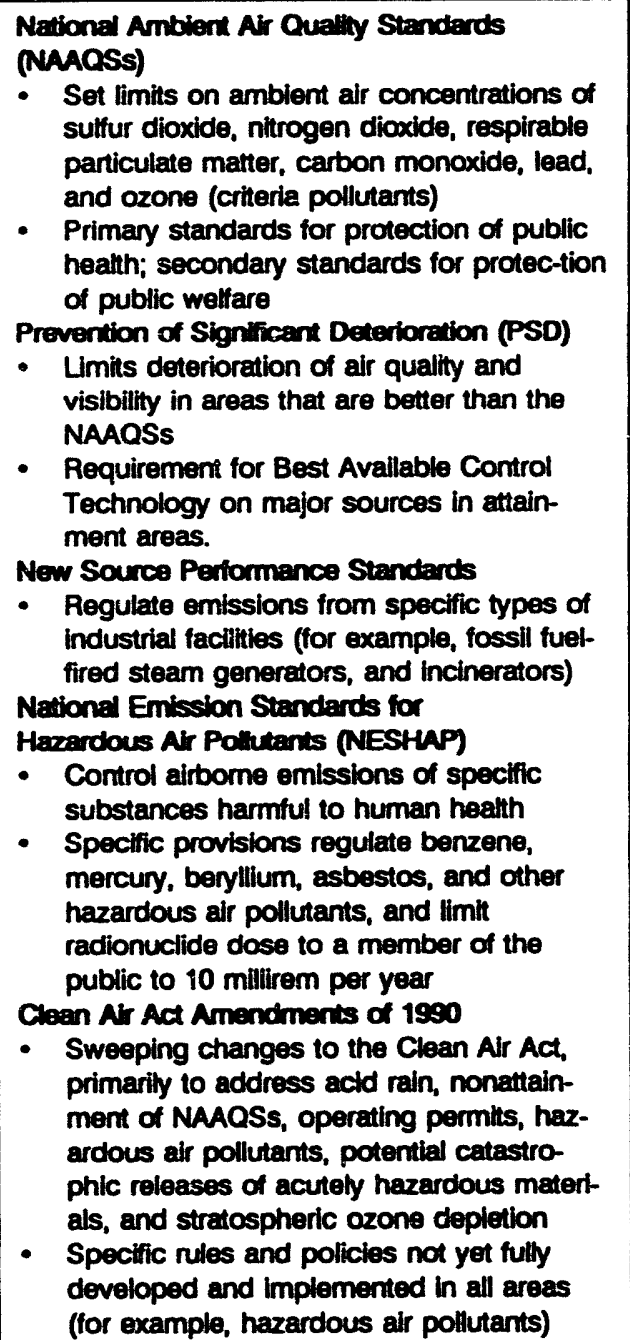 \\
\hline
\end{tabular}

\section{Clean Ar Act}

State of Idaho Administration Program

Current Regulations of the State of ldaho Department of Health and Welfare (IDHW 1994) include:

Idaho Ambient Air Quelly Standards (MaSs)

- Similar to NAAQSs but also include standards for total suspended particulates and fiuorides

New Source Program

- Permit to Construct (PTC) is required for essentially any construction or modification of a facility that emits an air pollutant

- Major facilties require PSD analysis and PTC

\section{Operating Permls}

- Required for nonexempt sources of air pollutants

- Define operating conditions and emissions limitations, as well as monitoring and reporting requirements

Now Source Roviow Policy for Toudc N

\section{Pollutants}

- Defines acceptable ambient concentrations for many specific toxic air pollutants associated with a new source

- Implemented through the New Source and Operating Permit Program

- Requires demonstration of preconstruction compliance with toxic air pollutant standards
DOE Complience Program

Policy to comply with applicable regulations and maintain emissions to lovels as low as reasonably achiovable

- Policy implemented through DOE orders

- DOE (Headquarters) orders apply to all DOE and DOE-contractor operations

- DOE-tdaho Operations Office (DOE-ID) supplemental directives provide direction and guidance spectic to the INEL The most relevant DOE orders and their DOE-1D supplemental directives are:

- DOE Order 5400.1 establishes genera: environmental protection program requirements and assigns responsibilities for ensuring compliance with appllcable laws, regulations, and DOE policy

- DOE Order 5400.5 provides guidelines and requirements for radiation protection of the public

- DOE Order 5480.1B establishes the Environment, Safety, and Health (ES\&H) Program for DOE operations (implemented via DOE-1D Supplemental Directive 5480.1)

- DOE Order 5480.4 prescribes the application of mandatory ES\&H standards that shall be used by all DOE and DOE-contractor operations implemented via DOE-1D Supplemental Directive 5480.4)

- DOE Order 5480.19 provides guideines and requirements for plans and procedures in conducting operations at DOE factities (molemented via DOEID Supplemental Directive 5480.19)

Figure 4.7-2 Overview of Federal, State and U.S. Department of Energy programs for air quality management. 
grounds). Concentrations of radionuclides in direct releases are monitored or estimated based on knowledge of the materials used and activities performed. Indirect releases are estimated using engineering calculations that relate surface contamination levels to expected airborne concentrations.

Emissions from INEL site facilities include the noble gases (argon, krypton, and xenon) and iodine; particulate fission products, such as ruthenium, strontium, and cesium; radionuclides formed by neutron activation, such as tritium (hydrogen-3), carbon-14, and cobalt-60; and heavy elements, such as uranium, thorium, plutonium, and their decay products. Historically, the radionuclide with the highest emission rate is the noble gas krypton-85, which is released mainly by chemical reprocessing of spent nuclear fuel and processing of high-level waste at the Idaho Chemical Processing Plant (ICPP). ${ }^{\mathrm{a}}$ Activities at the Idaho Chemical Processing Plant also release relatively small amounts of iodine-129, an isotope of concern because of its long half-life (16 million years) and biological properties. (Iodine isotopes taken into the body tend to accumulate in the thyroid gland.) Reactor operations release mainly noble gas isotopes with short half-lives, including argon-41 and isotopes of xenon (mainly xenon-131m, -133, -135 and -138 ). Other activities at the INEL site, including waste management operations, result in very low levels of airborne radionuclide emissions. Table 4.7-1 provides a summary of the principal types of airborne radioactivity emitted from existing INEL site facilities, plus estimated emissions from projects expected to become operational before June 1, 1995. For all existing facilities except the Idaho Chemical Processing Plant, these estimates are based on emissions data for 1991. Emission rates for the Idaho Chemical Processing Plant are based on actual 1993 emissions data, scaled upward to reflect operation of the New Waste Calcining Facility (a high-level waste processing operation) at maximum permitted levels. Thus, the radiological emissions are representative of a baseline year that includes processing of high-level waste, but not spent nuclear fuel processing.

\subsubsection{Existing Radlological Conditions. Monitoring and assessment activities are} conducted to characterize existing radiological conditions at the INEL site and surrounding environment. Results of these activities show that exposures resulting from airborne radionuclide emissions are well within applicable standards and are a small fraction of the dose from

a. Fuel reprocessing at the INEL site ceased in April 1992, and baseline emission rates do not include contributions from reprocessing. Rather, processing-related emissions are assessed in Section 5.7 as potential impacts associated with possible future spent nuclear fuel management activities. 
Table 4.7-1. Summary of airborne radionuclide emissions (in curies) from facility areas at the Idaho National Engineering Laboratory site."

\begin{tabular}{|c|c|c|c|c|c|}
\hline Facility & $\begin{array}{c}\text { Tritium/ } \\
\text { carbon-14 }\end{array}$ & Iodines & $\begin{array}{l}\text { Noble } \\
\text { gases }\end{array}$ & $\begin{array}{l}\text { Mixed } \\
\text { fission and } \\
\text { activation } \\
\text { products }^{b}\end{array}$ & $\mathrm{U} / \mathrm{Th} / \mathrm{TRU}^{\mathrm{c}}$ \\
\hline $\begin{array}{l}\text { Argonne National } \\
\text { Laboratory-West }\end{array}$ & $1.0 \times 10^{2}$ & (d) & $1.3 \times 10^{4}$ & $8.1 \times 10^{-4}$ & $1.8 \times 10^{-6}$ \\
\hline Central Facilities Area & $2.6 \times 10^{0}$ & $5.0 \times 10^{-7}$ & (d) & $1.9 \times 10^{-5}$ & $9.6 \times 10^{-7}$ \\
\hline $\begin{array}{l}\text { Idaho Chemical } \\
\text { Processing Plant }\end{array}$ & $4.3 \times 10^{1}$ & $6.4 \times 10^{-2}$ & $1.0 \times 10^{4}$ & $3.6 \times 10^{-2}$ & $9.4 \times 10^{-9}$ \\
\hline Naval Reactors Facility & $1.9 \times 10^{-1}$ & $6.3 \times 10^{-6}$ & $5.7 \times 10^{-1}$ & $5.6 \times 10^{-5}$ & (d) \\
\hline $\begin{array}{l}\text { Power Burst Facility/ } \\
\text { Waste Experimental } \\
\text { Reduction Facility }\end{array}$ & $4.9 \times 10^{1}$ & (d) & (d) & $1.3 \times 10^{0}$ & $9.8 \times 10^{-3}$ \\
\hline $\begin{array}{l}\text { Radioactive Waste } \\
\text { Management Complex }\end{array}$ & (d) & (d) & (d) & $2.6 \times 10^{-5}$ & $4.2 \times 10^{-6}$ \\
\hline Test Area North & $1.2 \times 10^{-1}$ & (d) & (d) & $5.6 \times 10^{-6}$ & $1.5 \times 10^{-5}$ \\
\hline Test Reactor Area & $1.6 \times 10^{2}$ & $1.6 \times 10^{-2}$ & $3.3 \times 10^{3}$ & $3.0 \times 10^{0}$ & $1.8 \times 10^{-6}$ \\
\hline INEL Total & $2.1 \times 10^{3}$ & $1.1 \times 10^{-1}$ & $1.2 \times 10^{5}$ & $5.6 \times 10^{0}$ & $1.0 \times 10^{-2}$ \\
\hline \multicolumn{6}{|c|}{$\begin{array}{l}\text { a. Except for the Idaho Chemical Processing Plant, emissions estimates are based on } 1991 \\
\text { operations. Idaho Chemical Processing Plant emissions are based on } 1993 \text { emissions but are } \\
\text { scaled upward to reflect operation of the New Waste Calcining Facility at maximum permitted } \\
\text { levels. Foreseeable projects in the baseline include the Waste Experimental Reduction Facility } \\
\text { (compacting and sizing operations but not incineration), Argonne National Laboratory-West } \\
\text { Fuel Cycle Facility, and Portable Water Treatment Unit, as described in Appendix F, Section } \\
\text { F-3, Air Resources. } \\
\text { b. Mixed fission and activation products that are primarily particulate in nature (for example, } \\
\text { cobalt-60, strontium-90, and cesium-137). } \\
\text { c. U/Th/TRU = Radioisotopes of uranium, thorium, or transuranic elements such as } \\
\text { plutonium, americium, and neptunium. } \\
\text { d. The eniissions for this group are negligibly small or zero. }\end{array}$} \\
\hline
\end{tabular}

background sources. These results are discussed separately below for onsite and offsite environments.

4.7.3.2.1 Onslte Doses-An indication of onsite radiological conditions is obtained by comparing measured concentrations with those from INEL site boundary communities 
and distant locations. Results from onsite and boundary community locations include contributions from background conditions and INEL site emissions, while distant locations represent background conditions beyond the influence of INEL site emissions. These data show that 1991 average airborne radioactivity and radiation exposure levels within and around the INEL site were no different than those at distant stations. The average annual dose (as measured by thermoluminescent dosimeters during 1991) was 130 millirem for distant locations and 126 millirem for boundary community locations.

Air dispersion models were applied to assess the radiation dose to workers at major INEL site facility areas as a result of cumulative emissions from existing facilities and those expected to become operational before June 1, 1995. Results of this assessment indicate that the maximum dose at any onsite area is currently about $\mathbf{0 . 2}$ millirem per year. This dose could increase to about 4 millirem per year if the maximum projected operation of the Portable Water Treatment Unit at the Power Burst Facility Area is included; however, that operation is temporary (one to two years) and is not representative of a permanent increase in the baseline. If only permanent facility emissions are considered, the baseline worker dose could increase to 0.32 millirem per year. The actual and foreseeable doses are a very small fraction of the DOE-established occupational dose limit (5,000 millirem per year) and are below the National Emissions Standard for Hazardous Air Pollutants (NESHAP) dose limit of 10 millirem per year. The National Emissions Standard for Hazardous Air Pollutants limit, established under the Clean Air Act, applies to the highest exposed member of the public (not to workers) but is the most restrictive limit for airborne releases and serves as a useful comparison for these results.

4.7.3.2.2 Offstte Doses-The offsite population may receive a radiation dose as a result of radiological conditions directly attributable to INEL site operations. The dose associated with baseline radiological emissions (existing facilities and those expected to become operational before June 1,1995 ) is assessed for a maximally exposed individual and for the population within 80 kilometers (50 miles). The maximally exposed individual is a hypothetical person whose habits and proximity to the INEL site are such that the person would receive the highest dose projected to result from sitewide radiological emissions. The dose calculated for the maximally exposed individual as a result of current and foreseeable sitewide emissions is about 0.05 millirem, which is well below both the National Emissions Standard for Hazardous Air Pollutants dose limit (10 millirem per year) and the dose received from background sources (351 millirem per year). 
Figure 4.7-3 illustrates a comparison of these dose rates. As evident in this figure, the 10-millirem dose limit is a very small fraction of the background level and provides a high degree of prctection.

The collective dose to the surrounding population as a result of INEL site emissions, assessed using 1990 U.S. Census Bureau data for the total population residing within a circular area with an 80 -kilometer (50-mile) radius extending from each facility, is about 0.3 person-rem. The population dose is distributed over a population of about 120,000 , resulting in an average individual dose of well below 0.001 millirem. The population dose of 0.3 person-rem is very small when compared with the dose received by the same population from background sources (over 40,000 person-rem). For future years, the baseline population dose is projected to increase (even though baseline emission rates do not rise) by an amount corresponding to the growth of the surrounding population.

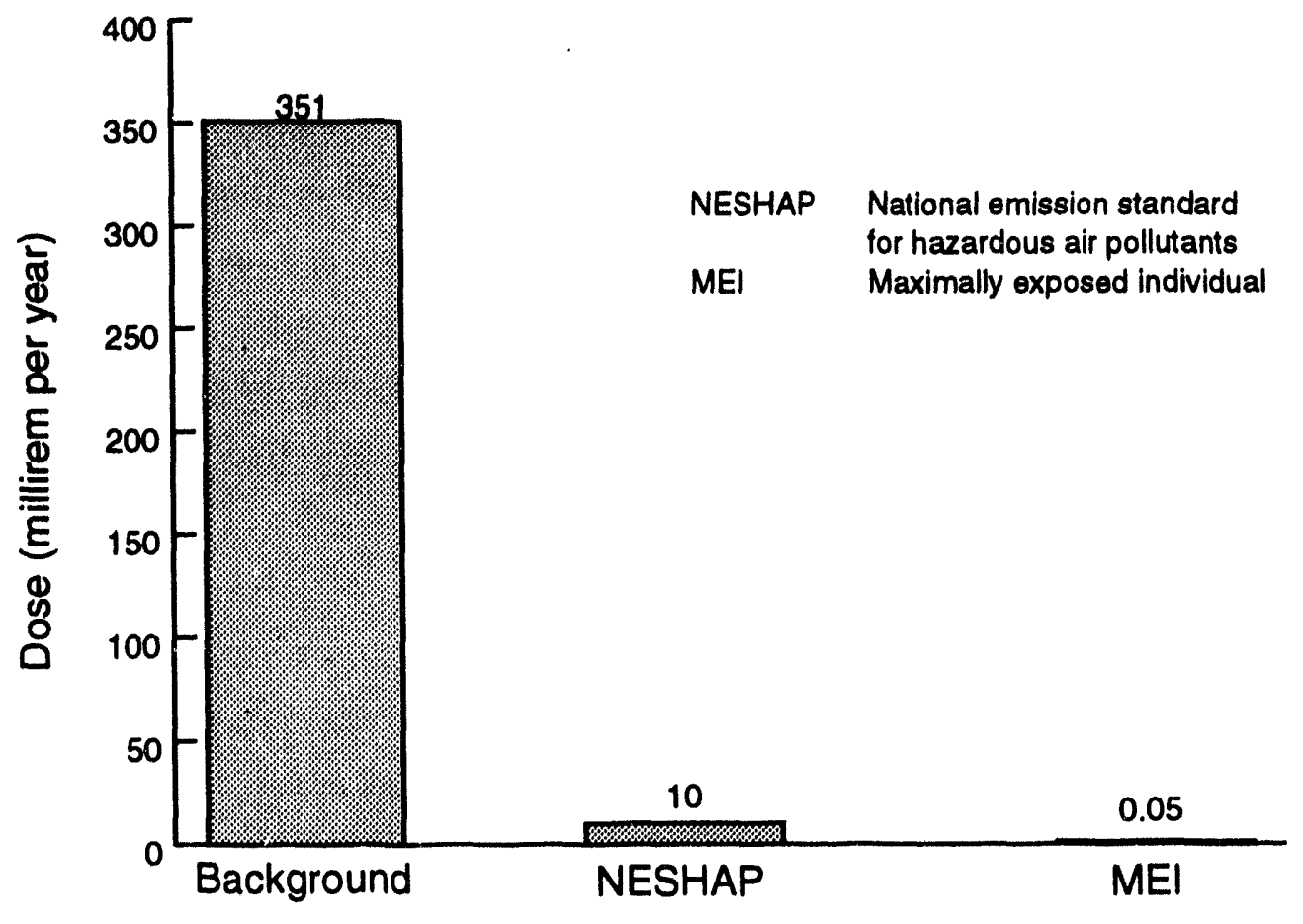

SAA0012

Figure 4.7-3. Comparison of radiation dose to the maximally exposed individual (due to current and foreseeable radiological emissions at the Idaho National Engineering Laboratory site) to the National Emission Standard for Hazardous Air Pollutants dose limit and the dose from background sources. 


\subsubsection{Summary of Radiological Conditions. Radioactivity and radiation levels}

resulting from INEL site emissions are very low, well within applicable standards, and negligible when compared to doses received from natural background sources. This applies both to onsite conditions to which INEL site workers or visitors may be exposed, and offsite locations where the general population resides. Health risks associated with maximum potential exposure levels in the onsite and offsite environments are described in Section 4.12, Health and Safety.

\subsubsection{Nonradlological Conditions}

Persons in the Eastern Snake River Plain are exposed to sources of air pollutants, such as agricultural and industria! activities, residential woodburning, wind-blown dust, and automobile exhaust. Many of the activities at the INEL also emit air pollutants. The types of pollutants that are assessed here include (a) the criteria pollutants regulated under the National and State Ambient Air Quality Standards and (b) other types of pollutants with potentially toxic properties called toxic (or hazardous) air pollutants. Criteria pollutants include nitrogen dioxide, sulfur dioxide, carbon monoxide, lead, ozone, and respirable particulate matter (particles less than 10 micrometers in diameter, which are small enough to pass easily into the lower respiratory tract), for which National Ambient Air Quality Standards have been established. Total suspended particulate matter is also designated by the State of Idaho as a criteria pollutant. Volatile organic compounds are assessed as precursors leading to the development of ozone. ${ }^{b}$ Toxic air pollutants include cancer-causing agents, such as arsenic, benzene, carbon tetrachloride, and formaldehyde, as well as materials with noncancer health hazards, such as fluorides, ammonia, and hydrochloric and sulfuric acids.

4.7.4.1 Sources of Air Emissions. The types of nonradiological emissions from INEL facilities and activities are similar to those of other major industrial complexes the size of the INEL. Combustion sources such as boilers and emergency generators emit both criteria and toxic air pollutants. Sources such as chemical processing operations, waste management activities (other than combustion), and research laboratories emit primarily toxic air pollutants. $A$ total of 26 toxic air pollutants have been identified that are emitted from existing INEL facilities in

b. Ozone is formed by reactions of oxides of nitrogen and oxygen in the presence of sunlight. Volatile organic hydrocarbons, sometimes called precursor organics, contribute to the formation of ozone. Oxides of nitrogen and volatile organic hydrocarbons are, therefore, regulated as precursors to ozone formation. 
quantities exceeding the screening level established by the State of Idaho. (The health hazard associated with toxic air pollutants emitted in lesser quantities is considered low enough by the State of Idaho not to require detailed assessment.) Waste management, construction, and related activities (such as excavation) also generate fugitive particulate matter.

Baseline emission rates for existing facilities have been characterized for two separate cases. The actual emissions case represents the collective emission rates of nonradiological pollutants experienced by INEL facilities during 1991 for criteria pollutants and 1989 for toxic air pollutants. These are the most recent years for which complete data are available. In contrast to this actual case, emissions have also been estimated for a hypothetical maximum year. This is appropriate because many facilities that are governed by conditions imposed by operating permits (such as maximum hours of operation or emission rates) typically operate at levels well below those allowed by the permit. It is conceivable that emission rates of currently operated facilities could increase greatly and still remain within the bounds of permitted conditions. The maximum emissions case has, therefore, been characterized. This baseline case represents a scenario in which all permitted sources at the INEL are assumed to operate in such a manner that they emit specific pollutants to the maximum extent allowed by operating permits or applicable regulations. The baseline also includes reasonably foreseeable increases (that is, emissions from projects expected to become operational before June 1, 1995.) A summary of criteria and toxic air pollutant emission rates for the actual and maximum emissions cases, including foreseeable increases, is provided in Table 4.7-2.

4.7.4.2 Existing Conditions. For most of the pollutants included in this assessment (including all toxic air pollutants), insufficient monitoring data exist to allow a meaningful description of existing air quality. Rather, the characterization of existing nonradiological conditions relies on an extensive program of air dispersion modeling. The modeling program applied for this purpose utilized computer codes, methods, and assumptions that are considered acceptable by the U.S. Environmental Protection Agency and the State of Idaho for regulatory compliance purposes and suitable for the terrain of this locale. In general, the Industrial Source Complex-2 (ISC-2) model was used for assessment of criteria pollutants and selected toxic air pollutants; the Fugitive Dust Model (FDM) was used to assess impacts due to fugitive dust emissions; and the simpler SCREEN model was used to assess other toxic air contaminants. The SCREEN model incorporates methods and data that tend to overestimate impacts, and it is useful 
Table 4.7-2 Annual average and maximum hourly emission rates of nonradiological air pollutants for the actual and maximum baseline cases at the Idaho National Engineering Laboratory.

\begin{tabular}{|c|c|c|c|c|c|c|}
\hline \multirow[b]{2}{*}{ Pollutant } & \multicolumn{2}{|c|}{ Actual case } & \multicolumn{2}{|c|}{ Maximum case } & \multicolumn{2}{|c|}{ Forenceable increasen } \\
\hline & $\begin{array}{l}\text { Annual } \\
\text { average } \\
\text { (kilograms } \\
\text { per year) }\end{array}$ & $\begin{array}{c}\text { Maximum } \\
\text { hourly } \\
\text { (kilograms per } \\
\text { hour) }\end{array}$ & $\begin{array}{l}\text { Annual } \\
\text { average } \\
\text { (kilograms } \\
\text { per year) }\end{array}$ & $\begin{array}{l}\text { Maximum } \\
\text { hourty } \\
\text { (kilograms per } \\
\text { hour) }\end{array}$ & $\begin{array}{l}\text { Annual } \\
\text { average } \\
\text { (kilograms } \\
\text { per year) }\end{array}$ & $\begin{array}{l}\text { Maximum } \\
\text { hourly } \\
\text { (kilograms per } \\
\text { hour) }\end{array}$ \\
\hline \multicolumn{7}{|c|}{ Criteria polintants } \\
\hline Carbon monoxide & 300,000 & 150 & $2,200,000$ & 250 & 1,300 & 25 \\
\hline Nitrogen dicuide & 740,000 & 450 & $3,000,000$ & 780 & 6,100 & 130 \\
\hline Sulfur diaxide & 200,000 & 120 & $1,700,000$ & 350 & 2,000 & 9 \\
\hline Particulate matter ${ }^{b}$ & 300,000 & 220 & 900,000 & 290 & 250 & 3.3 \\
\hline Lead & 4.1 & 0.084 & 68 & 0.8 & 0.07 & $8.3 \times 10^{-6}$ \\
\hline \multicolumn{7}{|c|}{ To ic pollotente } \\
\hline Acetaldehyde & 31 & 0.39 & 180 & 0.68 & o & $\mathbf{0}$ \\
\hline Ammonia & 1,600 & 3.4 & 6,500 & 3.4 & $\mathbf{0}$ & $\mathbf{0}$ \\
\hline Arenic & 4.2 & $9.0 \times 10^{-4}$ & 24 & $6.3 \times 10^{-3}$ & $\mathbf{0}$ & $\mathbf{0}$ \\
\hline Benzene & 340 & 15 & 530 & 16 & 30 & 0.86 \\
\hline 1,3-Butadiene & 220 & 0.81 & 390 & 1.8 & o & 0 \\
\hline Carbon tetrachloride & 28 & 0.083 & 28 & 0.083 & $4.5 \times$ & $9.1 \times 10^{-7}$ \\
\hline Chloroform & 1.9 & $5.5 \times 10^{-3}$ & 1.9 & $5.5 \times 10^{-3}$ & 0.045 & $4.5 \times 10^{-6}$ \\
\hline Chromium - trivalent & 3.1 & $2.5 \times 10^{-3}$ & 38 & 0.013 & 0.0295 & $3.4 \times 10^{-6}$ \\
\hline Chromium - hexavalent & 0.4 & $6.2 \times 10^{-4}$ & 26 & $7.2 \times 10^{-3}$ & 0.0016 & $1.8 \times 10^{-7}$ \\
\hline Cyclopentane & 350 & 0.58 & 350 & 0.58 & $\mathbf{0}$ & 0 \\
\hline Dichloromethane & 620 & 0.29 & 1,100 & 0.29 & 0.0091 & $4.1 \times 10^{-5}$ \\
\hline Formaldehyde & 740 & 1.3 & 3,300 & 27 & 2200 & 7.6 \\
\hline Hydrazine & 8.3 & $9.5 \times 10^{-4}$ & 8.3 & $9.5 \times 10^{-4}$ & $\mathbf{0}$ & 0 \\
\hline Hydrochloric acid & 1,500 & 0.34 & 1,500 & 0.34 & $\mathbf{0}$ & $\mathbf{0}$ \\
\hline Mercury & 200 & 0.023 & 200 & 0.023 & $\mathbf{0}$ & $\mathbf{0}$ \\
\hline Napthalene & 16 & 2.2 & 16 & 2.2 & $\mathbf{0}$ & $\mathbf{0}$ \\
\hline Nickel & 270 & 0.057 & 1,000 & 0.24 & 0.35 & $4.5 \times 10^{-5}$ \\
\hline Nitric scid & 1,500 & 1.7 & 97,000 & 12 & $\mathbf{0}$ & $\mathbf{0}$ \\
\hline Phosphorus & 56 & 0.024 & 210 & 0.072 & $\mathbf{0}$ & $\mathbf{0}$ \\
\hline Potassium hydroxide & 990 & 0.24 & 2,100 & 0.24 & $\mathbf{0}$ & 0 \\
\hline Propionaldehyde & 62 & 0.24 & 110 & 0.41 & 0 & $\mathbf{0}$ \\
\hline Styrene & 4.7 & 0.74 & 4.7 & 0.74 & 0 & 0 \\
\hline Tetrachloroethylene & 980 & 0.11 & 980 & 0.11 & 0 & $\mathbf{0}$ \\
\hline Toluene & 580 & 56 & 580 & 56 & 0 & 0 \\
\hline Trichloroethylene & 4.5 & 0.013 & 4.5 & 0.013 & 0.18 & $6.4 \times 10^{-5}$ \\
\hline Trimethylbenzene & 87 & 12 & 87 & 12 & 0 & $\mathbf{0}$ \\
\hline $\begin{array}{l}\text { a. Reasonably foreseeat } \\
\text { Center expansion; and th } \\
\text { b. All particulate matte } \\
\text { PM-10 emisaions from th } \\
\text { c. Toxics that are listed }\end{array}$ & $\begin{array}{l}\text { rojects inclu } \\
\text { tility Syetem } \\
\text { isumed to c } \\
\text { ve sources. } \\
\text { tate of Idah }\end{array}$ & $\begin{array}{l}\text { the Fuel Cycle F } \\
\text { Jperade Project } \\
\text { sist of respirable } \\
\text { egulations and an }\end{array}$ & $\begin{array}{l}\text { ility at Argo } \\
\text { the Idaho Ch } \\
\text { irticles leas t } \\
\text { emitted in le }\end{array}$ & $\begin{array}{l}\text { National Labor } \\
\text { jical Proceasing P } \\
10 \text { microns in d } \\
\text { that exceed sere }\end{array}$ & $\begin{array}{l}\text { ny-Weat; the } \\
\text { ne. } \\
\text { neter (that is, } \\
\text { ing criteria. }\end{array}$ & $\begin{array}{l}\text { JEL Research } \\
\text { M-10); includes }\end{array}$ \\
\hline
\end{tabular}


for identifying cases that require additional, more refined (ISC-2) assessment. The methodology applied in these assessments is described in detail in Appendix F, Section F-3, Air Resources. The remainder of this section describes the results of the air dispersion modeling effort in terms of air quality conditions associated with the actual and maximum baseline cases. In particular, assessment results are presented for concentrations of pollutants in air within and around the INEL site.

\subsection{Onsite Conditions-The existing conditions have been assessed for} each facility area as a result of cumulative emissions from sources located within that area as well as other areas of the INEL site. Except for public roads, criteria pollutant levels are not assessed for onsite locations because standards for these pollutants apply only to ambient air locations (that is, locations to which the general public has access). Toxic air pollutants, however, are assessed because of potential exposure of workers to these hazardous substances. Typically, the dominant contributors to pollutant levels at each of these areas are sources within that area. Onsite levels of specific toxics are compared to occupational exposure limits set for these substances by either the Occupational Safety and Health Administration (OSHA) or the American Conference of Government Industrial Hygienists. (The lower of the two limits is used.)

Results of the onsite assessment for both the actual and maximum emissions are presented in Table 4.7-3. For most of the toxics, the estimated onsite concentrations of toxic air pollutants are well below levels established for protection of workers. The maximum short-term benzene concentration (that is, the highest level predicted to occur over an eight-hour period) is approximately equal to the standard at the highest predicted location within the Central Facilities Area. These levels result primarily from emissions associated with petroleum fuel storage, handling, and combustion. All other toxic pollutant levels at onsite locations were well within the most restrictive occupational exposure limits.

\subsection{Offsite Conditions-Estimated maximum offsite pollutant}

concentrations were calculated for locations along the INEL site boundary and for public roads within the site boundary. These are considered ambient air locations because the public has general access. Pollutant levels were also calculated for Craters of the Moon Wilderness Area. The results for criteria pollutants are presented in Table 4.7-4 and indicate that all concentrations 
Table 4.7-3. Highest predicted concentrations of toxic air pollutants at onsite locations for the maximum baseline case at the Idaho National Engineering Laboratory site, including foreseeable increases.

\begin{tabular}{|c|c|c|c|c|}
\hline Toxic air pollutant & $\begin{array}{c}\text { Location of } \\
\text { maximum } \\
\text { concentration }\end{array}$ & $\begin{array}{c}\text { Maximum } \\
\text { eight-hour } \\
\text { concentration } \\
\left(\mu \mathrm{g} / \mathrm{m}^{3}\right)\end{array}$ & $\begin{array}{c}\text { Occupational } \\
\text { exposure } \\
\text { limit }^{\mathrm{b}} \\
\left(\mu \mathrm{g} / \mathrm{m}^{3}\right) \\
\end{array}$ & $\begin{array}{l}\text { Percent of } \\
\text { standard }\end{array}$ \\
\hline \multicolumn{5}{|c|}{ Carcinogens } \\
\hline Acetaldehyde & ANL-W & $1.1 \times 10^{2}$ & $1.8 \times 10^{5}$ & $<1$ \\
\hline Arsenic & CFA & $2.8 \times 10^{-1}$ & $1.0 \times 10^{1}$ & $<1$ \\
\hline Benzene & CFA & $3.1 \times 10^{3}$ & $3.0 \times 10^{3}$ & 103 \\
\hline Butadiene & TRA & $3.8 \times 10^{3}$ & $2.2 \times 10^{4}$ & 17 \\
\hline Carbon tetrachloride & RWMC & $2.5 \times 10^{2}$ & $1.3 \times 10^{4}$ & 2 \\
\hline Chloroform & RWMC & $1.7 \times 10^{1}$ & $9.8 \times 10^{3}$ & $<1$ \\
\hline Formaldehyde & ANL-W & $5.7 \times 10^{1}$ & $3.7 \times 10^{2}$ & 15 \\
\hline Hexavalent chromium & ICPP/TAN & $2.4 \times 10^{0}$ & $5.0 \times 10^{1}$ & 5 \\
\hline Hydrazine & TRA & $1.8 \times 10^{-3}$ & $1.0 \times 10^{2}$ & $<1$ \\
\hline Methylene chloride & CFA/ICPP & $3.2 \times 10^{0}$ & $1.7 \times 10^{5}$ & $<1$ \\
\hline Nickel & CFA & $4.1 \times 10^{1}$ & $1.0 \times 10^{2}$ & 41 \\
\hline Perchloroethylene & CFA & $4.3 \times 10^{2}$ & $1.7 \times 10^{5}$ & $<1$ \\
\hline Trichloroethylene & RWMC & $4.0 \times 10^{1}$ & $1.7 \times 10^{5}$ & $\leq 1$ \\
\hline \multicolumn{5}{|c|}{ Noncarcitogens } \\
\hline Ammonia & ICPP & $9.7 \times 10^{2}$ & $1.7 \times 10^{4}$ & 6 \\
\hline Cyclopentane & ICPP & $1.1 \times 10^{3}$ & $1.7 \times 10^{6}$ & $<1$ \\
\hline Hydrochloric acid & CFA & $1.1 \times 10^{2}$ & $7.0 \times 10^{3}$ & 2 \\
\hline Mercury & ICPP & $3.0 \times 10^{0}$ & $5.0 \times 10^{1}$ & 6 \\
\hline Napthalene & CFA & $2.3 \times 10^{3}$ & $5.0 \times 10^{4}$ & 5 \\
\hline Nitric acid & ICPP & $7.7 \times 10^{2}$ & $5.0 \times 10^{3}$ & 15 \\
\hline Phosphorus & TAN & $5.5 \times 10^{1}$ & $1.0 \times 10^{2}$ & 55 \\
\hline Potassium hydroxide & TAN & $1.4 \times 10^{1}$ & $2.0 \times 10^{3}$ & $<1$ \\
\hline Proprionaldehyde & ANL-W & $6.5 \times 10^{1}$ & $4.3 \times 10^{2}$ & 15 \\
\hline Styrene & ICPP & $3.4 \times 10^{2}$ & $2.1 \times 10^{5}$ & $<1$ \\
\hline Toluene & CFA & $3.1 \times 10^{4}$ & $1.9 \times 10^{5}$ & 16 \\
\hline Trimethylbenzene & CFA & $1.3 \times 10^{4}$ & $1.2 \times 10^{5}$ & 11 \\
\hline Trivalent chromium & TAN & $3.4 \times 10^{0}$ & $5.0 \times 10^{2}$ & $<1$ \\
\hline \multicolumn{5}{|c|}{$\begin{array}{l}\text { a. ANL-W = Argonne National Laboratory-West; ICPP = Idaho Chemical Processing Plant; CFA = } \\
\text { Central Facilities Area; TRA = Test Reactor Area; TAN = Test Area North; RWMC = Radioactive } \\
\text { Waste Management Complex. } \\
\text { b. Occupational exposure limits are eight-hour, time-weighted averages established by the American } \\
\text { Conference of Governmental Industrial Hygienists (ACGIH) or Occupational Safetiy and Health } \\
\text { Administration (OSHA); the lower (most restrictive) of the two limits is used. }\end{array}$} \\
\hline
\end{tabular}


Table 4.7-4. Ambient air concentrations of criteria pollutants for the maximum baseline scenario at the Idaho National Engineering Laboratory site, including foreseeable increases.

\begin{tabular}{|c|c|c|c|c|c|c|c|c|}
\hline \multirow[b]{2}{*}{ Pollutant } & \multirow[b]{2}{*}{$\begin{array}{l}\text { Averaging } \\
\text { time }\end{array}$} & \multicolumn{3}{|c|}{$\begin{array}{l}\text { Baseline concentration } \\
\left(\mu g / \mathrm{m}^{3}\right)\end{array}$} & \multirow[b]{2}{*}{$\begin{array}{l}\text { Applicable } \\
\text { otandand } \\
\left(\mu g / \mathrm{m}^{3}\right)\end{array}$} & \multicolumn{3}{|c|}{ Percent of standard } \\
\hline & & $\begin{array}{c}\text { Site } \\
\text { boundary }\end{array}$ & $\begin{array}{l}\text { Public } \\
\text { roads }\end{array}$ & $\begin{array}{l}\text { Craters of } \\
\text { the Moon }\end{array}$ & & $\begin{array}{c}\text { Site } \\
\text { boundary }\end{array}$ & $\begin{array}{l}\text { Public } \\
\text { roads }\end{array}$ & $\begin{array}{l}\text { Craters of } \\
\text { the Moon }\end{array}$ \\
\hline \multirow[t]{2}{*}{ Carbon monoxide } & One-hour & 600 & 1,200 & 170 & 40,000 & 1.5 & 3.0 & 0.4 \\
\hline & Eight-hour & 180 & 340 & 35 & 10,000 & 1.8 & 3.4 & 0.4 \\
\hline Nitrogen dioxide & Annual & 5 & 9 & 1 & 100 & 4.6 & 9.4 & 0.8 \\
\hline Lead & Quarterty & 0.0008 & 0.002 & 0.0002 & 1.5 & 0.1 & 0.1 & 0.01 \\
\hline \multirow[t]{2}{*}{ Particulate matter } & 24-hour & 17 & 31 & 8 & 150 & 11 & 21 & 5.5 \\
\hline & Annual & 1 & 3 & 0.3 & so & 2.6 & 5.2 & 0.6 \\
\hline \multirow[t]{2}{*}{ Particulate matter } & 24-hour & 50 & $80^{d}$ & 10 & 150 & 33 & 53 & 7 \\
\hline & Annual & 2 & $s^{d}$ & 1 & 50 & 4 & 10 & 2 \\
\hline \multirow[t]{3}{*}{ Sulfur diaxide } & 24-hour & 100 & 230 & 39 & 365 & 27 & 63 & 11 \\
\hline & Three-hour & 240 & 520 & 88 & 1,300 & 18 & 40 & 6.8 \\
\hline & Annual & 2 & 4 & 1 & 80 & 2.6 & 5.4 & 1.0 \\
\hline \multicolumn{9}{|c|}{$\begin{array}{l}\text { a. National Ambient Air Quality Standards; all standards are primary except for three-hour sulfur dioxide, which is secondary. } \\
\text { b. Particulate matter from stationary emission points. All particulate matter is aseumed to consiat of respirable particles less than } \\
10 \text { microns in diameter (that is, PM-10). The State of Idaho also has a standard for total suspended particulates, but the Federal } \\
\text { standard for PM-10 is more restrictive. } \\
\text { c. Cumulative contributions from stationary point sources, fugitive emissions sources (such as vehicle travel on paved and unpaved } \\
\text { roads), and landfills and concrete batch plant operations. } \\
\text { d. Does not include fugitive emissions caused by vehicular traffic. }\end{array}$} \\
\hline
\end{tabular}

are well within the ambient air quality standards for both the actual and maximum emissions cases. For the maximum emissions baseline, the highest sulfur dioxide concentration (over a 24-hour period) at the site boundary is about 27 percent of the standard, while the highest 24-hour particulate matter level is about 33 percent of the standard. Levels of all other pollutants are below 10 percent of applicable standards. The highest offsite levels are estimated to occur at the boundary south and south-southwest of the Central Facilities Area. Somewhat higher resuits were obtained for public roads traversing the site, with 24-hour sulfur dioxide and particulate matter at 63 and 53 percent of the standards, respectively. Values at Craters of the Moon Wilderness Area were below 10 percent of applicable standards in all cases except 24-hour sulfur dioxide (11 percent). It should be noted that actual emissions from INEL site facilities are much lower than those assumed for the maximum scenario, so there is a wide margin of protection inherent in 
these results. Figure 4.7-4 illustrates the difference in actual and maximum emissions for criteria and toxic air pollutants.

Concentrations of toxic air pollutants are compared to the ambient air standards recently promulgated for new sources by the State of Idaho Standards for Control of Air Pollution in Idaho (IDHW 1994). Although the standards apply only to new (not existing) sources, these standards are useful as reference levels for comparing current conditions with recommendations for ensuring public health protection in association with new sources of emissions. Thus, the discussion that follows refers to these standards as reference levels. Annual average concentrations of carcinogenic toxics are assessed for offsite locations (site boundary and Craters of the Moon Wilderness Area), while short-term concentrations of noncarcinogenic toxics are assessed for locations along public roads as well as offsite locations.

Maximum offsite concentrations of carcinogenic toxics, which are summarized in Table 4.7-5, are observed to occur at the site boundary due south of the Central Facilities Area. All carcinogenic air pollutant levels are below the reference levels. Noncarcinogenic air pollutant levels are summarized in Table 4.7-6. For site boundary locations, these levels are all well below the reference levels. Levels at some public road locations, which are closer to emissions sources, are higher than site boundary locations, but still below the reference levels. All pollutani levels estimated for Craters of the Moon Wilderness Area are well below reference levels appropriate for comparison.

4.7.4.3 Summany of Nonradiological Air Quallty. The baseline conditions of nonradiological air quality on and around the INEL site have been estimated for actual and maximum emissions scenarios. The air quality is good and within applicable guidelines. The area around the INEL site is designated as in attainment of all air quality standards. Levels of criteria pollutants are well within the ambient air quality standards for both scenarios. For toxic emissions, all INEL site boundary and public road levels are below reference levels appropriate for comparison. Within the INEL site, a very localized and slight exceedance occurs for levels of benzene at the Central Facilities Area. All other toxic pollutant levels at onsite locations are well below applicable limits. Health risks associated with maximum potential exposure levels in the onsite and offsite environments are described in Section 4.12 , Health and Safety. 

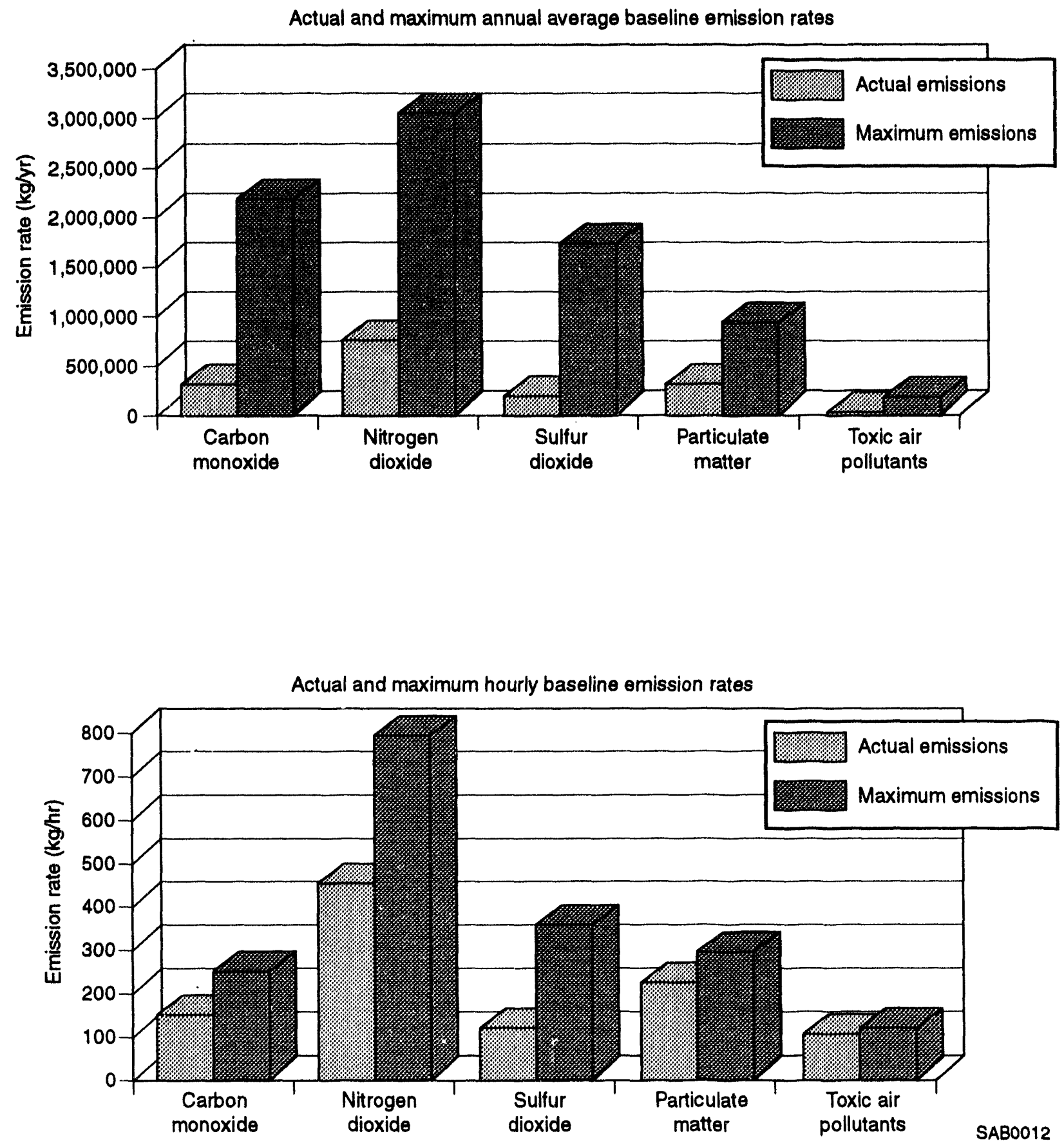

Figure 4.7-4. Comparison of actual hourly emission rates from criteria and toxic air pollutants at the Idaho National Engineering Laboratory site with the annual rates assumed for the maximum emissions scenario. 
Table 4.7-5. Highest predicted concentrations of carcinogenic air pollutants at site boundary locations for the maximum baseline case at the Idaho National Engineering Laboratory site, including foreseeable increases.

\begin{tabular}{lccc}
\hline \multicolumn{1}{c}{ Toxic air pollutant } & $\begin{array}{c}\text { Annual average } \\
\text { concentration } \\
\left(\mu \mathrm{g} / \mathrm{m}^{3}\right)\end{array}$ & $\begin{array}{c}\text { Standard } \\
\left(\mu \mathrm{g} / \mathrm{m}^{3}\right)\end{array}$ & $\begin{array}{c}\text { Percent of } \\
\text { standard }\end{array}$ \\
\hline Arsenic & $9.0 \times 10^{-5}$ & $2.3 \times 10^{-4}$ & 39 \\
Benzene & $2.9 \times 10^{-2}$ & $1.2 \times 10^{-1}$ & 25 \\
Butadiene & $1.0 \times 10^{-3}$ & $3.6 \times 10^{-3}$ & 28 \\
Carbon tetrachloride & $4.8 \times 10^{-3}$ & $6.7 \times 10^{-2}$ & 7 \\
Chloroform & $3.2 \times 10^{-4}$ & $4.3 \times 10^{-2}$ & $<1$ \\
Formaldehyde & $1.2 \times 10^{-2}$ & $7.7 \times 10^{-2}$ & 16 \\
Hexavalent chromium & $6.0 \times 10^{-5}$ & $8.3 \times 10^{-5}$ & 72 \\
Hydrazine & $1.0 \times 10^{-6}$ & $1.0 \times 10^{2}$ & $<1$ \\
Methylene chloride & $6.0 \times 10^{-3}$ & $2.4 \times 10^{-1}$ & 3 \\
Nickel & $2.7 \times 10^{-3}$ & $4.2 \times 10^{-3}$ & 65 \\
& & & \\
\hline & & & \\
a. Acceptable air concentrations for carcinogens (AACC) listed in Rules for the Control of Air \\
Pollution in Idaho. Acceptable air concentrations for carcinogens apply only to new (not \\
existing) sources and are used here only as reference levels.
\end{tabular}


Table 4.7-6. Highest predicted eight-hour concentrations of noncarcinogenic toxic air pollutants at site boundaries and public road locations at the Idaho National Engineering Laboratory site, including foreseeable increases.

\begin{tabular}{|c|c|c|c|c|}
\hline Toxic air pollutant & Location & $\begin{array}{c}\text { Maximum } \\
\text { 8-hour } \\
\text { concentration } \\
\left(\mu \mathrm{g} / \mathrm{m}^{3}\right)\end{array}$ & $\begin{array}{l}\text { Standard } \\
\left(\mu g / m^{3}\right)\end{array}$ & $\begin{array}{l}\text { Percent of } \\
\text { standard }\end{array}$ \\
\hline \multirow[t]{2}{*}{ Ammonia } & Public road & $3.3 \times 10^{1}$ & $1.7 \times 10^{4}$ & $<1$ \\
\hline & Site boundary & $2.3 \times 10^{0}$ & & $<1$ \\
\hline \multirow[t]{2}{*}{ Cyclopentane } & Public road & $1.5 \times 10^{1}$ & $1.7 \times 10^{4}$ & $<1$ \\
\hline & Site boundary & $2.2 \times 10^{-1}$ & & $<1$ \\
\hline \multirow[t]{2}{*}{ Hydrochloric acid } & Public road & $5.5 \times 10^{0}$ & $7.5 \times 10^{0}$ & 73 \\
\hline & Site boundary & $5.4 \times 10^{-1}$ & & 7 \\
\hline \multirow[t]{2}{*}{ Mercury } & Public road & $2.4 \times 10^{-1}$ & $1.0 \times 10^{0}$ & 24 \\
\hline & Site boundary & $7.4 \times 10^{-2}$ & & 7 \\
\hline \multirow[t]{2}{*}{ Napthalene } & Public road & $1.0 \times 10^{2}$ & $5.0 \times 10^{2}$ & 20 \\
\hline & Site boundary & $1.1 \times 10^{-2}$ & & $<1$ \\
\hline \multirow[t]{2}{*}{ Nitric acid } & Public road & $3.6 \times 10^{0}$ & $5.0 \times 10^{1}$ & 7 \\
\hline & Site boundary & $1.4 \times 10^{0}$ & & 3 \\
\hline \multirow[t]{2}{*}{ Phosphorus } & Public road & $4.4 \times 10^{-2}$ & $1.0 \times 10^{0}$ & 4 \\
\hline & Site boundary & $5.1 \times 10^{-3}$ & & $<1$ \\
\hline \multirow[t]{2}{*}{ Potassium hydroxide } & Public road & $1.1 \times 10^{0}$ & $2.0 \times 10^{1}$ & 6 \\
\hline & Site boundary & $1.1 \times 10^{0}$ & & 6 \\
\hline \multirow[t]{2}{*}{ Proprionaldehyde } & Public road & $1.7 \times 10^{0}$ & $4.3 \times 10^{0}$ & 39 \\
\hline & Site boundary & $3.6 \times 10^{-2}$ & & $<1$ \\
\hline \multirow[t]{2}{*}{ Styrene } & Public road & $7.10 \times 10^{0}$ & $1.0 \times 10^{3}$ & $<1$ \\
\hline & Site boundary & $1.3 \times 10^{-3}$ & & $<1$ \\
\hline \multirow[t]{2}{*}{ Toluene } & Public road & $2.1 \times 10^{3}$ & $3.8 \times 10^{3}$ & 55 \\
\hline & Site boundary & $3.5 \times 10^{-1}$ & & $<1$ \\
\hline \multirow[t]{2}{*}{ Trimethylbenzene } & Public road & $5.7 \times 10^{2}$ & $1.2 \times 10^{3}$ & 46 \\
\hline & Site boundary & $5.7 \times 10^{-2}$ & & $<1$ \\
\hline \multirow[t]{2}{*}{ Trivalent chromium } & Public road & $2.0 \times 10^{-1}$ & $5.0 \times 10^{0}$ & 4 \\
\hline & Site boundary & $1.2 \times 10^{-2}$ & & $<1$ \\
\hline
\end{tabular}




\subsection{Water Resources}

This section describes existing regional and INEL site hydrologic conditions and discusses existing water quality for surface and subsurface water, water use, and water rights. The subsurface water section also describes the saturated zone below the water table and the vadose zone (or unsaturated zone and perched water bodies) located between the land surface and the water table. Technical support for this section is provided in Appendix F, Section F-2, Geology and Water.

\subsubsection{Surface Water}

Other than intermittent streams and surface water bodies (formed from the infrequent accumulation of runoff during snowmelt or heavy precipitation) and manmade percolation and infiltration and evaporation ponds (formed from intermittent groundwater pumping and discharge from operations), there is little surface water at the INEL site. The following sections discuss regional drainage conditions, local runoff, flood plains, and surface water quality. Figure 4.8-1 supports discussions in this section.

4.8.1.1 Regional Drainage. The INEL site is located in the Mud Lake-Lost River Basin, a closed drainage basin that includes three main tributaries-the Big and Little Lost Rivers and Birch Creek. These surface water features drain mountain watersheds located directly west and north of the INEL site. However, most of the surface water flow is diverted for irrigation before it reaches site boundaries (Barraclough et al. 1981), resuiting in little or no surface water flow for periods of up to several years in duration within the boundaries of the INEL site (Pittman et al. 1988).

The Big Lost River drains approximately 3,755 square kilometers (1,450 square miles) of land before reaching the INEL site. Approximately 48 kilometers (30 miles) upstream of Arco, Idaho, Mackay Dam controls and regulates river flow, which continues southeast past the towns of Moore and Arco and onto the Eastern Snake River Plain. The river channel then crosses the southwestern boundary of the INEL site, where surface water flow can be controlled by the INEL Diversion Dam. During heavy runoff events, surface water is diverted to a series of natural 


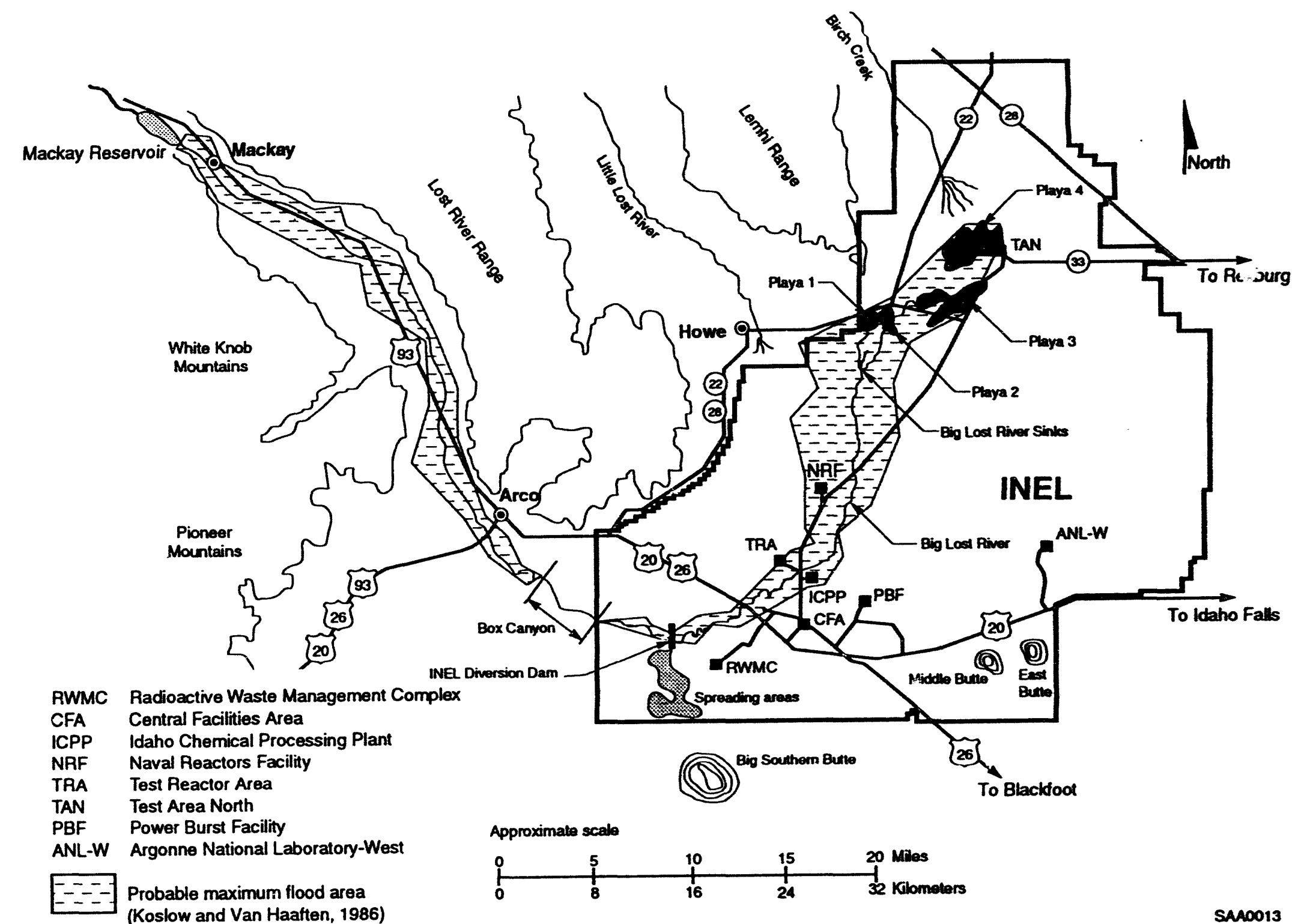

Figure 4.8-1. Locations of selected Idaho National Engineering Laboratory site facilities shown with the predicted inundation area for the probable maximum flood-induced overtopping failure of the Mackay Dam (Bennett 1990). 
depressions, designated as spreading areas. The purpose of the diversion system is to prevent flooding of downstream facilities and ice jams from developing in the channel. The Big Lost River continues northeasterly across the INEL site to an area of natural infiltration basins (playas or sinks) near Test Area Nortn. Surface water from the Big Lost River does not usually reach the western boundary of the INEL site; however, during an unusually wet year, flow can continue as far north as the Birch Creek Playa (Playa 4).

Birch Creek drains an area of approximately 1,943 square kilometers (750 square miles). In the summer, upstream of the INEL site, surface water from Birch Creek is diverted for irrigation and hydropower production. In the winter, water flow crosses the northwest corner of the INEL site, entering a manmade channel constructed 6.4 kilometers (4 miles) north of Test Area North, where it then infiltrates into channel gravels, recharging the aquifer (Irving 1993).

The Little Lost River drains an area of approximately 1,826 square kilometers (705 square miles). Streamflow is diverted for irrigation use north of Howe. Surface water from the Little Lost River has not reached the INEL site in recent times; however, during high stream flow years, water from the Little Lost River has reached the INEL site, where it then infiltrated into the subsurface (EG\&G Idaho 1984).

4.8.1.2 Local Runoff. Surface water generated from local precipitation will flow into topographic depressions (lower elevations than the surrounding terrain) on the INEL site. This surface water either evaporates or infiltrates into the ground. Ponding of the runoff in a few low areas may increase subsurface moisture content, enhancing subsurface attenuation and migration of localized contaminants in the unsaturated zone (Wilhelmson et al. 1993).

Localized flooding can occur at the INEL site when the ground is frozen and runoff from melting snow is combined with heavy spring rains. The Radioactive Waste Management Complex was flooded in 1962, 1969, and 1982 by local runoff from rapid spring thaws; and Test Area North was flooded in 1969 due to rapid snowmelt (Koslow and Van Haaften 1986). After the flooding events, the addition of dikes, diversion channels, settling basins, and sump pumps at the Subsurface Disposal Area at the Radioactive Waste Management Complex and Test Area North have alleviated snowmelt flooding at these facilities (Dames \& Moore 1992, Koslow and Van Haaften 1986). 
The Dames \& Moore study (1992) evaluated the design of these flow systems for minimizing the potential for flood waters to come into contact with stored waters and to ensure that flood-induced erosion did not expose buried or covered-up radioactive waste materials (Dames \& Moore 1992, DOE 1990a). Peak flows, water surface elevations, and velocities for the 100-, 500-, and 1,000-year floods, the one-half probable maximum flood, and the probable maximum flood were estimated at key locations along the Radioactive Waste Management Complex Main and East Channel flow systems. This analysis indicated that the existing Adams Boulevard culvert would be overtopped by the one-half probable maximum flood and probable maximum flood events, allowing for potential erosion in the vicinity. Field inspection of dikes, railroad embankments, and culverts indicated that these structures may not be able to withstand a severe flood event, for which their failure would result in higher flood peaks at downstream locations. Evaluation of the impacts of any potential overtopping breaches was beyond the scope of the study.

\subsubsection{Flood Plains. Intermittent surface water flow and the INEL Diversion Dam} (constructed in 1958 and enlarged in 1984) have effectively prevented flooding from the Big Lost River onto the INEL site. However, flooding from the Big Lost River might occur onsite if high water in the Mackay Dam or the Big Lost River were coupled with a dam failure. Koslow and Van Haaften (1986) examined the consequences of a Mackay Dam failure during a seismic event, structural failure coincident with the 100- and 500-year recurrence interval floods, and during a probable maximum flood (hypothetical flood that is considered to be the most severe event possible). The results from all dam failures studied indicate flooding would occur outside the banks of the Big Lost River from Mackay Dam to Test Area North, except within Box Canyon (Figure 4.8-1). The water velocity on the INEL site would range from 0.18 to 0.91 meters per second ( 0.6 to 3.0 feet per second), with water depths outside the banks of the Big Lost River ranging from 0.61 to 1.22 meters ( 2 to 4 feet) (Koslow and Van Haaften 1986). Because of the low velocity and shallow depth of the water, flooding would not pose a threat of structural damage to facilities.

4.8.1.4 Surface Water Qualty. Water quality in the Big and Little Lost Rivers and Birch Creek is similar and has not varied a great deal over the period of record. Measured physical, chemical, and radioactive parameters have not exceeded applicable drinking water quality standards (USGS 1982-1993). Chemical composition is determined primarily by the carbonate 
mineral composition of the rocks in surrounding mountain ranges northwest of the INEL site and by the chemical composition of irrigation water return flow to the surface water (Robertson et al. 1974).

INEL site activities do not directly affect the quality of surface water outside the INEL site because surface water does not flow directly offsite (Hoff et al. 1990). Discharges from INEL site facilities are made to manmade seepage and evaporation basins, rather than to natural surface water bodies in accordance with the Clean Water Act. However, water from the Big Lost River System, as well as seepage from wastewater disposal facilities (in other words, percolation and evaporation ponds and septic tank systems) and storm water injection wells, does infiltrate into the Snake River Plain Aquifer (Robertson et al. 1974, Wood and Low 1988, Bennett 1990). These areas are inspected, monitored, and sampled as stipulated in the INEL Stormwater Pollution Prevention Program (DOE-ID 1993).

\subsubsection{Subsurface Water}

Subsurface water at the INEL site occurs in the Snake River Plain Aquifer and the vadose zone. This section describes regional and local hydrogeologic conditions and subsurface water quality. Generally, the term groundwater refers to water in the saturated zone that enters freely into wells under confined and unconfined conditions (Driscoll 1986). Subsurface water in the vadose zone, or unsaturated zone, is referred to as vadose water. (See Section 4.8.2.5.3, Perched Water Quality, for a description of vadose zone hydrology.)

\subsubsection{Regional Hydrogeology. The IN.EL site overlies the Snake River Plain} Aquifer, the largest aquifer in Idaho (Figure 4.8-2). This aquifer underlies the Eastern Snake River Plain and covers an area of approximately 24,900 square kilometers (9,611 square miles). Groundwater in the aquifer generally flows to the south and southwest. Water storage in the aquifer is estimated at $2.5 \times 10^{12}$ cubic meters ( 2 billion acre-feet), which is approximately the same as the volume of water contained in Lake Erie (Robertson et al. 1974). Irrigation wells can yield as much as 26.5 cubic meters per minute (7,000 gallons per minute) of water (Garabedian 1992). The Snake River Plain Aquifer is among the most productive aquifers in the nation. 


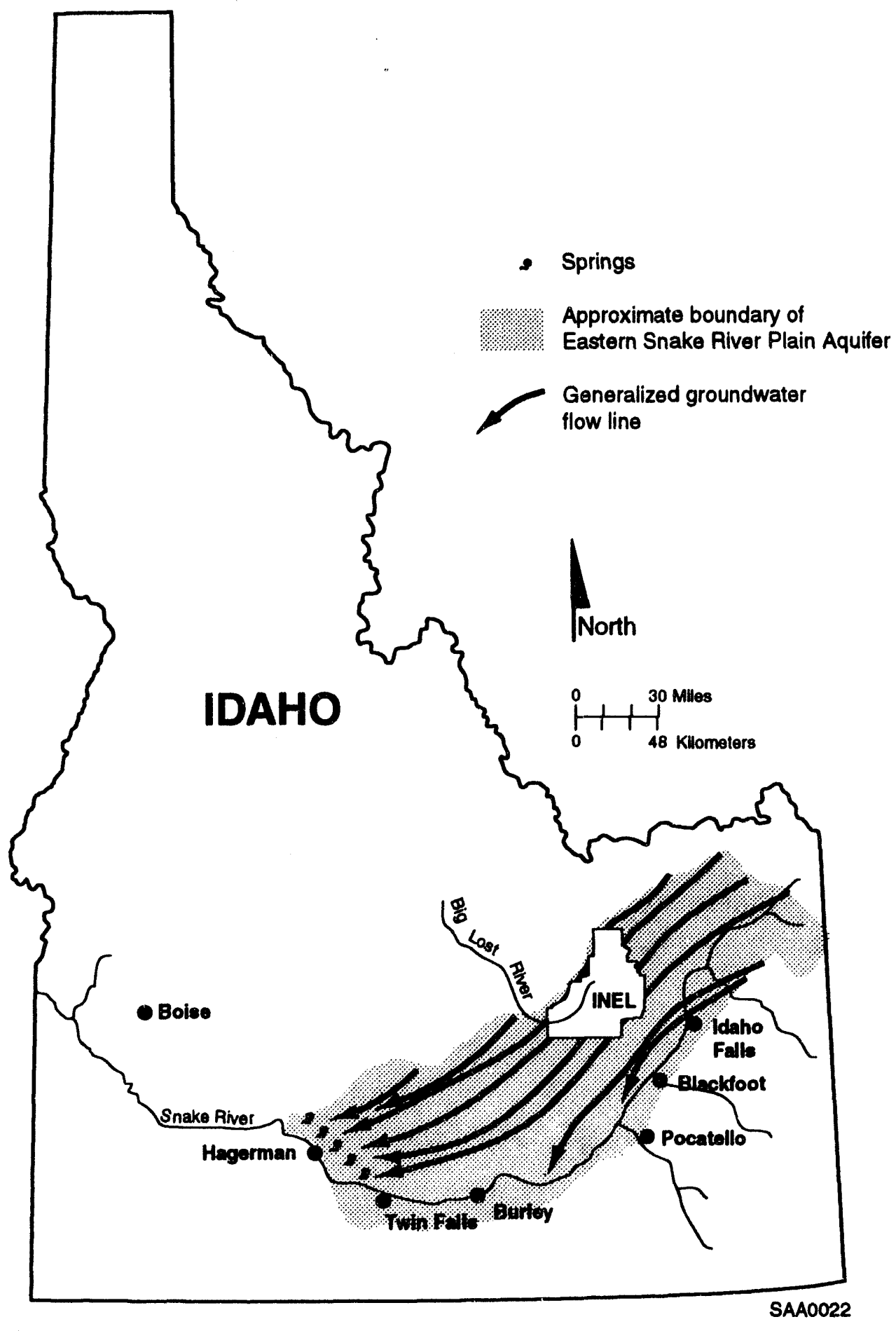

Figure 4.8-2. Location of the Idaho National Engineering Laboratory site, Snake River Plain, and generalized groundwater flow direction of the Snake River Plain Aquifer (Barraclough et al. 1)81). 
The drainage basin recharging the Snake River Plain Aquifer covers an area of approximately 90,643 square kilometers (35,000 square miles). The aquifer is recharged by infiltration of irrigation water, seepage from stream channels and canals, underflow from tributary stream valleys extending into the watershed, and direct infiltration from precipitation (Garabedian 1992). Most recharge occurs in surface water-irrigated areas and along the northeastern margins of the plain. Groundwater is primarily discharged from the aquifer through springs that flow into the Snake River and pumping for irrigation. Major springs and seepages that flow from the aquifer are located near the American Falls Reservoir (southwest of Pocatello), the Thousand Springs area between Milner Dam and King Hill (near Twin Falls), and between Lorenzo and Louisville, along the Snake River.

4.8.2.2 Local Hydrogeology. The INEL site covers 2,305 square kilometers (390 square miles) of the north-central portion of the Snake River Plain Aquifer. Depth to groundwater from the land surface at the INEL site ranges from approximately 61 meters (200 feet) in the north to over 274 meters (900 feet) in the south (Pittman et al. 1988). Groundwater flow is generally toward the south-southwest, and the upper surface is primarily unconfined (not overlain by impermeable soil or bedrock). However, the aquifer $t$.haves as if it were partially confined because of localized geologic conditions (Whitehead 1991). The occurrence and movement of groundwater in the aquifer is dependent on the geologic setting and the recharge and discharge of water within that setting. Most of the aquifer is comprised primarily of numerous relatively thin, basaltic flows with interbedded sediments extending to depths of 1,067 meters (3,500 feet) below the land surface (Irving 1993). A majority of the groundwater migrates horizontally through fractured interflow zones (broken and rubble zones) that occur at various depths. Water also migrates vertically along joints and the interfingering edges of interflow zones (Garabedian 1986). Sedimentary interbeds may restrict the vertical movement of groundwater. The rate water moves through the ground depends on the hydraulic gradient (change in elevation and pressure with distance in a given direction) of the aquifer, the effective porosity (percentage of void spaces), and hydraulic conductivity (capacity of a porous media to transport water) of the sediments and basalt. The upper 61 to 244 meters ( 200 to 800 feet) of the basalts have a markedly higher hydraulic conductivity than rocks below 458 meters (1,500 feet). Therefore, the base of the aquifer is considered to range from 244 to 458 meters ( 800 to 1,500 feet) below land surface. Estimated flow rates within the aquifer range from 1.5 to 6.1 meters per day (5 to 20 feet per day) (Barraclough et al. 1981). 
The ability to transmit water (transmissivity) and the ability to store water (storativity) are important physical properties of the aquifer. In general, the hydraulic characteristics of the aquifer allow water to be readily transmitted, particularly in the upper portions. The variability in how the aquifer transmits and stores water increases the difficulty in aquifer investigations and modeling.

Near the INEL site, the aquifer is recharged by irrigation return and precipitation in the mountains to the west and north. Most of the inflow to the aquifer results from underflow of groundwater along alluvial-filled valleys adjacent to the Eastern Snake River Plain and secondarily from adjacent surface water drainages (that is, Big and Little Lost Rivers and Birch Creek). Recharge at the INEL site is also related to the amount of precipitation, particularly snowfall, for a given year (Barraclough et al. 1981).

4.8.2.3 Vadose Zone Hydrology. The vadose zone (unsaturated zone) extends from the land surface down to the regional water table. Within the vadose zone, the geologic materials are occupied partially by water and partially by air. Subsurface water occurring in the vadose zone is referred to as vadose water. This complex zone at the INEL site consists of surface sediments (primarily clay and silt, with some sand and gravel) and numerous relatively thin, basaltic flows, with some sedimentary interbeds. Thick surficial deposits are found in the northern part of the INEL site, which thin southward where basalt is exposed at the surface.

The vadose zone protects the groundwater by filtering out many contaminants through adsorption, buffering dissolved chemical wastes, and slowing the transport of contaminated liquids to the aquifer. The vadose zone also protects the aquifer by storing large volumes of liquid or dissolved contaminants released to the environment through spills or migration from disposal pits or ponds, allowing natural decay processes to occur.

Travel times for water through the vadose zone are important for understanding contaminant movement. The flow rates in the vadose zone are directly dependent on the extent of fracturing and clay coatings on the fractures, the percentage of sediments versus basalt, and the moisture content of vadose zone material. Flow increases under wetter conditions and slows under dryer conditions. For example, under unsaturated flow conditions near the Radioactive Waste Management Complex, an investigation into water movement in surface sediments found 
that infiltration ranged from 0.36 to 1.1 centimeters per year $(0.14$ to 0.43 inches per year) (Cecil et al. 1992). However, under nearly saturated conditions in surface sediments, standing water at land surface in the same area moved vertically 2.1 meters ( 6.9 feet) in less than 24 hours (Kaminsky 1991). Under saturated conditions and matrix flow, over 100 days were required for saturation of a 50-centimeter- (20-inch)-long basalt rock from the Radioactive Waste Management Complex (Bishop 1991).

4.8.2.4 Perched Water. Locally, saturated conditions may exist within the vadose zone above the water table and are called perched water. Perched water occurs when water migrates vertically and laterally from the surface until it encounters an impermeable layer of dense basalt or fine sedimentary material (Irving 1993). Perched water may spread laterally, sometimes hundreds of meters, and then move over the edges of the impermeable layer and continue downward. Several perched water bodies can form between the land surface and the water table.

In general, the formation of perched water bodies slows the downward migration of fluids that infiltrate into the vadose zone from the surface. The occurrence of perched water at the INEL site is generally related to the presence of disposal ponds or other surface water bodies. These bodies have been detected at the Idaho Chemical Processing Plant, Test Reactor Area, Test Area North, and Radioactive Waste Management Complex (Irving 1993). For example, a field study performed in 1986 at the Idaho Chemical Processing Plant showed that perched water occurs in three areas at possibly three depth zones. These bodies are located at depths ranging from approximately 9 meters ( 30 feet) to 98 meters ( 322 feet) below ground surface and extend laterally as much as 1,097 meters (3,600 feet) (Irving 1993). In general, the chemical concentrations, shape, and size of these bodies have fluctuated over time in response to the volume of water discharged to the infiltration ponds.

4.8.2.5 Subsurface Water Quality. Subsurface water quality is affected by natural water chemistry and contaminants originating at the INEL site. Monitoring programs are conducted under the INEL Groundwater Protection Management Program (Case et al. 1990). Under this program, the INEL Groundwater Monitoring Plan (Sehlke and Bickford 1993) was established to fulfill the groundwater monitoring requirements of DOE Order 5400.1, "General Environmental Protection Program" (DOE 1990b). As specified in the plan, samples are collected from surface 
water, perched water, and aquifer wells to identify contaminants and contaminant migration to and within the aquifer.

4.8.2.5.1 Natural Water Chemistry-The natural groundwater chemistry of the Snake River Plain Aquifer beneath the INEL site is determined by several factors. These factors include the weathering reactions that occur as water interacts with minerals in the aquifer and the chemical composition of (a) groundwater originating outside of the INEL site; (b) precipitation falling directly on the land surface; and (c) streams, rivers, and runoff infiltrating into the aquifer (Wood and Low 1986, 1988). The chemistry of the groundwater is different, depending on the source areas. For example, groundwater from the northwest contains calcium, magnesium, and bicarbonate leached from sedimentary rocks; and groundwater from the east contains sodium, fluorine, and silicate resulting from contact with volcanic rocks (Robertson et al. 1974).

The natural chemistry affects the mobility of contaminants introduced into the subsurface from INEL site activities. Many dissolved contaminants are adsorbed (or attached) to the surface of rocks and minerals in the subsurface, thereby retarding the movement of contaminants in the aquifer and inhibiting further migration of contamination. However, many naturally occurring chemicals compete with contaminants for adsorption sites on the rocks and minerals or react with contaminants to reduce their attraction to the rock and mineral surfaces.

4.8.2.5.2 Groundwater Quality-Previous waste discharges to unlined ponds and injection wells have introduced radionuclides, nonradioactive metals, inorganic salts, and organic compounds into the subsurface. Solid low-level and transuranic wastes have also been disposed of in several pits at the Subsurface Disposal Area within the Radioactive Waste Management Complex since 1952. (Transuranic waste disposal at the Complex was discontinued in 1970; however, disposal of low-level waste is projected to continue until 2020.) Table 4.8-1 summarizes highest detected concentrations of contaminants observed in the aquifer between 1985 and 1992 , concentrations near the INEL site boundary, existing and proposed U.S. Environmental Protection Agency maximum contaminant levels, and DOE Derived Concentration Guides. The following paragraphs discuss each category of conteminants and comparisons of observed concentrations to maximum contaminant levels. Trends in groundwater quality are discussed in Section 5.8, Water Resources. 
Table 4.8-1. Summary of highest detected contaminant concentrations in groundwater within the Idaho National Engineering Laboratory site (1985 to 1992).

\begin{tabular}{|c|c|c|c|c|}
\hline Parameter & $\begin{array}{c}\text { Highest detected } \\
\text { recent concentration }{ }^{\mathrm{a}} \\
\text { (Year) }\end{array}$ & $\begin{array}{c}\text { Recent boundary } \\
\text { concentration } \\
\text { (year) }\end{array}$ & $\begin{array}{c}\text { Maximum contaminant } \\
\text { level (MCL) } \\
\text { current/propoed }\end{array}$ & $\begin{array}{c}\text { Derived } \\
\text { concentration } \\
\text { guide (DCG) }\end{array}$ \\
\hline \multicolumn{5}{|c|}{ Radionuclides in picocuries per liter } \\
\hline Americium-241 & $0.91^{\mathrm{b}}(1990)$ & $<$ detection limit ${ }^{c}(1988)$ & $6.45^{6}$ & $30^{f}$ \\
\hline Cesium-137 & $2,050^{b}(1988)$ & $<$ detection limit ${ }^{c}(1986)$ & 2003 & $3,000^{f}$ \\
\hline Cobalt -60 & $890^{\mathrm{b}}(1987)$ & $<$ detection limit' (1987) & $218^{6}$ & $10,000^{f}$ \\
\hline lodine-129 & $3.6^{b}(1987)$ & 0.00083-Background ${ }^{h}(1992)$ & $21^{e}$ & $500^{f}$ \\
\hline Plutonium-238 & $1.28^{b}(1990)$ & $<$ detection limit ${ }^{c}(1988)$ & $7.15^{e}$ & $40^{f}$ \\
\hline Plutonium-239/240 & $1.08^{b}(1990)$ & $<$ detection limit ${ }^{c}(1988)$ & $64.90^{\circ}$ & $30^{f}$ \\
\hline Strontium-90 & $640^{\mathrm{b}}(1992)$ & $<$ detection limit ${ }^{c}(1988)$ & $42^{2}$ & $1,000^{f}$ \\
\hline Tritium & $61,600^{b}(1988)$ & Backgroundi (1988) & $20,000^{8} 60,900^{6}$ & $2,000,000^{f}$ \\
\hline \multicolumn{5}{|c|}{ Noaradioactive metals in milligrams per liter } \\
\hline Cadmium & $0.0073^{b}(1992)$ & Background ${ }^{c}(1988)$ & $0.005^{d}$ & Not applicable \\
\hline Chromium (total) & $0.21^{b}(1988)$ & Background ${ }^{c}$ (1988) & $0.1^{\mathrm{d}}$ & Not applicable \\
\hline Lead & $0.009^{b}(1987)$ & Background ${ }^{c}$ (1987) & $0.015^{d}$ & Not applicable \\
\hline Mercury & $0.0004^{b}(1987)$ & Background $^{c}(1987)$ & $0.002^{d}$ & Not applicable \\
\hline \multicolumn{5}{|c|}{ Inorganic salts in milligrams per liter } \\
\hline Chloride & $200^{\mathrm{b}}(1991)$ & - & $250^{d}$ & Not applicable \\
\hline Nitrate & ${ }_{24}{ }^{c}$ (as $\left.\mathrm{NO}_{3}\right)(1988)$ & Background $\mathfrak{j}$ (1988) & $45(\operatorname{as~NO})^{d}$ & Not applicable \\
\hline & & & $10(\operatorname{as~} N)^{d}$ & \\
\hline Sulfate & $140^{k}(1985)$ & Background ${ }^{j}$ (1985) & $250^{d}$ & Not applicable \\
\hline \multicolumn{5}{|c|}{ Organic compounds in milligrams per liter } \\
\hline Carbon tetrachloride & $0.0066^{b}(1993)$ & $<$ detection limit $^{\prime}$ (1988) & $0.005^{d}$ & Not applicable \\
\hline Chloroform & $0.95^{1}(1988)$ & $<$ detection limit' (1988) & $0.1^{\mathrm{d}, \mathrm{m}}$ & Not applicable \\
\hline 1,1-dichloroethylene & $0.009^{b}(1989)$ & <detection limit' (1989) & $0.007^{d}$ & Not applicable \\
\hline Cis-1,2-dichloroethylene & $3.9^{b}(1992)$ & <detection limit ${ }^{1}$ (1988) & $0.07^{d}$ & Not applicable \\
\hline Trans-1,2-dichloroethylene & $2.6^{b}(1988)$ & <detection limit ${ }^{\top}$ (1988) & $0.1^{\mathrm{d}}$ & Not applicable \\
\hline Tetrachloroethylene & $0.051^{b}(1992)$ & <detection limit (1988) & $0.005^{d}$ & Not applicable \\
\hline 1,1,i-trichloroethane & $0.012^{b}(1989)$ & $<$ detection limit ${ }^{l}(1988)$ & $0.2^{d}$ & Not applicable \\
\hline Trichloroethylene & $4.6^{b}(1992)$ & <detection limit ${ }^{1}$ (1989) & $0.005^{d}$ & Not applicable \\
\hline Vinyl chloride & $0.027^{\prime}(1989)$ & <detection limit' (1989) & $0.002^{d}$ & Not applicable \\
\hline
\end{tabular}

a. Concentrations are generally for the period 1987 to 1992

b. Values taken from Golder (1993).

c. Values taken from Orr and Cecil (1991)

d. MCL values taken from EPA (1993).

e. Proposed MCL values in italics taken from EPA (1991a). Values correspond to a lifetime cancer risk of $1 / 10,000$, assuming each radionuclide emits only one type of particle and that each person drinks 2 liters of water per day. These are proposed values and are not regulatory standards unless/until they are adopted by Environmental Protection Agency as final.

f. DCGs for radionuclides taken from DOE Order 5400.5, "Radiation Protection of the Public and the Environment" (DOE 1990c).

g. MCL values taken from EPA (1989).

h. Value taken from Mann (1994).

i. Value taken from Mann and Cecil (1990).

j. Values taken from Robertson et al. (1974); Edwards et al. (1990).

k. Values taken from Pittman et al. (1988)

1. Values taken from Mann (1990) and Liszewski and Mann (1992).

m. Value is for total trihalomethanes, which is the sum of the concentrations of bromodichloromethane, dibromochloromethane, tribromomethane (bromoform), and trichloromethane (chloroform). 
Radionuclides. Radionuclide concentrations in the Snake River Plain Aquifer beneath the INEL site have generally decreased since the mid-1980s because of changes in disposal practices, radioactive decay, adsorption of radionuclides to rocks and minerals, and dilution by natural surface water and groundwater entering the aquifer (Pittman et al. 1988, Orr and Cecil 1991). Radionuclides released and observed in the groundwater include tritium, strontium-90, iodine-129, cobalt-60, cesium-137, plutonium-238, plutonium-239/240, and americium-241 (Golder 1993). Most of the radionuclides released have been observed at the Idaho Chemical Processing Plant and Test Reactor Area facility areas. However, radionuclides have also been observed in the Test Area North disposal well, near the Central Facilities Area, and in perched water near the Radioactive Waste Management Complex.

As of 1992, concentrations of iodine-129, cobalt-60, tritium, strontium-90, and cesium-137 exceeded the U.S. Environmental Protection Agency maximum contaminant levels for radionuclides in drinking water in localized areas inside the INEL site boundary (Mann et al. 1988, Orr and Cecil 1991). Plutonium-238, plutonium-239/240, and americium-241 have not been detected at concentrations above the proposed maximum contaminant levels at the INEL site (Golder 1993).

Extremely low concentrations of iodine-129 and tritium have migrated outside of INEL site boundaries. In 1992, iodine-129 concentrations were measured in two wells south of the INEL site boundary below the U.S. Environmental Protection Agency's maximum contaminant level, as follows: (a) $10 \times 10^{-6}$ picocuries per liter in Well No. 11, located approximately 6 kilometers ( 4 miles) beyond the boundary, and (b) $30 \times 10^{-6}$ picocuries per liter in Well No. 14, located 13 kilometers ( 8 miles) beyond the boundary (Mann 1994). Tritium concentrations were observed much below maximum contaminant levels just south of the INEL site boundary in 1985. By 1988, the tritium plume had receded to within the INEL site boundary, and its size has continued to decrease (Orr and Cecil 1991). Cobalt-60, strontium-90, cesium-139, plutonium-238, plutonium-240/241, and americium-241 have not been detected outside the INEL site boundaries.

Nonradioactive Metals. Sodium, chromium, lead, and mercury have been released on the INEL site and into the subsurface through unlined ponds and deep wells. Of these metals, sodium was released in the greatest quantity from water treatment processes; however, it is not considered toxic and does not have an established maximum contaminant level. 
In 1988, chromium concentrations exceeding the maximum contaminant level were measured near the Test Reactor Area. Lead and mercury have been observed at concentrations below the maximum contaminant level near the Idaho Chemical Processing Plant (Orr and Cecil 1991).

Inorganic Salts. Chloride, sulfate, and nitrate have been released into the subsurface by human activities at the INEL site. Although ch'oride and sulfate have been released, only nitrate has exceeded maximum contaminant levels (near the Idaho Chemical Processing Plant in 1981). By 1988, the levels of nitrate decreased to below the maximum contaminant level. Irrigation in the Mud Lake area may be causing these contaminants to enter the northeastern portion of the INEL site in concentrations comparable to those in nearby irrigated areas (Robertson et al. 1974, Edwards et al. 1990).

Organic Compounds. Concentrations of volatile organic compounds have been detected in the aquifer beneath the INEL site. Many of these compounds were detected at amounts near the detection limit ( 0.002 milligrams per liter), which is the lowest concentration at which a contaminant can be detected by a specific analytical method. However, concentrations of the following compounds exceeding the maximum contaminant levels have been observed in and near the Test Area North disposal well: chloroform, 1,2-cis-dichloroethylene, 1,1dichloroethylene, 1,2-trans-dichloroethylene, trichloroethylene, tetrachloroethylene, and vinyl chloride (Leenheer and Bagby 1982, Mann and Knobel 1987, Mann 1990, Liszewski and Mann 1992, Golder 1993). Carbon tetrachloride was detected beneath the Radioactive Waste Management Complex in the aquifer at concentrations above the maximum contaminant level; however, this concentration was only observed once.

\subsection{Perched Water Quality-Wastewater disc'.darges from INEL site} operations have infiltrated into the vadose zone and created locally perched water beneath the INEL site. Elevated concentrations of the following contaminants have been detected in samples collected tom tollowing locations: tritium, cobalt-60, chromium, and sulfate concentrations in deep perched water near the Test Reactor Area; tritium in shallow perched water and carbon tetrachloride, chloroform, 1,1,1-trichloroethane, tricholorethylene, tetrachloroethylene, and 1,1,dichlorethylene in deep perched water near the Radioactive Waste Management Complex; anci strontium-90 in perched water near the Idaho Chemical Processing Plant (Irving 1993). Potential 
concentrations of contaminants in all perched water bodies have not yet been measured. Trends in perched water quality are discussed in Section 5.8, Water Resources.

\subsubsection{Water Use and Rights}

Surface water is not withdrawn at the INEL site. The three surface water features at or near the INEL site (Big and Little Lost Rivers and Birch Creek) have the following designated uses: agricultural water supply, cold-water biota, salmonid spawning, and primary and secondary contact recreation. However, surface water is not used for any of these designations within the INEL site boundaries. In addition, waters in the Big Lost River and Birch Creek have been designated for domestic water supply and as special resource waters.

Groundwater use on the Snake River Plain includes irrigation, food processing, aquaculture, and domestic, rural, public, and livestock supply. Water use for the upper Snake River drainage basin and Snake River Plain Aquifer was $16.4 \times 10^{9}$ cubic meters per year $(4.3 \times$ $10^{12}$ gallons per year) during 1985 , which was over 50 percent of the water used in Idaho and approximately 7 percent of agricultural withdrawals in the nation. Most of the water withdrawn from the Eastern Snake River Plain [1.8 $\times 10^{9}$ cubic meters per year $\left(4.7 \times 10^{11}\right.$ gallons per year)] is used for agriculture. The aquifer is the source of all water used at the INEL site. INEL site activities withdraw water at an average rate of $7.7 \times 10^{6}$ cubic meters per year $\left(2.03 \times 10^{9}\right.$ gallons per year) (DOE-ID 1991, 1992). Of the quantity of water pumped from the aquifer, approximately 65 percent is eventually returned to the aquifer. Therefore, the annual net usage of water withdrawn from the aquifer is $2.7 \times 10^{6}$ cubic meters $\left(7.1 \times 10^{8}\right.$ gallons) per year (DOEID 1991, 1992). This rate is equal to approximately 0.03 percent of the water consumed from the Snake River Plain Aquifer, or 56 percent of the maximum annual yield of a typical irrigation well, if pumped 365 days a year.

As designated by the Safe Drinking Water Act (42 USC, Section 1427), a sole-source aquifer is defined as one that supplies 50 percent of the drinking water consumed in the area overlying the aquifer. Sole-source aquifer areas have no alternative source or combination of sources that could physically, legally, and economically supply all who obtain their drinking water from the aquifer. Because groundwater supplies 100 percent of the drinking water consumed within the Eastern Snake River Plain (Gaia Northwest 1988) and an alternative drinking water 
source or combination of sources is not available, the U.S. Environmental Protection Agency designated the Snake River Plain Aquifer a sole-source aquifer in 1991 (EPA 1991b).

DOE holds a Federal Reserved Water Right for the INEL site, which permits a water pumping capacity of 2.3 cubic meters per second ( 80 cubic feet per second) and a maximum water consumption of 43 million cubic meters per year $\left(11.4 \times 10^{9}\right.$ gallons per year) for drinking, process water, and noncontact cooling. Because it is a Federal Reserved Water Right, the INEL site's priority on water rights dates back to its establishment in 1949. 


\subsection{Ecologlcal Resources}

This section describes the biotic resources on the INEL site, which are typical of the Great Basin and Columbia Plateau. Threatened and endangered species, wetlands, and the extent of human-caused radionuclides in plants and animals are discussed. Because the existing major facility areas are expected to be affected most by the proposed actions, the biotic resources in those areas are emphasized. However, because other resources (for example, more mobile species like pronghorn) could be affected, biotic resources for the entire INEL site also are briefly described.

\subsubsection{Flora}

Vegetation on the INEL site is primarily of shrub-steppe vegetation and is a small fraction of the 45 million hectares (111.2 million acres) of this vegetation type found in the Intermountain West. The 15 vegetation associations identified on the INEL site range from primarily shadscalesteppe vegetation at lower altitudes through sagebrush- and grass-dominated communities to juniper woodlands along the foothills of the nearby mountains and buttes (EG\&G Idaho undated, Rope et al. 1993, Kramber et al. 1992, Anderson 1991). These associations can be grouped into six types: juniper woodland, native grassland, shrub-steppe, lava, modified, and wetland vegetation types (Figure 4.9-1). Over 90 percent of the INEL is covered by shrub-steppe vegetation, which is dominated by big sagebrush (Artemisia tridentata), saltbush (Atriplex spp.), and rabbitbrush (Chrysothamnus spp.). Grasses include cheatgrass (Bromus tectorum), Indian ricegrass (Oryzopsis hymenoides), wheatgrasses, (Agropyron spp.), and squirreltail (Sitanion hysterix). Herbaceous plants include phlox (Phlox spp.), wild onion (Allium), milkvetch (Astragalus spp.), Russian thistle (Salsola kali), and various mustards. Additional detailed information on plant communities is described in Rope et al. (1993) and EG\&G Idaho (undated).

Disturbed areas (grazing not included) cover only 1.3 percent of the INEL site. Disturbed areas frequently are dominated by introduced annuals, including Russian thistle and cheatgrass. These species usually provide less food and cover for wildlife compared to perennial native species and are competitive with perennial native species. Therefore, these disturbed areas serve as a source of seeds that may increase the potential for the increased establishment of Russian 


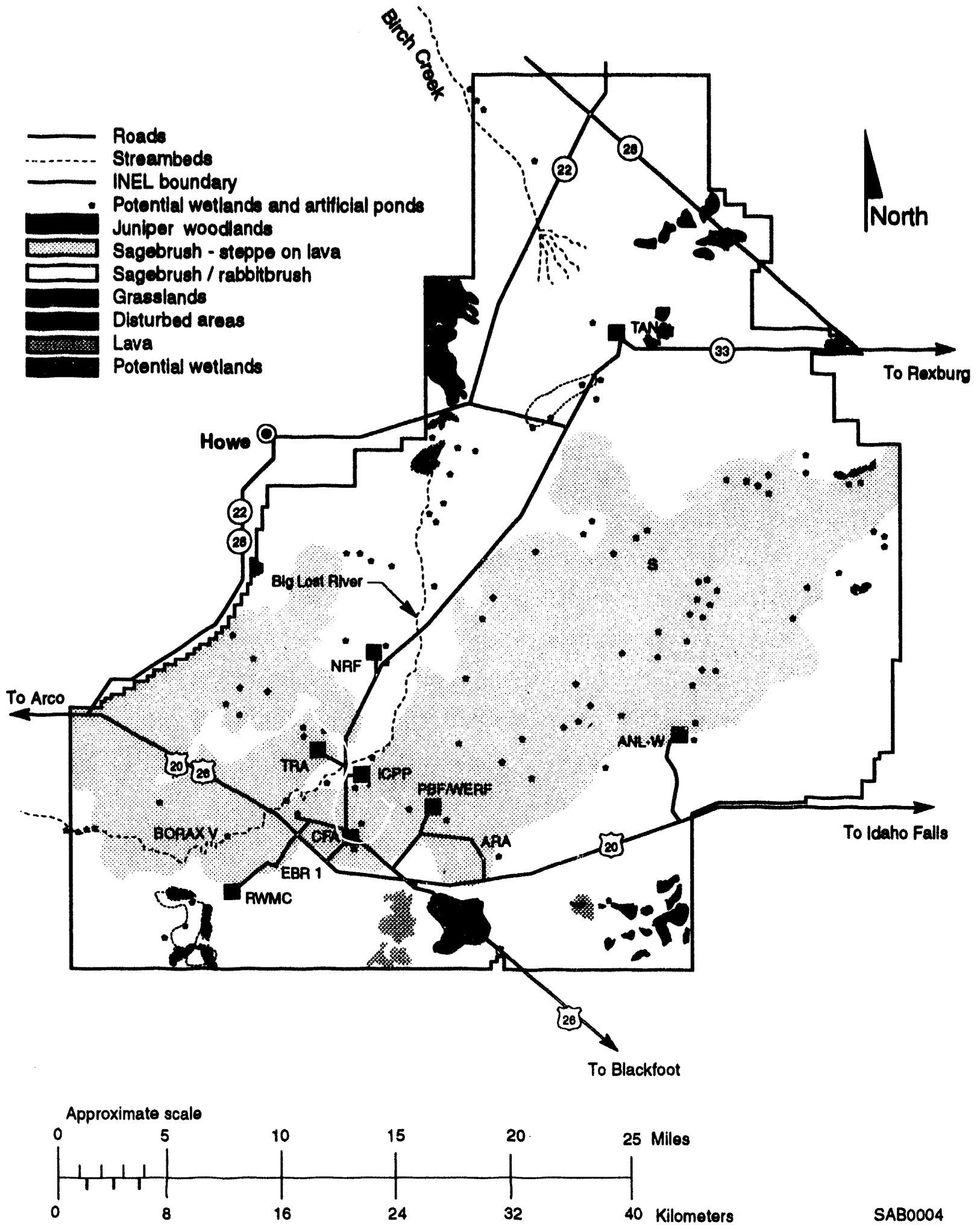

Figure 4.9-1. Approximate distribution of vegetation map at the Idaho National Engineering Laboratory site. 
thistle and cheatgrass into the surrounding undisturbed areas. Vegetation adjacent to each facility is generally similar to the vegetation types mapped in Figure 4.9-1. Vegetation within each facility area is primarily disturbed or landscaped. Species diversity on the INEL is similar to diversity on like-sized areas and physiogomy in the Intermountain West. The diversity on the INEL is heavily influenced by the shrub-steppe vegetation covering over 90 percent of the INEL. Diversity is lower on disturbed and modified areas and higher on areas of greater moisture content.

\subsubsection{Fauna}

The INEL site supports animal communities typical of shrub-steppe vegetation and habitats. Over 270 vertebrate species have been observed, including 46 mammal, 204 bird, 10 reptile, 2 amphibian, and 9 fish species (Arthur et al. 1984, Reynolds et al. 1986). Common species include small mammals (mice, ground squirrels, rabbits, and hares), elk, songbirds (sage sparrow, western meadowlark), sage grouse, lizards, and snakes (rattlesnakes). Migratory species, including pronghorn, waterfowl, and raptors, use the INEL site for part of the year. (Some pronghorn rumain on the site year round.) Predators observed on the INEL site include bobcats, mountain lions, and coyotes. Trout and salmon species have been observed in the Big Lost River when it has flowed on to the INEL site. Additional information on fauna is provided in Rope et al. (1993) and EG\&G Idahr (undated).

\subsubsection{Threatened, Endangered, and Sensitive Specles}

Federal- and State-protected, candidate, and sensitive species were identified using State and Federal regulatory agency lists (Lobdell 1992), the Idaho Department of Fish and Game Conservation Data Center list, and information from INEL site surveys.

Two Federal endangered and six Federal Category 2 candidate animal species were identified as potentially occurring on the INEL site (Table 4.9-1). Federal endangered peregrine falcons have been observed within the boundary of the INEL infrequently only in winter and for only brief periods. Federal endangered bald eagles are observed each winter near or on the INEL, but only in the remote areas of the INEL about 32 kilometers (20 miles) north of the Test Area North and on the INEL site near Howe. Neither of these areas are close to proposed activities. 

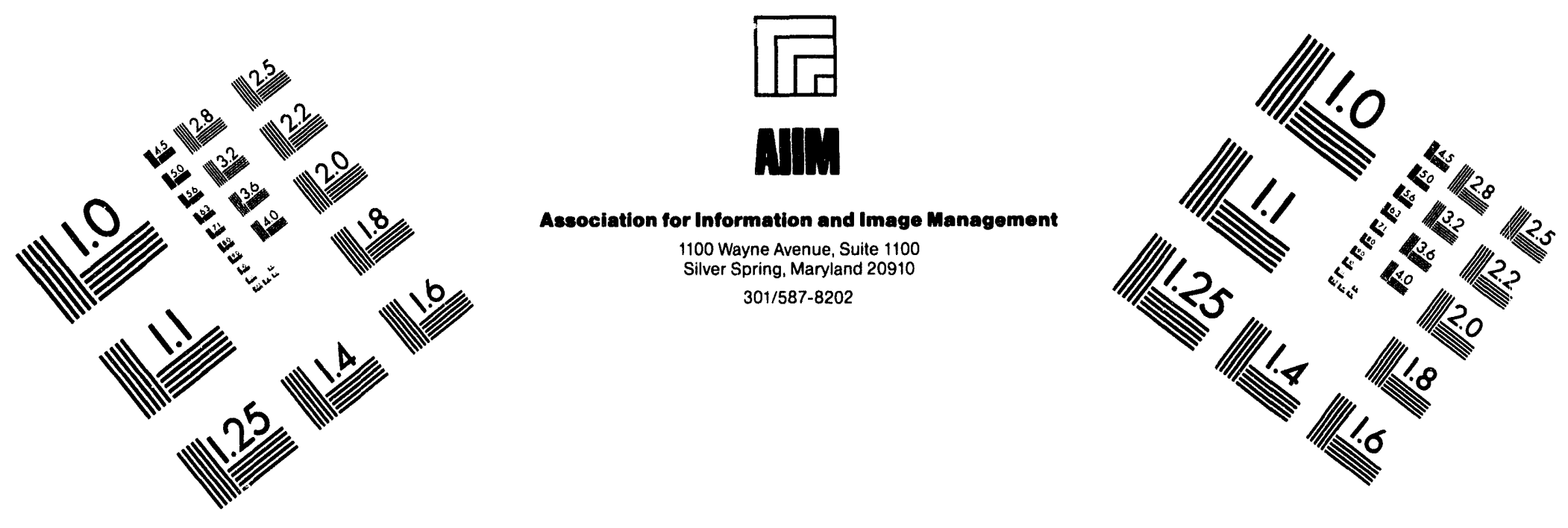

\section{Centimeter}

1
2 Inches
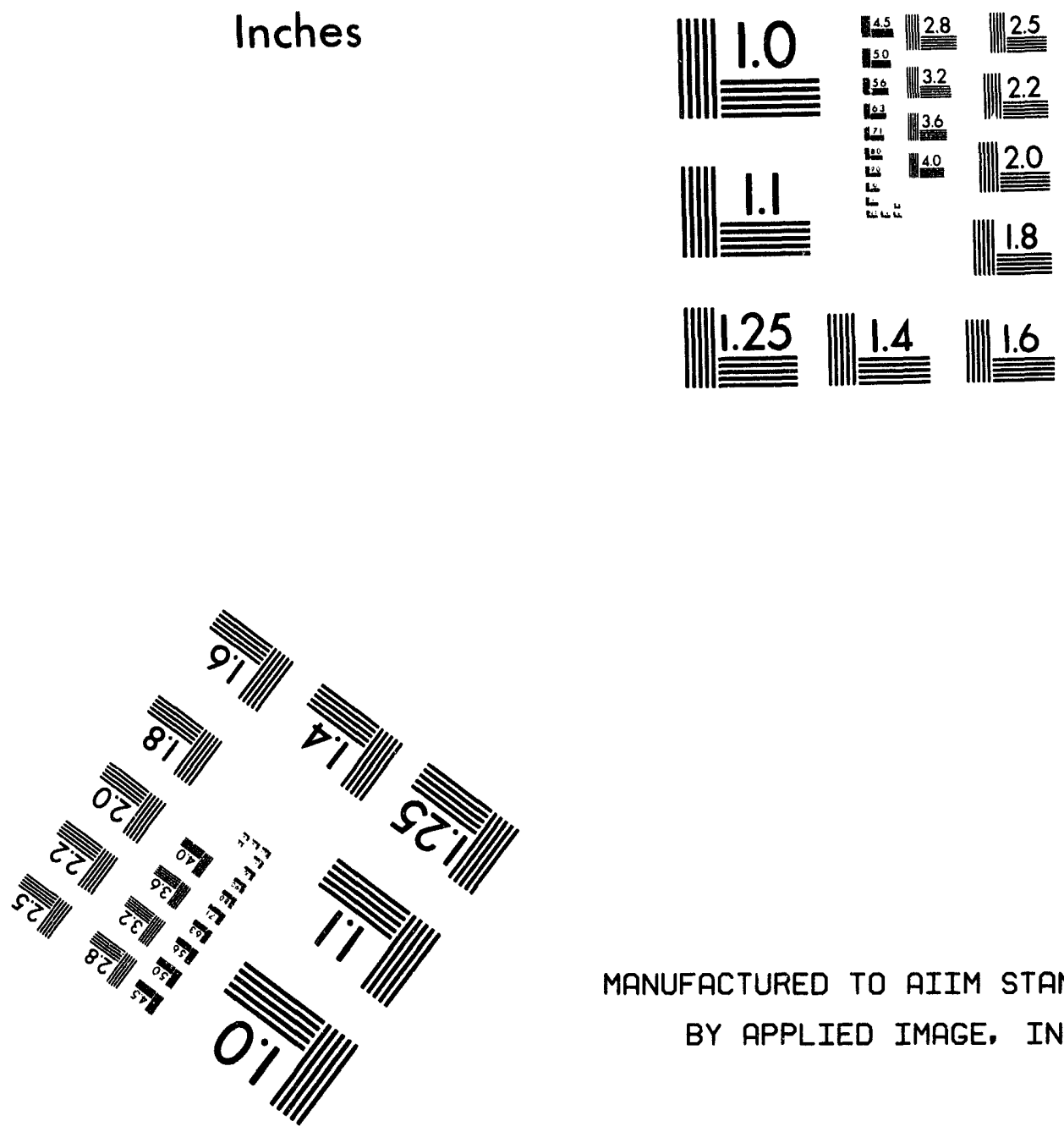

MANUFACTURED TO AIIM STANDARDS

$$
\text { BY APPLIED IMAGE. INC. }
$$

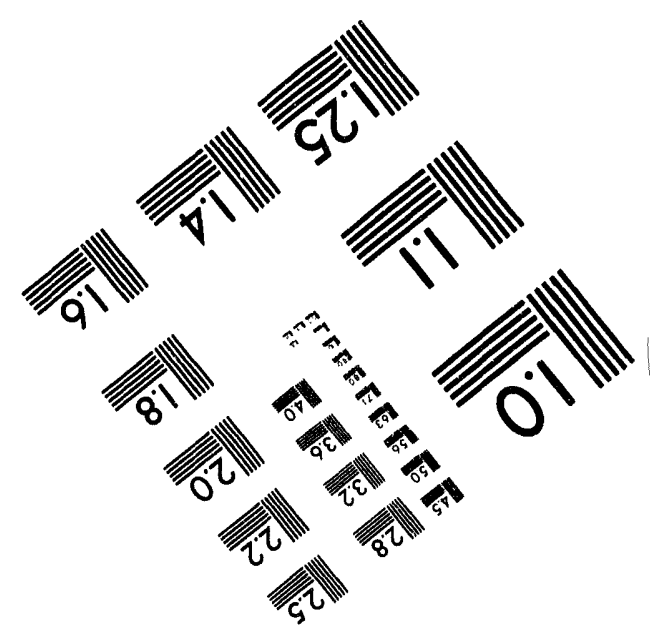



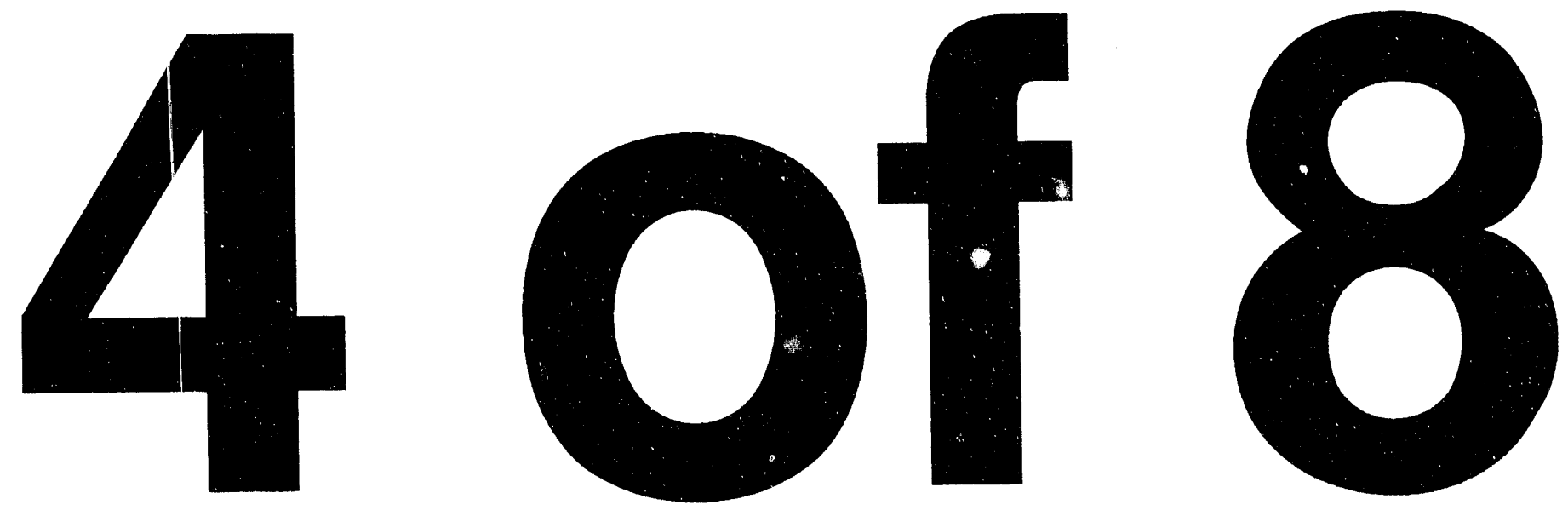
Table 4.9-1. Threatened and endangered species, species of special concern, and sensitive species that may be found on the Idaho National Engineering Laboratory site.

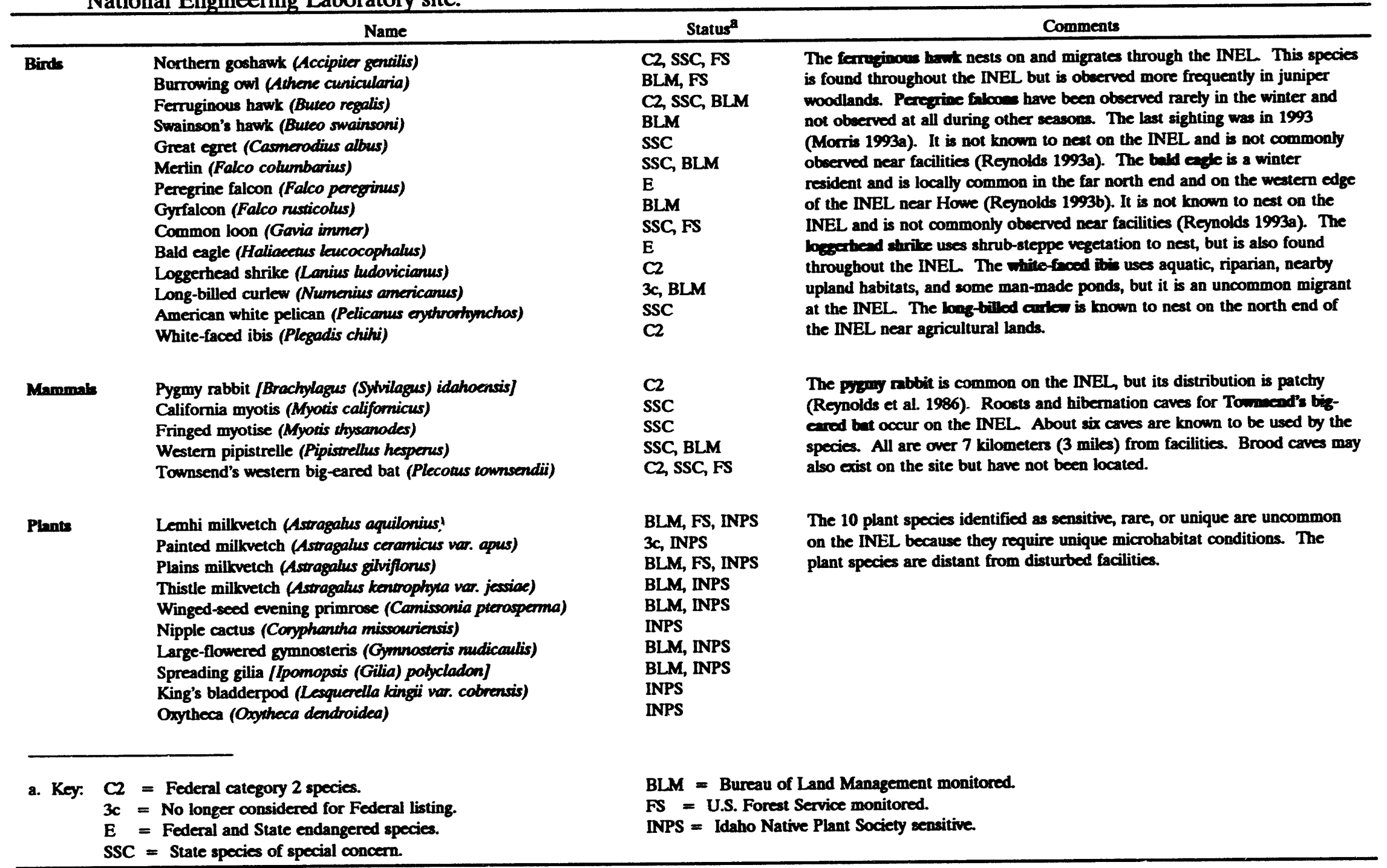


The Federal candidate Category 2 ferruginous hawk nests and is observed primarily near juniper woodlands. This habitat is remote from facilities. The Federal candidate Category 2 white-faced ibis is an infrequent migrant that uses aquatic and upland areas. The Federal candidate Category $3 c$ long-billed curlew nests at the far north end of the INEL site several miles from the nearest location of any activities and uses aquatic and grassland habitats that would not be affected by proposed activities. Caves used by the Townsend's big-eared bat are several miles from proposed activities.

No State-protected species are known to occur on the INEL site. Seven animal species listed by the State as species of special concern occur on the INEL site. None of the Federal- or State-listed animal species have been observed near any of the facilities where proposed actions would occur (Rope et al. 1993, Reynolds 1993a). No Federal- or State-listed plant species were identified as potentially occurring on the INEL site. Ten plant species identified by other Federal agencies and the Idaho Native Plant Society as sensitive, rare, or unique are known to occur on the INEL site (Chowlewa and Henderson 1984).

\subsubsection{Wetlands}

Aquatic habitats on the INEL site are limited to scattered wet areas, artificial ponds, and intermittent waters. The U.S. Fish and Wildlife Service National Wetlands Inventory maps show over 130 potential wetlands; these maps and a subsequent survey (Hampton et al. 1993) indicate these potential wetlands cover about 0.25 percent $(3,322$ hectares or 8,206 acres) of the INEL site. Over 70 percent of the potential wetlands are found near the Big Lost River and its spreading areas and playas, the Birch Creek Playa, and in an area north of and in the general vicinity of Argonne National Laboratory-West. The rest are scattered throughout the INEL site. In 1994, the INEL expects to begin reviewing which of these potential wetlands meet the U.S. Corps of Engineers definition of jurisdictional wetlands (COE 1987). In addition, the functional use and importance of the potential wetlands would be evaluated.

Approximately 20 potential wetlands listed by the U.S. Fish and Wildlife Service are near facilities and are mostly man-made (for example, industrial waste and sewage treatment ponds, borrow pits, and gravel pits) and, therefore, may not be considered regulated jurisdictional wetlands (Figure 4.9-1). Other potential wetlands include portiors of the Big Lost River channel 
near the Idaho Chemical Processing Plant and the Birch Creek Playa containing Test Area North facilities. Limited riparian (riverbank) communities with mature trees are found along the Big Lost River (Reynolds 1993a), reflecting the intermittent flow in the river (1986 and 1993 were the last two years with flow reported on the site). The scattered artificial ponds, potential wetlands, and intermittent waters serve as water sources to many wildlife species including bats, song birds, and mammals. Some artificial ponds are not fenced (for example, ponds at Argonne National Laboratory-West) and are used by pronghorn.

\subsubsection{Radioecology}

Potential radiological effects on plants and animals are measured at the population, community, or ecosystem level. However, for threatened and endangered species, harm to individuals is important. Radionuclides are found above background levels in individuals belonging to some plant and animal species on and surrounding the INEL site (Morris 1993c). Measurable effects of radionuclides on plants and animals, however, have only been observed in individuals on areas adjacent to INEL facilities, and not at the population, community, or ecosystem levels. The following is information on doses, concentrations, and effects reported for animals on the INEL site.

Halford and Markham (1978) and Arthur et al. (1986) studied maximally exposed small mammals at the Test Reactor Area radioactive waste percolation pond and at the Subsurface Disposal Area at the Radioactive Waste Management Complex. These studies concluded that the small mammals received doses similar to those shown to reduce life expectancies in other small mammals at other locations. Statistically significant differences in several physiological parameters were found between deer mice inhabiting the Test Reactor Area radioactive waste percolation pond, the Subsurface Disposal Area, and control areas (Evenson 1981). However, radiation exposures were too small to cause cellular changes in the mice. A comparison between barn swallow nestlings exposed to sediments from the Test Reactor Area pond and control birds revealed a statistically significant difference in growth rates (Millard et al. 1990). However, this difference could not definitely be attributed to exposure. All studies reported that doses to individual organisms were too low to cause any effects at the population level. Doses and exposures to animals from 1992 at both the Subsurface Disposal Area and the Test Reactor Area are probably lower than the doses reported in the above studies because 0.6 meter ( 2 feet) of 
additional soil cover the contaminated pits and trenches (Wilhelmsen and Wright 1992), and the percolation pond is now less attractive to animals (Morris 1993b).

Elevated radionuclide concentrations have been observed in some individual animals and plants outside the boundaries of INEL facilities and off the INEL site. Iodine-129 concentrations in vegetation and in rabbit thyroids have been reported in excess of background up to $\mathbf{3 0}$ kilometers (18.6 miles) from the Idaho Chemical Processing Plant fence (Markham 1974). Iodine-129 has also been detected above background in pronghorn tissue collected on the INEL site (Markham 1974) and from pronghorn collected as far away as Craters of the Moon National Monument and Monida Pass (Markham et al. 1982). In a study of raptor nesting, Craig et al. (1979) concluded that detectable radionuclide levels would only be observed within 3.5 kilometers (2.2 miles) from the Radioactive Waste Management Complex. In these examples, the dose from internal consumption of radionuclides was less than is thought to be required for observable effects to occur to individual animals (IAEA 1992). Also, on the basis of limited data and the infrequent and few bald eagles and ferruginous hawks observed near contaminated areas, these species probably are not consuming harmful concentrations of radioactive contaminants in their prey (Morris 1993b). A similar conclusion can be made for peregrine falcons because they have rarely been seen on or near the INEL site, and have never been seen near contaminated INEL ponds. 


\subsection{Noise}

Existing INEL-related noises of public significance stem from buses, trucks, private vehicles, helicopters, and freight trains that transport people and materials to and from the INEL site and DOE's Idaho Falls facilities. During the normal work week, most of the 4,000 to 5,000 employees who work at the INEL site are transported daily to the site from surrounding communities and back again over approximately 300 bus routes. Three hundred to 500 private vehicles also travel to and from the INEL site each day. Noise measurements taken along U.S. Highway 20 about 15 meters (50 feet) from the roadway during a peak commuting period indicate that the sound level from traffic ranges from 64 to 86 decibels (dBA) (Abbott et al. 1990), with the primary source coming from buses ( 71 to $81 \mathrm{dBA}$ ). Although few people reside within 15 meters ( 50 feet) of the roadway, the results indicate that INEL traffic noise may be objectionable to members of the public residing near principal highways or bıisy bus routes.

Public exposure to aircraft noise is also due in part to INEL-related activities. Air cargo and business travel of INEL personnel via commercial air transport represents a substantial portion of all such travel in and out of regional airports. Onsite INEL security patrol and surveillance flights do not adversely affect individuals offsite because of the INEL's remoteness. However, INEL helicopter flights that originate or terminate in Idaho Falls do expose members of the public to the unique noises produced by these aircraft. But, since the number of flights per day is limited and most flights occur during daylight hours when people are not sleeping, public exposure to aircraft nuisance noise is not considered to be great.

Normally, no more than one train per day and usually fewer than one train per week services the INEL via the Scoville spur. Rail transport noises originate from diesel engines, wheel/track contact, and whistle-warnings at rail crossings. Even with only one or two exposures to these sources per day, individuals residing near the railroad tracks find the noises mildly objectionable.

The noise level at the INEL ranges from $10 \mathrm{dBA}$ for the rustling of grass to $115 \mathrm{dBA}$, the upper limit for unprotected hearing exposure established by the Occupational Safety and Health Administration (OSHA), from the combined sources of industrial operations, construction activities, and vehicular traffic, including aircraft. The playas and remote lava flows of the INEL 
site have relatively low ambient noise levels of about 35 to $40 \mathrm{dBA}$. Onsite, in accordance with INEL procedures, industrial hygiene practices assure hearing protection for workers. Noise limits for the workplace are established to protect workers in accordance with OSHA standards (CFR 1992). Site workers are required by OSHA to wear ear protection devices when exposed to noise levels above $85 \mathrm{dBA}$ eight-hour time-weighted average. Shredding and painting operations at the Central Facilities Area produced the highest noise levels measured at the INEL at $104 \mathrm{dBA}$ and $99 \mathrm{dBA}$, respectively. The computer room measured $88 \mathrm{dBA}$ and the snack bar measured 60 dBA. The noise generated at the INEL site is not propagated at detectable levels offsite, since all public areas are at least 5 miles away from site facility areas.

Previous studies of the effects of noise on wildlife indicate that even very high intermittent noise levels at the INEL (over $100 \mathrm{dBA}$ ) would have no deleterious effect on wildlife productivity (Leonard 1993). 


\subsection{Traffic and Transportation}

Roads are the primary access to and from the INEL site. Commercial shipments are transported by truck and plane, some bulk materials are transported by train, and waste is transported by truck and train. This section discusses the existing traffic volumes, transportation routes, transportation accidents, and waste and materials transportation, including historical waste and materials transportation and baseline radiological exposures from waste and materials transportation. The information in this section has been summarized from Lehto (1993).

\subsubsection{Roadways}

4.11.1.1 Infrastructure-Regional and Site Systems. The existing regional highway system is shown in Figure 4.11-1. Two interstate highways serve the regional area. Interstate 15, a north-south route that connects several cities along the Snake River, is approximately 40 kilometers ( 25 miles) east of the INEL site. Interstate 86 intersects Interstate 15 approximately 64 kilometers ( 40 miles) south of the INEL site and provides a primary linkage from Interstate 15 to points west. Interstate 15 and U.S. Highway 91 are the primary access routes to the Shoshone Bannock reservation. U.S. Highways 20 and 26 are the main access routes to the southern portion of the INEL site. Idaho State Routes 22, 28, and 33 pass through the northern portion of the INEL, with State Route 33 providing access to the northern INEL site facilities. Table 4.11-1 shows the baseline (1991) traffic for several of these access routes. The level of service of these segments currently is designated "free flow," which is defined as "operation of vehicles is virtually unaffected by the presence of other vehicles."

An onsite road system of approximately 140 kilometers ( 87 miles) of paved surface has been developed, including about 29 kilometers (18 miles) of service roads that are closed to the public. Most of the roads are adequate for the current level of normal transportation activity and could handle some increased traffic volume. Reconstruction is planned for several deteriorating INEL roads built in the 1950 s that have been and will continue to be used to transport heavierthan-normal loads.

4.11.1.2 Infrastructure_Idaho Falls. Approximately 4,000 DOE and DOE contractor personnel administer and support INEL work through offices in Idaho Falls. DOE shuttle vans 


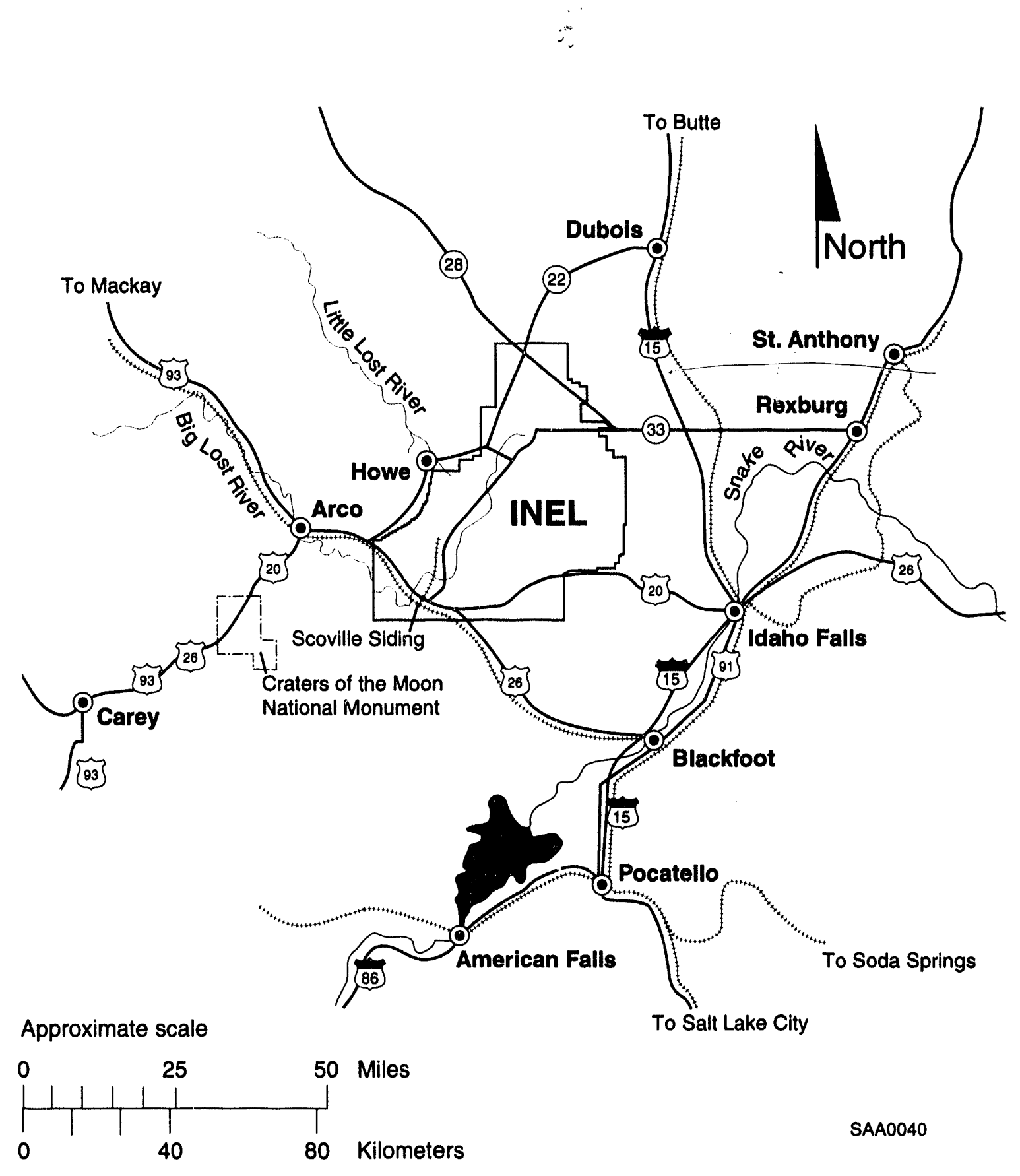

Figure 4.11-1. Transportation routes in the vicinity of the Idaho National Engineering 2 Laboratory. 
Table 4.11-1. Baseline traffic for selected highway segments in the vicinity of the Idaho National Engineering Laboratory site. ${ }^{a}$

\begin{tabular}{lcc}
\hline \multicolumn{1}{c}{ Route } & Average daily traffic & Peak hourly traffic \\
\hline U.S. Highway 20 -Idaho Falls to INEL & 2,290 & 344 \\
U.S. Highway 20/26_INEL to Arco & 1,500 & 225 \\
U.S. Highway 26-Blackfoot to INEL & 1,190 & 179 \\
State Route 33-west from Mud Lake & 530 & 80 \\
Interstate 15-Blackfoot to Idaho Falls & 9,180 & 1,380 \\
& & \\
a. Source: 1991 Rural Traffic Flow Map, State of Idaho. & \\
b. Estimated as 15 percent of average daily traffic. & \\
\hline
\end{tabular}

provide hourly transport between in-town facilities. Currently, one of the busiest intersections is at Science Center Drive and Fremont Avenue, which serves the Willow Creek Building, Engineering Research Office Building, INEL Electronic Technology Center, and DOE office buildings. It is congested during peak weekday hours, but the intersection is designed for the current traffic.

4.11.1.3 Transit Modes. Four major modes of transit use the regional highways, community streets, and INEL site roads to transport people and commodities: DOE buses and shuttle vans, DOE motor pool vehicles, commercial vehicles, and personal vehicles. Table 4.11-2 summarizes the baseline miles for INEL-related traffic.

\subsubsection{Railroads}

Union Pacific Railroad lines in southeastern Idaho are shown on Figure 4.11-1. Idaho Falls receives railroad freight service from Butte, Montana, to the north, and from Pocatello and Salt Lake City to the south. The Union Pacific Railroad's Mackay Branch, which crosses the southern portion of INEL, provides rail service to the INEL site. This branch connects with a DOE-owned spur line at Scoville Siding, then links with developed areas within the INEL. Rail shipments to and from the INEL site usually are limited to bulk commodities, spent nuclear fuel, and radioactive waste. Table 4.11-3 shows the rail shipments for Fiscal Years 1988 through 1992. 
Table 4.11-2 Baseline annual vehicle miles traveled for traffic related to the Idaho National Engineering Laboratory site."

\begin{tabular}{lc}
\multicolumn{1}{c}{ Mode of travel and transportation } & Vehicle miles traveled $^{\mathrm{b}}$ \\
\hline DOE buses & $6,068,200$ \\
Other DOE vehicles & $9,183,100$ \\
Personal vehicles on highways to INEL & $7,500,000$ \\
Commercial vehicles & $\underline{905,900}$ \\
$\quad$ TOTAL & $23,657,200$ \\
& \\
a. Source: Lehto (1993). & \\
b. To convert from miles to kilometers, multiply by 1.609. & \\
\hline
\end{tabular}

Table 4.11-3. Loaded rail shipments to and from the Idaho National Engineering Laboratory site $(1988-1992) .^{a}$

\begin{tabular}{ccc} 
Fiscal year & Inbound & Outbound \\
\hline 1988 & 63 & 44 \\
1989 & 43 & 19 \\
1990 & 34 & 3 \\
1991 & 18 & 0 \\
1992 & 23 & 0
\end{tabular}

a. Sources: DOE Shipment Mobility/Accountability Collection System database; Volume 1 of this EIS (Appendix D, Attachment A, Transportation of Naval Spent Nuclear Fuel). 


\subsubsection{Airports and Air Traffic}

Delta Airlines provides Idaho Falls with jet aircraft passenger and cargo service. Horizon and Skywest provide commuter service to both the Idaho Falls and Pocatello airports. In addition, local charter service is available in Idaho Falls, and private aircraft use the major airport and numerous other fields in the area. The total number of landings at the Idaho Falls airports for 1991 and 1992 were 5,367 and 5,598, respectively. The Idaho Falls and Pocatello airports collectively record nearly 7,500 landings annually.

Non-DOE air traffic over the INEL site is limited to altitudes greater than 305 meters (1,000 feet) over buildings and populated areas, and non-DOE aircraft are not permitted to use the site. The primary air traffic at the INEL site is DOE helicopters, which are used for security and very rare emergency purposes. Specific operations stations and duties are designated for these helicopters.

\subsubsection{Accidents}

For the years 1987 through 1992, the average motor vehicle accident rate was 0.94 accidents per million kilometers (1.5 accidents per million miles) for INEL vehicles, which compares with an accident rate of 1.5 accidents per million kilometers ( 2.4 accidents per million miles) for all DOE complex vehicles and 8 accidents per million kilometers (12.8 accidents per million miles) nationwide for all motor vehicles (Lehto 1993). There are no recorded air accidents associated with the INEL.

\subsubsection{Transportation of Waste and Materials}

Hazardous, radioactive, industrial, commercial, and recyclable wastes are transported on the INEL site. Numerous regulations and requirements govern transportation of hazardous and radioactive materials (Lehto 1993). Hazardous materials include commercial chemical products and hazardous wastes that are $n$ onradioactive and are regulated and controlled based on their chemical toxicity. Four main cat sgories of radioactive materials are associated with environmental restoration and waste manageme nt activities: spent nuclear fuel, transuranic wastes, mixed low- 
level wastes, and low-level wastes. High-level wastes are stored at the INEL, but shipments of high-level wastes are not planned within the time frame of this EIS.

\subsubsection{Baseline Radiological Doses from Waste and Materials Transportation.}

To establish a baseline of radiological doses from incident-free, onsite waste and materials transportation at the INEL that is not related to the shipments for the alternatives evaluated in this EIS, six years of data (1987 through 1992, inclusive) were used. Results are presented in Table 4.11-4 in terms of the collective doses and cancer fatalities for 1995 to 2005 . The baseline includes no offsice shipments; offsite shipments are addressed in the analyses of alternatives in Chapter 5.

Table 4.11-4. Cumulative doses and fatalities from incident-free onsite shipments at the Idaho National Engineering Laboratory site for 1995 to 2005.

\begin{tabular}{lccc}
\hline & $\begin{array}{c}\text { Estimated } \\
\text { collective dose } \\
\text { (person-rem) }\end{array}$ & $\begin{array}{c}\text { Estimated } \\
\text { cancer } \\
\text { fatalities }\end{array}$ & $\begin{array}{c}\text { Estimated } \\
\text { nonradiological } \\
\text { fatalities }\end{array}$ \\
\hline Occupational & 6.6 & 0.0026 & 0 \\
General population & 0.14 & 0.000070 & 0
\end{tabular}

a. Source: Maheras (1993).

b. There are no nonradiological accident-free fatalities for onsite shipments. These fatalities are only applicable to urban areas and the INEL site is a rural area. 


\subsection{Health and Safety}

The purpose of this section is to present the potential health effects to workers and the public as a result of current operations at the INEL. For the purpose of this assessment, current operations include all existing facilities and reasonably foreseeable projects. Reasonably foreseeable projects are those expected to be completed by June 1, 1995.

This section provides estimates of health impacts from releases of radioactive and nonradioactive contaminants to the atmosphere and to groundwater. It also summarizes historical health and safety data and INEL programs designed to protect workers. A detailed explanation of the health effects methodology is contained in Appendix F, Section F-4, Health and Safety.

\subsubsection{Public Health and Safety}

Health risks from air emissions are estimated by modeling worst case emission scenarios. These emissions have been estimated for a baseline case. This baseline case represents a scenario in which all permitted sources at the INEL are assumed to operate in such a manner that they emit specific pollutants to the maximum extent allowed by operating permits or applicable regulations. Further information on these baseline atmospheric emissions is found in Section 4.7, Air Resources. These modeled emissions are used to postulate maximum potential exposure levels in the onsite and offsite environments. Health effects calculated using this type of information provide an extremely conservative "worst case" estimate of potential health effects.

Health effects estimates from groundwater contaminants were calculated using the highest reported drinking water supply system concentrations or, in the case of public exposure, the highest reported offsite groundwater concentrations. These concentration estimates are based on those discussed in Section 4.8, Water Resources.

4.12.1.1 Health Effects Resulting from Atmospheric Releases. For routine airborne releases from facilities, health effects were assessed for the following three categories of exposed individuals: (a) maximally exposed individual located at the site boundary, (b) population within 80 kilometers (50 miles) of the operating facilities, and (c) maximally exposed onsite worker. 
4.12.1.1.: Radiological Health Risk-The human health risk associated with radiological air emissions is assessed based on risk factors contained in 1990 Recommendations of the International Commission on Radiological Protection (ICRP 1991). The measure of impact used for evaluating potential radiation exposures is risk of fatal cancers. Population effects are reported as collective radiation dose (in person-rem) and the estimated number of fatal cancers in the affected population. The maximum individual effects are reported as individual radiation dose (in millirem) and the estimated lifetime probability of fatal cancer.

For the calculation of health effects from exposure to airborne radionuclides, the modeled annual doses provided in Section 4.7, Air Resources were multiplied by the appropriate risk factors from ICRP (1991). The risk, from one year of exposure, is expressed as the increased lifetime chance of developing fatal cancer. A detailed explanation of the health effects methodology is contained in Appendix F, Section F-4, Health and Safety.

Tables 4.12-1 and 4.12-2 provide summaries of the annual dose, risk factor, and estimated increased lifetime risk of developing fatal cancer based on the annual exposure. These data are presented for the maximally exposed onsite worker, maximally exposed individual near the site boundary, and surrounding population for the year 1995.

Table 4.12-1. Lifetime excess fatal cancer risk due to annual exposure to routine airborne releases at the Idaho National Engineering Laboratory site.

\begin{tabular}{lccc}
\hline $\begin{array}{c}\text { Maximally exposed } \\
\text { individual }\end{array}$ & $\begin{array}{c}\text { Annual dose } \\
\text { (millirem) }\end{array}$ & $\begin{array}{c}\text { Risk factor } \\
\text { (risk/millirem) }\end{array}$ & $\begin{array}{c}\text { Risk } \\
\text { (excess fatal cancer) }\end{array}$ \\
\hline Onsite worker & $3.2 \times 10^{-1}$ & $4.0 \times 10^{-7}$ & $1.3 \times 10^{-7}$ \\
Offsite individual (public) & $5.0 \times 10^{-2}$ & $5.0 \times 10^{-7}$ & $2.5 \times 10^{-8}$ \\
\hline
\end{tabular}

Table 4.12-2. Increased population risk of developing excess fatal cancers due to routine airborne releases at the Idaho National Engineering Laboratory site.

\begin{tabular}{cccc}
\hline Year & $\begin{array}{c}\text { Population dose } \\
\text { (person-rem) }\end{array}$ & $\begin{array}{c}\text { Risk factor } \\
\text { (risk/person-rem) }\end{array}$ & $\begin{array}{c}\text { Risk } \\
\text { (number of fatal cancers) }\end{array}$ \\
\hline $1995^{\mathrm{a}}$ & $3.0 \times 10^{-1}$ & $5.0 \times 10^{-4}$ & $1.5 \times 10^{-4}$
\end{tabular}

a. The population dose and cancer risk for 1995 is based on data provided in Section 4.7. 
The offsite individual annual dose of 0.05 millirem corresponds to a lifetime increased fatal cancer risk of approximately 1 in 40 million. The worker dose of 0.32 millirem corresponds to a lifetime increased fatal cancer risk of approximately 1 in 7 million.

Table 4.12-2 provides summaries of the dose, risk factor, and estimated increased lifetime risk of developing fatal cancer based on the annual exposure to the surrounding population for the year 1995. The surrounding population consists of approximately 120,000 people within a 80-kilometer (50-mile) radius of the individual INEL sources. The total baseline collective population dose of 0.30 person-rem corresponds to approximately 0.0002 fatal cancers occurring within the population over the next 70 years.

4.12.1.1.2 Nonradiological Health Risk-For nonoccupational exposures, data concerning the toxicity of carcinogenic and noncarcinogenic constituents were obtained from dose-response values approved by the U.S. Environmental Protection Agency. These values include slope factors and unit risks for evaluating cancer risks, reference doses and reference concentrations for evaluating exposure to noncarcinogens, and primary National Ambient Air Quality Standards for evaluating criteria pollutants. For evaluating occupational exposures, the applicable occupational standards were used.

For the evaluation of occupational health effects, the modeled chemical concentration was compared with the applicable occupational standard. The comparison was made by calculating a hazard quotient. The hazard quotient is the ratio between the calculated concentration in air and the applicable standard. If the hazard quotient is less than one, then no adverse health effects are expected.

Table 4.12-3 presents hazard quotients for onsite toxic air pollutants. The noncarcinogenic hazard index (summed hazard quotients) for each facility is less than one. This indicates that no adverse health effects are projected as a result of noncarcinogenic emissions.

Table 4.12-4 provides the hazard quotients for onsite carcinogens. These modeled concentrations are not representative of average workplace concentrations, but reflect the maximum potential concentrations that could occur. In all cases, with the exception of benzene, the hazard quotients for individual chemicals are less than one. 
Table 4.12-3. Hazard quotients for highest predicted concentrations of noncarcinogenic toxic air pollutants at Idaho National Engineering Laboratory site locations for the maximum baseline case, including foreseeable increases.

\begin{tabular}{lcccc}
\hline Toxic air pollutant & $\begin{array}{c}\text { Location of } \\
\text { maximum } \\
\text { concentration }\end{array}$ & $\begin{array}{c}\text { Baseline } \\
\text { concentration } \\
\left(\mu \mathrm{g} / \mathrm{m}^{3}\right)\end{array}$ & $\begin{array}{c}\text { Occupational } \\
\text { exposure limit } \\
\left(\mu \mathrm{g} / \mathrm{m}^{3}\right)\end{array}$ & $\begin{array}{c}\text { Hazard } \\
\text { quotient }\end{array}$ \\
\hline Ammonia & ICPP & $9.7 \times 10^{2}$ & $1.7 \times 10^{4}$ & 0.06 \\
Cyclopentane & ICPP & $1.1 \times 10^{3}$ & $1.7 \times 10^{6}$ & $<0.01$ \\
Hydrochloric acid & CFA & $1.1 \times 10^{2}$ & $7.0 \times 10^{3}$ & 0.02 \\
Mercury & ICPP & $3.0 \times 10^{0}$ & $5.0 \times 10^{1}$ & 0.06 \\
Naphthalene & CFA & $2.3 \times 10^{3}$ & $5.0 \times 10^{4}$ & 0.05 \\
Nitric acid & ICPP & $7.7 \times 10^{2}$ & $5.0 \times 10^{3}$ & 0.15 \\
Phosphorus & TAN & $5.5 \times 10^{1}$ & $1.0 \times 10^{2}$ & 0.55 \\
Potassium hydroxide & TAN & $1.4 \times 10^{1}$ & $2.0 \times 10^{3}$ & $<0.01$ \\
Propionaldehyde & ANLW & $6.5 \times 10^{1}$ & $4.3 \times 10^{2}$ & 0.15 \\
Styrene & ICPP & $3.4 \times 10^{2}$ & $2.1 \times 10^{5}$ & $<0.01$ \\
Toluene & CFA & $3.1 \times 10^{4}$ & $1.9 \times 10^{5}$ & 0.16 \\
Trimethylbenzene & CFA & $1.3 \times 10^{4}$ & $1.2 \times 10^{5}$ & 0.11 \\
Trivalent chromium & TAN & $3.4 \times 10^{0}$ & $5.0 \times 10^{2}$ & $<0.01$
\end{tabular}

a. ANL-W $=$ Argonne National Laboratory-West; ICPP = Idaho Chemical Processing Plant; CFA $=$ Central Facilities Area; TRA $=$ Test Reactor Area; RWMC $=$ Radioactive Waste Management Complex; TAN $=$ Test Area North.

b. Occupational exposure limits are eight-hour time-weighted averages established by the American Conference of Governmental Industrial Hygienists or Occupational Safety and Health Administration; the lower (most restrictive) of the two limits is used.

Carcinogenic Effects. For carcinogenic effects to the public, risks are estimated as the incremental probability of an individual developing cancer over a lifetime as a result of exposure to the potential carcinogen (that is, incremental or excess individual lifetime cancer risk).

Values for slope factors and unit risks were taken from the U.S. Environmental Protection Agency's Integrated Risk Information System database (EPA 1994). If the information was not available in this database, other sources were used, primarily the U.S. Environmental Protection Agency's Health Effects Assessment Summary Tables (EPA 1993). 
Table 4.12-4. Hazard quotients for highest predicted concentrations of carcinogenic toxic air pollutants at Idaho National Engineering Laboratory site locations for the maximum baseline case, including foreseeable increases.

\begin{tabular}{lcccc}
\hline Toxic air pollutant & $\begin{array}{c}\text { Location of } \\
\text { maximum } \\
\text { concentration }\end{array}$ & $\begin{array}{c}\text { Baseline } \\
\text { concentration } \\
\left(\mu \mathrm{g} / \mathrm{m}^{3}\right)\end{array}$ & $\begin{array}{c}\text { Occupational } \\
\text { exposure limit } \\
\left(\mu \mathrm{g} / \mathrm{m}^{3}\right)\end{array}$ & $\begin{array}{c}\text { Hazard } \\
\text { quotient }\end{array}$ \\
\hline Acetaldehyde & ANL-W & $1.1 \times 10^{2}$ & $1.8 \times 10^{5}$ & $<0.01$ \\
Arsenic & CFA & $2.8 \times 10^{-1}$ & $1.0 \times 10^{1}$ & 0.03 \\
Benzene & CFA & $3.1 \times 10^{3}$ & $3.0 \times 10^{3}$ & 1.03 \\
Butadiene & TRA & $3.8 \times 10^{3}$ & $2.2 \times 10^{4}$ & 0.17 \\
Carbon tetrachloride & RWMC & $2.5 \times 10^{2}$ & $1.3 \times 10^{4}$ & 0.02 \\
Chloroform & RWMC & $1.7 \times 10^{1}$ & $9.8 \times 10^{3}$ & $<0.01$ \\
Formaldehyde & ANL-W & $5.7 \times 10^{1}$ & $3.7 \times 10^{2}$ & 0.15 \\
Hexavalent chromium & ICPP/TAN & $2.4 \times 10^{0}$ & $5.0 \times 10^{1}$ & 0.05 \\
Hydrazine & TRA & $1.8 \times 10^{-3}$ & $1.0 \times 10^{2}$ & $<0.01$ \\
Methylene chloride & CFAICPP & $3.2 \times 10^{0}$ & $1.7 \times 10^{5}$ & $<0.01$ \\
Nickel & CFA & $4.1 \times 10^{1}$ & $1.0 \times 10^{2}$ & 0.41 \\
Perchloroethylene & CFA & $4.3 \times 10^{2}$ & $1.7 \times 10^{5}$ & $<0.01$ \\
Trichloroethylene & RWMC & $4.0 \times 10^{1}$ & $2.7 \times 10^{5}$ & $<0.01$
\end{tabular}

a. ANL-W = Argonne National Laboratory-West; ICPP = Idaho Chemical Processing Plant; CFA = Central Facilities Area; TRA $=$ Test Reactor Area; $R$ WMC $=$ Radioactive Waste Management Complex; TAN $=$ Test Area North.

For carcinogenicity, the probability of an individual developing cancer over a lifetime is estimated by multiplying the slope factor (milligram per kilogram-day) for the substance by the chronic (70-year average) daily intake. Hence, the slope factor converts estimated daily intakes averaged over a lifetime of exposure directly to incremental risk of an individual developing cancer. This risk is considered a conservative estimate because the upper bound estimate for the slope factor is used, with the "true" risk likely being less.

Noncarcinogenic Effects. Noncarcinogenic effects are presented using the method described in the U.S. Environmental Protection Agency's Risk Assessment Guidance for Superfund, Volume I: Human Health Evaluation Manual (Part A) (EPA 1989). This approach presents noncarcinogenic effects in terms of a hazard quotient, which is the ratio between the calculated 
concentrations in air or drinking water and the reference dose or reference concentration, respectively. Doses or concentrations for each chemical and exposure pathway are compared with the route-specific reference dose or reference concentration. If the hazard quotient is less than one, then no adverse health effects are expected. For onsite toxic pollutants, the applicable standard, instead of the reference concentration, was used to calculate hazard quotients.

For criteria pollutants (ozone, carbon monoxide, nitrogen dioxide, sulfur dioxic' :, particulate matter, and lead) that are regulated through the National Ambient Air Quality Standards, the potential for health effects was based on a hazard quotient given by the ratio of calculated air concentration to the appropriate regulatory limit.

Table 4.12-5 provides hazard quotients based on maximum noncarcinogenic concentrations at INEL site boundary and public highway locations. The locations of these modeled concentrations are dependent on different points and times of release, so that no single individual could be exposed to all of these chemicals at once. Therefore, these chemical hazard quotients are evaluated separately and not summed. For the individual chemicals, all hazard quotients, with the exception of toluene (hazard quotient 5.3), are less than one. This indicates that no adverse health effects are projected as a result of noncarcinogenic emissions with the possible exception of toluene. Based on these results, the possibility of adverse health effects from toluene cannot be ruled out. However, because of the conservative methods and assumptions used in the assessment, any adverse health effects are unlikely.

Table 4.12-6 provides an estimate of the excess cancer risk for 70-year exposure to the maximum baseline offsite carcinogenic concentrations. Like the data in Table 4.12-5, the locations of these modeled concentrations are dependent on different points and times of release so the risks are not summed. The results of this assessment indicate that the offsite lifetime excess cancer risk ranges from $1.6 \times 10^{-7}$ (about one chance in 6 million) to $2.8 \times 10^{-9}$ (about one chance in 357 million).

Table 4.12-7 presents hazard quotients for maximum baseline offsite criteria air pollutants. The hazard quotient for each chemical at the various locations is less than one. This indicates that no adverse health effects are projected as a result of criteria pollutant emissions. Because 
Table 4.12-5. Hazard quotients for highest predicted noncarcinogenic toxic air pollutant concentrations at the Idaho National Engineering Laboratory-eight-hour site boundary and public road exposures.

\begin{tabular}{|c|c|c|c|c|}
\hline Toxic air pollutant & Location & $\begin{array}{c}\text { Maximum } \\
\text { concentration } \\
\left(\mu \mathrm{g} / \mathrm{m}^{3}\right)\end{array}$ & $\begin{array}{c}\text { Reference } \\
\text { concentration } \\
\left(\mu \mathrm{g} / \mathrm{m}^{3}\right)\end{array}$ & $\begin{array}{c}\text { Hazard } \\
\text { quotient }\end{array}$ \\
\hline Ammonia & $\begin{array}{l}\text { Public road } \\
\text { Site boundary }\end{array}$ & $\begin{array}{l}3.3 \times 10^{1} \\
2.3 \times 10^{0}\end{array}$ & $\begin{array}{l}1.0 \times 10^{2} \\
1.0 \times 10^{2}\end{array}$ & $\begin{array}{l}0.33 \\
0.02\end{array}$ \\
\hline Cyclopentane & $\begin{array}{l}\text { Public road } \\
\text { Site boundary }\end{array}$ & $\begin{array}{l}1.5 \times 10^{1} \\
2.2 \times 10^{-1}\end{array}$ & $\begin{array}{l}1.7 \times 10^{4} \\
1.7 \times 10^{4}\end{array}$ & $\begin{array}{l}<0.01 \\
<0.01\end{array}$ \\
\hline Hydrochloric acid & $\begin{array}{l}\text { Public road } \\
\text { Site boundary }\end{array}$ & $\begin{array}{l}5.5 \times 10^{0} \\
5.4 \times 10^{-1}\end{array}$ & $\begin{array}{l}7.0 \times 10^{0} \\
7.0 \times 10^{0}\end{array}$ & $\begin{array}{l}0.79 \\
0.08\end{array}$ \\
\hline Mercury & $\begin{array}{l}\text { Public road } \\
\text { Site boundary }\end{array}$ & $\begin{array}{l}2.4 \times 10^{-1} \\
7.4 \times 10^{-2}\end{array}$ & $\begin{array}{l}3.0 \times 10^{-1} \\
3.0 \times 10^{-1}\end{array}$ & $\begin{array}{l}0.75 \\
0.25\end{array}$ \\
\hline Naphthalene & $\begin{array}{l}\text { Public road } \\
\text { Site boundary }\end{array}$ & $\begin{array}{l}1.0 \times 10^{2} \\
1.1 \times 10^{-2}\end{array}$ & $\begin{array}{l}5.0 \times 10^{2} \\
5.0 \times 10^{2}\end{array}$ & $\begin{array}{l}0.20 \\
<0.01\end{array}$ \\
\hline Nitric acid & $\begin{array}{l}\text { Public road } \\
\text { Site boundary }\end{array}$ & $\begin{array}{l}3.6 \times 10^{0} \\
1.4 \times 10^{0}\end{array}$ & $\begin{array}{l}5.0 \times 10^{1} \\
5.0 \times 10^{1}\end{array}$ & $\begin{array}{l}0.07 \\
0.03\end{array}$ \\
\hline Phosphorus & $\begin{array}{l}\text { Public road } \\
\text { Site boundary }\end{array}$ & $\begin{array}{l}4.4 \times 10^{-2} \\
5.1 \times 10^{-3}\end{array}$ & $\begin{array}{l}1.0 \times 10^{2} \\
1.0 \times 10^{2}\end{array}$ & $\begin{array}{l}<0.01 \\
<0.01\end{array}$ \\
\hline Potassium hydroxide & $\begin{array}{l}\text { Public road } \\
\text { Site boundary }\end{array}$ & $\begin{array}{l}1.1 \times 10^{0} \\
1.1 \times 10^{0}\end{array}$ & $\begin{array}{l}2.0 \times 10^{1} \\
2.0 \times 10^{1}\end{array}$ & $\begin{array}{l}0.06 \\
0.06\end{array}$ \\
\hline Propionaldehyde & $\begin{array}{l}\text { Public road } \\
\text { Site boundary }\end{array}$ & $\begin{array}{l}1.7 \times 10^{0} \\
3.6 \times 10^{-2}\end{array}$ & $\begin{array}{l}4.3 \times 10^{0} \\
4.3 \times 10^{0}\end{array}$ & $\begin{array}{l}0.39 \\
0.01\end{array}$ \\
\hline Styrene & $\begin{array}{l}\text { Public road } \\
\text { Site boundary }\end{array}$ & $\begin{array}{l}7.1 \times 10^{0} \\
1.3 \times 10^{-3}\end{array}$ & $\begin{array}{l}3.0 \times 10^{3} \\
3.0 \times 10^{3}\end{array}$ & $\begin{array}{l}<0.01 \\
<0.01\end{array}$ \\
\hline Toluene & $\begin{array}{l}\text { Public road } \\
\text { Site boundary }\end{array}$ & $\begin{array}{l}2.1 \times 10^{3} \\
3.5 \times 10^{-1}\end{array}$ & $\begin{array}{l}4.0 \times 10^{2} \\
4.0 \times 10^{2}\end{array}$ & $\begin{array}{l}5.30 \\
<0.01\end{array}$ \\
\hline Trimethylbenzene & $\begin{array}{l}\text { Public road } \\
\text { Site boundary }\end{array}$ & $\begin{array}{l}5.7 \times 10^{2} \\
5.7 \times 10^{-2}\end{array}$ & $\begin{array}{l}1.2 \times 10^{3} \\
1.2 \times 10^{3}\end{array}$ & $\begin{array}{l}0.48 \\
<0.01\end{array}$ \\
\hline Trivalent chromium & $\begin{array}{l}\text { Public road } \\
\text { Site boundary }\end{array}$ & $\begin{array}{l}2.0 \times 10^{-1} \\
1.2 \times 10^{-2}\end{array}$ & $\begin{array}{l}5.0 \times 10^{0} \\
5.0 \times 10^{0}\end{array}$ & $\begin{array}{l}0.04 \\
<0.01\end{array}$ \\
\hline
\end{tabular}


Table 4.12-6. Excess cancer risk based on 70-year exposure to the highest predicted concentrations of carcinogenic air pollutants at Idaho National Engineering Laboratory site boundary locations.

\begin{tabular}{lccc}
\hline \multicolumn{1}{c}{ Toxic air pollutant } & $\begin{array}{c}\text { Baseline } \\
\text { concentration } \\
\left(\mu \mathrm{g} / \mathrm{m}^{3}\right)\end{array}$ & $\begin{array}{c}\text { Unit risk } \\
(\text { risk } \mathrm{jer} \\
\left.\mu \mathrm{g} / \mathrm{m}^{3}\right)\end{array}$ & $\begin{array}{c}\text { Risk } \\
\text { (excess cancers) }\end{array}$ \\
\hline Arsenic & $9.0 \times 10^{-5}$ & $4.3 \times 10^{-3}$ & $3.9 \times 10^{-7}$ \\
Benzene & $2.9 \times 10^{-2}$ & $8.3 \times 10^{-6}$ & $2.4 \times 10^{-7}$ \\
Butadiene & $1.0 \times 10^{-3}$ & $2.8 \times 10^{-4}$ & $2.8 \times 10^{-7}$ \\
Carbon tetrachloride & $4.8 \times 10^{-3}$ & $1.5 \times 10^{-5}$ & $7.1 \times 10^{-8}$ \\
Chloroform & $3.2 \times 10^{-4}$ & $2.3 \times 10^{-5}$ & $7.4 \times 10^{-9}$ \\
Formaldehyde & $1.2 \times 10^{-2}$ & $13 \times 10^{-5}$ & $1.6 \times 10^{-7}$ \\
Hexavalent chromium & $6.0 \times 10^{-5}$ & $1.2 \times 10^{-2}$ & $7.2 \times 10^{-7}$ \\
Hydrazine & $1.0 \times 10^{-6}$ & $4.9 \times 10^{-3}$ & $4.9 \times 10^{-9}$ \\
Methylene chloride & $6.0 \times 10^{-3}$ & $4.7 \times 10^{-7}$ & $2.8 \times 10^{-9}$ \\
Nickel & $2.7 \times 10^{-3}$ & $2.4 \times 10^{-4}$ & $6.5 \times 10^{-7}$ \\
& & & \\
\hline
\end{tabular}

the locations of these modeled concentrations are dependent on point and time of release, the hazard quotients are not summed.

4.12.1.2 Health Effects Resulting from Groundwater Releases. This section summarizes potential health effects to both onsite and offsite populations from radionuclides and carcinogenic and noncarcinogenic chemicals in water. More detailed information on concentrations of these pollutants is contained in Section 4.8, Water Resources. A discussion of health effects calculations is contained in Appendix F, Section F-4, Health and Safety. To calculate health effects from radionuclide concentrations in water, the total quantity of radionuclide ingested must be converted to an effective dose equivalent and then the appropriate risk factor applied. This is accomplished by multiplying the concentration of radionuclide in the drinking water (microcuries per liter) by the consumption rate (liters per day) and by the consumption period (days) to obtain the quantity of radionuclide ingested. This ingested quantity (microcuries) is then multiplied by the appropriate dose conversion factor (millirems per microcurie) to obtain the dose that is then multiplied by the appropriate risk factor. 


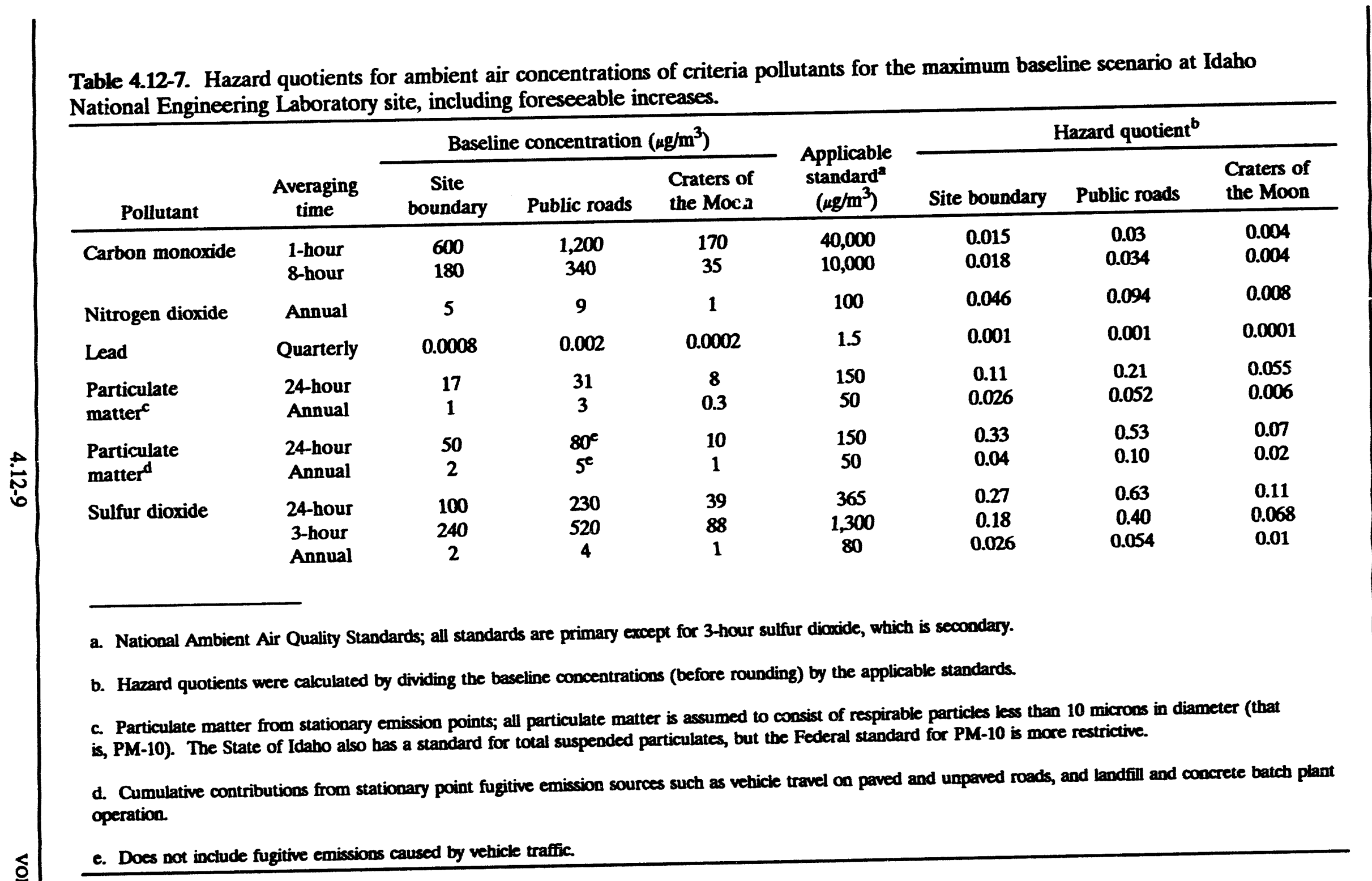


Dose conversion factors were obtained from Federal Guidance Report No. 11, Limiting Values of Radionuclide Intake and Air Concentration and Dose Conversion Factors for Inhalation, Submersion, and Ingestion (EPA 1988). These dose conversion factors were used to convert a quantity of intake to an effective dose equivalent for the subsequent application of the appropriate risk factor obtained in ICRP (1991). Table 4.12-8 lists the exposure-to-dose conversion factors.

\subsection{Potentlal Health Effects to the Onsite Population-Estimates of} potential health effects for onsite workers were made assessing drinking water sampling data reported by Anderson and Peterson-Wright (1993). The highest average radionuclide concentration in any INEL site drinking water distribution system occurred at the Central Facilities Area. The radionuclide measured was tritium, at a concentration of 16,470 picocuries per liter. This level is below regulatory limits and is projected to decrease because of changes in facility procedures, dilution in the aquifer, and the radioactive decay of tritium. Consumption of this water for 50 years would result in an estimated dose equivalent of 14 millirem, with a corresponding estimated fatal cancer risk of about one chance in 180,000 .

No chemical carcinogens were detected in a drinking water distribution system in excess of maximum contaminant levels. This would indicate an excess incidence of cancer risk of less than one chance in 1 million.

For all reported noncarcinogenic chemical contaminants, the calculated hazard quotient (that is, the ratio of contaminant to reference dose) was less than one. This indicates that no adverse health effects are expected as a result of these contaminants.

Table 4.12-8. Exposure-to-dose conversion factors for selected radionuclides.

\begin{tabular}{lc}
\hline Isotope & $\begin{array}{c}\text { Dose conversion factor } \\
\text { (millirem per microcurie) }\end{array}$ \\
\hline Tritium & $6.40 \times 10^{-2}$ \\
Iodine-129 & $2.76 \times 10^{2}$ \\
Strontium-90 & $1.42 \times 10^{2}$ \\
\hline
\end{tabular}


4.12.1.2.2 Potential Health Effects to the Offslte Population-For the offsite population, health effects were estimated using an indine- 129 concentration of 0.00083 picocuries per liter, measured at the INEL site boundary in 1992 (Mann 1994). Consumption of this water for the lifetime of an individual would result in an estimated dose equivalent of 0.012 millirem, with a corresponding estimated fatal cancer risk of about one chance in 170 million.

\subsubsection{Occupational Health and Safety}

This section summarizes historical health and safety data and INEL programs designed to protect workers. The radiation doses and nonradiological hazards presented here are based on monitoring results and reported injuries. For routine workplace hazards, the health risk is presented as reported injuries, illness, and fatalities in the work force. For occupational exposure to ionizing radiation, health efferts assessments are based on actual exposure measurements. In addition, there is a potential for small increments of radiation dose and exposure to toxic materials from atmospheric and groundwater releases on the INEL site. Information on these potential impacts is presented above in Section 4.12.1.

4.12.2.1 Radiological Exposure and Health Effects. Radiological protection programs for INEL occupational workers are based on requirements in DOE orders and on guidance in DOE and INEL radiological control manuals.

Workers at the INEL may be exposed either internally or externally to radiation. The largest fraction of dose received by INEL workers is from external radiation. All personnel who could receive annual external radiation exposures greater than 100 millirem are assigned a thermoluminescent dosimeter that is worn at all times during work on the INEL site. The dosimeter measures the amount and type of external radiation dose the worker receives. Internal radiation doses constitute a small fraction of the occupational dose at the INEL. All instances of measurable internal radioactivity are investigated to determine the cause and assess the potential for additional internal dose to the workforce.

Between 1987 and 1991, out of an average of 10,980 workers per year, about 6,000 individuals were monitored annually at the INEL for radiation exposure. Of those monitored, about 32 percent received measurable radiation doses. For those five years, the average 
occupational dose to individuals with measurable doses was about $0.16 \mathrm{rem}$, giving an average collective dose of about 300 rem. The resulting number of expected excess fatal cancers would be less than one for each year of operation (about 0.12 fatal cancers).

\subsubsection{Nonradlological Exposure and Health Effects to the Onstie Population.}

At the INEL, occupational nonradiological health and safety programs are composed of industrial hygiene programs and occupational safety programs. Industrial hygiene programs address such subjects as toxic chemicals and physical agents, carcinogens, noise, biological hazards, lasers, asbestos, ergonomic factors, and surplus materials. Occupational safety programs address such subjects as machine safety, hoisting and rigging, electrical safety, building codes, welding safety, and compressed gas cylinders.

The monitoring and sampling programs established by industrial hygienists provide data to characterize the more common toxic chemicals, such as asbestos, beryllium, cadmium, lead, welding fumes, oxides of nitrogen, hydrogen fluuride, and acids. Through industrial hygiene surveys and job hazard analyses to evaluate workplace hazards, measures are imposed to control exposures within permissible exposure limits.

The DOE recordkeeping and reporting system is aimed at accurately measuring the safety performance of DOE and DOE contractors. Total injury and illness incidence rates at the INEL varied from an annual average of 1.8 to 4.9 per 200,000 work hours from 1987 to 1991 . There were 1,337 total recordable injury and illness cases at the INEL from 1987 to 1991 for an average of 8,385 employees per year working a total of $79,654,000$ hours. Of the 1,337 cases at the INEL, 114 (8.5 percent) were classified as occupational illnesses (55-repeated trauma disorders; $34-$ skin diseases or disorders; 13-respiratory condition because of toxic agents; 6-all other illnesses; 4-disorders because of physical agents; and 2-dust diseases of the lungs). Total injury and illness rates for INEL workers are comparable to those for DOE and its contractors, which averaged 3.4 per 200,000 work hours from 1988 to 1992 (DOE 1993). For comparison, rates in private industry across the United States were 8.5 per 200,000 work hours for 1983 to 1992 (NSC 1993).

Only one fatal accident occurred at the INEL over the period from 1987 to 1991 . A worker at the Idaho Chemical Processing Plant was killed in a pedestrian-forklift accident ir. 1991. 
The motor vehicle accident rate at the INEL (for government vehicles) for 1987 to 1991 averaged 1.4 accidents (over $\$ 500$ loss) per 1 million miles.

Only two reportable losses over $\$ 1,000$ caused by fire occurred from 1987 to 1991 : $\$ 25,000$ damage in 1989 and $\$ 63,000$ in 1991 . A total of 20 reportable nonfire property damage losses (over $\$ 1,000$ ) occurred from 1987 to 1991 . The total value of the loss from these 20 cases was $\$ 1,292,000$. In 1988 , seven cases accounted for a loss of $\$ 1,026,000$ and represented 80 percent of the five-year total. 


\subsection{Idaho National Englneering Laboratory Services}

This section discusses water, electricity, and fuel capacities and consumption, waste water disposal, and security and emergency protection at INEL facilities.

\subsubsection{Water Consumption}

The water supply for the INEL site is provided by a system of about 30 wells, with pumps and storage tanks, administered by DOE. Idaho Falls facilities are provided water by the City of Idaho Falls water supply system, which includes about 16 wells. Because of the distance between site facility areas, the water supply systems for each facility are independent of each other.

Groundwater use at the INEL site is regulated under a Water Rights Agreement between DOE and the State of Idaho. Under this agreement, INEL has claim to 2.3 cubic meters per second (36,000 gallons per minute) of groundwater, not to exceed 43 million cubic meters (11.3 billion gallons) per year. The average INEL site water consumption from 1987 through 1991 was 7.36 million cubic meters (1.94 billion gallons) per year, calculated based on the cumulative volumes of water withdrawn from the wells. Shutdown of the A1W and S5G training facilities at the Naval Reactors Facility, which use about 1.0 million cubic meters (265 million gallons) per year, should result in a projected 1995 baseline usage of about 6.4 million cubic meters (1.7 billion gallons) per year. The average water consumption of Idaho Falls facilities is estimated to be 300,000 cubic meters ( 79 million gallons) per year. The total pumping rate from the aquifer is not measured and would depend on the number of pumps operating. There is a slight possibility that the pumping rate of 2.3 cubic meters per second (36,000 gallons per minute) could be exceeded for very short periods, such as during recovery from an extended power outage when many pumps would be running to refill depleted storage tanks.

\subsubsection{Electricity Consumption}

Commercial electrical power is supplied to the INEL site from the Antelope substation through two feeders to the federally owned Scoville substation. The Scoville substation supplies electrical power directly to the INEL site electrical power distribution system. The present contract to supply electrical power to the INEL site is with Idaho Power Company and provides 
for Idaho Power Company to furnish "up to 45,000 kilowatts monthly" at 13.8 kilovolts (IPC/DOE 1986). Electric power supplied by Idaho Power is generated by hydroelectric generators located along the Snake River in southern Idaho and by the Bridger and Valmy coal-fired thermal electric generation plants located in southwestern Wyoming and northern Nevada. The Experimental Breeder Reactor-II also can provide approximately 12 to 15 megavolt-amperes of electrical capacity for the electrical power loop.

Rated capacity of the INEL site power transmission loop line is 124 megavolt-amperes. Peak demand on the system from 1990 through 1993 was about 40 megavolt-amperes, and the average usage was about 217,000 megawatt-hours per year. This usage rate would be expected to decrease by about 4 percent by 1995 due to shutdown of the A1W and S5G facilities. Addition of the new substation for the Radioactive Waste Management Complex is expected to be completed in 1996 and is accounted for in the impact analysis of the power usage for the Radioactive Waste Management Complex facilities included in Section 5.13, Idaho National Engineering Laboratory Services.

INEL facilities in Idaho Falls receive electric power from the City of Idaho Falls, which operates four hydroelectric power generation plants on the Snake River along with substation and distribution facilities. Supplemental power is supplied to the City of Idaho Falls by the Bonneville Power Administration, which operates hydroelectric plants on the Columbia River system. In 1993, Idaho Falls facilities used 31,500 megawatt-hours of electricity.

\subsubsection{Fuel Consumption}

Fuels consumed at the INEL site include several liquid petroleum fuels, coal, and propane gas. All fuels are transported to the site for storage and use. Natural gas is the only reported fuel consumed at the INEL Idaho Falls facilities; this fuel is provided by the Intermountain Gas Company through a system of underground lines.

The average annual fuel consumption at the INEL site from 1990 through 1992 is: heating oil, 10,578,00 0 liters (2,795,000 gallons); diesel fuel, 5,690,000 liters (1,500,000 gallons); propane gas, 568,000 liters (150,000 gallons); gasoline, 2,107,000 liters (557,000 gallons); jet fuel, 276,600 liters (73,100 gallons); and kerosene, 128,000 liters (33,800 gallons). About 8,200 metric 
tons (9,000 tons) of coal are also used at the INEL site. Fuel storage is provided for each facility, and fuel inventories are restocked as necessary. No fossil fuel shortage has ever occurred at the INEL site.

\subsubsection{Wastewater Dloposal}

Wastewater systems at the smaller onsite facility areas consist primarily of septic tanks, drain fields, and lagoons. The larger facility areas, such as the Central Facilities Area, Idaho Chemical Processing Plant, and Test Reactor Area, have wastewater treatment facilities. Idaho Falls facilities are serviced by the City of Idaho Falls wastewater treatment system.

Average annual wastewater discharge volume at the INEL site for 1989 through 1991 was 537 million liters (142 million gallons). Wastewater from Idaho Falls facilities is not metered but is estimated to be 300 million liters ( 79 million gallons) per year. The difference between water pumped and estimated wastewater discharge is caused mainly by evaporation from ponds and cooling towers, irrigation of landscaped areas, and discharge of unmetered wastewater.

\subsubsection{Securlty and Emergency Protection}

This section describes the fire protection/fire prevention, security, and emergency preparedness :esources for the INEL site and the surrounding INEL areas. The discussion includes the Fire Department for the area, the Safeguards and Security Division, and the Emergency Preparedness Organization.

\subsubsection{Idaho Natjonal Engineering Laboratory Fire Department. The contractor-} operated Fire Department staffs and operates three fire stations on the INEL site that support the entire INEL site. These stations are located on the north end at Test Area North, at Argonne National Laboratory-West, and at the Central Facilities Area. Each station has a minimum of one engine company capable of supporting any fire emergency in their assigned area. The Fire Department has a staff of 44 fire fighters and 11 support personnel and operates with a minimum critical staff of 7 fire fighters at any one time. Besides providing fire fighting services, the Fire Department provides the INEL site ambulance, emergency medical technician (EMT), and hazardous material response services. The Fire Department has mutual aid agreements with 
other fire-fighting entities, such as the Bureau of Land Management and the Cities of Idaho Falls, Blackfoot, and Arco. Through these agreements, DOE facilities within the City of Idaho Falls are served by the Idaho Falls Fire Department.

\subsubsection{Department of Energy and Idaho National Engineering Laboratory}

Emergency Preparedness. Each DOE INEL contractor administers and staffs its own emergency preparedness program under the direction and supervision of DOE. All contractor programs for emergency control and response are compatible. The Warning Communications Center, with oversight from DOE, is the communication and overall control center for support to the on-scene commanders in charge of the emergency response. The DOE emergency preparedness system includes mutual aid agreements with all regional county and major city fire departments, police, and medical facilities. Through the agreements, DOE facilities within the City of Idaho Falls are serviced by the Idaho Falls emergency preparedness organizations.

\subsubsection{Department of Energy and Idaho National Engineering Laboratory}

Security. DOE has oversight responsibility for safeguards and security at the INEL. The security program is divided into three categories: security operations, personnel security, and safeguards. Security operations provides for asset protection (classified matter, special nuclear material, facilities, and personnel) and technical security (computer and information). The INEL protective force, supplied by contract, is administered under this category. Personnel security processes personnel security clearances. Safeguards is responsible for the management and accountability of special nuclear materials. The INEL protective force, consisting of approximately 200 armed guards and approximately 350 support personnel, provides the onsite personnel that administer the programs. Each INEL contractor has a safeguards and security staff, subdivided in a similar manner, to manage the security associated with their specific facilities. Contractor safeguards and security staffs range in size from about 5 to 60 persons, depending on the size and complexity of their associated facilities. Each staff works in combination with the INEL protective forces. 


\section{ENVIRONMENTAL CONSEQUENCES}

\subsection{Introduction}

Chapter 5 describes the environmental consequences to the Idaho National Engineering Laboratory site, Idaho Falls facilities, and surrounding region that may result from implementing each of the spent nuclear fuel and Invironmental Restoration and Waste Management Program alternatives. In addition to the potential consequences associated with each alternative, potential consequences associated with certain specific projects are discussed in more detail.

Tables in Chapter 3, Alternatives, list projects to be implemented under each alternative. Appendix C, Information Supporting the Alternatives, identifies acres disturbed, resources used (energy, services, and so forth), personnel required, and other important attributes of each project. These attributes were used to determine the potential impacts of each alternative as discussed below.

The potential effects for each alternative have been estimated by evaluating each individual project proposed for the alternative, summing the projects' collective effects under each alternative, and including synergistic interactions among the individual projects that comprise each alternative. The environmental impact analyses are based on conservative assumptions (tend to overestimate) and analytical approaches that are designed to be a reasonable projection of the upper bound of the consequences.

As described in Chapter 3, Alternative A (No Action) is characterized by operating and maintaining most current facilities and programs. Alternative A provides a basis for comparison with the impacts of other alternative actions, although it may result in noncompliance with existing government policies, agreements, and environmental requirements. Under Alternative B (Ten-Year Plan), the historical program role and level of support would continue. This would include activities described under Alternative $A$ that would be enhanced to comply with regulatory requirements, protect the environment, and support INEL missions. Alternative $\mathrm{C}$ (Minimum Treatment, Storage, and Disposal) would, to the extent possible, minimize spent nuclear fuel, waste management, and environmental restoration activities at the INEL. Under Alternative D 
(Maximum Treatment, Storage, and Disposal), the INEL would receive and manage the maximum amount of waste and spent nuclear fuel (as defined in Volume 1 of this EIS and in the Programmatic EIS for Environmental Restoration and Waste Management) that DOE could ship to the INEL while complying with legal and environmental requirements.

The structure of Chapter 5 closely parallels that of Chapter 4, Affected Environment. The 13 sections of Chapter 4 have corresponding sections in Chapter 5. 


\subsection{Land Use}

This section discusses the potential effects of the four environmental restoration and waste management alternatives and five specific project decisions on land use at the INEL site and in the surrounding area.

\subsubsection{Methodology}

The methodology used in this assessment consisted of comparing proposed land uses and plans to existing land uses and plans. The evaluation of potential effects from each alternative were qualitatively assessed. Potential effects, if any, from converting existing land uses to other uses were also evaluated.

\subsubsection{Land Use Impacts from Alternative A (No Action)}

Alternative A (No Action) would result in the disturbance of approximately 40 acres (0.2 square kilometer). Out of this total, 35 acres ( $>0.1$ square kilometer) have been previously disturbed and 5 acres ( $<0.1$ square kilometer) are open space. Of the 40 acres that would be disturbed, all are inside of existing facility area fencelines and boundaries. Existing and planned land uses within INEL facility areas would not change as a result of Alternative $A$ activities. Proposed activities would be consistent with the existing DOE plans listed in Section 4.2, Land Use, for continued operations, environmental restoration, and waste management, and would be similar to uses in existing developed areas on the site. Under this alternative, proposed activities would not be conducted outside of the INEL boundaries and no effects on surrounding land uses or local land use plans are expected.

\subsubsection{Land Use Impacts from Alternative B (Ten-Year Plan)}

Alternative B (Ten-Year Plan) would result in the disturbance of approximately 800 acres ( 3 square kilometers). Out of this total, approximately 243 acres (1 square kilometer) have been previously disturbed and 557 acres ( 2 square kilometers) are open space. Of the 800 acres that would be disturbed, about 50 percent ( 400 acres) are inside existing facility area fencelines or 
boundaries and 50 percent ( 400 acres) are outside of these boundaries. Proposed activities would be consistent with existing DOE plans for continued operations, environmental restoration, and waste management and would be similar to uses in existing developed areas on the site. Under this alternative, proposed activities would not be conducted outside of the INEL boundaries and no effects on surrounding land uses or local land use plans are expected. Due to the greater number of acres that would be disturbed, particularly acreage outside of existing facility areas, and the withdrawal of some acreage for the disposal of radioactive waste (see Section 5.18, Irreversible and Irretrievable Effects), the potential effects on land use from Alternative B activities would be greater than those associated with Alternative A (No Action) activities.

The specific activities associated with Alternative B (Ten-Year Plan) include the selection of incineration at the Waste Experimental Reduction Facility for treatment of low-level and mixed low-level waste, and the selection of technologies for processing sodium-bearing liquid waste and calcined high-level waste. None of these projects would result in changes in types of land use or in irreversible or irretrievable effects on land use.

No new or previously disturbed acreage would be disturbed by the addition of storage racks or by the decision to use incineration, and neither project would have a quantifiable impact on land use. In themselves, the selection of technologies for the treatment of sodium-bearing waste or for the treatment of calcined waste would not create any quantifiable land use impacts. The Waste Immobilization Facility project would result in the disturbance of less that 1 acre of previously disturbed acreage. Replacement of high-level waste storage tanks would result in the disturbance of less than 20 acres of previously disturbed land.

\subsubsection{Land Use Impacts from Alternative C (Minimum Treatment, Storage, and Disposal)}

Alternative C (Minimum Treatment, Storage, and Disposal) would result in the disturbance of 349 acres (1.4 square kilometers). Out of this total, approximately 222 acres (0.9 square kilometer) have been previously disturbed and 127 acres ( 0.5 square kilometer) are open space. Of the 349 acres that would be disturbed, almost all (346 acres) are inside existing facility area fencelines or boundaries. Proposed activities would be consistent with existing DOE plans for continued operations, environmental restoration, and waste management and would be similar 
to uses in existing developed areas on the site. Under this alternative, proposed activities would not be conducted outside of INEL boundaries and no effects on surrounding land uses or local land use plans are expected. Due to the greater number of acres that would be disturbed, potential effects from Alternative $C$ activities would be greater than those associated with Alternative A (No Action) activities.

The specific activities associated with Alternative C (Minimum Treatment, Storage, and Disposal) are the selection of technologies for processing sodium-bearing liquid waste and calcined high-level waste and replacement of high-level waste storage tanks. None of these projects would result in changes in types of land use or in irreversible or irretrievable effects on land use.

In themselves, the selection of technologies for the treatment of sodium-bearing waste or for the treatment of calcined waste would not create any quantifiable land use impacts. The Waste Immobilization Facility project would result in the disturbance of less that 1 acre of previously disturbed acreage. The replacement of high-level waste storage tanks would result in the disturbance of less than 20 acres of previously disturbed land.

\subsubsection{Land Use Impacts from Alternative D (Maximum Treatment, Storage, and Disposal)}

Alternative D (Maximum Treatment, Storage, and Disposal) would result in the disturbance of approximately 1,117 acres (4.5 square kilometers). Out of this total, approximately 275 acres (1.1 square kilometers) have been previously disturbed and 842 acres ( 3.4 square kilometers) are open space. Of the 1,117 acres that would be disturbed, about 35 percent (391 acres) are inside existing facility fencelines or boundaries, and 65 percent ( 726 acres) are outside these boundaries. Proposed activities would be consistent with existing DOE plans for continued operations, environmental restoration, and waste management and would be similar to uses in existing developed areas on the site. Under this alternative, proposed activities would not be conducted outside of INEL boundaries, and no effects on surrounding land uses or local land use plans are expected. Due to the greater number of acres that would be disturbed, particularly acreage outside of existing facility areas, and the withdrawal of some acreage for the disposal of radioactive waste and hazardous waste (see Section 5.18, Irreversible and Irretrievable Effects), 
the potential effects of Alternative D would be greater than those associated with Alternative A (No Action) activities.

The specific activities associated with Alternative D (Maximum Treatment, Storage, and Disposal) are additional racks in spent nuclear fuel storage pools at the Idaho Chemical Processing Plant Fluorinel and Storage (FAST) Facility, selection of technologies for processing sodium-bearing liquid waste and calcined high-level waste, the replacement of high-level waste storage tanks, and selection of incineration at the waste experimental reduction facility for treatment of low-level and mixed low-level waste. As with Alternatives B (Ten-Year Plan) and C (Minimum Treatment, Storage and Disposal), none of these projects would result in changes in types of land use or in irreversible or irretrievable effects on land use. 


\subsection{Socloeconomice}

Socioeconomic resources, such as employment, income, population, housing, community services, and public finance, are interrelated in their response to implementation of an action. This section describes the potential effects of the INEL environmental restoration and waste management alternatives on the socioeconomic resources of the region of influence. Proposed changes in DOE-related expenditures and workforce levels have the potential to generate economic impacts that may affect local employment, population, and community resources. Mitigation of potential impacts is discussed in Section 5.19, Mitigation. Technical support for this section is provided by Appendix F, Section F-1, Socioeconomics.

\subsubsection{Methodology}

Socioeconomic impacts are addressed in terms of both direct and secondary effects. Direct effects are changes in INEL employment and expenditures expected to take place under each alternative and include both construction and operations phase impacts. Secondary effects include both indirect and induced impacts. Indirect effects are impacts to regional businesses and employment resulting from changes in DOE regional purchases or nonpayroll expenditures. Induced effects are impacts to regional businesses and employment that result from changes in payroll spending by affected INEL employees. The total economic impact to the region is the sum of direct and secondary effects. Both the direct and secondary effects were estimated for the region of influence (ROI) described in Section 4.3, Socioeconomics.

The direct impacts estimated in the socioeconomic analysis are based on project summary data developed by DOE in cooperation with INEL contractors and their representatives. Direct employment impacts represent actual increases or decreases in INEL staffing; they do not include changes in staffing due to reassignment of existing INEL workforce. Total employment and earnings impacts were estimated using RIMS II multipliers developed specifically for the INEL region of influence by the U.S. Bureau of Economic Analysis. A comprehensive discussion of the methodology may be found in Appendix F, Section F-1, Socioeconomics.

The importance of the actions and their impacts is determined relative to the context of the affected environment. Projected baseline conditions in the region of influence, as presented 
in Section 4.3, Socioeconomics, provide the framework for analyzing the importance of potential socioeconomic impacts that could result from implementation of any of the alternatives. Each alternative is expected to generate initial increases in employment and earnings within the region of influence, primarily due to expected construction activities. Alternatives A (No Action) and C (Minimum Treatment, Storage, and Disposal), which include phaseout of the Expended Core Facility, will result in employment declines by 2004; Alternatives B (Ten-Year Plan) and D (Maximum Treatment, Storage, and Disposal) result in moderate employment increases.

As presented in Section 4.3, Socioeconomics, baseline employment at the INEL is projected to decline over the study period. The projected declines in baseline INEL employment will likely generate secondary job losses in the region of influence and may also contribute to effects on regional population, housing, and community services. The results of the socioeconomic analysis indicate that the impacts associated with the alternatives are expected to offset the effects of these baseline declines during certain years and under some alternatives and may compound the effects under others. The focus of the socioeconomic analysis has been to estimate the potential socioeconomic impacts associated with the implementation of each alternative. The offsetting (or contributing) effect on projected baseline conditions is addressed in general; however, a comprehensive analysis of potential impacts resulting from the projected decline in baseline INEL activity was not the objective of this study and, therefore, was not included. A discussion of cumulative impacts can be found in Section 5.15, Cumulative Impacts and Impacts from Connected or Similar Actions.

\subsubsection{Socloeconomic Impacts from Alternative A (No Action)}

The impacts from Alternative A (No Action) on employment and earnings, population and housing, and community services in the region of influence are discussed below.

5.3.2.1 Employment and Earnings. Implementation of Alternative $A$ (No Action) is expected to generate about 490 direct jobs during the peak employment year (1996), representing a 4.9 percent increase over the 1995 baseline INEL employment of approximately 10,000 (Table 5.3-1). This increase primarily would be due to construction jobs for the projects approved before 
Table 5.3.1. Net and cumulative employment and population impacts on the region of influence surrounding the Idaho National Engineering Laboratory by alternative and fiscal year.

\begin{tabular}{|c|c|c|c|c|c|c|c|c|c|c|}
\hline Impact & 1995 & 1996 & 1997 & 1998 & 1999 & 2000 & 2001 & 2002 & 2003 & 2004 \\
\hline Change in beseliac employmeat rehtive to 1995 & 0 & -1217 & -1695 & -2133 & -2440 & -2490 & -2510 & -2510 & -2510 & -2510 \\
\hline Change in bescliese populntion rehtative to 1995 & $\mathbf{0}$ & -1617 & -2251 & -2831 & -3240 & -3306 & -3333 & -3333 & -3333 & -3333 \\
\hline \multicolumn{11}{|c|}{ Aleanative A (No Action) } \\
\hline Employment impact & 1142 & 1176 & 870 & 180 & -28 & -585 & -1233 & -1283 & -1283 & -1283 \\
\hline Direct & 474 & 488 & 358 & 75 & -2 & -223 & -480 & -500 & -500 & -500 \\
\hline Secondary & 668 & 688 & 512 & 105 & -26 & -362 & -753 & -783 & -783 & -783 \\
\hline Cumulative empioyment change relative to 1995 & 1142 & -41 & -825 & -1953 & -2468 & -3075 & -3740 & -3793 & -3793 & -3793 \\
\hline Population impact & 478 & 493 & 471 & 69 & -359 & -942 & -1636 & -1703 & -1703 & -1703 \\
\hline Cumulative population change relative to 1995 & 478 & -1124 & -1780 & -2762 & -3599 & -4248 & -4969 & -5036 & -5036 & -5036 \\
\hline \multicolumn{11}{|c|}{ Alernative B (Ten-Year Plen) } \\
\hline Employment impact & 1391 & 1815 & 1862 & 2986 & 3233 & 3414 & 1079 & 1442 & 1385 & 1435 \\
\hline Direct & 578 & 753 & 770 & 1236 & 1339 & 1408 & 439 & 590 & 566 & 587 \\
\hline Secondary & 813 & 1062 & 1092 & 1750 & 1894 & 2006 & 640 & 852 & 819 & 848 \\
\hline Cumulative employment change relative to 1995 & 1391 & 598 & 167 & 853 & 793 & 924 & -1431 & -1068 & -1125 & -1075 \\
\hline Population impact & 583 & 760 & 900 & 1371 & 1474 & 1777 & 767 & 919 & 895 & 916 \\
\hline Cumulative population change relative to 1995 & 583 & -857 & -1351 & -1460 & -1766 & -1529 & -2566 & -2414 & -2438 & -2417 \\
\hline \multicolumn{11}{|c|}{ Altamative C (Minimum Treatment, Storages and Diposed) } \\
\hline Employment impact & 1233 & 1268 & 950 & 260 & 98 & -413 & -786 & 836 & -857 & 857 \\
\hline Direct & 512 & 526 & 392 & 108 & 50 & -152 & -295 & -315 & -324 & -324 \\
\hline Secondary & 721 & 742 & 558 & 152 & 48 & -261 & -491 & -521 & -533 & -533 \\
\hline Cumulative employment change relative to 1995 & 1233 & 51 & -745 & -1873 & -2342 & -2903 & -3295 & -3346 & -3367 & -3367 \\
\hline Population impact & 517 & 531 & 505 & 102 & -306 & -870 & -1449 & -1516 & -1502 & -1502 \\
\hline Cumulative population change relative to 1995 & 517 & -1086 & -1746 & -2729 & -3546 & -4176 & -4782 & -4849 & -4835 & -4835 \\
\hline \multicolumn{11}{|c|}{ 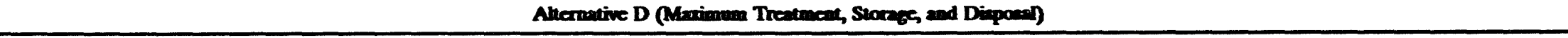 } \\
\hline Employment impact & 1391 & 1815 & 1862 & 2986 & 3233 & 3414 & 1131 & 1495 & 1438 & 1561 \\
\hline Direct & 578 & 753 & 770 & 1236 & 1339 & 1408 & 461 & 612 & 588 & 639 \\
\hline Secondary & 813 & 1062 & 1092 & 1750 & 1894 & 2306 & 670 & 883 & 850 & 922 \\
\hline Cumulative employment change relative to 1995 & 1391 & 598 & 167 & 853 & 793 & 924 & -1379 & -1015 & -1072 & -949 \\
\hline Population impact & 583 & 760 & 900 & 1371 & 1474 & 1777 & 789 & 941 & 917 & 969 \\
\hline Cumulative population change relative to 1995 & 583 & -857 & -1351 & -1460 & -1766 & -1529 & -2544 & -2392 & -2416 & -2364 \\
\hline
\end{tabular}


June 1, 1995. By 2004, however, direct employment would decrease by 500 jobs (a 5.0 percent decrease from baseline), due primarily to the phase out of the Expended Core Facility. Secondary employment generated under Alternative $A$ is expected to range from an increase of about 690 jobs in 1996 to a decrease of about 780 jobs in 2002 . The total employment impact (direct plus secondary) in the region of influence is estimated to range from an increase of about 1,180 jobs in 1996 to a decrease of about 1,280 jobs in 2002, with an average employment impact of about 230 jobs (Figure 5.3-1). Total employment impacts expected under this alternative amount to less than 1.2 percent of total regional employment in any given year of the study period. It is unlikely that employment impacts of this size would generate any long-term adverse effects on the economic activity of the region.

Direct earnings, or payrolls, generated under Alternative A (No Action) would amount to an increase of \$13.3 million in 1996 and a decrease of \$21.6 million in 2002 . Total earnings generated in the region of influence are estimated to be an increase of \$25.6 million in 1996 and a decrease of $\$ 39.5$ million in 2002 . Similar to the estimated employment impacts, earnings are expected to vary considerably within this range over the study period.

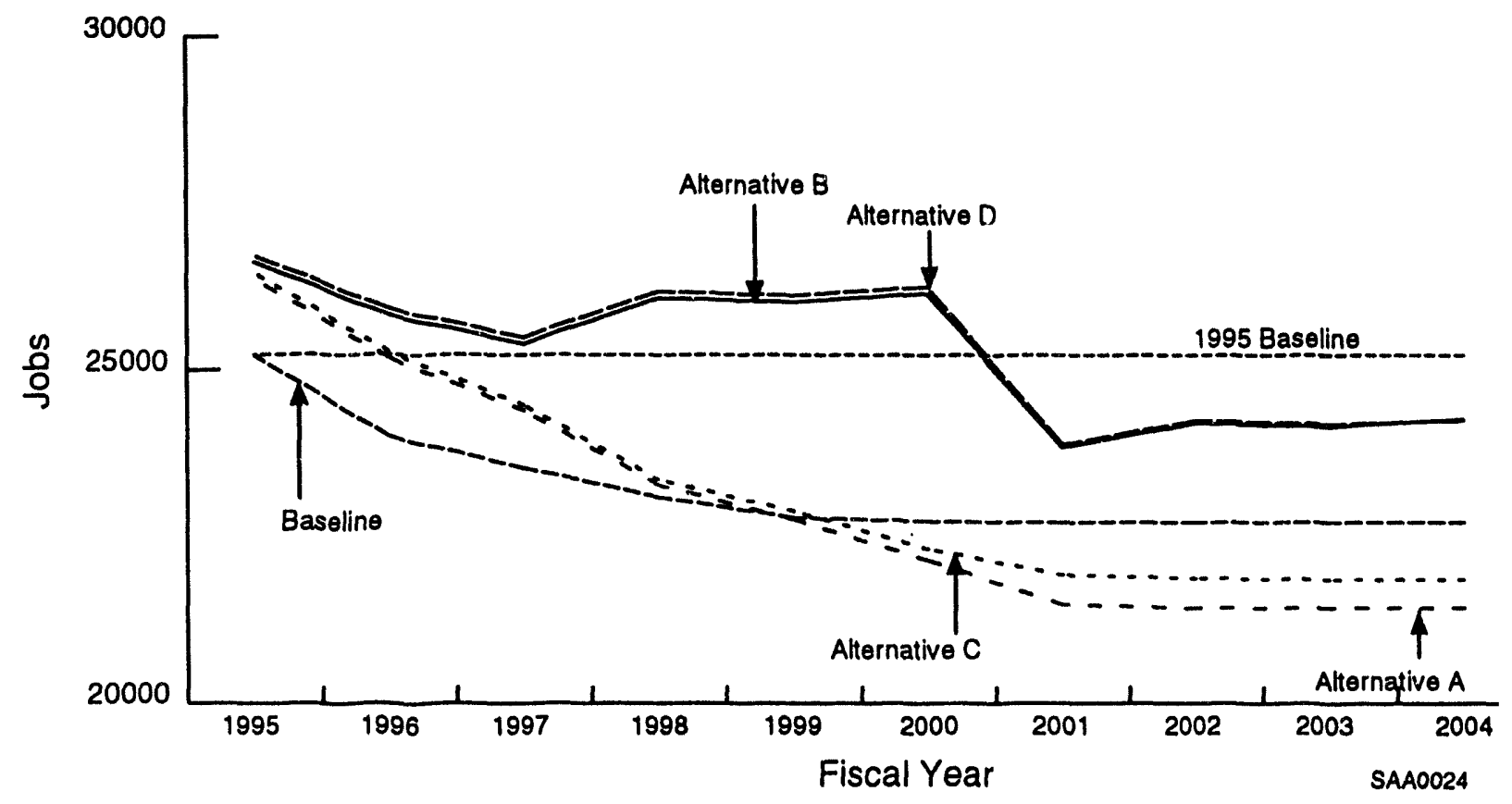

Figure 5.3-1. Total direct and secondary employment by alternatives in the region of influence surrounding the Idaho National Engineering Laboratory. 
Employment and earnings impacts expected under Alternative A (No Action) would initially offset projected declines in baseline INEL employment and earnings; however, after 1998, employment losses expected under Alternative A would compound projected baseline declines. The cumulative employment losses expected in the region of influence by 2004 amount to about 1,480 direct jobs and about 3,790 total jobs.

5.3.2.2 Population and Housing. As the demand for workers in a region varies, the population within the region also tends to vary depending on the nature of the change in employment demand. For example, as worker demand increases (or decreases) in a region, some potential workers and their families may move to (rr out of) the region in search of new jobs. Likewise, changes in employment expected under Alternative A (No Action) would presumably generate in-migration to the region of influence, in the case of employment increases, and outmigration, in the case of employment decreases.

Based on expected relocation ratios and average household size data, population inmigration associated with the implementation of Alternative A (No Action) may amount to about 490 persons during the peak employment year, an increase which represents less than 0.2 percent of the total regional population (Table 5.3-2). By 2004, however, Alternative A could result in the out-migration of about 1,700 persons, a 0.6 percent decrease in regional population.

Under projected baseline employment conditions at the INEL, the number of direct and secondary jobs in the region of influence could fall by 2,510 over the ten-year period from 1995 to 2004. The elimination of these jobs could induce the relocation of a number of these workers and their families, resulting in the possible out-migration of approximately 3,330 persons by 2004 . Through the loss of additional jobs, the implementation of Alternative A (No Action) would contribute to this potential population decline, generating a cumulative population out-migration of approximately 5,040 persons. The actual magnitude of the total population effect would depend to a large extent on the future availability of comparable employment opportunities within the region relative to the availability of employment elsewhere and to a variety of subjective criteria.

During the peak employment period, implementation of Alternative A (No Action) could result in a temporary increase in housing demand of about 140 units, representing less than 0.2 
Table 5.3-2 Impacts on the population of the region of influence surrounding the Idaho National Engineering Laboratory for baseline and alternatives by fiscal year.

\begin{tabular}{|c|c|c|c|c|c|c|c|c|c|c|}
\hline & 1995 & 1996 & 1997 & 1998 & 1999 & 2000 & 2001 & 2002 & 2003 & 2004 \\
\hline Region of influence & 247,990 & 251,518 & 255,096 & 258,726 & 262,406 & 266,140 & 268,667 & 271,279 & 273,795 & 276,395 \\
\hline Population change due to baseline declines & $\mathbf{0}$ & $-1,617$ & $-2,251$ & $-2,831$ & $-3,240$ & $-3,306$ & $-3,333$ & $-3,333$ & $-3,333$ & $-3,333$ \\
\hline Region of influence less baseline declines & 247,990 & 249,901 & 252,845 & 255,895 & 259,166 & 262,834 & 265,334 & 267,946 & 240,462 & 273,062 \\
\hline \multicolumn{11}{|c|}{ Alternative A (No Action) } \\
\hline Population impact & 478 & 493 & 471 & 69 & -359 & -942 & $-1,636$ & $-1,703$ & $-1,703$ & $-1,703$ \\
\hline Total regional population & 248,468 & 250,394 & 253,316 & 255,964 & 258,807 & 261,892 & 263,698 & 266,243 & 268,759 & 271,359 \\
\hline \multicolumn{11}{|c|}{ Atternative B (Ten-Year Plan) } \\
\hline Population impact & 583 & 760 & 900 & 1,371 & 1,474 & 1,777 & 767 & 919 & 895 & 916 \\
\hline Total regional population & 248,573 & 250,661 & 253,745 & 257,266 & 260,640 & 264,611 & 266,101 & 268,865 & 271,357 & 273,978 \\
\hline \multicolumn{11}{|c|}{ Alter alive C (Minimum Treatment, Storage, and Disposal) } \\
\hline Population impact & 517 & 531 & 505 & 102 & -306 & -870 & $-1,449$ & $-1,516$ & $-1,502$ & $-1,502$ \\
\hline Total regional population & 248,507 & 250,432 & 253,350 & 255,997 & 258,860 & 261,964 & 263,885 & 266,430 & 268,960 & 271,560 \\
\hline \multicolumn{11}{|c|}{ Alternative D (Maximum Treatment, Storage, and Disposal) } \\
\hline Population impact & 583 & 760 & 900 & 1,371 & 1,474 & $1, \pi 77$ & 789 & 941 & 917 & 969 \\
\hline Total regional population & 248,573 & 250,661 & 253,745 & 257,266 & 260,640 & 264,611 & 266,123 & 268,887 & 271,379 & 274,031 \\
\hline
\end{tabular}


percent of the current housing stock in the region of influence. Assuming that the general conditions associated with the current housing market continue (see Section 4.3.2.2), this small, temporary increase in demand should easily be accommodated. By 2004, the potential outmigration expected under Alternative A could reduce the demand for housing in the region of influence by approximately 490 units, representing approximately 0.7 percent of total available housing units. Given current housing preferences and current vacancy rates of 2.1 percent for homeowner-occupied housing and 4.6 percent for rental housing, the decline in housing demand anticipated under Alternative $A$ could result in vacancy rates for owner-occupied and rental units of 2.7 percent and 5.3 percent, respectively. The decline in projected baseline activity at the INEL could reduce the demand for housing by an additional 960 units by 2004, resulting in a cumulative decrease in demand of about 1,450 units, or 2.0 percent of the current housing stock.

5.3.2.3 Community Services and Public Finance. The population decrease of $\mathbf{1 , 7 0 3}$ persons expected under Alternative A (No Action) by 2004 represents a decline of less than one percent in the total regional population. It is unlikely that such a small change in regional population would generate any discernible impact on community services and public finance within the region of influence. The effects of the decline in baseline INEL activity, however, could result in a cumulative population decrease of about 5,040 persons under Alternative A, a 1.9 percent decline in total regional population. School enrollments could decline by approximately 2.0 percent, accompanied by similar decreases in demand for other community services. Similarly, revenues received by the county governments within the region of influence may decrease slightly as a result of the projected declines in regional economic activity.

5.3.2.4 Impacts from Speciflc Activities. There are no specific activities associated with Alternative A (No Action).

\subsubsection{Socioeconomic Impacts from Alternative B (Ten-Year Plan)}

The impacts from Alternative B (Ten-Year Plan) on employment and earnings, population and housing, and community services in the region of influence are discussed below.

5.3.3.1 Employment and Earnings. Implementation of Alternative B (Ten-Year Plan) is expected to generate about 1,410 direct jobs in the region of influence during the peak 
employment year (2000), representing a 14.1 percent increase over the 1995 baseline INEL employment of approximately 10,000 (Table 5.3-1). By 2004, direct employment would amount to about 590 jobs, a 5.9 percent increase from baseline. Secondary employment generated under Alternative $B$ is expected to reach about 2,010 jobs in the peak year and fall to about 850 jobs by 2004. The total employment impact (direct plus secondary) in the region of influence is estimated to range from an increase of about 3,410 jobs in 2000 to about 1,440 jobs in 2004, with an average employment impact of about 2,000 jobs (Figure 5.3-1). Total employment impacts expected under Alternative B amount to less than 3.4 percent of total regional employment in any given year of the study period. It is unlikely that employment impacts of this size would generate any long-term adverse effects on the economic activity of the region.

Direct earnings, or payrolls, generated under Alternative B (Ten-Year Plan) would amount to $\$ 40.6$ million in 2000 , decreasing to $\$ 18.2$ million in 2004 . Total earnings generated in the region of influence are estimated to be $\$ 77.9$ million in 2000 , decreasing to $\$ 34.5$ million by 2004. Similar to the estimated employment impacts, earnings are expected to vary within this range over the study period.

The positive employment and earnings impacts expected under Alternative B (Ten-Year Plan) would tend to offset the magnitude of the effects of projected declines in baseline INEL employment and earnings. Baseline employment at the INEL is expected to steadily decline over the ten-year study period, resulting in a loss of approximately 980 direct jobs and 1,530 secondary jobs by 2004. The cumulative effect of Alternative B would reduce these job losses to about 390 and 680, respectively, by 2004 .

5.3.3.2 Population and Housing. Population in-migration associated with the implementation of Alternative B (Ten-Year Plan) may amount to about 1,780 persons during the peak employment year, an increase that represents less than 0.7 percent of the total regional population (Table 5.3-2). By 2004, population increases would decline to approximately 920 persons, a 0.3 percent increase in regional population.

Under projected baseline employment conditions at the INEL, the number of direct and secondary jobs in the region of influence could fall by 2,510 over the ten-year period from 1995 to 2004. The elimination of these jobs could induce the relocation of a number of these workers 
and their families, resulting in the possible out-migration of approximately 3,330 persons by 2004 . Through the demand for additional workers, the implementation of Alternative B (Ten-Year Plan) would alleviate the effects of this potential population decline, reducing the cumulative outmigration to approximately 2,420 persons. The degree of offset depends to a large extent on whether the persons losing jobs at the INEL under projected baseline conditions possess the skills required to fill the new jobs generated under Alternative B.

During the peak employment period, implementation of Alternative B (Ten-Year Plan) could result in a temporary increase in housing demand of about 510 units, representing approximately 0.7 percent of the current housing stock in the region of influence. Given current housing preferences and current vacancy rates of 2.1 percent for homeowner-occupied housing and 4.6 percent for rental housing, the increase in housing demand anticipated under Alternative B could reduce the vacancy rates for owner-occupied and rental units to 1.4 percent and 3.9 percent, respectively. Assuming that the general conditions associated with the current housing market continue (see Section 4.3.2.2, Housing), this increase in demand could place additional strain on the existing market. By 2004, the expected housing demand associated with population in-migration under Alternative B (Ten-Year Plan) would amount to approximately 260 units, representing approximately 0.4 percent of total available housing units. The projected decline in baseline activity at the INEL, however, would more than offset the potential increases in demand for housing expected under Alternative $B$, resulting in a cumulative decrease in housing demand of about 700 units, or 1.0 percent of the current housing stock.

5.3.3.3 Community Services and Public Finance. The expected population inmigration of 916 persons anticipated under Alternative B (Ten-Year Plan) by 2004 represents an increase of less than 0.5 percent in the total regional population. It is unlikely that such a small change in regional population would generate any discernible impact on community services and public finance within the region of influence. The effects of the decline in projected baseline INEL activity could result in a cumulative population decrease of about 2,420 persons under Alternative B, a 0.9 percent decline in total regional population. Again, an impact of this magnitude is not expected to be sufficient to notably affect community services and public finance in the region of influence. 
5.3.3.4 Impacts from Specific Activities. The specific activities associated with Alternative B (Ten-Year Plan) are additional racks in the spent nuclear fuel storage pools at the Idaho Chemical Processing Plant Fluorinel and Storage (FAST) Facility, selection of technologies for processing sodium-bearing liquid waste and calcined high-level waste, and incineration of lowlevel and mixed low-level waste at the Waste Experimental Reduction Facility. Decisions related to these specific activities would have negligible impacts on socioeconomic resources in the region of influence.

\subsubsection{Socioeconomic Impacts from Alternative C (Minimum Treatment, Storage, and Disposal)}

The impacts from Alternative C (Minimum Treatment, Storage, and Disposal) on employment and earnings, population and housing, and community services in the region of influence are discussed in the following subsections.

\subsubsection{Employment and Earnings. Implementation of Alternative C (Minimum} Treatment, Storage, and Disposal) is expected to generate about 530 direct jobs in the region of influence during the peak employment year (1996), representing a 5.3 percent increase over the 1995 baseline INEL employment of approximately 10,000 (Table 5.3-1). By 2004, however, direct employment would decrease by about 320 jobs (a 3.2 percent decrease from baseline), due primarily to the phase-out of the Expended Core Facility. Secondary employment generated under Alternative $C$ is expected to range from an increase of about 740 jobs in 1996 to a loss of about 530 jobs in 2004. The total employment impact (direct plus secondary) in the region of influence is estimated to range from an increase of about 1,270 jobs in 1996 to a decrease of about 860 jobs in 2004, with an average employment impact of about 6 jobs (Figure 5.3-1). Total employment impacts expected under Alternative $C$ amount to less than 1.2 percent of total regional employment in any given year of the study period. It is unlikely that employment impacts of this size would generate any long-term adverse effects on the economic activity of the region.

Direct earnings, or payrolls, generated under Alternative C (Minimum Treatment, Storage, and Disposal) would amount to an increase of $\$ 14.3$ million in 1996 and a decrease of $\$ 16.7$ million in 2004. Total earnings generated in the region of influence are estimated to be an increase of $\$ 27.6$ million in 1996 and a decrease of $\$ 30.0$ million in 2004 . Similar to the estimated 
employment impacts, earnings are expected to vary considerably within this range over the study period.

Employment and earnings impacts expected under Alternative C (Minimum Treatment, Storage, and Disposal) would initially offset projected declines in baseline INEL employment and earnings; however, after 1999, employment losses expected under Alternative $\mathrm{C}$ would compound projected baseline declines. The cumulative employment losses expected in the region of influence by 2004 amount to about 1,300 direct jobs and 3,370 total jobs.

5.3.4.2 Population and Housing. Population in-migration associated with the implementation of Alternative C (Minimum Treatment, Storage, and Disposal) may amount to about 530 persons during the peak employment year, an increase that represents less than 0.2 percent of the total regional population (Table 5.3-2). By 2004, however, Alternative $\mathrm{C}$ could result in the out-migration of about 1,500 persons, a 0.6 percent decrease in regional population.

Under projected baseline employment conditions at the INEL, the number of direct and secondary jobs in the region of influence could fall by 2,510 over the ten-year period from 1995 to 2004. The elimination of these jobs could induce the relocation of a number of these workers and their families, resulting in the possible out-migration of approximately 3,330 persons by 2004 . Through the loss of additional jobs, the implementation of Alternative C (Minimum Treatment, Storage, and Disposal) would contribute to this potential population decline, generating a cumulative out-migration of approximately 4,840 persons. The actual magnitude of the total population effect would depend to a large extent on the future availability of comparable employment opportunities within the region relative to the availability of employment elsewhere and to a variety of subjective criteria.

During the peak employment period, implementation of Alternative $C$ (Minimum Treatment, Storage, and Disposal) could result in a temporary increase in housing demand of about 150 units, representing approximately 0.2 percent of the current housing stock in the region of influence. Assuming that the general conditions associated with the current housing market continue (see Section 4.3.2.2, Housing), this small, temporary increase in demand should easily be accommodated. By 2004, the potential out-migration expected under Alternative $\mathrm{C}$ could reduce the demand for housing in the region of influence by approximately 430 units, representing 
approximately 0.6 percent of total available housing units. Given current housing preferences and current vacancy rates of $\mathbf{2 . 1}$ percent for homeowner-occupied housing and 4.6 percent for rental housing, the decline in housing demand anticipated under Alternative $\mathrm{C}$ could result in vacancy rates for owner-occupied and rental units of 2.7 percent and 5.3 percent, respectively. The decline in projected baseline activity at the INEL could reduce the demand for housing by an additional 960 units by 2004 , resulting in a cumulative decrease in demand of about 1,390 units, or 2.0 percent of the current housing stock.

5.3.4.3 Community Senvices and Public Finance. The population decrease of about 1,500 persons expected under Alternative C (Minimum Treatment, Storage, and Disposal) by 2004 represents a decline of less than one percent in the total regional population. It is unlikely that such a small change in regional population would generate any discernible impact on community services and public finance within the region of influence. The effects of the decline in baseline INEL activity, however, could result in a cumulative population decrease of about 4,840 persons under Alternative $C$, a 1.8 percent decline in total regional population. School enrollments could decline by approximately 2.0 percent, accompanied by similar decreases in demand for other community services. Similarly, revenues received by the county governments within the region of influence may decrease slightly as a result of the projected declines in regional economic activity.

5.3.4.4 Impacts from Specific Actlvities. The specific activities associated with Alternative C (Minimum Treatment, Storage, and Disposal) are the selection of technologies for processing sodium-bearing liquid waste and calcined high-level waste and replacement of highlevel waste storage tanks at the Idaho Chemical Processing Plant. Decisions related to these specific activities would have negligible impacts on socioeconomic resources in the region of influence.

\subsubsection{Socioeconomic Impacts from Alternative D (Maximum Treatment, Storage, and Disposal)}

The impacts from Alternative D (Maximum Treatment, Storage, and Disposal) on employment and earnings, population and housing, and community services in the region of influence are discussed below. 


\subsubsection{Employment and Earnings. Implementation of Alternative D (Maximum}

Treatment, Storage, and Disposal) is expected to generate about 1,410 direct jobs in the region of influence during the peak employment year (2000), representing a 14.1 percent increase over the 1995 baseline INEL employment of approximately 10,000 (Table 5.3-1). By 2004, direct employment would amount to about 640 jobs, a 6.4 percent increase from baseline. Secondary employment generated under Alternative $D$ is expected to reach about 2,010 jobs in the peak year and fall to about 920 jobs by 2004 . The total employment impact (direct plus secondary) in the region of influence is estimated to range from an increase of about 3,410 jobs in 2000 to 1,560 jobs in 2004, with an average employment impact of about 2,030 jobs (Figure 5.3-1). Total employment impacts expected under Alternative $D$ amount to less than 3.4 percent of total regional employment in any given year of the study period. It is unlikely that employment impacts of this size would generate any long-term adverse effects on the economic activity of the region.

Direct earnings, or payrolls, generated under Alternative D (Maximum Treatment, Storage, and Disposal) would amount to $\$ 40.6$ million in 2000, decreasing to $\$ 19.6$ million in 2004 . Total earnings generated in the region of influence are estimated to be $\$ 77.9$ million in 2000 , decreasing to $\$ 37.2$ million by 2004 . Similar to the estimated employment impacts, earnings are expected to vary within this range over the study period.

The positive employment and earnings impacts expected under Alternative D (Maximum Treatment, Storage, and Disposal) would tend to offset the magnitude of the effects of projected declines in baseline INEL employment and earnings. Baseline employment at the INEL is expected to steadily decline over the ten-year study period, resulting in a loss of approximately 980 direct jobs and 1,530 secondary jobs by 2004 . The cumulative effect of Alternative D would reduce these job losses to about 340 and 610 , respectively, by 2004 .

The potential effects of Spent Fuel Processing (PA-58) under Alternative D (Maximum Treatment, Storage, and Disposal) were not included in the quantitative socioeconomic analysis conducted for this Environmental Impact Statement. However, preliminary review of the PA-58 project data indicates that during Phase 2, construction activities associated with this facility could result in approximately 450 additional direct jobs in the region of influence. During Phases 1 and 3, however, the workforce required under this project would be filled primarily by existing personnel, resulting in minor impacts to direct or secondary employment (fewer than 50 jobs). 
The temporary employment increases expected during Phase 2 would likely generate additional secondary employment in the region, perhaps as many as about 680 jobs, and would also result in temporary population increases. Because these construction-related effects would be temporary, long-term socioeconomic effects in the region of influence are expected to be negligible.

5.3.5.2 Population and Housing. Population in-migration associated with the implementation of Alternative D (Maximum Treatment, Storage, and Disposal) may amount to about 1,780 persons during the peak employment year, an increase that represents less than 0.7 percent of the total regional population (Table 5.3-2). By 2004, population increases would decline to approximately 970 persons, a 0.4 percent increase in regional population.

Under projected baseline employment conditions at the INEL, the number of direct and secondary jobs in the region of influence could fall by 2,510 over the ten-year period from 1995 to 2004. The elimination of these jobs could induce the relocation of a number of these workers and their families, resulting in the possible out-migration of approximately 3,330 persons by 2004 . Through the demand for additional workers, the implementation of Alternative D (Maximum Treatment, Storage, and Disposal) would alleviate the effects of this potential population decline, reducing the cumulative out-migration to approximately 2,360 persons. The degree of offset depends to a large extent on whether the persons losing jobs at the INEL under projected baseline conditions possess the skills required to fill the new jobs generated under Alternative D.

During the peak employment period, implementation of Alternative D (Maximum Treatment, Storage, and Disposal) could result in a temporary increase in housing demand of about 510 units, representing approximately 0.7 percent of the current housing stock in the region of influence. Given current housing preferences and current vacancy rates of 2.1 percent for homeowner-occupied housing and 4.6 percent for rental housing, the increase in housing demand anticipated under Alternative $\mathrm{D}$ could reduce the vacancy rates for owner-occupied and rental units to 1.4 percent and 3.9 percent, respectively. Assuming that the general conditions associated with the current housing market continue (see Section 4.3.2.2 Housing), this increase in demand could place noticeable strain on the market. By 2004, the expected housing demand associated with population in-migration under Alternative D (Maximum Treatment, Storage, and Disposal) would amount to approximately 280 units, representing approximately 0.4 percent of total available housing units. The projected decline in baseline activity at the INEL, however, would 
more than offset the potential increases in demand for housing expected under Alternative D, resulting in a cumulative decrease in housing demand of 681 units, or 0.9 percent of the current housing stock.

5.3.5.3 Community Services and Publlc Finance. The expected population inmigration of about 970 persons anticipated under Alternative D (Maximum Treatment, Storage, and Disposal) by 2004 represents an increase of less than 0.5 percent in the total regional population. It is unlikely that such a small change in regional population would generate any discernible impact on community services and public finance within the region of influence. The effects of the decline in projected baseline INEL activity could result in a cumulative population decrease of about 2,360 persons under Alternative $\mathrm{D}$, a 0.9 percent decline in total regional population. Again, an impact of this magnitude is not expected to be sufficient to notably affect community services and public finance in the region of influence.

5.3.5.4 Impacts from Speciflc Activities. The specific activities associated with Alternative D (Maximum Treatment, Storage, and Disposal) are additional storage racks in the spent nuclear fuel storage pools at the Idaho Chemical Processing Plant Fluorinel and Storage (FAST) Facility, replacement of high-level waste storage tanks at the Idaho Chemical Processing Plant, selection of technologies for processing sodium-bearing liquid waste and calcined high-level waste, and incineration of low-level and mixed low-level waste at the Waste Experimental Reduction Facility. Decisions related to these specific activities would have negligible impacts on socioeconomic resources in the region of influence. 


\subsection{Cultural Resources}

This section discusses the potential impacts of the four environmental restoration and waste management alternatives on cultural resources; that is, archeological and historic sites, areas of cultural or religious importance to local Native Americans, and paleontological localities on the INEL site.

\subsubsection{Methodology}

The methodology for identifying, evaluating, and mitigating impacts to cultural resources has been established through Federal laws and regulations including the National Historic Preservation Act as amended (NHPA 1966), the Archeological Resource Protection Act (ARPA 1979), the Native American Graves Protection and Repatriation Act (NAGPRA 1990), and the American Indian Religious Freedom Act (AIRFA 1978). A project affects a significant resource when it alters the property's characteristics, including relevant features of its environment or use, that qualify it as significant according to criteria used for the National Register of Historic Places. Effects may include those listed in the "Protection of Historic Property" (CFR 1986). Impacts to cultural resources of value to Native Americans, such as sacred or hunting and gathering areas, should be determined through consultation with the affected Native American groups. Such consultation is also required for assessing impacts to archeological sites and when encountering human remains.

Potential impacts are assessed by (a) identifying project activities that could directly or indirectly affect significant resources, (b) identifying the known or expected significant resources in areas of potential impact, and (c) determining whether a project activity would have no effect, no adverse effect, or an adverse effect on significant resources (CFR 1986).

Both direct and indirect impacts due to the proposed alternatives were evaluated. At the INEL site, direct impacts to archeological resources are usually those associated with ground disturbance from construction activities. Direct impacts to existing historic structures may result from demolition, modification, or deterioration of the structures; isolation from or alteration of the property's setting; or the introduction of visual, auditory, or atmospheric elements that are 
out of character or that alter the property's setting. Direct impacts to traditional resources may occur through land disturbance, vandalism, or by changing the environmental setting of traditional use and sacred areas. Impacts may result from pollution, noise, and contamination that may affect traditional hunting and gathering areas, or the visual or auditory setting of sacred areas. Direct impacts to archeological sites as traditional resources may result from vandalism due to increased access to sites. Because these sites and structures have not been formally evaluated, they are considered to be potentially eligible to the National Register of Historic Places. Indirect impacts to cultural resources may also occur due to an overall increase in activity at the INEL, which would bring a larger construction workforce in closer proximity to significant sites.

Until construction plans are finalized, it is impossible to determine the total number of sensitive sites that would be affected by each alternative. However, it is possible at this time to list the number of known sites that may be affected and the historic structures that may sustain direct impacts as a result of modification or demolition under the four proposed alternatives. Table 5.4-1 provides this preliminary listing, along with detailed information on acreage, survey areas, sites, and structures affected by projects for each alternative.

\subsubsection{Cultural Resource Impacts from Alternative A (No Action)}

Alternative $\mathbf{A}$ activities include the construction of new facilities and the modification of existing facilities that would disturb 40 acres of land and may affect a minimum of 9 structures. In areas that have not been subject to intensive cultural resource surveys (18 acres have been surveyed, 22 acres have not), there is a potential for adverse impacts to archeological, Native American, and paleontological resources under this alternative. Proposed structural modifications may also adversely affect historically significant structures and would require consultation with the Idaho State Historic Preservation Office. A signed Memorandum of Agreement between DOE, the Advisory Council on Historic Preservation, and the State Historic Preservation Office (DOE 1993) outlines mitigation procedures for eight structures that may be affected by this alternative within the Auxiliary Reactor Area I, II, and III complex, and that are potentially eligible for nomination to the National Register of Historic Places. Impacts due to alteration in the setting of a traditional, archeological, or historic resources through the introduction of additional noise, air emissions, or night lights are unlikely, since these activities will take place within or immediately adjacent to existing facilities currently engaged in similar activities. 
Table 5.41. Potential impacts to cultural resources at the Idaho National Engineering Laboratory site by project and alternative.

\begin{tabular}{|c|c|c|c|c|c|}
\hline $\begin{array}{r}\text { Project name } \\
\end{array}$ & Alternative ${ }^{2}$ & $\begin{array}{l}\text { Acres } \\
\text { disturbed }\end{array}$ & Surveyed & $\begin{array}{l}\text { Number of } \\
\text { sites } b\end{array}$ & $\begin{array}{l}\text { Number of } \\
\text { structures } b\end{array}$ \\
\hline Test Area North pool fuel transfer & ABD & 0.8 & Yes & 0 & 0 \\
\hline Remediation of groundwater contamination & $A B C D$ & 3.0 & Yes & $\mathbf{0}$ & $\mathbf{0}$ \\
\hline High-level tank farm replacement (upgrade phase) & $A B C D$ & 2.8 & Yes & $\mathbf{0}$ & $\mathbf{0}$ \\
\hline Health Physic Instrument Lab & $\mathrm{ABCD}$ & 1.3 & Yes & $\mathbf{0}$ & $\mathbf{0}$ \\
\hline $\begin{array}{l}\text { Radiological and Environmental Sciences Laboratory } \\
\text { replacement }\end{array}$ & $A B C D$ & 2.8 & Yes & $\mathbf{0}$ & 2 \\
\hline $\begin{array}{l}\text { Auxiliary Reactor Area-II decontamination and } \\
\text { decommissioning (D\&D) }\end{array}$ & $A B C D$ & 6.5 & Yes & $\mathbf{0}$ & 5 \\
\hline Boiling Water Reactor Experiment-V D\&D & $A B C D$ & 0.2 & Unknown & 0 & 2 \\
\hline Pit 9 retrieval & $A B C D$ & 5.2 & Unknown & Unknown & $\mathbf{0}$ \\
\hline Transuranic Storage Area enclosure and storage project & $A B C D$ & 12.4 & Unknownc & Unknown & $\mathbf{0}$ \\
\hline Vadose zone remediation & $A B C D$ & 2.1 & Unknown & Unknown & $\mathbf{0}$ \\
\hline Waste Characterization Facility & $A B C D$ & 2.1 & No & Unknown & $\mathbf{0}$ \\
\hline Waste Handling Facility & ABCD & 0.3 & Yesc & Unknown & $\mathbf{0}$ \\
\hline Engineering Teat Reactor D\&D & BD & 5.0 & Yes & $\mathbf{0}$ & 12 \\
\hline Materials Teat Reactor D\&D & BD & 2.0 & Yes & $\mathbf{0}$ & 20 \\
\hline New Calcine Storage & D & 0.5 & Yes & $\mathbf{0}$ & $\mathbf{0}$ \\
\hline Fuel Processing Complex D\&D (CPP-601) & BD & 0.6 & Yes & $\mathbf{0}$ & 1 \\
\hline Fuel Receipt/Storage Facility (CPP-603) D\&D & BD & 0.5 & Yes & $\mathbf{0}$ & 1 \\
\hline Headend Processing Plant D\&D (CPP-640) & BD & 0.0 & (d) & $\mathbf{0}$ & 1 \\
\hline Additional increased rack capacity (CPP-666) & BD & 0.0 & (d) & 0 & 1 \\
\hline Dry Fuel Storage Facility; fuel receiving, canning/ & B & 18.5 & Unknown & Unknown & 0 \\
\hline characterization, and shipping & c & Unknown & Yes & 0 & 1 \\
\hline & D & 30.0 & Unknown & Unknown & $\mathbf{0}$ \\
\hline Waste Calcine Facility, D\&D & BD & 0.5 & Yes & o & 1 \\
\hline Waste Immobilization Facility & $\mathrm{BCD}$ & 0.8 & Yes & 0 & 1 \\
\hline Mixed/Low-Level Waste Disposal Facility & B & 200 & Unknownc & Unknown & $\mathbf{0}$ \\
\hline Mixed/Low-Level Waste Disposal Facility & D & 400 & Unknown & Unknown & $\mathbf{0}$ \\
\hline Mixed Low-Level Waste Treatment Facility & D & 200 & Unknown & Unknown & $\mathbf{0}$ \\
\hline Central Liquid Waste Processing Facility D\&D & BD & 0.0 & (d) & 0 & 1 \\
\hline Remote Mixed Waste Treatment Facility & BD & 1.0 & Yesc & Unknown & $\mathbf{0}$ \\
\hline Fort St. Vrain spent nuclear fuel shipment \& storage & BD & 0.0 & (d) & 0 & $\mathbf{0}$ \\
\hline Greater-than-Class-C dedicated storage & BD & 1.7 & Yes & 0 & \\
\hline Idaho Waste Processing Facility & BD & 20.0 & Unknown & Unknown & $\mathbf{0}$ \\
\hline Gravel pit expansion & B & 20.12 & Partiallyc & 23 & 0 \\
\hline Gravel pit expansion & D & 99.5 & Partiallyc & 23 & $\mathbf{0}$ \\
\hline Radioactive Scrap/Waste Facility & BCD & 0.0 & (d) & $\mathbf{0}$ & 1 \\
\hline Increased rack capacity for CPP-666 & BD & 0.0 & (d) & $\mathbf{0}$ & 1 \\
\hline $\begin{array}{l}\text { Private sector alpha-mixed low-level waste (MLLW) } \\
\text { treatment }\end{array}$ & BD & 200 & Unknown & Unknown & 0 \\
\hline $\begin{array}{l}\text { Radioactive Waste Management Complex modifications to } \\
\text { support private sector treatment of alpha-MLLW }\end{array}$ & BD & 1.0 & Unknown & Unknown & 6 \\
\hline Nonincinerable mixed waste treatment & B & 0.0 & (d) & $\mathbf{0}$ & 4 \\
\hline Nonincinerable mixed waste treatment & D & 0.0 & (d) & $\mathbf{0}$ & 4 \\
\hline Expended Core Facility dry cell expansion project & BD & 0.0 & (d) & 0 & 1 \\
\hline Waste Experimental Reduction Facility incineration & BD & 0.0 & (d) & 0 & 1 \\
\hline Shipping/transfer station & C & 5.0 & Yes & 0 & 0 \\
\hline Tank farm heel removal project & BCD & 10.0 & Yes & $\mathbf{0}$ & Unknown \\
\hline Plasma hearth process project & BD & 0.0 & (d) & 0 & 1 \\
\hline Actinide recycle demonstration & $\mathrm{BCD}$ & 0.0 & (d) & $\mathbf{0}$ & 2 \\
\hline High-level tank farm new tanks & $\mathrm{CD}$ & 20.0 & Yes & $\mathbf{0}$ & $\mathbf{0}$ \\
\hline Sodium Processing Project & BD & 0.03 & Yes & 0 & $\mathbf{0}$ \\
\hline $\begin{array}{l}\text { Hazardous Waste Treatment, Disposal, and Storage } \\
\text { Facility }\end{array}$ & D & 5.0 & Yes & 0 & 0 \\
\hline Calcine Transfer Project (Bin Set \#1) & BD & 0.5 & Yes & 0 & 0 \\
\hline Industrial/commercial landfill expansion & BCD & 280.0 & Partiallyc & Unknown & 0 \\
\hline $\begin{array}{l}\text { Central Facilities Area Clean Laundry and Respirator } \\
\text { Facility }\end{array}$ & BD & 0.0 & (d) & 0 & 1 \\
\hline \multicolumn{6}{|c|}{$\begin{array}{l}\text { a. A = Alternative A (No Action); B = Alternative B (Ten-Year Plan); } C=\text { Alternative C (Minimum Treatment, Storage, and } \\
\text { Disposal), D }=\text { Alternative } D \text { (Maximum Treatment, Storage, and Disposal). } \\
\text { b. Sites and structures not evaluated, assumed to be potentially significant. } \\
\text { c. Archeologically sensitive area; known sites in vicinity. } \\
\text { d. Not applicable because no new building is involved. }\end{array}$} \\
\hline
\end{tabular}




\subsubsection{Cultural Resource Impacts from Alternative B (Ten-Year Plan)}

Impacts to cultural resources under Alternative B (Ten-Year Plan) would be similar to those under Alternative A (No Action), with the following additions: facility expansion, new facility construction, and gravel pit expansion would affect about 800 acres of land and 66 structures would be modified, decommissioned, or demolished. A total of 33 acres have been surveyed and 23 sites, which may be affected by the project, have been identified. The remaining 767 acres have not been surveyed. Additional projects associated with this alternative that are not yet specified may also cause additional ground disturbance. In all areas, ground disturbance has the potential to affect archeological, traditional, and paleontological sites located on the surface of the ground or buried beneath recent sediments. In locations that have been intensively surveyed, many areas of concern can be identified, but in unsurveyed locations, the sensitive areas would not be known until field work is completed. Potential impacts may occur due to alteration in the setting of a traditional, archeological, or historic resource through the introduction of additional noise, air emissions, or night lights. Although most of these activities will take place within or immediately adjacent to existing facilities currently engaged in similar activities, some construction is proposed for areas outside of existing facilities. If significant archeological or historic sites or traditional resources are in proximity, the additional noise, pollution, contamination, or lighting may adversely affect these resources.

The specific activities associated with Alternative B are additional storage racks in the Idaho Chemical Processing Plant Fluorinel and Storage (FAST) Facility, selection of technologies for processing sodium-bearing liquid waste and calcined high-level waste, and selection of incineration at the Waste Experimental Reduction Facility for treatment of low-level and mixed low-level waste.

Reracking of storage area within FAST (CPP-666) may result in the alteration of a potentially significant structure. However, this action would not affect prehistoric or historic archeological sites or traditional or paleontological resources, since construction would take place within an existing facility that is already highly disturbed and which contains no significant archeological sites. There would be no new ground disturbance or alteration of setting. 
The construction of new facilities and use of existing facilities for interim storage for processing sodium-bearing liquid waste and calcined high-level waste may result in the alteration of potentially significant structures. However, no impacts would occur to prehistoric or historic archeological sites or to traditional or paleontological resources since construction would take place within the Idaho Chemical Processing Plant, an existing facility that is already highly disturbed.

Upgrading an existing facility for the selection of incineration at the Waste Experimental Reduction Facility for treatment of low-level and mixed low-level waste would result in the alteration of a potentially significant structure. However, no impacts would occur to prehistoric or historic archeological sites or to traditional or paleontological resources since there would be no ground disturbance or alteration of setting.

\subsubsection{Cultural Resource Impacts from Alternative C (Minimum Treatment, Storage, and Disposal)}

Impacts to cultural resources from Alternative C (Minimum Treatment, Storage, and Disposal) could occur during ground disturbance within a 349-acre area or during the modification and dismantling of 9 structures A total of 46 acres have been surveyed, but no sites are currently known to exist in the project areas. The remaining 303 acres have not been surveyed. A signed Memorandum of Agreement between DOE, the Advisory Council on Historic Preservation, and the State Historic Preservation Office outlining mitigation measures for some structures within the Auxiliary Reactor Area complex (DOE 1993) may have application for mitigation under this alternative. However, projects involving excavation or other ground disturbance could affect archeological, paleontological, or traditional resources. Impacts due to alteration in the setting of a traditional, archeological, or historic resource through the introduction of additional noise, air emissions, or night lights are unlikely, since these activities will take place within or immediately adjacent to existing facilities currently engaged in similar activities.

The specific activities associated with Alternative $\mathbf{C}$ are the selection of technologies for processing sodium-bearing liquid waste and calcined high-level waste, and the replacement of high-level waste storage tanks at the Idaho Chemical Processing Plant. The construction of new 
facilities and use of existing facilities for interim storage may result in the alteration of potentially significant structures. However, no impacts would occur to prehistoric or historic archeological sites or to traditional or paleontological resources since construction would take place within the Idaho Chemical Processing Plant, an existing facility that is already highly disturbed.

\subsubsection{Cultural Resource Impacts from Alternative D (Maximum Treatment, Storage, and Disposal)}

Impacts to cultural resources from Alternative D (Maximum Treatment, Storage, and Disposal) would disturb a total of 1,117 acres of ground, 66 structures, and 23 archaeological sites, with the potential for greater impacts to cultural resources than Alternative $B$, due to the expanded scope of projects dealing with construction and modification of buildings, and construction of new structures at several facilities. A minimum of 1,000 acres that have not been surveyed are likely to contain archaeological, traditional, and paleontological sites. Potential impacts may occur due to alteration in the setting of a traditional, archeological, or historic resource through the introduction of additional noise, air emissions, or night lights. Although most of these activities will take place within or immediately adjacent to existing facilities currently engaged in similar activities, some construction is proposed for areas outside of existing facilities. If significant archeological or historic sites or traditional resources are in proximity, the additional noise, pollution, contamination, or lighting may adversely affect these resources.

Alternative D (Maximum Treatment, Storage, and Disposal) would include five specific activities: additional storage racks in the Idaho Chemical Processing Plant Fluorinel and Storage (FAST) Facility, replacement of high-level waste storage tanks, selection of technologies for processing sodium-bearing liquid waste and calcined high-level waste, and selection of incineration at the Waste Experimental Reduction Facility for treatment of low-level and mixed low-level waste.

Reracking of storage area within the Idaho Chemical Processing Plant Fluorinel and Storage (FAST) Facility (CPP-666) and construction of tanks for storing high-level wastes at the Idaho Chemical Processing Plant may result in the alteration of a potentially significant structure. However, neither of these actions would affect prehistoric or historic archeological sites or traditional or paleontological resources, since construction would take place within an existing 
facility that is already highly disturbed and which contains no significant archeological sites. There would be no new ground disturbance or alteration of setting.

Selection of technologies for processing sodium-bearing liquid waste and calcined highlevel waste would result in the construction of new facilities and use of existing facilities for interim storage, which may result in the alteration of potentially significant structures. However, no impacts would occur to prehistoric or historic archeological sites or to traditional or paleontological resources since construction would take place within the Idaho Chemical Processing Plant, an existing facility that is already highly disturbed.

Selection of incineration at the Waste Experimental Reduction Facility for treatment of low-level and mixed low-level waste would mean upgrading an existing facility which may result in the alteration of a structure of potential cultural significance. No impacts would occur to prehistoric or historic archeological sites or to traditional or paleontological resources since there would be no ground disturbance or alteration of setting. 


\subsection{Aesthetic and Scenic Resources}

This section discusses the potential effects of the four environmental restoration and waste management alternatives on aesthetic and scenic resources at the INEL site and the surrounding area.

\subsubsection{Methodology}

Potential impacts to aesthetic and scenic resources include (a) the addition or modification of structures, and (b) the addition of pollutants which may alter the view. The impact analyses for all the alternatives focus on the effects of proposed construction activities on the INEL site. Where the facility design of some of the structures has yet to be determined, a more general analysis is provided; however, where construction specifications are known, a more detailed assessment is given. Determination of significant visual resource degradation due to structures is based on the extent of modification to the area. The definition of the "degree of acceptable modification" considers the nature, density, and extent of sensitive visual resources that contribute to the visual character of an area. If construction activities and ground disturbances associated with the proposed action alternative result in a visual impact that is incompatible with the general setting, impacts would be considered significant.

Potential impacts to aesthetics and visual resources include factors resulting from on-going operations that would be detrimental to the available views, such as visibility degradation caused by air emissions from operating plants. To determine impacts to visibility on Craters of the Moon Wilderness Area, a nearby Class I area within Craters of the Moon National Monument, the results from the air quality analysis were reviewed. Additional pollutants released into the atmosphere during both the construction and operation of facilities would result in visual resource degradation by reducing contrast and causing discoloration. In particular, emissions of oxides of nitrogen and particulate matter may decrease contrast, such as that of a daik object against the horizon, and/or cause a discoloration of the sky or viewed objects. Visibility has been specifically designated as an air quality issue under the 1977 Prevention of Significant Deterioration Amendments to the Clean Air Act. A screening-level air quality analysis has been conducted in accordance with a U. S. Environmental Protection Agency-developed methodology and criterion 
to determine if the potential for unacceptable visual degradation exists. The methodology for determining air quality impacts is discussed in detail in Air Resources, Section 5.7.4.3.

\subsubsection{Aesthetic and Scenic Resource Impacts from Alternative A (No Action)}

Under Alternative A (No Action), most project activities would be conducted within existing facility boundaries. These projects are not expected to result in an adverse impact as the proposed structures would be within the facility fenceline and similar to others in the vicinity. However, the Transuranic Storage Area Retrieval Enclosure and Storage Project consists of 2 acres of new construction outside the existing facility boundaries. Another 10.4 acres of this facility would be located within the Radioactive Waste Management Complex, which is located approximately 4 miles from U.S. Highway 20. Structure height would be similar to other storage areas (30-40 $\mathrm{ft}$ ). Due to the low building height and the distance from the highway and the Experimental Breeder Reactor-I, a National Historic Landmark, no adverse impact is expected from this pro .used action.

The air quality analysis of contrast reduction due to project emissions was well below the acceptable criterion for views within Craters of the Moon; however, the analysis of color shift indicated the potential for visual degradation associated with project emissions as proposed. The analysis was, therefore, repeated with assumed controls on certain projects which, due to oxides of nitrogen emissions, contribute significantly to the excess color shift value. Combustion control equipment to effect at least 70 percent control of oxides of nitrogen would be required on an incinerator at the Radioactive Waste Management Complex in order to pass the screening-level analysis.

Construction of the proposed facilities and demolition of existing facilities would produce fugitive dust that may affect visibility temporarily in localized areas. Such activities would be of limited duration, however, and the INEL would follow standard construction practices to minimize both erosion and dust. 


\subsubsection{Aesthetic and Scenic Resource Impacts from Alternative B (Ten-Year Plan)}

Alternative B (Ten-Year Plan) includes several decommissioning and decontamination projects, construction of new facilities, and upgrading or replacement of buildings and infrastructure, as well as those projects listed in Alternative A (No Action). Although most projects are expected to be confined to developed areas, five major facilities proposed for construction would not be located within facility fencelines. These are the Dry Fuels Storage Facility, the Mixed Low-Level Waste Disposal Facility, the Mixed Low-Level Waste Treatment Facility, and either the Idaho Waste Processing Facility or the Private Sector Alpha-Mixed LowLevel Waste Treatment Facility.

In those instances where upgrading or replacement of buildings and infrastructure, and decommissioning and decontamination projects occur within an established facility area boundary, the visual sensitivity of the proposed action would be low. For example, the decommissioning and decontamination of the Fuel Processing Complex (Building CPP-601) would take place at its current location within the Idaho Chemical Processing Plant facility area boundary. This facility area is in the vicinity of public highways, a rest area, and the Experimental Breeder Reactor-I (a National Historic Landmark), but it is far enough away from these locations (approximately 3 miles) that the planned activities would not be noticeable to the public. The proposed new construction projects would be similar in size and shape to the existing structures.

The five facilities located outside of fencelines are estimated to cover about 459 acres when completed. Although no final siting determination has been made, these facilities would probably be located within about two miles of existing site facilities and at least half a mile from any public roads. The proposed 200-acre Private Sector Alpha-Mixed Low-Level Waste Treatment facility is not currently sited. Areas within the INEL site that are considered to have moderate visual sensitivity include the Experimental Breeder Reactor-I and Goodale's Cutoff, a portion of the Oregon Trail that crosses the southwestern section of the site (see Section 4.4.1). A potential visual impact could occur if the facilities not currently sited or any of the proposed facilities located outside of fencelines were to be located in these vicinities. However, because all of these facilities would be located within the INEL site and would be similar in size and character to existing structures, no adverse visual impact would be expected. 
While the INEL site may be visible from Craters of the Moon National Monument and its Class I Wilderness Area under certain atmospheric conditions, the viewing distance of approximately 15 miles negates any adverse impacts that might be caused by the siting and construction of the proposed facilities or night lighting associated with the proposed activities. As with Alternative A (No Action), the air quality analysis of contrast reduction due to project emissions was well below the acceptable criterion for views within Craters of the Moon, however, the analysis of color shift indicated the potential for even greater visual degradation associated with project emissions as proposed. For Alternative B (Ten-Year Plan), more stringent oxides of nitrogen emission controls of at least 90 percent would be required on an incinerator at the Radioactive Waste Management Complex, the Waste Immobilization Facility at the Idaho Chemical Processing Plant, and the Idaho Waste Processing Facility; an additional 70 percent control on a boiler at the Radioactive Waste Management Complex would be required in order to pass the screening-level analysis.

Construction of the proposed facilities and demolition of existing facilities would produce fugitive dust that may affect visibility temporarily in localized areas. Such activities would be of limited duration, however, and the INEL would follow standard construction practices to minimize both erosion and dust.

The following specific activities which are included in Alternative B (Ten-Year Plan) would have no impacts on aesthetic and scenic resources at the INEL site, because all of the activities or combinations of activities would take place within currently existing structures and would, therefore, not alter the existing visual environment.

- Additional storage racks in the Idaho Chemical Processing Plant Fluorinel and Storage (FAST) Facility

- Selection of technology for processing sodium-bearing liquid waste

- Selection of technology for processing calcined high-level waste

- Selection of incineration at the Waste Experimental Reduction Facility for treatment of low-level and mixed low-level waste. 
This last activity, the selection of incineration at the Waste Experimental Reduction Facility for treatment of low-level and mixed low-level waste, would have no noticeable effects on visibility.

\subsubsection{Aesthetic and Scenic Impacts from Alternative C (Minimum Treatment, Storage, and Disposal)}

There are fewer action projects proposed under Alternative $C$ (Minimum Treatment, Storage, and Disposal) than under Alternative B (Ten-Year Plan). All of the proposed action projects are located near or next to other buildings of similar structure except for 2 acres in the Transuranic Storage Area Enclosure and Storage Project, which is located adjacent to the Radioactive Waste Management Complex boundary. With regard to construction projects, since no adverse impacts are associated with the proposed action under Alternative B, presumably the impacts would be even less under Alternative $C$.

As with the other alternatives, the air quality analysis of contrast reduction due to project emissions was well below the acceptable criterion for views within Craters of the Moon, but the color shift indicated the potential for visual degradation associated with project emissions as proposed. Oxides of nitrogen emission controls, as discussed for Alternative B, would be required in order to pass the screening-level analysis.

Construction of the proposed facilities and demolition of existing facilities would produce fugitive dust that may affect visibility temporarily in localized areas. Such activities would be of limited duration, however, and the INEL would follow standard construction practices to minimize both erosion and dust.

The following specific activities which are included in Alternative C (Minimum Treatment, Storage, and Disposal) would have no impacts on aesthetic and scenic resources at the INEL site, because all of the activities or combinations of activities would take place within currently existing structures and would, therefore, not alter the existing visual environment.

- Replacement of high-level waste storage tanks 
- Selection of technology for processing sodium-bearing liquid waste

- Selection of technology for processing calcined high-level waste.

\subsubsection{Aesthetlc and Scenic Impacte from Alternatlve D (Maximum Treatment, Storage, and Disposal)}

Alternative D (Maximum Treatment, Storage, and Disposal) would implement the maximum number of treatment, storage, and disposal projects. The proposed projects include those described under Alternative B (Ten-Year Plan) or expanded versions of those projects. For example, the proposed Mixed Low-Level Waste Disposal Facility would include 400 acres (instead of 200 acres for Alternative B) under this alternative. The proposed Gravel Pit Expansion and the Dry Fuels Storage Facility would also involve an expanded version of these projects relative to Alternative B. An additional project not included under the Alternative B analysis is the proposed Mixed Low-Level Waste Treatment Facility. This facility would include about 200 acres and be located outside of the Radioactive Waste Management Complex. Approximately 950 acres of construction projects would be located outside of the fencelines under this alternative. (Refer to Chapter 3 for a complete description of the proposed actions under Alternative D.) It is not expected, however, that the increase in scope or the additional projects would affect the impact analysis under Alternative B. Therefore, since no adverse impacts are associated with the proposed action under Alternative B with regard to construction and siting, no adverse impacts. are anticipated for the proposed action projects under this alternative.

As with the other alternatives, the air quality analysis of contrast reduction due to project emissions was well below the acceptable criterion for views within Craters of the Moon, but the color shift indicated the potential for visual degradation associated with project emissions as proposed. Oxides of nitrogen emission controls, as discussed for Alternative B (Ten-Year Plan), would be required in order to pass the screening-level analysis.

Construction of the proposed facilities and demolition of existing facilities would produce fugitive dust that may affect visibility temporarily in localized areas. Such activities would be of limited duration, however, and the INEL would follow standard construction practices to minimize both erosion and dust. 
The following specific activities which are included in Alternative $D$ would have no impacts on aesthetic and scenic resources at the INEL site, because all of the activities or combinations of activities would take place within currently existing structures and would, therefore, not alter the existing visual environment.

- Additional storage racks in the Idaho Chemical Processing Plant Fluorinel and Storage (FAST) Facility

- Replacement of high-level waste storage tanks

- Selection of technology for processing sodium-bearing liquid waste

- Selection of technology for processing calcined high-level waste

- Selection of incineration at the Waste Experimental Reduction Facility for treatment of low-level and mixed low-level waste.

This last activity, the selection of incineration at the Waste Experimental Reduction Facility for treatment of low-level and mixed low-level waste, would have no noticeable effects on visibility. 


\subsection{Geology}

This section discusses the potential effects of the four environmental restoration and waste management alternatives on geology at the INEL site.

\subsubsection{Methodology}

Impacts to geologic resources would be associated with (a) excavating surface deposits at new facility construction sites and (b) using aggregate resources to construct and operate new facilities. Information contained in this section is based on a review of available information on the geology of the INEL site.

\subsubsection{Ceologic Impacte from Alternatives}

Proposed INEL environmental restoration and waste management activities would only have minor, localized impacts on the geology of the INEL site for all alternatives evaluated. Direct impacts to geologic resources at the INEL site would be associated with disturbing or extracting surface deposits to construct new facilities and for use as fill for remediation activities, as needed. These impacts may include excavations into the soil and rock of the INEL site, soil mounding and banking, and extracting aggregate materials from gravel and borrow pits on the INEL site. A secondary impact to geology from construction or remediation activities would be the potential for increased soil erosion. Table 5.6-1 gives estimated extraction of aggregate from INEL site gravel and borrow pits. The following specific activities would have no quantifiable impacts on geologic resources:

- Additional storage racks in the Idaho Chemical Processing Plant Fluorinel and Storage Facility (CPP-666)

- Replacement of high-level waste tanks

- Selection of technology for processing sodium-bearing liquid waste

- Selection of technology for processing calcined high-level waste 
- Selection of incineration at the Waste Experimental Reduction Facility for treatment of low-level and mixed low-level waste.

Other indirect impacts to geologic resources considered in this Environmental Impact Statement are the consumption of fossil fuels, concrete, and other earth resources (Section 5.13, Idaho National Engineering Laboratory Services) and fugitive dust emissions (Section 5.7, Air Resources).

Table 5.6-1. Estimated extraction volumes from gravel and borrow pits on the Idaho National Engineering Laboratory site by alternative."

\begin{tabular}{lc}
\hline \multicolumn{1}{c}{ Alternative ${ }^{b}$} & $\begin{array}{c}\text { Estimated } \\
\text { gravel/borrow use } \\
\left(\mathrm{m}^{3}\right)^{c}\end{array}$ \\
\hline A (No Action) & 226,000 \\
B (Ten-Year Plan) & 408,000 \\
C (Minimum Treatment, Storage, Disposal) & 285,000 \\
D (Maximum Treatment, Storage, Disposal) & $1,772,000$ \\
\hline & \\
a. Refer to Appendix C, Information Supporting the Alternatives, for more information on \\
gravel/borrow pits at the INEL site. \\
b. See Chapter 3, Alternatives, for a description of alternatives identified in this EIS. \\
c. To convert from cubic meters to cubic yards, multiply by 1.31.
\end{tabular}




\subsection{Alr Resources}

This section discusses the potential effects that the four environmental restoration and waste management alternatives may have on regional air quality. In particular, it gives the results of assessments on the impacts of construction and operation of facilities associated with each alternative in terms of expected radiation dose and nonradiological pollutant concentration levels. In addition to cumulative impacts, analyses have been performed with respect to projects associated with specific waste management options within each alternative. Additional details on assessment methods, assumptions, and related information are contained in Appendix F, Section F-3, Air Resources.

\subsubsection{Methodology}

The assessments predict the maximum consequences at onsite and offsite locations resulting from the release of contaminants from various categories of sources. The types of emissions assessed are the same radiological and nonradiological emissions as those assessed in the baseline cases described in Section 4.7, Air Resources; namely, criteria pollutants (carbon monoxide, nitrogen dioxide, sulfur dioxide, lead, respirable and particulate matter), toxic air pollutants, and radionuclides. Volatile organic compounds, which can lead to the formation of ozone, are also assessed. The categories of sources assessed include stationary sources (such as stacks at proposed facilities), fugitive sources (such as construction and demolition activities), and mobile sources associated with INEL site activities.

5.7.1.1 Methodology for Radiological Consequences. The method for estimating radiological consequences of airborne radionuclide releases from alternative courses of action is described in detail in Appendix F, Section F-3, Air Resources. The principal components of the methodology are source term estimation and dispersion modeling. Source terms for specific projects associated with the four alternatives were estimated using conservative engineering calculations based on knowledge of the proposed facility or activity. Typically, these evaluations considered the processes to be incorporated, materials to be used, activities to be performed within the systems, and operating experience with similar systems. For some projects, emissions estimates had previously been made and documented as part of an Environmental Assessment, Permit to Construct, or other action. In such cases, the previously estimated source terms were 
either used directly or were revised to reflect updated project definition. The dispersion modeling used the GENII computer code (Napier et al. 1988), which is well-suited for applications such as this, has been extensively tested, and conforms to applicable software quality assurance criteria. Meteorological and population data specific to the INEL site were incorporated into the model. The GENII model calculates doses from all important pathways of exposure, including external and inhalation dose from immersion in contaminated air, external dose from deposition of radionuclides on ground surfaces, and ingestion of contaminated food products. The ingestion pathway, however, is not a realistic exposure pathway for onsite workers and was not used for those assessments. Doses were assessed separately for each project, then added according to the association of projects with alternatives and waste stream options.

As in the case for baseline radiological assessment, conservative assumptions are applied to avoid underestimating the dose. These include adding of maximum doses calculated for separate projects, even though the locations of maximum impact may be different.

\subsubsection{Mothodology for Nonradiological Consequences. The consequences of} criteria pollutant and toxic air pollutant emissions from stationary sources were assessed using methods and data considered acceptable for regulatory compliance determination by Federal and State agencies. In general, these methods were identical to those used in the baseline assessments described in Section 4.7, Air Resources. One difference was the application of the Industrial Source Complex-2 (ISC-2) atmospheric dispersion computer code (EPA 1992a) to assess both criteria and toxic air pollutant emissions, whereas the baseline assessment of toxics relied principally on the simpler, more conservative SCREEN model (EPA 1992b). Dispersion modeling using ISC-2 allows for a reasonable prediction of the impacts of proposed facilities and therefore is suitable for use in this process.

Atmospheric visibility has been specifically designated as an air-quality-related value under the 1977 Prevention of Significant Deterioration Amendments to the Clean Air Act. To estimate potential worst-case visibility impacts of proposed alternatives at Craters of the Moon Wilderness Area, analysts used the computer code VISCREEN (EPA 1992c), developed by the U.S. Environmental Protection Agency which implements the "Level 1" analysis. This model gives conservative estimates of impacts. (In other words, calculations and assumptions are used that yield results that would be larger than those calculated with more realistic input and modeling 
assumptions.) The model calculates contrast and color shift (referred to as delta E) for two assumed plume-viewing backgrounds-the horizon sky and a dark terrain object. Results were then compared to acceptable criteria for these parameters.

The nonradiological assessment did not include methods for quantifying impacts related to ozone formation because (a) emissions of volatile organic compounds (which are precursors of ozone formation) are below the significance level designated by the State of Idaho; (b) no simple, well-defined method exists to assess ozone formation potential (Wilson 1993); and (c) ozone is not recognized as a problem in the region (Johnson 1993).

5.7.1.3 Methodology for Mobile Source Impacts. The ambient air quality impacts at offsite receptor locations due to the INEL bus fleet operations, INEL fleet light- and heavy-duty vehicles, privately owned vehicles, and heavy-duty commercial vehicles servicing the INEL site facilities were quantitatively predicted using emission factors and a computerized methodology recommended by the U.S. Environmental Protection Agency. The CALINE-3 model, used to implement the U.S. Environmental Protection Agency methodology, is considered a screeninglevel model designed to simulate traffic flow conditions and pollutant dispersion from traffic (Benson 1979). The model was used to predict maximum one-hour ambient air concentrations of carbon monoxide and inhalable particulate matter. Regulatory-approved averaging time adjustment factors were used to scale results for other applicable averaging times. All receptor locations were selected within 3 meters ( 9.8 feet) from the edge of the roadway, in accordance with U.S. Environmental Protection Agency guidance. Modeling was conducted for 1993 to quantify the impact due to INEL buses and traffic serving the latest possible projects and activities on the INEL site and projected impact of projects that will be constructed before 1995 , together with the projected impacts of alternatives.

5.7.1.4 Methodology for Fugitive Dust Impacts. The impacts of existing and proposed sources of fugitive dust were estimated using the U.S. Environmental Protection Agencyrecommended Fugitive Dust Model (FDM) (Winges 1992). Twenty-four hour and annual average concentrations were calculated to correspond with ambient air quality standards. Inhalable particulate fractions were estimated to be 64 percent of total dust loading. This value is based on the U.S. Environmental Protection Agency-recommended value (35 percent) for aggregate 
handling and storage piles, adjusted for the fact that dust suppression by watering tends to preferentially remove larger sized particles.

\subsubsection{Emission Rates}

Air contaminant emission rates were estimated for each project proposed under the four environmental restoration and waste management alternatives. In some cases, the analysis used release estimates made previously (for example, as part of an Environmental Assessment). Other estimates were based on knowledge of the materials used and activities performed and on experience with operating facilities having similar features or functions. Where applicable, the analysis used emission factors from authoritative reference sources such as EPA (1992d).

Many of the projects proposed under the various waste management options are likely to involve some airborne emission of radionuclides. These releases will occur primarily through controlled release points such as stacks or vents, although some fugitive emissions may also result (for example, from the cleanup of contaminated soils or demolition of contaminated structures). Wherever practicable, these releases will be minimized by mitigation measures such as confinement or filtration.

Estimates of the type and amount of airborne radionuclide emissions likely to result from alternative courses of action are presented in Table 5.7-1. These estimates, which are listed by alternative and waste stream, have been made on the basis of knowledge of the materials used and activities performed and on experience with operating facilities that have similar features or functions. These estimates indicate that the types of emissions from proposed activities are similar to those emitted by current INEL site operations, although the quantities may vary substantially depending on the waste management option.

Projected releases of criteria pollutants by alternative and waste stream are presented in Table 5.7-2. Volatile organic compounds (VOCs), while not designated as criteria pollutants, are listed in Table 5.7-2 since thizy may lead to the formation of ozone, which is a criteria pollutant. Because of the many toxic air pollutants, analysts used a screening approach to reduce the number requiring assessment to only those toxic emissions that have the potential to result in 
Table 5.7-1. Summary of radionuclide emissions at the Idaho National Engineering Laboratory site by alternative and source group.

\begin{tabular}{|c|c|c|c|c|c|c|c|c|c|c|c|c|}
\hline \multirow[b]{2}{*}{$\begin{array}{l}\text { Waste or } \\
\text { source group }\end{array}$} & \multicolumn{12}{|c|}{$\begin{array}{l}\text { Radionuclide emission rates } \\
\text { (curies per year) }\end{array}$} \\
\hline & $\begin{array}{l}\text { Hydrogen-3/ } \\
\text { carbon-14 }\end{array}$ & Cobalt-60 & Krypton-85 & $\begin{array}{c}\text { Xenon-131m/ } \\
\text { xenon-133 }\end{array}$ & $\begin{array}{l}\text { Strontium- } \\
\qquad 0^{\mathbf{a}}\end{array}$ & $\begin{array}{l}\text { Antimony- } \\
125\end{array}$ & $\begin{array}{l}\text { lodine-129/ } \\
\text { iodine-131 }\end{array}$ & $\begin{array}{l}\text { Cexium-134/ } \\
\text { cesium-135 }\end{array}$ & Uranium & Plutonium & $\begin{array}{l}\text { Americium- } \\
241\end{array}$ & Other \\
\hline \multicolumn{13}{|c|}{ Ahernative A (No Action) } \\
\hline $\begin{array}{l}\text { Spent nuclear } \\
\text { fuel }\end{array}$ & $9.6 \times 10^{2}$ & $0.0 \times 10^{0}$ & $0.0 \times 10^{0}$ & $0.0 \times 10^{0}$ & $2.9 \times 10^{-2}$ & $0.0 \times 10^{0}$ & $3.4 \times 10^{-2}$ & $0.0 \times 10^{0}$ & $0.0 \times 10^{0}$ & $6.6 \times 10^{-4}$ & $2.2 \times 10^{-4}$ & $0.0 \times 10^{0}$ \\
\hline Transuranic & $0.0 \times 10^{0}$ & $0.0 \times 10^{0}$ & $0.0 \times 10^{0}$ & $0.0 \times 10^{0}$ & $0.0 \times 10^{0}$ & $0.0 \times 10^{0}$ & $0.0 \times 10^{0}$ & $0.0 \times 10^{0}$ & $0.0 \times 10^{0}$ & $2.7 \times 10^{-5}$ & $93 \times 10^{-6}$ & $0.0 \times 10^{0}$ \\
\hline $\begin{array}{l}\text { Environmental } \\
\text { restoration }\end{array}$ & $0.0 \times 10^{0}$ & $0.0 \times 10^{0}$ & $0.0 \times 10^{0}$ & $0.0 \times 10^{0}$ & $0.0 \times 10^{0}$ & $0.0 \times 10^{0}$ & $0.0 \times 10^{0}$ & $0.0 \times 10^{0}$ & $0.0 \times 10^{0}$ & $8.5 \times 10^{-3}$ & $4.4 \times 10^{-3}$ & $0.0 \times 10^{0}$ \\
\hline Total $^{b}$ & $9.6 \times 10^{2}$ & $0.0 \times 10^{0}$ & $0.0 \times 10^{0}$ & $0.0 \times 10^{0}$ & $2.9 \times 10^{-2}$ & $0.0 \times 10^{0}$ & $3.4 \times 10^{-2}$ & $0.0 \times 10^{0}$ & $0.0 \times 10^{0}$ & $9.2 \times 10^{-3}$ & $4.6 \times 10^{-3}$ & $0.0 \times 10^{0}$ \\
\hline \multicolumn{13}{|c|}{ Allernative B (Ten-Year Plan) } \\
\hline $\begin{array}{l}\text { Spent nuclear } \\
\text { fuel }\end{array}$ & $2.0 \times 10^{3}$ & $20 \times 10^{-6}$ & $1.9 \times 10^{4}$ & $1.8 \times 10^{2}$ & $2.9 \times 10^{-2}$ & $2.2 \times 10^{-3}$ & $3.9 \times 10^{-2}$ & $1.4 \times 10^{-5}$ & $0.0 \times 10^{0}$ & $6.6 \times 10^{-4}$ & $22 \times 10^{-4}$ & $1.0 \times 10^{-4}$ \\
\hline High-level waste $c$ & $4.2 \times 10^{2}$ & $0.0 \times 10^{0}$ & $0.0 \times 10^{0}$ & $0.0 \times 10^{0}$ & $1.6 \times 10^{-1}$ & $0.0 \times 10^{0}$ & $15 \times 10^{-1}$ & $3.8 \times 10^{-2}$ & $0.0 \times 10^{0}$ & $0.0 \times 10^{0}$ & $0.0 \times 10^{0}$ & $3.0 \times 10^{-1}$ \\
\hline High-level waste ${ }^{d}$ & $4.2 \times 10^{2}$ & $0.0 \times 10^{0}$ & $0.0 \times 10^{0}$ & $0.0 \times 10^{0}$ & $9.0 \times 10^{-4}$ & $0.0 \times 10^{0}$ & $1.5 \times 10^{-1}$ & $1.1 \times 10^{-2}$ & $0.0 \times 10^{0}$ & $0.0 \times 10^{0}$ & $0.0 \times 10^{0}$ & $1.0 \times 10^{-3}$ \\
\hline Transuranic & $0.0 \times 10^{0}$ & $7.0 \times 10^{-6}$ & $0.0 \times 10^{0}$ & $0.0 \times 10^{0}$ & $1.5 \times 10^{-4}$ & $0.0 \times 10^{0}$ & $0.0 \times 10^{0}$ & $1.7 \times 10^{-4}$ & $7.0 \times 10^{-5}$ & $4.0 \times 10^{-2}$ & $1.3 \times 10^{-2}$ & $26 \times 10^{-4}$ \\
\hline Low-level & $1.3 \times 10^{0}$ & $7.3 \times 10^{-2}$ & $0.0 \times 10^{0}$ & $0.0 \times 10^{0}$ & $1.2 \times 10^{-2}$ & $27 \times 10^{-2}$ & $0.0 \times 10^{0}$ & $3.1 \times 10^{-1}$ & $26 \times 10^{-3}$ & $1.3 \times 10^{-3}$ & $1.7 \times 10^{-4}$ & $6.1 \times 10^{-1}$ \\
\hline $\begin{array}{l}\text { Greater-than- } \\
\text { Class-C }\end{array}$ & $3.2 \times 10^{-8}$ & $0.0 \times 10^{0}$ & $0.0 \times 10^{0}$ & $0.0 \times 10^{0}$ & $1.4 \times 10^{-5}$ & $0.0 \times 10^{0}$ & $0.0 \times 10^{0}$ & $5.3 \times 10^{-2}$ & $8.6 \times 10^{-8}$ & $7.8 \times 10^{-4}$ & $5.1 \times 10^{-5}$ & $1.2 \times 10^{-5}$ \\
\hline Mixed low-level & $1.7 \times 10^{3}$ & $73 \times 10^{-2}$ & $1.6 \times 10^{3}$ & $0.0 \times 10^{0}$ & $1.2 \times 10^{-2}$ & $27 \times 10^{-2}$ & $0.0 \times 10^{0}$ & $3.1 \times 10^{-1}$ & $25 \times 10^{-3}$ & $1.9 \times 10^{-3}$ & $3.0 \times 10^{-4}$ & $1.9 \times 10^{-1}$ \\
\hline Hazardous & $0.0 \times 10^{0}$ & $0.0 \times 10^{0}$ & $0.0 \times 10^{0}$ & $0.0 \times 10^{0}$ & $0.0 \times 10^{0}$ & $0.0 \times 10^{0}$ & $0.0 \times 10^{0}$ & $0.0 \times 10^{0}$ & $23 \times 10^{-7}$ & $1.6 \times 10^{-7}$ & $9.4 \times 10^{-10}$ & $7.6 \times 10^{-10}$ \\
\hline $\begin{array}{l}\text { Environmental } \\
\text { restoration }\end{array}$ & $0.0 \times 10^{0}$ & $0.0 \times 10^{0}$ & $0.0 \times 10^{0}$ & $0.0 \times 10^{0}$ & $0.0 \times 10^{0}$ & $0.0 \times 10^{0}$ & $0.0 \times 10^{0}$ & $0.0 \times 10^{0}$ & $0.0 \times 10^{0}$ & $8.5 \times 10^{-3}$ & $4.4 \times 10^{-3}$ & $0.0 \times 10^{0}$ \\
\hline Total $^{b, c}$ & $4.1 \times 10^{3}$ & $7.3 \times 10^{-2}$ & $2.1 \times 10^{4}$ & $1.8 \times 10^{2}$ & $2.0 \times 10^{-1}$ & $29 \times 10^{-2}$ & $1.9 \times 10^{-1}$ & $4.1 \times 10^{-1}$ & $4.2 \times 10^{-3}$ & $5.1 \times 10^{-2}$ & $1.8 \times 10^{-2}$ & $9.2 \times 10^{-1}$ \\
\hline Total b,d & $4.1 \times 10^{3}$ & $7.3 \times 10^{-2}$ & $2.1 \times 10^{4}$ & $1.8 \times 10^{2}$ & $4.1 \times 10^{-2}$ & $29 \times 10^{-2}$ & $1.9 \times 10^{-1}$ & $3.8 \times 10^{-1}$ & $4.2 \times 10^{-3}$ & $5.1 \times 10^{-2}$ & $1.8 \times 10^{-2}$ & $6.2 \times 10^{-1}$ \\
\hline
\end{tabular}




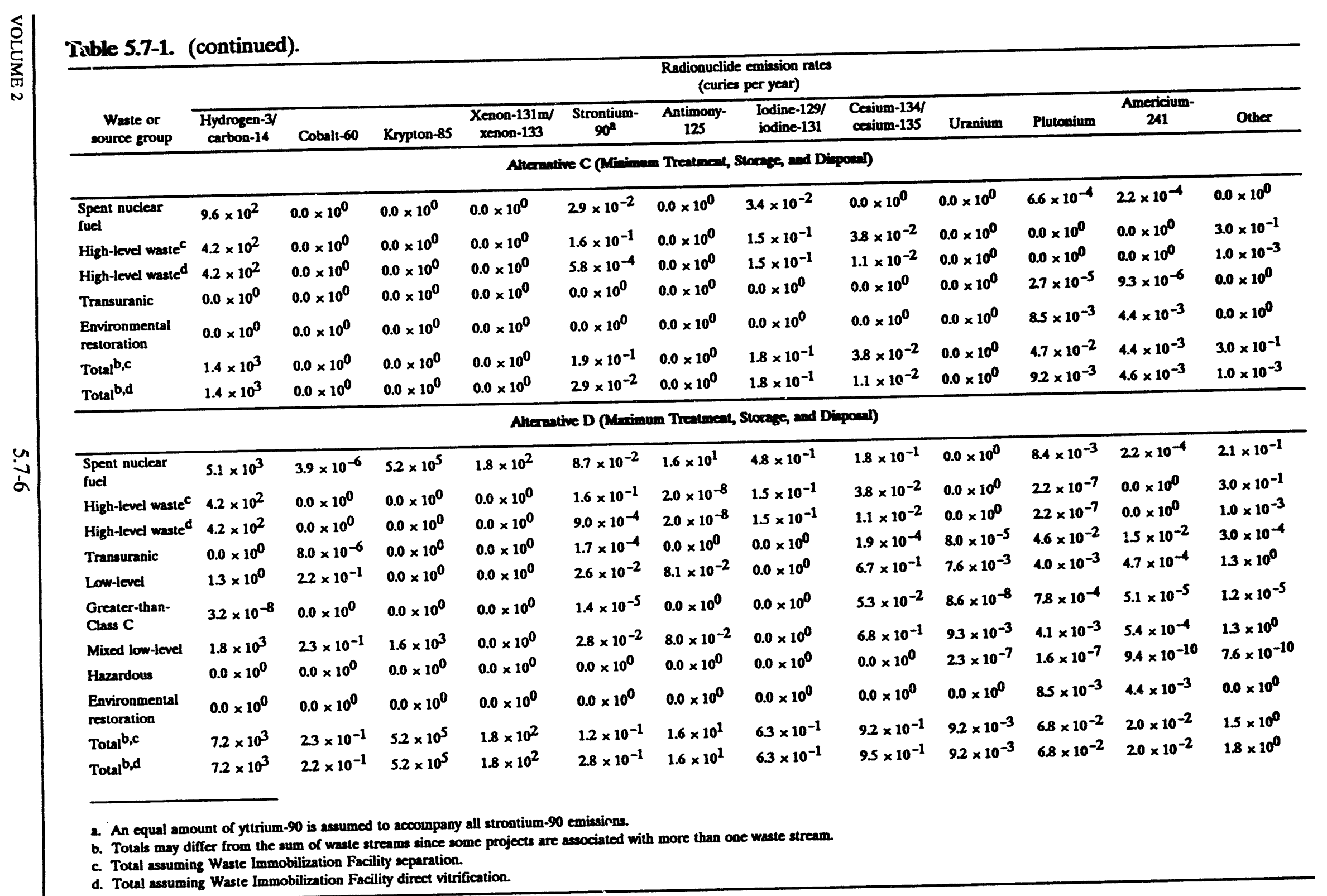




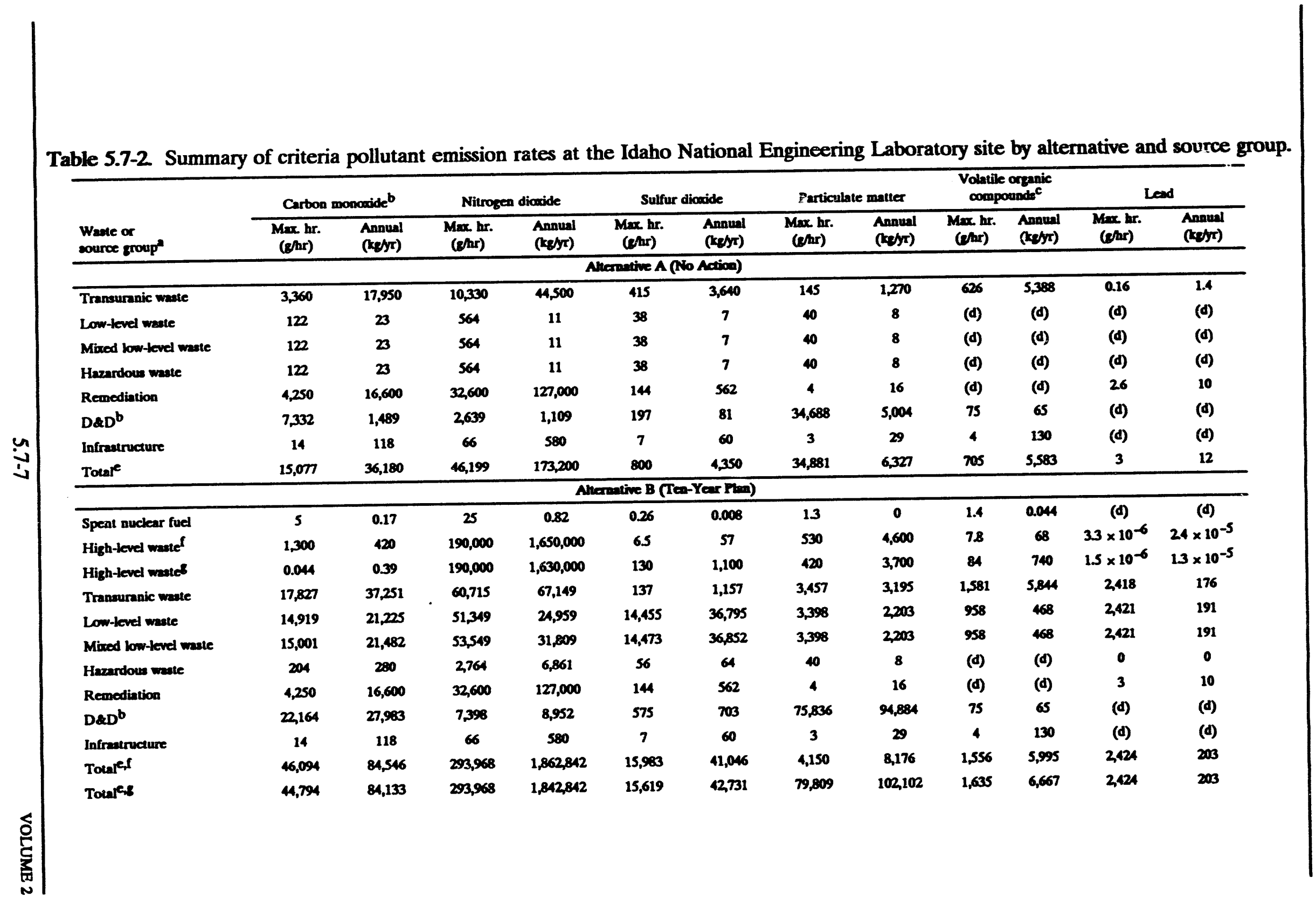




\begin{tabular}{|c|c|c|c|c|c|c|c|c|c|c|c|c|}
\hline \multirow[b]{2}{*}{$\begin{array}{l}\text { Waste or } \\
\text { source group }\end{array}$} & \multicolumn{2}{|c|}{ Carbon monoxide ${ }^{\mathbf{b}}$} & \multicolumn{2}{|c|}{ Nitrogen diaxide } & \multicolumn{2}{|c|}{ Sulfur dioxide } & \multicolumn{2}{|c|}{ Particulate matter } & \multicolumn{2}{|c|}{$\begin{array}{l}\text { Volatile organic } \\
\text { compounds }\end{array}$} & \multicolumn{2}{|c|}{ Lead } \\
\hline & $\begin{array}{l}\text { Max. hr. } \\
\text { (g/hr) }\end{array}$ & $\begin{array}{l}\text { Annual } \\
\text { (keyr) }\end{array}$ & $\begin{array}{l}\text { Max hr. } \\
\text { (ghr) }\end{array}$ & $\begin{array}{l}\text { Annual } \\
\text { (kefyr) }\end{array}$ & $\begin{array}{l}\text { Max hr. } \\
\text { (efrr) }\end{array}$ & $\begin{array}{l}\text { Annual } \\
\text { (kglyr) }\end{array}$ & $\begin{array}{l}\text { Max hr. } \\
\text { (g/hr) }\end{array}$ & $\begin{array}{l}\text { Annual } \\
\text { (kgfyr) }\end{array}$ & $\begin{array}{l}\text { Max hr. } \\
(\mathrm{g} / \mathrm{hr})\end{array}$ & $\begin{array}{l}\text { Annual } \\
\text { (kefyr) }\end{array}$ & $\begin{array}{l}\text { Max hr. } \\
\text { (efhr) }\end{array}$ & $\begin{array}{l}\text { Annual } \\
\text { (kefyr) }\end{array}$ \\
\hline \multicolumn{13}{|c|}{ 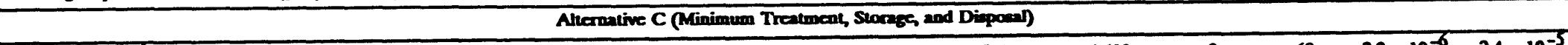 } \\
\hline High-level waste & 1,300 & 420 & 190,000 & $1,650,000$ & 7 & 57 & 530 & 4,600 & 8 & 68 & $3.3 \times 10^{-6}$ & $24 \times 10^{-5}$ \\
\hline High-level wasteb & 0 & 0 & 190,000 & $1,630,000$ & 130 & 1,100 & 420 & 3,700 & 84 & 740 & $15 \times 10^{-6}$ & $1.3 \times 10^{-5}$ \\
\hline Transuranic waste & 3,360 & 17,950 & 10,330 & 44,500 & 415 & 3,640 & 145 & 1,270 & 626 & 5,388 & 0.16 & 1.4 \\
\hline Low-level waste & 122 & 23 & 564 & 11 & 38 & 7 & 40 & 8 & (d) & (d) & (d) & (d) \\
\hline Mixed low-level waste & 122 & 23 & 564 & 11 & 38 & 7 & 40 & 8 & (d) & (d) & (d) & (d) \\
\hline Hazardous waste & 122 & 23 & 564 & 11 & 38 & 7 & 40 & 8 & (d) & (d) & (d) & (d) \\
\hline Remediation & 4,250 & 16,600 & 32,600 & 127,000 & 144 & 562 & 4 & 16 & (d) & (d) & 26 & 10 \\
\hline D\&D & 7,332 & 1.489 & 2,639 & 1,109 & 197 & 81 & 34,688 & 5,004 & 75 & 65 & (d) & (d) \\
\hline Infrastructure & 14 & 118 & 66 & 580 & 6.9 & 60 & 3 & 29 & 4 & 130 & (d) & (d) \\
\hline Total e, f & 16,377 & 36,600 & 236,199 & $1,823,200$ & 807 & 4,407 & 35,411 & 10,927 & 712 & 5,651 & 3 & 12 \\
\hline Totale, & 15,077 & 36,180 & 236,199 & $1,803,200$ & 930 & 5,450 & 35,301 & 10,027 & 789 & 6,323 & 3 & 12 \\
\hline \multicolumn{13}{|c|}{ Altarnative D (Mnimum Tratment, Stocage, and Dipposal) } \\
\hline Spent nuclear fucl & 5 & 0.17 & 25 & 0.82 & 0.26 & 0.008 & 1.3 & 0.041 & 1.4 & 0.044 & (d) & (d) \\
\hline High-level wastef & 1,300 & 420 & 190,000 & $1,650,000$ & 6.5 & 57 & 530 & 4,600 & 7.8 & 68 & $3.3 \times 10^{-6}$ & $24 \times 10^{-5}$ \\
\hline High-level wasteg & 0.044 & 0.39 & 190,000 & $1,630,000$ & 130 & 1,100 & 420 & 3,700 & 84 & 740 & $1.5 \times 10^{-6}$ & $13 \times 10^{-5}$ \\
\hline Transuranic waste & 18,846 & 39,899 & 63,480 & $6 \AA .230$ & 14,271 & 36,705 & 3,457 & 3,195 & 1,585 & 5,845 & 2,781 & 201 \\
\hline Low-level waste & 20,022 & 24,220 & 73,146 & 28,349 & 15,871 & 37,327 & 4,739 & 2,273 & 15,185 & 2,624 & 2,788 & 245 \\
\hline Mixed low-level waste & 20,104 & 24,477 & 75,346 & 34,002 & 15,889 & 37,384 & 4,739 & 2,273 & 15,185 & 2,624 & 2,789 & 245 \\
\hline Hazardous waste & 204 & 280 & 2.764 & 6,861 & 56 & 64 & 40 & 8 & (d) & (d) & 0.14 & 0.42 \\
\hline Remediation & 4,250 & 16,600 & 32,600 & 127,000 & 144 & 562 & 4 & 16 & (d) & (d) & 3 & 10 \\
\hline$D \& D^{b}$ & 22,164 & 27,983 & 7,398 & 8,952 & 575 & 703 & 75,836 & 94,884 & 75 & 65 & (d) & (d) \\
\hline Infrastructure & 14 & 118 & 66 & 580 & 7 & 60 & 3 & 29 & 4 & 130 & (d) & (d) \\
\hline Totale,f & 51,196 & 87,549 & 315,765 & $1,865,034$ & 17,037 & 42,406 & 81,259 & 103,072 & 15,787 & 8,150 & 2791 & 257 \\
\hline Totale.8 & 49,896 & 87,129 & 315,765 & $1,865,034$ & 17,161 & 43,449 & 81,149 & 102,172 & 15,863 & 8,882 & 2,791 & 257 \\
\hline $\begin{array}{l}\text { a. Only those sources } \\
\text { b. Max hr. = maximul } \\
\text { c. Volatile organic com } \\
\text { d. No projected emissi } \\
\text { c. Totals may differ fro } \\
\text { f. Total assuming Wast } \\
\text { g. Tolal assuming Was }\end{array}$ & $\begin{array}{l}\text { jected crite } \\
\text { y, kqfyr }=1 \\
\text { (VOCs) a } \\
\text { orted. } \\
\text { sum of was } \\
\text { obilization I } \\
\text { obilization }\end{array}$ & $\begin{array}{l}\text { pollutant } \\
\text { grams per } \\
\text { ot designa } \\
\text { creams sin } \\
\text { lity separa } \\
\text { ility direct }\end{array}$ & $\begin{array}{l}\text { ssions are li } \\
\text { as criteria } \\
\text { ome project } \\
\text { ification. }\end{array}$ & $\begin{array}{l}\text { d. } \\
\text { per hour, } \\
\text { lutants; how } \\
\text { tre associate }\end{array}$ & $\begin{array}{l}D=\text { deoor } \\
x, \text { they can } \\
\text { nith more } t\end{array}$ & $\begin{array}{l}\text { ination an } \\
\text { is the for } \\
\text { one waste }\end{array}$ & $\begin{array}{l}\text { comminsic } \\
\text { ion of oes } \\
\text { am. }\end{array}$ & which is & eria $p$ & & & \\
\hline
\end{tabular}


concentrations approaching applicable standards or guidelines. The screening method used was to assess only those toxic air pollutants that were either (a) included in the baseline assessment and emitted by any proposed project or (b) emitted by proposed projects in a cumulative quantity that exceeds the screening level emission rate prescribed by the State of Idaho (IDHW 1994), even if the toxic air pollutant was not assessed in the baseline. The emission rates of toxic air pollutants considered in this assessment are listed by alternative in Table 5.7-3.

A visual comparison of maximum hourly and annual average emission rates for the four alternatives is presented in Figure 5.7-1. As can be seen, these emissions are dominated by nitrogen dioxide emissions, which are primarily attributable to the Waste Immobilization Facility, a high-level waste treatment facility at the Idaho Chemical Processing Plant proposed under Alternatives B (Ten-Year Plan), C (Minimum Treatment, Storage, and Disposal), and D (Maximum Treatment, Storage, and Disposal). The significance of these emissions, including potential means for reduction, is discussed in Sections 5.12, Health and Safety, and Subsection 5.19.4 of Section 5.19, Mitigation.

\subsubsection{Alr Resource Impacts from Alternatives Due to Radiological Sources}

This section describes the effects that the proposed alternatives have on the radiological air quality in the Eastern Snake River Plain. Sources of airborne radionuclide emissions from INEL site facilities associated with the alternative actions are described, emissions are estimated, and their impacts on the prevailing conditions are assessed and described.

\subsubsection{Radiological Impacts. Radiation doses associated with emissions from} environmental restoration and waste management alternatives have been calculated for (a) a worker at the location of highest predicted radioactivity level, (b) the maximally exposed individual (MEI) at an offsite location (see Glossary for definition), and (c) the entire population (adjusted for future growth) within an 80-kilometer (50-mile) radius of each source of emission within the INEL site. These doses, which are presented in Table 5.7-4, represent the maximum amount of radiation dose received as a result of radioactivity released to the air over a one-year period. 
Table 5.7-3. Maximum hourly and annual average emissions of toxic air pollutants at the Idaho National Engineering Laboratory site by alternative.

\begin{tabular}{|c|c|c|c|c|c|}
\hline \multirow[b]{2}{*}{ Todic air pollutant } & \multicolumn{2}{|c|}{ Emincion rate } & \multirow[b]{2}{*}{ Toode air pollutant } & \multicolumn{2}{|c|}{ Emindion nete } \\
\hline & $\begin{array}{l}\text { Orams } \\
\text { per hour }\end{array}$ & $\begin{array}{l}\text { Kilogram } \\
\text { per year }\end{array}$ & & $\begin{array}{l}\text { Orame } \\
\text { per hour }\end{array}$ & $\begin{array}{l}\text { Kilogrime } \\
\text { per year }\end{array}$ \\
\hline \multicolumn{3}{|c|}{ Allemative A (No Action) } & \multicolumn{3}{|c|}{ 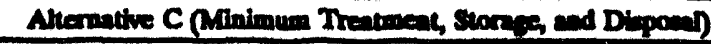 } \\
\hline Ammonia & $1.1 \times 10^{2}$ & $1.6 \times 10^{0}$ & Ammonia & $1.1 \times 10^{2}$ & $1.6 \times 10^{0}$ \\
\hline Asbestos & $1.1 \times 10^{-1}$ & $4.4 \times 10^{-1}$ & Albestos & $1.1 \times 10^{-1}$ & $4.4 \times 10^{-1}$ \\
\hline Benzene & $1.2 \times 10^{1}$ & $7.7 \times 10^{1}$ & Benzene & $1.2 \times 10^{1}$ & $7.7 \times 10^{1}$ \\
\hline Beryllium & $9.8 \times 10^{-3}$ & $3.8 \times 10^{-2}$ & Beryllium & $9.8 \times 10^{-3}$ & $3.8 \times 10^{-2}$ \\
\hline Cadmium compounds & $7.5 \times 10^{-12}$ & $20 \times 10^{-11}$ & Cadmium compounds & $8.1 \times 10^{-5}$ & $7.1 \times 10^{-4}$ \\
\hline Carbon tetrachloride & $6.2 \times 10^{0}$ & $1.1 \times 10^{1}$ & Carbon tetrechloride & $6.2 \times 10^{0}$ & $1.1 \times 10^{1}$ \\
\hline Chlorolorm & $1.3 \times 10^{0}$ & $2.1 \times 10^{0}$ & Chloroform & $1.3 \times 10^{0}$ & $2.1 \times 10^{0}$ \\
\hline Chromilum compounde & $7.0 \times 10^{-2}$ & $6.1 \times 10^{-1}$ & Chromium compounde & $7.0 \times 10^{-2}$ & $6.1 \times 10^{-1}$ \\
\hline Formaldehyde & $1.1 \times 10^{2}$ & $2.3 \times 10^{1}$ & Formaldehyde & $1.1 \times 10^{2}$ & $23 \times 10^{1}$ \\
\hline Hydrochloric acld & $3.6 \times 10^{1}$ & $1.1 \times 10^{2}$ & Hydrochloric acid & $3.6 \times 10^{2}$ & $1.1 \times 10^{2}$ \\
\hline Mercury & $9.3 \times 10^{-1}$ & $3.6 \times 10^{0}$ & Hydrofluoric acid & $1.2 \times 10^{2}$ & $1.2 \times 10^{3}$ \\
\hline Methylene chloride & $1.1 \times 10^{3}$ & $20 \times 10^{3}$ & Mercury & $28 \times 10^{1}$ & $24 \times 10^{2}$ \\
\hline Nickel & $8.0 \times 10^{-1}$ & $7.0 \times 10^{0}$ & Methylene chloride & $1.1 \times 10^{3}$ & $20 \times 10^{3}$ \\
\hline Nitric scid & $1.1 \times 10^{2}$ & $1.9 \times 10^{2}$ & Nickel & $8.0 \times 10^{-1}$ & $7.0 \times 10^{0}$ \\
\hline Polychlorinated biphenyl & $9.0 \times 10^{-9}$ & $1.8 \times 10^{-8}$ & Nitric acid & $1.1 \times 10^{2}$ & $1.9 \times 10^{2}$ \\
\hline Perchloroethylene & $1.4 \times 10^{0}$ & $3.1 \times 10^{0}$ & Polychlorinated biphenyt & $9.0 \times 10^{-9}$ & $1.8 \times 10^{-8}$ \\
\hline Sulfuric acid & $3.4 \times 10^{1}$ & $6.5 \times 10^{1}$ & Perchloroethylene & $1.4 \times 10^{0}$ & $3.1 \times 10^{0}$ \\
\hline \multirow[t]{3}{*}{ Trichloroethylene } & $21 \times 10^{0}$ & $3.6 \times 10^{0}$ & Sulfuric acid & $3.4 \times 10^{1}$ & $6.5 \times 10^{1}$ \\
\hline & & & Tributyl phosphate & $1.1 \times 10^{2}$ & $9.5 \times 10^{2}$ \\
\hline & & & Trichloroethylene & $2.1 \times 10^{0}$ & $3.6 \times 10^{0}$ \\
\hline \multicolumn{3}{|c|}{ Aliemative B (Tea-Year Plan) } & \multicolumn{3}{|c|}{ Alemntive D (Minimum Treatureat, storace, and Dippoen) } \\
\hline Ammonia & $1.1 \times 10^{2}$ & $1.6 \times 10^{0}$ & Ammonia & $1.8 \times 10^{4}$ & $1.6 \times 10^{3}$ \\
\hline Anenic & $8.9 \times 10^{-2}$ & $4.9 \times 10^{-1}$ & Arsenic & $23 \times 10^{-1}$ & $1.3 \times 10^{0}$ \\
\hline Asbestos & $29 \times 10^{-1}$ & $4.4 \times 10^{-1}$ & Albeatoe & $3.2 \times 10^{-1}$ & $4.4 \times 10^{-1}$ \\
\hline Benzene & $4.6 \times 10^{1}$ & $8.5 \times 10^{1}$ & Benzene & $1.1 \times 10^{2}$ & $8.8 \times 10^{1}$ \\
\hline Beryllium & $5.6 \times 10^{-2}$ & $1.8 \times 10^{-1}$ & Beryllium & $6.0 \times 10^{-2}$ & $1.8 \times 10^{-1}$ \\
\hline Cadmium compounds & $25 \times 10^{-1}$ & $1.3 \times 10^{0}$ & Cadmium compounds & $4.5 \times 10^{1}$ & $24 \times 10^{0}$ \\
\hline Carbon tetrachloride & $9.5 \times 10^{0}$ & $1.3 \times 10^{1}$ & Carbon tetrachloride & $1.0 \times 10^{1}$ & $1.3 \times 10^{1}$ \\
\hline Chlorolorm & $1.3 \times 10^{0}$ & $2.1 \times 10^{0}$ & Chlorotorm & $1.3 \times 10^{0}$ & $21 \times 10^{0}$ \\
\hline Chromium compounds & $8.8 \times 10^{-1}$ & $4.7 \times 10^{0}$ & Chromium compounds & $8.8 \times 10^{-1}$ & $4.7 \times 10^{0}$ \\
\hline Formaldehyde & $1.9 \times 10^{2}$ & $8.8 \times 10^{1}$ & Formaldehyde & $3.1 \times 10^{2}$ & $9.4 \times 10^{1}$ \\
\hline Hydrochloric acid & $4.9 \times 10^{3}$ & $1.7 \times 10^{4}$ & Hydrochloric acid & $4.9 \times 10^{3}$ & $1.7 \times 10^{4}$ \\
\hline Hydrofluoric acid & $25 \times 10^{2}$ & $1.2 \times 10^{3}$ & Hydroquoric acid & $1.7 \times 10^{2}$ & $1.3 \times 10^{3}$ \\
\hline Lithium & $8.1 \times 10^{2}$ & $3.7 \times 10^{1}$ & Lithium & $9.3 \times 10^{2}$ & $4.3 \times 10^{1}$ \\
\hline Mercury & $6.6 \times 10^{2}$ & $4.4 \times 10^{2}$ & Mercury & $7.6 \times 10^{2}$ & $4.5 \times 10^{2}$ \\
\hline Methylene chloride & $1.1 \times 10^{3}$ & $20 \times 10^{3}$ & Methyt isoturyl ketone & $27 \times 10^{3}$ & $23 \times 10^{4}$ \\
\hline Nickel & $4.0 \times 10^{0}$ & $1.8 \times 10^{1}$ & Methylene chloride & $1.1 \times 10^{3}$ & $2.2 \times 10^{3}$ \\
\hline Nitric scid & $1.1 \times 10^{2}$ & $1.9 \times 10^{2}$ & Nickel & $4.0 \times 10^{-0}$ & $1.8 \times 10^{1}$ \\
\hline Polychlorinated biphenyl & $3.7 \times 10^{1}$ & $3.0 \times 10^{0}$ & Nitric acid & $1.1 \times 10^{2}$ & $1.9 \times 10^{2}$ \\
\hline Perchloroethylene & $4.7 \times 10^{0}$ & $3.3 \times 10^{0}$ & Polychlorinated biphenyl & $4.3 \times 10^{1}$ & $3.4 \times 10^{0}$ \\
\hline Sulfuric acid & $3.4 \times 10^{1}$ & $6.5 \times 10^{1}$ & Perchloroethylene & $5.2 \times 10^{0}$ & $3.4 \times 10^{0}$ \\
\hline Tributyl phosphate & $1.1 \times 10^{2}$ & $9.5 \times 10^{2}$ & Sulfuric acid & $3.4 \times 10^{1}$ & $6.5 \times 10^{1}$ \\
\hline \multirow[t]{3}{*}{ Trichloroethylene } & $1.4 \times 10^{1}$ & $1.3 \times 10^{1}$ & Tributyl phosphate & $1.2 \times 10^{2}$ & $1.0 \times 10^{3}$ \\
\hline & & & Trichloro-trifluoroethane & $4.2 \times 10^{0}$ & $2.2 \times 10^{0}$ \\
\hline & & & Trichloroethylene & $1.5 \times 10^{1}$ & $1.3 \times 10^{1}$ \\
\hline
\end{tabular}




\section{Annual Criteria Pollutant Emission Rates by Alternative}

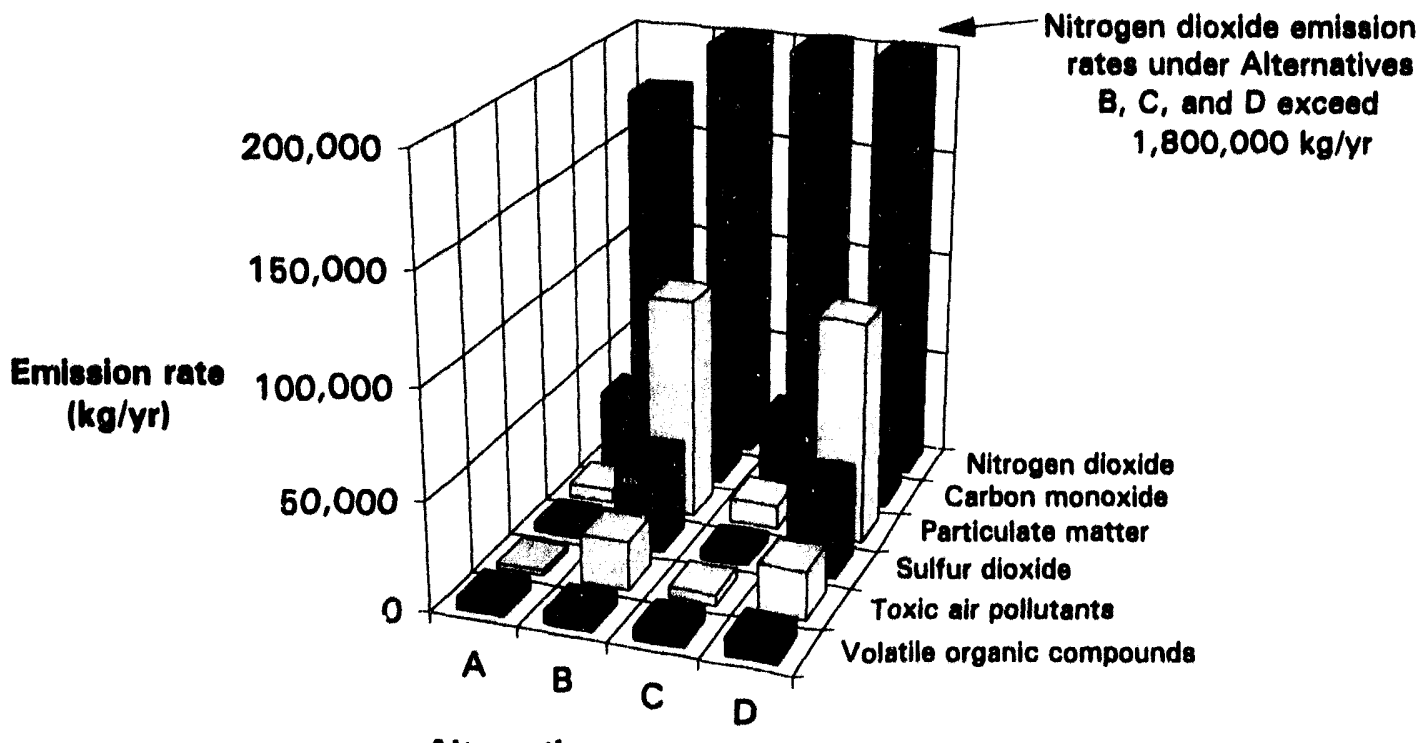

Alternative

\section{Maximum Hourly Criteria Pollutant Emission Rates by Alternative}

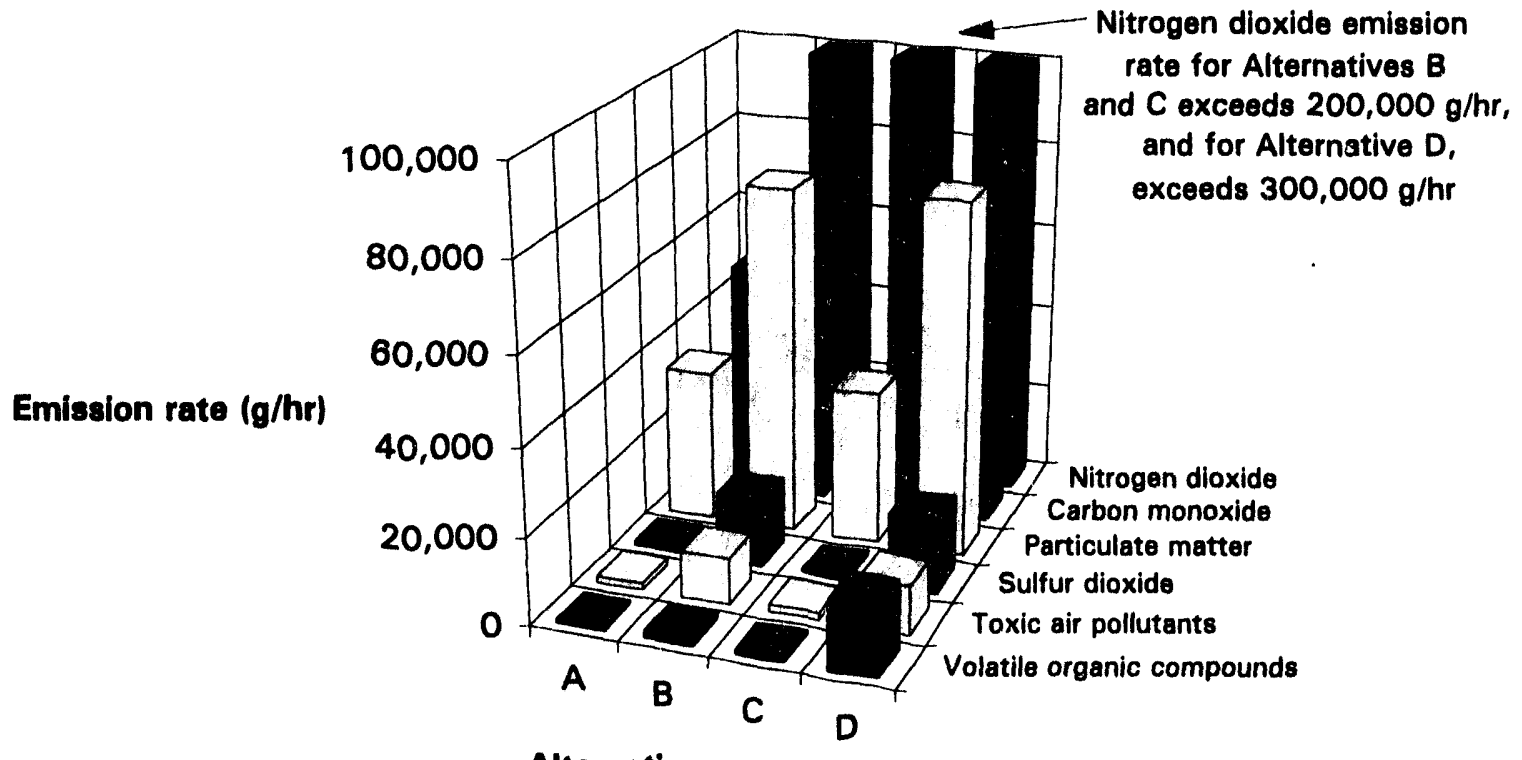

Alternative

Figure 5.7-1. Comparison of criteria pollutant emission rates at the Idaho National Engineering Laboratory site for alternatives. 
Table 5.7-4. Cumulative dose from airborne emissions at the Idaho National Engineering Laboratory site by alternative and source group.

\begin{tabular}{|c|c|c|c|c|c|c|c|c|c|}
\hline \multirow[b]{2}{*}{ Source group } & \multicolumn{3}{|c|}{$\begin{array}{l}\text { Dose to maximally coposed worker } \\
\text { (millirem per year) }\end{array}$} & \multicolumn{3}{|c|}{$\begin{array}{l}\text { Doec to maximally expoed indinitual } \\
\text { (millirem per year) }\end{array}$} & \multicolumn{3}{|c|}{$\begin{array}{l}\text { Collective propheion dose } \\
\text { (pencen-rem per year) }\end{array}$} \\
\hline & Baseline $^{6}$ & lncrement ${ }^{c}$ & Cumulative & Baseline ${ }^{6}$ & Increment ${ }^{c}$ & Cumnetetive & Breline $^{6}$ & lncremeat ${ }^{c}$ & Comalative \\
\hline \multicolumn{10}{|c|}{ Alecrative A (No Action) } \\
\hline Spent nuclear fuel & 0.32 & 0.00033 & $\sqrt{32}$ & 0.05 & 0.0035 & 0.05 & $7 \sqrt[3]{3}$ & 0.1 & $7 \times 10$ \\
\hline Transuranic waste & 0.32 & 0.000042 & 0.32 & 0.05 & 0.00034 & 0.05 & 0.3 & 0.0011 & 0.30 \\
\hline Environmental restoration & 0.32 & 0.014 & 0.33 & 0.05 & 0.088 & 0.14 & 0.3 & 0.3 & 260 \\
\hline Total $^{d}$ & 0.32 & 0.014 & 0.33 & 0.05 & 0.092 & 0.14 & 0.3 & 0.37 & 0.67 \\
\hline \multicolumn{10}{|c|}{ Aleramive B (TE-Year $\mathrm{Fen})$} \\
\hline Spent nuctear fuel & 0.32 & 0.0033 & 0.32 & 0.05 & 0.008 & 6.06 & $2 \sqrt{3}$ & 0.19 & O.4.5 \\
\hline High-level wate & 0.32 & 0.0021 & 0.32 & 0.05 & 0.018 & 0.07 & 0.3 & 0.099 & 0.40 \\
\hline Transuranic waste & 0.32 & 0.33 & 0.55 & 0.05 & 0.42 & 0.47 & 0.3 & 69 & 720 \\
\hline Low-level waste & 0.32 & 0.026 & 0.35 & 0.05 & 0.034 & 0.08 & 0.3 & 0.25 & 0.55 \\
\hline Greater-than-Class-C waste & 0.32 & 0.00019 & 0.32 & 0.05 & 0.00063 & 0.05 & 0.3 & 0.021 & 0.32 \\
\hline Mixed low-level waste & 0.32 & 0.027 & 0.35 & 0.05 & 0.069 & 0.12 & 0.3 & 0.66 & 0.96 \\
\hline Hazardous wante & 0.32 & $24 \times 10^{-8}$ & 0.32 & 0.05 & $5.7 \times 10^{-7}$ & 0.05 & 0.3 & $8.3 \times 10^{-6}$ & 0.30 \\
\hline Emvironmental restoration & 0.32 & 0.014 & 0.33 & 0.05 & 0.088 & 0.14 & 03 & 03 & aco \\
\hline Totsil & 0.32 & 0.25 & 0.57 & 0.05 & 0.60 & 0.65 & 0.3 & 80 & 83 \\
\hline \multicolumn{10}{|c|}{ 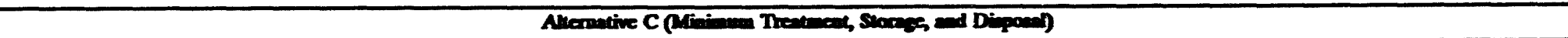 } \\
\hline Spent nuclear fuel & 0.32 & 0.0000 & 0.32 & 0.05 & 0.0039 & 0.05 & 0.3 & 0.0 .83 & 0.38 \\
\hline High-level wate & 0.32 & 0.0021 & 0.32 & 0.05 & 0.018 & 0.01 & 0.3 & 0.099 & 0.40 \\
\hline Transuranic waste & 0.32 & 0.000042 & 0.32 & 0.05 & 0.00034 & 0.05 & 0.3 & 0.0011 & 0.30 \\
\hline Environmental restoration & 0.32 & 0.014 & 0.33 & 0.05 & 0.088 & 0.14 & 0.3 & 0.3 & 0.60 \\
\hline Tocald & 0.32 & 0.014 & 0.33 & 0.05 & 0.21 & 0.16 & 0.3 & 0.4 & 0.70 \\
\hline \multicolumn{10}{|c|}{ 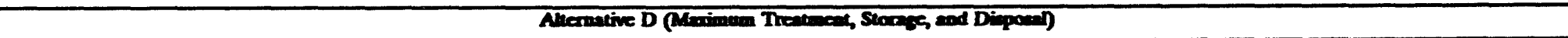 } \\
\hline Spent nuclear fuel & 032 & 0.0042 & 0.32 & 0.05 & 0.048 & 0.10 & $\sqrt{3}$ & 635 & 6.69 \\
\hline High-tevel waste & 0.32 & 0.0021 & 0.32 & 0.05 & 0.018 & 0.07 & 0.3 & 0.099 & 0.40 \\
\hline Transuranic waste & 0.32 & 0.26 & 0.58 & 0.05 & 0.48 & 0.53 & 0.3 & 79 & 82 \\
\hline Low-level waste & 0.32 & 0.11 & 0.43 & 0.05 & 0.14 & 0.19 & 0.3 & 0.58 & 0.88 \\
\hline Greater-than-Class-C waste & 0.32 & 0.00019 & 0.32 & 0.05 & 0.00063 & 0.05 & 0.3 & 0.021 & 0.32 \\
\hline Mired low-level waxte & 0.32 & 0.11 & 0.43 & 0.05 & 0.072 & 0.12 & $\mathbf{0 . 3}$ & 0.59 & 0.89 \\
\hline Hezardous waste & 0.32 & $24 \times 10^{-8}$ & 0.32 & 0.05 & $5.7 \times 10^{-7}$ & 0.05 & 0.3 & $8.3 \times 10^{-6}$ & 0.30 \\
\hline Environmental reatoration & 0.32 & 0.014 & 0.33 & 0.05 & 0.008 & 0.14 & 0.3 & 0.3 & 260 \\
\hline Total & 0.32 & 0.31 & 0.63 & 0.05 & 0.79 & 0.84 & 0.3 & 9.5 & 98 \\
\hline $\begin{array}{l}\text { a. Highest population done } \\
\text { b. Location of maximum on } \\
\text { c. Incremental dose specifie } \\
\text { d. Totals mxy differ from th }\end{array}$ & $\begin{array}{l}\text { years } 2000 \\
\text { dose is Te } \\
\text { eat predicte } \\
\text { arces since }\end{array}$ & $\begin{array}{l}2010 . \\
\text { eactor Area; d } \\
\text { ea (not necese } \\
\text { e projects are }\end{array}$ & the andese lo & os a maxi & Ing and forever & calitien. & & & \\
\hline
\end{tabular}


Projects associated with Alternative A (No Action) projected to have radiological emissions include the spent nuclear fuel dry cask storage project and radioactive waste characterization, retrieval, and cleanup activities at the Radioactive Waste Management Complex (RWMC). The dose- for Alternative A would result from emissions from projects associated with the management of spent nuclear fuel and transuranic waste and from environmental restoration activities. All doses estimated for Alternative $A$ would be a very small fraction of that received from natural background sources and are well below applicable standards.

Projects associated with Alternative B (Ten-Year Plan) projected to have radiological emissions include spent nuclear fuel and high-level waste activities at the Idaho Chemical Processing Plant, transuranic waste processing and mixed and low-level waste treatment (assumed to be located at a new site east of the Radioactive Waste Management Complex), mixed low-level waste incineration at the Waste Experimental Reduction Facility, treatment of nonincinerable mixed waste at the Special Power Excursion Reactor Test area, spent fuel conditioning and mixed low-level and hazardous waste treatment at Argonne National Laboratory-West, and storage of greater-than-Class-C forms of low-level waste at Test Area North. In addition, the projects specified above for Alternative A (No Action) are also included in Alternative B. The doses for Alternative $B$ are due mainly to transuranic waste processing and are somewhat higher than those for Alternative $A$. The dose to the maximally exposed offsite individual is about 0.6 millirem per year ( 6.75 millirem per year when the baseline dose is added), which is still very low with respect to appiicable standards and the natural background dose. The dose to the maximally exposed worker is 0.25 millirem per year ( 0.57 millirem per year including baseline), which is a small fraction of the occupational dose limit of 5,000 millirem per year. (The offsite dose can be higher than the worker dose since workers do not receive any dose by the food ingestion pathway.)

Doses resulting from airborne emissions from projects associated with Alternative C (Minimum Treatment, Storage, and Disposal) are essentially the same as Alternative A (No Action) for the highest worker dose and slightly higher than Alternative A for offsite dose. This small increase is mainly due to the inclusion of the Waste Immobilization Facility with Alternative C.

The type and number of projects assumed for Alternative D (Maximum Treatment, Storage, and Disposal) are similar to Alternative B (Ten-Year Plan). Two important differences, 
however, are (a) the assumption that processing of spent nuclear fuel at the Idaho Chemical Processing Plant will occur in Alternative D but not in Alternative B and (b) increased processing of transuranic and mixed low-level wastes at two proposed incineration facilities: the Idaho Waste Processing Facility and the Private Sector Treatment Facility. These activities increase the maximum offsite individual dose to about 0.79 millirem per year ( 0.84 including baseline). Worker and collective population doses are also somewhat higher than those for Alternative $B$. Nevertheless, these doses are still very low with respect to applicable standards and the natural background dose. The relative magnitude of the doses for the four alternatives is illustrated by the comparisons presented in Figure 5.7-2.

5.7.3.2 Regulatory Compllance Evaluation. In all cases assessed, the dose to the maximally exposed worker is well below radiation dose limits set for protection of workers. The highest worker dose results from Alternative D (Maximum Treatment, Storage, and Disposal) and is estimated at 0.31 millirem per year. When added to the baseline dose (that is, the dose of 0.32 millirem per year from existing and foreseeable emissions, as reported in Section 4.7, Air Resources), the cumulative result of 0.63 millirem per year remains a small fraction of the annual occupational dose limit. This dose is low even with respect to offsite dose limits, which are much more stringent than occupational limits.

The highest dose estimated for the maximally exposed individual is associated with Alternative D (Maximum Treatment, Storage, and Disposal). This dose (0.79 millirem per year), when added to the baseline dose of 0.05 millirem per year, remains well below the dose limit of 10 millirems per year specified in the National Emission Standards for Hazardous Air Pollutants (NESHAP).

The baseline population dose as a result of existing INEL site facilities is about 0.3 person-rem. The maximum dose projected as a result of alternative courses of action is 9.5 person-rem, most of which is due to large-scale incineration of transuranic wastes under Alternative D (Maximum Treatment, Storage, and Disposal). The maximum cumulative population dose of about 10 person-rem, which would be distributed over about 132,000 people," represents a very small fraction of the dose that the population would receive over the same

a. This number represents the current population of about 120,000 increased by 10 percent to account for future growth. 


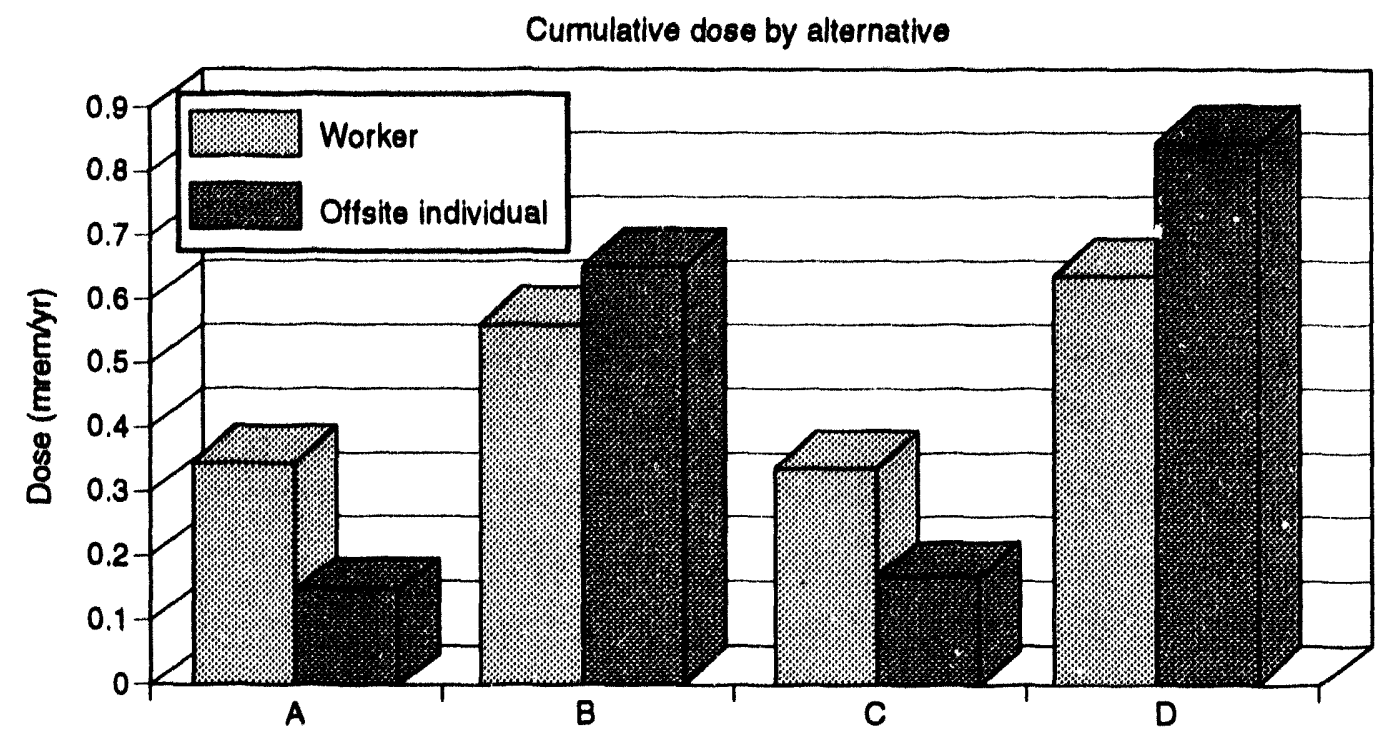

Total population dose by alternative

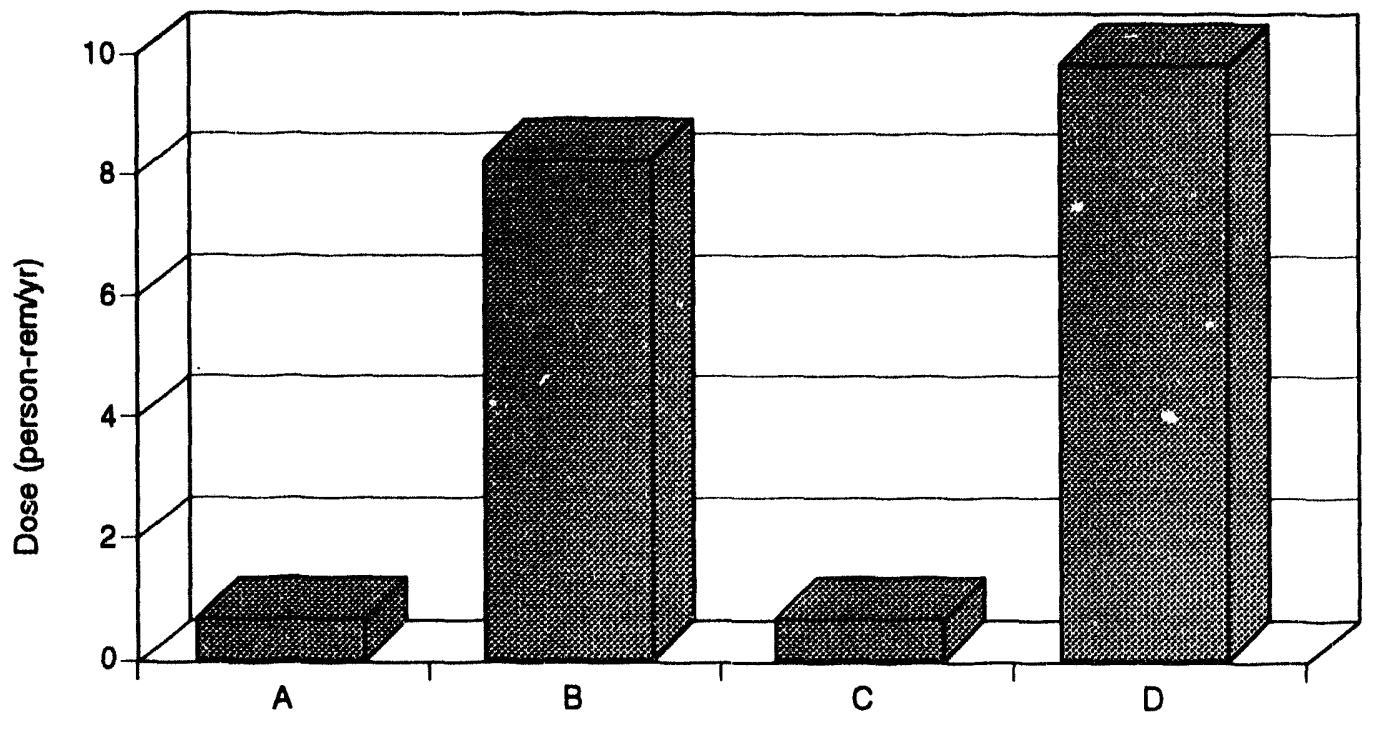

SAB0010

Figure 5.7-2. Cumulative dose for the maximally offsite individual, worker, and total population due to Idaho National Engineering Laboratory site emissions. 
period of time from natural background sources (about 46,000 person-rem). No applicable standards exist for collective population dose; however, DOE policy requires that doses resulting from radioactivity in effluents be reduced to the lowest levels reasonably achievable. The radiological health effects associated with these doses are presented in Section 5.12, Health and Safety.

\subsubsection{Air Resource Impacts from Alternatlves Due to Nonradiological Sources}

This section presents results of the air quality assessments for sources of nonradiological air pollutants. Results are presented with the goal of facilitating comparisons of relative impacts between alternatives. The importance of the results as they apply to specific alternatives and the regulatory compliance aspects of predicted consequences are also discussed.

For both criteria and toxic air pollutants, consequences are notably similar for Alternative B (Ten-Year Plan) and Alternative D (Maximum Treatment, Storage, and Disposal), despite the large differences in the alternatives in terns of spent nuclear fuel and other wastes to be managed. For some of the candidate alternatives and waste management options, the amount of emissions (hourly or annual average) is not always highly dependent on the volume of waste to be managed. Increases in projected facility operating life, for example, may offset increases in hourly or annual average emission rates. Also, impacts are sometimes dominated by emissions from a single facility, which may be included in more than one alternative. With the exception of nitrogen dioxide emissions from high-level waste processing, the dominant sources of nonradiological emissions and impacts are associated with management of transuranic and mixed low-level waste streams.

\subsubsection{Concentrations of Pollutants in Ambient Air at Offsite Locations. Maximum} concentrations of criteria pollutants in ambient air (that is, at locations of public access) are presented in Table 5.7-5. Rusults are presented for the maximum levels predicted to occur at INEL site boundary locations, along public roads, and at Craters of the Moon Wilderness Area. In all cases, these results are well within the primary National Ambient Air Quality Standards. At INEL site boundary locations, the cumulative impacts (that is, the predicted concentrations from sources related to the respective alternatives added to the maximum baseline) differ little between alternatives. This is not due so much to the fact that emissions from the alternatives are similar, 
Tajle 5.7-5. Maximum concentrations of criteria pollutants at public access locations at the Idaho National Engineering Laboratory site by alternative.

\begin{tabular}{|c|c|c|c|c|c|c|c|c|c|c|c|}
\hline \multirow[b]{2}{*}{ Pollutant } & \multirow[b]{2}{*}{$\begin{array}{l}\text { Averaging } \\
\text { time }\end{array}$} & \multicolumn{3}{|c|}{$\begin{array}{l}\text { Maximum baseline concentration } \\
\text { (micrograms per cubic meter) }\end{array}$} & \multicolumn{3}{|c|}{$\begin{array}{l}\text { Baseline plus alternative } \\
\text { (micrograms per cubic meter) }\end{array}$} & \multirow{2}{*}{$\begin{array}{l}\text { Applicable } \\
\text { standard } \\
\text { (micrograms/ } \\
\text { cubic meter) }\end{array}$} & \multicolumn{3}{|c|}{ Percent of standard } \\
\hline & & $\begin{array}{c}\text { Site } \\
\text { boundary }\end{array}$ & Public rouds & $\begin{array}{l}\text { Craters of } \\
\text { the Moon }\end{array}$ & $\begin{array}{c}\text { Site } \\
\text { boundary }\end{array}$ & Public roads & $\begin{array}{l}\text { Craters of } \\
\text { the Moon }\end{array}$ & & $\begin{array}{c}\text { Sire } \\
\text { boundary }\end{array}$ & Public ronds & $\begin{array}{l}\text { Craters of } \\
\text { the Moon }\end{array}$ \\
\hline \multicolumn{12}{|c|}{ Arernative A (No Action) } \\
\hline \multirow[t]{2}{*}{ Carbon monoxide } & 1-hour & 600 & 1,200 & 170 & 649 & 1,253 & 180 & 40,000 & 1.6 & 3.1 & 0.5 \\
\hline & 8-hour & 180 & 340 & 35 & 197 & 357 & 37 & 10,000 & 2 & 3.6 & 0.4 \\
\hline \multirow[t]{3}{*}{ Sulfur diaxide } & 3-hour & 240 & 520 & 88 & 242 & 522 & 88 & 1,300 & 19 & 40 & 6.8 \\
\hline & 24-hour & 100 & 230 & 39 & 100 & 230 & 39 & 365 & 28 & 63 & 11 \\
\hline & Annual & 2 & 4 & 1 & 2 & 4 & 1 & 80 & 25 & 5 & 1.3 \\
\hline \multirow{2}{*}{ Particulate matter } & 24-hour & so & 80 & 10 & so & 80 & 10 & 150 & 33 & 53 & 6.7 \\
\hline & Annual & 2 & 5 & 1 & 2 & 5 & 1 & so & 4 & 10 & 2 \\
\hline Nitrogen dioxide & Annual & 5 & 9 & 1 & 6 & 10 & 1.1 & 100 & 6 & 10 & 1.1 \\
\hline \multirow[t]{2}{*}{ Lead } & Quanerty & 0.0008 & 0.002 & 0.0002 & 0 & $\mathbf{0}$ & 0.0002 & 1.5 & 0.1 & 0.1 & 0.01 \\
\hline & \multicolumn{11}{|c|}{ Alecrantive B (Ten-Year Plan) } \\
\hline \multirow[t]{2}{*}{ Carbon monoxide } & 1-hour & 600 & 1,200 & 170 & 710 & 1,382 & 192 & 40,000 & 1.8 & 3.5 & 0.5 \\
\hline & 8-hour & 180 & 340 & 35 & 208 & 374 & 40 & 10,000 & 2.1 & 3.7 & 0.4 \\
\hline \multirow[t]{3}{*}{ Sulfur dioxide } & 3-hour & 240 & 520 & 88 & 334 & 619 & 95 & 1,300 & 26 & 48 & 7.3 \\
\hline & 2a-hour & 100 & 230 & 39 & 114 & 257 & 40 & 365 & 31 & 70 & 11 \\
\hline & Annual & 2 & 4 & 1 & 2.3 & 4.7 & 1 & 80 & 29 & 5.9 & 1.3 \\
\hline \multirow[t]{2}{*}{ Particulate matter } & 24-hour & 50 & 80 & 10 & $\$ 3$ & 86 & 10 & 150 & 35 & 57 & 6.9 \\
\hline & Annual & 2 & $\mathbf{s}$ & 1 & 2 & 5.1 & 1 & so & 4 & 10 & 2 \\
\hline Nitrogen dioxide & Annual & 5 & 9 & 1 & 8 & 14 & 1.3 & 100 & 8 & 14 & 1.3 \\
\hline \multirow[t]{2}{*}{ Lead } & Quarterty & 0.0008 & 0.002 & 0.0002 & 0.003 & 0.006 & 0.0004 & 1.5 & 0.2 & 0.4 & 0.02 \\
\hline & & & Aher & antive $\mathbf{C M}$ & mem Treat & eat, Sharces a & Diponen & & & & \\
\hline \multirow[t]{2}{*}{ Carton monaxide } & 1-hour & 600 & 1.200 & 170 & 649 & 1,253 & 180 & 40,000 & 1.6 & 3.1 & 0.5 \\
\hline & 8-hour & 180 & 340 & 35 & 197 & 357 & 37 & 10,000 & 2 & 3.6 & 0.4 \\
\hline \multirow[t]{3}{*}{ Sulfur dionide } & 3-hour & 240 & 520 & 88 & 242 & 522 & 88 & 1,300 & 19 & 40 & 6.8 \\
\hline & 24-hour & 100 & 230 & 39 & 100 & 230 & 39 & 365 & 28 & 63 & 11 \\
\hline & Annual & 2 & 4 & 1 & 2 & 4 & 1 & 80 & 25 & 5 & 1.3 \\
\hline \multirow[t]{2}{*}{ Particulate matter } & 2A-hour & so & 80 & 10 & so & 80 & 10 & 150 & 33 & 53 & 6.7 \\
\hline & Annual & 2 & 5 & 1 & 2 & 5 & 1 & so & 4 & 10 & 2 \\
\hline Nitrogen dioxide & Annual & 5 & 9 & 1 & 8 & 14 & 1.3 & 100 & 8 & 14 & 1.3 \\
\hline \multirow[t]{2}{*}{ Lead } & Quarterty & 0.0008 & 0.002 & 0.0002 & 0.001 & 0.002 & 0.0002 & 1.5 & 0.1 & 0.1 & 0.01 \\
\hline & & & Aner & ative D M & mum Tropt & ent, Sharcis : & (Dipoen) & & & & \\
\hline \multirow[t]{2}{*}{ Carton monowide } & 1-hour & 600 & 1,200 & 170 & 736 & 1,413 & 200 & 40,000 & 18 & 3.5 & 0.5 \\
\hline & 8-hour & 180 & 340 & 35 & 215 & 300 & 41 & 10,000 & 22 & 38 & 0.4 \\
\hline \multirow[t]{3}{*}{ Sulfur dioxide } & 3-hour & 240 & 520 & 88 & 334 & 619 & 95 & 1,300 & 26 & 48 & 7.3 \\
\hline & 2A-hour & 100 & 230 & 39 & 114 & 257 & 40 & 365 & 31 & 70 & 11 \\
\hline & Anaual & 2 & 4 & 1 & 2.3 & 4.7 & 1 & 80 & 29 & 5.9 & 1.3 \\
\hline Particulate matter & 24-hour & so & 80 & 10 & 54 & 88 & 10 & 150 & 36 & 59 & 6.9 \\
\hline & Anaual & 2 & 5 & 1 & 2 & 5.1 & 1 & 50 & 4 & 10.1 & 2 \\
\hline Nitrogen dioxide & Annual & 5 & 9 & 1 & 8 & 15 & 1.4 & 100 & 8 & 15 & 1.4 \\
\hline Lead & Quarienty & 0.0008 & 0.002 & 0.0002 & 0.004 & 0.007 & 0.0004 & 1.5 & 0.3 & 0.5 & 0.03 \\
\hline
\end{tabular}


but rather that in all cases the incremental impacts are small with respect to the maximum baseline. This condition is illustrated by the INEL site boundary impacts presented in Figure 5.7-3. It should be noted that the scale of these graphs does not extend to 100 percent (which facilitates comparison) and the sum of the maximum baseline plus alternative impacts is much less than 100 percent of the applicable standards in all cases.

Concentrations at public road locations within the INEL site boundary could increase significantly from the baseline, especially if a major combustion or fugitive source is located relatively close to a public road. Increases in baseline concentrations at Craters of the Moon are very minor in all cases, although potential impacts on visibility in this area need further assessment (see Section 5.7.4.3.3).

The concentration results reflect the cumulative impact of alternative sources; that is, the conditions associated with the maximum baseline and the effects of foreseeable increases to the baseline have been taken into account. Since maximum baseline concentrations are much greater than baseline conditions that actually exist, these results are conservative and likely overstate the consequences that would actually result by a substantial margin. Background concentrations have not been added because (a) reliable data on background levels in the INEL environs are not available for most pollutants and (b) background levels are low and are more than offset by the use of the maximum (as opposed to actual) baseline. Some pollutants have been monitored onsite, but those results reflect INEL site facility contributions and are not indicative of actual background. (INEL site facility contributions are accounted for in the current assessment by application of dispersion modeling.) Concentrations of particulate matter have been monitored by the State of Idaho at Craters of the Moon (IDHW 1991). The maximum 24-hour result for total suspended particulates was 48 micrograms per cubic meter. Even if this concentration is taken into account, the predicted consequences would remain well below the standard.

Results of assessments for toxic air pollutants at offsite locations are presented separately for carcinogenic (that is, capable of inducing cancer) and noncarcinogenic toxic air pollutants in Tables 5.7-6 and 5.7-7, respectively. As described in Section 4.7.4.2.2, Offsite Conditions, standards have been recently promulgated by the State of Idaho for the control of toxic pollutants in ambient air. It is notable, however, that the standards apply only to new sources and would not normally require the evaluation of cumulative impacts (incremental plus baseline). Nevertheless, 

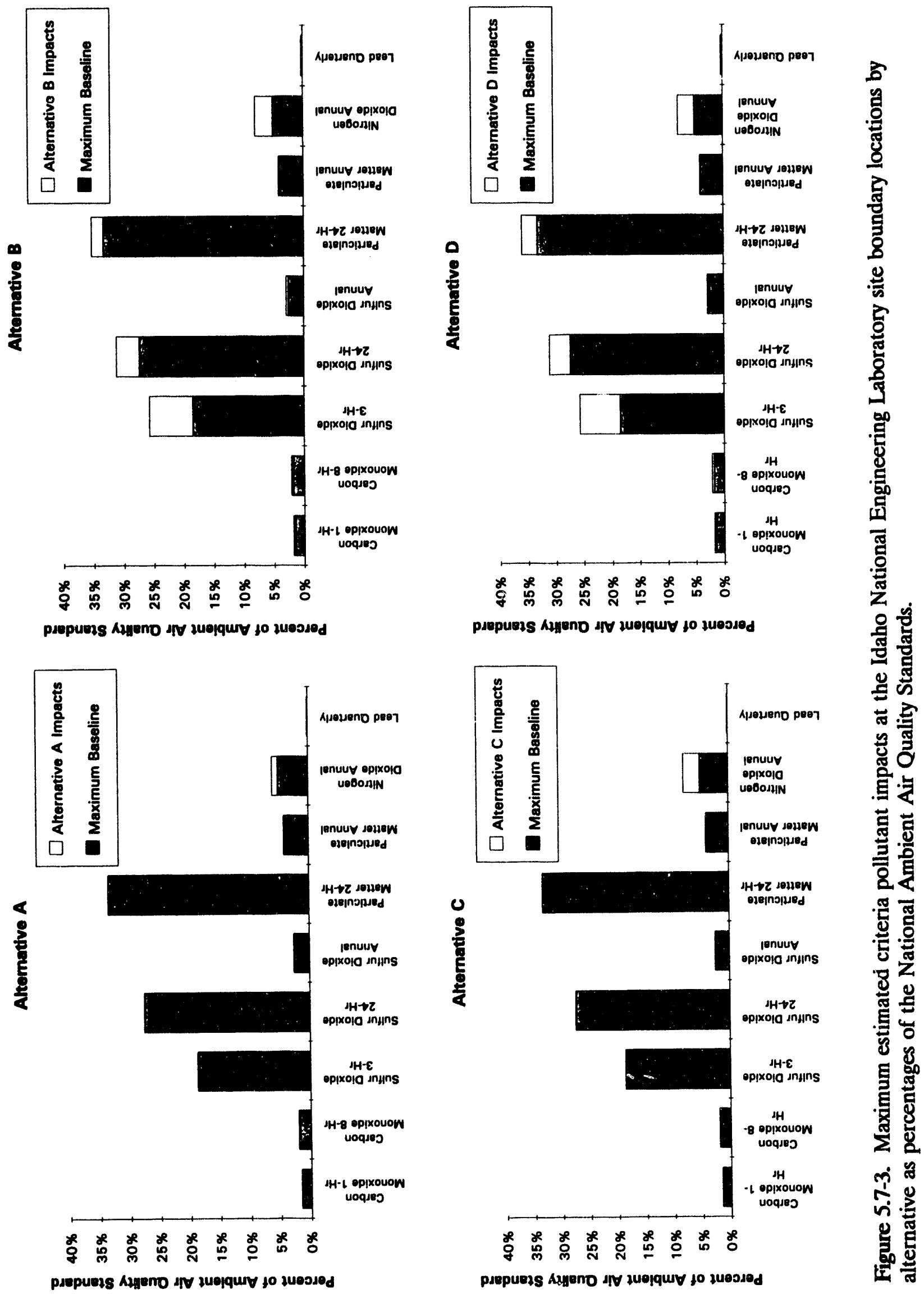

pappuess hmono it zuejquY to juosded 
Table 5.7-6. Highest predicted concentrations of carcinogenic toxic air pollutants at Idaho National Engineering Laboratory site boundary locations, including cumulative impacts of alternatives and the maximum baseline case.

\begin{tabular}{|c|c|c|c|c|c|c|c|c|c|c|}
\hline \multirow[b]{2}{*}{ Tocic air pollutant } & \multirow[b]{2}{*}{ Baseline $^{b}$} & \multicolumn{4}{|c|}{$\begin{array}{l}\text { Annual average concentration } \\
\text { (micrograms per cubic meter) }\end{array}$} & \multirow{2}{*}{$\frac{\text { Standand }}{\left(\mu g / m^{3}\right)}$} & \multicolumn{4}{|c|}{$\begin{array}{l}\text { Cumulative impact of alternatives as a } \\
\text { percent of standard }\end{array}$} \\
\hline & & $\mathbf{A}$ & B & C & D & & $\mathbf{A}$ & $\mathbf{B}$ & C & D \\
\hline Arsenic & $9.0 \times 10^{-5}$ & $0.0 \times 10^{0}$ & $2.3 \times 10^{-6}$ & $23 \times 10^{-6}$ & $3.8 \times 10^{-6}$ & 0.00023 & 39 & 40 & 40 & 41 \\
\hline Asbestos & (d) & $2.7 \times 10^{-6}$ & $2.8 \times 10^{-6}$ & $2.7 \times 10^{-6}$ & $28 \times 10^{-6}$ & 6.0 & $<0.01$ & $<0.01$ & $<0.01$ & $<0.01$ \\
\hline Benzene & $2.9 \times 10^{-2}$ & $5.7 \times 10^{-4}$ & $6.3 \times 10^{-4}$ & $5.7 \times 10^{-4}$ & $6.3 \times 10^{-4}$ & 0.12 & 25 & 25 & 25 & 25 \\
\hline Beryllium & (d) & $23 \times 10^{-7}$ & $5.0 \times 10^{-7}$ & $2.3 \times 10^{-7}$ & $5.3 \times 10^{-7}$ & 2.0 & $<0.01$ & $<0.01$ & $<0.01$ & $<0.01$ \\
\hline Cadmium compound & $1.0 \times 10^{-8}$ & $0.0 \times 10^{0}$ & $4.6 \times 10^{-6}$ & $1.0 \times 10^{-8}$ & $1.1 \times 10^{-5}$ & 20 & $<0.01$ & $<0.01$ & $<0.01$ & $<0.01$ \\
\hline Carbon tetrachloride & $4.8 \times 10^{-3}$ & $7.4 \times 10^{-5}$ & $8.3 \times 10^{-5}$ & $7.4 \times 10^{-5}$ & $8.5 \times 10^{-5}$ & 0.067 & 7 & 7 & 7 & 7 \\
\hline Chloroform & $3.2 \times 10^{-4}$ & $1.4 \times 10^{-5}$ & $1.4 \times 10^{-5}$ & $1.4 \times 10^{-5}$ & $1.4 \times 10^{-5}$ & 0.043 & 0.8 & 0.8 & 0.8 & 0.8 \\
\hline Formaldehyde & $1.2 \times 10^{-2}$ & $1.4 \times 10^{-4}$ & $7.8 \times 10^{-4}$ & $1.4 \times 10^{-4}$ & $8.4 \times 10^{-4}$ & 0.077 & 16 & 17 & 16 & 17 \\
\hline Hexavalent chromium & $6.0 \times 10^{-5}$ & $2.3 \times 10^{-7}$ & $4.9 \times 10^{-7}$ & $2.3 \times 10^{-7}$ & $1.0 \times 10^{-6}$ & 0.000083 & 73 & 73 & 73 & 74 \\
\hline Methylene chloride & $6.0 \times 10^{-3}$ & $1.6 \times 10^{-2}$ & $1.6 \times 10^{-2}$ & $1.6 \times 10^{-2}$ & $1.6 \times 10^{-2}$ & 0.24 & 9 & 9 & 9 & 9 \\
\hline Nickel & $2.7 \times 10^{-3}$ & $7.5 \times 10^{-5}$ & $1.3 \times 10^{-4}$ & $7.5 \times 10^{-5}$ & $1.3 \times 10^{-4}$ & 0.0042 & 66 & 68 & 66 & 68 \\
\hline Penchloroethylene & $8.9 \times 10^{-2}$ & $2.3 \times 10^{-5}$ & $2.4 \times 10^{-5}$ & $2.3 \times 10^{-5}$ & $24 \times 10^{-5}$ & 21 & 4 & 4 & 4 & 4 \\
\hline Polychlorinated biphenyls & (d) & $0.0 \times 10^{0}$ & $1.8 \times 10^{-5}$ & $0.0 \times 10^{0}$ & $2.2 \times 10^{-5}$ & None & $\mathbf{0}$ & $\mathbf{0}$ & $\mathbf{0}$ & $\mathbf{0}$ \\
\hline Trichloroethylene & $7.8 \times 10^{-4}$ & $2.5 \times 10^{-5}$ & $4.0 \times 10^{-5}$ & $2.5 \times 10^{-5}$ & $0.0 \times 10^{0}$ & 0.077 & 1.0 & 1.1 & 1.0 & 1.1 \\
\hline
\end{tabular}

a. $A=$ Alternative A (No Action); B = Alemative B (Ten-Year Plan); C = Alternative C (Minimum Treatment, Storage, and Dixposal); D = Alternative D (Maximum Treatment, Storage, and Dispoeal).

b. Includes foreaceable increases to the baseline.

c. Acceptabie sir concentrations for carcinogens (AACC) listed in Rules for the Control of Air Pollution in Idaho.

d. Tocic air pollutant was not asesed in beseline because emission rates from existing facilities are below screening level criteria. 
Table 5.7-7. Highest predicted eight-hour concentrations of noncarcinogenic toxic air pollutants at the Idaho National Engineering Laboratory site boundary and public roads, including cumulative impacts of alternatives and the maximum baseline case.

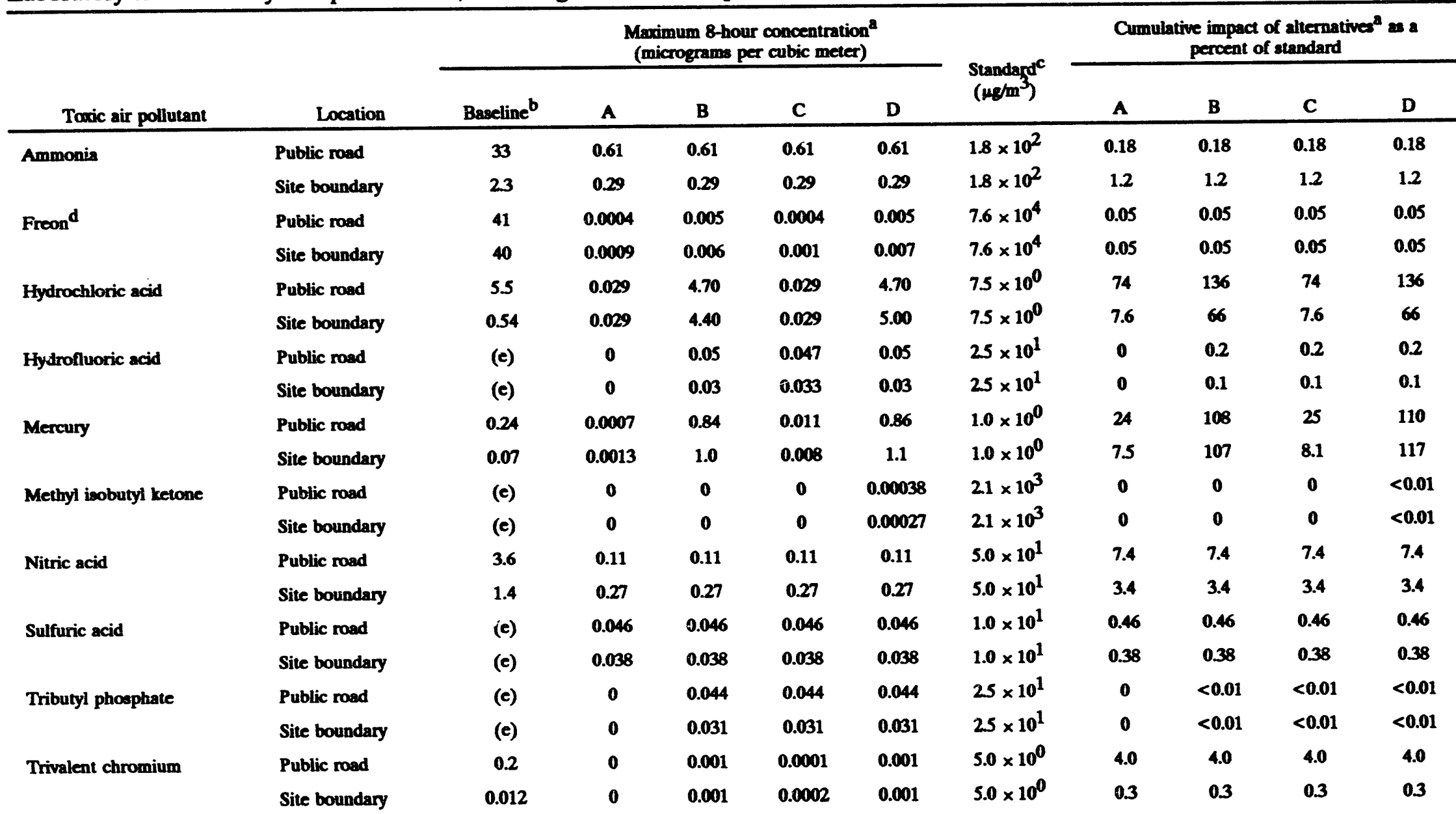

a. $A=$ Alternative A (No Action); B $=$ Alternative B (Ten-Year Plan); C = Alernative C (Minimum Treatment, Storage, and Dispoeal); D = Alternative D (Maximum Treatment, Storage, and Disposal).

b. Includes forescesble incieases to baseline.

c Acceptable air concentrations (AACs) listed in Rules for the Control of Air Pollution in Idaho.

d. Assessed as 1,1,2-trichloro, 1,2,2-trifluoroethane.

d. Asscaced as 1,1,2 ic 
cumulative impacts are presented and compared to these standards (referred to below as reference levels) for the sake of completeness and perspective.

In two cases, the cumulative impacts of emissions from alternative sources exceed the reference levels by a small amount: mercury levels at the INEL site boundary and road locations and hydrochloric acid levels at a public road location. The mercury levels are due almost entirely to the maximum projected emissions from incineration of mixed low-level and transuranic wastes at either the Idaho Waste Processing Facility or the Private Sector Treatment Facility. These projects are proposed under Alternatives B (Ten-Year Plan) and D (Maximum Treatment, Storage, and Disposal) as competing projects to treat existing wastes stored at the Radioactive Waste Management Complex, some of which contain high levels of mercury. Administrative controls (such as limits on waste stream feed rates) and/or engineered controls (such as mercury vapor recovery systems) would be used to reduce emissions to achieve levels that are below the standard.

Hydrochloric acid levels are attributable primarily to maximum projected emissions from mixed and low-level waste incineration at the Waste Experimental Reduction Facility, which is proposed under Alternatives B (Ten-Year Plan) and D (Maximum Treatment, Storage, and Disposal). These levels are below the reference level at the INEL site boundary, but the maximum level along public roads would exceed the reference level by about one-third. Administrative controls (such as limits on total chloride content of waste materials) would be used to reduce emissions to achieve levels that are below the standard. Verification would be provided on a continuous basis by a hydrochloric acid monitoring system installed in the effluent system.

Concentrations of carcinogenic air pollutants at INEL site boundary locations are well below the reference levels in all cases.

5.7.4.2 Concentrations of Pollutants at Onsite Locations. Onsite concentrations of toxic air pollutants are presented in Table 5.7-8. These levels reflect maximum predicted levels averaged over an eight-hour period to which workers might be exposed. These results are compared to occupational standards recommended by either the American Conference of Governmental Industrial Hygienists or the Occupational Safety and Health Administration, whichever is lower. The incremental impacts at onsite locations of toxic air pollutant emissions 
Table 5.7-8. Highest predicted concentrations of toxic air pollutants on the Idaho National Engineering Laboratory site from total emissions by alternative.

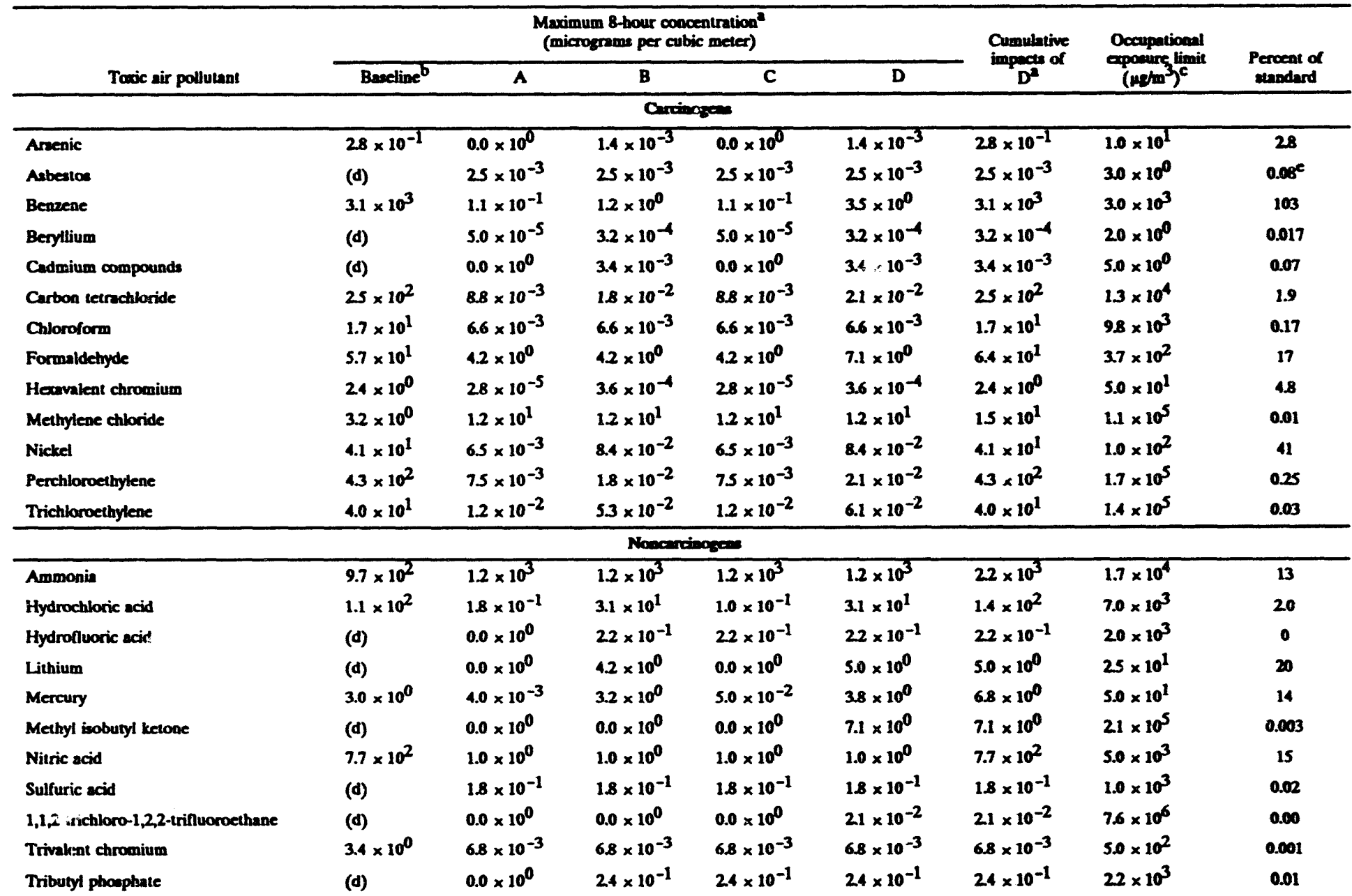

2. A = Alernative A(No Action); B = Nternative B (Ten-Year Plan); C = Ntermative C (Minimum Treatment, Storage, and Diapoeal); D = Ntermative D (Merimum Treatment, Storage, and Diapoeal)

b. Bascline includes foresesble increaser. Safety and Health Administration (OSHA); the lower of the two is ueed.

d. Bemeline was not meeved for this toric air pollutunt.

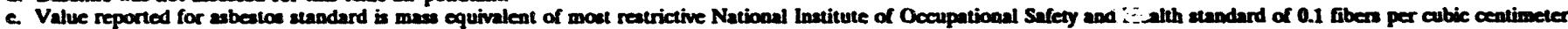


are well below occupational exposure limits in all cases. When the cumulative effect of maximum baseline levels is considered, the highest predicted level of benzene (near gasoline storage tanks at the Central Facilities Area) is slightly above the occupational exposure limit. However, this condition is due almost entirely to maximum baseline emissions.

5.7.4.3 Regulatory Compllance Evaluatinn. The Clean Air Act and the State of Idaho have established ambient air quality standards for designated criteria air pollutants. Proposed major projects or modifications must demonstrate that project emissions would not cause an established ambient air quality standard to be exceeded. While cumulative annual emission rates associated with most pollutants do not exceed the threshold level to be designated as major according to the State of Idaho Rules for the Control of Air Pollution in Idaho (IDHW 1994), the in:pact of each criteria pollutant has been assessed.

In addition to the comparison of ambient air standards presented in Section 5.7.4.1, evaluations have been performed for (a) potential for ozone formation, (b) Prevention of Significant Deterioration increment consumption, (c) degradation of visibility at Craters of the Moon Wilderness Area, (d) impacts to soil and vegetation and impacts due to secondary growth, (e) stratospheric ozone depletion, (f) acidic deposition, and (g) global warming. The results of these analyses are summarized below.

5.7.4.3.1 Ozone Formation-In addition to the above-mentioned criteria pollutants, the Clean Air Act designates ozone as a criteria air pollutant and establishes a National Ambient Air Quality Standard (NAAQS) of 235 micrograms per cubic meter for a onehour averaging period. Ozone, unlike the other criteria pollutants, is not emitted directly from facility sources but is formed in the atmosphere through photochemical reactions involving nitrogen oxides and volatile organic compounds, referrec 'o as nonmethane hydrocarbons. Therefore, the regulation of ozone is effected by the control of emissions of ozone-producing compounds or precursors, that is, nitrogen oxides and volatile organic compounds. The Idaho Division of Environmental Quality has determined that ozone levels within the State are well below the standard. The State, therefore, does not require evaluation of projected increases in ambient ozone concentrations under application procedures for major stationary sources, unless a new or modified major facility will result in a net increase in volatile organic compounds of 100 tons per year or greater (IDHW 1994). Part of the reason for the lack of required analysis at 
lesser emittant levels is because no simple, well-defined mithods exist to evaluate ozone generation potential (Wilson 1993).

Emissions of volatile organic compounds have been estimated to establish the need to perform detailed ozone generation modeling. The maximum cumulative emission rates for the environmental restoration and waste management alternatives range from 6 tons per year [for Alternative A (No Action)] to 10 tons per year [Alternative D (Maximum Treatment, Storage, and Disposal)]. The maximum value is well below the threshold emission level of 100 tons per year for which analyses are required by the State and the 40-ton-per-year threshold for designation as a major source. Therefore, ozone precursor emissions of volatile organic compounds are expected to be a negligible contribution to ozone generation and no further analyses have been conducted.

\subsection{Prevention of Significant Deterioration Increment}

Consumption-Prevention of Significant Deterioration regulations require that proposed major projects or modifications be assessed for their incremental contribution to increases of ambient pollutant levels. A proposed major project, together with the sum of other major projects in the same impact area, may not contribute to an increase in attainment pollutants above an allowable increment. Increments have been established for specific averaging times associated with nitrogen dioxide, sulfur dioxide, and particulate matter.

The INEL site is in a Class II area as designated by Prevention of Significant Deterioration regulations. Previous Prevention of Significant Deterioration permits for INEL site projects have consumed a portion of the available Class II increment. Proposed project emissions associated with each alternative would contribute to further increment consumption. The maximum increment consumption for environmental restoration and waste management alternatives has been assessed and found to not exceed 41 percent of the allowable increment for 24-hour sulfur dioxide concentrations, and lesser amounts for all other averaging times and pollutants. Craters of the Moon Wilderness Area, approximately 20 kilometers (12 miles) southwest of the INEL site, is the only nearty Class I area. No previous projects have consumed any increment at this location. Alternatives B (Ten-Year Plan) or D (Maximum Treatment, Storage, and Disposal) could consume as much as 28 percent of the 24-hour, and 20 percent of the three-hour sulfur dioxide increments. All others are less than 20 percent of the allowable 
increment. Increment consumption is significantly less for project emissions associated with Alternatives A (No Action) and C (Minimum Treatment, Storage, and Disposal).

\subsection{Visibllity Degradation-Conservative visibility screening analysis} indicates that a potential exists for visual impacts at the Craters of the Moon Wilderness Area. While contrast evaluations show no potential for objectional impact, the criterion for acceptable color shift is exceeded for each alternative as proposed. This excess shift (delta $\mathrm{E}$ ) is due mainly to nitrogen dioxide emissions. The Waste Immobilization Facility at the Idaho Chemical Processing Plant and an incineration project at the Radioactive Waste Management Complex each exceed the criterion alone. In combination with other projects, the Idaho Waste Processing Facility (which has not been sited but was modeled at the reference location approximately one to two miles west of the Radioactive Waste Management Complex) and a boiler at the Waste Characterization Facility at the Radioactive Waste Management Complex contribute significantly to the total. The potential for visibility degradation would be lessened by use of combustion control equipment to reduce nitrogen dioxide emissions or by relocation of projects to areas more distant from Craters of the Moon. Also, the use of more refined visibility models such as PLUVUE-2 (in place of the more conservative screening methods) could result in lower predicted impacts. Emission controls would be required if more refined modeling still predicts visibility impacts and may, in fact, be required by other regulations, even if visibility degradation criteria are not exceeded.

Further screening analyses have been performed to evaluate the level of nitrogen oxide emissions reduction required for the cumulative impacts of each alternative to pass the screening criterion for color shift. Analyses were performed both with a minimum (70 percent on each of the aforementioned projects) and maximum (70 percent on the boiler and 90 percent on all others) level of control. Under this screening analysis, the maximum level of control would be required for cumulative emissions to result in an acceptable level of visibility degradation at Craters of the Moon National Area under Alternatives B (Ten-Year Plan), C (Minimum Treatment, Storage, and Disposal), and D (Maximum Treatment, Storage, and Disposal). Only Alternative A (No Action) achieves an acceptable level of visibility degradation under the minimum control scenario. For comparison, the screening results for the uncontrolled, minimum, and maximum control cases are depicted in Figure 5.7-4. 
Summary of visual degradation modeling results by alternative

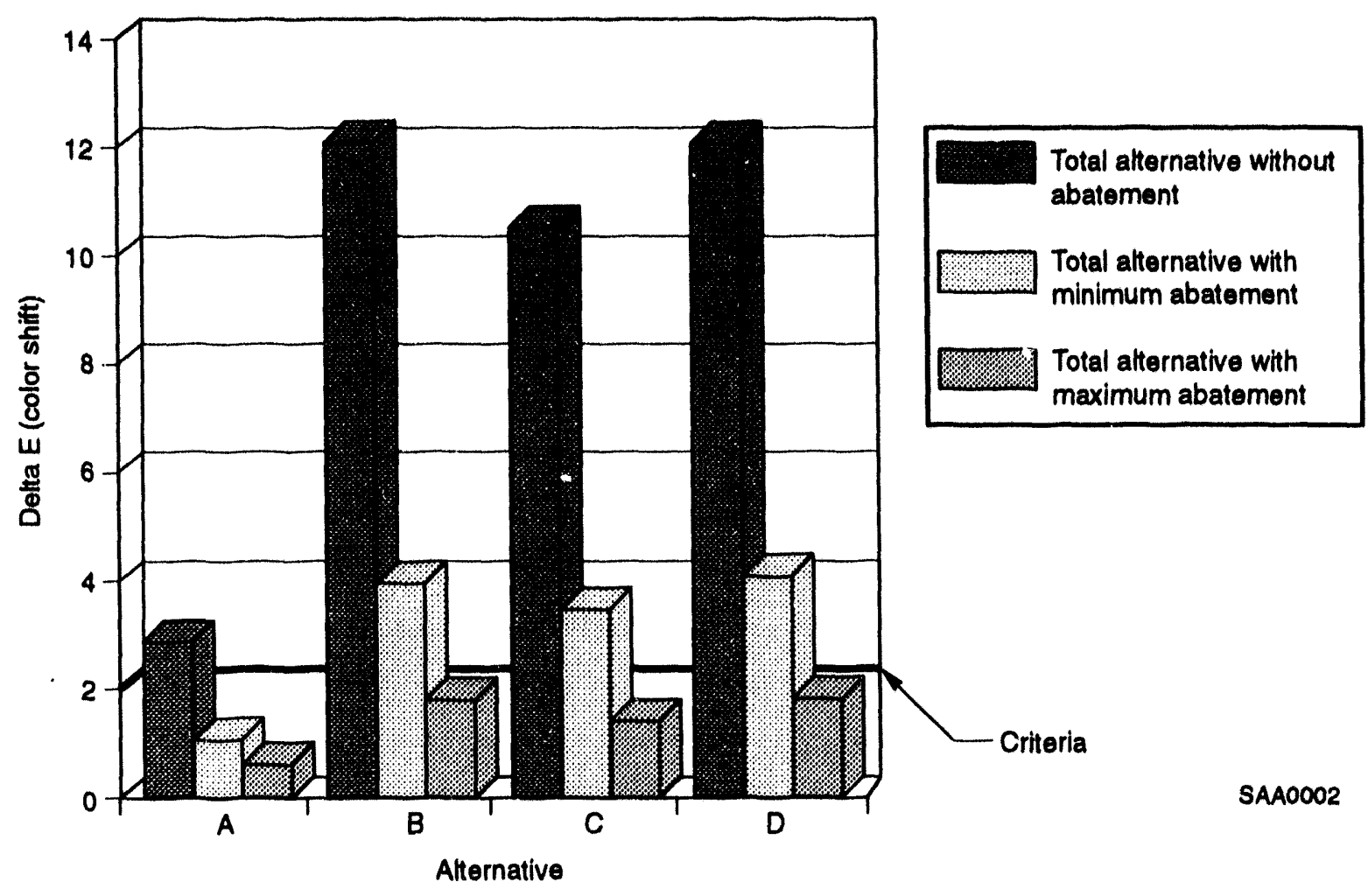

Figure 5.7-4. Summary of modeling results for visual degradation at the Idaho National Engineering Laboratory site by alternative.

\subsection{Impacts to Solls and Vegetation and Impacts Due to Secondary}

Growth-Due to the projected minor increase in ambient criteria pollutant concentrations, no impacts to local soils or vegetation, including the local sagebrush vegetation community, grazing habitats, or distant agricultural areas, are expected. Similarly, the alternatives are associated with a minor growth in employee population and would not result in any air quality impacts due to general commercial, residential, industrial, or other growth.

5.7.4.3.5 Stratospheric Ozone Depletion-The 1990 amendments to the Clean Air Act address the protection of stratospheric ozone through a phaseout of the production and sale of stratospheric ozone-depleting substances. While environmental restoration and waste management alternatives do not involve production or use of jzone-depleting substances, waste management activities can release some substances of concern. A review of projected emissions indicates that the only ozone-depleting substances emitted in levels that exceed the State 
screening level are carbon tetrachloride (all alternatives) and freon [Alternative D (Maximum Treatment, Storage, and Disposal) only]. The combined annual emissions range from 11 kilograms (24 pounds) for Alternatives A (No Action) and C (Minimum Treatment, Storage, and Disposal) to 15 kilograms (33 pounds) for Alternative D (Maximum Treatment, Storage, and Disposal) and are associated mainly with incineration projects. These releases are extremely small compared to global loading and can be considered to have negligible effects.

5.7.4.3.6 Aclulic Depostion-Emissions of sulfur and nitrogen compounds and, to a lesser extent, other pollutants, including volatile organic compounds, contribute to a

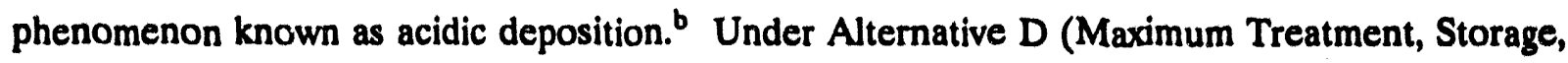
and Disposal), emissions of sulfur compounds from proposed projects could reach levels of up to 43,500 kilograms (48 tons) per year, while emissions of nitrogen compounds could reach almost 2 million kilograms (about 2,055 tons) per year. However, these emission rates are likely overstated, because controls would be incorporated on a number of projects to meet the Best Available Control Technology requirements of State and Federal requirements. Nevertheless, emissions of these levels are not expected to contribute significantly to acidity levels in precipitation in the region, nor will they have effects over greater distances, such as may occur with tall stacks associated with large utility power plants.

5.7.4.3.7 Global Warming-Emissions of carbon dioxide, methane, nitrous oxides, and chlorofluorocarbons (commonly known as greenhouse gases) are associated with potential for atmospheric global warming. Project alternatives would result in emissions of greenhouse gases through the combustion of fossil fuels (carbon dioxide and methane) and management of certain waste streams that contain small amounts of chlorofluorocarbons. New or increased use of chlorofluorocarbons is not proposed. There are currently no requirements that limit emissions of carbon dioxide or methane from the sources associated with project alternatives. In terms of the global emission of these gases, emissions associated with the implementation of these alternatives are exceedingly small and would not have any detectable effect.

b. One form of acidic deposition is commonly referred to as acid rain. 


\subsubsection{Alr Resource Impacts from Alternatives Due to Mobile Sources}

The ambient air quality impacts at offsite receptor locations due to the INEL bus fleet operations, INEL fleet light- and heavy-duty vehicles, privately owned vehicles, and heavy-duty commercial vehicles servicing the INEL site facilities has been predicted. For the most part, alternatives will realize minor increases in employment, which can be absorbed by the existing bus fleet. Alternatives will result in some minor increase in service vehicles and employee vehicles, especially during construction activities. The peak cumulative impacts (in other words, baseline plus alternative impacts) are predicted to occur at the INEL site Main Gate. These maximum impacts are just a few (approximately 5 to 30 ) percent of applicable standards and are due almost entirely to existing traffic conditions. The alternatives are expected to have no or very little impact on traffic volume at the INEL site and provide only a negligible increase in vehicularinduced air quality impacts.

\subsubsection{Air Resource Impacts from Alternatives Due to Construction}

Construction activities will occur intermittently throughout the period of implementation. The nrimary impact related to construction activities is the generation of fugitive dust, which includes respirable particulate matter. While dust generation would be mitigated by the application of water, relatively high levels of particulates could still occur in localized areas. Emissions of other criteria pollutants from construction-related combustion equipment may also result in impacts to air quality. Impacts have been assessed, taking into account the proposed construction schedule, in order to estimate maximum impacts. The impacts reported below are for the highest single year over the period 1995 through 2005.

For any of the alternatives, annual average concentrations of particulate matter (both respirable and total particulates) do not exceed one and three percent of the applicable standard at the maximum INEL site boundary and public road locations, respectively. Over shorter periods (24-hour averaging time), respirable and total particulate levels are one percent or less of the standards at the INEL site boundary. However, it is typical of major construction activities to intermittently produce relatively high levels of fugitive dust in the vicinity of the activity. For each of the alternatives assessed, the construction of associated facilities is estimated to result in short-term, localized levels of particulate matter than exceed applicable standards. 

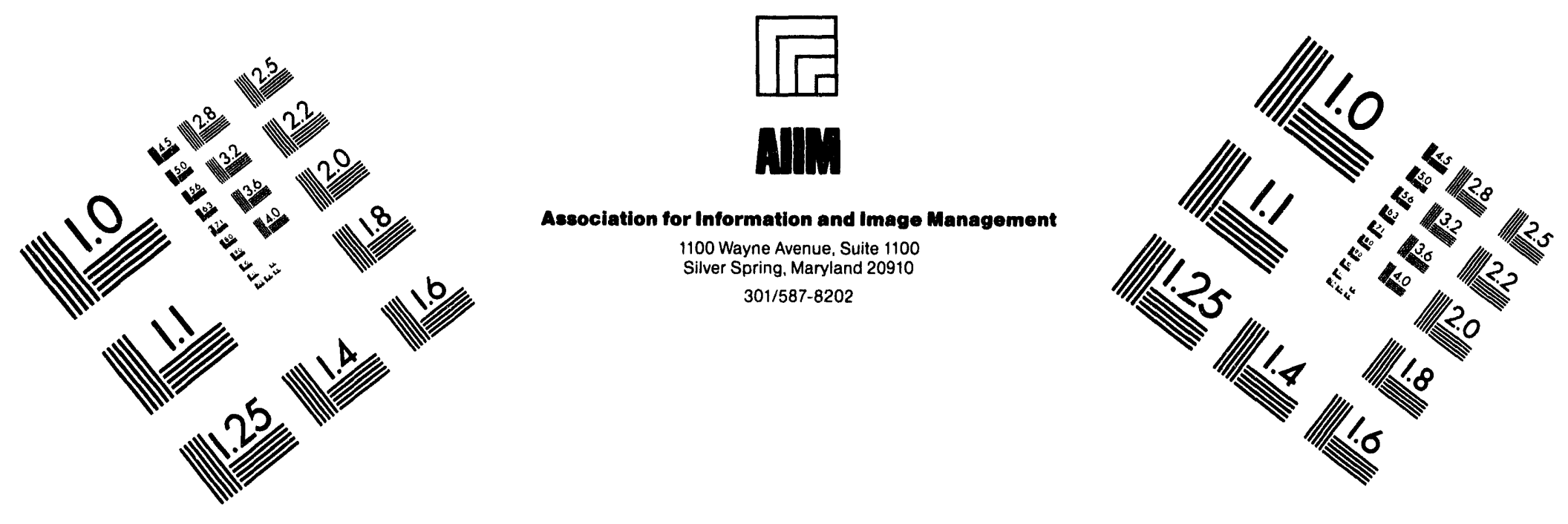

\section{Centimeter}

$\begin{array}{llllllllllllllll}1 & 2 & 3 & 4 & 5 & 6 & 7 & 8 & 9 & 10 & 11 & 12 & 13 & 14 & 15 & \mathrm{~mm}\end{array}$

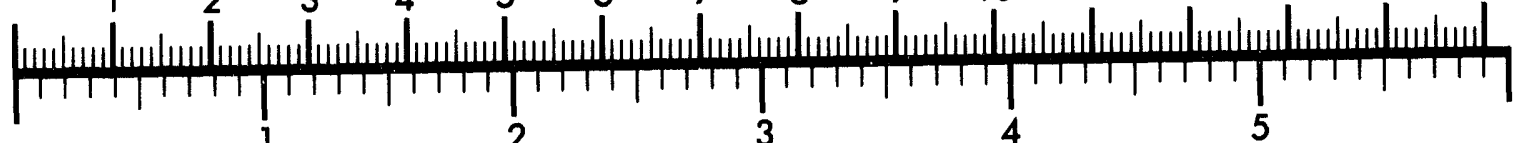
Inches

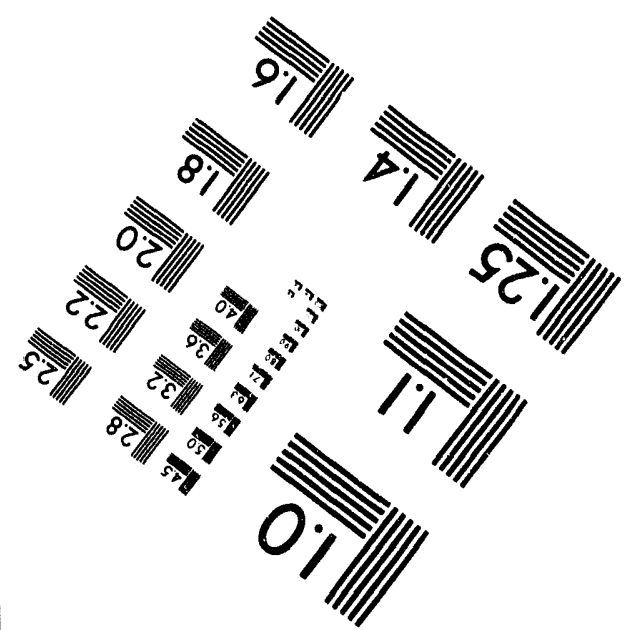

MANUFACTURED TO AIIM STANDARDS

BY APPLIED IMAGE, INC.

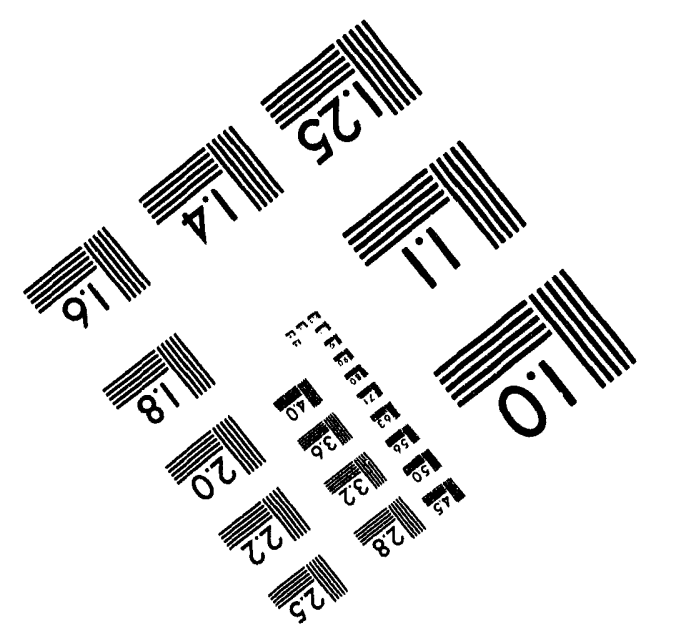



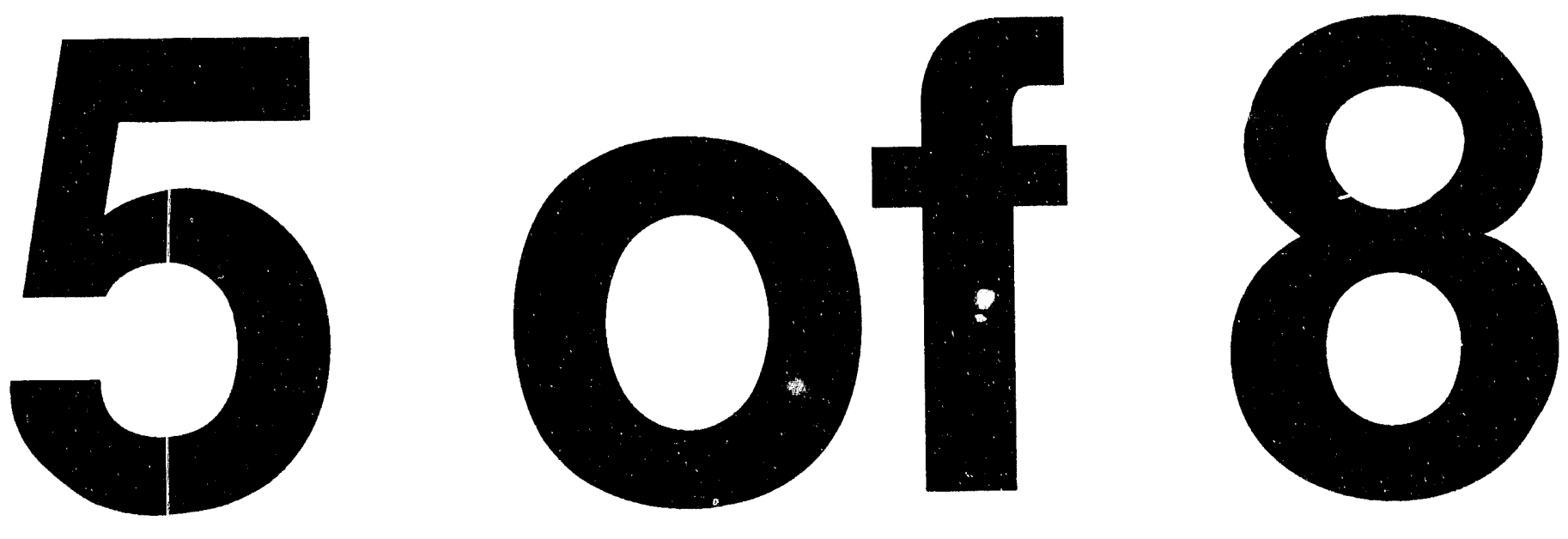
The maximum 24-hour levels of particulate matter at the highest predicted public road locations are approximately the same for Alternatives A (No Action), B (Ten-Year Plan), and C (Minimum Treatment, Storage, and Disposal). These are 210 micrograms per cubic meter for respirable particulates and 330 micrograms per cubic meter for total suspended particulates. These values exceed the Federal and Idaho primary air quality standards of 150 micrograms per cubic meter for respirable particulates and the Idaho primary standard of 260 micrograms per cubic meter for total suspended particulates. For Alternative D (Maximum Treatment, Storage, and Disposal), the maximum impacts are estimated at 390 micrograms per cubic meter for respirable particulates and 610 micrograms per cubic meter for total suspended particulates.

All levels of other criteria pollutants are predicted to be a small fraction of applicable standards. For Alternative D (Maximum Treatment, Storage, and Disposal), carbon monoxide levels are not expected to exceed three and eight percent of the standards at the INEL site boundary and public road locations, respectively. All other criteria pollutant levels are one percent or less of applicable standards at INEL site boundary locations and three percent or less of the standards at public roads. Impacts from other alternatives are slightly less.

\subsubsection{Air Resource Impacts from Alternatives Due to Specific Activities}

Potential impacts on air resources from five selected activities are described below.

\subsubsection{Additional Storage Racks in the Spent Nuclear Fuel Storage Pools at the} Idaho Chemical Processing Plant Fluorinel and Storage (FAST) Facility. This activity is proposed under Alternatives B (Ten-Year Plan) and D (Maximum Treatment, Storage, and Disposal) and would allow more wet fuel storage capacity at the INEL site. The increased inventory would contribute to a small increase in radionuclide emissions and onsite and offsite dose. The additional dose to the maximally exposed individual and regional population would be negligible. The activity would not result in any nonradiological emissions.

5.7.7.2 Replacement of High-Level Waste Storage Tanks. This activity is proposed under Alternatives C (Minimum Treatment, Storage, and Disposal) and D (Maximum Treatment, Storage, and Disposal). Replacement tanks are proposed to upgrade the safety of liquid highlevel waste storage at the INEL site. The construction activities would result in temporary 
increases in emissions of fugitive dust and gaseous exhaust from construction vehicles and equipment exhaust. Fugitive dust generation would be mitigated with frequent watering, and impacts to air quality would be expected to remain within acceptable levels. The action would result in no measurable increase in radiological emissions.

\subsubsection{Selection of Technology for Processing Sodlum-Bearing Liquid Waste.}

This activity is proposed under Alternatives B (Ten-Year Plan), C (Minimum Treatment, Storage, and Disposal), and D (Maximum Treatment, Storage, and Disposal). The activity would have minimal change in emission rates and is expected to have no impact on radiological and nonradiological air quality.

\subsubsection{Selection of Technology for Processing Calcined High-Level Waste. This} activity is proposed under Alternatives B (Ten-Year Plan), C (Minimum Treatment, Storage, and Disposal), and D (Maximum Treatment, Storage, and Disposal). Processing of calcine to a final waste form would require retrieval of the calcine from current storage in the bin sets, processing (utilizing a chosen technology), and storage, pending shipment to a disposal facility. The emissions associated with technology selection are included in the projects assessed under highlevel waste, in particular the Waste Immobilization Facility.

\subsubsection{Incineration of Low-Level and Mixed Low-Level Waste at the Waste}

Experimental Reduction Facility. This activity is proposed under Alternatives B (Ten-Year Plan) and D (Maximum Treatment, Storage, and Disposal). Projected emissions from the Waste Experimental Reduction Facility would result in increases in air pollutant loading of both radiological and nonradiological emissions. Impacts from incineration at the Waste Experimental Reduction Facility were assessed separately and as part of the mixed and low-level waste management options under Alternatives B and D. The projected dose to the maximally exposed offsite individual due to Waste Experimental Reduction Facility emissions is 0.03 millirem per year, while the collective population dose is about 0.23 person-rem. The offsite dose is well below the applicable limit of 10 millirem per year even when combined with cumulative emissions of other INEL site activities. Nonradiological pollutant levels are well below standards in all cases, with the possible exception of hydrochloric acid levels at the highest predicted location 
along public roads traversing the INEL site. Administrative controls might be required to reduce hydrochloric acid emissions, which can be verified by installed monitoring equipment. 


\subsection{Water Resources}

This section discusses potential environmental consequences to water resources inside and outside the INEL site boundaries under each of the four environmental restoration and waste management alternatives during the implementation period (1995 to 2005) and beyond. Because conclusions on future contaminant fate and transport are based in part on past contamination and existing plume migration, computer modeling of contaminant transport has been done through 2035. Modeling beyond the implementation period adds assurance to the conclusions reached.

Each alternative was evaluated with respect to its impacts on water quality (both surface and subsurface water) and water use. Computer modeling of vadose zone and saturated zone contaminant transport shows that existing plumes do not affeci the regional groundwater quality and that no contaminants will migrate offsite in concentrations above U.S. Environmental Protection Agency maximum contaminant levels allowable in drinking water. Additional technical details on assessment methods, assumptions, and results are presented in Appendix F, Section F-2, Geology and Water.

\subsubsection{Methodology}

The methodology used to assess the impacts to water resources from treatment, storage, and disposal practices and environmental restoration activities identified under the alternatives was to integrate available studies and technical information with computer modeling to evaluate aquifer contaminant transport and predict future trends in water quality during the implementation period. The steps involved in computer modeling were (a) a literature review to determine the source terms, (b) determination of the water level contours, (c) evaluation of the subsurface geology, (d) development of a conceptual model, (e) selection of appropriate codes, (f) calibration of the codes, (g) computer simulation for prediction purposes, and (h) a parameter sensitivity analysis. The assessment includes an evaluation of the types and volumes of liquid effluent discharges and airborne releases, associated waste management practices, and their subsequent effect on water resources.

The primary assumption used to evaluate consequences to water resources under any of the alternatives was that no future intentional discharge of radioactive liquid effluents to the 
subsurface and natural water resources would occur exceeding the standards established in DOE Order 5400.5, "Radiation Protection of the Public and the Environment" (DOE 1993).

Environmental restoration and waste management projects proposed under the alternatives have been reviewed to identify potential waste streams and water usage. No project will intentionally discharge radioactive liquid effluents to the vadose zone but rather will use other technologies, such as waste evaporators or lined evaporation basins. There are currently no radioactive discharges directly to the Snake River Plain Aquifer from existing operations. Deep well injection of radioactive waste was discontinued in 1985. Some trace quantities of radioactive discharges to the vadose zone still exist via infiltration ponds; however, samples collected from these discharges show that radionuclide concentrations are below the U.S. Environmental Protection Agency Primary Drinking Water Standards (Bennett 1994). Efforts are being made to eliminate sources by implementing system design upgrades or repairs, as applicable. Liquid effluent discharges from INEL site activities to the surface and subsurface via insiltration ponds are monitored for the presence of radioactive and chemical constituents and determined suitable for land disposal, as required under applicable Federal and State regulations (Lehto 1993).

Any liquid effluents from spent nuclear fuel facilities proposed under the alternatives would be contained in tanks, sumps, or lined evaporation basins; and, under normal operating conditions, radioactive discharges to the soil or directly to the aquifer would not occur. Some existing storage pools may have leakage. However, these pools are being phased out during the implementation period.

Analysis is currently being performed to determine the consequences from a hypothetical leak at a new spent nuclear fuel storage facility proposed for construction under the alternatives. A new facility would be similar in design to the Fluorinel and Storage Facility at the Idaho Chemical Processing Plant. This type of facility would be built using state-of-the-art technologies, including leak detection and water balance monitoring equipment. Monitoring and surveillance are performed daily and weekly. The analysis assumes leakage to the environment of $1.9 \times 10^{-2}$ cubic meters (five gallons) per day left undetected for a month. This volume is more than that which would be detected with monitoring equipment and surveillance. This release and analysis is for comparison purposes only and should not be construed as a planned or operational release. Based on the bounding accident scenario for high-level waste tank failure, the impacts to water resources are expected to be negligible from this leakage rate (see Section 5.14, Facility 
Accidents). Potential release of hazardous or radioactive materials as a result of accidents is discussed in Section 5.14.

Constant process monitoring and mass-balance, and design to current standards, including double-wall confinement of all vessels and piping, would be included in design and operating standards by DOE to limit potential operational releases from a new spent nuclear fuel processing facility to essentially zero. Any operational releases postulated would result from degraded equipment. Design data for a proposed new spent nuclear fuel processing facility have not evolved sufficiently to allow for detailed analysis of potential operational releases to groundwater.

\subsubsection{Water Resource Impacts from Alternative A (No Action)}

Under Alternative A (No Action), environmental restoration and waste management facilities, including existing spent fuel-related facilities, would continue, but under the assumption of no unallowable discharge of hazardous or radioactive wastes to the vadose zone, as specified under Federal and State regulations. The evaluation of water resources consequences for Alternative $\mathbf{A}$ involves looking at the impact from past activities and predicting what might occur in the future.

5.8.2.1 Surface Water. No direct impacts would result to the Big and Little Lost Rivers and Birch Creek from continuation of existing activities and normal operations at the INEL site because liquid effluent discharges (with the exception of cooling water and storm water) are not directly discharged to natural surface water bodies. Commingling of operational liquid effluents with storm water is minimized by separating process water from storm water and directing process water to onsite treatment and disposal systems. As of 1993, any previous detections of contaminants in water samples collected from the Big and Little Lost Rivers and Birch Creek have not exceeded U.S. Environmental Protection Agency Primary Drinking Water Standards (Mann 1994). Wastewaters discharged via land disposal systems would be monitored to ensure that any levels of contaminants present are suitable for land application, as specified under Federal and State requirements. Discharge limits for wastewater discharges to the environment are currently under development and proposed to be finalized in October 1994. 
The INEL site flood diversion system, which diverts flow from the Big Lost River to four spreading areas (along with associated dikes, culverts, and bridges constructed at the facilities) is believed to effectively prevent flooding from the Big Lost River into facility areas. Gates also control the release of water from Playa 2 to Playa 3 (Bennett 1990). However, in localized areas where the plain is very wide and flat, shallow water depths with low flow velocities could occur under maximum flood conditions combined with a hypothetical failure of Mackay Dam (Koslow and Van Haaften 1986).

The local basin snowmelt study [Appendix A of Koslow and Van Haaften (1986)] indicates a low potential for flooding from heavy rains and snowmelt runoff at the INEL site facilities. The 25-year combined rain and snowmelt was determined to be approximately 7 centimeters per day ( 2.74 inches per day) of available water. This runoff could be diverted from the facilities with properly installed culverts, channels, and the use of flood control basins.

Floodwaters outside the banks of the Big Lost River channel would spread and pond in low-lying areas on the flood plain. Pumping of these ponded waters to other settling basins away from facilities would reduce the impact of standing water.

5.8.2.2 Subsurface Water. The model. ig performed by Arnett and Rohe (1993) for predicting contaminant migration considered the following radionuclides: tritium, iodine-129, and strontium-90. These radionuclides were considered because they appear to have had the greatest impact on the aquifer from previous disposal activities and are the main constituents within contaminant plumes. They are significant in the vadose zone, but $u$ ther radionuclides are also important. The Idaho Chemical Processing Plant and the Test Reactor Area were considered because they are the two largest facilities contributing to the plumes in the aquifer. Isolated radionuclide contamination does occur at the other facilities but has not been detected consistently in monitoring wells to constitute plumes. Contaminant transport modeling was performed for the period from 1990 through 2035 (30 years beyond the implementation period) or until the contaminant dropped below the U.S. Environmental Protection Agency maximum contaminant level in the aquifer (Arnett and Rohe 1993, Arnett et al. 1992, 1993).

The vadose zone has a beneficial effect on consequences to water resources because it helps buffer contaminants from the regional aquifer by sorption and restricted migration pathways. 
The surficial sediments and sedimentary interbeds sorb some radionuclides and allow them to decay within the vadose zone. Results of the vadose transport model are presented in Arnett and Rohe (1993) and were incorporated into the aquifer transport model MT3D code (Zheng 1992) as input data.

A brief summary of the results will help illustrate what effects vadose zone transport would have in the future. Modeling was performed for the Test Reactor Area and the Idaho Chemical Processing Plant perched water zones and percolation ponds. In both cases, the amount of water entering and exiting the perched water zones took a few years to reach a steady state (that is, amount in equals amount out). The amounts of tritium released from the vadose zone to the regional aquifer increased from 1962 to the mid-1970s and decreased slightly from the mid1970s to the present at the Test Reactor Area. Discharges of tritium and iodine-129 at the Idaho Chemical Processing Plant have decreased since 1984. Assuming no new radioactive liquid effluent waste discharges, the code predicts for both facility areas that levels of iodine-129 and tritium would continue to migrate from the vadose zone but concentrations would decrease over time due to natural dispersion/dilution and radioactive decay. By 2010, most of the water in the perched water zones beneath the Idaho Chemical Processing Plant would have migrated to the aquifer and only very small quantities $\left(1 \times 10^{-4}\right.$ curies per day) of the remaining radionuclides would continue to enter the aquifer after 2010 . The same results are predicted for the Test Reactor Area perched zones but here discharges of effluents meeting the DOE standards would continue. The perched water zones would remain, and existing contaminants would continue to migrate into the aquifer.

Strontium-90 is not predicted to migrate to the regional aquifer in significant quantities from either source because of retardation within the vadose zone. Predictions in studies by Arnett and Rohe (1993) were the same as those of Robertson (1977). Tritium was predicted to migrate from the vadose zone unretarded, whereas strontium-90 would not migrate.

Predictions of groundwater modeling indicate that current plumes will continue to migrate but concentrations within the plume would continue to decrease and decay with time. By the year 2000 , the maximum concentrations of tritium would be reduced by one-half and fall below the current maximum contaminant level. By 2010, the maximum concentration in the plume is predicted to be about one-fourth of the maximum contaminant level. Iodine-129 behaves similarly 
to tritium but has a much longer half-life. The predicted plume does not have a large decrease in concentration by 2030 , but it is not expected to migrate offsite, except for very small concentrations less than 1 picocurie per liter (the maximum contaminant level). The existing strontium-90 plume resulted from previous releases directly to the aquifer from the Idaho Chemical Processing Plant disposal well. (Routine injection well use was discontinued in 1985.) Results of transport modeling predict that by 2000 , strontium- 90 would decrease slightly in concentration and would remain relatively stationary because of retardation. By 2030, the highest levels of strontium- 90 within the plume would decrease in concentration to approximately onehalf of the maximum contaminant level for strontium-90. By 2030, the plume front is predicted to migrate approximately one kilometer ( 0.62 miles) beyond the 1990 position, far short of the INEL site boundary.

Arnett and Rohe (1993) performed a study similar to Robertson (1974) to evaluate the potential migration of tritium, chloride, and strontium-90 through 2000 . The results by Robertson (1974) showed that both tritium and chlorine could migrate southward and extend about 1 mile south of the INEL site boundary by 2000 , but would be below U.S. Environmental Protection Agency maximum contaminant levels. Predictions for strontium-90 using estimates of contaminant releases to the aquifer for the period beyond 1972 indicate migration a few miles south of the Idaho Chemical Processing Plant, but not offsite. Results reported by Arnett and Rohe (1993) are consistent for strontium-90, but not for tritium. Most of the tritium differences can be attributed, however, to estimated versus actual tritium discharges used for the 1971-1990 period, as actual data were unavailable to Robertson in 1974. Results are consistent in the sense that neither predicts offsite contamination in excess of maximum contaminant levels. Field monitoring observations show decreasing concentrations of tritium, iodine-129, and strontium-90 within the contaminant plumes for the past seven years and are consistent with the prediction of continucd decrease in plume concentrations (EG\&G Idaho 1993).

Organic contamination is a concern at Test Area North and the Radioactive Waste Management Complex. Water sampling performed by the U.S. Geological Survey at the Radioactive Waste Management Complex after 1980 has shown that the perched zones beneath the Subsurface Disposal Area have some level of organic contamination; however, radionuclides have not been detected above the method detection limits (Cecil et al. 1991). Contaminant migration modeling of volatile organic compounds by Dames \& Moore (1993) shows a potential 
for the migration of carbon tetrachloride, trichloroethene, trichloroethane, and 1,1,1trichloroethane, with peak concentrations occurring in 2070 within the vadose zone. Vapor vacuum extraction wells used to remove volatile organic compounds from the subsurface have been installed and tested at the Radioactive Waste Management Complex with positive results (Sisson and Ellis 1990). However, full-scale remediation efforts have not yet begun. With the extraction system operational, volatile organic compounds would pose a negligible impact to the groundwater or vadose zone.

Test Area North also has volatile organic compounds within the subsurface, resulting from the disposal of organic-rich sludge into the Test Area North injection well (TSF-05). Much of the sludge was removed from the well in 1990. A modeling study was performed by Schafer-Perini (1993) to predict the potential for residual contaminant migration. This study was based on two assumptions: (a) that the residual sludge would remain as a constant infinite source and (b) that the sludge would be free to migrate and would act as a dissolved source. Results under the two assumptions both predict that the organics would be likely to migrate a minimum of $\mathbf{1 2}$ kilometers (7.5 miles) southward to the boundary of the model grid by 2024 and would continue to migrate southward at about 0.33 meters per day (one foot per day). The difference in the assumptions is that concentrations would be higher under the first assumption everywhere in the plume. The radionuclides were not affected by the choice of assumptions. Tritium would nut migrate very far and would never be in concentrations above the maximum contaminant level. Strontium-90 would continue to have elevated concentrations but would not migrate more than 1 kilometer ( 0.6 miles) away from Test Area North. Organics could pose a problem, but a planned remediation project would pump and treat the groundwater to Federal drinking water standards. Even if no further remedial action were taken, the location of Test Area North relative to the regional aquifer system makes it highly unlikely that contamination would ever reach the INEL site boundary at concentrations approaching U.S. Environmental Protection Agency maximum contaminant levels.

A preliminary scoping risk assessment of radioaciive waste disposal practices during the time period from 1952 to 1996 is currently being performed as part of a Comprehensive Environmental Response, Compensation, and Liability Act investigation. Results of the preliminary risk assessment indicate that contaminants would not reach the INEL site boundary exceeding Federal primary drinking water standards through 2005 (Loehr et al. 1994). 
A radiological performance assessment was also conducted for low-level waste buried at the Radioactive Waste Management Complex from 1984 through present operations and projected to be disposed through 2020 (Maheras et al. 1994). The results of the assessment indicate that the maximum total pathway exposure occurring by 2060 at the INEL site boundary would be less than 0.60 millirem per year (Maheras et al. 1994). No significant impacts are expected to occur within the implementation period of this Environmental Impact Statement.

Other facilities at the INEL site contain some levels of contamination above maximum contaminant levels (for example, chromium at Test Reacior Area), but the contaminants are isolated to INEL site facility areas and do not occur consistently in monitoring wells. Radionuclides of chromium-51, cesium-137, and cobalt- 60 have also been detected above maximum contaminant levels in isolated areas, but typically they are sorbed in the soil or subsurface sediments and would not migrate to the saturated zone. These isolated areas of contamination impact the local ground and vadose water near the INEL site facilities but do not pose a threat to the regional aquifer system.

Although no current contamination of the aquifer can be attributed to air emissions, precipitation may have an effect of flushing contaminants that have settled to the ground out of air emissions down into the vadose zone. Any subsequent effect to the aquifer would be negligible for the following reasons:

- Because the annual precipitation is 22 centimeters ( 8.62 inches) per year and the evaporation rate is 125 centimeters ( 49.0 inches) per year, very little of the precipitation would reach the aquifer during the summer and fall. Increased filtration would occur after thawing of snow during the spring. However, the amount of water reaching the aquifer would still be small. Robertson et al. (1974) estimates that overall only 15 percent of the annual precipitation would recharge the aquifer.

- The vac ose zone ranges from approximately 61 meters (198 feet) to 274 meters (890 fer $t$ ) and has a large capacity for sorbing contaminants (Cecil et al. 1992). Therefore, for sorbed isotopes that have short half-lives, most of the radioactivity may decay before migrating through the vadose zone. 
- The wide area distribution of radionuclides resulting from atmospheric dispersion in precipitation would result in concentrations of contaminants in precipitation less than maximum contaminant levels at land surface.

- Under highly unsaturated conditions with low moisture content in the vadose zone, water migration is very slow and requires two to five years to reach the aquifer, allowing for radioactive decay.

The consumption of water from the Snake River Plain Aquifer under Alternative A (No Action) would be 106,700 cubic meters ( 28.2 million gallons) per year. However, since total consumption of water at the INEL site averages 7.7 million cubic meters ( 2.03 billion gallons) per year, the additional water would have a negligible impact on the quantity of water in the Snake River Plain Aquifer ( 0.43 percent of the water passing under the INEL site yearly). Of the quantity pumped from the aquifer, approximately 5 million cubic meters (1.3 billion gallons) ${ }_{3}$ or 65 percent, is eventually returned to the aquifer (DOE-ID 1991, 1992). This is much less than the INEL site's consumptive use water right of 43 million cubic meters (11.4 billion gallons) per year.

5.8.2.3 Impacts from Specific Activities. There are no specific activities associated with Alternative A (No Action).

\subsubsection{Water Resource Impacts from Alternative B (Ten-Year Plan)}

Impacts to water resources would essentially be the same for Alternative B (Ten-Year Plan) as for Alternative A (No Action) except for water consumption. Continued shipments of spent nuclear fuel would not affect the quality of water resources because it is stored in contained storage pools or above-grade dry storage containers and isolated from the environment. Additional activities under Alternative B would not discharge waste to the subsurface; hence, it would not affect source terms identified by Lehto (1993) and used in modeling. Water consumption would be the greatest of any alternative through the implementation period (2005). The increased consumption is estimated at 299,800 cubic meters ( 79.2 million gallons), which represents an increase of 3.9 percent. Given that 1.77 billion cubic meters (470 billion gallons) (Robertson et al. 1974) of water flow under the INEL site each year, the volume of water 
consumed under this alternative would only be 0.45 percent of that passing under the INEL site. This would have a negligible impact on the quantity of water in the Snake River Plain Aquifer.

Select activities associated with Alternative B (Ten-Year Plan) are additional storage racks in the spent nuclear fuel storage pools at the Idaho Chemical Processing Plant Fluorinel and Storage (FAST) Facility, selection of technologies for processing sodium-bearing liquid and calcined high-level waste, and incineration of low-level and ruixed low-level waste at the Waste Experimental Reduction Facility.

The addition of storage racks at the Idaho Chemical Processing Plant Fluorinel and Storage Facility would allow for more wet spent nuclear fuel storage capacity at the INEL site. This project should not affect the quality of water resources because this facility is a state-of-the art facility, with double wall containment and leak detection systems. In addition to the facility construction, routine water quality monitoring is performed. The construction phase of this project would require 26.9 cubic meters ( 7,109 gallons) of water; however, the operational phase would require no increase in water usage above the current level.

The processing activities (listed above) should not affect water quality at the INEL site. Activities would be performed indoors, and facility designs would prevent discharge of liquid effluents (accidental or routine). Additionally, the resultant waste form would be in a safer configuration than current high-level waste storage at the INEL site. Construction on this activity would begin during the implementatior: period for this EIS; however, operations would not begin until three years after the end of the implementation period. (Operation dates have been assumed for purposes of analysis.) The construction phase of these projects would require 11,300 cubic meters ( 3 million gallons) of water. Water usage for processing sodium-bearing liquid and calcined high-level waste would increase the total usage by 150,000 cubic meters (39.6 million gallons) per year from the year 2008 through the year 2043. Given that 1.77 billion cubic meters (470 billion gallons) of water flow under the INEL site each year (Robertson et al. 1974), the volume used for these activities would only be 0.44 percent of that passing under the INEL site.

Water consumption for incineration would be 602 cubic meters $(159,000$ gallons per year). When compared to the total passing under the INEL site, this amount is negligible. 


\subsubsection{Water Resource Impacts from Alternative C (Minimum Treatment, Storage and Disposal)}

Impacts to surface and subsurface water would be the same for Alternative $C$ (Minimum Treatment, Storage, and Disposal) as for Alternatives A (No Action) and B (Ten-Year Plan). The only difference in impacts would be in the consumption of water. Less water would be used than for either Alternative D (Maximum Treatment, Storage, and Disposal) or B (Ten-Year Plan). A total of 158,600 cubic meters (41.9 million gallons) would be consumed above baseline, representing an increase of 2.0 percent. The effects on the quantity of water in the aquifer would be negligible.

The selected activities associated with Alternative C (Minimum Treatment, Storage, and Disposal) are the replacement of high-level waste storage tanks at the Idaho Chemical Processing Plant and selection of technologies for processing sodium bearing liquid waste and calcined high level waste.

The replacement of the high-level waste storage tanks is proposed to upgrade the safety of liquid high-level waste storage at the INEL site. Any impacts to water resources resulting from this project would be positive. The risk of accidents or leakage would be decreased because replacement tanks would be constructed in accordance with current design requirements and would include features such as double-wall confinement and seismic-resistant design. There is no increase in water usage for this activity.

The effect of processing activities on water resources has been discussed previously (Section 5.8.3). The only change under Alternative C (Minimum Treatment, Storage, and Disposal) would be the dates of operation assumed for purposes of analysis. Under Alternative $\mathrm{C}$, the operation would begin in 2015 and continue through 2050. This is 10 years after the end of the implementation period for this Environmental Impact Statement. 


\subsubsection{Water Resource Impacts from Alternative D (Maximum Treatment, Storage and Disposal)}

Alternative D (Maximum Treatment, Storage, and Disposal) represents the second largest volume of water consumed of all the alternatives-208,200 cubic meters (55.0 million gallons) through 2005 . This increased usage represents only a 2.7 percent increase over average water consumption and is negligible when compared to the volume of water in the aquifer. The impacts to the saturated zone, vadose zone, and surface water would be negligible because liquid effluents would not be discharged to the surface or subsurface above levels suitable for land application. Other wastewater disposal methods that could degrade groundwater beyond designated beneficial uses are controlled by Federal and State regulations.

The selected activities associated with Alternative D (Maximum Treatment, Storage, aild Disposal) are additional storage racks in the spent nuclear fuel storage pools at the Idaho Chemical Processing Plant Fluorinel and Storage (FAST) Facility, selection of technologies for processing sodium-bearing liquid waste and calcined high-level waste, incineration of low-level and mixed low-level waste at the Waste Experimental Reduction Facility, and the replacement of highlevel waste storage tanks at the Idaho Chemical Processing Plant. The impacts to water resources from all of these activities have been discussed under Alternatives B (Ten-Year Plan) and C (Minimum Treatment, Storage, and Disposal) and would not change under Alternative D. The dates of operation for processing sodium-bearing liquid and calcined high-level waste are the same under this alternative as under Alternative $\mathrm{C}$.

\subsubsection{Conclusions}

Under all of the alternatives considered, the possible future sources of contamination would be negligible compared to previous practices. Therefore, in this section, DOE concludes that (a) only contaminant concentrations below U.S. Environmental Protection Agency maximum contaminant levels and DOE derived concentration guides would migrate beyond the site boundary, resulting in negligible impact to the quality of groundwater leaving the INEL site;

(b) adverse effects to groundwater quality have occurred in localized areas within the INEL site (contaminant plumes), but these plumes have not affected the regional quality of water; (c) stateof-the-art waste management practices applied under the alternatives would result in further 
reduction of contaminants existing in water resources (through source reduction and reduction of existing contamination through normal attenuation and radioactive decay); (d) computer modeling of vadose zone and saturated zone contaminant transport indicates that contaminant plumes with concentrations above the primary maximum contaminant levels would continue to decrease at least through 2030 and the overall quality of the groundwater would be improving; and (e) water use at the INEL site for any alternative would have a minimal effect on the quantity of water within the aquifer. 


\subsection{Ecology}

This section discusses the potential effects of the four environmental restoration and waste management alternatives on ecology at the INEL site and the surrounding area. Technical support for this section is provided in Rope et al. (1993). Effects from the alternatives are tabulated in this section for ease of comparison.

\subsubsection{Methodology}

Potential effects on biological resources from each alternative were qualitatively assessed. The potentially affected areas (sites and facilities to be used, constructed, or remediated and surrounding habitat where effluents, emissions, light, or noise may be present) were identified in Chapter 3, Appendix C, and Section 4.9, Ecological Resources. Biological attributes currently found or that may be found on the site were identified and characteristics were discussed in Section 4.9.

The assessment of potential effects is based on an evaluation of the location of activities in relation to the location of the biological attributes. Information about the potential effects was developed from studies evaluating effects from similar types of activities on biota similar to those found at the INEL site. Also, the potential effects associated with Alternative A (No Action) serve as the basis of comparison for the other alternatives.

Disturbance of various types (for example, earthmoving, noise) would constitute the primary source of impacts such as loss of productivity, displacement of individuals, and habitat fragmentation. Table 5.9-1 summarizes land disturbance associated with general activities for each alternative.

\subsubsection{Ecological Impacts from Alternative A (No Action)}

A variety of general activities would occur under Alternative A (No Action) that may affect biological resources. Sources of disturbance that may affect ecological resources include loss or change of habitat from construction of new facilities; mortality from land clearing or 
Table 5.9-1. Acres disturbed by alternative from proposed projects to manage or conduct waste stream, spent nuclear fuel, environmental restoration, or infrastructure activities at the Idaho National Engineering Laboratory site.

\begin{tabular}{|c|c|c|c|c|c|c|c|c|c|c|c|c|}
\hline & \multicolumn{12}{|c|}{ Alternatives ${ }^{\mathbf{a}}$} \\
\hline & \multicolumn{3}{|c|}{$\mathbf{A}$} & \multicolumn{3}{|c|}{ B } & \multicolumn{3}{|c|}{ C } & \multicolumn{3}{|c|}{ D } \\
\hline & $\mathrm{N}^{\mathbf{b}}$ & $\mathbf{P D}^{\mathbf{b}}$ & $\mathbf{R}^{\mathbf{b}}$ & $\mathbf{N}$ & PD & $\mathbf{R}$ & $\mathbf{N}$ & PD & $\mathbf{R}$ & $\mathbf{N}$ & PD & $\mathbf{R}$ \\
\hline Spent nuclear fuel & $\mathbf{0}$ & 0.8 & $\mathbf{0}$ & $\mathbf{0}$ & 19.3 & 0 & $\mathbf{0}$ & 0 & 0 & $\mathbf{0}$ & 30.8 & 0 \\
\hline Remediation & 3 & 7.3 & $\mathbf{0}$ & 3 & 7.3 & $\mathbf{0}$ & 3 & 7.3 & $\mathbf{0}$ & 3 & 7.3 & $\mathbf{0}$ \\
\hline $\begin{array}{l}\text { Decommissioning and } \\
\text { decontamination }\end{array}$ & 0 & 6.7 & $\mathbf{0}$ & $\mathbf{0}$ & 16.1 & $\mathbf{0}$ & $\mathbf{0}$ & 6.7 & $\mathbf{0}$ & 0 & 16.1 & $\mathbf{0}$ \\
\hline High-level waste & $\mathbf{0}$ & 2.8 & $\mathbf{0}$ & $\mathbf{0}$ & 14.1 & 0 & O & 23.6 & 0 & 0 & 34.6 & 0 \\
\hline Mixed low-level waste & $\mathbf{0}$ & 0.3 & $\mathbf{0}$ & 220 & 1.3 & $\mathbf{0}$ & 5 & 0.3 & 0 & 420 & 1.3 & $\mathbf{0}$ \\
\hline Low-level waste ${ }^{c}$ & $\mathbf{0}$ & 0.3 & 0 & 220 & 0.3 & $\mathbf{0}$ & 5 & 0.3 & $\mathbf{0}$ & 420 & 0.3 & 0 \\
\hline Transuranic $^{c}$ & 2 & 12.5 & $\mathbf{0}$ & 222 & 12.5 & $\mathbf{0}$ & 7 & 12.5 & $\mathbf{0}$ & 222 & 12.5 & $\mathbf{0}$ \\
\hline $\begin{array}{l}\text { Greater-than-Class C } \\
\text { low-level waste }\end{array}$ & 0 & $\mathbf{0}$ & $\mathbf{0}$ & $\mathbf{0}$ & 1.7 & 0 & 0 & $\mathbf{0}$ & $\mathbf{0}$ & $\mathbf{0}$ & 1.7 & $\mathbf{0}$ \\
\hline Hazardous Waste & $\mathbf{0}$ & 0.3 & 0 & $\mathbf{0}$ & 0.3 & $\mathbf{0}$ & $\mathbf{0}$ & 0.3 & $\mathbf{0}$ & 5 & 0.3 & $\mathbf{0}$ \\
\hline Infrastructure & 0 & 2.8 & 0 & 132 & 170.8 & 225 & 112 & 170.8 & 225 & 212 & 170.8 & 225 \\
\hline Total & 5 & 33.5 & 0 & 557 & 243.4 & 225 & 127 & 221.8 & 225 & 842 & 275.4 & 225 \\
\hline
\end{tabular}

a. $\mathbf{A}=$ No Action; $\mathbf{B}=$ Ten-Year Plan; $\mathbf{C}=$ Minimum Treatment, Storage, and Disposal; D = Maximum Treatment, Storage ${ }_{2}$ and Disposal.

$$
\begin{array}{lll}
\mathbf{N} & = & \text { Acres not previously disturbed } \\
\mathbf{P D} & = & \text { Acres previously disturbed } \\
\mathbf{R} & = & \text { Acres disturbed during proposed action that will be revegetated. }
\end{array}
$$

c. Totals do not equal summation of columns because many projects are found in two or more waste streams. (As an example, all proposed projects for low-level waste are also found in the mixed low-level waste stream.) Therefore, the projects impacts were counted only once to comprise the total. See Appendix C for project specific information and waste stream-project associations. 
facility removal operations; mortality from vehicular traffic; human presence; noise; night lights; and exposure to radionuclides and hazardous contaminants and wastes. A potential beneficial effect from these activities would be revegetation of currently disturbed areas once any remediation activities are completed.

Approximately 16 hectares (40 acres) would be disturbed under Alternative A (No Action), 2 hectares ( 5 acres) of undisturbed habitat and 14 hectares ( 35 acres) of previously disturbed habitat. The 2 hectares (5 acres) of previously undisturbed habitat would be within the fence lines or boundaries of existing facilities and currently disturbed acres. The 14 hectares (35 acres) of previously disturbed habitat would be within the boundaries of existing facilities.

The potential short-term effects of the disturbance of the 2 hectares ( 5 acres) of previously undisturbed habitat would include a loss of plant productivity, localized loss of biodiversity, displacement of animals currently occupying the areas, and direct mortality of less mobile species (for example, nesting birds) and species using burrows. The plant productivity and localized biodiversity loss would be the result of the loss of species common to the shrub-steppe vegetation that covers over 90 percent of the INEL site. The majority of animal species that would be displaced include insects, reptiles, and small mammals. Displaced/dispersing animals tend to have low survivorship (Emlen 1984, Ralls et al. 1986), especially if surrounding areas are at or near carrying capacity. Direct mortality of the previously listed animals plus nesting birds and their nests may occur during land disturbance activities. An additional potential effect would be the establishment of Russian thistle and cheatgrass, which are non-native annual species. These species, less desirable than native species, at times can establish in undisturbed native vegetation and competitively exclude less vigorous native species that are important food or cover sources for insects, small mammals, and birds.

The potential short-term effects of the disturbance of the 14 hectares ( 35 acres) of previously disturbed habitat would be similar to the effects discussed for the 2 hectares ( 5 acres) of previously undisturbed habitat with the exception that biodiversity loss, plant productivity loss, animal displacement, and animal mortality would be less. This is because previously disturbed habitats are less diverse, primarily dominated by landscaped vegetation (such as lawns), Russian thistle and cheatgrass, or non-native, perennial crested wheatgrass. These vegetation types are 
less diverse and provide less cover and food for animals compared to undisturbed native vegetation.

Other potential short-term effects include increased traffic noise, human presence, night lights, removal of contaminated ponds, and deposition of radionuclide air emissions from waste treatment and remediation operations (see Secticn 5.9.2.3 for discussion of potential effects). Potential mortality associated with increased vehicle traffic would be small because the increased number of trips and miles anticipated under Alternative A (No Action) would be similar to the current traffic levels. No, or limited, effects to plants and animals are anticipated from hurnan presence, noise, or night lights. About eight new generators would be used during the day and lights would be used at night on seven projects. All generators and noise sources (both night and day) would produce noise levels similar to existing sources. Also, all activities would be within or immediately adjacent to existing activities that have existing night lights, noise, human presence, and air emissions. Therefore, exposure of animal populations near facilities to these disturbances and resulting effects would increase slightly under Alternative A. In addition, species currently using areas near existing facilities (hawks, songbirds, small mammals, elk, and pronghorn) demonstrate tolerance to human presence and activities. Night lights may serve as an attractant to insects and, thus, to nocturnal insect-feeders such as bats. Conversely, some nocturnal small mammal species may alter activity periods or be displaced from areas adjacent to night lights. This effect may alter success of hunting by nocturnal predators such as owls. Ponds and lagoons that are removed may reduce availability of drinking water or food sources for bats, birds, rodents, and small mammals. However, removal of these ponds would reduce the likelihood of exposure to contaminants.

Long-term effects of construction and operation would include loss of plant and animal productivity on the 16 hectares ( 40 acres) occupied by facilities, attraction or avoidance of structures, and effects to habitat immediately surrounding facilities. These potential long-term effects to habitat surrounding facilities would be from noise, human presence, night lights, and deposition of air emissions from operations. With the exception of air emissions, effects associated with the sources of disturbance would be localized to areas immediately surrounding the new activities and probably would affect biota in the same manner as described for potential short-term effects. 
5.9.2.1 Protected, Candidate, and Sensitive Species. It is not likely that Federal protected and candidate species and State and agency sensitive species would be affected under Alternative A (No Action). Preactivity surveys would be conducted on areas before initiation of projects to ensure that impacts to protected species would not occur and that appropriate mitigations are implemented as needed (see Section 5.19, Mitigation).

5.9.2.2 Wetlands. Wetlands and aquatic resources likely would not be affected under Alternative A (No Action). Based on recent surveys (Hampton et al. 1993), no jurisdictional wetlands are known to exist on or near any of the facilities. See Section 5.19 for additional steps to ensure that no effects would occur.

5.9.2.3 Radloecology. Under Alternative A (No Action), biota would continue to be exposed to radionuclides and contaminants in water and soil that would not be treated, removed, or remediated. This exposure would continue beyond through the year 2035 . In addition, shortterm exposure may increase because of contaminant resuspension during soil removal and treatment (for example, air stripper, bioremediation) operations. However, soil removal and treatment operations would reduce long-term contaminant exposure levels for biota in some locations of the INEL site. Currently, contaminated areas at the site are small, relative to the INEL as a whole, and are not increasing in size or contamination levels (Morris 1993a,b). As discussed in Section 4.9, observable effects to individual small animals have been noted at small isolated areas on the INEL site; however, no effects on population were observed. Therefore, effects to populations are not likely under Alternative A (No Action).

With respect to Federal endangered and candidate species, it is unlikely that the bald eagle, peregrine falcon, northern goshawk, ferruginous hawk, white-faced ibis, long-billed curlew, and pygmy rabbit are consuming harmful concentrations of radiological contaminants through feeding. This is because these species rarely use areas near exposed contaminants. It is unknown whether individuals of the other candidate species (Townsend's western big-eared bat and loggerhead shrike) use contaminated areas for a sufficiently long time or consume a sufficient amount of prey to receive radiation doses that would have a measurable effects on the individuals. Removal of contaminated ponds and lagoons would have a beneficial effect of further minimizing the potential for Townsend's big-eared bats to be exposed to contaminants. 


\subsubsection{Ecological Impacts from Alternative B (Ten-Year Plan)}

Generally, potential nonradiological and radiological effects to biota from Alternative B (Ten-Year Plan) are similar in nature, but larger in scale, to those described under Alternative $\mathbf{A}$ (No Action). About 323 hectares ( 800 acres) would be disturbed under Alternative B, 225 hectares (557 acres) of undisturbed habitat and 98 hectares ( 243 acres) of previously disturbed habitat. To minimize the potential short-term effects of the disturbances described above, about 91 hectares ( 225 acres) of the 323 hectares ( 800 acres) to be disturbed would be revegetated. Consequently, there would be a long-term net loss of 232 hectares ( 575 acres). The majority of the long-term acreage loss would be from the construction and operation of two new facilities (private sector Alpha-Mixed Low-Level Waste Treatment Facility and the Idaho Waste Processing Facility) several kilometers from existing facilities and the expansion of the landfill. Each of these new facilities would encompass about 81 hectares ( 200 acres), while the landfill expansion would encompass about 113 hectares (280 acres).

When possible, revegetation would be accomplished using native perennial grasses and forbs. Plant productivity and diversity on revegetated areas that were part of the 64 hectares (158 acres) of previously disturbed habitat probably would become more productive and diverse compared to the preexisting habitat. Previously undisturbed habitat that would be revegetated probably would not provide cover, food, or biodiversity similar to undisturbed habitats during the first three to five years after seeding. Cover probably would be similar to undisturbed vegetation absut five years after reseeding. Composition of plant species (and, therefore, diversity and animal food supplies) would continue to be lower compared to undisturbed habitat ten years after reseeding. This is because slower growing seeded species such as some shrub species and less competitive forb species require more time to become established. In addition, many species found in undisturbed areas would not be part of the seed mixture because commercial seed is not available.

Over a longer period, diversity and animal food supplies may more closely approximate native vegetation. Animal species probably would reestablish in reseeded areas as vegetation success occurred. Animal species preferring open areas and using annual plants would be the first species to reestablish in revegetated areas. As seeded species became productive, species requiring greater cover or perennial grasses and shrubs would begin to use the areas. Similar to 
the vegetation community, the reestablished animal communities may remain less diverse than undisturbed animal communities. In addition, revegetation of the 91 hectares ( 225 acres) would linit the ability of Russian thistle, cheatgrass, and other less desirable speciss to establish or dominate vegetation communities.

An additional potential effect that may be a result of Alternative B (Ten-Year Plan) that would not be associated with Alternative A (No Action) would be habitat fragmentation resulting from the construction and operation of the two facilities outside of existing facilities (see above). Fragmentation probably would alter the movement of individual mobile species such as pronghorn and elk in, and through, the area. Effects of fragmentation from the proposed facilities probably would not eliminate or severely restrict movements of animals. Historical data show that elk and pronghorn continue to use and move through areas immediately adjacent to developed areas similar to the proposed facilities (Rope et al. 1993). Also, habitat adjacent to new facilities may be avoided by species because of human presence, night lighting, or noise. After construction is completed, additional habitat disturbance would not occur and human astivity and presence would be minimal in surrounding undisturbed habitat.

Other sources of potential effects would include the addition of about 20 temporary and 7 permanent generators during the day, 24 night lights, and the addition of 2 artificial surface water sources. These additions (with the exception of two generators and two night lights) would be within the boundaries of existing facilities where similar facilities are present. The ponds would be fenced and have no vegetation surrounding them to minimize access and to make them less attractive to wildlife.

5.9.3.1 Protected, Candidate, and Sensitive Species. Implementation of Alternative B (Ten-Year Plan) likely would not affect protected, candidate, or sensitive species. Proposed locations for the new two, 81-hectare (200-acre) area facilities would not affect protected, candidate, or sensitive species. As discussed in Section 5.9.2.1, locations of current facilities do not affect these species. However, preactivity surveys would be conducted before construction to identify any protected or sensitive resources in the specific areas proposed for the facilities. Mitigations, including relocating the facilities, would be considered and implemented as needed based on the findings of the surveys and appropriate consultation with the U.S. Fish and Wildlife Service. 
5.9.3.2 Wetlands. Potential wetlands and aquatic resources would not be affected under Alternative B (Ten-Year Plan). Currently, no jurisdictional wetlands are known to exist on or near any of the facilities. Projects that would disturb habitat (especially outside of facility boundaries) would be evaluated to determine if jurisdictional wetlands are present. Activities would be modified to avoid affecting any identified wetlands. If avoidance is not possible, DOE would consult with the U.S. Corps of Engineers to obtain permits and develop any needed mitigation (for example, construction of new wetlands, enhancement of existing wetlands).

5.9.3.3 Potential Radiological Impacts. During the remediation period, potential radionuclide exposure and uptake by plants and animals in and near affected areas may increase compared with current exposure and uptake. Potential long-term exposure and uptake would be lower compared to Alternative $A$ (No Action) as additional sites and facilities are remediated. A positive effect of Alternative B (Ten-Year Plan) would be that radionuclide uptake and accumulation by animals and plants would decrease toward background levels after cleanup activities have taken place. Biotic populations and communities exposed to current radionuclide levels do not appear to be different in abundance or species composition compared with populations in similar nearby habitat that are not exposed to elevated radionuclides (Morris 1993b).

5.9.3.4 Ecological Impacts from Specific Activities. Reracking of spent nuclear fuel at CPP-666 will not disturb vegetation nor result in emissions that would be detrimental to biological resources because all activities are within a building. The construction and operation of the Waste Immobilization Facility (processing sodium-bearing liquid waste or calcined high-level waste) would remove about 0.4 hectare ( 1 acre) of previously disturbed habitat from production permanently. In addition, animals would be displaced from the sites and may be displaced from the immediate vicinity. Habitat fragmentation would be minimal because the facility would be constructed within the boundary of an existing industrialized area. Incineration at the existing Waste Experimental Reduction Facility would result in an increase in air emissions. However, the increase is below levels considered harmful to resources. 


\subsubsection{Ecological Impacts from Alternative C (Minimum Treatment, Storage, and Dlaposal)}

Effects to biological resources would be similar to those described under Alternative B (Ten-Year Plan); however, the scale of impact would be lower (see Section 5.9.3) with the exception that benefits associated with revegetation would not be gained. About 141 hectares (349 acres) would be disturbed under Alternative C (Minimum Treatment, Storage, and Disposal), 51 hectares (127 acres) of previously undisturbed habitat (within existing facilities) and 90 hectares (222 acres) of previously disturbed habitat. About 91 hectares (225 acres) would be revegetated under this alternative. Consequently, there would be a long-term net loss of 50 hectares (124 acres). Also, 2 new artificial water sources would be created, less than 20 new night lights would be installed, and 3 temporary and 2 permanent generators would be operated during the day.

The replacement of high-level waste storage tanks would disturb about 8 hectares (20 acres) of previously disturbed habitat in close proximity to industrial activities. Human activity during periods when new tanks are built and old tanks removed may temporarily displace animals using habitat in surrounding areas during the day. Air emissions would not have measurable effects on biota. The construction and operation of the Waste Immobilization Facility would remove about 0.4 hectare ( 1 acre) of previously disturbed habitat from production permanently. In addition, animals would be displaced from the sites and may be displaced from the immediate vicinity. Habitat fragmentation would be minimal because the facility would be constructed within the boundary of an existing industrialized area.

\subsubsection{Ecological Impacts from Alternative D (Maximum Treatment, Storage, and Disposal)}

Effects to biological resources including protected species and wetlands would be similar to those described under Alternative B (Ten-Year Plan), but larger in scale because of the increase in area disturbed. About 451 hectares (1,117 acres) of land would be disturbed under Alternative D (Maximum Treatment, Storage, and Disposal), 340 hectares (842 acres) of undisturbed habitat and 111 hectares (275 acres) of previously disturbed habitat. To minimize the potential short-term effects of the disturbance described above, about 91 hectares (225 acres) of the 451 hectares $(1,117$ acres) to be disturbed would be revegetated. Consequently, there would 
be a long-term net loss of 360 hectares ( 892 acres). The majority of the long-term loss of the $\mathbf{3 6 0}$ hectares (892 acres) would be from construction and operation of the Private Sector Alpha-Mixed Low-Level Waste Treatment and Disposal Facilities and the Idaho Waste Processing Facility; all three to be located several kilometers from existing facilities. Additional acres to be disturbed are primarily associated with the expansion of the gravel pits [about 40 hectares (100 acres)] and the expansion of the landfill [about 113 hectares (280 acres)]. The number and type of other effects would be similar as described in Alternative B (Ten-Year Plan) except vehicular traffic and air emissions would be greater. Mitigations would be used as needed (see Section 5.19).

Reracking of spent nuclear fuel at CPP-666 will not disturb vegetation nor result in emissions that would be detrimental to biological resources because all activities are within a building. The construction and operation of the Waste Immobilization Facility (processing sodium-bearing liquid waste or calcined high-level waste) would remove about 0.4 hectare ( 1 acre) of previously disturbed habitat from production permanently. In addition, animals would be displaced from the sites and may be displaced from the immediate vicinity. Habitat fragmentation would be minimal because the facility would be constructed within the boundary of an existing industrialized area. Incineration at the existing Waste Experimental Reduction Facility would result in an increase in air emissions. However, the increase is below levels considered harmful to resources. 


\subsection{Nolse}

This section discusses the potential effects of the four environmental restoration and waste management alternatives and the five specific project activities on noise at the INEL site and in the surrounding area.

\subsubsection{Methodology}

As discussed in Section 4.10, noises generated on the INEL site do not propagate offsite at levels that impact the general population. Therefore, INEL noise impacts for each alternative come from noises generated during the transportation of personnel and materials to and from the site and within nearby communities. These noises are largely a function of the size of the workforce. The INEL operations workforce is expected to decrease from the 10,091 job level in 1995 for all alternatives and all years through the year 2005 (see Section 5.3). Approximately one-half of the total workforce is stationed at the INEL site and one-half is stationed in facilities in Idaho Falls. The increase in the number of construction workers during some years for Alternatives B (Ten-Year Plan) and D (Maximum Treatment, Storage, and Disposal) were not considered relevant to noise impacts, since these workers would be driving private vehicles to and from work, and, as mentioned in Section 4.10, buses are the primary source of roadway noise.

Roadway, aircraft, and railroad noises have been considered. The roadway noises considered are noises caused by busing personnel to and from site work stations, and transporting waste and spent nuclear fuel by truck.

\subsubsection{Nolse Impacts from Alternatives}

Because the operations workforce stationed at the INEL site is expected to be less than the baseline for all years of all alternatives, the overall noise level resulting from site transportation would be expected to be generally lower than the baseline. The lower noise level would probably not be detectable by the average individual in most cases, however, and because there is no evidence of substantial resistance to current noise levels, there is no anticipated impact on noise due to personnel transportation. The number of trucks carrying waste and spent nuclear fuel under any alternative is expected to be, at most, a few per day (see Section 5.11). These 
trucks would be virtually undetectable from a noise perspective and certainly would not represent an environmental impact compared with the several hundred buses (about 300 routes) that travel to and from the INEL each day.

With regard to aircraft noises, the modest changes in the workforce for each alternative would be insufficient to change the combined number of aircraft landings in the Idaho Falls and Pocatello airfields. Likewise, regional freight trains would not be expected to increase or decrease in number as a result of any alternative. Rail shipments of spent nuclear fuel, regardless of alternative, are a small fraction of the rail traffic on the Mackay Branch of the Union Pacific System that traverses the INEL site and services the site via the Scoville spur.

The following specific activities, which must be evaluated in the Record of Decision, would have no quantifirole impacts on noise at the INEL site, because none of the activities or combinations of activities would result in an increase in bus traffic of more than 2 or 3 out of 150300 buses.

- Additional storage racks in the Idaho Chemical Processing Plant Fluorinel and Storage (FAST) Facility under Alternatives B (Ten-Year Plan) and D (Maximum Trestment, Storage, and Disposal)

- $\quad$ Replacement of high-level waste storage tanks under Alternatives C (Minimum Treatment, Storage, and Disposal) and D

- Selection of technology for processing sodium-bearing liquid waste under Alternatives B, C, and D

- Selection of technology for processing calcined high-level waste under Alternatives $B, C$, and D

- Selection of incineration at the Waste Experimertal Reduction Facility for treatment of low-level and mixed low-level waste under Alternatives B and D. 
In summary, no environmental impact due to noise is expected from any of the alternatives or the five specific activities being considered. 


\subsection{Traffic and Transportatior.}

Environmental restoration and waste management activities included in the scope of this Environmental Impact Statement involve the transportation of hazardous and radioactive materials within the boundaries of the INEL (onsite) and on highways and rail systems outside the boundaries of the INEL (offsite). Hazardous materials include commercial chemical products and hazardous wastes that are nonradioactive and are regulated and controlled based on their chemical toxicity. Four main cal gories of radioactive materials are associated with environmental restoration and waste management activities: spent nuclear fuel, transuranic wastes, mixed lowlevel wastes, and low-level wastes. High-level wastes are stored at the INEL, but shipments of high-level wastes are not planned within the time frame of this EIS.

This section summarizes the methods of analysis, potential impacts, and mitigative actions related to transportation of these materials under normal (incident-free) and accident conditions. The impacts are presented by alternative and include doses and health effects.

\subsubsection{Methodology}

This section summarizes the methods of analysis used in determining the environmental consequences of transporting these materials under normal (incident-free) and accident conditions.

5.11.1.1 Methodology for Incident-Free Transportation. Radiological impacts were determined for two groups of people during normal, incident-free transportation: (a) crewmen and (b) general population. For truck shipments, the crewmen were the drivers of the shipment. For rail shipments, the crewmen were workers in close proximity to the shipping containers during the inspection or classification of railcars. The general population was persons within 2,625 feet (800 meters) of the transport link (off-link), persons sharing the transport link (on-link), and persons at stops. Off-link doses, on-link doses, and doses at stops were evaluated for offsite shipments. Because the general population does not reside on the INEL and the INEL facilities are located far from major roads, no off-link doses or doses at stops were calculated for onsite shipments. However, on-link doses were evaluated for onsite shipments because the general population does have access to the majority of the roads on the INEL. Radiological impacts were 
calculated using the RADTRAN 4 computer code (Neuhauser and Kanipe 1992) and the RISKIND computer code (Yuan et al. 1993).

Each category of material to be transported was assigned a dose rate based on its radiological characteristics, and all shipments were made by exclusive use vehicle. Remotehandled transuranic waste and remote-handled low-level waste were assigned a dose rate of 5 millirem per hour at 3.28 feet (1 meter) from the shipping container (DOE 1990); contacthandled transuranic waste and contact-handled low-level waste were assigned a dose rate of 1 millirem per hour at 3.28 feet (1 meter) from the shipping container (DOE 1990); and spent nuclear fuel was assigned a dose rate of 14 millirem per hour at 3.28 feet ( 1 meter) from the shipping container. A dose rate of 14 millirem per hour at 3.28 feet (1 meter) from the shipping container yielded a dose rate of 10 millirem per hour at 6.56 feet ( 2 meters) from the edge of the transport vehicle, the regulatory limit for an exclusive use vehicle (Madsen et al. 1986). A dose rate of 1 millirem per hour at 3.28 feet (1 meter) was used for naval-type spent nuclear fuel shipments, which was based on measured dose rates from previous naval spent nuclear fuel shipments.

The calculation of the doses was based on the development of unit risk factors. Unit risk factors provide an estimate of the dose to an exposure group from transporting one shipment of radioactive material over a unit distance of travel in a given population density zone (rural, suburban, and urban). Unit risk factors have units of person-rem per kilometer and may be combined with routing information, such as the shipment distances in various population density zones and the total number of shipments, to determine the dose for a series of shipments between a given origin and destination. Using RADTRAN 4, unit risk factors were developed based on travel within rural, suburban, and urban population zones. Truck routes were determined using the HIGHWAY computer code (Johnson et al. 1993a), and train routes were determined using the INTERLINE computer code (Johnson et al. 1993b). Table 5.11-1 contains the route data for waste shipments, and Appendix I of Volume 1 of this EIS contains the route data for spent nuclear fuel. The routes were chosen to be representative and to conform to current routing practices and guidelines. The unit risk factors for waste shipments are presented in Tables 5.11-2 and 5.11-3. The unit risk factors for spent nuclear fuel shipments are presented in Appendix I of Volume 1 of this EIS. 
Table 5-11.1. Transportation distances letween facilities for waste shipments.

\begin{tabular}{|c|c|c|c|c|c|}
\hline & Route & Miles & $\begin{array}{l}\text { Percent } \\
\text { rural }\end{array}$ & $\begin{array}{l}\text { Percent } \\
\text { suburban }\end{array}$ & $\begin{array}{c}\text { Percent } \\
\text { urban }\end{array}$ \\
\hline \multicolumn{6}{|c|}{ Truct routes } \\
\hline INEL & Rocky Flats, Golden, CO & 730.0 & 90.2 & 8.4 & 1.4 \\
\hline INEL & $\begin{array}{l}\text { Waste lsolation Pilot Plant, } \\
\text { Carlsbad, NM }\end{array}$ & 1396.0 & 90.5 & 8.3 & 1.1 \\
\hline INEL & $\begin{array}{l}\text { Engineering Technology Engineering } \\
\text { Center, Ventura County, CA }\end{array}$ & 1553.0 & 77.2 & 15.8 & 7.0 \\
\hline INEL & $\begin{array}{l}\text { Inhalation Toxicology Reacarch } \\
\text { Institute, Abuquerque, NM }\end{array}$ & 1181.0 & 88.7 & 9.7 & 1.6 \\
\hline INEL & PANTEX, Amarillo, TX & 1472.0 & 89.8 & 8.6 & 1.6 \\
\hline INEL & $\begin{array}{l}\text { Argonne National Laboratory-East, } \\
\text { Argonne, IL }\end{array}$ & 1586.0 & 91.2 & 8.2 & 0.6 \\
\hline INEL & $\begin{array}{l}\text { Los Alamos National Laboratory, } \\
\text { Los Alamos, NM }\end{array}$ & 1148.0 & 88.8 & 9.8 & 1.4 \\
\hline INEL & $\begin{array}{l}\text { Sandia National Laboratories, } \\
\text { Albuquerque, NM }\end{array}$ & 1172.0 & 88.7 & 9.8 & 1.5 \\
\hline INEL & Nevada Test Site, NV & 716.0 & 82.9 & 13.6 & 3.5 \\
\hline INEL & Hanford Site, WA & 603.0 & 91.3 & 7.6 & 1.1 \\
\hline INEL & $\begin{array}{l}\text { Private Sector Facility, } \\
\text { (Southeastem United States) }\end{array}$ & 2513.0 & 81.4 & 17.3 & 1.3 \\
\hline \multicolumn{6}{|c|}{ Train routes } \\
\hline INEL & Rocky Flats, Golden, CO & 756.2 & 87.4 & 10.9 & 1.7 \\
\hline INEL & $\begin{array}{l}\text { Waste Lolation Pilot Plant, } \\
\text { Carisbad, NM }\end{array}$ & 1447.1 & 91.1 & 8.0 & 0.9 \\
\hline INEL & $\begin{array}{l}\text { Engineering Technology Engineering } \\
\text { Center, Ventura County, CA }\end{array}$ & 1005.6 & 84.2 & 10.1 & 5.7 \\
\hline INEL & $\begin{array}{l}\text { Inhalation Toxicology Research } \\
\text { Institute, Albuquerque, NM }\end{array}$ & 1250.0 & 90.8 & 7.8 & 1.4 \\
\hline INEL & PANTEX, Amarillo, TX & 1154.6 & 92.1 & 6.6 & 1.2 \\
\hline INEL & $\begin{array}{l}\text { Argonne National Laboratory-East, } \\
\text { Argonne, IL }\end{array}$ & 1561.8 & 89.4 & 8.2 & 2.3 \\
\hline INEL & $\begin{array}{l}\text { Los Alamos National Laboratory, } \\
\text { Los Alamos, NM }\end{array}$ & 1182.0 & 91.9 & 7.1 & 1.0 \\
\hline INEL & $\begin{array}{l}\text { Sandia National Laboratorica, } \\
\text { Albuquerque, NM }\end{array}$ & 1250.0 & 90.8 & 7.8 & 1.4 \\
\hline INEL & Nevads Test Site, NV & 756.1 & 92.8 & 5.9 & 1.3 \\
\hline INEL & Hanford Site, WA & 675.6 & 91.7 & 6.9 & 1.4 \\
\hline INEL & $\begin{array}{l}\text { Private Sector Facility } \\
\text { (Southeastern United States) }\end{array}$ & 2661.1 & 81.4 & 15.6 & 3.0 \\
\hline
\end{tabular}


Table 5.11-2 Incident-free unit risk factors for truck and rail shipments of remote-handled transuranic waste and low-level waste.

\begin{tabular}{|c|c|c|c|c|}
\hline \multirow[b]{2}{*}{ Mode } & \multirow[b]{2}{*}{ Exposure group } & \multicolumn{3}{|c|}{ Unit risk factors (person-rem per kilometer) } \\
\hline & & Rural & Suburban & Urban \\
\hline \multicolumn{5}{|l|}{ Truck } \\
\hline & Occupational & $7.4 \times 10^{-5}$ & $1.6 \times 10^{-4}$ & $2.7 \times 10^{-4}$ \\
\hline \multicolumn{5}{|c|}{ General population } \\
\hline & Off-link $k^{b}$ & $4.4 \times 10^{-8}$ & $5.8 \times 10^{-6}$ & $3.9 \times 10^{-5}$ \\
\hline & On-link $k^{c}$ & $1.8 \times 10^{-6}$ & $5.2 \times 10^{-6}$ & $5.3 \times 10^{-5}$ \\
\hline & Stops & $4.3 \times 10^{-5}$ & $4.3 \times 10^{-5}$ & $4.3 \times 10^{-5}$ \\
\hline & $\begin{array}{l}\text { General population } \\
\text { total }\end{array}$ & $4.5 \times 10^{-5}$ & $5.4 \times 10^{-5}$ & $1.3 \times 10^{-4}$ \\
\hline \multicolumn{5}{|l|}{ Rail } \\
\hline & Occupational $^{d}$ & $3.6 \times 10^{-6}$ & $3.6 \times 10^{-6}$ & $3.6 \times 10^{-6}$ \\
\hline \multicolumn{5}{|c|}{ General population } \\
\hline & Off-link $k^{b}$ & $6.1 \times 10^{-8}$ & $1.2 \times 10^{-5}$ & $1.0 \times 10^{-4}$ \\
\hline & On-link ${ }^{c}$ & $2.4 \times 10^{-8}$ & $3.0 \times 10^{-7}$ & $8.4 \times 10^{-7}$ \\
\hline & Stops $^{\mathrm{e}}$ & $1.7 \times 10^{-6}$ & $1.7 \times 10^{-6}$ & $1.7 \times 10^{-6}$ \\
\hline & $\begin{array}{l}\text { General population } \\
\text { total }\end{array}$ & $1.8 \times 10^{-6}$ & $1.4 \times 10^{-5}$ & $1.1 \times 10^{-4}$ \\
\hline \multicolumn{5}{|c|}{$\begin{array}{l}\text { a. The methodology, equations, and data used to develop the unit risk factors are discussed in Madsen } \\
\text { et al. (1986) and Neuhauser and Kanipe (1992). Cashwell et al. (1986) contains a detailed explanation } \\
\text { of the use of unit risk factors. } \\
\text { b. Off-link general population was persons within } 800 \text { meters }(2,625 \text { feet) of the road or railway. } \\
\text { c. On-link general population was persons sharing the road or railway. } \\
\text { d. The nonlinear component of incident-free rail dose for crew workers because of railcar inspections } \\
\text { and classifications is } 0.0040 \text { person-rem per shipment. Ostmeyer (1986) contains a detailed explanation } \\
\text { of the rail exposure model. } \\
\text { e. The nonlinear component of incident-free rail dose for the general population because of railcar } \\
\text { inspections and classifications is } 0.0031 \text { person-rem per shipment. Ostmeyer (1986) contains a detailed } \\
\text { explanation of the rail exposure model. }\end{array}$} \\
\hline
\end{tabular}


Table 5.11-3. Incident-free unit risk factors for truck and rail shipments of contact-handled transuranic waste, low-level waste, and mixed low-level waste.

\begin{tabular}{|c|c|c|c|c|}
\hline \multirow[b]{2}{*}{ Mode } & \multirow[b]{2}{*}{ Exposure group } & \multicolumn{3}{|c|}{ Unit risk factors (person-rem per kilometer) } \\
\hline & & Rural & Suburban & Urban \\
\hline \multicolumn{5}{|l|}{ Truck } \\
\hline & Occupational & $1.5 \times 10^{-5}$ & $3.3 \times 10^{-5}$ & $5.4 \times 10^{-5}$ \\
\hline & \multicolumn{4}{|l|}{ General population } \\
\hline & Off-link ${ }^{b}$ & $8.8 \times 10^{-9}$ & $1.2 \times 10^{-6}$ & $7.7 \times 10^{-6}$ \\
\hline & On-link ${ }^{c}$ & $3.6 \times 10^{-7}$ & $1.0 \times 10^{-6}$ & $1.110^{-5}$ \\
\hline & Stops & $8.6 \times 10^{-6}$ & $8.6 \times 10^{-6}$ & $8.6 \times 10^{-6}$ \\
\hline & $\begin{array}{l}\text { General population } \\
\text { total }\end{array}$ & $9.0 \times 10^{-6}$ & $1.1 \times 10^{-5}$ & $2.7 \times 10^{-5}$ \\
\hline \multicolumn{5}{|l|}{ Rail } \\
\hline & Occupational $^{d}$ & $7.2 \times 10^{-7}$ & $7.2 \times 10^{-7}$ & $7.2 \times 10^{-7}$ \\
\hline & \multicolumn{4}{|l|}{ General population } \\
\hline & Off-link $\mathbf{b}^{\mathrm{b}}$ & $1.2 \times 10^{-8}$ & $2.3 \times 10^{-6}$ & $2.1 \times 10^{-5}$ \\
\hline & On-link ${ }^{c}$ & $4.7 \times 10^{-9}$ & $6.1 \times 10^{-8}$ & $1.7 \times 10^{-7}$ \\
\hline & Stops ${ }^{e}$ & $3.4 \times 10^{-7}$ & $3.4 \times 10^{-7}$ & $3.4 \times 10^{-7}$ \\
\hline & $\begin{array}{l}\text { General population } \\
\text { total }\end{array}$ & $3.6 \times 10^{-7}$ & $2.7 \times 10^{-6}$ & $2.1 \times 10^{-5}$ \\
\hline \multicolumn{5}{|c|}{$\begin{array}{l}\text { a. The methodology, equations, and data used to develop the unit risk factors are discussed in Madsen } \\
\text { et al. (1986) and Neuhauser and Kanipe (1992). Cashwell et al. (1986) contains a detailed explanation } \\
\text { of the use of urit risk factors. } \\
\text { b. Off-link general population was persons within } 800 \text { meters ( } 2,625 \text { feet) of the road or railway. } \\
\text { c. On-link general population was persons sharing the road or railway. } \\
\text { d. The nonlinear component of incident-free rail dose for crew workers because of railcar inspections } \\
\text { and classifications is } 0.00080 \text { person-rem per shipment. Ostmeyer (1986) contains a detailed } \\
\text { explanation of the rail exposure model. } \\
\text { e. The nonlinear component of incident-free rail dose for the general population because of railcar } \\
\text { inspections and classifications is } 0.00062 \text { person-rem per shipment. Ostmeyer (1986) contains a detailed } \\
\text { explanation of the rail exposure model. }\end{array}$} \\
\hline
\end{tabular}


Radiological doses were converted to cancer fatalities using risk conversion factors of $5.0 \times 10^{-4}$ fatal cancers per person-rem for members of the public and $4.0 \times 10^{-4}$ fatal cancers per person-rem for workers. These risk conversion factors are from Publication 60 of the International Commission on Radiological Protection (ICRP 1991).

Nonradiological health effects were also evaluated using unit risk factors. The nonradiological unit risk factors used in this analysis for truck and train transport were $1.0 \times 10^{-7}$ and $1.3 \times 10^{-7}$ health effects per kilometer, respectively (Rao et al. 1982). These unit risk factors account for the fatalities associated with emission of particulates and sulfur dioxide and are applicable only to the urban population zone (Rao et al. 1982). The distance used in the nonradiological analyses must be doubled to reflect the round trip distance because these impacts occur whether or not the shipment contains radioactive material.

Maximum individual doses were calculated using the RISKIND computer code (Yuan et al. 1993). The maximum individual doses for the routine transport offsite were estimated for transportation workers, as well as members of the general population. For rail shipments, the three general population scenarios were (a) a railyard worker who might be working at a distance of 32.8 feet (10 meters) from the shipping container for two hours, (b) a resident who might live 98.4 feet ( 30 meters) from the rail line where the shipping container was being transported, and (c) a resident who could be living 656.2 feet (200 meters) from a rail stop where the shipping container was sitting for 20 hours. For train shipments, the maximum exposed transportation worker was an individual in a railyard who spent a time- and distance-weighted average of 0.16 hours inspecting, classifying, and repairing railcars (Wooden 1986).

For offsite truck shipments, the three scenarios for the general population were: (a) a person who might be caught in traffic and located 3.28 feet (1 meter) away from the surface of the shipping container for one-half hour, (b) a resident who might be living 98.4 feet (30 meters) from the highway used to transport the shipping container, and (c) a service station worker who might be working at a distance of 65.6 feet ( 20 meters) from the shipping container for two hours. The hypothetical maximum exposed individual radiological doses were accumulated over the tenyear period. However, for the situation involving an individual who might be caught in traffic next to a truck, the radiological exposures were only calculated for one event because it was considered unlikely that the same individual would be caught in traffic next to all containers for 
all shipments. For truck shipments, the maximum exposed transportation worker is the driver, who was assumed to drive shipments for up to 2,000 hours per year.

The hypothetical maximally exposed individual scenarios for the general population described above were not applicable for onsite shipments for two reasons. First, there is essentially no traffic during the onsite shipments and an obstruction, if encountered, would be safely avoided by the driver. Second, there are no residents or businesses onsite. Two alternate scenarios were developed. They were: (a) a site employee in a disabled vehicle along the transport route, located 3.28 feet (1 meter) from the container, and (b) a site employee traveling behind the slow-moving transport vehicle for the entire trip. These scenarios were considered to be single-event occurrences.

\subsubsection{Mothodology for Onsite Transportation Accident Analysis. The onsite} transportation accident analysis considers the impacts of accidents during the transportation of spent nuclear fuel and radioactive waste by truck, which is the primary mode of transport onsite. This analysis addresses only shipments within the boundaries of the INEL that originate at one INEL facility and terminate at another INEL facility. The onsite portions of offsite shipments that originate or terminate at the INEL are included in the offsite transportation accident analysis.

Within the boundaries of the INEL, spent nuclear fuel is transported in specially designed casks that have been approved by the DOE. In most cases, these casks have not been approved for transport of spent nuclear fuel over public highways and, therefore, use of these casks is restricted to onsite. Onsite transportation of radioactive wastes is normally conducted using U.S. Department of Transportation Type A containers. In some cases, transuranic wastes are required to be transported onsite using a U.S. Department of Transportation Type B container, for example, the TRUPACT-II shipping container.

A maximum reasonably foreseeable assessment was performed for potential spent nuclear fuel and radioactive waste transportation accidents. Impacts are assessed for areas within a 50mile (80-kilometer) radius. Because of the extensive land area occupied by the INEL and the distances between facilities, the potential impacts to surrounding communities from an onsite transportation accident are highly dependent on where the accident occurs. 
Because it is not possible to predict where on the INEL an accident might occur and the specific public areas that might be affected, the accident analysis assesses impacts in terms of generic rural and suburban population areas. The generic rural population area has an average population density of six persons per square kilometer and is typical of most areas within 30 miles ( 48 kilometers) of the geographical center of the INEL site. The generic suburban population area has an average population density of 719 persons per square kilometer and bounds the most densely populated areas within 50 miles ( 80 kilometers) of the INEL.

The consequences of the maximum reasonably foreseeable onsite transportation accident were calculated using the RISKIND computer code (Yuan et al. 1993). Consequences were assessed under both neutral and stable atmospheric conditions. Neutral conditions are typical of average conditions that result in good dispersion and dilution of atmospheric contaminants. Stable atmospheric conditions occur less than 5 percent of the time and result in low dispersion and dilution of atmospheric contaminants. Calculated radiation doses were used to estimate the potential for fatal cancers in the exposed populations using risk factors developed by the International Commission on Radiological Protection (ICRP 1991).

The maximum reasonably foreseeable onsite transportation accidents are extremely unlikely events, with estimated probabilities of occurrence ranging from $1 \times 10^{-7}$ to $3.9 \times 10^{-5}$ per year. The impacts of maximum reasonably foreseeable accidents are represented by an estimate of risk obtained by multiplying the consequences (fatal cancers) by the probability of the accident.

\subsubsection{Methodology for Offsite Transportation Accident Analysis. For offsite} spent nuclear fuel and radioactive waste transportation accidents, accident risk assessment was performed using methodology developed by the U.S. Nuclear Regulatory Commission for calculating the probabilities and consequences from a spectrum of unlikely accidents. Although it is not possible to predict where along the transport route such accidents might occur, the accident risk assessment used route-specific information for accident rates and population densities. Radiation doses for population zones (rural, suburban, and urban) were weighted by the accident probabilities to yield "dose risk" using the RADTRAN 4 computer code. To represent the maximum reasonably foreseeable impacts to individuals and populations should an accident occur, radiological consequences were calculated for an accident of maximum credible severity in each population zone using the RISKIND computer code. 
Accident analyses for spent nuclear fuel and radioactive waste shipments are performed similarly except for the methodology used in the assessment of accident severity categories, conditional probabilities, and radioactive material release characteristics. For spent nuclear fuel shipments, the methodology contained in a U.S. Nuclear Regulatory Commission report commonly known as the Modal Study (Fischer et al. 1987) was used. For radioactive waste shipments, the methodology derives from NUREG-0170 (NRC 1977). Accident rates, atmospheric conditions, population density zones, and health risk conversion factors are the same for both sets of analyses.

Differences in spent nuclear fuel types translate into different radioactive material release characteristics under accident conditions; thus, analyses were performed for each of nine representative spent nuclear fuel types. Characterization data for the representative spent nuclear fuel types were developed based on published reports and computer calculations using the ORIGEN2 computer code (Croff 1980). Similarly, an important variable in the assessment of impacts from radioactive waste transportation accidents is the type and amount of radioactive and other hazardous material in radioactive waste. Transuranic waste characterization data were derived from the Final Supplement Environmental Impact Statement for the Waste Isolation Pilot Plant (DOE 1990). Low-level waste characterization data were derived from DOE waste management databases and computational models (Cornelius 1993). The radiological component of mixed low-level waste was characterized the same as low-level waste. The nonradiological component of mixed low-level waste was characterized based on data from the DOE Integrated Data Base (DOE 1992).

Accident severity categories for all potential spent nuclear fuel transportation accidents and radioactive waste transportation accidents are described in the Modal Study (Fischer et al. 1987) and NUREG-0170 (NRC 1977), respectively. Severity is a function of the magnitudes of the mechanical forces (impact) and thermal forces (fire) to which a cask may be subjected during an accident. The accident severity scheme takes into account all credible transportation accidents. Spent nuclear fuel transportation accidents are grouped into $\mathbf{2 0}$ accident severity categories, ranging from high-probability events with low consequences to low-probability events with high consequences. The accident severity scheme for radioactive waste shipments is similar, but only eight severity categories are assigned. Each accident severity category is assigned a conditional 
probability, which is the probability, given that an accident occurs, that the accident will be of the indicated severity.

Radioactive material releases from transportation accidents were calculated by assigning release fractions (the fraction of the radioactivity in the shipment that could be released in a given severity of accident) to each accident severity category for each chemically and physically distinct radioisotope. Representative release fractions were developed for each of the representative spent nuclear fuel types based on the Modal Study and other published reports. Release fractions for transuranic waste were derived from the Waste Isolation Pilot Plant Supplemental Environmental Impact Statement (DOE 1990), which based its analysis on the accident severity model in NUREG-0170. Representative release fractions for low-level and mixed low-level waste were derived from NUREG-0170 and recommended values from Elder et al. (1986).

Radioactive material released to the atmosphere is transported by wind. The amount of dispersion, or dilution, of the radioactive material concentrations in the air depends on the meteorological conditions at the time of the accident. Neutral meteorological conditions are the most frequently occurring atmospheric stability conditions in the United States and, therefore, are most likely to be present in the event of an accident involving a spent nuclear fuel or radioactive waste shipment. For accident risk assessment, neutral weather conditions (Pasquill Stability Class D) were assumed (Doty et al. 1976). For the accident consequence assessment, doses were assessed under both neutral (Class D) and stable (Class F) atmospheric conditions, representing the most likely consequences and a worst-case weather situation, respectively.

Radiological doses were calculated for an individual located near the scene of the accident and for populations within 50 miles ( 80 kilometers) of the accident. Three population density zones (rural, suburban, and urban) were assessed. Dose calculations considered a variety of exposure pathways, including inhalation and direct exposure (cloudshine) from the passing cloud, ingestion from contaminated crops, direct exposure (groundshine) from radioactivity deposited on the ground, and inhalation of resuspended radioactive particles from the ground. Human health effects that could result from the radiation doses received were estimated using risk factors recommended by the International Commission on Radiological Protection (ICRP 1991). 
The transportation of spent nuclear fuel and radioactive waste also results in nonradiological accident risks, such as injuries or fatalities sustained by physical impact with the transport vehicle. Nonradiological fatal accident risks for truck transportation were calculated for each postulated transport route, using state-specific accident fatality rates for interstate highways in urban and rural areas (Saricks and Kvitek 1991). Accident fatality risks for rail transportation were calculated using a nationwide average rate of $2.64 \times 10^{-8}$ fatalities per rail-kilometer (Cashwell et al. 1986).

\subsubsection{Methodology for Hazardous Material Transportation Accident Analysis.}

This section describes the analysis of the maximum reasonably foreseeable accident for the planned transportation of hazardous materials to a id from the INEL during the period covered by this EIS. The information in this section has been summarized from Wierman (1994).

The accident analysis assesses only truck transportation because all of the hazardous materials transported to or from the INEL are transported by truck. The accident scenario postulates a truck accident leading to a breach of chemical containers and release of chemicals to the environment. The resulting spill either evaporates (liquid spill) or escapes directly to the atmosphere (gas release). Extenuating circumstances, such as an accompanying fire or explosion, are not analyzed. The accident consequences are assessed for rural, suburban, and urban population density zones.

The HIGHWAY computer code was used to generate distances, population densities, and correlation of distance and population densities. The probability of a releasing accident is calculated based on the type of region the truck is traveling through and the type of truck. $A$ cross-classification study conducted in California matched accident data and corresponding exposures (shipment-miles) for selected sites statewide to generate accident involvement rates by category of highway and truck configuration. The probability of hazardous material release given an accident were cierived from an evaluation of Highway Patrol accident reports from the State of Missouri. The accident reports contained data identifying whether each vehicle involved in an accident was carrying hazardous materials, what type(s) of material were carried, and whether or not a hazardous material release occurred. 
In the maximum reasonably foreseeable case truck accident scenario, the hazardous chemical of interest is nitric acid, because it has the capability to affect the largest number of persons in a population due to the relatively high toxicity of nitric acid and the large quantities in which it is transported. The release is modeled as a total release of the nitric acid inventory for a shipment (4,200 gallons).

The consequences of the offsite hazardous material transportation accidents are expressed in terms of Emergency Response Planning Guidelines. Emergency Response Planning Guidelines have been developed to provide estimates of concentration ranges above which one could reasonably anticipate observing adverse effects as described in the definitions for Emergency Response Planning Guideline-1, Emergency Response Planning Guideline-2, and Emergency Response Planning Guideline-3. The Emergency Response Planning Guidelines are the maximum airborne concentrations below which it is believed that nearly all individuals could be exposed for up to one hour (a) without adverse health effects or perceiving a clearly defined objectionable odor (Emergency Response Planning Guideline-1), (b) without experiencing or developing irreversible or other serious health effects or symptoms that could impair their abilities to take protective action (Emergency Response Planning Guideline-2), or (c) without experiencing or developing life-threatening health effects (Emergency Response Planning Guideline-3).

5.11.1.5 Methodology for Regional Traffic Impact Analysis. Transportation by road of people and materials that are required because of increased construction and operational activities due to the various alternatives could impact the regional traffic system around the INEL and result in increases in traffic accidents, injuries, and fatalities. These impacts, such as increased vehicle mileage, accidents, and traffic congestion, are measured using the level of service for road segments.

The level-of-service concept is defined as a qualitative measure describing operational conditions within a traffic stream and their perception by motorists and passengers. A level of service is defined for each roadway or section of roadway in terms of speed and travel time, freedom to maneuver, traffic interruptions, comfort and convenience, and safety. The six levels of service are defined below (Transportation Research Board 1985). 
- Level-of-Service A represents free flow. Individual users are virtually unaffected by the presence of others in the traffic stream. Freedom to select desired speeds and to maneuver within the traffic stream is extremely high. The general level of comfort and convenience provided to the motorist, passenger, or pedestrian is excellent.

- Level-of-Service B is in the range of stable flow, but the presence of other users in the traffic stream begins to be noticeable. Freedom to select desired speeds is relatively unaffected, but there is a slight decline in the freedom to maneuver within the traffic stream from Level-of-Service $A$. The level of comfort and convenience provided is somewhat less than at Level-of-Service $A$ because the presence of others in the traffic stream begins to affect individual behavior.

- Level-of-Service $C$ is in the range of stable flow, but marks the beginning of the range of flow in which the operation of individual users becomes significantly affected by interactions with others in the traffic stream. The selection of speed is now affected by the presence of others, and maneuvering within the traffic stream requires substantial vigilance on the part of the user. The general level of comfort and convenience declines noticeably at this level.

- Level-of-Service D represents high-density, but stable, flow. Speed and freedom to maneuver are severely restricted, and the driver or pedestrian experiences a generally poor level of comfort and convenience. Small increases in traffic flow will generally cause operational problems at this level.

- Level-of-Service E represents operating conditions at or near the capacity level. All speeds are reduced to a low, but relatively uniform, value. Freedom to maneuver within the traffic stream is extremely difficult, and it is generally accomplished by forcing a vehicle or pedestrian to "give way" to accommodate such maneuvers. Comfort and convenience levels are extremely poor, and driver or pedestrian frustration is generally high. Operations at this level are usually unstable because small increases in flow or minor perturbations within the traffic stream will cause breakdowns. 
- Level-of-Service $\mathrm{F}$ is used to define forced or breakdown flow. This condition exists wherever the amount of traffic approaching a point exceeds the amount that can traverse the point. Queues form behind such locations. Operations within the queue are characterized by stop-and-go waves, and they are extremely unstable. Vehicles may progress at reasonable speeds for several hundred feet or more, then be required to stop in a cyclic fashion. Level-of-Service $F$ is used to describe the operating conditions within the queue, as well as the point of the breakdown. It should be noted, however, that in many cases, operating conditions of vehicles or pedestrians discharged from the queue may be quite good. Nevertheless, it is the point at which arrival flow exceeds discharge flow which causes the queue to form, and Level-of-Service $\mathrm{F}$ is an appropriate designation for such points.

For purposes of evaluating impacts of increased traffic and usage, the capacity of the roadway in terms of vehicles per hour for a given level of service is first established using the procedures in Transportation Research Board (1985). The level of service based on existing traffic flow is then established. A new level of service is then calculated, based on the number of shipments of waste, spent nuclear fuel, and construction materials, and the number of workers associated with each alternative. These levels of service are then compared to determine if the capacity of the highway is exceeded or if the level of service has changed.

\subsubsection{Traffic and Transportation Impacts from Alternatlves}

This section summarizes the impacts on traffic and transportation for the various environmental restoration and waste management alternatives being considered.

5.11.2.1 Shipments. The waste shipments associated with Alternatives $A$ through $D$ are summarized in Table 5.11-4. For Alternative A (No Action), no transuranic waste would be transported to INEL, but INEL potentially would transport transuranic waste to the Waste Isolation Pilot Plant. Low-level waste would be transported offsite for treatment, and the treated waste would be transported back to the INEL. No offsite shipment of mixed low-level waste is expected to occur. The INEL would continue to make periodic shipments of hazardous waste to offsite disposal facilities, and shipments of bulk hazardous chemicals used by INEL operations would continue. 


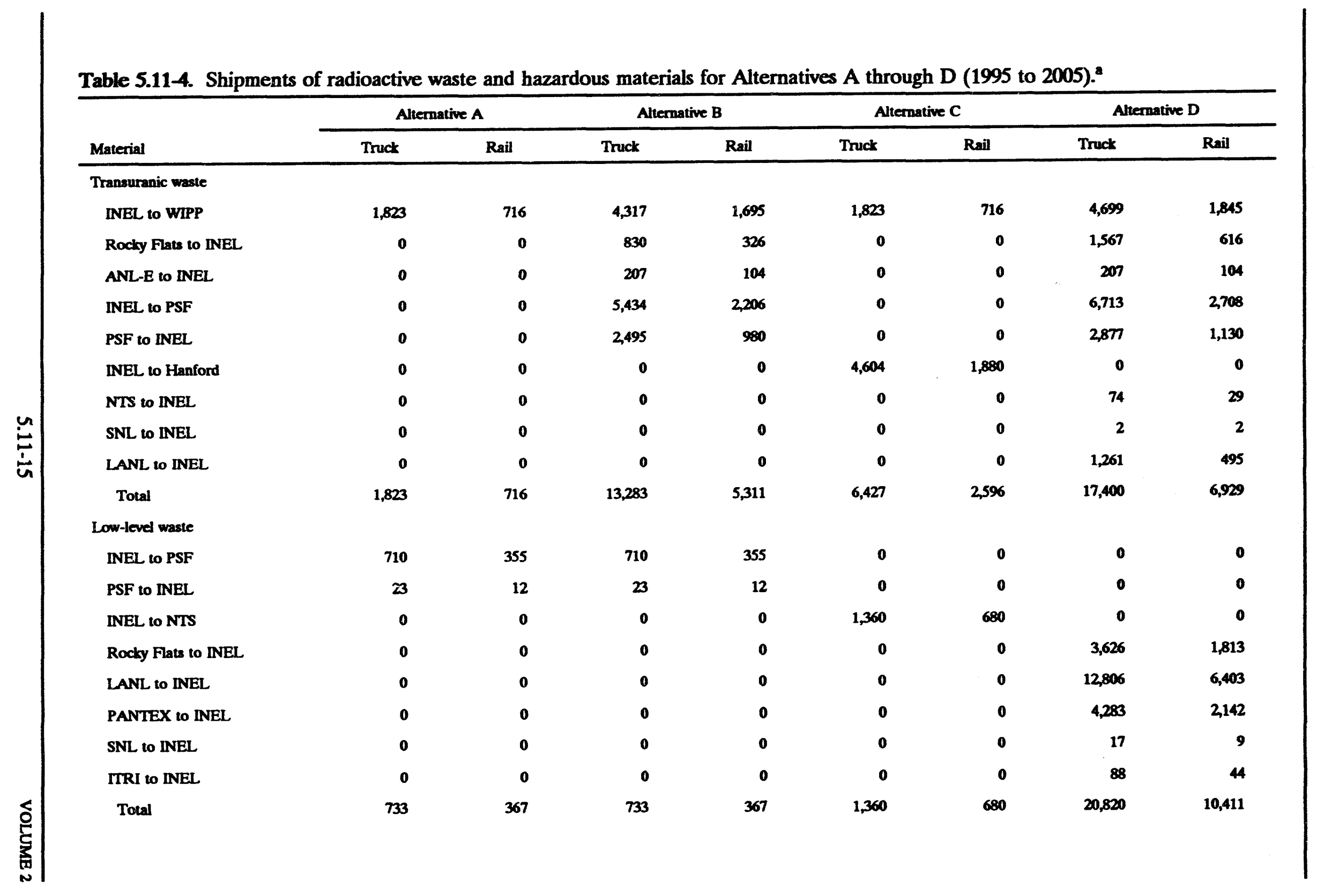


Table 5.11-4. (continued).

\begin{tabular}{|c|c|c|c|c|c|c|c|c|}
\hline \multirow[b]{2}{*}{ Material } & \multicolumn{2}{|c|}{ Alternative A } & \multicolumn{2}{|c|}{ Atternative B } & \multicolumn{2}{|c|}{ Alternative C } & \multicolumn{2}{|c|}{ Alternative D } \\
\hline & Truck & Rail & Truck & Rail & Truck & Rail & Truck & Rail \\
\hline \multicolumn{9}{|l|}{ Mixed low-level waste } \\
\hline INEL to NTS or Hanford & $\mathbf{0}$ & $\mathbf{0}$ & $\mathbf{0}$ & $\mathbf{0}$ & 447 & 224 & $\mathbf{0}$ & $\mathbf{0}$ \\
\hline Rocky Flats to INEL & $\mathbf{0}$ & $\mathbf{0}$ & 0 & $\mathbf{0}$ & $\mathbf{0}$ & $\mathbf{0}$ & 4,203 & 2,102 \\
\hline LANL to INEL & $\mathbf{0}$ & 0 & $\mathbf{0}$ & 0 & $\mathbf{0}$ & $\mathbf{0}$ & 176 & 88 \\
\hline PANTEX to INEL & $\mathbf{0}$ & $\mathbf{0}$ & $\mathbf{0}$ & 0 & 0 & $\mathbf{0}$ & 56 & 28 \\
\hline ETEC to INEL & $\mathbf{0}$ & $\mathbf{0}$ & $\mathbf{0}$ & $\mathbf{0}$ & 0 & $\mathbf{0}$ & 44 & 22 \\
\hline Total & $\mathbf{0}$ & $\mathbf{0}$ & $\mathbf{0}$ & $\mathbf{0}$ & 447 & 224 & 4,479 & 2,240 \\
\hline Onsite radiosctive waste & 100 & $\mathbf{0}$ & 1,365 & 0 & 100 & $\mathbf{0}$ & 1,365 & $\mathbf{0}$ \\
\hline
\end{tabular}

a. Shipment counts represent 100 percent by truck or 100 percent by rail, except for onsite shipments that only use truck.

Note: WIPP $=$ Waste Isolation Pilot Plant, ANL-E = Argonne National Laboratory-East, PSF $=$ Private Sector Facility, NTS = Nevada Test Site, SNL $=$ Sandia National Nos Alamos National Laboratory, ITRI = Inhalation Toxioology Research Institute, ETEC = Engincering Technolozy Engineering Center. 
For Alternative B (Ten-Year Plan), offsite shipments of low-level waste and mixed lowlevel waste would be the same as Alternative A (Nó Action). Increased transuranic waste shipment activity would occur with Rocky Flats and Argonne National Laboratory-East shipments to INEL, shipments of INEL waste to and from offsite treatment facilities, and potentially increased shipments to the Waste Isolation Pilot Plant. The INEL would make increased shipments of hazardous waste to offsite disposal facilities as a result of increased environmental restoration activities. Shipments of bulk hazardous chemicals to the INEL would be similar to Alternative A.

For Alternative C (Minimum Treatment, Storage, and Disposal), the INEL potentially would transport all stored transuranic waste to the Waste Isolation Pilot Plant and the Hanford Site. The INEL would transport stored low-level and mixed low-level waste to the Nevada Test Site. Shipments of hazardous waste for offsite disposal and shipments of bulk hazardous chemicals to the INEL would be similar to Alternative A (No Action).

For Alternative D (Maximum Treatment, Storage, and Disposal), the INEL would receive increased shipments of transuranic, low-level, and mixed low-level waste from various DOE sites. Increased shipments of transuranic waste to private-sector treatment facilities would be made. Shipments of hazardous waste to offsite disposal facilities and shipments of bulk hazardous chemicals to the INEL site would be similar to Alternative B (Ten-Year Plan).

The spent nuclear fuel shipments associated with Alternatives $A$ through $D$ are summarized in Table 5.11-5. Alternative A corresponds to No Action, Alternative $B^{\prime}$ corresponds to 1992/1993 Planning Basis, Alternative B" corresponds to Regionalization by fuel type, Alternative C corresponds to Centralization at Hanford, Savannah River, Oak Ridge, or Nevada Test Site, and Alternative D corresponds to Centralization at the INEL (see Volume 1 of this Environmental Impact Statement). Heiselmann (1994) and Attachment A to Appendix D of Volume 1 of this Environmental Impact Statement contain detailed descriptions of the shipments that occur for each alternative. For Alternative $A$, there would be no offsite shipments except for limited naval spent nuclear fuel and test specimen shipments. 


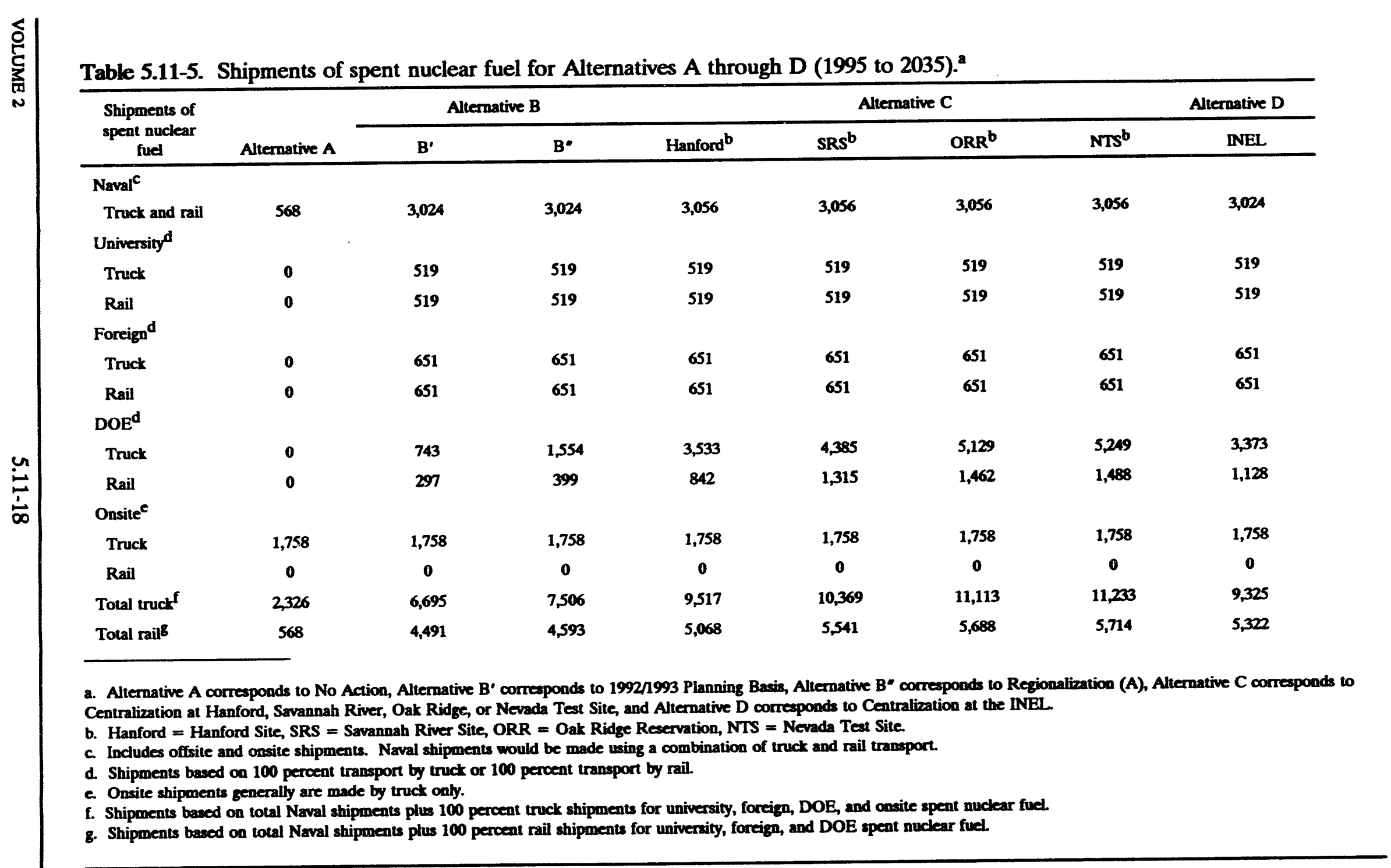


For Alternatives $B^{\prime}$ and $B^{\prime \prime}$, the Navy would resume shipments of spent nuclear fuel from the shipyards to the INEL and shipments of irradiated test specimens from the INEL to offsite locations. All of the Fort Saint Vrain spent nuclear fuel currently in storage in Colorado and all commercial-type spent nuclear fuel stored at the West Valley Demonstration Project in New York would be transported to the INEL site. The INEL site would receive shipments of some of the DOE research and test reactor spent nuclear fuel currently stored at other DOE sites with a greater amount received under Alternative B". In addition, the INEL site would receive spent nuclear fuel shipments from various domestic university and foreign research reactors and other non-DOE U.S. government reactors.

For Alternative C (Minimum Treatment, Storage, and Disposal), all spent nuclear fuel currently stored at the INEL site would be transported offsite to one of four DOE sites: Hanford, Savannah River Site, Oak Ridge, or Nevada Test Site. No shipments of spent nuclear fuel would be made to the INEL site.

For Alternative D (Maximum Treatment, Storage, and Disposal), all spent nuclear fuel currently stored at other DOE sites, Fort Saint Vrain, university, and foreign research reactors, and other non-DOE U.S. government reactors would be transported to the INEL.

5.11.2.2 Incident-Free Transportation. The impacts of incident-free transport of waste (transuranic, low-level, and mixed low-level) are summarized in Table 5.11-6, and the impacts for spent nuclear fuel are summarized in Tables 5.11-7 and 5.11-8. For truck shipments of waste, it can be seen that Alternative D (Maximum Treatment, Storage, and Disposal) yielded the largest collective doses (1,700 person-rem occupational, 940 person-rem general population), and Alternative A (No Action) yielded the smallest collective doses (120 person-rem occupational, 66 person-rem general population). Alternatives B (Ten-Year Plan) and C (Minimum Treatment, Storage, and Disposal) yielded lower collective doses, 870 and 180 person-rem occupational and 460 and 100 person-rem general population, respectively. For Alternative $D$, approximately one cancer fatality was estimated. Train shipments yielded doses that were much less than truck shipments, ranging from 3.2 to 38 person-rem for workers and 4.1 to 58 for the general population. Nonradiological fatalities from vehicular emissions were about one-third of the total cancer fatalities for truck shipments and about 5 times the number of total cancer fatalities for train shipments. 
Table 5.11-6. Cumulative doses and fatalities from incident-free transport of waste for Alternatives A through D (1995 to 2005 ).

\begin{tabular}{|c|c|c|c|c|c|c|c|c|}
\hline \multirow[b]{3}{*}{ Exposure group } & \multicolumn{8}{|c|}{ Alternative } \\
\hline & \multicolumn{2}{|c|}{ A } & \multicolumn{2}{|c|}{ B } & \multicolumn{2}{|c|}{ c } & \multicolumn{2}{|c|}{ D } \\
\hline & Truck & Rail & Truck & Rail & Truck & Rail & Truck & Rail \\
\hline \multicolumn{9}{|c|}{ Extimated mainum indivituel doece $(\mathrm{rcm})$} \\
\hline Occupational & 27 & 0.17 & 27 & 0.91 & 27 & 0.56 & 27 & 3.1 \\
\hline General population & 0.049 & 0.086 & 0.27 & 0.45 & 0.16 & 0.28 & 0.81 & 1.5 \\
\hline \multicolumn{9}{|c|}{ Estimatod collective dore (panour-rem) } \\
\hline \multicolumn{9}{|l|}{ Occupational } \\
\hline Low-level waste & 54 & 1.4 & 54 & 1.4 & 29 & 1.1 & 650 & 22 \\
\hline Mixed low-level waste & $\mathbf{0}$ & 0 & o & $\mathbf{0}$ & 9.6 & 0.38 & 92 & 38 \\
\hline Transuranic waste & 69 & 1.8 & 810 & 18 & 140 & 4.8 & 1,000 & 23 \\
\hline Onsite & 0.072 & $\mathbf{0}$ & 1.0 & o & 0.072 & $\mathbf{0}$ & 1.0 & 0 \\
\hline Total & 120 & 3.2 & 870 & 20 & 180 & 6.3 & 1700 & 48 \\
\hline \multicolumn{9}{|l|}{ General population } \\
\hline Low-level waste & 28 & 24 & 28 & 24 & 15 & 1.1 & 360 & 21 \\
\hline Mixed low-level waste & $\mathbf{0}$ & $\mathbf{0}$ & $\mathbf{0}$ & $\mathbf{0}$ & 5.1 & 0.35 & 51 & 4.1 \\
\hline Transuranic waste & 38 & 1.7 & 439 & 27 & 80 & 4.5 & 530 & 33 \\
\hline Onsite & 0.00038 & 0 & 0.0054 & 0 & 0.00038 & $\mathbf{0}$ & 0.0054 & $\mathbf{0}$ \\
\hline Total & 66 & 4.1 & 460 & 29 & 100 & 5.9 & 940 & 58 \\
\hline \multicolumn{9}{|c|}{ Extimuled cowoer fotalitios } \\
\hline \multicolumn{9}{|l|}{ Occupational } \\
\hline Low-level waste & 0.022 & 0.00056 & 0.022 & 0.00056 & 0.012 & 0.00044 & 0.26 & 0.0088 \\
\hline Mixed low tevel waste & $\mathbf{0}$ & $\mathbf{0}$ & 0 & $\mathbf{0}$ & 0.0038 & 0.00015 & 0.037 & 0.0015 \\
\hline Transuranic waste & 0.028 & 0.00072 & 0.32 & 0.0072 & 0.056 & 0.0019 & 0.40 & 0.0092 \\
\hline Onsite & $29 \times 10^{-5}$ & 0 & 0.00040 & o & $29 \times 10^{-5}$ & 0 & 0.00040 & 0 \\
\hline Total & 0.048 & 0.0013 & 0.35 & 0.0080 & 0.072 & 0.0025 & 0.68 & 0.019 \\
\hline
\end{tabular}


Table 5.11-6. (continued).

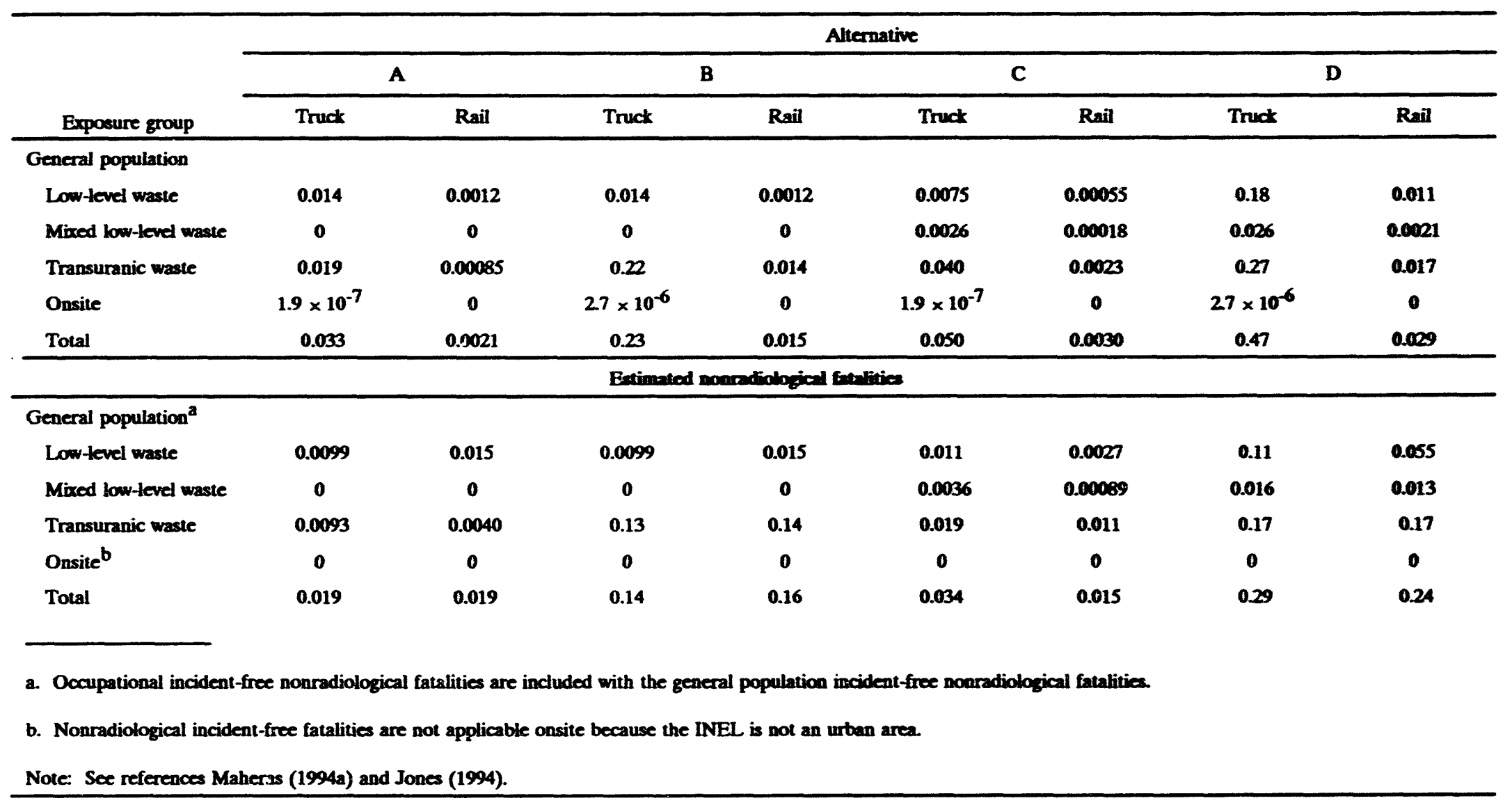




\begin{tabular}{|c|c|c|c|c|c|c|c|c|}
\hline $\begin{array}{l}\text { Table 5.11-7. } \\
\text { (1995 to 2035) }\end{array}$ & llativ & ad fa & & ree trans & spent & fuel $b$ & for $\mathbf{A}$ & s A \\
\hline \multirow[b]{3}{*}{ Exposure group } & \multicolumn{8}{|c|}{ Alternatives, $\mathbf{a}$} \\
\hline & \multirow{2}{*}{$\begin{array}{l}\mathbf{A} \\
\mathbf{A}\end{array}$} & \multicolumn{2}{|c|}{ B } & \multicolumn{4}{|c|}{ C } & \multirow{2}{*}{$\frac{\text { D }}{\text { INEL }}$} \\
\hline & & $\mathbf{B}^{\prime}$ & $\mathbf{B}^{*}$ & Hanfond & SRS & $\mathbf{O R R}^{\mathbf{c}}$ & NTSe & \\
\hline \multicolumn{9}{|c|}{ 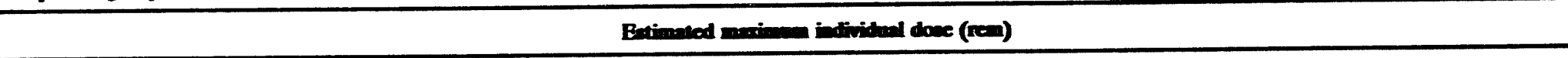 } \\
\hline Occupational & 0.35 & 160 & 160 & 160 & 160 & 160 & 160 & 160 \\
\hline $\begin{array}{l}\text { General } \\
\text { population }\end{array}$ & 0.039 & 0.78 & 1.1 & 1.9 & 23 & 26 & 26 & 18 \\
\hline \multicolumn{9}{|c|}{ 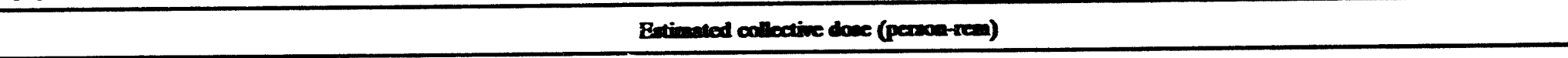 } \\
\hline \multicolumn{9}{|l|}{ Occupational } \\
\hline Naval & 1.5 & 73 & 7.3 & 9.8 & 15 & 14 & 11 & 73 \\
\hline Foreign & $\mathbf{0}$ & 63 & 86 & 130 & $n$ & 71 & 130 & 120 \\
\hline Univeraity & $\mathbf{0}$ & 59 & 54 & 100 & 53 & 42 & 94 & 86 \\
\hline DOE & $\mathbf{0}$ & 66 & 150 & 430 & 830 & 750 & 590 & 380 \\
\hline Onsite & 3.4 & 3.4 & 3.4 & 3.4 & 3.4 & 3.4 & 3.4 & 3.4 \\
\hline Total & 4.9 & 200 & 300 & 670 & 980 & 880 & 830 & 600 \\
\hline \multicolumn{9}{|l|}{$\begin{array}{l}\text { General } \\
\text { population }\end{array}$} \\
\hline Naval & 0.34 & 2.1 & 2.1 & 4.7 & 12 & 11 & 6.0 & 21 \\
\hline Foreign & 0 & 150 & 200 & 320 & 180 & 170 & 310 & 200 \\
\hline University & $\mathbf{0}$ & 140 & 120 & 250 & 110 & 91 & 230 & 210 \\
\hline DOE & 0 & 140 & 340 & 990 & 1900 & 1800 & 1400 & 880 \\
\hline Onsite & 0.087 & 0.087 & 0.087 & 0.087 & 0.087 & 0.087 & 0.087 & 0.087 \\
\hline Total & 0.43 & 430 & 660 & 1600 & 2000 & 2100 & 1900 & 1400 \\
\hline
\end{tabular}


Table 5.11-7 (continued)

\begin{tabular}{|c|c|c|c|c|c|c|c|c|}
\hline \multirow[b]{3}{*}{ Exposure group } & \multicolumn{8}{|c|}{ Aleernatives, $b$} \\
\hline & \multirow{2}{*}{ A } & \multicolumn{2}{|c|}{$\mathbf{B}$} & \multicolumn{4}{|c|}{$\mathbf{C}$} & \multirow{2}{*}{$\begin{array}{c}\text { D } \\
\text { INEL }\end{array}$} \\
\hline & & $\mathbf{B}^{\prime}$ & $\mathbf{B}^{\prime \prime}$ & Hanfond $c$ & SRSC & ORR ${ }^{c}$ & NTSe & \\
\hline \multicolumn{9}{|c|}{ Extimeded cancer fentitios } \\
\hline \multicolumn{9}{|l|}{ Occupational } \\
\hline Total & 0.0020 & 0.080 & 0.12 & 0.27 & 0.39 & 0.35 & 0.33 & 0.24 \\
\hline \multicolumn{9}{|l|}{$\begin{array}{l}\text { General } \\
\text { population }\end{array}$} \\
\hline Total & 0.00022 & 0.22 & 0.33 & 0.80 & 1.1 & 1.1 & 0.95 & 0.70 \\
\hline \multicolumn{9}{|c|}{ 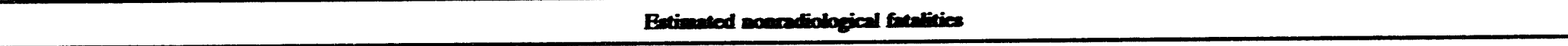 } \\
\hline \multicolumn{9}{|l|}{$\begin{array}{l}\text { General } \\
\text { populationd }\end{array}$} \\
\hline Naval & 0.059 & 0.025 & 0.025 & 0.035 & 0.033 & 0.028 & 0.037 & 0.025 \\
\hline Foneign & $\mathbf{0}$ & 0.0052 & 0.0079 & 0.0084 & 0.0074 & 0.0065 & 0.011 & 0.0082 \\
\hline University & $\mathbf{0}$ & 0.0025 & 0.0026 & 0.0028 & 0.0025 & 0.0021 & 0.0033 & 0.0025 \\
\hline Onsite & $\mathbf{0}$ & $\mathbf{0}$ & $\mathbf{0}$ & 0 & 0 & 0 & 0 & 0 \\
\hline DOE & 0 & 0.0027 & 0.0049 & 0.013 & 0.028 & 0.021 & 0.029 & 0.011 \\
\hline Total & 0.059 & 0.035 & 0.040 & 0.059 & 0.071 & 0.058 & 0.080 & 0.047 \\
\hline $\begin{array}{l}\text { a. Alemative A } \\
\text { Alternative C co } \\
\text { b. Doses and fat } \\
\text { (offsite and onsit } \\
\text { fuel (see Mahera } \\
\text { c. Hanford = H } \\
\text { d. Occupational } \\
\text { e. Nonradiologic }\end{array}$ & $\begin{array}{l}\text { sponds to } \\
\text { ads to Ce } \\
\text { include s } \\
\text { Maheras } \\
\text { Ad). } \\
\text { d Site, SR: } \\
\text { ent-free no } \\
\text { ident-free }\end{array}$ & $\begin{array}{l}\text { Alterna } \\
\text { at Hanf } \\
\text { f naval \& } \\
\text { Maheras } \\
\text { ah River } \\
\text { cal fatalit } \\
\text { re not ap }\end{array}$ & $\begin{array}{l}\text { responds } \\
\text { nah Rive } \\
\text { or fuel (o } \\
\text { iiversity } \\
=\text { Oak } \\
\text { luded wit } \\
\text { asite beca }\end{array}$ & $\begin{array}{l}1993 \text { Ptanni } \\
\text { idge, or Ner } \\
\text { onsite, nee } \\
\text { reactor spen } \\
\text { eservation, } \\
\text { incident-fre } \\
\text { NEL is not }\end{array}$ & $\begin{array}{l}\text { Ahernativ } \\
\text { Site, and } \\
\text { nt A to } \\
\text { fued (see } \\
\text { erada Te: } \\
\text { sogical fa } \\
\text { area. }\end{array}$ & $\begin{array}{l}\text { xpoeds } \\
\text { D corre } \\
\text { of Volur } \\
\text { seac), an }\end{array}$ & $\begin{array}{l}\text { antion b } \\
\text { Centraliz } \\
\text { EIS), } \\
\text { caearch }\end{array}$ & $\begin{array}{l}\text { INEL } \\
\text { anclear for } \\
\text { it nuclear }\end{array}$ \\
\hline
\end{tabular}




\begin{tabular}{|c|c|c|c|c|c|c|c|c|}
\hline \multirow[b]{3}{*}{ Exposure group } & \multicolumn{8}{|c|}{ Alternatives $^{\text {a,b }}$} \\
\hline & \multirow{2}{*}{$\begin{array}{l}\mathbf{A} \\
\mathbf{A}\end{array}$} & \multicolumn{2}{|c|}{ B } & \multicolumn{4}{|c|}{ c } & \multirow{2}{*}{$\frac{\text { D }}{\text { INEL }}$} \\
\hline & & $\mathbf{B}^{\prime}$ & B* & Hanforde & SRS $^{C}$ & ORR $^{c}$ & NTSC & \\
\hline \multicolumn{9}{|c|}{ Extionted maximum indivitual doce (rem) } \\
\hline Occupational & 0.35 & 5.0 & 5.3 & 6.8 & 8.4 & 8.9 & 9.0 & 78 \\
\hline $\begin{array}{l}\text { General } \\
\text { population }\end{array}$ & 0.039 & 24 & 26 & 3.4 & 4.1 & 4.4 & 4.4 & 3.8 \\
\hline \multicolumn{9}{|c|}{ Estimned oolloctive doee (persoon-rem) } \\
\hline \multicolumn{9}{|l|}{ Oocupational } \\
\hline Naval & 1.5 & 7.3 & 7.3 & 9.8 & 15 & 14 & 11 & 73 \\
\hline Foreign & $\mathbf{0}$ & 19 & 24 & 33 & 22 & 22 & 34 & 30 \\
\hline University & $\mathbf{0}$ & 16 & 15 & 26 & 15 & 13 & 25 & 22 \\
\hline DOE & $\mathbf{0}$ & 73 & 11 & 32 & 60 & 58 & 52 & 36 \\
\hline Onsite & 3.4 & 3.4 & 3.4 & 3.4 & 3.4 & 3.4 & 3.4 & 3.4 \\
\hline Total & 4.9 & 53 & 61 & 100 & 120 & 110 & 130 & 99 \\
\hline \multicolumn{9}{|l|}{$\begin{array}{l}\text { General } \\
\text { population }\end{array}$} \\
\hline Naval & 0.34 & 2.1 & 2.1 & 4.7 & 12 & 11 & 6.0 & 2.1 \\
\hline Foreign & o & 29 & 41 & 53 & 38 & 36 & $3 \mathbf{1}$ & 48 \\
\hline University & $\mathbf{0}$ & 29 & 33 & 38 & 340 & 25 & 37 & 33 \\
\hline DOE & o & 12 & 12 & 45 & 85 & 67 & 67 & 49 \\
\hline Onsite & 0.087 & 0.087 & 0.087 & 0.087 & 0.087 & 0.087 & 0.087 & 0.087 \\
\hline Total & 0.43 & 72 & 93 & 140 & 170 & 140 & 140 & 130 \\
\hline
\end{tabular}


Table 5.11-8 (continued)

\begin{tabular}{|c|c|c|c|c|c|c|c|c|}
\hline \multirow[b]{3}{*}{ Exposure group } & \multicolumn{8}{|c|}{ Alternatives $\mathbf{a}, \mathbf{b}$} \\
\hline & \multirow{2}{*}{$\begin{array}{l}\mathbf{A} \\
\mathbf{A}\end{array}$} & \multicolumn{2}{|c|}{$\mathbf{B}$} & \multicolumn{4}{|c|}{ C } & \multirow{2}{*}{$\begin{array}{c}\text { D } \\
\text { INEL }\end{array}$} \\
\hline & & $\mathbf{B}^{\prime}$ & $\mathbf{B}^{*}$ & Hanford $c$ & SRSC & ORR $^{c}$ & NTSc & \\
\hline \multicolumn{9}{|c|}{ Brimed cancer fintalitio } \\
\hline \multicolumn{9}{|l|}{ Occupational } \\
\hline Total & 0.0020 & 0.021 & 0.024 & 0.040 & 0.048 & 0.044 & 0.052 & 0.040 \\
\hline \multicolumn{9}{|l|}{$\begin{array}{l}\text { General } \\
\text { population }\end{array}$} \\
\hline Total & 0.00022 & 0.036 & 0.047 & 0.070 & 0.085 & 0.070 & 0.070 & 0.065 \\
\hline \multicolumn{9}{|c|}{ Extimated nomradiologienl fatalitios } \\
\hline \multicolumn{9}{|l|}{$\begin{array}{l}\text { General } \\
\text { populationd }\end{array}$} \\
\hline Naval & 0.059 & 0.025 & 0.025 & 0.035 & 0.033 & 0.028 & 0.037 & 0.025 \\
\hline Foreign & $\mathbf{0}$ & 0.0098 & 0.015 & 0.020 & 0.013 & 0.010 & 0.019 & 0.019 \\
\hline University & $\mathbf{0}$ & 0.0058 & 0.0068 & 0.0068 & 0.0071 & 0.0046 & 0.0067 & 0.0060 \\
\hline Onsite $^{e}$ & $\mathbf{0}$ & $\mathbf{0}$ & $\mathbf{0}$ & $\mathbf{0}$ & $\mathbf{0}$ & 0 & 0 & o \\
\hline DOE & 0 & 0.0032 & 0.0041 & 0.012 & 0.016 & 0.012 & 0.014 & 0.012 \\
\hline Total & 0.059 & 0.044 & 0.051 & 0.074 & 0.069 & 0.055 & 0.077 & 0.062 \\
\hline $\begin{array}{l}\text { a. Alternative A } \\
\text { Alternative C or } \\
\text { b. Doses and fat } \\
\text { (offsite and onsit } \\
\text { fuel (see Mahera } \\
\text { c. Hanford = H } \\
\text { d. Oocupational } \\
\text { e. Nonradiologic }\end{array}$ & $\begin{array}{l}\text { esponds to } \\
\text { onds to Ce } \\
\text { s include st } \\
\text { Maheras } \\
\text { 4d). } \\
\text { d Site, SRS } \\
\text { lent-free no } \\
\text { cident-free }\end{array}$ & $\begin{array}{l}\text { a, Alterna } \\
\text { a at Hanf } \\
\text { of naval s } \\
\text { I Maheras } \\
\text { nah River } \\
\text { ical fatalit } \\
\text { are not ap }\end{array}$ & $\begin{array}{l}\text { responds } \\
\text { nah Rive } \\
\text { ar fuel (o } \\
\text { aiversity } \\
\text { = Oak } \\
\text { luded wi } \\
\text { asite bee }\end{array}$ & $\begin{array}{l}1993 \text { Planni } \\
\text { idge, or Nev } \\
\text { onsite, see } \\
\text { reactor spen } \\
\\
\text { eservation, } \\
\text { incident-frex } \\
\text { INEL is not }\end{array}$ & $\begin{array}{l}\text { Alternati } \\
\text { Site, and } \\
\text { at A to } \\
\text { fuel (see } \\
\text { evada Te } \\
\text { ological f } \\
\text { area. }\end{array}$ & $\begin{array}{l}\text { Donds t } \\
\text { D corre } \\
\text { of Volu } \\
994 \text { ), an }\end{array}$ & $\begin{array}{l}\text { zation b } \\
\text { Centraliz } \\
\text { EIS), } \\
\text { esearch }\end{array}$ & $\begin{array}{l}\text { INEL. } \\
\text { nuclear fue } \\
\text { it nuclear }\end{array}$ \\
\hline
\end{tabular}


For spent nuclear fuel, it can be seen that Alternative C (Centralization at Savannah River) yielded the largest collective doses (980 person-rem occupational, 2,200 person-rem general population). Alternative A (No Action) yielded the smallest collective doses (4.9 person-rem occupational, 0.43 person-rem general population). Alternatives B' (1992/1993 Planning Basis) and B" (Regionalization) yielded approximately equal collective doses; 200 and 300 person-rem (occupational) and 430 and 660 person-rem (general population).

5.11.2.3 Onsite Transportation Accidents. Tables 5.11-9 and 5.11-10 summarize the bounding impacts for onsite transportation of spent nuclear fuel and radioactive wastes, respectively.

The maximum reasonably foreseeable onsite spent nuclear fuel transportation accident involves the inadvertent shipment of a short-cooled fuel element (fuel out of the reactor for 10 to 25 days) from the Advanced Test Reactor to the Idaho Chemical Processing Plant. For this accident to occur, errors must occur to allow loading the wrong fuel element into the shipping cask, and radiation surveys of the loaded cask must fail to detect abnormally high radiation levels. In addition, the transport vehicle must break down or rollover during the short transit between the Advanced Test Reactor and the Idaho Chemical Processing Plant. Finally, operators must fail to maintain adequate cooling water inside the cask. The probability of this accident is, therefore, extremely unlikely with an annual frequency on the order of one in one million years for neutral meteorology to one in ten million years for stable meteorology. Because the estimated number of spent nuclear fuel shipments is expected to be the same for all alternatives, the annual frequency and consequences of the maximum reasonably foreseeable accident are identical for all alternatives. Table 5.11-9 shows that the fatal cancer risk for the population within 50 miles (80 kilometers) is on the order of one in one million years for a rural population zone and about one in 90,000 years for a suburban population zone.

Onsite transuranic waste shipments are expected to be dominated by shipments between the INEL Radioactive Waste Management Complex and Argonne National Laboratory-West as part of the characterization and certification program required for shipments of INEL transuranic waste to the Waste Isolation Pilot Plant. The maximum reasonably foreseeable accident is sufficient to breach a Type B shipping container and release its contents. Because of the rigorous 
Table 5.11-9. Maximum reasonably foreseeable accident doses and health effects for onsite transport of spent nuclear fuel for Alternatives A through D (1995 to 2035).

\begin{tabular}{|c|c|c|c|c|c|c|}
\hline \multirow[b]{2}{*}{$\begin{array}{l}\text { Population density } \\
\text { category }^{\mathbf{2}}\end{array}$} & \multirow[b]{2}{*}{ Meteorology } & \multirow[b]{2}{*}{$\begin{array}{c}\text { Accident frequencyc } \\
\text { (events/year) }\end{array}$} & \multirow[b]{2}{*}{$\begin{array}{l}\text { Dose to MEI } \\
\text { (rem) }\end{array}$} & \multirow{2}{*}{$\begin{array}{c}\text { Offsite population } \\
\text { dose } \\
\text { (person-rem) }\end{array}$} & \multicolumn{2}{|c|}{ Risk of fatal cancer per yeare } \\
\hline & & & & & $\mathrm{MEI}^{\mathbf{d}}$ & Population \\
\hline Rural & Neutral & $1 \times 10^{-6}$ & 76 & 1,500 & $\begin{array}{c}6.1 \times 10^{-8} \\
(0.061)\end{array}$ & $\begin{array}{c}7.5 \times 10^{-7} \\
(0.75)\end{array}$ \\
\hline Rural & Stable & $1 \times 10^{-7}$ & 250 & 12,000 & $\begin{array}{c}20 \times 10^{-8} \\
(0.20)\end{array}$ & $\begin{array}{c}6.0 \times 10^{-7} \\
(6)\end{array}$ \\
\hline Suburban & Neutral & $1 \times 10^{-6}$ & 76 & 21,000 & $\begin{array}{c}6.1 \times 10^{-8} \\
(0.061)\end{array}$ & $\begin{array}{c}1.1 \times 10^{-5} \\
(11)\end{array}$ \\
\hline Suburban & Stable & $1 \times 10^{-7}$ & 250 & 170,000 & $\begin{array}{c}20 \times 10^{-8} \\
(0.20)\end{array}$ & $\begin{array}{c}8.5 \times 10^{-6} \\
(85)\end{array}$ \\
\hline
\end{tabular}

a. Results are presented for generic rural and suburban population densities. The generic rural population density has an average population of 6 persons per square kilometer, the generic suburban population density has an average population of 719 persons per square kilometer. For comparison, the sector with the highest population density within 50 miles ( 80 kilometers) is due east of the Idaho Chemical Processing Plant-Test Reactor Area at the INEL with an average population density of 53 persons per square kilometer.

b. Neutral meteorology is characterized by Stability Class D, 4 meters ( 13 feet) per second wind speed, and occurs approximately 50 percent of the time. Stable meteorology is characterized by Stability Class F, 1 meter ( 3.28 feet) per second wind speed, and occurs approximately 5 percent of the time.

c. Accident frequency includes both the event frequency and the frequency of the meteorology. The frequency of stable meteorology is approximately one-tenth the frequency of neutral meteorology.

d. Maximally Exposed Individual located at the point of maximum exposure to the airborne release approximately 525 to 1,280 feet (160 to 390 meters) downwind, depending on meteorology. For onsite accidents, the MEI is assumed to be an INEL worker.

e. Fatal cancer rist $=$ dose $\times$ accident frequency $\times$ (ICRP 60 risk factor for fatal cancers). The ICRP 60 risk factor is $5 \times 10^{-4}$ fatal cancers per rem for the public, $4 \times 10^{-4}$ fatal cancers per rem for workers. For doses $\geq 20 \mathrm{rem}$, the ICRP 60 conversion factor is doubled. Numbers in parentheses indicate likelihood of fatal cancer for the MEI or total number of fatal cancers in the population if the accident occurs. 
Table 5.11-10. Maximum reasonably foreseeable accident doses and health effects for onsite transport of waste for Alternatives A through D (1995 to 2005).

\begin{tabular}{|c|c|c|c|c|c|c|c|}
\hline \multirow[b]{2}{*}{ Waste type } & \multirow{2}{*}{$\begin{array}{c}\text { Population } \\
\text { density } \\
\text { category }^{a}\end{array}$} & \multirow[b]{2}{*}{ Meteorology ${ }^{b}$} & \multirow{2}{*}{$\begin{array}{l}\text { Accident frequency } \\
\text { (eventsłyear) }\end{array}$} & \multirow{2}{*}{$\begin{array}{c}\text { Dose to } \mathrm{MEI}^{\mathrm{d}} \\
\text { (rem) }\end{array}$} & \multirow{2}{*}{$\begin{array}{c}\begin{array}{c}\text { Offsite population } \\
\text { dose } \\
\text { (person-rem) }\end{array} \\
\end{array}$} & \multicolumn{2}{|c|}{ Risk of fatal cancer per year ${ }^{e}$} \\
\hline & & & & & & $\mathrm{MEI}^{\mathbf{d}}$ & Population \\
\hline \multirow{4}{*}{ Transuranic } & Rural & Neutral & $5.4 \times 10^{-6}$ & 0.41 & 0.75 & $\begin{array}{c}8.9 \times 10^{-10} \\
(0.00016)\end{array}$ & $\begin{array}{r}2.0 \times 10^{-9} \\
(0.00038)\end{array}$ \\
\hline & Rural & Stable & $5.4 \times 10^{-7}$ & 1.4 & 6 & $\begin{array}{c}3.0 \times 10^{-10} \\
(0.00056)\end{array}$ & $\begin{array}{c}1.6 \times 10^{-9} \\
(0.003)\end{array}$ \\
\hline & Suburban & Neutral & $5.4 \times 10^{-6}$ & 0.41 & 86 & $\begin{array}{c}8.9 \times 10^{-10} \\
(0.00016)\end{array}$ & $\begin{array}{c}2.3 \times 10^{-7} \\
(0.043)\end{array}$ \\
\hline & Suburban & Stable & $5.4 \times 10^{-7}$ & 1.4 & 680 & $\begin{array}{c}3.0 \times 10^{-10} \\
(0.00056)\end{array}$ & $\begin{array}{c}1.8 \times 10^{-7} \\
(0.34)\end{array}$ \\
\hline \multirow{4}{*}{$\begin{array}{l}\text { Low-level and } \\
\text { mixed-low-level }\end{array}$} & Rural & Neutral & $3.9 \times 10^{-5}$ & 12 & 31 & $\begin{array}{c}1.9 \times 10^{-7} \\
(0.0048)\end{array}$ & $\begin{array}{c}6.0 \times 10^{-7} \\
(0.016)\end{array}$ \\
\hline & Rural & Stable & $3.9 \times 10^{-6}$ & 41 & 250 & $\begin{array}{c}6.4 \times 10^{-8} \\
(0.016)\end{array}$ & $\begin{array}{c}4.9 \times 10^{-7} \\
(0.13)\end{array}$ \\
\hline & Suburban & Neutral & $3.9 \times 10^{-5}$ & 12 & 2,900 & $\begin{array}{c}1.9 \times 10^{-7} \\
(0.0048)\end{array}$ & $\begin{array}{c}5.7 \times 10^{-5} \\
(1.5)\end{array}$ \\
\hline & Suburban & Stable & $3.9 \times 10^{-6}$ & 41 & 23,000 & $\begin{array}{c}6.4 \times 10^{-8} \\
(0.016)\end{array}$ & $\begin{array}{c}4.5 \times 10^{-5} \\
(12)\end{array}$ \\
\hline
\end{tabular}

a. Results are presented for generic rural and suburban population densities. The generic rural population density has an average population of 6 persons per square kilometer, the generic suburban population density has an average population of 719 persons per square kilometer. For comparison, the sector with the highest population density within 50 miles (80 kilometers) is due east of the Idaho Chemical Processing Plant-Test Reactor Area at the INEL with an average population density of 53 persons per square kilometer.

b. Neutral meteorology is characterized by Stability Class D, 4 meters (13 feet) per second wind speed, and occurs approximately 50 percent of the time. Stable meteorology is characterized by Stability Class F, 1 meter ( 3.28 feet) per second wind speed, and occurs approximately 5 percent of the time.

c. Accident frequency includes both the event frequency and the frequency of the meteorology. The frequency of stable meteorology is appraximately one-tenth the frequency of c. Accident frequency in

d. Maximally Exposed Individual located at the point of maximum exposure to the airborne release approximately 525 to 1,280 feet (160 to 390 meters) downwind, depending on

meteorology. For onsite accidents, the MEI is assumed to be an INEL worker.
e. Fatal cancer risk $=$ dose $\times$ accident frequency $\times$ (ICRP 60 risk factor for fatal cancers). The ICRP 60 risk factor is $5 \times 10^{-4}$ fatal cancers per rem for the public, $4 \times 10^{-4}$ fatal cancers per rem for workers. For doses $220 \mathrm{rem}$, the ICRP 60 conversion factor is doubled. Numbers in parentheses indicate likelihood of fatal cancer for the MEI or total number of fatal cancers in the population if the accident occurs.

f. Maximum reasonably foreseeable accident results for transuranic waste are the same for Aternatives A-D. For low-level and mixed low-level wastes, maximum reasonably foreseeable accident doses are the same for all alternatives, but the accident frequencies (and, therefore, the fatal cancer risks) for Alternatives B and D (shown in table) are about 40 percent higher than Alternatives $\mathrm{A}$ and $\mathrm{C}$. 
safety standards required for Type B containers, the probability of the maximum reasonably foreseeable accident is extremely unlikely, with an annual frequency on the order of one accident in 200,000 years for neutral meteorology to one accident in two million years for stable meteorology. Because the estimated number of onsite transuranic waste shipments is expected to be approximately the same for all alternatives, the annual frequency and consequences of the maximum reasonably foreseeable accident are identical for all alternatives. Table 5.11-10 shows that the fatal cancer risk for the population within 50 miles ( 80 kilometers) is on the order of one in $\mathbf{5 0 0}$ million years for a rural population zone and about one in four million years for a suburban population zone.

Onsite low-level and mixed low-level waste shipments are expected to be dominated by shipments of routine operational waste from INEL facilities to INEL treatment, storage, and disposal facilities. Some variability in the number of shipments, and consequently the probability of accidents, is seen as a result of environmental restoration and decontamination and decommissioning activities. Total waste shipment mileage for Alternatives B (Ten-Year Plan) and $D$ (Maximum Treatment, Storage, and Disposal) is about 40 percent higher than Alternatives $A$ (No Action) and C (Minimum Treatment, Storage, and Disposal). Consequently, the maximum reasonably foreseeable accident doses are the same for all alternatives, but the annual frequencies are highest for Alternatives $B$ and D. The results shown in Table 5.11-10 reflect the higher accident frequencies for Alternatives $B$ and D. Table 5.11-10 shows that the fatal cancer risk for the population within 50 miles ( 80 kilometers) is on the order of one in two million years for a rural population zone and about one in 18,000 years for a suburban population zone.

\subsubsection{Offsite Transportation Accidents. Tables 5.11-11 and 5.11-12 summarize} accident risks for offsite transportation of radioactive wastes and spent nuclear fuel, respectively, for all alternatives. Tables 5.11-13 and 5.11-14 summarize maximum reasonably foreseeable accident consequences for the radioactive waste and spent nuclear fuel shipments under all alternatives.

5.11.2.5 Hazardous Material Transportation Accidents. Table 5.11-15 shows the results of the analysis of the maximum reasonably foreseeable-case truck accident scenario for all alternatives. Meteorological conditions were specified at 50 and 95 percent to develop plumes for each Emergency Response Planning Guideline using the EPIcode ${ }^{\mathrm{m}}$. The probability of a 
Table 5.11-11. Accident risks for offsite transport of waste for Alternativ s A through D (1995 to 2005).

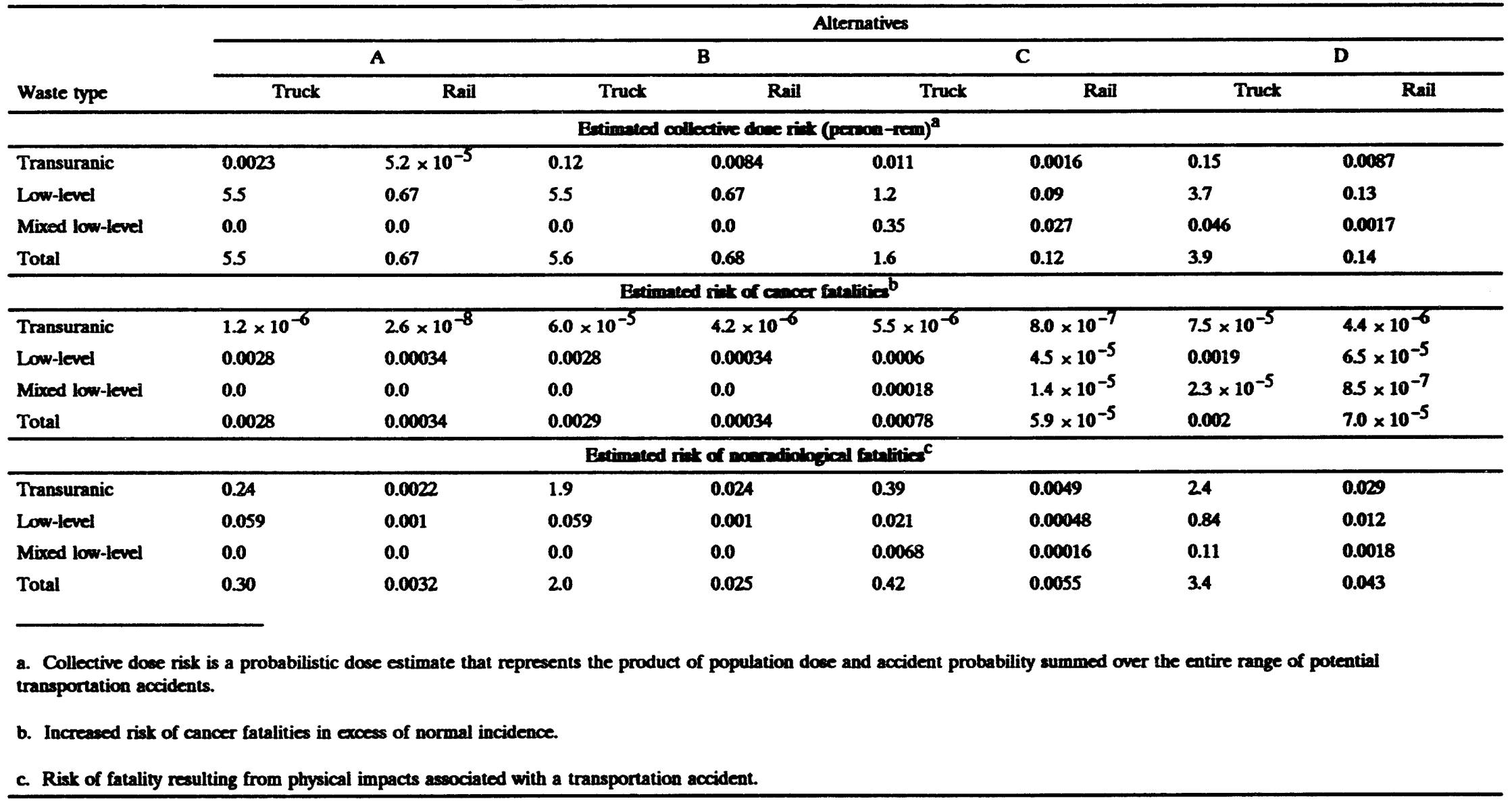


Table 5.11-12. Accident risks for offsite transport of spent nuclear fuel for Alternatives A through D (1995 to 2035 ).

\begin{tabular}{|c|c|c|c|c|c|c|c|c|}
\hline \multirow[b]{3}{*}{ Tramaport mode } & \multicolumn{8}{|c|}{ Nternatives, $\mathbf{a}, \mathbf{b}$} \\
\hline & \multirow{2}{*}{$\mathbf{A}$} & \multicolumn{2}{|c|}{ B } & \multicolumn{4}{|c|}{$\mathbf{C}$} & \multirow{2}{*}{$\frac{\text { D }}{\text { INEL }}$} \\
\hline & & $\mathbf{B}^{\prime}$ & $\mathbf{B}^{*}$ & HS & SRS & ORR & NTS & \\
\hline \multicolumn{9}{|c|}{ 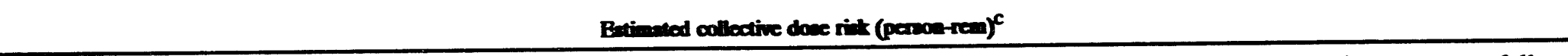 } \\
\hline Truck & 0.0083 & 0.29 & 0.40 & 0.75 & 23 & 1.8 & 1.2 & 0.61 \\
\hline Rail & 0.0083 & 0.14 & 0.16 & 0.27 & 1.1 & 0.76 & 0.41 & 0.19 \\
\hline \multicolumn{9}{|c|}{ Extimeted rint of conoc frentitied } \\
\hline Truck & $4.2 \times 10^{-6}$ & 0.00015 & 0.0002 & 0.00038 & 0.0012 & 0.0009 & 0.0006 & 0.00031 \\
\hline Rail & $4.2 \times 10^{-6}$ & $7.0 \times 10^{-5}$ & $8.0 \times 10^{-5}$ & 0.00014 & 0.00055 & 0.00038 & 0.00021 & $9.5 \times 10^{-5}$ \\
\hline \multicolumn{9}{|c|}{ 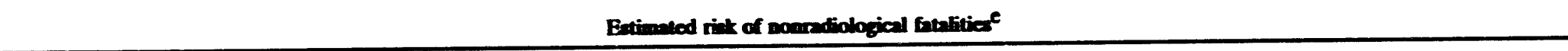 } \\
\hline Truck & 0.047 & 0.57 & 0.61 & 0.79 & 1.0 & 0.94 & 0.93 & 0.72 \\
\hline Rail & 0.047 & 0.58 & 0.59 & 0.74 & 0.80 & 0.76 & 0.85 & 0.68 \\
\hline
\end{tabular}

Alternative A corresponds to No Action, Alternative B' corresponds to 1992/1993 Planning Basis, Alternative B" corresponds to Regionalization, Alternative C corresponds to Centralization at Hanford (HS), Sa unnah River (SRS), Oak Ridge (ORR), or Nevada (NTS), and Alternative D cocresponds to Centralization at the INEL.

b. Doses and health effects include offsite shipments of naval spent nuclear fuel (see Attachment A to Appendix D of Volume 1 of this Emvironmental Impact Statement), Department of Energy spent nuclear fuel, university research reactor spent nuclear fuel, and foreign research reactor spent nuclear fuel.

c. Collective dose risk is a probabilistic dose estimate that represents the product of population dose and accident probability summed over the entire range of potential transportation accidents.

d. Increased risk of cancer fatalities in excess of normal incidence.

c. Risk of fatality resulting from physical impacts associsted with a transportation accident. 
Table 5.11-13. Maximum reasonably foreseeable accident doses and health effects for offsite transport of waste for Alternatives A through D (1995 to 2005).

\begin{tabular}{|c|c|c|c|c|c|c|c|c|}
\hline \multirow[b]{3}{*}{ Waste type } & \multicolumn{8}{|c|}{ Alernatives } \\
\hline & \multicolumn{2}{|c|}{$\mathbf{A}$} & \multicolumn{2}{|c|}{ B } & \multicolumn{2}{|c|}{ C } & \multicolumn{2}{|c|}{ D } \\
\hline & Neutral & Stable & Neutral & Stable & Neutral & Stable & Neutral & Stable \\
\hline \multicolumn{9}{|c|}{ Mrimum reasoanbly forcocenble scocident probability (per year) } \\
\hline Transuranic & $3.3 \times 10^{-6}$ & $3.3 \times 10^{-7}$ & $3.4 \times 10^{-4}$ & $3.4 \times 10^{-5}$ & $6.1 \times 10^{-5}$ & $6.1 \times 10^{-6}$ & $4.1 \times 10^{-4}$ & $4.1 \times 10^{-5}$ \\
\hline Low-level & $3.8 \times 10^{-3}$ & $3.8 \times 10^{-4}$ & $3.8 \times 10^{-3}$ & $3.8 \times 10^{-4}$ & $8.8 \times 10^{-5}$ & $8.8 \times 10^{-6}$ & $1.6 \times 10^{-3}$ & $1.6 \times 10^{-4}$ \\
\hline Mixed low-level & 0.0 & 0.0 & 0.0 & 0.0 & $2.9 \times 10^{-5}$ & $29 \times 10^{-6}$ & $27 \times 10^{-4}$ & $27 \times 10^{-5}$ \\
\hline \multicolumn{9}{|c|}{ Extimated maximum individual dose (xcm) } \\
\hline Transuranic & 1.0 & 3.5 & 3.6 & 12 & 1.8 & 6.1 & 10 & 34 \\
\hline Low-level & 0.10 & 0.34 & 0.10 & 0.34 & 0.04 & 0.14 & 6.5 & 22 \\
\hline Mixed low-level & 0.0 & 0.0 & 0.0 & 0.0 & 0.04 & 0.14 & 4.7 & 15 \\
\hline \multicolumn{9}{|c|}{ Estimated colloctive done (person-rem) ${ }^{b}$} \\
\hline Transuranic & 1,200 & 9,400 & 4,000 & 32,000 & 2,100 & 16,000 & 11,000 & 92,000 \\
\hline Low-level & 130 & 1,100 & 130 & 1,100 & 53 & 420 & 7,200 & 58,000 \\
\hline Mixed low-level & 0.0 & 0.0 & 0.0 & 0.0 & 53 & 420 & 5,200 & 42,000 \\
\hline \multicolumn{9}{|c|}{ Extimated cancer fotalitics } \\
\hline Transuranic & 0.6 & 4.7 & 20 & 16 & 1.1 & 8.0 & 5.5 & 46 \\
\hline Low-level & 0.07 & 0.55 & 0.07 & 0.55 & 0.03 & 0.21 & 3.6 & 29 \\
\hline Mixed low-level & 0.0 & 0.0 & 0.0 & 0.0 & 0.03 & 0.21 & 26 & 21 \\
\hline
\end{tabular}

a. Annual accident probability, 1995 through 2005 . Rail transportation accidents are bounding for all alternatives.

b. Collective dose based on urban population density. Corresponding doses for suburban and rural population zones would be approximately 19 percent and 0.3 percent, respectively, of the urban doses. 
Table 5.11-14. Maximum reasonably foreseeable accident doses and health effects for offsite transport of spent nuclear fuel for Alternatives A-D (1995 to 2035).

\begin{tabular}{|c|c|c|c|c|c|c|c|c|}
\hline \multirow{3}{*}{$\begin{array}{l}\text { Atmospheric } \\
\text { conditions }\end{array}$} & \multicolumn{8}{|c|}{ Alternatives $^{\mathbf{a}, \mathbf{b}}$} \\
\hline & \multirow{2}{*}{$\begin{array}{l}\mathbf{A} \\
\mathbf{A}\end{array}$} & \multicolumn{2}{|c|}{ B } & \multicolumn{4}{|c|}{ C } & \multirow{2}{*}{$\begin{array}{c}\text { D } \\
\text { NEL }\end{array}$} \\
\hline & & $\mathbf{B}^{\prime}$ & $\mathbf{B}^{\prime \prime}$ & HS & SRS & ORR & NTS & \\
\hline \multicolumn{9}{|c|}{ Moximum remonably for weenble scoident probability (per year) ${ }^{C}$} \\
\hline Neutral & $1.4 \times 10^{-6}$ & $1.9 \times 10^{-7}$ & $27 \times 10^{-7}$ & $5.2 \times 10^{-6}$ & $1.7 \times 10^{-7}$ & $1.1 \times 10^{-7}$ & $1.0 \times 10^{-7}$ & $4.9 \times 10^{-7}$ \\
\hline Stable & $24 \times 10^{-7}$ & $1.0 \times 10^{-7}$ & $1.3 \times 10^{-7}$ & $3.7 \times 10^{-7}$ & $1.2 \times 10^{-7}$ & $5.9 \times 10^{-7}$ & $5.2 \times 10^{-7}$ & $3.5 \times 10^{-7}$ \\
\hline \multicolumn{9}{|c|}{ Estimnted maximun individual dose (nem) } \\
\hline Neutral & 0.0034 & 54 & 54 & 54 & 54 & 54 & 54 & 54 \\
\hline Stable & 0.014 & 180 & 180 & 180 & 180 & 180 & 180 & 180 \\
\hline \multicolumn{9}{|c|}{ Entimated collective doee (perwoen-rem) $)^{d}$} \\
\hline Neutral & $13^{\mathrm{U}}$ & $13,000^{5}$ & $13,000^{5}$ & $13,000^{5}$ & $72,000^{\mathrm{U}}$ & $72,000^{4}$ & $72,000^{4}$ & $13,000^{5}$ \\
\hline Stable & $25^{u}$ & $3,500^{r}$ & $3,500^{r}$ & $3,500^{\mathrm{T}}$ & $110,000^{s}$ & $3,500^{r}$ & $3,500^{r}$ & $3,500^{r}$ \\
\hline \multicolumn{9}{|c|}{ Extimaled conocer fatalities } \\
\hline Neutral & 0.0065 & 7 & 7 & 7 & 36 & 36 & 36 & 7 \\
\hline Stable & 0.013 & 2 & 2 & 2 & 55 & 2 & 2 & 2 \\
\hline
\end{tabular}

a. Alternative A corresponds to No Action, Alternative B' corresponds to $1992 / 1993$ Planning Basis, Alternative B' corresponds to Regionalization, Alternative C corresponds to Centralization at Hanford (HS), Savannah River (SRS), Oak Ridge (ORR), or Nevada (NTS), and Alternative D corresponds to Centralization at the INEL.

b. Doses and health effects include offsite shipments of naval spent nuclear fuel (see Attachment A to Appendix D of Volume 1 of this Environmental Impact Statement), Department of Energy spent nuclear fuel, university research reactor spent nuclear fuel, and foreign research reactor spent nuclear fuel.

c. Annual accident probability for 1995 through 2035 . Rail transportation accidents are bounding for all alternatives except A.

d. Collective doses presented for the highest population density zone where the probability of the maximum reasonabiy foresceable accident is greater than or equal to $1 \times$ $10^{-7}$ per year. Urban zone doses denoted by " $u$ "; suburban zone doses denoted by "s"; rural zone doses denoted by "r". 
Table 5.11-15. Summary of releasing accident probability and consequences for nitric acid.

Meteorological

conditions

\begin{tabular}{|c|c|c|c|}
\hline \multirow[b]{2}{*}{$\begin{array}{l}\text { Population } \\
\text { area }\end{array}$} & \multirow[b]{2}{*}{ Probability and affected population } & \\
\hline & & Neutral & Stable \\
\hline \multirow{4}{*}{$\begin{array}{l}\text { Rural } \\
\text { population }\end{array}$} & Probability of releasing accident & 0.00047 & 0.000047 \\
\hline & $\begin{array}{l}\text { Emergency Response Planning Guideline-1 } \\
\text { maximum affected population }\end{array}$ & 11 & $\mathbf{0}$ \\
\hline & $\begin{array}{l}\text { Emergency Response Planning Guideline-2 } \\
\text { maximum affected population }\end{array}$ & 1 & $\mathbf{0}$ \\
\hline & $\begin{array}{l}\text { Emergency Response Planning Guideline-3 } \\
\text { maximum affected population }\end{array}$ & 1 & $\mathbf{0}$ \\
\hline \multirow{4}{*}{$\begin{array}{l}\text { Suburban } \\
\text { population }\end{array}$} & Probability of releasing accident & 0.00025 & 0.000025 \\
\hline & $\begin{array}{l}\text { Emergency Response Planning Guideline-1 } \\
\text { maximum affected population }\end{array}$ & 683 & 28,420 \\
\hline & $\begin{array}{l}\text { Emergency Response Planning Guideline-2 } \\
\text { maximum affected population }\end{array}$ & 81 & 1,626 \\
\hline & $\begin{array}{l}\text { Emergency Response Planning Guideline-3 } \\
\text { maximum affected population }\end{array}$ & 38 & 668 \\
\hline \multirow{4}{*}{$\begin{array}{l}\text { Urban } \\
\text { population }\end{array}$} & Probability of releasing accident & 0.000047 & 0.0000047 \\
\hline & $\begin{array}{l}\text { Emergency Response Planning Guideline-1 } \\
\text { maximum affected population }\end{array}$ & 3,445 & 143,338 \\
\hline & $\begin{array}{l}\text { Emergency Response Planning Guideline-2 } \\
\text { maximum affected population }\end{array}$ & 410 & 8,203 \\
\hline & $\begin{array}{l}\text { Emergency Response Planning Guideline-3 } \\
\text { maximum affected population }\end{array}$ & 190 & 3,368 \\
\hline
\end{tabular}


releasing accident is summed over shipments originating with each contractor for each population density. This shows the probability per year of a particular population being exposed to a certain chemical. The maximum affected population is the maximum number of receptors to all possible accident events.

In this assessment, it has been assumed that anyone residing within an Emergency Response Planning Guideline contour would experience an adverse effect. In other words, 100 percent probability of effect was assumed. This is a conservative assumption, because the adverse effect levels have incorporated uncertainty factors to account for sensitive human subpopulations. It is more likely that only a portion of the exposed population would experience adverse effects.

5.11.2.6 Regional Traffic Impacts. Using the methodology described in Section 5.11.1.5 and Transportation Research Board (1985), the baseline level of service for the road system surrounding the INEL is Level-of-Service A or free flowing (Lehto 1994). This was based on data for U.S. Highway 20, the regional highway with the highest use around the INEL and a likely route for materials that are shipped to the INEL. In addition, the peak number of vehicles per hour would have to increase from 122 to 291 to transform U.S. Highway 20 from Level-ofService A to Level-of-Service B. The peak number of vehicles per hour on U.S. Highway 20 would have to increase from 122 to 2,126 to exceed the capacity of the highway.

Using the shipment counts outlined in Lehto (1994), the increased movements of materials and people due to all alternatives would increase the maximum number of vehicles per hour to 150, which is still within the range of Level-of-Service $A$ and would result in no change to the level of service associated with US Highway 20. This maximum number of vehicles per hour is associated with Alternative D (Maximum Treatment, Storage, and Disposal). In addition, the number of vehicles per hour would have to increase by a factor of over 10 to exceed the capacity of the highway. Based on these results, the impacts to the regional traffic system around the INEL would be minimal for all alternatives.

Reracking of storage areas within the CPP-666 building will have no additional impacts for transportation at the INEL to those included in the analysis of Alternatives A through $D$. Constructing tanks for storing high-level wastes at the Idaho Chemical Processing Plant, 
constructing a new facility for processing sodium-bearing liquid waste or calciried high-level waste or using an existing facility for interim storage, and upgrading the Waste Experimental Reduction Facility will have no additional impacts for transportation at the INEL to those included in the analysis of Alternatives $A$ through $D$. 


\subsection{Health and Safety}

The purpose of this section is to present the potential health effects to both workers and the public as a result of the environmental restoration and waste management alternatives under consideration at the INEL. The potential health effects in this section are estimated to result from operations at the INEL from 1995 to 2005.

This section provides estimates of health impacts to workers and the public from releases of radioactive and nonradioactive contaminants to the atmosphere and groundwater. It also estimates injury, illness, and occupational fatalities based on observed rates for DOE and its contractors. Radiological impacts to workers are estimated using the average dose rate per year for INEL employees. A detailed explanation of the health effects methodology is contained in Appendix F, Section F-4, Health and Safety.

Radiation exposure and its consequences are topics of interest to the general public near nuclear facilities. For this reason, this EIS places more emphasis on the consequences of exposure to radiation than on other topics, even though the effects of radiation exposure under most of the circumstances evaluated in this EIS are small. This subsection explains basic concepts used in the evaluation of radiation effects in order to provide the background for later discussions of impacts.

The effects on people of radiation that is emitted during disintegration (decay) of a radioactive substance depends on the kind of radiation (alpha and beta particles, and gamma and $x$-rays) and the total amount of radiation energy absorbed by the body. The total energy absorbed per unit quantity of tissue is referred to as absorbed dose. The absorbed dose, when multiplied by certain quality factors and factors that take into account different sensitivities of various tissues, is referred to as effective dose equivalent, or where the context is clear, simply dose. The common unit of effective dose equivalent is the rem.

An individual may be exposed to ionizing radiation externally, from a radioactive source outside the body, and/or internally, from ingesting radioactive material. The external dose is different from the internal dose. An external dose is delivered only during the actual time of exposure to the external radiation source. An internal dose, however, continues to be delivered 
as long as the radioactive source is in the body, although both radioactive decay and elimination of the radionuclide by ordinary metabolic processes decrease the dose rate with the passage of time. The dose from internal exposure is calculated over $\mathbf{5 0}$ years following the initial exposure.

The maximum annual allowable radiation dose to the members of the public from DOEoperated nuclear facilities is 100 millirem per year, as stated in DOE Order 5400.5. All DOE and Naval facilities covered by this EIS operate well below this limit. It is estimated that the average individual in the United States receives a dose of about 300 millirem ( $0.3 \mathrm{rem}$ ) per year from all sources combined, including natural and medical sources of radiation. For perspective, a modern chest $x$-ray results in an approximate dose of 8 millirem, while a diagnostic hip $x$-ray results in an approximate dose of $\mathbf{8 3}$ millirem. A person must receive an acute (short-term) dose of approximately 600,000 millirem before there is a high probability of near-term death (NAS/NRC 1990).

Radiation can also cause a variety of ill-health effects in people. The most significant illhealth effect to depict the consequences of environmental and occupational radiation exposures is induction of latent cancer fatalities. This effect is referred to as latent cancer fatalities because the cancer may take many years to develop and for death to occur and may never actually be the cause of death.

The collective (or population) dose to an exposed population is calculated by summing the estimated doses received by each member of the exposed population. This total dose received by the exposed population is measured in person-rem. For example, if 1,000 people each received a dose of 1 millirem ( $0.001 \mathrm{rem})$, the collective dose would be 1,000 persons $\times 0.001 \mathrm{rem}=1.0$ person-rem. Alternatively, the same collective dose (1.0 person-rem) would result from 500 people each of whom received a dose of 2 millirem.

The factor that this EIS uses to relate a dose to its effect is $\mathbf{0 . 0 0 0 4}$ latent cancer fatalities per person-rem for workers and $\mathbf{0 . 0 0 0 5}$ latent cancer fatalities per person-rem for individuals among the general population. The latter factor is slightly higher because of the presence of individuals in the general public that may be more sensitive to radiation than workers (for example, infants). 
These concepts may be applied to estimate the effects of exposing a population to radiation. For example, in a population of 100,000 people exposed only to background radiation ( 0.3 rem per year), 15 latent cancer fatalities per year would be inferred to be caused by the radiation $(100,000$ persons $\times 0.3$ rem per year $\times 0.0005$ latent cancer fatalities per person-rem $=$ 15 latent cancer fatalities per year).

Sometimes, calculations of the number of latent cancer fatalities associated with radiation exposure do not yield whole numbers, and, especially in environmental applications, may yield numbers less than 1.0. For example, if a population of 100,000 were exposed as above, but to a total dose of only $0.001 \mathrm{rem}$, the collective dose would be 100 person-rem, and the corresponding estimated number of latent cancer fatalities would be $0.05(100,000$ persons $\times 0.001$ rem $\times 0.0005$ latent cancer fatalities/person-rem $=0.05$ fatal cancers).

How should one interpret a nonintegral number of latent cancer fatalities, such as 0.05 ? The answer is to interpret the result as a statistical estimate. That is, 0.05 is the average number of deaths that would result if the same exposure situation were applied to many different groups of 100,000 people. In most groups, no one ( 0 people) would incur a latent cancer fatality from the 1 millirem dose each member would have received. In a small fraction of the groups, one fatal cancer would result; in exceptionally few groups, two or more fatal cancers would occur. The average number of deaths over all the groups would be 0.05 fatal cancers (just as the average of $0,0,0$, and 1 is $1 / 4$, or 0.25 ). The most likely outcome is 0 latent cancer fatalities.

These same concepts apply to estimating the effects of radiation exposure on a single individual. Consider the effects, for example, of exposure to background radiation over a lifetime. The "number of latent cancer fatalities" corresponding to a single individual's exposure over a (presumed) 72-year lifetime to 0.3 rem per year is the following:

1 person $\times 0.3$ rem/year $\times 72$ years $\times 0.0005$ latent cancer fatalities/person-rem $=0.011$ latent cancer fatalities.

Again, this should be interpreted in a statistical sense; that is, the estimated effect of background radiation exposure on the exposed individual would produce a 1.1-percent chance that the individual might incur a fatal cancer caused by the exposure. Said another way, this method 
estimates that about 1.1 percent of the population might die of cancers induced by the radiation background.

The factors presented above and used in this EIS to relate radiation exposures to latent cancer fatalities are based on the 1990 Recommendations of the International Commission on Radiation Protection (ICRP 1991). These factors are consistent with those used by the U.S. Nuclear Regulatory Commission in its rulemaking Standards for Protection Against Radiation (56 Federal Register 23363, May 21, 1991). The factors apply where the dose to an individual is less than 20 rem and the dose rate is less than 10 rem per hour. At doses greater than 20 rem, the factors used to relate radiation doses to latent cancer fatalities are doubled. At much higher doses, prompt effects, rather than latent cancer fatalities, ray be the primary concern. Unusual accident situations that may result in high radiation doses to individuals are considered special cases.

In addition to latent cancer fatalities, other health effects could result from environmental and occupational exposures to radiation. These effects include nonfatal cancers among the exposed population and genetic effects in subsequent generations. For simplicity, this EIS presents estimated effects of radiation only in terms of latent cancer fatalities. The nonfatal cancers and genetic effects are less probable consequences of radiation exposure, and in some respects less serious. Further discussion on this topic is provided in Appendix F, Section F-4.

\subsubsection{Health Effects to the Public and Worker from Releases to the Environment}

In general, health impacts are estimated for releases of radioactive and nonradioactive contaminants to air and groundwater. The impact analysis and discussion focuses on those contaminants and exposure pathways that have the potential to contribute to adverse environmental consequences. For example, there are no permanent surface waters on the INEL and no surface drainage from the INEL to offsite locations. Therefore, the INEL ER\&WM EIS does not include a detailed analysis of this exposure pathway.

Health risks from air emissions to workers and the public are estimated by modeling worst-case emission scenarios for the various alternatives. These health effects are presented and compared with baseline health effects originally presented in Section 4.12. These modeled 
emissions are used to postulate maximum potential exposure levels in the onsite and offsite environments over the period of evaluation. Health effects calculated using this type of information provide an extremely conservative "worst case" estimate of potential health effects.

Health risks from water for onsite workers were made using either modeled groundwater data (described in Appendix F) or, where current levels represent the highest projected contaminant levels, drinking water distribution sample data reported by Anderson and PetersonWright (1993). Health effects estimates from offsite groundwater contaminants were calculated using the highest of either modeled or reported groundwater concentrations. These concentration estimates are based on those discussed in Section 5.8, Water Resources.

5.12.1.1 Health Effects Resulting from Atmospheric Releases. For routine airborne releases from facilities, health effects were assessed for the following three categories of exposed individuals: (a) the maximally exposed individual located at the INEL site boundary, (b) the population within 50 miles ( 80 kilometers) of the operating facilities, and (c) the maximally exposed onsite worker.

5.12.1.1.1 Radiological Health Risk-The human health risk associated with radiological air emissions is assessed based on risk facters contained in 1990 Recommendations of the International Commission on Radiological Protection (ICRP 1991). The measure of impact used for evaluating potential radiation exposures is risk of fatal cancers. Population effects are reported as collective radiation dose (in person-rem) and the estimated number of fatal cancers in the affected population. The maximum individual effects are reported as individual radiation dose (in millirem) and the estimated lifetime probability of fatal cancer.

For the calculation of health effects from exposure to airborne radionuclides, the modeled doses provided in Section 5.7 were multiplied by the appropriate risk factors from ICRP (1991). The risk for individuals is expressed as the increased lifetime risk of developing fatal cancer. The risk for the public is expressed as the number of estimated fatal cancers in the affected population. For both the individual and the public, the estimated risk, as presented in this section, is calculated from the ten-year dose; that is, the total radiation dose received during the ten-year period from 1995 to 2005 . A detailed explanation of the health effects methodology is contained in Appendix F. 
Tables 5.12-1 and 5.12-2 provide summaries of the ten-year dose, risk factor, and estimated increased lifetime risk of developing fatal cancer based on the exposure associated with the four alternatives and the baseline exposure (Sections 4.7 and 4.12). These data are presented for the maximally exposed onsite worker, the maximally exposed individual at the site boundary, and the surrounding population for the period from 1995 to 2005 . Incremental doses are those that result from activities conducted under the alternatives. Baseline doses result from other activities at the INEL. They assume all permitted sources of the INEL release pollutants to the maximum allowed by operating permits or applicable regulation.

INEL Worker. The risks to an INEL worker at the location of highest dose from airborne radionuclide emissions would vary between the alternatives. As shown in Table 5.12-1, the maximum risk would be for Alternative D (Maximum Treatment, Storage, and Disposal)-about one chance in 40,000 for fatal cancer. The minimum risk would be for Alternative A (No Action)-about one chance in 769,000 for fatal cancer.

Maximally Exposed Individual. As shown in Table 5.12-1, the risk to the maximally exposed individual in the vicinity of the INEL would be highest for Alternative D (Maximum Treatment, Storage, and Disposal). The fatal cancer risk would be about one chance in 238,000 . These risks, while very low, are somewhat higher than the other alternatives because of the release of radionuclides associated with spent nuclear fuel processing on a large scale. The risk to the maximally exposed individual would be lowest for Alternative A (No Action)-about one chance in one million.

Public. As shown in Table 5.12-2, the risk of a fatal cancer effect among the entire surrounding population would be highest for Alternative D. For this alternative, based on the total ten-year exposure, there would be 0.05 fatal cancers expected over the next 70 years. The lowest risks are for Alternatives A and C. For each of these alternatives, based on the total ten-year exposure, there would be 0.003 fatal cancers expected over the next 70 years.

5.12.1.1.2 Nonradiological Heakth Risk-An assessment has been performed to estimate the potential effects on human health associated with each of the environmental restoration and waste management alternatives. All of the risks presented in this section are cumulative in that they include risks associated with the maximum baseline, foreseeable increases 
Table 5.12-1. Ten-year dose and resulting lifetime fatal cancer risk for maximally exposed individuals by Idaho National Engineering Laboratory alternative.

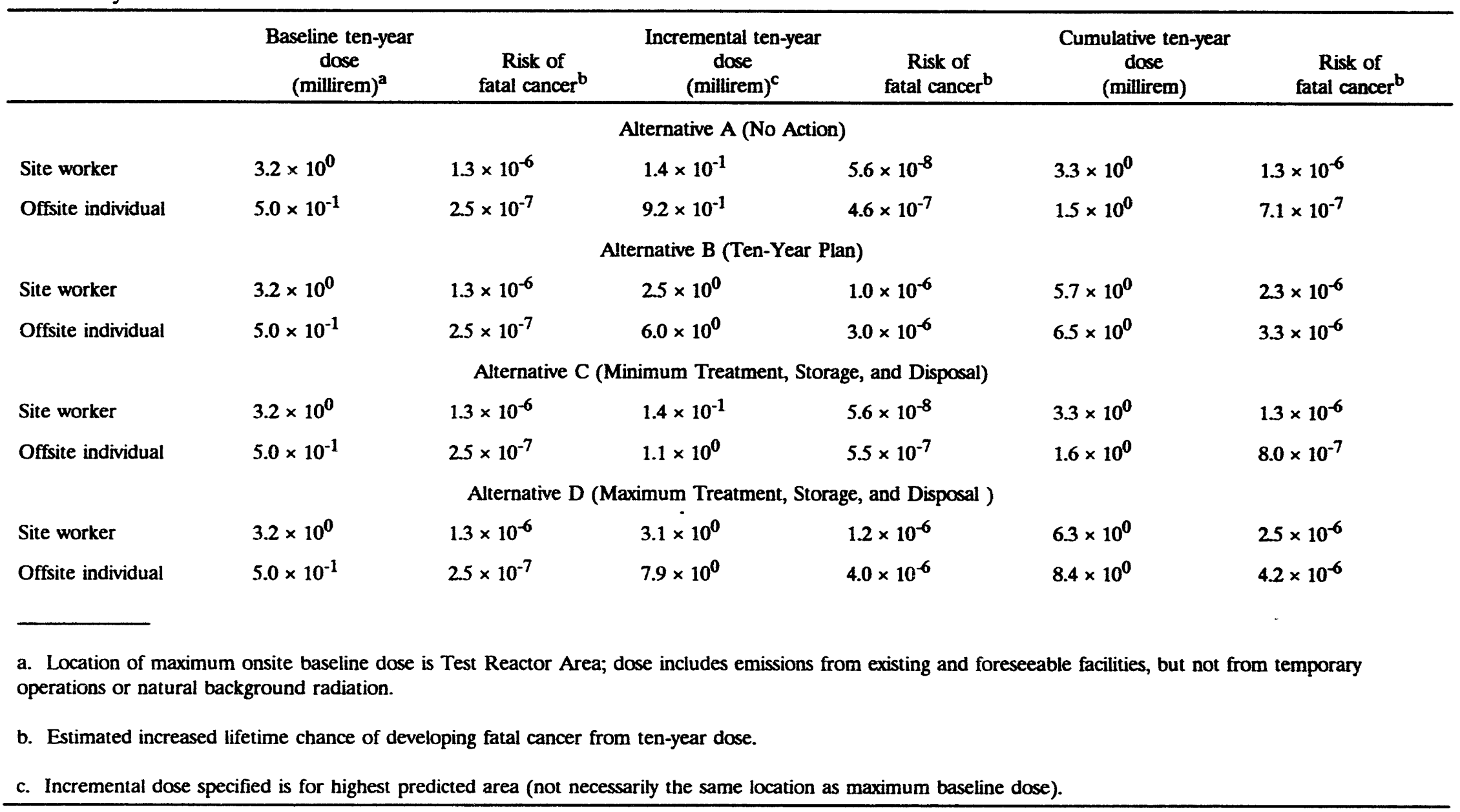


Table 5.12-2 Ten-year population dose and estimated resulting fatal cancers by Idaho National Engineering Laboratory alternative. ${ }^{a}$

\begin{tabular}{|c|c|c|c|c|c|c|c|c|}
\hline & $\begin{array}{c}\begin{array}{c}\text { Ten-year } \\
\text { dose } \\
\text { (person-rem) }\end{array} \\
\end{array}$ & $\begin{array}{c}\text { Total fatal } \\
\text { cancers }^{\mathrm{b}}\end{array}$ & $\begin{array}{c}\text { Ten-year } \\
\text { dose } \\
\text { (person-rem) }\end{array}$ & $\begin{array}{c}\text { Total fatal } \\
\text { cancers }\end{array}$ & $\begin{array}{c}\begin{array}{c}\text { Ten-year } \\
\text { dose } \\
\text { (person-rem) }\end{array} \\
\end{array}$ & $\begin{array}{c}\text { Total fatal } \\
\text { cancers }^{\mathrm{b}}\end{array}$ & $\begin{array}{c}\begin{array}{c}\text { Ten-year } \\
\text { dose } \\
\text { (person-rem) }\end{array} \\
\end{array}$ & $\begin{array}{c}\text { Total fatal } \\
\text { cancers }^{\mathrm{b}}\end{array}$ \\
\hline & \multicolumn{2}{|c|}{ Alternative $\mathbf{A}^{\mathfrak{c}}$} & \multicolumn{2}{|c|}{ Alternative $B^{d}$} & \multicolumn{2}{|c|}{ Alternative $C^{e}$} & \multicolumn{2}{|c|}{ Alternative $D^{f}$} \\
\hline Baseline & $3.0 \times 10^{0}$ & $1.5 \times 10^{-3}$ & $3.0 \times 10^{0}$ & $1.5 \times 10^{-3}$ & $3.0 \times 10^{0}$ & $1.5 \times 10^{-3}$ & $3.0 \times 10^{0}$ & $1.5 \times 10^{-3}$ \\
\hline Increment & $3.7 \times 10^{0}$ & $1.9 \times 10^{-3}$ & $8.0 \times 10^{1}$ & $4.0 \times 10^{-2}$ & $4.0 \times 10^{0}$ & $2.0 \times 10^{-3}$ & $9.5 \times 10^{1}$ & $4.8 \times 10^{-2}$ \\
\hline Cumulative & $6.7 \times 10^{0}$ & $3.4 \times 10^{-3}$ & $8.3 \times 10^{1}$ & $4.2 \times 10^{-2}$ & $7.0 \times 10^{0}$ & $3.5 \times 10^{-3}$ & $9.8 \times 10^{1}$ & $4.9 \times 10^{-2}$ \\
\hline
\end{tabular}

a. Cumulative radiation dose (person-rem) to the population within 50 miles (80 kilometers) of site facilities resulting from INEL operations from 1995 to 2005.

b. Total number of fatal cancers over the lifetime of all individuals in the exposed population.

c. Alternative A (No Action).

d. Alternative B (Ten-Year Plan).

e. Alternative C (Minimum Treatment, Storage, and Disposal).

f. Alternative D (Maximum Treatment, Storage, and Disposal) 
to the baseline, and the actions. Criteria pollutants, carcinogens, and noncarcinogenic toxic air pollutants were evaluated for potential health effects utilizing the methodology outlined in Appendix F, Section F-4, Health and Safety.

Estimated onsite levels of toxic air pollutants reflect maximum predicted levels averaged over an eight-hour period to which site workers might be exposed. These results are compared to occupational standards recommended by either the American Conference of Governmental Industrial Hygienists or the Occupational Safety and Health Administration, whichever is lower. The results indicate that the onsite hazard quotients for carcinogenic and noncarcinogenic toxic air pollutants, with the exception of benzene, from any alternative are less than one. As described in Section 4.12, the onsite baseline hazard quotient for benzene is approximately one. Benzene contributions from Alternative D (Maximum Treatment, Storage, and Disposal), the highest of the alternatives, represent a very small increase (about one-tenth of 1 percent) to the baseline hazard quotient. The hazard quotients of all other toxic air pollutants are well below one.

Hazard quotients, at the site boundary and public roads, associated with the various alternatives are presented in Table 5.12-3. The air concentrations producing these hazard quotients are presented in Sections 4.7 and 5.7. The locations of these modeled concentrations are dependent on different points and times of release, so that no individual could te exposed to all of these chemicals at once. The hazard quotients for these chemicals are less than one for all chemicals under Alternatives A (No Action) and C (Minimum Treatment, Storage, and Disposal), with the exception of toluene (hazard quotient 5.3). For Alternatives B (Ten-Year Plan) and D (Maximum Treatment, Storage, and Disposal), the hazard quotients are less than one svith the exception of mercury, toluene, and hydrochloric acid, which have maximum hazard quotients of about 3.7, 5.3, and 1.5, respectively. The mercury hazard quotient is due to the increased mercury concentration from the alternatives. The toluene hazard quotient is due, almost entirely, to the baseline concentration. The hydrochloric acid hazard quotient is contributed to equally by the baseline and alternatives. Based on these results, the possibility of adverse health effects cannot be ruled out. However, because of the conservative methods and assumptions used in the assessment, these effects are unlikely. 
Table 5.12-3. Hazard quotients from noncarcinogenic toxic air pollutants at the site boundary and public roads on the Idaho National Engineering Laboratory site by alternative."

\begin{tabular}{|c|c|c|c|c|c|c|}
\hline \multirow[b]{2}{*}{ Toxic air pollutant } & \multirow[b]{2}{*}{ Location } & \multirow{2}{*}{$\begin{array}{c}\text { Baseline } \\
\text { hazard } \\
\text { quotient }\end{array}$} & \multicolumn{4}{|c|}{ Hazard quotient (alternative + baseline) } \\
\hline & & & $\begin{array}{c}\text { Alternative } \\
\mathbf{A}^{\mathrm{b}}\end{array}$ & $\begin{array}{c}\text { Alternative } \\
\mathbf{B}^{\mathrm{c}}\end{array}$ & $\begin{array}{c}\text { Alternative } \\
C^{d}\end{array}$ & $\begin{array}{c}\text { Alternative } \\
D^{e}\end{array}$ \\
\hline \multirow[t]{2}{*}{ Ammonia } & Public road & 0.33 & 0.34 & 0.34 & 0.34 & 0.34 \\
\hline & Site boundary & 0.02 & 0.03 & 0.03 & 0.03 & 0.03 \\
\hline \multirow[t]{2}{*}{ Freon } & Public road & $<0.01$ & $<0.01$ & $<0.01$ & $<0.01$ & $<0.01$ \\
\hline & Site boundary & $<0.01$ & $<0.01$ & $<0.01$ & $<0.01$ & $<0.01$ \\
\hline \multirow[t]{2}{*}{ Hydrochloric acid } & Public road & 0.79 & 0.79 & 1.46 & 0.79 & 1.46 \\
\hline & Site boundary & 0.08 & 0.08 & 0.71 & 0.08 & 0.79 \\
\hline \multirow[t]{2}{*}{ Hydrofluoric acid } & Public road & NA & - & 0.05 & 0.05 & 0.05 \\
\hline & Site boundary & NA & - & 0.03 & 0.03 & 0.03 \\
\hline \multirow[t]{2}{*}{ Mercury } & Public road & 0.78 & 0.79 & 3.58 & 0.82 & 3.65 \\
\hline & Site boundary & 0.25 & 0.25 & 3.58 & 0.27 & 3.91 \\
\hline \multirow[t]{2}{*}{ Nitric acid } & Public road & 0.07 & 0.07 & 0.07 & 0.07 & 0.07 \\
\hline & Site boundary & 0.03 & 0.03 & 0.03 & 0.03 & 0.03 \\
\hline \multirow[t]{2}{*}{ Sulfuric acid } & Public road & NA & 0.05 & 0.05 & 0.05 & 0.05 \\
\hline & Site boundary & NA & 0.04 & 0.04 & 0.04 & 0.04 \\
\hline \multirow[t]{2}{*}{ Toluene } & Public road & 5.30 & 5.30 & 5.30 & 5.30 & 5.30 \\
\hline & Site boundary & $<0.01$ & $<0.01$ & $<0.01$ & $<0.01$ & $<0.01$ \\
\hline \multirow[t]{2}{*}{ Tributyl phosphate } & Public road & NA & - & 0.04 & 0.04 & 0.04 \\
\hline & Site boundary & NA & - & 0.03 & 0.03 & 0.03 \\
\hline \multirow[t]{2}{*}{ Trivalent chromium } & Public road & 0.04 & 0.04 & 0.04 & 0.04 & 0.04 \\
\hline & Site boundary & $<0.01$ & $<0.01$ & $<0.01$ & $<0.01$ & $<0.01$ \\
\hline
\end{tabular}

a. Highest predicted eight-hour concentrations.

b. Alternative A (No Action).

c. Alternative B (Ten-Year Plan).

d. Alternative C (Minimum Treatment, Storage, and Disposal).

e. Alrernative D (Maximum Treatment, Storage, and Disposal). 
Lifetime cancer risks from offsite concentration of carcinogenic air pollutants are presented in Table 5.12-4. The human health risk for carcinogens is assessed for individuals offsite at areas with the highest estimated carcinogen air concentrations. The offsite cancer risk is approximately $2.0 \times 10^{-6}$ for each alternative. This corresponds to about one chance in 500,000 of developing cancer. For each alternative, the majority (greater than 90 percent) of the total risk is attributable to emissions associated with the maximum baseline and foreseeable increases to that baseline. The incremental impacts due to the alternatives make only small additions to the baseline.

For all criteria pollutants, both onsite and offsite, the calculated hazard quotients, both onsite and offsite, were less than one. This indicates that no additional adverse health effects are projected as a result of criteria pollutant emissions from any of the alternatives. For carcinogen emissions associated with Alternatives A (No Action) and C (Minimum Treatment, Storage, and Disposal), calculated hazard quotients, both onsite and offsite, were less than one. This indicates that no adverse health effects are expected as a result of criteria pollutant emissions from either of these alternatives.

\subsubsection{Health Effects Resulting from Groundwater Releases. This section} summarizes potential health effects to both onsite and offsite populations due to radionuclides and carcinogenic and noncarcinogenic chemicals in water. More detailed information on concentrations of these pollutants is contained in Section 5.8, Water Resources. Discussion of health effects calculations are contained in Appendix F.

\subsection{Potential Health Effects to the Worker-Estimates of potential} health effects for onsite workers were made using either modeled groundwater data (described in Appendix F) or, where current levels represent the highest projected contaminant levels, drinking water distribution sample data reported by Anderson and Peterson-Wright (1993).

The highest average radionuclide concentration in a site drinking water distribution system occurred at the Central Facilities Area (Anderson and Peterson-Wright 1993). The radionuclide measured was tritium, at a concentration of approximately 16,000 picocuries per liter. This concentration also represents the highest projected tritium concentration to reach a drinking water distribution system. This level is below U.S. Environmental Protection Agency drinking 


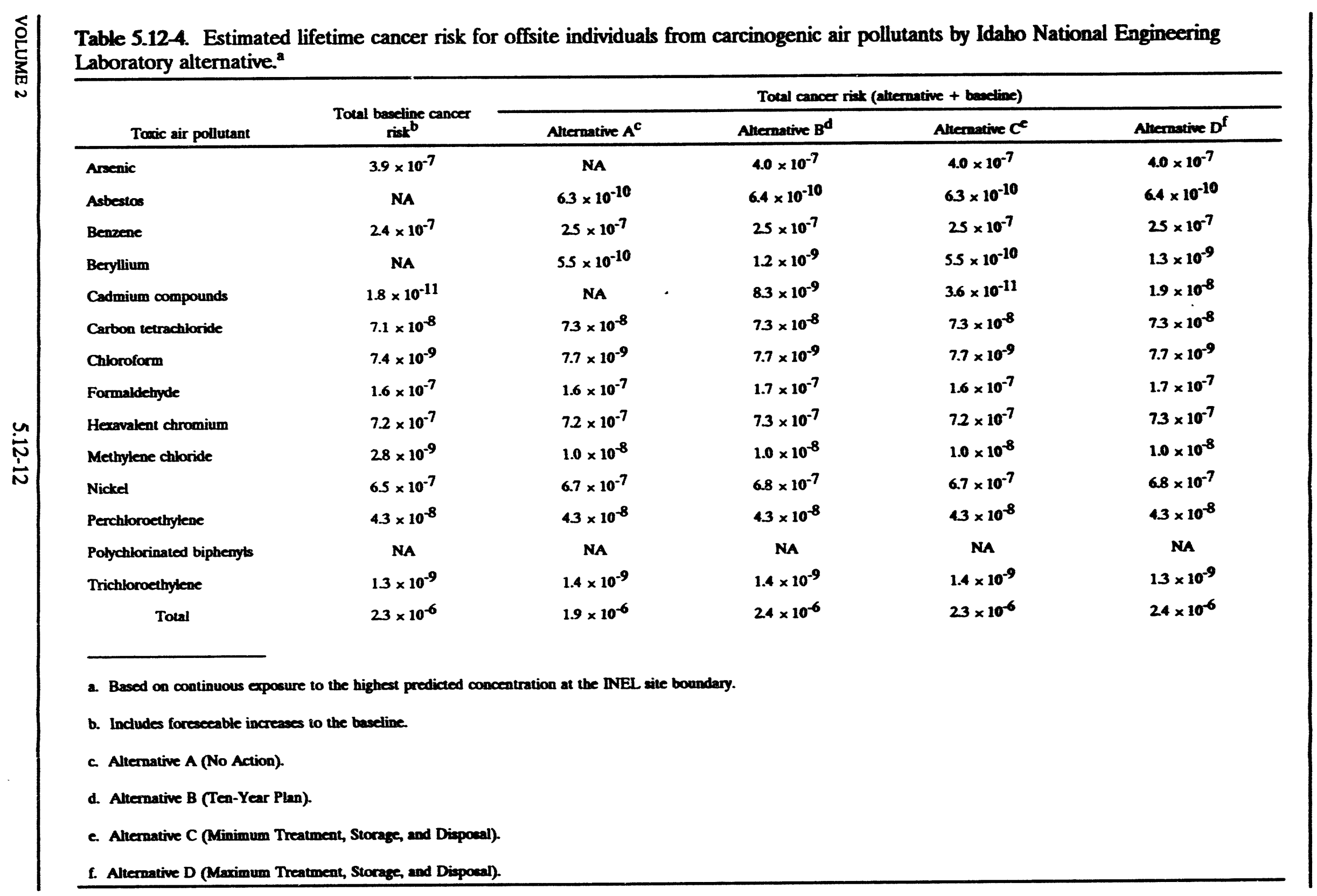


water standard of 20,000 picocuries per liter and is projected to decrease because of changes in facility procedures, dilution in the aquifer, and radioactive decay.

Consumption of this water for 50 years would result in an estimated dose equivalent of 14 millirem, with a corresponding estimated fatal cancer risk of about one chance in 180,000 .

Iodine-129, at a concentration of 0.75 picocuries per liter (maximum contaminant level = 1 picocurie per liter) is projected to reach Well No. 2 at the Central Facilities Area in the year 2010. Consumption of this water for 50 years would result in an estimated dose equivalent of 2.7 millirem, with a corresponding estimated fatal cancer risk of about one chance in 929,000 .

Groundwater with a strontium-90 concentration of 1.5 picocuries per liter (maximum contaminant level of 8 picocuries per liter) and an iodine-129 concentration of 0.65 picocuries per liter is projected to reach Well No. 2 at the Central Facilities Area in the year 2030. Consumption of this water for 50 years would result in an estimated dose equivalent of 5.1 millirem, with a corresponding estimated fatal cancer risk of about one chance in 489,000 .

Trichloroethylene at concentrations above the U.S. Environmental Protection Agency standards is projected to reach Test Area North drinking water supply wells. The maximum concentration of $\mathbf{0 . 0 5 8}$ milligrams per liter is projected to occur at the Water Reactor Research Test Facility Well (TAN-644) in the year 2024. However, if concentrations exceed maximum contaminant levels, then either a sparging system would be installed or the well would no longer be used for drinking water. Trichloroethylene concentrations in drinking water below the maximum contaminant level ( 0.005 milligrams per liter) would indicate an excess incidence of cancer risk of less than one chance in one million.

For all reported noncarcinogenic chemical contaminants, the calculated hazard quotients (that is, the ratio of contaminant to reference dose) were less than one. This indicates that no adverse health effects are expected as a result of these contaminants.

5.12.1.2.2 Potential Health Effects to the Public-For the public, health effects were estimated using an iodine-129 concentration of 0.00083 picocuries per liter, measured at the site boundary in 1992 (Mann 1994). Consumption of this water for the lifetime of an individual 
would result in an estimated dose equivalent of 0.012 millirem, with a corresponding estimated fatal cancer risk of about one chance in 170 million.

\subsubsection{Impacts to the Publlc from Specific Actlvilles. Reracking of CPP-666,} replacing the high-level waste storage tanks at the Idaho Chemical Processing Plant, and using new technology selections for sodium-bearing and calcined waste treatment are not anticipated to result in large amounts of additional releases of radioactivity or hazardous chemicals to the environment. Therefore, no public health impacts are expected. Incineration at the Waste Experimental Reduction Facility has some potential for additional releases of radioactivity or hazardous chemicals to the atmosphere. However, operation of the facility for low-level wastes was included as a foreseeable project in the baseline radiological assessment for atmospheric emissions. These operations contribute about 25 percent of the estimated baseline dose to a maximally exposed individual.

\subsubsection{Occupational Health and Safoty}

All of the activities to be performed by workers under each of the alternatives are similar to those currently performed at the INEL. Some of the workers involved in the alternatives would be engaged in activities that may expose them to radiation and other workplace hazards at levels greater than current averages. However, other workers will be engaged in activities that are much less hazardous. Therefore, for all alternatives, the potential hazards encountered in the workplace will be similar to those that currently exist at the INEL. Furthermore, these hazards will be mitigated by occupational and radiological safety programs operating under the same regulatory standards and limits that currently apply at the INEL. For these reasons, the average radiation dose and the number of reportable cases of injury and illness are anticipated to be proportional to the number of workers at the INEL under each alternative.

The estimated occupational impacts reported in this section are based on the current average occupational radiation dose rates and injury/illness and workplace fatality incidence rates presented in Section 4.12, Health and Safety. These rates have been applied to the estimated number of INEL workers under each alternative as presented in Section 5.3, Socioeconomics. A more complete discussion of health and safety analysis methods appears in Appendix F, Section F-4, Health and Safety. 
5.12.2.1 Radlological Exposure and Hoath Effocts. Estimated radiological impacts to workers are presented in Table 5.12-5. The average dose rate per year for each employee is based on actual monitoring data for the INEL over the period 1987 to 1991 (Appendix F). The table distinguishes between those workers involved in activities under each alternative (incremental workforce) and those INEL workers engaged in other activities (baseline workforce). The baseline number of workers under Alternative A (No Action) reflects the projected shutdown of the Expended Core Facility. This reduces the baseline by an average of 258 workers per year over the period 1995 to 2005. The shutdown of the Expended Core Facility is also an option under Alternative C (Minimum Treatment, Storage, and Disposal). However, to ensure a bounding analysis of potential worker health effects, this reduction in force was not included in Alternative C.

The measures of impact in Table 5.12-5 are: (a) average annual collective dose over the workforce, (b) total collective dose to the workforce over the time period addressed by the EIS (1995 to 2005), and (c) total number of excess fatal cancers expected over the lifetimes of the workers due to radiation received during the period covered by the EIS.

There is a potential for small increments of additional radiation dose to some workers from exposure to atmospheric emissions from INEL facilities or drinking water from production wells on the site. The maximum potentials for impacts from atmospheric releases are presented in Table 5.12-1. Impacts from onsite drinking water supplies are presented in Section 5.12.1.2.1. The average impact to workers exposed by these pathways cannot be estimated precisely but will be much smaller than the maximum potential amounts reported above. These exposure pathways are not expected to make a significant contribution to the values presented in Table 5.12-5.

Collective radiation dose and resulting health effects are expected to be less than current levels for all alternatives. This is because, for all alternatives, total employment at the INEL is expected to decline from the current number of about 11,000 . Furthermore, the total average workforce at the INEL for the period from 1995 to 2005 is similar for all alternatives so that the differences in radiological impacts to the workforce are small.

5.12.2.2 Nonradiological Occupational Hazards. Estimated nonradiological impacts to workers are presented in Table 5.12-6. The rates for injury and illness and occup tional 


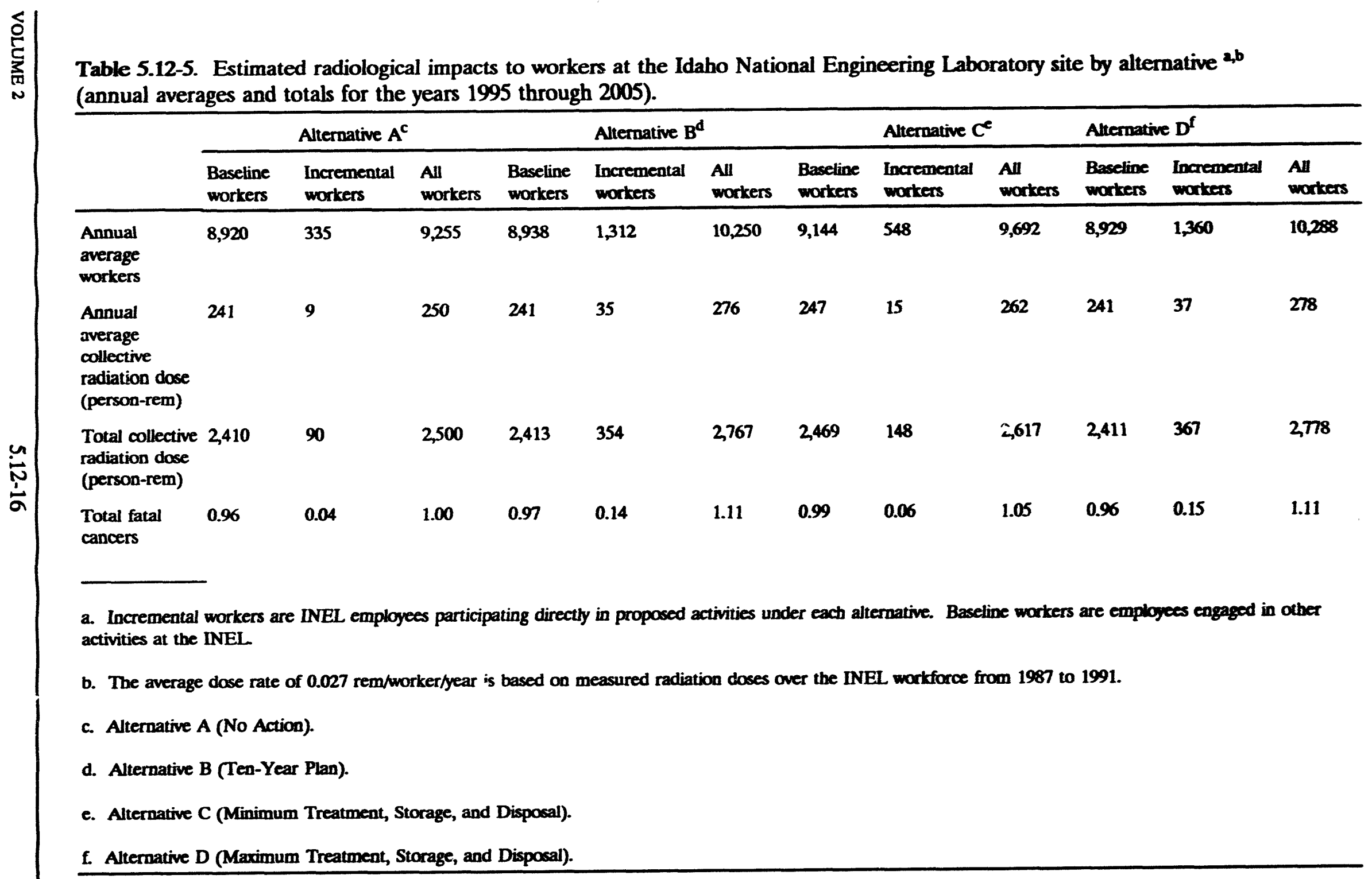


Table 5.12-6. Estimated nonradiological impacts to workers at the Idaho National Engineering Laboratory site by alternative

(annual averages and totals for the years 1995 through 2005).

\begin{tabular}{|c|c|c|c|c|c|c|c|c|c|c|c|c|}
\hline & \multicolumn{3}{|c|}{ Alternative $A^{b}$} & \multicolumn{3}{|c|}{ Alternative $B^{C}$} & \multicolumn{3}{|c|}{ Alternative $C^{d}$} & \multicolumn{3}{|c|}{ Alternative $\mathbf{D}^{\mathrm{e}}$} \\
\hline & $\begin{array}{l}\text { Baseline } \\
\text { workers }\end{array}$ & $\begin{array}{l}\text { Incremental } \\
\text { workers }\end{array}$ & $\begin{array}{l}\text { All } \\
\text { workers }\end{array}$ & $\begin{array}{l}\text { Baseline } \\
\text { workers }\end{array}$ & $\begin{array}{l}\text { Incremental } \\
\text { workers }\end{array}$ & $\begin{array}{l}\text { All } \\
\text { Eorkers }\end{array}$ & $\begin{array}{l}\text { Baseline } \\
\text { workers }\end{array}$ & $\begin{array}{l}\text { Incremental } \\
\text { workers }\end{array}$ & $\begin{array}{l}\text { All } \\
\text { workers }\end{array}$ & $\begin{array}{l}\text { Baseline } \\
\text { workers }\end{array}$ & $\begin{array}{l}\text { Incremental } \\
\text { workers }\end{array}$ & $\begin{array}{l}\text { All } \\
\text { workers }\end{array}$ \\
\hline \multicolumn{13}{|c|}{ Nonconstruction } \\
\hline $\begin{array}{l}\text { Annual } \\
\text { average } \\
\text { workers }\end{array}$ & 8,793 & 138 & 8,931 & 8,911 & 318 & 9,229 & 9,015 & 176 & 9,191 & 8,897 & 323 & 9,220 \\
\hline $\begin{array}{l}\text { Annual } \\
\text { average } \\
\text { injury/iliness }\end{array}$ & 282 & 4.4 & 296 & 285 & 10.2 & 295 & 288 & 5.6 & 294 & 285 & 10.3 & 295 \\
\hline $\begin{array}{l}\text { Annual } \\
\text { average } \\
\text { fatalities }\end{array}$ & 0.28 & 0.00 & 0.28 & 0.29 & 0.01 & 0.30 & 0.29 & 0.01 & 0.29 & 0.28 & 0.01 & 0.30 \\
\hline $\begin{array}{l}\text { Total } \\
\text { injury/illness }\end{array}$ & 2,820 & 44 & 2,864 & 2,851 & 102 & 2,953 & 2,884 & 56 & 2,941 & 2,847 & 103 & 2,950 \\
\hline Total fatalities & 2.8 & 0.04 & 2.84 & 2.9 & 0.10 & 3.0 & 2.9 & .06 & 2.94 & 2.9 & 0.10 & 2.9 \\
\hline \multicolumn{13}{|c|}{ Construction } \\
\hline $\begin{array}{l}\text { Annual } \\
\text { average } \\
\text { workers }\end{array}$ & 127 & 197 & 324 & 36 & 994 & 1,030 & 129 & 372 & 501 & 32 & 1,037 & 1,069 \\
\hline $\begin{array}{l}\text { Annual } \\
\text { average } \\
\text { injuryfillness }\end{array}$ & 7.9 & 12.2 & 20.1 & 2.2 & 61.6 & 63.9 & 8.0 & 23.1 & 31.1 & 20 & 64.3 & 66.3 \\
\hline $\begin{array}{l}\text { Annual } \\
\text { average } \\
\text { fatalities }\end{array}$ & 0.01 & 0.02 & 0.04 & 0.00 & 0.11 & 0.11 & 0.01 & 0.04 & 0.06 & 0.00 & 0.11 & 0.12 \\
\hline $\begin{array}{l}\text { Total } \\
\text { injuryfillness }\end{array}$ & 79 & 122 & 201 & 22 & 616 & 639 & 80 & 231 & 311 & 20 & 643 & 663 \\
\hline Total fatalities & 0.14 & 0.22 & 0.36 & 0.04 & 1.09 & 1.13 & 0.14 & 0.41 & 0.55 & 0.03 & 1.14 & 1.18 \\
\hline
\end{tabular}


Table 5.12-6 (continued)

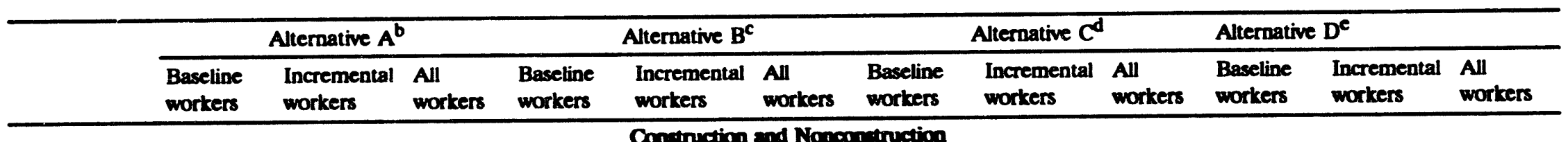

Total fatalities

$\begin{array}{llllllllllll}2.96 & 0.26 & 3.20 & 2.89 & 1.20 & 4.09 & 3.03 & 0.47 & 3.49 & 2.88 & 1.24 & 4.13\end{array}$

a. Incremental workers are INEL employees participating directly in activities under each alternative. Baseline workers are employees engaged in other activities at the INEL.

b. Alternative A (No Action).

c. Alternative B (Ten-Year Plan).

d. Alternative C (Minimum Treatment, Storage, and Disposal).

e. Alternative D (Maximum Treatment, Storage, and Disposal). 
fatalities are based on observed rates for DOE and its contractors over the period from 1988 to 1992 (Appendix F). The table distinguishes between those workers involved in activities under each alternative and those INEL workers engaged in other activities. The table also presents separate estimates of potential hazards to construction workers under each alternative. This is because construction work is considerably more hazardous than other activities under the alternatives. Like the analysis of occupational radiation dose, the shutdown of the Expended Core Facility is included in the baseline for Alternative A (No Action) but not for Alternative C (Minimum Treatment, Storage, and Disposal).

The measures of impact in Table 5.12-6 are: (a) average annual cases of reportable injury and illness, (b) average annual number of fatalities, (c) total cases of reportable injury and illness over the time period addressed by the EIS (1995 to 2005), and (d) the total number of occupational fatalities during the period covered by the EIS.

There is a potential for small increments of additional exposure to toxic materials due to atmospheric emissions from INEL facilities or drinking water from production wells on the site. The maximum potentials for these impacts are presented in Sections 5.12.1.1.2 and 5.12.1.2.1, respectively. The average impact to workers exposed by th.se pathways cannot be estimated precisely, but will be much smaller than the maximum potential amounts reported above. These exposure pathways are not expected to make a significant contribution to the values presented in Table 5.12-6.

The number of reportable injury and illness cases is expected to be less than current levels for all alternatives. This is because, for all alternatives, total employment at the INEL is expected to decline from the current number of about 11,000. For those injuries and illnesses of an occupational nature, the current proportions of different types of health impacts are expected to apply to all alternatives. These are repeated trauma disorders, 48 percent; skin disorders, 30 percent; respiratory conditions, 11 percent; and other impacts, 11 percent.

The total average workforce at the INEL for the period from 1995 to 2005 is similar for all alternatives so that the differences in impacts from nonradiological hazards to the workforce are small. Most of the differences are a result of the different proportion of construction workers for each alternative. 


\subsubsection{Impacts to the Worker from Specific Activities. Reracking of CPP-666,}

replacing the high-level waste storage tanks at the Idaho Chemical Processing Plant, and constructing a new facility and using an existing facility for interim storage of sodium-bearing liquid waste and calcined high-level waste, and upgrading the existing Waste Experimental Reduction Facility will involve additional construction workers not included in the analysis of Alternatives A through D. This could result in an additional potential for injuries or illness from normal workplace hazards. However, the incremental impact to the total workforce will be small because the number of workers will be a small percentage of the total.

Handling of radioactive material could result in additional radiation dose to workers during the reracking of CPP-666 and the interim storage of waste for calcined waste and sodiumbearing treatment technologies. Also, some potential exists for additional releases of radioactivity or hazardous chemicals to the atmosphere during the upgrade of the Waste Experimental Reduction Facility. 


\subsection{Idaho National Engineering Laboratory Services}

This section discusses the potential effects of the four environmental restoration and waste management alternatives and five specific project decisions on utilities and energy and security and emergency services at the INEL. The consumption of water, electrical energy, fossil-based fuels, and wastewater discharges at the INEL site and the Idaho Falls support facilities are considered.

\subsubsection{Methodology}

To determine the potential impacts of the alternatives on the INEL site utilities and energy systems, the projected usage rates for water, electricity, fuel, and wastewater treatment and discharge systems required by new facilities were evaluated and compared. In addition, the total demands, composed of baseline plus new facilities, were compared with supply capabilities. Since increased use of services is normally associated with new buildings, the total number of new buildings and the total area occupied by new buildings is shown in Figure 5.13-1 for each alternative. The project descriptions given in Appendix $\mathrm{C}$ and the project distribution by alternative (given in Chapter 3, Alternatives) were used to evaluate the alternative-dependent increases in demand. The potential impact on Idaho Falls facilities depends on any change in workforce at these facilities.

\subsubsection{Idaho National Engineering Laboratory Services Impacts from Alternative A (No Action)}

Alternative A (No Action) encompasses 13 new projects. Five projects include construction and operation of 16 new buildings on the INEL site, having about 74,000 square meters $(800,000$ square feet) of floor space, and three projects include substantial construction of other facilities, such as concrete pads and vaults. The estimated increases in utility and energy usage rates resulting from these projects are 20,000 megawatt-hours per year of electricity, 106,700 cubic meters ( 28.2 million gallons) per year of water, and 3.8 million liters (1.0 million gallons) per year of wastewater discharge (Hendrickson 1994). These increases represent small increases ranging from 0.7 percent to 10 percent above the baseline and are well within current 


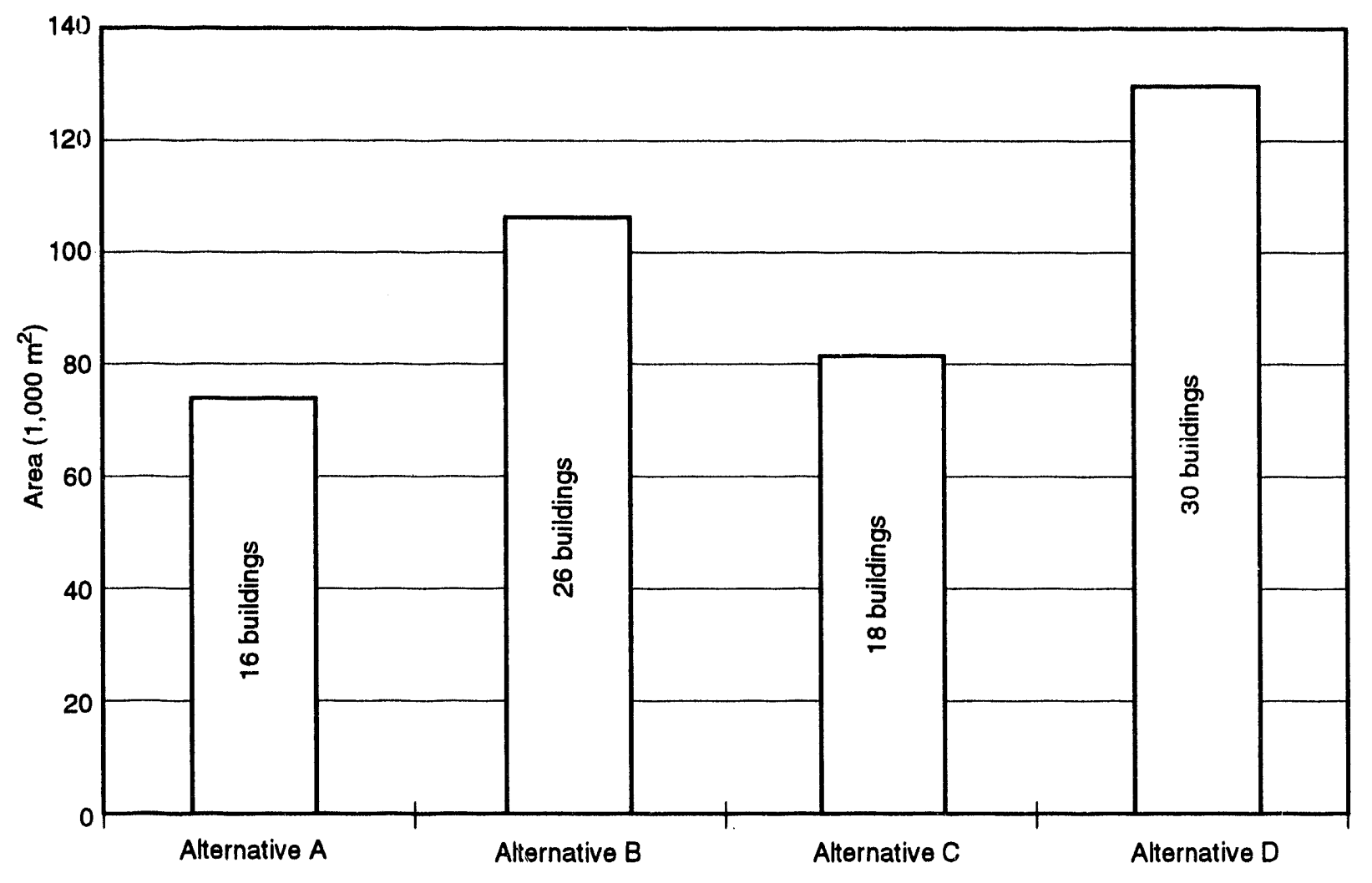

Figure 5.13-1. Total area of new buildings at the Idaho National Engineering Laboratory under all the alternatives.

system capabilities and usage limits (see Section 4.13, Idaho National Engineering Laboratory Services).

Fossil fuel usage would increase by 910,000 liters (240,000 gallons) of heating oil, 362,000 liters (96,000 gallons) of diesel fuel, and 1,190,000 liters (314,000 gallons) of propane annually (Hendrickson 1994). These increases in heating oil and diesel fuel are less than 10 percent above the baseline, but propane usage increases by over 200 percent to support building heating for new projects. The available supply of fossil fuels at the INEL site should support these usage levels.

The primary construction materials are concrete and steel. The buildings and related construction projects for Alternative A (No Action) are estimated to include about 25,000 cubic meters $(32,700$ cubic yards) of concrete. The amount of steel is not currently defined, but is considered recyclable when the project is decommissioned. 
Alternative A (No Action) is not expected to require increases in INEL site fire, security, or emergency services.

\subsubsection{Idaho National Engineering Laboratory Services Impacts from Alternative B (Ten- Year Plan)}

Alternative B (Ten-Year Plan) encompasses 43 new projects. Eighteen projects include construction and operation of 26 new buildings on the INEL site, having about 107,000 square meters $(1,150,000$ square feet) of floor space, and six projects include substantial construction of other facilities. The estimated increases in utility and energy usage rates above baseline resulting from these projects are 98,400 megawatt-hours per year of electricity (47 percent increase), 299,800 cubic meters (79.2 million gallons) per year of water ( 5 percent increase), and 10.8 million liters (2.9 million gallons) per year of wastewater discharge ( 2 percent increase) (Hendrickson 1994). The increase in usage rate for electricity is about 50 percent of the baseline usage but is within the contracted supply level. Increases in water and wastewater are 5 percent or less and are very moderate increases, well within INEL site capabilities.

Fossil fuel usage would increase by 5,445,000 liters (1,438,000 gallons) of heating oil, $1,110,000$ liters (293,000 gallons) of diesel fuel, and 2,700,000 liters (715,000 gallons) of propane annually (Hendrickson 1994). These increases in usage rates range from increases of 20 percent for diesel fuel, 50 percent for heating oil, and 475 percent for propane. The large increase in propane results from both facility heating and incineration. Fossil fuel supply to the INEL site is adequate to meet these demands.

The quantity of concrete estimated for construction of Alternative B (Ten-Year Plan) buildings and facilities is 60,000 cubic meters (78,500 cubic yards).

Alternative B (Ten-Year Plan) may result in the need for expanded INEL site fire protection, security, and emergency services.

The specific activities associated with Alternative B (Ten-Year Plan) are additional racks in the spent nuclear fuel storage pools at the Idaho Chemical Processing Plant Fluorinel and Storage (FAST) Facility, selection of technologies for processing sodium-bearing liquid waste and 
calcined high-level waste, and incineration of low-level and mixed low-level waste at the Waste Experimental Reduction Facility. Decisions related to these activities would have no additional impacts on INEL services.

\subsubsection{Idaho National Engineering Laboratory Services Impacts from Alternative C (Minimum Treatment, Storage, and Disposal)}

Alternative C (Minimum Treatment, Storage, and Disposal) encompasses 19 new projects. Eleven projects include construction and operation of 18 new buildings on the INEL site, having about 81,000 square meters $(870,000$ square feet) of floor space, and three projects include substantial construction of other facilities. The estimated increase in utility and energy usage rates resulting from these projects are 74,800 megawatt-hours per year of electricity ( 35 percent increase), 158,600 cubic meters (41.9 million gallons) per year of water ( 2.5 percent increase), and 5.4 million liters (1.4 million gallons) per year of wastewater discharge (1 percent increase) (Hendrickson 1994). These usage rates lie between those of Alternatives A (No Action) and B (Ten-Year Plan) and are within system capabilities and usage limits.

Fossil fuel usage would increases by 848,000 liters (225,000 gallons) of heating oil, 416,000 liters (110,000 gallons) of diesel fuel, and 1,246,000 liters (330,000 gallons) of propane annually (Hendrickson 1994). The increases in heating oil and diesel fuel are about 7 percent above baseline, and propane use increases about 220 percent to support facility heating. These increases are very similar to increases associated with Alternative A (No Action) and are expected to be within INEL supply capability.

The construction associated with Alternative C (Minimum Treatment, Storage, and Disposal) projects is expected to require about 35,000 cubic meters $(45,800$ cubic yards) of concrete.

Alternative C (Minimum Treatment, Storage, and Disposal) is not exfected to require increases in INEL site fire, security, or emergency services.

The specific activities associated with Alternative C (Minimum Treatment, Storage, and Disposal) are selection of technologies for processing sodium-bearing liquid waste and calcined 
high-level waste and the replacement of high-level waste storage tanks at the Idaho Chemical Processing Plant. Any decisions related to these activities would have no additional impact on INEL services.

\subsubsection{Idaho Natlonal Engineering Laboratory Services Impacts from Alternative D (Maximum Treatment, Storage, and Disposal)}

Alternative D (Maximum Treatment, Storage, and Disposal) includes all of the projects in Alternative B (Ten-Year Plan) plus five additional projects with four additional new buildings. In addition, the scope of three of the projects is expanded under Alternative $D$ to accommodate the increased quantities of materials. The new buildings constructed on the INEL would have 130,000 square meters $(1,400,000$ square feet) of floor space. Accordingly, Alternative D increases in usage rates for utilities are estimated to be 127,700 megawatt-hours per year of electricity (61 percent increase), 206,000 cubic meters (54.6 million gallons) per year of water (3.2 percent increase), and 12.3 million liters ( 3.2 million gallons) per year of wastewater discharge (2.2 percent increase) (Hendrickson 1994). These usage rates represent the maximum increases for all the alternatives and, when added to the baseline usage rates, are still below existing system capabilities and use limits.

Fossil fuel usage would increase by 5,860,000 liters (1,548,000 gallons) of heating oil, $1,203,000$ liters $(320,000$ gallons) of diesel fuel, and 2,732,000 liters (730,000 gallons) of propane annually (Hendrickson 1994). Alternative D (Maximum Treatment, Storage, and Disposal) heating oil usage is 53 percent above baseline, diesel fuel usage is 21 percent above baseline, and propane usage is $\mathbf{5 8 0}$ percent above baseline. These increases are comparable to Alternative B (Ten-Year Plan) and are within the INEL supply capability.

The construction associated with Alternative D (Maximum Treatment, Storage, and Disposal) projects is expected to require about 100,000 cubic meters $(130,000$ cubic yards) of joncrete.

Alternative D (Maximum Treatment, Storage, and Disposal) may result in the need for expanded INEL site fire protection, security, and emergency services. 
The specific activities associated with Alternative D (Maximum Treatment, Storage, and Disposal) are additional racks in the spent nuclear fuel storage pools at the Idaho Chemical Processing Plant Fluorinel and Storage (FAST) Facility, selection of technologies for processing sodium-bearing liquid waste and calcined high-level waste, and incineration of low-level and mixed low-level waste at the Waste Experimental Reduction Facility. Decisions related to these activities would have no additional impacts on INEL services.

\subsubsection{Summary of Impacts from Alternatives}

Alternative D (Maximum Treatment, Storage, and Disposal) would put the greatest demand on INEL site services. For Alternative D, electrical consumption was estimated to be 127,700 megawatt-hours per year, which is an increase of about 61 percent above baseline usage. The expected total usage (baseline plus expected increase) is about 336,000 megawatt-hours per year, which is just over 85 percent of the existing supply and 34 percent of system capacity; thus, the existing INEL site electrical system could accommodate the electrical load for Alternative D. All the other alternatives create less electrical demand, so all alternatives could be accommodated without exceeding about 77 percent of contracted supply for average load.

The corresponding increases in water usage and wastewater discharge for Alternative D (Maximum Treatment, Storage, and Disposal) were less than about 5 percent above baseline. A comparison of the increases in electrical usage, water usage, and wastewater discharge for all four alternatives is shown graphically in Figure 5.13-2.

The corresponding increases in fossil fuel usage are also shown graphically in Figure 5.13-2. The fossil fuel usage increases for Alternatives $A$ (No Action) and $C$ (Minimum Treatment, Storage, and Disposal) are very comparable, as are those for Alternatives B (Ten-Year Plan) and D (Maximum Treatment, Storage, and Disposal).

The facilities at the INEL site are the major consideration in evaluating the potential impact on utilities and energy; however, scme minor impact could also be expected from staff housed in Idaho Falls facilities. City of Idaho Falls services and natural gas supplies accommodate current staff adequately. Since the overall INEL workforce is expected to decline, no staff increases in Idaho Falls offices are anticipated and there would be no negative impact on city 

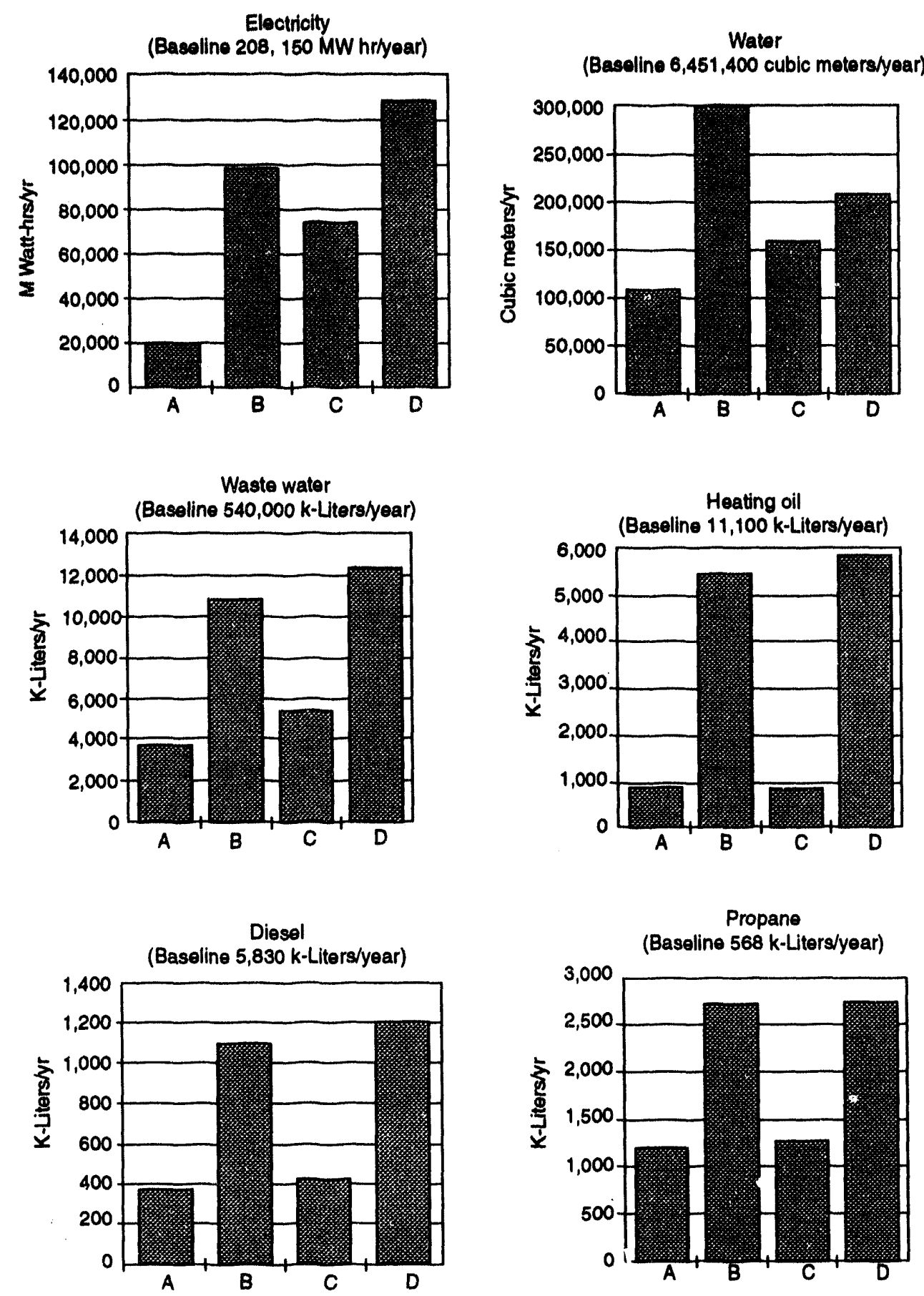

$A=$ Altemative $A$ (No Action)

$\mathbf{B}=$ Altemative B (Ten-Year Plan)

C = Altemative C (Minimum Treatment, Storage, and Disposal)

$D=$ Altemative D (Maximum Treatment, Storage, and Disposal)

SAA0023

Figure 5.13-2 A summary of peak utility usage increases above baseline at the Idaho National Engineering Laboratory for all alternatives. 
services or natural gas supplies. The City of Idaho Falls provides fire, police, and emergency services to the INEL facilities in town and would not be impacted by any of the alternatives. 


\subsection{Facllity Accidents}

A potential exists for accidents at facilities associated with the treatment, storage, and disposal of radioactive and hazardous materials. Accidents can be categorized into events that are abnormal (for example, minor spills), events a facility was designed to withstand, and events a facility is not designed to withstand (but whose consequences it may nevertheless mitigate). These categories are termed abnormal, design basis," and beyond design basis accidents, respectively. Summarized here are consequences of possible facility accidents in these categories for a member of the public at the nearest site boundary, for the collective population within 80 kilometers ( 50 miles), for workers, and for the environment. Details of assessments of the accidents are in DOE-ID (1994). Section 5.11 (Traffic and Transportation) summarizes the assessment of transportation accidents.

An accident is a series of unexpected or undesirable "initiating" events leading to a release of radioactive or hazardous materials within a facility or to the environment. This analysis defines initiating events that can lead to a facility accident in three broad categories: external initiators, internal initiators, and natural phenomena initiators. External initiators originate outside the facility and may impact the ability of the facility to confine radioactive or hazardous material. These initiators may be related to fires and explosions nearby, or caused by events at nearby facilities. Internal initiators originate within a facility (for example, equipment failures or human error) and usually are the result of the facility's operation. Sabotage and terrorist activities (that is, intentional human initiators; may be classified as either external or internal initiators. Natural phenomena initiators include weather-related (for example, floods and tornadoes) and seismic events. For this analysis, initiators are defined in terms of those events that cause, directly or indirectly, a release of radioactive or hazardous materials within a facility or to the environment by failure or bypass of confinement.

The historical record of accidents at the INEL is summarized in the following section. Methods used to assess potential future events are summarized in Sectior :.14.2. Evaluations of accident impacts by alternative are summarized in Sections 5.14.3 through 5.14.6. A summary comparison of accident impacts by alternative is given in Section 3.3, Comparison of Impacts.

a. For tacilities where design basis accident analyaes were unavailable, evaluation basis accidents (postulated accidents used where documented design basis accidents do not exist) were $\alpha$ ssiderad per DOE-DP-STD-3005-93 (DOE 1993a). 


\subsubsection{Historical Perspectlve}

Many of the INEL actions proposed under the alternatives are continuations or variations of past practices. Injuries, illnesses, and the potential for increased cancer risk for workers are addressed in Section 5.12, Health and Safety. Most historical accidents, such as the April 15, 1994, release of chlorine gas at Argonne National Laboratory-West, are less severe than the postulated accidents discussed here. As discussed below, the primary historical cause of fatalities to INEL workers has been industrial accidents, and risks to the public from INEL accidents have been analyzed in detail and have been determined to be very low (DOE-ID 1991).

Consequences of accidents can involve fatalities, injuries, or illnesses. Fatalities can be prompt (immediate), such as in construction accidents, or latent (delayed), such as cancer caused from radiation exposure. While public comments received in scoping meetings for Volume 2 of this EIS included many concerns about potential accidents, the historical record shows DOE facilities have had a very good safety record. Figure 5.14-1 illustrates the rate of worker fatalities at the INEL (Millet 1993) compared to the rate in the overall DOE complex (DOE 1993b) as well as national-average rates compiled for various industry groups by the National Safety Council (NSC 1993) and Idaho averages compiled from state statistics by Hendrix (1994). All statistics apply to the period 1983 through 1992 . The worker accident fatality rate for the INEL is very low compared to the rates from industry groups such as agriculture and construction and is comparable to those for trade and services groups. None of the INEL fatalities in this ten-year period resulted from exposure to radiation or hazardous material. While past accident rates are not necessarily indicative of future rates, the historical record reflects DOE's emphasis on safe operations.

For accidents involving radiation exposure, a total of three prompt worker fatalities have occurred in the 40-year history of INEL facilities. These workers were killed by a steam explosion resulting from a nuclear criticality (uncontrolled chain reaction) in an experimental reactor (Stationary Low-Power Reactor No. 1) in 1961. The workers were manually moving reactor control elements when the accident occurred. The dose from this accident to an individual at the nearest site boundary has been estimated at approximately 3 millirem (DOE-ID 1991). A number of nonfatal accidental radiation exposures have occurred to INEL workers. Neither prompt nor delayed fatalities are known to have occurred to members of the public from radiation exposure 

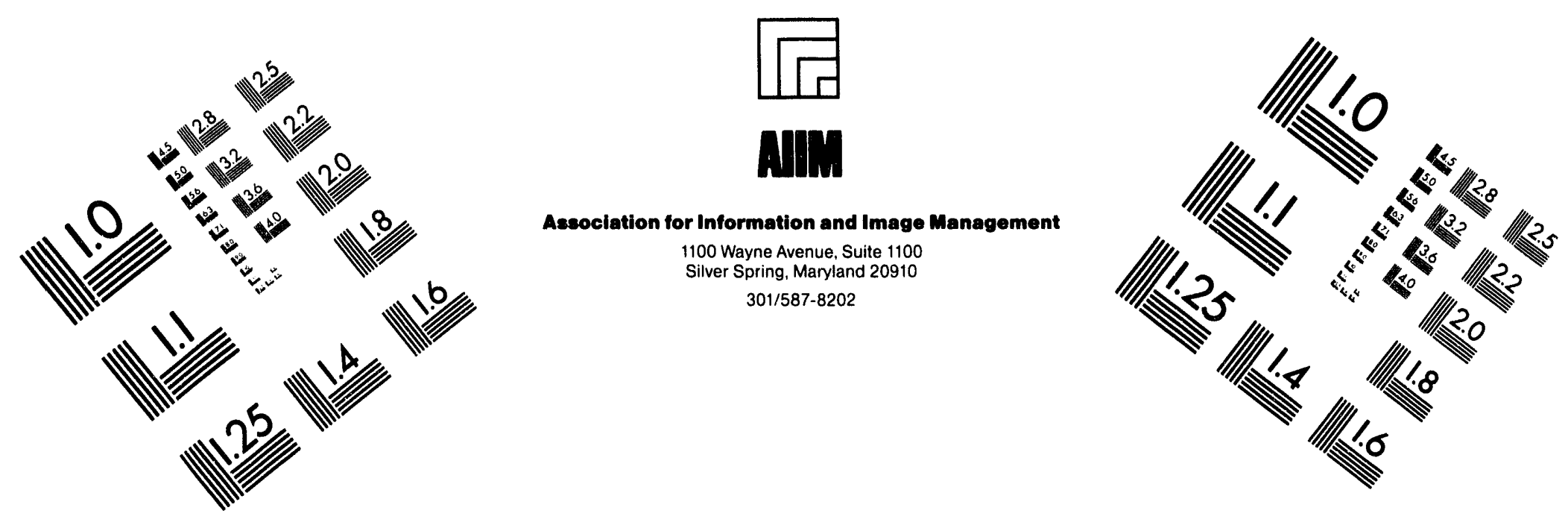

\section{Centimeter}

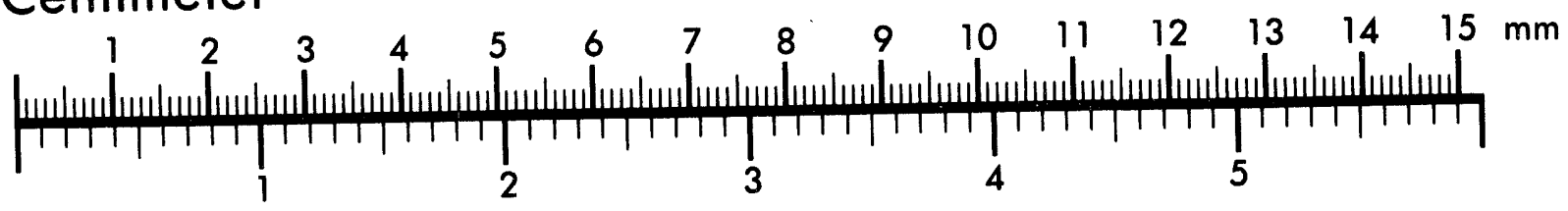
Inches
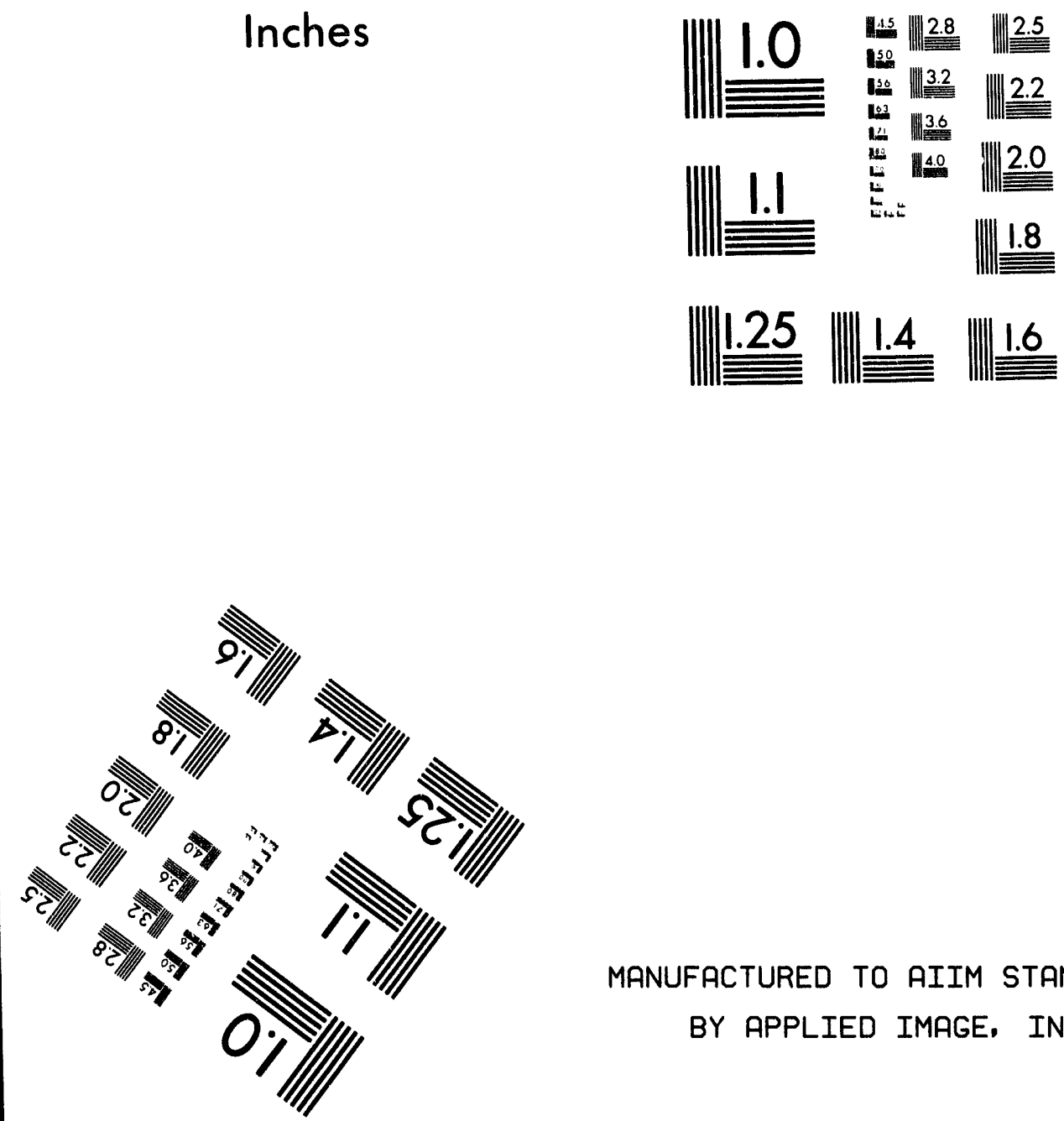

MANUFACTURED TO AIIM STANDARDS

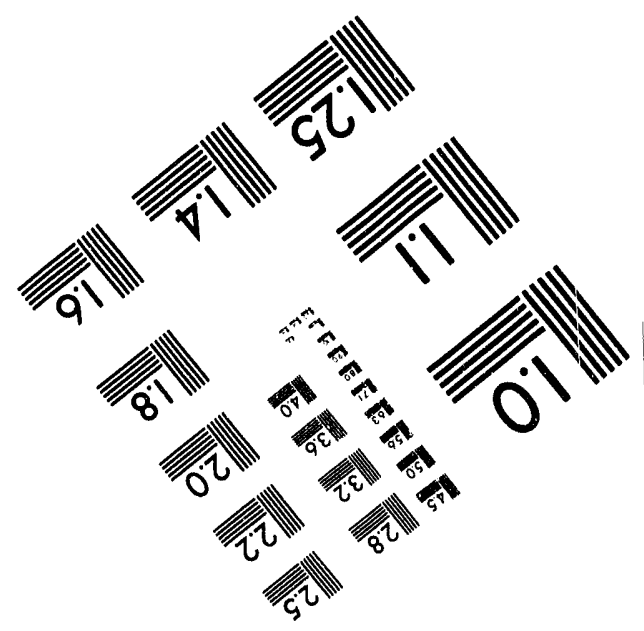



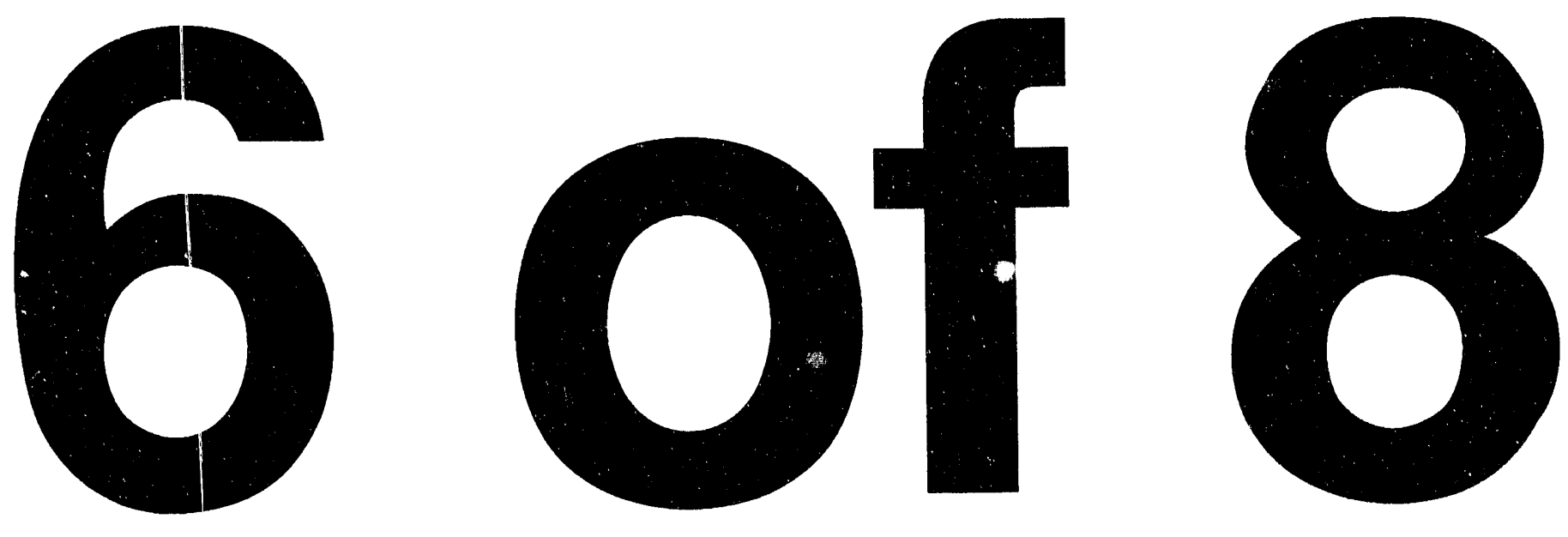


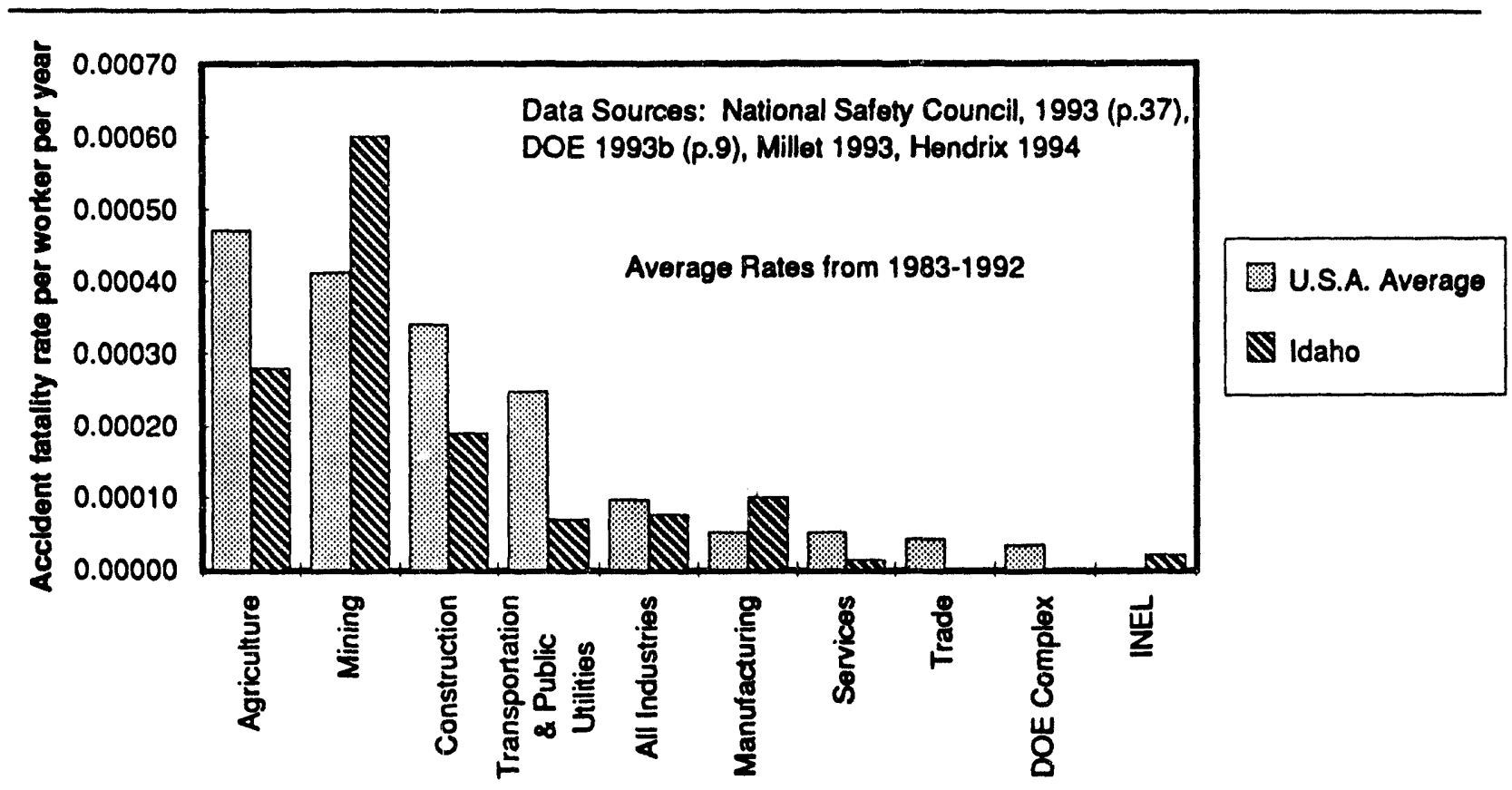

Figure 5.14-1. Comparison of fatality rates among workers in var'ious industry groups.

accidents at the INEL. Accidents have caused radiological contamination of equipment and land on the site that has required cleanup. Irreversible impacts to the environment have been negligible.

\subsubsection{Methodology}

Possible accidents involving spent nuclear fuel and waste management and environmental restoration operations at the INEL were analyzed for Volume 2 of this EIS. To obtain a perspective on potential accidents, the approach was to

- Summarize accidents that have occurred at the INEL (historical accidents)

- Review previous accident analyses for spent nuclear fuel, waste management, and environmental restoration activities

- Identify potential internal, external, and natural phenomena events that could initiate accidents other than those previously analyzed

- Perform independent analyses of the accidents with the greatest consequences. 
To characterize potential impacts at INEL facilities and operations, accidents with a range of frequencies are reported for each proposed alternative. Three broad frequency ranges are used: abnormal events with frequencies greater than $10^{-3}$ per year, design (or evaluation) basis accidents with frequencies in the range from $10^{-6}$ to $10^{-3}$ per year, and beyond design basis events with frequencies in the range from $10^{-7}$ to $10^{-6}$ per year. Within each frequency range, a bounding accident is determined so that any other reasonably foreseeable accident within a frequency range would be expected to have smaller consequences (see Appendix F-5, Facility Accidents). The results are point estimates of maximum reasonably foreseeable accidents by frequency category rather than a cumulative assessment of all possible accidents in each category.

Possible causes, assumptions, likelihood of occurrence, and consequences are discussed for the bounding accident within each frequency category analyzed. Some accidents in the abnormal and design basis frequency ranges are based on existing analyses (for example, facility safety analysis reports). Because these analyses generally evaluate only consequences to an individual at the nearest site boundary, population health risks are unavailable for most such events. For accidents for which independent analyses were performed as reported in DOE-ID (1994), population health risks were analyzed and are reported in this section. Fatal cancer effects are reported for these accidents; other health effects such as nonfatal cancer and hereditary effects from radiation exposure occur at a rate approximately 50 percent more often for a given exposure than fatal cancer (ICRP 1991). Ecological impacts are assessed qualitatively. Details on the analyses, including supporting references, are given in DOE-ID (1994).

Most of the accidents analyzed herein relate to existing INEL facilities or projections based on existing facilities. These evaluations are appropriate to characterize accident impacts at the INEL but do not provide meaningful comparisons among different sites. For site-to-site comparisons of the same accident set at different sites using consistent assumptions, see Volume 1, Appendix D of this EIS. Because some of the existing facilities manage fuel that recently has been removed from INEL reactors, accidents for existing facilities bound the impacts associated with fuel that could be transported to Idaho from other DOE facilities, universities, and foreign research reactors. 
5.14.2.1 Accident Screening and Selection Process. Many types of postulated events could lead to an accidental release of radioactive or hazardous material or both. Some of these postulated events have the potential for only local (within the INEL site boundaries) consequences with no potential for a release that would have consequences for a member of the public at the nearest site boundary.

Internal and external initiators associated with a wide range of activities not necessarily covered in existing safety analyses were considered. For example, potential radiological accident scenarios initiated by construction activities associated with constructing new facilities or modifying existing facilities (as proposed under the various alternatives) were postulated. Typically, events involved in the construction of new facilities would act as external initiators while events involved in modifying existing facilities would act as internal initiators. Examples of construction or industrial-type events considered included fires, confinement impacts or puncture events, equipment failure, terrorism, and human error.

The INEL site has nine major operating areas within the site boundaries. These areas are listed in Table 5.14-1. Each area was screened for quantities of spent nuclear fuel, radioactive waste, and hazardous material (including materials in inventory) that have the potential for being involved in a substantive release and thus worthy of consideration.

- Spent nuclear fuel or irradiated fuel is stored in substantial quantities at the Idaho Chemical Processing Plant, Argonne National Laboratory-West, Test Reactor Area, Test Area North, and Naval Reactors Facility. Some spent nuclear fuel remains at the Auxiliary Reactor Area/Power Burst Facility but is scheduled to be removed to the Idaho Chemical Processing Plant in 1996. No spent nuclear fuel is located in other areas.

- High-level waste is stored in substantial quantities at the Idaho Chemical Processing Plant in the form of liquids (liquid waste storage tanks), solid calcines (calcine storage bins), residual liquid and calcine waste (New Waste Calcining Facility), and residual high-level contaminants on high-efficiency particulate air filters (Atmospheric Protection System). Only small quantities, if any, are located in other areas. 


\begin{tabular}{|c|c|c|c|c|c|c|c|c|c|c|}
\hline \multirow{2}{*}{\multicolumn{2}{|c|}{$\begin{array}{l}\text { Spent nuclear fuel, waste, and } \\
\text { activity types }\end{array}$}} & \multicolumn{9}{|c|}{ Idaho National Engineering Laboratory locations ${ }^{\mathbf{a}}$} \\
\hline & & ICPP & ANL-W & TRA & TAN & RWMC & CFA & ARA/PBF & IRC & NRF \\
\hline \multicolumn{2}{|c|}{ Spent nuclear fuel } & Yes & Yes & Yes & Yes & No & No & Yes & No & Yes \\
\hline \multicolumn{2}{|c|}{ Transuranic waste } & No & No & No & No & Yes & No & No & No & No \\
\hline \multicolumn{2}{|c|}{ Low-level waste } & No & No & No & No & Yes & No & Yes & No & No \\
\hline \multicolumn{2}{|c|}{ Mixed low-level waste } & No & Yes & No & No & Yes & No & Yes & No & No \\
\hline \multicolumn{2}{|c|}{$\begin{array}{l}\text { Hazardous waste and toxic } \\
\text { material }\end{array}$} & Yes & Yes & No & Yes & No & Yes & Yes & Yes & No \\
\hline \multicolumn{2}{|c|}{ Remediation } & No & No & No & No & Yes & No & No & No & No \\
\hline $\begin{array}{l}\text { a. Location } \\
\text { ANL-W } \\
\text { ARA } \\
\text { CFA } \\
\text { ICPP } \\
\text { IRC } \\
\text { NRF } \\
\text { PBF } \\
\text { RWMC } \\
\text { TAN } \\
\text { TRA }\end{array}$ & $\begin{array}{ll}\text { acronyms: } \\
\text { - } & \text { Argonne National } \\
- & \text { Auxiliary Reactor } \\
\text { - } & \text { Central Facilities } \\
\text { - } & \text { Idaho Chemical Pr } \\
\text { - } & \text { INEL Research C } \\
\text { - } & \text { Naval Reactors Fa } \\
\text { - } & \text { Power Burst Facili } \\
- & \text { Radioactive Waste } \\
- & \text { Test Area North } \\
- & \text { Test Reactor Area }\end{array}$ & $\begin{array}{l}\text { boratory } \\
\text { ea } \\
\text { ea } \\
\text { essing Pl } \\
\text { er } \\
\text { ity } \\
\text { lanageme }\end{array}$ & Complex & & & & & & & \\
\hline
\end{tabular}


- Transuranic waste is stored in large quantities at the Radioactive Waste Management Complex only. Other areas may have small quantities insufficient to result in consequences to the public.

- Low-level waste is stored in substantial quantities at the Radioactive Waste Management Complex and at the Auxiliary Reactor Area/Power Burst Facility area.

- Mixed low-level waste is stored in substantial quantities at the Argonne National Laboratory-West (contaminated sodium reactor coolant), Radioactive Waste Management Complex, and Auxiliary Reactor Area/Power Burst Facility area (Mixed Low-Level Waste Facilities).

- Hazardous waste and material is stored in substantial quantities at the Idaho Chemical Processing Plant (chlorine, acids), Argonne National Laboratory-West (chlorine, sodium), Test Area North (depleted uranium), Central Facilities Area (Hazardous Waste Storage Facility), INEL Research Center (various chemicals), and Auxiliary Reactor Area/Power Burst Facility (waste storage facilities).

- Decontamination and decommissioning activities with potential for consolidation of substantial quantities of radioactive and hazardous materials sould occur at the Idaho Chemical Processing Plant (Fuel Processing Complex, CPP-601, and Waste Calcining Facility), Argonne National Laboratory-West (Central Liquid Waste Processing), Test Reactor Area (Engineering Test Reactor and Materials Test Reactor), and Auxiliary Reactor Area (Auxiliary Reactor Area-III).

- Remediation activities with potential for consolidation of substantial quantities of radioactive and hazardous materials will occur at the Radioactive Waste Management Complex (buried waste retrieval). Other remediation activities may occur as future site investigations warrant.

Initiating events were defined in three broad categories: external initiators, internal initiators, and natural phenomena initiators. External initiators originate outside the facility and may impact the ability of the facility to maintain confinement of radioactive or hazardous material. 
These may be related to fires and explosions nearby, or caused by events at co-located facilities. Internal initiators (for example, equipment failures or human error) originate within a facility and are a result of operating the facility. Natural phenomena initiators include weather-related and seismic events. All types of initiators were defined in terms of those events that cause or may lead to a release of materials by failure of confinement or a bypass of confinement.

Seismic events (see Section 4.6.3) were found to be the most likely common-cause initiators with the potential to cause releases at more than one facility and involve more than one waste type. Thus, some individual impacts presented herein for seismically initiated accidents could be additive. However, because the screening methods focused on facilities with the largest inventories rather than all possible facilities, summing impacts from the assessed seismic accidents could be misleading and was not attempted. No cases were found where an accident in one facility could cause an accident in a co-located facility.

Each facility area was screened for initiating events with the potential to cause nonnegligible consequences. Only those locations identified with substantial quantities of materials and listed in Table 5.14-1 were considered. The initiating event screening results are summarized in Table 5.14-2 for the six waste and material types and two types of environmental restoration activities. Accidents with bounding consequences from this table were assessed as discussed below.

5.14.2.2 Analysis of Accident Consequences. For health effects to occur, an accident must involve (a) a direct radiation exposure such as in a criticality, or (b) a loss of confinement of the hazardous and/or radioactive material and a release of some fraction of the material to the immediate environment. For the latter, the material must then be transported to human beings. Emergency Preparedness Plans (DOE 1993c) and Protective Action Guides (EPA 1991) can be invoked to reduce human exposures for scenarios where time is available to take action. The quantities of materials that reach people and the ways the materials interact with human beings are important factors in determining health effects.

In determining the consequences (radiological and toxicological) associated with the postulated maximum reasonably foreseeable accidents, the following definitions were used: 
Table 5.14-2 Potential initiating events for accidents at the Idaho National Engineering Laboratory by estimated frequency range and material type.

\begin{tabular}{|c|c|c|c|c|c|c|c|}
\hline \multirow[b]{2}{*}{ Spent nuclear fuel } & \multirow[b]{2}{*}{ High-level waste } & \multicolumn{3}{|c|}{ Spent nuclear fuel, waste, and activity types } & \multirow[b]{2}{*}{$\begin{array}{l}\text { Hazardous waste } \\
\text { and toxic material }\end{array}$} & \multirow[b]{2}{*}{$\begin{array}{l}\text { Decontamination/ } \\
\text { decommissioning }\end{array}$} & \multirow[b]{2}{*}{ Remediation } \\
\hline & & Transuranic waste & Low-level waste & Mixed low-level waste & & & \\
\hline \multicolumn{8}{|c|}{ Abnormal Events" } \\
\hline $\begin{array}{l}\text { - Fuel handling } \\
\text { accident }\end{array}$ & $\begin{array}{l}\text { Upsets with localized } \\
\text { impacts only }\end{array}$ & $\begin{array}{l}\text { Upsets with localized } \\
\text { impacts only }\end{array}$ & $\begin{array}{l}\text { - WWSB fire } \\
\text { - RWMC SDA fire }\end{array}$ & -WWSB fire & $\begin{array}{l}\text { Movement/ } \\
\text { handling accident }\end{array}$ & $\begin{array}{l}\text { Upsets with } \\
\text { localized impact } \\
\text { only }^{b}\end{array}$ & $\begin{array}{l}\text { - Pit } 9 \text { stack/vent } \\
\text { release }\end{array}$ \\
\hline \multicolumn{8}{|c|}{ Design Basis Accidents ${ }^{a}$} \\
\hline $\begin{array}{l}\text { - ICPP } 603 \text { seismic } \\
\text { pool drain criticality } \\
\text { - Aircraft impact }\end{array}$ & - Aircraft impact & $\begin{array}{l}\text { - Aircraft impact } \\
\text { - RWMC external } \\
\text { fire/explosion } \\
\text { - RWMC criticality }\end{array}$ & $\begin{array}{l}\text { - Aircraft impact } \\
\text { - RWMC external } \\
\text { fire/explosion } \\
\text { - RWMC criticality }\end{array}$ & $\begin{array}{l}\text { - Aircraft impact } \\
\text { - RWMC external fire/ } \\
\text { explosion } \\
\text { - RWMC criticality } \\
\text {-WWSB major fire }\end{array}$ & $\begin{array}{l}\text { - Aircraft impact } \\
\text {-TAN SMC } \\
\text { depleted uranium } \\
\text { fire }\end{array}$ & - Aircraft impact & $\begin{array}{l}\text { - Pit } 9 \text { aircraft } \\
\text { impact }\end{array}$ \\
\hline
\end{tabular}
a. Abnormal events are in the frequency range of $10^{-3}$ per year or greater. Design basis accidents are generally in the range from $10^{-6}$ to $10^{-3}$ per year. Beyond design basis
accidents are generally in the range of $10^{-7}$ to $10^{-6}$ per year.

b. Family of incidents involving spilts, drops, seal failures, etc. that could have an impact in the immediate vicinity only.

Definition of acronyms:

ANL-W - Argonne National Laboratory-West

APS - Atmospheric Protection System

CFA - Central Facilities Area

HFEF - Hot Fuel Experimental Facility

HLW - high-level waste
HWSF - Hazardous Waste Storage Facility ICPP - Idaho Chemical Processing Plant

IRC - INEL Research Center

NWCF - New Waste Calcining Facility

RWMC - Radioactive Waste Management Complex WCF - Waste Characterization Facility
WERF - Waste Experimental Reduction

Facility

WWSB - WERF Waste Storage Building 
- Facility Worker. The facility worker is defined as an individual located 100 meters (328 feet) downwind of the facility location where the release occurs.

- Nearest Public Access. The nearest public access is the location of the nearest public highway where members of the public could be present.

- Maximally Exposed Individual (MEI). The MEI is defined as a hypothetical individual located at the nearest site boundary from the facility location where the release occurs.

- Offsite Population. The offsite population is defined as the collective sum of individuals located within an 80-kilometer (50-mile) radius of the INEL facility and within the path of the plume with the wind blowing in the most populous direction.

The ways radioactive material reaches human beings, how it is absorbed and retained in the body, and the resulting health effects have been studied in great detail. The International Commission on Radiological Protection has made specific recommendations for quantifying these health effects. This organization is the recognized body for establishing standards for protecting workers and the public from the effects of radiation exposure. Health effects include acute damage (up to and including death) and latent effects, including cancers and genetic damage. An INEL-developed computer code, RSAC-5 (Wenzel 1993), estimates potential radiation doses to maximally exposed individuals or population groups from accidental releases of radionuclides. This code, which is adapted to INEL conditions, uses well-established scientific and engineering principles as the basis for the various calculational steps. The code has been validated to accepted standards for this kind of computer software.

For hazardous materials, several government agencies recommend quantifying health effects as threshold values of concentrations in air or water that cause short-term effects. The long-term health consequences of exposure to hazardous materials are not as well understood as those for radiation. Thus, the potential health effects reported here for hazardous materials are more qualitative than for radioactive materials. EPIcode ${ }^{\mathrm{TM}}$ (Homann 1988) was the computer code chosen for most releases of hazardous materials. 


\subsubsection{Impacts from Alternative A (No Action)}

Impacts from accidents under Alternative A (No Action) are described in this section, and changes from these impacts under other alternatives are evaluated in subsequent sections.

5.14.3.1 Spent Nuclear Fuel. Spent nuclear fuel is managed at the following facility areas at the INEL site: Idaho Chemical Processing Plant, Naval Reactors Facility, Test Reactor Area, Auxiliary Reactor Area/Power Burst Facility, Argonne National Laboratory-West, and Test Area North. In addition, irradiated nuclear fuels (whether "spent" or "in-process") are managed in association with the reactor operations at the Advanced Test Reactor in the Test Reactor Area and the Experimental Breeder Reactor-II in the Argonne National LaboratoryWest facility area. In-process fuels include fuel elements being staged or recycled to return to reactor systems. For this analysis, both spent and in-process fuels were included in the assessment. Fuels within reactors were considered only after discharge to storage, processing, or examination areas. Maximum reasonably foreseeable accidents associated with transporting, receiving, handling, and storing naval spent nuclear fuel at the Naval Reactors Facility have been identified and are analyzed in Appendix D of Volume 1 of this EIS.

In November 1993, DOE issued a report (DOE 1993d) discussing vulnerabilities associated with various spent nuclear fuel-related facilities across the DOE complex. One INEL facility, the CPP-603 Underwater Fuel Storage Facility, was identified as requiring immediate management attention to avoid unnecessary increases in worker exposures, cleanup costs, and postulated accidents. Although activities have already been initiated to stabilize inventories of spent nuclear fuel in CPP-603 and relocate the fuel to CPP-666, these activities will continue for several years after the scheduled 1995 Record of Decision for this EIS. Therefore, postulated accident scenarios associated with stabilizing and relocating CPP-603 spent nuclear fuel inventories were considered in determining potential accident initiators and the maximum reasonably foreseeable radiological accidents summarized in this EIS.

Activities historically associated with spent nuclear fuel at the INEL site include transportation (see Section 5.11), handling, inspection, storage, and reprocessing. Handling includes moving spent nuclear fuel within facility areas, cutting and removing nonfuel components attached to fuel elements, cask loading, and cask unloading. Inspections include destructive and 
nondestructive testing and characterization of elements for research and development of improved fuels. Handling and inspection activities are performed both in underwater and dry environments. Storage of spent nuclear fuel occurs under water in pools, above ground in dry storage casks, and under ground in dry storage vaults. All of these activities, except reprocessing, are ongoing and apply to Alternative A (No Action). New activities include handling and stabilization of degraded fuel in CPP-603 and removal of fuels from pool storage at Test Area North.

Using existing safety analysis reports and independent calculations, accidents selected from the screening process were assessed for risks to the public, workers, and the environment. Based on quantity of fuel present, storage configuration (wet/dry), and cooling time in the various fuelhandling and storage facilities, the accidents given in Table 5.14-3 were determined to have maximum radiological consequences within the abnormal, design basis, and beyond design basis frequency categories (see Appendix F-5). Also listed in the table are the estimated frequency of occurrence, exposures to hypothetical individuals at the nearest public access and nearest site boundary, point estimates of the annualized risk ${ }^{a}$ of this individual contracting a fatal cancer during his or her lifetime as a result of this radiation exposure, and point estimates of risk and the expected number of fatal cancers to members of the public for each postulated accident in the most populous wind direction from the accident. The estimates for fatal cancers are listed for average (50 percent) and conservative (95 percent) meteorological conditions.

Radiation doses that a hypothetical member of the public at the nearest site boundary could receive as a result of the spent nuclear fuel accidents are illustrated in Figure 5.14-2 along with impacts from accidents involving other radioactive waste streams. Each symbol represents the dose from a discrete accident from Table 5.14-3. Illustrated for perspective is the natural background dose persons receive from natural radiation (NRC 1990). DOE-ID (1994) lists doses in nearby communities.

The incremental risk of the hypothetical individual developing a fatal cancer as a result of these exposures is illustrated in Figure 5.14-3. For reference, the figure shows the annual likelihood of a fatal cancer from all other causes (NRC 1990) and the DOE National Safety

a. For these analyses, point estimate of risk (fatal cancers per year) is defined as accident frequency (events per year) multiplied by the resulting dose (person-rem), and then multiplied by the likelihood that the dose causes a fatal cancer (fatal cancers per person rem). 
Table 5.14-3. Impacts from selected maximum reasonably foreseeable radiological accidents at the Idaho National Engineering Laboratory site ${ }^{a}$ Alternative A (No Action).

\begin{tabular}{|c|c|c|c|c|c|c|c|c|}
\hline \multirow[b]{2}{*}{ Accident } & \multirow[b]{2}{*}{$\begin{array}{l}\text { Frequency } \\
\text { (events/yr) }\end{array}$} & \multirow[b]{2}{*}{$\begin{array}{l}\text { Facility } \\
\text { worker dose } \\
(\mathrm{rem})^{c}\end{array}$} & \multirow{2}{*}{$\begin{array}{l}\text { Dose at } \\
\text { nearest } \\
\text { public } \\
\text { access } \\
\text { (rem) }\end{array}$} & \multirow[b]{2}{*}{$\begin{array}{l}\text { Dose to } \\
\text { MEI } \\
\text { (rem) }\end{array}$} & \multirow[b]{2}{*}{$\begin{array}{l}\text { Offsite population } \\
\text { dose (person-rem) } \\
95 \% \text { meteorology }\end{array}$} & \multicolumn{3}{|c|}{ Risk of fatal cancer per year ${ }^{b}$} \\
\hline & & & & & & MEI & $\begin{array}{l}\text { Population, } \\
50 \% \text { meteorology }\end{array}$ & $\begin{array}{l}\text { Population, } \\
\text { 95\% meteorology }\end{array}$ \\
\hline \multicolumn{9}{|c|}{ Spent Nuclear Fued Accidents } \\
\hline $\begin{array}{l}\text { Fuel-handling accident, } \\
\text { fuel pin breach, venting of } \\
\text { noble gases and iodine } \\
\text { (bounded by HFEF fuel- } \\
\text { handling accident) }\end{array}$ & $1 \times 10^{-2}$ & $(\mathfrak{n}$ & $($ ( ) & $20 \times 10^{-3}$ & (f) & $1.0 \times 10^{-8}$ & (f) & (f) \\
\hline $\begin{array}{l}\text { Uncontrolled chain } \\
\text { reaction (criticality) } \\
\text { accident at ICPP }\end{array}$ & $\mathrm{g}_{1 \times 10^{-3}}$ & $9.7 \times 10^{-2}$ & $1.4 \times 10^{-3}$ & $1.0 \times 10^{-3}$ & $5.9 \times 10^{-1}$ & $5.0 \times 10^{-10}$ & $6.5 \times 10^{-9}\left(6.5 \times 10^{-6}\right)$ & $3.0 \times 10^{-7}\left(3.0 \times 10^{-4}\right)$ \\
\hline $\begin{array}{l}\text { Severe seismic event, cell } \\
\text { breach, and fuel melting } \\
\text { at ANL-W HFEF }\end{array}$ & $1 \times 10^{-5}$ & $6.2 \times 10^{-1}$ & $6.5 \times 10^{-1}$ & $5.0 \times 10^{0}$ & $1.4 \times 10^{4}$ & $2.5 \times 10^{-8}$ & $4.5 \times 10^{-7}\left(4.5 \times 10^{-2}\right)$ & $7.0 \times 10^{-5}\left(7.0 \times 10^{0}\right)$ \\
\hline $\begin{array}{l}\text { Aircraft crash into HFEF } \\
\text { at ANL-W }\end{array}$ & $1 \times 10^{-7}$ & $4.6 \times 10^{0}$ & $3.2 \times 10^{-1}$ & $5.0 \times 10^{0}$ & $20 \times 10^{3}$ & $2.5 \times 10^{-10}$ & $3.6 \times 10^{-8}\left(3.6 \times 10^{-1}\right)$ & $1.0 \times 10^{-7}(1.0)$ \\
\hline \multicolumn{9}{|c|}{ High-Levd Waste Accidentsh } \\
\hline ICPP main stack toppling ${ }^{\mathrm{i}}$ & $3 \times 10^{-4}$ & $8.3 \times 10^{2}$ & $2.8 \times 10^{-1}$ & $9.1 \times 10^{-2}$ & $1.7 \times 10^{1}$ & $1.4 \times 10^{-8}$ & $7.2 \times 10^{-7}\left(2.4 \times 10^{-3}\right)$ & $2.6 \times 10^{-6}\left(8.5 \times 10^{-3}\right)$ \\
\hline $\begin{array}{l}\text { Severe seismic event, } \\
\text { calcine storage bin failure }\end{array}$ & $1 \times 10^{-5}$ & $1.2 \times 10^{0}$ & $2.3 \times 10^{-2}$ & $7.6 \times 10^{-2}$ & $4.3 \times 10^{2}$ & $3.8 \times 10^{-10}$ & $3.0 \times 10^{-8}\left(3.0 \times 10^{-3}\right)$ & $2.2 \times 10^{-6}\left(2.2 \times 10^{-1}\right)$ \\
\hline $\begin{array}{l}\text { Fire in ICPP atmospheric } \\
\text { protection system filters }\end{array}$ & $3 \times 10^{-5}$ & $1.3 \times 10^{-3}$ & $8.2 \times 10^{-5}$ & $1.2 \times 10^{-5}$ & $1.3 \times 10^{-1}$ & $1.8 \times 10^{-13}$ & $3.9 \times 10^{-10}\left(1.3 \times 10^{-5}\right)$ & $2.0 \times 10^{-9}\left(6.5 \times 10^{-5}\right)$ \\
\hline $\begin{array}{l}\text { ICPP New Waste } \\
\text { Calcining Facility } \\
\text { explosion }\end{array}$ & $3 \times 10^{-6}$ & (f) & (f) & $20 \times 10^{-1}$ & (D) & $3.0 \times 10^{-10}$ & (f) & (f) \\
\hline $\begin{array}{l}\text { Aircraft crash into calcine } \\
\text { bin set }\end{array}$ & $2 \times 10^{-7}$ & $4.1 \times 10^{0}$ & $3.0 \times 10^{-1}$ & $1.1 \times 10^{0}$ & $1.0 \times 10^{4}$ & $1.1 \times 10^{-10}$ & $1.9 \times 10^{-7}\left(9.5 \times 10^{-1}\right)$ & $1.0 \times 10^{-6}(5.0)$ \\
\hline \multicolumn{9}{|c|}{ Traneuranic Waste Aocidents } \\
\hline Explosion at RWMC TSA & $2 \times 10^{-4}$ & $(I)$ & $(\mathfrak{l})$ & $2.0 \times 10^{-7}$ & (f) & $2.0 \times 10^{-14}$ & (f) & (f) \\
\hline Lava flow over RWMC & $2 \times 10^{-5}$ & Evacuate & Evacuate & $9.4 \times 10^{-2}$ & $9.6 \times 10^{1}$ & $9.4 \times 10^{-10}$ & $2.4 \times 10^{-7}\left(1.2 \times 10^{-2}\right)$ & $9.6 \times 10^{-7}\left(4.8 \times 10^{-2}\right)$ \\
\hline Fire in RWMC TSA & $4 \times 10^{-6}$ & (f) & (f) & $1.0 \times 10^{-6}$ & (I) & $2.0 \times 10^{-15}$ & (f) & (f) \\
\hline Aircraft impact at & $1 \times 10^{-7}$ & (I) & (f) & $6.0 \times 10^{-4}$ & (f) & $3.0 \times 10^{-14}$ & (f) & (f) \\
\hline
\end{tabular}


Table 5.14-3. (continued)

\begin{tabular}{cccc}
\hline & & & Dose \\
& & Facility & neares \\
& Frequency & worker dose & pub \\
Accident & (events/yr) & (rem) & (rem \\
\hline
\end{tabular}

$\begin{array}{ll}\text { Fire in RWMC SDA } & 1 \times 10^{-3} \\ \begin{array}{l}\text { Design basis fire at } \\ \text { WERF Waste Storage }\end{array} & 1 \times 10^{-3} \\ \text { Building } & \end{array}$

Minod Low-Level/Lon-Leved Waste Accidents

(f) $4.0 \times 10^{-4}$

(f)

$$
\begin{aligned}
& 2.0 \times 10^{-10} \\
& 1.4 \times 10^{-9}
\end{aligned}
$$

Risk of fatal cancer per year

Building
Beyond design basis fire
at WERF Waste Storage
Building

Pit 9 fire/vent release

Pit 9 design basis fire

$$
\begin{aligned}
& 2 \times 10^{-3} \\
& 9 \times 10^{-5} \\
& 1 \times 10^{-5}
\end{aligned}
$$

$2.8 \times 10^{-3}$

(f)

$1.4 \times 10^{-2}$

(f)

$7.0 \times 10^{-13}$

(f)

\section{Environmental Remodiatioa/Decontamination and Decommissioning Accidents}

Pit 9 earthquake and

$$
5.1 \times 10^{-2}
$$

$$
\begin{aligned}
& 5.1 \times 10^{-8} \\
& 3.6 \times 10^{-8} \\
& 1.7 \times 10^{-9}
\end{aligned}
$$$$
3.3 \times 10^{-1}
$$
(I)

(I)

Accidents involving hazardous materials for Alternative A (No Action) are summarized in Table 5.14-5 (Section 5.14.3.5).

a. Accidents involving hazardous materials for Alternative A (No Action) are summanized in Table $5.14-5$ (Section) if dose is $<20 \mathrm{rem}$. For doses $220 \mathrm{rem}$, the ICRP-60 conversion b. Fatal cancer risk $=$ dose $\times$ accident frequency $\times\left(5.0 \times 10^{-4}\right.$ fatal cancers/rem) $($ ICRP-60 conversion factor $)$ if dose is

factor (ICRP 1991) is doubled, or $1.0 \times 10^{-3}$. Numbers in parentheses indicate total number of fatal

c. A facility worker is defined as a worker located 100 meters ( 328 feet) from the point of release.
d. Member of the public on a highway at the nearest point to the facility within the site boundary.

e. $\mathrm{MEI}=$ maximally exposed hypothetical individual whose residence is located at the nearest site boundary.

f. The safety analysis report utilized for this accident does not provide this information because it was developed before DOE orde the consequences from the spent nuclear fuel and demonstrated by the dose to the MEI, consequences to the

high-level waste accidents with population doses calculated.

g. Frequency lowers to $1 \times 10^{-4}$ per year when all CPP-603 fuel is moved to the Fluorinel and Storage Facility (CPP-666).

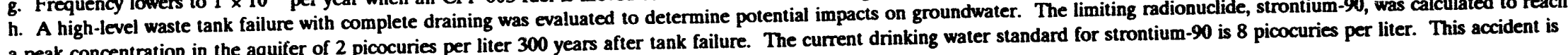

a peak concentration in the aquifer of 2 picocur

i. The dose to a facility worker is from a puff release of respirable particles.

Definition of acronyms:

ANL-W - Argonne National Laboratory-West

HFEF - Hot Fuel Examination Facility

ICPP - Idaho Chemical Processing Plant

MEI - maximally exposed individual at the nearest site boundary

RWMC - Radioactive Waste Management Complex

SDA - Subsurface Disposal Area

TSA - Transuranic Storage Area

WERF - Waste Experimental Reduction Facility 


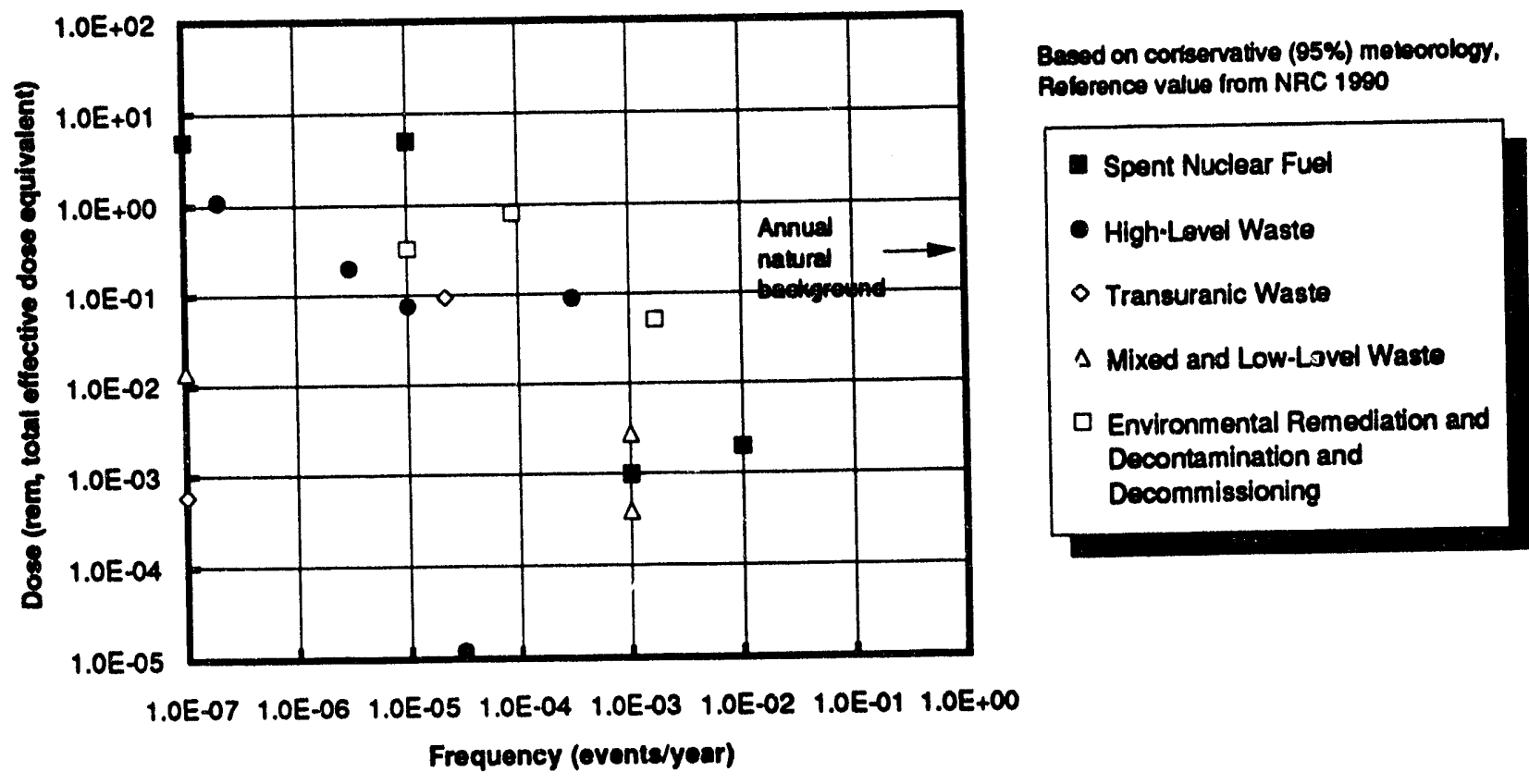

Figure 5.14-2. Potential radiation exposures from accidents to individual at nearest Idaho National Engineering Laboratory site boundary for Alternative A (No Action).

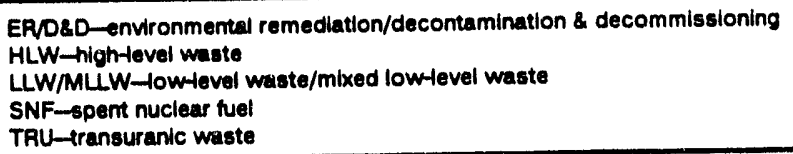

Based on conservative (95\%) meteorology

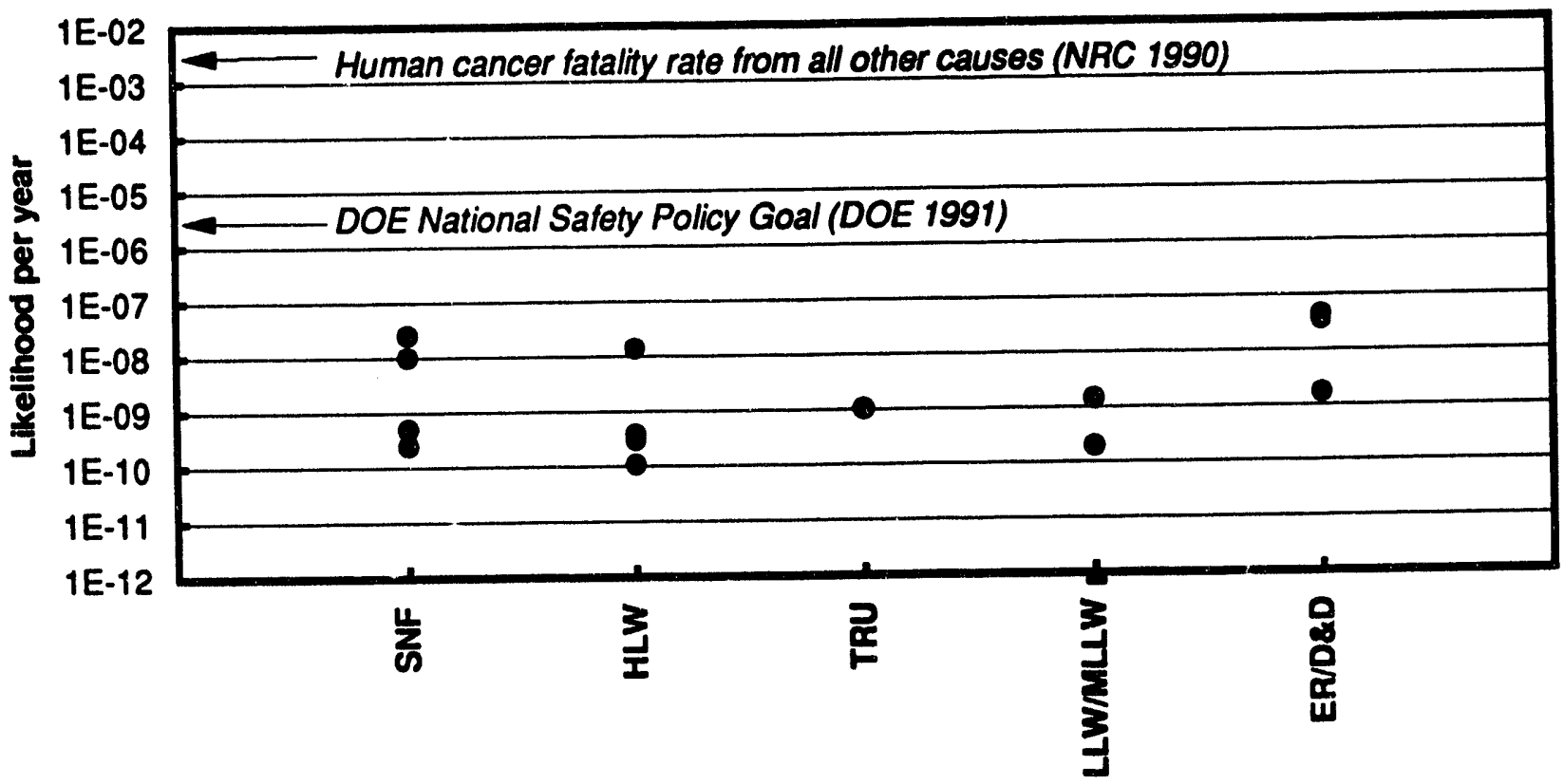

Figure 5.14-3. Risk of fatal cancer to individual at nearest Idaho National Engineering Laboratory site boundary from radiation accidents for Alternative A (No Action). 
Policy Goal SEN-35-91 (DUE 1991), as derived in DOE-ID (1994). The policy states that the cancer fatality risk to the population within one mile of the site boundary of a DOE nuclear facility should not exceed 0.1 percent of the sum of all cancer fatality risks resulting from all other causes. This goal represents the integrated operational and accident aiming point for DOE facilities and does not represent an acceptance criterion. Illustration of the goal allows the reader to see the contribution of the maximum foreseeable accidents to the integrated goal. Excess cancer fatality rates in the population from the analyzed accidents are illustrated in Figure 5.14-4.

From an assessment of a maximum reasonably foreseeable accident for an exposed population of 33 workers, the risk of cancer fatalities as a result of an earthquake-induced criticality at the Test Area North Hot Shop is about $8.1 \times 10^{-5}$ per year (DOE-ID 1994). If a criticality were to occur in an unshielded area, fatal doses could occur up to 40 meters from the source. Table 5.14-4 lists the potential secondary environmental impacts of accidents (that is, impacts other than possible human health effects).

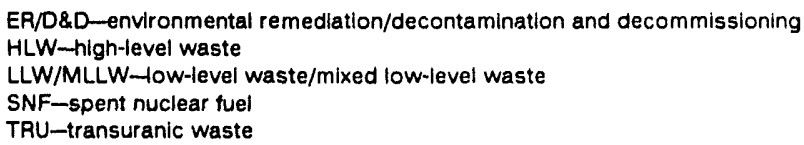

Based on conservative (95\%) meteorology

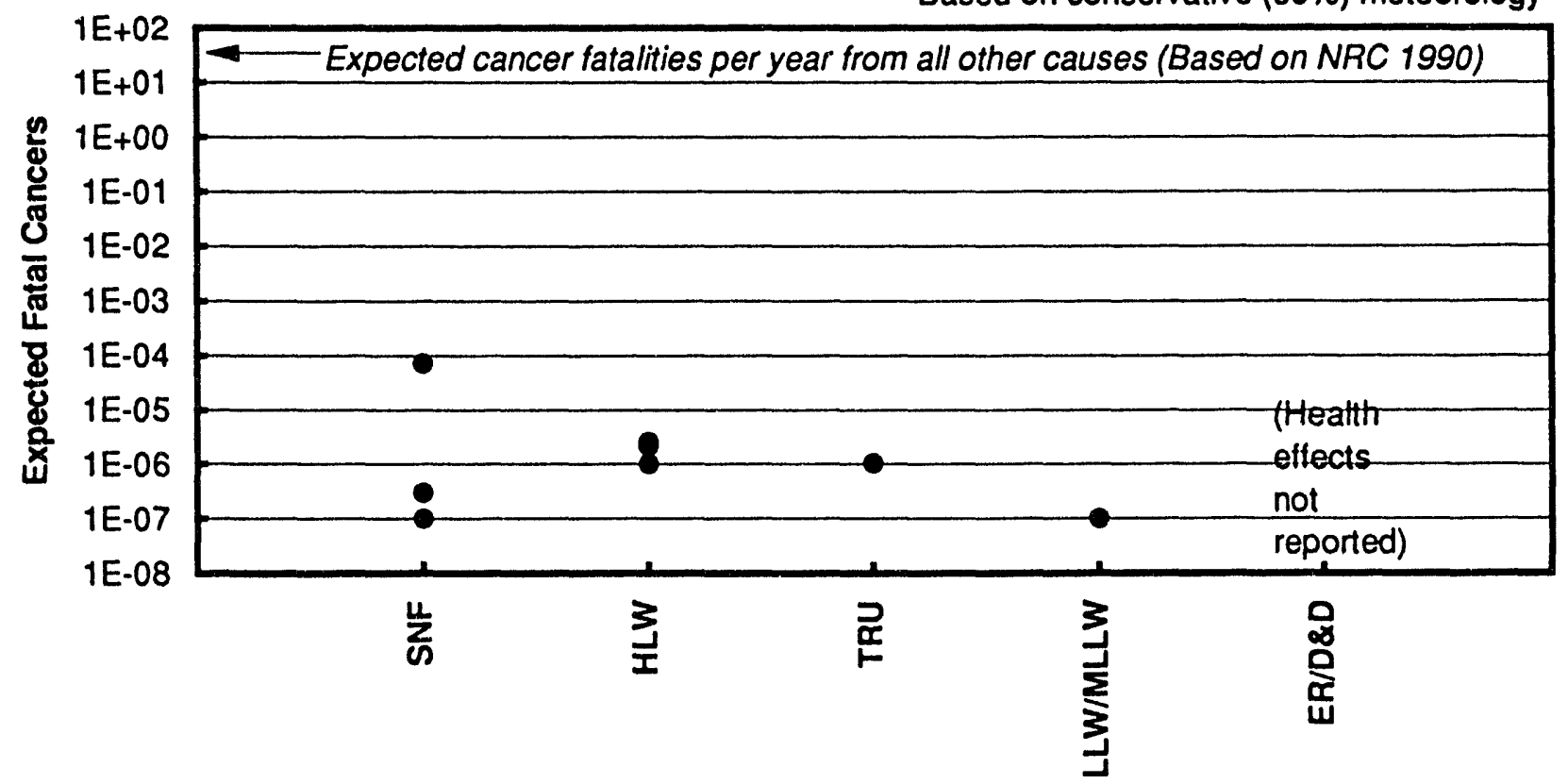

Figure 5.14-4. Excess fatal cancers in exposed population from radiation accidents at Idaho National Engineering Laboratory facilities for Alternative A (No Action). 
Table 5.14-4. Assessment of potential secondary impacts of accidents at the Idaho National Engineering Laboratory site (applicable to all alternatives. ${ }^{a}$

\begin{tabular}{|c|c|c|c|c|c|c|c|c|}
\hline \multirow[b]{2}{*}{ Accident } & \multicolumn{8}{|c|}{ Environmental or social factor } \\
\hline & Biotic resources & Water resources & Economic impacts ${ }^{b}$ & National defense & $\begin{array}{l}\text { Environmental } \\
\text { contamination }\end{array}$ & Endangered species & Land use & Tribal resources \\
\hline
\end{tabular}

\section{Spent Nudear Fuel Aocidents}

\begin{tabular}{|c|c|c|c|c|c|c|c|c|}
\hline $\begin{array}{l}\text { Severe carthquake } \\
\text { at Hot Fuel } \\
\text { Examination } \\
\text { Facility (HFEF) }\end{array}$ & $\begin{array}{l}\text { Limited adverse } \\
\text { effects expected to } \\
\text { vegetation or wildlife }\end{array}$ & $\begin{array}{l}\text { Limited adverse } \\
\text { effects expected to } \\
\text { surface water or } \\
\text { groundwater }\end{array}$ & $\begin{array}{l}\text { Potential interdiction } \\
\text { of affected agri- } \\
\text { cultural products on } \\
\text { nearby land. Local } \\
\text { cleanup in the } \\
\text { vicinity of HFEF. }\end{array}$ & $\begin{array}{l}\text { No effect on } \\
\text { national defense }\end{array}$ & $\begin{array}{l}\text { Local contamination } \\
\text { requiring cleanup } \\
\text { expected around site } \\
\text { of accident }\end{array}$ & $\begin{array}{l}\text { No impacts expected } \\
\text { to endangered or } \\
\text { threatened species }\end{array}$ & $\begin{array}{l}\text { Potential for one } \\
\text { year agricultural } \\
\text { land withdrawal of } \\
\text { up to } 10,000 \text { acres } \\
\text { (on and off INEL) }\end{array}$ & $\begin{array}{l}\text { Potential for } \\
\text { temporary } \\
\text { restricted access to } \\
\text { affected public land } \\
\text { (less than } 10,000^{\text {acres)c }}\end{array}$ \\
\hline $\begin{array}{l}\text { Aircraft crash into } \\
\text { HFEF }\end{array}$ & $\begin{array}{l}\text { Limited adverse } \\
\text { effects expected to } \\
\text { vegetation or wildlife }\end{array}$ & $\begin{array}{l}\text { Limited adverse } \\
\text { effects expected to } \\
\text { surface water or } \\
\text { groundwater }\end{array}$ & $\begin{array}{l}\text { Potential interdiction } \\
\text { of affected agri- } \\
\text { cultural products on } \\
\text { nearby land. Local } \\
\text { cleanup in the } \\
\text { vicinity of HFEF. }\end{array}$ & $\begin{array}{l}\text { No effect on } \\
\text { national defense }\end{array}$ & $\begin{array}{l}\text { Local contamination } \\
\text { requiring cleanup } \\
\text { expected around site } \\
\text { of accident }\end{array}$ & $\begin{array}{l}\text { No impacts expected } \\
\text { to endangered or } \\
\text { threatened species }\end{array}$ & $\begin{array}{l}\text { Potential for one } \\
\text { year agricultural } \\
\text { land withdrawal of } \\
\text { up to } 10,000 \text { acres } \\
\text { (on and off INEL) }\end{array}$ & $\begin{array}{l}\text { Potential for } \\
\text { temporary } \\
\text { restricted access to } \\
\text { affected public tand } \\
\text { (less than } 10,000 \\
\text { acres) }\end{array}$ \\
\hline
\end{tabular}

High-Loved Waste Aocidents

Aircraft crash into Limited adverse Limited calcine bin set effects expected to effects expected to vegetation or wildlife surface water or

groundwater

Potential interdiction No effect on
of affected agri- national defense
cultural products on
nearby land. Local
cleanup in the
vicinity of Calcined
Solids Storage
Facility (CSSF).

Local contamination No impacts expected Potential for one requiring cleanup to endangered or year agricultural expected around site threatened species land withdrawal of of accident up to 4,000 acres Potential for temporary restricted access to affected public land acres $)^{c}$

Transuranic Waste Aocidents

\begin{tabular}{|c|c|c|c|c|c|c|c|c|}
\hline $\begin{array}{l}\text { Lava flow over } \\
\text { Radioactive Waste } \\
\text { Management } \\
\text { Comple (RWMC) }\end{array}$ & $\begin{array}{l}\text { Potential biotic } \\
\text { concentration of } \\
\text { heavy metals }\end{array}$ & $\begin{array}{l}\text { Limited adverse } \\
\text { effects expected to } \\
\text { surface water or } \\
\text { groundwater }\end{array}$ & $\begin{array}{l}\text { Local cleanup in the } \\
\text { vicinity of RWMC }\end{array}$ & $\begin{array}{l}\text { No effect on } \\
\text { national defense }\end{array}$ & $\begin{array}{l}\text { Local contamination } \\
\text { requining cleanup } \\
\text { expected around site } \\
\text { of accident }\end{array}$ & $\begin{array}{l}\text { No impacts expected } \\
\text { to endangered or } \\
\text { threatened species }\end{array}$ & $\begin{array}{l}\text { No change in land } \\
\text { use expected }\end{array}$ & $\begin{array}{l}\text { No impacts to } \\
\text { tribal resources } \\
\text { expected }\end{array}$ \\
\hline
\end{tabular}

Complex (RWMC) groundwater

expocted to have secondary impacts limited to the immediate facility area.

b. In addition to economic impacts listed, facility repair or replacement costs may be incurred.

c. Estimated area of land contaminated with radioactivity greater than 100 millirem per year. 
5.14.3.2 High-Level Waste. High-level waste results as a byproduct of the reprocessing of spent nuclear fuel. During the past several decades at the INEL, fuel reprocessing at the Idaho Chemical Processing Plant produced high-level waste in a liquid form that is stored in underground tanks. Much of this liquid has been immobilized through a high-temperature calcine process that converts the liquid to a granular solid that is stored in bins inside concrete storage vaults. Both the liquid and granular solid are high-level waste, but the granular solid is less susceptible to leakage than liquid. Although reprocessing of spent nuclear fuel at the INEL has terminated, inventories of liquid and granular high-level waste remain. The accident analysis considers the potential for release of both the liquid and granular high-level waste forms. The process to convert the liquid high-level waste to granular calcine is ongoing and applies to Alternative A (No Action). Construction associated with upgrades to underground storage tanks could result in construction accidents.

Using existing safety analysis reports and independent calculations, the accidents selected in the screening process were assessed for risks to the public, workers, and the environment. The DOE did not consider high-level waste tank explosions as reasonably foreseeable because the chemicals in the tanks do not generate hydrogen or other explosive gases. On the basis of the quantity of highlevel waste present, and handling in the calcine process, the accidents with airborne releases given in Table 5.14-3 were determined to have bounding radiological consequences within the abnormal, design basis, and beyond design basis frequency categories (Appendix F-5). Impacts from these accidents are illustrated in Figures 5.14-2, 5.14-3, and 5.14-4. For an earthquake-caused collapse of the main stack at the Idaho Chemical Processing Plant, the risk of fatal cancer to a population of 50 workers is estimated to be $1.1 \times 10^{-2}$ per year (DOE-ID 1994). Workers near the source of the release have a potential risk of injury or death.

A high-level waste tank failure with complete draining was evaluated to determine potential impacts on groundwater. Infiltration to the aquifer would occur over approximately 200 years, and the concentration of the limiting radionuclide, strontium-90, would reach a peak concentration of 2 picocuries per liter 300 years after tank rupture. The current drinking water permissible limit for strontium-90 is 8 picocuries per liter.

Table 5.14-4 lists the potential secondary environmental impacts of accidents (that is, impacts other than possible human health effects). The hazardous constituents of high-level waste were 
analyzed (DOE-ID 1994) and found to be bounded by the hazardous material releases considered in Section 5.14.3.5.

5.14.3.3 Transuranic Waste. Transuranic waste is stored and buried at the Radioactive Waste Management Complex at the INEL site. Transuranic waste activities under Alternative A (No Action) would be continued storage and characterization, and retrieval of stored and buried wastes. If the Waste Isolation Pilot Plant is available, waste that is certifiable would be shipped offsite to the Waste Isolation Pilot Plant. If the Waste Isolation Pilot Plant is unavailable, the total inventory of transuranic waste would change very little in the 1995 to 2005 time period; however, the storage configuration would change for some waste. The waste retrieved in environmental remediation activities at Pit 9 would change from disposed of to stored status. On the basis of the quantity of transuranic waste present and storage configuration (stored or buried), the accidents given in Table 5.14-3 were determined to have maximum reasonably foreseeable consequences (see Appendix F-5). Radiological impacts from these accidents are illustrated in Figures 5.14-2, 5.14-3, and 5.14-4. Hazardous constituents in transuranic waste are evaluated in Section 5.14.3.5.

For a fire at the Radioactive Waste Management Complex, the risk of fatal cancer to an estimated population of 20 exposed workers is estimated to be $7.7 \times 10^{-4}$ per year (DOE-ID 1994). Workers near the source of the release have a potential risk of injury or death. Table 5.14-4 lists the potential secondary impacts of accidents (that is, economics and land use, biotic and water resources, tribal resources, national defense capability, and environmental contamination).

5.14.3.4 Mixed and Low-Level Waste. Under Alternative A (No Action), low-level waste would continue to be buried at the Radioactive Waste Management Complex, and mixed low-level waste would continue to be stored at the Mixed Waste Storage Facility and the Waste Experimental Reduction Facility Waste Storage Building in the Power Burst Facility area. On the basis of the quantity of mixed low-level waste/low-level waste present and the storage configuration, the accidents given in Table 5.14-3 were determined to have maximum radiological consequences within the abnormal, design basis, and beyond design basis frequency categories (Appendix F-5). Radiological impacts from these accidents are illustrated in Figures 5.14-2, 5.14-3, and 5.14-4. Worker risk of fatal cancers is less than that for the materials considered above; workers near the source of the release have a potential risk of injury or death. No secondary impacts would be expected from mixed or low-level waste accidents. The hazardous constituents of mixed low-level waste were analyzed (DOE-ID 1994) and found to be bounded by the releases considered in Section 5.14.3.5. 
5.14.3.5 Hazardous Materials. The scope of the accident assessment of hazardous materials includes hazardous wastes and hazardous constituents of radioactive waste streams. Under Alternative A (No Action), hazardous waste would continue to be stored at the Hazardous Waste Storage Facility, the Hazardous and Radioactive Mixed Waste Staging Area, and the Hazardous Chemical/Radioactive Waste Facility. In addition, for the purposes of accident analysis, materials that are not considered hazardous waste by the Resource Conservation and Recovery Act, but are toxic to humans, are also assessed for accidents. Such materials at the INEL include chlorine, sodium, acids and bases, laboratory chemicals, and depleted uranium used at Test Area Nr th for the manufacture of military tank armor. Hazardous constituents of other waste streams involve materials such as cadmium in high-level waste and mercury in transuranic wastes.

On the basis of the screening of threshold quantities of toxic and flammable materials (EPA 1990, FR 1994) and the quantities of materials present and their storage configuration, the accidents given in Table 5.14-5 were determined to have maximum reasonably foreseeable consequences. Also listed in the table are the estimated frequency of occurrence, and maximum exposure to a hypothetical individual at the nearest site boundary in terms of percentage of Emergency Response Planning Guide Level 3 values. The Emergency Response Planning Guide 3 values represent the concentration where, without evacuation, one would experience or develop life-threatening health effects. Concentrations that a hypothetical member of the public at the INEL site boundary could be exposed to as a result of accidents are illustrated in Figure 5.14-5. Concentrations at the nearest public access and in nearby communities are given in (DOE-ID 1994). The risk of prompt fatalities to an estimated population of 100 exposed workers as a result of a chlorine release at Argonne National Laboratory-West is estimated to be $1.0 \times 10^{-3}$ per year (DOE-ID 1994). Impacts to workers would range from minor irritation to eyes and lungs to death. No secondary impacts would result from hazardous waste accidents.

\subsubsection{Environmental Remediation and Decontamination and Decommissioning.}

Approved environmental remediation and decontamination and decommissioning projects would continue under Alternative A (No Action). Activities would include remediation of Pit 9 and the vadose zone at the Radioactive Waste Management Complex and decontamination and decommissioning of the Auxiliary Reactor Area-II and Boiling Water Reactor Experiment-V. 
Table 5.14-5. Impacts from selected maximum reasonably foreseeable accidents involving hazardous materials at the Idaho National Engineering Laboratory for Alternative A (No Action).

\begin{tabular}{|c|c|c|c|}
\hline Accident & $\begin{array}{l}\text { Frequency } \\
\text { (events/yr) }\end{array}$ & $\begin{array}{l}\text { MEI chemical } \\
\text { concentration } \\
\left(\mathrm{mg} / \mathrm{m}^{3}\right)\end{array}$ & $\begin{array}{l}\text { MEI chemical } \\
\text { concentration } \\
\text { (percentage of ERPG3) }^{b}\end{array}$ \\
\hline $\begin{array}{l}\text { Chlorine release at Argonne National } \\
\text { Laboratory-West (ANL-W) }\end{array}$ & $1 \times 10^{-5}$ & 20 & 35 \\
\hline $\begin{array}{l}\text { Chlorine release at Central Facilities } \\
\text { Area }(\mathrm{CFA})^{\mathrm{c}}\end{array}$ & $1 \times 10^{-4}$ & 6.0 & 10 \\
\hline $\begin{array}{l}\text { Chlorine release at Idaho Chemical } \\
\text { Processing Plant (ICPP) }\end{array}$ & $5 \times 10^{-6}$ & 4.2 & 7 \\
\hline Nitric acid release at ICPPC & $1 \times 10^{-5}$ & 0.12 & 0.05 \\
\hline $\begin{array}{l}\text { Lava flow over Radioactive Waste } \\
\text { Management Complex (RWMC) }\end{array}$ & $2 \times 10^{-5}$ & $\begin{aligned} \text { Mercury: } & 3.0 \\
\text { Nitric acid: } & 20 \\
\text { Phosgene gas: } & 0.10\end{aligned}$ & $\begin{array}{c}\text { Mercury: } 30 \\
\text { Nitric acid: } 6 \\
\text { Phosgene gas: } 3\end{array}$ \\
\hline $\begin{array}{l}\text { Fire in depleted uranium scrap at } \\
\text { Test Area Northc }\end{array}$ & $1 \times 10^{-7}$ & 0.20 & 1 \\
\hline $\begin{array}{l}\text { Handling accident involving existing } \\
\text { quantities of sulfur dioxide at INEL } \\
\text { Research Center }\end{array}$ & $1 \times 10^{-4}$ & 13 & 33 \\
\hline \multicolumn{4}{|c|}{$\begin{array}{l}\text { a. MEI - maximally exposed individual at the nearest site boundary. } \\
\text { b. ERPG3 - Emergency Response Planning Guide Level } 3 \text { (immediately dangerous to life and health). } \\
\text { c. Hazardous materials in inventory. } \\
\text { d. Hazardous constituents of transuranic and products of combustion. }\end{array}$} \\
\hline
\end{tabular}

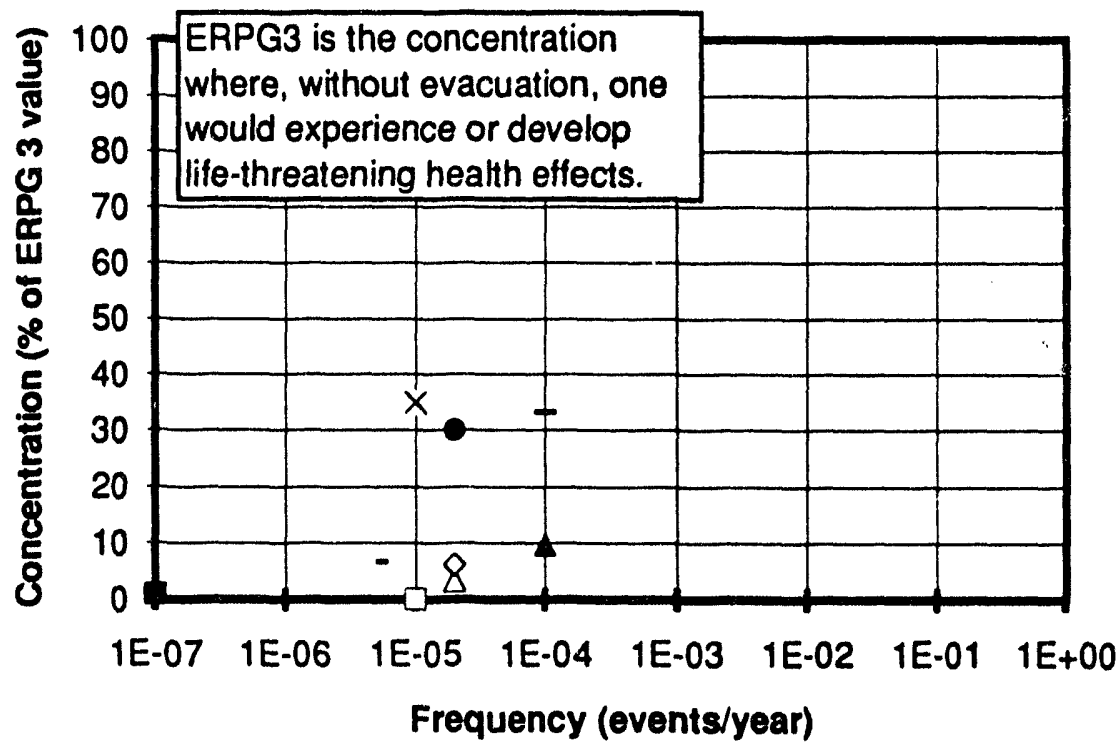

$\times$ ANL-W Chlorine

- RWMC Mercury

$\triangle$ RWMC Phosgene

$\diamond$ RWMC Nitric Acid

$\triangle$ CFA Chlorine

TAN Depleted Uranium

- ICPP Chlorine

- IRC Sulfur Dioxide

ICPP Nitric Acid

Figure 5.14-5. Potential maximum hazardous chemical concentrations at nearest Idaho National Engineering Laboratory site boundary as a percentage of ERPG3 concentration for Alternative A (No Action). 
Based on quantities of radioactive material present, the accidents given in Table 5.14-3 were determined to have bounding consequences within the abnormal, design basis, and beyond design basis frequency categories. Impacts from these accidents are illustrated in Figures 5.14-2 and 5.14-3. No secondary impacts or worker fatalities would be expected.

\subsubsection{Impacts from Alternative B (Ten-Year Plan)}

Secondary impacts are shown in Table 5.14-4. Worker risks are similar to those characterized in Alternative A (No Action); workers near the source of releases have a potential risk of injury or death. The accident impacts from several Alternative B (Ten-Year Plan) projects are evaluated.

5.14.4.1 Spent Nuclear Fuel. The incremental risk of accidents over those assessed in Alternative A (No Action) (Section 5.14.3.1) would be related to construction activities and the receipt of additional offsite spent nuclear fuel shipments (including Fort St. Vrain fuels) at the INEL site. The increased quantity of relatively long-cooled fuel would be managed and stored in the Fluorinel and Storage (FAST) Facility (CPP-666) basins, the CPP-749 Underground Storage Facility, and a proposed new dry storage/ canning and characterization facility at the Idaho Chemical Processing Plant. On the basis of the estimated changes in spent fuel-handling activities under Alternative B, the frequency of a fuel-handling accident is increased by a factor of 4.8. The offsite consequences would not increase over those analyzed for Alternative A. For a criticality accident at the CPP-603 Underwater Fuel Storage Facility resulting from a handling accident associated with degraded spent nuclear fuel, the estimated frequency considered under Alternative $A\left(1 \times 10^{-3}\right.$ or 0.001 events per year $)$ is based on the number of handling activities associated with relocating the CPP-603 spent nuclear fuel inventories to CPP-666. Because handling events associated with relocating spent nuclear fuel from CPP-603 to CPP-666 are unaffected by proposed changes in INEL inventories under the different alternatives, the estimated frequency for this event would not change.

Adding storage racks to CPP-666, as proposed under this alternative, would allow more wet fuel storage capacity at the INEL site. The increased handling of spent fuel necessary to add racks may increase the probability of a mechanical damage or criticality accident. The construction activities would increase the likelihood of an industrial accident and worker injury or death. 
Operations at Argonne National Laboratory-West would continue as in Alternative A (No Action), and because of the short-cooled fuel handled at this facility, the Alternative A accidents would continue to bound the design basis and beyond design basis accident frequency categories under Alternative B (Ten-Year Plan). The bounding accident characteristics within each frequency category that differ from those specified in Alternative A (Section 5.14.3.1) are summarized in Table 5.14-6. The Alternative B accident impacts for spent nuclear fuel and other radioactive waste streams are illustrated in Figures 5.14-6, 5.14-7, and 5.14-8.

5.14.4.2 High-Level Waste. The frequency of construction accidents and minor radiological accidents would increase as a result of proposed actions. However, the consequences of accidents associated with high-level waste facilities under Alternative B (Ten-Year Plan) are bounded by those analyzed under Alternative A (No Action).

One Alternative B project is the selection of technologies for processing sodium-bearing liquid waste and calcined high-level waste. Accidents associated with current storage of sodiumbearing liquid waste and with calcining activities bound chosen technologies because the chosen technology would use current design requirements and best available treatment technologies. The resultant waste form would be more safe than the current high-level waste form stored at the INEL site.

5.14.4.3 Transuranic Waste. Construction accidents and minor radiological accidents could occur as a result of proposed actions under Alternative B (Ten-Year Plan). Additional transuranic waste would be received for storage. The frequency of a fire in the Radioactive Waste Management Complex transuranic storage area is assumed to increase by approximately a factor of 5 on the basis of estimated handling requirements. The consequences of a lava flow accident would increase by approximately 10 percent on the basis of the projected change in inventory of transuranic waste at the Radioactive Waste Management Complex.

\subsubsection{Mixed and Low-Level Waste. Under Alternative B (Ten-Year Plan),} additional mixed and low-level waste would be generated on the INEL site by proposed projects and by decontamination and decommissioning activities. The frequency of fires in mixed waste storage and the Radioactive Waste Management Complex subsurface disposal area is estimated 


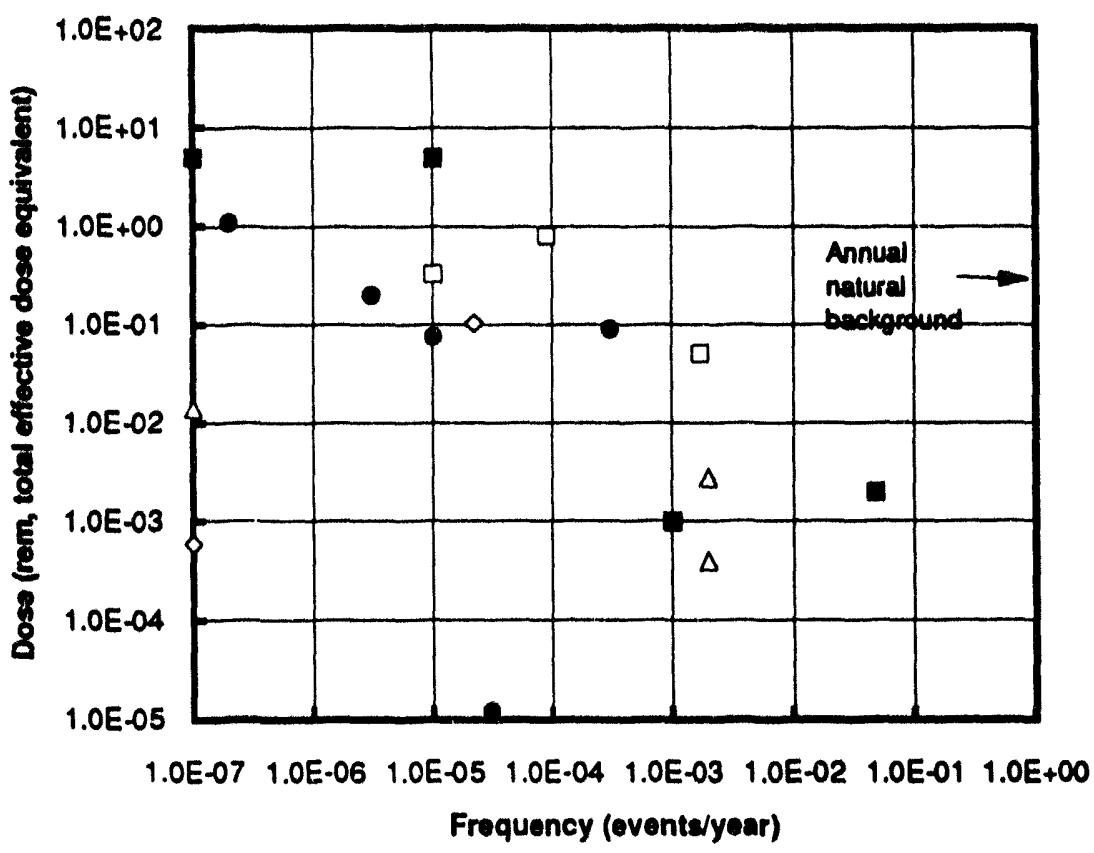

Based on conservative (95\%) moteorology. Relerence value irom NRC 1000

Spent Nuclear Fuel

- High-Level Waste

- Transuranic Waste

$\Delta$ Mixed and Low-Level Waste

Environmental Remediation and Decontamination and Decommissioning

Figure 5.14-6. Potential radiation exposures from accidents to individual at nearest Idaho National Engineering Laboratory site boundary for Alternative B (Ten-Year Plan).

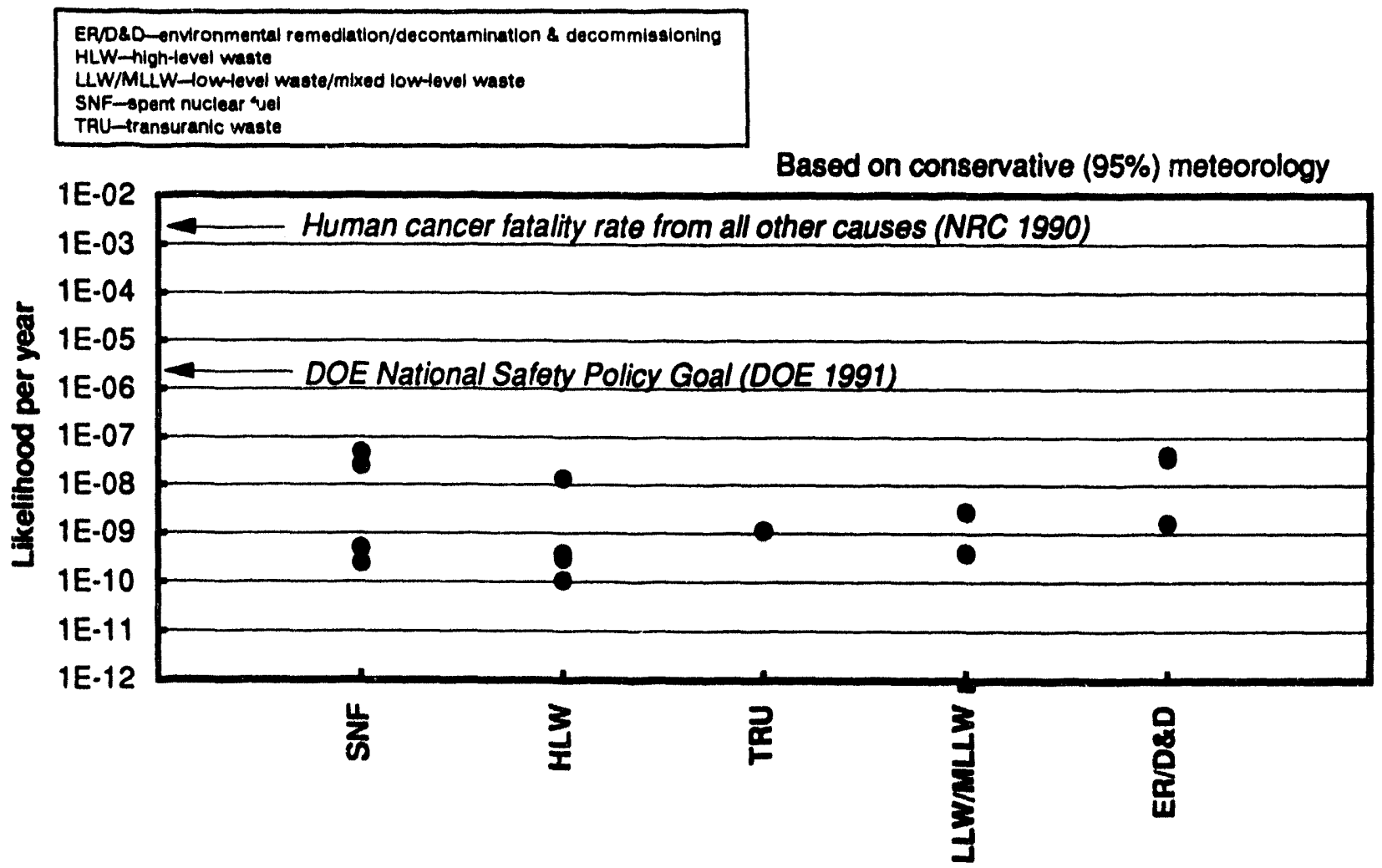

Figure 5.14-7. Risk of fatal cancer to individual at nearest Idaho National Engineering Laboratory site boundary from radiation accidents for Alternative B (Ten-Year Plan). 
ER'O\&D-environmental remediation/decontamination \& decommissloning

H'W-Wigh-level waste

I.LW/MLLW-low-level waste/mixed low-level waste

SNF-spent nuclear fuel

TRU-transuranic waste

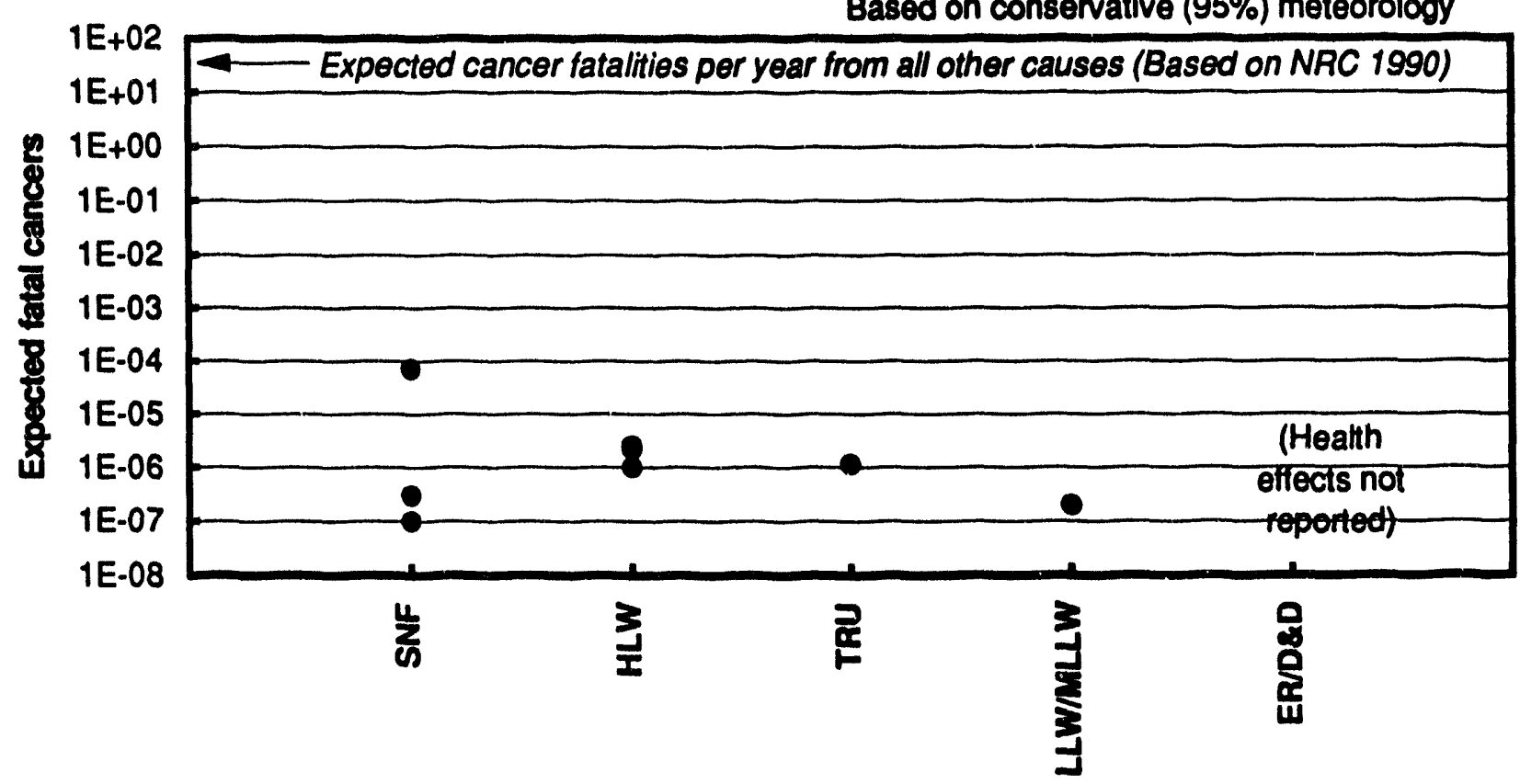

Figure 5.148. Excess fatal cancers in exposed population from radiation accidents at Idaho National Engineering Laboratory facilities for Alternative B (Ten-Year Plan).

to increase by a factor of two on the basis of projected waste-handling requirements. Accidents with lower consequences and construction accidents could occur as a result of proposed actions, for example, the Alternative B project, incineration of low-level and mixed low-level waste at the Waste Experimental Reduction Facility.

5.14.4.5 Hazardous Materials. The consequences of maximum reasonably foreseeable accidents associated with hazardous waste or chemicals would be the same under Alternative B (Ten-Year Plan) as those analyzed under Alternative A (No Action). Lower consequence accidents could occur as a result of proposed actions.

\subsubsection{Environmental Remediation and Decontamination and Decommissioning.} The incremental risk of accidents over those assessed in Alternative A (No Action) would be related to expanded environmental remediation and decontamination and decommissioning activities (including construction) on the basis of current plans. However, accidents associated 
with environmental remediation at Pit 9 at the Radioactive Waste Management Complex would bound consequences of accidents at other activities on the INEL site. Therefore, the consequences of maximum reasonably foreseeable accidents associated with environmental remediation and decontamination and decommissioning activities would be the same under Alternative B (Ten-Year Plan) as those analyzed under Alternative A (No Action).

\subsubsection{Impacts from Alternatlve C (Minimum Treatment, Storage, and Disposal)}

Secondary impacts are shown in Table 5.14-4. Worker risks are similar to those characterized in Alternative A (No Action); workers near the source of releases have a potential risk of injury or death. The accident impacts from several Alternative C (Minimum Treatment, Storage, and Disposal) projects are evaluated

5.14.5.1 Spent Nuclear Fuel. The incremental risk of accidents over those assessed in Alternative A (No Action) (Section 5.14.3.1) would be related to the eventual shipment offsite of the majority of spent nuclear fuel stored at the INEL. During the shipment phase, the additional fuel-handling activities may increase the frequency ( 8.6 times Alternative $\mathrm{A})$, but not the offsite consequences, of fuel handling-type accidents. The decrease in total spent nuclear fuel at the INEL would decrease the frequency of accidents associated with storing spent nuclear fuel. Operations at Argonne National Laboratory-West would continue as in Alternative A, and because of the short-cooled fuel handled at this facility, Alternative $A$ accidents would continue to bound the design basis and beyond design basis accident frequency categories under Alternative $\mathrm{C}$ (Minimum Treatment, Storage, and Disposal). The bounding accidents within each frequency category that differ from those specified in Alternative A characteristics (Section 5.14.3.1) are summarized in Table 5.14-7. The Alternative $\mathrm{C}$ accident consequences for spent nuclear fuel and other radioactive waste streams are illustrated in Figures 5.14-9, 5.14-10, and 5.14-11. After shipment of all spent nuclear fuel offsite, only impacts associated with spent nuclear fuel at reactor operations would continue.

5.14.5.2 High-Level Waste. The consequences of maximum reasonably foreseeable accidents associated with high-level waste facilities would be the same under Alternative $C$ (Minimum Treatment, Storage, and Disposal) as those analyzed under Alternative A (No Action). 
Table 5.147. Characteristics of radiological accidents at the Idaho National Engineering Laboratory site under Alternative C (Minimum Treatment, Storage, and Disposal) that differ from those under Alternative A (No Action).

\begin{tabular}{|c|c|c|c|c|c|c|c|c|}
\hline \multirow[b]{2}{*}{ Accident } & \multirow[b]{2}{*}{$\begin{array}{l}\text { Frequency } \\
\text { (events/yr) }\end{array}$} & \multirow[b]{2}{*}{$\begin{array}{c}\text { Facility } \\
\text { worker dose } \\
(\text { rem })^{c}\end{array}$} & \multirow[b]{2}{*}{$\begin{array}{c}\text { Dose at } \\
\text { nearest public } \\
\text { access (rem) }\end{array}$} & \multirow[b]{2}{*}{$\begin{array}{l}\text { Dase to } \\
\text { MEI }^{\mathrm{e}} \\
\text { (rem) }\end{array}$} & \multirow[b]{2}{*}{$\begin{array}{l}\text { Offsite population } \\
\text { dose (person-rem) } \\
95 \% \text { meteorology }\end{array}$} & \multicolumn{3}{|c|}{ Risk of fatal cancer per year ${ }^{b}$} \\
\hline & & & & & & MEI & $\begin{array}{l}\text { Population, } \\
50 \% \text { meteorology }\end{array}$ & $\begin{array}{l}\text { Population, } \\
\text { 95\% meteorology }\end{array}$ \\
\hline
\end{tabular}

\section{Spent Nectear Fued Axcidents}

$\begin{aligned} & \text { Fuel-handling accident, } \\ & \text { fuel pin breach, venting of } \\ & \text { noble gases and iodine }\end{aligned}$
(bounded by HFEF fuel-
handling accident)

High-Level Waste Accidents - No Chenge from Ahemative A

Transuranic Waste Accidents

\begin{tabular}{|c|c|c|c|c|c|c|c|}
\hline Fire in RWMC TSA & $4 \times 10^{-5}$ & (f) & (f) & $1.0 \times 10^{-6}$ & (f) & $2.0 \times 10^{-14}$ & (f) \\
\hline \multicolumn{8}{|c|}{ Mised Low-Level/Low-Leved Waste Accidents } \\
\hline $\begin{array}{l}\text { Design basis fire at } \\
\text { WERF Waste Storage } \\
\text { Building }\end{array}$ & $2 \times 10^{-3}$ & (f) & (f) & $2.8 \times 10^{-3}$ & (f) & $2.8 \times 10^{-9}$ & (f) \\
\hline
\end{tabular}

Environmental Remodiation/Docortamination and Decommiasioning Accidents - No Change from Altemative A

a. Accidents involving hazarfous materials for Alternative A are summarized in Table 5.14-5 (Section 5.14.3.5). b. Fatal cancer risk $=$ dose $\times$ accident frequency $\times(5.0 \times 10$ fat cancers per rem) ICPR-60 conversion factor is doubled, or $1.0 \times 10^{-3}$ (ICRP 1991$)$. Numbers in parentheses in

c. A facily wo the public on a highway at the nearest point to the facility within the site boundary.

d. Member of the public on highethetical individual whose residence is located at the nearest site boundary.

e. MEI = maximally exposed hypothetical individual whose residence is located at the because it was developed before DOE orders specifically required this information. As

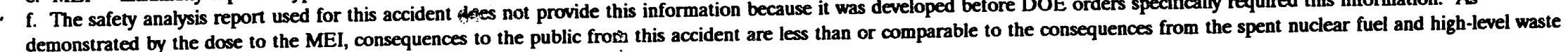
accidents in Table 5.14-3 with calculated population doses.

Definition of acronyms:

HFEF - Hot Fuel Examination Facility

MEI - maximally exposed individual at the nearest site boundary
RWMC - Radioactive Waste Management Complex

SDA - Subsurface Disposal Area
WERF - Waste Experimental Reduction Facility

TSA - Transuranic Storage Area 


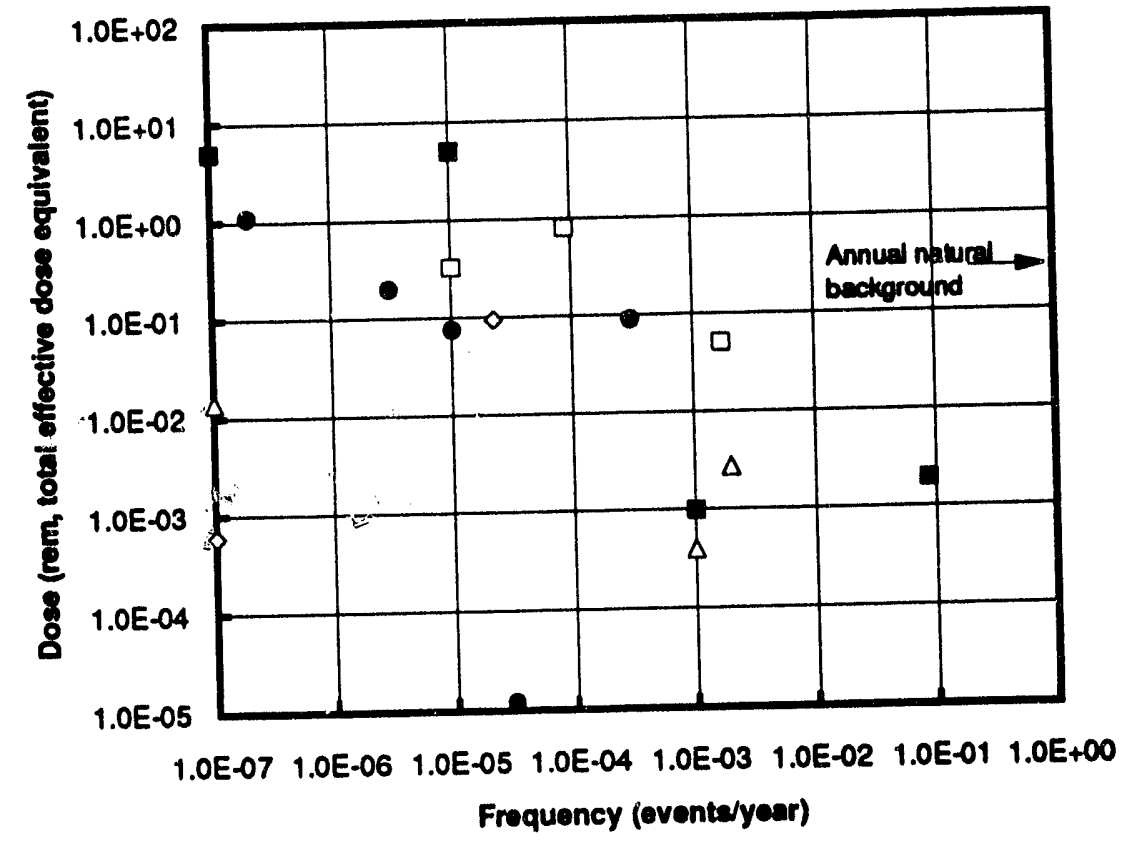

Based on conservative (95\%) meleorology, Relerence value from NRC 1900

- Spent Nuclear Fuel

- High-Level Waste

- Transuranic Wasto

$\Delta$ Mixed and Low-Level Waste

Environmental Remediation and Decontamination and Decommissioning

Figure 5.14-9. Potential radiation exposures from accidents to individual at nearest Idaho National Engineering Laboratory site boundary for Alternative C (Minimum Treatment, Storage, and Disposal).

ERD\&D-environmental remediation/decontamination \& decommissioning

HLW-high-level waste

LWTMLLW-low-level waste/mixed low-level waste

SNF-spent nuclear tuel

TRU-transuranic waste

Based on conservative (95\%) meteorology

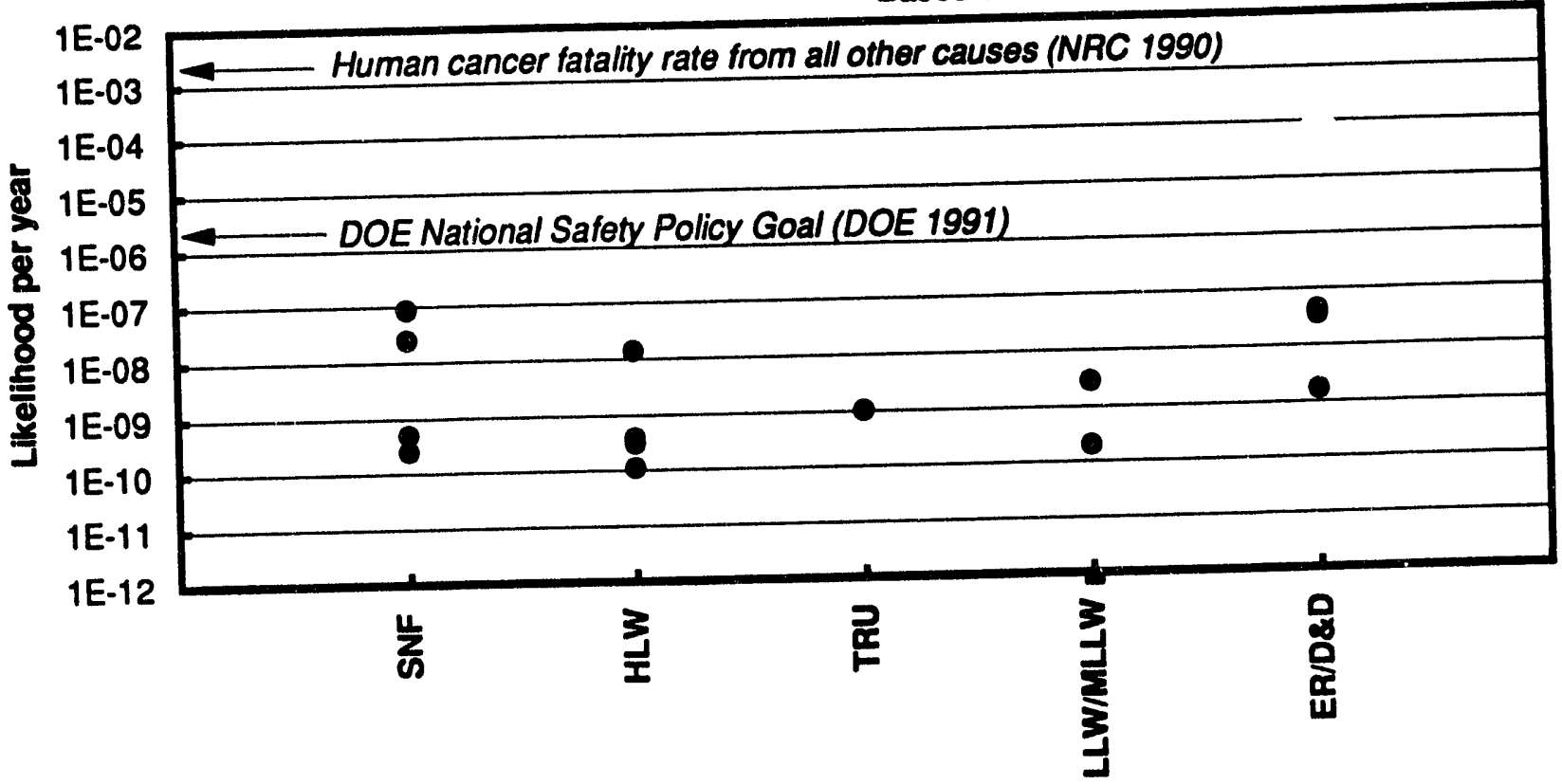

Figure 5.14-10. Risk of fatal cancer to individual at nearest Idaho National Engineering Laboratory site boundary from radiation accidents for Alternative C (Minimum Treatment, Storage, and Disposal). 
ERYQD-environmental remedlation/decontamination \& decommissioning

HLW-high-level waste

LLW/MLLW-low-level waste/mlxed low-level waste

SNF-spent nuclear tuel

TRU-transuranle waste

Based on conservative (95\%) meteorology

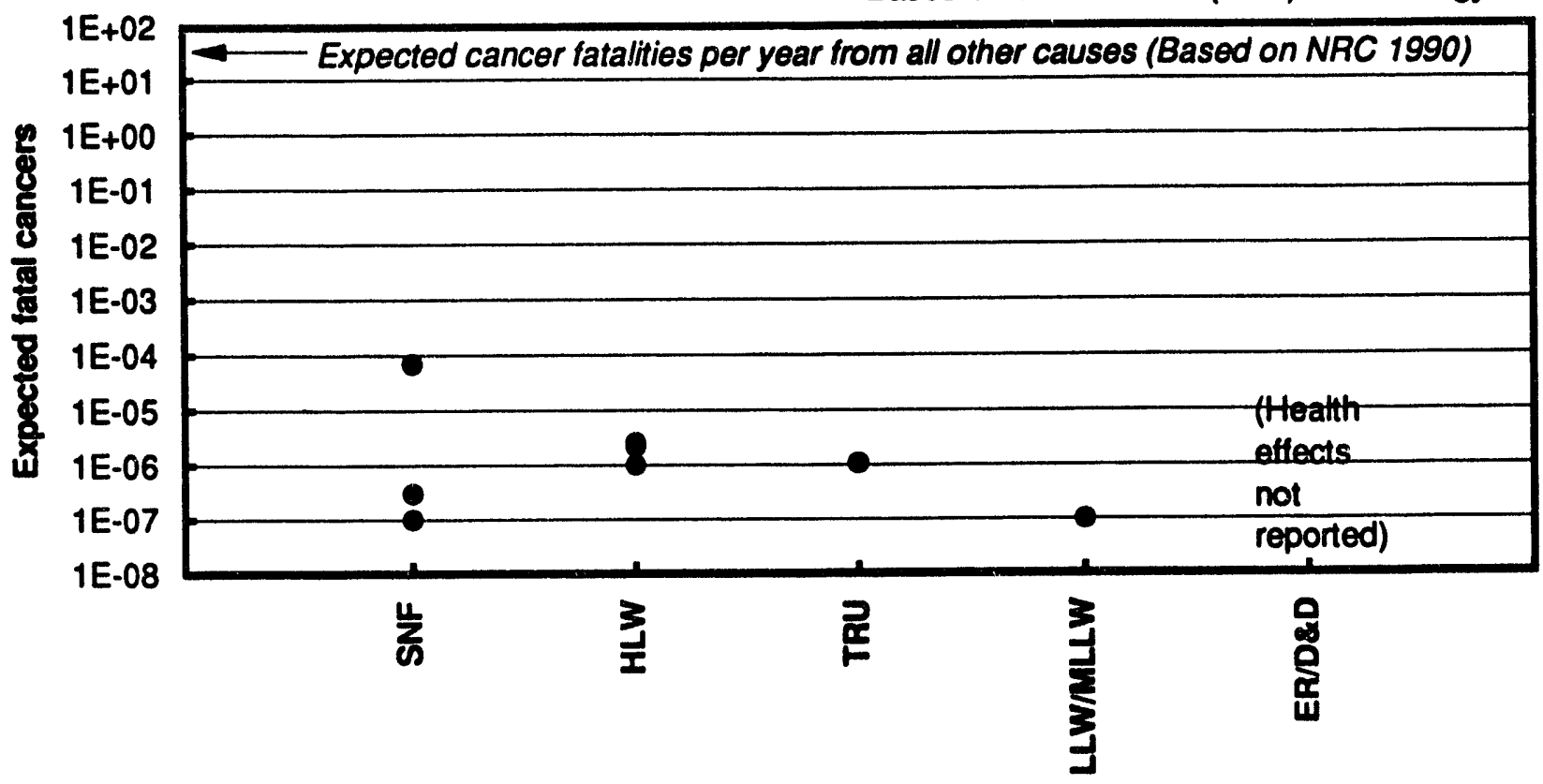

Figure 5.14-11. Excess fatal cancers in exposed population from radiation accidents at Idaho National Engineering Laboratory facilities for Alternative C (Minimum Treatment, Storage, and Disposal).

Lower consequence accidents and construction accidents could occur as a result of proposed Alternative $\mathrm{C}$ actions, for example, replacement of high-level waste tanks. Replacement tanks would upgraile the safety of liquid high-level waste storage at the INEL site. Ultimately, the risk of accidents would be decreased because the tanks would be constructed in accordance with current design requirements, and would include features such as double wall confinement, leak detection, and seismic-resistant design. The construction activities would increase the likelihood of an industrial accident and worker injury or death. Another Aiternative $\mathrm{C}$ project, selection of technologies for processing sodium-bearing liquid waste and calcined high-level waste was discussed under Alternative B.

5.14.5.3 Transuranic Waste. Under Alternative C (Minimum Treatment, Storage, and Disposal), the majority of transuranic waste stored at the INEL site would be transported offsite to a different storage location. The increased handling necessary to retrieve, package, and transport transuranic waste from the INEL site would increase the frequency of fires less than 
ten-fold. After shipment of transuranic wastes offsite, only impacts associated with INELgenerated transuranic wastes would continue.

5.14.5.4 Mixed and Low-Level Waste. Under Alternative C (Minimum Treatment, Storage, and Disposal), all stored and newly generated mixed low-level waste/low-level waste would be transported offsite for treatment, storage, and disposal. The increased handling necessary to package and transport mixed low-level waste/low-level waste from the INEL site would increase the frequency of a design basis fire in the Waste Experimental Reduction Facility Waste Storage Building by less than double. Following offsite shipment, only those quantities staged for offsite shipment from operating facilities would remain.

5.14.5.5 Hazardous Materials. The frequency and consequences of maximum reasonably foreseeable accidents associated with hazardous wastes and hazardous materials in inventory would be the same under Alternative C (Minimum Treatment, Storage, and Disposal) as those analyzed under Alternative $\mathrm{A}$ (No Action). Under Alternative $\mathrm{C}$, mixed waste with hazardous constituents stored at the Radioactive Waste Management Complex would be transported offsite, eventually eliminating that source of hazardous material.

\subsubsection{Environmental Remediation and Decontamination and Decommissioning.}

The frequency and consequences of accidents associated with environmental remediation and decontamination and decommissioning activities would be the same under Alternative $\mathrm{C}$ (Minimum Treatment, Storage, and Disposal) as those analyzed under Alternative A (No Action).

\subsubsection{Impacts from Alternative D (Maximum Treatment, Storage, and Disposal)}

Secondary impacts are shown in Table 5.14-4. Worker risks are similar to those characterized in Alternative A (No Action); workers near the source of releases have a potential risk of injury or death. The accident impacts from several Alternative D (Maximum Treatment, Storage, and Disposal) projects are evaluated.

5.14.6.1 Spent Nuclear Fuel. The incremental risk of accidents over those assessed in Alternative A (Section 5.14.3.1) would be related to two factors: (a) receipt of additional offsite shipments of relatively long-cooled spent nuclear fuel, and (b) processing of spent nuclear fuel for ultimate disposal. The additional handling necessary to receive and store spent nuclear fuel would be approximately 20 times that under Alternative A. The fuel received would be managed at a new dry storage/canning and characterization facility at the Idaho Chemical Processing Plant. The 
additional fuel-handling and dry storage activities would be expected to . Icrease by 20 times the frequency, but not the consequences, of fuel-handling-type accidents. Stabilization of the fuel for long-term storage would be performed in a new waste immobilization facility at the Idaho Chemical Processing Plant. Consequences of potential accidents at the waste immobilization facility are bounded by spent nuclear fuel activities involving short-cooled fuel as assessed in Alternative A.

Fuel processing would take place in the Fluorinel and Storage (FAST) facility (CPP-666) and the Fuel Processing Restorat 'on Facility (CPP-691). Processing would consist of dissolving spent nuclear fuel in an acid solution, and processing the dissolved fuel to immobilize radionuclides for final waste disposal. On the basis of accidents previously analyzed in EG\&G Idaho (1991), bounding accidents associated with fuel processing are nuclear criticality, dissolver hydrogen explosion, and accidental dissolution of 30-day cooled fuel.

Operations at Argonne National Laboratory-West would continue as in Alternative A (No Action), and because of the short-cooled fuel handled at this facility, Alternative $A$ accidents would continue to bound the design-basis and beyond-design-basis accident frequency categories under Alternative D (Maximum Treatment, Storage, and Disposal). The bounding accident characteristics within each frequency category that differ from those specified in Alternative A (Section 5.14.3.1) are summarized in Table 5.14-8. The Alternative D accident consequences for spent nuclear fuel and all radioactive waste streams are illustrated in Figures 5.14-12, 5.14-13, and 5.14-14.

5.14.6.2 High-Level Waste. Because of spent fuel processing activities, additional highlevel waste would be generated and processed at the Idaho Chemical Processing Plant under Alternative D (Maximum Treatment, Storage, and Disposal). However, the frequency and consequences of accidents associated with high-level waste facilities would be bounded by those analyzed under Alternative A (No Action) because existing calcine facilities would continue to be used, and because of proposed safety upgrades to liquid waste management facilities under Alternative D. Several example Alternative D projects involving high-level waste (selection of technologies for processing sodium-bearing liquid waste and calcined high-level waste and replacement of high-level waste tanks) were discussed briefly under Alternatives B (Ten-Year Plan) and C (Minimum Treatment, Storage, and Disposal), respectively. 
Table 5.148. Characteristics of radiological accidents at the Idaho National Engineering Laboratory site under Alternative D (Maximum Treatment, Storage, and Disposal) that differ from those under Alternative A (No Action).

\begin{tabular}{|c|c|c|c|c|c|c|c|c|}
\hline \multirow[b]{2}{*}{ Accident } & \multirow[b]{2}{*}{$\begin{array}{l}\text { Frequency } \\
\text { (events/yr) }\end{array}$} & \multirow[b]{2}{*}{$\begin{array}{l}\text { Facility } \\
\text { worker dose } \\
(\text { rem })^{\mathrm{c}}\end{array}$} & \multirow[b]{2}{*}{$\begin{array}{l}\text { Dose at } \\
\text { nearest publig } \\
\text { access (rem) }\end{array}$} & \multirow[b]{2}{*}{$\begin{array}{l}\text { Dose to MEI } \\
\text { (rem) }^{\mathrm{e}}\end{array}$} & \multirow[b]{2}{*}{$\begin{array}{l}\text { Offsite population } \\
\text { dose (person-rem) } \\
95 \% \text { meteorology }\end{array}$} & \multicolumn{3}{|c|}{ Risk of fatal cancer per year ${ }^{b}$} \\
\hline & & & & & & MEI & $\begin{array}{c}\text { Population, } \\
\text { 50\% meteorology }\end{array}$ & $\begin{array}{l}\text { Population, } \\
\text { 95\% meteorology }\end{array}$ \\
\hline
\end{tabular}

Fuel handling accident, fuel
pin breach, venting of noble
gases and iodine (bounded by
HFEF fuel handling accident)
Inadvertent nuclear criticality

during processing

Dissolver hydrogen explosion

$20 \times 10^{-1} \quad$ (f) $\quad$ Spent Nuctear Fued Accidents

(rem) ${ }^{c}$

(f)

$20 \times 10^{-7}$

(f)

Inadvertent dissolution of

30-day cooled fuel

$\begin{array}{lccccc}\mathrm{g}_{1} \times 10^{-3} & 9.1 \times 10^{0} & 4.9 \times 10^{-2} & 2.8 \times 10^{-2} & 5.6 \times 10^{0} & 1.4 \times 10^{-8} \\ 1 \times 10^{-5} & \text { (f) } & \text { (f) } & 6.3 \times 10^{-4} & h_{8.1 \times 10^{-1}} & 3.2 \times 10^{-12} \\ 1 \times 10^{-6} & \text { (f) } & \text { (f) } & 3.0 \times 10^{-2} & h_{2.9} \times 10^{1} & 1.5 \times 10^{-11}\end{array}$

High-Leved Waste Accidents - No Chonge from Alvernative A

\section{Lava flow over RWMC \\ Fire in RWMC TSA}

Fire in RWMC SDA

Design basis fire at WERF

Waste Storage Building

$\begin{array}{cc}2 \times 10^{-5} & \text { Evacuate } \\ 4 \times 10^{-5} & (\text { f) } \\ 1 \times 10^{-2} & \text { (f) } \\ 1 \times 10^{-2} & \text { (f) }\end{array}$

\section{Transuranic Waste Accidents}

\begin{tabular}{|c|c|c|}
\hline \multirow[b]{2}{*}{ Evacuate } & \multicolumn{2}{|c|}{ 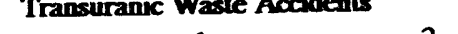 } \\
\hline & $1.1 \times 10^{-1}$ & $1.2 \times 10^{2}$ \\
\hline (f) & $1.0 \times 10^{-6}$ & (f) \\
\hline \multicolumn{3}{|c|}{ Mixed Low-Level/Low-Laved Waste Accidents } \\
\hline (f) & $4.0 \times 10^{-3}$ & (f) \\
\hline
\end{tabular}

(f)

$2.8 \times 10^{-3}$

(f)
$1.1 \times 10^{-9}$

$2.0 \times 10^{-14}$

$2.0 \times 10^{-8}$

$1.4 \times 10^{-8}$ (f)

$3.1 \times 10^{-6}\left(3.1 \times 10^{-3}\right)$

$2.8 \times 10^{-6}\left(2.8 \times 10^{-3}\right)$

(f)

(f)

Emvironmental Remediation/Decontamination and Decommissioning Accidents - No Change from Abemative A

$2.9 \times 10^{-7}\left(1.4 \times 10^{-2}\right) \quad 1.2 \times 10^{-6}\left(5.8 \times 10^{-2}\right)$

(f)

Accidents involving hazardous materials for Alternative A (No Action) are summarized in Table 5.14-5 (Section 5.14.3.5).

a. Accidents involving hazardous materials for Alters b. Fatal cancer risk $=$ dose $\times$ accident frequency $\times\left(5.0 \times 10^{-3}\right.$ tatal cancers per rem $)($ CR

conversion factor is doubled, or $1.0 \times 10^{-3}$. Numbers in parentheses indicate total noche $100 \mathrm{~m}(330 \mathrm{ft}$ ) from the point of release.

d. Member of the public on a highway at the nearest point to the facility within the site boundary.

e. MEI = maximally exposed hypothetical individual whose residence is located at the nearest site boundary.

e. MEI = maximally exposed hypothetical individual whase solys repon utilized for this accident does not provide this information because it was developed before DOE orders specifically required this information. As demonstrated by

the dose to the MEI, consequences to the public from this accident are less than or comparable to the consequences from the spent nuclear fuel and high-tevel waste accidents in Table S.14-3

with calculated population doses.
g. Idaho Chemical Processing Plant has experienced three inadvertent criticalities during its operating history, the last one 14 years ago. The frequency shown is based on modern facility

design and safeguards.
h. The safety analysis report utilized for this accident used a population of 100,000 . Assuming worst-case atmospheric conditions and wind direction, the projected maximum sector within 50 miles of the accident is approximately 9,100 .

Definition of acronyms:

HFEF - Hot Fuel Examination Facility

MEI - maximally exposed individual at nearest site boundary

RWMC - Radioactive Waste Management Complex

SDA - Subsurface Disposal Area
TSA - Transuranic Storage Area

WERF - Waste Experimental Reduction Facility 


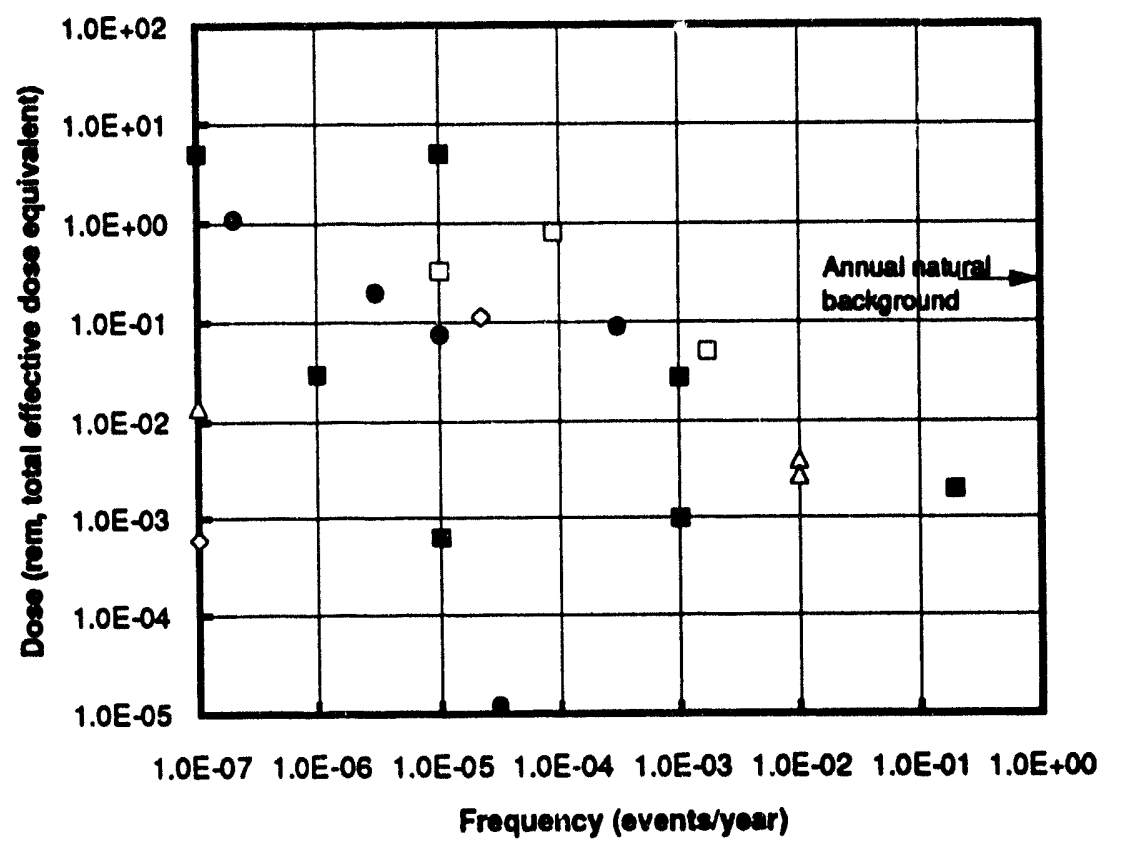

Based on conservative (\$6\%) moleorology. Relerence value from NRC 1000

- Spent Nuclear Fual

- High-Level Waste

- Transuranic Wasto

$\Delta$ Mixed and Low-Level Wasto

Environmental Remediation and Decontamination and Decommissioning

Figure 5.14-12. Potential radiation exposures from accidents to individual at nearest Idaho National Engineering Laboratory site boundary for Alternative D (Maximum Treatment, Storage, and Disposal).

ER/D\&D-environmental remediation/decontamination and decommissioning

HLW-high-level waste

LLW/MLLW-low-level waste/mixed low-level waste

SNF-spent nuclear fuel

TRU-transuranic waste

Based on conservative (95\%) meteorology

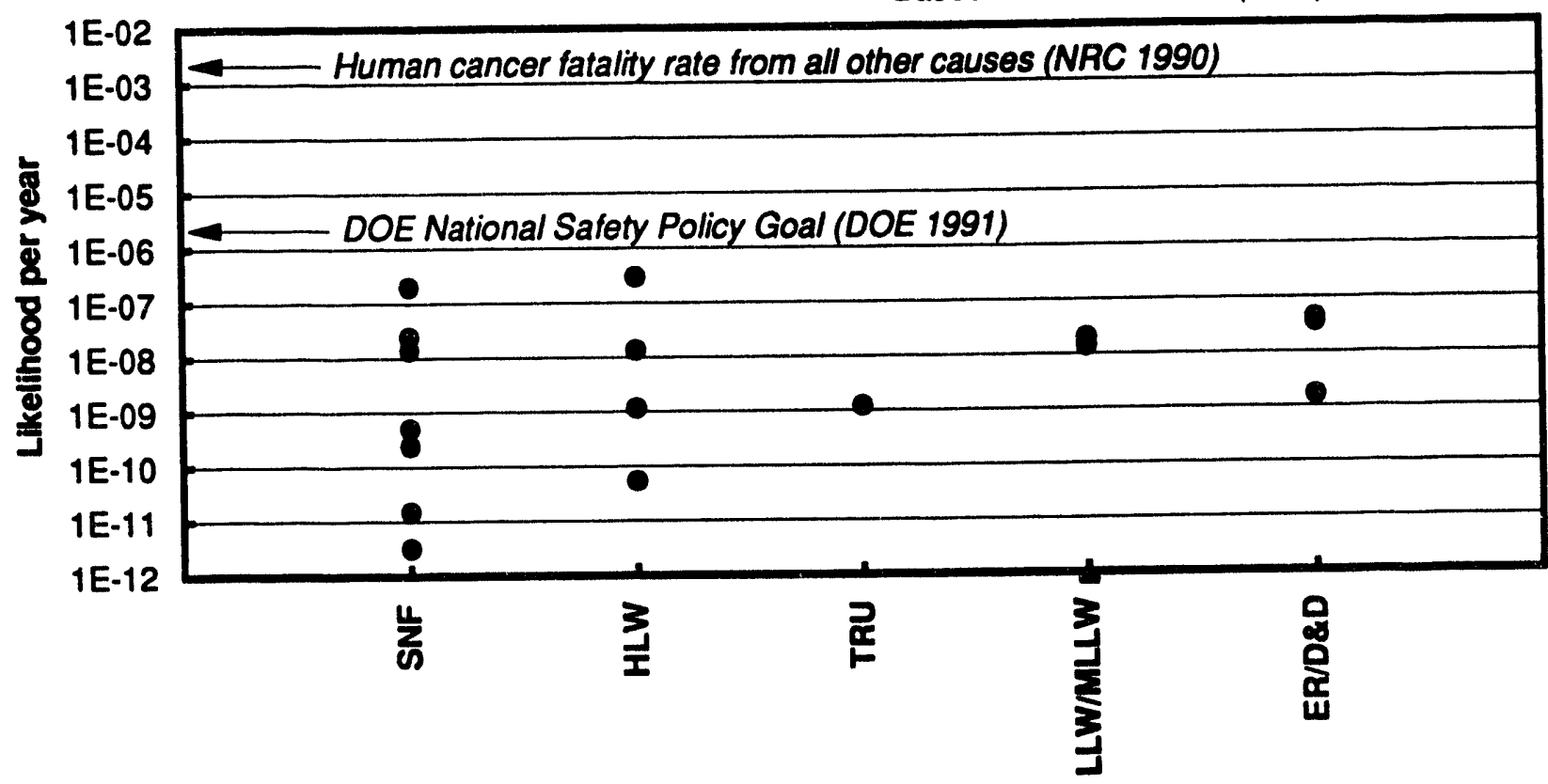

Figure 5.14-13. Risk of fatal cancer to individual at nearest Idaho National Engineering Laboratory site boundary from radiation accidents for Alternative D (Maximum Treatment, Storage, and Disposal). 
ER/D\&D-onvironmental remediation/decontamination and decommissioning

HLW-high-level waste

LLW/MLLW-low-level waste/mixed low-level waste

SNF-spent nuclear fuel

TRU-transuranlc waste

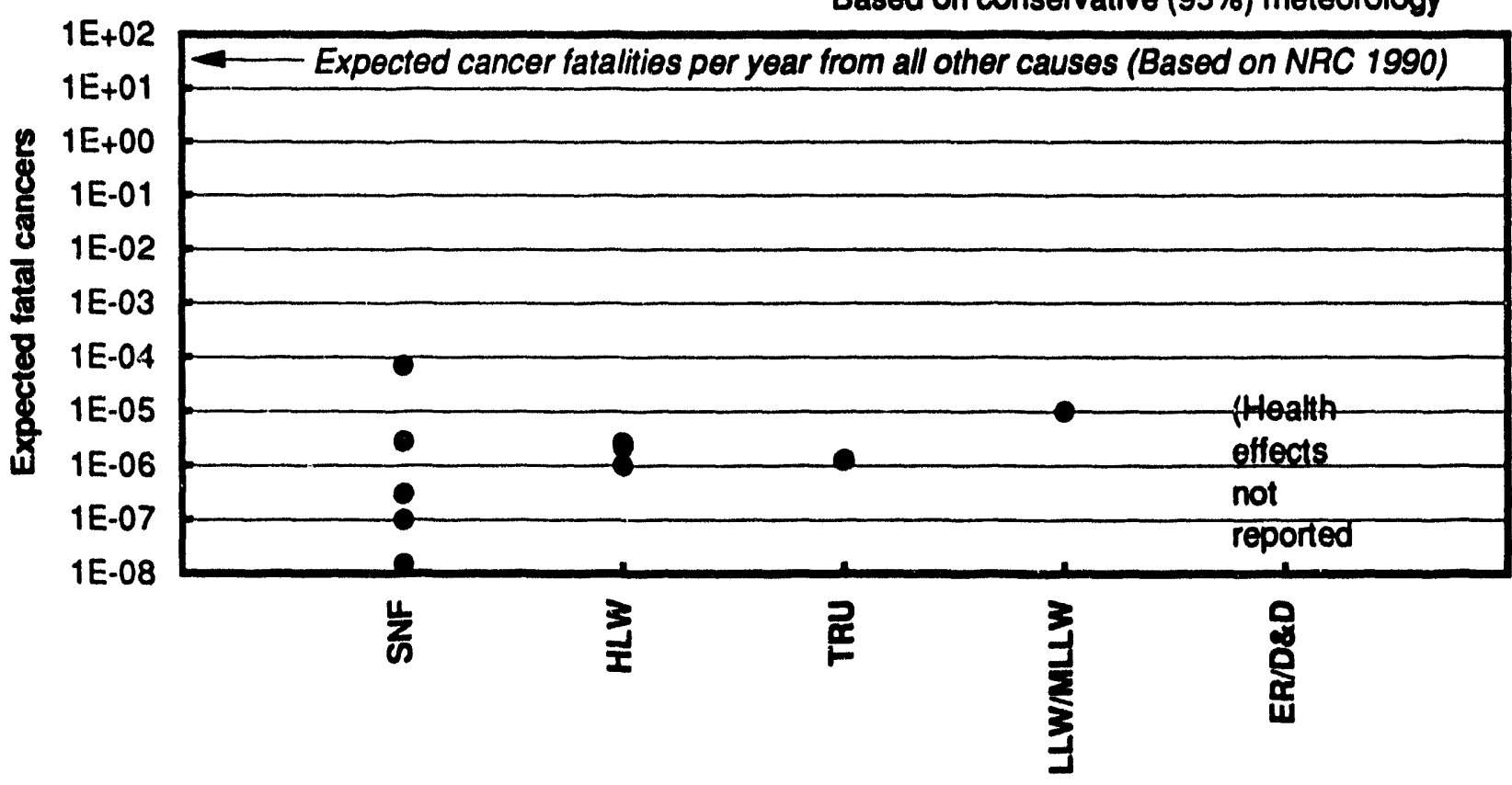

Figure 5.14-14. Excess fatal cancers in exposed population from radiation accidents at Idaho National Engineering Laboratory facilities for Alternative D (Maximum Treatment, Storage, and Disposal).

5.14.6.3 Transuranic Waste. The incremental risk of accidents over those assessed in Alternative A (No Action) would be related to the receipt of DOE complex-wide waste for examination, treatment, storage, and preparation for shipping for disposal at the Waste Isolation Pilot Plant. The transuranic waste inventory at the INEL site would be increased by approximately 20 percent. The frequency of fires is assumed to increase by no more than a factor of ten because not all fires are associated with the increased handling and storage of waste. The frequency of a lava flow event would be the same as that assessed under Alternative $\mathrm{A}$, but the consequences are assumed to increase by a factor of 20 percent under Alternative D (Maximum Treatment, Storage, and Disposal) because of the increased inventory.

5.14.6.4 Mixed and Low-Level Waste. The incremental risk of accidents over those assessed in Alternative A (No Action) would be related to the receipt of DOE complex-wide waste for treatment, storage, and disposal. The annual mixed low-level waste/low-level waste volume managed at the INEL site would be increased approximately ten-fold. Waste would be managed by additional inventory turnover in existing storage facilities. The frequency of fires is assumed to increase by no more than ten-fold because not all fires are associated with the increased handling 
and storage of waste. No increase in consequence was assumed because facilities with the same maximum capacity as assumed under Alternative $A$ would be used. The frequency and consequence of a fire at the Subsurface Disposal Area at the Radioactive Waste Management Complex was assumed to increase ten-fold on the basis of the receipt of additional offsite shipments and wastes from decontamination and decommissioning activities. Accidents associated with incineration at the Waste Experimental Reduction Facility are the same for this alternative as those considered in the Alternative B (Ten-Year Plan) analyses for low-level and mixed low-level waste streams.

5.14.6.5 Hazardous Materia/s. The incremental risk of accidents over those assessed in Alternative A (No-Action) would be related to two factors: (a) increased inventory of chemicals at the Idaho Chemical Processing Plant in support of spent fuel processing, and (b) receipt of additional transuranic waste containing hazardous constituents. Additional chemicals at the Idaho Chemical Processing Plant in support of fuel processing would be hydrofluoric acid and anhydrous ammonia. As discussed in Section 5.14.6.3, the volume of transuranic waste containing hazardous constituents at INEL would increase by 20 percent. The frequency of a lava flow event would be the same as that assessed under Alternative $\mathrm{A}$, but the toxicological consequences are assumed to increase by 20 percent under Alternative D (Maximum Treatment, Storage, and Disposal). The bounding accident characteristics that differ from those specified in Alternative A (Section 5.14.3.5) are summarized in Table 5.14-9.

Table 5.149. Characteristics of hazardous material accidents at the Idaho National Engineering Laboratory under Alternative D (Maximum Treatment, Storage, and Disposal) that differ from those under Alternative A (No Action).

\begin{tabular}{lccc}
\hline \multicolumn{1}{c}{ Accident } & $\begin{array}{c}\text { Frequency } \\
\text { (events/year) }\end{array}$ & $\begin{array}{c}\text { MEI chemical } \\
\text { concentration } \\
\left(\mathrm{mg} / \mathrm{m}^{3}\right)\end{array}$ & $\begin{array}{c}\text { MEI chemical } \\
\text { concentration } \\
\text { (percentage of ERPG3) }\end{array}$ \\
\hline $\begin{array}{l}\text { Lava flow over Radioactive Waste } \\
\text { Management Complex }\end{array}$ & $2 \times 10^{-5}$ & $\begin{array}{c}\text { Mercury: } 3.6 \\
\text { Nitric acid: } 24 \\
\text { Phosgene gas: } 0.12\end{array}$ & $\begin{array}{c}\text { Mercury: } 36 \\
\text { Nitric acid: } 7 \\
\text { Phosgene gas: } 4\end{array}$ \\
$\begin{array}{l}\text { Hydrofluoric acid spill at Idaho } \\
\text { Chemical Processing Plant }\end{array}$ & $1 \times 10^{-5}$ & 0.078 & 0.2 \\
$\begin{array}{l}\text { Anhydrous ammonia release at } \\
\text { Idaho Chemical Processing Plant }\end{array}$ & $1 \times 10^{-6}$ & 82 & 12 \\
\hline & & & \\
a. MEI - maximally exposed individual at the nearest site boundary. \\
b. ERPG3 - Emergency Response Planning Guide Level 3 (immediately dangerous to life and health).
\end{tabular}

\subsubsection{Environmental Remediation and Decontamination and Decommissioning.}

The frequency and consequences of accidents associated with environmental remediation and decontamination and decommissioning activities would be the same under Alternative D (Maximum Treatment, Storage, and Disposal) as those analyzed under Alternative A (No Action). 


\subsection{Cumulative Impacts and Impacts from Connected or SImllar Actions}

The following section represents the framework for evaluation of cumulative impacts. Site-specific data were included where possible.

Evaluation of cumulative impacts is necessary to develop an understanding of the implications for implementation of the alternatives. A cumulative impact is the result of the incremental impact of the proposed action added to all other past, present, and reasonably foreseeable future actions. These other actions may include DOE projects not associated with the Spent Nuclear Fuel or Environmental Restoration and Waste Management (ER\&WM) Programs and any offsite projects conducted by government agencies, businesses, or individuals.

Table 5.15-1 lists additional onsite and offsite projects to be assessed. This table represents the largest anticipated future offsite projects identified by the appropriate county agencies, Chambers of Commerce, and local development groups as of the printing of this EIS and are commensurate with the level of reasonably foreseeable development within the communities surrounding the INEL. These projects also represent most of the new sources of impacts not associated with the proposed actions.

In most cases, cumulative impacts are obtained by combining impacts caused by the alternative with those caused by other past, present, and reasonably foreseeable future actions. However, in some cases, impacts are population-specific and are not appropriate to combine. For example, estimated excess fatal cancers for workers as a result of radiological exposures from all facilities at the INEL can be combined quantitatively to estimate excess fatal cancers derived from INEL operations; however, it would be inappropriate to combine estimated excess fatal cancers for workers at another location that produces radiological emissions, such as in Pocatello, Idaho, with those estimated at INEL because the populations are almost entirely independent of one another.

Evaluation of cumulative impacts is important because a significant impact can arise from several small actions that, by themselves, do not have significant impacts. Nonhealth-related 
Table 5.15-1. Other projects to be included for assessment of cumulative impacts.

\begin{tabular}{c}
\hline Project \\
\hline At the Idaho National Engineering Laboratory \\
\hline
\end{tabular}

Test Area North-616 Liquid Waste Treatment Support Facility

Test Train Assembly Facility

Power Burst Facility

Underground Storage Tank Upgrade (Argonne National Laboratory-West)
Facility consists of a one-story cast-in-place, reinforced concrete building ( $11 \times 14 \times 4.5$ meters high; $36 \times 46 \times 15$ feet high) with a basement and mechanical penthouse on the roof. Ground floor divided into an evaporator pit, valve-operating room, caustic pump room, control room, and a vestibule. Basement contains a pump room and a cooling tower; heating/ventilating room is located on the roof. The facility operated from 1958 to 1970; rated Zone III. Decontamination and decommissioning (D\&D) would begin in Fiscal Year 1999. Until then, facility is in surveillance and maintenance mode while undergoing environmental assessment.

Located in the basement of the Materials Test Reactor building, D\&D of this facility would include removal and treatment of radioactively contaminated shielding water (MTR-603 Water Canal) and decontamination of canal walls, floor, and associated equipment. The canal is 2.5 meters ( 8.0 feet) wide, 4.7 meters (15.5 feet) below floor level, and 37 meters (121.5 feet) long [25 meters ( 81.5 feet) outside of the reactor building]. Water depth in the main canal is 5.3 meters (17.5 feet). The canal contains irradiated fuel elements that would be removed prior to D\&D. Canal would be partially drained until radiation level reaches 10 millirem per hour; remaining water would be responsibility of D\&D project. Decontamination would be completed in Fiscal Year 1999.

D\&D of facility including capping of SL-1 burial ground $[0.02$ square kilometer (4.6 acres)] and remediation of two injection wells. Facility includes a reactor (in shutdown mode), the Waste Experimental Reduction Facility for treatment of lowlevel waste (compaction of waste and incineration of combustible waste), and the Mixed Waste Storage Facility (interim status under the Resource Conservation and Recovery Act). Facility remains candidate for the site of Boron Neutron Capture Therapy, if program should become revitalized.

Replacement of two emergency support generator tanks with tanks that meet current underground storage tank regulations. Replacement would involve less than 0.008 square kilometer (2 acres) of previously disturbed land. 
Table 5.15-1. (continued).

Project $\quad$ Description

Fuel Cycle Facility Water Storage and Delivery Improvements (Argonne National LaboratoryWest)

Site Utilities Upgrade (Argonne National Laboratory-West)

Experimental Breeder Reactor-II External Fuel Handling Upgrade (Argonne National LaboratoryWest)

Fuel Handling and Plant Support (Argonne National LaboratoryWest)
Upgrade of existing water system with redundant water tank and supply, in accordance with DOE Order 6431.A. Upgrade would involve less than 0.02 square kilometer ( 5 acres) of previously disturbed land.

General repair on steam condensate system, water supply, electric utilities, and communication services. Project would involve less than 0.04 square kilometer (10 acres) of previously disturbed land.

Improve fuel handling capabilities outside of reactor including the Fuel Cycle Facility. Improvements would involve less than 0.02 square kilometer ( 5 acres) of previously disturbed land.

Improve fuel handling capabilities for the Fuel Cycle Facility. Improvements would involve less than 0.004 square kilometer (1 acre) of previously disturbed land.

\section{Offsite}

Housing Development, Idaho Falls

Business Park, Rexburg

Manufacturer, Pocatello

Food, Machinery, and Chemical Corp., Pocatello

Target Department Store, Idaho Falls 300-unit single family housing development planned on approximately 61 hectares (150 acres) of vacant land.

20 hectares ( 50 acres) of vacant land between two light industrial facilities are planned for an expansion into a light industrial/business park for $30-40$ businesses.

Existing manufactured home factory to expand from approximately 50 to between 140 and 150 employees. Expansion of 8.9 hectares (22 acres) in Pocatello Airport Industrial Park.

FMC phosphate manufacturing plant to reduce number of furnaces from 4 to 3 within the next two years; $25-30$ jobs could be lost.

Opening of Target discount store and associated commercial development planned on vacant land near the Teton Mall in Idaho Falls. 
cumulative impacts are summarized in Table 5.15-2 and discussed in Sections 5.15.1 through 5.15.6 and 5.15.9. Transportation-related cumulative health effects and occupational and public health cumulative effects are discussed in Sections 5.15.7 and 5.15.8.

\subsubsection{Land Use}

Implementation of any of the alternatives would contribute to the cumulative loss of land with open-space land use. As discussed in Section 5.2, Land Use, the maximum amount of space that would be disturbed on the INEL site would be 842 acres ( 3.4 square kilometers) under Alternative D (Maximum Treatment, Storage, and Disposal). A list of activities that are unrelated to the alternatives but that are projected to take place at the INEL and in nearby communities is presented in Table 5.15-1. While exact maximum figures are not available, over 200 acres (0.8 square kilometers) of vacant land in nearby communities are scheduled for development. It is unknown what types of land uses currently exist on this vacant land. Projects that would potentially disturb previously disturbed land are scheduled to take place on more than 20 acres ( 0.08 square kilometers) at the INEL site. None of these other activities would create irreversible or irretrievable effects on land use, except for a project at the Power Burst Facility that would cap a currently existing piece of ground [approximately 5 acres (0.02 square kilometers)] containing buried radioactive items.

Combining the acreage of onsite and offsite projects, less than 1,100 acres (4.4 square kilometers) of undeveloped land would be disturbed. The five-county region (Bingham, Bonneville, Butte, Jefferson, and Clark counties) in which the INEL site is situated contains approximately 795,000 acres (3,221 square kilometers) of land classified as barren. In addition, approximately 791,500 acres (3,203 square kilometers) are classified as forest or wetland, and another 2,945,700 acres (11,921 square kilometers) are classified as range (Bingham County 1986, Bonneville County 1976, Butte County 1992, Clark County 1986, Clark County 1992, Jefferson County 1988, Jefferson County 1990). Combined, these acreages make up more than 75 percent of the land use in the region. The disturbance of undeveloped land that would take place as a result of activities at the INEL and unrelated offsite activities would represent about 0.02 percent of the five-county land uses summarized above. 


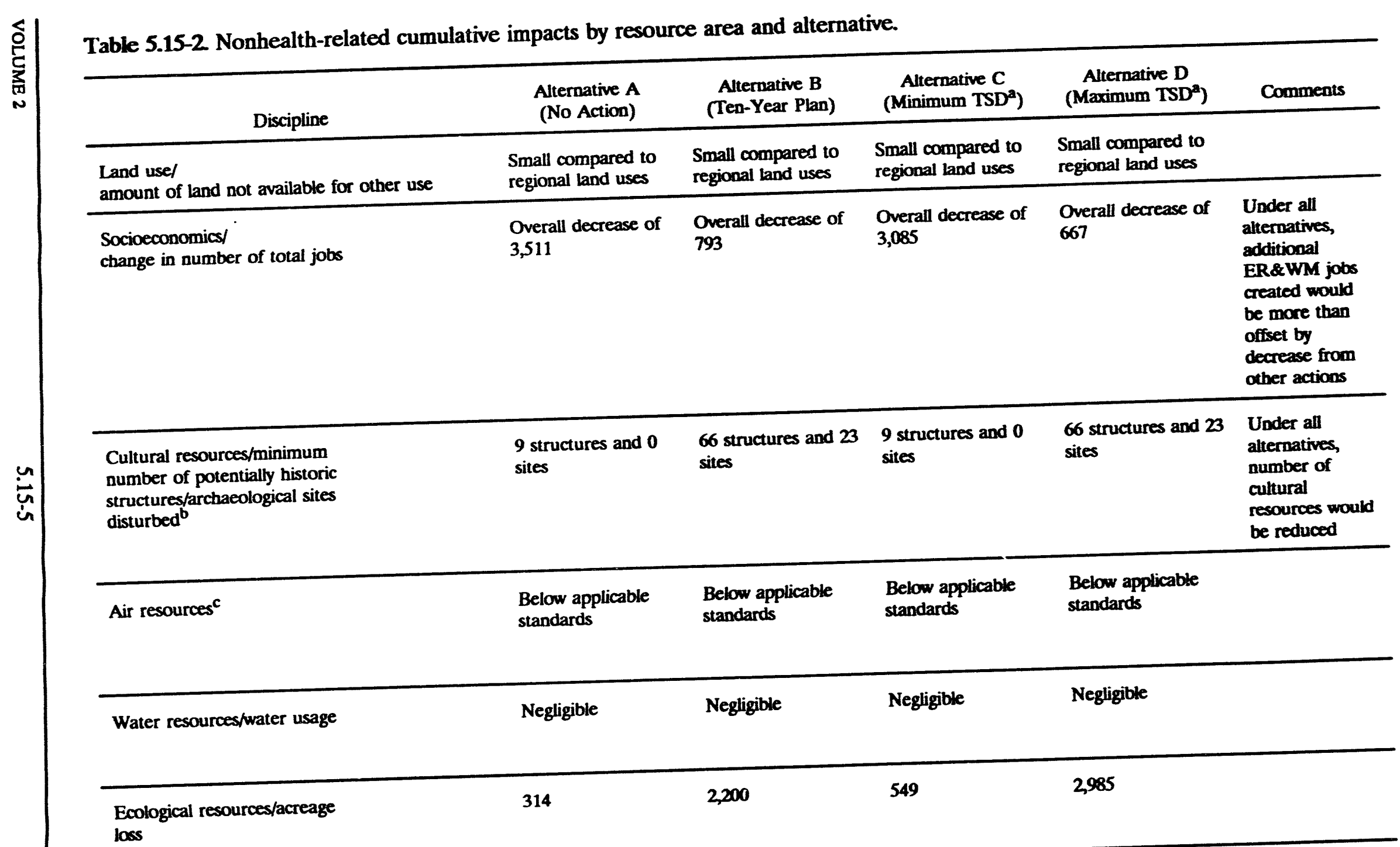


Table 5.15-2 (continued).

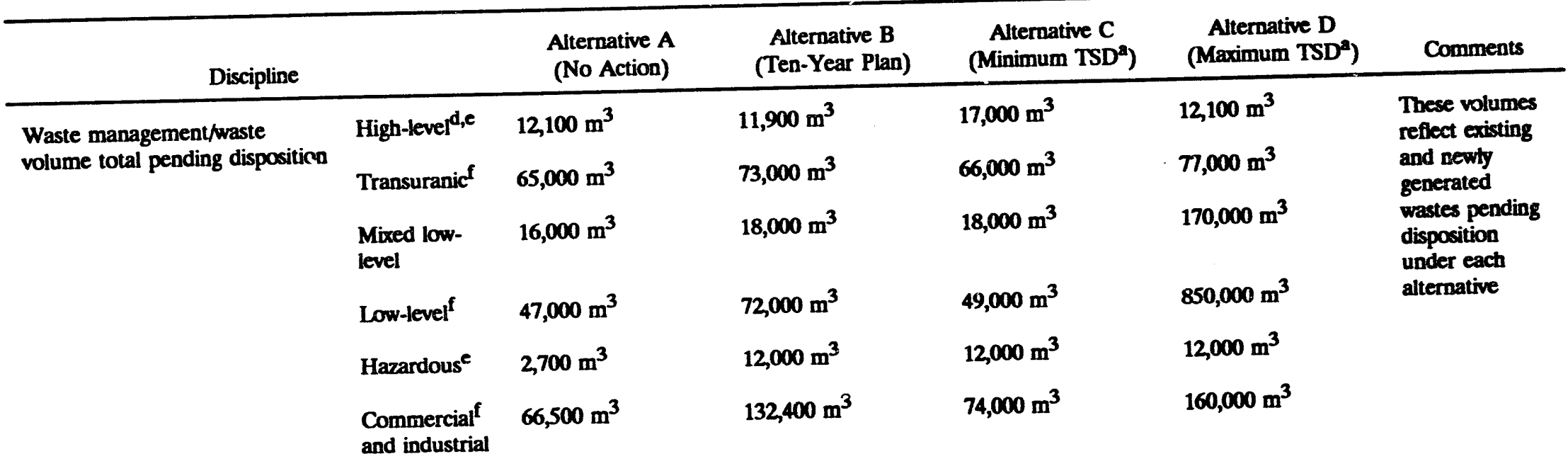

a. Treatment, storage, and disposal.

b. Numbers for archaeological sites potentially impacted would be expected to increase as cultural resource surveys are conducted for onsite and offsite projects on acreage previousty unsurveyed.

c. See Health and Safety (Section 5.15 .8 and associated table) for cumulative health rists related to radiological dose from air emissions.

d. High-level waste includes both liquid and calcine forms. Liquid high-level waste totals do not include processing which would increase these reported totals by some degree. Numbers represent all high-level waste onsite.

e. Numbers represent total volume stored onsite.

f. Numbers do not include existing dispositioned waste stored or buried onsite. 


\subsubsection{Socloeconomics}

The cumulative impact on regional employment under implementation of any of the alternatives would be an overall decline during the ten-year timeframe of this EIS (see Table 5.15-2). Initially, implementation of any of the alternatives would generate temporary increases in employment within the region surrounding INEL, primarily due to construction activities. The magnitude of the cumulative impact on regional employment under implementation of any of the alternatives is not expected to be sufficient to notably affect the socioeconomic resources of the region.

Alternatives B (Ten-Year Plan) and D (Maximum Treatment, Storage, and Disposal) would continue to generate moderate employment increases through fiscal year 2004, while Alternatives A (No Action) and C (Minimum Treatment, Storage, and Disposal), which include phase out of the Expended Core Facility, would ultimately result in employment declines.

Based on currently available data, it is expected that additional employment would be generated by larger offsite projects planned to occur in the communities surrounding INEL (Table 5.15-1). Upon implementation, the offsite projects could contribute approximately 280 jobs to the regional economy. However, the expected future declines in baseline employment at the INEL would more than offset any increases associated with Alternatives B (Ten-Year Plan) and D (Maximum Treatment, Storage, and Disposal) and the offsite projects. The level of the cumulative employment effect ranges from a loss of 3,511 jobs under Alternative $\mathbf{A}$ (No Action), representing a 3.2-percent decline in total regional employment, to a loss of 667 jobs under Alternative D, representing a 0.6-percent decline in total regional employment.

The magnitude of the cumulative effect on regional employment under implementation of any of the alternatives is not expected to be sufficient to adversely affect the socioeconomic resources of the region. Potential population declines associated with the cumulative effect on regional employment are estimated to represent less than 2 percent of the total regional population. It is unlikely that a change in population of this size would generate any notable long-term adverse impacts to housing, community services, or public finance in the region. Further discussion regarding potential impacts to population and community services can be found in Section 5.3, Socioeconomics. 


\subsubsection{Cultural Resources}

The types of cumulative impacts on cultural resources are the same for all alternatives. Projects under each of the alternatives, when combined with associated offsite activities (see Table 5.15-1), would reduce the number of cultural resources in southeastern Idaho. However, surveying, recording, and stabilizing archeological and historic sites and structures at the INEL site would increase scientific knowledge of the region's cultural resources, although stabilizing resources may adversely affect their significance to Native American groups. The unchecked deterioration of both structures and historical documents on nuclear facilities at the INEL site could have a long-term adverse impact on these resources. Long-term effects may also occur to traditional resources that may not be mitigated through scientific studies. Cumulative impacts associated with Alternative B (Ten-Year Plan) and Alternative D (Maximum Treatment, Storage, and Disposal) have the greatest potential for impacts. Alternative A (No Action) would have the least impact.

\subsubsection{Air Resources}

The cumulative impacts of radiological and nonradiological air emissions have been assessed for each of the four alternatives (see Section 5.7, Air Resources) and for individual waste management options within each alternative. These impacts are assessed for emissions from maximum operation of existing facilities, construction and operation of new facilities, demolition activities associated with decontamination and decommissioning of existing facilities, environmental restoration activities, and mobile sources such as vehicular traffic and heavy equipment operation within the INEL.

For radiological emissions, all impacts at onsite and offsite locations are well below applicable standards and are a small fraction of the dose received from natural background sources. The highest dose to an offsite individual is associated with Alternative D (Maximum Treatment, Storage, and Disposal) and is about 0.8 millirem per year. When added to the maximum baseline dose of 0.06 millirem per year, this dose remains well below the dose limit of 10 millirem per year specified in the National Emissions Standards for Hazardous Air Pollutants. This dose is considered an upper bound to the cumulative emissions from existing and proposed sources at the INEL, as well as other sources of human origin (notably, the Food, Machinery and 
Chemical Corp. phosphorus plant in Pocatello, Idaho, which releases polonium-210 and other naturally occurring radionuclides in airborne effluents). The cumulative dose to the collective population is about 10 person-rem per year, most of which is attributable to incineration of transuranic waste, which is an option contemplated under Alternative D (Maximum Treatment, Storage, and Disposal). Health risks related to radiological doses from the airborne pathway are discussed in Section 5.15.8.

Cumulative nonradiological impacts are expressed in terms of concentrations of criteria and toxic air pollutants in ambient air (that is, locations to which the public has access, such as outside the INEL site boundary and along public roads traversing the site) and general deterioration of existing air quality. At site boundary locations, the highest predicted concentrations of criteria pollutants [from Alternative D (Maximum Treatment, Storage, and Disposal)] remain well below applicable air quality standards. Concentrations at public road locations within the INEL boundary could increase significantly from current levels, especially if a major construction project or combustion source is located relatively close to a public road, but remain well below applicable standards. Offsite levels of toxic air pollutants are below reference levels (there are currently no applicable standards for the substances) for all cases except mercury and hydrochloric acid, in which maximum projected emission levels result in concentrations exceeding the reference levels by a small amount. These concentrations would be reduced by administrative and/or engineered controls at the associated facilities [incineration projects proposed under Alternatives B (Ten-Year Plan) and D].

The incremental impacts at onsite locations of toxic air pollutant emissions are well below occupational standards in all cases. However, when the cumulative effect of maximum baseline levels is considered, the highest predicted level of benzene (near gasoline storage tanks at the Central Facilities Area) is approximately equal to the occupational exposure limit.

Cumulative impacts related to ozone formation and stratospheric ozone depletion are well below the levels considered "significant" by State or Federal standards. The potential for impacts on atmospheric visibility at Craters of the Moon National Monument and its associated Wilderness Area has been found to exist under worst-case modeling conditions (see Section 5.7.4.3, Regulatory Compliance Evaluation). These impacts could be averted by more extensive 
use of combustion control equipment to further reduce nitrogen dioxide emissions or by relocation of specific projects to onsite locations more distant from Craters of the Moon.

\subsubsection{Water Resources}

Cumulative impacts to water quality are the same for all alternatives. Past disposal practices have resulted in some adverse impacts to water resources, but primarily in isolated areas within INEL site boundaries. These impacts are observed in the tritium, strontium-90, and iodine129 plumes. Only portions of the plumes have concentrations above the U.S. Environmental Protection Agency's drinking water standards. Future predictions beyond the timeframe of this EIS show that concentrations detected within the plumes would decrease with time and, by 2035 , only iodine-129 would be present above maximum contaminant levels. No contaminants are predicted to migrate past the INEL site boundaries in concentrations exceeding the maximum contaminant levels. Compared to previous practices, impacts from projects under the alternatives and reasonably foreseeable future actions listed in Table 5.15-1 would not result in concentrations above the U.S. Environmental Protection Agency's maximum contaminant levels beyond the INEL site boundaries, and impacts are expected to have a minimal effect on water resources.

The INEL's contribution to the cumulative impact on regional water quality is far less than contributions from other commercial, industrial, and agricultural activities (such as pesticides and fertilizer use), which have impacted a number of municipal water supplies in the communities surrounding the INEL site. Therefore, the contribution from the INEL to the cumulative impact on regional groundwater quality is expected to be minimal.

Water usage from all INEL operations and proposed projects would have a negligible effect on the quantity of water in the aquifer. Given that 1.77 billion cubic meters ( 470 billion gallons) of water pass under the INEL site every year (Robertson et al. 1974), the maximum cumulative increase represents approximately 0.41 percent of the volume of water passing under the INEL site. 


\subsubsection{Ecological Resources}

The types of cumulative impacts on ecological resources would be the same for all alternatives. However, the scale of the impacts could vary because of the differences in scale among the alternatives (see Section 5.9, I cology). At least an additional 8 hectares (20 acres) of previously disturbed habitat would be disturbed on the INEL site from activities not associated with the proposed action, and about 81 hectares ( 200 acres) of habitat would be disturbed in nearby communities. Therefore, the minimal cumulative loss of habitat and vegetation for each alternative would be 127 hectares (314 acres) under Alternative A (No Action), 889 hectares (2,200 acres) under Alternative B (Ten-Year Plan), 222 hectares (549 acres) under Alternative C (Minimum Treatment, Storage, and Disposal), and 1,206 hectares (2,985 acres) under Alternative D (Maximum Treatment, Storage, and Disposal). Other potential effects, besides lost productivity and reduced biodiversity on the disturbed acres, would include additional displacement of animals from the disturbed habitat and habitats in close proximity. Some habitat fragmentation may occur; however, it should be limited because the new construction would be contiguous or within existing industrial, residential, or commercial areas. Potential impacts from traffic would be the same or reduced, because overall population would be similar or lower compared to current levels.

\subsubsection{Transportation}

5.15.7.1 Radiological Impacts. The cumulative impacts of the transportation of radioactive material consist of impacts from (a) historical shipments of waste and spent nuclear fuel to the INEL site, (b) the alternatives evaluated in this EIS, (c) reasonably foreseeable actions that include transportation of radioactive material, and (d) general radioactive materials transportation that is not related to a particular action. The discussion of cumulative transportation impacts concentrates on the cumulative impacts of offsite transportation, because offsite transportation yields larger doses to the general population than does onsite transportation. The collective dose to the general population and workers is the measure used to quantify cumulative transportation impacts. This measure of impact was chosen because it can be directly related to estimates of cancer fatalities using a cancer risk coefficient, and because of the difficulty in identifying a maximally exposed individual for shipments that take place all over the U.S. over an extended period of time, 1953 through 2005 (53 years). 
Collective doses from historical shipments of waste and spent nuclear fuel to the INEL were summarized in Maheras (1994). The historical waste shipments consisted of shipments from offsite waste generators to the INEL Radioactive Waste Management Complex from 1957 through 1993. These data were linearly extrapolated back to 1954, the year that transuranic waste was first shipped to the Radioactive Waste Management Complex from the Rocky Flats Plant, because data for 1954 through 1956 were not available.

The historical shipments of spent nuclear fuel to the INEL site consisted of shipments of naval spent nuclear fuel and test specimens from 1957 through 1995 (see A:tachment $A$ to Appendix D of Volume 1 of this EIS). No extrapolation of naval shipments was necessary because a detailed records search accounted for all shipments. Historical spent nuclear fuel also consisted of shipments of other DOE spent nuclear fuel to the INEL besides naval shipments, such as research reactor spent nuclear fuel, commercial spent nuclear fuel, and Three Mile Island core debris. Data for these shipments were available for 1973 through 1993 and were linearly extrapolated back to 1953, the start of operations at the Idaho Chemical Processing Plant, because data for 1953 through 1972 were not available.

For workers, historical offsite shipments of waste and spent nuclear fuel to the INEL yielded a collective dose of 110 person-rem or 0.044 cancer fatalities. For the general population, historical offsite shipments of waste and spent nuclear fuel to the INEL site yielded a collective dose of 60 person-rem or 0.030 cancer fatalities.

There are considerable uncertainties in these historical estimates of collective dose. For example, the population densities and transportation routes used in the dose assessments were based on census data for 1990 and the U.S. highway and rail system as it existed in 1993 . Using census data for 1990 will overestimate historical collective doses because the U.S. population has continuously increased over the time covered in these assessments. Basing collective dose estimates on the U.S. highway and rail as it existed in 1993 may slightly underestimate doses for shipments that occurred in the 1950 s and 1960 s, because a larger portion of the transport routes would have been on non-interstate highways where the population may have been slightly closer to the road. Data were not available that correlated transportation routes and population densities for the 1950s, 1960s, and 1970s; so it was necessary to use more recent data in order to 
make dose estimates. By the 1970s, the structure of the interstate highway system was largely fixed and most truck shipments would have been made on interstates.

Shipment data were linearly extrapolated for years when data were unavailable, which also results in uncertainty. However, this technique was validated by linearly extrapolating the data in SAIC (1991) for 1973 through 1989 to estimate the number of shipments that took place over 1964 through 1972 (also contained in SAIC 1991). The 1973 through 1989 time period corresponded to the time period when data were available for the Idaho Chemical Processing Plant. The data in SAIC (1991) could not be used directly because only shipment counts are presented for 1964 through 1982 and no origins or destinations were listed for years prior to 1983. Based on the data in SAIC (1991), linearly extrapolating the data for 1973 through 1989 overestimates the shipments for 1964 through 1972 by 20 percent when compared to the actual shipment counts for 1964 through 1972.

Collective doses for waste shipments associated with all alternatives are summarized in Section 5.11, Traffic and Transportation, of this volume of the EIS. For truck shipments, the collective dose to workers ranged from 120 person-rem (Alternative A, No Action) to 1700 person-rem (Alternative D, Maximum Treatment, Storage, and Disposal), or 0.048 to 0.68 cancer fatalities. Collective dose to the general population ranged from 66 person-rem (Alternative $\mathrm{A}$ ) to 940 person-rem (Alternative D), or 0.033 to 0.47 cancer fatalities.

For train shipments, the collective dose to workers ranged from 3.2 person-rem (Alternative A) to 48 person-rem (Alternative D), or 0.0013 to 0.019 cancer fatalities. Collective dose to the general population ranged from 4.1 person-rem (Alternative $A$ ) to 58 person-rem (Alternative D), or 0.0021 to 0.029 cancer fatalities.

Collective doses for spent nuclear fuel shipments associated with all alternatives are summarized in Section 5.11, Traffic and Transportation, of this volume of the EIS. For truck shipments, the collective dose to workers ranged from 1.5 person-rem (Alternative A) to 980 person-rem (Alternative 5, Centralization at Savannah River), or 0.00060 to 0.39 cancer fatalities. Collective dose to the general population ranged from 0.34 person-rem (Alternative $A$ ) to 2200 person-rem (Alternative 5, Centralization at Savannah River), or 0.00017 to 1.1 cancer fatalities. 
(See Volume 1 for a more complete discussion of the Centralization Alternative discussed in this section.)

For train shipments, the collective dose to workers ranged from 1.5 person-rem (Alternative A) to 120 person-rem (Alternative 5, Centralization at Nevada Test Site), or 0.00060 to 0.048 cancer fatalities. Collective dose to the general population ranged from 0.34 person-rem (Alternative A) to 170 person-rem (Alternative 5, Centralization at Savannah River), or 0.00017 to 0.085 cancer fatalities.

Transportation impacts may also result from reasonably foreseeable projects. Two major proposed projects that would involve transportation of radioactive material are (a) shipments of spent nuclear fuel and defense high-level waste to a geologic repository and (b) proposed shipments of transuranic waste to the Waste Isolation Pilot Plant, located in Carlsbad, New Mexico. The U.S. Department of Energy is presently studying the Yucca Mountain, Nevada site to determine its suitability for a geologic repository for commercial spent nuclear fuel and defense high-level waste; therefore, the geologic repository was assumed to be located in Yucca Mountain, Nevada for the transportation cumulative impacts analysis.

Based on the transportation dose assessments presented in DOE (1986), the worker collective dose for truck shipments to a repository was 8600 person-rem or 3.4 cancer fatalities. The collective dose to the general population from truck shipments to a repository was 48,000 person-rem or 24 cancer fatalities. The worker collective dose for train shipments to a repository was 750 person-rem or 0.30 cancer fatalities. The collective dose to the general population from train shipments to a repository was 740 person-rem or 0.37 cancer fatalities.

Based on the transportation dose assessments presented in DOE (1990), the worker collective dose from truck shipments to the Waste Isolation Pilot Plant was 1900 person-rem or 0.76 cancer fatalities. The collective dose to the general population from truck shipments to the Waste Isolation Pilot Plant was 1500 person-rem or 0.75 cancer fatalities. The worker collective dose from train shipments to the Waste Isolation Pilot Plant was 180 person-rem or 0.072 cancer fatalities. The collective dose to the general population from train shipments to the Waste Isolation Pilot Plant was 990 person-rem or 0.50 cancer fatalities. These collective doses include the 5-year Test Phase and the 20-year Disposal Phase. 
There are also two other reasonably foreseeable projects that involve limited transportation of radioactive material: (a) 100 shipments of submarine reactor compartments from the Puget Sound Naval Shipyard to the Hanford Site for burial and (b) 15 shipments of foreign research reactor spent nuclear fuel from Sunny Point, North Carolina to the Savannah River Site. The shipment of submarine reactor compartments is an ongoing activity that is not yet completed; therefore, it was categorized as a reasonably foreseeable action. Based on the transportation dose assessment presented in USN (1984), the shipment of submarine reactor compartments was estimated to result in a collective dose of $\mathbf{0 . 0 5 3}$ person-rem for the general population. Based on the transportation dose assessment presented in DOE (1994), the 15 shipments of foreign research reactor spent nuclear fuel were estimated to result in a collective dose of 0.0017 personrem to the general population and 0.16 person-rem to workers.

There are also general transportation activities that take place that are unrelated to the alternatives evaluated in this EIS or to reasonably foreseeable actions. Examples of these activities are shipments of radiopharmaceuticals to nuclear medicine laboratories and shipments of commercial low-level radioactive waste to commercial disposal facilities. The U.S. Nuclear Regulatory Commission evaluated these types of shipments based on a survey of radioactive materials transportation published in 1975 (NRC 1977). Categories of radioactive material evaluated in NRC (1977) included (a) limited quantity shipments, (b) medical, (c) industrial, (d) fuel cycle, and (e) waste. The U.S. Nuclear Regulatory Commission estimated that the annual collective worker dose for these shipments was 5600 person-rem or 2.2 cancer fatalities. The annual collective general population dose for these shipments was estimated to be $\mathbf{4 2 0 0}$ personrem or 2.1 cancer fatalities. Because comprehensive transportation doses were not available, these collective dose estimates were used to estimate transportation collective doses for 1953 through 1982 (30 years). These dose estimates included spent nuclear fuel and radioactive waste shipments.

Based on the transportation dose assessments in NRC (1977), the cumulative transportation collective doses for 1953 through 1982 were 170,000 person-rem for workers and 130,000 person-rem for the general population. These collective doses correspond to 68 cancer fatalities for workers and 65 cancer fatalities for the general population. 
In 1983, another survey of radioactive materials transportation in the U.S. was conducted (Javitz et al. 1985). This survey included U.S. Nuclear Regulatory Commission and Agreement State licensees and the U.S. Department of Energy. Both spent nuclear fuel and radioactive waste shipments were included in the survey. Weiner et al. $(1991 \mathrm{a}, \mathrm{b})$ used the survey by Javitz et al. (1985) to estimate collective doses from general transportation. The transportation dose assessments in Weiner et al. (1991a,b) were used to estimate transportation doses for 1983 through 2005 (23 years). The interval 1995 through 2005 corresponds to the interval of time associated with the ER\&WM activities evaluated in this EIS.

Weiner et al. (1991a) evaluated eight categories of radioactive material shipments by truck: (a) industrial, (b) radiography, (c) medical, (d) fuel cycle, (e) research and development, (f) unknown, (g) waste, and (h) other. Based on a median external exposure rate, an annual collective worker dose of 1400 person-rem and an annual collective general population dose of 1400 person-rem were estimated. These collective doses correspond to 0.56 and 0.70 cancer fatalities/year for workers and the general population, respectively. Over the 23-year time period from 1983 through 2005, the collective worker and general population doses would be 32,000 person-rem or 13 and 16 cancer fatalities for workers and the general population, respectively.

Weiner et al. (1991b) also evaluated six categories of radioactive material shipments by plane: (a) industrial, (b) radiography, (c) medical, (d) research and development, (e) unknown, and (f) waste. Based on a median external exposure rate, an annual collective worker dose of 290 person-rem and an annual collective general population dose of $\mathbf{4 5 0}$ person-rem were estimated. These collective doses correspond to 0.12 and 0.23 cancer fatalities/year for workers and the general population, respectively. Over the 23-year time period from 1983 through 2005 , the collective worker dose would be 6700 person-rem and the general population collective dose would be 10,000 person-rem or 2.7 and 5.0 cancer fatalities for workers and the general population, respectively.

Like the historical transportation dose assessments, the estimates of collective doses due to general transportation also exhibit considerable uncertainty. For example, data for 1975 were applied to all general transportation activities from 1953 through 1982 . This approach probably overestimates doses because the amount of radioactive material that was transported in the 1950s and 1960 s was less than the amount that was shipped in the 1970s. For example, in 1968, the 
shipping rate for radioactive material packages was estimated to be 300,000 packages/year (Patterson 1968); in 1975 this rate was estimated to be 2,000,000 packages/year (NRC 1977). However, because comprehensive data that would enable a more realistic transportation dose assessment to be made are not available, the dose estimates developed by the U.S. Nuclear Regulatory Commission were used.

The total worker and general population collective doses are summarized in Table 5.15-3. Total collective worker doses from all types of shipmests (historical, the alternatives, reasonably foreseeable actions, and general transportation) were estimated to be 220,000 person-rem ( 88 cancer fatalities), for the period of time 1953 through 2005 (53 years). Total general population collective doses were also estimated to be 220,000 person-rem (110 cancer fatalities). The majority of the collective dose for workers and the general population was due to general transportation of radioactive material. The total number of cancer fatalities from 1953 through 2005 was estimated to be 200 . Over this same period of time (53 years), approximately $16,000,000$ people would die from cancer, based on 300,000 cancer deaths/year (NRC 1977). The transportation-related cancer deaths are 0.0013 percent of this total.

5.15.7.2 Vohicular Accident Impacts. Fatalities involving the shipment of radioactive materials were surveyed for 1971 through 1993 using the Radioactive Material Incident Report data base (Cashwell and McClure 1992), which includes accident data from the U. S. Department of Transportation, U. S. Nuclear Regulatory Commission, U. S. Department of Energy, and state radiation control offices. For 1971 through 1993, 21 vehicular accidents involving 36 fatalities occurred. These were fatalities that resulted from vehicular accidents and were not associated with the radioactive nature of the cargo; no radiological fatalities due to transportation accidents have ever occurred in the U.S. During the same period of time, over $1,000,000$ persons were killed in vehicular accidents in the U.S.

For all alternatives, 0.35 to 4.1 vehicular accident fatalities are estimated to occur. During the ten-year time period from 1995 through 2005, approximately 400,000 people would be killed in vehicular accidents in the U.S. 
Table 5.15-3. Cumulative transportation-related radiological collective doses and cancer fatalities (1953-2005).

\begin{tabular}{|c|c|c|}
\hline Category & $\begin{array}{l}\text { Collective } \\
\text { occupational } \\
\text { dose } \\
\text { (person-rem) }\end{array}$ & $\begin{array}{c}\text { Collective } \\
\text { general } \\
\text { population dose } \\
\text { (person-rem) }\end{array}$ \\
\hline
\end{tabular}

Historical

Waste (1954-1995)

DOE spent nuclear fuel (1953-1995)

Naval spent nuclear fuel (1957-1995)

$56 \quad 30$

6.0

\section{Waste Shipments for Alternatives A-D}

Truck (1995-2005)

Alternative A (No Action)

LLW

TRU

Total

Alternative B (Ten-Year Plan)

LLW

TRU

Total

Alternative C (Minimum Treatment, Storage,
LLW
MLLW
TRU
Total

Alternative D (Maximum Treatment, Storage,
LLW
MLLW
TRU
Total

Train (1995-2005)

Alternative A (No Action)

$$
\text { LLW }
$$

TRU

Total

Alternative B (Ten-Year Plan)
LLW
TRU
Total

54

69

120

54

810

870

29

9.6

140

180

650

92

1000

1700
430

460

28

38

66

28

15

5.1

80

100

360

51

530

940

$\begin{array}{ll}1.4 & 2.4 \\ 18 & 27 \\ 20 & 29\end{array}$


Table 5.15-3. (continued).

\begin{tabular}{ccc}
\hline Category & $\begin{array}{c}\text { Collective } \\
\text { occupational } \\
\text { dose } \\
\text { (person-rem) }\end{array}$ & $\begin{array}{c}\text { Collective } \\
\text { general } \\
\text { population dose } \\
\text { (person-rem) }\end{array}$ \\
\hline
\end{tabular}

Waste Shipments for Alternatives A-D

Train (1995-2005)

Alternative C (Minimum Treatment, Storage,

LLW
MLLW
TRU
Total

ternative D
LLW
MLLW
TRU
Total

1.1

1.1

0.38

0.35

$4.8 \quad 4.5$

$6.3 \quad 5.9$

Alternative D (Maximum Treatment,

22

3.8

21

23

48

33

58

Spent Nuclear Fuel Shipments

for Alternatives A-D

Truck (1995-2035)

Alternative A (No Action)

Naval spent nuclear fuel

Foreign spent nuciear fuel

1.5

(b)

(b)

DOE spent nuclear fuel

(b)

Total

1.5

0.34

(b)

(b)

(b)

Alternative B' (1992/1993 Planning Basis)

Naval spent nuclear fuel

Foreign spent nuclear fuel

University spent nuclear fuel

DOE spent nuclear fuel

Total

7.3

2.1

63

59

66

200

150

140

140

430

Alternative B" (Regionalization by Fuel Type)

Naval spent nuclear fuel

Foreign spent nuclear fuel

7.3

86

2.1

University spent nuclear fuel

54

DOE spent nuclear fuel

150

Total

300

660 
Table 5.15-3. (continued).

\begin{tabular}{ccc}
\hline & $\begin{array}{c}\text { Collective } \\
\text { occupational } \\
\text { dose } \\
\text { Category }\end{array}$ & $\begin{array}{c}\text { Collective } \\
\text { general } \\
\text { population dose } \\
\text { (person-rem) }\end{array}$ \\
\hline
\end{tabular}

Spent Nuclear Fuel Shipments

for Alternatives A-D

Truck (1995-2035)

Alternative C (Centralization)

Hanford

Naval spent nuclear fuel

Foreign spent nuclear fuel

130

320

University spent nuclear fuel

100

250

DOE spent nuclear fuel

430

990

Total

670

1600

Savannah River Site

Naval spent nuclear fuel

Foreign spent nuclear fuel

University spent nuclear fuel

DOE spent nuclear fuel

Total

Oak Ridge Reservation

Naval spent nuclear fuel

Foreign spent nuclear fuel

University spent nuclear fuel

980

DOE spent nuclear fuel

Total

$\begin{array}{rr}14 & 11 \\ 71 & 170 \\ 42 & 91 \\ 750 & 1800 \\ 880 & 2100\end{array}$

Nevada Test Site

Naval spent nuclear fuel

Foreign spent nuclear fuel

130

University spent nuclear fuel

DOE spent nuciear fuel

590

1400

Total

830

1900

Alternative D (Centralization)

Naval spent nuclear fuel

Foreign spent nuclear fuel

University spent nuclear fuel

DOE spent nuclear fuel

Total

$\begin{array}{rr}7.3 & 2.1 \\ 120 & 280 \\ 86 & 210 \\ 380 & 880 \\ 590 & 1400\end{array}$




\begin{tabular}{ccc}
\hline & $\begin{array}{c}\text { Collective } \\
\text { occupational } \\
\text { dose } \\
\text { (person-rem) }\end{array}$ & $\begin{array}{c}\text { Collective } \\
\text { general } \\
\text { population dose } \\
\text { (person-rem) }\end{array}$ \\
\hline
\end{tabular}

Spent Nuclear Fuel Shipments

for Alternatives A-D

Train (1995-2035)

Alternative A (No Action)

Naval spent nuclear fuel

1.5

Foreign spent nuclear fuel

(b)

(b)

University spent nuclear fuel

(b)

DOE spent nuclear fuel

Total

(b)

(b)

(b)

Alternative B' (1992/1993 Planning Basis)

Naval spent nuclear fuel

Foreign spent nuclear fuel

19

2.1

University spent nuclear fuel

DOE spent nuclear fuel

Total

Alternative B" (Regionalization by Fuel Type)

Naval spent nuclear fuei

Foreign spent nuclear fuel

University spent nuclear fuel

DOE spent nuclear fuel

Alternative $\mathbf{C}$ (Centralization)

\section{Hanford}

Naval spent nuclear fuel

Foreign spent nuclear fuel

University spent nuclear fuel

26

DOE spent nuclear fuel 
Table 5.15-3. (continued).

\begin{tabular}{ccc}
\hline & $\begin{array}{c}\text { Collective } \\
\text { occupational } \\
\text { dose } \\
\text { (person-rem) }\end{array}$ & $\begin{array}{c}\text { Collective } \\
\text { general } \\
\text { population dose } \\
\text { (person-rem) }\end{array}$ \\
\hline
\end{tabular}

Spent Nuclear Fuel Shipments

for Alternatives A-D

Train (1995-2035)

Alternative C (Centralization)

Savannah River Site

Naval spent nuclear fuel $\quad 15 \quad 12$

Foreign spent nuclear fuel $\quad 22 \quad 38$

University spent nuclear fuel $\quad 15 \quad 34$

DOE spent nuclear fuel $\quad 60 \quad 85$

$\begin{array}{lll}\text { Total } & 110 & 170\end{array}$

Oak Ridge Reservation

Naval spent nuclear fuel $\quad 14 \quad 11$

Foreign spent nuclear fuel $\quad 22 \quad 36$

University spent nuclear fuel $\quad 13 \quad 25$

DOE spent nuclear fuel $\quad 58 \quad 67$

$\begin{array}{lrr}\text { Total } & 110 & 140\end{array}$

Nevada Test Site

Naval spent nuclear fuel $\quad 11 \quad 6.0$

Foreign spent nuclear fuel $\quad 34 \quad 31$

University spent nuclear fuel $\quad 25 \quad 37$

DOE spent nuclear fuel $\quad 52 \quad 63$

$\begin{array}{lrr}\text { Total } & 120 & 140\end{array}$

Alternative D (Centralization)

Naval spent nuclear fuel

Foreign spent nuclear fuel

University spent nuclear fuel

DOE spent nuclear fuel

Total

$95 \quad 130$

Reasonably Foreseeable Actions

Geologic Repositoryc

Truck

8,600

750

48,000

Train 
Table 5.15-3. (continued).

\begin{tabular}{ccc}
\hline & $\begin{array}{c}\text { Collective } \\
\text { occupational } \\
\text { dose } \\
\text { (person-rem) }\end{array}$ & $\begin{array}{c}\text { Collective } \\
\text { general } \\
\text { population dose } \\
\text { (person-rem) }\end{array}$ \\
\hline
\end{tabular}

Reasonably Foreseeable Actions

Waste Isolation Pilot Plant ${ }^{d}$

Test Phase

110

48

Disposal Phase

Truck

1800

1500

Train

68

940

Submarine Reactor Compartments ${ }^{\mathbf{e}}$

(b)

0.053

Foreign Research Reactor

0.16

0.0017

Spent Nuclear Fuel

General Transportation

1953-1982

170,000

130,000

1983-2005

39,000

42,000

Summary

Historical

110

60

Waste shipments for Alternatives A-D

Truck (100 percent)

Train (100 percent)

120-1700

66-940

$3.2-48$

4.1-58

Spent nuclear fuel shipments for Alternatives A-D

Truck (100 percent)

$1.5-980$

$0.34-2200$

Train (100 percent)

$1.5-120$

0.34-170

Reasonably foreseeable actions

Truck

11,000

50,000

Train

820

1700

General transportation (1953-2005)

210,000

170,000

Total collective dose

220,000

220,000

Total cancer fatalities

88

110

a. $L L W=$ low-level waste; $M L L W=$ mixed low-level waste; $T R U=$ transuranic waste.

b. Information not available.

c. Reference: DOE (1986).

c. Reference: DOE (1990).

e. Reference: USN (1984).

f. Reference: DOE (1994). The shipments for this action are limited to a maximum of 15. 


\subsubsection{Health and Safety}

A number of potential exposure pathways exist by which radioactive materials from INEL operations could affect workers onsite or could be transported to offsite environments. The airborne pathway is the principal pathway by which radioactive materials released on the INEL site could reach an offsite member of the public.

A summary of the health effects from these individual exposure pathways is presented in Table 5.15-4. The health effects from radiation exposure are presented as the estimated number of fatal cancers in the affected population. The health effects for chemical carcinogens are presented as the estimated number of lifetime cancers in the affected population. For exposure to noncarcinogenic chemicals, the health effects are presented as estimated fatalities. It is important to note that with the exception of the occupational exposures, these data are estimations derived from modeling analysis. Occupational exposure data are calculated from actual dosimeter measurements of INEL personnel. The methodology for health effects calculations as well as the exact numbers calculated are provided in Appendix F, Section F-4, Health and Safety.

Although highly unlikely, it is possible that an individual could simultaneously receive exposure from more than one of the environmental pathways listed in Table 5.15-4. For example, the maximally exposed onsite worker could also reside at the site boundary and theoretically be exposed to the highest onsite and offsite chemical and/or radionuclide concentrations. However, assuming that the individual were exposed to both maximum modeled onsite and offsite radiation doses, total estimated dose over the ten-year period would range from approximately 4.8 millirem for Alternative A (No Action) to 14.7 millirem for Alternative D (Maximum Treatment, Storage, and Disposal). These potential radiation doses would be in addition to natural background radiation, which averages about 360 millirem per year (3600 millirem over 10 years).

This section provides a brief discussion of the historical radiation releases and subsequent offsite doses associated with the operation of the INEL. The cumulative impacts of occupational health and public health are discussed in Sections 5.15.8.2 and 5.15.8.3, respectively. Detailed discussions of collective offsite doses to the public through the air and water pathways are found 
Table 5.15-4. Health-related cumulative impacts by alternative.

\begin{tabular}{|c|c|c|c|c|c|c|c|}
\hline Radiological $^{\mathbf{a}}$ & Pathway & $\begin{array}{l}\text { Type of } \\
\text { impact }\end{array}$ & $\begin{array}{r}\text { Alternative A } \\
\text { (No Action) }\end{array}$ & $\begin{array}{l}\text { Alternative B } \\
\text { (Ten-Year Plan) }\end{array}$ & $\begin{array}{l}\text { Alternative C } \\
\text { (Minimum TSD }\end{array}$ & $\begin{array}{l}\text { Alternative D } \\
\text { (Maximum TSD }\end{array}$ & Comments \\
\hline \multirow[t]{3}{*}{ Public } & Atmospheric & $\begin{array}{l}\text { Estimated } \\
\text { excess fatal } \\
\text { cancers }\end{array}$ & $<1$ & $<1$ & $<1$ & $<1$ & \\
\hline & Groundwater & $\begin{array}{l}\text { Estimated } \\
\text { excess fatal } \\
\text { cancers }\end{array}$ & $<1$ & $<1$ & $<1$ & $<1$ & \\
\hline & Biotic & $\begin{array}{l}\text { Estimated } \\
\text { excess fatal } \\
\text { cancers }\end{array}$ & $<1$ & $<1$ & $<1$ & $<1$ & \\
\hline Workers $^{c}$ & Atmospheric & $\begin{array}{l}\text { Estimated } \\
\text { excess fatal } \\
\text { cancers }\end{array}$ & Negligible & Negligible & Negligible & Negligible & $\begin{array}{l}\text { Overall cancers } \\
\text { expected to be } \\
\text { less than base- } \\
\text { line because } \\
\text { fewer employ- } \\
\text { ees under all } \\
\text { alternatives. }\end{array}$ \\
\hline
\end{tabular}

$\begin{array}{lllllll}\text { Occupational } & \begin{array}{l}\text { Estimated } \\ \text { excess fatal } \\ \text { cancers }\end{array} & 1 & 1 & 1 & 1 \\ \text { Public } & \begin{array}{l}\text { Atmospheric } \\ \text { (Carcinogens) }\end{array} & \begin{array}{l}\text { Estimated } \\ \text { lifetime } \\ \text { cancers }\end{array} & <1 & <1 & <1 & <1 \\ & & & & & \end{array}$


Table 5.15-4. (continued).

\begin{tabular}{|c|c|c|c|c|c|c|c|}
\hline Radiological $^{\mathbf{a}}$ & Pathway & $\begin{array}{l}\text { Type of } \\
\text { impact }\end{array}$ & $\begin{array}{r}\text { Alternative A } \\
\text { (No Action) }\end{array}$ & $\begin{array}{l}\text { Alternative B } \\
\text { (Ten-Year Plan) }\end{array}$ & $\begin{array}{l}\text { Alternative C } \\
\text { (Minimum TSD })\end{array}$ & $\begin{array}{l}\text { Alternative D } \\
\text { (Maximum TSD })\end{array}$ & Comments \\
\hline & $\begin{array}{l}\text { Almospheric } \\
\text { (Noncarcino- } \\
\text { gens) }\end{array}$ & $\begin{array}{l}\text { Estimated } \\
\text { adverse health } \\
\text { effects }\end{array}$ & $\mathbf{0}$ & $\mathbf{0}$ & $\mathbf{0}$ & $\mathbf{0}$ & \\
\hline \multirow[t]{3}{*}{ Workers } & $\begin{array}{l}\text { Atmospheric } \\
\text { (Carcinogens) }\end{array}$ & $\begin{array}{l}\text { Estimated } \\
\text { lifetime } \\
\text { cancers }\end{array}$ & $<1$ & $<1$ & $<1$ & $<1$ & \\
\hline & $\begin{array}{l}\text { Atmospheric } \\
\text { (Noncarcino- } \\
\text { gens) }\end{array}$ & $\begin{array}{l}\text { Estimated } \\
\text { adverse health } \\
\text { effects }\end{array}$ & 0 & $\mathbf{0}$ & 0 & $\mathbf{0}$ & \\
\hline & $\begin{array}{l}\text { Routine } \\
\text { workplace } \\
\text { safety hazards }\end{array}$ & $\begin{array}{l}\text { Estimated } \\
\text { fatalities }\end{array}$ & 3 & 3 & 3 & 3 & $\begin{array}{l}\text { Estimates differ } \\
\text { only slightly } \\
\text { between } \\
\text { alternatives due } \\
\text { to changes in } \\
\text { number of } \\
\text { workers. }\end{array}$ \\
\hline
\end{tabular}

a. Approximate numbers. See Section 5.12, Health and Safety, and Appendix F-4, Health and Safety, for detailed discussion and analyses.

b. Treatment, storage, and disposal.

c. Estimated excess fatal cancers calculated from dosimeter measurements.

d. Air modeling indicates potential chemical concentrations of mercury, toluene, and hydrochloric acid in excess of chronic exposure reference concentrations. However, for these concentrations to have an adverse effect on human heaith, prolonged exposure at the modeled concentrations would have to occur. For this reason, projected public adverse health effects due to noncarcinogen emissions is zero. 
in Section 5.12.1. Transportation-related occupational and offsite population doses are discussed in Section 5.15.7.

5.15.8.1 Historical Dose Perspective. Historical offsite airborne radiation doses associated with the operation of the INEL were evaluated and summarized in the Idaho National Engineering Laboratory Historical Dose Evaluation (DOE-ID 1991). The total amount of radioactivity released during operational activities is summarized in Figure 5.15-1. Evaluation of these data indicates that the total amount of radioactivity associated with annual operational releases at the INEL site was largest during the late 1950s and early 1960 s and, since that time, radioactive releases have decreased dramatically. For example, the largest release of radioactivity in any given year during the 1981-1991 timeframe was about one-tenth of the 1,500,000 curies released during 1961, the historical peak year (DOE-ID 1991).

Estimated radiation doses from airborne releases over the operating history of the INEL site have always been within the radiation protection standards applicable at that time. Offsite doses from operational and episodic releases during the late 1950s may have been as high as 9 percent of the whole body dose standard (500 millirem) (DOE-ID 1991). Since 1985, when more restrictive standards were put in place, offsite doses to a maximally exposed individual were only about 1 percent of the whole body count dose standard ( 25 millirem). Furthermore, doses from airborne releases over the operation history of the INEL site have been small compared to doses from sources of natural background radiation in the vicinity of the INEL site (DOE-ID 1991).

Occupational health data concerning historic accidents are incomplete and not readily available. Though historical records of accidents at the INEL are available, occupational doses were not always known and reported. Worker dose data are currently being collected and analyzed under a National Institute of Occupational Safety and Health (NIOSH) program. An assessment of the cumulative impacts of accidents at the site to the health of INEL workers is not available at this time.

Liquid-borne radioactive effluents from the INEL have not, to this time, produced measurable exposure to an offsite member of the public living in the vicinity of the INEL. In the past, liquid radioactive materials have been disposed of directly to the Snake River Plain Aquifer through injection wells. The practice was discontinued in 1984. Radiological and nonradiological 


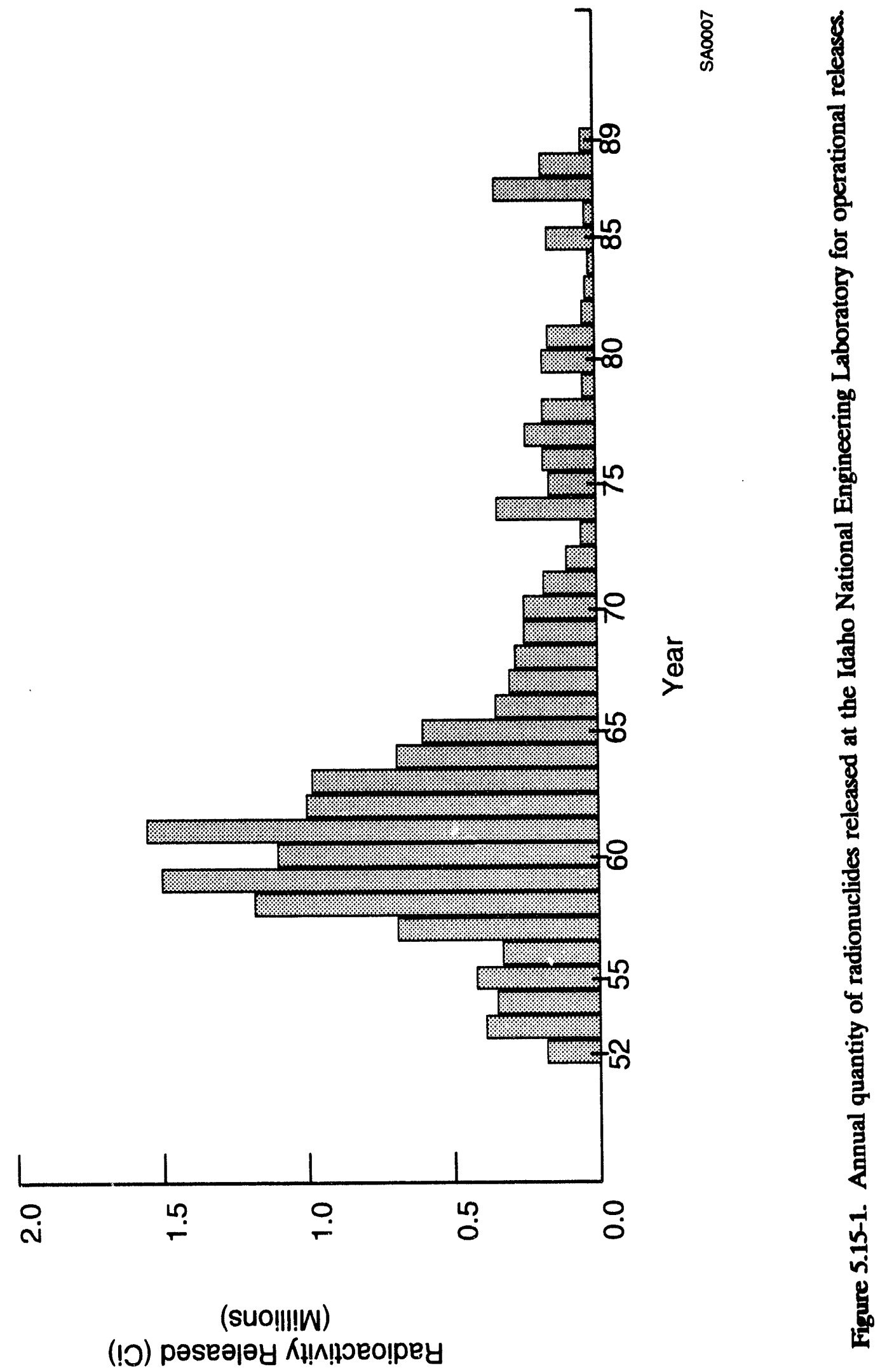


effluents attributable to the INEL operations have not been detected in wells beyond the INEL site boundary nor has there been a significant dose to an offsite member of the public through the Snake River Plain Aquifer pathway.

Some potential biotic pathways (animals and vegetation) also exist at the INEL. The most important biotic pathway has been game animals that can assimilate some radioactivity onsite. However, the probability of a hunter shooting one of these animals shortly after the animal migrates off the INEL is small. The potential for radiation dose to people offsite through game animals, although unlikely, could be up to 10 millirem per hunting season (DOE-ID 1991).

5.15.8.2 Occupational Health. The activities to be performed by workers under each of the alternatives are similar to those currently performed at each site. Therefore, the potential hazards encountered in the work place would be similar to those that currently exist. For these reasons, the average measured radiation dose and the number of reportable cases of injury and illness are anticipated to be proportional to the number of workers employed under each alternative (see Appendix F-4, Health and Safety). The airborne pathway, by which radioactive materials released on the INEL site could affect workers, was modeled but was found to add negligible amounts to actual measured data.

Based on occupational radiation monitoring results, the average reportable radiation dose to an INEL worker is about 27 millirem per year ( 270 millirem over the 10 years covered by this EIS). In addition, there is a potential for small additional radiation dose due to atmospheric releases from INEL facilities. For the maximally exposed worker, the additional dose over the period from 1995 to 2005 could range from 3.3 millirem for Alternative A (No Action) to 6.3 millirem for Alternative D (Maximum Treatment, Storage, and Disposal). These potential radiation doses would be in addition to natural background radiation which averages about 360 millirem per year (3600 millirem over 10 years).

For each alternative, occupational radiation dose received by the entire INEL workforce (about 10,000 workers) from 1995 to 2005 would result in about one fatal cancer. The natural lifetime incidence of fatal cancers in the same population from all other causes would be about 2000 . 
For the evaluation of occupational health effects from chemical emissions, the modeled chemical concentration was compared with the applicable occupational standard. Modeled concentrations below the occupational standards were considered acceptable. As a result, no adverse health effects for onsite workers are projected as a result of normal chemical emissions.

Routine workplace safety hazards can also result in injury or fatality. Total injury and illness rates for INEL workers are comparable to those for DOE and its contractors, which average 3.2 per $\mathbf{2 0 0 , 0 0 0}$ hours worked. For comparison, rates in private industry across the U.S. are 8.4 per 200,000 hours worked.

For each alternative, about three fatalities would result in the entire INEL workforce (about 10,000 workers) from 1995 to 2005 due to workplace safety hazards. Estimates differ only slightly between alternatives because the total number of workers for all alternatives is similar.

These analyses indicate that the cumulative impacts of radiological health effects, nonradiological health effects, and workplace safety hazards to the INEL workforce would be similar for all alternatives. The combined occupational risks are less than those encountered by the average worker in private industry.

5.15.8.3 Publlc Health. The airborne pathway is the principal pathway by which radioactive materials released on the INEL site can reach an offsite member of the public. The potential for radiation dose to the public in the vicinity of the INEL site due to atmospheric releases is similar for all alternatives. For the maximally exposed member of the public, the additional radiation dose over the period from 1995 to 2005 could range from 1.5 millirem for Alternative A (No Action) to 8.4 millirem for Alternative D (Maximum Treatment, Storage, and Disposal). These potential radiation doses would be in addition to natural background radiation, which averages about 360 millirem per year (3600 millirem over 10 years). For each alternative, less than one fatal cancer would result from radiation dose received by the population within 50 miles $(80 \mathrm{~km})$ of the INEL site from 1995 to 2005 . The natural lifetime incidence of fatal cancers in the same population from all other causes would be about 24,000 out of a population of 120,000 . 
Other regional sources of atmospheric radioactivity have the potential to contribute to the radiation dose of the public near the INEL. The primary source is emissions from ph ssphate processing operations in Pocatello, Idaho. These emissions have been evaluated by the U.S. Environmental Protection Agency (EPA 1989). The number of fatal cancers in the population within 50 miles $(80 \mathrm{~km})$ of Pocatello would be about one over a ten-year period comparable to that covered in this EIS. However, the INEL site and the Pocatello phosphate plants are separated by a large enough distance that the population evaluated by the U.S. Environmental Protection Agency does not completely overlap the population evaluated in this EIS. The population exposed to the cumulative impact of both facilities would be small.

In addition to radiation dose from atmospheric emissions, there is a potential for impacts to the public from exposure to carcinogenic chemicals released to the air. The highest risks calculated for any alternative are small compared to the risks from radioactive releases and imply less than one fatal cancer in the exposed population over the ten-year period covered in the EIS. There is no basis currently available for evaluating risks from chemical exposure from other regional commercial, industrial, and agricultural sources, such as combustion of diesel and gasoline fuels and agricultural uses of pesticides, herbicides, and fertilizers.

The volume of surface water that flows from the INEL site to offsite areas is negligible. There are no liquid discharges from INEL operations to the intermittent streams in the vicinity. Therefore, the cumulative impacts from the surface water pathway on public health is negligible.

Surface disposal ponds are used to dispose of low-level radioactive liquic's. Water from these ponds percolates through the soil and basalt bedrock to the Snake River Plain Aquifer. The collective dose to an offsite member of the public through the Snake River Plain Aquifer pathway over the period 1995 to 2005 would be negligible.

\subsubsection{Waste Management}

Table 5.15-2 presents, by waste stream for each alternative, the total volumes of waste existing and projected to be generated at or shipped to the INEL site that would be pending disposition over the ten-year timeframe of this EIS. The conversion of liquid high-level waste to calcine is scheduled to continue over the ten-year period of this EIS, but no provision to satisfy 
the requirement to cease the use of existing liquid storage tanks has been incorporated under Alternative A (No Action). Existing dispositioned waste stored or buried onsite includes approximately 145,000 cubic meters (190,000 cubic yards) of low-level waste and about 37,000 cubic meters (48,000 cubic yards) of transuranic waste (Pole et al. 1993). Although the volume of commercial and industrial waste deposited previously in the INEL Landfill Complex is unknown, it is estimated that the Landfill Complex would provide adequate capacity for the next $\mathbf{3 0}$ to $\mathbf{5 0}$ years (see Chapter 2, Background). Furthermore, the capacity of the Landfill Complex may be prolonged as a result of an active onsite recycling program (see Chapter 2, Background). Without available treatment or disposal under Alternative $A$, it is anticipated that the permitted storage capacity for mixed low-level waste would be exceeded during the first year of the ten-year timeframe of the EIS. All other alternatives include facility construction for storage or shipping of mixed low-level waste; therefore, storage capacity is accounted for. 


\subsection{Adverse Environmental Effects Which Cannot Be Avolded}

The construction and operation of facilities under any of the four alternatives at the INEL would result in some adverse impacts to the environment. Although discipline-dependent, changes in project design and other methods of mitigation (for example, sound engineering practices duriniy construction) could eliminate, avoid, or reduce many of these to minimal levels (see Section 5.19, Mitigation). This section only includes discussion of adverse impacts that mitigation could not reduce or avoid. These adverse impacts are identified by discipline for each of the alternatives.

\subsubsection{Cultural Resources}

The unchecked deterioration of both structures and historical documents on nuclear facilities at the INEL site could have a long-term adverse impact on these resources. However, some potentially adverse impacts could be avoided by preserving the historic value of the property through appropriate research or by conducting limited rehabilitation on these structures. Adverse impacts related to removal or alteration of potentially significant historic structures could occur under Alternatives A (No Action) and C (Minimum Treatment, Storage, and Disposal). Under either of these alternatives, nine potentially significant historic structures could be affected. Impacts to eight structures have been addressed in a Memorandum of Agreement between DOE, the Advisory Council on Historic Preservation, and the State Historic Preservation Office (DOE 1993). Mitigation measures are addressed in Section 5.19. Adverse impacts may also occur to archeological sites of importance to Native Americans and areas of traditional or religious importance.

Unavoidable adverse impacts under Alternatives B (Ten-Year Plan) and D (Maximum Treatment, Storage, and Disposal) are the same as those described under Alternative A (No Action). However, 23 potentially important significant archeological sites and an additional 66 potentially significant historic structures could be affected. Although most adverse effects to sites can be mitigated through scientific study, effects to sites that are important to Native American groups may remain adverse. 


\subsubsection{Aesthetic and Scenic Resources}

Potential impacts on visibility impairment at Craters of the Moon Wilderness Area as a result of nitrogen dioxide emissions are associated with each alternative. These impacts would be further defined and resolved during the air permitting process before projects could proceed.

\subsubsection{Air Resources}

Discharge of combustion products and particulate matter into the air from proposed actions contribute to localized reduction of air quality. Atmospheric visibility modeling indicates that the critericn for acceptable color shift may be exceeded under all alternatives (see Section 5.16.2).

\subsubsection{Water Resources}

An unavoidable adverse impact of all alternatives would be that only limited contaminant remediation is proposed and would not include comprehensive remediation of all contaminated media and areas. Adverse impacts for water resources would be the greatest under Alternative $A$ (No Action).

Unavoidable adverse impacts under Alternative D (Maximum Treatment, Storage, and Disposal) would include a greater potential for accidental releases of contaminants due to the volume of wastes proposed to be handled, stored, and disposed of at the INEL site.

\subsubsection{Ecology}

Unavoidable impacts to biota under Alternative A (No Action) would include disturbance of approximately 15 hectares ( 40 acres): 2 hectares (5 acres) of undisturbed habitat and 13 hectares (35 acres) of previously disturbed habitat that is of low quality and limited use to wildlife. Mortality or displacement of species would include those species that are less mobile such as burrowing animals, insects, and rodents. Nesting birds could also be adversely impacted if construction activities occur during prime nesting seasons. Short-term adverse impacts could potentially include temporary elevated exposure of hazardous materials and radionuclides to biota 
during and immediately after soil remediation activities. Residual radionuclides and hazardous materials from past activities, not part of the proposed action, would still be potentially consumed by animals and absorbed by plants. These materials may result in injury to individual animals or plants, but have not historically resulted in measurable impacts to populations on of off the INEL site.

Unavoidable adverse impacts to biota in previously disturbed habitat under Alternative B (Ten-Year Plan) would be similar to those described for Alternative A, but on a larger scale as discussed in Section 5.9, Ecology. Utilization of this additional acreage increases the amount of habitat loss and, unlike Alternative $A$, would have the potential :o enhance habitat fragmentation on the INEL site.

Unavoidable adverse impacts to biota under Alternative C (Minimum Treatment, Storage, and Disposal) would be similar to those described for Alternative A; about 21 hectares (51 acres) of previously disturbed land would be cleared for construction activities. Of the total 26 hectares (66 acres) to be disturbed, 6 hectares (15 acres) would be in previously undisturbed habitat.

Unavoidable adverse impacts under Alternative D (Maximum Treatment, Storage, and Disposal) would be similar as those described for Alternatives A and B; however, the scale would be larger (see Section 5.9, Ecology). 


\subsection{Relationship Between Short-Term Use of the Environment and the Malntenance and Enhancement of Long-Term Productivity}

Implementation of any of the alternatives would cause some adverse impacts to the environment and would permanently commit certain resources. However, under several of the alternatives these uses of the environment would be of short duration and offset by long-term enhancements to the environmental productivity of the region. The following is a brief comparison of the short-term influences each alternative would have on the environment and the associated effects on the maintenance and enhancement of long-term productivity of the environment.

\subsubsection{Alternative A (No Action)}

- General: Under Alrernative A (No Action), short-term uses of many resources would not aid in the maintenance and enhancement of long-term environmental productivity. The resources that do not have this relationship include socioeconomics, cultural, aesthetic and scenic, geology, air, water, noise, transportation, health and safety, INEL services, and accidents.

- Land Use: Environmental impacts under Alternative A include only a very small amount of additional land disturbance. No effect on the long-term productivity of the environment is expected.

- Ecology: There would be a potential short-term productivity loss in habitats adjacent to INEL facilities. There would be a long-term loss of about 15 hectares (38 acres) of habitat. These losses would be offset at least partially by a minor reduction in contaminant exposure to ecological resources, thereby increasing environmental productivity. Under Alternative A, offset environmental productivity would be enhanced the least compared to the other alternatives.

- Environmental Restoration and Waste Management (ER\&WM): Alternative A includes only short-term interim actions and does not provide for long-term 
disposition and enhanced management of waste or environmental cleanup as specified in the Federal Facility Agreement and Consent Order. Therefore, these short-term interim actions would provide little enhancement of the environment in the long-term.

\subsubsection{Alternative B (Ten-Year Plan)}

- General: Under Alternative B (Ten-Year Plan), short-term uses of some resources would not aid in the maintenance and enhancement of long-term environmental productivity. The resources that do not have this relationship include socioeconomics, aesthetic and scenic, water, noise, transportation, health and safety, INEL services, and accidents.

- Land Use: Environmental impacts under Alternative B include land disturbance and land-use category changes from open space to industrial uses. These land-use changes occur on acreage within or adjacent to existing industrial facilities, therefore minimizing any land-use impacts. Subsequently, no effect on long-term productivity of the surrounding environs is expected.

- Cultural Resources: Additional information gained during preactivity surveys for archaeological, historical, or paleontological resources could be compiled into a database or added to an existing database to improve the knowledge of area history. Also, coordination with affected Native Americans would increase sensitivity to their concerns and show greater confidentiality of areas that hold cultural and religious significance for them. Increasing the historical knowledge and understanding of the area would provide a basis for the enhancement of future management of cultural resources in the region.

- Geology: In areas undergoing short-term uses, such as construction or remediation activities, some soil loss would be expected. However, these activities would be of short duration and soil loss would be minimized by initiating the mitigation measures outlined in Section 5.19.3. Therefore, no long-term effect on environmental productivity of the habitat surrounding these sites is expected. 
- Air Quality: Areas disturbed for construction or remediation activities would result in short-term, elevated levels of particulate matter in these areas of disturbance. Instigating mitigation measures outlined in Section 5.19.4 would reduce fugitive dust potential. No long-term effect on air quality is expected from construction or remediation activities.

- Ecology: The potential short-term productivity loss in habitats adjacent to INEL facilities would be offset by a reduction in contaminant exposure to ecological resources, thereby increasing environmental productivity. There would be a longterm loss of productivity and biodiversity associated with the approximately 233 hectares ( 575 acres) that would be disturbed and used.

- ER\&WM: All ER\&WM actions started or scheduled in the next 10 years as outlined in the Federal Facility Agreement and Consent Order would be completed. These activities would enhance the long-term productivity of the area by decreasing the risk to onsite workers and surrounding biota through exposure to toxic and radioactive substances.

\subsubsection{Alternative C (Minimum Treatment, Storage, and Disposal)}

- General: Under Alternative C (Minimum Treatment, Storage, and Disposal), short-term uses of many resources would not aid in the maintenance and enhancement of long-term environmental productivity. The resources that do not have this relationship include socioeconomics, cultural, aesthetic and scenic, geology, air, water, noise, transportation, health and safety, INEL services, and accidents.

- Land Use: Environmental impacts under this alternative include only a very small amount of additional land disturbance. No effect on long-term environmental productivity is expected.

- Ecology: The potential short-term productivity loss in habitats adjacent to INEL facilities would be offset by a minor reduction in contaminant exposure to 
ecological resources, thereby increasing environmental productivity. There would be a long-term loss of productivity and biodiversity associated with the disturbance and use of approximately 50 hectares (124 acres).

- ER\&WM: To the extent that those cleanups of groundwater and soil already mandated by the Federal Facility Agreement and Consent Order would be completed to minimum requirements under this alternative, there would be, in the long term, a slight decrease in risk to onsite workers and biota through exposure to toxic and radioactive substances. However, because neither cleanups beyond those mandated nor major upgrades in waste management would occur, these long-term enhancements on the productivity of the environment would be appreciably less than those described under Alternative B (Ten-Year Plan).

\subsubsection{Alternative D (Maximum Treatment, Storage, and Disposal)}

- General: Under Alternative D (Maximum Treatment, Storage, and Disposal), short-term uses of some resources would not aid in the maintenance and enhancement of long-term environmental productivity. The resources that do not have this relationship include socioeconomics, aesthetic and scenic, water, noise, transportation, health and safety, INEL services, and accidents.

- Land Use: Environmental impacts under this alternative include land disturbance and land-use category changes from open space to industrial uses. No effect on long-term productivity of the environment is expected.

- Cultural Resources: Additional information gained during preactivity surveys for archaeological, historical, or paleontological resources could be compiled into a database or added to an existing database to improve the knowledge and understanding of area history. Also, coordination with affected Native Americans would increase sensitivity to their concerns and allow greater confidentiality of areas that hold cultural and religious significance for them. Creating and/or improving these databases would provide a basis for enhancement of management of cultural resources in the region. 
- Geology: In areas undergoing short-term uses, such as construction or remediation activities, some soil loss would be expected. However, these activities would be of short-duration with soil loss minimized by initiating the mitigation measures outlined in Section 5.19.3. No long-term effect on productivity is expected.

- Air Quality: Areas disturbed for construction or remediation activities would result in short-term, elevated levels of particulate matter in these areas of disturbance. Instigating mitigation measures outlined in Section 5.19.4 would reduce fugitive dust potential. Subsequently, no long-term effect on air quality is expected.

- Ecology: The potential short-term loss in habitats adjacent to INEL facilities would be offset by a reduction in contaminant exposure to ecological resources, thereby increasing environmental productivity. Also, there would be a long-term loss of productivity and biodiversity associated with the disturbance and use of approximately 361 hectares ( 892 acres).

- ER\&WM: Environmental restoration at all contaminated sites identified for remediation and waste management actions would be completed under this alternative. These activities would enhance the long-term environmental productivity of the area by decreasing the risk to onsite workers and surrounding biota through exposure to toxic and radioactive substances. However, some of the reduction in risk would be potentially offset by the increase of toxic and radioactive waste and spent nuclear fuel that would be disposed, treated, or stored at INEL under this alternative. 


\subsection{Irreversible and Irretrievable Commitments of Resources}

Irreversible and irretrievable commitment of resources for each alternative would potentially include land, groundwater (areas of contamination), air resources, aggregate, and energy resources. However, some materials (for example, structural and stainless steel) and resources (for example, water use) are considered recyclable and are not considered an irreversible and irretrievable commitment of resources. These resource commitments would be caused by past activities, construction and operation of new storage or disposal facilities, and potential remediation actions that would be identified through the comprehensive and project-specific Remedial Investigations/Feasibility Studies and the resulting Records of Decision.

Disposal of radioactive and/or hazardous wastes would cause irreversible and irretrievable commitments of land resources under Alternatives B (Ten-Year Plan) and D (Maximum Treatment, Storage, and Disposal). Under Alternative D, mixed low-level waste and low-level waste disposal would irreversibly and irretrievably commit approximately 162 hectares (400 acres) of previously open-space land. Hazardous waste treatment, storage, and disposal under the same alternative would irreversibly and irretrievably affect 2 hectares (5 acres) of open-space land. Under Alternative B, mixed low-level waste and low-level waste disposal would irreversibly and irretrievably affect 81 hectares (200 acres) of previously open-space land. Services potentially lost from the commitment of these acreages would include lost vegetation productivity, lost wildlife productivity, and lost multiple-use or alternative-use opportunities (for example, disposal sites would not undergo future decommissioning or decontamination and habitat reclamation). Under Alternatives A (No Action) and C (Minimum Treatment, Storage, and Disposal), there would be no land resources irreversibly or irretrievably committed to waste disposal facilities.

The aggregate resources (sand, gravel, pumice, and landscaping cinders) extracted on the site would be irreversibly and irretrievably committed in support of INEL spent nuclear fuel and ER\&WM activities. Aggregate would also be utilized during construction for concrete production, foundation preparation, and road construction and maintenance. Aggregate demands would be highest under Alternative D (Maximum Treatment, Storage, and Disposal) with an estimated volume of approximately $1,772,000$ cubic meters $(2,317,000$ cubic yards). Estimated aggregate demands commensurate with the level of construction activities proposed under 
Alternatives B, C, and A, would be 408,000; 285,000; and 226,000 cubic meters, respectively (534,000; 373,000; and 296,000 cubic yards).

Portions of air resources at the INEL site would be committed under the alternatives that may implement the proposed action. As discussed in Section 5.7, Air Resources, emission deposition from activities under the alternatives would result. Lost services associated with commitments of air resources may include lower visitor use of portions of the region because of lowered visual quality.

As discussed in Sections 4.8, Water Resources, and 5.8, Water Resources, activities at the INEL site have resulted in the irreversible and irretrievable commitment of groundwater in the Snake River Plain Aquifer that has been affected by chemical and radioactive contaminant plumes. However, these plumes occur in localized areas within INEL site boundaries and are not expected to migrate beyond the site's boundaries within the timeframe of this EIS (see Section 5.8). Services lost from these commitments may include limiting the locations and use of certain types of wells (for example, drinking water supply) or the volume of water pumped from the aquifer by DOE for activities at the INEL site. All potable water wells on the INEL site are monitored routinely to ensure that water withdrawn from the aquifer is utilized appropriately, as specified under Federal and State regulations.

Commitment of energy and other resources would be greatest under Alternative D (Maximum Treatment, Storage, and Disposal). Alternative $D$ would require (above the baseline usage of these resources) about 127,700 megawatt-hours per year of electricity, 5.86 million liters (1.55 million gallons) per year of heating oil, 1.2 million liters $(320,000$ gallons) per year of diesel fuel, and 2.73 million liters (730,000 gallons) per year of propane. Construction associated with this alternative is estimated to require approximately 100,000 cubic meters $(130,000$ cubic yards) of concrete. All other alternatives would have smaller demands on these resources, commensurate with the level of construction and operation activities proposed. 


\subsection{Mitigation}

An overview of all mitigation measures for the proposed activities outlined in this EIS is presented in the following discussion. Mitigation measures discussed for each discipline are the same under each alternative. Mitigation measures are not required under any of the alternatives for land use, socioeconomics, and noise.

\subsubsection{Cultural Resources}

Detailed specifications associated with proposed construction projects at INEL have not been completed for all proposed projects. This precludes identifying specific project impacts in all cases for particular structures and facilities. Section 106 of the National Historic Preservation Act, as amended, (NHPA 1966) requires a Federal agency head with jurisdiction over a Federal, federally funded, federally assisted, or federally licensed undertaking to take into account the effects of the agency's undertakings on properties included in or eligible for the National Register of Historic Places, and, prior to approval of an undertaking, to afford the Advisory Council on Historic Preservation a reasonable opportunity to comment on the undertaking. Under the regulations of the National Historic Preservation Act, as amended, impacts to significant resources that would otherwise be found to be adverse may be reduced by preserving the historic value of a property through the conduct of appropriate scientific or historic research, or by rehabilitating buildings and structures when this work is supported by appropriate planning documents.

Basic compliance under cultural resource law involves steps that would be essentially the same under all alternatives. These steps are (a) initiate consultation process with the Idaho State Historic Preservation Office and conduct a preactivity survey for identification and evaluation of resources in danger of impact, (b) assess effects to these resources in consultation with the State Historic Preservation Office, (c) develop plans and documents to minimize any adverse effects, (d) consult with the Advisory Council on Historic Preservation as to the appropriateness of mitigation arrangements, and (e) implement mitigation arrangements. Therefore, if a cultural resource survey has not been performed in an area planned for ground disturbance under one of the proposed alternatives, consultation would be initiated with the Idaho State Historic Preservation Office and the survey would be conducted prior to any disturbance. If cultural resources are 
discovered, they would be evaluated according to National Register of Historic Places criteria. Whenever possible, important resources would be left undisturbed. If the impacts are determined to be adverse and it is not feasible to leave the resource undisturbed, then measures would be initiated to reduce impacts. In most cases this would involve an expanded data recovery program to collect significant information before it is lost; elements of this program might include archaeological excavation, study of archival materials, consultation with concerned Native American tribes (where appropriate), and detailed drawings and photographs. All mitigation plans would be developed in consultation with Native American Tribes (where appropriate), the State Historic Preservation Office, and the Advisory Council on Historic Preservation and would conform to appropriate standards and guidelines established for historic preservation activities by the Secretary of the Interior.

In situations where historically significant facilities on the INEL site are likely to be affected, the compliance process would be essentially the same as outlined above. In this context, if it is not possible to leave these facilities intact, then historical information would be collected to evaluate the eligibility of the structure for the National Register of Historic Places. Eligibility would be determined in consultation with the State Historic Preservation Office and the Advisory Council on Historic Preservation. Mitigation may include the development of a Memorandum of Agreement or Programmatic Agreement between DOE, the State Historic Preservation Office, and the Advisory Council on Historic Preservation, which may include provisions for historic documentation, development of a historic context for the facility, and preservation of historic photographs, plans, and records.

Some actions may affect areas of religious, cultural, or historic value to Native Americans. DOE has implemented a Working Agreement (DOE 1992a) to ensure communication with the Shoshone-Bannock Tribe, especially relating to the treatment of archeological sites during excavation as mandated by the Archeological Resources Protection Act (ARPA 1979) and the protection of human remains as required under the Native American Graves Protection and Repatriation Act (NAGPRA 1990) and the free exercise of religion under the American Indian Religious Freedom Act (AIRFA 1978). In keeping with DOE's Native American policy (DOE 1990) and DOE Order 1230.2 (DOE 1992b), DOE would conduct Native American consultations during the planning and implementation of all proposed alternatives. If human remains are discovered, DOE would notify all tribes that have expressed an interest in the repatriation of 
graves as required under the Native American Graves Protection and Repatriation Act, including the Shoshone-Bannock, Shoshone-Paiute, and the Northwestern Band of the Shoshoni Nation. These tribes would then have an opportunity to claim the remains and associated artifacts in accordance with the reruirements of the Native American Graves Protection and Repatriation Act.

Projects involving excavation or other ground disturbance could also adversely affect paleontological resources. Before construction or excavation begins, the area would be axsessed as to the likelihood of disturbing potentially important paleontological resources. Assessment may include archival research, surface surveys, consultation with knowledgeable individuals, or limited test excavation in previously disturbed areas. If the disturbance would take place within sensitive areas (for example, basalt, fluvial deposits, playas), then ground disturbance would be monitored by a qualified professional paleontologist. A plan for recovering, stabilizing, and curating important paleontological resources found during construction would be prepared before ground disturbing activities begin.

\subsubsection{Aesthetic and Scenic Resources}

With regard to visibility degradation due to operations, mitigation measures could include use of umbustion control equipment to further reduce nitrogen dioxide emissions, relocation of projects, or application of refined modeling methods (in lieu of the conservative screening methods). Refer to Section 5.7, Air Resources and Related Consequences, for a complete discussion of visibility degradation.

\subsubsection{Geology}

Potential soil erosion in areas of ground disturbance would be mitigated through minimizing areas of surface disturbance and by utilizing engineering practices such as storm water runoff control including sediment catchment basins, slope stability (for example, rip-rap placement), and soil stockpiling with wind erosion protection (for example, covering of stockpiles). Furthermore, wind erosion (for example, fugitive dust) would be controlled by spraying disturbed areas with water and other methods mentioned in this section. 


\subsubsection{Alr Resources}

Controls to reduce radiological emissions and doses would be evaluated based on the nature of the specific process under evaluation and the types and amounts of radionuclides that may be released. For example, controls would include limiting iodine-129 emissions from spent nuclear fuel or high-level waste processing by means such as filtration based on adsorption of gaseous forms of iodine on charcoal or silver zeolite filtering media. High-efficiency particulate air filters would be used extensively to reduce emissions of radionuclides that are particulates.

State of Idaho regulations dictate that any modification of a major facility that would result in significant emissions increases is considered a major modification and would be subject to requirements for best available control technology to limit emissions. Best available control technology is defined as an "emission standard based on the maximum control of emissions achievable through application of production processes or available methods, systems, and techniques (including fuel cleaning or treatment or innovative fuel combination techniques) for control of such contaminants. The best available control technology shall be determined on a case-by-case basis, taking into account energy, environmental and economic impacts...." (IDHW 1994). Best available control technology must be designed for each pollutant associated with a significant emissions increase as defined in the State regulation. As a minimum, air pollutant control equipment, administrative controls, changes in raw material feed or design changes would be required on several proposed projects to reduce emissions of nitrogen dioxide, sulfur dioxide, hydrochloric acid, and mercury for Alternatives B (Ten-Year Plan) and D (Maximum Treatment, Storage and Disposal). Control of emissions of nitrogen dioxide would be required for Alternative A (No Action) and for nitrogen dioxide and mercury on Alternative D. A listing of potential means and levels of control for specific projects is contained in Belanger et al. (1994). Proposed methods, levels of control, and controlled emission rates would be developed for use within each alternative.

Fugitive dust control methods would be similar to those described in Section 5.19.3. 


\subsubsection{Water Resources}

The development of pollution prevention plans, such as the INEL Storm Water Pollution Prevention Plan (DOE-ID 1993a,b) and the INEL Groundwater Protection Management Plan (Case et al. 1990), and implementation of best management practices are important to preventing future sources of pollution to water resources. These practices develop standard procedures for handling waste materials and preventing accidental discharges. Existing monitoring and surveillance programs around tanks and ponds would also reduce impacts of inadvertent liquid release by restricting their duration and volume. An extensive sitewide groundwater monitoring network, vadose zone monitoring, and drinking water monitoring program allow for early detection of contaminant migration. Contaminants (principally organics) in the vadose zone and groundwater could be removed through treatment and remediation using state-of-the-art technologies, where feasible. For example, the volatile organic compound remediation program at the Radioactive Waste Management Complex is designed to extract volatile organic compound contaminants before they affect the regional environment. Remediation efforts have already successfully removed 640 kilograms (1411 pounds) of volatile organic material at the Radisactive Waste Management Complex, and concentrations of organics and radionuclides in the Test Area North injection well dropped after sludge removal in 1990. In addition, the natural decay of radionuclides and the change in waste management practices would decrease the contaminant concentrations in the aquifer.

Best management practices and storm water monitoring have been implemented under the INEL Storm Water Pollution Prevention Program (DOE-ID 1993a,b) to reduce the potential of liquid effluent discharges from commingling with storm water runoff under normal operations and during spills. Storm water runoff from facility areas of concern would be monitored during snowmelt and rain events to ensure that any contaminants present are identified. If problem areas are identified during field inspections or monitoring, additional best management practices would be implemented to further decrease impacts to natural surface water. 


\subsubsection{Ecology}

Unavoidable impacts to biota would include disturbance of a limited amount of habitat, mortality or displacement of some animals (primarily small mammals, reptiles, and birds), and possibly temporary elevated exposure levels to airborne radionuclides and hazardous materials.

The DOE would implement several actions to ensure that activities do not adversely affect protected, candidate, or sensitive species. If bald eagles or peregrine falcons are observed during activities, DOE would consult with the U.S. Fish and Wildlife Service to ensure that individual eagles and falcons observed are not harassed and that incidental take does not occur. Preactivity surveys would be conducted to determine if endangered or candidate species or their habitat are present in the area. If candidate or sensitive species or important habitat (such as rattlesnake hibernacula, sage grouse mating grounds, or bat roosts) are observed during preactivity surveys, DOE would evaluate the project design to determine if modifications would minimize potential negative effects. Where practicable, modifications would be implemented.

Projects that would disturb habitat would be evaluated to determine if jurisdictional wetlands are present. Activities would be modified to avoid affecting the wetland. If avoidance is not possible, DOE would consult with the U.S. Army Corps of Engineers to obtain permits and develop any needed mitigation (for example, construction of new wetlands, enhancement of existing wetlands). Jurisdictional wetlands within or near remediation activities would be avoided and discussions with the U.S. Army Corps of Engineers would identify any required mitigation. In addition, workers would be informed of wetland locations so that inadvertent disturbance (for example, filling, dredging, or draining) would not occur to wetlands.

Other mitigation measures would include minimizing ground disturbance using temporary drainage structures during facility removal to minimize erosion and grading and seeding bare ground with native plant species for long-term stability (see Section 5.19.3). A speed limit would be maintained to ensure that animal mortality from vehicles would be limited. During remediation, potential increased exposure and uptake of radionuclides would be minimized by (a) using dust-suppression and containment methods to minimize resuspension, (b) removing buried contaminants as soon as possible after they are exposed, and (c) using erosion-control measures to minimize water-erosion movement of radionuclides. After cleanup, the potential of 
exposure to radionuclides would be diminished to acceptable levels that probably would not result in acute or chronic effects to biota (IAEA 1992).

\subsubsection{Transportation}

The impacts of transportation associated with the alternatives may be mitigated in a number of different ways. For example, the routes used for truck shipments may be chosen using U.S. Department of Transportation routing guidelines. These guidelines are designed to reduce the radiological impacts associated with transportation. According to the guidelines, primary factors include (a) the radiation exposure from incident-free transport, (b) the risk to public health from an accidental release of radioactive material, and (c) the economic risk from an accidental release of radioactive material. Secondary factors, according to the guidelines, include (a) emergency response effectiveness, (b) evacuation capabilities, (c) location of special facilities such as schools or hospitals, and (d) traffic fatalities and injuries unrelated to the radioactive nature of the cargo.

Potential mitigation would also be provided through the use of approved shipment containers. For shipments containing small amounts of radioactivity, such as low-level waste, Type A containers may be sufficient. These containers are designed to withstand the rigors of normal transport. For shipments containing large amounts of radioactivity, such as spent nuclear fuel or transuranic waste, Type B containers would be used. These containers are designed to withstand normal transport conditions and hypothetical accident conditions.

The U.S. Department of Transportation also has requirements that help to mitigate transportation impacts. For example, there are requirements for drivers, packaging, labeling, marking, and placarding. There are also requirements that specify the maximum dose rate associated with radioactive material shipments, which help to reduce incident-free transportation doses.

If an accident did occur, Federal, State, local, and tribal authorities are trained in emergency' response. For example, the Shoshone-Bannock Tribes, the State of Idaho, Bingham County, Bingham Memorial Hospital, Bannock Regional Medical Center, Pocatello Regional Medical Center, Idaho Power Company, Intermountain Gas Company, and DOE participated in a 
comprehensive, cooperative Transportation Accident Exercise held in Idaho in 1992 (TRANSAX '92).

The U.S. Environmental Protection Agency has developed protective action guides and protective actions that are designed to limit doses in the event of a nuclear incident. Use of these guides and actions would also mitigate the impacts of transportation accidents involving radioactive material.

\subsubsection{Health and Safety}

Hazards would be mitigated by best management practices and occupational and radiological safety programs operating under the same regulatory standards and limits that currently apply at the INEL.

\subsubsection{Idaho National Engineering Laboratory Services}

Practices would be implemented to reduce inefficient use of utilities and energy services. Initiatives would include using effective thermal insulation, installing state-of-the-art heating furnaces, and incorporating water conservation measures. Also, recycling of materials generated during decontamination and decommissioning activities would be given appropriate consideration.

\subsubsection{Accidents}

Mitigations to exposure and, therefore, mitigations to dose that would affect the postulated results of the accident scenarios are discussed in this section. In general, limited credit was assumed for emergency response.

INEL facilities employ emergency response programs to mitigate impacts of accidents to workers and the public in accordance with the 5500 series of DOE orders. These programs typically involve emergency planning, emergency preparedness, and emergency response. Each plan utilizes resources specifically dedicated to assist the facility in emergency management. These resources include the following: 
- INEL Warning Communications Center

- INEL Fire Department

- Facility emergency command centers

- DOE Emergency Operations Center

- County and State emergency command centers

- Medical, health physics, and industrial hygiene specialists

- Protective clothing and equipment (respirators, breathing air supplies, etc.).

The radiation doses estimated in this document for the various radiological accident scenarios are the doses that would be received by the population if only limited protective actions were taken. INEL has detailed plans for responding to accidents of the type described here, and the response activities would be closely coordinated with State and local officials. INEL personnel are trained and drilled in the protective actions to be taken if a release of radioactive or otherwise toxic material occurs. Limited credit is taken for this training in the exposure durations for workers.

In most bounding accidents, the passage time of the gaseous plume at the receptor would be less than tho assumed 2-hour evacuation time for a motorist at the nearest public access highway. However, in a few accidents, the assumed release time is $\mathbf{2 4}$ hours, so credit is taken for evacuation in reducing the dose at the nearest public access. 
For the offsite population, the need for any protective action would be based on the predicted radiation doses. The emergency response would be based on the guidance provided in the protective action guides developed by the U.S. Environmental Protection Agency. The underlying principle for the protective action guides is that under emergency conditions all reasonable measures would be taken to minimize the radiation exposure of the general public and emergency workers. In the absence of significant constraints, protective actions may be implemented when projected doses are lower than the ranges given in the protective action guides.

Interdiction activities by INEL accident recovery personnel are expected to take place following the accident to limit doses to offsite individuals at risk. This interdiction could limit ingestion exposure so that the maximally exposed individuals would derive much less than the assumed 10 percent of their diet from locally grown crops and livestock. 


\subsection{Environmental Justice}

In accordance with Executive Order 12898, "Federal Actions to Address Environmental Justice in Minority Populations and Low-Income Populations," DOE has reviewed the proposed projects and facilities contemplated by the proposed actions addressed in this EIS, and has considered the extent to which minority or low-income populations may be affected by activities proposed at the INEL. None of the alternatives under consideration would result in significant adverse environmental, human health, or economic effects on surrounding populations, including any minority or low-income populations that may exist in the area. 


\section{LIST OF PREPARERS AND REVIEWERS}

This Environmental Impact Statement (EIS) was prepared under the supervision of the U.S. Department of Energy (DOE) Idaho Operations Office. The organizations and individuals who contributed to the preparation of this document are listed below accompanied by each person's project role and level of experience and training. Table 6.1-1 lists contributors and the chapters or appendices for which they provided input or analysis.

\subsection{Preparers}

\section{U.S. Department of Energy Idaho Operations Office}

Thomas L. Wichmann, Manager EIS Project Office, U.S. DOE

U.S. Naval Nuclear Propulsion Program Graduate

Light Water Breeder Reactor/Expended Core Facility Project Officer

S1W Naval Nuclear Reactor Prototype Project Officer

Years of Experience: 24

EIS Project Manager

Kathleen B. Whitaker, Public Affairs Specialist

BA, 1973, English, University of Utah

Years of Experience: 16

EIS Deputy Project Manager

John E. Medema, Health Physicist

BS, Biology, Central Michigan University

MS, Biology, Central Michigan University

Years of Experience: 14

Volume 2 Manager

Analytical Lead - Spent Nuclear Fuel and Materials \& Waste Management

Mary V. Willcox, Physical Scientist

BS, 1990, Chemistry, University of New Mexico

Years of Experience: 4

EIS Technical Sections Manager

Robert Brown, PE, General Engineer

BS, Electrical Engineering

MA, Business Administration

Years of Experience: 23

Analytical Lead - Utilities and Energy 
Robert Creed, Jr., PG, Physical Scientist/Geologist

AS, 1980, Geology, Santa Barbara City College

AS, 1980, Geoscience Technology, Santa Barbara City College

BA, 1983, Earth Sciences, University of California, Santa Cruz

Years of Experience: 6

Analytical Lead - Geology and Water Resources

John A. Herritt, Health Physicist

BS, 1968, Physics, Pennsylvania State University

MS, 1976, Nuclear Physics, Pennsylvania State University

Years of Experience: 12

Analytical Lead - Occupational Health and Safety

Mark W. Howard, Packaging and Transportation Program Manager

BS, 1989, Mechanical Engineering, University of Idaho

Years of Experience: 5

Analytical Lead - Traffic and Transportation, Transportation Accidents

Paul Martin, Environmental Protection Specialist

BA, English

BS, Wildlife

Years of Experience: 20

Analytical Lead - Land Use

Mary McKnight, Attorney

BA, 1982, Communications, University of Nebraska

JD, 1989, Creighton University

Years of Experience: 5

Analytical Lead - Environmental Justice, Consultations and Environmental Requirements

Mark S. Pellechi, PE, Nuclear Engineer

BS, 1979, Nuclear Engineering, Polytechnic Institute of New York

Years of Experience: 15

Analytical Lead - Accident Analysis

Ralph W. Russell, Environmental Engineer

BS, 1970, Chemical Engineering, Texas A\&M University

Years of Experience: 17

Analytical Lead - Air Resources, Air Quality

Roger Twitchell, Physical Scientist

BS, 1977, Botany, Weber State College

Years of Experience: 17

Analytical Lead - Cultural Resources, Ecological Resources

C. Brooks Weingartner, Environmental Engineer

BS, 1988, Geological Engineering, Montana Tech.

MS, 1991, Environmental Engineering, Montana Tech.

Years of Experience: 3

Analytical Lead - Socioeconomics 


\section{Science Applications International Corporation}

Dee H. Walker, Vice President/Technical Staff Consultant

BS, Chemical Engineering

MS, Chemical Engineering

$\mathrm{PhD}$, Chemical Engineering

Years of Experience: 39

SAIC Project Manager

Ted B. Doerr, Senior Environmental Specialist

BS, Wildlife and Fisheries Sciences

MS, Range Management

$\mathrm{PhD}$, Wildlife and Fisheries Sciences

Years of Experience: 15

Volume 2 Manager

Analyst - Summary, Purpose and Need, Background, Ecology, Consultation Letters

R. Kingsley House, PE, Technical Staff Consultant

BS, Mechanical Engineering

MS, Engineering Science/Nuclear Option

Years of Experience: 34

Technical Support Coordinator

Analyst - Purpose and Need, Background, Noise, INEL Services

Barbara Brown, Principal Communication Specialist

BS, Mathematics

Years of Experience: 15

Analyst - Index

Christopher Clayton, Principal Analyst

BA, Geography

MA, Geography

$\mathrm{PhD}$, Geography

Years of Experience: 21

Analyst - Socioeconomics, Technical Methodologies and Key Data

David Cummings, Senior Scientist

BS, Geology

MS, Geology

PhD, Geology

Years of Experience: 30

Analyst - Geology, Water Resources, Technical Methodologies and Key Data

Mark A. Dagel, Senior Hydrogeologist

BS, Geology

MS, Geological Sciences

Years of Experience: 10

Analyst - Cumulative Impacts, Unavoidable Adverse Effects, Short-Term Use vs. Long-

Term Productivity, Irreversible and Irretrievable Resource Commitments, Mitigation 
Thomas D. Enyeart, CHP, Senior Staff Scientist

BS, Physics

MS, Nuclear Engineering

MS, Environmental Engineering

Years of Experience: 18

Analyst - Background, Transportation Accident Analysis, Technical Methodologies and Key

Data

Michele A. Fikel, Environmental Specialist

BA, Geography

Years of Experience: 8

Analyst - Aesthetic and Scenic Resources

George A. Freund, PE, Chemical/Nuclear Engineer

BS, Chemical Engineering

MS, Chemical Engineering

Years of Experience: 44

Analyst - Background, Alternatives, Facility Accidents, Information Supporting the

Alternatives, Technical Methodologies and Key Data

Paul D. Freund

BS, Human Resource Management

Years of Experience: 4

Analyst - References

Gayla Gross, Environmental Specialist

BS, Geology

MS, Environmental Geology

Years of Experience: 9

Analyst - Summary, Purpose and Need, Alternatives

Lorraine S. Gross, Archaeologist

BA, Archaeology

MA, Archaeology

Years of Experience: 14

Analyst - Cultural Resources

Morris Hall, Senior Scientist

AS, Nuclear Industrial Operations

BS, Mathematics \& Science

MS, Health Physics

Years of Experience: 8

Analyst - Health and Safety, Technical Methodologies and Key Data

Joel B. Hebdon, Principal Engineer

BS, Engineering Geology

MBA, Management

Years of Experience: 11

Analyst - Background, Alternatives 
William E. House, Staff Scientist

BS, Geological Engineering

Years of Experience: 8

Analyst - Alternatives, Geology, Facility Accidents, Information Supporting the Alternatives,

Technical Methodologies and Key Data

Michael Ingram, Senior Communications Specialist

BA, Journalism

Years of Experience: 16

Analyst - Primer on Radioactivity and Toxicology

Irene Johnson, Environmental/Socioeconomic Analyst

BS, Economics

MA, Economics

Years of Experience: 5

Analyst - Socioeconomics, Technical Methodologies and Key Data

Dan Kevin, Environmental Specialist

BA, Political Science

MA, Political Science

ABD, Political Science

Years of Experience: 14

Analyst - Land Use

Barbara Larsen, Economist

BA, Economics

Years of Experience: 5

Analyst - Socioeconomics, Technical Methodologies and Key Data

Anne Lundahl, Scientist

BS, Geology

Years of Experience: 7

Analyst - Geology, Water Resources, Technical Methodologies and Key Data

Steven J. Maheras, CHP, Environmental Health Physicist

BA, Zoology

MS, Health Physics

PhD, Health Physics

Years of Experience: 10

Analyst - Traffic and Transportation, Incident-Free Transportation Dose Assessments

Diane Morton, Senior Engineer

BS, Chemical Engineering

Years of Experience: 14

Analyst - Background, Alternatives, Glossary 
Mark Otis, CHP, Division Manager

BS, Physics

MS, Radiation Health

PhD, Radioecology

Years of Experience: 22

Analyst - Health and Safety, Technical Methodologies and Key Data

John Raudsep, Senior Engineer

BS, Chemical Engineering

Years of Experience: 23

Analyst - Air Resources, Technical Methodologies and Key Data

James L. Rudolph, Archaeologist

BA, Anthropology

MA, Anthropology

Years of Experience: 20

Analyst - Purpose and Need, Background

Teresa Rudolph, Senior Archaeologist

MA, Anthropology

Years of Experience: 17

Analyst - Cultural Resources

Deborah A. Ryan, Air Quality Meteorologist

BS, Meteorology

Years of Experience: 16

Analyst - Air Resources, Technical Methodologies and Key Data

Angela Sewall, Environmental Geoscientist

BA, Earth Science

MS, Geoscience

Years of Experience: 6

Analyst - Cumulative Impacts, Unavoidable Adverse Effects, Short-Term Use vs. Long-Term

Productivity, Irreversible and Irretrievable Resource Commitments, Mitigation

Samuel E. Shepley

JD, Doctor of Law

Years of Experience: 15

Analyst - Alternatives, Information Supporting the Alternatives

Brenda Shim, Economist

BA, Economics/International Area Studies

Years of Experience: 2

Analyst - Socioeconomics, Technical Methodologies and Key Data 
Donald C. Slaughterbeck, Senior Engineer

BS, Mechanical Engineering

MS, Mechanical Engineering

Years of Experience: 27

Analyst - Facility Accidents, Technical Methodologies and Key Data

Donald Stadelman, Project Manager/Senior Economist

BS, Forest Resources

MA, Public Finance

$\mathrm{PhD}$, Economics

Years of Experience: 20

Analyst - Impact Analysis

Jane Tallman, Junior Engineer

BS, Mechanical Engineering

Years of Experience: 1

Analyst - Traffic and Transportation

Todd B. Thompson, Senior Communication Specialist

BS, Journalism

Years of Experience: 10

Analyst - Primer on Radioactivity and Toxicology

John von Reis, Program Manager

BA, English and Prelegal Studies

JD, Doctor of Law

Years of Experience: 24

Analyst - Comparison of Impacts

Price L. Worrell, Technical Support Specialist

Years of Experience: 4

Graphics Coordinator

Analyst - Acronyms and Abbreviations

Jon Young, Senior Program Miañager

BA, Mathematics

Years of Experience: 25

Analyst - Cumulative Impacts, Unavoidable Adverse Effects, Short-Term Use vs. Long-Term

Productivity, Irreversible and Irretrievable Resource Commitments, Mitigation

Science Applications International Corporation (Consultants)

Richard Belanger, CHP, Air Quality Consultant

BA, Biology

MS, Radiological Physics

Years of Experience: 17

Analyst - Air Resources, Technical Methodologies and Key Data 
Kenneth D. Bulmahn, Consulting Engineer

BS, Mechanical Engineering

Years of Experience: 20

Analyst - Spent Nuclear Fuel, High-Level Waste

Robert N. Ferguson, PE, Senior Engineer

BS, Mechanical Engineering

MA, Business Administration

Years of Experience: 34

Analyst - Background, Alternatives, Information Supporting the Alternatives

Ecology and Environment. Inc.

Wendy Green, Environmental Planner

MPA, Public Affairs

Years of Experience: 9

Public Information Coordinator

Analyst - Consultations and Environmental Requirements, Consultation Letters

David J. Lechel, Environmental Consultant

BS, Fisheries Biology

MS, Fisheries Biology

Years of Experience: 21

Analyst - Summary

\section{Jason Associates Corporation}

Harry Fugate, Environmental Engir,eer

BS, Civil/Environmental Engineering

MS, Environmental Engineering

Years of Experience: 8

Analyst - Background

Daniel A. Reny, Senior Consultant

BS, Applied Physics

Years of Experience: 14

Analyst - Facility Accidents 

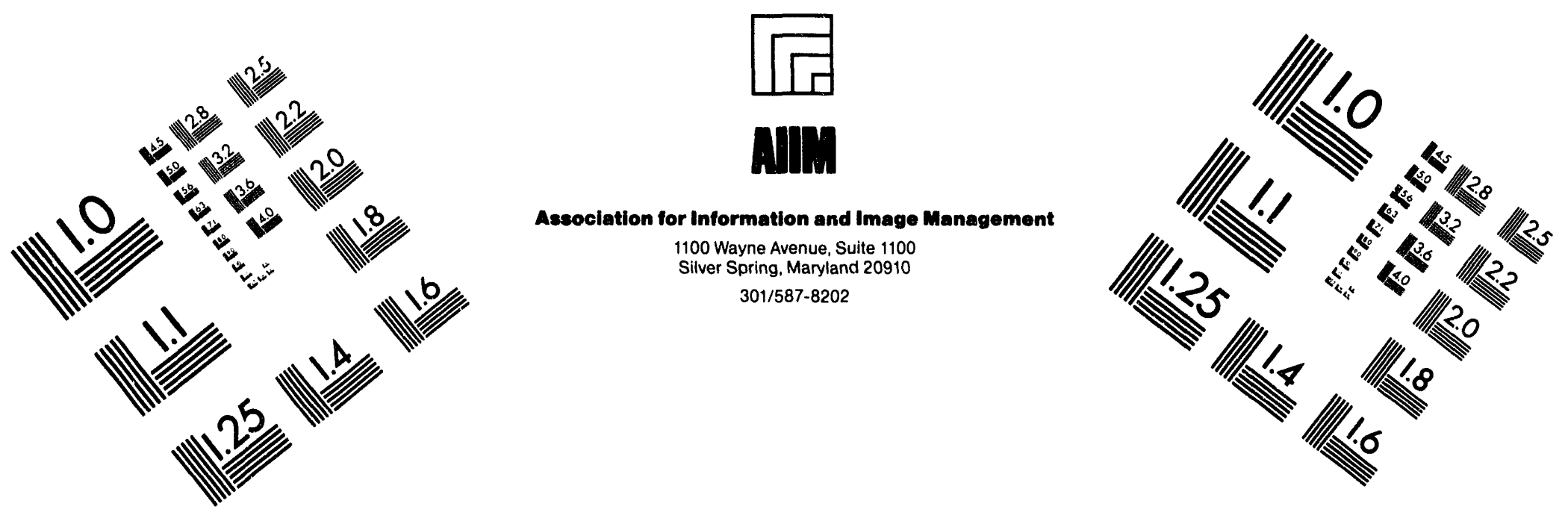

\section{Centimeter}

$\begin{array}{llllllllllllllll}1 & 2 & 3 & 4 & 5 & 6 & 7 & 8 & 9 & 10 & 11 & 12 & 13 & 14 & 15 & \mathrm{~mm}\end{array}$

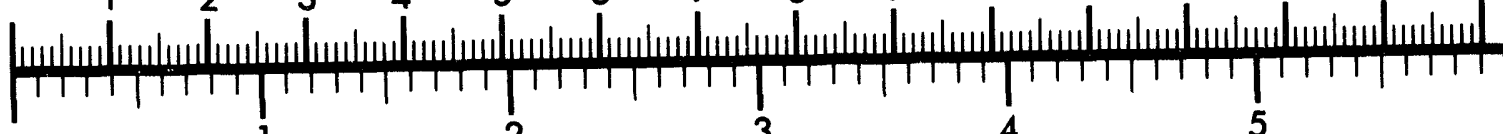
Inches

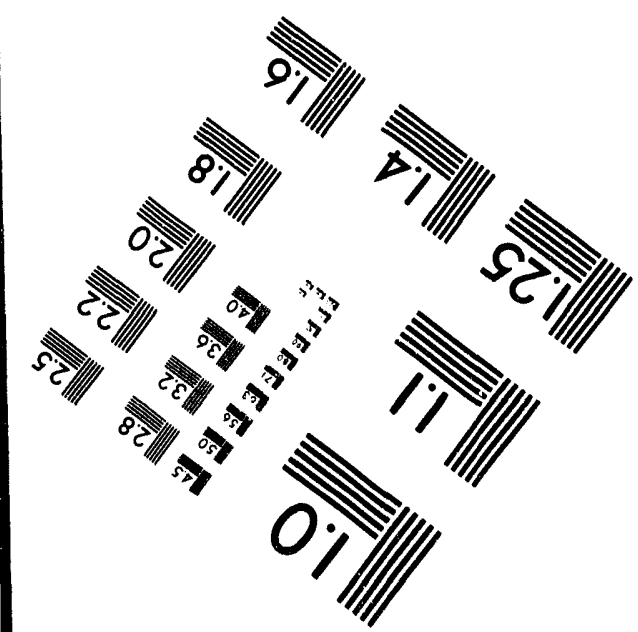

MANUFACTURED TO AIIM STANDARDS BY APPLIED IMAGE, INC.

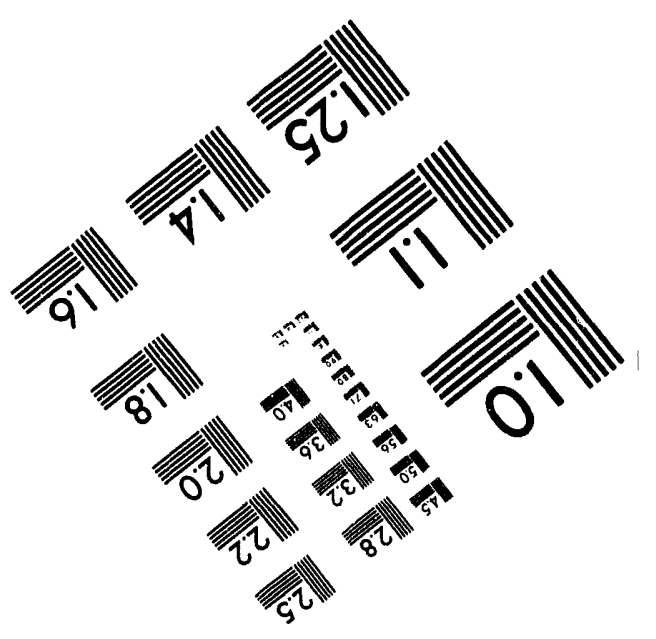



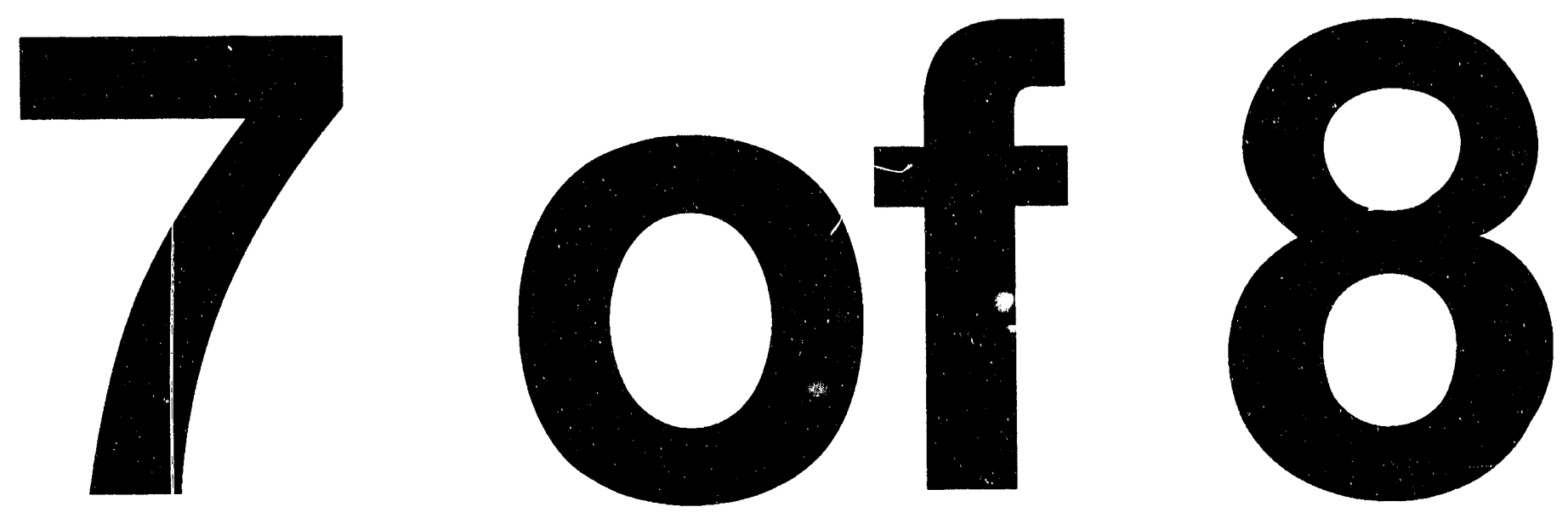
Naval Nuclear Propulsion Program

Richard A. Guida, PE, Associate Director for Regulatory Affairs

BS, Electrical Engineering

MS, Nuclear Engineering

MBA, Business

Years of Experience: 21

Analyst - Coordinator Naval Nuclear Fuel Management Program

Craig S. Hansen, Manager Finance and Administration, Naval Reactors-ID

BA, Operations Management

Years of Experience: 7

EIS Project Office Liaison

Michael A. Kuprenas, Deputy Manager, Non-prototype Operations, Naval Reactors-ID

BS, Chemical Engineering

Years of Experience: 12

Analyst - Spent Nuclear Fuel

Lisa S. Megargle, Special Assistant to the Associate Director for Regulatory Affairs

BS, Operations Research and Industrial Engineering

MEng, Civil Engineering

Years of Experience: 4

Analyst - Assistant Coordinator, Nuclear Fuel Management Program 
Table 6.1-1. Contributors to the Environmental Impact Statement.

\begin{tabular}{|c|c|c|c|c|c|c|c|c|c|c|c|c|c|c|c|c|}
\hline \multirow[b]{2}{*}{ Contributor } & \multicolumn{5}{|c|}{ Section } & \multirow[b]{2}{*}{5} & \multirow[b]{2}{*}{6} & \multicolumn{9}{|c|}{ Appendix } \\
\hline & $\mathbf{S}$ & 1 & 2 & 3 & 4 & & & 7 & 8 & 9 & $\mathbf{A}$ & B & C & $\mathbf{D}$ & $\mathbf{E}$ & $\mathbf{F}$ \\
\hline \multicolumn{17}{|l|}{ Department of Energy } \\
\hline Tom Wichmann & $\mathbf{x}$ & $\mathbf{x}$ & $x$ & $\mathbf{x}$ & & $\mathbf{x}$ & & & & & & & & & & \\
\hline Kathleen Whitaker & $\mathbf{x}$ & $\mathbf{x}$ & & & & & $x$ & $\mathbf{x}$ & $x$ & $\mathbf{x}$ & & & & & & \\
\hline John Medema & $\mathbf{x}$ & $\mathbf{x}$ & $x$ & $\mathbf{x}$ & $\mathbf{x}$ & $x$ & & $x$ & & & & & $x$ & & & \\
\hline Mary Willcox & $x$ & $\mathbf{x}$ & $\mathbf{x}$ & $x$ & $x$ & $x$ & & & & & & & & & & \\
\hline Robert Brown & & & & & $\mathbf{x}$ & $\mathbf{x}$ & & & & & & & & & & \\
\hline Robert Creed, Jr. & & & & & $x$ & $x$ & & & & & & & & & & \\
\hline John Herritt & & & & & $x$ & $x$ & & & & & & & & & & \\
\hline Mark Howard & & & & & $\mathbf{x}$ & $x$ & & & & & & & & & & \\
\hline Paul Martin & & & & & $x$ & $x$ & & & & & & & & & & \\
\hline Mary McKnight & & & & & & $\mathbf{x}$ & & $x$ & & & & & & & & \\
\hline Mark Pellechi & & & & & & $x$ & & & & & & & & & & \\
\hline Ralph W. Russell & & & & & $x$ & $\mathbf{x}$ & & & & & & & & & & \\
\hline Roger Twitchell & & & & & $\mathbf{x}$ & $\mathbf{x}$ & & & & & & & & & & \\
\hline C. Brooks Weingartner & & & & & $\mathbf{x}$ & $x$ & & & & & & & & & & \\
\hline \multicolumn{17}{|c|}{ Science Applications International Corporation } \\
\hline Dee H. Walker & $\mathbf{x}$ & $\mathbf{x}$ & $\mathbf{x}$ & $\mathbf{x}$ & & & & & & & & & & & & \\
\hline Ted B. Doerr & $\mathbf{x}$ & $\mathbf{x}$ & $\mathrm{x}$ & & $\mathbf{x}$ & $\mathbf{x}$ & & & & & & $\mathbf{x}$ & & & & \\
\hline R. Kingsley House & & $\mathbf{x}$ & $x$ & & $x$ & $\mathbf{x}$ & & & & & & & & & & \\
\hline Barbara Brown & & & & & & & & & $\mathbf{x}$ & & & & & & & $\mathbf{x}$ \\
\hline Christopher Clayton & & & & & $\mathbf{x}$ & $\mathbf{x}$ & & & & & & & & & & \\
\hline David Cummings & & & & & $\mathbf{x}$ & $\mathbf{x}$ & & & & & & & & & & $\mathbf{x}$ \\
\hline Mark A. Dagel & & & & & & $\mathbf{x}$ & & & & & & & & & & \\
\hline Thomas D. Enyeart & & & $\mathbf{x}$ & & $\mathbf{x}$ & $\mathbf{x}$ & & & & & & & & & & $\mathbf{x}$ \\
\hline Michele A. Fikel & & & & & $\mathbf{x}$ & $\mathbf{x}$ & & & & & & & & & & \\
\hline George A. Freund & & & $x$ & $x$ & & $\mathbf{x}$ & & & & & & & $\mathbf{x}$ & & & $\mathbf{x}$ \\
\hline Paul D. Freund & & & & & & & & & & $\mathbf{x}$ & & & & & & \\
\hline Gayla Gross & $\mathbf{x}$ & $\mathbf{x}$ & & $\mathbf{x}$ & & & & & & & & & & & & \\
\hline Lorraine S. Gross & & & & & $\mathbf{x}$ & $x$ & & & & & & & & & & \\
\hline Morris Hall & & & & & $\mathbf{x}$ & $x$ & & & & & & & & & & $x$ \\
\hline Joel B. Hebdon & & & $\mathbf{x}$ & $\mathbf{x}$ & & & & & & & & & & & & \\
\hline
\end{tabular}


Table 6.1-1. (continued).

\begin{tabular}{|c|c|c|c|c|c|c|c|c|c|c|c|c|c|c|c|c|}
\hline \multirow[b]{2}{*}{ Contributor } & \multicolumn{5}{|c|}{ Section } & \multirow[b]{2}{*}{5} & \multirow[b]{2}{*}{6} & \multicolumn{9}{|c|}{ Appendix } \\
\hline & $\mathbf{s}$ & 1 & 2 & 3 & 4 & & & 7 & 8 & 9 & $\mathbf{A}$ & B & $\mathbf{C}$ & D & $\mathbf{E}$ & $\mathbf{F}$ \\
\hline William E. House & & & & $\mathbf{x}$ & $\mathbf{x}$ & $\mathbf{x}$ & & & & & & & $\mathbf{x}$ & & & $\mathbf{x}$ \\
\hline Michael Ingram & & & & & & & & & & & $\mathbf{x}$ & & & & & \\
\hline Irene Johnson & & & & & $\mathbf{x}$ & $\mathbf{x}$ & & & & & & & & & & $\mathbf{x}$ \\
\hline Don Kevin & & & & & $\mathbf{x}$ & $\mathbf{x}$ & & & & & & & & & & \\
\hline Barbara Larsen & & & & & $\mathbf{x}$ & $\mathbf{x}$ & & & & & & & & & & $\mathbf{x}$ \\
\hline Anne Lundahl & & & & & $x$ & $\mathbf{x}$ & & & & & & & & & & $\mathbf{x}$ \\
\hline Steven J. Maheras & & & & & $\mathbf{x}$ & $\mathbf{x}$ & & & & & & & & & & \\
\hline Diane Morton & & & $x$ & $\mathbf{x}$ & & & & & & & & & & & $\mathbf{x}$ & \\
\hline Mark Otis & & & & & $\mathbf{x}$ & $\mathbf{x}$ & & & & & & & & & & $\mathbf{x}$ \\
\hline John Raudsep & & & & & $\mathbf{x}$ & $\mathbf{x}$ & & & & & & & & & & $\mathbf{x}$ \\
\hline James Rudolph & & $\mathbf{x}$ & $\mathbf{x}$ & & & & & & & & & & & & & \\
\hline Teresa Rudolph & & & & & $\mathbf{x}$ & $\mathbf{x}$ & & & & & & & & & & \\
\hline Deborah A. Ryan & & & & & $x$ & $\mathbf{x}$ & & & & & & & & & & $\mathbf{x}$ \\
\hline Angela Sewall & & & & & & $\mathbf{x}$ & & & & & & & & & & \\
\hline Samuel E. Shepley & & & & $\mathbf{x}$ & & & & & & & & & $\mathbf{x}$ & & & \\
\hline Brenda Shim & & & & & $\mathbf{x}$ & $\mathbf{x}$ & & & & & & & & & & $\mathbf{x}$ \\
\hline Donald C. Slaughterbeck & & & & & & $\mathbf{x}$ & & & & & & & & & & $\mathbf{x}$ \\
\hline Donald Stadelman & & & & & $\mathbf{x}$ & $\mathbf{x}$ & & & & & & & & & & \\
\hline Jane Tallman & & & & & $\mathbf{x}$ & $\mathbf{x}$ & & & & & & & & & & \\
\hline Todd B. Thompson & & & & & & & & & & & $\mathbf{x}$ & & & & & \\
\hline John von Reis & & & & $\mathbf{x}$ & & & & & & & & & & & & \\
\hline Price L. Worrell & & & & & & & & & & & & & & $\mathbf{x}$ & & \\
\hline Jon Young & & & & & & $\mathbf{x}$ & & & & & & & & & & \\
\hline Science Applications Inter & onal & orpo & tion & Con & $\tan$ & & & & & & & & & & & \\
\hline Richard Belanger & & & & & $\mathbf{x}$ & $\mathbf{x}$ & & & & & & & & & & $\mathbf{x}$ \\
\hline Kenneth D. Bulmahn & & & $\mathbf{x}$ & $\mathbf{x}$ & $\mathbf{x}$ & $\mathbf{x}$ & & & & & & & & & & \\
\hline Robert N. Ferguson & & & $\mathbf{x}$ & $\mathbf{x}$ & & & & & & & & & $\mathbf{x}$ & & & \\
\hline Ecology and Environment. & & & & & & & & & & & & & & & & \\
\hline Wendy Green & & & & & & & & $\mathbf{x}$ & & & & $\mathbf{x}$ & & & & \\
\hline David J. Lechel & $\mathbf{x}$ & & & & & & & & & & & & & & & \\
\hline
\end{tabular}


Table 6.1-1. (continued).

\begin{tabular}{|c|c|c|c|c|c|c|c|c|c|c|c|c|c|c|c|c|}
\hline \multirow[b]{2}{*}{ Contributor } & \multicolumn{7}{|c|}{ Section } & \multicolumn{9}{|c|}{ Appendix } \\
\hline & $\mathbf{S}$ & 1 & 2 & 3 & 4 & 5 & 6 & 7 & 8 & 9 & $\mathbf{A}$ & B & C & D & $\mathrm{E}$ & $\mathbf{F}$ \\
\hline \multicolumn{17}{|c|}{ Jason Associates Corporation } \\
\hline Harry Fugate & & & $\mathbf{x}$ & & & & & & & & & & & & & \\
\hline Daniel A. Reny & & & & & & $\mathbf{x}$ & & & & & & & & & & \\
\hline \multicolumn{17}{|c|}{ Naval Nuclear Propulsion Program } \\
\hline Richard A. Guida & $\mathbf{x}$ & & & $\mathbf{x}$ & & $\mathbf{x}$ & & $\mathbf{x}$ & & & & & $\mathbf{x}$ & & & $\mathbf{x}$ \\
\hline Craig S. Hansen & $\mathbf{x}$ & & & $\mathbf{x}$ & & $\mathbf{x}$ & & $\mathbf{x}$ & & & & & $\mathbf{x}$ & & & $\mathbf{x}$ \\
\hline Michael A. Kuprenas & $\mathbf{x}$ & & & $\mathbf{x}$ & & $\mathbf{x}$ & & $\mathbf{x}$ & & & & & $\mathbf{x}$ & & & $\mathbf{x}$ \\
\hline Lisa S. Megargle & $\mathbf{x}$ & & & $\mathbf{x}$ & & $\mathbf{x}$ & & $\mathbf{x}$ & & & & & $\mathbf{x}$ & & & $\mathbf{x}$ \\
\hline
\end{tabular}




\subsection{Reviewers}

Michael L. Abbott

Senior Engineering Specialist

EG\&G Idaho, Inc.

Ronald C. Arnett

Senior Engineering Specialist

EG\&G Idaho, Inc.

Fred Balkovetz

Senior Engineering Specialist

EG\&G Idaho, Inc.

Brad S. Bowman

Senior Analyst

Jason Associates Corporation

Keener Earle

Manager, Environmental Restoration and

Assessments

Westinghouse Idaho Nuclear Company

Tom Ferrara

Air Scientist

Ecology and Environment, Inc.

Richard H. Holder

Program Manager

Halliburton NUS Environmental Corp.

Suzette M. Jackson

Senior Scientist

EG\&G Idaho, Inc.

Wayne K. Lehto

Nuclear Engineer

Private Consultant

Edward J. Lipke

Manager, Nuclear Technical Services

Westinghouse Idaho Nuclear Company

Suzanne J. Miller

Senior Scientist

EG\&G Idaho, Inc.
Bruce M. Angle

Technical Program Manager

Westinghouse Idaho Nuclear Company

Carolyn Bishop

Scientist, Applied Geosciences Unit

EG\&G Idaho, Inc.

Robert J. Budnitz

Physicist and President

Future Resources Associates, Inc.

Robert Erdmann

Attorney

Brazier and Erdmann

William R. Hackett

Geologist

WRH Associates

John S. Irving

Senior Scientist

EG\&G Idaho, Inc.

Larry Kripps

Senior Executive Consultant

Halliburton NUS Environmental Corp.

Patrick R. Leonard, CHP

Engineering Specialist

EG\&G Idaho, Inc.

Jeff Manship

Geologist

Ecology and Environment, Inc.

Kenneth S. Moor

Scientific Specialist

EG\&G Idaho, Inc.

Robert L. Nitschke

Unit Manager, Chemical and Radiological

Risk Assessment

EG\&G Idaho, Inc. 
Meredith Newman

Senior Scientist, Applied Geosciences Unit EG\&G Idaho, Inc.

Gail L. Olson

Scientist

EG\&G Idaho, Inc.

Brenda L. Ringe

Scientist

EG\&G Idaho, Inc.

Shann on M. Rood

Scientist

EG\&G Idaho, Inc.

Kirsten Shelly

Environı.. zntal Planner

Ecology and Environment, Inc.

Kenneth Stein

Regulatory Compliance Specialist

Ecology and Environment, Inc.

Chris S. Staley

Senior Scientist

EG\&G Idaho, Inc.

Alfred J. Unione

Engineer and Vice President

Jason Associates Corporation

Thomas R. Wood

Manager, Applied Geosciences Unit

EG\&G Idaho, Inc.
Samuel B. Pole

Senior Engineering Specialist

EG\&G Idaho, Inc.

John Poloski

Scientific Specialist

EG\&G Idaho, Inc.

Ronald C. Rope

Senior Scientist

EG\&G Idaho, Inc.

Richard P. Smith

Scientific Specialist

EG\&G Idaho, Inc.

Wayne Tolbert

Senior Program Manager

Science Applications International Corp.

Paul Tronolone

Land Use Planner

Ecology and Environment, Inc.

Debra J. Wilcox

Regulatory Analyst

Ecology and Environment, Inc.

Bruce Wattle

Air Scientist

Ecology and Environment, Inc. 


\section{CONSULTATIONS AND ENVIRONMENTAL REQUIREMENTS}

\subsection{Consultations}

The National Environmental Policy Act (NEPA) requires that Federal, State, and local agencies with jurisdiction or special expertise regarding any environmental impact be consulted and involved in the NEPA process. Agencies involved include those with authority to issue applicable permits, licenses, and other regulatory approvals, as well as those responsible for protecting significant resources (for example, endangered species, critical habitat;, or historic resources). These agencies will be sent copies of the Environmental Impact Statement (EIS) and will be invited to comment.

Consultations with Federal and state agencies have been initiated by the U.S. Department of Energy (DOE) pursuant to the preparation of this Environmental Impact Statement (EIS). Letters regarding consultation under the Endangered Species Act and National Historic Preservation Act have been received (see Appendix B, Consultation Letters). 


\subsection{Environmental Requirements}

This section identifies and summarizes the major laws, regulations, executive orders, and U.S. Department of Energy (DOE) orders that may apply to the proposed action and alternatives at the INEL. This section also provides information concerning the status of permits and regulatory compliance at the INEL.

The discussion includes the major Federal statutes that impose environmental protection and compliance requirements upon DOE (Section 7.2.1), as well as those State and local measures applicable to the proposed action because Federal law delegates enforcement or implementation authority to state or local agencies (Section 7.2.4). Section 7.2.2 addresses environmentally related presidential executive orders that clarify issues of national policy and set guidelines under which Federal agencies, including DOE, must act. The DOE implements its responsibilities for protection of public health, safety, and the environment through a series of departmental orders that are mandatory for operating contractors of DOE-owned facilities. Section 7.2.3 discusses those DOE orders related to environmental, health, and safety protection.

Section 7.2.5 discusses the status of regulatory compliance at the INEL and includes a table identifying all permits currently held by DOE governing various INEL activities. Secion 7.2.5 also briefly describes DOE's internal compliance program that includes self-assessments and the recent Tiger Team reviews.

\subsubsection{Federal Environmental Statutes and Regulations}

\subsubsection{National Environmental Policy Act of 1969, as amended (42 USC $\$ 4321$ et}

seq.). The National Environmental Policy Act establishes a national polic; promoting awareness of the environmental consequences of major Federal activities on the environment and promoting consideration of the environmental impacts during the planning and decisionmaking stages of a project. The National Environmental Policy Act requires all agencies of the Federal government 
to prepare a detailed statement on the environmental effects of proposed major Federal actions that may significantly affect the quality of the human environment.

The Council on Environmental Quality and DOE have promulgated regulations for implementing the National Environmental Policy Act (40 CFR Parts 1500-1508 and 10 CFR Part 1021).

\subsubsection{Atomic Energy Act of 1954, as amended (42 USC \$2011 et seq.). The} Atomic Energy Act of 1954 authorizes the DOE to establish standards to protect health or minimize dangers to life or property (42 USC \$2011 et seq.) with respect to activities under its jurisdiction. Through a series of DOE orders, the DOE has established an extensive system of standards and requirements to ensure safe operation of its facilities.

7.2.1.3 Clean Air Act, as amended (42 USC $\$ 7401$ ot seq.). The Clean Air Act, as amended, is intended to "protect and enhance the quality of the Nation's air resources so as to promote the public health and welfare and the productive capacity of its population." Section 118 of the Clean Air Act, as amended, requires that each Federal agency, such as DOE, with jurisdiction over any property or facility that might result in the discharge of air pollutants, comply with "all Federal, State, interstate, and local requirements" with regard to the control and abatement of air pollution.

The law requires the U.S. Environmental Protection Agency (EPA) to establish national primary and secondary ambient air quality standards as necessary to protect public health, with an adequate margin of safety, from any known or anticipated adverse effects of a regulated pollutant (42 USC \$7409). The Clean Air Act also requires establishment of (a) national standards of performance for new stationary sources of atmospheric pollutants; (b) emissions limitations for any new or modified building, structure, facility, or installation that emits or may emit an air pollutant (42 USC 87411 ); and (c) standards for emission of hazardous air pollutants (42 USC \$7412). In addition, the Clean Air Act requires specific emission increases to be evaluated so as to prevent a significant deterioration in air quality (42 USC \$7470). 
To comply with these requirements, the EPA issued: (a) Primary and Secondary National Ambient Air Quality Standards, including standards for emissions of sulfur dioxide, oxides of nitrogen, carbon monoxide, particulate matter with a diameter of less than or equal to 10 micrometers (PM-10), ozone, and lead (40 CFR Part 50); (b) the Standards of Performance for New Stationary Sources within specific source categories enumerated in 40 CFR Part 60.16, including electric steam-generating units, industrial-commercial-institutional steam-generating units, and stationary gas turbines (40 CFR Part 60); (c) the National Emission Standard for Hazardous Air Pollutants, including radionuclides (40 CFR Part 61); and (d) the Prevention of Significant Deterioration of Air Quality review regulations (40 CFR Part 52.21).

The Clean Air Act requires each state to develop and submit for approval to the EPA implementation plans to control air pollution and air quality in that state. Under EPA regulations, Idaho has been delegated authority under the Clean Air Act to maintain the Primary and Secondary National Ambient Air Quality Standards (40 CFR Part 52, Subpart N), to issue permits under the Prevention of Significant Deterioration (40 CFR Part 52.683), and to enforce performance standards for new stationary sources. The entire INEL facility is treated as a single pollutant source and, therefore, is a major stationary source for Prevention of Significant Deterioration review. To date, the State of Idaho does not have authority to administer the National Emission Standards for Hazardous Air Pollutants program regulating emissions of radionuclides at DOE facilities. Therefore, National Emission Standards for Hazardous Air Pollutants approvals authorizing release of radionuclides are obtained from the EPA Region 10. However, the State does regulate radionuclides under its Prevention of Significant Deterioration program and, therefore, DOE coordinates any National Emission Standards for Hazardous Air Pollutants approvals obtained from the EPA with the State of Idaho to fulfill applicable requirements of the State's Prevention of Significant Deterioration program.

On November 15, 1990, the Clean Air Act Amendments were signed into law. Under these amendments, new standards will be imposed on major sources emitting air pollutants in nonattainment areas, and states will have to submit new State Implementation Plans to address these new requirements. Mobile sources of air pollutants, such as cars, trucks, buses, and certain off-the-road engines, also will have to meet new standards. 


\subsubsection{The Clean Water Act, as amended (33 USC $\$ 1251$ ot seq.). The Clean}

Water Act, which amended the Federal Water Pollution Control Act, was enacted to "restore and maintain the chemical, physical and biological integrity of the Nation's water." The Clean Water Act prohibits the "discharge of toxic pollutants in toxic amounts" to navigable waters of the United States. Section 313 of the Clean Water Act, as amended, requires all branches of the Federal government engaged in any activity that might result in a discharge or runoff of pollutants to surface waters to comply with Federal, State, interstate; and local requirements.

In addition to setting water quality standards for the nation's waterways, the Clean Water Act supplies guidelines and limitations for effluent discharges from point-source discharges, and provides authority for the U.S. Environmental Protection Agency (EPA) to implement the National Pollutant Discharge Elimination System permitting program. The National Pollutant Discharge Elimination System program is administered by the Water Management Division of the EPA pursuant to regulations in 40 CFR Part 122 et seq. Idaho has not applied for National Pollutant Discharge Elimination System authority from the EPA. Thus, all National Pollutant Discharge Elimination System permits required for the INEL would be obtained by DOE through the EPA Region 10 (40 CFR Part 122 et seq.).

Sections 401 and 405 of the Water Quality Act of 1987 added Section 402(p) to the Clean Water Act. Section 402(p) requires that the Environmental Protection Act establish regulations for issuing permits for storm water discharges associated with industrial activity. Although any storm water discharge associated with industrial activity requires a National Pollutant Discharge Elimination System permit application, regulations implementing a separate storm water permit application process have not yet been adopted by the EPA.

7.2.1.5 Safe Drinking Water Act, as amended (42 USC \$300f of seq.). The primary objective of the Safe Drinking Water Act, as amended, is to protect the quality of the public water supplies and all so urces of drinking water. The implementing regulations are found in $\mathbf{4 0}$ CFR Part 141, National Interim Primary Drinking Water Regulations. These regulations, administered by the U.S. Envirormental Protection Agency (EPA) unless delegated to the states, establish standards applicable to public water systems. They promulgate maximum contaminant 
levels, including those for radioactivity, in community water systems, which are defined as public water systems that serve at least 15 service connections used by year-round residents or regularly serve at least 25 year-round residents. For radioactive material, the regulations specify that the average annual concentration of man-made radionuclides in drinking water as delivered to the user by such a system shall not produce a dose equivalent to the total body or an internal organ greater that 4 millirem per year beta activity. Other programs established by the Safe Drinking Water Act include the Sole Source Aquifer Program, the Wellhead Protection Program, and the Underground Injection Control Program. The Snake River Plain Aquifer, a portion of which flows beneath the INEL, has been designated by the EPA as a sole source aquifer pursuant to the Sole Source Aquifer Program. The State of Idaho has received authorization from the EPA to implement the public drinking water system program and the underground interjection control program under the Safe Drinking Water Act.

\subsubsection{Resource Conservation and Recovery Act, as amended (42 USC 56901,}

seq.). The treatment, storage, or disposal of hazardous and nonhazardous waste is regulated under the Solid Waste Disposal Act, as amended by the Resource Conservation and Recovery Act and the Hazardous and Solid Waste Amendments of 1984. Pursuant to Section 3006 of the Act, any state that seeks to administer and enforce a hazardous waste program pursuant to the Resource Conservation and Recovery Act may apply for U.S. Environmental Protection Agency (EPA) authorization of its program. The EPA regulations implementing the Resource Conservation and Recovery Act are found in 40 CFR Parts 260-280. 'These regulations define hazardous wastes and specify hazardous waste transportation, handling, treatment, storage, and disposal requirements.

The regulations imposed on a generator or a treatment, storage, and/or disposal facility vary according to the type and quantity of material or waste generated, treated, stored, and/or disposed. The method of treatment, storage, and/or disposal also impacts the extent and complexity of the requirements.

7.2.1.7 Current Status of Spent Nuclear Fuel. Historically, the U.S. Department of Energy chemically reprocessed spent nuclear fuel to recover valuable products and fissionable 
materials, and, as such, the spent nuclear fuel was not a solid waste under the Resource Conservation and Recovery Act (RCRA).

World events have resulted in significant changes in DOE's direction and operations. In particular, in April 1992, DOE announced the phase-out of reprocessing for the recovery of special nuclear materials. With these changes, DOE's focus on most of its spent nuclear fuel has changed from reprocessing and recovery of materials to storage and ultimate disposition. This, in turn, has created uncertainty in regard to the regulatory status of some of DOE's spent nuclear fuel relative to RCRA.

DOE has initiated discussion with the U.S. Environmental Protection Agency (EPA) on the potential applicability of RCRA to spent nuclear fuel. Further discussions with EPA Headquarters, EPA Regional Offices, and state regulators are ongoing to develop a path forward toward meeting any RCRA requirements that might apply.

\subsubsection{Federal Facillty Compllance Act. The Federal Facility Compliance Act,} enacted on October 6, 1992, waives sovereign immunity for fines and penalties for Resource Conservation and Recovery Act violations at Federal facilities. However, a provision postpones

fines and penalties after 3 years for mixed waste storage prohibition violations at DOE sites and requires DOE to prepare plans for developing the required treatment capacity for mixed waste stored or generated at each facility. Each plan must be approved by the host state or the U.S. Environmental Protection Agency, after consultation with other affected states, and a consent order must be issued by the regulator requiring compliance with the plan. The Federal Facility Compliance Act further provides that the DOE will not be subject to fines and penalties for land disposal restriction storage prohibition violations for mixed waste as long as it is in compliance with such an approved plan and consent order and meets all other applicable regulations.

\subsubsection{Comprehensive Environmental Response, Compensation, and Lability Act,} as amended (42 USC 59601 et seq.). The Comprehensive Environmental Response, Compensation, and Liability Act, as amended, provides a statutory framework for the cleanup of waste sites containing hazardous substances and-as amended by the Superfund Amendments and 
Reauthorization Act-provides an emergency response program in the event of a release (or threat of a release) of a hazurdous substance to the environment. Using the Hazard Ranking System, Federal and private sites are ranked and may be included on the National Priorities List. The Comprehensive Environmental Response, Compensation, and Liability Act, as amended, requires such Federal facilities having such sites to undertake investigations and remediation as necessary. The Act also includes requirements for reporting releases of certain hazardous substances in excess of specified amounts to State and Federal agencies.

\subsubsection{Emergency Planning and Communty Right-to-Know Act of 1986 (42 USC} $\$ 11001$ ot seq.) (also known as "SARA Thle III). Under Subtitle A of this Act, Federal facilities, including those owned by the DOE, provide various information such as inventories of specific chemicals used or stored and releases that occur from these sites, to the State Emergency Response Commission and to the Local Emergency Planning Committee to ensure that emergency plans are sufficient to respond to unplanned releases of hazardous substances. Implementation of the provisions of this Act began voluntarily in 1987, and inventory and annual emissions reporting began in 1988, based on 1987 activities and information. The DOE also requires compliance with Title III as matter of agency policy.

In addition, under Subtitle B the Act, Material Safety Data Sheets reports (SARA 8311), Emergency and Hazardous Chemical Inventory Reports, (Superfund Amendments and Reauthorization Act, 8312), and Toxic Chemical Release Inventory Reports (Superfund Amendments and Reauthorization Act \$313), must be provided to appropriate State, local, national, and Federal authorities. Executive Order 12856 requires Federal facilities to adhere to the same planning and reporting provisions of Federal right-to-know and pollution prevention laws that cover private industry.

\subsubsection{Hazardous and Radioacthe Materials Transportation Regulations.}

Transport of hazardous and radioactive materials, substances, and wastes are governed by U.S. Department of Transportation (DOT), U.S. Nuclear Regulatory Commission (NRC), and U.S. Environmental Protection Agency (EPA) regulations. These regulations may be found in 49 CFR Parts 100-178, 10 CFR Part 71, and 40 CFR Part 262, respectively. 
DOT regulations contain requirements for identification of a material as hazardous or radioactive. These regulations may hand off to NRC or EPA regulations for identification of material. However, DOT hazardous material regulations govern the hazard communication (for example, marking, hazard labeling, vehicle placarding, and emergency response telephone number) and transport requirements, such as required entries on shipping papers or EPA waste manifest.

NRC regulations applicable to radioactive materials transportation are found in 10 CFR Part 71 and detail packaging design requirements, including the testing required for package certification. Complete documentation of design and safety analysis as well as results of the required testing is submitted to the NRC for certification of the package for use. This certification testing involves the following components: heat, physical drop onto an unyielding surface, water submersion, puncture by dropping a package onto a rigid spike, and gas tightress. Some of the testing is designed to simulate maximum credible accident conditions.

EPA regulations pertaining to hazardous waste transportation are found in 40 CFR Part 262. These regulations deal with the use of the EPA waste manifest, which is the shipping paper used when transporting Resource Conservation and Recovery Act hazardous waste.

\subsubsection{National Historic Preservation Act, as amended (16 USC $\$ 470$ et seq.).} The National Historic Preservation Act, as amended, provides that sites with significant national historic value be placed on the National Register of Historic Places. There are no permits or certifications required under the Act. However, if a particular Federal activity may impact a historic property resource, consultation with the Advisory Council on Historic Preservation will usually generate a Memorandum of Agreement, including stipulations that must be followed to minimize adverse impacts. Coordinations with the State Historic Preservation Officer are also undertaken to ensure that potentially significant sites are properly identified and appropriate mitigative actions implemented.

\subsubsection{Archaeological Resource Protection Act, as amended (16 USC $\$ 470$ et}

seq.). This Act provides for the preservation of historical and archaeological data (including relics and specimens) which might otherwise be irreparably lost or destroyed as the result of 
(a) flooding, the building of access road, the erection of workmen's communities, the relocation of railroads and highways, and other alterations of the terrain caused by the construction of a dam, by any agency of the United States, or by any private person or corporation holding a license issued by any such agency or (b) any alteration of the terrain caused as a result of any Federal construction project or federally licensed activity or program. The law also requires that, whenever any Federal agency finds that its activities may cause irreparable loss or destruction of significant scientific, prehistorical, historical, or archaeological data, the agency must notify the U.S. Department of Interior (DOI) and may request DOI to undertake the recovery, protection, and preservation of such data. Excavations must be undertaken for the purpose of furthering archaeological knowledge in the public interest, and resources removed are to remain the property of the United States. Consent must be obtained from the Indian tribe owning lands on which a resource is located before issuance of a permit, and the permit must contain terms or conditions requested by the tribe.

\subsubsection{Endangered Species Act, as amended (16 USC $\$ 1531$ et seq.). The} Endangered Species Act, as amended, is intended to prevent the further decline of endangered and threatened species and to restore these species and their habitats. The Act is jointly administered by the U.S. Departments of Commerce and the Interior. Section 7 of the Act requires consultation to determine whether endangered and threatened species are known to have critical habitats on or in the vicinity of the proposed action.

\subsubsection{Migratory Bird Treaty Act, as amended (16 USC \$703 ot seq.). The} Migratory Bird Treaty Act, as amended, is intended to protect birds that have common migration patterns between the United States and Canada, Mexico, Japan, and Russia. It regulates the harvest of migratory birds by specifying the mode of harvest, hunting seasons, bag limits, and so forth. The Act stipulates that it is unlawful to take, pursue, molest, or disturb bald (American) and golden eagles, their nests, or their eggs anywhere in the United States (Section 668, 668c). A permit must be obtained from the U.S. Department of the Interior to relocate a nest that interferes with resource development or recovery operations. 
7.2.1.16 Nolse Control Act of 1972, as amended (42 USC \$4901 ot seq.). Section 4 of the Noise Control Act of 1972, as amended, directs all Federal agencies to carry out "to the fullest extent within their authority" programs within their jurisdictions in a manner that furthers a national policy of promoting an environment free from noise that jeopardizes health and welfare.

\subsubsection{Toxic Substance Ccntrol Act (15 U.S.C. \$2601 ot seq.). This Act provides} the U.S. Environmental Protection Agency with the authority to require testing of both new and old chemical substances entering the environment and to regulate them where necessary. The law supplements existing toxic substance laws such as $\$ 112$ of the Clean Air Act and $\$ 307$ of the Clean Water Act. The Toxic Substances Control Act (TSCA) came about as a result of concerns that there were no general Federal regulations for the thousands of new chemicals developed each year for their potential environmental or health effects prior to their introduction to the public or into aimmerce. TSCA also regulates the treatment, storage, and disposal of certain toxic substances not regulated by Resource Conservation Recovery Act or other statutes, particularly polychlorinated biphenyls (PCBs), cholorofluorocarbons (CFCs), and asbestos.

\subsubsection{American Indian Religious Freedom Act of 1978 (42 USC \$1996). This} Act reaffirms Native American religious freedom under the First Amendment and sets U.S. policy to protect and preserve the inherent and constitutional right of American Indians to believe, express, and exercise their traditional religions. The Act requires that Federal actions avoid interfering with access to sacred locations and traditional resources that are integral to the practice of religions.

\subsubsection{Native American Graves Protection and Repatriation Act of 1990 (25 USC} \$3001). This law directs the Secretary of Interior to guide responsibilities in repatriation of Federal archaeological collections and collections held by museums receiving Federal funding that are culturally affiliated to Native American tribes. Major actions to be taken under this law include: (a) establishing a review committee with monitoring and policy-making responsibilities; (b) developing regulations for repatriation, including procedures for identifying lineal descent or cultural affiliation needed for claims; (c) overseeing museum programs designed to meet the 
inventory requirements and deadlines of this law; and (d) developing procedures to handle unexpected discoveries of graves and/or grave goods during activities on Federal or tribal land.

7.2.1.20 Nuclear Waste Policy Act (42 USC $\$ 10101$ ot seq.). The Act authorizes the Federal agencies to develop a geologic repository for the disposal of high-level radioactive waste and spent nuclear fuel from commercial reactors. The Act specifies the process for sele ting a repository site and constructing, operating, closing, and decommissioning the repository. The law also establishes programmatic guidance for these activities.

7.2.1.21 Low-Level Radioactive Waste Policy Act of 1980. This law establishes twn major national policies: (a) each state is responsible for assuring adequate disposal capacity for the low-level commercially generated waste generated within its own borders, with the exception of waste generated by Federal defense or research and development activities; and (b) the required disposal facilities can best be provided through regional groupings of states allied through interstate agreements called compacts. A compact ratified by a group of states must be approved by Congress before it takes full effect.

\subsubsection{Occupational Safety and Health Act of 1970, as amended (29 U.S.C. $\$$}

651 ot seq.). The Occupational Safety and Healthy Act establishes standards to enhance safe and healthful working conditions in places of employment throughout the United States. The Act is administered and enforced by the Occupational Safety and Health Administration (OSHA), a U.S. Department of Labor agency. While OSHA and the U.S. Environmental Protection Agency both have a mandate to reduce exposures to toxic substances, OSHA's jurisdiction is limited to safety and health conditions that exist in the workplace environment. In general, under the Act, it is the duty of each employer to furnish all employees a place of employment free of recognized hazards likely to cause death or serious physical harm. Employees have a duty to comply with the occupational safety and health standards and all rules, regulations, and orders issued under the Act. OSHA regulations (published in Title 29 of the Code of Federal Regulations) establish specific standards telling employers what must be done to achieve a safe and healthful working environment. DOE places emphasis on compliance with these regulations at DOE facilities and prescribes through DOE orders the OSHA standards that contractors sha"! meet, as applicable to 
their work at government-owned, contractor-operated facilities (DOE Orders 5480.1B, 5483.1A). DOE keeps and makes available the various records of minor illnesses, injuries, and work-related deaths as required by OSHA regulations.

\subsubsection{Rellgious Freedom Restoration Act of 1993 (42 USC \$2000bb et seq.).}

This Act prohibits the government, including Federal departments, from substantially burdening the exercise of religion unless the government demonstrates a compelling governmental interest and the action furthers a compelling government interest and is the least restrictive means of furthering that interest.

\subsubsection{Bald and Golden Eagle Protection Act, as amended (16 USC 5668-668d).}

This Act makes it unlawful to take, pursue, molest, or disturb bald (American) and golden eagles, their nests, or their eggs anywhere in the United States (Section 668, 668c). A permit must be obtained from the U.S. Department of the Interior to relocate a nest that interferes with resource development or recovery operations.

\subsubsection{Executive Orders}

\subsubsection{Executive Order 12088 [Federal Compliance with Pollution Control} Standards (October 13, 1978), as amended by Executive Order 12580 (January 23, 1987)]. Federal Compliance with Pollution Control Standards requires Federal agencies, including the DOE, to comply with applicable administrative and procedural pollution control standards established by, but not limited to, the Clean Air Act, Noise Control Act, Clean Water Act, Safe Drinking Water Act, Toxic Substances Control Act (15 USC \$2061 et seq.), and Resource Conservation and Recovery Act.

\subsubsection{Executive Order 11593 (May 13, 1971) (National Historic Presenvation).}

This Order requires Federal agencies, including DOE, to locate, inventory, and nominate properties under their jurisdiction or control the National Register of Historic Places if those properties qualify. This process requires the DOE to provide the Advisory Council on Historic 
Preservation the opportunity to comment on the possible impacts of the proposed activity on any potential eligible or listed resources.

7.2.2.3 Executive Order 11514 (NEPA). This Order requires Federal agencies to continually monitor and control their activities to protect and enhance the quality of the environment and to develop procedures to ensure that fullest practicable provision of timely public information and understanding of the Federal plans and programs with environmental impact to obtain the views of interested parties. The DOE has issued regulations (10 CFR Part 1021) and DOE Order 5440.1E for compliance with this Executive Order.

7.2.2.4 Executive Order 12580 (Superfund Implementation). This Order delegates to the heads of executive departments and agencies the responsibility for undertaking remedial actions for releases, or threatened releases that are not on the National Priority List and removal actions other than emergencies where the release is from any facility under the jurisdiction or control of executive departments and agencies.

\subsubsection{Executive Order 11988 (Floodplain Management). This Order requires} Federal agencies to establish procedures to ensure that the potential effects of flood hazards and floodplain management are considered for any action undertaken in a floodplain and that floodplain impacts be avoided to the extent practicable.

\subsubsection{Executive Order 11990 (Protection of Wetlands). This Order requires} governmental agencies to avoid, to the extent practicable, any short- and long-term adverse impacts on wetlands wherever there is a practicable alternative.

\subsubsection{Executive Order 12898 (Environmental Justice). This Order directs Federal} agencies to achieve environmental justice by identifying and addressing, as appropriate, disproportionately high and adverse human health or environmental effects of its programs, policies, and activities on minority populations and low-income populations in the United States and its territories and possessions. The Order creates an Interagency Working Group on Environmental Justice and directs each Federal agency to develop strategies within prescribed 
time limits to identify and address environmental justice concerns. The Order further directs each Federal agency to collect, maintain, and analyze information on the race, national origin, income level, and other readily accessible and appropriate information for areas surrounding facilities or sites expected to have a substantial environmental, human health, or economic effect on the surrounding populations, when such facilities or sites become the subject of a substantial Federal el, rironmental administrative or judicial action, and to make such information publicly available.

\subsubsection{Executive Order 12344 (Naval Nuclear Propulsion Program). [enacted as} permanent law by Public Law 98-525 (42 USC 7158)]. This Order prescribes the authority and responsibility of the Naval Nuclear Propulsion Program, a joint Navy/DOE organization, for all matters pertaining to naval nuclear propulsion. These responsibilities include all environmental and occupational safety and health aspects of the program.

\subsubsection{Executive Order 12856 (Right-to-Know Laws and Pollution Prevention}

Requirements). This Order requires all Federal agencies to reduce and report toxic chemicals entering any waste stream; improve emergency planning, response and accident notification; and encourage clean technologies and testing of innovative prevention technologies. The Order also provides that Federal agencies are persons for purposes of the Emergency Planning and Community Right-to-Know Act (SARA Title III), which obliges agencies to meet the requirements of the Act.

\subsubsection{Department of Energy Regulations and Orders}

Through the authority of the Atomic Energy Act, the DOE is responsible for establishing a comprehensive health, safety, and environmental program for its facilities. The regulatory mechanisms through which DOE manages its facilities are the promulgation of regulations and the issuance of DOE orders.

DOE regulations generally are found in Volume 10 of the Code of Federal Regulations. These regulations address such areas as energy conservation, administrative requirements and procedures, and classified information. For purposes of this EIS, relevant subchapters include 
Part 961, Standard Contract for Disposal of Spent Nuclear Fuel and/or High Level Radioactive Waste; Part 1021, Compliance with the National Environmental Policy Act; and Part 1022, Compliance with Floodplains/Wetlands Environmental Review Requirements.

DOE orders generally set forth policy and the programs and procedures for implementing that policy. The following sections provide a brief discussion of selected orders.

\subsubsection{DOE Order 5440.1E, National Environmental Pollcy Act. This Order} establishes responsibilities and sets forth procedures necessary for implementing the National Environmental Policy Act of 1969, as amended, to operate each of its facilities in full compliance with the letter and spirit of the Act. This Order was revised and reissued by DOE on November 19, 1992.

\subsubsection{DOE Order 5000.3B, Occurrence Reporting and Processing of Operations} Information. This Order establishes the requirements for reporting and processing occurrences relating to safety, health, security, property, operations, and environment up to and including emergencies.

\subsubsection{DOE Order 5480.1B, Environment Safety and Health Program for} Department of Energy Operations. This Order establishes the Environment, Safety and Health Program for DOE operations.

\subsubsection{DOE Order 5480.3, Safety Requirements for the Packaging and} Transportation of Hazardous Materials, Hazardous Substances, and Hazardous Wastes. This Order provides DOE policy, sets forth requirements, and assigns responsibilities for the safe transport of hazardous materials, hazardous substances, hazardous wastes, and radioactive materials.

7.2.3.5 DOE Order 5480.9, Construction Safety and Health Program. This Order establishes procedures and provides guidelines for the protection of the DOE and DOE contractor employees engaged in construction activities; protection of the general public from 
hazards in connection with DOE construction activities; protection of adjacent property from damage; and prevention of delay or interruption of DOE programs caused by accident or fires.

\subsubsection{DOE Order 5483.1A, Occupational Safoty and Health Program for DOE} Contractor Employees at Government-Owned Contractor-Operated Facilliles. This Order establishes requirements and procedures to assure that occupational safety and health standards prescribed pursuant to the Atomic Energy Act of 1954, as amended, the Energy Reorganization Act of 1974, and the DOE Organization Act of 1977, provide occupational safety and health protection for DOE contractor employees in Government-owned contractor-operated facilities that is consistent with the protection afforded private industry employees by the occupational safety and health standards promulgated under the Occupational Safety and Health Act of 1970.

7.2.3.7 DOE Order 5700.6B, Quality Assurance. This Order provides DOE policy, sets forth requirements, and assigns responsibilities for establishing, implementing, and maintaining plans and actions to assure quality achievement in DOE programs.

\subsubsection{DOE Order 5820.2A, Radioactive Waste Management. This Order} establishes policies and guidelines by which the DOE manages its radioactive waste, waste byproducts, and radioactively contaminated surplus facilities.

\subsubsection{DOE Order 5400.1, General Environmental Protection Program. This Order} establishes environmental protection program requirements, authorities, and responsibilities for DOE operations for assuring compliance with applicable Federal, State, and local environmental protection laws anci iegulations as well as internal DOE policies.

\subsubsection{DOE Order 5400.5, Radiation Protection of the Public and the}

Environment. This Order establishes standards and requirements for operation of the DOE and DOE contractors with respect to protection of members of the public and the environment against undue risk from radiation. 


\subsubsection{DOE Order 5480.4, Environmental Protection, Safoty, and Health}

Protection Standards. This Order specifies and provides requirements for the application of the mandatory environmental, safety, and health standards applicable to all DOE and DOE contractor operations.

7.2.3.12 DOE Order 5480.10, Contractor Industrlal Hygiene Program. This Order establishes the requirements and guidelines applicable to DOE contractor operations for maintaining an effective industrial hygiene piogram to preserve employee health and well-being.

\subsubsection{DOE Order 5480.11, Radiation Protection for Occupational Workers. This}

Order establishes radiation protection standards and program requirements for the DOE and DOE contractor operations with respect to the protection of the worker from ionizing radiation.

\subsubsection{DOE Order 5484.1, Environmental Protection, Safety, and Health}

Protection Information Reporting Requirements. This Order establishes the requirements and procedures for the reporting of information having environmental protection, safety, or health protection significance for DOE operations.

\subsubsection{Idaho Laws and Regulations}

The Idaho Environmental Protection and Health Act (Idaho Code, Title 39, Chapter 101 et seq.) establishes general provisions for the protection of the environment and public health. The Act created the Idaho Department of Health and Welfare and its subordinate Division of Environmental Quality, thus consolidating all State public health and environmental protection activities under one department. The Idaho Department of Health and Welfare is authorized to implement these environmental, health, and social services requirements. The Act authorizes the Department to promulgate standards, rules, and regulations relating to water and air quality, noise reductions, and solid waste disposal and grants authority to issue required permits, collect fees, establish compliance schedules, and review plans for the construction of sewage and public water treatment and disposal facilities. 
Authorization is also granted to the Idaho Department of Health and Welfare by the Idaho Water Pollution Control Act (Idaho Code, Title 39, Chapter 36) for the protection of the waters of Idaho. General language concerning the prevention of water pollution and the provision of financial assistance to municipalities is contained in the law.

The Idaho Department of Health and Welfare is also responsible for enforcem $n$ t and implementation of the Hazardous Waste Management Act of 1983, as amended (Idaho code, Title 39, Chapter 44), which provides for the protection of health and the environment from the effects of improper or unsafe management of hazardous wastes and for the establishment of a tracking or manifesting system for these wastes. This program is intended to be consistent with and not more stringent than Federal regulations as established under the Resource Conservation and Recovery Act. At this time, Idaho has primacy over hazardous and mixed waste promulgated by the U.S. Environmental Protection Agency. The Hazardous Waste Management Act sets forth requirements for the development of plans that address identification of hazardous wastes, unauthorized treatment, storage, release, use, or disposal of these wastes, and permit requirements for hazardous waste facilities. Rules and regulations concerning the transportation, monitoring, reporting, and record keeping of hazardous wastes have also been promulgated by Idaho Department of Health and Welfare under authority of this Act.

The following sections discuss the major requirements and regulations pursuant to these State laws.

7.2.4.1 Idaho Air Pollution Control Regulations. Pursuant to the Rules and Regulations for the Control of Air Pollution in Idaho (Idaho Administrative Procedures Act Title 1, Chapter 1), the Department of Health and Welfare established ambient air quality standards for particulate matter, sulfur dioxide, ozone, oxides of nitrogen, carbon monoxide, and fluorides.

Title 1, Chapter 1, of the Rules and Regulations for the Control of Air Pollution in Idaho is intended to provide authority and standards in compliance with the Clean Air Act. The Department of Health and Welfare has been granted authority to implement the requirements of the Clean Air Act and to adopt rules to implement the requirements of the Clean Air Act for 
that purpose. These rules and regulations include provisions for establishing compliance schedules and emission limits, reporting and correction of emissions that exceed established limits, and permitting requirements for construction and operation of facilities or activities that may generate emissions in excess of the prescribed standards. The Prevention of Significant Deterioration, control of open burning, and fugitive dust are addressed by these rules, as are specified types of facilities that may exceed emission limits. Also required by the Idaho Air Pollution Control Regulations is the formulation of a plan for the prevention and alleviation of air pollution emergencies. The plan includes definitions of the severity of the emergency, requirements for public notification, and recommended actions to be taken in abating an air pollution emergency.

\subsubsection{Idaho Water Quality Standards and Wastewater Treatment Requirements} and Wastewater Land Application Permit Regulations. Provisions are set forth by these regulations (Idaho Department of Health and Welfare, Rules and Regulations, Title 1, Chapter 2) for protection of designated water uses and the establishment of water quality standards that will protect those uses. The Department of Health and Welfare has been authorized to develop and enforce these regulations by Section 39-105 of the Idaho Code. Restrictions are outlined by these regulations for control of point-source and nonpoint-source discharges and other activities that may adversely affect waters of the State of Idaho, including surface water and groundwater. These regulations identify water-use classifications, specifically prohibited discharges, water quality criteria, and requirements for treatment of wastewater before discharge in the waters of Idaho. In addition, State regulations require that a permit be obtained for the application of wastewater to the land surface.

\subsubsection{Idaho Regulations for Public Drinking Water Systems. Maximum}

contaminant levels for public drinking water systems are provided by these regulations. The Water Quality Bureau, as a subdivision of the Department of Health and Welfare, sets forth monitoring and reporting requirements for inorganic and organic chemicals and radiochemicals. Other water quality and locational standards are also included in these regulations. The Department reserves the authority to determine whether the contamination is caused by nuclear facilities and to require further monitoring. 
7.2.4.4 Idaho Hazardous Waste Management Regulations. Pursuant to the Hazardous Waste Management Act, the Department of Health and Welfare (Title 1, Chapter 5) has adopted by reference the Federal regulations regarding hazardous waste rulemaking, hazardous waste delisting, and identification of wastes. Included in these regulations are requirements for hazardous waste generators, transporter, and management facilities as well as detailed procedures for permitting these activities. The general requirements for generators, transporters, and management facilities have been incorporated by reference; however, some sections have been revised to reflect Idaho's permitting program. Section 39-4404 (14) of the Act identifies "restricted hazardous waste" that includes liquid hazardous wastes containing specified concentrations of constituents as well as hazardous wastes containing concentrations of halogenated compounds.

7.2.4.5 Idaho Solid Waste Management Regulations. These regulations, as developed by the Idaho Department of Health and Welfare in Title 1, Chapter 6, of the Solid Waste Management Regulations and Standards Manual, provide standards for the management of solid wastes to minimize the detrimental effects of disposal. These standards include requirements for the review of plans and approval of procedures and operational and postoperational standards for landfills, incinerators, and processing facilities and for transportation and storage of solid waste.

\subsubsection{Idaho Rules and Regulations for Construction and Use of Injection Wells.}

Requirements for the construction, location, and usage of injection wells within the State of Idaho are set forth in these regulations. The Department of Water Resources has been granted administrative authority over injection wells. Injection of radioactive or hazardous materials through an existing well or above a drinking water source is prohibited. Parameters for quality of fluids discharged and allowable uses of injection wells are included in these regulations as are classifications of well types and permitting requirements for injection wells. 


\subsubsection{Compliance Status at the Idaho National Engineering Laboratory}

The INEL is committed to operating in compliance with all environmental laws, regulations, executive orders, DOE orders, and permits and compliance agreements with regulatory agencies. Regulatory agencies conduct inspections at the INEL to assure compliance with permits and other applicable legal requirements are being met.

In addition to oversight through external regulatory agencies, the DOE has a comprehensive program for conducting internal audits or inspections and self-assessments, including periodic reviews conducted by interdisciplinary teams of experts. DOE-ID has also prepared and issued an Environmental Compliance Planning Manual (DOE-ID-10166) that identifies the various requirements of Federal and State agencies that DOE-ID considers to be pertinent to activities at the INEL. This Manual provides guidance and step-by-step methods needed to maintain compliance with applicable environmental requirements. A summary of the INEL's current compliance with major environmental statutes and regulations is presented in the discussion that follows.

\subsubsection{Comprehensive Environmental Response, Compensation, and Liablity Act.} In November 9, 1989, the INEL was placed on the Environmental Protection Agency's (EPA's) National Priority List, which is the nationwide list of private- and Federal-owned sites identified by the EPA as requiring response actions under the Comprehensive Environmental Response, Compensation, and Liability Act. Following this listing, the DOE entered into negotiations with the State of Idaho and EPA Region 10, leading to execution of a Federal Facility Agreement and Consent Order on December 4, 1991. The purpose of the Federal Facility Agreement and Consent Order is to establish a procedural framework and schedule for developing, prioritizing, implementing, and monitoring appropriate response actions at the INEL in accordance with the Comprehensive Environmental Response, Compensation, and Liability Act, which will also be deemed to meet any corrective action requirements of the Resource Conservation and Recovery Act Section 3008(h) Consent Order and Compliance Agreement (see discussion below). The Action Plan portion of the Federal Facility Agreement and Consent Order sets forth a schedule for accomplishing the required activities. In conjunction with the EPA Region 10 and State of 
Idaho Project Managers, DOE-ID is engaged in various characterization, sampling, investigation, and interim action activities that are intended to provide the basis for selection of remedies at the operable units located on the INEL. The activities accomplished to date are summarized in Table 7.2-1.

\subsubsection{Emergency Planning and Community Right-to-Know Act of 1986 (SARA}

Title III). Authority for the programs under the Superfund Amendments and Reauthorization Act Title III reporting has been delegated by the U.S. Environmental Protection Agency to each individual state. In accordance with Subtitle A (Emergency Response Planning and Release Notification), the State of Idaho has established an Emergency Response Commission to handle the statewide work and the counties have established emergency planning committees to manage local activities. The INEL is subject to and complies with the reporting requirements established in Title III. DOE-ID also prepares and submits reports required by Sections 311, 312, and 313 of the Superfund Amendments and Reauthorization Act.

7.2.5.3 National Environmental Policy Act. A comprehensive program to assure compliance with the National Environmental Policy Act requirements is in place at the INEL and is described in the DOE-ID Environmental Compliance Planning Manual (DOE/ID-10166). This program has evolved over the last several years, culminating recently in promulgation of DOE National Environmental Policy Act regulations (10 CFR Part 1021) and the issuance of numerous guidance memoranda by the DOE Office of National Environmental Policy Act Oversight (EH-25). Table 7.2-2 is a list of the Environmental Assessments and EISs that are related to this EIS and that have either been approved or are under preparation.

\subsubsection{Safe Drinking Water Act. The Safe Drinking Water Act Underground Injection} Control regulations require that deep injection wells be permitted or that permits be submitted to the State, and shallow wells be inventoried. The injection wells are used to dispose of storm water runoff. The DOE also inventoried shallow injection wells at the INEL and submitted the information to the State as required. The Idaho Department of Environmental Quality conducts periodic sanitation surveys. A sanitation survey was conducted by the Idaho Department of Environmental Quality in December 1990. Additionally, both the State of Idaho and the City of 
Table 7.2-1. Federal Facility Agreement/Consent Order status. ${ }^{a}$

\begin{tabular}{|c|c|c|c|c|}
\hline Operable Unit No. & Site Description & Interim Action & RI/FS ${ }^{\mathbf{b}}$ & Status \\
\hline $1-07 A$ & Test Support Facility & $\mathbf{x}$ & & ROD $^{c}$ signed 9/92-remedial action commenced 5/93 \\
\hline $1-07 \mathrm{~B}$ & Test Area North & & $\mathbf{x}$ & RI/FS and PPd complete \\
\hline 2-10 & Test Reactor Area & $\mathbf{x}$ & & "ROD signed 12/91; remedial action complete 1/94 \\
\hline $2-12$ & Test Reactor Area & & $\mathbf{x}$ & ROD signed $12 / 92$ - No Action \\
\hline 4-11 & Central Facilities Area & & $\mathbf{x}$ & ROD signed $1 / 93$ - No Action \\
\hline 4-12 & Central Facilities Area & & $\mathbf{x}$ & RL/FS under preparation \\
\hline 5-05 & SL-1 Burial Ground & & $\mathbf{x}$ & Final SOWe $12 / 93$ \\
\hline $5-10$ & Auxiliary Reactor Area & & $\mathbf{x}$ & ROD signed 12/92 - No Action \\
\hline \multirow[t]{2}{*}{$5-13$} & $\begin{array}{l}\text { Power Burst Facility Reactor Area Corrosive } \\
\text { Waste Disposal Sump Brine Tank }\end{array}$ & $\mathbf{X}$ & & ROD signed $9 / 92 ; R D / R A^{f}$ in process \\
\hline & $\begin{array}{l}\text { Power Burst Facility Reactor Area } \\
\text { Evaporation Pond }\end{array}$ & $\mathbf{x}$ & & ROD signed 9/92; RD/RA in process \\
\hline $7-08$ & Organic Contamination in Vadose Zone & & $\mathbf{x}$ & RI/FS complete 1/94; PP complete; ROD in process \\
\hline $7-10$ & Pit 9 Process Demonstration & $\mathbf{x}$ & & ROD signed 10/93; RD/RA in process \\
\hline $7-12$ & $\operatorname{Pad} \mathbf{A}$ & & $\mathbf{x}$ & ROD signed 6/92; draft RA report submitted 1/94 \\
\hline 8-07 & $\begin{array}{l}\text { Naval Reactors Facility Industrial Waste } \\
\text { Ditch }\end{array}$ & & $\mathbf{x}$ & RI/FS complete 2/94; PP complete 4/94; ROD in process \\
\hline $10-5$ & Unexploded Ordnance & $\mathbf{x}$ & & ROD signed 6/92; draft RA report submitted 1/94 \\
\hline $10-6$ & Radioactively Contaminated Soils & $\mathbf{x}$ & & SOW completed $12 / 93$ \\
\hline $\begin{array}{l}\text { a. This table retlocts or } \\
\text { Other Track } 1 \text { and Trac } \\
\text { b. Remedial Investigati } \\
\text { c. Record of Decision. } \\
\text { d. Project Plan. } \\
\text { c. Soope of Work. } \\
\text { f. Remedial Desiga/Re }\end{array}$ & $\begin{array}{l}\text { y those actions under the rederal Facility Agreeme } \\
2 \text { actions are not reflected in the table, although } \infty \\
\text { on/Feasibility Study. } \\
\text { nedial Action. }\end{array}$ & $\begin{array}{l}\text { Consent Order tha } \\
\text { siderable action has }\end{array}$ & $\begin{array}{l}\text { have been } \\
\text { een perfor }\end{array}$ & $\begin{array}{l}\text { signated as internm actions or RI/FSS. } \\
\text { ed at these various operabte units. }\end{array}$ \\
\hline
\end{tabular}


Table 7.2-2 National Environmental Policy Act documents.

\begin{tabular}{|c|c|c|c|}
\hline Description of Action & Status $^{\mathbf{a}}$ & EIS & EA \\
\hline Waste management operations at the INEL & ROD issued 1977 & $\mathbf{X}$ & \\
\hline Special Isotope Separation Project & ROD issued January 1989 & $\mathbf{X}$ & \\
\hline Siting, construction and operation of New Production Reactor capacity & Draft EIS issued April 1991 & $\mathbf{X}$ & \\
\hline Transportation, receipt, and storage of spent nuclear fuel from the Fort St. Vrain Reactor to the INEL & FONSI issued February $1991^{b}$ & & $\mathbf{X}$ \\
\hline $\begin{array}{l}\text { INEL Federal Aviation Administration Explosive Detection System Independent Validation and } \\
\text { Verification Program }\end{array}$ & FONSI issued May 1991 & & $\mathbf{X}$ \\
\hline Test Reactor Area evaporation pond & FONSI issued December 1991 & & $\mathbf{X}$ \\
\hline Expansion of the INEL Research Center & FONSI issued March 1994 & & $\mathbf{x}$ \\
\hline High Level Waste Tank Farm Replacement Project & FONSI issued June $1993^{c}$ & & $\mathbf{x}$ \\
\hline Decontamination and selective demolition of Auxiliary Reactor Areas II and III & FONSI issued September 1993 & & $\mathbf{x}$ \\
\hline Low-level and mixed waste processing at the Waste Experimental Reduction Facility & FONSI issued June 1994 & & $\mathbf{x}$ \\
\hline Retrieval and re-storage of Transuranic Storage Area waste at the INEL & FONSI issued May 1992 & & $\mathbf{x}$ \\
\hline INEL Sewer System Upgrade Project & FONSI issued April 1994 & & $\mathbf{x}$ \\
\hline INEL Consolidated Transportation Facility & FONSI issued April 1993 & & $\mathbf{x}$ \\
\hline Waste Characterization Facility & In preparation & & $\mathbf{x}$ \\
\hline Test Area North Pool Stabilization Project & In preparation & & $\mathbf{x}$ \\
\hline Replacement of the Radiological and Environmental Sciences Laboratory & In preparation & & $\mathbf{x}$ \\
\hline Interim Action for the cleanup of Pit 9 at Radioactive Waste Management Complex & FONSI issued July 1993 & & $\mathbf{x}$ \\
\hline
\end{tabular}


Table 7.2-2 (continued).

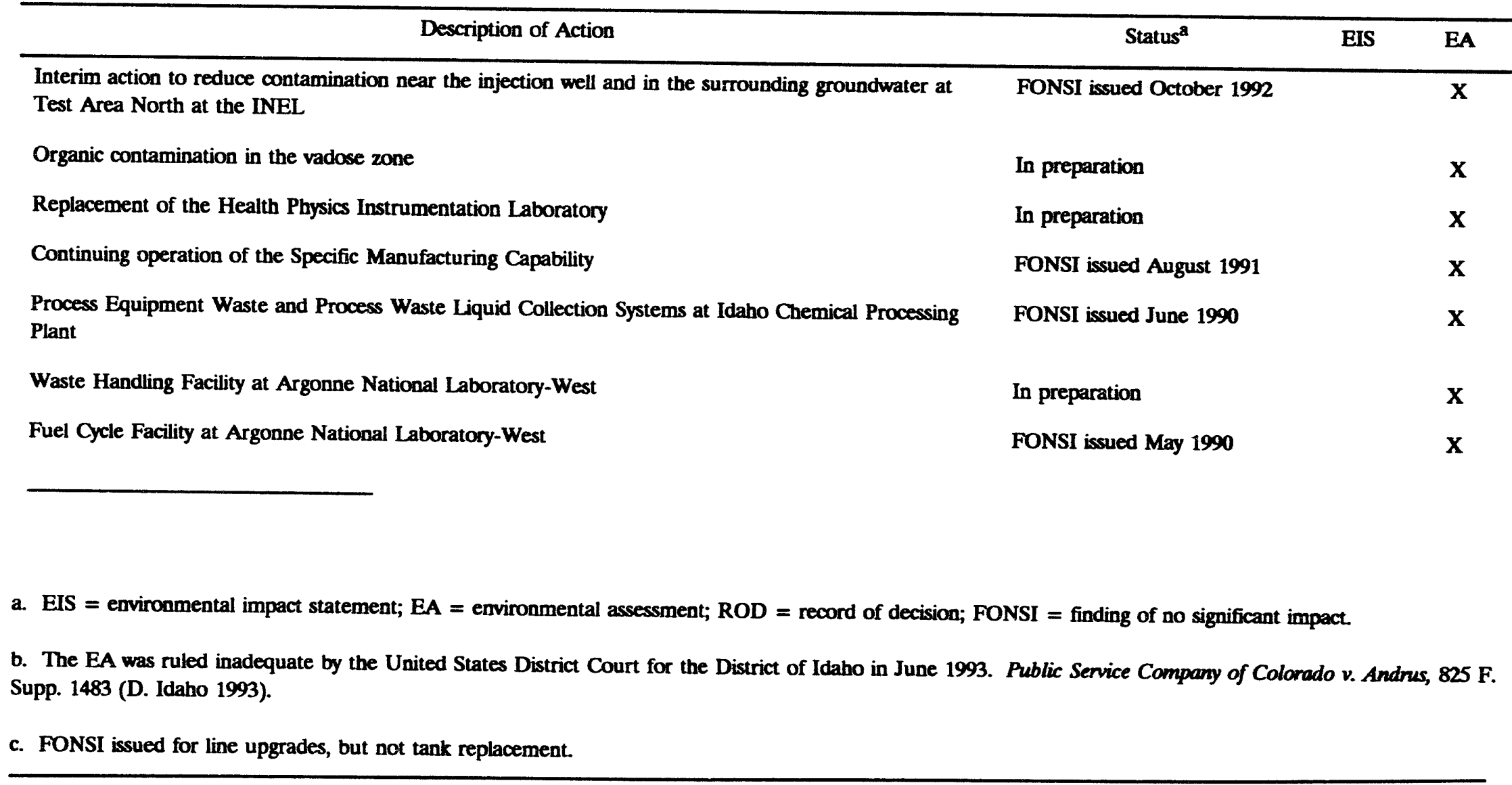


Idaho Falls regularly monitor the INEL's drinking water supply system. The most recent State audit was conducted in December 1990.

7.2.5.5 Clean Alr Act. The INEL has several facilities with air quality permits from the State of Idaho. These facilities are operated in compliance with permit conditions. Permit applications currently are pending with the State of Idaho for proposed new or modified emission sources. Table 7.2-3 lists current air permits, under the Clean Air Act, in effect and pending at the INEL.

An inventory of all potential radioactive and criteria pollutant emission sources was completed and sent to the State of Idaho in April 1991. The inventory contains information necessary to issue the INEL a Permit to Operate.

The Idaho Department of Health and Welfare, Division of Environmental Quality, and Air Quality Bureau conduct annual inspections of the INEL facility to determine whether the operating portions of the facility are in compliance with the Rules and Regulations for the Control of Air Pollution in Idaho. The most recent inspections were conducted in February and March 1992.

Additionally, pursuant to 40 CFR Part $61.94(\mathrm{H})$, the DOE submits on an annual basis a report documenting compliance with National Emission Standards for Hazardous Air Pollutants at the INEL.

On September 12-14, 1990, and again on March 18-21, 1991, the Idaho Department of Health and Welfare inspected the status of INEL's compliance with air quality regulations. As a result of these inspections, the DOE was issued an Air Quality Notice of Violation on June 5, 1991. This Air Quality Notice of Violation was recently resolved by the DOE and the State by execution of a consent order.

7.2.5.6 Clean Water Act. The INEL does not discharge liquid effluents to surface waters of the United States. Sewage treatment plants are operated in compliance with applicable 
Table 7.2-3. Permits held or applied for by the Idaho National Engineering Laboratory.

\begin{tabular}{|c|c|c|c|c|c|}
\hline Permit No. & $\begin{array}{l}\text { Regulatory } \\
\text { agency }\end{array}$ & Permit type & Facility permitted & Application date & Date issued \\
\hline PSD-X81-11 & EPA & PTC/PSD & Coal Fired Steam Generating Facility, ICPP & & $2 / 86$ \\
\hline 0340-0001-300 & IAQB & PTC/PSD & $\begin{array}{l}\text { Fuel Processing Restoration Project, ICPP. Includes all boilers } \\
\text { from ICPP, CFA, ARA, ANL-W, PBF, RWMC, TRA, NRF, } \\
\text { WERF Incinerator }\end{array}$ & $4 / 88$ & $8 / 89$ \\
\hline $0140-0022$ & IAQB & PTC/PSD & Hot Fuel Examination Facility/South Modifications, ANL-W & $1 / 88$ & Pending \\
\hline 900809 & IAQB & PTC/PSD & SMC TAN 607 R\&D Facility & $8 / 90$ & $12 / 90$ \\
\hline $0140-0022$ & IAQB & PTC/PSD & Paint Spray Booth at ANL-W & $10 / 89$ & $2 / 92$ \\
\hline $0340-0001$ & IAOB & PTC & Classified Incinerator, SMC & $1 / 86$ & 3/86 \\
\hline $0260-0030$ & IAQB & PTC & 2B Paint Process, SMC & $11 / 89$ & 3/90 \\
\hline $0340-0001$ & IAQB & PTC & CFA 609 Boiler & $3 / 87$ & $5 / 87$ \\
\hline $0340-0001$ & IAQB & PTC & ICPP Hazardous Waste Chemical Handling Facility (637) & $12 / 91$ & Pending \\
\hline 0340-0001-11 & IAQB & PTC & $\begin{array}{l}\text { Waste Experimental Reduction Facility and Waste Engineering } \\
\text { Development Faciity }\end{array}$ & $\begin{array}{l}\text { Revision Submitted } \\
5 / 93\end{array}$ & $10 / 87$ \\
\hline $0340-0001$ & IAQB & PTC & $\begin{array}{l}\text { Transuranic Storage Area Retrieval Enclosure and Transuranic } \\
\text { Waste Storage Facility }\end{array}$ & 3/90 & $12 / 90$ \\
\hline $0340-0001$ & IAQB & PTC/PSD & Test Reactor Area Evaporation Pond & $11 / 88$ & $10 / 90$ \\
\hline 0340-0001-300 & IAQB & PTC & Process Experimental Pilot Plant & $10 / 86$ & $12 / 86$ \\
\hline $0340-0001$ & IAQB & PTC & ICPP Hazandous Chemical Handling Facility (660) & $2 / 88$ & $8 / 88$ \\
\hline \multirow[t]{2}{*}{$0340-0001$} & IAQB & PTC & Fuoric Acid Supply System ICPP & 6/88 & $3 / 90$ \\
\hline & IAQB & PTC/BRC & Diesel Pump for Fire Water at ICPP & 4/90 & $4 / 90$ \\
\hline $0340-0001$ & IAQB & PTC & HF Acid Storage Tank, ICPP & & \\
\hline \multirow[t]{4}{*}{$0340-0001$} & IAQB & PTC & ARVFS NaK D\&D Project, TAN & $12 / 88$ & $10 / 89$ \\
\hline & IAQB & PTC/PSD & SMC Facility Permit & $12 / 91$ & Pending \\
\hline & IAQB & PTC/PTO & IRC Chemistry Wing Addition & $4 / 91$ & Pending \\
\hline & IAQB & PTC/BRC & Perchloric Acid Hood, IRC & $7 / 91$ & $9 / 91$ \\
\hline
\end{tabular}




\begin{tabular}{|c|c|c|c|c|c|}
\hline \multirow[t]{18}{*}{ Permit No. } & $\begin{array}{l}\text { Regulatory } \\
\text { agency }\end{array}$ & Permit type & Facility permitted & Application date & Date issued \\
\hline & & PTC & Expended Core Facility Dry Cell Project & & \\
\hline & IAQB & PTC & FDP Development and Support Faciity, ICPP & $1 / 90$ & Pending \\
\hline & LAQB & PTC/BRC & Anti-C Safety Equipment Building, ICPP & 3/91 & $11 / 91$ \\
\hline & IAQB & PTC/BRC & Ongoing R\&D Project (MOD. 2), SMC TAN-679 & $8 / 91$ & Pending \\
\hline & IAQB & PTC/PTO & ICPP Pilot Plants & $12 / 90$ & $3 / 92$ \\
\hline & IAQB & PTC/PSD & SIS Production Plant, ICPP and Stand Alone Storage Vault & $\begin{array}{l}12 / 87 \text { Resubmitted } \\
2 / 88\end{array}$ & $\begin{array}{l}\text { Withdrawn } \\
2 / 90\end{array}$ \\
\hline & IAQB & PTC/BRC & Acid Fractionator Pilot Plant, ICPP & & \\
\hline & IAQB & PTC/BRC & $\mathrm{NO}_{x}$ Abatement Pilot Plant ICPP & $12 / 91$ & $2 / 92$ \\
\hline & IAQB & PTC/BRC & PEW Evaporator, ICPP & & \\
\hline & IAQB & PTC/BRC & Diesel Pump at ICPP Injection Well & $1 / 89$ & Pending \\
\hline & IAQB & PTC/BRC & $\begin{array}{l}\text { TAN Fire Station Emergency Generator and Vehicle Trunks, } \\
\text { TAN } 688\end{array}$ & $11 / 88$ & Pending \\
\hline & IAQB & PTC & CFA 665 Boiler Replacement & & \\
\hline & IAQB & PTC/BRC & TREAT Facility at ANL-W & & \\
\hline & IAQB & PTC/BRC & Emergency Diesel Generator at ANL-W & 3/90 & 4/90 \\
\hline & IAQB & PTC/BRC & Electrolytic Dissolver Pilot Ptant, ICPP & & \\
\hline & IAQB & PTC/BRC & Cold-Feed Make-up Pilot Plant, ICPP & & \\
\hline & IAQB & PTC/BRC & In-Situ Vitrification Intermediate Scale Demo at WRRTF & & $7 / 89$ \\
\hline Phase 2d & IDHW & RCRA Part B & RWMC & $5 / 91$ & Pending \\
\hline Phase 2h & IDHW & RCRA Part B & HWSF & $11 / 91$ & Pending \\
\hline Phase 2j & IDHW & RCRA Part B & HCWHF & $6 / 92$ & Pending \\
\hline Phase 2k & IDHW & RCRA Part B & NWCF & $11 / 91$ & Pending \\
\hline
\end{tabular}


Table 7-3. (continued).

\begin{tabular}{|c|c|c|c|c|c|}
\hline Permit No. & $\begin{array}{l}\text { Regulatory } \\
\text { agency }\end{array}$ & Permit type & Facility permitted & Application date & Date issued \\
\hline
\end{tabular}

NWCF = New Waste Calcining Facility

RWMC = Radioactive Waste Management Complex

HWSF = Hazardous Waste Storage Facility

ICPP = Idaho Chemical Processing Plant

SMC = Special Manufacturing Capability

IRC $=$ INEL Research Center

IAOB = Idaho Air Quality Bureau

EPA = U.S. Environmental Protection Agency

BRC $=$ Below Regulatory Concern

PTC $=$ Permit to Construct

PTO = Permit to Operate

PSD $=$ Prevention of Significant Deterioration

a. Permit issued but suspended after June 1993 following Court Ruling; DOENaval Reactors will apply for reinstatement if Dry Cell Project is determined to proceed after the Record of Decision. 
State regulations. The DOE has obtained a general permit for storm water discharges under the National Pollution Discharge Elimination System regulations, and has prepared storm water pollution prevention plans for industrial facilities at the INEL and for construction activities.

7.2.5.7 Toxlc Substances Control Act. Efforts to comply with the Toxic Substances Control Act included the implementation of a plan at INEL to remove or retrofill polychlorinated biphenyl and polychlorinated biphenyl-contaminated transformers and capacitors. Following a September 1988 inspection, the U.S. Environmental Protection Agency (EPA) issued a Complaint and Notice for Opportunity for Negotiation concerning alleged Toxic Substances Control Act violations. The Complaint alleged that the INEL violated the record keeping and use provisions of the polychlorinated biphenyl regulations. After attending a settlement conference with the EPA, the DOE implemented a plan to remove or retrofill polychlorinated biphenyl and polychlorinated biphenyl-contaminated transformers and capacitors. During 1990, 69 polychlorinated biphenyl capacitors and 16 polychlorinated biphenyl-contaminated transformers were removed from service or retrofilled and reclassified as non-polychlorinated biphenyl. There are currently no polychlorinated biphenyl capacitors and only two polychlorinated biphenylcontaminated transformers in service at the INEL.

In conjunction with efforts at DOE Headquarters, DOE-ID is in the process of preparing a strategy to address management of radioactively contaminated polychlorinated biphenyls and "mixed" polychlorinated biphenyls (polychlorinated biphenyls mixed with Resource Conservation and Recovery Act hazardous wastes) currently in storage at the INEL.

\subsubsection{Resource Conservation and Recovery Act and State of Idaho Hazardous}

Waste Management Act. The State of Idaho was granted final authorization by the U.S.

Environmental Protection Agency (EPA) to operate its hazardous waste program in lieu of the Federal Resource Conservation and Recovery Act program (with the exception of the Hazardous and Solid Waste Amendments corrective action provisions) on April 9, 1990. Before this point, the EPA administered the entire Resource Conservation and Recovery Act program in Idaho. On June 5, 1992, the State of Idaho received final authorization for the Hazardous and Solid Waste Amendments corrective action provisions. 
In October 1985, Resource Conservation and Recovery Act Part A and B permit applications were submitted by DOE-ID to EPA Region 10 for a number of hazardous waste units at the INEL. In November 1985, the EPA requested additional information on hazardous waste land disposal units at the INEL. It was determined that corrective action for these units would be the subject of a Consent Order and Compliance Agreement that was signed by the EPA, DOE-ID, and the U. S. Geological Survey in July 1987. In December 1991, the Federal Facility Agreement and Consent Order was signed. The Federal Facility Agreement and Consent Order superseded the Consent Order and Compliance Agreement that resulted in corrective action requirements at the INEL being investigated under 40 CFR Part 120 (Comprehensive Environmental Response, Compensation, and Liability Act).

After DOE-ID's submittal of an initial Part A and B permit application in October 1985, the State of Idaho and EPA Region 10 concluded the application was incomplete. On September 23, 1988, the EPA announced that hazardous waste management units involving radioactive waste mixed with hazardous waste in existence on or before July 3,1986 , were eligible for interim status if Resource Conservation and Recovery Act Part A permit applications identifying these units were submitted by March 23, 1989. On November 8, 1988, DOE-ID submitted a revised Part A and B permit application for Resource Conservation and Recovery Act units at the INEL. The permit application addressed all hazardous and mixed waste management units potentially subject to the Resource Conservation and Recovery Act, thus qualifying these units for interim status. Because of the large number of units involved, adequate time was not available for submittal of all of the Part B permit application by November 8, 1988. Thus, a schedule was negotiated for submitting the Part B permit applications on a phased basis (see Table 7.2-4). The State of Idaho issued a determination in March 1990 that the units listed in the DOE-ID November 1988 Part A permit application were eligible for interim status. On March 19, 1991, the State of Idaho approved interim status for all INEL units listed in the September 1990 submittal of the INEL Permit Application. 
Table 7.2-4. Resource Conservation Recovery Act permitting status table.

\begin{tabular}{|c|c|c|c|}
\hline \multirow[b]{2}{*}{ RCRA unit } & \multirow[b]{2}{*}{ Part A status } & \multicolumn{2}{|c|}{ Part B status } \\
\hline & & $\begin{array}{l}\text { Submitted/planned submittal } \\
\text { date }\end{array}$ & Permit issued \\
\hline ANL-W Radicactive Scrap and Waste Facility & Interim status & $780 / 90$ & $12 / 93$ \\
\hline ANL-W Waste Characterization Facility & Interim status & $7 / 30 / 90$ & \\
\hline ANL-W Radioactive Sodium Storage Facility & Interim status & $7 / 30 / 90$ & 12993 \\
\hline RWMC Waste Storage Facility & Interim status & $5 / 30 / 91$ & \\
\hline ILTSF (Pad 1) & Interim status & To be closed & \\
\hline ILTSF (Pad 2) & Interim status & $5 / 30 / 91$ & \\
\hline New Waste Calcining Facility & Interim status & 10/01/91 & \\
\hline CPP-633 WCF Evaporator & Interim status & To be closed & \\
\hline CPP-633 WCF Storage Tanks (4) & Interim status & To be closed & \\
\hline CPP-633 WCF HEPA Filter Storage & Interim status & To be closed & \\
\hline CPP-640 Headend Holdup Storage Tanks (3) & Interim status & To be closed & \\
\hline CPP-633 Hot Shop Storage Tank & Interim status & To be closed & \\
\hline ICPP Percolation Ponds & Interim status & To be closed & \\
\hline ICPP Tank Farm (15 of 19 Tanks) & Interim status & To be closed & \\
\hline CPP-666 FAST Storage and Treatment Tanks (2) & Interim status & To be closed & \\
\hline CPP-1619 HCRWSF Hazardous Waste Compactor & Interim status & To be closed & \\
\hline $\mathrm{NO}_{x}$ Abatement Storage Tanks & Interim status & To be closed & \\
\hline FPR Storage Tanks & Interim status & To be closed & \\
\hline CPP-659 Organic Solvent Storage Tanks & Interim status & To be closed & \\
\hline Hazardous Waste Storage Facility & Interim status & $11 / 29 / 91$ & \\
\hline HCWHNF & Interim status & $6 / 30992$ & \\
\hline Waste Experimental Reduction Facility & Interim status & $10 / 30 / 92$ & \\
\hline FAST HEPA Fitter Storage & Interim status & $6 / 30 / 93$ & \\
\hline
\end{tabular}




\begin{tabular}{|c|c|c|c|}
\hline \multirow[b]{2}{*}{ RCRA unit } & \multirow[b]{2}{*}{ Part A status } & \multicolumn{2}{|c|}{ Part B status } \\
\hline & & $\begin{array}{l}\text { Submitted/planned submittal } \\
\text { date }\end{array}$ & Permit issued \\
\hline NWCF HEPA Fitter Leaching System & Interim status & $6 / 30 / 93$ & \\
\hline LET\&D Facility & Interim status & $6 / 30 / 93$ & \\
\hline NWCF & Interim status & 6/30/93 & \\
\hline Mixed Waste Storage Facility & Interim status & $7 / 31 / 93$ & \\
\hline Portable Storage Units & Interim status & $7 / 31 / 93$ & \\
\hline WERF Waste Storage Building & Interim status & $7 / 31 / 93$ & \\
\hline SMC Hazardous Waste Storage Area & Interim status & $7 / 31 / 93$ & \\
\hline Evaporators at TAN-607A and TAN-681 & Interim status & To be closed & \\
\hline TSA-RE Retrieval Modification Facility & Interim status & $2 / 28 / 94$ & \\
\hline Waste Characterization Facility & Interim status request & $2 / 28 / 94$ & \\
\hline TSA-3 (SWEPP) & Interim status & $2 / 28 / 94$ & \\
\hline PREPP Incinerator & Interim status & To be closed & \\
\hline PREPP Waste Stabilization & Interim status & To be closed & \\
\hline Reactives Storage and Treatment Area & Interim status & To be closed & \\
\hline TAN-726 Chromate Waste Storage & Interim status & To be closed & \\
\hline TAN-647 Sodium Storage & Interim status & To be closed & \\
\hline IET Mercury Storage & Interim status & To be closed & \\
\hline HTRE-3 Assembly & Interim status & To be closed & \\
\hline ARVFS Storage (NaK) & Interim status & To be closed & \\
\hline ARVFS Chemical Treatment (NaK) at WRRTF & Interim status & To be closed & \\
\hline TAN-726A Chromate Treatment & Interim status & To be closed & \\
\hline TSA-1TSA-R & Interim status & To be closed & \\
\hline TSA-2 & Interim status & To be closed & \\
\hline
\end{tabular}


Table 7.2-4. (continued).

\begin{tabular}{|c|c|c|c|}
\hline \multirow[b]{2}{*}{ RCRA unit } & \multirow[b]{2}{*}{ Part A status } & \multicolumn{2}{|c|}{ Part B status } \\
\hline & & $\begin{array}{l}\text { Submitted/planned submittal } \\
\text { date }\end{array}$ & Permit issued \\
\hline TSA-3 (C\&S Building) & Interim status & To be closed & \\
\hline TSA-610 Lead Storage Building & Interim status & To be closed & \\
\hline NODA Treatment & Interim status & To be closed & \\
\hline ICPP Tank Farm & Interim status & $7 / 30 / 94$ & \\
\hline PEW System & Interim status & $7 / 30 / 94$ & \\
\hline Calcine Bin Sets & Interim status & $7 / 30 / 94$ & \\
\hline RMWSF & Interim status & $6 / 30 / 95$ & \\
\hline HCRWSF & Interim status & $6 / 30 / 95$ & \\
\hline Westside Holdup Storage Tanks & Interim status & $6 / 30 / 95$ & \\
\hline WG/WH Cells Storage and Treatment Tanks & Interim status & 6/30/95 & \\
\hline CPP-601 Container Storage & Interim status requested & $6 / 30 / 95$ & \\
\hline WEDF Waste Stabilization & Interim status & $11 / 30 / 95$ & \\
\hline WEDF Storage & Interim status & $11 / 30 / 95$ & \\
\hline Evaporation & New facility & $11 / 30 / 95$ & \\
\hline Ion Exchange & Interim status & $11 / 30 / 95$ & \\
\hline Neutralization & Interim status & $11 / 30 / 95$ & \\
\hline Amalgamation & Interim status & $11 / 30 / 95$ & \\
\hline Macroencapsulation & New facility & $11 / 30 / 95$ & \\
\hline TAN-647 Waste Storage Facility & Interim status & $11 / 30 / 95$ & \\
\hline TAN-666 Storage Tanks & Interim status & $11 / 30 / 95$ & \\
\hline TAN-666 Treatment & Interim status & $11 / 30 / 95$ & \\
\hline TAN Potable Water Treatment Unit & Interim Status & $11 / 30 / 95$ & \\
\hline MLLWTF & New facility & $10 / 30 / 96$ & \\
\hline
\end{tabular}




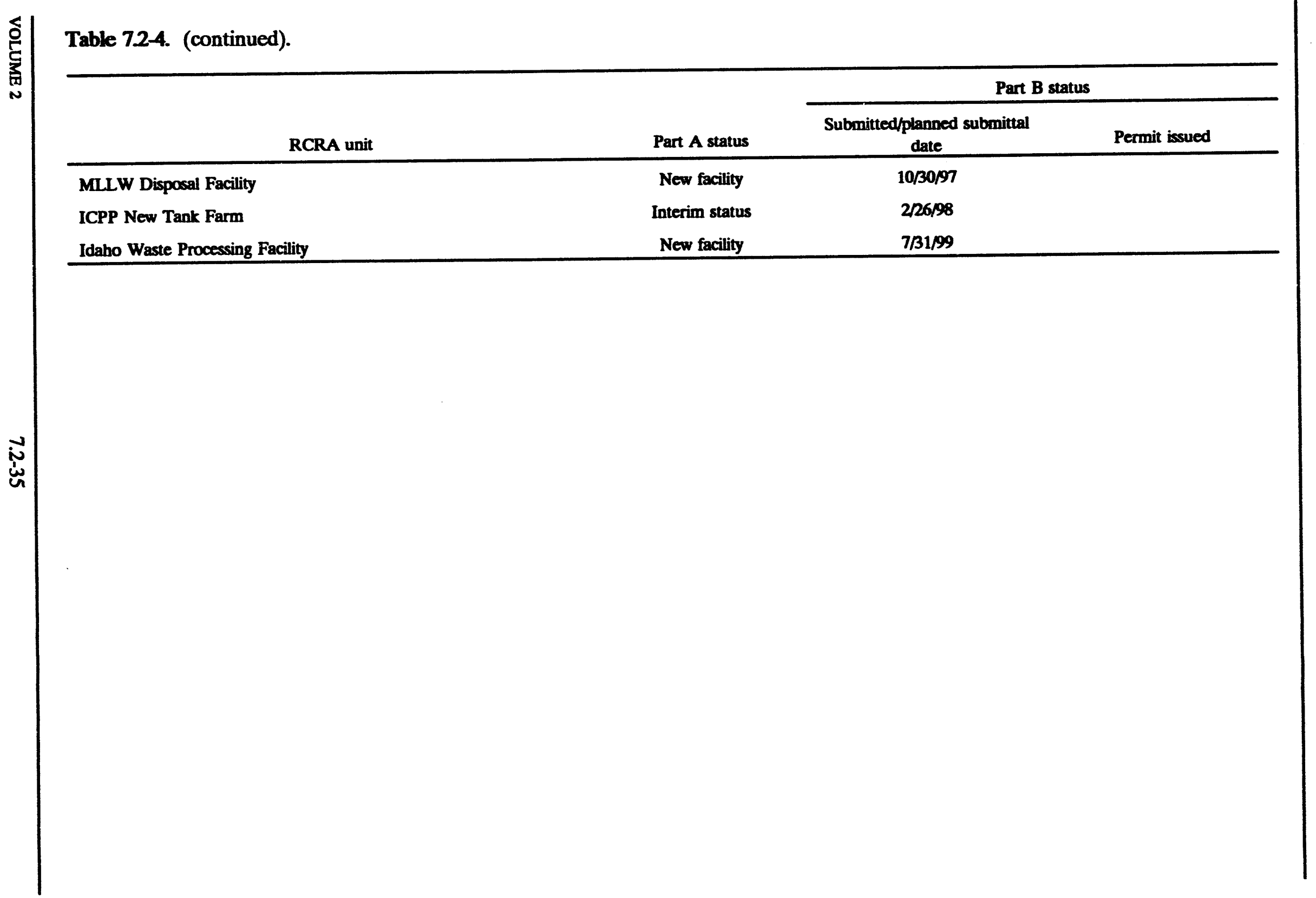


One Notice of Noncompliance and two Notices of Violation have been received from the EPA and the State of Idaho, respectively, for INEL Resource Conservation and Recovery Act hazardous waste management activities. The Notice of Noncompliance was receive by DOE-ID on January 29, 1990, and the resulting consent order was signed on April 3, 1992. The Notice of Noncompliance was based primarily on secondary containment issues for the Idaho Chemical Processing Plant Tank Farm and hazardous waste storage issues including those at the Radioactive Waste Management Complex. The consent order provides schedules for either bringing the Tank Farm into compliance with secondary containment requirements or closing the tanks. Additionally, a schedule for developing more storage capacity at the Radioactive Waste Management Complex was provided, as well as requirements for correcting the remaining violation cited in the Notice of Noncompliance. The Notice of Noncompliance Consent Order was modified on March 17, 1994, to incorporate terms of the settlement agreement among DOE, the State of Idaho, and the Navy. The first Notice of Violation was received by DOE-ID on June 5, 1991, and the resulting consent order was signed on October 23, 1992. This Notice of Violation required DOE to cease use of the Idaho Chemical Processing Plant Percolation Ponds for disposal of hazardous waste and begin Resource Conservation and Recovery Act closure. This Notice of Violation also addressed minor storage-related violations. The consent order provides a schedule for ceasing use of the Idaho Chemical Processing Plant Percolation Ponds and beginning Resource Conservation and Recovery Act ciosure. The consent order also sets requirements for coming into compliance on the storage-related violations. The second Notice of Violation was received by DOE-ID in February 1993, and the resulting consent order is under negotiation. This Notice of Violation alleged minor labeling, recordkeeping, and waste characterization violations. Except for a disagreement about proper procedures for handling Comprehensive Environmental Response, Compensation, and Liability Act investigation derived waste, the minor violations were either addressed by on-the-spot corrective action or dismissed by the State of Idaho.

The INEL currently is in compliance with all applicable underground storage tank requirements (40 CFR Parts 280-281). On September 25, 1992, the EPA conducted an overview and audit of the underground storage tank program at the INEL site. The EPA physically inspected various tanks and reviewed the status of DOE's recordkeeping system. In the course of this review, potential deficiencies in contractor monthly reconciliations of tank inventory 
records were identified by the EPA. DOE-ID has provided the reconciliation records and the EPA has concurred that the potential deficiencies no longer exit. The State of Idaho routinely observes underground storage tank closure and remediation.

7.2.5.9 INEL Foderal Facllity Compliance Act Status. The DOE is developing an inventory of the mixed waste subject to the Federal Facility Compliance Act. The Interim Mixed Waste Inventory Report was completed and published by the DOE in April 1993. The Final Mixed Waste Inventory Report is scheduled to be completed during the Spring of 1994. In coordination with the development of the Interim Mixed Waste Inventory Report and the Final Mixed Waste Inventory Report, the DOE is developing a Site Treatment Plan that will identify the selected treatment for DOE's mixed waste streams. The Conceptual Site Treatment Plan was completed during October 1993. In accordance with DOE's Federal Register Notice of April 6, 1993, 58 FR 17875, the Draft Site Treatment Plan will be completed before August 1994. The Final Site Treatment Plan is scheduled to be completed before February 1995. The Consent Order based on the Site Treatment Plan will be completed before October 1995.

7.2.5.10 Transportation Requirements. All transport of hazardous and radioactive materials made offsite (that is, on public roads) is made in compliance with U.S. Department of Transportation and U.S. Nuclear Regulatory Commission requirements.

7.2.5.11 Water Quality and Wastewater Land Application. Separate from the Clean Water Act, the State of Idaho has a program that provides for the protection of all "waters of the State." Specifically, water quality standards established by the State of Idaho are met for current operations at the INEL. In addition, DOE-ID is in the process of obtaining wastewater land application permits for appropriate facilities at the INEL. Table 7.2-5 indicates those permits that have been issued in draft and those that have been applied for. 
Table 7.2-5. Wastewater Land Application Permit status.

\begin{tabular}{|c|c|c|c|c|c|}
\hline Permit No. & Regulatory & Permit Type & Facility Permitted & Application Date & Date Issued \\
\hline LA-000130 & $\mathrm{DEQ}^{\mathrm{a}}$ & WLAP & $\begin{array}{l}\text { Idaho Chemical Processing Plant } \\
\text { Percolation Ponds }\end{array}$ & August 1992 & \\
\hline \multirow[t]{3}{*}{ LA-000115 } & DEQ & WLAP & $\begin{array}{l}\text { Idaho Chemical Processing Plant } \\
\text { Sewage Treatment Plant Infiltration } \\
\text { Trenches }\end{array}$ & September 1992 & \\
\hline & DEQ & WLAP & $\begin{array}{l}\text { Central Facilities Area Sewage } \\
\text { Treatment Plant Sprinkler System }\end{array}$ & August 1993 & \\
\hline & DEQ & WLAP & $\begin{array}{l}\text { Test Area North Sewage Treatment } \\
\text { Plant Infiltration Pond }\end{array}$ & In preparation & \\
\hline
\end{tabular}




\subsection{Environmental Permits and Licenses}

This section lists, by project in Table 7.3-1, the Federal permits, licenses, and other entitlements that may be required to be obtained in implementing the proposed actions. Because some of the proposed actions are not yet clearly defined, it is not certain whether permits will be required for some of the proposed facilities. As such, this list is not complete nor absolute, and the requirements listed may be deleted, modified, or supplemented as further information becomes available. Appendix C, Information Supporting the Alternatives, givis more details on the individual projects listed in the table.

The permitting requirements are described in a general manner. For example, the designation of "solid and hazardous waste" would encompass any permitting requirements under the Resource Conservation and Recovery Act, or any state solid or hazardous waste permitting requirements. "Air" would include any permitting requirements under the Clean Air Act or state equivalent, and would also include any approvals needed to be obtained, such as the approvals required under the National Emissions Standards for Hazardous Air Pollutants program. Finally, "water" would encompass any permitting requirements under the Clean Water Act, and related programs, including National Pollutant Discharge Elimination System (NPDES in general and storm water discharge permits), waste water land application permits (specific to the State of Idaho), and any approvals required under the Safe Drinking Water Act. 
Table 7.3-1. Project-specific list of permits, licenses, and so forth, that may be required.

\begin{tabular}{|c|c|c|c|}
\hline Project & $\begin{array}{c}\text { Solid \& } \\
\text { Hazardous } \\
\text { Waste }\end{array}$ & Air & Water \\
\hline Expended Core Facility Dry Cell Project & & $\mathbf{x}$ & \\
\hline Increased Rack Capacity for Building CPP-666 & & $\mathbf{x}$ & \\
\hline Additional Increased Rack Capacity (CPP-666) & & $\mathbf{x}$ & \\
\hline $\begin{array}{l}\text { Dry Fuel Storage Facility; Fuel Receiving, Canning/Characterization \& } \\
\text { Shipping }\end{array}$ & & $\mathbf{x}$ & \\
\hline Fort St. Vrain Spent Nuclear Fuel Shipment \& Storage & & $\mathbf{X}$ & \\
\hline Spent Fuel Processing & $\mathbf{x}$ & $\mathbf{x}$ & \\
\hline Experimental Breeder Reactor-II Blanket Processing & & $\mathbf{x}$ & \\
\hline Actinide Recycle Demonstration & & $\mathbf{X}$ & \\
\hline $\begin{array}{l}\text { Central Liquid Waste Processing Facility Decontamination \& } \\
\text { Decommissioning (D\&D) }\end{array}$ & & $\mathbf{x}$ & \\
\hline \multicolumn{4}{|l|}{ Engineering Test Reactor D\&D } \\
\hline \multicolumn{4}{|l|}{ Materials Test Reactor D\&D } \\
\hline Fuel Processing Complex (CPP-601) D\&D & $\mathbf{x}$ & & \\
\hline Fuel Receipt/Storage Facility (CPP-603) D\&D & $\mathbf{x}$ & & \\
\hline Headend Processing Plant (CPP-640) D\&D & $\mathbf{x}$ & & \\
\hline Waste Calcine Facility (CPP-633) D\&D & $\mathbf{X}$ & $\mathbf{X}$ & \\
\hline Tank Farm Heel Removal Project & $\mathbf{x}$ & $\mathbf{X}$ & \\
\hline Waste Immobilization Facility & $\mathbf{x}$ & $\mathbf{x}$ & \\
\hline High-Level Tank Farm New Tanks & $\mathbf{X}$ & $\mathbf{X}$ & \\
\hline New Calcine Storage & $\mathbf{x}$ & $\mathbf{x}$ & \\
\hline \multicolumn{4}{|l|}{ Radioactive Scrap/Waste Facility } \\
\hline Private Sector Alpha-Contaminated Mixed Low-Level Waste Treatment & $\mathbf{x}$ & $\mathbf{x}$ & $\mathbf{x}$ \\
\hline $\begin{array}{l}\text { Radioactive Waste Management Complex Modifications to Support } \\
\text { Private Sector Treatment of Alpha-Contaminated Mixed Low-Level } \\
\text { Waste }\end{array}$ & $\mathbf{x}$ & $\mathbf{x}$ & $\mathbf{x}$ \\
\hline Idaho Waste Processing Facility & $\mathbf{x}$ & $\mathbf{x}$ & $\mathbf{x}$ \\
\hline Shipping/Transfer Station & & $\mathbf{x}$ & \\
\hline Waste Experimental Reduction Facility Incineration & $\mathbf{x}$ & $\mathbf{X}$ & \\
\hline Mixed/Low-Level Waste Treatment Facility & $\mathbf{X}$ & $\mathbf{X}$ & $\mathbf{x}$ \\
\hline Mixed/Low-Level Waste Disposal Facility & $\mathbf{x}$ & $\mathbf{X}$ & $\mathbf{x}$ \\
\hline
\end{tabular}


Table 7.3-1. (continued).

\begin{tabular}{lccc}
\multicolumn{1}{c}{ Project } & $\begin{array}{c}\text { Solid \& } \\
\text { Hazardous } \\
\text { Waste }\end{array}$ & Air & Water \\
\hline Nonincinerable Mixed Waste Treatment & $\mathbf{X}$ & $\mathbf{X}$ & \\
Remote Mixed Waste Treatment Facility & $\mathbf{X}$ & $\mathbf{X}$ & $\mathbf{X}$ \\
Sodium Processing Project & $\mathbf{X}$ & $\mathbf{X}$ & \\
Greater-Than-Class-C Dedicated Storage & $\mathbf{X}$ & $\mathbf{X}$ & $\mathbf{X}$ \\
Hazardous Waste Treatment, Storage, and Disposal Facilities & $\mathbf{X}$ & $\mathbf{X}$ & $\mathbf{X}$ \\
Industrial/Commercial Landfill Expansion & $\mathbf{X}$ & $\mathbf{X}$ & $\mathbf{X}$ \\
Gravel Pit Expansions & & $\mathbf{X}$ & $\mathbf{X}$ \\
Central Facilities Area Clean Laundry and Respirator Facility & & $\mathbf{X}$ & \\
Calcine Transfer Project (Bin Set $\# 1$ 1) & & & \\
Plasma Hearth Process Project & & & \\
\hline
\end{tabular}




\section{INDEX}

Subjects are lidered by wection, figure, table, and appendiv designations only.

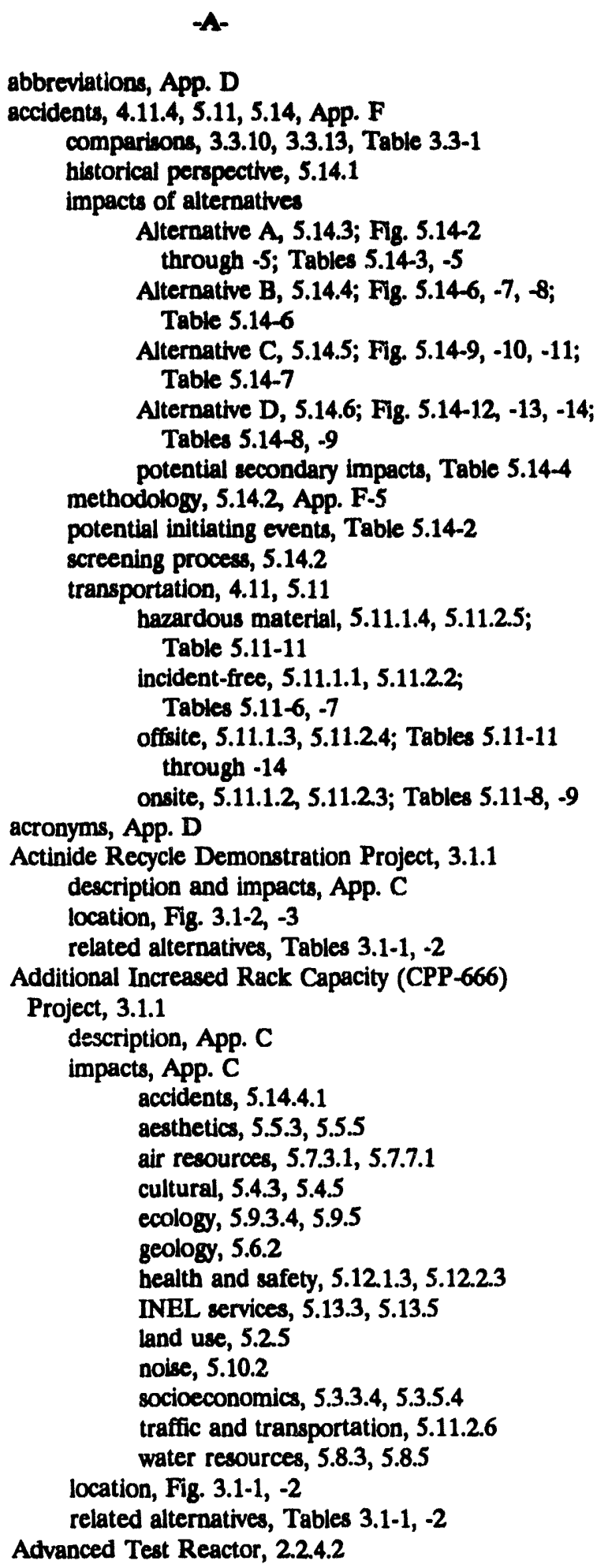

$-1-$

abbreviations, App. D

accidents, 4.11.4, 5.11, 5.14, App. F

comparisons, 3.3.10, 3.3.13, Table 3.3-1

historical perspective, 5.14 .1

impacts of alternatives

Alternative A, 5.14.3; Fig. 5.14-2

through .5; Tables 5.14-3, -5

Alternative B, 5.14.4; Fig. 5.14-6, -7, -8;

Table 5.14-6

Alternative C, 5.14.5; Fig. 5.14-9, -10, -11; Table 5.14-7

Alternative D, 5.14.6; Fig. 5.14-12, -13, -14;

Tables 5.14-8, -9

potential secondary impacts, Table 5.14-4

methodology, 5.14.2, App. F-5

potential initiating events, Table 5.14-2

screening process, 5.14 .2

transportation, 4.11, 5.11

hazardous material, 5.11.1.4, 5.11.2.5;

Table 5.11-11

incident-free, 5.11.1.1, 5.11.2.2;

Tables 5.11-6, -7

offisite, 5.11.1.3, 5.11.2.4; Tables 5.11-11

through -14

onsite, 5.11.1.2, 5.11.2.3; Tables 5.11-8, -9

acronyms, App. D

Actinide Recycle Demonstration Project, 3.1.1

description and impacts, App. C

location, Fig. 3.1-2, -3

related alternatives, Tables $3.1-1,-2$

Additional Increased Rack Capacity (CPP-666)

Project, 3.1.1

description, App. C

impacts, App. C

accidents, 5.14.4.1

aesthetics, 5.5.3, 5.5.5

air resources, 5.7.3.1, 5.7.7.1

cultural, 5.4.3, 5.4.5

ecology, 5.9.3.4, 5.9.5

geology, 5.6.2

health and safety, 5.12.1.3, 5.12.2.3

INEL services, 5.13.3, 5.13.5

land use, 5.2 .5

noise, 5.10 .2

socioeconomics, 5.3.3.4, 5.3.5.4

traffic and transportation, 5.11.2.6

water resources, 5.8.3, 5.8.5

location, Fig. 3.1-1, -2

related alternatives, Tables 3.1-1, -2

Advanced Test Reactor, 2.2.4.2

adverse environmental effects, 5.16

aesthetic and scenic resources

characterization, 4.5

impacts of alternatives, 5.5

adverse, 5.16 .2

Alternative A, 5.5.2

Alternative B, 5.5.3

Alternative C, 5.5.4

Alternative D, 5.5.5

comparison, 3.3.4, Table 3.3-1

cumulative, $\mathbf{5 . 1 5 . 2}$

irreversible and irretrievable, 5.18

methodology, 5.5.1

mitigation, 5.19.2

scenic areas, 4.5.2

visual character of INEL, 4.5.1

affected environment, Chapter 4

see specific discipline

air quality, 4.7

nonradiological, 4.7 .3

emission sources, 4.7.3.1, Fig. 4.7-4, Table 4.7-2

existing conditions, 4.7.3.2, Table 4.7-3

through 4.7-6

summary, 4.7.3.3

radiological, 4.7 .4

emission sources, 4.7.4.1, Table 4.7-1

existing conditions: 4.7.4.2, Fig. 4.7-3

summary, 4.7.4.3

regulations, 4.7.2, Fig. 4.7-2

compliance status at INEL, 7.2.5

environmental, 7.2

Federal, 7.2.1

State of Idaho, 7.2.4

air resource impacts, 5.7

acidic deposition, 5.7.4.3

adverse, 5.16 .3

comparison, 3.3.6

concentrations, Tables 5.7-5 through -8

cumulative, 5.15.4, Fig. 5.7-2, Table 5.15-2

emission rates, 5.7-2; Fig. 5.7-1; Tables 5.7-1, $-2,-3$

from construction, 5.7.6

from mobile sources, 5.7.5

from nonradjological sources, 5.7.4,

Tables 5.7-5 through -8

from radiological sources, 5.7.3, Table 5.7-4

Fig. 5.7-2

global warming, 5.7.4.3

irreversible and irretrievable commitment

of resources, 5.18

methodology, 5.7.1, App. F-3 
air resource impacts (continued)

mitigation, 5.19 .4

ozone effects, 5.7.4.3

regulatory compliance, 5.7 .4 .3

from specific activities, 5.7 .7

visibility degradation, Fig. 5.7-4

air resources

characteribation, 4.7

climate, 4.7.1

meteorology, 4.7.1

see also air quality and air resource impacts

aircraft noise, 4.10

airports, 4.11 .3

alpha low-level waste definition, 2.1, App. E

Alternative A: No Action

description, 2.1.1, 3.1

high-level waste, Fig. 3.1-12

impacts

adverse, 5.16

cumulative, 5.15

irreversible and irretrievable, 5.18

mitigation, 5.19

impacts on

accidents, 5.14 .3

aesthetic resources, 5.5.2

air, 5.7

cultural resources, $\mathbf{5 . 4 . 2}$

ecology, 5.9.2

geology, 5.6.2

health and safety, 5.12

occupational, 5.12.2

public, 5.12 .1

INEL services, 5.13 .2

land use, $\mathbf{5 . 2 . 2}$

noise, 5.10 .2

socioeconomics, 5.3.2

traffic/transportation, $\mathbf{5 . 1 1 . 2}$

water, 5.8.2

low-level waste, Fig. 3.1-23

mixed low-level waste, Fig. 3.1-29

projects, Fig. 3.1-2, Table 3.1-1

spent nuclear fuel, Fig. 3.1.3

transuranic waste, Fig. 3.1-18

Alternative B: Ten-Year Plan

description, 2.1.1, 3.1

high-level waste, Fig. 3.1-13

impacts

adverse, 5.16

cumulative, 5.15

irreversible and irretrievable, 5.18

mitigation, 5.19

impacts on

accidents, 5.14.4

aesthetic resources, 5.5.3

air, 5.7

cultural resources, 5.4.3

ecology, 5.9 .3

geology, 5.6.2
Aternative B impects (continued)

health and axfety, 5.12

occupational, 5.12 .2

public, $\mathbf{5 . 1 2 . 1}$

INEL services, 5.13.3

land use, 5.2 .3

noive, 5.10 .2

socioeconomics, 5.3.3

trafic/transportation, 5.11 .2

water, 5.8.3

low-level waste, Fig. 3.1-24

mixed low-level waste, Fig. 3.1-30

projects, Fig. 3.1-2, Table 3.1-1

spent nuclear fuel, Fig. 3.1-4

transuranic waste, Fig. 3.1-19

Alternative C: Minimum Treatment, Storage,

and Disposal

description, 2.1.1, 3.1

high-level waste, Fig. 3.1-14

impacts

adverse, 5.16

cumulative, 5.15

irreversible and irretrievable, 5.18

mitigation, 5.19

impacts on

accidents, 5.14.5

aesthetic resources, 5.5 .4

air, 5.7

cultural resources, 5.4 .4

ecology; 5.9 .4

geology, 5.6.2

health and safety, 5.12

occupational, 5.12.2

public, 5.12.1

INEL services, 5.13 .4

land use, 5.2 .4

noise, 5.10 .2

sociocconomics, 5.3.4

traffic/transportation, 5.11 .2

water, 5.8 .4

low-level waste, Fig. 3.1-25

mixed low-level waste, Fig. 3.1-31

projects, Fig. 3.1-2, Table 3.1-1

spent nuclear fuel, Fig. 3.1-5

transuranic, Fig. 3.1-20

Alternative D: Maximum Treatment, Storage, and Disposal

description, 2.1.1, 3.1

high-level waste, Fig. 3.1-15

impacts

adverse, 5.16

cumulative, 5.15

irreversible and irretrievable, 5.18

mitigation, 5.19

impacts on

accidents, 5.14.6

aesthetic resources, $\mathbf{5 . 5 . 5}$

air, 5.7

cultural resources, 5.4 .5 
Alternative D impacts (continued)

ecology, 5.9.5

geology, 5.6.2

health and safety, 5.12

occupational, 5.12 .2

public, 5.12 .1

INEL services, 5.13.5

land ure, 5.2 .5

noive, 5.10 .2

socioeconomics, 5.3.5

traffic/transportation, 5.11.2

water, 5.8.4

low-level waste, Fig. 3.1-26

mixed low-level waste, Flg. 3.1-32

projects, Fig. 3.1-2, Table 3.1-1

transuranic waste, Fig.3-22

alternatives, Chapter 3

comparivon, 3.3

consequences, Chapter 5

descriptions, 2.1.1, 3.1

development, 3.1

eliminated from detailed analysis, 3.2

see also specific alternative

American Indian Religious Freedom Act, 4.4.2,

5.4.1, 7.2.1.17

aquifer, see Snake River Plain Aquifer

Archaeological Resource Protection Act, 4.4.2,

5.4.1, 7.2.1.12

archeological sites, 4.4.1

impacts on, 5.4

Argonne National Laboratory-West

description, 2.2 .49

potential accidents, Tables 5.14-2, -3

projects, Fig. 3.1-1

waste information, Table 2.3

atmospheric releases

baseline health effects, 4.12 .1

impacts from alternatives, 5.12.1

Atomic Energy Act of 1954, 7.2.1.2

Auxiliary Reactor Area

description, 2.2.4.5

location, Fig. 2-3

projects, Table 3.1-1

Auxiliary Reactor Area-II D\&D Project

description and impacts, App. C

location, Fig. 3.1-1, Fig. 3.1-8

related aiternatives, Table 3.1-1

\section{$-\mathrm{B}$}

background

of EIS, Chapter 2

INEL facilities, Chapter 2

radiation, 5.14, App.A

Bald Eagle and Golden Eagle Protection Act, 7.2.1.23

Big Butte Resource Area, 4.2.1, Fig. 4.2-1

Black Canyon Wilderness Study Area, 4.2, 4.5.2,

Fig. 4.2-i
Boiling Water Reactor Experiment (BORAX) deacription, 2.2.4.6

location, Fig. 2-3

Bolling Water Reactor Experiment (BORAX)-II

D\&D Project, 3.1.2.2

description and impacts, App. C

location, Fig. 3.1-1, -9

related alternatives, Tables 3.1.1, -3

$$
\text { c. }
$$

Calcine Transfer Project, 3.1.4

description and impacts, App. C

location, Fig. 3.1-1, -37

related alternatives, Table 3.1-1

calcined high-level waste processing technology

selection impacts, see Waste Immobilization Facility

impacts

cancer riak from

accidents, 5.14

alternatives, Table 5.15-4

nonradiological releases, 5.7, 5.12

radiological releases, 5.7, 5.12

see also health effects

Central Faclities Area

accidents, 5.14; Tables 5.14-2, -3

description, 2.2.4.4

Landfill Complex, 2.2.7.3

location, Fig. 2.2-2

projects, Table 3.1-1

waste information, Table 2-3

Central Facilities Area Clean Laundry and

Respirator Facility Project, 3.1.2.1

description and impacts, App. C

location, Fig. 3.1-1, -8

related alternatives, Tables 3.1-1, -3

Central Liquid Waste Processing Facility

D\&D Project, 3.1.2.2

description and impacts, App. C

location, Fig. 3.1-1, -9

related alternatives, Tables 3.1-1, -3

Clean Air Act, 4.5, 4.7.2, 5.5.1, 7.2.1.3, 7.2.5.5

Clean Water Act, 4.8.1, 7.2.1.4, 7.2.5.6

cleanup technologies, potential, 2.2.6.1

climate, 4.7.1

comment period, scoping, 2.1.4

comments and issues, Fig. 2.1-1

community services in INEL region

background, 4.3.3

impacts of alternatives, 5.3

comparisons of alternatives

impacts, 3.3, Table 3.3-1

short-term use/long-term productivity, 5.17

compliance status at INEL, 7.2.5

Comprehensive Environmental Response,

Compensation, and Liability Act (CERCLA), 7.2.1.8, 7.2.5.1

concentrations, see criteria pollutants

connected or similar actions, impacts of, 5.15 
consultations (agency), 7.1
contaminants

ground water within INEL, Table 4.8-1

and waste area groups, Table 2-3

corrective actions for SNF, Table 2-2

Council on Environmental Quality, 2.1.1

Craters of the Moon National Monument, 4.5.1, 4.5.2, 4.9.5

Craters of the Moon Wilderness Area, 4.5.2, 4.7.1,

5.5.1, 5.7.4.1

criteria pollutants, concentrations

by alternative, Fig. 5.7-3

maximum baseline scenario, Table $4.7-4$

cultural resources

characterization, 4.4

archeological sites, 4.4.1

historic structures, 4.4 .1

Native American resources, 4.4.2

paleontological resources, 4.4 .2

impacts of alternatives, 5.4

adverse, 5.16 .1

Alternative A, 5.4 .2

Alternative B, 5.4.3

Alternative C, 5.4 .4

Alternative D, 5.4.5

comparison, 3.3.3; Tables 3.3-1, 5.4-1

cumulative impacts, 5.15.3, Table 5.15-2

irreversible and irretrievable, 5.18

methodology, 5.4.1

mitigation, 5.19.1

nonhealth-related, Table 5.15-2

transportation-related, Table 5.15-3

-D-

decontamination and decommissioning, 2.2.6.2

accident assessment, 5.14

alternatives, 3.1.2.2

description of program, 2.2 .6 .2

management activities, Fig. 3.1-9

definitions, App. $\mathbf{E}$

disturbed areas, Table 5.9-1

DOE orders and regulations, 7.2.3

doses, see radiological exposures and health effects

drainage

subsurface, 4.8 .2

surface, 4.8 .1

Dry Fuel Storage Facility; Fuel Receiving Canning/

Characterization, and Shipping Project, 3.1.1

description and impacts, App. C, App. F-3

location, Fig. 3.1-1, -2

related alternatives, Tables $3.1-1,-2$

$-\mathbf{R}$

earthquakes

as accident initiator, 5.14

historical, Fig. 4.6-3

magnitudes, 4.6.3, Fig. 4.6-3
Bastern Snake River Plain, Fig. 4.6-1, -2

EBR, see Experimental Breeder Reactor

coological resources

characterization, 4.9

consultation letters, App. B

endangered, threatened, sensitive species, 4.9.3,

Table 4.9.1

fauna, 4.9 .2

flora, 4.9.1

impacts of alternatives, 5.9

adverse, 5.16 .5

Alternative A, 5.9 .2

Alternative B, 5.9.3

Alternative C, 5.9.4

Altemative D, 5.9.5

comparison, 3.3.8, Table 3.3-1

cumulative, 5.15.6, Table 5.15-2

irreversible and irretrievable, 5.18

methodology, 5.9.1

mitigation, 5.19.6

radioecology, 4.9 .5

wetlands, 4.9 .4

electricity consumption

existing, 4.13.2

impacts of alternatives, Fig. 5.13-2

see also INEL services

Emergency Planning and Community

Right-to-Know Act, 2.2.10.1, 7.2.1.9, 7.2.5.2

emergency preparedness, 4.13.5.2

emergency protection, 4.13.5

emission rates

existing

nonradiological, Table 4.7-2

radiological, Table 4.7-1

impacts of alternatives

criteria pollutant, Table 5.7-2

radiological, Table 5.7-1

see also air quality

employment

existing, 4.3.1.1, Fig. 4.3-1

impacts of alternatives, 5.3, Table 5.3-1, Fig. 5.3-1

see also socioeconomics

endangered species, 4.9.3, Table 4.9-1

Endangered Species Act, 7.2.1.13

Engineering Test Reactor, 2.2.4.2

Engineering Test Reactor D\&D Project, 3.1.2.2

description and impacts, App. C

location, Fig. 3.1-1, -9

related alternatives, Tables 3.1-1, -3

environmental characterization, Chapter 4

see also specific disciplines

environmental consequences, Chapter 5

comparison, 3.3, Table 3.3-1

cumulative, 5.15

unavoidable adverse, 5.16

see also specific alternatives and specific disciplines 
Environmental Impact Statement (SNF and

INEL ER\&WM EIS)

activities outulde scope, 2.1.2.4

content, 2.1 .1

purpose and need, Chapter 1

related documents

ER\&WM Programmatic EIS, 2.1.3.2

Foreign Research Reactors EIS, 21.3.5

Nuclear Weapons Complex Reconfiguration Programmatic EIS, 2.1.3.3

Waste Isolation Pilot Plant EIS, 21.3.4

Waste Management Operations EIS, 2.1.3.1

scope, 21.2

scoping process, 2.1 .4

timeframe, 2.1.2.3

environmental justice, 5.20

environmental regulations, 2.2.11, Chapter 7

environmental restoration

alternatives, 3.1.2

definition, 2.1

description of program, 2.2 .6

location of projects, Fig. 3.1-1

proposed projects, Table 3.1-3

regulatory framework, 2.2.11

Environmental Restoration and Waste Management

Programmatic EIS, 2.1.3.2

Executive Orders, 7.2.2

Expended Core Facility, 2.2.4.8

Expended Core Facility Dry Cell Project, 3.1.2.2

description and impacts, App. C

location, Fig. 3.1-1, -9

related alternatives, Tables $3.1-1,-3$

Experimental Breeder Reactor-I

description, 22.4.6

location, Fig. 2.2-2

as National Historic Landmark, 2.2.4.6, 4.4.1, 4.5.1

projects, Table 3.1-1

waste information, Table 2.2-2

Experimental Breeder Reactor-II, 2.2.4.9 spent nuclear fuel from, 2.2.5.1

Experimental Breeder Reactor-II Blanket Processing

Project, 3.1.1

description and impacts, App. C air resources, 5.7.3.1

location, Fig. 3.1-1, -2

related alternatives, Tables 3.1-1, -2

exposure-to-dose conversion factors, Table 4.12-8

exposures, see radiological exposures and health

effects and nonradiological health effects

$-\mathbf{F}$

facility areas, Fig. 2.2-2

Argonne National Laboratory-West, 2.2.4.9

Central Facilities Area, 2.2.4.4

Experimental Breeder Reactor-I/Boiling Water Reactor Experiment, 2.2.4.6 facility areas (continued)

Idaho Chemical Processing Plant, 2.2.4.3

Idaho Falls Operation, 2.2.4.10

Naval Reactors Facility, 2.2.4.8

Power Burst Facility/Auxillary Reactor Area, 2.2.4.5

Radioactive Waste Management Complex, 2.2.4.7

Teat Area North, 2.2.4.1

Teat Reactor Area, 2.2.4.2

fauna see also specific facility

INEL, 4.9 .2

impacts of alternatives, 5.9

see also ecological resources

Federal environmental regulations, 7.2.1

Federal Facility Agreement/Consent Order status, 2.2.3.1, 3.1.2.1; Table 7.2-1

Federal Facility Compliance Act, 2.2.7.1.4, 7.2.1.7 status, 7.2.5.9

fire

accidental, 5.14

protection, 4.13 .5

flood plains, 4.8.1.3

floods, 4.8.1.2, 4.8.1.3

flora at INEL, 4.9.1

Foreign Research Reactors EIS, 2.1.3.5

Fort Hall Reservation, 4.2, 4.3, 4.4.2

Fort St. Vrain spent nuclear fuel, 2.2.5.1

Fort St. Vrain Spent Nuclear Fuel Shipment and

Storage Project, 3.1.1

description and impacts, App. C

location, Fig. 3.1-1, -2

related alternatives, Tables $3.1-1,-2$

fuel, spent nuclear, 2.2.5

accident assessment, 5.14

alternatives for managing, 3.1.1

current management, 2.2.5.1, Fig. 2.2-3

basic management decisions for, Fig. 3.0-1

vulnerability assessment, $\mathbf{2 . 2 . 5 . 2}$

see also spent nuclear fuel

fuel consumption

existing, 4.13.3

impacts of alternatives, Fig. 5.13-2

see also INEL services

Fuel Cycle Facility, 2.2.4.9

Fuel Processing Complex (CPP-601) D\&D

Project, 3.1.2.2

description and impacts, App. C

location, Fig. 3.1-1, -9

related alternatives, Tables 3.1-1, -3

Fuel Receipt and Storage Facility (CPP-603)

D\&D Project, 3.1.2.2

description and impacts, App. C

location, Fig. 3.1-1, -9

related alternatives, Tables 3.1-1, -3 


\section{-G-}

geological resources

characterization, 4.6, Fig. 4.6-1

impacts of alternatives, 5.6.2

comparisons, 3.3.5, Table 3.3-1

gravel/borrow pit extraction, Table 5.6-1

irreversible and irretrievable, 5.18

methodology, 5.6.1, App. F-2

mitigation, 5.19.3

global warming, 5.7.4.3

glossary, App. E

gravel/borrow pit extraction, Table 5.6-1

Gravel Pit Expansion Project, 3.1.3.7

description and impacts, App. C

location, Fig. 3.1-1, -36

related alternatives, Table 3.1-1

Greater-than-Class-C Dedicated Storage Project, 3.1.3.5

description and impacts, App. C air resources, 5.7.3.1

location, Fig. 3.1-1, -34

related alternatives, Table 3.1-1

greater-than-Class-C low-level waste, 3.1.3.5

background, 2.2.7.1.5

definition, 2.1, App. E

proposed projects, Fig. 3.1-35

groundwater

accident affecting, 5.14.3.2

chemistry, 4.8.2.5.1

contaminants, Table 4.8-1

health effects from, 4.12.1.2

impacts of alternatives, 5.12.1.2

INEL, 4.8.2.2

perched water, 4.8.2.4

quality, 4.8.2.5

regional, 4.8.2.1, Fig. 4.8-2

see also water resources

-H-

hazard quotients, Tables 4.12-3, $-4,-5,-7$

Hazardous and Radioactive Materials Transportation

Regulations, 7.2.1.10

Hazardous and Radioactive Mixed Waste Staging Area, 2.2.4.3

Hazardous Chemical/Radinactive Waste Facility, 2.2.4.3

hazardous materials

accident assessment, 5.11.2.5, 5.1\%;

Tables 5.14-2, -3

definition, 2.2.10.1

inventory, 2.2.10.1

transportation, 4.11.5, 5.11

volumes, 2.2.10.1

hazardous waste

alternatives, 3.1.3.5, Fig. 3.1-35

background at INEL, 2.2.7.2

current management, Fig. 2-10

definition, 2.1, App. E

disposal, 2.2.7.2 hazardous waste (continued)

location, 2.2.7.2

proposed projects, Table 3.1-9

location, Fig. 3.1-34

and management functions, Table 3.1-9

Hazardous Waste Storage Facility, 22.4.4

Hazardous Waste Treatment, Storage, and Disposal

Facilities Project, 3.1.3.6

description and impacts, App. C

location, Fig. 3.1-1

related alternatives, Tables 3.1-1, -9

Headend Processing Plant (CPP-640) D\&D

Project, 3.1.2.2

description and impacts, App. C

location, Fig. 3.1-1, -9

related alternatives, Tables 3.1-1, -3

health and safety

characterization, 4.12

impacts of alternatives

comparison, 3.3.11, Table 3.3-1

cumulative, 5.15.8, Table 5.15-4

irreversible and irretrievable, 5.18

methodology, 5.12.1, F-4

mitigation, 5.19.8

public safety, 5.12.1

worker safety, 5.12.2

health effects

from accidents, $5.11,5.14$

from atmospheric releases, 4.12.1.1, 5.12.1.1

from groundwater releases, 4.12.1.2, 5.12.1.2

hazard quotients, 5.12

occupational, 4.12.2, 5.12.2

Health Physics Instrument Lab Project, 3.1.3.7

description and impacts, App. C

location, Fig. 3.1-1, -36

NEPA review status, Table 2-1

related alternatives, Table 3.1-1

High-Level Tank Farm Replacement (upgrade phase)

Project, 3.1.3.1

description and impacts, 5.6.2, App. C

location, Fig. 3.1-1, -10

related alternatives, Tables 3.1-1, -5

High-Level Tank Farm New Tanks Project, 3.1.3.1 description, App. C

impacts

accidents, 5.14.5.2

aesthetics, 5.5.4, 5.5.5

air resources, 5.7.7.2

cultural, 5.4.4

ecology, 5.9.4

geology, 5.6.2

health and safety, 5.12.1.3, 5.12.2.3

INEL services, 5.13.4, 5.13.5

land use, 5.2 .5

ncise, 5.10 .2

socioeconomics, 5.3.4.4, 5.3.5.4

traffic and transportation, 5.11.2.6

water resources, 5.8 .4 
High-Level tank project (continued)

location, Fig. 3.1-1, -10

NEPA review status, Table 2-1 related alternatives, Table 3.1-1, -5

high-level waste accident assessment, 5.14, Tables 5.14-2, -3 alternatives, 3.1.3.1

Alternative A, Fig. 3.1-12

Alternative B, Fig. 3.1-13

Alternative C, Fig. 3.1-14

Alternative D, Fig. 3.1-15

background, 2.2.7.1.1

current management, Fig. 2.2-5

definition, 2.1, 2.2.7.1.1, App. $\mathrm{E}$

location of projects, Fig. 3.1-10

proposed projects, Table 3.1-4

volumes by alternative, Fig. 3.1-11

historic structures

impacts of alternatives, 5.4

INEL, 4.4.1

see also cultural resources

hospitals, see community services

housing in INEL region

background, 4.3.2, Table 4.3-3

impacts of alternatives, 5.3

see also socioeconomics

hydrogeology, regional, 4.8 .2

see also water resources

$-$

Idaho, State of

laws and regulations, 7.2.4

Idaho Air Pollution Control Regulations, 7.2.4.1

Idaho Chemical Processing Plant

accident at, 5.14, Tables 5.14-2, -3

description, 2.2.4.3

location, Fig. 2.2-2

projects, Table 3.1-1

waste information, Table 2.2-2

Idaho Falls operations

accidents at, 5.14, Tables 5.14-2, -3

description, 2.2.4.10

Idaho Hazardous Waste Management Regulations, 7.2.4.4

Idaho National Engineering Laboratory (INEL)

administration, 2.2 .2

history, 2.2 .3

impacts of alternatives, see specific alternatives and specific disciplines

infrastructure, 2.2.8, 3.1.3.6

location, Fig. 2.2-1, Fig. 4.2-1

major facility areas, 2.2.4, Fig. 2.2-2

meteorology, 4.7.1

mission, 2.3

monitoring program, 2.2 .8

organization, $\mathbf{2 . 2 . 2}$
Idaho National Engineering Laboratory (continued)

overview, 2.2

permits

INEL, Table 7.2-3

project-specific, Table 7.2-6

RCRA status, Table 7.2-4

wastewater, Table 7.2-5

site description, 2.2.1; Fig. 2.2-1, -2

support services, 2.2.10.2

see also INEL services

visual character, 4.5.1

see also specific disciplines

Idaho Regulations for Public Drinking Water

Systems, 7.2.4.3

Idaho Solid Waste Management Regulations, 7.2.4.5

Idaho Waste Processing Facility Project, 3.1.3.2-3.1.3.4

description and impacts, App. C

air resources, 5.7.3.1, 5.7.4.1, 5.7.4.3.3

location, Fig. 3.1-1, -16, $-22,-28$

related alternatives, Tables $3.1-1,-6,-7,-8$

Idaho Water Quality Standards, 7.2.4.2

impacts, environmental, Chapter 5

see also alternatives and environmental consequences

income

baseline, 4.3.1

impacts of alternatives, 5.3

Increased Rack Capacity for CPP-666 Project description and impacts, App. C

location, Fig. 3.1-1, -2

related alternatives, Tables 3.1-1, -2

Industrial/Commercial Landfill Expansion Project description and impacts, App. C location, Fig. 3.1-1, -36

related alternatives, Table 3.1-1

industrial commercial waste background, 2.2.7.3

current management, Fig. 2.2-10

definition, 2.1, App. E, 2.2.7.3

and recycling, 2.2.7.3

volumes, 2.2 .7 .3

INEL, see Idaho National Engineering Laboratory

INEL services

characterization, 4.13

electricity consumption, 4.13 .2

emergency preparedness, 4.13.5.2

fire department, 4.13.5.1

security and emergency protection, 4.13 .5

wastewater disposal, 4.13.4

water consumption, 4.13 .1

impacts of alternatives, 5.13

Alternative A, 5.13.2

Alternative B, 5.13.3

Alternative C, $\mathbf{5 . 1 3 . 4}$

Alternative D, 5.13 .5

comparisons, 3.3.12, Table 3.3-1

methodology, 5.13.1

mitigation, 5.19.9 
infrastructure

aiternatives, 3.1.3.6

current upgrades, $\mathbf{2 . 2 . 8}$

proposed projects locations, Fig. 3.1-36

Integral Fast Reactor, 2.2.4.9

irreversible and irretrievable resource commitment, 5.18

$$
\begin{aligned}
& \text { J, } \mathbf{K}- \\
& -\mathbf{L}
\end{aligned}
$$

labor force, regional

historical, Table 4.3-1

land use

projected, Table 4.3-2

characterization, 4.2, Fig. 4.2-2

impacts of alternatives, 5.2

Alternative A, 5.2 .2

Alternative B, 5.2.3

Alternative C, 5.2 .4

Alternative $\mathrm{D}, 5.2 .5$

comparison, 3.3.1, Table 3.3.1

cumulative impacts, 5.15.1, Table 5.15-2

irretrievable and irreversible, 5.18

methodology, 5.2.1

mitigation, 5.19

law enforcement, see community services

legal requirements, see regulatory requirements

lithologic logs of deep drill holes, Fig. 4.6-2

low-level waste

accident assessment, 5.14; Tables 5.14-2, -3

alternatives, 3.1.3.3

background, 2.2.7.1.3

current management, Fig. $2-8$

definition, 2.1, 2.2.7.1.3, App. E

disposal, 2.2.7.1.3

proposed projects

locations, Fig. 3.1-22

management functions, Table 3.1-7

volumes by alternative, Fig. 3.1-27

Low-Level Waste Policy Act of 1985, 2.2.7.1.5, 7.2.1.20

\section{$-\mathbf{M -}$}

Mackay dam, 4.8.1, Fig. 4.8-1

maps

geologic features, Fig. 4.6-1

INEL vicinity, Fig. 4.2-1

land use, Fig. 4.2-2

regional transportation routes, 4.11-1

vegetation distribution, Fig. 4.9-1

Materials Test Reactor, 2.2.4.2

Materials Test Reactor D\&D Project, 3.1.2.2

description and impacts, App. C

location, Fig. 3.1-1, -9

related alternatives, Tables 3.1-1, -3

Maximum Treatment, Storage, and Disposal Alternative see Alternative D
Medicine Lodge Resource Area, 4.2.1, Fig. 4.2-2

meteorology of INEL, 4.7.1

methodologies for impact analyses

technical, App. F

see also specific disciplines

Migratory Bird Treaty Act, 7.2.1.14

Minimum Treatment, Storage, and Disposal Alternative see Alternative $\mathbf{C}$

mission, INEL, 2.2 .3

mitigation measures, 5.19

accidents, 5.19.10

gesthetic and scenic resources, 5.19.2

air resources, 5.19.4

cultural resources, 5.19 .1

ecological resources, 5.19 .6

geological resources, 5.19 .3

health and safety, 5.19 .8

INEL services, 5.19.9

noise, 5.19

socioeconomics, 5.19

transportation, 5.19 .7

water resources, 5.19 .5

mixed low-level waste

accident assessment, 5.14

accidents, Tables 5.14-2, -3

alternatives, 3.1.3.4

background, 2.2.7.1.4

current management, Fig. $2-9$

definition, 2.2.7.1.4

proposed projects, Table $3.1-8$

location, Fig. 3.1-28

and management functions, Table $3.1-8$

volumes, 2.2.7.1.4, Fig. 3.1-33

Mixed/Low-Level Waste Treatment Facility Project,

3.1.3.4

description and impacts, App. C air resources, 5.7.3.1

location, Fig. 3.1-1, -28

related alternatives, Tables $3.1-1,-8$

mixed waste definition, 2.1, App. $\mathrm{E}$

Mixed Waste Storage Facility, 2.2.4.5

monitoring program, 2.2 .8

$$
-\mathbf{N}-
$$

National Environmental Policy Act of 1969, 2.1.3,

7.2.1.1

compliance status, 7.2.5.3

documents, Table 7.2-2

required EIS analyses and content, 2.1

reviews of INEL decisions, Table 2.1-1

National Environmental Research Park, 4.2.1

National Historic Landmark (EBR-I), 2.2.4.6,

4.2.1, 4.5.1

National Historic Preservation Act, 4.4.2, 5.4.1, 7.2.1.11

National Priorities List, 2.2.3.1

National Register of Historic Places, 5.4.1

Native American cultural resources, 4.4.2 
Native American Graves Protection and Repatriation Act, 4.4.2, 5.4.1, 7.2.1.18

natural resources, 4.6 .2

naval fuel examination options, Table 3.1-2

Naval Reactors Facility

description, 2.2.4.8

location, Fig. 2.2-2

projects, Table 3.1-1

waste information, Table 2.2-2

New Calcine Storage Project, 3.1.3.1

description and impacts, App. C

location, Fig. 3.1-1, -10

related alternatives, Tables $3.1-1,-5$

New Waste Calcining Facility, 2.2.4.3, 2.2.7.1.1

accidents at, 5.14; Tables 5.14-2, -3

nitric acid transportation accident, Table 5.11-15

No Action alternative, see Alternative $A$

noise

characterization, 4.10

impacts of alternatives, 5.10.2

comparizon, 3.3.9, Table 3.3-1

methodology, 5.10.1

mitigation, 5.19

Noise Control Act, 7.2.1.15

Nonincinerable Mixed Waste Traatment Project, 3.1.3.4

description and impacts, App. C air resources, 5.7.3.1

location, Fig. 3.1-1, -28

related alternatives, Tables 3.1-1, -8

nonradiological air quality

see air quality

nonradiological health effects, $\mathbf{5 . 1 2}$

air, 5.7

transportation, 5.11

worker, 4.12.2.2, 5.12

see also health and safety and health effects

Notice of Intent, 2.1.4

Notice of Opportunity, 2.1.4

Nuclear Waste Policy Act, 7.2.1.19

Nuclear Weapons Complex Reconfiguration

Programmatic EIS, 2.1.3.3

\section{-}

occupational health and safety

baseline, 4.12 .2

impacts from alternatives, 5.12.2; Tables 5.12-5, -6

Occupational Safety and Health Act of 1970, 7.2.1.21

offsite transportation accidents, 5.11.2.4;

Tables 5.11-11 through -14

methodology, 5.11.1.3, 5.11.1.4

onsite facility accidents, 5.14

onsite transportation accidents, 5.11.1.2, 5.11.2.3;

Tables 5.11-9, -10

ozone effects, 5.7.4.3
-P-

paleontological resources on INEL, 4.4.3

perched water, 4.8.2.4, 5.8.2.2

permits

NNEL, Table 7.2-3

project-specific, Table 7.2-6

RCRA status, Table 7.2-4

wastewater, Table 7.2.5

Pit 9 Retrieval Project, 3.1.2.1

description and impacts, App. C

location, Fig. 3.1-1, -8

NEPA review status, Table 2-1

potential accidents, 5.14.4.6

related alternatives, Table $3.1-1,-3$

Plasma Hearth Process Project, 3.1.4

description and impacts, App. C

location, Fig. 3.1-1, -37

related alternatives, Table 3.1-1

population in INEL region

background, 4.3.2, Fig. 4.3-3

impacts of alternatives, 5.3, Table 5.3-2

see also socioeconomics

potential cleanup technologies, 2.2.6.1

Power Burst Facility/Auxiliary Reactor Area

accidents, 5.14; Tables 5.14-2, -3

description, 2.2.4.5

location, Fig. 2.2-2

projects, Table 3.1-1

waste information, Table 2.2-2

preparers, list of, 6.1

Private Sector Apha-Contaminated Mixed Low-Level

Waste Treatment Project, 3.1.3.2

description and impacts, App. C air resources, 5.7.3.1, 5.7.4.1

Jocation, Fig. 3.1-1, -16

related alternatives, Tables 3.1-1, -6

probable maximum flood, 4.8.1.2, Fig. 4.8-1

programmatic EISs (DOE), 1.2

projects, Table 3.1-1, App. C decontamination and decommissioning, 3.1.2.2

descriptions, App. C

environmental remediation, 3.1.2.1, Table 3.1-3

greater-than-Class-C, 3.1.3.5, Fig. 3.1-35

hazardous, 3.1.3.6, Table 3.1-9

high-level waste, 3.1.3.1, Fig. 3.1-11, Table 3.1-5

impacts, see specific project

infrastructure, 3.1.3.7, Fig. 3.1-37

locations, Fig. 3.1-1

low-level waste, 3.1.3.3, Fig. 3.1-23, Table 3.1-7

mixed low-level waste, 3.1.3.4, Fig. 3.1-29,

Table 3.18

related alternatives, Table 3.1-1

research and development, 3.1.4, Fig. 3.1-38

spent nuclear fuel, 3.1.1, Fig. 3.1-3, Table 3.1-2

transuranic, 3.1.3.2, Fig. 3.1-17, Table 3.1-6 
public finance

background, 4.3.3.2, Table 4.3-5

impacts of alternatives on, 5.3.2.3 through 5.3.5.3

public health and safety, 4.12 .1

see also health and safety

public services

background, 4.1, Table 4.3-4

impacts on, 5.3

purpose and need, Chapter 1

$$
\begin{aligned}
& -\mathbf{-} \\
& -\mathbf{R}-
\end{aligned}
$$

Radioactive Scrap/Waste Facility Project,

3.1.3.1-3.1.3.4

description and impacts, App. C air resources, 5.7.3.1

location, Fig. 3.1-1, -10, -16, -22, -28

related alternatives, Tables $3.1-1,-5$ through -8

radioactive waste

definition, 2.1, App. E

management, 2.2.7.1

Radioactive Waste Management Complex accidents at, 5.14; Table 5.14-2, -3; App. F-5

description, 2.2.4.7

location, Fig. 2.2-2

projects, Table 3.1-1

waste information, Table 2-3

Radioactive Waste Management Complex Modification

to Support Private Sector Treatment of Alpha-

Contaminated Low-Level Waste, 3.1.3.2

description and impacts, App. C

location, Fig. 3.1-1, -16

related alternatives, Tables 3.1-1, -6

radioactivity primer, App. A

radioecology, 4.9.5, 5.9

radiological air quality, 4.7 .3

doses

offsite, 4.7.3.2.2

onsite, 4.7.3.2.1

emissions, Table 4.7-1

existing, 4.7.3.2

management programs, Fig. 4.7-2

Radiological and Environmental Sciences Laboratory

Replacement Project, 3.1.3.7

description and impacts, App. C

location, Fig. 3.1-1, -36

NEPA review status, Table 2-1

related alternatives, Table 3.1-1

radiological exposures and bealth effects

from airborne releases, 4.7, 5.7

from facility accidents, 5.14

from groundwater releases, 4.12.1.2, 5.12.1.2

occupational health and safety, 4.12.2, 5.12.2

public, 4.12.1, 5.12.1 radiological exposures and effects (continued)

from transportation of waste and materials baseline, 4.11.5.1

incident-free transport, 5.11.2.2;

Tables 5.11-6, -7

offsite accidents, 5.11.2.4; Tables 5.11-11

through -14

onsite accidents, 5.11.2.3; Tables 5.11-8, -9

RADTRAN, 5.11.1 worker, Table 5.12-5

railroads, 4.11.2

RCRA, see Resource Conservation and Recovery Act reconfiguration programmatic EIS, 2.1.3.3

Record of Decision, 2.1.2.3

recycling, 2.2.7.3

references, Chapter 9

region of influence, 4.3, 5.3, App. F-1

regulatory requirements, Chapter 7

DOE orders, 7.2.3

Executive Orders, 7.2.2

Federal regulations, 7.2.1

as framework for ER\&WM, 2.2.11

State of Idaho, 7.2.4

Religious Freedom Restoration Act of 1993, 7.2.1.22

remedial action process, Fig. 2-5

remediation

accident assessment, 5.14

accidents, Tables 5.14-2, -3

background at INEL, 2.2.6.1

process, 2.2.6.1, Fig. 2-5

waste area groups, 2.2.6.1, Table 2.2-2

Remediation of Groundwater Contamination Project,

3.1.2.1

description and impacts, 5.8.2, App. C

location, Fig. 3.1-1, -8

NEPA review status, Table 2-1

related alternatives, Table $3.1-1,-3$

Remote Mixed Waste Treatment Facility Project,

3.1.3.4

description and impacts, App. C

location, Fig. 3.1-1, -28

related alternatives, Table $3.1-1,-8$

reprocessing, 2.2.5.1

research and development options, SNF, Table 3.1-2

Resource Conservation and Recovery

Act (RCRA), 7.2.1.6, 7.2.5.8

permitting status, Table 7.2-4

reviewers, list of, 6.2

risk factors, transportation, Tables 5.11-2, -3

RISKIND, 5.11.1.1

roadways, 4.11.1, Fig. 4.11-1

s.

Safe Drinking Water Act, 4.8.3, 7.2.1.5, 7.2.5.4

scenic resources, see aesthetic and scenic resources 
schools, see community services

scope, EIS Volume 2, 2.1.2

scoping process, 2.1.4, Fig. 2.1-1

security, INEL, 4.13.5.3

seismic hazards, 4.6 .3

see also earthquake

sensitive species, 4.9.3, Table 4.9-1

services, see INEL services

shipments, waste and materials

from alternatives, 5.11.2.1; Tables 5.11-2, -5

baseline, 4.11.5, Table 4.11-3

distances, Table 5.11-1

see also traffic and transportation

Shipping/Transfer Station Project, 3.1.3.4

description and impacts, App. C

location, Fig. 3.1-1, -28

related alternatives, Table $3.1-1,-8$

short-term use and long-term productivity, 5.17

Alternative A, 5.17.1

Alternative B, 5.17.2

Alternative C, 5.17.3

Alternative D, 5.17.4

Shoshone-Bannock tribe, 4.4, 5.4

site remediation, see remediation

site services, see INEL services

Snake River Plain aquifer, 4.8.2, Fig. 4.8-2

waste information, Table 2-3

socioeconomics

characterization, 4.3

community services, 4.3.3, Table 4.3-4 employment, 4.3.1.1, Fig. 4.3-1, Table 4.3-2 housing, 4.3.2, Table 4.3-3

income, 4.3.1.2

population, 4.3.2, Fig. 4.3-3, Table 4.3-2

public finance, 4.3 .3 , Table $4.3-5$

impacts of alternatives, 5.3, App. F-1

Alternative A, 5.3.2

Alternative B, 5.3.3

Alternative C, 5.3.4

Alternative D, 5.3.5

comparison, 3.3.2, Table 3.3-1

cumulative, 5.15.2, Table 5.15-2

methodology, 5.3.1, App. F-1

mitigation, 5.19

sodium-bearing liquid waste processing technology

selection impacts, see Waste Immobilization

Facility impacts

Sodium Processing Project, 3.1.3.4

description and impacts, App. C

location, Fig. 3.1-1, -28

related alternatives, Tables 3.1-1, -8

Special Power Excursion Reactor Tests, 2.2.4.5

species-threatened, endangered, and sensitive identification, 4.9.3, Table 4.9-1 impacts on, 5.9

Spent Fuel Processing Project, 3.1.1 description and impacts, App. C air resources, 5.7.3.1
Spent Fuel Processing Project (continued)

location, Fig. 3.1-1, -2

potential accident, 5.14.6.1

related alternatives, Tables 3.1-1, -2

spent nuclear fuel, 2.2 .5

accident assessment, 5.14

accidents, Tables 5.14-2, -3

activities addressed by EIS, 2.1.2.2

alternatives for managing, 3.1.1

Alternative A, Fig. 3.1-3

Alternative B, Fig. 3.1-4

Alternative C, Fig. 3.1-5

Alternative D, Fig, 3.1-6

background, 2.2.5.1, Fig. 2.2-3

basic management decisions, Fig. 3.0-1

current management, 2.2.5.1, Fig. 2.2-3

definition, 2.1, 2.2.5, App. $\mathrm{E}$

generation, 2.2.5.1

projects, proposed and management functions, Table 3.1-2 locations, Fig. 3.1-2

shipments by alternative, Table 5.11-5

volumes by alternative, Fig. 3.1-6

stabilization options, SNF, Table 3.1-1

State of Idaho, see Idaho, State of

storage options, SNF, Table 3.1-1

Stored Waste Examination Pilot Plant, 2.2.4.7

Subsurface Disposal Area capacity, 2.2.7.1.3

subsurface water

characterization, 4.8.2, Fig. 4.8-2

impacts of alternatives, 5.8 .2 through 5.8 .5

support services, INEL, 2.2.10.2

surface water

characterization, 4.8.1

impacts of alternatives, 5.8.2 through $\mathbf{5 . 8 . 5}$

Surplus Facilities List, 2.2.6.2

$-\mathbf{T}$.

Tank Farm Heel Removal Project, 3.1.3.1

description and impacts, App. C

location, Fig. 3.1-1, -10

related alternatives, Tables 3.1-1, -5

technical methodologies, App. F

see also specific disciplines

technology development at INEL, 2.2.9

alternatives, 3.1.4, Table 3.1-1

proposed project locations, Fig. 3.1-37

Ten-Year Plan alternative see Alternative $B$

Test Area North

accident assessment, 5.14

accidents, Tables 5.14-2, -3

description, 2.2.4.1

location, Fig. 2.2-2

projects, Table 3.1-1

waste information, Table 2.2-2 
Test Area North Pool Fuel Transfer Project, 3.1.1 description and impacts, App. C air resources, 5.7.3.1

location, Fig. 3.1-1, -2

related alternatives, Table 3.1-1, -2

Test Reactor Area

accident assessment, 5.14

accidents, Tables 5.14-2, -3

description, 2.2 .4 .2

location, Fig. 2.2-2

projects, Table 3.1-1

waste information, Table $\mathbf{2 . 2 - 2}$

threatened species, 4.9.3, Table 4.9-1

timeframe (of EIS), 2.1.2.3

Toxic Substance Control Act, 7.2.1.16, 7.2.5.7

toxicology, primer, App. A

traffic and transportation

accidents, 4.11, 5.11

air traffic, 4.11 .3

baseline traffic, Table 4.11-1

characterization, 4.11

distances for waste shipments, Table 5.11-1

impacts of alternatives, 5.11.2

comparison, 3.3.10, Table 3.3-1

cumulative, 5.15.7, Table 5.15-3

hazardous materials, 5.11.1.4, 5.11.2.5

on incident-free transportation, 5.11.1.1, 5.11.2.2; Tables 5.11-6, -7

irreversible and irretrievable, 5.18

on offsite accidents, 5.11.1.4, 5.11.2.4;

Tables 5.11-11 through 14

on onsite accidents, 5.11.1.2, 5.11.2.3;

Tables 5.11-9, -10

methodology, 5.11.1

mitigation, 5.19.7

risk factors, Tables 5.11-2, -3

noise, 4.10

options, Table 3.1-2

projects, 3.1-1

railways, 4.11.2, Fig. 4.11-1

requirements, 7.2.5.10

roadways, 4.11.1, Fig. 4.11-1

shipments

alternative comparison, 5.11.2.1,

Table 5.11-2

baseline, Table 4.11-3

distances, Table 5.11-1

traffic impact methodology, 5.11.1.5

Transient Reactor Test Facility, 2.2.4.9

transportation

see traffic and transportation

Transuranic Storage Area, 2.2.4.7

Transuranic Storage Area Enclosure and Storage

Project, 3.1.3.2

description and impacts, App. C

location, Fig. 3.1-1, -16

related alternatives, Tables $3.1-1,-6$ transuranic waste

accident assessment, 5.14

accidents, Tables 5.14-2, -3; App. F-5

alternatives, 3.1.3.2

Alternative A, Fig. 3.1-18

Alternative B, Fig. 3.1-19

Alternative C, Fig. 3.1-20

Alternative D, Fig. 3.1-21

background, 2.2.7.1.2

current management, Fig. 2.2-6

definition, 2.1, App. E, 2.2.7.1.2

disposal, 2.2.7.1.2

generation, 2.7.1.2

proposed projects

locations, Fig. 3.1-16

and management functions, Table 3.1-5

volumes, 2.2.7.1.2 by alternative, Fig. 3.1-17

TRUPACT container, 2.2.7.1.2

$$
\text { -U- }
$$

unsaturated zone, 4.8.2.3

see also groundwater

utility and energy impacts, Fig. 5.13-2

see also INEL services

$$
-\mathbf{V} \text { - }
$$

vadose zone, 4.8.2.3, 5.8.2.2

see also groundwater

Vadose Zone Remediation, 3.1.2.1

description and impacts, App. C

location, Fig. 3.1-1, -8

related alternatives, Tables 3.1-1, -3

vegetation (INEL), 4.9.1, Fig. 4.9-1

volcanic hazards, 4.6 .4

vulnerability assessment, 2.2.5.2, Table 2.2-1

$$
-\mathbf{W}-
$$

waste, see specific waste streams

waste and materials shipment impacts, 5.11 .2 transportation, 4.11.5

waste area groups, 2.2.6.1, Table 2.2-2

Waste Calcine Facility (CPP-633) D\&D Project, 3.1.2.2 description and impacts, App. C location, Fig. 3.1-1, -9 related alternatives, Tables 3.1-1, -3

Waste Characterization Facility Project, 3.1.3.2 description and impacts, App. C air resources, 5.7.4.3.3

location, Fig. 3.1-1, -16

related alternatives, Tables $3.1-1,-6$

Waste Engineering Development Facility, 2.2.4.5 
Waste Experimental Reduction Facility

description, 2.2.4.5, 2.2.7.1.3, 2.2.7.1.4

incineration project

description, 3.1.3.3, 3.1.3.4, App. C

impacts, App. C

accidents, 3.3.13, 5.14.5.4, 5.14.6.4

aesthetic and scenic resources, 5.5.3, 5.5.5

air resources, 3.3.6, 4.7.3.1;

Table 4.7-1, 5.7.4.1, 5.7.4.3, 5.7.7.5

cultural resources, 5.4.3, 5.4.5

ecological resources, 5.9.3.4, 5.9.5

geology, 5.6.2

health and safety, 5.12.1.3, 5.12.2.3

INEL services, 5.13.3, 5.13.5

land use, 5.2.3, 5.2.5

noise, 5.10 .2

socioeconomics, 5.3.3.4, 5.3.5.4

traffic and transportation, 5.11.2.6

water resources, 5.3.3, 5.3.5

location, Figures 3.1-1, -22, -28

NEPA review documentation, Table 2-1

related alternatives, Tables $3.1-1,-7,-8$

Waste Immobilization Facility Project, 3.1.3.1

description and impacts, App. C

impacts of technology selection projects accidents, 5.14.4.2, 5.14.5.2, 5.14.6.2

gesthetics, 5.5.3, 5.5.4. 5.5.5

air resources, 5.7.2; Tables 5.7-1, -2; 5.7.3.1, 5.7.4.3.3, 5.7.7.3, 5.7.7.4

cultural, 5.4.3, 5.4.4, 5.4.5

ecology, 5.9.3.4, 5.9.4, 5.9.5

geology, 5.6.2

health and safety, 5.12.1.3, 5.12.2.3

INEL services, 5.13.3, 5.13.4, 5.13.5

land use, 5.2.3, 5.2.4, 5.2.5

noise, 5.10 .2

socioeconomics, 5.3.3.4, 5.3.4.4, 5.3.5.4

traffic and transportation, 5.11.2.6

water resources, 5.8.3.4, 5.8.4, 5.8.5

location, Fig. 3.1-1, -10

potential accident, 5.14.6.1

related alternatives, Table 3.1-1, -5

and transuranic waste, 2.2 .7 .1 .2

Waste Isolation Pilot Plant EIS, 2.1.3.4

Waste Handling Facility Project, 3.1.3.3-3.1.3.4

description and impacts, App. C

location, Fig. 3.1-1, -22, -28

related alternatives, Table $3.1-1,-7,-8$

waste management

activities by alternative, Table $3.1-4$

alternatives, 3.1.3, see also alternatives

and specific waste stream

background at INEL, 2.2.7

cumulative impacts, 5.15.9, Table 5.15-2

definition, 2.1, App. E

Waste Management Operations EIS, 2.1.3.1 waste shipments, see shipments

waste volumes

high-level, Fig. 3.1-11

industrial commercial, 2.2.7.3

low-level, Fig. 3.1-27

mixed low-level, Fig. 3.1-28

transuranic, 2.2.7.1.2, Fig. 3.1-17

wastewater disposal, 4.13.4, Fig. 5.13-2

water resources

characterization, 4.8

subsurface (hydrogeology)

local, 4.8.2.2

perched, 4.8.2.4

quality, 4.8.2.5

regional, 4.8.2.1

vadose zone, 4.8 .2 .3

surface

flood plains, 4.8.1.3

local runoff, 4.8 .1 .2

quality, 4.8.1.4

regional drainage, 4.8.1.1

impacts of alternatives, 5.8

adverse, 5.16 .4

Alternative A, 5.8.2

Alternative $B, 5.8 .3$

Alternative $C, 5.8 .4$

Alternative $D, 5.8 .5$

comparison, 3.3.7, Table 3.3-1

cumulative, 5.15.5, Table 5.15-2

irreversible and irretrievable, 5.18

methodology, 5.8.1, App. F-2

mitigation, 5.19.5

quality, existing

State of Idaho program, 7.2.5.12

subsurface, 4.8.2.5

surface, 4.8 .1 .4

water rights, 4.8 .3

water use, 4.8.3, 4.13.1, Fig. 5.13-2

wetlands, 4.9.4, 5.9

wind roses for INEL, Fig. 4.7-1

workers

impacts from alternatives

accidents, 5.14

cumulative, Table 5.15-4

industry fatality rates, Fig. 5.14-1

see also occupational health and safety

$$
-\mathbf{X}, \mathbf{Y}, \mathbf{Z} \text { - }
$$

Zero Power Physics Reactor, 2.2.4.9 


\section{REFERENCES}

\section{Chapter 2, Background}

Buckland, R. J., D. J. Kenoyer, D. H. Preussner, 1993, INEL D\&D Long-Range Plan, EGG-WM10924, EG\&G Idaho, Inc., Idaho Falls, Idaho, October.

DOE (U.S. Department of Energy), 1977, Final Environmental Impact Statement, Waste Management Operations, Idaho National Engineering Laboratory, ERDA-1536, Energy Research and Development Administration, Idaho Falls, Idaho.

DOE (U.S. Department of Energy), 1989, Commercial Greater-Than-Class-C Low-Level Radioactive Waste Long-Range Planning Document, DOE/LLW-77T, Revision 0, National Low-Level Radioactive Waste Management Program, Washington, D. C., February.

DOE (U.S. Department of Energy), 1992, Integrated Data Base for 1992: U.S. Spent Fuel and Radioactive Waste Inventories, Projections, and Characteristics, DOE/RW-0006, Revision 8, Office of Civilian Radioactive Waste Management, Office of Environmental Restoration and Waste Management, Washington, D.C., October.

DOE (U.S. Department of Energy), 1993a, Implementation Plan for the Department of Energy Programmatic Spent Nuclear Fuel Management and Idaho National Engineering Laboratory Environmental Restoration and Waste Management Programs Environmental Impact Statement, U.S. Department of Energy, Idaho Falls, Idaho, October 29.

DOE (U.S. Department of Energy), 1993b, Spent Fuel Working Group Report on Inventory and Storage of the Department's Spent Nuclear Fuel and other Reactor Irradiated Nuclear Materials and Their Environmental Assessment, Safety and Health Vulnerabilities, Volumes I, II, and III, U.S. Department of Energy, Washington, D. C., November.

DOE (U.S. Department of Energy), 1993c, Environmental Assessment, Idaho National Engineering Laboratory Low-Level and Mixed Waste Processing, DOE/EA-0843, Office of Environmental Restoration and Waste Management, Washington, D. C., June.

DOE (U.S. Department of Energy), 1994a, Plan of Action To Resolve Spent Nuclear Fuel Vulnerabilities, Phase I, Volumes I and II, February.

DOE (U.S. Department of Energy), 1994b, Plan of Action To Resolve Spent Nuclear Fuel Vulnerabilities, Phase II, April.

DOE-ID (U.S. Department of Energy, Idaho Operations Office), 1991, Idaho National Engineering Laboratory Environmental Restoration and Waste Management Site-Specific Plan for Fiscal Year 1992, DOE/ID-10253 (FY92), U.S. Department of Energy, Idaho Operations Office, Idaho Falls, Idaho, September. 
DOE-ID (U.S. Department of Energy, Idaho Operations Office), 1992, Idaho National Engineering Laboratory Environmental Monitoring Plan: Baseline Document, DOE/ID-10395(92), U.S. Department of Energy, Idaho Falls, Idaho, June.

DOE-ID (U.S. Department of Energy, Idaho Operations Office), 1993a, Idaho National Engineering Laboratory Waste, Excess Property, and Recyclable Materials Acceptance Criteria, DOE/ID-10381, U.S. Department of Energy, Idaho Falls, Idaho, September.

DOE-ID (U.S. Department of Energy, Idaho Operations Office), 1993b, Idaho National Engineering Laboratory Conceptual Site Treatment Plan, DOE/ID-10453, U.S. Department of Energy, Idaho Falls, Idaho, October.

DOE-ID (U.S. Department of Energy, Idaho Operations Office), 1993c, Idaho National Engineering Laboratory Environmental Restoration and Waste Management Site-Specific Plan for Fiscal Year 1993, DOE/ID-10253 (FY93), U.S. Department of Energy, Idaho Falls, Idaho, March.

DOE-ID (U.S. Department of Energy, Idaho Operations Office), 1993d, Idaho National Engineering Laboratory/West Valley Demonstration Project Emergency Plan, Vol. 1, Operational Emergency Plan, Rev. 1, U.S. Department of Energy, Idaho Falls, Idaho, November 1.

FR (Federal Register), 1990, 55 FR 204, "Intent to Prepare a Programmatic Environmental Impact Statement on the Department of Energy's Proposed Integrated Environmental Restoration and Waste Management Program, and to Conduct Public Scoping Meetings," Department of Energy, October 22, pp. 42633-42638.

FR (Federal Register), 1992, 57 FR 193, "Notice of Intent to Prepare an Environmental Impact Statement for Environmental Restoration and Waste Management Activities at the Idaho National Engineering Laboratory," Department of Energy, Idaho Field Office, Idaho Falls, Idaho, October 5, pp. 45773-45778.

Fugate, H. N., R. L. Billau, C. Whalen, 1993, Draft Idaho National Engineering Laboratory EIS Environmental Restoration Program Assessment, Jason Associates Corporation, Idaho Falls, Idaho, May 14.

Palmer, W. B., M. J. Beer, M. Cukurs, J. P. Law, C. B. Millet, J. A. Murphy, J. A. Nenni, C. V. Park, J. I. Pruitt, E. C. Thiel, F. S. Ward, J. Woodard, 1994, ICPP Tank Farm Systems Analysis, WINCO-1192, Westinghouse Idaho Nuclear Company, Idaho Falls, Idaho, January.

Pole, S., 1993, Projected INEL Waste Inventories, ER\&WM-EDF-0015-93, Revision 6, EG\&G Idaho Inc., Idaho Falls, Idaho, November 24.

Priestly, T. B., 1992, "Dbase File - Chemical Inventory Used for Preparation of SARA 312 Report for the Idaho National Engineering Laboratory," personal transmittal via Doug Brown, Advanced Sciences, Inc. 
Slaughterbeck, D., Science Applications International Corporation, Idaho Falls, Idaho, 1993, letter to R. Rothman, U. S. Department of Energy, Idaho Operations Office, Idaho Falls, Idaho, June 11, regarding transmittal of text on chemical inventories.

\section{Section 4.2, Land Use}

Bingham County, 1986, 1986 Bingham County Planning Handbook, Bingham County Planning Commission, Blackfoot, Idaho.

Bonneville County, 1976, Bonneville County Comprehensive Plan, Bonneville County Planning Commission, Idaho Falls, Idaho, November 11.

Butte County, 1992, Butte County, Idaho, County Comprehensive Plan, Butte County Planning Resource Board, Arco, Idaho.

City of Idaho Falls, 1989, The Zoning Ordinance of the City of Idaho Falls, Idaho, Ordnance No. 1941, Idaho Falls, Idaho, May.

City of Idaho Falls, 1992, Comprehensive Plan, City of Idaho Falls, for the Year 2000, Division of Planning and Building, Idaho Falls, Idaho.

Clark County, 1992, Clark County Interim Land Use Plan (Proposed), Clark County Planning, Zoning, and Land Use Commission, Dubois, Idaho, July 21.

Clark County, 1986, Clark County Planning and Zoning Ordinances, Clark County Commissioners, Dubois, Idaho.

DOE-ID (U. S. Department of Energy, Idaho Operations Office), 1993a, Institutional Plan for FY 1994-1999 (Draft), U.S. Department of Energy, Idaho Falls, Idaho, June.

DOE-ID (U.S. Department of Energy, Idaho Operations Office), 1993b, Idaho National Engineering Laboratory Long-Term Land Use Future Scenarios, DOE/ID-10440, Revision 1, Idaho Falls, Idaho, June.

Jefferson County, 1988, Jefferson County Idaho Comprehensive Plan, Rigby, Idaho, Jefferson County Planning Commission, Rigby, Idaho, May 23.

Smith, L. D., C. L. Jacobson, J. R. Cunningham, INEL Technical Site Information Report, DOE/ID-10401, U.S. Department of Energy, Idaho Falls, Idaho.

State of Idaho Code, 1975, Local Planning Act of 1975 (I.C. \#67-6501 et seq.), Boise, Idaho. 


\section{Section 4.3, Socloeconomice}

Bingham County, circa 1992, "General Purpose Financial Statements for Bingham County, Idaho for Year Ended September 30, 1991," Blackfoot, Idaho.

CFR (Code of Federal Regulations), 1991, 40 CFR 257 and 258, "Solid Waste Disposal Facility Criteria: Final Report", Office of the Federal Register, October 9.

DOE-ID (U.S. Department of Energy, Idaho Operations Office), 1991, Personnel Survey Results, Idaho National Engineering Laboratory, Idaho Falls, Idaho, July 31.

DOE-ID (U.S. Department of Energy, Idaho Operations Office), 1993, reference on INEL contractor sales and use tax contributions.

Draney, Searle \& Associates, 1992, Jefferson County General Purpose Financial Statements and Supplementary Information with Independent Auditors Report for Year Ended September 30, 1991, Idaho Falls, Idaho, March 8.

Ghan, Larry W., 1992, Bannock County, Idaho Comprehensive Annual Financial Report for the Fiscal Year Ended September 30, 1991, Pocatello, Idaho, January 15.

Hardinger, D., 1990, Socioeconomic Database for Southeastern Idaho, EG\&G Idaho, Inc., Idaho Falls, Idaho, April.

IDE (Idaho Department of Education), 1991, Public and Non-Public School Certified Personnel and Employees in Noncertified Positions 1990-1991, Idaho Department of Education, Finance Division, Boise, Idaho.

IDHW (Idaho Department of Health and Welfare), circa 1990, 1990 Hospital Utilization Report, Idaho Department of Health and Welfare, Office of Health Policy and Rescue, Boise, Idaho.

IDLE (Idaho Department of Law Enforcement), 1991, Crime in Idaho, Idaho Department of Law Enforcement, Bureau of Criminal Identification, Boise, Idaho.

ISDE (Idaho State Department of Employment), 1992, Idaho Employment, Research and Analysis Bureau, Boise, Idaho, February.

Kouris, C., 1992a, Ecology and Environment, Idaho Falls, Idaho, records of personal communications provided to I. Johnson, Science Applications International Corporation, Portland, Oregon, regarding fire protection statistics.

Kouris, C., 1992b, Ecology and Environment, Idaho Falls, Idaho, records of personal communications provided to I. Johnson, Science Applications International Corporation, Portland, Oregon, regarding municipal solid waste disposal.

McFadden, J., circa 1992, 1991 Annual Financial Report of Bonneville County, Idaho at the Close of Business September 30, 1991, Idaho Falls, Idaho. 
SAIC (Science Applications International Corporation), 1994, "Forecast of Labor Force, Employment, and Population Based on Historical Data from the Idaho State Department of Employment," data sheet, March.

Schwendiman \& Sutton, 1992, Madison County, Idaho Financial Statements, Supplemental Data and Independent Auditor's Reports for Year Ended September 30, 1991, Rexburg, Idaho, January 28.

Swager \& Swager, 1992a, Clark County, Idaho General Purpose Financial Statements and Supplementary Information with Report of Certified Public Accountant Year Ended September 30, 1991, Rigby, Idaho, December 27.

Swager \& Swager, 1992b, Butte County, Idaho Audited General Purpose Financial Statements with Report of Certified Public Accountant for Year Ended September 30, 1991, Rigby, Idaho, December 27.

USBC (U.S. Bureau of the Census), 1982, 1980 Census of Population and Housing, Washington, D.C.

USBC (U.S. Bureau of the Census), 1992, 1990 Census of Population and Housing, Washington, D.C.

U.S. West Directories, 1992, Easy Reference Guide, Salt Lake City, Utah.

\section{Section 4.4, Cultural Resources}

AIRFA (American Indian Religious Freedom Act), 1978, Public Law 95-341, 42 U.S.C. 1966.

ARPA (Archeological Resources Protection Act), 1979, Public Law 96-95; Public Law 100-555, 100-588, 1988; 16 U.S.C. $470 \mathrm{aa}-470 \mathrm{~mm}$.

Braun, J. B., S. J. Miller, B. L. Ringe, 1993, Historically Significant Scientific and Technical Facilities at the INEL, EGG-CS-10699, EG\&G Idaho, Inc., Idaho Falls, Idaho.

DOE (U.S. Department of Energy), 1990, Memorandum EH-231, "Management of Cultural Resources at Department of Energy Facilities," February 23.

DOE (U.S. Department of Energy), 1992a, Order 1230.2, "American Indian Tribal Government Policy," U.S. Department of Energy, Washington, D.C., April 8.

DOE (U.S. Department of Energy), 1992b, "Working Agreement, Policy on Native American Consultation," U.S. Department of Energy, Washington, D.C., September 29.

DOE (U.S. Department of Energy), 1993a, "Memorandum of Agreement among the U.S. DOEIdaho Field Office, the Idaho State Historic Preservation Office, and the Advisory Council on Historic Preservation," (for Test Area North 629 Hangar), U.S. Department of Energy, Washington, D.C.. 
DOE (U.S. Department of Energy), 1993b, "Memorandum of Agreement among the U.S. DOEIdaho Field Office, the Idaho State Historic Preservation Office, and the Advisory Council on Historic Preservation," (for Auxiliary Reactor Areas I, II, and III), U.S. Department of Energy, Washington, D.C.

Gilbert, H. K, and B. L. Ringe, 1993, Inventory of Known Historical Cultural Resources on the INEL and Preliminary Analysis of Historic Sensitivity, EGG-CS-10707, EG\&G Idaho, Inc., Idaho Falls, Idaho.

Miller, S. J., 1992, Idaho National Engineering Laboratory Management Plan for Cultural Resources (Draft), DOE/ID-10361, U.S. Department of Energy, Idaho Falls, Idaho.

NAGPRA (Native American Graves Protection and Repatriation Act), 1990, Public Law 101-601.

NEPA (National Environmental Policy Act), 1969, Public Law 91-190, 42 U.S.C. 4321-4361, 1976; 40 CFR 1500-1508; 10 CFR 1021; EO 11514, 11991.

NHPA (National Historic Preservation Act), 1966, Public Law 89-665, 16 U.S.C. 470; 36 CFR 6068.800; 48 FR 44716-44742; Public Law 102-575.

Ringe, B. L., 1993, Locational Analysis and Preliminary Predictive Model for Prehistoric Cultural Resources on the INEL (Draft), EGG-CS-10706, EG\&G Idaho, Inc., Idaho Falls, Idaho.

Yohe, R., 1993, Idaho State Historical Preservation Office, Boise, Idaho, personal communication to T. Rudolph, Science Applications International Corporation, Boise, Idaho, September 10.

Section 4.5, Aesthetic and Scenic Resources

BLM (Bureau of Land Management), 1984, Medicine Lodge Resource Management Plan Environmental Impact Statement, U.S. Department of Interior, Bureau of Land Management, Idaho Falls District, Idaho Falls, Idaho.

BLM (Bureau of Land Management), 1986, Final Environmental Impact Statement Eastern Idaho Wilderness Study, U.S. Department of Interior, Bureau of Land Management, Idaho Falls District, Idaho Falls, Idaho.

Braun, J., 1993, EG\&G Idaho, Inc., Idaho Falls, Idaho, personal communication to M. Fikel, Science Applications International Corporation, Boise, Idaho, September 8.

CFR (Code of Federal Regulations), 1977, 40 CFR 50, "National Primary and Secondary Ambient Air Quality Standards," Office of the Federal Register, Washington, D.C., August.

CFR (Code of Federal Regulations), 1990, 40 CFR 51, "Requirements for Preparation, Adoption, and Submittal of Implementation Plans," Office of the Federal Register, Washington, D.C., November. 
Notar, J., 1993, U. S. National Park Service, personal communication to D. A. Ryan, Science Applications International Corporation, Idaho Falls, Idaho, November 22.

\section{Section 4.6, Ceology}

Anders, M. H., and N. H. Sleep, 1992, "Magmatism and Extension: Thermal and Mechanical Effects of the Yellowstone Hotspot," Journal of Geophysical Research, 97, B11, pp. 15379. 15393.

Anders, M.H., J.W. Geissman, L.A. Piety, J.T. Sullivan, 1989, "Parabolic Distribution of Circumeastern Snake River Plain Seismicity and Latest Quaternary Faulting: Migratory Pattern and Association with the Yellowstone Hotspot," Journal of Geophysical Research, 94, B2, pp. 1589-1621.

Brott, C. A., D. D. Blackwell, J. P. Ziagos, 1981, "Thermal Implications of the Heat Flow in the Eastern Snake River Plain, Idaho," Journal of Geophysical Research, 86, B12, pp. 11709 11734.

Doherty, D. J., 1979a, Drilling Data from Exploration Well 1, NE 1/4, sec. 22, T.2N., R.32E., Bingham County, Idaho, U.S. Geological Survey Open-File Report 79-1225, 1 sheet.

Doherty, D. J., 1979b, Drilling Data from Exploration Well 2-2A, NW 1/4, sec. 15, T.SN., R.31E., Idaho National Engineering Laboratory, Butte County, Idaho, U.S. Geological Survey Open-File Report 79-851, 1 sheet.

Doherty, D. J., L. A. McBroome, M. A. Kuntz, 1979, Preliminary Geologic Interpretation and Lithologic Log of the Exploratory Geothermal Test Well (INIEL-1), Idaho National Engineering Laboratory, Eastern Snake River Plain, Idaho, U.S. Geological Survey OpenFile Report 79-1248.

Hackett, W. R., and R. P. Smith, 1992, "Quaternary Volcanism, Tectonics, and Sedimentation in the Idaho National Engineering Laboratory Area," in Field Guide to Geologic Excursions in Utah and Adjacent areas of Nevada, Idaho, and Wyoming, J. R. Wilson, editor, Geological Society of America Rocky Mountain Section Guidebook, Utah Geological Survey Miscellaneous Publication 92-3, pp. 1-18.

Jackson, S. M., 1985, "Acceleration data from the 1983 Borah Peak, Idaho earthquake recorded at the Idaho National Engineering Laboratory," in Proceedings of Workshop XXVIII On the Borah Peak, Idaho, Earthquake, R. S. Stein and R. C. Bucknam (eds.), U. S. Geological Survey Open-File Report 85-290, pp. 385-400.

Jackson, S. M., I. G. Wong, G. S. Carpenter, D. M. Anderson, S. M. Martin, 1993, "Contemporary Seismicity in the Eastern Snake River Plain, Idaho, Based on Microearthquake Monitoring," Bulletin of the Seismological Society of America, 83, 3, pp. 680-695. 
King, J. J., T. E. Doyle, S. M. Jackson, 1987, "Seismicity of the Eastern Snake River Plain Region, Idaho, Prior to the Borah Peak, Idaho Earthquake: October 1972 - October 1983," Bulletin of the Seismological Society of America, 77, 3, pp. 809-818.

Kuntz, M. A., B. Skipp, M. A. Lanphere, W. E. Scott, K. L. Pierce, G. Dalrymple, L. A. Morgan, D. E. Champion, G. R. Embree, R. P. Smith, W. R. Hackett, D. W. Rodgers, compiled by W. R. Page, 1990, Revised Geologic Map of the INEL and Adjoining Areas, Eastern Idaho, U.S. Geological Survey Open-File Report 90-333, scale 1:100,000.

Kuntz, M. A., H. R. Covington, L. J. Schorr, 1992, "An Overview of Basaltic Volcanism of the Eastern Snake River Plain, Idaho," in Regional Geology of Eastern Idaho and Western Wyoming, P. K. Link, M. A. Kuntz, L. B. Platt (eds.), Geological Society of America Memoir 179, pp. 227-267.

Mitchell, J. C., L. L. Johnson, J. E. /Anderson, 1980, Geothermal Investigations in Idaho, Part 9, Potential for Direct Heat Application of Geothermal Resources, IDWR Water Information Bulletin No. 30, Plate 1, Idaho Department of Water Resources, Boise, Idaho.

Mitchell, V. E., W. B. Strowd, G. S. Hustedde, E. H. Bennett, 1981, Mines and Prospects of the Dubois Quadrangle, Idaho, Idaho Bureau of Mines and Geology, Mines and Prospects Map Series.

Parsons, T., and G. A. Thompson, 1991, "The Role of Magma Overpressure in Suppressing Earthquakes and Topography: Worldwide Examples," Science, 253, pp. 1399-1402.

Pelton, J. R., R. J. Vincent, N. J. Anderson, 1990, "Microearthquakes in the Middle Butte/East Butte Area, Eastern Snake River Plain, Idaho," Bulletin of the Seismological Society of America, 80, no. 1, pp. 209-212.

Pierce, K. L., and L. A. Morgan, 1992, "The track of the Yellowstone hotspot: Volcanism, faulting, and uplift," in Regional Geology of Eastern Idaho and Western Wyoming, P. K. Link, M. A. Kuntz, and L. B. Platt (eds.), Geological Society of America Memoir 179, pp. 1-53.

Rodgers, D. W., W. R. Hackett, H. T. Ore, 1990, "Extension of the Yellowstone Plateau, Eastern Snake River Plain, and Owyhee Plateau," Geology 18, pp. 1138-1141.

Smith, R. B., and W. J. Arabasz, 1991, "Seismicity of the Intermountain Seismic Belt," in Neotectonics of North America; D. B. Slemmons, E. R. Engdahl, M. D. Zoback, and D. D. Blackwell (eds.), Geological Society of America, Decade Map Volume 1, Boulder Colorado, pp. 185-221.

Smith, R. B., and M. L. Sbar, 1974, "Contemporary Tectonics and Seismicity of the Western United States with Emphasis on the Intermountain Seismic Belt," Geological Society of America Bulletin, 85, pp. 1205-1218.

Stickney, M. C., and M. J. Bartholomew, 1987, "Seismicity and Late Quaternary Faulting of the Northern Basin and Range Province, Montana and Idaho," Bulletin of the Seismological Society of America, Vol. 77, No. 5, pp. 1602-1625, October. 
Strowd, W. B., V. E. Mitchell, G. S. Hustedde, E. H. Bennett, 1981, Mines and Prospects of the Idaho Falls Quadrangle, Idaho, Idaho Bureau of Mines and Geology, Mines and Prospects Map Series.

Volcanism Working Group, 1990, Assessment of Potential Volcanic Hazards for the New Production Reactor Site at the Idaho National Engineering Laboratory, EGG-NPR-10624, EG\&G Idaho, Inc., Idaho Falls, Idaho.

Weaver, C. S., A. M. Pitt, D. P. Hill, 1979, "Crustal Spreading Direction of the Snake River PlainYellowstone system," EOS, 60, p. 946.

WCC (Woodward Clyde Consultants), 1990, Earthquake Strong Ground Motion Estimates for the Idaho National Engineering Laboratory: Final Report, three volumes, EGG-BG-9350, EG\&G Idaho, Inc., Idaho Falls, Idaho, November.

WCC (Woodward Clyde Consultants), 1992, Earthquake Strong Ground Motion Evaluations for the Proposed New Production Reactor at the Idaho National Engineering Laboratory, two volumes, EGG-GEO-10304, EG\&G Idaho, Inc., Idaho Falls, Idaho, June.

Wong, I., M. Hemphill-Haley, T. Sawyer, K. Coppersmith, R. Youngs, W. Silva, and C. Stark, 1993, Site-Specific Probabilistic Seismic Hazard Analysis for the Idaho National Engineering Laboratory, Draft, EG\&G Idaho, Inc., Idaho Falls, Idaho, June.

Zoback, M. L., and M. D. Zoback, 1989, "Tectonic stress field of the continental United States," in Geophysical Framework of the Continental United States, L. C. Pakiser and W. D. Mooney (eds.), Geological Society of America Memoir 172, pp. 523-539.

\section{Section 4.7, Air Resources}

Clawson, K. L., G. E. Start, N. R. Ricks, 1989, Climatography of the Idaho National Engineering Laboratory, $2^{\text {nd }}$ Edition, DOE/ID-12118, U.S. Department of Commerce, National Oceanic and Atmospheric Administration, Environmental Research Laboratories, Air Resources Laboratory, Field Research Division, Idaho Falls, Idaho.

DOE-ID (U.S. Department of Energy, Idaho Operations Office), 1992, The Idaho National Engineering Laboratory Site Environmental Report for Calendar Year 1991, DOE/ID-12082 (91), U.S. Department of Energy, Idaho Operations Office, Idaho Falls, Idaho, September.

IDHW (Idaho Department of Health and Welfare), 1994, Revised Title 1, Chapter 1, Rules for the Control of Air Pollution in Idaho, Idaho Department of Health and Welfare, Division of Environmental Quality, Boise, Idaho, August 18.

NCRP (National Council on Radiation Protection and Measurements), 1987, Ionizing Radiation Exposure of the Population of the United States, NCRP Report No. 93, National Council on Radiation Protection and Measurements, Bethesda, Maryland, December. 
Notar, J., 1993, U. S. National Park Service, personal communication with D. A. Ryan, Science Applications International Corporation, Idaho Falls, Idaho, November 22.

\section{Section 4.8, Water Resources}

Barraclough, J. T., B. D. Lewis, R. G. Jensen, 1981, Hydrologic Conditions at the Idaho National Engineering Laboratory, Idaho-Emphasis: 1974-1978, U.S. Geological Survey, Water Resources Investigations, Open-File Report 81-526, IDO-22060, U.S. Department of Energy, Idaho Falls, Idaho.

Bennett, C. M., 1990, Streamflow Losses and Ground-Water Level Changes Along the Big Lost River at the Idaho National Engineering Laboratory, Idaho, U.S. Geological Survey WaterResources Investigations Report 90-4067, DOE/ID-22091, U.S. Department of Energy, Idaho Falls, Idaho, 49 p.

Bishop, C. W., 1991, Hydraulic Properties of Vesicular Basalt, Masters Thesis, University of Arizona, Tucson, Arizona.

Case, J., W. House, P. Austin, 1990, Idaho National Engineering Laboratory Groundwater Protection Management Plan, DOE/ID-10274, U.S. Department of Energy, Idaho Falls, Idaho, May.

Cecil, D. L., T. M. Beasley, J. R. Pittman, R. L. Michel, P. W. Kubik, P. Sharma, U. Fehn, H. E. Gove, 1992, "Water Infiltration Rates in the Unsaturated Zone at the Idaho National Engineering Laboratory Estimated from Chlorine-36 and Tritium Profiles, and Neutron Logging," Proceedings of the 7th International Symposium on Water-Rock Interaction, Park City, Utah, 13-18 July 1992.

Dames \& Moore, 1992, Revised Draft Flood Evaluation Study, Radioactive Waste Management Complex, Idaho National Engineering Laboratory, Idaho Falls, Idaho, July.

DOE (U.S. Department of Energy), 1990, General Environmental Protection Program, DOE Order 5400.1, U.S. Department of Energy, Washington, D.C., January 7.

DOE (U.S. Department of Energy), 1993, Radiation Protection of the Public and the Environment, DOE Order 5400.5, Change 2, U.S. Department of Energy, Washington, D.C., January 7.

DOE-ID (U.S. Department of Energy, Idaho Operations Office), 1991, INEL Nonradiological Waste Management Information System (NWIMS), DOE/ID-10057 (1991), U.S. Department of Energy, Idaho Falls, Idaho.

DOE-ID (U.S. Department of Energy, Idaho Operations Office), 1992, INEL Nonradiological Waste Management Information System (NWIMS), DOE/ID-10057 (1992), U.S.

Department of Energy, Idaho Falls, Idaho. 
DOE-ID (U.S. Department of Energy, Idaho Operations Office), 1993, Idaho National Engineering Laboratory Storm Water Pollution Prevention Plan for Construction Activities-Generic Plan, DOE/ID-10425, U.S. Department of Energy, Idaho Falls, Idaho, September.

Driscoll, F. G., 1986, Groundwater and Wells, Second Edition, St. Paul, Minnesota: Johnson Filtration Systems, Inc., p. 61.

Edwards, D. D., R. C. Bartholomay, C. M. Bennett, 1990, Nutrients, Pesticides, Surfactants, and Trace Metals in Groundwater from the Howe and Mud Areas Upgradient from the Idaho National Engineering Laboratory, Idaho, U.S.Geological Survey Open File Report 90-565, DOE/ID-22093, U.S. Department of Energy, Idaho Falls, Idaho.

EG\&G Idaho (EG\&G Idaho, Inc.), 1984, INEL Environmental Characterization Report, EGG-NPR-6688, EG\&G Idaho, Inc., Idaho Falls, Idaho.

EPA (U.S. Environmental Protection Agency), 1991a, "National Primary Drinking Water Regulations; Final Rule," Federal Register, Vol. 56, No. 3593, 3594, 3614, 26547-64, 30280, and 33050.

EPA (U.S. Environmental Protection Agency), 1991b, "Sole Source Designation of the Eastern Snake River Plain Aquifer, Southern Idaho: Final Determination," Federal Register, Vol. 40, No. 100-149, October 7.

EPA (U.S. Environmental Protection Agency), 1993a, "Drinking Water Regulations and Health Advisories," December.

EPA (U.S. Environmental Protection Agency), 1993b, Code of Federal Regulations, Title 40, Parts 100-149, "Protection of the Environment."

Gaia Northwest, Inc., 1988, Drinking Water Consumption and Alternative Sources for the Eastern Snake River Plain, Idaho, November.

Garabedian, S. P., 1986, Application of a Parameter Estimation Technique to Modeling the Regional Aquifer Underlying the Eastern Snake River Plain, Idaho, U.S. Geological Survey WaterSupply Paper 2278, 60 p.

Garabedian, S. P., 1989, Hydrology and Digital Simulation of the Regional Aquifer System, Eastem Snake River Plain, Idaho, U.S. Geological Survey Open-File Report 87-237.

Golder Associates, 1992, Assessment of Trends in Groundwater Quality at the Idaho National Engineering Laboratory, Report No. 933-1151, Golder Associates, Idaho Falls, Idaho, October 29.

Hoff, D. L., R. G. Mitchell, G. C. Bowman, R. Moore, 1990, The Idaho National Engineering Laboratory Site Environmental Report for Calendar Year 1989, DOE/ID-12082(89), Environmental Sciences Branch, Radiological and Environmental Sciences Laboratory, U.S. Department of Energy, Idaho Falls, Idaho. 
Irving, J. S., 1993, Environmental Resource Document for the Idaho National Engineering Laboratory, EGG-WMO-10279, EG\&G Idaho, Inc., Idaho Falls, Idaho, July.

Kaminsky, J. F., 1991, In Situ Characterization of Unsaturated Hydraulic Properties of Surficial Sediments Adjacent to the Radioactive Waste Management Complex, Idaho National Engineering Laboratory, Idaho, Master's Thesis, ISU-91-000, Idaho State University, Pocatello, Idaho.

Kennedy, R. P., S. A. Short, J. R. McDonald, M. W. McCann, Jr., R. C. Murran, J. R. Hill, 1990, Design and Evaluation Guidelines for Department of Energy Facilities Subjected to Natural Phenomena Hazards, UCRL-15910.

Koslow, K. N., and D. H. Van Haaften, 1986, Flood Routing Analysis for a Failure of Mackay Dam, EGG-EP-7184, EG\&G Idaho, Inc., Idaho Falls, Idaho, 78 p.

Leenheer, J. A, and J. C. Bagby, 1982, Organic Solutes in Groundwater at the Idaho Engineering Laboratory, U.S. Geological Survey Open File Report 82-15, IDO-22061, U.S. Department of Energy, Idaho Falls, Idaho.

Liszewski, M. J., and L. J. Mann, 1992, Purgeable Organic Compounds in Groundwater at the Idaho National Engineering Laboratory, Idaho--1990 and 1991, U.S. Geological Survey Open File Report 92-174, DOE/ID-22104, U.S. Department of Energy, Idaho Falls, Idaho.

Mann, L. J., 1990, Purgeable Organic Compounds in Groundwater at the Idaho National Engineering Laboratory, Idaho, U.S. Geological Survey Open File Report 90-387, DOE/ID22089.

Mann, L. J., 1994, U.S. Geological Survey, INEL Field Office, Idaho Falls, Idaho, personal communication with A. L. Lundahl, Science Applications International Corporation, Idaho Falls, Idaho, January 17.

Mann, L. J., and L. D. Cecil, 1990, Tritium in Groundwater at the Idaho National Engineering Laboratory, Idaho, U.S. Geological Survey Open File Report 90-4090, DOE/ID-22090.

Mann, L. J., E. W. Chew, J. S. Morton, 1988, Iodine-129 in the Snake River Plain Aquifer at the Idaho National Engineering Laboratory, Idaho, U.S. Geological Survey Open File Report 884165, DOE/ID-22076, U.S. Department of Energy, Idaho Falls, Idaho.

Mann, L. J., and L. L. Knobel, 1987, Purgeable Organic Compounds in Groundwater at the Idaho National Engineering Laboratory, Idaho, U.S. Geological Survey Open File Report 87-766, DOE/ID 22074, U.S. Department of Energy, Idaho Falls, Idaho.

Orr, B. R., and L. D. Cecil, 1991, Hydrologic Conditions and Distribution of Selected Chemical Constituents in Water, Snake River Plain Aquifer, Idaho National Engineering Laboratory, Idaho, 1986 to 1988, U.S. Geological Survey Open File Report 91-4047, DOE/ID-22096, U.S. Department of Energy, Idaho Falls, Idaho. 
Orr, B. R., L. D. Cecil, L. L. Knobel, 1991, Background Concentrations of Selected Radionuclides, Organic Compounds, and Chemical Constituents in Groundwater in the Vicinity of the Idaho National Engineering Laboratory, U.S. Geological Survey Open File Report 91-4015, DOE/ID-22094, U.S. Department of Energy, Idaho Falls, Idaho.

Pittman, J. R., R. G. Jensen, P. R. Fischer, 1988, Hydrologic Conditions at the Idaho National Engineering Laboratory, 1982 to 1985. U.S. Geological Survey Water-Resources Investigation Report 89-4008, DOE/ID-22078, U.S. Department of Energy, Idaho Falls, Idaho, December.

Robertson, J. B., R. Schoen, J. T. Barraclough, 1974, The Influence of Liquid Waste Disposal on the Geochemistry of Water at the National Reactor Testing Station, Idaho: 1952-1970, IDO22053, U.S. Department of Energy, Idaho Falls, Idaho.

Sehlke, G., and F. E. Bickford, 1993, Idaho National Engineering Laboratory Groundwater Monitoring Plan, Volume 1, DOE/ID-10441, U.S. Department of Energy, Idaho Operations Office, Idaho Falls, ID, June.

USGS (U.S. Geological Survey), 1982-1993, Water Data Storage Retrieval System (WATSTORE), water quality file.

Whitehead, R. L., 1982, Geohydrologic Framework of the Snake River Plain Regional Aquifer System, Idaho and Eastern Oregon, U.S. Geological Survey, Professional Paper 1408-B.

Wilhelmsen, R. N., K. C. Wright, D. W. McBride, 1993, Annual Report-1992 Environmental Surveillance for EG\&G Idaho Waste Management Facilities at the Idaho National Engineering Laboratory, EGG-2679(92), EG\&G Idaho, Inc., Idaho Falls, Idaho, August.

Wood, W. W., and W. H. Low, 1986, "Aqueous Geochemistry and Digenesis in the Eastern Snake River Plain Aquifer System," Idaho, Geological Society of America Bulletin, 97 (12), pp. 14561466.

Wood, W. W., and W. H. Low, 1988, Solute Geochemistry of the Snake River Plain Regional Aquifer System, Idaho and Eastern Oregon, U.S. Geological Survey Professional Paper 1408-D.

\section{Section 4.9, Ecological Resources}

Anderson, J. E., 1991, Final Report: Vegetation Studies to Support the NPR Environmental Impact Statement, Subcontract No. C34-110421, Task Order No. 72, EG\&G Idaho, Inc., Idaho Falls, Idaho.

Arthur, W. J., J. W. Connelly, D. K. Halford, T. D. Reynolds, 1984, Vertebrates of the Idaho National Engineering Laboratory, DOE/ID-12099, U.S. Department of Energy, Idaho Falls, Idaho. 
Arthur, W. J., O. D. Markham, C. R. Groves, B. L. Keller, D. K. Halford, 1986, "Radiation Dose to Small Mammals Inhabiting a Solid Radioactive Waste Disposal Area," Journal of Applied Ecology, 23, pp. 13-26.

Chowlewa, A. F., and D. M. Henderson, 1984, A Survey and Assessment of the Rare Vascular Plants of the INEL, DOE/ID-12100, U.S. Department of Energy, Idaho Operations Office, Radiological and Environmental Sciences Laboratory, Idaho Falls, Idaho.

COE (U.S. Corps of Engineers), 1987, Corps of Engineers Wetlands Delineation Manual, Technical Report 4-87-1, Waterways Experiment Station, Vicksburg, Mississippi, 100 pp plus appendices.

Craig, T. H., D. K. Halford, O. D. Markham, 1979, "Radionuclide Concentrations in Nestling Raptors near Nuclear Facilities," Wilson Bulletin, 91, pp. 71-77.

EGG (EG\&G Idaho, Inc.), undated, Ecology and Wetlands, Draft File Report prepared for U.S. Department of Energy, Contract No. DE-AC07-76IDO1570.

Evenson, L. M., 1981, Systemic Effects of Radiation Exposure on Rodents Inhabiting Liquid and Solid Radioactive Waste Disposal Areas, Master's Thesis, Colorado State University, Fort Collins, Colorado.

Halford, D. K, and O. D. Markham, 1984, "Iodine-129 in Waterfowl Muscle from a Radioactive Leaching Pond Complex in Southern Idaho," Health Physics, 46, 6, pp. 1259-1263.

Hampton, N. L., R. C. Rope, J. M. Glennon, K. S. Moor, 1993, A Preliminary Survey of Designated Wetlands on the Idaho National Engineering Laboratory, EGG-EEL-10629, EG\&G Idaho, Inc., Idaho Falls, Idaho, March.

IAEA (International Atomic Energy Agency), 1992, Effects of Ionizing Radiation on Plants and Animals at Levels Implied by Current Radiation Protection Standards, Technical Report Series No. 332, Vienna, Austria.

Kramber, W. L., R. C. Rope, J. Anderson, J. Giennon, A. Morse, 1992, "Producing a Vegetation Map of the Idaho National Engineering Laboratory Using Landsat Thematic Mapper Data," in Proceedings of ASPRS 1992 Annual Meeting, Albuquerque, New Mexico, March, 1992.

Lobdell, C., U.S. Fish and Wildlife Service, 1992, letter to R. Rothman, U.S. Department of Energy, Idaho Operations Office, Idaho Falls, Idaho, providing a list of endangered, threatened, proposed, and candidate species that may be present within the area of the proposed action sent in response to Notice of Intent, FWS-1-4-93-SP-84, December 15.

Markham, O. D., 1974, "Environmental and Radiological Monitoring at the National Reactor Testing Station during FY-1973 (July 1972-June 1973)," Radiation Data Report, 15, pp. 227 246.

Markham, O. D., D. K. Halford, R. E. Autenrieth, R. L. Dickson, 1982, "Radionuclides in Pronghorn Resulting from Nuclear Fuel Reprocessing and Worldwide Fallout," Journal of Wildlife Management, 46, 1, pp. 30-42. 
Millard, J. B., F. W. Whicker, O. D. Markham, 1990, "Radionuclide Uptake and Growth of Barn Swallows Nesting by Radioactive Leaching Ponds," Health Physics, 58, 4, pp. 429-439.

Morris, R. C., 1993a, "The Implications of Lined Radioactive Waste Ponds for Waterfowl Contamination," in Environmental Health Physics, Proceedings of the Twenty-Sixth Midyear Topical Meeting of the Health Physics Society, Coeur d'Alene, Idaho, January 24-28, 1993, R. L. Kathren, D. H. Denham, K. Salmon, eds., Richland, Washington, Columbia Chapter, Health Physics Society, pp. 147-155.

Morris, R. C., 1993b, personal communication with T. Doerr, Science Applications International Corporation, Idaho Falls, Idaho, August 16.

Morris, R. C., 1993c, Radioecology of the Idaho National Engineering Laboratory, Draft U.S. Department of Energy file report, Idaho Falls, Idaho, August 16.

Reynolds, T. D., 1993a, U.S. Department of Energy, Idaho Operations Office, Idaho Falls, Idaho, personal communication with T. Doerr, Science Applications International Corporation, September 8.

Reynolds, T. D., 1993b, U.S. Department of Energy, Idaho Operations Office, Idaho Falls, Idaho, personal comm. inication with T. Doerr, Science Applications International Corporation, October 17.

Reynolds, T. D., J. W. Connelly, D. K. Halford, W. J. Arthur, 1986, "Vertebrate Fauna of the Idaho National Environmental Research Park," Great Basin Naturalist 46, 3, pp. 513-527.

Rope, R. C., N. L. Hampton, K A. Finley, 1993, "Ecological Resources," in Irving, J. S., Environmental Resource Document for the Idaho National Engineering Laboratory, Volumes 1 and 2, EGG-WMO-10279, EG\&G Idaho, Inc., Idaho Falls, Idaho, July.

Wilhelmsen, R. N., and K. C. Wright, 1992, Annual Report-1991, Environmental Surveillance for EG\&G Idaho Waste Management Facilities at the Idaho National Engineering Laboratory, EGG-2679(91), EG\&G Idaho, Inc., Idaho Falls, Idaho.

\section{Section 4.10, Nolse}

Abbott, M.L., J. M. Brooks, K. L. Martin, 1990, NPR Environmental Impacts at the INEL: Air Quality, Cooling Tower, and Noise, NPRD-90-059, EG\&G Idaho, Inc., Idaho Falls, Idaho.

CFR (Code of Federal Regulations), 1992, 29 CFR 1910.95, "Occupational Noise Exposure," Office of the Federal Register, Washington, D.C.

Leonard, P.R., 1993, "Air Resources," Environmental Resource Document for the Idaho National Engineering Laboratory, J. S. Irving, Principal Investigator, Volume 1, WMO-10279, EG\&G Idaho, Inc., Idaho Falls, Idaho. 


\section{Section 4.11, Traffic and Transportation}

Lehto, W. K, 1993, Traffic and Transportation, Engineering Design File, ER\&WM-EDF-0020-93, Revision 1, EG\&G Idaho, Inc., Idaho Falls, Idaho, December.

Maheras, S. J., 1993, Health Effects from Onsite INEL Baseline Incident-Free Transportation, Engineering Design File, EIS-TRANS-07, Science Applications International Corporation, Idaho Falls, Idaho.

\section{Section 4.12, Occupational Health and Safety}

Anderson, B. D., and L. J. Peterson-Wright, 1993, Drinking Water Program, 1992 Annual Report, EGG-2678(92), EG\&G Idaho, Inc., Idaho Falls, Idaho, August.

DOE (U.S. Department of Energy), 1993, Occupational Injury and Property Damage Summary, January-March 1993, DOE/EH/01570, U.S. Department of Energy, Washington, D.C., March.

EPA (U.S. Environmental Protection Agency), 1988, Limiting Values of Radionuclide Intake and Air Concentration and Dose Conversion Factors for Inhalation, Submersion, and Ingestion, Federal Guidance Report No. 11, Washington, D.C.

EPA (U.S. Environmental Protection Agency), 1989, Risk Assessment Guidance for Superfund, Volume 1, Human Health Evaluation Manual (Part A), Interim Final, EPA/540/1-89/002, Washington, D.C., December.

EPA (U.S. Environmental Protection Agency), 1993, Health Effects Assessment Summary Tables, FY-1993 Supplement No. 1, EPA 540-R-93-058A, Washington, D.C., July.

EPA (U.S. Environmental Protection Agency), 1994, IRIS (Integrated Risk Information System) database.

ICRP (International Commission on Radiological Protection), 1991, 1990 Recommendations of the International Commission on Radiological Protection, ICRP Publication 60, Annals of the ICRP, Volume 21, No. 1-3, Pergamon Press, New York, New York.

Mann, L. J., 1994, U.S. Geological Survey, INEL Field Office, Idaho Falls, Idaho, personal communication with A. L. Lundahl, Science Applications International Corporation, Idaho Falls, Idaho, February 3.

NSC (National Safety Council), 1993, National Safety Council, Accident Facts, 1993 Edition. 


\section{Section 4.13, Idaho National Engineoring Laboratory Servicea}

IPC/DOE (Idaho Power Company/U.S. Department of Energy), 1986, Contract for Electric Service between Idaho Power Company and United States Department of Energy Idaho Operations

Office, Contract No. DE-AC07-86ID12588, effective date November 1, 1986.

\section{8ection 5.4 Cultural Resources}

AIRFA (American Indian Religious Freedom Act), 1978, Public Law 95-341, 42 U.S.C. 1966.

ARPA (Archeological Resources Protection Act), 1979, Public Law 96-95; Public Law 100-555, 100-588, 1988; 16 U.S.C. $470 \mathrm{aa}-470 \mathrm{~mm}$.

CFR (Code of Federal Regulations), 1986, 36 CFR 800, "Protection of Historic Property," Advisory Council on Historic Preservation, Vol. 51 FR 31115, September 2.

DOE (U.S. Department of Energy), 1993, "Memorandum of Agreement among the U.S. DOEIdaho Field Office, the Idaho State Historic Preservation Office, and the Advisory Council on Historic Preservation," (for Auxiliary Reactor Areas I, II, and III).

NAGPRA (Native American Graves Protection and Repatriation Act), 1990, Public Law 101-601.

NHPA (National Historic Preservation Act), 1966, Public Law 89-665, 16 U.S.C. 470; 36 CFR 6068.800; 48 FR 44716-44742; Public Law 102-575.

Sectlon 5.7, Alr

Belanger, R., J. Raudsep, D. A. Ryan, 1994, Technical Support Document for Air Resounces, INEL Environmental Restoration and Waste Management Program (draft), Science Applications International Corporation, Idaho Falls, Idaho, May.

Benson, P.E., 1979, CALINE-3--A Versatile Dispersion Model for Predicting Air Pollutant Levels Near Highways and Arterial Streets, FWHA/CA/TL-79/23, NTIS PB80-220 841, Federal Highway Administration.

EPA (U.S. Environmental Protection Agency), 1992a, User's Guide for the Industrial Source Complex (ISC2) Dispersion Models, "Volume I - User's Instructions," Office of Air Quality Planning and Standards, Research Triangle Park, North Carolina, March.

EPA (U.S. Environmental Protection Agency), 1992b, SCREEN2 Model User's Guide, Office of Air Quality Planning and Standards, Research Triangle Park, North Carolina, September. 
EPA (U.S. Environmental Protection Agency), 1992c, Workbook for Plume Visual Impact Screening and Analysis (Revised), EPA-454/R-92-023, Office of Air Quality Planning and Standards, Research Triangle Park, North Carolina, October.

EPA (U.S. Environmental Protection Agency), 1992d, Compilation of Air Pollutant Emission Factors, "Volume 1: Stationary Point and Area Sources," AP-42, (1985 with Supplements through October 1992), Office of Air Quality Planning and Standards, Research Triangle Park, North Carolina, September.

IDHW (Idaho Department of Health and Welfare, Division of Environmental Quality), 1991, 1990 Idaho Air Quality Annual Report.

IDHW (Idaho Department of Health and Welfare, Division of Environmental Quality), 1994, Revised Title 1 (draft), Chapter 1, "Rules for the Control of Air Pollution in Idaho," August 18.

Johnson, C., 1993, Meteorologist, Idaho Department of Health and Welfare, Division of Environmental Quality, personal communication with D. Ryan, Science Applications International Corporation, San Diego, California, November 22.

Napier, B.A., R.A. Peloquin, D.L. Strenge, J.V. Ramsdell, 1988, GENII - The Hanford Radiation Dosimetry Software System, PNL-6584, Pacific Northwest Laboratories, November.

Wilson, R., 1993, Regional Meteorologist, U.S. Environmental Protection Agency, personal communication with D. Ryan, Science Applications International Corporation, San Diego, California, November 15.

Winges, K., 1992, User's Guide for the Fugitive Dust Model (FDM) (Revised) - User's Instructions, EPA-910/9-88-202R, U.S. Environmental Protection Agency, Region 10, Seattle, Washington, January

Section 5.8, Water

Arnett, R. C., and M. J. Rohe, 1993, Predicted Consequences on the Snake River Plain Aquifer of Alternative Actions 1 and 2 (Draft), EGG-ER-XXX, EG\&G Idaho Inc., Idaho Falls, ID.

Arnett, R. C., J. M. McCarthy, G. T. Norell, A. L. Schafer-Perini, T. R. Wood, 1992, Basis for Initial Code Selection for WAG 10 Groundwater and Contaminant Transport Modeling at the Idaho National Engineering Laboratory, EGG-ER-XXX, DRAFT, EG\&G Idaho, Inc., Idaho Falls, Idaho.

Arnett, R. C., M. J. Rohe, R. K. Springer, 1993, Groundwater Transport Model Calibration Data and Bounding Assumptions, ER\&WM-EDF-0006-93, DRAFT, EG\&G Idaho, Inc., Idaho Falls, Idaho. 
Bennett, C. M., 1994, U.S. Department of Energy, Idaho Operations Office, Idaho Falls, Idaho, personal communication with A. L. Lundahl, Science Applications International Corporation, Idaho Falls, Idaho, January 28.

Bennett, C. M., 1990, Streamflow and Groundwater Level Changes Along the Big Lost River at the Idaho National Engineering Laboratory, Idaho, U.S. Geological Survey Water Resources Investigations Report 90-4067, U.S. Geological Survey, Idaho Falls, ID.

Case, J., W. House, P. Austin, 1990, Groundwater Protection Management Plan, U.S. Department of Energy, Idaho Falls, Idaho, May.

Cecil, L. D., B. R. Orr, T. Norton, S. R. Anderson, 1991, Formation of Perched Groundwater Zones and Concentrations of Selected Chemical Constituents in Water, Idaho National Engineering Laboratory, Idaho, 1986-88, U. S. Geological Survey Water Resources Investigations Report 91-4166, DOE/ID-22100, U.S. Department of Energy, Idaho Falls, Idaho.

Cecil, L. D., T. M. Beasley, J. R. Pittman, R. L. Michel, P. W. Kubik, P. Sharma, U. Fehn, H. E. Gove, 1992, "Water Infiltration Rates in the Unsaturated Zone at the Idaho National Engineering Laboratory Estimated from Chlorine-36 and Tritium Profiles, and Neutron Logging," Proceedings of the 7th International Symposium on Water-Rock Interaction, Park City, Utah, July 13-18, 1992.

Dames \& Moore, 1993, Remedial Investigation/Feasibility Study Report for the Organic Contamination in the Vadose Zone-Operable Unit 7-08, Volume I: Remedial Investigation, Draft, EGG-ER-1069184, prepared for EG\&G by Dames \& Moore, Denver, Colorado 80202.

DOE (U.S. Department of Energy), 1993, Radiation Protection of the Public and the Environment, DOE Order 5400.5, Change 1, U.S. Department of Energy, Washington, D.C., February 8.

DOE-ID (U.S. Department of Energy, Idaho Operations Office), 1991, INEL Nonradiological Waste Management Information System (NWIMS), DOE/ID-10057 (1991), U.S. Department of Energy, Idaho Falls, Idaho.

DOE-ID (U.S. Department of Energy, Idaho Operations Office), 1992, INEL Nonradiological Waste Management Information System (NWIMS), DOE/ID-10057 (1992), U.S. Department of Energy, Idaho Falls, Idaho.

DOE-ID (U.S. Department of Energy, Idaho Operations Office), 1993, Idaho National Engineering Laboratory Storm Water Pollution Prevention Plan for Construction Activities-Generic Plan, DOE/ID-10425, U.S. Department of Energy, Idaho Falls, Idaho.

EG\&G Idaho (EG\&G Idaho, Inc.), 1993, Hydrogeologic and Geochemical Assessment of Contaminated Groundwater at the Idaho Chemical Processing Plant, EGG-ER-XXX (Draft), Revision 2, EG\&G Idaho, Inc., Idaho Falls, Idaho.

Koslow, K. N., ard D. H. Van Haaften, 1986, Flood Routing Analysis for a Failure of Mackay Dam, EGG-EP-7184, EG\&G Idaho, Inc., Idaho Falls, Idaho, 78 p. 
Lehto, W. K, 1993, INEL Groundwater Sounce Term, ER\&WM-EDF-0018-93, EG\&G Idaho, Inc., Idaho Falls, Idaho, September.

Lochr, C. A. B. H. Becker, D. E. Burns, R. M. Huntley, S. M. Rood, P. Sinton, T. H. Smith, 1994, Preliminary Scoping Risk Assessment for Waste Pits, Trenches, and Soil Vaults at the Subsurface Disposal Area, Idaho National Engineering Laboratory, EGG-WM-11181, EG\&G Idaho, Inc., Idaho Falls, Idaho, April.

Maheras, S. J., A. S. Rood, S. W. Magnuson, M. E. Sussman, R. N. Bhatt, 1994, Radioactive Waste Management Complex Low-Level Waste Radiological Performance Assessment, EGGWM-8773, EG\&G Idaho, Inc., Idaho Falls, Idaho, April.

Mann, L. J., 1994, U.S. Geological Survey, INEL Field Office, Idaho Falls, Idaho, personal communication with A. L. Lundahl, Science Applications International Corporation, Idaho. Falls, Idaho, February 3.

Robertson, J. B., 1974, Digital Modeling of Radioactive and Chemical Waste Transport in the Snake River Plain Aquifer at the National Reactor Testing Station, Idaho, IDO-22054, U.S.

Department of Energy, Idaho Falls, Idaho.

Robertson, J. B., 1977, Numerical Modeling of Subsurface Radioactive Solute Transport from Waste-Seepage Ponds at the Idaho National Engineering Laboratory, U.S. Geological Survey Open File Report 76-717, IDO-22057, U.S. Department of Energy, Idaho Falls, Idaho.

Robertson, J. B., R. Schoen, J. T. Barraclough, 1974, The Influence of Liquid Waste Disposal on the Geochemistry of Water at the National Reactor Testing Station, Idaho: 1952-1970, U.S. Geological Survey Open File Report, IDO-22053, U.S. Department of Energy, Idaho Falls, Idaho.

Schafer-Perini, A. L., 1993, TAN Groundwater RI/FS Contaminant Fate and Transport Modeling Results, ER-WAG1-21, EDF, EG\&G Idaho, Inc., Idaho Falls, Idaho.

Sisson, J. B., and G. C. Ellis, 1990, Summary Report of Results of the Vapor Vacuum Extraction Test at the RWMC, EGG-WM-9301, EG\&G Idaho, Inc., Idaho Falls, Idaho.

Zheng, C., 1992, MT3D: A Modular Three-Dimensional Transport Model for Simulation of Advection, Dispersion and Chemical Reactions of Contaminants in Groundwater Systems, S.S. Papadopulous and Associates, Inc., 7944 Wisconsin Avenue, Bethesda, Maryland 20814.

\section{Section 5.9, Ecology}

Emlen, S. T., 1984, "Cooperative Breeding in Birds and Mammals," Chapter 12 in Behavioral Ecology, an Evolutionary Approach, 2nd edition, J. R. Krebs and N. B. Davies (eds.), Sunderland, Massachusetts: Sinauer Associates. 
Hampton, N. L., R. C. Rope, J. M. Glennon, K. S. Moor, 1993, A Preliminary Survey of Designated Wetlands on the Idaho National Engineering Laboratory, EG\&G Idaho, Inc., Idaho Falls, Idaho, March.

Morris, R. C., 1993a, personal communication with T. Doerr, Science Applications International Corporation, Idaho Falls, Idaho, August 16.

Morris, R. C., 1993b, Radioecology of the Idaho National Engineering Laboratory, Draft U.S. Department of Energy File Report, Idaho Falls, Idaho, August 16.

Ralls, K, P. H. Harvey, A. M. Lyles, 1986, "Inbreeding in Natural Populations of Birds and Mammals," Chapter 3 in Conservation Biology, The Science of Scarcity and Diversity, M. E. Soule, ed., Sunderland, Massachusetts: Sinauer Associates.

Rope, R. C., N. L. Hampton, K. A. Finley, 1993, "Ecological Resources," in Irving, J. S., Environmental Resource Document for the Idaho National Engineering Laboratory, Volumes 1 and 2, EGG-WMO-10279, EG\&G Idaho, Inc., Idaho Falls, Idaho, July.

\section{Section 5.11, Traffic and Transportation}

Cashwell, J. W., K. S . Neuhauser, P. C. Reardon, G. W. McNair, 1986, Transportation Impacts of the Commercial Radioactive Waste Management Program, SAND85-2715, Sandia National Laboratories report.

Cornelius, K, 1993, Argonne National Laboratory-East, Argonne, Illinois, letter and data to J. Medema, U.S. Department of Energy, Idaho Operations Office, Idaho Falls, Idaho, regarding "Sizing/Emissions for INEL TSD Facilities for LLW," December 7.

Croff, A. G., 1980, ORIGEN2 - A Revised and Updated Version of the Oak Ridge Isotope Generation and Depletion Code, ORNL-5621, Oak Ridge National Laboratory, Oak Ridge, Tennessee, July.

DOE (U. S. Department of Energy), 1990, Waste Isolation Pilot Plant Final Supplement, Environmental Impact Statement, DOE/Environmental Impact Statement-0026-FS, January, 518 pp.

DOE (U. S. Department of Energy), 1992, Integrated Data Base for 1992: U.S. Spent Fuel and Radioactive Waste Inventories, Projections, and Characteristics, DOE/RW-0006, Revision 8, October, 341 pp.

Doty, S. R., B. L. Wallace, G. C. Holzworth, 1976, A Climatological Analysis of Pasquill Stability Categories Based on 'STAR' Summaries, National Oceanic and Atmospheric Administration, National Climatic Center, Asheville, North Carolina, April.

Elder, J. C., J. M. Graf, J. M. Dewart, T. E. Buhl, W. J. Wenzel, L. J. Walker, A. K. Stoner, 1986, $A$ Guide to Radiological Accident Considerations for Siting and Design of DOE Nonreactor Nuclear Facilities, LA-10294-MS. 
Fischer, L. E., C. K. Chou, M. A. Gerhard, C. Y. Kimura, R. W. Martin, R. W. Mensing, M. E. Mount, M. C. Witte, 1987, Shipping Container Response to Severe Highway and Railway Accident Conditions, NUREG/CR-4829, Lawrence Livermore National Laboratory, Berkeley, California.

Heiselmann, H. W., 1994, DOE Complex Wide Spent Nuclear Fuel Shipment Estimates for DOE Programmatic Spent Nuclear Fuel Management Environmental Impact Statement, Engineering Design File (EDF) EIS-TRANS-20, Science Applications International Corporation, Idaho Falls, Idaho.

ICRP (International Commission on Radiological Protection), 1991, 1990 Recommendations of the International Commission on Radiological Protection, ICRP Publication 60, Annals of the ICRP, Volume 21, No. 1-5, Pergamon Press, New York, New York.

Johnson, P. E., D. S. Joy, D. B. Clarke, J. M. Jacobi, 1993a, HIGHWAY 3.1 - An Enhanced Highway Routing Model: Program Description, Methodology, and Revised User's Manual, ORNL/TM-12124, Oak Ridge National Laboratory, Oak Ridge, Tennessee.

Johnson, P. E., D. S. Joy, D. B. Clarke, J. M. Jacobi, 1993b, INTERLINE 5.0 - An Expanded Railroad Routing Model: Program Description, Methodology, and Revised User's Manual, ORNL/TM-12090, Oak Ridge National Laboratory, Oak Ridge, Tennessee.

Jones, S. P., 1994, Doses and Health Effects From INEL Onsite Incident-Free Transportation for Alternatives $A, B, C$, and $D$, Engineering Design File (EDF) EIS-TRANS-12, Science Applications International Corporation, Idaho Falls, Idaho.

Lehto, W. K, 1994, Waste and Materials Transportation for Environmental Restoration and Waste Management Environmental Impact Statement Alternatives $A-D$, Engineering Design File EISTRANS-27, Science Applications International Corporation, Idaho Falls, Idaho.

Madsen, M. M., J. M. Taylor, R. M. Ostmeyer, P. C. Reardon, 1986, RADTRAN III, SAND840036, Sandia National Laboratories, Albuquerque, New Mexico.

Maheras, S. J., 1994a, Doses and Health Effects From Offsite Incident-Free Transportation of Waste For Alternatives A-D, Engineering Design File (EDF) EIS-TRANS-17, Science Applications International Corporation, Idaho Falls, Idaho.

Maheras, S. J., 1994b, Doses and Health Effects From Offsite Incident-Free Transportation of Non-Naval Spent Nuclear Fuel For Alternatives 1-5, Engineering Design File (EDF) EIS-TRANS-18, Science Applications International Corporation, Idaho Falls, Idaho.

Maheras, S. J., 1994c, Doses and Health Effects From Incident-Free Transportation of University Research Reactor Spent Nuclear Fuel For Alternatives 1-5, Engineering Design File (EDF) EIS-TRANS-14, Science Applications International Corporation, Idaho Falls, Idaho.

Maheras, S. J., 1994d Doses and Health Effects From Incident-Free Transportation of Foreign Research Reactor Spent Nuclear Fuel from Ports to INEL, Savannah River, and Hanford For Alterratives 1-5, Engineering Design File (EDF) EIS-TRANS-15, Science Applications International Corporation, Idaho Falls, Idaho. 
Maheras, S. J., 1994e, Doses and Health Effects From Incident-Free INEL Onsite Non-Naval Spent Nuclear Fuel Transpostation For Alternatives 1 through 5, Engineering Design File (EDF) EIS-TRANS-13, Science Applications International Corporation, Idaho Falls, Idaho.

Neuhauser, K. S. and F. L. Kanip̃, 1992, RADTRAN 4 User Guide, SAND89-2370, Sandia National Laboratories resport.

NRC (U. S. Nuclear Regulatory Commission), 1977, Final Environmental Impact Statement on the Transportation of Radioactive Material By Air and Other Modes, NUREG-0170, U.S. Nuclear Regulatory Commission, Washington, D.C.

Ostmeyer, R. M., 1986, A Kevised Rail-Stop Exposure Model for Incident-Free Transport of Nuclear Waste, SAND85-2149, Sandia National Laboratories report.

Rao, R. K. E. L. Wilmot, R. E. Luna, 1982, Non-Radiological Impacts of Transporting Radioactive Material, SAND81-1703, Sandia National Laboratories, Albuquerque, New Mexico.

Saricks, C. and T. Kvitek, 1991, Trends in State-Level Freight Accident Rates: An Extension of Risk Factor Development for RADTRAN, unpublished report submitted to Reactor Technology and Transportation Division, U.S. Department of Energy, Chicago Operations Office, Argonne, Illinois, April.

Transportation Research Board, 1985, Highway Capacity Manual, Special Report 209, National Research Council, Washington, D.C.

Wierman, T. E., 1994, On and Off-INEL Hazardous Material Transportation Accident Analysis, Engineering Design File (EDF) EIS-TRANS-11, Science Applications International Corporation, Idaho Falls, Idaho.

Wooden, D. G., 1986, Railroad Transportation of Spent Nuclear Fuel, SAND86-7083, Sandia National Laboratories report.

Yuan, Y. C., S. Y. Chen, D. J. LePoire, R. Rothman, 1993, RISKIND - A Computer Program for Calculating Radiological Consequences and Health Risks from Transportation of Spent Nuclear Fuel, ANL/EAIS-6, Revision 0, Argonne National Laboratory, Argonne, Illinois, February.

\section{Section 5.12, Occupational Health and Safety}

Anderson, B. D., and L. J. Peterson-Wright, 1993, Drinking Water Program, 1992 Annual Report, EGG-2678(92), EG\&G Idaho, Inc., Idaho Falls, ID, August.

ICRP (International Commission on Radiological Protection), 1991, 1990 Recommendations of the International Commission on Radiological Protection, ICRP Publication 60, Annals of the ICRP, Volume 21, No. 1-3, Pergamon Press, New York, New York. 
Mann, L. J., 1994, U.S. Geological Survey, INEL Field Office, Idaho Falls, Idaho, personal communication with A. L. Lundahl, Science Application International Corporation, Idaho Falls, Idaho, February 2.

NAS/NRC (National Academy of Sciences/National Research Council), 1990, Committee on the Biological Effects of Ionizing Radiations, Health Effects of Exposure to Low Levels of Ionizing Radiation, BEIR V, National Academy Press, Washington.

\section{Section 5.13, INEL Services}

Hendrickson, K. D., 1994, Estimates of Utility Usage, Engineering Design File No. EIS-SERV-001, Science Applications International Corporation, Idaho Falls, Idaho.

\section{Section 5.14, Accident Analysis}

DOE (U.S. Department of Energy), 1991, Secretary of Energy Notice, "Nuclear Safety Policy," SEN-35-91, Washington, D.C., September 9.

DOE (U. S. Department of Energy), 1993a, Definitions and Criteria for Accident Analysis, DOE Standard DOE-DP-STD-3005-93, Proposed, Washington, D.C.

DOE (U.S. Department of Energy), 1993b, Occupational Injury and Property Damage Summary, DOE/EH/01570-H2, Washington, D.C., January-March 1993, page 9.

DOE (U.S. Department of Energy), 1993c, Idaho National Engineering Laboratory/West Valley Demonstration Project Emergency Plan, Volume 1, "Operational Emergency Plan," Revision 1, Washington, D.C., November 1.

DOE (U.S. Department of Energy), 1993d, Spent Fuel Working Group Report on Inventory and Storage of the Department's Spent Nuclear Fuel and other Radioactive Irradiated Nuclear Materials and Their Environmental, Safety, and Health Vulnerabilities, Volume 1, Washington, D.C., November.

DOE-ID (U.S. Department of Energy, Idaho Operations Office), 1991, Idaho National Enginsering Laboratory Historical Dose Evaluation, DOE/ID-12119, Idaho Falls, Idaho, August.

DOE-ID (U.S. Department of Energy, Idaho Operations Office), 1994, Draft Accident Assessments for Idaho National Engineering Laboratory Facilities, DOE/ID-10471, Idaho Falls, Idaho, June.

EG\&G Idaho (EG\&G Idaho, Inc.), 1993, NPR-MHTGR, Generic Reactor Plant Description \& Source Terms, Addenda I\&II, Adaptations for Siting the Heavy-Water Reactor (HWR) and Light-Water Reactor (LWR) at the INEL, EGG-NPR-8522, Vol. II, Rev. A, Idaho Falls, Idaho, April. 
EPA (U.S. Environmental Protection Agency), 1990, "EPA Title III List of Lists," EPA 560/4-90011, Office of Toxic Substances, and Office of Solid Waste and Emergency Response, Washington, D.C., January.

EPA (U.S. Environmental Protection Agency), 1991, Manual of Protective Action Guides and Protective Actions for Nuclear Incidents, EPA 400-R-92-001, Office of Radiation Programs, Washington, D.C., October.

FR (Federal Register), 1994, 59 FR 20, Environmental Protection Agency, 40 CFR Part 9 and 68, "List of Regulated Substances and Thresholds for Accidental Release Prevention and Risk Management Programs for Chemical Accident Release Prevention; Final Rule and Notice, January 31, pp 4478-4501.

Hendrix, C. E., 1994, "Occupational Fatality Rates for the State of Idaho," Engineering Design File, Science Applications International Corporation, February 25.

Homann (Homann Associates, Inc.), 1988, EPIcode ${ }^{\mathrm{TM}}$ (Emergency Prediction Information Manual), Fremont, California.

ICRP (International Committee Radiation Protection), 1991, 1990 Recommendations of the International Commission on Radiological Protection, ICRP Publication 60, Annals of the ICRP, Volume 21, No. 1-3, Pergamon Press, New York, New York.

Millet, W. H., EG\&G Idaho, Inc., 1993, Letter to C. E. Hendrix, Science Applications International Corporation, regarding "Response to a Request for INEL Fatality Statistics," WHM-25-93, December 21.

NRC (National Research Council), 1990, Health Effects of Exposure to Low Levels of Ionizing Radiation (Biological Effects of Ionizing Radiation (BEIR V) report), Committee on the Biological Effects of Ionizing Radiation, National Academy Press, Washington, D.C.

NSC (National Safety Council), 1993, Accident Facts, 1993 Edition, Itasca, Illinois, page 37.

Wenzel, D. R., 1993, The Radiological Safety Analysis Computer Program (RSAC-5), WINCO1123, Westinghouse Idaho Nuclear Company, Inc., Idaho Falls, Idaho, March.

\section{Section 5.15, Cumulative Impacts}

Bingham County, 1986, 1986 Bingham County Planning Handbook, Bingham County Planning Commission, Blackfoot, Idaho.

Bonneville County, 1976, Bonneville County Comprehensive Plan, Boinneville County Planning Commission, Idaho Falls, Idaho, November 11.

Butte County, 1992, Butte County, Idaho, County Comprehensive Plan, Butte County Planning and Resource Board, Arco, Idaho. 
Cashwell, C. E., and J. D. McClure, 1992, "Transportation Accidents/Incidents Involving Radioactive Materials (1971-1991)," presented at PATRAM 92, 10th International Symposium on the Packaging and Transportation of Radioactive Materials, September 13-18, 1992, Yokohama City, Japan.

Clark County, 1986, Clark County Planning and Zoning Ordinances, Clark County Commissioners, Dubois, Idaho.

Clark County, 1992, Clark County Interim Land Use Plan (Proposed), Clark County Planning, Zoning, and Land Use Commission, Dubois, Idaho, July 21.

DOE (U.S. Department of Energy), 1986, Environmental Assessment, Yucca Mountain Site, Nevada Research and Development Area, Nevada, DOE/RW-0073, U.S. Department of Energy, Washington, D.C..

DOE (U.S. Department of Energy), 1990, Final Supplement, Environmental Impact Statement, Waste Isolation Pilot Plant, DOE/EIS-0026-FS, U.S. Department of Energy, Washington, D.C.

DOE (U.S. Department of Energy), 1994, Environmental Assessment of Ungent-Relief Acceptance of Foreign Research Reactor Spent Nuclear Fuel, DOE/EA-0912, U.S. Department of Energy, Washington, D.C.

DOE-ID (U.S. Department of Energy, Idaho Operations Office), 1991, Idaho National Engineering Laboratory Historical Dose Evaluation, DOE/ID-12119, Volume I, U.S. Department of Energy, Idaho Falls, Idaho, August.

EPA (Environmental Protection Agency), 1989, Risk Assessments, Environmental Impact Statement, NESHAPS for Radionuclides, "Background Information Document, Vol. 2," EPA/520/1-89-006-1, Office of Radiation Programs, September.

Javitz, H. S., T. R. Lyman, C. Maxwell, E. L. Myers, C. R. Thompson, 1985, Transport of Radioactive Material in the United States: Results of a Survey to Determine the Magnitude and Characteristics of Domestic, Unclassified Shipments of Rualioactive Materials, SAND84-7174, Sandia National Laboratories, Albuquerque, New Mexico.

Jefferson County, 1988, Jefferson County Idaho Comprehensive Plan, Jefferson County Planning Commission, Rigby, Idaho, May 23.

Jefferson County Soil and Water Conservation District, 1990, Five-Year Resource Conservation Plan-1990-1993, Roberts, Idaho.

Maheras, S. J., 1994, Summary of Doses and Health Effects From Historical Offsite Spent Nuclear Fuel and Waste Shipments to the INEL, Engineering Design File (EDF) EIS-TRANS-26, Science Applications International Corporation, Idaho Falls, Idaho.

NRC (U.S. Nuclear Regulatory Commission), 1977, Final Environmental Impact Statement on the Transportation of Radioactive Materials By Air and Other Modes, NUREG-0170. 
Patterson, D. E., 1968, "The Accident Experience of the USAEC in the Shipment of Radioactive Material," Proceedings of the Second International Symposium on Packaging and Transportation of Radioactive Materials, CONF-681001, Gatlinburg, Tennessee, October 14-18, 1968, pp. 199-209.

Pole, S., T. A. Benzen, K. J. Izbicki, J. Banger, K. D. Bulmahn, K. S. Moor, 1993, Historical and Current Status of INEL Waste Streams, ER\&WM-EDF-0014-93, Revision 2, EG\&G Idaho Inc., Idaho Falls, Idaho, September 23.

Robertson, J.B., R. Schoen, J. T. Barraclough, 1974, The Influence of Liquid Waste Disposal on the Geochemistry of Water at the National Reactor Testing Station, Idaho: 1952-1970, IDO22053, U.S. Department of Energy, Idaho Falls, Idaho.

SAIC (Science Applications International Corporation), 1991, Historical Overview of Domestic Spent Fuel Shipments--Update, DE91 016051, July.

USN (U.S. Department of the Navy), 1984, Final Environmental Impact Statement on the Disposal of Decommissioned, Defueled Naval Submarine Reactor Plants, PB90-193855.

Weiner, R. F., P. A. LaPlante, J. P. Hageman, 1991a, "An Approach to Assessing the Impacts of Incident-Free Transportation of Radioactive Materials: II. Highway Transportation," Risk Analysis, 11, 4, pp. 661-666.

Weiner, R. F., P. A. LaPlante, J. P. Hageman, 1991b, "An Approach to Assessing the Impacts of Incident-Free Transportation of Radioactive Materials: I. Air Transportation," Risk Analysis, 11,4 , pp. 655-660.

\section{Section 5.16, Adverse Environmental Effects Which Cannot Be Avoided}

DOE (U.S. Department of Energy), 1993, "Memorandum of Agreement among the U.S. DOEIdaho Field Office, the Idaho State Historic Preservation Office, and the Advisory Council on Historic Preservation" (for Auxiliary Reactor Areas I, II, and III), U.S. Department of Energy, Washington, D.C.

\section{Section 5.19, Mitigation}

AIRFA (American Indian Religious Freedom Act), 1978, Public Law 95-341, 42 U.S.C. 1966.

ARPA (Archaeological Resources Protection Act), 1979, Public Law 96-95; Public Law 100-555, 100-588, 1988; 16 U.S.C. 470aa-470mm.

Belanger, R., J. Raudsep, D. A. Ryan, 1994, Technical Support Document for Air Resources, INEL Environmental Restoration and Waste Management Program (draft), Science Applications International Corporation, Idaho Falls, Idaho, May. 
Case, J., W. House, P. Austin, 1990, Groundwater Protection Management Plan, U.S. Department of Energy, Idaho Falls, Idaho, May.

DOE (U.S. Department of Energy), 1990, Memorandum EH-231: "Management of Cultural Resources at Department of Energy Facilities," U.S. Department of Energy, Washington, D.C., February 23.

DOE (U.S. Department of Energy), 1992a, Working Agreement, Policy on Native American Consultation, U.S. Department of Energy, Washington, D.C., September 29.

DOE (U.S. Department of Energy), 1992b, Order 1230.2, American Indian Tribal Government Policy, U.S, Department of Energy, Washington, D.C., April 8.

DOE-ID (U.S. Department of Energy, Idaho Operations Office), 1993a, Idaho National Engineering Laboratory Storm Water Pollution Prevention Plan for Industrial Activities, DOE/ID-10431, U.S. Department of Energy, Idaho Falls, Idaho, April 1.

DOE-ID (U.S. Department of Energy, Idaho Operations Office), 1993b, Idaho National Engineering Laboratory Storm Water Pollution Prevention Plan for Construction Activities-Generic Plan, DOE/ID-10425, U.S. Department of Energy, Idaho Falls, Idaho, September.

IAEA (International Atomic Energy Agency) 1992, Effects of Ionizing Radiation on Plants and Animals at Levels Implied by Current Radiation Protection Standards, Technical Report Series No. 332, Vienna, Austria.

IDHW (Idaho Department of Health and Welfare), 1994, Revised Title 1 (draft), Chapter 1, Rules for the Control of Air Pollution in Idaho, Idaho Department of Health and Welfare, Division of Environmental Quality, August 18.

NAGPRA (Native American Grave Protection and Repatriation Act), 1990, Public Law 101-601.

NHPA (National Historic Preservation Act), 1966, Public Law 89-665, 16 U.S.C. 470; 36 CFR 6068.800; 48 FR 44716-44742; Public Law 102-575.

\section{Appendix A, Primer on Radioactivity and Toxicology}

Kamrin, M. A., 1988, Taxicology--A Primer on Toxicology Principles and Applications, Chelsea, Michigan: Lewis Publishers, Inc.

Maheras, S. J., and D. J. Thorne, 1993, New Production Reactor Exposure Pathways at the Idaho National Engineering Laboratory, EGG-NPR-8957, EG\&G Idaho, Inc. Idabo Falls, Idaho, January.

Ottoboni, M. A., 1991, The Dose Makes the Poison: A Plain-Language Guide to Taxicology, second edition, New York: Van Nostrand Reinhold. 
WINCO (Westinghouse Idaho Nuclear Co., Inc.), 1988, Introduction to Radiological Safety: Study Guide, Rev. 2, Westinghouse Idaho Nuclear Company, Inc., Idaho Falls, Idaho.

\section{Appendix C, Information Supporting the Alternatives}

Belanger, R., J. Raudsep, D. A. Ryan, 1994, Technical Support Document for Air Resources, INEL Environmental Restoration and Waste Management Programs, (Draft unnumbered report), Science Application International Corporation, Idaho Falls, Idaho, May.

DOE (U.S. Department of Energy), 1988, Radioactive Waste Management, DOE Order 5820.2A, Chapter V, U.S. Department of Energy, Washington, D.C.

DOE (U.S. Department of Energy), 1989, Commercial Greater-Than-Class-C Low-Level Radioactive Waste Long-Range Planning Document, DOE/LLW-77T, Revision O, National Low-Level Radioactive Waste Management Program, Washington, D.C., February.

DOE (U.S. Department of Energy, Office of Nuclear Energy), 1991, Environmental Assessment, Transportation, Receipt, and Storage of Ft. St. Vrain Spent Fuel at the Iradiated Fuel Storage Facility at the Idaho Chemical Processing Plant, Idaho National Engineering Laboratory, U.S. Department of Energy, Washington D.C., February.

DOE (U.S. Department of Energy), 1992, Environmental Assessment for the Retrieval and ReStorage of Transuranic Storage Area Waste, DOE/EA-0692, U.S. Department of Energy, Washington D.C.

DOE (U.S. Department of Energy), 1993a, Environmental Assessment of the Interim Action for Cleanup of Pit 9 at the Radioactive Waste Management Complex, DOE/EA-0854, U.S. Department of Energy, Washington, D.C.

DOE (U.S. Department of Energy), 1993b, Environmental Assessment, Idaho National Engineering Laboratory Low-Level and Mixed Waste Processing, DOE/EA-0843, U.S. Department of Energy, Office of Environmental Restoration and Waste Management, Washington, D.C., June.

DOE (U.S. Department of Energy), 1994, Environmental Assessment for Waste Characterization Facility, DOE/EA-0906, (draft), U.S. Department of Energ, Washington, D.C.

DOE-ID (U.S. Department of Energy, Idaho Operations Office), 1993, Environmental Assessment: High Level Waste Tank Farm Replacement Project for the Idaho Chemical Processing Plant at the Idaho National Engineering Laboratory, DOE/EA-0831, U.S. Department of Energy, Washington, D.C., June.

DOE-ID (U.S. Department of Energy, Idaho Operations Office), 1993, Environmental Assessment for Decontamination and Selective Demolition of Auxiliary Reactor Areas II and III, DOE/EA0858, U.S. Department of Energy, Washington, D.C. 
WINCO (Westinghouse Idaho Nuclear Company), Initial Performance Assessment for the Disposal of Spent Nuclear Fuel and High-Level Wastes Stored at the INEL, Volumes I \& II, SAND-932330/1/2, Westinghouse Idaho Nuclear Company, Idaho Falls, Idaho.

WINCO (Westinghouse Idaho Nuclear Company), 1993, Preliminary Waste Acceptance Criteria for Idaho Chemical Processing Plan Spent Fuel and Waste Management Technology Development, WINCO-1157, Westinghouse Idaho Nuclear Company, Idaho Falls, Idaho, September.

WINCO (Westinghouse Idaho Nuclear Company), 1994, ICPP Radioactive Liquid and Calcine Waste Technologies Evaluation Interim Report, Westinghouse Idaho Nuclear Company, Idaho Falls, Idaho, June.

\section{Appendlx F, Section F-1}

Cartwright, J.V., R.M. Beemiller, R.D. Gustely, 1981, RIMS II, Regional Input-Output Modeling System, U.S. Department of Commerce, Bureau of Economic Analysis, Washington, D.C.

U.S. Bureau of Economic Analysis, 1993, Regional Input-Output Modeling System (RIMS II), Machine-readable regionalized input-output multipliers for the INEL region of influence, U.S. Department of Commerce, Washington, D.C.

\section{Appendix F, Section F-2}

Ackerman, D. J., 1991, Transmissivity of the Snake River Plain Aquifer at the Idaho National Engineering Laboratory, Idaho, U.S. Geological Survey Water Resources Investigations Report 91-4058, DOE/ID-22097, U.S. Department of Energy, Idaho Falls, Idaho.

Ackerman, D.J., 1992, Transmissivity of Perched Aquifers at the Idaho National Engineering Laboratory, Idaho, U.S. Geological Survey Water Resources Investigations Report 91-4114, DOE/ID-22099, U.S. Department of Energy, Idaho Falls, Idaho.

Arnett, R. C., EG\&G Idaho, Inc., Idaho Falls, Idaho, 1994, memorandum to A. L. Bowman, EG\&G Idaho, Inc., Idaho Falls, Idaho, subject: "Calculated Contaminant Releases from Spent Nuclear Fuel Wet Transfer and Storage Systems," RCA-05-94, May 10.

Arnett, R. C., and M. J. Rohe, 1993, Predicted Consequences on the Snake River Plain Aquifer of Alternative Actions 1 and 2, EGG-ER-xxxx, in support of the Idaho National Engineering Laboratory Environmental Restoration and Waste Management Environmental Impact Statement, EG\&G Idaho, Inc., Idaho Falls, Idaho, October.

Arnett, R.C., and R.K. Springer, 1993, Calibration of the Groundwater Flow Model for a Portion of the Snake River Plain Aquifer at the INEL, ER\&WM-EDF-0024-93, DRAFT, EG\&G Idaho, Inc., Idaho Falls, Idaho. 
Arnett, R.C., J.M. McCarthy, G.T. Norell, A.L. Schafer-Perini, T.R. Wood, 1992, Basis for Initial Code Selection for WAG 10 Groundwater and Contaminant Transport Modeling at the Idaho National Engineering Laboratory, EGG-xx-nnn, DRAFT, EG\&G Idaho, Inc., Idaho Falls, Idaho.

Barraclough, J. T., J. B. Robertson, V. J. Janzer, 1976, Hydrology of the Solid Waste Burial Ground as Related to the Potential Migration of Radionuclides, Idaho National Engineering Laboratory, August, 1976, U.S. Geological Survey Open File Report 76-471, IDO-22056, U.S. Department of Energy, Idaho Falls, Idaho.

Barraclough, J. T., B. D. Lewis, R. G. Jensen, 1981, Hydrologic Conditions at the Idaho National Engineering Laboratory, Idaho-Emphasis: 1974-1978, U.S. Geological Survey Water Resources Investigations Report 81-256, IDO-22060, U.S. Department of Energy, Idaho Falls, Idaho.

Bishop, C. W., 1991, Hydraulic Properties of Vesicular Basalts, Masters Thesis, University of Árizona, Tucson, Arizona.

Bishop, C. W., A. H. Wylie, J. L. Mattick, 1992, Results of Perched Water Aquifer Testing at the Test Reactor Area, Idaho National Engineering Laboratory, Idaho, EGG-WM-10014, EG\&G Idaho, Inc., Idaho Falls, Idaho.

Bobo, R., 1993, A Review of the Production, Use, and Disposal of Groundwater and the Generation, Storage, and Processing of Radioactive Liquid Waste at the Idaho Chemical Processing Plant, INEL, INEL Oversight Program Technical Report 93-03, INEL Oversight Program, Idaho Falls, Idaho, August.

Cecil, L. D., J. R. Pittman, T. M. Beasley, R. L. Michel, P. W. Kubik, P. Sharma, U. Fehn, H. E. Gove, 1992, "Water Infiltration Rates in the Unsaturated Zone at the Idaho National Engineering Laboratory Estimated from Chlorine-36 and Tritium Profiles, and Neutron Logging," Proceedings of the 7th International Symposium on Water-Rock Interaction, Park City, Utah, July 13-18.

Cecil, L. D., B. R. Orr, T. Norton, S. R. Anderson, 1991, Formation of Perched Groundwater Zones and Concentrations of Selected Chemical Constituents in Water, Idaho National Engineering Laboratory, Idaho, 1986-88, U.S. Geological Survey Water Resources Investigations Report 91-4166, DOE/ID-22100, U.S. Department of Energy, Idaho Falls, Idaho.

Creed, B., 1994, Non-Zero Source Term Maxima for Spent Nuclear Fuel (SNF) Wet Transfer and Storage, and Criteria Checklist Compliance, U.S Department of Energy, Idaho Operations Office, Idaho Falls, Idaho, March 25.

Dames \& Moore, 1993, Remedial Investigation/Feasibility Study Report for the Organic Contamination in the Vadose Zone-Operable Unit 7-08, Volume I: Remedial Investigation, Draft, EGG-ER-1069184, prepared for EG\&G by Dames \& Moore, Denver, Colorado 80202. 
DOE-ID (U.S. Department of Energy, Idaho Operations Office), 1993a, DOE-ID Architectural Engineering Standards, Revision No. 14, U.S. Department of Energy, Idaho Falls, Idaho, September.

DOE-ID (U.S. Department of Energy, Idaho Operations Office), 1993b, Idaho National Engineering Laboratory Storm Water Pollution Prevention Plan for Industrial Activities, DOE/DD-10431, U.S. Department of Energy, Idaho Falls, Idaho, September 15.

Domenico, P.A. and F.W. Schwartz, 1990, Physical and Chemical Hydrogeology, John Wiley \& Sons, Inc., Toronto, Ontario.

Drever, J. I., 1988, The Geochemistry of Natural Waters, Second Edition, Prentice Hall, Englewood Cliffs, New Jersey.

Driscoll, F. G., 1989, Groundwater and Wells, Second Edition, St. Paul, Minnesota: Johnson Filtration Systems, Inc.

EG\&G (EG\&G Idaho, Inc.), 1993, Hydrogeologic and Geochemical Assessment of Contaminated Groundwater at the Idaho Chemical Processing Plant, EGG-ER-XXX (Draft), Revision 2, EG\&G Idaho, Inc., Idaho Falls, Idaho.

FR (Federal Register), 1992a, 57 FR 41176, "Final NPDES General Permits for Storm Water Discharges from Construction Sites," Federal Register, U.S. Environmental Protection Agency, December 9.

FR (Federal Register), 1992b, 57 FR 41327, "Final NPDES General Permits for Storm Water Discharges Associated with Industrial Activity," Federal Register, U.S. Environmental Protection Agency, September 9.

Freeze, R. A., and J. A. Cherry, 1979, Groundwater, Prentice-Hall, Inc., Englewood Cliffs, New Jersey 07632.

Garabedian, S. P., 1986, Application of a Parameter Estimation Technique to Modeling the Regional Aquifer Underlying the Eastern Snake River Plain, Idaho, U.S. Geological Survey Water Supply Paper 2278.

Garabedian, S. P., 1992, Hydrology and Digital Simulation of the Regional Aquifer System, Easterm Snake River Plain, Idaho, U.S. Geological Survey Professional Paper 1408-F, U.S. Government Printing Office, Washington, D.C.

Golder (Golder Associates, Inc.), 1993, Assessment of Trends in Groundwater Quality at the Idaho National Engineering Laboratory, Report No. 933-1151, Golder Associates, Idaho Falls, Idaho, October 29.

Hale, D., 1994, Description of a Generic Spent Nuclear Fuel Infrastructure for the Programmatic Environmental Impact Statement, B430-94-079, EG\&G Idaho, Inc., Idaho Falls, Idaho, February. 
Hoff, D. L., R. G. Mitchell, G. C. Bowman, R. Moore, 1990, The Idaho National Engineering Laboratory Site Environmental Report for Calendar Year 1989, DOE/ID-12082(89),

Environmental Sciences Branch, Radiological and Environmental Sciences Laboratory, U.S. Department of Energy, Idaho Falls, Idaho, June.

Hubbell, J. M., 1990, Monitoring and Sampling Perched Ground Waver in a Basaltic Terrain, EGGM-89411, EG\&G Idaho, Inc., Idaho Falls, Idaho.

Kaminsky, J. F., 1991, In Situ Characterization of Unsaturated Hydraulic Properties of Surficial Sediments Adjacent to the Radioactive Waste Management Complex, Idaho National Engineering Laboratory, Idaho, Master's Thesis, ISU-91-000, Idaho State University, Pocatello, Idaho.

Koslow, K. N., and D. H. Van Haaften, 1986, Flood Routing Analysis for a Failure of Mackay Dam, EGG-EP-7184, EG\&G Idaho, Inc., Idaho Falls, Idaho.

Lehto, W.K, 1993, INEL Groundwater Source Term, ER\&WM-EDF-0018-93, DRAFT, EG\&G Idaho, Inc., Idaho Falls, Idaho, September.

Liszewski, M. J., and L. J. Mann, 1992, Purgeable Organic Compounds in Groundwater at the Idaho National Engineering Laboratory, Idaho - 1990 and 1991, U.S. Geological Survey Open File Report 92-174, DOE/ID-22104, U.S. Department of Energy, Idaho Falls, Idaho, July.

Loehr, C. A., B. H. Becker, D. E. Burns, R. M. Huntley, S. M. Rood, P. Sinton, T. H. Smith, 1994, Preliminary Scoping Risk Assessment for Waste Pits, Trenches, and Soil Vaults at the Subsurface Disposal Area, Idaho National Engineering Laboratory, EGG-WM-11181, EG\&G Idaho, Inc., Idaho Falls, Idaho, April.

Lundahl, A. L., M. Estes, S. Willixms, K. Fischer, 1994, Water Resources Supporting Document for the INEL ER\&WM EIS, Engineering Design File EIS-WATER-XXX (Draft), Science Applications International Corporation, Idaho Falls, Idaho.

Maheras, S. J., A. S. Rood, S. W. Magnuson, M. E. Sussman, R. N. Bhatt, Radioactive Waste Management Complex Low-Level Waste Radiological Performance Assessment, EGG-WM8773, EG\&G Idaho, Inc., Idaho Falls, Idaho, April.

Mann, L. J., 1990, Purgeable Organic Compounds in Groundwater at the Idaho National Engineering Laboratory, Idaho-1988 and 1989, U.S. Geological Survey Open File Report 90367, DOE/ID-22089, U.S. Department of Energy, Idaho Falls, Idaho, July.

Mann, L. J., and L. L. Knobel, 1987, Pungeable Onganic Compounds in Groundwater at the Idaho National Engineering Laboratory, Idaho, U.S. Geological Survey Open . Ile Report OFR 87766, DOE/ID 22074, U.S. Department of Energy, Idaho Falls, Idaho, December.

Martineau, R.C., D. H. Hoggan, K. N. Keck, T. R. Wood, 1990, Hydrologic Modeling Study of Potential Flooding at the Subsurface Disposal Area from A Hypothetical Breach of Dike 2 at the Idaho National Engineering Laboraiury, EGG-WM-9502, EG\&G Idaho, Inc., Idaho Falls, Idaho. 
Marts, K, and W. Barrash, 1991, Duplicate Sampling of Perched Groundwater Beneath the Percolation Ponds at the Idaho Chemical processing Plant, Idaho National Engineering Laboratory, State of Idaho, INEL Oversight Program Technical Report 91-03, INEL Oversight Program, Idaho Falls, Idaho, December 1991.

McCurry M., M. Estes, J. Fromm, J. Welhan, W. Barrash, 1994, "Three-dimensional Chemical Structure of the INEL Aquifer System near the Idaho Chemical Processing Plant," in Hydrology, Waste Disposal, Science and Politics, Proceedings of the 30th Symposium on Engineering Geology and Geotechnical Engineering, Link P.K. (ed.), College of Engineering, Idaho State University, Pocatello, Idaho, pp. 207-219.

McKinney, J. D., 1985, Big Last River 1983-1984 Flood Threat, PPD-FPB-002, EG\&G Idaho, Inc., Idaho Falls, Idaho.

Pittman, J. R., R. G. Jensen, P. R. Fischer, 1988, Hydrologic Conditions at the Idaho National Engineering Laboratory, 1982 to 1985. U.S. Geological Survey Water Resources Investigations Report 89-4008, DOE/ID-22078, U.S. Department of Energy, Idaho Falls, Idaho, December.

Robertson, J. B., 1974, Digital Modeling of Radioactive and Chemical Waste Transport in the Snake River Plain Aquifer at the National Reactor Testing Station, Idaho, IDO-22054, U.S. Department of Energy, Idaho Falls, Idaho, May

Robertson, J. B., 1977, Numerical Modeling of Subsurface Radioactive Solute Transport from Waste-Seepage Ponds at the Idaho National Engineering Laboratory, U.S. Geological Survey Open File Report 76-717, IDO-22057, Idaho Falls, Idaho, January.

Robertson, J. B., R. Schoen, J. T. Barraclough, 1974, The Influence of Liquid Waste Disposal on the Geochemistry of Water at the National Reactor Testing Station, Idaho: 1952-1970, IDO22053, U.S. Department of Energy, Idaho Falls, Idaho.

Sagendorf, J., 1991, Meteorological Information for RWMC Flood Potential Studies, National Oceanic and Atmospheric Administration, Idaho Falls, Idaho, August 14.

Schafer-Perini, A. L., 1993, TAN Groundwater RI/FS Contaminant Fate and Transport Modeling Results, ER-WAG1-21, EDF, EG\&G Idaho, Inc., Idaho Falls, Idaho.

Schreiber, D. L., 1986, Probable Maximum Flood on the Big Lost River at Mackay Dam, Idaho, EG\&G Idaho, Inc., Idaho Falls, Idaho.

USGS (U.S. Geological Survey), 1963-1993, Water Data Storage Retrieval System (WATSTORE), Water Quality File, Idaho National Engineering Laboratory Project Office.

Volcanism Working Group, 1990, Assessment of Potential Volcanic Hazards for New Production Reactor Site at the Idaho National Engineering Laboratory, EGG-NPR-10624, EG\&G Idaho, Inc., Idaho Falls, Idaho.

Whitehead, R. L., 1987, Geohydrologic Framework of the Snake River Plain Regional Aquifer System, Idaho and Eastern Oregon, U.S. Geological Survey Professional Paper 1408-B, U.S. Geological Survey, Idaho Falls, Idaho. 

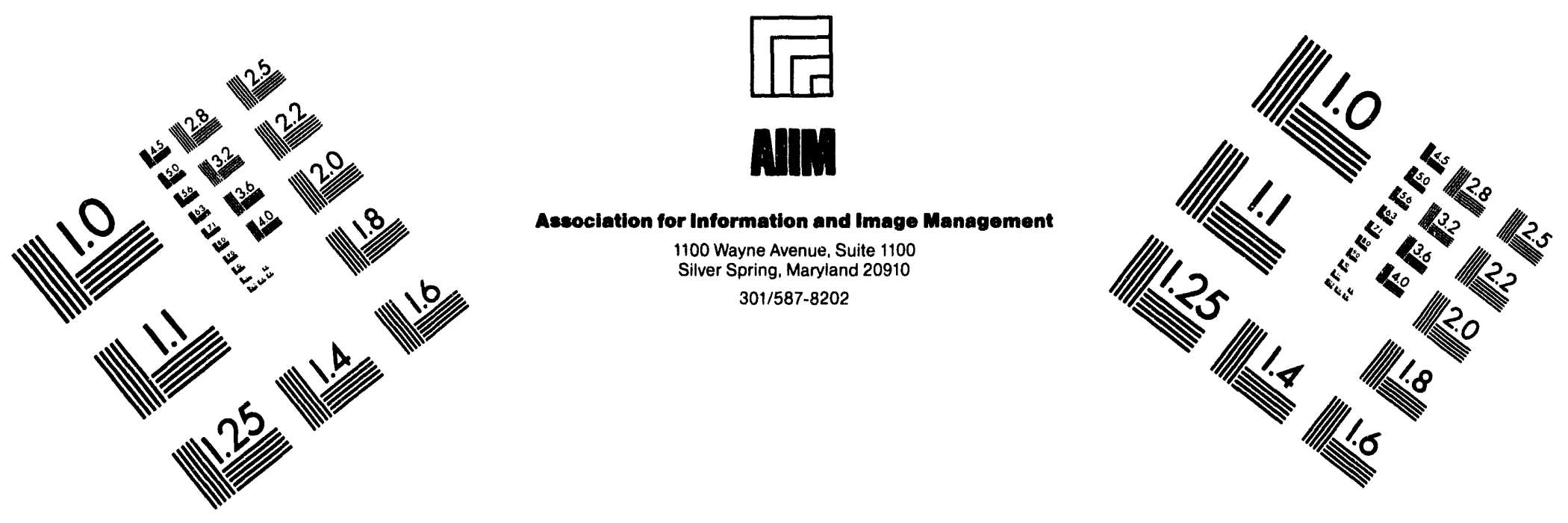

Centimeter

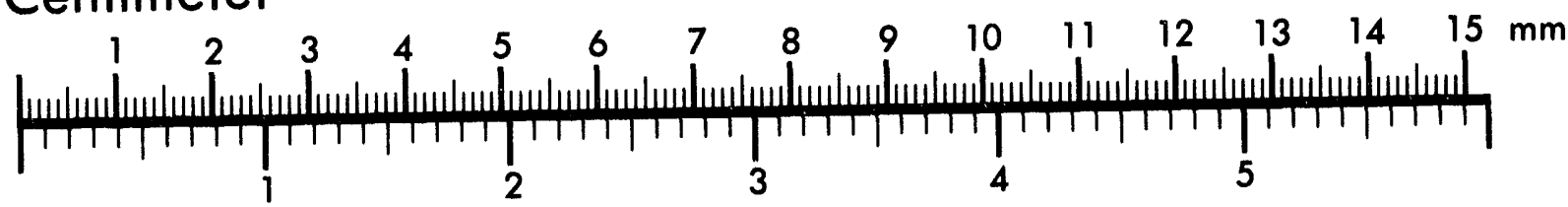
Inches
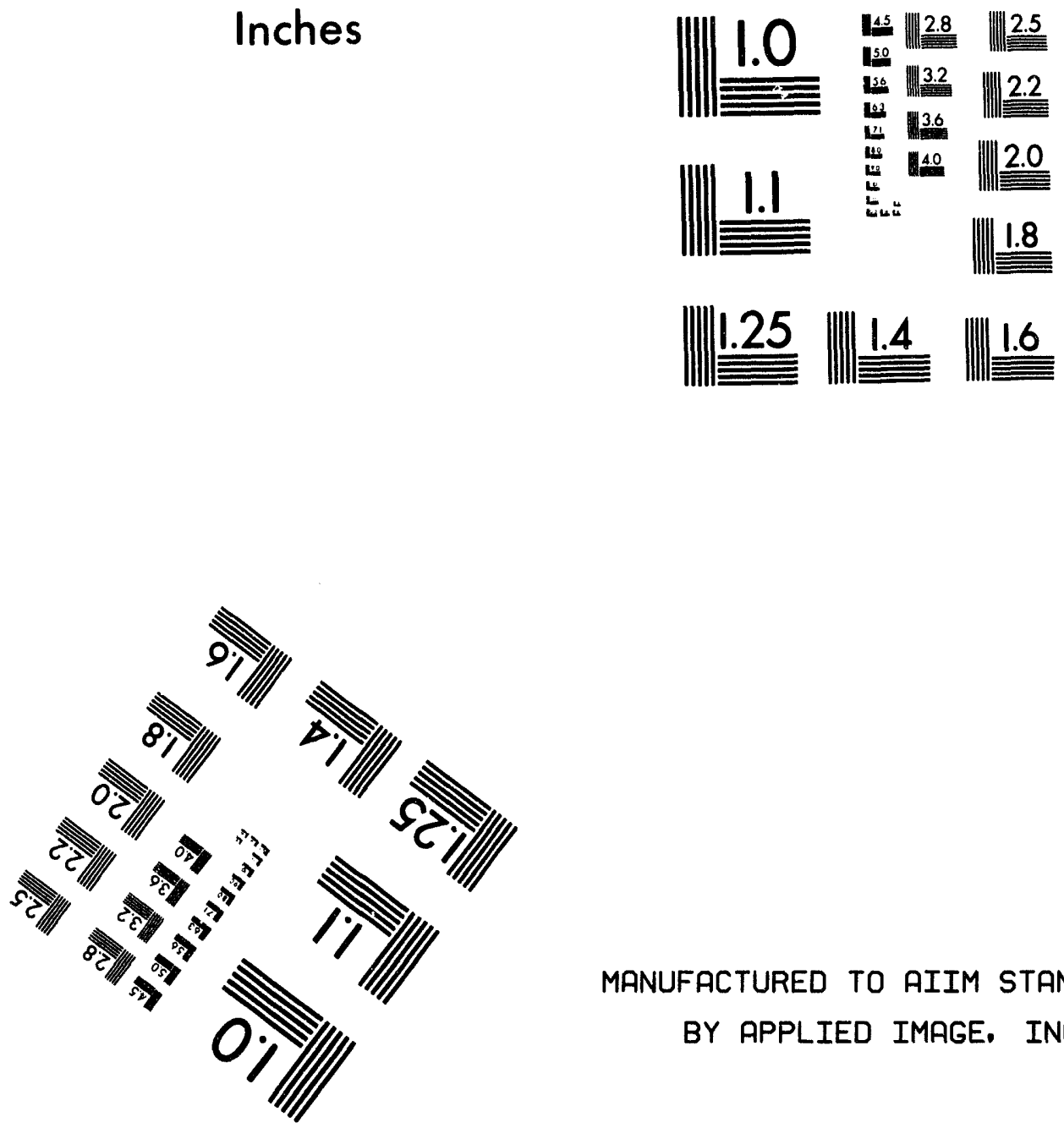

MANUFACTURED TO AIIM STANDARDS BY APPLIED IMAGE. INC.

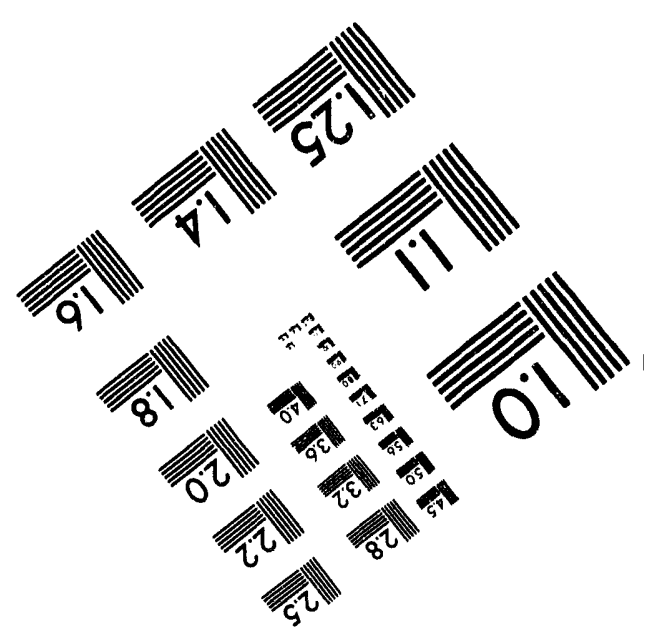



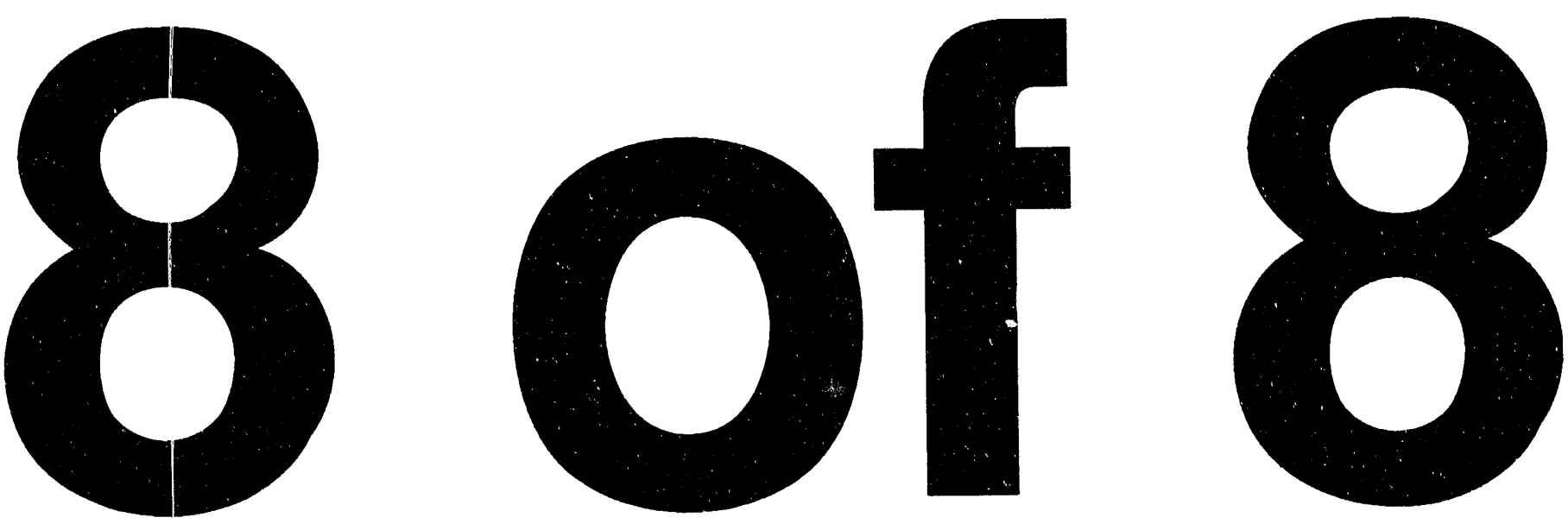
Wong, I., M. Hemphill-Haley, T. Sawyer, K. Coppersmith, R. Youngs, W. Silva, and C. Stark, 1993, Site-Specific Probabilistic Seismic Hazard Analysis for the Idaho National Engineering Laboratory, (draft), EG\&G Idaho, Inc., Idaho Falls, Idaho, June.

Wood, T. R., G. T. Norrell, A. W. Wylie, K. J. Dooley, G. S. Johnson, E. R. Neher, 1994, "Design of the Idaho National Engineering Laboratory Intcgrated Field Scale Pumping and Infiltration Test," in Hydrology, Waste Disposal, Science and Politics, Proceedings of the 30th Symposium on Engineering Geology and Geotechnical Engineering, pp. 152-164.

Wood, W. W., and W. H. Low, 1986, "Aqueous Geochemistry and Digenesis in the Eastern Snake River Plain Aquifer System," Geological Society of America Bulletin, 97, 12, pp. 1456-1466, December.

Wood, W. W., and W. H. Low, 1988, Solute Geochemistry of the Snake River Plain Regional Aquifer System, Idaho and Eastern Oregon, U.S. Geological Survey Professional Paper 1408-D.

Woodward-Clyde Consultants, 1990, Earthquake Strong Ground Motion Estimates for the Idaho National Engineering Laboratory: Final Report, Volume i: Summary, Volume II:

Methodology and Analyses, and Volume III: Appendices, EGG-BG-9350, EG\&G Idaho, Inc., Idaho Falls, Idaho, November.

Woodward-Clyde Consultants, 1992, Earthquake Strong Ground Motion Evaluations for the Proposed New Production Reactor at the Idaho National Engineering Laboratory: Final Report, Volume I: Deterministic Evaluation and Volume II: Probabilistic Evaluation, EGGGEO-10304, EG\&G Idaho, Inc., Idaho Falls, Idaho, June.

Zukauskas, J. F., D. H. Hoggan, R. M. Neupauer, J. F. Sagendorf, 1992, Conceptual Design for Surface Water Drainage Control Upgrades for the RWMC Watershed and the Transuranic Storage Area, EGG-ESQ-9994, EG\&G Idaho, Inc., Idaho Falls, Idaho, August.

\section{Appendix F, Section F-3}

Belanger, R., J. Raudsep, D. A. Ryan, 1994, Technical Support Document for Air Resources, INEL Environmental Restoration and Waste Management Programs, (Draft), Science Applications International Corporation, Idaho Falls, Idaho, May.

Benson, P.E., 1979, CALINE-3--A Versatile Dispersion Model for Predicting Air Pollutant Levels Near Highways and Arterial Streets, FWHA/CA/TL-79/23, NTIS PB80-220 841, Federal Highway Administration.

Clawson, K. L., G. E. Start, N. R. Ricks, 1989, Climatography of the Idaho National Engineering Laboratory, $2^{\text {nd }}$ Edition, DOE/ID-12118, U.S. Department of Commerce, National Oceanic and Atmospheric Administration, Environmental Research Laboratories, Air Resources Laboratory, Field Research Division, Idaho Falls, Idaho. 
DOE (U.S. Department of Energy) 1991, Environmental Regulatory Guide for Radiological Effluent Monitoring an Environmental Surveillance, DOE/EH-0173T, U.S. Department of Energy, Washington, D.C., January.

DOE-ID (U.S. Department of Energy, Idaho Operations Office) 1991, Air Permitting Handbook, DOE/ID-10324, U.S. Department of Energy, Idaho Falls, Idaho, February.

DOE-ID (U.S. Department of Energy, Idaho Operations Office) 1992a. The Idaho National Engineering Laboratory Site Environmental Report for Calendar Year 1991, DOE/ID-12082 (91), U.S. Department of Energy, Idaho Falls, Idaho, September.

DOE-ID (U.S. Department of Energy, Idaho Operations Office) 1992b, 1991 INEL National Emission Standard for Hazardous Air Pollutants, Annual Report, DOE/ID-10342(91), U.S. Department of Energy, Idaho Falls, Idaho, June.

DOE-ID (U.S. Department of Energy, Idaho Operations Office) 1992c. Supplement to 1991 INEL National Emission Standard for Hazardous Air Pollutants, Annual Report, U.S. Department of Energy, Idaho Falls, Idaho, August.

DOE-ID (U.S. Department of Energy, Idaho Operations Office) 1992d, Air Emission Inventory for the Idaho National Engineering Laboratory, 1990 and 1991 Emissions Report, U.S. Department of Energy, Idaho Falls, Idaho, June.

DOE-ID (U.S. Department of Energy, Idaho Operations Office) 1993a. The Idaho National Engineering Laboratory Site Environmental Report for Calendar Year 1992, DOE/ID-12082 (92), U.S. Department of Energy, Idaho Falls, Idaho, September.

DOE-ID (U.S. Department of Energy, Idaho Operations Office) 1993b. Draft Toxic Pollutant Emission Inventory of the Idaho National Engineering Laboratory, U.S. Department of Energy, Idaho Falls, Idaho, August.

DOE-ID (U.S. Department of Energy, Idaho Operations Office) 1993c, 1992 INEL National Emission Standard for Hazardous Air Pollutants, Annual Report, DOE/ID-10342(92), U.S. Department of Energy, Idaho Falls, Idaho, June.

Ecology \& Environment, Inc., 1993, Air Quality Impact of Construction and Mobile Sources at the Idaho National Engineering Laboratory, unnumbered report transmitted to R.W.Russell, U.S. Department of Energy, Idaho Operations Office, December 29.

Ecology \& Environment, Inc., 1994, Baseline Air Toxics Impact Assessment of the Idaho National Engineering Laboratory, Unnumbered report transmitted to R.W. Russell, U.S. Department of Energy, Idaho Operations Office, January 28 (with supplemental update on March 16).

EPA (U.S. Environmental Protection Agency), 1992a, User's Guide for the Industrial Source Complex (ISC2) Dispersion Models, "Volume I - User's Instructions," Office of Air Quality Planning and Standards, Research Triangle Park, North Carolina, March.

EPA (U.S. Environmental Protection Agency), 1992b, SCREEN2 Model User's Guide, Office of Air Quality Planning and Standards, Research Triangle Park, North Carolina, September. 
EPA (U.S. Environmental Protection Agency), 1992c, Workbook for Plume Visual Impact Screening and Analysis (Revised), Environmental Protection Agency-454/R-92-023, Office of Air Quality Planning and Standards, Research Triangle Park, North Carolina, October.

EPA (U.S. Environmental Protection Agency), 1993a, Compilation of Air Pollutant Emission Factors, "Volume 1: Stationary Point and Area Sources," AP-42, (1985 with Supplements through October 1993), Office of Air Quality Planning and Standards, Research Triangle Park, North Carolina, September.

EPA (U.S. Environmental Protection Agency), 1993b, Guideline in Air Quality Models (Revised), Environmental Protection Agency-450/2-78-027R, February.

ICRP (International Commission on Radiological Protection), 1977, Recommendations of the International Commission on Radiological Protection, ICRP Publication 30, Pergamon Press.

ICRP (International Commission on Radiological Protection), 1979, Limits for Intakes of Radionuclide by Workers, ICRP Publication 30, Pergamon Press.

IDHW (Idaho Department of Health and Welfare), 1991, 1990 Idaho Air Quality Annual Report, Idaho Department of Health and Welfare, Division of Environmental Quality, Boise, Idaho.

IDHW (Idaho Department of Health and Welfare), 1994, Revised Title 1, Chapter 1, Rules for the Control of Air Pollution in Idaho, Idaho Department of Health and Welfare, Division of Environmental Quality, Boise, Idaho.

Johnson, C., 1993, Meteorologist, Idaho Department of Health and Welfare, Division of Environmental Quality, personal communication with D. Ryan, Science Applications International Corporation, San Diego, California, November 22.

Leonard, P. R., 1992, Formal Documentation of 1987-1991 INEL Wind Files Used in GENII,EG\&G Idaho Engineering Design File SEM-CX21-91-001, EG\&G Idaho, Inc., Idaho Falls, Idaho, January 29.

Leonard, P. R., 1993, Estimated Radiological Doses Resulting from Airborme Radionuclide Released by Facilities at the Idaho National Engineering Laboratory, EGG-WTD-10676, EG\&G Idaho, Inc., Idaho Falls, Idaho, July.

Leonard, P. R., 1994, Maximum Individual, Collocated Worker, and Population Doses from INEL Proposed Action and No Action Sources, SNF\&EIS-0003-94, EG\&G Idaho, Inc., Idaho Falls, Idaho, February.

Litteer, 1992, INEL Radioactive Waste Management Information System (RWMIS), EG\&G Idaho, Inc, Idaho Falls, Idaho.

Litteer, 1993, INEL Radioactive Waste Management Information System (RWMIS), EG\&G Idaho, Inc, Idaho Falls, Idaho. 
Maheras, S.J., 1992, 1990 and 1991 NESHAPS Annual Report CAP-88 Dose Assessment and Verification and Validation Report for Diffuse Emissions, EG\&S EDF NESHAP-91DIFFUSE, EG\&G Idaho, Inc., Idaho Falls, Idaho, August 3.

Napier, B.A., R.A. Peloquin, D.L. Strenge, J.V. Ramsdell, 1988, GENII - The Hanford Radiation Dosimetry Software System, PNL-6584, Pacific Northwest Laboratories, Washington, November.

NCRP (National Council on Radiation Protection and Measurements), 1987, Ionizing Radiation Exposure of the Population of the United States, NCRP Report No. 93, Bethesda, Maryland, December.

NCRP (National Council on Radiation Protection and Measurements), 1989, Screening Techniques for Determining Compliance with Environmental Standards, NCRP Commentary No. 3, Bethesda, Maryland.

Notar, J., 1993a, Air Quality Specialist, National Park Servics, Denver Regional Office, Personal Communication with D. Ryan, Science Applications International Corporation, Idaho Falls, Idaho, December 21.

Notar, J., 1993b, Air Quality Specialist, National Park Service, Denver Regional Office, Summary Seasonal and Annual Results of the Craters of the Moon National Monument Visual Range from "IMPROVE" Fine Particle Sampler, 1992 - 1993, FAX Transmittal, December 12.

Ritter, P.D., 1992, 1991 NESHAPS Annual Report CAP-88 Dose Assessment and Verification and Validation Report for Unmonitored Emissions, EG\&S EDF NESHAP-91-UNMON, August 24.

Staley, C.S., 1993a, Air Emission Source Terms for No Action Projects, EG\&G Idaho Engineering Design File ER\&WM-EDF-0013-93 (Draft), EG\&G Idaho, Inc., Idaho Falls, Idaho, August.

Staley, C.S., 1993b, Air Emission Source Terms for Proposed Action Projects, EG\&G Idaho Engineering Design File ER\&WM-EDF-0012-93 (Draft), EG\&G Idaho, Inc., Idaho Falls, Idaho, August.

Wilson, R., 1993, Regional Meteorologist, U.S. Environmental Protection Agency, personal communication with D. Ryan, Science Applications International Corporation, San Diego, California, November 15.

Winges, K, 1992, User's Guide for the Fugitive Dust Model (FDM) (Revised) - User's Instructions, EPA-910/9-88-202R, U.S. Environmental Protection Agency, Region 10, Seattle, Washington, January.

Appendix F, Section F-4

ACGIH (American Conference of Governmental Industrial Hygienists), 1993, Guide to Occupational Exposure Values-1993, Cincinnati, Ohio. 
CFR (Code of Federal Regulations), 1977, "National Primary and Secondary Ambient Air Quality Standards," 40 CFR 50, Office of the Federal Register, Washington D.C., November.

DOE (U.S. Department of Energy), 1993a, Recommendations for the Preparation of Environmental Assessments and Environmental Impact Statements, Office of National Environmental Policy Act Oversight, Washington, D.C., May.

DOE (U.S. Department of Energy), 1993b, Occupational Injury and Property Damage Summary, January-March 1993, DOE/EH/01570, Washington, D.C., March 1993

DOE-ID (U.S. Department of Energy Idaho Operations Office), 1988, The Idaho National Engineering Laboratory Site Environmental Report for Calendar Year 1987, DOE/ID12082(87), U.S. Department of Energy, Idaho Falls, Idaho.

DOE-ID (U.S. Department of Energy Idaho Operations Office), 1989, The Idaho National Engineering Laboratory Site Environmental Report for Calendar Year 1988, DOE/ID12082(88), U.S. Department of Energy, Idaho Falls, Idaho.

DOE-ID (U.S. Department of Energy Idaho Operations Office), 1990, The Idaho National Engineering Laboratory Site Environmental Report for Calendar Year 1989, DOE/ID12082(89), U.S. Department of Energy, Idaho Falls, Idaho.

DOE-ID (U.S. Department of Energy Idaho Operations Office), 1991a, The Idaho National Engineering Laboratory Site Environmental Report for Calendar Year 1990, DOE/ID12082(90), U.S. Department of Energy, Idaho Falls, Idaho.

DOE-ID (U.S. Department of Energy Idaho Operations Office), 1991b, Idaho National Engineering Laboratory Historical Dose Evaluation, Volume 1, DOE/ID-12119, U.S. Department of Energy, U.S. Department of Energy, Idaho Falls, Idaho.

DOE-ID (U.S. Department of Energy Idaho Operations Office), 1992, The Idaho National Engineering Laboratory Site Environmental Report for Calendar Year 1991, DOE/ID12082(91), U.S. Department of Energy, Idaho Falls, Idaho.

EG\&G Idaho (EG\&G Idaho, Inc.), 1993a, Response to a Special Request for INEL Illness Descriptions by Contractor 1987 to 1991, Safety Performance Measurement System, EG\&G Idaho, Inc., Idaho Falls, Idaho.

EG\&G Idaho (EG\&G Idaho, Inc.) 1993b, Response to a Special Request for INEL Performance Data and Graphs, Injury, Property, and Vehicle, Safety Performance Measurement System, EG\&G Idaho, Inc., Idaho Falls, Idaho.

EG\&G Idaho (EG\&G Idaho Inc.), 1993c, One Line Description of INEL Lost Workday Cases, 1987 to 1991, Safety Performance Measurement System, EG\&G Idaho, Inc., Idaho Falls, Idaho.

EG\&G Idaho (EG\&G Idaho, Inc.), 1993d, INEL Composite Statistical Summary, Safety Performance Measurement System, EG\&G Idaho, Inc., Idaho Falls, Idaho. 
EPA (U.S. Environmental Protection Agency), 1987, Technical Guidance for Hazards Analysis, Washington, D.C., December, 1987.

EPA (U.S. Environmental Protection Agency), 1988, Limiting Values of Radionuclide Intake and Air Concentration and Dose Conversion Factors for Inhalation, Submersion, and Ingestion, Federal Guidance Report No. 11, Washington, D.C.

EPA (U.S. Environmental Protection Agency), 1989, Risk Assessment Guidance for Superfund, Volume 1, Human Health Evaluation Manual (Part A), Interim Final, EPA/540/1-89/002, Washington, D.C., December.

EPA (U.S. Environmental Protection Agency), 1993, Health Effects Assessment Summary Tables, FY-1993 Supplement No. 1, EPA 540-R-93-058A, Washington, D.C., July.

EPA (U.S. Environmental Protection Agency), 1994, IRIS (Integrated Risk Information System) database.

FR (Federal Register), 1986, 51 FR 34014, "Guideline for Health Risk of Chemical Mixtures," U.S. Environmental Protection Agency, September 24.

FR (Federal Register), 1991, 56 FR 23363, "Preamble to Standards for Protection Against Radiation," U.S. Nuclear Regulatory Commission, May 21.

Homann (Homann Associates, Inc.), 1988, EPIcode ${ }^{\mathrm{m}}$ (Emergency Prediction Information) Manual, Fremont, California.

ICRP (International Commission on Radiological Protection), 1991, 1990 Recommendations of the International Commission on Radiological Protection, ICRP Publication 60, Annals of the ICRP, Volume 21, No. 1-3, Pergamon Press, New York, New York.

IDHW (Idaho Department of Health and Welfare), 1994, Revised Title 1, Chapter 1, Rules for the Control of Air Pollution in Idaho, Idaho Division of Health and Welfare, Division of Environmental Quality, Boise, Idaho, June.

NIOSH (National Institute for Occupational Safety and Health), 1990, Pocket Guide to Chemical Hazards, Washington D.C., June.

NSC (National Safety Council), 1993, National Safety Council, Accident Facts, 1993 Edition.

\section{Appendix F, Section F.5}

Abrahamson, S., M. Bender, S. Book, C. Buncher, C. Denniston, E. Gilbert, F. Hahn, V. Hertzberg, H. Maxon, B. Scott, W. Schull, S. Thomas, 1989, "Scientific Basis for Health Effects Models," Part II of Heath Effects Models for Nuclear Power Plant Accident Consequence Analysis, NUREG/CR-4214, Rev. 1, Sandia National Laboratories, Albuquerque, New Mexico. 
ACGIH (American Conference of Governmental Industrial Hygienists), 1988, Threshold Limit Values and Biological Exposure Indices for 1989-1990, Cincinnati, Ohio.

Baes, C.F. III, R. D. Sharp, A. L. Sjoreen, R. W. Shor, 1984, A Review and Analysis of Parameters for Assessing Transport of Environmentally Released Radionuclides through Agriculture, ORNL-5786, Oak Ridge National Laboratory, Oak Ridge, Tennessee.

CFR (Code of Federal Regulations), 1993a, 40 CFR 355, "Appendices A and B, SARA Section 302, Lists of Extremely Hazardous Substances and Their Threshold Planning Quantities," Office of the Federal Register.

CFR (Code of Federal Regulations), 1993b, 40 CFR 302, "Table 302.4, Comprehensive Environmental Response, Compensation, and Liability Act) Hazardous Substances, Lists of r.1azardous Substances and Reportable Quantities," Office of the Federal Register, July 1.

CFR (Code of Federal Regulations), 1993c, 40 CFR 372, "SARA Section 313 Toxic Chemicals," Office of the Federal Register.

CFR (Code of Federal Regulations), 1993d, 40 CFR 261.33, "Resource Conservation and Recovery Act (RCRA), "Identification and Listing of Hazardous Waste," Office of the Federal Register.

Clawson, K. L., G. E. Start, N. R. Ricks, 1989, Climatography of the Idaho National Engineering Laboratory, 2nd ed., U. S. Department of Commerce, National Oceanic and Atmospheric Administration, Environmental Research Laboratories, Air Resources Laboratory Field Research Division, Idaho Falls, Idaho.

Croff, A. G., 1983, "ORIGEN2: A Versatile Computer Code for Calculating the Nuclide Compositions and Characteristics of Nuclear Materials," Nuclear Technology, 62, p. 335, September.

DOE (U.S. Department of Energy), 1988, Internal Dose Conversion Factors for Calculation of Dose to the Public, DOE/EH-0071, Washington, D.C.

DOE (U.S. Department of Energy), 1992a, Order 5480.23, "Nuclear Safety Analysis Reports," Washington, D.C., April 30.

DOE (U.S. Department of Energy), 1992b, DOE Standard, "Hazard Categorization and Accident Analysis Techniques for Compliance with DOE Order 5480.23, Nuclear Safety Analysis Reports," DOE-STD-1027-92, Washington, D.C., December.

DOE (U.S. Department of Energy), 1992c, Order 5480.11, Change 3, "Radiation Protection for Occupational Workers" Washington, D.C., June 17.

DOE (U.S. Department of Energy), 1993, DOE HANDBOOK: Recommended Values and Technical Bases for Airborne Release Fractions, Airborne Release Rates, and Respirable Fractions at DOE Non-Reactor Nuclear Facilities, DOE-STD-0013-93, Washington, D.C., July. 
DOE-ID (U.S. Department of Energy, Idaho Operations Office), 1994, Accident Assessments for Facilities at the Idaho National Engineering Laboratory, DOE/ID-10471, U.S. Department of Energy, Idaho Falls, Idaho, June.

Elder, J. C., J. M. Graf, J. M. Dewart, T. E, W. J. Wenzel, L. J. Walker, A. K. Stoker, 1986, A Guide to Radiological Accident Considerations for Siting and Design of DOE Nonreactor Nuclear Facilities, LA-10294-MS, Los Alamos National Laboratory, Los Alamos, New Mexico.

EPA (U.S. Environmental Protection Agency), 1990, "EPA Title III List of Lists," EPA 560/4-90011, Office of Toxic Substances, and Office of Solid Waste and Emergency Response, Washington, D.C., January.

EPA/FEMA/DOT (U.S. Environmental Protection Agency/Federal Emergency Management Agency/U.S. Department of Transportation), 1987, Technical Guidance for Hazards Analysis: Emergency Planning for Extremely Hazardous Substances, Washington, D.C., December.

FR (Federal Register), 1994, 40 CFR 9 \& 68, "List of Regulated Substances and Thresholds for Accidental Release Prevention and Risk Management Programs for Chemical Accident Release Prevent; Final Rule and Notice," January 31, pp. 4478-4501.

Grove (Grove Engineering, Inc.), 1988, Microshield Version 3 Manual, Rockville, Maryland, April 12.

Homann (Homann Associates, Inc.), 1988, EPIcode ${ }^{\mathrm{MM}}$ (Emergency Prediction Information Manual), Fremont, California.

ICRP (International Commission on Radiological Protection), 1977, Report of the Task Group on Reference Man, ICRP Publication 23, Pergamon Press, Oxford, Great Britain.

ICRP (International Commission on Radiological Protection), 1979, Limits for Intakes of Radionuclides by Workers, Part 1, ICRP Publication 30, Pergamon Press, Oxford, Great Britain.

ICRP (International Commission on Radiological Protection), 1991, 1990 Recommendations of the International Commission on Radiological Protection, Publication 60, Annals of the ICRP, Volume 21, Number 1-3, Pergamon Press, New York, New York.

Markee, E. H. Jr., 1967, "A Parametric Study of Gaseous Plume Depletion by Ground Surface Adsorption," in Proceedings of USAEC Meteorological Information Meeting, C. A. Mawson, ed., AECL-2787, pp. 602-613.

Moore, R. E., C. F. Baes III, L. M. McDowell-Boyer, A. P. Watson, F. O. Hoffman, J. C. Pleasant, C. W. Miller, 1979, AIRDOS-EPA: A Computerized Methodology for Estimating Environmental Concentrations and Dose to Man from Airborne Releases of Radionuclides, ORNL-5532, Oak Ridge National Laboratory, Oak Ridge, Tennessee.

NCRP (National Council on Radiation Protection and Measurements), 1985, Induction of Thyroid Cancer by Ionizing Radiation, Regulatory Guide 80, Washington, D.C. 
NIOSH (National Institute for Occupational Safety and Health), 1990, Pocket Guide to Chemical Hazards, Washington, D.C., June.

NRC (U.S. Nuclear Regulatory Commission), 1977a, Assumptions Used for Evaluating the Potential Radiological Consequences of Accidental Nuclear Criticality in a Fuel Reprocessing Plant, Regulatory Guide 3.33, Washington, D.C., April.

NRC (U.S. Nuclear Regulatory Commission), 1977b, Calculation of Annual Doses to Man from Routine Releases of Reactor Effluents for the Purpose of Evaluating Compliance with 10 CFR Part 50, Appendix I, Regulatory Guide 1.109, Rev. 1, Washington, D.C., October.

NRC (U.S. Nuclear Regulatory Commission), 1979a, Assumptions Used for Evaluating the Potential Radiological Consequences of Accidental Nuclear Criticalities of Accidental Criticality in a Uranium Fuel Fabrication Plant," Regulatory Guide 3.34, Rev. 1, Washington, D.C., July.

NRC (U.S. Nuclear Regulatory Commission), 1979b, Assumptions Used for Evaluating the Potential Radiological Consequences of Accidental Nuclear Criticalities of Accidental Criticality in a Plutonium Processing And Fuel Fabrication Plant, Regulatory Guide 3.35, Rev. 1, July.

Priestley, T. B., EG\&G Idaho, Inc., 1992, personal communication to D. Brown, Advanced Sciences, Inc., transmittal of "dBASE File - Chemical Inventory Used for Preparation of SARA 312 Report for the Idaho National Engineering Laboratory."

RSIC (Radiation Shielding Information Center), 1991, "ORIGEN2.1, Isotope Generation and Depletion Code Matrix Exponential Method," CCC-371, RSIC Computer Code Collection, Oak Ridge, Tennessee.

Rupp, E. M., 1980, "Age Dependent Values of Dietary Intake for Assessing Human Exposures to Environmental Pollutants," Health Physics, 39, pp. 151-163.

Rusch, G. M., 1993, "The History and Development of Emergency Response Planning Guidelines," Journal of Hazardous Materials, 33, pp 193-202, Elsevier Publishers, Amsterdam.

Weitzman, D. J. (EH-412), 1992, U.S. Department of Energy memorandum to J. E. Fairobent (OE-11); regarding "Status of Emergency Response Planning Guides (ERPGs)," Washington, D.C., September 23.

Wenzel, D. R., 1993, The Radiological Safety Analysis Computer Program (RSAC-5), WINCO1123, Westinghouse Idaho Nuclear Company, Inc., Idaho Falls, Idaho, March. 

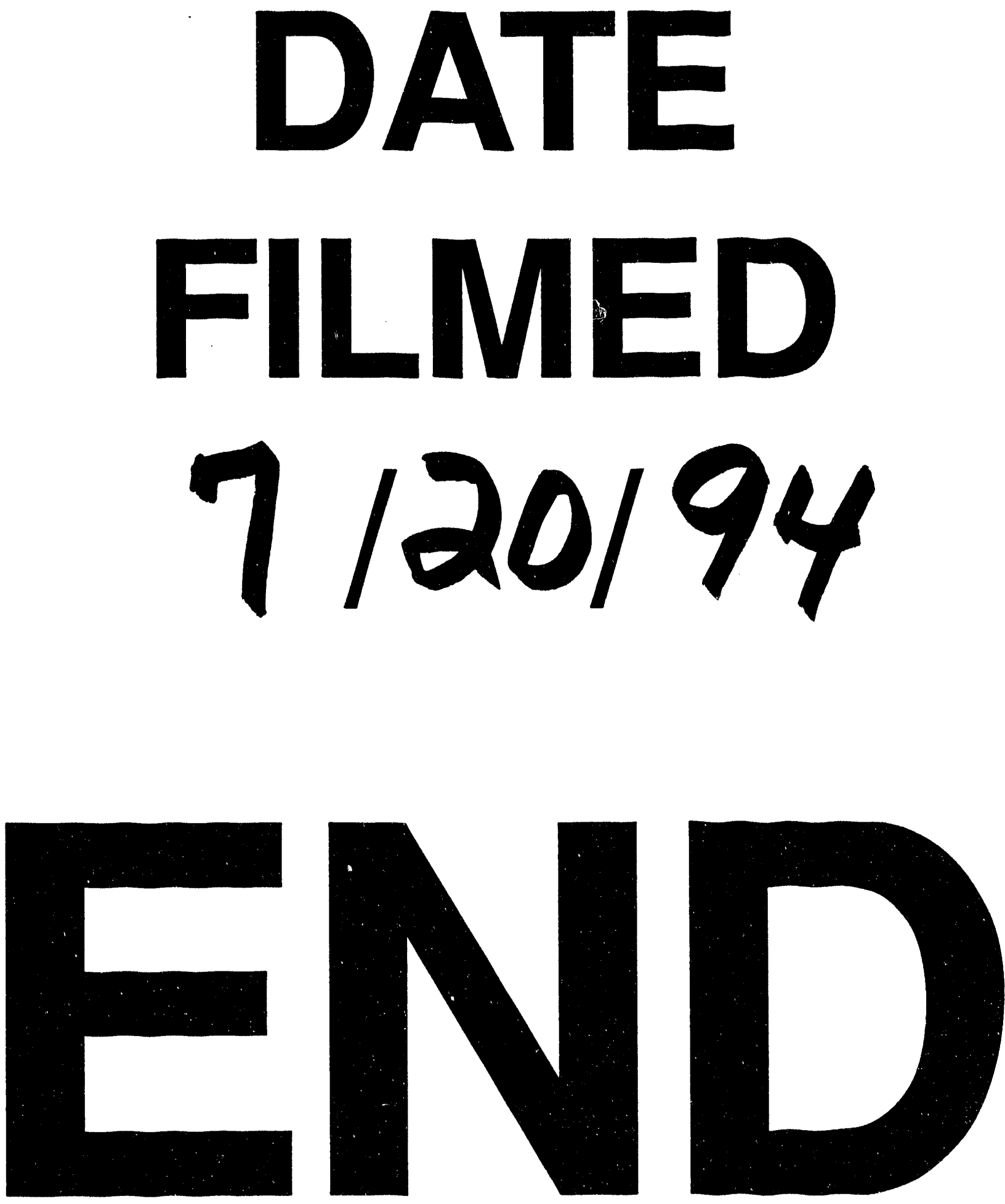

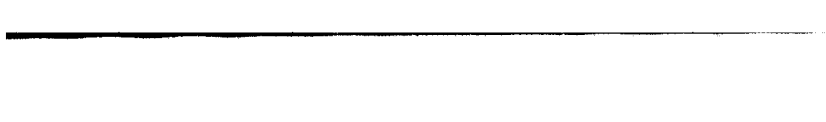